\title{
MODERNOS Y MILITANTES CALIFORNIA A TRAVÉS DE HARWELL HAMILTON HARRIS Y GORDON DRAKE
}

autor: JOSÉ PARRA MARTÍNEZ directora: CARMEN JORDÁ SUCH

[ universidad politécnica de valencia]

[ departamento de composición arquitectónica ]

[ ETSAV ] ...

[ tesis doctoral $\quad . . \quad$ Valencia, junio de 2012 ] 


\section{MODERNOS Y MILITANTES CALIFORNIA A TRAVÉS DE HARWELL HAMILTON HARRIS Y GORDON DRAKE}





\section{PREVIOS}

Contenido, estructura y objetivos de la tesis

En torno a metodología y fuentes de la investigación

Notas y referencias bibliográficas

\section{CONSTRUYENDO SUEÑOS (1910-1950)}

NOTAS INTRODUCTORIAS A LOS PAISAJES RESIDENCIALES

DELSURDECALIFORNIA.

La promoción del paraíso. El Grupo del Arroyo

El bungalow, instrumento de colonización territorial

Los Ángeles entre la Gran Depresión y el Fair Deal

El cooperativismo de posguerra, oasis de vida moderna

Notas y referencias bibliográficas

DISCUSSIONS IN A GARDEN

DE OLIVE HILL A KINGS ROAD

085

Chicago, The Little Theatre

Una acrópolis para Los Ángeles

Olive Hill, media década de proyectos

California Romaza

Wright en Beverly Hills: visiones de una nueva arquitectura

El parque Barnsdall, jardín de trayectorias que se bifurcan

Kings Road y el ideal de California

PAULINE GIBLING (SCHINDLER),

PROMOTORADELAMODERNIDADCALIFORNIANA

De nuevo Chicago, ciudad de intercambio

Focos de militancia: Los Ángeles (1920) y la gestación del salón Gibling-Schindler

Pauline en Kings Road, 1922-27

El círculo de Carmel, The Carmelite

Contemporary Creative Architecture in California, una exposición inaugural (1930)

Dune Forum, la mística de las dunas

Otros hitos editoriales. CA\&A (1935) y la influencia sobre Esther McCoy

EDWARD WESTON EN LOS INICIOS DE LA FOTOGRAFÍA DE

ARQUITECTURAENCALIFORNIA.

Un nuevo paisaje creativo: artistas, amigos y amantes

Los encargos Lovell, algunas hipótesis. Edward Weston en Newport Beach

Neutra y la familia Weston, colaboraciones con la vanguardia 


\section{II \\ DISCÍPULOS Y MAESTROS}

RICHARD NEUTRAY LA IDEALIZACIÓN PUBLICITARIA

DE LATECNOLOGÍA EN AMÉRICA.

¿Cómo se construye en California?

Más hipótesis en torno a Lovell. La versión de Esther McCoy

Academy of Modern Art, clase del 29

Demostration Health House: fotografiando en Dundee Drive

HARWELL HAMILTON HARRIS EN CALIFORNIA

Mi América realmente es California

Jean Murray Bangs (Harris)

Los años 30, casas con buenos modales

Una vivienda para John Entenza

Weston Havens House, la arquitectura y sus fotógrafos

Nueva York: What is Happening to Modern Architecture?

El descubrimiento de Greene \& Greene.

Un regionalismo liberador

Silver Lake, a modo de recapitulación

GORDON DRAKE: NO MAN IS AN ISLAND

Una estrella fugaz (1946-1952)

Beverly Glen House, la casa que hizo a Gordon Drake

La casa modular de la Costa Oeste

El sueño de Carmel

San Francisco, un nuevo comienzo

Harris en memoria de Gordon Drake

Repercusión mediática: Drake y la fotografía arquitectónica de Shulman

Reivindicación de Gordon Drake

Notas y referencias bibliográficas

\section{APUNTE HISTORIOGRÁFICO}

ESTHER MCCOYY JOHN ENTENZA, CREADORES DE MITOS MODERNOS.

Notas y referencias bibliográficas

\section{BIBLIOGRAFÍA}

BIBLIOGRAFÍA ESPECÍFICA

Sobre Harwell Hamilton Harris

Sobre Gordon Drake

BIBLIOGRAFÍA CONSULTADA 
004 | 005 

Estoy en deuda con muchas personas e instituciones en California que, durante el tiempo que ha durado esta investigación y, más allá de su profesionalidad, han hecho gala de la extraordinaria hospitalidad y amabilidad que caracteriza a esta región.

Quiero dar las gracias en primer lugar a los propietarios y clientes originales de las viviendas visitadas en Los Ángeles. Todos ellos respondieron de manera entusiasta a cuantas cuestiones les fueron planteadas sobre sus casas, facilitando asimismo todo tipo de información acerca su historia familiar, las condiciones en las que se produjeron los encargos y su relación con los arquitectos. En este sentido, es imprescindible mencionar a Mike Deasy, Dion Neutra, Kirk Nozaky, Adolph Tischler y Betty Topper.

Deseo agradecer la atención prestada por Robert Winter, decano de los historiadores de arquitectura del Sur de California quien, además de abrir las puertas de su casa, compartió su sabiduría y sus conocimientos sobre la obra de los arquitectos modernos californianos.

Fue de inestimable ayuda también el equipo de arquitectos de Michael Folonis en Santa Mónica, estudio responsable de la restauración de las casas Entenza y Pumphrey de Harwell Hamilton Harris.

Gracias igualmente a los fotógrafos John Ellis y Juergen Nogai, asistente de Julius Shulman durante sus últimos años. En este sentido, es imprescindible agradecer toda la colaboración prestada por Judy Shulman McKee en la organización de la entrevista y en la consulta de los documentos de su padre.

No puedo olvidarme de Thomas Hines y Barbara Lamprecht, especialistas en la obra de Neutra y de que quienes he tenido el privilegio de aprender durante sus visitas guiadas a diversas viviendas construidas por el arquitecto en el área de Los Ángeles. Igualmente deseo expresar mi gratitud a Cory Buckner, por descubrirme algunos de los rincones más especiales de la Mutual Housing Association; y a Don Kubly, antiguo Director del Art Center College of Design de Pasadena, por sus relatos de primera mano sobre Craig Ellwood.

Han resultado de gran ayuda los consejos y comentarios de Beatriz Colomina sobre determinadas cuestiones, en especial las relacionadas con el matrimonio Eames y John Entenza, proporcionando además contactos, como el de Stanley Tigerman, cuyas opiniones han sido realmente valiosas para el acercamiento a la compleja personalidad del editor de Arts \& Architecture.

El apoyo recibido por parte de todas las instituciones visitadas en California ha sido enorme. Tanto en la Universidad de California en Los Ángeles, como en la Universidad del Sur de California, fue decisiva la colaboración de su personal y toda la atención recibida por parte de los responsables de sus bibliotecas, archivos y colecciones especiales. Ha sido un placer investigar en Los Angeles Public Library y en la Santa Monica Library; así como en el MAK Center; la Hollyhock House; y los Departamentos de Recreations \& Parks y Cultural Affairs de la Municipalidad de Los Ángeles.

Debo un especial agradecimiento a Miranda Hambro, archivera de los Environmental Design Archives de la Universidad de Berkeley por su refuerzo en la búsqueda de los materiales específicos sobre Gordon Drake en la Douglas and Maggie Baylis Collection. Igualmente, debo agradecer la inestimable colaboración de Melisa Gandara, archivera de la Architecture and Design 
Collection del University Art Museum de la Universidad de California en Santa Bárbara.

Le estoy muy agradecido también a Ann Sheid por su asistencia en las búsquedas realizadas en la Huntington Library en San Marino; a Win de Witt, por todo el apoyo recibido en el Getty Researh Institute; y a Ted Bosley, Director de la Gamble House y a todo su equipo, por el trato recibido en dicha institución. Asimismo deseo mencionar la ayuda prestada por Kelly Mcleod, arquitecta restauradora de la Gamble House por compartir excelentes ratos en su estudio y en su casa de Long Beach discutiendo acerca de múltiples cuestiones, desde la arquitectura de los hermanos Greene hasta su experiencia profesional con Reyner Banham. Y, por supuesto, de inestimable valor han sido los comentarios y aportaciones de Susan Morgan, Raymond Neutra y Meredith Clausen sobre Esther McCoy.

En España, agradezco al Colegio Oficial de Arquitectos de Murcia por la concesión de una beca de investigación que sufragó parte de la estancia en California en 2010.

Quiero destacar asimismo la labor de mis amigos, que han contribuido a esta tesis de todas las maneras posibles: a mis compañeros de estudio, Ginés Sabater, Lola Jiménez y Emilio Jarrín porque además de colaborar en la maquetación, han asumido una carga de trabajo que no les correspondía. También agradezco a Gema Arias, Dorleta Uribe y Pablo Conesa sus aportaciones en la revisión del documento y, muy especialmente, a Cristina Pellicer. A Enrique Nieto y Miguel Mesa, compañeros en la Universidad de Alicante, agradezco su apoyo y las estimulantes conversaciones mantenidas a lo largo de los últimos meses. Además, quiero mostrar mi agradecimiento a Mentxu Castelló por sus aportaciones al análisis de las fotografías históricas discutidas en este documento.

Y, sobre todo, me siento en deuda con John Crosse, con quien se han intercambiado versiones preliminares de varios capítulos, facilitando además una conexión en tiempo real con otras fuentes y autores en California. Esta tesis se ha beneficiado de sus enciclopédicos conocimientos, así como de la consulta de su fantástica hemeroteca en Playa del Rey, donde ha sido un privilegio investigar.

Finalmente, y de modo muy especial, deseo agradecer toda la generosidad intelectual y personal de mi amigo Ted Wells, sin cuya ayuda, difícilmente, esta investigación podría haberse llevado a cabo.

Esta tesis está dedicada a mi padre, que no llegó a verla terminada.

José Parra

Valencia, junio de 2012 
A través del establecimiento de una genealogía moderna que recorre tres generaciones de arquitectos californianos entre mediados de los años 20 y finales de los años 40, desde Richard Neutra a Gordon Drake pasando por Harwell Hamilton Harris, esta tesis aborda el modo en que estos autores entendieron y expresaron su particular vinculación con el medio físico y el paisaje creativo del Sur de California. El análisis de las obras donde estos arquitectos coincidieron en su condición de discípulos y maestros $y$, sobre todo, la identificación de sus círculos de influencias, permiten describir algunos de los episodios formativos que mejor explican los cauces por los que se gestaron y transmitieron las tradiciones modernas más originales de la región.

Harwell Hamilton Harris y Gordon Drake son dos arquitectos genuinamente californianos cuya obra, a pesar de su calidad, resulta bastante desconocida para la cultura arquitectónica europea. Esta situación es representativa del modo en que la historia de la arquitectura moderna californiana se ha transmitido sólo a través de unos cuantos relatos incompletos, cuyas principales fuentes deben ser examinadas con mayor profundidad crítica. Éste sería el caso de Esther McCoy, la primera historiadora de este periodo y a quien se suele citar sin atender a su frecuente implicación personal en los hechos mismos que recogen sus estudios.

Harris llegó al despacho de Neutra en 1928. Éste residía entonces en la vivienda que Rudolph y Pauline Schindler habían construido en Kings Road, y allí ultimaba el proyecto de ejecución de la Lovell House, la obra a la que mayor esfuerzo de promoción dedicó en toda su vida y la casa que confirmó su celebridad internacional. Poco más de una década después, Gordon Drake fue admitido en el estudio de Harris donde colaboró, precisamente, en la vivienda que más reconocimiento le valió a su mentor, la Weston Havens House, concluida semanas antes de la entrada de los Estados Unidos en la Segunda Guerra Mundial. La portada del número de marzo de 1940 de California Arts \& Architecture reproduciendo a toda página la inspirada sección transversal de esta casa constituyó para Harris un punto de inflexión en su carrera, un momento que resultó igualmente decisivo para John Entenza. Para el arquitecto marcó el final de su relación con la revista; para el escritor supuso su primera portada y el inicio de una trayectoria editorial orientada a fabricar prestigio. Por su parte, Drake ganó con su primera obra, su propia casa en Los Ángeles (1946), el primer concurso de la revista Progressive Architecture. Las fotografías que Julius Shulman tomó de aquella vivienda catapultaron a la fama a una joven promesa de la arquitectura cuya meteórica carrera se vio truncada por un accidente que le costó la vida antes de cumplir los 35 años.

El interés mediático que despertó el trabajo de todos ellos brinda la oportunidad de explorar los mecanismos de fijación de la memoria y las políticas editoriales de la época, también sus estrategias publicitarias e, incluso, la importancia concedida por algunos protagonistas de estas historias cruzadas a la elaboración de su propia biografía. Asimismo esta tesis incide en la construcción de afectos y relaciones personales que hicieron posible aquellas arquitecturas. $Y$, en este sentido, fue fundamental el compromiso militante de Pauline Schindler quien, a lo largo de su vida, movilizó una red de arquitectos, artistas, fotógrafos, escritores, activistas políticos, intelectuales y clientes progresistas sin cuya fricción, seguramente, la historia de la arquitectura californiana habría sido otra muy distinta. 
Mitjançant l'establiment d'una genealogia moderna que recorre tres generacions d'arquitectes californians entre la segona meitat dels anys 20 i finals dels anys 40, des de Richard Neutra a Gordon Drake passant per Harwell Hamilton Harris, aquesta tesi aborda la manera en què aquests autors van entendre i van expressar la seva particular vinculació amb el mitjà físic i el paisatge creatiu del Sud de Califòrnia. L'anàlisi de les obres en les quals aquests arquitectes van coincidir en la seva condició de deixebles i mestres i, sobretot, la identificació dels seus cercles d'influències, permeten descriure alguns dels episodis formatius que millor expliquen els camins pels quals es van gestar i es van transmetre les tradicions modernes més originals de la regió.

Harwell Hamilton Harris i Gordon Drake són dos arquitectes genuïnament californians l'obra dels quals, malgrat la seva qualitat, és pràcticament desconeguda per a la cultura arquitectònica europea. Aquesta situació és representativa de la manera en què la història de l'arquitectura moderna californiana s'ha transmès només mitjançant uns quants relats incomplets, les principals fonts dels quals han de ser examinades amb major profunditat crítica. Aquest seria el cas d'Esther McCoy, la primera historiadora d'aquest període i a qui s'acostuma a citar sense atendre la seva freqüent implicació personal en els mateixos fets que recullen els seus estudis.

Harris va arribar al despatx de Neutra en 1928. Aquest residia llavors en l'habitatge que Rudolph i Pauline Schindler havien construït en Kings Road, i allà ultimava el projecte d'execució de la Lovell House, l'obra a la qual major esforç de promoció va dedicar en tota la seva vida i que va confirmar la seva celebritat internacional. Poc més d'una dècada després, Gordon Drake va ser admès en l'estudi d'Harris on va col-laborar, precisament, en la vivenda que més reconeixement li va valer al seu mentor, la Weston Havens House, conclosa setmanes abans de l'entrada dels Estats Units en la Segona Guerra Mundial. La portada de març de 1940 de California Arts \& Architecture reproduint a tota pàgina la inspirada secció transversal d'aquesta casa va constituir per a Harris un punt d'inflexió en la seva carrera, un moment que va resultar igualment decisiu per a John Entenza. Per l'arquitecte va marcar el final de la seva relació amb la revista; per l'escriptor va suposar la seva primera portada i l'inici d'una trajectòria editorial orientada a fabricar prestigi. D'altra banda, Drake va guanyar amb la seva primera obra, la seva pròpia casa a Los Angeles (1946), el primer concurs de la revista Progressive Architecture. Les fotografies que Julius Shulman va prendre d'aquella vivenda van catapultar a la fama a una jove promesa de l'arquitectura, la meteòrica carrera de la qual es va veure truncada per un accident que li va costar la vida abans de complir els 35 anys.

L'interès mediàtic que va despertar el treball de tots ells brinda l'oportunitat d'explorar els mecanismes de fixació de la memòria i les polítiques editorials de l'època, també les seves estratègies publicitàries i, fins i tot, la importància concedida per alguns protagonistes d'aquestes històries creuades a l'elaboració de la seva pròpia biografia. Així mateix aquesta tesi incideix en la construcció d'afectes i relacions personals que van fer possible aquelles arquitectures. I en aquest sentit, va ser fonamental el compromís militant de Pauline Schindler qui, al llarg de la seva vida, va mobilitzar una xarxa d'arquitectes, artistes, fotògrafs, escriptors, activistes polítics, intel.lectuals i clients progressistes sense la interacció dels quals, segurament, la història de l'arquitectura californiana hauria estat una altra molt diferent. 
In presenting the significant influence of Richard Neutra over Harwell Hamilton Harris and the way Harris' legacy affected Gordon Drake's work, a modern genealogy spanning three generations of California architects -from the mid-20s to late 40s- is established on this thesis to discuss how these authors understood and expressed their special links with the physical environment and the creative landscape of Southern California. The analysis of the buildings and projects in which these architects worked together as disciples and masters and, above all, the identification of their circles of influences, can describe some of the formative events that best explain the channels through which the most original modern traditions in the region were generated and transmitted.

Harwell Hamilton Harris and Gordon Drake are two genuine California architects. Despite the quality of their work, it remains quite unknown to the European architectural culture. This situation is representative of how the history of modern architecture has approached California only through a few incomplete reports whose main sources should be furthermore examined. This is the case of Esther McCoy, the first architectural historian of the California modern period whose writings are often quoted without considering her frequent personal involvement in the very facts that she describes.

Harris reached Neutra's office in 1928. Richard Neutra was by then living at Pauline and Rudolph Schindler's home in Kings Road, where he was completing the executive project of the Lovell House, the building to which Neutra devoted the most important promotional effort in his career and the work that confirmed his international celebrity. Just over a decade later, Gordon Drake joined Harris' office where he worked in fact on the Weston Havens House project. This house assured the recognition to his mentor. The Weston Havens House was completed some weeks before the US entry into World War II. The cover of March 1940 issue of California Arts \& Architecture portraying full-page the inspired cross-section of this house meant a turning point in Harris' career that was equally decisive for John Entenza. For the architect it entailed the end of his relationship with the magazine. Regarding the editor, it was his first cover and the beginning of a thriving publishing career oriented to make prestige. Meanwhile, Drake won with his first work, his own home in Los Angeles (1946), the first contest of Progressive Architecture magazine. The photographs that Julius Shulman took of Drake's house catapulted him to fame. The architect was a young promise whose meteoric career was suddenly interrupted by an accident that cost him his life before turning 35 years old.

The Media interest aroused by the work of these architects brings the opportunity to explore the mechanisms of fame and the editorial policies of the time, as well as the publicity strategies of these authors and even the importance that some protagonists of these stories conceded to the elaboration of their own biography. This thesis insists as well on the importance of the construction of the affections and relationships that made possible those architectures. In this sense the militant commitment of Pauline Schindler was vital. Throughout her life, she mobilized a network of architects, artists, photographers, writers, political activists, intellectuals and progressive clients without whose friction the history of California modern architecture would have probably been quite another matter. 



\section{PREVIOS}

[ Contenido, estructura y objetivos de la tesis En torno a fuentes y metodología

]... 
CONTENIDO, ESTRUCTURA Y

OBJETIVOS DE LA TESIS >> 
En 1951, dando por finalizada una etapa profesional que había durado dos décadas, Harwell Hamilton Harris dejaba definitivamente California para aceptar el puesto de Director de la Escuela de Arquitectura de la Universidad de Texas en Austin. Su trabajo era entonces extraordinariamente conocido y admirado, tanto que tras coincidir con Alvar Aalto en San Francisco a finales de los años 30 y visitar con él algunas de sus obras, éste dijo de él que se trataba del segundo mejor arquitecto norteamericano, tan sólo superado por Frank Lloyd Wright ${ }^{1}$. Curiosamente, algunas décadas más tarde, a pesar del interés que habían despertado varias de sus obras y de haber llevado a cabo una encomiable labor académica al frente de un grupo de arquitectos y críticos entre los que se encontraban John Heduk o Colin Rowe, cuando Harris dio por terminada su carrera profesional hacia mediados de los 70, su fama se había desvanecido casi por completo. Entonces, sólo algunas de sus casas californianas quedaban en el recuerdo de los historiadores de la región.

En enero de 1952, meses después de la partida de Harris, la prometedora trayectoria de su discípulo quedaba truncada por un accidente que le costó la vida cuando disfrutaba de unos días de vacaciones en las montañas del norte de California. Aunque sólo tenía 34 años cuando murió, Gordon Drake dejó una obra admirable por la madurez e intensidad de sus temas, algunos de ellos, como la democratización del diseño, centrales en el debate arquitectónico de finales de los años 40. La escasa producción de Drake estuvo influenciada principalmente por Harwell Hamilton Harris, a quien había conocido en uno de los cursos que éste impartía en la Universidad del Sur de California en el verano de 1940 y en cuyo despacho trabajó durante los meses previos e inmediatamente posteriores a la Segunda Guerra Mundial.

Por su parte, Harris se había formado en el estudio de Richard Neutra, el arquitecto que, como él mismo dijo en una ocasión, se ocupó de trazar el rumbo de su carrera ${ }^{2}$. A través de Neutra, Harris entró en contacto con las ideas de la modernidad internacional; aprendió sus estrategias publicitarias; tuvo la oportunidad de trabajar en proyectos experimentales de considerable escala y complejidad; y fue testigo directo, tanto en los tableros de dibujo como a pie de obra en la Lovell House, de las aspiraciones de su maestro de lograr una expresión arquitectónica universal a partir del paradigma industrial norteamericano. Harris tomó buena nota de los éxitos y fracasos de Richard Neutra y, armado con un sólido bagaje intelectual, supo reinterpretar de manera crítica la relación de su mentor con la tecnología de su tiempo para iniciar un recorrido, justamente en sentido contrario, hacia las fuentes de una auténtica tradición regional.

Cuando Harris comenzó su vinculación profesional con Richard Neutra en 1928, éste vivía y trabajaba todavía en una de las alas de la vivienda-estudio que Rudolph y Pauline Schindler habían construido en Kings Road y que, desde 1922, se había convertido en un centro de referencia para la vanguardia local. Aunque Schindler nunca le propuso colaborar con él y Pauline acababa de abandonar la casa, ambos ejercieron una gran influencia en sus inicios como arquitecto. Por un lado, Harris se mantuvo muy atento a la obra y a las ideas de Schindler; compartió con él la fascinación de su primera época por la madera $y$, también -aunque sin tanto protagonismo-, el interés de sus últimos años por la experimentación con materiales industriales baratos $y_{\text {, }}$ en general, desacostumbrados en arquitectura doméstica como plásticos, chapas, mallas, tableros sintéticos, embalajes, etc. (se trataría de los inicios de una plástica low tech genuinamente californiana en la que, por ejemplo, también se enmarcaría la casa de Frank Gehry en Santa Mónica de 1978). Por 
otro lado, Pauline se convirtió en una de sus mejores amigas y principales admiradoras de su trabajo. Fue ella, a través de su labor editorial y, en este sentido, como precursora de Esther McCoy, quien consiguió para Harris su primera aparición relevante en un medio impreso.

Aunque sobre todo, si algo hubo a lo que Harris no pudo sustraerse fue al particular influjo creativo del universo arquitectónico y cultural de Kings Road y, más concretamente, a la idea de California que la casa representaba.

Precisamente, otro personaje también vinculado a Kings Road, Jane Murray Bangs, la mujer de Harris, fue quien desplegó la influencia más decisiva sobre su carrera y, en concreto durante su etapa californiana, mediante su descubrimiento de los hermanos Greene.

A diferencia de Harris, cuya obra californiana se enmarca en la tradición moderna anterior a la contienda bélica y cuyos principales clientes fueron profesionales liberales de ideas progresistas, Drake es un arquitecto de posguerra que supo distinguir inmediatamente en la familia americana media el destinatario de su arquitectura, respondiendo con todos los recursos a su alcance a las necesidades propias de una nueva era. Así, dando una vuelta de tuerca a las enseñanzas de Harris, el arquitecto logró una perfecta síntesis entre la sensibilidad regional y una modernidad de vocación internacional que, como Neutra, entendió también como parte del nuevo espacio de la producción arquitectónica: los medios de comunicación de masas.

Gordon Drake había irrumpido a lo grande en la escena arquitectónica de Los Ángeles en 1946 ganando con su ópera prima, su propia casa en Beverly Glen, el primer concurso lanzado por la revista Progressive Architecure, una convocatoria que, a partir de entonces, se convertiría en una de las principales plataformas de proyección pública para los arquitectos americanos de posguerra. Tras este éxito inicial y a pesar de la brevedad de su carrera, Drake realizó una serie de obras notables que, junto a su considerable producción de proyectos y propuestas teóricas -considerando el escaso tiempo de que dispuso-, superan por su calidad el legado de muchos de sus contemporáneos. Durante los años finales de la década de los 40, tanto las revistas populares como las publicaciones especializadas de todo el país a excepción de Arts \& Architecture e, incluso, medios extranjeros como L'Architecture d'Aujourd'hui, se rindieron ante las asequibles y seductoras viviendas propuestas por Gordon Drake3.

Ahora bien, mientras que Harwell Hamilton Harris sigue siendo una figura todavía muy poco conocida fuera de California', sobre todo en Europa, en el caso de Gordon Drake, la amnesia respecto a su obra aún es mucho mayor. La temprana desaparición del arquitecto en 1952 es la principal causa para este olvido histórico al que, por supuesto, ha contribuido su escasa obra construida y la práctica total desaparición de la misma, con sólo dos viviendas que han llegado muy transformadas hasta nuestros días. No obstante, incluso después de su muerte, algunas revistas siguieron publicando sus últimas realizaciones, manteniendo así un interés por su persona que, sin duda, promovieron durante años sus amigos más íntimos y estrechos colaboradores como Julius Shulman.

Con independencia de que pocos arquitectos, críticos o historiadores se hayan interesado recientemente por Gordon Drake, sólo la gran atención mediática que su obra llegó a despertar en vida del arquitecto sería suficiente 
para esta investigación acerca de aquel fenómeno. El interés de su arquitectura por supuesto es otra razón, a la que se suma la curiosidad ante el hecho de que, a pesar de su desconocimiento generalizado, el trabajo de Drake fue mencionado como fuente de inspiración por dos ganadores del Premio Pritzker tan dispares en sus planteamientos proyectuales como Glenn Murcutt y Frank Gehry.

Mediante el establecimiento de una serie de influencias sucesivas NeutraHarris-Drake, y a través del estudio de historias cruzadas con esa línea temporal y con los círculos de relaciones de Rudolph y Pauline Schindler, esta tesis examina el panorama arquitectónico y cultural de la modernidad del Sur de California a lo largo de tres décadas de la primera mitad del siglo pasado.

Podría hablarse de una cronología abierta que rondaría los años 1922-1952, más o menos coincidiendo con el periodo comprendido entre la primera y la última obra de Rudolph Schindler. El inicio de la misma vendría determinado por los episodios que llevaron a la construcción de su vivienda-estudio de Kings Road en 1922 y el final coincidiría aproximadamente con varios hitos ocurridos en el arranque de la segunda mitad del siglo. Entre ellos: el lanzamiento de la segunda fase del programa Case Study House y la incorporación de Esther McCoy a la redacción de la revista Arts \& Architecture (1950); el final de la etapa californiana de Harris tras su marcha a Texas en 1951; el punto álgido del macartismo y el final de los programas de vivienda pública en Los Ángeles en 1952; la muerte de Gordon Drake en enero de ese mismo año; y el fallecimiento de Schindler en julio de 1953.

Dichos episodios delimitadores del periodo estudiado en esta tesis vienen a significar que gran parte de las historias más interesantes de la arquitectura californiana habían ocurrido antes de la Segunda Guerra Mundial, o al menos, durante la primera etapa de la posguerra, es decir, hasta 1949, curiosamente la fecha que para Beatriz Colomina simboliza el despegue y a la vez la disolución de la vanguardia norteamericana. Pero, en cualquier caso, antes de que John Entenza lograse mediante un formidable esfuerzo publicitario (secundado internacionalmente por el entusiasmo de los arquitectos e historiadores vinculados al Independent Group) que la modernidad californiana quedase ligada en la memoria colectiva a los arquitectos de su programa y, en concreto, a aquellos autores de la tercera generación que, como Craig Ellwood, Pierre Koenig o Ed Killingsworth, estaban bajo su protección directa y cuyos nombres, probablemente, dicen mucho menos que las imágenes que Julius Shulman tomó de sus obras.

Frank Gehry, declarado admirador de la obra de Harris, denunciaría la actitud intransigente, e incluso el desprecio, de John Entenza hacia su propio trabajo cuando, a principios de los 60, y a pesar de la mediación de su amigo Julius Shulman, el editor le negó ser publicado en las páginas de Arts \& Architecture; una anécdota sobre la que, por cierto, Gehry escribió que siempre le había resultado llamativa "la radicalidad con la que Arts \& Architecture se afanaba por defender unas posturas tan opuestas al tipo de arquitectura en madera que tanto nos interesaba a Harwell $\mathrm{H}$. Harris como a mi"'5.

A lo largo del siglo $x x$, en general, los arquitectos más conocidos -que no por ello los más interesantes- han sido aquellos que mejor han sabido entender la lógica de los medios de comunicación. Curiosamente éste no fue el caso de Harris, cuya relación con los medios fue determinante en su etapa californiana aunque ésta fue siendo cada vez más borrosa conforme fue re- 
sintiéndose la calidad de su arquitectura desde su implicación en la docencia universitaria a partir de 1951. Y tampoco de Drake, que contó con el asesoramiento y el sentido de la oportunidad de Julius Shulman. Sin embargo, es cierto que algunos de los mejores arquitectos californianos no estuvieron especialmente interesados en la autopromoción ni en establecer contactos con determinadas esferas ideológicas afines a los principales aparatos editoriales del país. En otros casos, su trabajo no encajaba exactamente con aquello que los directores de revistas, historiadores y conservadores de influyentes instituciones estaban buscando para defender determinadas ideas, promocionar un determinado estilo de vida o realizar una crítica operativa. Es paradigmático el caso de Rudolph Schindler quien, frente al genio publicitario de Richard Neutra, fue uno de los primeros arquitectos de la región que experimentaron en primera persona cómo su propia evolución creativa al margen de las imágenes reconocibles de los estilos en boga limitó considerablemente su acceso a determinados medios e, incluso, le acarreó el veto de Philip Johnson para formar parte de la exposición del MoMA de 1932.

Respecto a Harris, a pesar de ser un arquitecto relativamente apreciado en California, los ciclos históricos de olvido y redescubrimiento-como él mismo propició con los hermanos Greene o también ocurrió con Schindler- aún no han acabado de hacer justicia a su obra. Puede afirmarse que ni siquiera la documentada monografía ${ }^{6}$ publicada por Lisa Germany en 1991, un año después de la muerte del arquitecto y seis de la exposición monográfica sobre el mismo organizada por la Universidad de Texas en Austin (1985), tuvo el impacto que hubiera sido deseable para un trabajo que ponía sobre la mesa tantas cuestiones acerca de la obra y el pensamiento de Harris, su fortuna histórica o sobre las complejas relaciones entre los núcleos de producción de la arquitectura californiana y los centros académicos, críticos y de difusión arquitectónica más influyentes de los Estados Unidos.

En este sentido, el conjunto de edificios celebrados internacionalmente como cimas de la arquitectura moderna del Sur de California cuenta sólo una parte de la historia. La complejidad de la realidad cultural y arquitectónica de la región durante la primera mitad del siglo xx parece poco accesible a la cultura arquitectónica europea, que ha asimilado como verdad tan sólo unos cuantos relatos incompletos. No obstante, incluso en los Estados Unidos, no son pocos los ambientes académicos que ofrecen todavía resistencia a abandonar clichés para cuestionar la oficialidad de muchas de las fuentes y de las historias que contribuyeron a crear el mito de la arquitectura moderna californiana.

La historiografía californiana ha sido una maquinaria de producir mitos que, sobre todo en Europa, apenas han sido cuestionados. Como resultado, ha habido un balance de cuantiosas víctimas: obras, trayectorias profesionales, ideas y personalidades sacrificadas al olvido en aras de la promoción de otros ${ }^{7}$. Afortunadamente, desde hace poco más de una década (aproximadamente desde finales de los años go), a pesar de la cantidad de textos que siguen redundando en los mismos clichés, nuevas investigaciones están forzando a las historias oficiales de la arquitectura californiana a dar paso a nuevos descubrimientos que arrojan luz sobre tantos episodios silenciados. Se comienza por fin a excavar en una memoria mitologizada para descubrir nuevas capas de información que, conforme proporcionan una pieza del puzle, obligan a su reescritura. Aún así, como ha afirmado recientemente Alan Hess, la totalidad de la historia apenas acaba de comenzar a ser contada 8 . 
Podrían citarse varias de esas historias todavía pendientes de ser desmitificadas: el mismo Case Study House Program promovido por John Entenza desde la plataforma de Arts \& Architecture, un episodio identificado aún como la principal contribución de California a la historia de la arquitectura moderna; el modo en que John Entenza asumió el control de la revista (un episodio sobre el que se pretende discutir ampliamente en esta tesis doctoral); el hecho de que la revista California Arts \& Architecture no fue realmente moderna hasta la llegada de Entenza (algo radicalmente falso, como el hecho de que Entenza asumiera la publicación en bancarrota); la explicación de que Harris no fuera seleccionado para participar en el CSH Program por su afinidad con las tradiciones constructivas locales vinculadas a la madera; la idea de que las viviendas CSH eran principalmente viviendas de acero, sufragadas por la industria local y destinadas a ser prototipos para grandes desarrollos urbanos (de hecho, excepto las viviendas de Quincy Jones, ninguna CSH tuvo realmente vocación de prototipo para producción en masa e, incluso, muchas de ellas eran denominadas así una vez construidas si le habían interesado a Entenza); el enfrentamiento de Richard Neutra con Rudolph Schindler por el proyecto de la Lovell Health House y su consiguiente ruptura (el mito fue iniciado por Esther McCoy); la excesiva importancia de Pierre Koenig (la fotografía de Shulman y el propio Entenza crearon ese mito); la leyenda de que los arquitectos excluidos por Entenza del CSH Program apenas alcanzaran celebridad (el caso de Gordon Drake prueba todo lo contrario); la importancia real de la obra de Raphael Soriano (autor al que Shulman encumbró tras haber realizado su propia casa; el mito de Ellwood como creador (que ya han comenzado a desmontar autores como Neil Jackson o Meredith Clausen, reparando en que sin arquitectos como Jerry Lomax o James Tyler, sus más allegados colaboradores, Ellwood jamás habría podido desarrollar su obra); la relativa importancia de la Escuela de Arquitectura de la USC (cuando esta institución abrazó la modernidad desde finales de los años 30 gracias a Neutra y sus discípulos Soriano, Harris y Ain ); la autoría compartida aún sin esclarecer de muchos de los proyectos de la oficina Eames; la inexistencia de una tradición de viviendas sociales en California (cuando, entre los años de la Gran Depresión y el inicio de la Guerra Fría, hubo movimientos y realizaciones extraordinarias); la absoluta falta de reconocimiento al papel fundamental que jugó Pauline Schindler en la gestación de la arquitectura moderna californiana; la infalibilidad de Esther McCoy como pionera en el establecimiento de una historia de la arquitectura de la región (cuando no le importó ocultar información para favorecer a sus amigos); y otras cuestiones que serán tratadas en esta tesis como el trasfondo cultural en el que se debe entender el alcance y significado de la obra de estos dos arquitectos que sirven de guía por estos fragmentos decisivos de la historia moderna de California. 
Esta tesis consta de unas notas introductorias, un bloque central y un apunte historiográfico. Por su parte, el núcleo de la misma está conformado por dos secciones o partes, integradas cada una por varios capítulos y denominadas, respectivamente, Discussions in a Garden y Discípulos y Maestros.

Discussions in a Garden adopta el mismo título que Pauline y Rudolph Schindler dieron a algunos de los eventos organizados en su vivienda de West Hollywood. Él, como arquitecto, y ella, como infatigable promotora de la modernidad, son dos figuras utilizadas como hilo conductor de los relatos que, en esta primera parte, tratan de explicar la singularidad del fermento creativo del Sur de California. Tomando como centro de gravedad la célula germinal de Kings Road, Discussions in a Garden, aborda la intersección de trayectorias profesionales y de círculos de amistades que forjaron el contexto arquitectónico y cultural de Los Ángeles. Personajes como los propios Schindler, el matrimonio Neutra, Frank Lloyd Wright, Galka Scheyer, Edward Weston, Willard Morgan, Jake Zeitlin, Merle Armitage, Harriet y Samuel Freeman y, por supuesto, Philip y Leah Lovell como prototipos de clientes progresistas, ejemplifican el esfuerzo colectivo de una comunidad de modernos y militantes que entendieron la frontera del Oeste como oportunidad para construir un futuro diferente de los planes que los intereses económicos y el conservadurismo político de las elites dominantes tenían en mente para la región. Convencidos del poder transformativo del diseño, todos ellos se vieron a sí mismos como agentes de cambio y, aunque no lograron hacer realidad su utopía moderna, sus encuentros festivos, discusiones intelectuales y trabajo colaborativo dieron como resultado obras memorables en diversos campos. A través de un recorrido por diferentes episodios arquitectónicos, artísticos, políticos, sociales o literarios, desde Chicago a Los Ángeles, desde Olive Hill a Kings Road, saltando a Carmel y de nuevo a Los Ángeles, los diferentes capítulos de esta primera sección exploran la construcción de afectos y relaciones personales sin los cuales difícilmente puede entenderse la segunda parte de la tesis.

La segunda sección, Discípulos y Maestros, aborda la línea de influencias sucesivas Neutra, Harris, Drake. Sus tres capítulos se centran respectivamente en los años de la trayectoria de Neutra en los que Harris colaboraba en su estudio (1928-1933); en la etapa californiana de éste (1933-1951); y, por último, en la breve carrera de Gordon Drake (1946-1952). En esta segunda parte se ha prestado una especial atención a las obras en las que estos tres arquitectos coincidieron en calidad de maestros y discípulos: la casa Lovell (192729) en el caso de Neutra-Harris y la Weston Havens House (1940-41) para el caso de Harris-Drake. Otro de los episodios formativos abordados en esta sección es la casa que Harwell Hamilton Harris construyó para John Entenza en Santa Mónica en 1937 y que supuso el inicio de una malograda relación profesional gracias a la cual, sin embargo, el ambicioso editor de Arts \& Architecture consiguió acceder a la revista que le valió su fama. Dado el talento literario de Harris y la calidad de sus artículos, sus escritos son usados recurrentemente en ambas secciones de la tesis para describir acontecimientos en los que el arquitecto participó como actor o de los que fue testigo. De este modo, en ocasiones, una misma historia es abordada en diversos capítulos atendiendo a diferentes puntos de vista, facilitando así varias lecturas de los mismos hechos.

Las notas introductorias tratan algunos fenómenos o episodios singulares en la conformación de la identidad geográfica, sociocultural y urbana del Sur 
de California. Cada una de estas cuatro notas correspondería, aproximadamente, con cada una de las cuatro décadas entre 1910 y 1950 es decir, entre los ciclos económicos del boom inmobiliario de los años 20, la Gran Depresión y los primeros años de posguerra. Las dos primeras notas se acercan al impacto en el medio físico y en el imaginario de la región de las campañas de promoción del Sur de California como paraíso mediterráneo, así como a la rápida instrumentalización por parte del mercado inmobiliario de la filosofía del Arts \& Crafts norteamericano para generar una tipología de colonización territorial, el bungalow -en el que puede identificarse un precedente de la seriación y producción industrial de viviendas a la que aspirarían los arquitectos modernos de posguerra. La tercera nota repasa brevemente algunos hitos de los programas federales de vivienda pública en Los Ángeles durante la época de la Gran Depresión y primeros años de posguerra. La última de ellas, dedicada al cooperativismo de los años 40, plantea los ejemplos de escala paisajística de algunos de los mejores complejos de este modelo asociativo de viviendas construidas a través de una fórmula mixta entre la promoción privada y el esfuerzo comunitario. Todos estos casos aportan un contexto en el que entender la encrucijada social a la que se enfrentaba la modernidad californiana a mediados del siglo pasado y que, con independencia del éxito mediático del programa Case Study Houses, podrían en evidencia el limitado alcance real de la iniciativa de John Entenza.

Precisamente, el apunte historiográfico final tiene como protagonistas a John Entenza y Esther McCoy, los dos principales creadores de la arquitectura-ficción del Sur de California. Mientras que McCoy, la primera historiadora de la modernidad local, se ha convertido en una autoridad incuestionable, John Entenza continúa siendo aún un personaje opaco del que apenas se conoce nada fuera de la oficialidad de la biografía que él mismo se construyó. Resulta llamativo pues que, salvo muy contadas excepciones ${ }^{9}$, ambas figuras, vinculadas por su amistad y clientelismo, no hayan sido tratadas más allá de la mera hagiografía. De hecho, si aún está pendiente un estudio monográfico sobre el editor de Arts \& Architecture, en el caso de la historiadora, en los dos trabajos publicados recientemente por Susan Morgan ${ }^{10}-2011$ y 2012- se echa en falta, por ejemplo, un análisis crítico de los procedimientos metodológicos y de las condiciones económicas, personales, etc., bajo las que se produjeron tanto los encargos como la investigación de los libros de Esther McCoy, una cuestión sobre la que se tratará en este último apartado. 
En primer lugar, se pretende establecer una genealogía de arquitectos californianos que partiendo de Richard Neutra llegaría hasta Gordon Drake. Este trasvase de influencias vendría determinado por la mediación de Harwell Hamilton Harris y su reinterpretación tanto de los principios modernos aprendidos de Neutra como de la herencia arquitectónica de los pioneros de la región. Dado que Harris y Drake son inseparables de su identidad californiana, un estudio de los principales episodios formativos de ambos autores permitiría poner de manifiesto la coexistencia de diversas tradiciones modernas con las que, en muchos casos, aún está poco familiarizada la cultura europea.

A su vez, se trata también de plantear lecturas transversales a dicha genealogía que permitan entender mejor la singularidad de la proteica modernidad del Sur de California, en concreto durante la primera mitad del siglo pasado, la etapa que a todas luces se argumenta como su momento de mayor intensidad. Por tanto, es necesario abordar la intersección de trayectorias de otros arquitectos, diseñadores, artistas, fotógrafos, mecenas, editores, historiadores y críticos cuyos vínculos forjaron las particularidades de un medio creativo sin el cual no se explican ni la arquitectura de Harwell Hamilton Harris ni la obra de Gordon Drake.

También, a partir de esas historias cruzadas se pretende poner en valor el papel de algunos personajes femeninos tratados hasta ahora de forma marginal, reivindicando con especial interés el peso específico de Pauline Schindler, pero también la labor de otras mujeres como Aline Barnsdall, Leah Lovell, Galka Scheyer o Jean Murrray Bangs propiciando situaciones decisivas para la historia de la arquitectura moderna californiana.

Por otro lado, reparando en la celebridad alcanzada en vida por Neutra, Harris y Drake así como las dificultades posteriores para la recepción de estos dos últimos arquitectos fuera de California, su caso permite discutir lo aleatorio de determinados mecanismos de fijación de la memoria. En una época en la que los medios impresos lo eran todo y el impacto de la fotografía de arquitectura el principal recurso para transmitir los valores de la obra construida, se trataría de sondear aquellas políticas editoriales que, junto con el papel de los historiadores, resultaron determinantes en la proyección de unas ideas, arquitecturas y autores frente a otros. En este sentido, una aproximación crítica a la historiografía californiana intentando examinar la exactitud de algunos relatos de John Entenza y de Esther McCoy constituye otro de los objetivos de esta tesis.

Finalmente, otro de los objetivos ha sido la búsqueda, revisión y discusión de la práctica totalidad de las fuentes bibliográficas disponibles sobre Harwell Hamilton Harris y Gordon Drake. El apartado de bibliografía específica disponible al final de esta tesis facilita un listado actualizado del conjunto de publicaciones periódicas, artículos, capítulos de libros, documentos históricos y trabajos recientes sobre arquitectura californiana donde han aparecido menciones a la obra de estos dos arquitectos ${ }^{11}$.

Esta tesis no tiene un apartado específico de conclusiones, entendiendo que éstas se hallan implícitas tanto en la exposición de objetivos, como en la estructura del índice y en el desarrollo del texto. 
METODOLOGÍA Y FUENTES DE LA INVESTIGACIÓN >> 
Se han efectuado un total de siete viajes a California con estancias de entre dos y ocho semanas cada uno. La primera toma de contacto con la arquitectura californiana tuvo lugar en marzo y diciembre de $2005 \mathrm{y}$, posteriormente, en julio de 2006. Las visitas guiadas por arquitectos locales, el contacto personal con algunos de los historiadores de la región y el descubrimiento de la extensión, diversidad y riqueza del periodo moderno californiano ratificaron la decisión de profundizar en el hecho distintivo de sus orígenes, así como en las fuentes de sus relatos. Propiamente, el inicio de la investigación tuvo lugar con la preparación de un cuarto viaje en marzo de 2008, a los que siguieron otros en diciembre de 2009, julio-agosto de 2010 y julio-agosto de 2011, estos dos últimos con estancias también en Texas.

Las dificultades de acceso a buena parte de las fuentes y la necesidad de programar con suficiente antelación los viajes para concentrar las citas en las instituciones que se detallarán a continuación exigieron unos plazos dilatados para llevar a cabo esta investigación. Paulatinamente, el proceso de recopilación de información se fue convirtiendo en una experiencia personal conforme se entablaban relaciones y lazos de amistad con arquitectos, historiadores, conservadores y docentes en Los Ángeles. Todos ellos han mostrado un apoyo total a este trabajo, compartiendo generosamente sus conocimientos, su tiempo y sus contactos profesionales. La familiaridad progresiva con autores, obras, fuentes, debates locales y el placer de nuevos hallazgos en cada viaje a California fue ampliando y complejizando temas de estudio. Por esta razón se decidió finalmente no entrar en un aspecto monográfico o un único episodio arquitectónico concreto sino, en lugar de ello, optar por un enfoque diferente para analizar determinados aspectos de un periodo cronológico que, como se ha justificado en el apartado anterior, se aborda a través de lecturas transversales, círculos de influencias e historias próximas a la arquitectura.

A lo largo de los últimos cinco años, los principales trabajos de campo en California han consistido en: la elaboración de una bibliografía específica a partir de hemerotecas especializadas; la investigación en archivos locales acerca de la obra de los arquitectos estudiados, en concreto examinando planos de proyecto, fotografías, manuscritos, correspondencia y documentos personales; contacto permanente con los responsables de las instituciones donde se localizan dichos materiales; discusión con arquitectos, historiadores y expertos californianos en diferentes temas relacionados con esta tesis; visitas de arquitectura; reportajes fotográficos y levantamiento de planos.

La investigación ha tenido como prioridad los archivos de las siguientes instituciones: Universidad de California en Santa Bárbara para el caso de Pauline y Rudolph Schindler, así como de Edward Weston; Universidad de California en Los Ángeles donde se custodia el archivo de proyectos de Richard Neutra; Universidad de California en Berkeley para Gordon Drake; y Universidad de Texas en Austin para Harwell Hamilton Harris.

Otro pilar de la investigación han sido las hemerotecas. En el caso de periódicos locales, como Los Angeles Times, o de las revistas de arquitectura norteamericanas de la época hay que señalar la dificultad de su acceso desde España. Puede citarse el ejemplo de algunos de los artículos publicados por Harwell Hamilton Harris en Architectural Record y que sólo aparecieron en su edición de la Costa Oeste, la cual no se recibía en Europa, adonde únicamente llegaba la versión editada en Nueva York. Por otra parte, las bibliotecas de los Colegios de Arquitectos tampoco disponen de todos los 
números de las revistas norteamericanas de las décadas de 1920, 1930 y 1940. Faltan de hecho los años de la Guerra Civil y primera posguerra, tanto en Madrid como en Barcelona. Ni siquiera en California es fácil encontrar la edición completa de California Arts \& Architecture, sólo existen tiradas enteras en las bibliotecas del Getty Reserach Institute, Huntington Library, UCLA, o Los Angeles Public Library, donde están custodias en sus Special Collections. Por otra parte, revistas populares como House \& Beautiful, House \& Home, Sunset Magazine, etc., no están disponibles en estas instituciones -exceptuando algunas en Los Angeles Public Library- por lo que su consulta ha requerido el desplazamiento a hemerotecas especializadas como la de la Santa Monica Public Library.

Han resultado igualmente determinantes para esta tesis las entrevistas con diversos clientes originales, herederos o propietarios actuales de algunas de las viviendas estudiadas. Pueden citarse los casos de Harris (Mike Deasy, Kirk Nozaki); Richard Neutra (Dion Neutra, Betty Topper); Schindler (Adolph Tischler); Craig Ellwood (Don Kuby), etc. Otra fuente de información de gran valor han sido fotógrafos de arquitectura como John Ellis, que ha completado un reportaje sobre casi dos docenas de viviendas de Harris en Los Ángeles.

Finalmente, entre los testimonios de primera mano más valiosos, figuran las entrevistas con Julius Shulman mantenidas en su casa de Hollywood en marzo de 2008.

Como se ha indicado previamente, una parte fundamental de la investigación ha consistido en la confección de un listado bibliográfico actualizado sobre Harwell Hamilton Harris y Gordon Drake. En ambos casos, se incluyen relaciones de capítulos de libros, artículos, fuentes online y, sobre todo, publicaciones periódicas de la época. En ambos casos, el considerable número de revistas históricas localizadas que incluían reportajes sobre Harris o Drake ponen de manifiesto el vacío de información al respecto detectado en listados temáticos como el Avery Index to Architecture Periodicals. Gran parte de este trabajo de identificación y discusión de fuentes bibliográficas específicas se ha realizado en estrecha colaboración con el historiador John Crosse. A través del mismo se ha llevado a cabo una labor de compilación por parte del autor de un fondo documental propio consistente en publicaciones de la época, revistas originales y catálogos de exposiciones adquiridos en librerías especializadas o por medio de coleccionistas y saldos de bibliotecas norteamericanas.

Para una mayor facilidad en la lectura del texto de esta tesis, se ha considerado oportuno traducir directamente al castellano todas las citas de los documentos de archivo, correspondencia, artículos de revistas y libros escritos originalmente en lengua inglesa. Sólo en aquellos casos en los que las sutilezas del lenguaje podrían revestir algún tipo de interés especial se ha optado por reproducir el texto original en la nota que acompaña a su traducción en castellano. Todas las traducciones han sido realizadas por el autor.

Aunque por su interés o porque incluso forman parte de la propia discusión, se ha preferido reproducir imágenes originales, en ocasiones se incluyen algunas fotografías recientes de las obras. En el caso de las imágenes actuales, salvo que se especifique lo contrario, proceden de los reportajes fotográficos realizados por el autor, así como los levantamientos de planos de algunas viviendas para las que se han realizado levantamientos de planos a partir de documentación de archivo y la toma de datos in situ. 


\section{Terminología, notas y observaciones}

A continuación se realizan algunas precisiones con respecto los términos empleados en esta tesis doctoral.

En general se utiliza el término "arquitecto" para los autores estudiados en esta tesis doctoral. No obstante, en Norteamérica esta denominación implica un reconocimiento oficial para poder realizar cualquier proyecto técnico en el que exista estructura nueva. Dicha condición se obtiene tras la aprobación de un examen específico para cada estado de la Unión. Es decir, si las Universidades otorgan el título son las Administraciones quienes conceden la capacidad para ejercer legamente sin necesidad de la firma de terceros. Estrictamente, ni Harwell Hamilton Harris ni Gordon Drake llegaron nunca a ejercer como arquitectos en California ${ }^{12}$. Harris obtuvo su licencia en 1952, una vez que ya había dejado Los Ángeles y 18 años después de haber construido su primera casa y Drake murió pocas semanas antes de presentarse a los exámenes. Aunque en California sí podían firmar residencias privadas, su estatus de hecho era el de "designers". En cualquier caso se ha preferido la denominación "arquitecto" atendiendo a una dimensión disciplinar antes que a cuestiones legales.

Respecto a las publicaciones de arquitectura, es necesario precisar el empleo en esta tesis de las palabras inglesas "editor" y "publisher". El primero haría referencia al director de una revista, el segundo a su propietario. El término "editor" se ha traducido pues en castellano tanto como "editor" o "director ", ambos en el sentido de responsabilidad intelectual en la selección de contenidos.

Aunque el principal ámbito geográfico estudiado en esta tesis doctoral es el Sur de California y, en concreto, la ciudad de Los Ángeles, se tratan también obras o episodios históricos en otras localizaciones de California. Por ello, aunque se utiliza la palabra "California" o el término "californiano" para designar todo el territorio del estado, a veces, para abreviar y siempre que el contexto no induzca a confusión, dichos términos se emplean también para hacer referencia al Sur de California. Precisamente, para identificar un área con personalidad propia que abarca desde Santa Bárbara a San Diego, se ha preferido dejar en mayúsculas "Sur de California" como traducción literal de Southern California. Igualmente se nombran como "Este" y "Oeste", respectivamente, las Costas Este y Oeste, también por influencia del inglés, idioma en el que ambos puntos cardinales designan regiones del país. Asimismo, con carácter general, se usan los sustantivos "América" y "Norteamérica", así como los calificativos "americano" o "norteamericano" para "Estados Unidos" y "estadounidense".

Respecto a las abreviaturas, como norma no se utilizan en este documento, excepto cuando evitan una repetición de nombres propios demasiado largos, en los pies de foto o cuando resultan sobradamente conocidos como: MOCA por Museum of Contemporay Art of Los Angeles ó MoMA por Museum of Modern Art. También se emplea a veces CSH por Case Study House Program; MHA por Mutual Housing Association; AIA por American Institute of Architects; USC por University of Southern California; UCLA por University of California Los Angeles, etc. En cualquier caso, todas ellas serán convenientemente introducidas en cada capítulo.

En lo concerniente a la denominación de las localidades con topónimo español en California, como Santa Mónica, Santa Bárbara, Los Ángeles, etc., 
se nombran en castellano, excepto para las citas textuales en inglés o en la bibliografía ya que, en ese caso, la ciudad donde ha aparecido publicado el libro en cuestión se indica escrita en su idioma original.

Por otra parte, en cuanto a los nombres de autores, éstos siempre se nombran por primera vez con nombre y apellido. Después, por economía lingüística o para huir de la repetición en el texto a veces sólo se utiliza el apellido. De manera excepcional, algunos personajes, como Pauline Schindler, aparecen mencionados simplemente por el nombre de pila. En este caso se trataría de evitar la confusión con Rudolph Schinlder a quien se conoce simplemente como Schindler. En los textos o correspondencia firmados por la autora antes de la fecha de su matrimonio en 1919 se menciona a Pauline Schindler por su apellido de soltera, Gibling.

Respecto al uso de la negrita se emplea únicamente para títulos de subcapítulo o para resaltar algún concepto en el texto. El uso de la cursiva, siempre que no se trate de citas textuales entrecomilladas, se restringe a títulos de obras o publicaciones, ya sean textos, libros, exposiciones, etc. La cursiva también puede ser empleada como énfasis del autor o como llamada sobre el doble sentido de un término; en este caso, el contexto no debe ofrecer dudas de que se trata de un énfasis propio.

El criterio adoptado para las notas ha sido iniciar la numeración de las mismas en cada una de las partes o secciones de esta tesis doctoral. Las notas se colocan al final de cada sección y la referencia a las fuentes bibliográficas se realiza independientemente en cada una de ellas, es decir, la abreviatura "Op. cit." hace referencia siempre a una obra citada exclusivamente dentro de la misma sección.

En el apartado de bibliografía, el orden de las obras de un mismo autor es alfabético en el caso de los libros. No así para los artículos de revista que es cronológico. Este criterio obedece al hecho de que se trata en su mayoría de fuentes históricas y la fecha de su publicación es un dato relevante que debe ser resaltado.

Por último, en cuanto a los créditos fotográficos, se aporta el nombre del autor de la imagen en cada pie de foto, así como la institución o archivo propietaria de la misma. En el caso de no mencionarse se trata del Getty Research Institute, depositario del archivo de Julius Shulman. 


\section{ARHIVO DE H. H. HARRIS}

Conservado en el Alexander Architectural Archive. University of Texas Libraries. University of Texas at Austin. Austin, Texas.

La colección alberga casi 10.000 dibujos y planos correspondientes a 212 proyectos. Los materiales datan de 1906 a 1990 y son relativos tanto a la vida y trayectoria profesional tanto del arquitecto como de su mujer Jean Murray Bangs (Harris). Entre los documentos custodiados figuran: información bibliográfica, premios y reconocimientos, datos financieros de la oficina, material para exposiciones, escritos, conferencias, notas para la preparación de clases, etc. Los archivos contienen un manuscrito con textos inéditos reunidos en un diario titulado "Portrait of an Architect". Entre los materiales visuales hay más de 3.600 fotografías y 1.200 diapositivas, negativos y una película en $16 \mathrm{~mm}$. Entre los fotógrafos sobre los que existe algún tipo de material figuran Man Ray, Fred Dapprich, Julius Shulman, y André Kertész. Entre los registros sonoros figuran las cintas de una entrevista concedida en 1979 y algunas conferencias.

\section{ARHIVO DE GORDON DRAKE}

Estrictamente no existe un archivo del arquitecto, sino la colección de documentos y materiales de proyecto que quedaron en posesión de su socio Douglas Baylis tras la muerte de Gordon Drake. Éstos fueron consultados en la Universidad de California en Berkeley, concretamente en la Douglas and Maggie Baylis Collection 1938-1998 (periodo 1943-1971) custodiada en los Environmental Design Archives del College of Environmental Design.

Entre los materiales de la oficina de Douglas Baylis que su viuda cedió a la Universidad de California se encuentra la documentación que sirvió de base para la edición del catálogo California Houses of Gordon Drake, realizado a partir de los planos, textos, imágenes, dibujos, etc. que el matrimonio conservaba de su amigo.

Las fotografías tomadas por Julius Shulman de su obra pueden consultarse en las Special Collections del Getty Research Institute mientras que algunos de los datos relativos a estos encargos pudieron ser consultados en el archivo personal del fotógrafo durante su visita en marzo de 2008.

Otros materiales relativos a Drake están en posesión de particulares, como la colección de imágenes de Betsy Roeth, prometida del arquitecto en el momento de su muerte. Después de varios intentos de localizar a su familia, recientemente, en el otoño de 2011, se logró contactar con el sobrino nieto de Gordon Drake, Ilamado también Gordon Drake, quien ha facilitado el acceso a la información sobre el arquitecto que guardaban sus herederos y que, hasta la fecha, no había sido consultada ni publicada. Entre esta documentación, aún sin clasificar, se han detectado los planos de la vivienda que Drake construyó para su hermano en Coronado, San Diego, así como el proyecto de la Malibu House, dos descubrimientos relevantes.

Se aporta a continuación una relación de las principales obras construidas por Gordon Drake, facilitando las direcciones de las dos casas que todavía se mantienen en un aceptable estado de conservación: 
ÁREA DE LOS ÁNGELES

Drake House, 1946, su propia casa en Beverly Glen.

Presley House, 1946 (2114 Fargo Street. Silver Lake, Los Angeles)

Rucker-Spillman House, 1947

Tom Damman House, 1948

Berns House, 1948-1951 (31654 Broad Beach Rd. Trancas Beach, Malibu)

CARMEL

Studio Office, 1949

Mesa House, 1949

Vacation House, 1949

SAN FRANCISCO

Scriber House (Unit House), Hayward, cerca de Oakland, 1950-51

Baylis Studio, 1952-1956

\section{OTROS ARCHIVOSY BIBLIOTECAS}

Archivo de Schindler (Architecture \& Design Collection). University Art Museum de la Universidad de California en Santa Bárbara

Richard and Dione Neutra Papers. Consultable en las Special Collections de la Biblioteca de la Universidad de California en Los Ángeles

Escuela de Arquitectura y Archivos de la Universidad del Sur de California

Art Center College of Design de Pasadena

Los Angeles Public Library

San Diego Public Library

Santa Monica Publica Library

Huntington Library, San Marino

Getty Research Institute

\section{Principales fuentes bibliográficas consultadas:}

TRABAJOS MONOGRÁFICOS SOBRE HARRIS:

\section{McCOY:The Second Generation}

El primer estudio comprehensivo sobre la obra de Harris fue el relato de primera mano realizado por su amiga Esther McCoy, con quien el arquitecto mantuvo una intensa correspondencia a finales de los años 70. The Second Generation (Gibbs Smith, Salt Lake City, UT, 1984) es un texto de referencia para la historiografía californiana. El libro está precedido por una introducción de Cesar Pelli sobre el ambiente cultural de la ciudad de Los Angeles que acogió a esta segunda generación de arquitectos californianos -por entonces bastante olvidados. Se compone de cuatro capítulos dedicados, respectivamente, a J. R. Davison, Harwell Hamilton Harris, Gregory Ain y Raphael Soriano. A diferencia de otros libros de McCoy The Second Generation incluye también una bibliografía de referencia, así como una serie de anexos con relaciones de obras y publicaciones en artículos de revista sobre las mismas que, aunque ciertamente incompleto, sirvieron como punto de partida para posteriores estudios sobre cada uno de estos autores -los cuales, llamativamente, no comenzaron a publicarse hasta varios años más tarde. En el caso concreto de Harris, son importantes las omisiones de proyectos significativos de su etapa californiana, aunque se recogen todos aquellos que, de un modo u otro, marcaron su evolución como arquitecto. Seguramente, por limitaciones de espacio en este trabajo de vocación generalista el análisis de las obras resulta a veces superficial. A pesar de ello, el libro es una valiosa 
fuente de información que aporta importantes datos para la contextualización de los autores estudiados. En este sentido, puede resultar también de interés la serie de entrevistas realizadas por Joseph Giovanninni a la historiadora en su casa de Santa Mónica entre junio y noviembre de 1987, editadas por Susan Morgan en julio de 2009 y registradas como Oral History Interview with Esther McCoy, 1987 June 7-Nov. 14, tal como se especifica en la bibliografía final, en el apartado de entrevistas.

\section{GERMANY: Harwell Hamilton Harris}

El principal trabajo publicado hasta la fecha sobre el arquitecto es la monografía de Lisa Germany ${ }^{13}$, escrita en 1991 y reeditada en 2000 [edición consultada GERMANY, Lisa: Harwell Hamilton Harris. (Prólogo de Kenneth Frampton e Introducción de Bruno Zevi). Berkeley, CA: University of California Press, 2000)]. Se trata de la única monografía existente sobre Harris y, como tal, el documento más importante publicado sobre el arquitecto hasta el momento. El libro sitúa, de una vez por todas, a Harris en el centro de la historia de la arquitectura moderna en los Estados Unidos, poniendo de manifiesto su relevancia en el contexto americano a pesar del relativo olvido en el que ha caído el arquitecto en la actualidad. El texto, exhaustivamente documentado, especialmente en lo que se refiere a datos biográficos de Harris y de su mujer, Jean Murray Bangs, es imprescindible para conocer la evolución del personaje. Otra aportación de Germany es su información de primera mano, obtenida a través de entrevistas y correspondencia con $\mathrm{Ha}$ rris poco antes de la muerte del arquitecto en 1990. Se trata además de un libro muy bien escrito que despierta el interés del lector desde la primera página. No obstante, a pesar de la extensa y ordenada relación de notas y fuentes documentales aportadas, se han detectado algunos errores en las citas bibliográficas y en la cronología de algunos hechos relevantes para esta investigación, como el polémico episodio de la ascensión de John Entenza a la dirección de la revista California Arts \& Architecture, hecho que puede comprobarse en los propios créditos de la misma, examinando los números de la revista publicados a principios de los años cuarenta. Se echan también en falta análisis en profundidad de los proyectos de Harris, la posibilidad de haber indagado más en el entramado de influencias y en el trasvase de temas entre los arquitectos de su generación y, sobre todo, imágenes actuales de la obras, un aspecto éste último que viene a solventar esta nueva monografía en fase de edición que se refiere a continuación:

3. WELLS: The California Architecture of Harwell Hamilton Harris (inédito) WELLS, Ted y ELLIS, John (fotógrafo): Romatic Modern: The California Architecture of Harwell Hamilton Harris (con contribuciones de Julius Shulman. Los Angeles: Guardian Stewardship y Marquand Books, s. d.). Es de inminente publicación un nuevo estudio sobre Harris, en este caso sobre 20 de sus casas californianas, escrito por el arquitecto Ted Wells y a cuyo trabajo se ha tenido acceso durante esta investigación, pudiendo leer y discutir con el autor el texto en sus fases finales de redacción. El texto del libro supone una revisión crítica de diversos aspectos de la trayectoria de Harris, algunos escasamente tratados por Germany, tanto en lo que se refiere a la influencia ejercida por su mujer Jean Murray Bang como a cuestiones espaciales y de detalles de ejecución de las obras. Las espléndidas fotografías de John Ellis, a todo color, captan sin falsear en modo alguno el estado actual de las viviendas, tanto aquellas que han sido objeto de una cuidadosa restauración, como las que aún siguen en manos de sus primeros propietarios y que como tal se muestran. Toda una emocionante visión que se echaba en falta en el libro de Lisa Germany. 
4. Oral History Program (UCLA): The Organic View of Design

Diversos datos biográicos, así como una copiosa información sobre la producción arquitectónica y teórica del arquitecto pueden obtenerse de la transcripción de la entrevista realizada a Harris por Judy Stonefield en agosto de 1985 y titulada The Organic View of Design, realizada en el marco del Oral History Program de la Universidad de California en Los Ángeles (UCLA), tal como se refiere en la bibliografía final. El archivo, recientemente disponible online, puede consultarse en http://catalog.library.ucla.edu

TRABAJOS MONOGRÁFICOS SOBRE GORDON DRAKE:

El único libro monográfico sobre el arquitecto es el catálogo que, en 1956 y a modo de homenaje póstumo editaron sus amigos Julius Shulman y Douglas Baylis con la escritora inglesa Joan Parry a partir de la información de que disponían sobre el arquitecto, principalmente las fotografías de Shulman y el redibujado de sus planos (BAYLIS, Douglas y PARRY, Joan: California Houses of Gordon Drake. New York: Reinhold Pub., 1956). La fecha de aparición, 1956, se debió a que sus autores esperaron hasta que la última obra proyectada por Drake, la vivienda estudio de los Baylis en Telegraph Hill (San Francisco) estuviera completada para que Shulman pudiera fotografiarla. Agotado desde los años 50, el librero de San Francisco William Stout y propietario de la casa editorial homónima especializada en arquitectura y libros raros acaba de reimprimir la monografía ${ }^{14}$ en el verano de 2011. El libro está introducido por un texto crítico de Pierluigi Serraino, y un prólogo de Glenn Murcutt. Durante la preparación del mismo se estuvo en contacto tanto con William Stout como con Pierluigi Serraino, teniendo acceso al borrador de su texto a finales de 2010. Dicho texto supone la única publicación de un ensayo crítico sobre Drake aparecido desde el artículo ${ }^{15}$ del historiador británico Neil Jackson en la revista londinense The Architectural Review en marzo de 1996.

\section{SOBRE ESTHER MCCOY:}

Los seis libros publicados por la historiadora, sobre los que se tratará con detalle en el último apartado de este documento son (ordenados por orden de aparición):

Esther McCOY: Five California Architects. New York: Reinhold, 1960.

Esther McCOY: Richard Neutra. New York: George Braziller, 1960.

Esther McCOY: Case Study Houses 1945-62. New York: Reinhold, 1962.

Esther McCOY: Craig Ellwood. Venezia: Alfieri, 1968 (New York: Walker Publishing Co., 1968).

Esther McCOY: Vienna to Los Angeles. Two Journeys. Letters Between R. M. Schindler y Richard Neutra. Prólogo de H. H. Harris. Santa Monica, CA: Arts + Architecture Press, 1979.

Esther McCOY: The Second Generation. Salt Lake City, UT: Gibbs Smith Publisher, 1984 .

Recientemente, finales de 2011 y principios de 2012, la historiadora Susan Morgan ha publicado dos trabajos sobre Esther McCoy. Se trata del catálogo de la exposición inaugurada en el MAK Center de Los Ángeles en septiembre de 2011 y de una recopilación de textos, respectivamente:

Susan MORGAN y Kimberli MEYER (ed.): Sympathetic Seeing: Esther McCoy and the Heart of American Modernist Architecture and Design. Los Angeles: MAK Center, 2011 (Catálogo de la exposición homónina); y Susan MORGAN (ed.): Piecing Together Los Angeles: An Esther McCoy Reader. Los Angeles, East Borneo, 2012. 
Ambos incluyen fragmentos o textos completos de McCoy. El primero de ellos está introducido por diversos apuntes biográficos que complementarían el ensayo publicado por Morgan en 2009 ("Being There: Esther McCoy the Accidental Architectural Historian". Archives of American Art Journal, primavera 2009, pp. 24-26). Morgan fue también responsable de la transcripción y edición de la entrevista de McCoy con Joseph Giovannini concedida poco antes de su muerte y propiedad de la Smithsonian Institution ${ }^{16}$. Igualmente, Morgan se ha ocupado de la organización de los documentos del archivo de McCoy en dicha institución. Dada la ingente información manejada por Morgan se echa en falta un posicionamiento crítico respecto a McCoy, a la que parece reacia a cuestionar bajo ningún supuesto, como se deduce de la correspondencia mantenida con ella y con el historiador John Crosse al respecto del apoyo incondicional que McCoy dio a la versión de John Entenza sobre su acceso a la revista Arts \& Architecture (una cuestión que se tratará más adelante en profundidad).

En paralelo, otra escritora e historiadora con la que también se han intercambiado opiniones ha sido Ann Scheid, quien ha abordado la tarea de clasificar y organizar los documentos de parte del archivo de Esther McCoy custodiados en los archivos de la Huntington Library, en San Marino, California.

Tras Esther McCoy, la siguiente generación de historiadores californianos, representada sobre todo por David Gebhard -el principal responsable de la supervivencia del archivo de Schindler ${ }^{17}$ - y Robert Winter, siguió su estela, citándola, como también hizo Reyner Banham, sin cuestionar la exactitud de sus escritos. Por supuesto, Kathryn Smith y Barbara Goldstein, como pupilas de McCoy, extendieron sus puntos de vista. Thomas Hines, sin embargo, ha demostrado ser un autor más crítico, como demuestra su voluntad por intentar esclarecer la verdad en torno al encargo Lovell, tanto en su monografía ${ }^{18}$ sobre Richard Neutra como en su más reciente y monumental historia de la arquitectura californiana Architecture of the Sun ${ }^{19}$.

\section{SOBRE PAULINE SCHINDLER:}

Pauline Gibling Schindler era una ávida escritora, especialmente de cartas. Seguramente, por el aprecio por su historia familiar y la elevada consideración que tenía hacia su círculo de amistades, Pauline conservó la correspondencia mantenida a lo largo de su vida. Gracias a ella es posible abordar la historia social y el ambiente de su casa de Kings Road. Su legado de casi 13.000 cartas permitiría además reconstruir detalladamente sus viajes, vínculos profesionales, proyectos editoriales y labor de promoción cultural de arquitectos y artistas, además de sus relaciones personales, tanto con Schindler como con John Cage, 20 años más joven que ella y de quien fue amante entre 1934 y 1935. También Dione Neutra dedicó numerosas cartas dirigidas a su familia a describir su experiencia en Kings Road. Una selección de las mismas fue publicada en 1986 en la compilación que ella misma realizó de su correspondencia personal ${ }^{20}$.

En el caso de Pauline este material se halla disperso. Se conservan numerosas cartas en el Archivo de Schindler en la Universidad de Santa Bárbara. Otras sin embargo están en posesión de Robert Sweeney quien, al parecer, trabaja en una biografía sobre Pauline Schindler. El arquitecto e historiador -ahora al frente de la sociedad de amigos de la Schindler House- conservaría más de 96 cajas de documentos, principalmente diarios y correspondencia. En buena parte son los materiales del archivo de Pauline Schindler que, como la propia Esther McCoy confesó en su entrevista con Jospeh Giovannini 
Kathryn Smith sacó de Kings Road bajo su amparo: "[...] después de la muerte de Pauline Schindler, Kathryn Smith me preguntó si yo podría ayudarle a sacar de la casa de Pauline algunos de sus documentos para guardarlos en lugar seguro y poder emplearlos en un libro sobre Pauline tan pronto como acabase el trabajo sobre la casa Barnsdall en el que estaba trabajando. Ella quería sobre todo mantenerlos alejados de Tom Hines, porque consideraba que quizás éste podría utilizarlos para favorecer a Neutra de algún modo [...] los documentos incluyen material sobre Wright, y también una novela inédita cuyo protagonista sería Schindler. Cualquier [escritor interesado en un] estudio de Schindler o de Wright debería saber de la existencia de este material ${ }^{\prime \prime 2}$.

Uno de los relatos más interesantes sobre la casa-estudio de Schinlder publicados hasta la fecha es el ensayo de Robert Sweeney Life at Kings Road: As It Was 1920-194022, que integra el catálogo homónimo de la exposición The Architecture of R. M. Schindler organizada por el Museum of Contemporary Art de Los Ángeles en 2001 y comisariada por Elizabeth A. T. Smith y Michael Darling. En su persuasivo ensayo, Sweeney se sirve de la figura de Pauline para ofrecer una aproximación distinta a este episodio fundacional de la historia de la arquitectura moderna en la ciudad de Los Ángeles.

El trabajo de Sweeney, complementando y contrastando la versión de los hechos ofrecida por Esther McCoy en Vienna To Los Angeles, así como la consulta de las cartas de Pauline conservadas en los archivos de la Universidad de Santa Bárbara y sus propios artículos (referidos en el apartado de bibliografía) han sido las principales fuentes para el capítulo de esta tesis dedicado a ella. La redacción del mismo se ha beneficiado de los consejos y la inestimable colaboración del historiador John Crosse quien, en la actualidad, prepara un libro sobre las relaciones entre los Schindler y la familia Weston.

Otras fuentes sobre Pauline Schindler han sido las entrevistas realizadas tanto a Harwell Hamilton Harris ${ }^{23}$ y como a Dione Neutra ${ }^{24}$ en el marco del Oral History Program de la University of California Los Angeles. También se han consultado las referencias de Thomas Hines a Pauline Schindler en sus citados estudios Richard Neutra and the Search for Modern Architecture y Architecture of the Sun: Los Angeles Modernism 1900-197025; así como las monografías sobre R. M. Schindler de David Gebhard y Judith Sheine publicadas, respectivamente, por Viking Press (Nueva York, 1971) y Phaidon (Londres, 2001).

REVISTAS DE AROUITECTURA CONSULTADAS

Vaciados de ediciones completas 1935-1953:

California Arts \& Architecture

Arts \& Architecture

Architectural Forum

Architectural Record

L'Architecture d'Aujourd'hui

Vaciados de ediciones completas 1945-1955:

AlA Journal

Architect \& Engineer

Architectural Review

Pencil Points / Progressive Architecture / Interiors

Sunset Magazine 
Vaciados parciales (investigación dirigida, artículos específicos o fuentes digitales): American Builder, Architectural Design, Casabella, Revista de Arquitectura (Buenos Aires), RIBA Architects' Journal, Better Homes \& Gardens, House Beautiful, House \& Garden, House \& Home, Harpers, Ladie's Home Journal, Los Angeles Times, Life Magazine, Time, The New Yorker.

Ordenados alfabéticamente, los principales arquitectos, autores y expertos consultados a través de entrevistas personales han sido:

Cory BUCKNER. Arquitecta. Especialista en Quincy Jones y autora de la monografía sobre el arquitecto publicada por Phaidon en 2002.

John CROSSE. Ingeniero retirado, historiador, coleccionista y bibliófilo residente en Playa del Rey, California. En la actualidad ultima un libro sobre las relaciones entre los Schindler y los Weston. Desde 2009 actualiza sus investigaciones en un blog denominado Southern California Architectural History (http://so-cal-arch-history.com/). Crosse ha sido una de las principales fuentes de esta investigación, compartiendo con el autor sus descubrimientos de archivo, guiando diversas búsquedas para esta tesis, discutiendo ideas, facilitando escaneados de materiales y abriendo el acceso a su extraordinaria biblioteca.

Michael FOLONIS. Arquitecto AIA. Restaurador de las viviendas Pumphrey y Entenza de Harwell Hamilton Harris en Santa Mónica. Ha proporcionado datos sobre el proceso de restauración de las mismas, así como fotografías y material gráfico para esta investigación.

Donald KUBLY. Antiguo Director del Art Center College de Pasadena, cliente y amigo de Craig Ellwood.

Barbara LAMPRECHT. Historiadora, especialista en Richard Neutra y autora de las monografías publicadas por Taschen.

Dion y Raymond NEUTRA. Arquitecto y médico respectivamente. Hijos de Richard Neutra.

Julius SHULMAN. Fotógrafo. Entrevistado en su casa estudio de Hollywood en marzo de 2008 , dos años antes de su muerte.

Ted WELLS. Arquitecto y divulgador, en la actualidad prepara la citada monografía de inmediata aparición sobre Harwell Hamilton Harris. Desde hace años, Wells ha sido el principal introductor y descubridor de las arquitecturas de la región.

Win DE WITT. Historiador y Conservador de Arquitectura del Getty Reseach Institute. 


\section{Notas y referencias bibliográficas}

1. Declaración de Harwell Hamilton Harris a Lisa Germany referida en Lisa GERMANY: Harwell Hamilton Harris. Berkeley, CA: University of California Press, 2000 (edición original Austin, TX: University of Texas Press, 1991), p. 179.

2. Harwell Hamilton HARRIS: The Organic View of Design. Entrevista con Judy Stonefield. Los Angeles: Oral History Program, University of California Los Angeles, 1985, p. 58.

3. Exceptuando algunos pocos trabajos como los realizados en Hawaii durante el tiempo que estuvo sirviendo en la marina estadounidense, y los proyectos no construidos como la Noble House in Ann Arbor, Michigan, y los diseños experimentales publicados en Woman's Home Companion o Sunset magazine, el resto de la obra de Drake gozó de total cobertura tanto dentro como fuera de los Estados Unidos.

4. Es revelador el número de críticos del Este como, por ejemplo, Beatriz Colomina que, en conversaciones con el autor, han confesado su poca familiaridad con la obra de Harris.

5. Frank GEHRY: Prólogo, en Julius SHULMAN, Frank GEHRY y Peter GOSSEL: Julius Shulman: Architecture and Its Photography. Köln, New York, Los Angeles: Taschen, 1998, p.10.

6. Lisa GERMANY: Op. cit.

7. Una explicación para ello sería la estrecha relación establecida tradicionalmente entre los círculos académicos del Este y Europa. En este sentido, como defiende Ted Wells, California ha constituido siempre una frontera, tanto en un sentido literal como metafórico. En los Estados Unidos, la expansión de la frontera hacia el Pacífico supuso el desplazamiento de personas pero también la transmisión de ideas que viajaron desde el este hacia el oeste. A principios del siglo pasado, esta condición fronteriza significó la posibilidad de un territorio virgen y lleno de oportunidades que fue colonizado a través de un proceso inflacionario de reinvención, tanto de su paisaje como de su cultura y modos de vida. Resultado de esa doble operación, la rápida transformación de la geografía física y mental del Sur de California dio lugar a una cultura moderna propia que, nutriéndose de la naturaleza de la región, de las particularidades del clima y de la idiosincrasia local produjo manifestaciones artísticas y una arquitectura de incuestionable originalidad. No obstante, su interpretación ha estado sujeta a prejuicios derivados precisamente de la actitud mantenida por las instituciones culturales del Este, reacias a aceptar que ideas valiosas también podían viajar en sentido contrario, es decir, de oeste a este. La mirada eurocéntrica y la búsqueda de reconocimiento por parte John Entenza, principal editor del Oeste, publicando aquello que era comprensible a través de los preconceptos de la modernidad internacional, habrían incidido en esa fijación histórica de determinadas arquitecturas y autores frente a otros episodios que pasaron más desapercibidos.

8. Alan Hess: Forgotten Modern: California Houses 1940-1970. Salt Lake City, UT: Gibbs Smith Publisher, 2007, p. 9

9. Principalmente John Crosse y, en menor medida, Meredith Clausen, los autores con los que se ha trabajado esta sección.

10. Susan MORGAN (ed.): Piecing Together Los Angeles: An Esther McCoy Reader. Los Angeles, East Borneo, 2012; y Susan MORGAN y Kimberli MEYER (ed.): Sympathetic Seeing: Esther McCoy and the Heart of American Modernist Architecture and Design. Los Angeles: MAK Center, 2011.
11. La confección del mismo ha sido una parte fundamental de la investigación y una tarea realizada en colaboración con el historiador John Crosse.

12. Tras un pleito por una cuestión de competencias en los inicios de su carrera profesional, Harris decidió enfatizar con humor su condición de diseñador en el propio rótulo de su oficina, en el que escribió: "Harwell Hamilton Harris, Not an Architect".

13. Lisa GERMANY: Harwell Hamilton Harris. Austin, TX: University of Texas Press, 1991. Germany publicó este estudio seis años más tarde de haber dado a conocer su primer texto crítico sobre Harris, que había escrito para el catálogo de la exposición monográfica sobre el arquitecto organizada por la Universidad de Texas en Austin en 1985.

14.Douglas BAYLIS y Joan PARRY: California Houses of Gordon Drake. Reimpresión de la monografía original. Prólogo de Glenn Murcutt e Introducción de Pier Luigi Serraino. San Francisco: William Stout, 2011.

15. Neil JACKSON: "Californian Promise", Architectural Review, marzo 1996, pp. 80-84.

16. Esther McCOY: Entrevista con Joseph Giovannini (junio-noviembre 1987), editada por Susan Morgan (julio 2009). Oral History Interview. Archives of American Art, Smithsonian Institution, 1987

17. Tras ser rechazado por varias Universidades, Gebhard consiguió depositarlo en la Universidad de California en Santa Bárbara donde era docente.

18. Thomas S. Hines: Richard Neutra and the Search for Modern Architecture: a Biography and History. New York: Oxford University Press, 1982

19. Thomas S. Hines: Architecture of the Sun: Los Angeles Modernism 1900-1970. New York: Rizzoli, 2010.

20. Dione NEUTRA ( compiladora y ed.): Richard Neutra. Promise and Fulfillment, 1919 1932. Selections from the Letters and Diaries of Richard and Dione Neutra. Carbondale, IL: Southern Illinois University Press, 1986

21. Esther McCOY: Entrevista con J. Giovannini. Oral History Interview with Esther McCoy, 7 junio-14 noviembre 1987, Archives of American Art, Smithsonian Institution, pp. 39-40.

22. Robert SWEENEY: en AA. VV., DARLING, Michael y SMITH, Elizabeth A. T. (eds.) The Architecture of R. M. Schindler. New York: Harry N. Abrams, 2001. (Catálogo de la exposición homónima, Museum of Contemporary Art, Los Angeles, 2001), pp. 86-115.

23. Harwell Hamilton HARRIS: Oral History Program, UCLA, Op. cit.

24. Dione NEUTRA: To Tell the Truth. Entrevista con Lawrence Weschler (abril, julio y agosto 1982). Los Angeles: Oral History Program, UCLA, 1983

25. Thomas S. HINES: Architecture of the Sun: Los Angeles Modernism 1900-1970. Op. cit. 26. De las varias ediciones publicadas sobre esta guía han sido consultadas Los Angeles. An architectural guide (1994) y su reedición del año 2003 An architectural Guidebook to Los Angeles (Salt Lake City: Gibbs Smith, 2003). Este exhaustivo trabajo de documentación y crítica, iniciado en 1965 y actualizado sucesivamente, es un referente inexcusable para inicar cualquier investigación sobre la arquitectura de la ciudad de Los Angeles. 


\section{CONSTRUYENDO SUEÑOS (1910-1950)}

[ NOTAS INTRODUCTORIAS A LOS PAISAJES

RESIDENCIALES DEL SUR DE CALIFORNIA

] $\ldots$ 


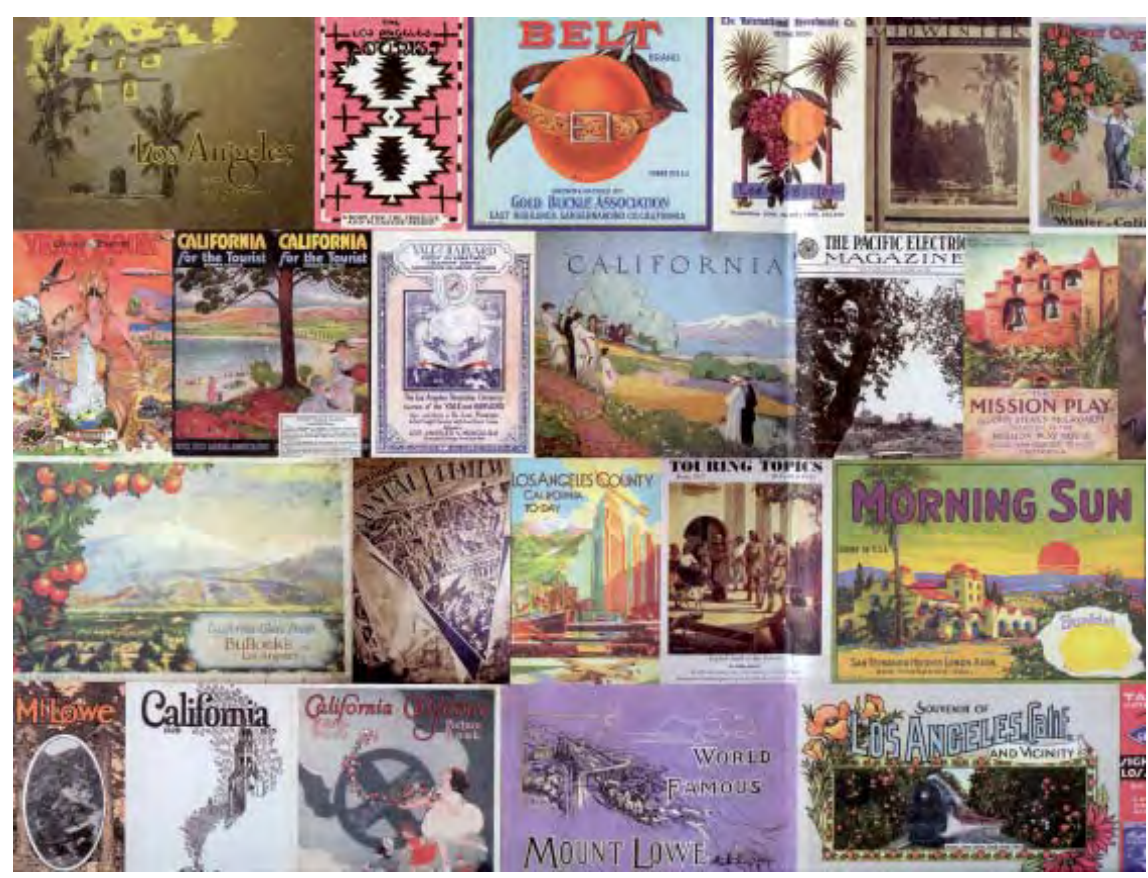

La promoción del paraíso. El Grupo del Arroyo

"El clima, el cine, los cítricos, la construcción y las cámaras de comercio produjeron esta moderna Cenicienta" ${ }^{\prime \prime}$.

Merle Armitage

Varias millas al noreste del distrito financiero de Los Ángeles, al pie de las montañas de San Gabriel, la apacible ciudad de Pasadena ${ }^{2}$ conserva uno de los distritos históricos más distintivos de la región. Sus amplias avenidas ajardinadas, sus espacios naturales y la claridad de su luz mediterránea trasmiten de inmediato la esencia de uno de los ambientes arquitectónicos que más contribuyeron a forjar el mito del Sur de California como Land of Sunshine, la tierra de la eterna primavera.

La ciudad se asienta sobre un abanico aluvial formado por corrientes de agua intermitentes que descienden ladera abajo hasta el valle. El principal de estos barrancos estacionales es el conocido como Arroyo Seco, un acusado accidente geográfico por el que circulan agradables brisas. Contradiciendo su topónimo español, el Arroyo Seco es un prodigio de vegetación. Salpicado de robles autóctonos, plantado con nogales, sicómoros, olivos y cítricos, su valor paisajístico fue muy apreciado por los primeros pobladores anglosajones, que transformaron su cauce en un parque urbano.

Pasadena había tenido su origen en los ranchos españoles dependientes de la misión de San Gabriel. Uno de los primeros colonos estadounidenses en hacerse con la titularidad de los terrenos más fértiles fue Benjamin Wilson ${ }^{3}$ quien, habiendo adquirido gran parte del Rancho San Pascual, promovió el cultivo de naranjos, inició la plantación de viñedos y puso en marcha una bodega. Años más tarde, con la incorporación de California a la Unión en 1850, las inmensas extensiones de tierra de los primitivos ranchos fueron segregadas y vendidas en lotes a agricultores llegados de Michigan, Illinois y, sobre todo, de Indiana, produciéndose un cambio
Colección de postales publicitarias de Los Ángeles (1870-1930). Fuente: Tom Zimmerman, Paradise Promoted 


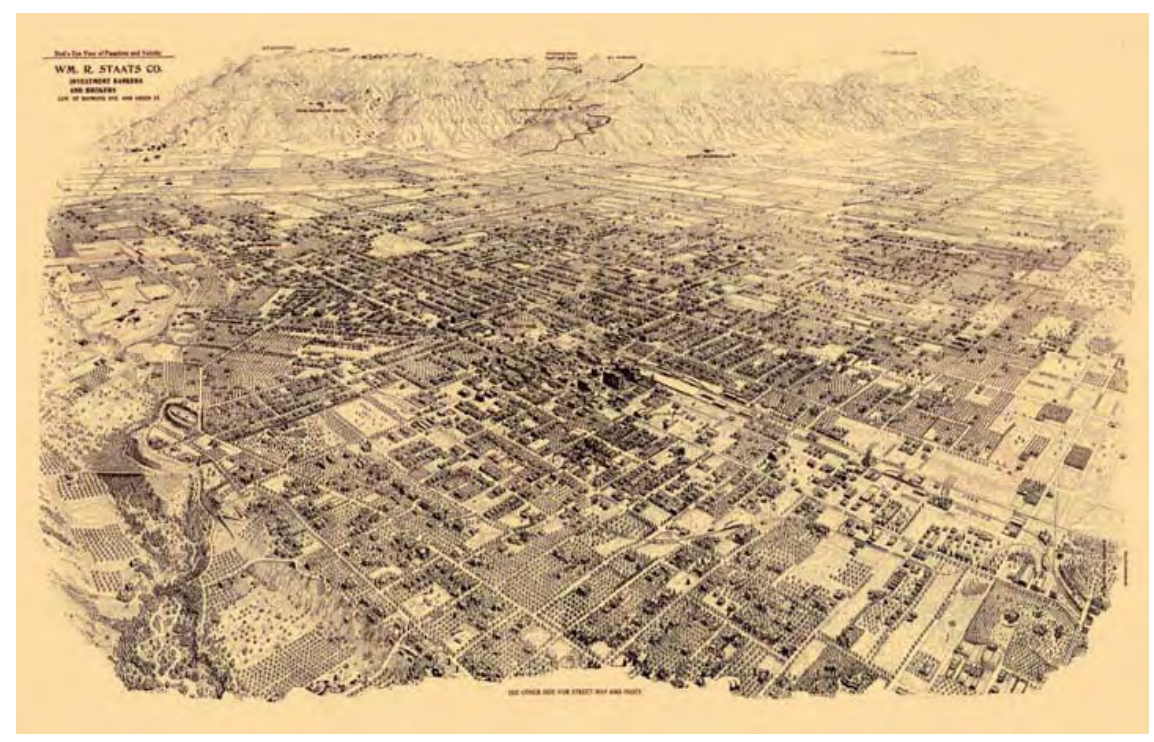

sustancial en la estructura de propiedad del suelo que rápidamente fue objeto de especulación.

Hasta ese momento, tras la infructuosa etapa de dominación mexicana, Pasadena, como toda la región de Los Ángeles, había sido un enclave rural escasamente poblado. Una situación que cambió repentinamente con la con la llegada del ferrocarril transcontinental. Las nuevas infraestructuras convirtieron aquel pequeño municipio en una parada estratégica en la línea férrea del Atchison, Topeka \& Santa Fe Railroad. Reduciendo a pocos días el tiempo de un viaje que antes duraba varias semanas desde Chicago, el tren fue el factor más determinante para el crecimiento económico de la zona. La red de comunicaciones no sólo impulsó su desarrollo sino que extendió su fama como un lugar de vacaciones que pronto codiciaron aquellos que podían permitirse escapar de los rigores de los inviernos del Medio Oeste.

Compendio de todos los alicientes del Sur de California, las bondades del clima, el sueño de una naturaleza idílica y el deseo de disfrutar de un modo de vida relajado fueron los reclamos más efectivos para los millonarios de las regiones industriales del país, que convirtieron esta ciudad en un exclusivo resort invernal. Charles Moore escribió que, hacia 1900, una visión del paraíso bien podría haber sido la de un día en Pasadena. Éste empezaría con un desayuno al sol, después una excursión en tren cremallera hasta las nieves del Monte Lowe, regresando para almorzar en un campo de naranjos e, incluso, gracias a la excelente red de tranvías de la Pacific Electric Railway, aún se dispondría de tiempo suficiente para ir a tomar un baño a la playa de Santa Mónica. Todo podía hacerse desde esta ciudad y, con suerte, alojándose en alguno de sus magníficos hoteles ${ }^{4}$.

Viajando con todos los adelantos de su civilización y una tecnología capaz de transfigurar el desierto, aquellos acomodados visitantes debieron encontrar en ella una versión mejorada de la arcadia narrada por Helen Hunt Jackson en su Ramona, la novela ${ }^{5}$ fundacional del mito misionero y cuyo "impacto electrizante en la región sólo puede compararse con el escalofrío nacional de la Exposición de Chicago"6.

Los atractivos del Sur de California, hábilmente promocionados por una oligarquía de terratenientes con intereses agrícolas, inmobiliarios e in- 


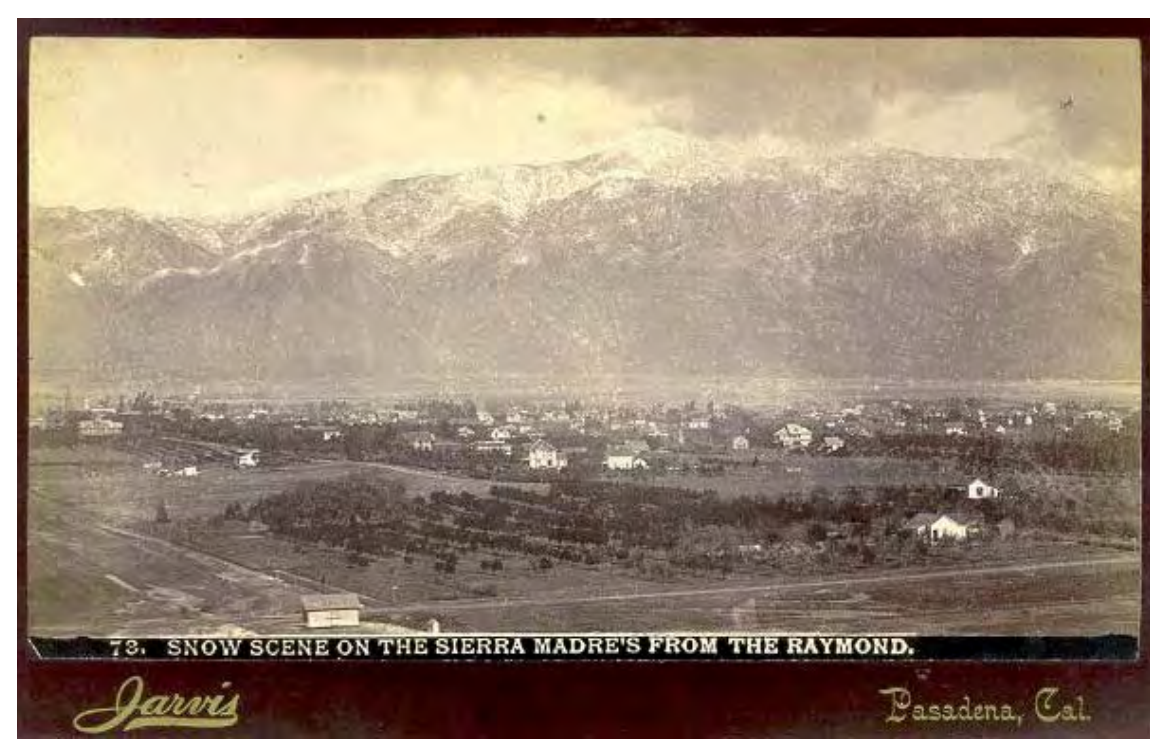

dustriales, comenzaron a atraer gentes de otros estados que se distribuyeron por la región en diversos asentamientos segregados en función de las rentas; desde las más altas en ciudades como Pasadena y las elegantes comunidades costeras hasta los poblados autoconstruidos de las clases más desfavorecidas que ocuparon los distritos centrales y las fronteras del Downtown. La polarización social fue de hecho uno de los primeros rasgos distintivos de esta metrópolis emergente, férreamente controlada, y minuciosamente concebida en su dimensión territorial antes incluso de ser habitada por una población acorde con la magnitud de las infraestructuras que se construyeron para propiciar su desarrollo.

Una red de tranvías que favorecía la dispersión urbana, el puerto de San Pedro para rivalizar con San Francisco, o el acueducto de Mulholland trayendo el agua del río Owens hasta la sedienta cuenca de Los Ángeles, son algunas de las colosales obras que, terminadas alrededor de 1910-1915, sentaron las bases de un crecimiento urbano perfectamente planificado desde la mesa de reuniones de un selecto club privado de magnates.

Como expresó Mike Davis: "Con el sol radiante y el aquí-no-hay-sindicatos como principales activos, y aliado con los grandes ferrocarriles transcontinentales (los mayores propietarios de tierras de la región), un sindicato de promotores, banqueros y magnates del transporte, dirigido por Otis y su yerno Harry Chandler, se dispuso a vender Los Ángeles -en mayor medida que ninguna otra ciudad ha sido vendida jamás- a la inquieta pero acaudalada burguesía babbitiana del Medio Oeste. Durante más de un cuarto de siglo una masiva migración sin precedentes [...] invirtió sus ahorros y pequeñas fortunas en propiedad inmobiliaria del sur de California. Este flujo masivo de riqueza entre regiones produjo estructuras de consumo, renta y población desproporcionadas con respecto a la base productiva real de Los Ángeles: la paradoja de la primera ciudad 'postindustrial' en su aspecto preindustrial"'

Al mismo tiempo que la abundancia de dinero y el ambiente de resort dejaban su impronta en los usos sociales y en el carácter conservador de la arquitectura de Pasadena, ya fuera en la tradición de festivales anuales como el Rose Parade, o en sus suntuosas mansiones historicistas, otro colectivo más culto, formado por profesionales liberales, artistas y artesanos seguidores del movimiento Arts \& Crafts se hizo responsable de su
Arriba: Postal de 1900 con panorámica de las Montañas de San Gabriel nevadas, vistas desde el Hotel Raymond

Abajo: Postal de época del Hotel Raymond, Pasadena

Pág. anterior: Dibujo de una vista área de Pasadena hacia 1890 con el fondo de las Montañas de San Gabriel y Mont Lowe

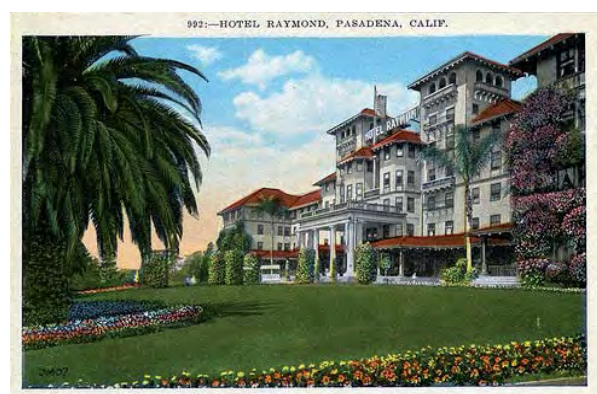



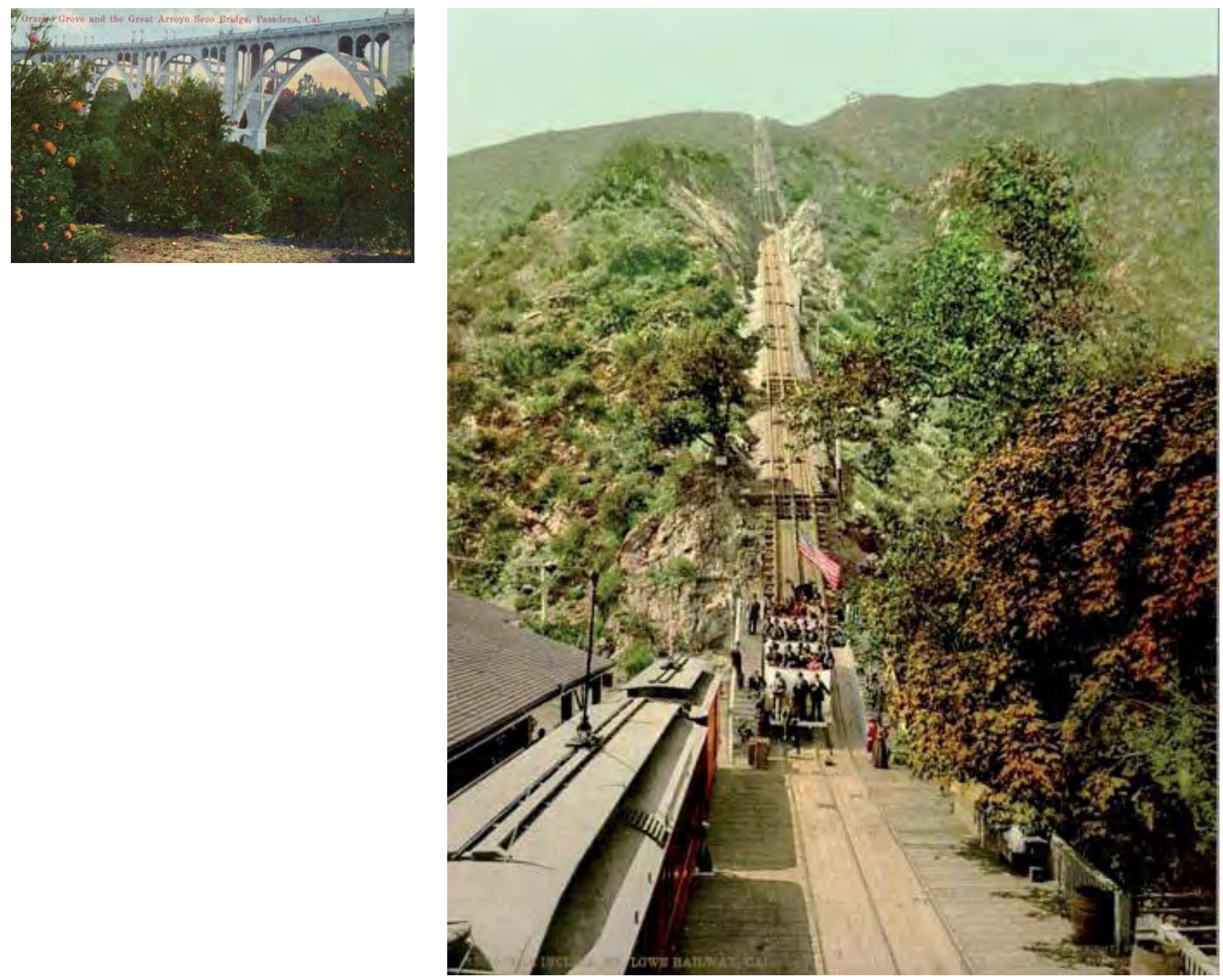

vida cultural. Ajenos al incipiente bullicio metropolitano, los miembros del llamado Grupo del Arroyo habían fijado su residencia en las pintorescas laderas del Arroyo Seco. Inspirados por el artista William L. Judson y el escritor George Wharton James ${ }^{8}$, los integrantes de este grupo compartían también muchas de las tesis de Charles F. Lummis, redactor jefe de la sección local de Los Angeles Times.

Pagado por el periódico de Harrison Gray Otis y la Cámara de Comercio, Lummis se convirtió involuntariamente en uno de los principales ideólogos del mito romántico de California. Su exaltación de los paisajes del Oeste, su entusiasmo por los modos de vida de las poblaciones indígenas y su celebración de herencia legada por un pasado español fueron poderosas armas publicitarias en manos de una camarilla de inversores que se encargó de empaquetar y vender hábilmente los sueños de la clase media norteamericana.

Como Lummis, de manera más o menos consciente, los miembros del Grupo del Arroyo proporcionaron con su trabajo y estilo de vida parte del material con el que se fueron alimentando los primeros mitos de la región. En su mayoría, los integrantes de este selecto grupo eran periodistas, críticos, artistas, arquitectos y urbanistas, educados en el Este. Mediante la organización de exposiciones, comités de artistas o reuniones literarias, su asociación traspasó las fronteras de sus respectivos oficios 

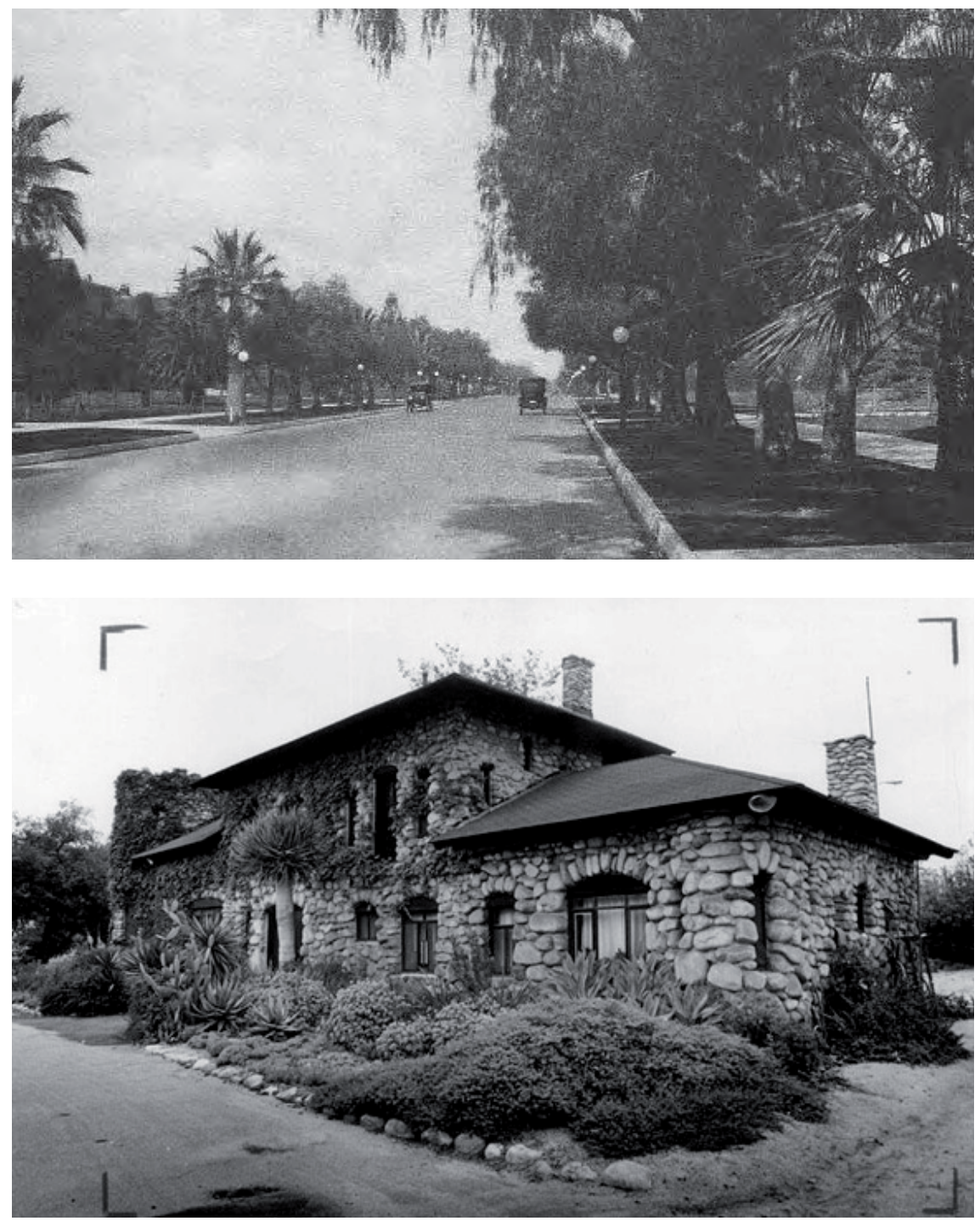

para fomentar el diálogo interdisciplinar y la creatividad del grupo. Independientemente de la mitología, de la apropiación sensible de la historia y de un cierto esnobismo, algunos de los artistas vinculados al Grupo del Arroyo, como los hermanos Greene, produjeron obras extraordinarias y todos ellos, como conjunto, definieron las tendencias de la arquitectura y de las artes visuales en Los Ángeles durante el cambio de siglo.

Uno de los principales focos del Grupo del Arroyo fue la residencia del ceramista y empresario Ernst Batchelder ${ }^{9}$, construida en 1909 en uno de los bordes del barranco. No es una obra conocida y, de hecho, no resulta fácil identificarla entre los numerosos bungalows Arts \& Crafts que pueblan el vecindario. La vivienda responde a algunas de las señas de identidad de esta tipología: una discreta construcción de madera, protegida por cubiertas inclinadas, y con una imagen indiscutiblemente doméstica. Su oscura fachada de secuoya está recubierta con tablillas claveteadas (shingles), un tipo de acabado muy popular en aquella época y, desde entonces, extendido por toda la costa californiana. Como contraste, las carpinterías han sido pintadas de blanco. La chimenea, elemento fundamental del lenguaje craftsman, sobresale del muro y remite a la posición del hogar, al núcleo de la vida familiar. Para reforzar esta lectura su base está revestida con grandes cantos que parecen anclarla al suelo y que, siguiendo la moda de la casa de El Alisal de Charles F. Lummis, son piedras extraídas del cauce mismo del Arroyo. Otro elemento característico
Izda arriba: Orange Grove, Pasadena, 1910 Izda abajo: Casa de Charles Lummis, El Alisal, 1910

Derecha: Batchelder House, Pasadena, 1909. Fotografía del autor

Pág. anterior izda: Fotografía coloreada del Arroyo Seco, Pasadena

Pág. anterior decha: Fotografía coloreada del tren cremallera de ascensión a Mont Lowe

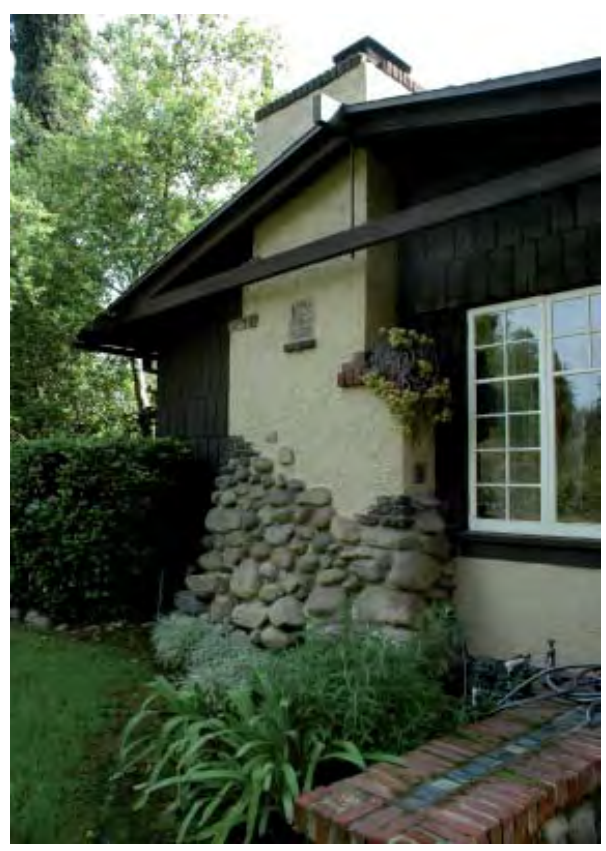



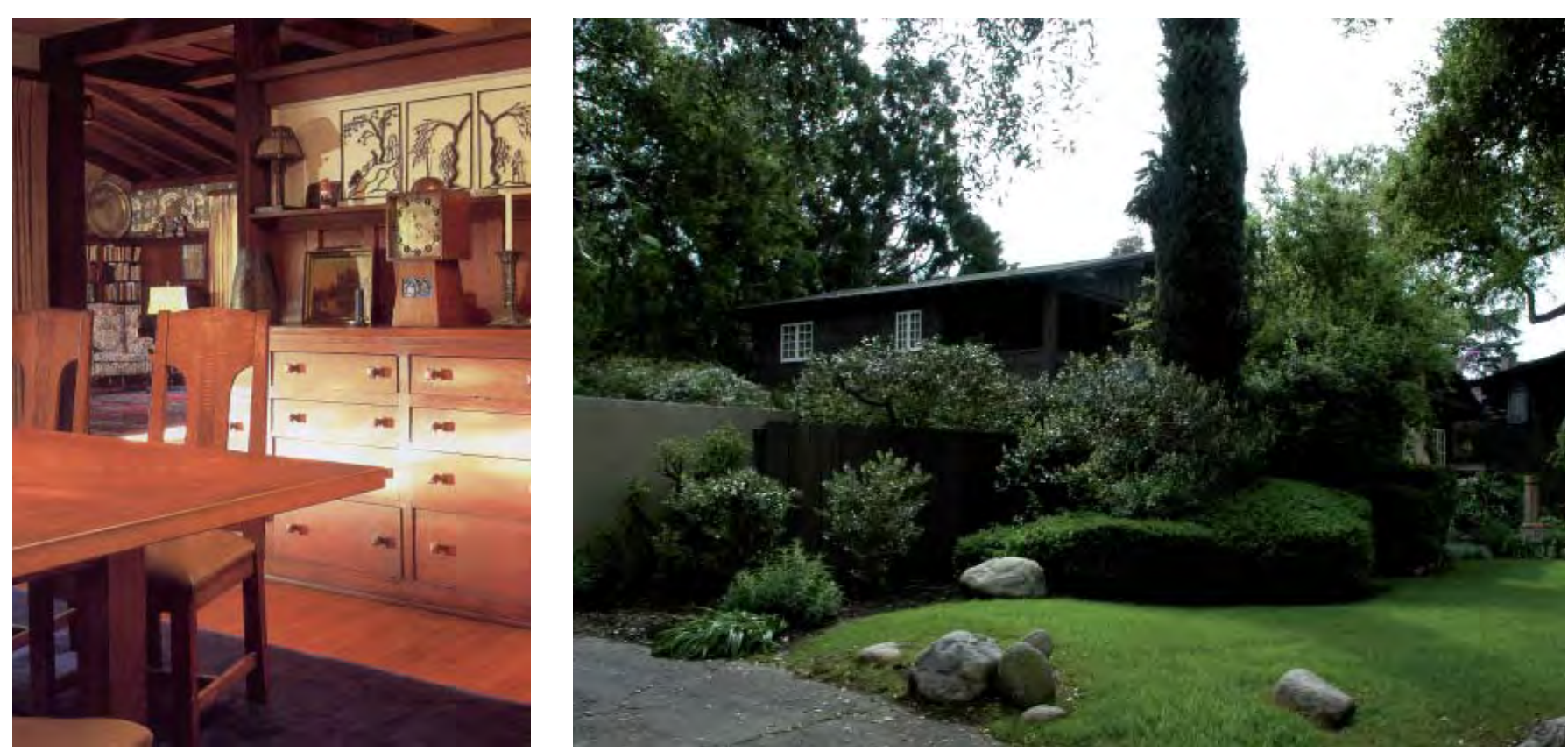

Izquierda: Detalle del comedor de la Batchelder House, Pasadena

Derecha: Batchelder House, exterior, vista del sleeping porche en primer término

Fotografías del autor, 2008

Página siguiente izda: Batchelder House, sala de estar

Página siguiente dcha: Stickley, The Craftsman, portada del número de julio de 1912 surcaliforniano son los sleeping porches de la primera planta. Son terrazas cubiertas, profundas sombras que elevándose sobre el plano del suelo buscan una mayor exposición a las brisas dominantes. Consecuencia del clima y del modo de vida desenfadado del Sur de California, el sleeping porche-que tanto influyó en la obra de autores como Greene \& Greene o Rudolph Schindler ${ }^{10}$ - era una estancia intermedia entre la casa y el jardín, un espacio exterior que prolongaba la vivienda y podía usarse para conversar, leer o, como sugiere su nombre, para dormitar al fresco durante las tardes de verano.

Batchelder y su casa, el bungalow craftsman, representan un tipo de arquitectura y un modo de vida genuinamente californiano al que aspiraron los artistas, escritores y personajes afines al Grupo del Arroyo. Casi todos ellos habían abandonado los rígidos cánones sociales de Nueva Inglaterra e, imbuidos del espíritu del Arts \& Crafts, propugnaron una forma de vida más sencilla, más auténtica, en contacto con la naturaleza y presidida por una concepción ruskiniana de perfeccionamiento moral a través del trabajo artístico. Estos ideales, expresados en su lema living simple \& high thinking, se materializaron en el esfuerzo del grupo por llevar la estética a todas las esferas de la vida cotidiana

Hacia finales del siglo XIX los principios del Arts \& Crafts habían cruzado el Atlántico atrayendo a artistas y empresarios que, desde los incipientes focos del diseño norteamericano, hicieron que el movimiento evolucionara con rapidez hasta adquirir su propia idiosincrasia. Pronto se extendió por todo el país y aglutinó diversas sensibilidades que tenían en común su rechazo de los estilos históricos y un interés creciente por lo vernáculo: las manufacturas de la Costa Este, los talleres de artesanos organizados en comunidades autosuficientes, el Prairie School de Frank Lloyd Wright o el Grupo del Arroyo en Pasadena compartían una visión integradora de las artes que situaba a la arquitectura en el centro de todas las actividades del diseño.

Bajo la denominación genérica de American Craftsman o Craftsman Style, y en su pretensión de lograr un primer estilo nacional, puede en- 


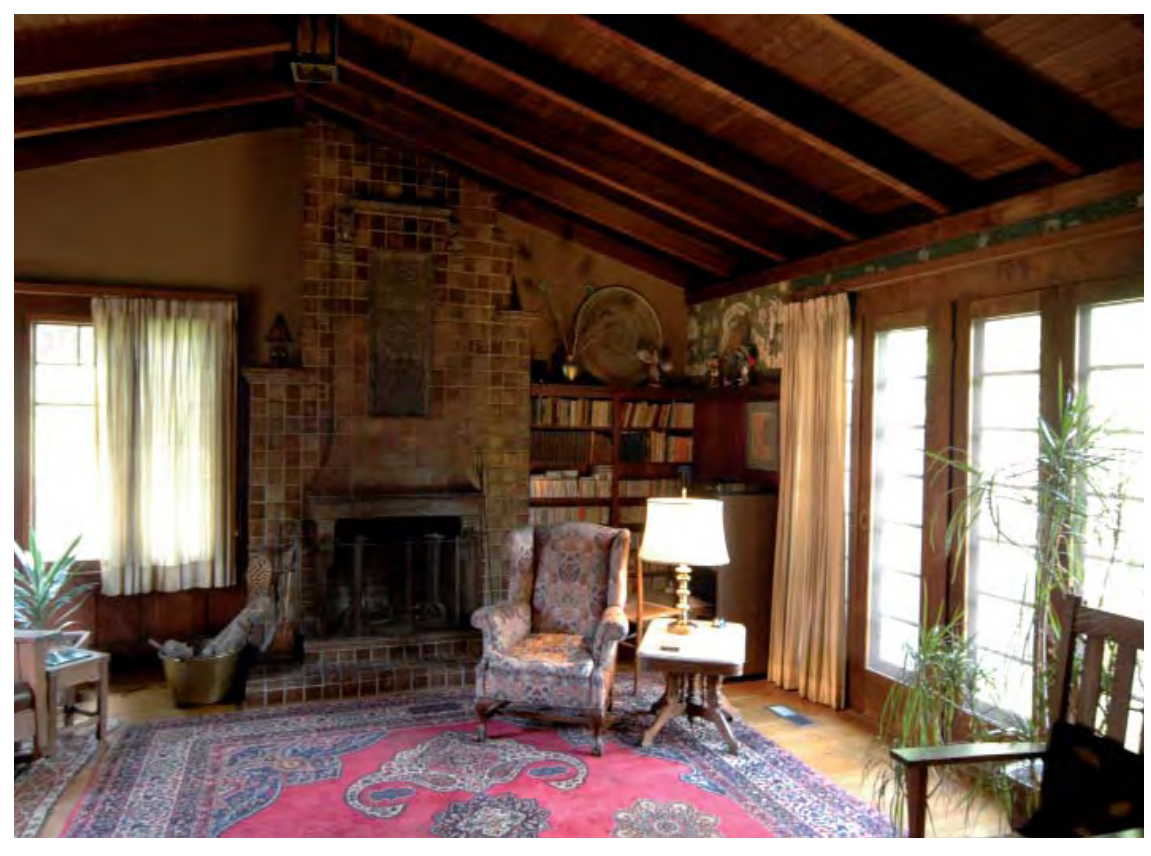

globarse todo un fenómeno social de enorme trascendencia en la conformación del ideal de vida norteamericano. Dada su popularidad, el movimiento estadounidense desplegó su influencia a través de la arquitectura doméstica, el mobiliario y las artes aplicadas, adoptando un sabor más burgués que el de su predecesor británico y prolongándose a través de sucesivas imitaciones hasta bien entrados los años treinta, y aun más allá.

En los Estados Unidos los acabados en madera cobraron todo el protagonismo. Su abundancia la convertía en un material democrático y sus posibilidades expresivas, asociadas a la autenticidad y a los valores identificados con la naturaleza del país, bastaban a los artistas norteamericanos para ennoblecer una vivienda sin necesidad de recurrir a tapices, papeles pintados o tejidos caros.

Uno de los más enérgicos impulsores del Craftsman Style fue Gustav Stickley ${ }^{11}$, diseñador y fabricante muebles asentado en Syracuse, Nueva York. A su regreso de un viaje a Europa, seducido por los planteamientos de los diseñadores británicos que había conocido, en 1898, Stickley abrió United Crafts -más tarde Craftsman Workshops- donde comenzó a producir el mission oak, una línea de mobiliario manufacturado en roble americano e inspirado en la rusticidad y el candor de los muebles de las misiones franciscanas de la Alta California.

La mayor aportación de Gustav Stickley fue la creación, en octubre de 1901, de la revista The Craftsman, que a lo largo de sus quince años de existencia actuó como el canal de transmisión más efectivo de las ideas del Arts \& Crafts en los Estados Unidos. En sus páginas, los miembros de su círculo escribían sobre interiorismo, jardinería, cuestiones relacionadas con la alimentación, la salud y hasta la educación de los hijos. Consagrado como la voz más autorizada del movimiento, a partir de 1903 Stickley comenzó a colaborar con el arquitecto Harvey Ellis, a quien encomendó la preparación de textos sobre arquitectura doméstica y la tarea de dibujar plantas, alzados y secciones de viviendas tipo para ilustrar sus artículos ${ }^{12}$.

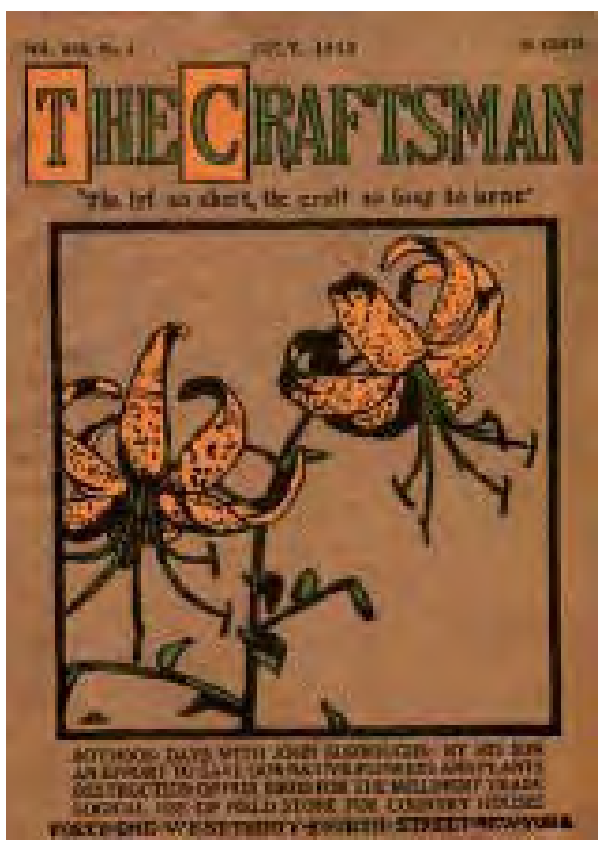



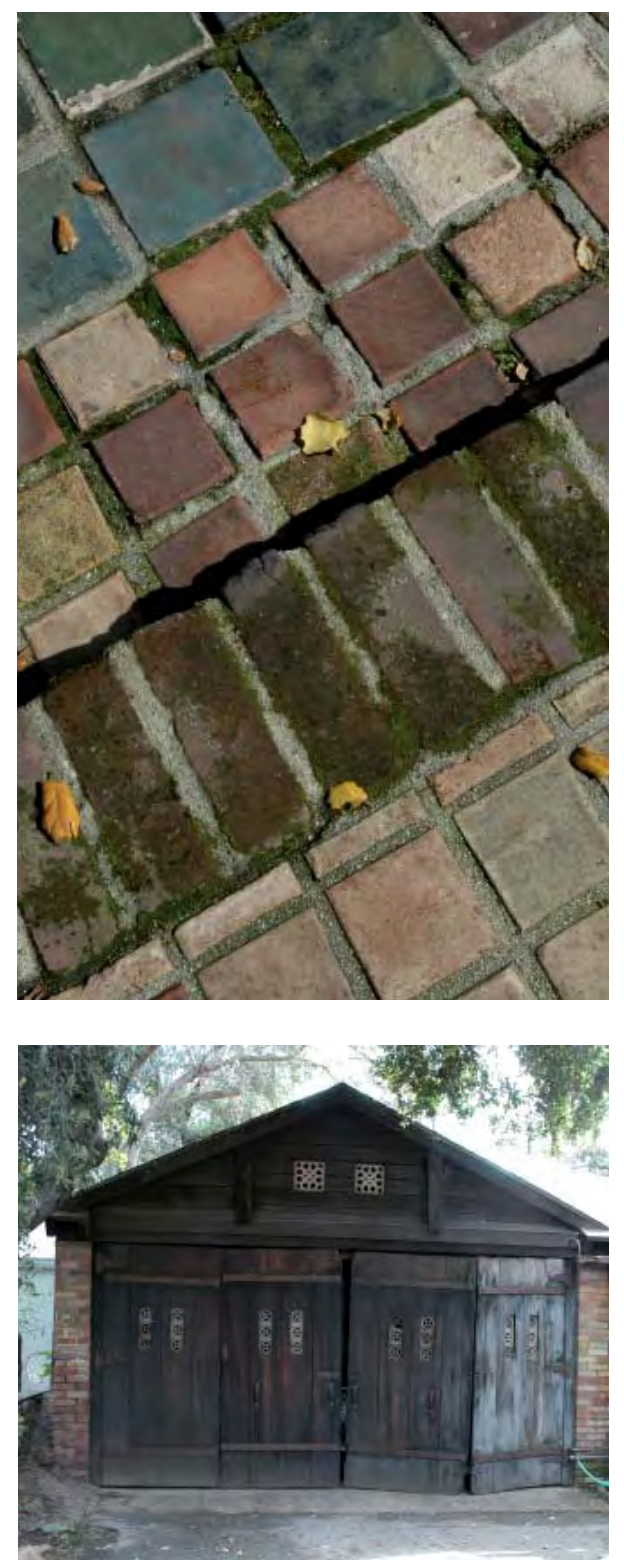

Izquierda: Imágenes de la Batchelder House: Detalle del pavimento del jardín (arriba); puerta del garaje (abajo). Fotografías del autor

Derecha arriba: Dibujo de la Batchelder House, publicado en el Pasadena Daily News en 1909. Fuente: Robert Winter

Derecha abajo: "Dak" bungalow, 1847 en el norte de la India, al pie del Himalaya (India Office, Londres). Fuente: The California Bungalow, Robert Winter
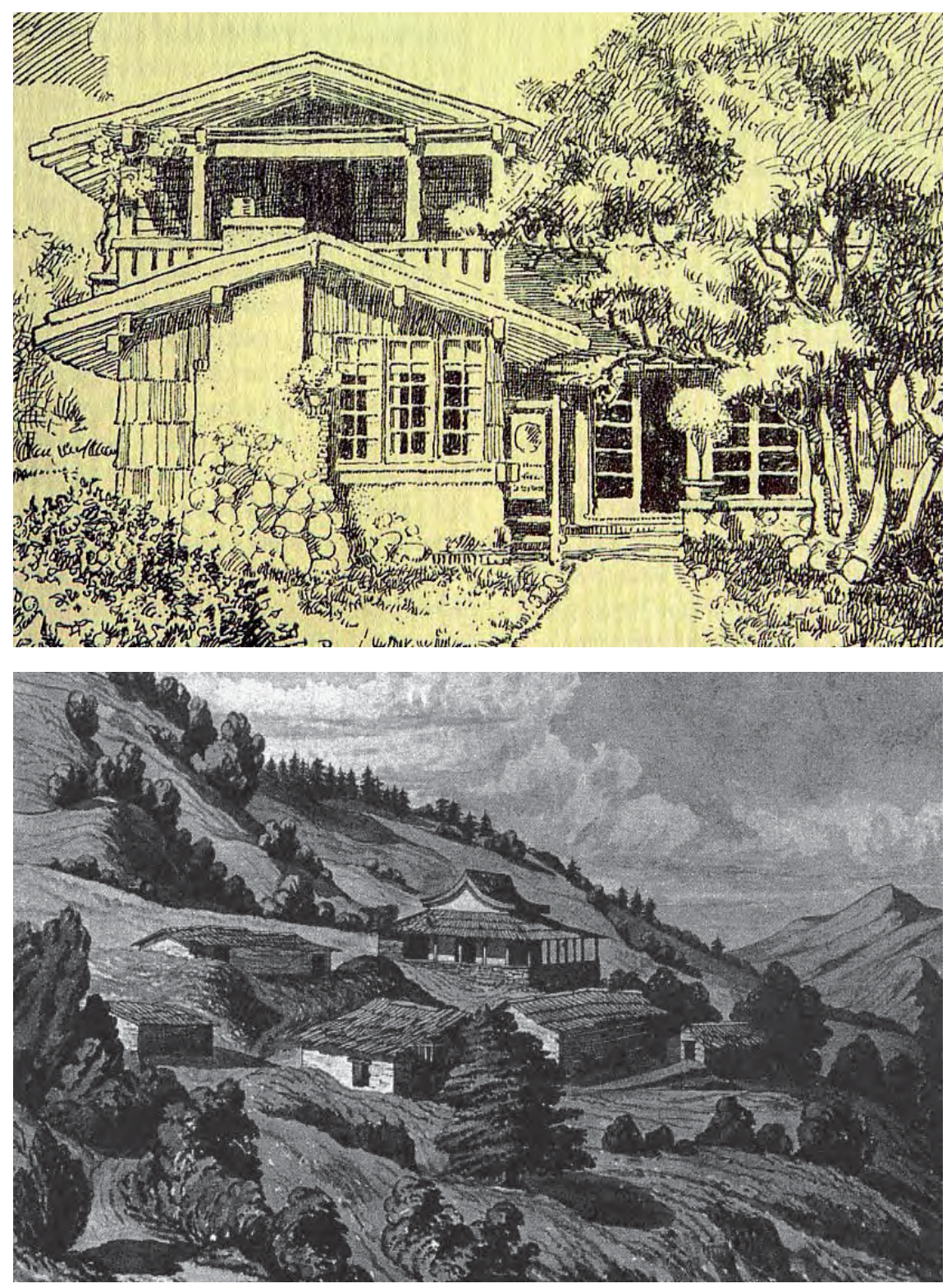

The Craftsman supuso un intento de elaborar una teoría material del diseño que alcanzara múltiples aspectos de la vida cotidiana. Para llevar sus ideas a la práctica, en 1906, Stickley fundó Craftsman Farms, una escuela para jóvenes vinculada a una granja autosuficiente que abastecía a una comunidad de artesanos fundada en las inmediaciones de su casa de campo de Nueva York. Aunque sus problemas económicos pronto frustraron este proyecto y Stickley no logró su objetivo de establecer una colonia rural, las comunidades utópicas inspiradas en los gremios de artesanos medievales, fueron uno de los principales exponentes del Arts $\&$ Crafts norteamericano ${ }^{13}$.

Sin llegar a ser propiamente una colonia, en Los Ángeles, los artistas del Grupo del Arroyo desarrollaron su propia versión del movimiento inspirada en la herencia hispano-mexicana, en el arte oriental y en la revisión de los estilos importados de la otra costa del país. Contando con el favor de una clientela adinerada, Charles y Henry Greene, sus figuras más preeminentes, incorporaron muchas de estas fuentes pero su trabajo dio una vuelta de tuerca al reinventarlas por completo en una arquitectura personal de indudable originalidad e importancia como respuesta pionera al medio californiano. 


\section{El bungalow californiano, instrumento de colonización territorial}

"En el centro de la popularidad del bungalow craftsman está la idea de que el diseño y la artisticidad también pueden encontrarse en una casa modesta. La eclosión del bungalow supuso una rara ocasión en la que la buena arquitectura no se quedó sólo en la esfera de la alta sociedad. El bungalow permitió a las clases medias alcanzar aquello que habían estado buscando durante tanto tiempo: respetabilidad. Garantizando estilo y sencillez, todas las comodidades domésticas, aislamiento, confort acústico y una excelente fontanería, el bungalow proporcionó algo más que una respuesta a la necesidad de refugio, encarnó la realización del sueño americano"14.

Robert Winter

Durante el cambio de siglo, en el Sur de California, un territorio tan real como fabulado, la necesidad de expresar su pertenecia a un lugar fue determinante para los arquitectos del movimiento Arts \& Crafts. En esta tarea, es decir, en la fijación y promoción de un tipo arquitectónico que vehiculara el ideal doméstico de la región, fue también decisiva la contribución teórica de Gustav Stickley. Siendo uno de los autores más admirados por los artistas de su generación, incluidos ellos los hermanos Greene ${ }^{15}$, su influencia llegó hasta California a través de su revista, donde el bungalow se había convertido en un tema central.

De acuerdo con Robert Winter ${ }^{16}$, los orígenes de esta tipología pueden rastrearse en la India, de donde procede el término bungalow como gentilicio deformado de Bengala. La misma raíz bangala o bangla hace alusión a las viviendas tradicionales de esta provincia hindú. En el siglo XIX los ingleses, se habían inspirado en estas construcciones para edificar las residencias veraniegas de los altos funcionarios y mandos militares de la colonia. Inspirándose a su vez en los English cottages, los primeros ${ }^{17}$ diseños de bungalows americanos muestran una planta donde dormitorios, baños, cocina y comedor se organizan alrededor de una estancia central.

En The Craftsman, Stickley había expuesto reiteradamente sus opiniones acerca del bungalow como tipología esencial de la vivienda norteamericana, razonando algunas de sus características más definitorias: una casa en armonía con su entorno, que empleara materiales locales y que, preferiblemente, se dispusiera en una sola planta, evitando barreras físicas que, como escaleras y pasillos, dificultasen la interacción entre sus habitantes.

Para Winter, en su formulación más estricta, un bungalow es una vivienda de una sola altura, aunque su definición podría ser extendida a otras soluciones basadas en una planta reuniendo los espacios principales de la casa más una media altura adicional. Las ventajas de esta tipología eran muchas, por un lado facilitaba el proceso de construcción ahorrando en estructura; igualmente permitía centralizar las instalaciones, especialmente la fontanería; y además, la ausencia de un piso adicional redundaba en eficiencia energética al eliminar las dobles alturas o las escaleras que dispersaban el aire caliente. 


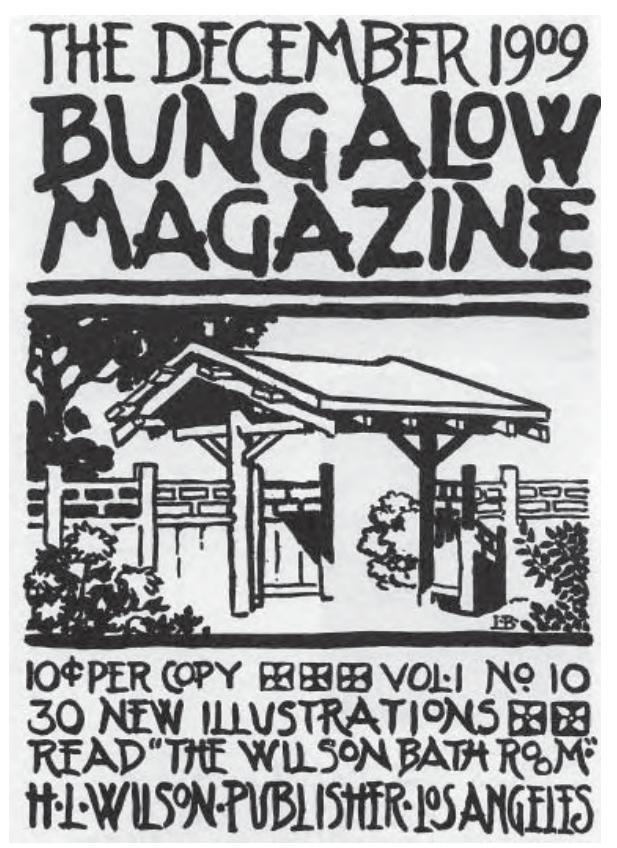

Izquierda: Portada de The Bungalow Magazine de 1909

Derecha: Dibujo de un bungalow, portada del libro The California Bungalow de Robert Winter

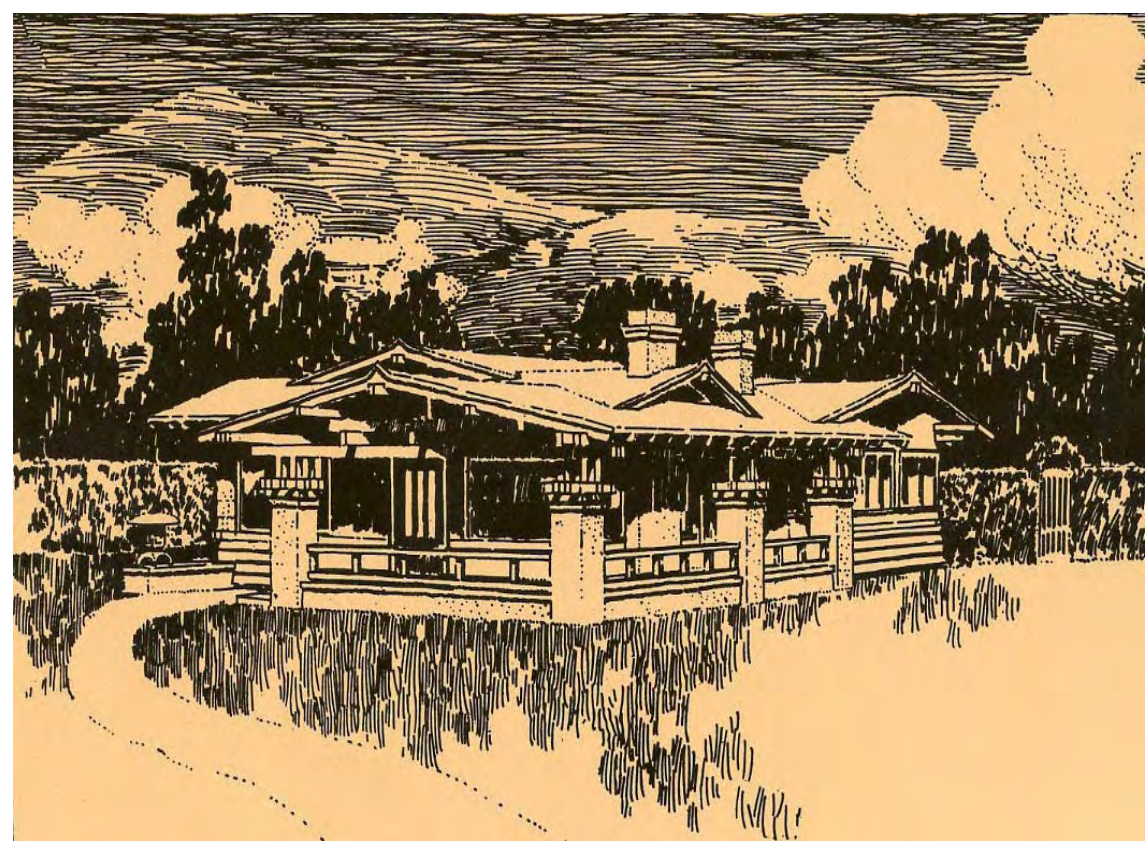

En correspondencia con los mismos criterios de calidad y simplicidad que aplicaba a su mobiliario, Stickley proponía que la textura de los materiales y la exposición de los elementos estructurales fuesen la única decoración de los interiores de la casa. Aconsejaba también usar pocos muebles $y$, a ser posible, que éstos fueran fijos: asientos corridos, bancos de trabajo, armarios o estanterías satisfacían funciones básicas como el almacenaje de enseres desde la propia arquitectura, sin necesidad de introducir piezas ajenas a la idea de la casa.

Las propuestas de bungalows publicados en su revista recomendaban agrupar ventanas para favorecer una mejor iluminación y potenciar las vistas más interesantes. La cubierta inclinada, asociada con la tradición democrática norteamericana, resuelta a pocas aguas y e iniciándose a una cota relativamente baja, tenía como misión unificar compositivamente la casa, evitando la complejidad de hastiales, vertientes, miradores y encuentros poligonales característicos de la arquitectura victoriana. El porche de planta baja, aun siendo una prolongación de la cubierta, debía aportar una cierta variedad al diseño. Como la cubierta inclinada, éste era otro elemento vinculado al individualismo democrático, un recinto privativo de la familia y un lugar de transición entre la vivienda y el jardín.

Considerando el Arts \& Crats como el equivalente estético del progresismo político norteamericano, el movimiento se distinguió por su aspiración de consolidar la vivienda de clase media como fuente de un nuevo orden social. Por su parte, siendo ésta el eje de las relaciones humanas, los arquitectos buscaron cohesionar las diferentes actividades de casa recurriendo para ello a organizaciones de plantas relativamente abiertas. En el bungalow craftsman, por primera vez, la cocina comenzó a participar de la vida del resto de las estancias, incorporándose a su dinámica y suprimiendo la necesidad de un acceso para el servicio ya que éste debía independizarse del núcleo familiar o, incluso, podría eliminarse por completo. En este sentido, antiguos espacios como el comedor del servicio, en lugar de desaparecer, fueron transformados en un pequeño rincón, provisto de una mesa y una ventana, idóneo para tomar el desayuno o para conversar mientras se preparaba la comida. 

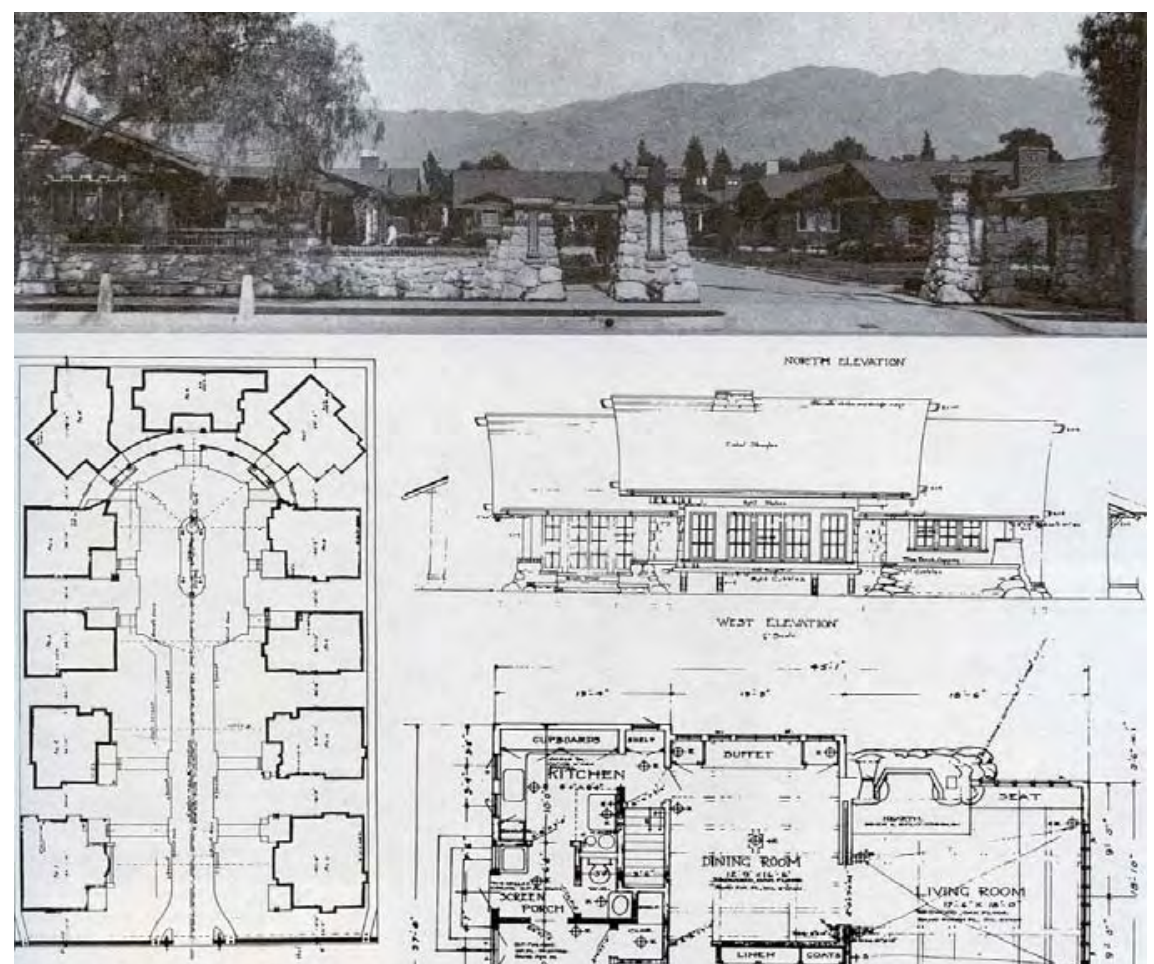

St. Francis Court, Sylvanus Marston, 1909; Pasadena. Probably the first bungalow court in America. When Robinson's Department Store was built It this site, some of these bungalows were moved, five of them to the inter. rection of Cornell and Catalina in Pasadena. The elevation pictures bun alow No. 11, the floor plan is shat of No. 4 .
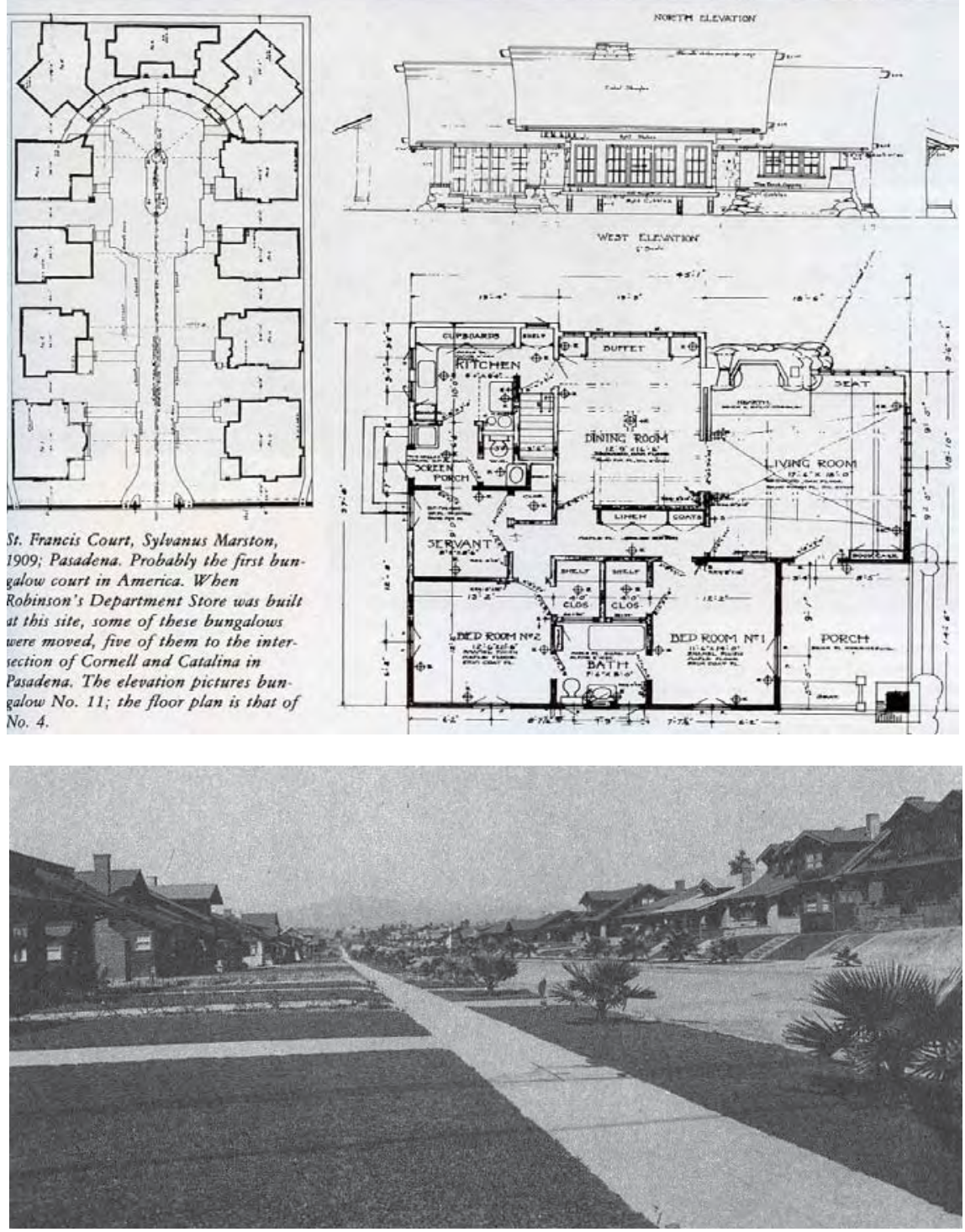

El arquitecto M. A. Darrach, en su artículo de 1906 Why Not a Bungalow?, publicado en la revista Country Life in America, realizaba una enumeración exhaustiva de las características básicas que debía reunir todo bungalow, concretando los siguientes puntos que definían esta tipología: "(1.) Estar limitado a una sola planta y carecer de escaleras. (2). Simplicidad (de diseño y constructiva). (3.) Concentración de la fontanería. (4.) Distribuciones con pocos pasillos de circulación. (5.) Simplificación de la estructura de madera para garantizar una mayor facilidad de construcción. (6.) Evitar techos altos para que no escape la calefacción. (7.) El interior debe responder más a los planteamientos de su distribución y proporciones que a sus acabados, de modo que pueda ejecutarse con sencillez y rapidez ${ }^{\prime \prime 18}$. A pesar de la similitud de los planteamientos de Darrach con los de Stickley, se distanciaba de éste al llevar la discusión sobre la tipología fuera de una esfera meramente estética o filosófica,
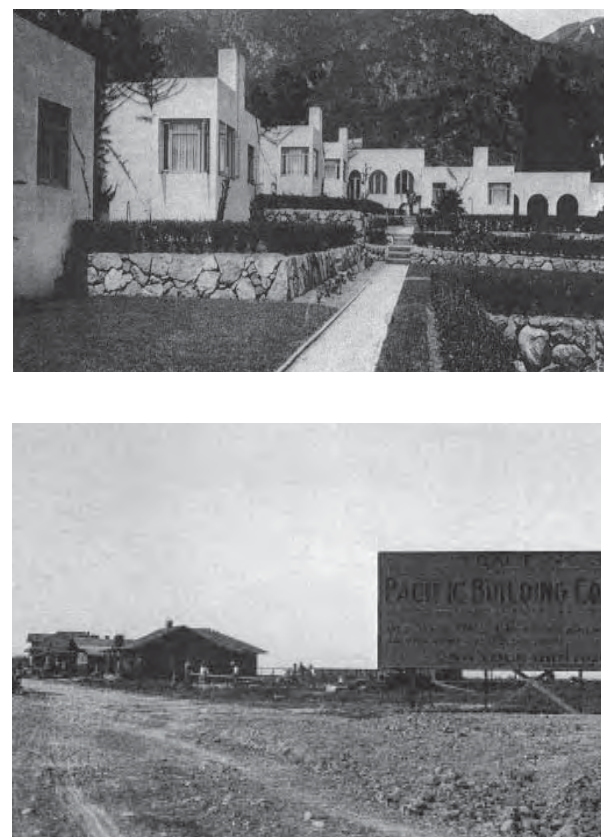

Izda arriba: Imagen y planos de implantación y planta de del conjunto de bungalows St. Francis Court, 1909, probablemente la primera promoción de "bungalow court" construida en Estados Unidos. Fuente: Robert Winter Izda abajo: Imagen de una calle de bungalows de Los Ángeles hacia 1915. Fuente: Greene \& Greene Library, Gamble House, Pasadena

Dcha arriba: Lewis Court de Irving Gill en Sierra Madre, 1910. Su imagen moderna es resultado de su racionalización constructiva Decha abajo: Pacific Building Company, Promoción de bungalows en Los Ángeles Fuente: Robert Winter 
Arriba: Página de un catálogo de la empresa Pacific Ready Cut Homes, modelo 396 de 1925 con todo tipo de especificaciones de acabados, medidas y previsión de instalaciones Abajo: Folleto publicitario de la empresa Aladdin Bungalow, 1917
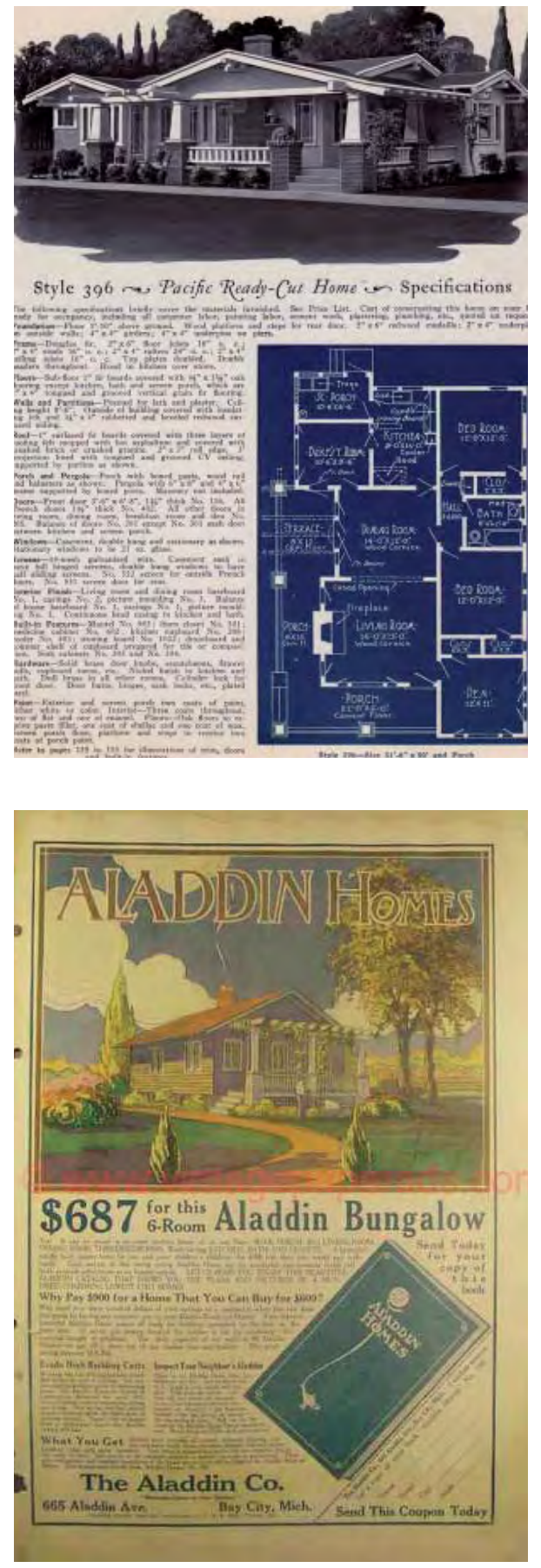

es decir, al desproveerla de sus valores morales para convertirla en un producto de mercado.

A principios del siglo pasado, el Sur de California reunía todas las condiciones para que esta tipología se popularizara en su aspecto más comercial: el clima, la geografía y una disponibilidad de suelo barato sin precedentes constituían el escenario más favorable para la industria inmobiliaria. A través de certeras campañas publicitarias el bungalow conquistó completamente el gusto de las clases medias. Su éxito fue tal que desencadenó un fenómeno sociológico de enorme impacto económico y territorial.

En la estela de The Craftsman proliferaron toda una serie de publicaciones periódicas especializadas en esta tipología, como Country Life in America, fundada en 1901, Western Architect, o Bungalow Magazine. Otras revistas como Ladies' Home Journal se sumaron pronto a la moda del bungalow. Se editaron también numerosos libros monográficos ${ }^{19}$, así como recopilaciones de artículos, muestrarios de plantas, compendios de problemas prácticos y, por supuesto, multitud de folletos de empresas, grandes almacenes o compañías como Alladin Homes que ofrecían a sus clientes la posibilidad de escoger, personalizar y construirse un bungalow acorde con sus propias necesidades y gustos.

El bungalow craftsman se divulgó a través de múltiples estilos como el English Tudor, las imitaciones de chalet suizo o de la misión española ${ }^{20}$. Aunque evocaban un tiempo pasado anterior a la irrupción de la tecnología, se recurría sin embargo a las instalaciones más avanzadas del momento, impensables sin embargo en las viviendas europeas de la época.

Los bungalows, perfectamente tipificados, variaban en la elección de un determinado estilo, o por su tamaño, pero respondían a unos mismos parámetros organizativos y a criterios de rentabilidad económica. Una planta eficientemente distribuida, alzados codificados, detalles simples y estandarizados, y el empleo de un material económico y abundante como la madera, aseguraban la rapidez constructiva y el abaratamiento de costes.

Hacia 1920, una vivienda grande y completamente equipada podía costar unos 3.000 ó 3.500 dólares. El precio medio de un bungalow rondaba los 900 dólares y no era difícil conseguirlo por menos dinero. Un cliente con recursos podía encargar su bungalow a un arquitecto de renombre. Si no se disponía de tales siempre era posible optar por adquirir uno en una gran operación inmobiliaria o, también, comprar un terreno, ojear un catálogo de soluciones y pedir una casa por correo y esperar a que ésta llegara por ferrocarril, desmontada y empaquetada con el lema constrúyasela usted mismo.

Antes incluso de la Primera Guerra Mundial, disponiendo de inmensas bolsas de suelo esperando a ser lotizado, el bungalow se había convertido ya en una eficaz herramienta de colonización del territorio. Aunque, paradójicamente, había surgido como vivienda de retiro fruto de una ideología anticomercial y antiurbana, la fiebre del bungalow terminó siendo responsable del desarrollo inflacionario de los paisajes residenciales del Sur de California. 


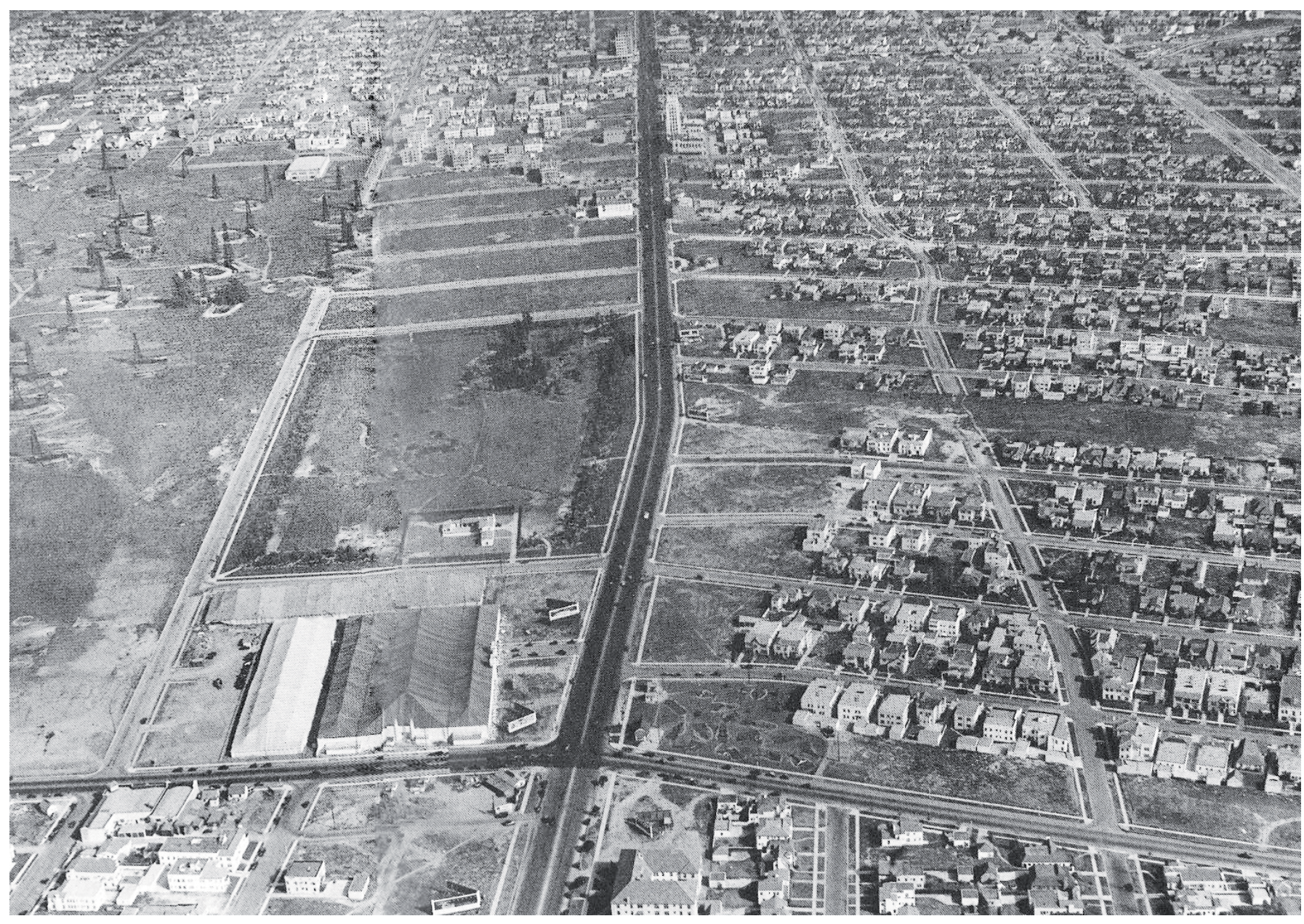

Los hiperactivos promotores inmobiliarios de Los Ángeles instrumentalizaron la mitología de la región para vender miles viviendas. En los años 20, la consolidación en Hollywood de la industria del cine, el medio más poderoso de comunicación de masas del siglo pasado, contribuyó a la producción y promoción definitiva de imágenes de un modo de vida objeto de deseo.

El bungalow era algo más que una simple casa, suponía la materialización de un sueño $y$, por tanto, una cuestión de estatus social. Proporcionaba privacidad e independencia; la posibilidad de poseer una porción de tierra, un jardín y un espacio para el coche, que era lo más parecido al ideal americano de una vida sencilla en la naturaleza. Las clases medias vieron en esta tipología una fuente de salud y bienestar, pero también una oportunidad de invertir en el mercado de la vivienda y ser partícipes del boom inmobiliario del Oeste. Conforme se prosperaba y las personas se mudaban a casas más grandes traspasaban su modesto bungalow a familias de recién llegados en busca de fortuna. Era pues una medida del éxito personal. En este sentido, el bungalow constituyó una de las primeras cimas del capitalismo norteamericano, contribuyendo a transformar para siempre el paisaje de la ciudad-región de Los Ángeles, cada vez más extensa en sus imprecisos límites.

Si en 1900 la población de la ciudad era de poco más de 100.000 personas, una década más tarde, ésta se había triplicado. En 1920 la duplicaba acercándose a los 600.000 y, de nuevo, otra década después, en 1930, volvía a doblarla superando 1.200 .000 habitantes.

Wilshire Bouleverd dirección este desde Fairfax Avenue, Los Ángeles, 1930. Fuente Los Angeles County Museum of Naural History. David Gebhard: LA in The Thirties 


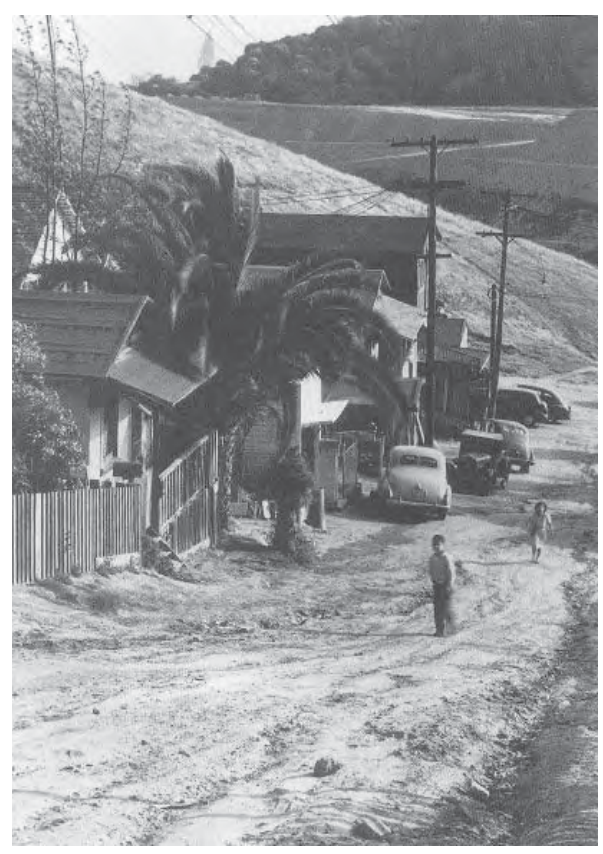

\section{Los Ángeles entre la Gran Depresión y el Fair Deal}

La crisis económica de 1929 certificó el primer fracaso de las doctrinas capitalistas del laissez-faire. Consecuencia de ello, el colapso del sistema financiero y la implosión de la industria de la construcción forzaron la intervención del gobierno norteamericano en el mercado de la vivienda. Las condiciones de insalubridad, la miseria y el hacinamiento de millares de familias que se habían quedado sin trabajo y sin hogar requerían soluciones de urgencia.

Aunque por razones que subyacen profundamente en su psicología como nación, la vivienda pública nunca ha sido un asunto fácil en los Estados Unidos ${ }^{21}$, durante las dos últimas décadas de la primera mitad del siglo XX las políticas urbanas basadas en la vivienda social fueron una de las principales apuestas de la ambiciosa agenda de infraestructuras y dotaciones públicas del New Deal.

Como bien expresó en 1930 Earl Browder, secretario general de partido comunista, el "New Deal fue quien puso a América en la senda del estado de bienestar"22. En efecto, en el intervalo de tiempo comprendido entre la Gran Depresión y el final de la Segunda Guerra Mundial, los programas de vivienda social llevados a cabo por el gobierno federal fueron acogidos positivamente por una amplia coalición de organizaciones ciudadanas, laborales y religiosas -la denominada coalición Roosevelt- que vieron en ellos una oportunidad para mejorar la calidad de vida de los sectores más desfavorecidos de la población. Aunque en buena medida el sistema de contratas y créditos a través del cual se produjo la intervención estatal beneficiaba a los propios bancos y empresas constructoras que habían contribuido a la ruina del país, un grupo de técnicos comprometidos y políticos de izquierdas supieron entender los proyectos de vivienda pública a gran escala como un motor de renovación urbana con el que impulsar las bases de una sociedad más justa.

Irónicamente, a principios de 1950, cuando la promoción privada se hubo recuperado gracias al esfuerzo colectivo del New Deal y a las inversiones gubernamentales en la industria de la defensa, los grupos de presión con intereses inmobiliarios utilizaron la coartada anticomunista del macartismo para desmontar los logros de dos décadas de políticas urbanas progresistas, volviendo así a dominar en solitario un mercado de la vivienda que había salido reforzado por la sociedad de consumo surgida tras la guerra.

El papel de la mujer en aquel momento estelar aunque breve de la historia urbana norteamericana fue determinante. Por ejemplo, el trabajo pionero de Catherine Bauer, líder del movimiento Houser, estableció los fundamentos conceptuales y los principios técnicos de los programas federales de vivienda asistida. Publicado en 1934, en su libro Modern Housing ${ }^{23}$, retaba a sus compatriotas a aprender, emular y adaptar en los

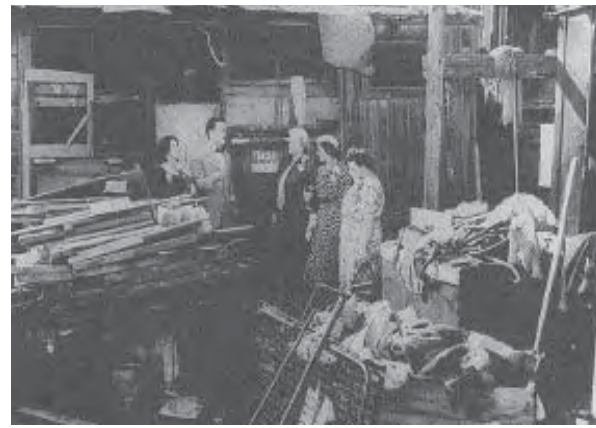
Estados Unidos las experiencias de vivienda social desarrolladas en los países europeos desde principios de siglo, sobre todo en Alemania, Holanda y Escandinavia. Formada en Europa y en Nueva York por su maestro y mentor Lewis Mumford, Bauer sostenía que la vivienda no podía ser considerada sólo una cuestión privada ya que, según argumentaba, se trataba ante todo de un problema de importancia nacional. Para la autora, las diferentes administraciones debían implicarse en la planificación, construcción, gestión y regulación de la vivienda como asunto de máxima prioridad ya que un elevado porcentaje de ciudadanos requería 


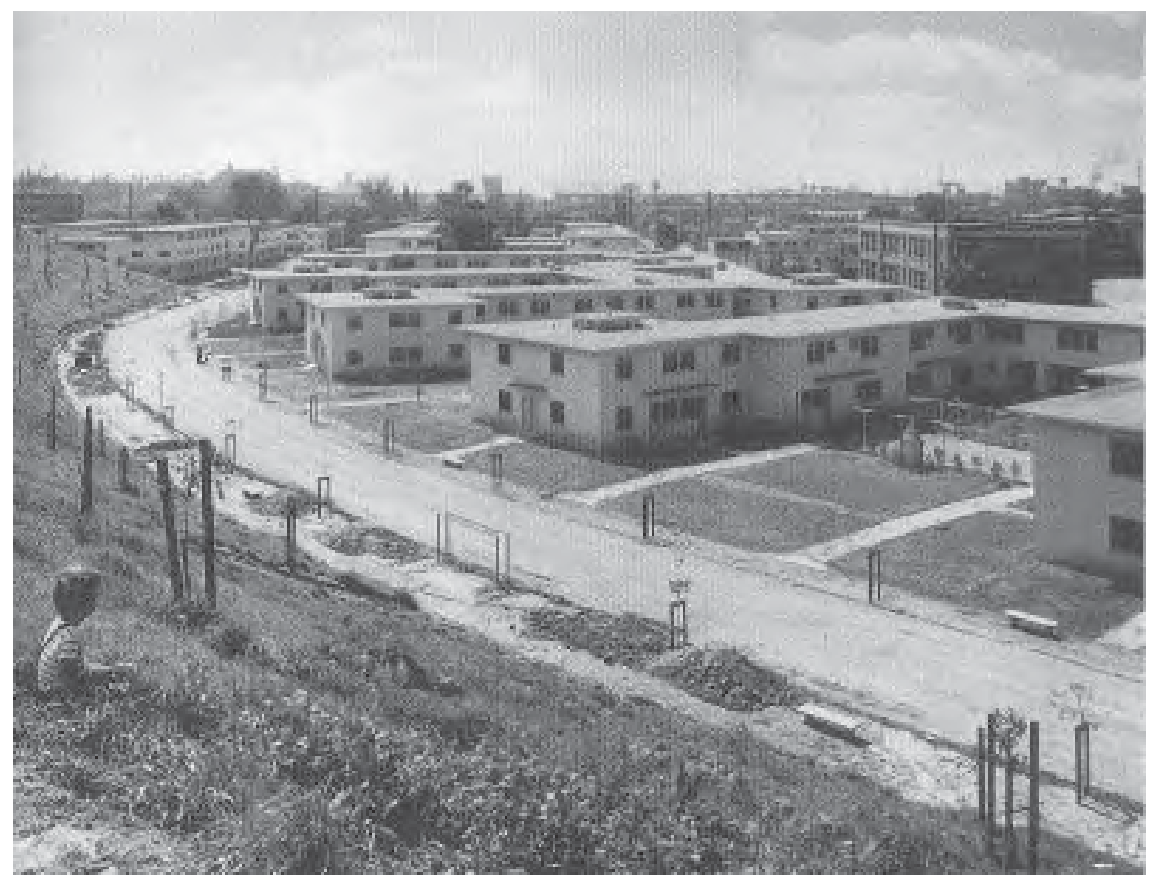

ayudas para poder acceder al alquiler o compra de una vivienda digna. El mismo año de la aparición de Modern Housing, el gobierno aprobaba la Federal Housing Act de 1934 y creaba una agencia federal dedicada a la gestión de ayudas a la vivienda, la Federal Housing Administration (FHA), institución que ha pervivido hasta la actualidad y cuyo primer cometido fue garantizar la estabilidad y fiabilidad del sistema hipotecario estadounidense.

Claramente influida durante su proceso de redacción y discusión por el trabajo de Baver, la aprobación, en 1937, de la Ley Wagner-Steagall, también conocida como la Public Housing Act de 1937, supuso una respuesta política a la altura de las dramáticas condiciones de la Gran Depresión. Mediante la provisión de fondos federales para generar empleos directos e indirectos con la construcción de viviendas, esta ley hacía frente a los insostenibles índices de pobreza, trataba de rebajar las tensiones sociales y se esforzaba por frenar la expansión del chabolismo, tanto en los suburbios como en el propio corazón de las ciudades norteamericanas hacia las que se estaba produciendo, especialmente en California, un éxodo masivo de población.

Muy pronto, los programas de vivienda auspiciados por la Administración Roosevelt revelaron su complejidad al intentar dar salida a las aspiraciones de diversas facciones políticas de un frente popular que aunaba tanto a intelectuales, empresarios progresistas, representantes sindicales y sectores de la población históricamente silenciados, como minorías raciales y asociaciones de mujeres.

En Los Ángeles y en general en el conjunto de toda California, la intervención del gobierno federal a través de su colaboración con las administraciones locales y la promoción privada en el terreno de la vivienda subvencionada contó con un amplio respaldo social mayor que en otros estados. Dicho apoyo se debió a la labor de un nutrido grupo de políticos, gestores, publicistas, técnicos y activistas. Entre ellos, arquitectos como Richard Neutra, Paul Williams, Lloyd Wright, Welton Wecket, Clarence Stein o Robert Alexander, consideraban que el diseño de viviendas a gran escala debía ser planteado desde la aplicación de teorías urbanas moder-

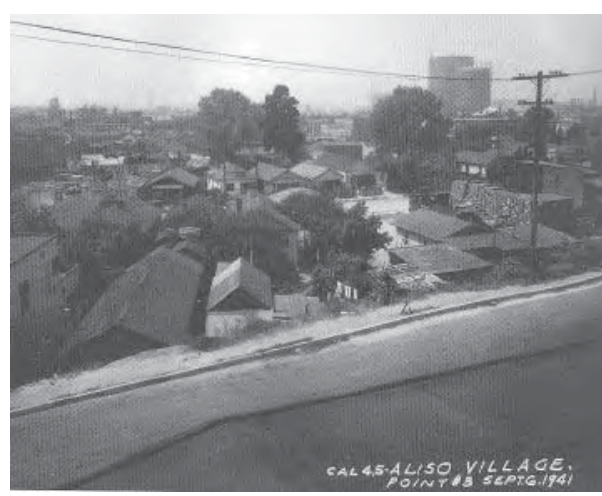

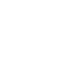

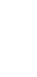




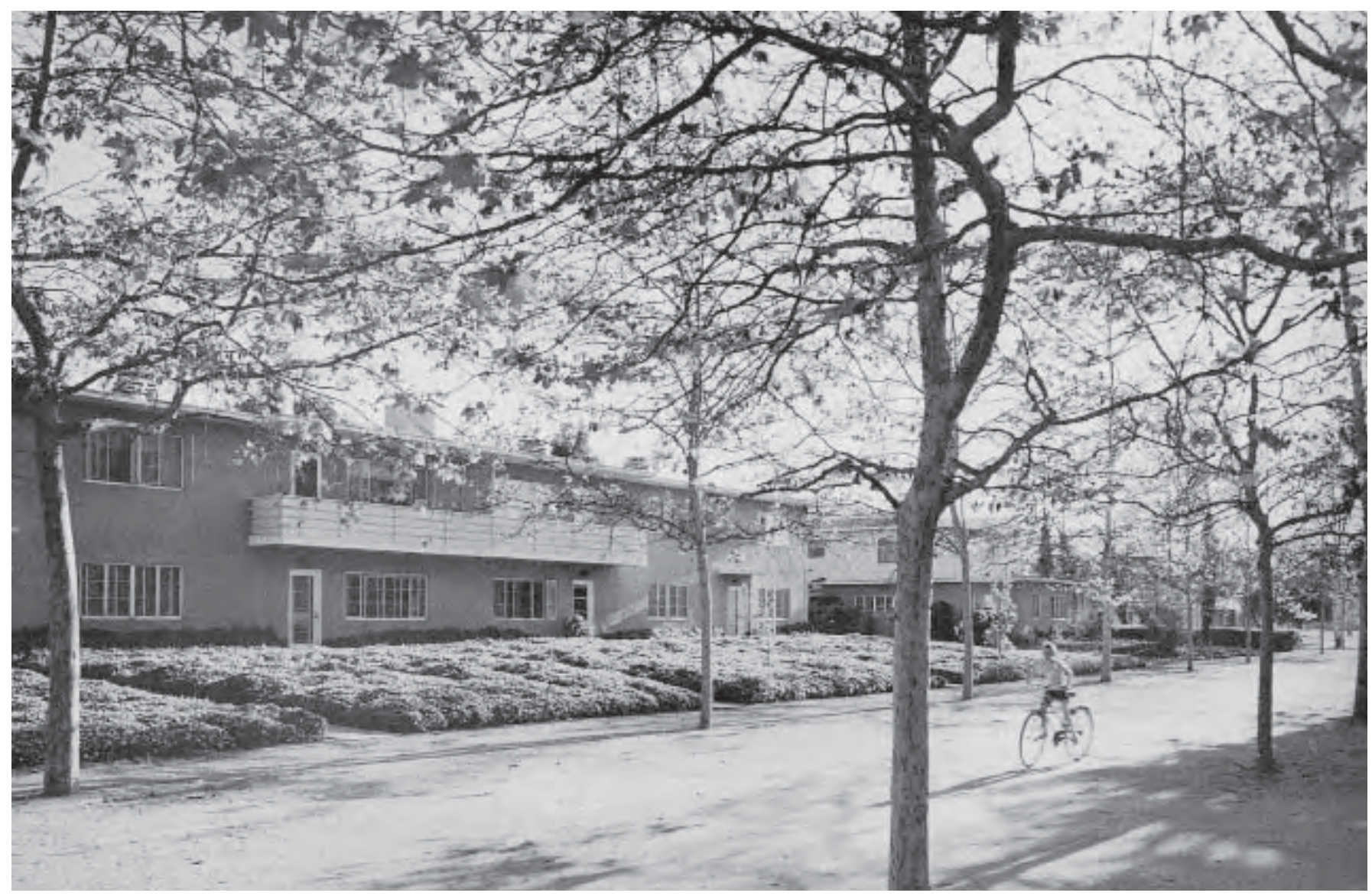

nas. Como es lógico, los arquitectos californianos, que durante la Gran Depresión habían experimentado un drástico descenso de sus encargos, entendieron rápidamente la importancia de su papel en los programas de vivienda pública, tanto como solución a la necesidad de alojamiento como oportunidad de empleo, incluido el suyo propio.

En el norte del estado William Wurster ${ }^{24}$ diseñó Valencia Gardens en San Francisco. Construido entre 1939 y 1943 fue uno de los primeros complejos terminados en la órbita de la Federal Housing Act de 1937. Su equivalente en Los Ángeles, Ramona Gardens, proyectado entre otros arquitectos por Lloyd Wright, fue inaugurado en enero de 1941.

El estallido de la Segunda Guerra Mundial agravó la crisis de la vivienda y proporcionó a los arquitectos nuevos ámbitos de acción en el terreno de la vivienda colectiva. Actuaciones como Hacienda Village, Pueblo Village, Amity Compton, Baldwin Hills Village y Aliso Village ${ }^{25}$, construido también por Lloyd Wright en el distrito obrero de Boyle Heights representan, con diferentes grados de éxito, un claro ejemplo de la variedad y densidad de los modelos de desarrollos de guerra y de posguerra llevados a cabo en California durante los años cuarenta. Por ejemplo, mientras Candlestick Cove, en San Francisco, que en uno de sus picos de ocupación dio alojamiento a más de 35.000 personas, fue descrito por el historiador Gerald Nash ${ }^{26}$ como un instant slum carente de servicios tan básicos como el pavimentado de calles o el alcantarillado, Channel Heights, en el límite de la Península de Palos Verdes, constituye una de las cimas de la vivienda pública en el Sur de California.

Por su parte, Channel Heights (1941-43), construido por Richard Neutra en un emplazamiento entre varios barrancos de indudable valor paisajís- 


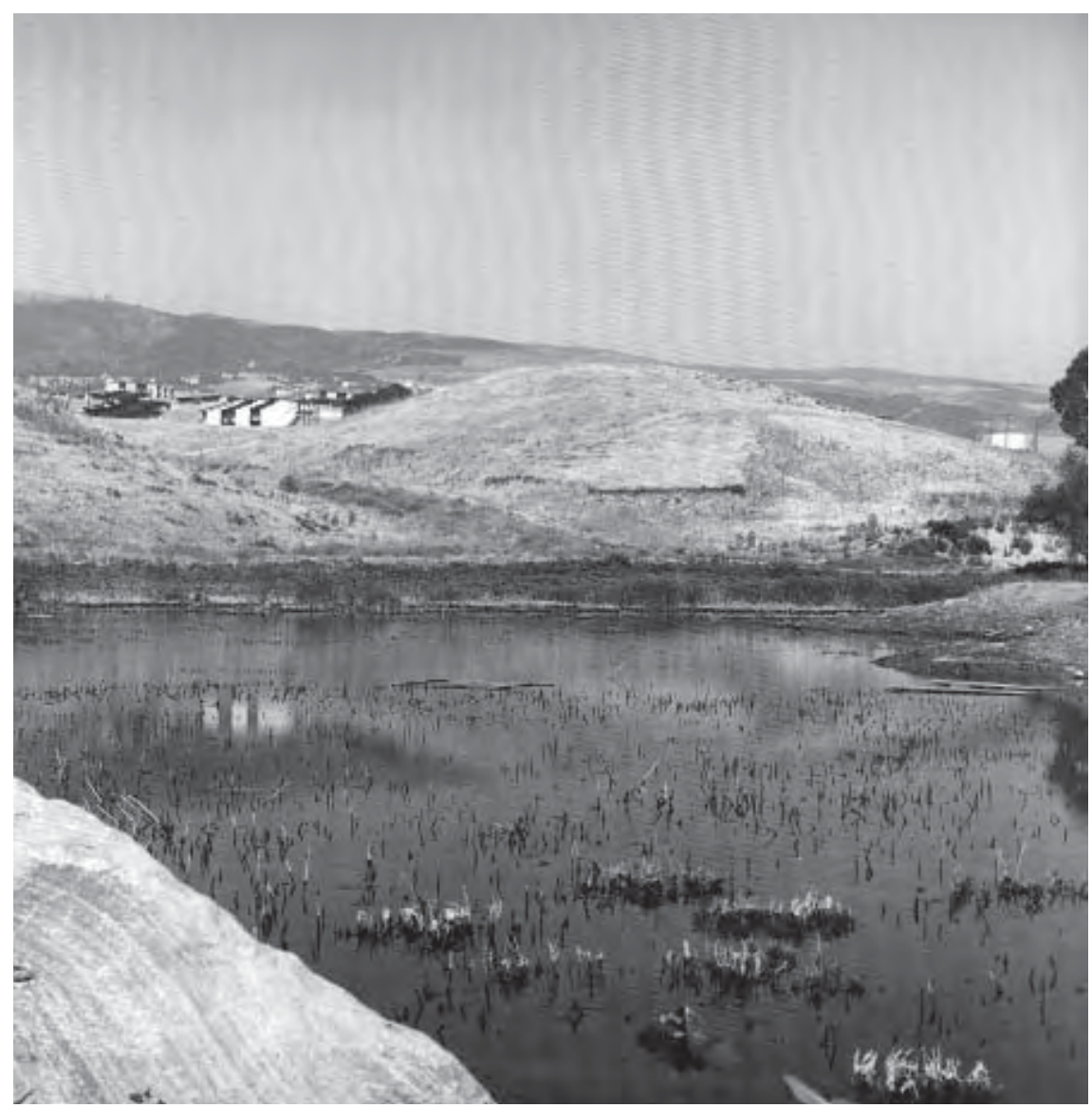

tico, estaba destinado a familias de obreros del puerto de San Pedro. Ahora desaparecido, fue el último de los conjuntos de viviendas permanentes financiado por la Federal Work Agency durante la guerra. Este complejo sorprendía por la modernidad de sus planteamientos urbanos y arquitectónicos. En el ámbito social, Channel Heights apostó por la integración racial, a pesar de estar prohibida por determinadas cláusulas que no fueron abolidas por la Corte Suprema de los Estados Unidos hasta 1948. Adaptándose a la topografía, Neutra proyectó 540 unidades ${ }^{27}$ de viviendas agrupadas en 222 edificaciones y distribuidas en una superficie de 150 acres. El coste de las viviendas, realizadas en madera para abaratar la operación, osciló entre los 2.600 y los 4.400 dólares. El planeamiento concedió gran importancia al diseño de los espacios públicos ajardinados y a los equipamientos comunes, algunos de ellos, como la escuela o el supermercado, eran piezas memorables.

El panorama de posguerra en Los Ángeles estuvo marcado por los esfuerzos del gobierno de Truman, desde la aprobación de la Housing Act de 1949, para continuar sufragando proyectos de vivienda frente a las presiones de los lobbies del sector inmobiliario. Finalmente, a principios de los años cincuenta, en connivencia con el conservadurismo político más reaccionario, éstos se sirvieron del paraguas de la amenaza roja para identificar vivienda social e ideología comunista y lograr así desactivar todo intento de intervención pública en sus intereses empresariales. En 1952, el proceso del Comité de Actividades Antiamericanas contra Frank Wilkinson, el idealista relaciones públicas de la Housing Authority de la ciudad de Los Ángeles fue seguido con gran atención por parte de los medios. Habiendo sido durante años una las voces más enérgicas en la defensa de los programas de vivienda del Fair Deal, su encarcelamiento escenificaba el final de una época.
Izquierda y derecha: R.Neutra, Channel Heights, San Pedro, Los Ángeles, 1942. Fotografías de Julius Shulman

Pág. anterior: Clarence Stein y Robert Alexander: Baldwin Hills, Los Ángeles, 1938-42. Fotografía de Julius Shulman
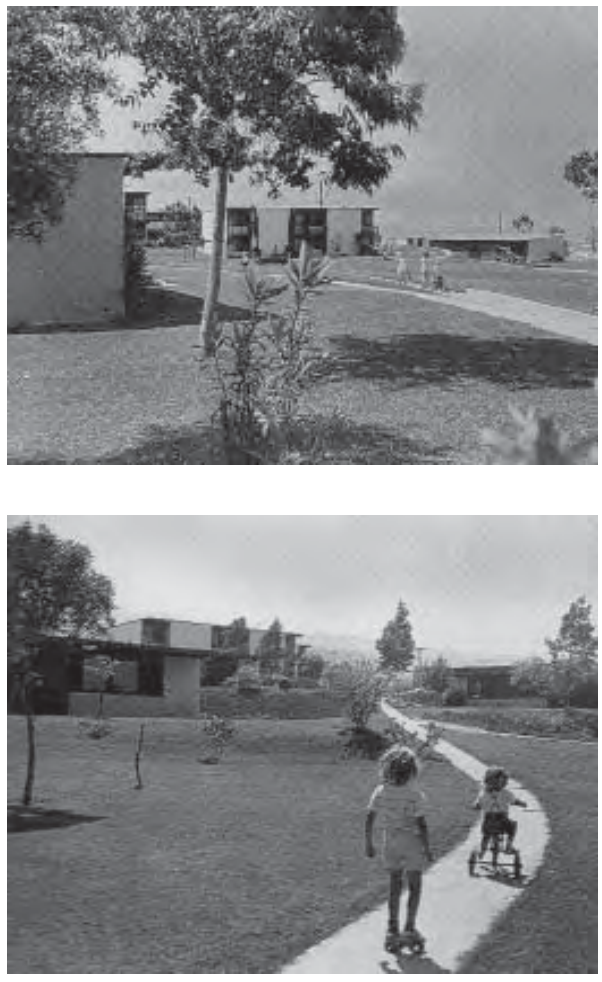
Derecha: Crestwood Hills, 1950. Fotografía de Julius Shulman

Abajo: Cartátula del proyecto de la MHA en Crestwood Hills. Fuente: Cory Buckner

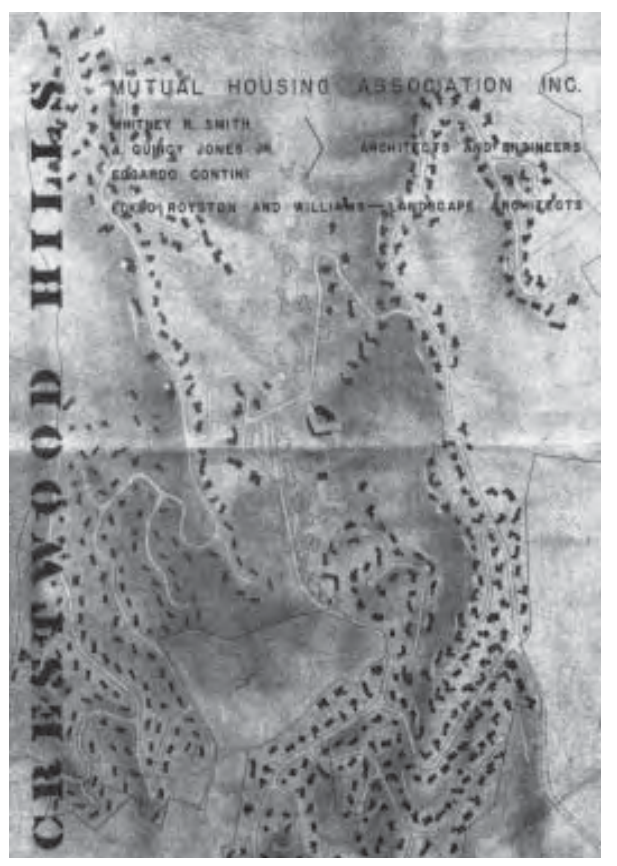

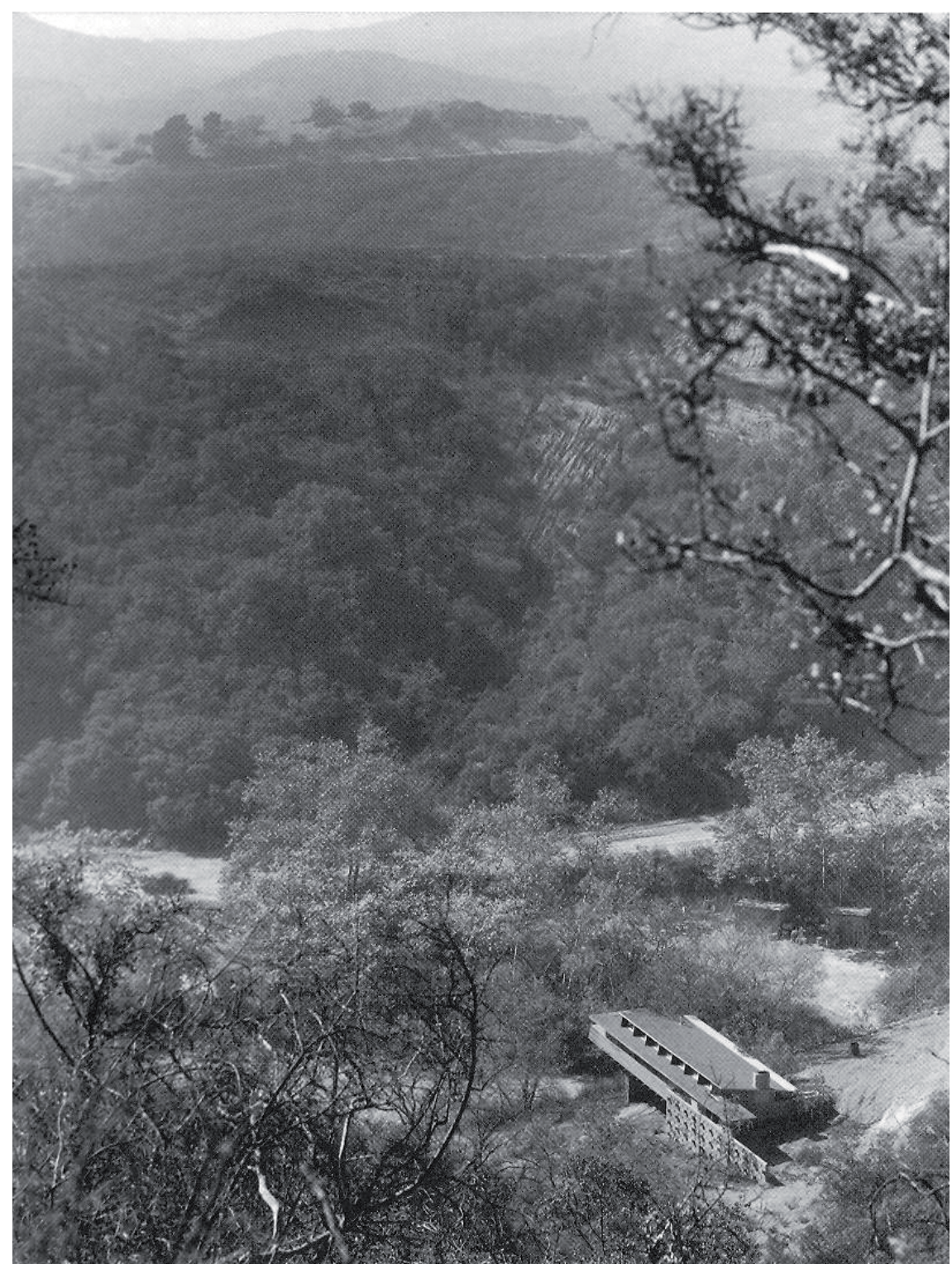

\section{El cooperativismo de posguerra, oasis de vida moderna}

En el transcurso de la contienda bélica, cientos de miles de norteamericanos trabajaron en la construcción naval, aeronáutica y en todo tipo de oficios relacionados con la industria bélica del país. Durante ese tiempo, al menos siete millones de personas se desplazaron por motivos laborales. Un porcentaje muy significativo se trasladó a California, donde se concentraban buena parte de las factorías y donde solamente en el condado de Los Ángeles se produjo un aumento de población de alrededor de un millón de habitantes entre 1940 y 1943. Tras el final de la guerra, al regreso masivo de veteranos del frente se sumó otra oleada de trabajadores que llegaron con sus familias atraídos por una nueva etapa de prosperidad. La consolidación de la clase media y la transformación radical del contexto socioeconómico hicieron que la necesidad de techo diera paso paulatinamente a la posibilidad de lograr el viejo sueño de una casa con jardín.

A pesar de la demanda exponencial y de la ocupación de nuevas áreas periféricas, en California, después de la guerra, comprar suelo al por mayor todavía resultaba relativamente barato. Muchos particulares consiguieron evitar al promotor privado asociándose para adquirir directamente 


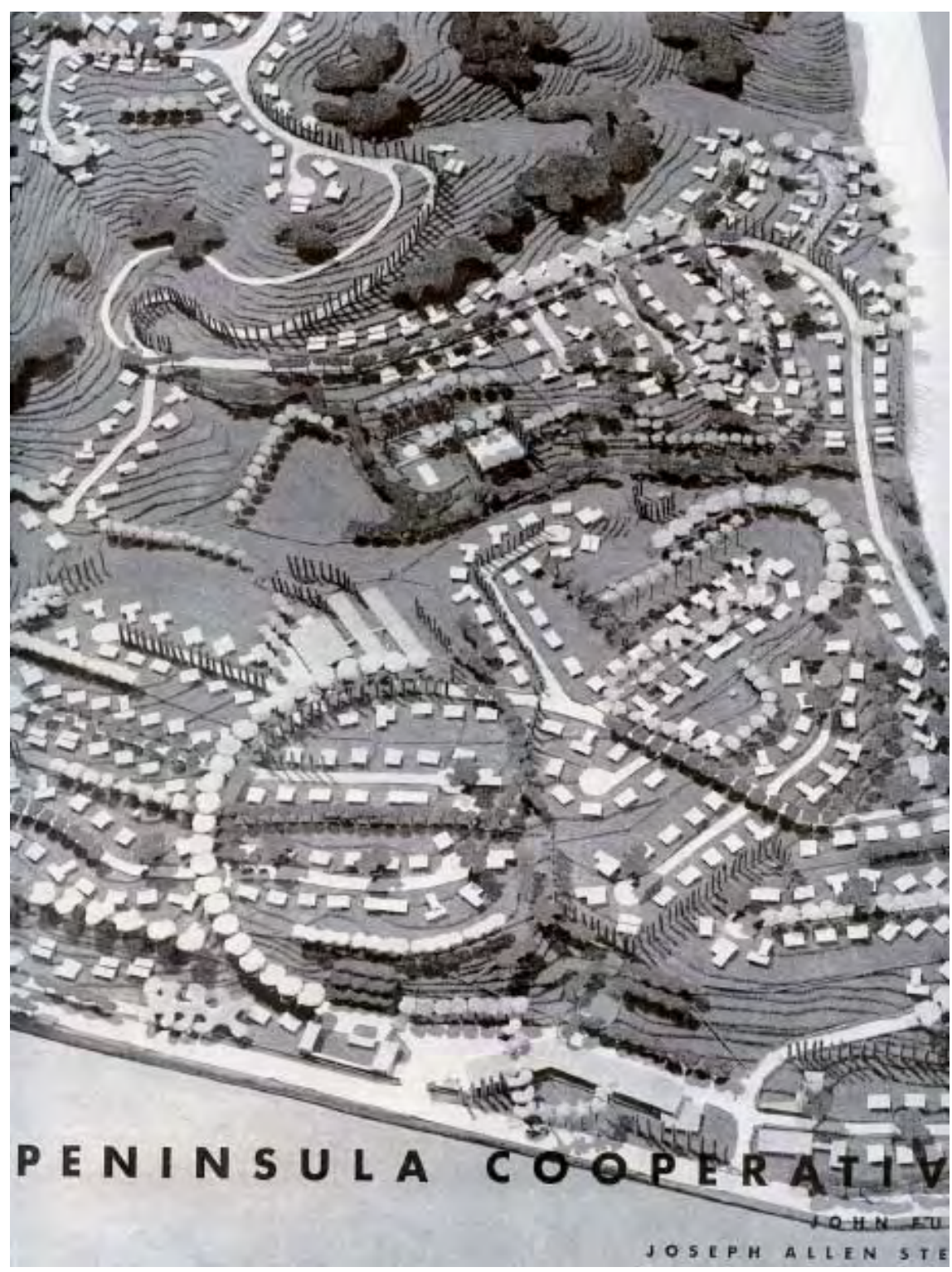

grandes extensiones de terreno que parcelaban y distribuían entre pequeños propietarios que habían invertido sus ahorros en la operación. En aquellos momentos en los que culminaba el proceso descentralizador de la ciudad de Los Ángeles, cada vez más dispersa, el cooperativismo permitió que muchas familias con recursos limitados pudiesen tener acceso a una vivienda unifamiliar y formar parte de una comunidad suburbana.

En el estado de California, las cooperativas venían mostrando su eficacia desde los tiempos de la Gran Depresión, a partir de la aprobación por el Congreso de la National Housing Act de 1934. Habían sido frecuentes en los alrededores de la Bahía de San Francisco, en el ámbito rural del Valle de San Joaquín y también en la expansión metropolitana de los distritos de Los Ángeles y de sus municipios adyacentes. El sistema se popularizó durante el boom inmobiliario de los años de posguerra. Estas agrupaciones se difundían en diversos medios como periódicos locales, revistas populares y hasta publicaciones especializadas y de gran tirada como House \& Garden, que se hacían eco de las cooperativas que se iban formando. Los poderes públicos controlaban de facto su constitución mediante decretos que regulaban las características que debían reunir para que la Federal Housing Authority avalara o no los préstamos solicitados

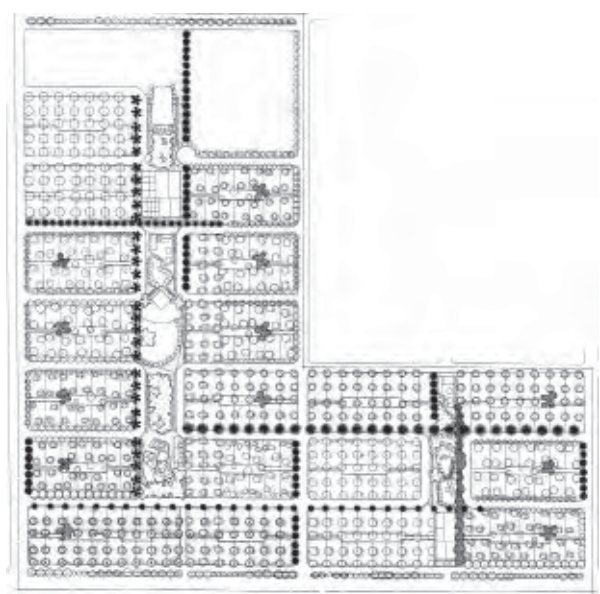

Izquierda: Artículo sobre el conjunto de viviendas Peninsula Cooperative en Palo Alto (Bahía de San Francisco). J. Funk y J. A. Stein, arquitectos, con G. Eckbo, paisajista. Publicado en Arts \& Architecture, septiembre de 1948 Derecha: G. Ain y G. Eckbo: Community Homes, 1946-49, plano de conjunto (proyecto no construido) 

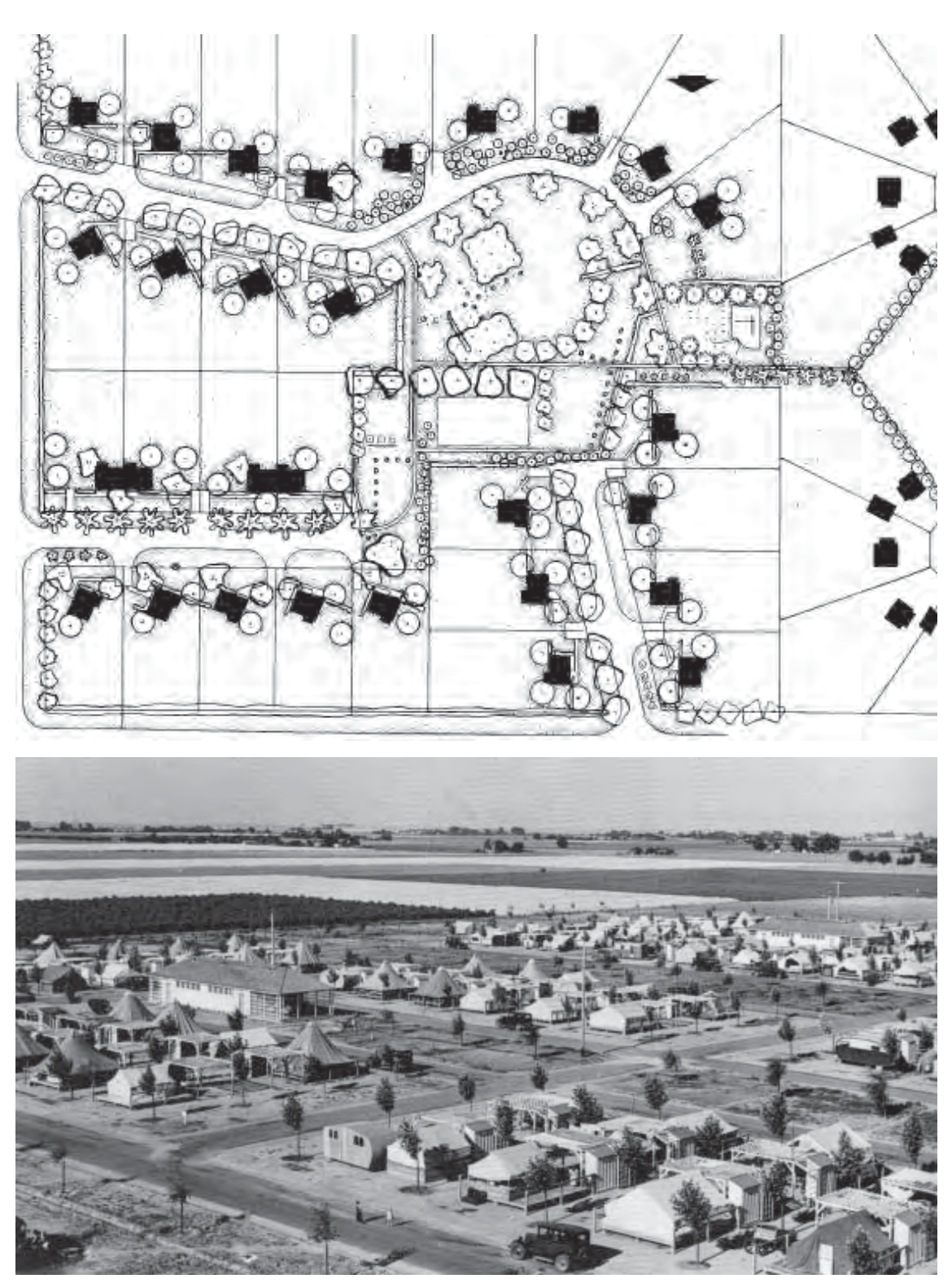

Dcha arriba: Shafter Camp en Tulare Basin, Valle de San Joaquin, 1938. G. Eckbo: Plano de asentamientos permanentes de jornaleros para la Farm Security Administration (FSA) Dcha abajo: Shafter Camp. Asentamientos provisionales para trabajadores agricolas de la FSA. Fuente: Oakland Museum of California Abajo: Gregory Ain: Park Planned Homes, Altadena, 1946-47. Fotografía de Julius Shulman

Pág. siguiente: Mar Vista Housing, Venice, $C A$, 1948-1949. Fotografía de J. Shulman (arriba) y planta de la ordenación (abajo)

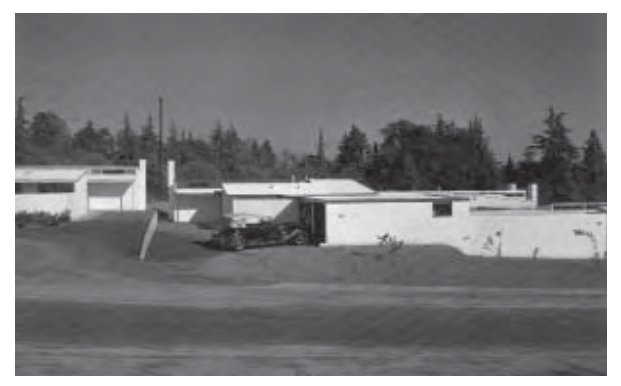

por las asociaciones de propietarios. Se subvencionaba la construcción de viviendas en función de su viabilidad económica, facilidad de venta, futura revaloración, etc. Obviamente, bajo dichos criterios tendía a imponerse la uniformidad en todas estas operaciones y las comunidades con planteamientos sociales arriesgados, como la integración racial, o proyectos arquitectónicos innovadores se encontraban con dificultades para obtener créditos o acceder a bonificaciones.

No obstante, entre estas últimas hay ejemplos notables de urbanizaciones proyectadas por arquitectos modernos de la importancia de Gregory Ain, quien colaboró estrechamente con el paisajista Garret Eckbo en actuaciones como Park Planned Homes en Altadena (1946-47); Mar Vista Housing (Modernique Homes) en Venice (1948-49); o Community Homes (1946-49), prevista para el Valle de San Fernando pero que no llegó a construirse.

De todas ellas, Community Homes fue la propuesta más idealista y ambiciosa. En su planificación había trabajado también Simon Eisner, concibiendo un esquema en forma de $L$ que organizaba 280 viviendas unifamiliares sobre un terreno llano que ocupaba una superficie de 100 acres. 

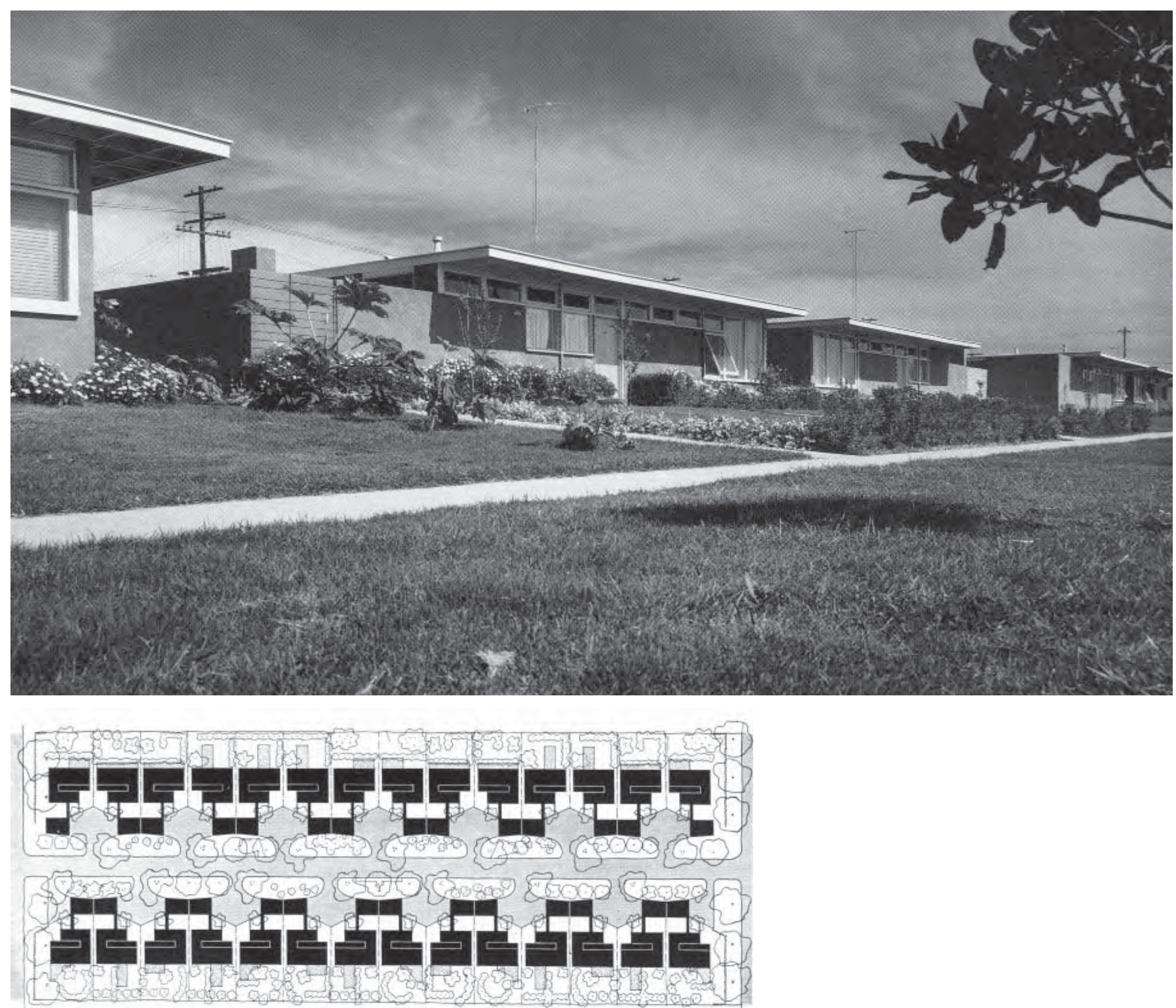

Lo más sorprendente-casi provocador para Los Ángeles-era la prioridad que se otorgaba a las circulaciones peatonales y a la introducción de espacios verdes de uso común sobre los jardines privados y el tráfico rodado. A pesar de haberse quedado en la mesa de dibujo, Community Homes puede considerarse como el precedente de otra cooperativa que se tratará con mayor detenimiento, la Mutual Housing Association (MHA). Por una parte, por la presencia de Garret Eckbo como paisajista, figura de referencia en el espíritu y en el diseño de este tipo de actuaciones; por otra parte, por las convicciones sociales con las que se abordaron ambos proyectos; y, por último, porque muchas de las actitudes de Gregory Ain, como la investigación arquitectónica y empleo de la técnica para elevar el nivel de la construcción de bajo coste, se encuentran en la MHA y caracterizan también la obra de Quincy Jones.

Gregory Ain fue uno de los arquitectos californianos ideológicamente más posicionados hacia la izquierda. Activo defensor del igualitarismo había sido educado por sus padres en el compromiso social. Parte de su infancia había trascurrido en una cooperativa socialista de raíz utópica en el desierto de Mojave, Llano del Rio. Por supuesto, se trataba del cooperativismo en su formulación más radical, pero la experiencia 


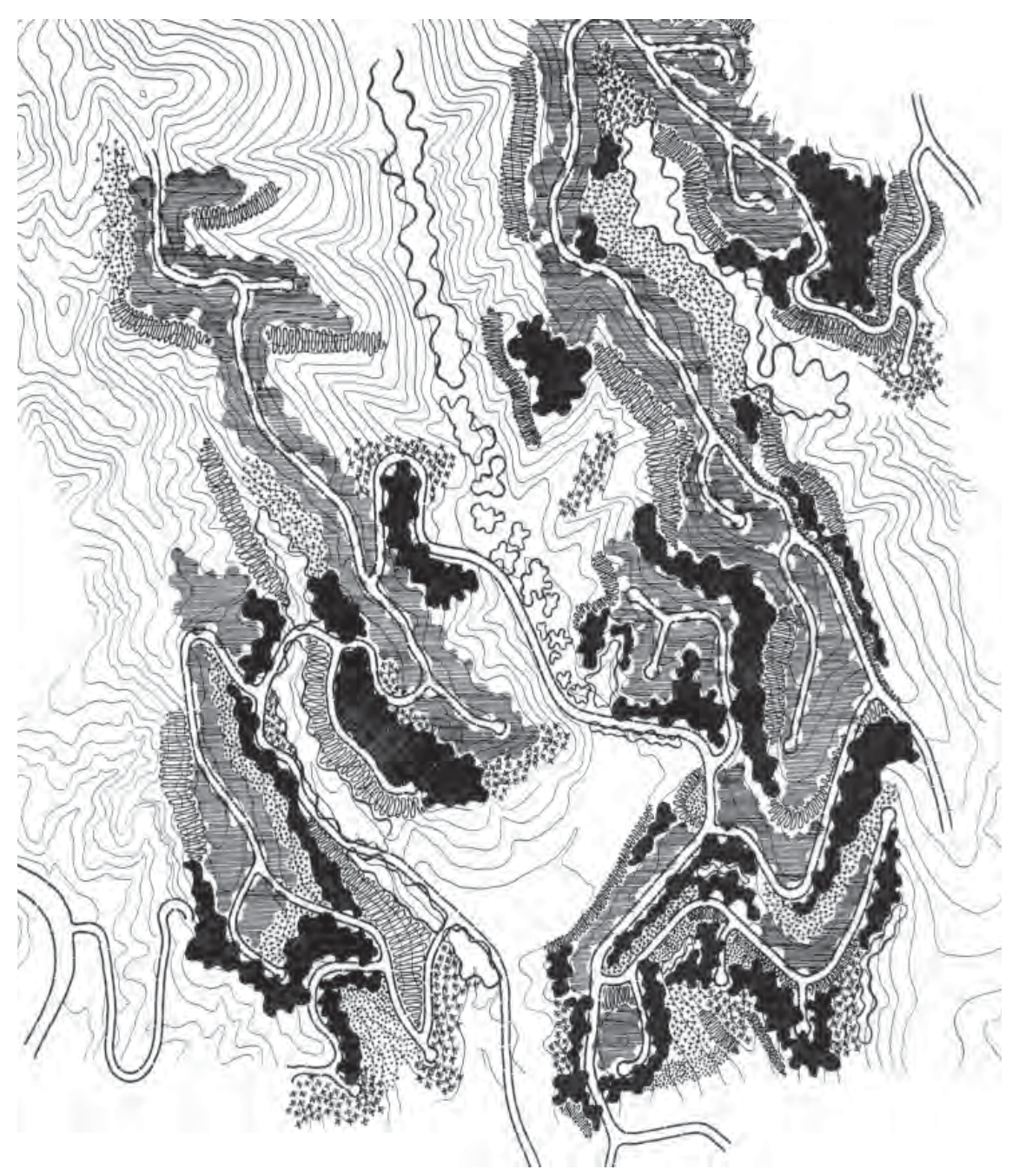

Arriba: $M H A$, esquema general de plantación de arbolado en Kenter Kanyon. Fuente: $G$. Eckbo, Landscape for Living Abajo: MHA, plano de implantación de las viviendas

Página siguiente: $M H A$, fotografía del movimiento de tierras publicada en Arts \& Architecture, septiembre 1948

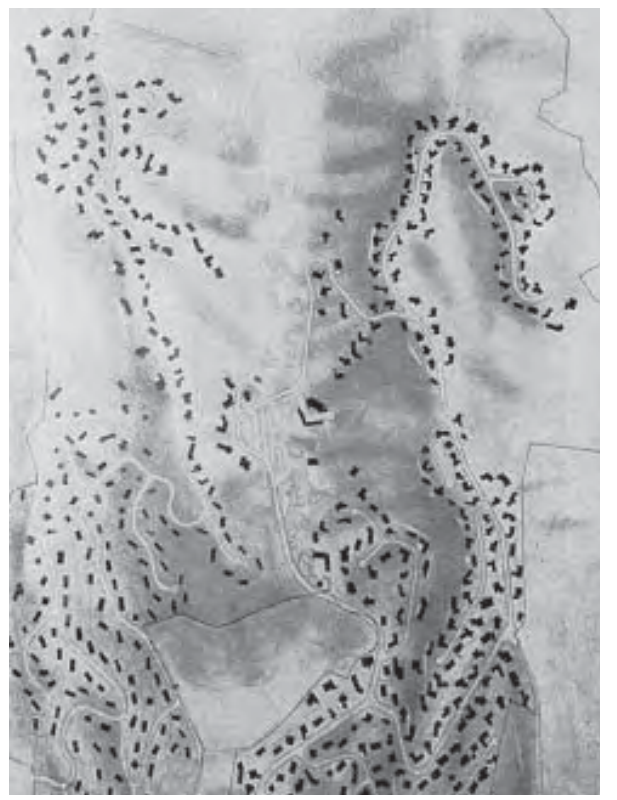

le había permitido conocer de primera mano las ventajas y dificultadas de habitar en colectividad. Ain estaba convencido de que la vivienda, más allá de satisfacer las necesidades de alojamiento y de resolver las funciones puramente mecánicas de una casa, tenía que contribuir al crecimiento personal del individuo y, por ello, debía evitar el aislamiento facilitando vínculos que desarrollaran el sentimiento de pertenencia a una comunidad. Estas mismas convicciones las había expresado por escrito tras su participación como jurado en el renombrado concurso Designs for Postwar Living promovido por la revista Arts \& Architecture en 1943. En su entusiasmo, Ain había comentado el concurso calificándolo de verdadero "simposio sobre la cooperativa" y en las páginas de la revis$\mathrm{ta}^{28}$ había afirmado que el éxito de las comunidades suburbanas residía, sobre todo, en la relación que cada una de sus viviendas establecía con el resto del vecindario ${ }^{29}$.

Dorothée Imbert, en su texto The Art of Social Landscape Design ${ }^{30}$, sostiene que de las obras surgidas de la colaboración entre Gregory Ain y Garret Eckbo, Community Homes es la más arriesgada y que sus innovadoras ideas tenían más de modelo europeo que de promoción acorde con la mentalidad individualista norteamericana. Fue desde luego un proyecto insólito por su dimensión social, énfasis en lo público, proceso democrático y planteamiento de comunidad interracial. Por eso mismo, Community Homes tuvo tantos frentes abiertos que, tras varios años para conseguir los terrenos, organizar a los propietarios, sortear obstáculos burocráticos obteniendo permisos de los departamentos implicados 


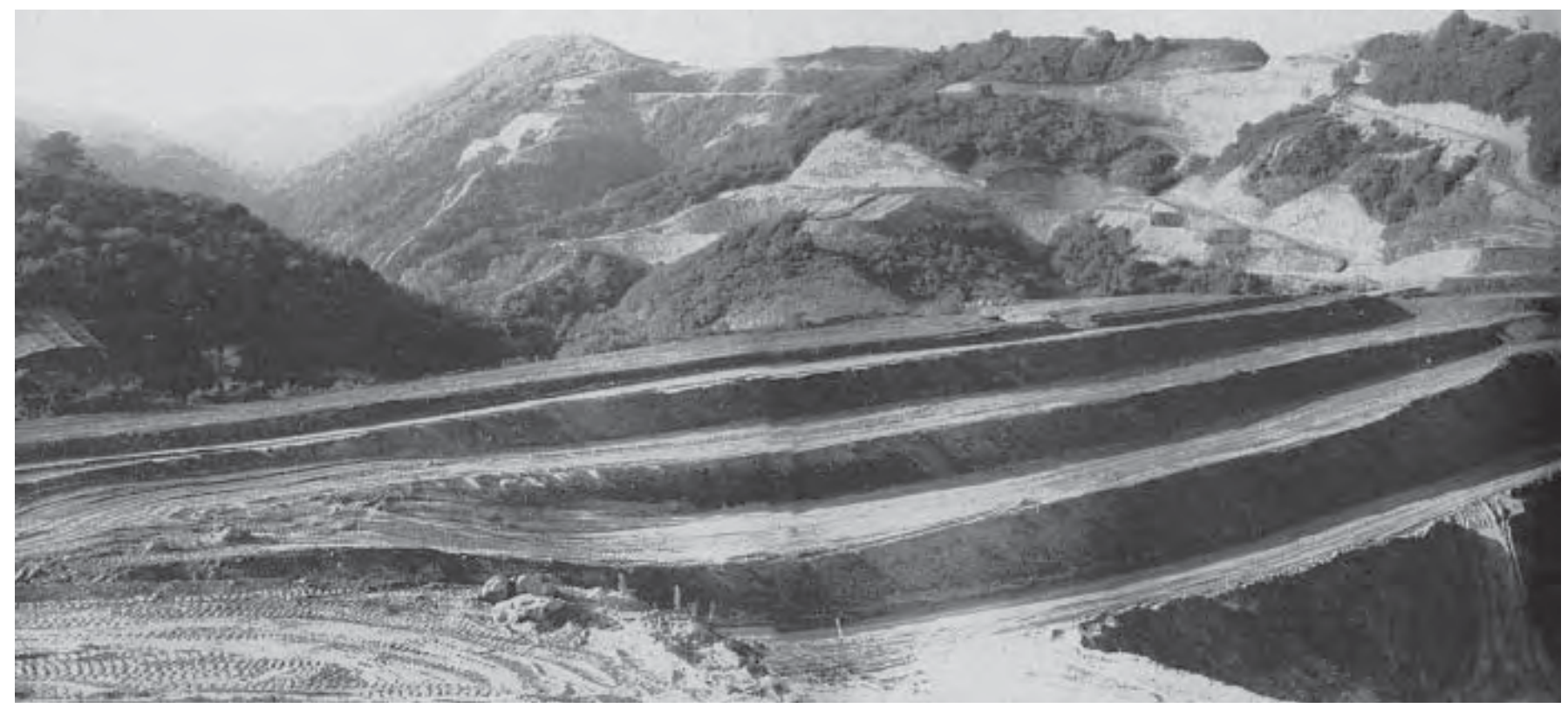

y modificar una vez y otra vez los planos, la propuesta se topó con la incomprensión de la Federal Housing Authority que negó toda forma de financiación, argumentando que la inclusión de minorías raciales ponía en peligro la solvencia de la operación. De haberse construido hubiera sido uno de los experimentos más progresistas de vivienda comunitaria en los Estados Unidos desde la histórica ciudad jardín de Radburn en Nueva Jersey (1929). Después del fracaso de Community Homes, sus miembros se dirigieron hacia otras cooperativas y algunos de ellos pasaron a integrase en la recién constituida Mutual Housing Association, que empezó a construirse en 1949.

La MHA ${ }^{31}$, urbanizada como Crestwood Hills en las colinas de Brentwood, al oeste de Los Ángeles, es una de las agrupaciones de viviendas más singulares de la época y supuso uno de los escasos ejemplos residenciales donde sus autores abordaron la gran escala del paisaje desde planteamientos modernos, materializando una aspiración que nunca logró ninguno de los prototipos del Case Study House Program.

La historia de la MHA había comenzado en 1945, cuando cuatro músicos ${ }^{32}$ de Los Ángeles decidieron invertir conjuntamente sus ahorros en la adquisición de un solar donde edificar sus respectivas viviendas. Buscaban un emplazamiento atractivo y una parcela con tamaño suficiente para albergar un gran jardín común y una piscina que, de forma individual, no hubieran podido costearse. Lo limitado de sus medios económicos y el deseo de hacer realidad un modelo de vida comunitario en un entorno natural inclinó a sus fundadores hacia la elección del sistema cooperativista y así, en 1946, crearon la Cooperative Housing Group. Difundieron sus planes entre varios amigos quienes, rápidamente, mostraron su disposición para involucrarse. De este modo, una vez que consiguieron ampliar el grupo a treinta miembros, animados por la buena acogida que había tenido su idea, comenzaron a publicitarla en periódicos locales como el Hollywood Citizen-News. Pronto cientos de personas secundaron la iniciativa. La cooperativa, que nació compartiendo el optimismo de Community Homes y su interés por los espacios públicos, terminó denominándose Mutual Housing Association y logró reunir a 500 familias de clase media, en general con cierto nivel cultural y moderados ingresos. 

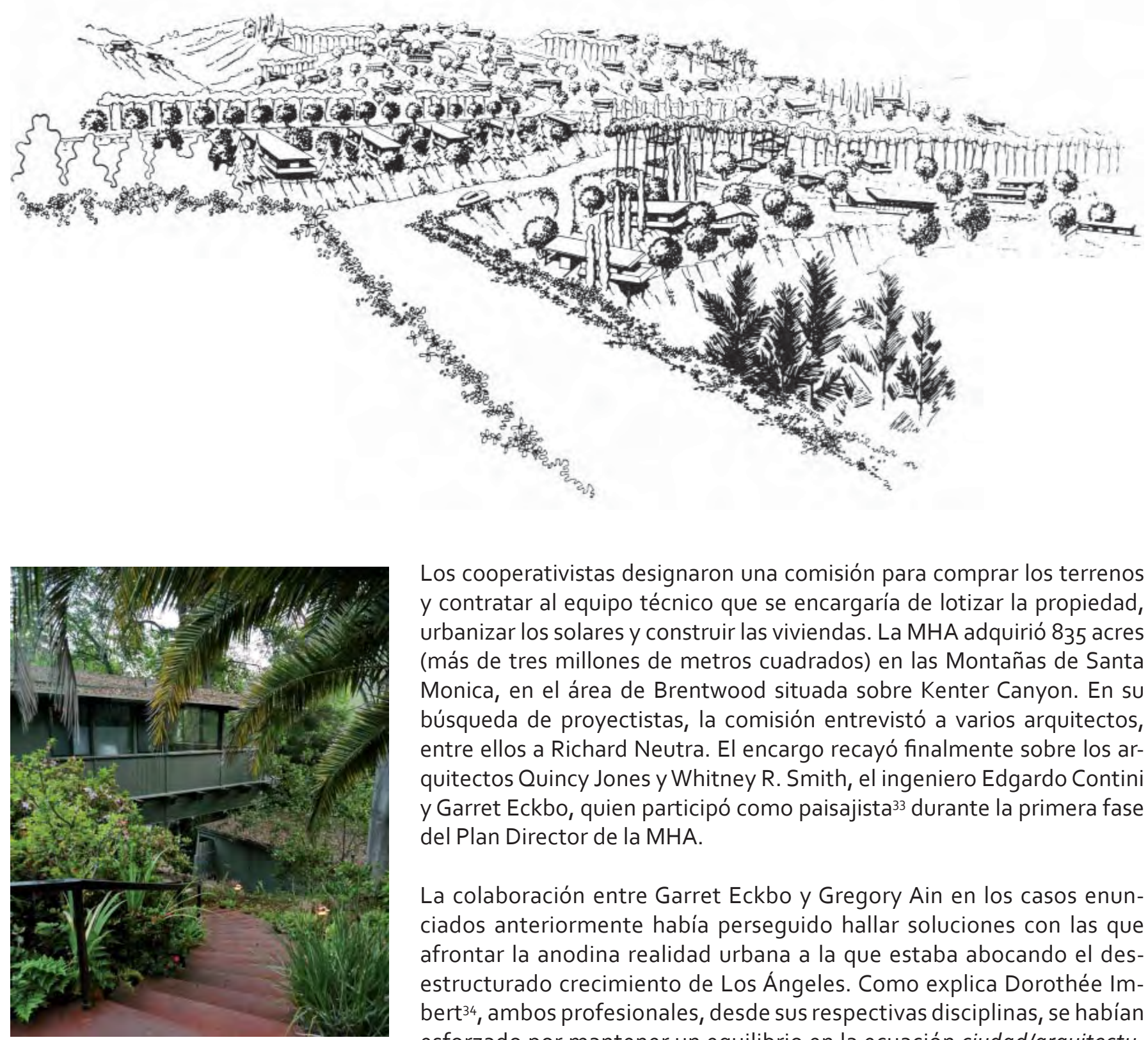

Los cooperativistas designaron una comisión para comprar los terrenos y contratar al equipo técnico que se encargaría de lotizar la propiedad, urbanizar los solares y construir las viviendas. La MHA adquirió 835 acres (más de tres millones de metros cuadrados) en las Montañas de Santa Monica, en el área de Brentwood situada sobre Kenter Canyon. En su búsqueda de proyectistas, la comisión entrevistó a varios arquitectos, entre ellos a Richard Neutra. El encargo recayó finalmente sobre los arquitectos Quincy Jones y Whitney R. Smith, el ingeniero Edgardo Contini y Garret Eckbo, quien participó como paisajista ${ }^{33}$ durante la primera fase del Plan Director de la MHA.

La colaboración entre Garret Eckbo y Gregory Ain en los casos enunciados anteriormente había perseguido hallar soluciones con las que afrontar la anodina realidad urbana a la que estaba abocando el desestructurado crecimiento de Los Ángeles. Como explica Dorothée Imbert ${ }^{34}$, ambos profesionales, desde sus respectivas disciplinas, se habían esforzado por mantener un equilibrio en la ecuación ciudad/arquitectura/paisaje. No obstante, en el caso de Crestwood Hills, el cometido de Garret Eckbo, como asesor del equipo de arquitectos, adquiría la máxima importancia, ya que el equilibrio en esta ecuación estaba descompensado por el enorme peso específico del paisaje. Ya no se trataba de una planicie indeterminada sino de las estribaciones de las Montañas de Santa Mónica, una de las mejores localizaciones de la ciudad. La promoción debía construirse sobre un terreno fuertemente caracterizado por su topografía de colinas y gargantas donde las pendientes, en las pronunciadas laderas del cañón, sobrepasaban el 30\%. El lugar, cubierto de sicomoros poseía además excelentes vistas y, dada su proximidad al océano, recibía directamente las brisas del Pacífico.

La Mutual Housing Association supuso una de las primeras oportunidades en California para experimentar la gran escala desde los principios modernos, abordando la transformación del territorio con sensibilidad paisajística y la construcción de una arquitectura de calidad bajo premisas de producción industrial y bajo coste. 


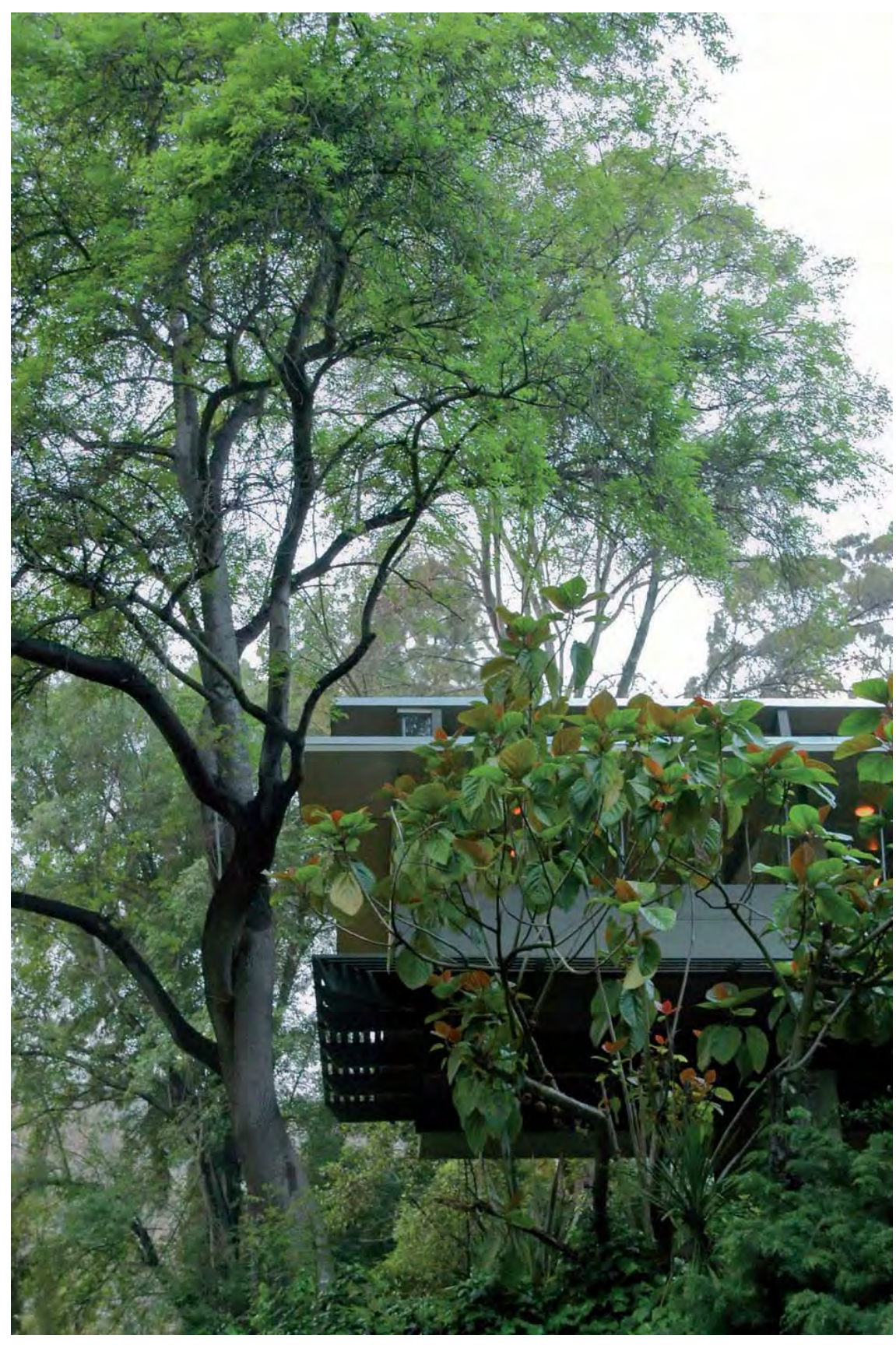

Asumiendo la topografía como primera condición de proyecto, Eckbo planteó un esquema organizativo que trataba de poner en valor las formas naturales de Kenter Canyon para que, una vez construidas las viviendas y plantados los jardines, ni la arquitectura ni la vegetación confundieran el perfil original de las montañas. En el plano de conjunto se aprecia cómo el trazado sinuoso de las calles responde a una lógica derivada de la propia orografía, ajustándose a una estructura simple, definida sólo por las dos principales alineaciones de crestas. De este modo, conseguía que las parcelas minimizaran la presencia de las pendientes, evitaba el amontonamiento y aprovechaba el vacío natural del cañón para que los espacios verdes separaran las áreas edificadas, ganando así mejores vistas sobre el paisaje.

Aunque esta estructura fue respetada en las sucesivas fases del planeamiento, no se tuvo exactamente en cuenta el proyecto de jardinería que acompañaba al Plan Director. Para las zonas de uso común, Eckbo había imaginado un ambiente mediterráneo donde las especies introduci-
Derecha y página anterior abajo: $M H A$, vistas actuales de una de las viviendas. Fotografías del autor

Página anterior arriba: $M H A$, perspectiva esquemática de ambiente con el paisajismo original de 1948. Fuente: Garret Eckbo, Landscape for Living 


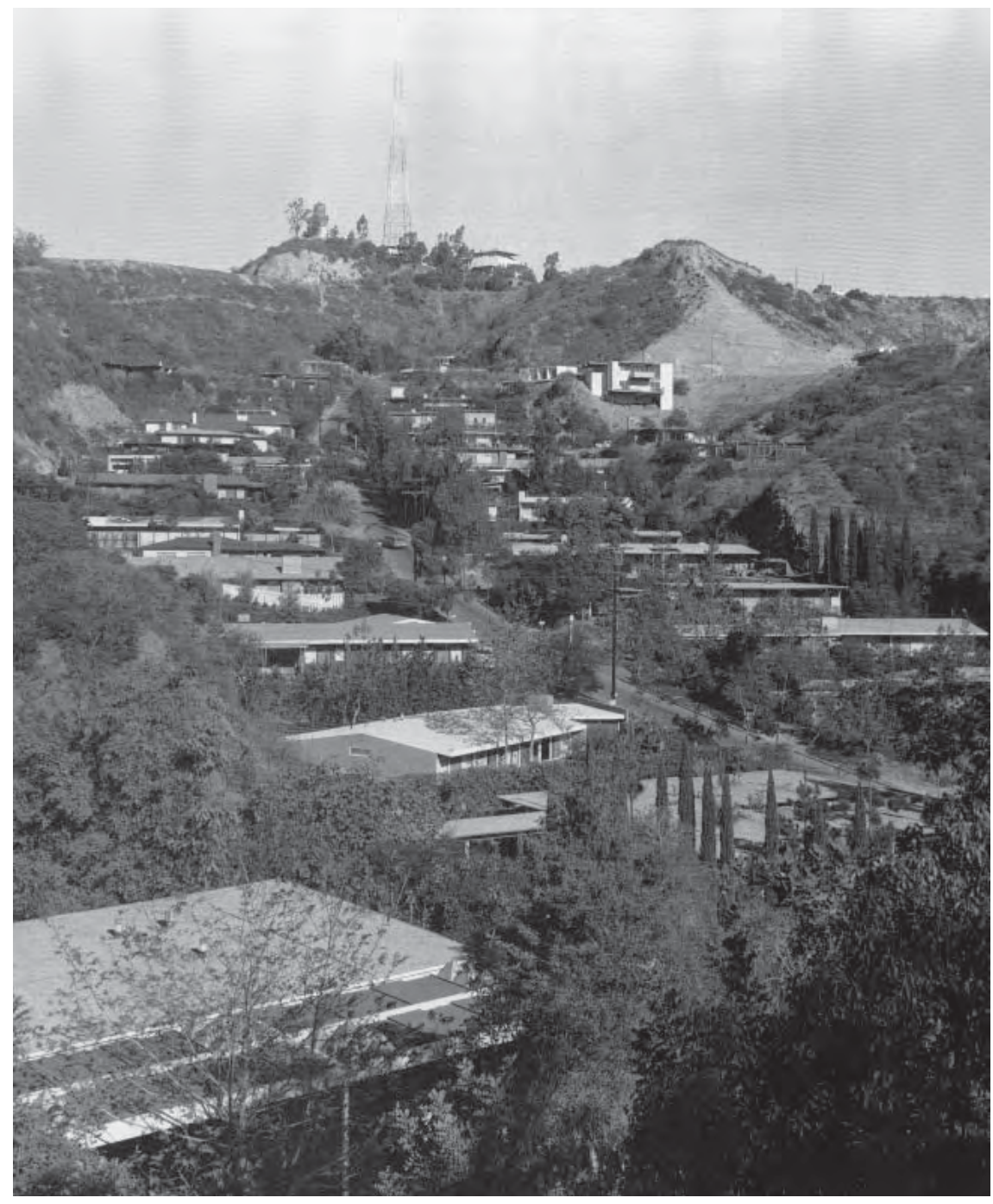

Garret Eckbo, Wonderland Park Cooperative en Laurel Canyon, Los Ángeles, 1955. Eckbo realizó el proyecto general de paisajismo y diseño numerosos jardines, incluido el suyo

Página siguiente izquierda: Portada del suplemento de vivienda de Los Ángeles Times de 2 de enero de 1948 ilustrando una de las grandes operaciones de track housing que estaban transformando el territorio metropolitano Página siguiente derecha: $M H A$, diferentes tipologías de jardines planteados por G. Eckbo. Fuente: Landscape for Living das debían armonizar con los jardines privados y completar la naturaleza existente en las colinas. También la vegetación escogida, además de considerar criterios de adaptación climática, respondía a las intenciones del paisajista de subrayar las formas naturales de Crestwood Hills, pero dotándolas de una nueva personalidad y articulando su percepción mediante las correcciones introducidas por el proyecto ya que, como él mismo no se cansaba de repetir, lo natural no tenía por qué ser la antítesis de lo formal.

Imbert describe del siguiente modo el carácter de la intervención: "para lograr este equilibro, las especies de gran copa y de menor altura serían plantadas en la cima de las colinas, empleando árboles cada vez más altos o esbeltos conforme se descendiera de cota. Los olivos dominarían las cumbres, apoyados de vez en cuando con alguna palmera; los aguacates se extenderían por los niveles intermedios seguidos por los cipreses, cedros y pinos y, más abajo, los eucaliptos; completando la paleta los álamos acompañarían a los sicomoros existentes en el fondo del valle" ${ }^{\prime \prime 35}$.

La mayoría de los clientes pensaron que este colorista programa vegetal resultaba demasiado exótico y lo rechazaron por considerarlo poco natural, como si desmontar cientos de miles de metros cúbicos de tierra virgen para construir una urbanización fuera una acción natural. Esta incomprensión desanimó profundamente a Eckbo, que siempre había sostenido que el papel del diseño era mejorar la relación entre las per- 


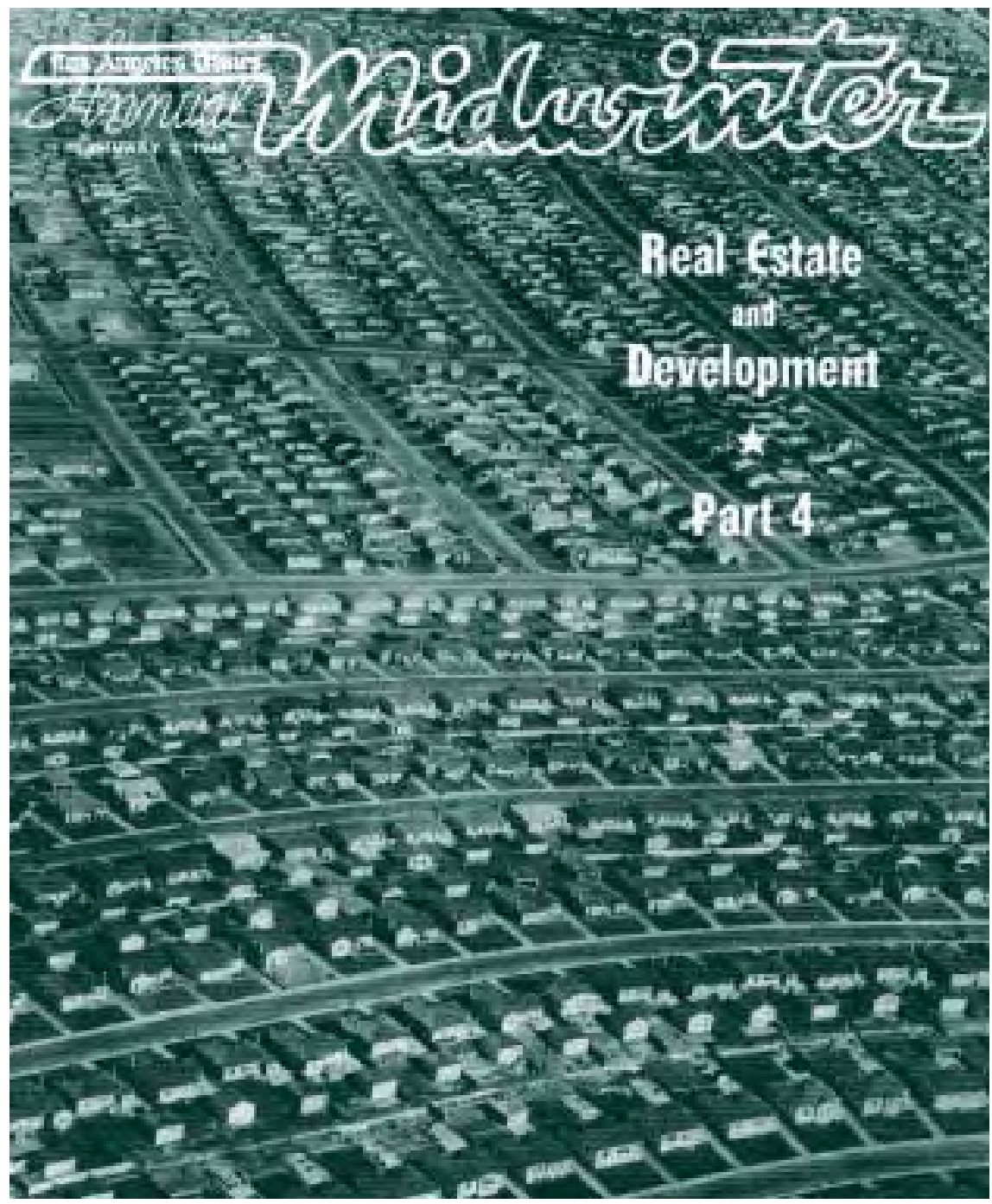

sonas y el medio en el que se desenvuelven, razonando que, antes que hacer desaparecer simplemente las viviendas entre la vegetación, su trabajo había consistido en procurar auténticas relaciones espaciales para humanizar el paisaje.

Las discrepancias con las que fue recibida la sugerente propuesta de Garret Eckbo tenían su origen en la esquiva definición de lo que es natural y en su aceptación por parte del público. Las voces más críticas con el trabajo de Eckbo procedían de aquellos que, preocupados por ocultar la edificación, pretendían recurrir a la plantación indiscriminada con tal de borrar las huellas de la presencia humana en Kenter Canyon. Eckbo se preocupó durante toda su carrera de rebatir estas actitudes y de defender que "reproducir a toda costa las formas de la naturaleza es lo opuesto a dar forma a la naturaleza" ${ }^{36}$ y que, en el fondo, es en lo que consiste crear un paisaje. No conviene entrar ahora en la compleja discusión sobre los borrosos límites entre realidad y ficción que caracterizan a los paisajes del Sur de California, bastaría contrastar las imágenes de Crestwood Hills durante su construcción con la profusión de arbolado y especies vegetales que recogen las fotografías actuales del barrio para admitir que, lo que hoy se ha convertido en una imagen natural y en la esencia del mismo, es resultado de una drástica operación de transformación del territorio.

En otro orden de escala, Garret Eckbo también había pensado diversas tipologías de jardín para las viviendas de la Mutual Housing Association.
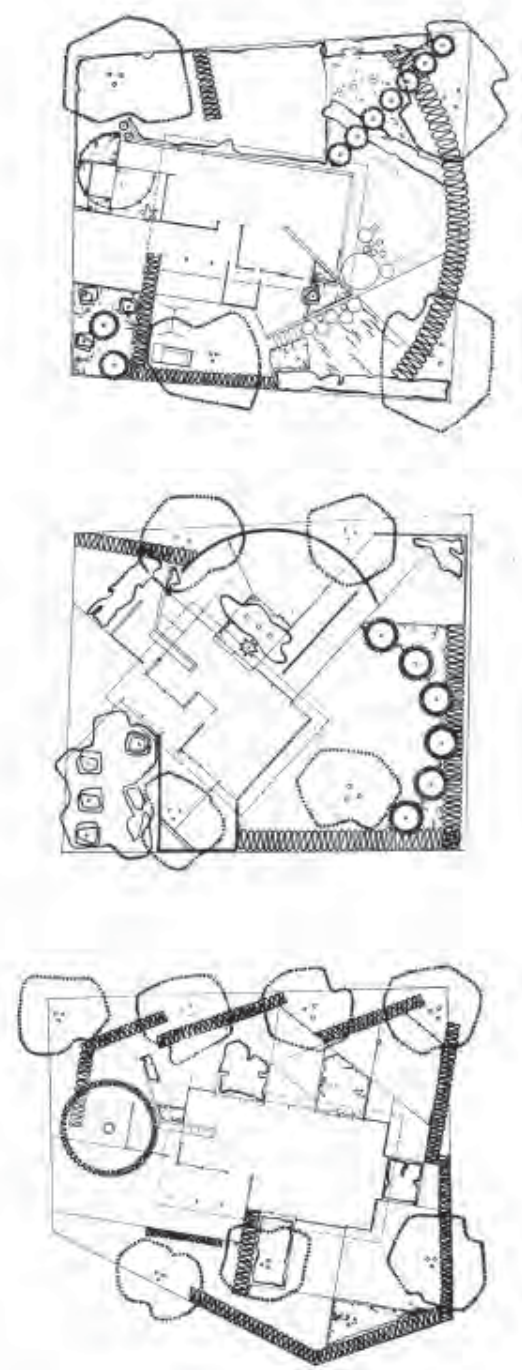


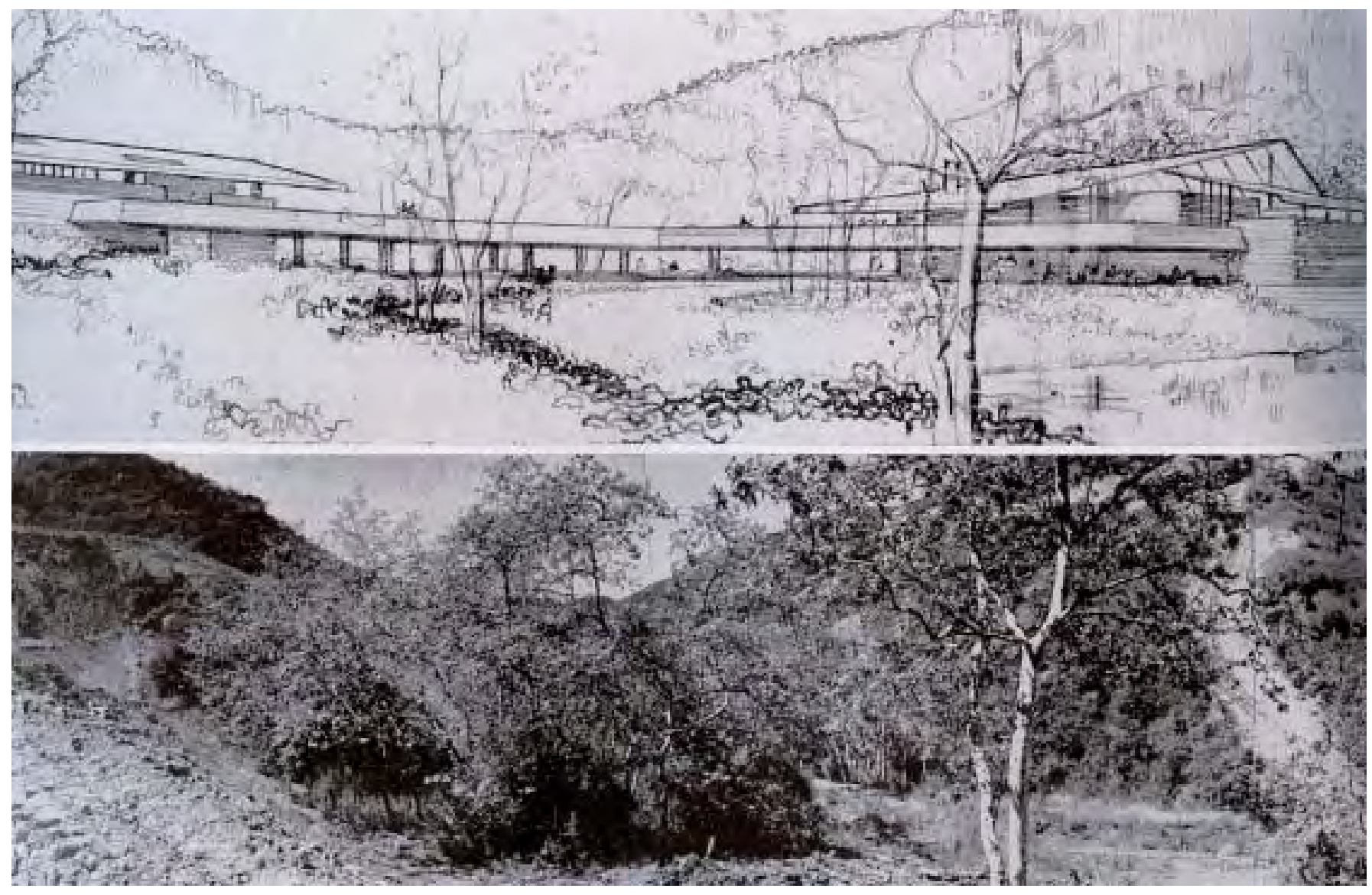

MHA, perspectiva de los arquitectos sobre una fotografía del estado sin transformar de Kenter Canyon (Arts \& Architecture, septiembre 1948)

Página siguiente izda: $M H A$, vista actual del acceso a la vivienda de Cory Buckner. Fotografía del autor

Página siguiente dcha: Prototipo de CSH \#22 (conjunto de viviendas), proyectado por $Q$. Jones y F. Emmons en 1961. Fotografía de la maqueta realizada por Leland Lee
Se trataba de meticulosos ejercicios compositivos donde los espacios exteriores se elaboraban como parte indisoluble de la casa. Los árboles y setos delimitaban recintos que resolvían necesidades de la vida cotidiana con la misma eficacia que los espacios interiores se plegaban a la función para la que estaban destinados. Desafortunadamente, estos diseños tampoco se llevaron a cabo, pero sirvieron de guía a los arquitectos a la hora de acometer la implantación de las viviendas en la parcela. En cualquier caso, la vegetación inicialmente prevista no fue tenida en cuenta y el paisaje de la MHA terminó condicionado por una suma de determinaciones individuales, tantas como propietarios decidiendo sobre el aspecto de su jardín.

Desilusionado, Eckbo dejó la Mutual Housing Association y se concentró en el paisajismo de otras actuaciones suburbanas, como Wonderland Park en Laurel Canyon, donde pudo integrar con más éxito el proyecto de jardinería inicialmente previsto para la MHA y el tratamiento del arbolado que había imaginado para Crestwood Hills. Curiosamente, Wonderland Park, que había sido promovido por antiguos miembros de Community Homes, marcaría el declive del sistema cooperativista. Cuando sus poco más de sesenta viviendas fueron terminadas a mediados de la década de los años cincuenta, muchos ciudadanos de Los Ángeles contaban ya con rentas más elevadas y habían dejado de interesarse por la dimensión social con la que habían surgido muchas de estas comunidades residenciales.

Tras la marcha de Eckbo, quedaron como técnicos responsables Quincy Jones, Whitney R. Smith y el ingeniero Edgardo Contini, además de James Charlton y Wyane Williams que completaban este equipo ${ }^{37}$ como arquitectos colaboradores. Su grado de implicación con la empresa fue tal que Jones, Williams y Contini se convirtieron en miembros de la cooperativa. 


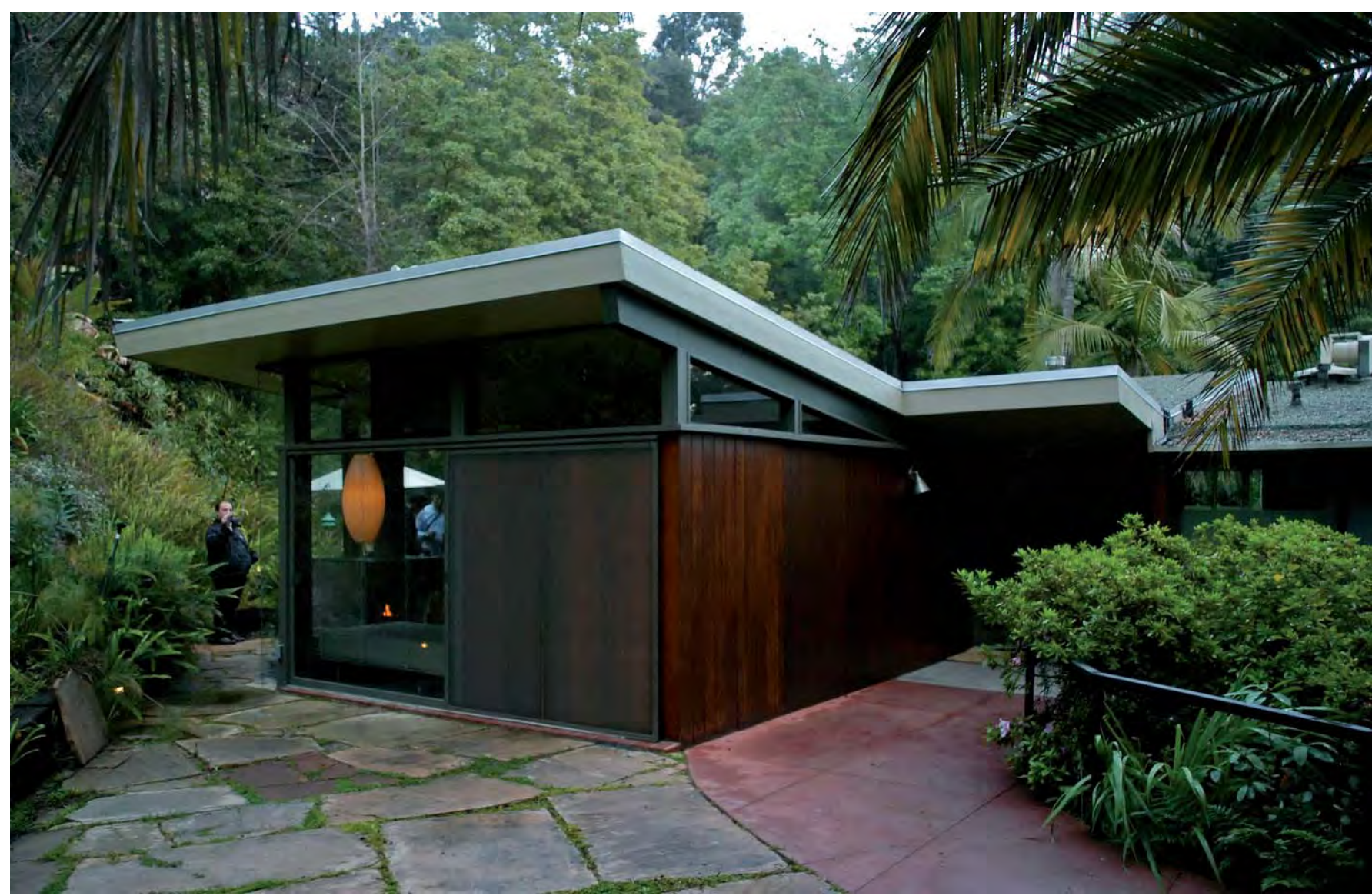

Originario de Kansas City, Missouri, Archibald Quincy Jones (1913-1979) pasó su infancia en California. Allí fue educado en la granja que sus abuelos poseían en Gardena, que como sugiere su nombre era una especie ciudad jardín al noreste de Los Ángeles. Su familia fomentó su interés por el paisaje y la vida al aire libre, características que recorren su obra. Comenzó a ejercer en Los Ángeles en 1936, haciendo prácticas en varios estudios hasta que, en 1940, fue contratado por la firma de ingeniería Allied Engineers Inc. para la que realizó, entre otros, el proyecto arquitectónico de la Base Roosevelt en el Puerto de San Pedro. Durante esta etapa conoció a Frederick Emmons con quien compartiría estudio desde 1951 hasta el retiro de éste en 1969. En 1942, obtenida la licencia para ejercer como arquitecto, fue asignado como oficial de la Marina al Portaaviones Lexintong, destinado en el frente del Pacífico. A través de su trabajo en las bases militares y durante su estancia en el portaaviones, Jones, como más tarde haría Gordon Drake, tuvo la oportunidad de reflexionar sobre distribuciones mínimas, optimización de materiales y espacios flexibles. Terminada la guerra regresó a Los Ángeles y abrió su despacho en uno de los dos pabellones de la casa que se había construido en Laurel Canyon.

En diciembre de 1950 la revista Architectural Forum nombró a Quincy Jones Arquitecto del año. En ese mismo número, Joseph Eichler aparecía galardonado como Promotor del año. Interesado por su coincidencia con el Arquitecto del año, Eichler contactó con Jones y le invitó a entrevistarse con él en Palo Alto, acompañándole a visitar una de sus promociones de viviendas más recientes donde le propuso que el arquitecto y el promotor del año trabajasen juntos. Ese mismo día se inició una fructífera relación profesional que perduró hasta la muerte de Eichler en 1974. Durante ese tiempo, Quincy Jones construyó para la empresa Eichler Homes alrededor de 5.000 viviendas, un esfuerzo que compartió asociándose

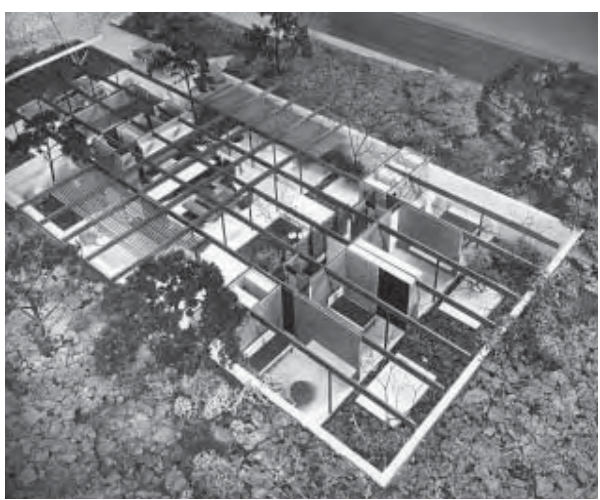



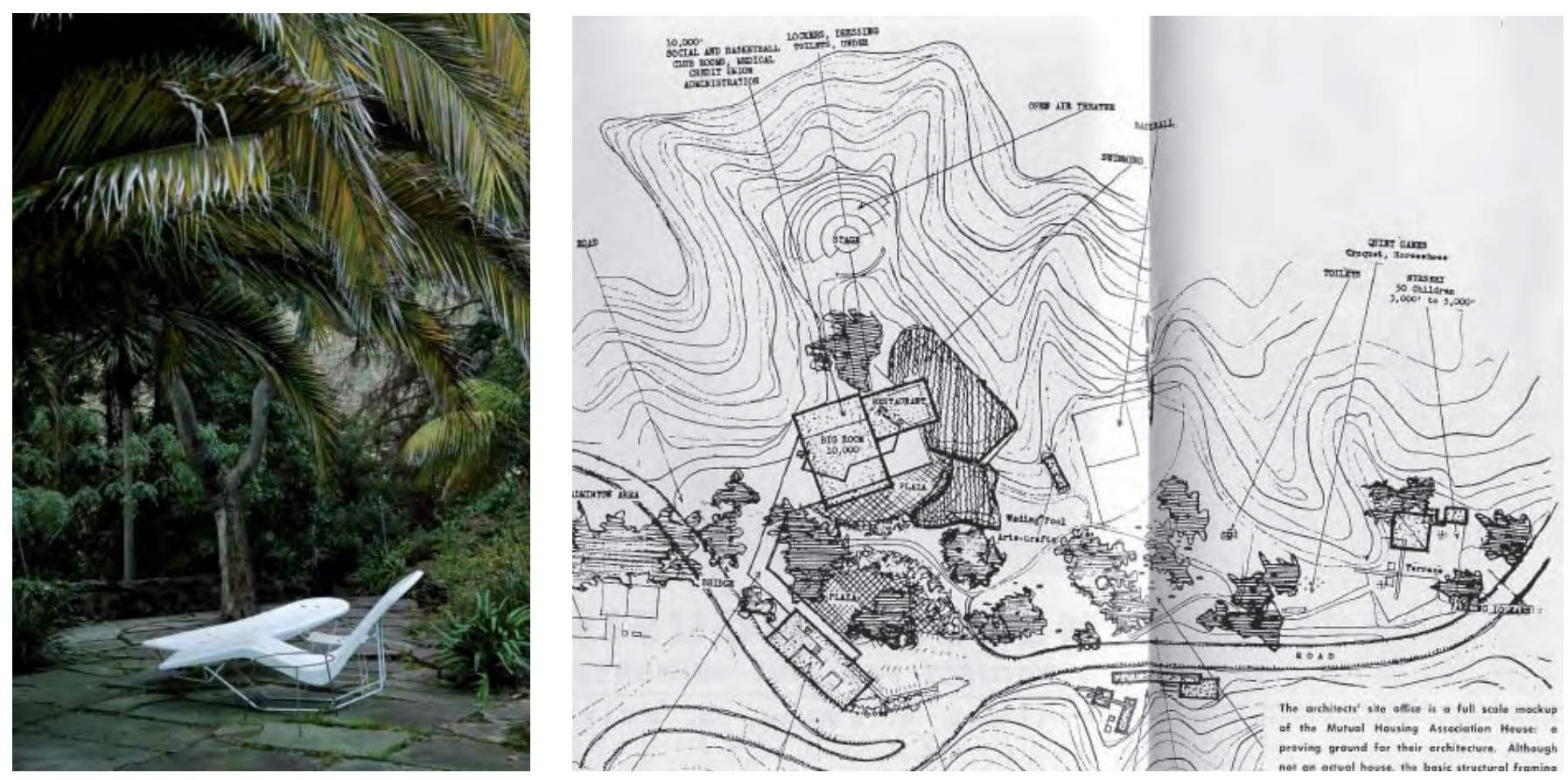

Izquierda: $M H A$, vista actual de uno de los jardines. Fotografía del autor, 2008

Derecha: MHA, detalle de implantación de los principales equipamientos de la cooperativa. (Arts \& Architecture, septiembre 1948)

Pág. siguiente izquierda: $M H A$, "House E". Página de Arts \& Architecture del número de septiembre de 1948 explicando uno de los prototipos de viviendas de la ordenación Pág. siguiente derecha arriba: $M H A$, detalle del aparejo de los bloques prefabricados de los muros. Estado actual. Fotografía del autor Pág. siguiente derecha centro y abajo: $M H A$, vistas actuales de una de las viviendas. Fotografías del autor con Emmons y abriendo un nuevo estudio en Santa Monica Boulevard. Joseph Eichler fue un promotor de ideas muy progresistas. Consciente de la responsabilidad de su misión como agente intermediario entre el proyectista y el destinatario final de las viviendas, otorgaba toda su confianza a los técnicos de los que buscó rodearse. Eichler estaba convencido que una sociedad libre debía apostar por una arquitectura capaz de resolver los aspectos de la vida cotidiana, transformando las formas tradicionales de habitar. Quincy Jones, por su parte, era un arquitecto de convicciones modernas y abordó sus obras desde principios de racionalidad, precisión y economía. Su sólida formación arquitectónica, interés por la cultura técnica y sensibilidad paisajística (fomentada a través de sus colaboraciones con paisajistas como Thomas Church y Garret Eckbo) debieron ser para Eichler buenas razones para contratarle.

La prolífica carrera de Quincy Jones estuvo ligada al crecimiento de la ciudad de Los Ángeles, que asumió en toda su complejidad para proponer alternativas válidas a los modelos de ocupación indiscriminada del territorio. Constatando que el aumento de población demandaba mayor densidad y mejores usos del suelo, defendía que sólo mediante la confluencia del planificador urbano, el arquitecto y el constructor podían acometerse con rigor los proyectos y evitar el caos que se estaba apoderando de la franja litoral del Sur de California. Para Jones, la repetición sistemática de pautas como las del tract housing ${ }^{38}$ estaba conduciendo a una situación alarmante donde, en ausencia de todo tipo de criterio urbanístico y arquitectónico, las periferias se habían ido convirtiendo en infinitas acumulaciones de viviendas, "bultos informes, simples baches a lo largo de la carretera sin otra misión que aguardar a que los árboles crecieran" ${ }^{\prime 39}$.

Jones criticaba la falta de planificación con la que se había producido parte del crecimiento del Sur de California, construyendo viviendas de manera espontánea sin diseñar eficientemente las infraestructuras ni dotar de carácter a los nuevos barrios. Como contrapartida proponía la creación de auténticas comunidades y argumentaba la necesidad de parques y cinturones verdes (greenbelts), edificios dotacionales (guarde- 


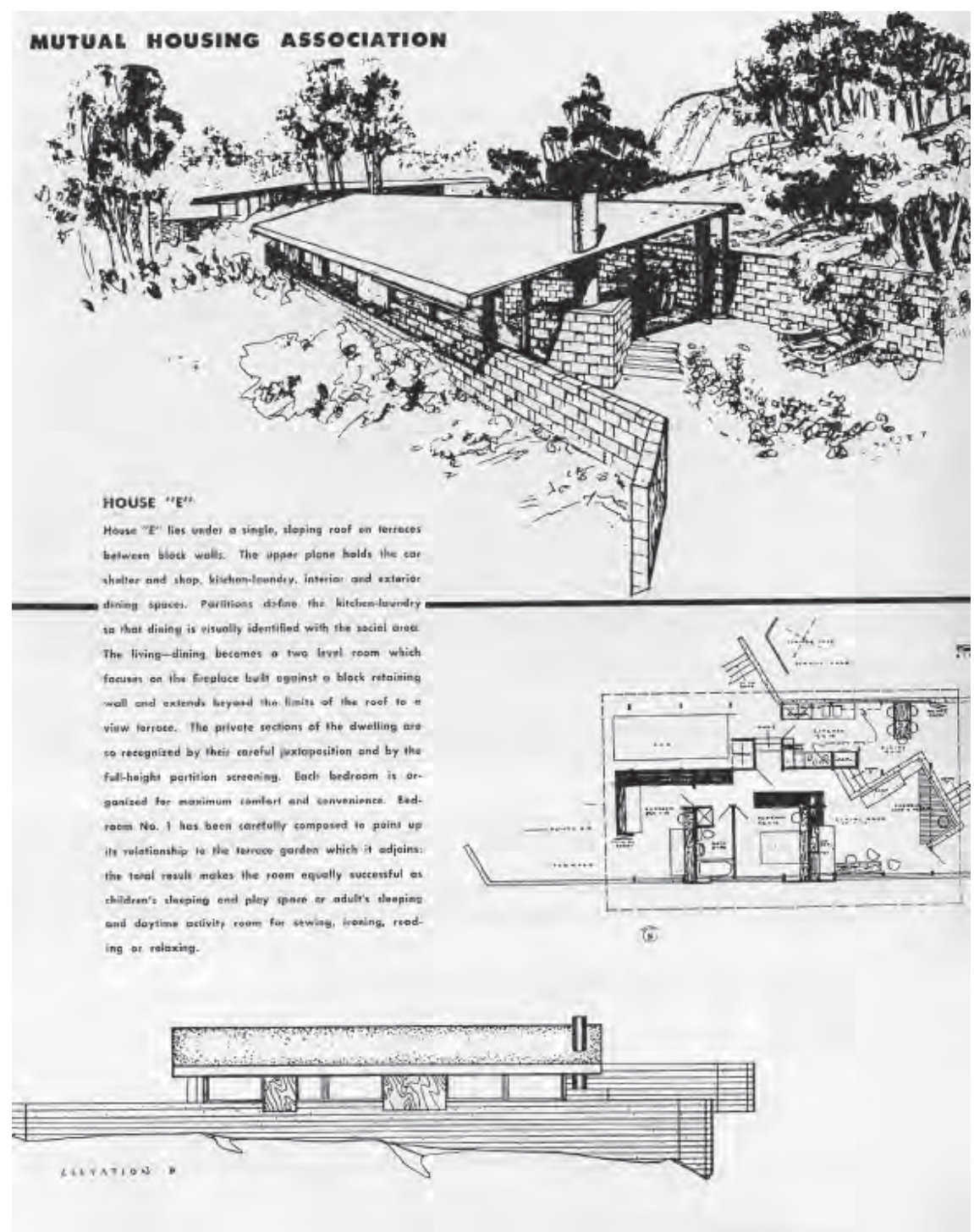

rías, pequeños comercios, centros vecinales) e instalaciones (piscinas y zonas deportivas de uso común) con los que fomentar la relación entre sus habitantes. A su perseverancia en la materialización de estas ideas y a su capacidad como técnico para cualificar los más diversos paisajes residenciales se debe el éxito relativo de ambiciosas operaciones inmobiliarias desarrolladas para cooperativas de propietarios (MHA); promotoras privadas de la envergadura de Eichler Homes; bases militares; e, incluso, superactuaciones como el proyecto para la ciudad de Irvine ${ }^{40}$ en Orange County, al que a petición de William Pereira se incorporó como colaborador en 1960. Proclive a llevar sus investigaciones hasta los límites de la normativa vigente y de las convenciones sociales, sus planteamientos no siempre fueron bien aceptados. Así ocurrió, por ejemplo, con la Case Study House número 24 (1961) ${ }^{41}$, la casa piloto para un complejo mucho más vasto que no pudo construir, pero con el que consiguió que Entenza redefiniera las condiciones de su programa para aceptar, en lugar de una única residencia unifamiliar, un modelo susceptible de ser repetido en una intervención de 260 viviendas originalmente previstas cerca de Northridge ${ }^{42}$.

Quincy Jones fue sobre todo un técnico preocupado por hallar la solución óptima a cada problema. Aunque sólo esta faceta de constructor vocacional justifica muchos aspectos de su trabajo, su actividad profe-
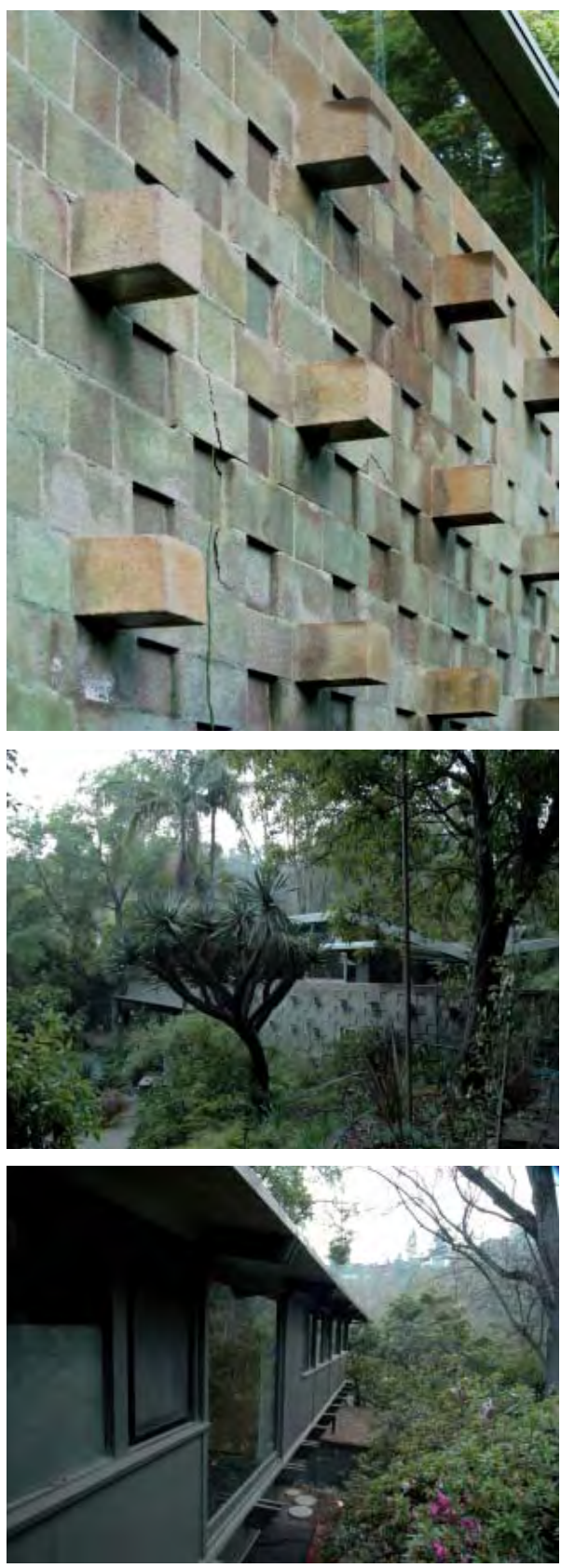


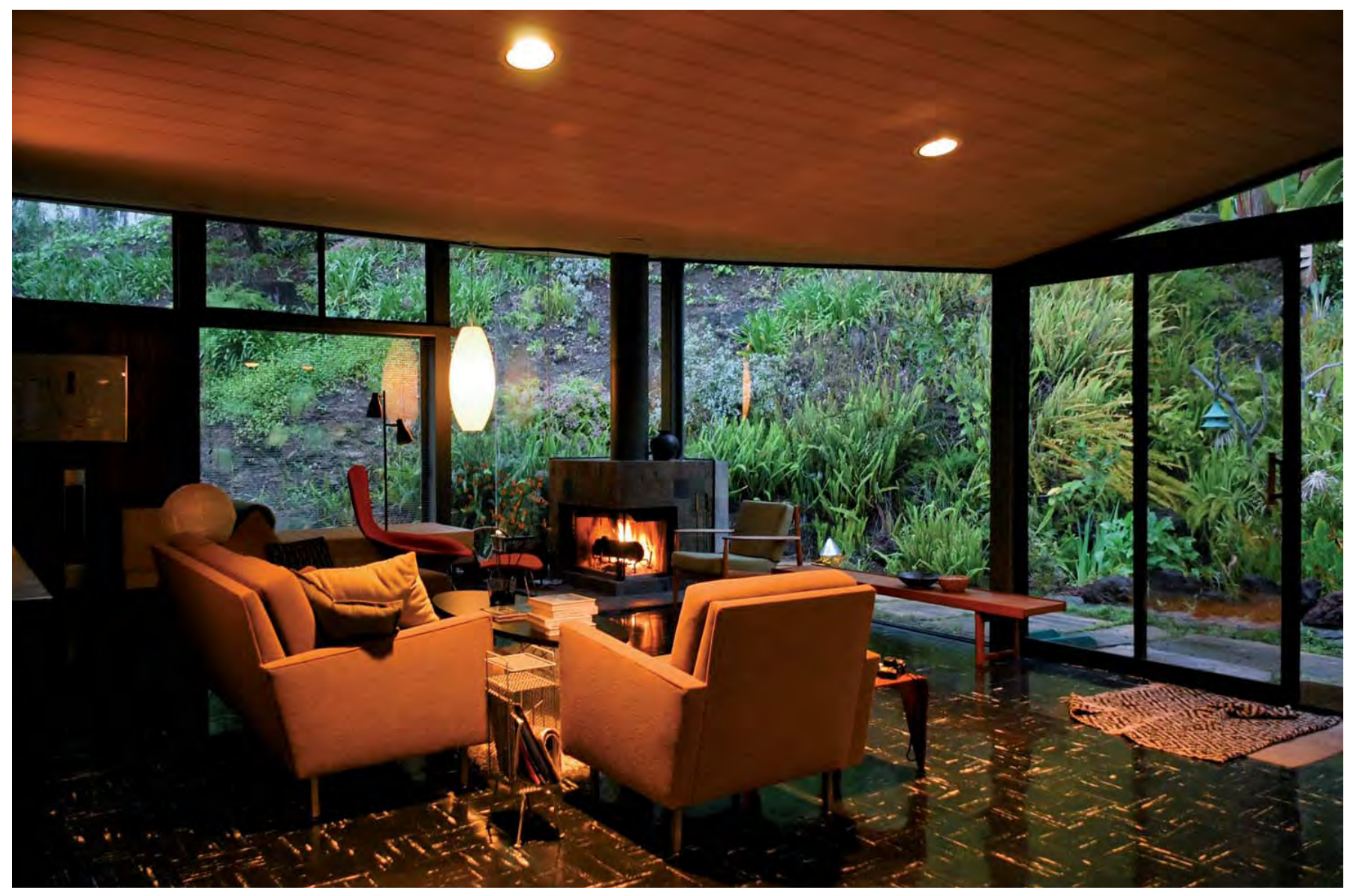

MHA, interior del estar de la vivienda de Cory Buckner (antiguas oficinas de los arquitectos en la cooperativa). Fotografía del autor

Página siguiente arriba: $M H A$, "House $C$ ", prototipo de vivienda publicado en Arts \& Architecture, septiembre 1948

Página siguiente abajo: $M H A$, vivienda modelo 111, Stonehill Lane. Fotografía de J. Shulman sional abarcó los más diversos ámbitos, desde el planeamiento hasta la jardinería e, incluso, la docencia, que impartió en la Escuela de Arquitectura de la Universidad del Sur de California de la que llegó a ser Director. Publicó también varios textos, aunque debido a su condición de arquitecto de oficio nunca se mostró interesado por las ideologías y, por ello, Builders' Homes for Better Living 43 , escrito en colaboración con Emmons y Chapman en 1957 es, ante todo, un manual de buenas prácticas.

Quincy Jones participaba de la opinión de Garret Eckbo de que los americanos, tras los sacrificios de la guerra, no merecían mínimos sino óptimos estándares, tanto en planeamiento como en edificación. Para ambos, se trataba de una cuestión de responsabilidad que sus proyectos de grandes complejos suburbanos, generados por medio de pocas pero excelentes tipologías de vivienda y de jardín, permitieran a las familias de clase media acceder a un hogar dotado de calidad espacial y de un grado de confort cercanos a los de una casa diseñada específicamente para un cliente. De hecho, aunque a lo largo de su carrera Quincy Jones compaginó estas investigaciones acerca de la gran escala residencial con la construcción de viviendas unifamiliares de cierta singularidad y de edificios institucionales, su principal preocupación fueron siempre los problemas de la vivienda de escaso presupuesto.

De este modo, apoyándose como Eckbo en la planificación territorial y en el diseño de espacios verdes, Quincy Jones entendió que el reto de dignificar la construcción de bajo coste pasaba también por la introducción de materiales y tecnologías que, procedentes de la investigación militar, abrían al arquitecto un mundo de posibilidades y de adelantos 
constructivos. Prescindiendo del bungalow y de la casita de madera y estuco, consiguió abaratar precios y producir viviendas asequibles sirviéndose de las ventajas del diseño modular, la utilización de estándares industriales y la rapidez del montaje en seco con elementos prefabricados. La madera laminada, por ejemplo, permitía diseñar piezas estructurales para su montaje en obra; los tableros fenólicos, elementos de compartimentación; los bloques de hormigón aseguraban un cerramiento sin necesidad de acabados; y el vidrio plano, una inusitada transparencia la que subrayaba el carácter abierto de la arquitectura local.

Gracias al empleo de grandes paños acristalados podía ampliarse la continuidad entre el interior y el exterior, una relación que la benignidad del clima invitaba a explorar en todas sus posibilidades. En los conjuntos de Quincy Jones sus viviendas, prolongando el ámbito doméstico hacia el jardín, popularizaron una forma de habitar que fomentaba el disfrute del medio natural. El conjunto de su obra residencial, permitiendo la democratización del estilo de vida californiano, se reveló como el nexo más efectivo entre la casa de autor y la vivienda de masas.

Como consecuencia de su empeño por los cinturones verdes y las zonas comunitarias, el proyecto arquitectónico de la Mutual Housing Association en Crestwood Hills se inició con un compromiso de cesión desde el dominio privado hacia los espacios públicos. Así, al proyectar la urbanización se redujo el tamaño de las parcelas que hubiera sido previsible con el terreno y las ordenanzas disponibles, y se destinó la superficie así obtenida a la creación de una pequeña estación de servicio, una tienda de ultramarinos, una clínica, una guardería y un parque con equipamientos deportivos de uso vecinal.

Teniendo en cuenta el Plan Director sobre el que había trabajado Garret Eckbo, Quincy Jones y su equipo de arquitectos asignaron a cada familia un lote de un cuarto de acre (unos $1.000 \mathrm{~m}^{2}$ ). Con la intención de distanciar al máximo las viviendas estudiaron su posición más estratégica dentro de cada propiedad $y$, para asegurar su privacidad, las dispusieron siguiendo ángulos de giro sucesivos respecto a la calle, de manera que la vista desde una casa no tropezara con la siguiente y la perspectiva consiguiera abrirse paso a través de todas las parcelas. Debido a la generosa separación del viario, los cinturones verdes parecen fundirse con los jardines particulares y la vegetación que durante más de medio siglo ha ido creciendo en estas colinas, ha terminado fundiéndose con la arquitectura, contribuyendo a que las viviendas parezcan más alejadas de lo que en realidad están.

Aparte de su indudable atractivo visual, los cinturones verdes desempeñaban importantes funciones, entre ellas, fijar el suelo frente a la erosión en una zona geológicamente sensible a desprendimientos durante las lluvias torrenciales; suavizar los efectos del clima seco y caluroso de Los Ángeles proporcionando sombras y regulando la temperatura con la humedad acumulada por la vegetación; amortiguar el ruido del tráfico rodado; y cohesionar la vida comunitaria, aumentando su calidad al proveer de espacios lúdicos y de relación para pasear, practicar ejercicio o simplemente entablar conversación.

Las áreas dotacionales fueron emplazadas en las inmediaciones del parque, situado en la zona más llana de Crestwood Hills, mientras que las
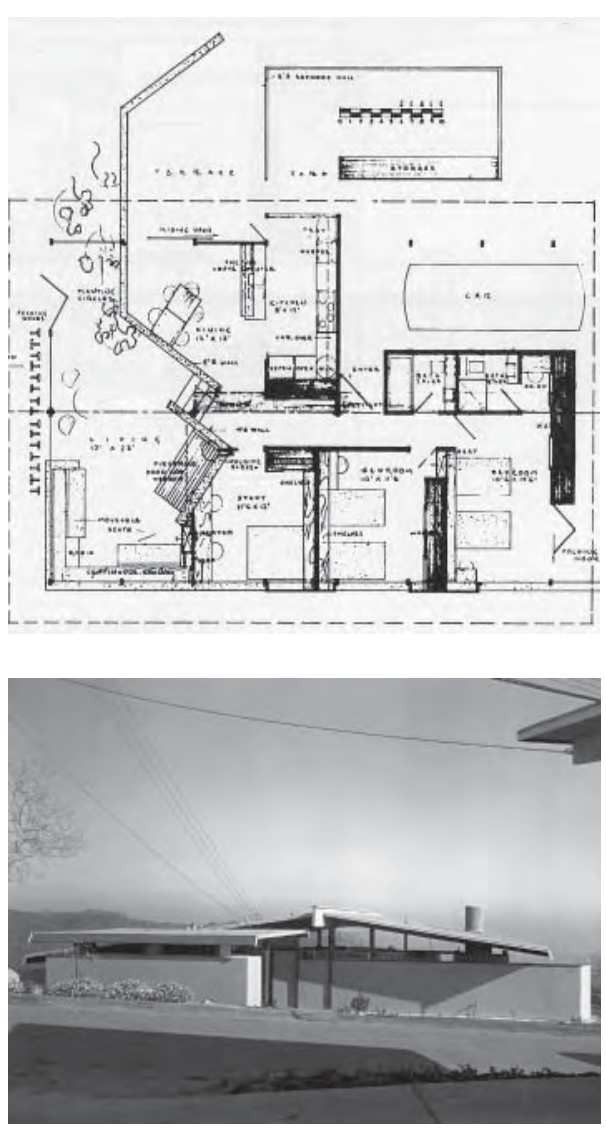


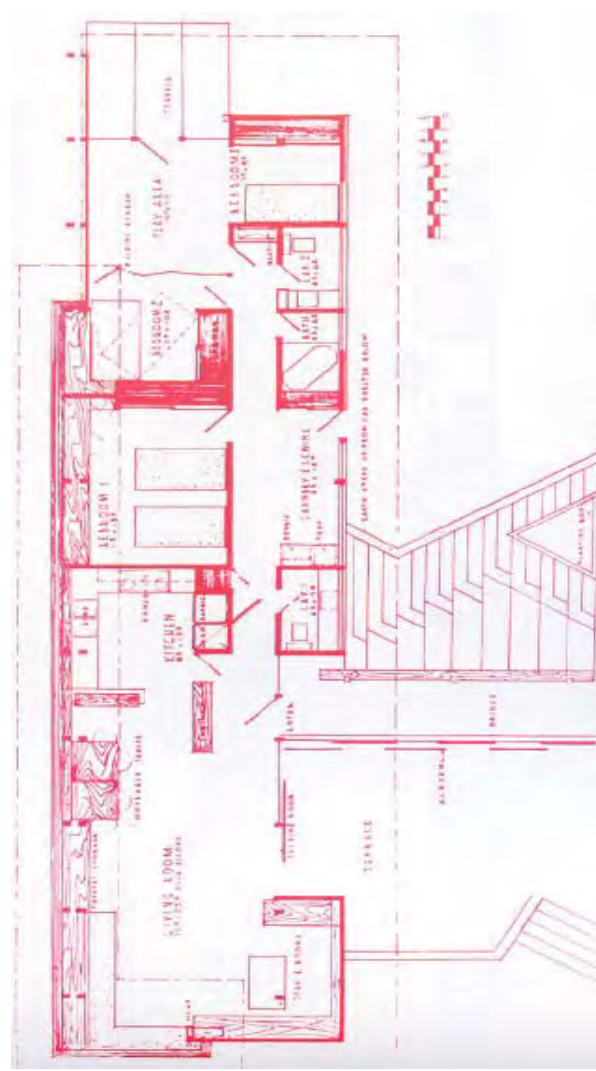

Izquierda: MHA, Planta de la vivienda piloto. Publicada en proyecto en Arts \& Architecture, septiembre de 1948 y construida en Arts \& Architecture, marzo 1949.

Derecha: MHA, viviendas en Stonehill Lane en construcción. Fotografía de Julius Shulman

Página siguiente arriba: $M H A$, viviendas en Hanley Avenue recién ocupadas. Fotografía de Julius Shulman

Página siguiente abajo: MHA, modelo 102, estar. Fotografía de Garber Sturgis, 1949

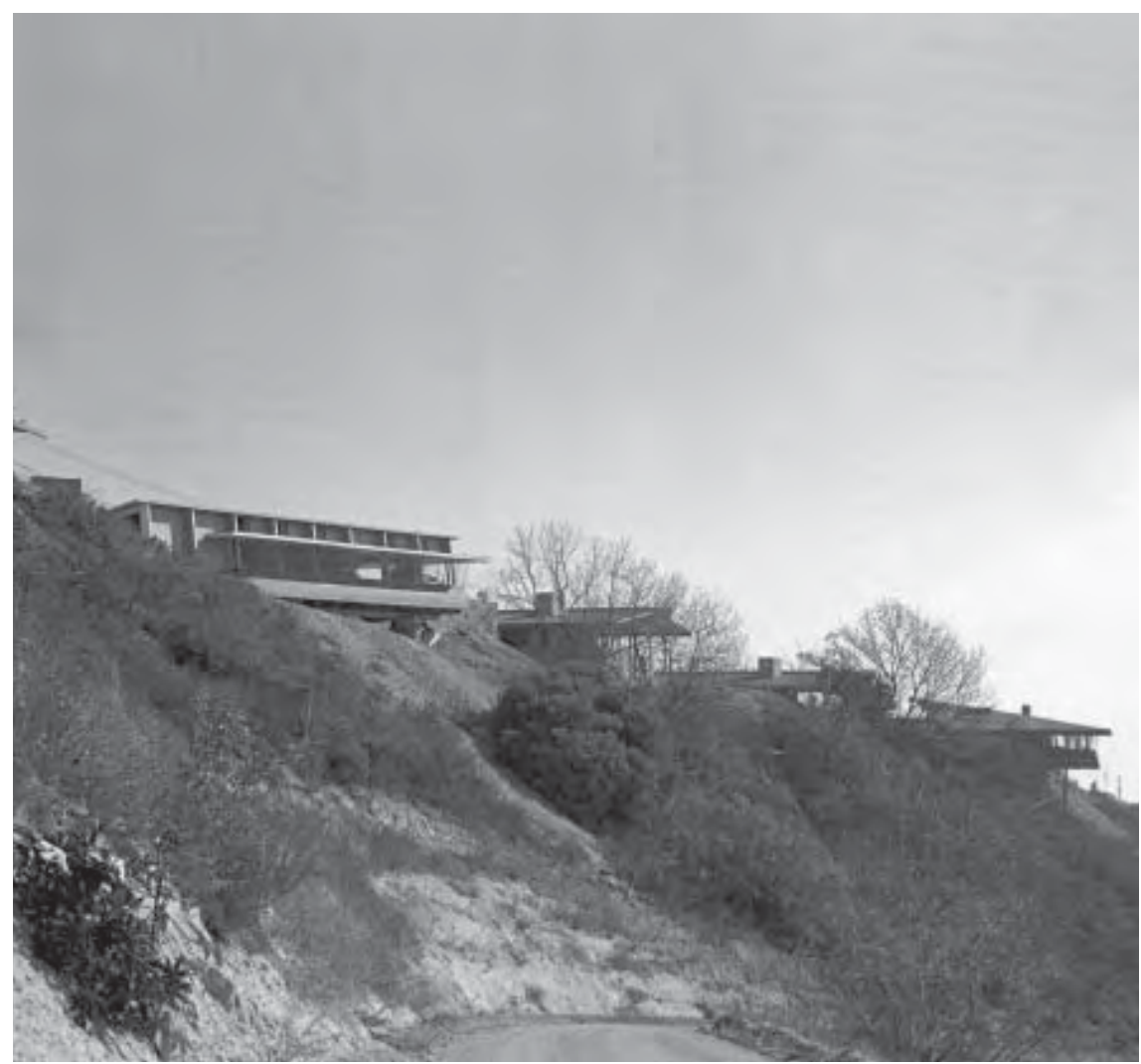

viviendas, ubicadas en las laderas del cañón, debían resolver con su implantación en la parcela la pendiente de la montaña. Para definirlas, los arquitectos trabajaron sucesivamente diversos esquemas de distribución hasta que, en 1948, llegaron a un acuerdo con los propietarios. Jones y Smith presentaron a sus clientes una recopilación de todos sus estudios previos, el Mutual Plans donde, a modo de catálogo, detallaban 28 tipologías diferentes de vivienda unifamiliar entre las que la MHA debía escoger unas cuantas para que sirvieran de modelo. Tras convocar una serie de debates, la comisión optó por fijar en ocho los distintos prototipos que debían desarrollarse. Finalmente, de las 500 parcelas segregadas, en 160 de ellas sus propietarios optaron por construir sus viviendas según los diseños originales de los arquitectos.

Para simplificar su ejecución, estos diseños partían de un sencillo esquema portante consistente en costillas de madera ensambladas en obra. En esta solución de vigas y pilares (post-and-beam construction) -muy barata en California- las jácenas inclinadas formaban la pendiente de la cubierta ayudando a definir el volumen habitable. Buscando reducir costes, la estructura quedaba expuesta y se reducían a su mínima expresión los materiales que conformaban su envolvente. Para realizar los cerramientos se recurrió a generosas superficies de vidrio y sistemas modulares de paneles contrachapados de abeto Douglas, madera de secuoya (redwood) y bloques prefabricados, evitando en la mayoría de los casos la necesidad de enfoscados o pinturas. Como consecuencia de este ejercicio de contención, la imagen de las viviendas es moderna en la medida en que el lenguaje empleado remite estrictamente a su verdad constructiva.

Por razones presupuestarias, la mayoría de las casas de la MHA están organizadas en una sola planta. Esta disposición facilita que todas las estancias tengan acceso directo a la parcela, permitiendo la incorporación de los espacios exteriores como parte del programa. A su vez, en 


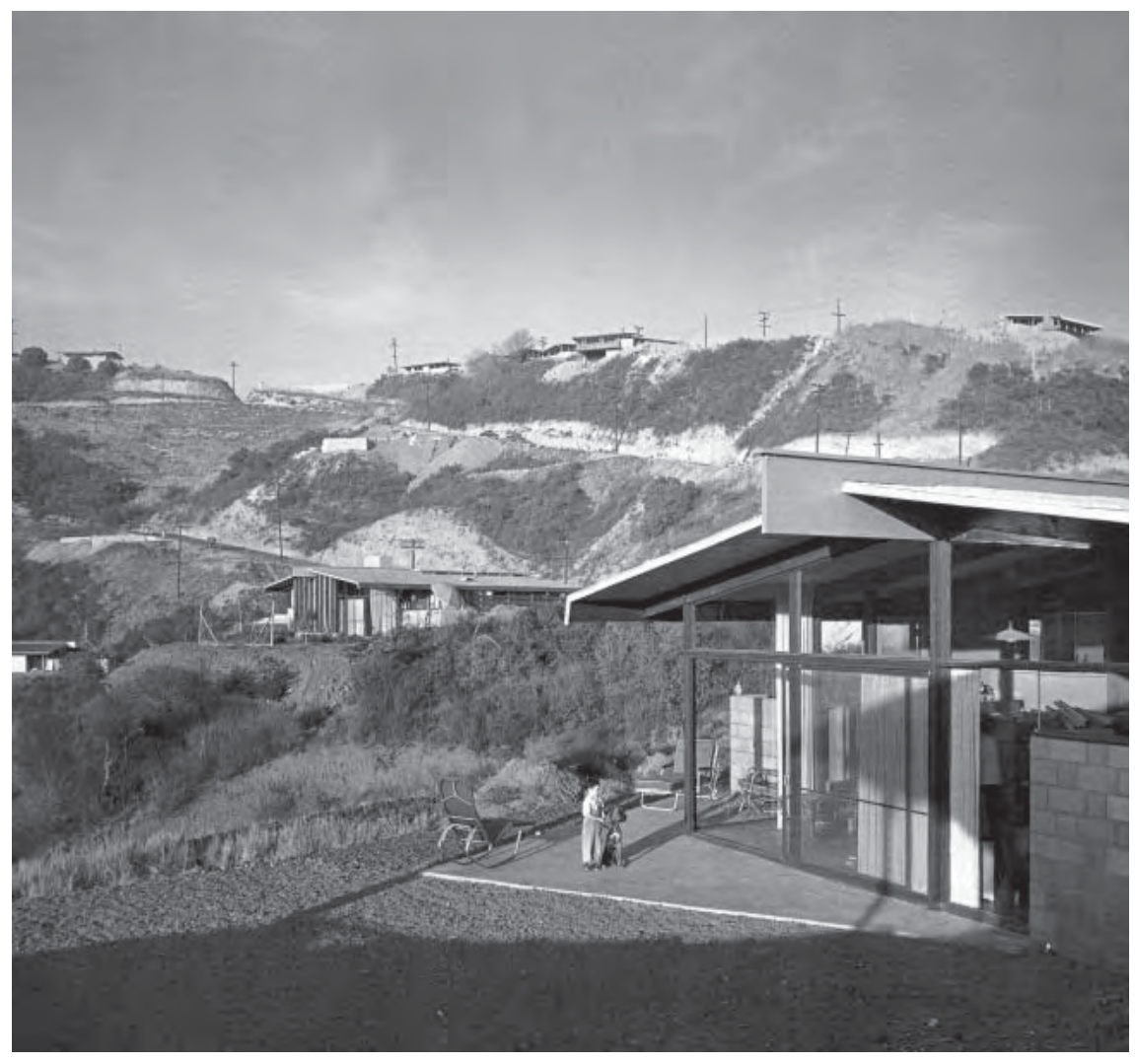

este esquema abierto los recintos se organizan alrededor del estar y de la cocina, minimizando la superficie destinada a circulaciones. Todas las viviendas tienen alrededor de $110 \mathrm{~m}^{2}$ pero parecen más amplias porque la vista es atraída por el jardín, con lo que los recintos de la casa parecen continuar más allá de las puertas correderas de vidrio.

A costa de sus propios honorarios los arquitectos compraron en 1950 un pequeño terreno en pendiente en otro distrito de la ciudad donde edificaron una casa piloto, la Model 102, en la cual los cooperativistas pudieron experimentar por sí mismos el espacio de sus futuras viviendas. Su planta era rectangular y fue construida con madera y bloques prefabricados de hormigón. La cubierta inclinada a una sola agua reproducía la pendiente del solar y su diferencia de cota se asumía con una franja acristalada superior entre los paneles de contrachapado y el techo.

Con el fin de abaratar costes se impuso la repetición sistemática de los ocho modelos de casa seleccionados y la supresión de detalles que pudieran complicar el proceso de montaje. A pesar de ello, los arquitectos estudiaron fórmulas para personalizar las distribuciones e, incluso, se previó que con el tiempo cada familia pudiese ampliar su vivienda según sus necesidades, aprovechando la superficie disponible en la parte trasera de la misma. Como contrapartida, los intentos por flexibilizar los programas, las complicaciones en obra para ajustar las uniones entre los elementos estructurales fabricados en taller-que debían encajar perfectamente con cada pieza específica- y la ejecución del diseño singular de las bandas de huecos altos, consumieron más tiempo del que se había previsto y generaron gastos adicionales que motivaron el abandono sucesivo de dos contratistas diferentes.

Durante las obras de la MHA las dificultades también se presentaron en muchos otros ámbitos. La Federal Housing Authority, por su parte, se

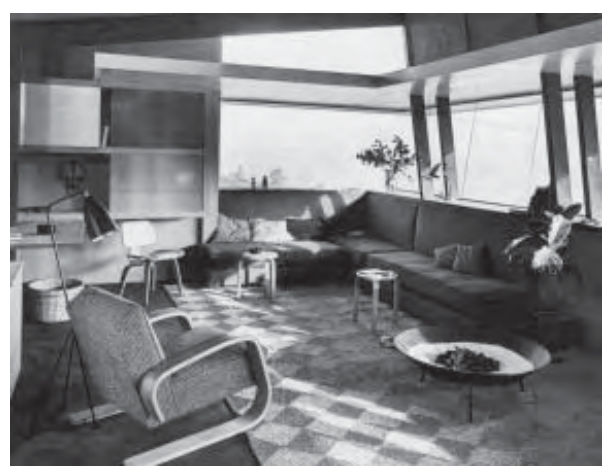



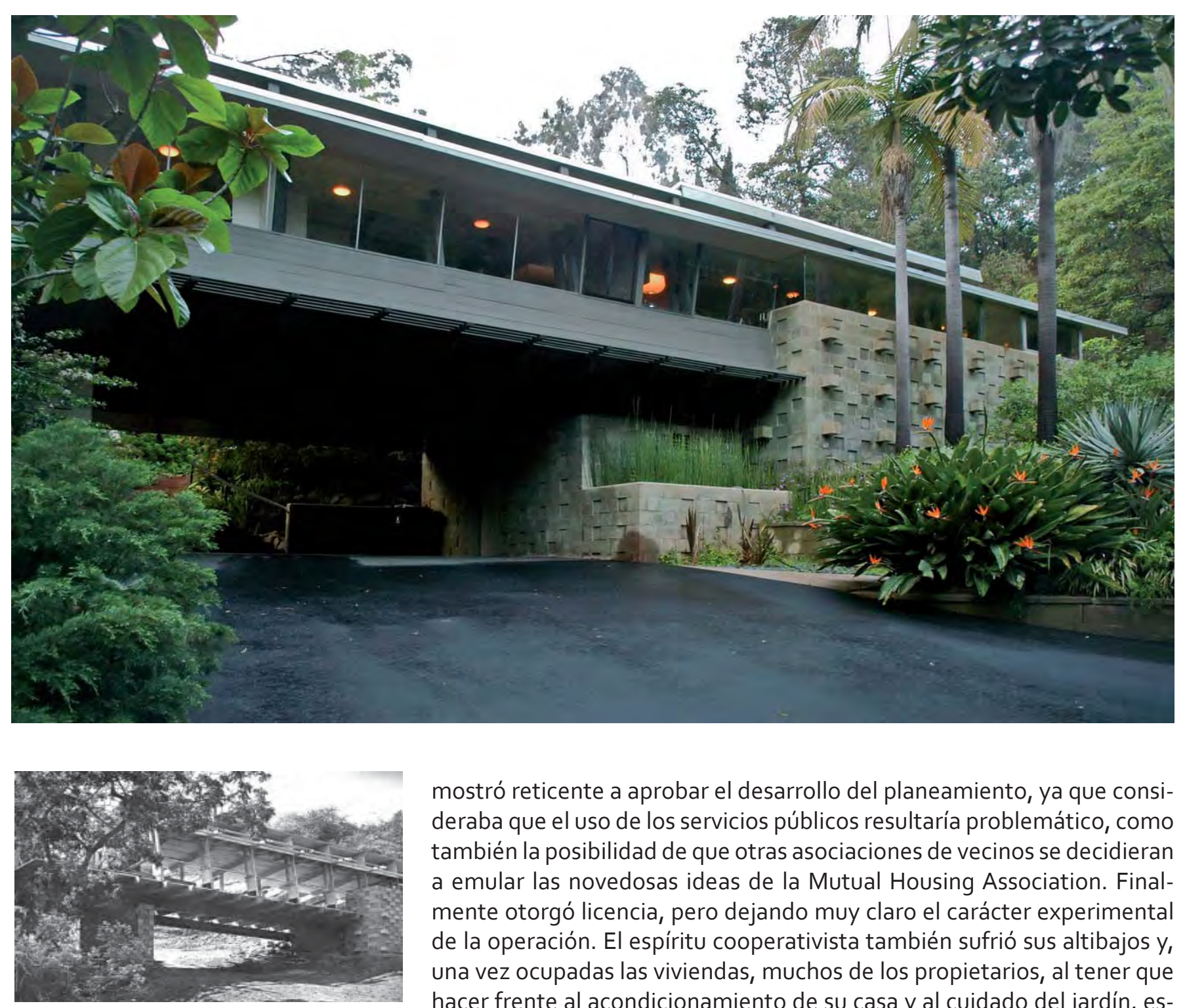

mostró reticente a aprobar el desarrollo del planeamiento, ya que consideraba que el uso de los servicios públicos resultaría problemático, como también la posibilidad de que otras asociaciones de vecinos se decidieran a emular las novedosas ideas de la Mutual Housing Association. Finalmente otorgó licencia, pero dejando muy claro el carácter experimental de la operación. El espíritu cooperativista también sufrió sus altibajos y, una vez ocupadas las viviendas, muchos de los propietarios, al tener que hacer frente al acondicionamiento de su casa y al cuidado del jardín, estimaron conveniente reducir los gastos de mantenimiento y suprimir algunas de las dotaciones comunes. Por ello, de los espacios de uso público contemplados en las primeras fases del proyecto, sólo vieron la luz el parque con sus equipamientos y la escuela infantil, situada en el lugar que las oficinas de la cooperativa ocuparon durante las obras del conjunto.

El tiempo ha demostrado la vigencia de los planteamientos comunitarios de Quincy Jones y de su equipo de arquitectos. En la actualidad, los innumerables tonos del verde presiden el horizonte de Crestwood Hills y los espacios públicos originales no sólo siguen siendo utilizados sino que han sido completados con más instalaciones deportivas, una sala de reuniones, un gimnasio y un centro social gestionado por la comunidad y en cuyas aulas son programadas regularmente actividades recreativas. Obviando otros factores como la cercanía del océano o su proximidad a los barrios más caros de la ciudad como Westwood o Bel Air, puede afirmarse que, a pesar de la raíz cooperativista de la MHA y de su escasez de medios inicial, la presencia de estos servicios comunes y la calidad ambiental proporcionada por la vegetación han hecho de este lugar uno de los vecindarios más exclusivos del oeste de Los Ángeles.

Un ejemplo de vivienda es la actual casa de la historiadora Cory Buckner, edificada por Quincy Jones y Whitney Smith en 1949, y que había servido 


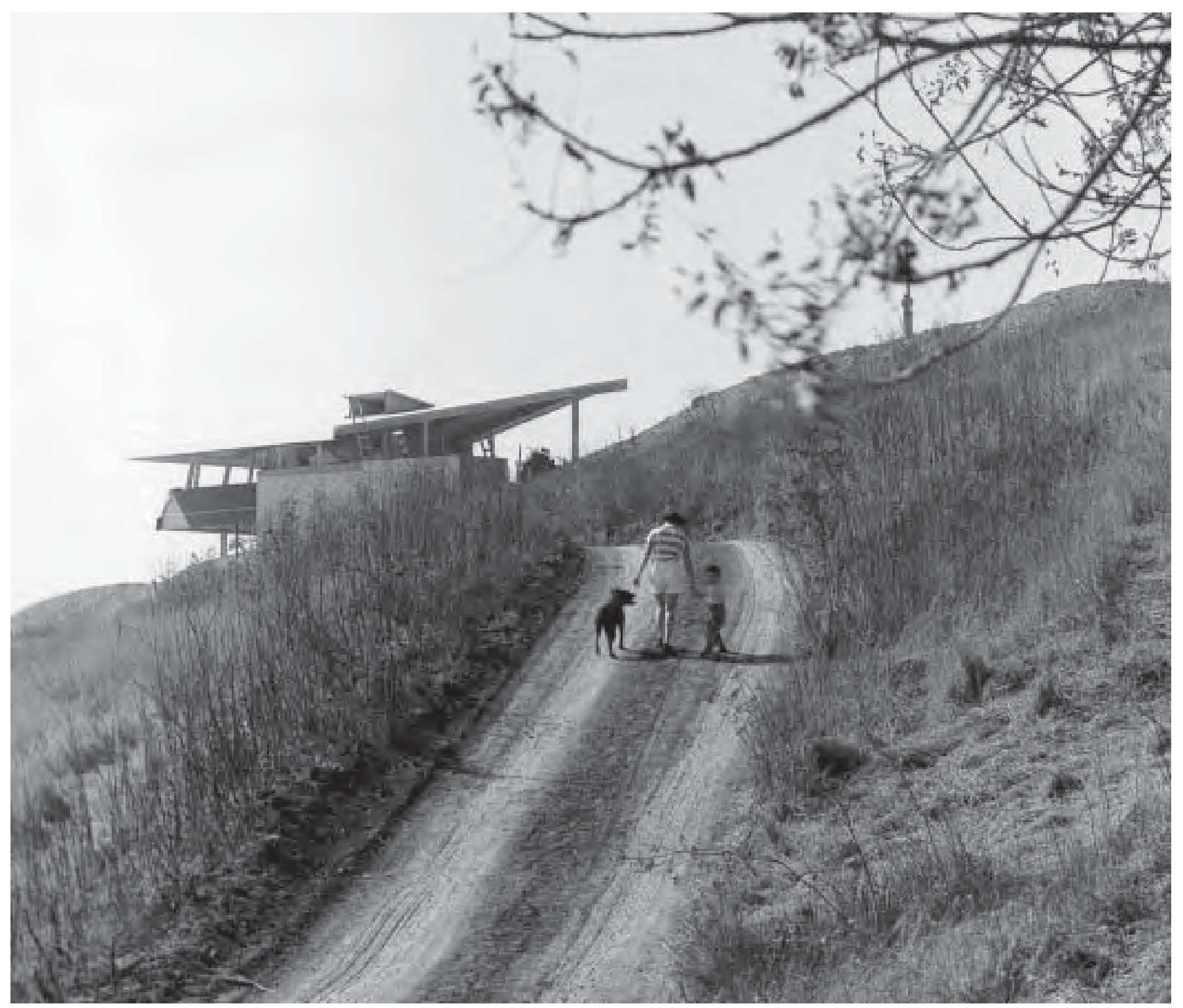

como despacho para los arquitectos durante el tiempo que duraron las obras. Dicha vivienda se halla ubicada en el extremo sureste del parque, en una propiedad literalmente sumergida en el boscaje y colindante con la escuela infantil y el centro social emplazados, respectivamente, en los números 986 y 1000 de la avenida Hanley. Fue proyectada como reelaboración del Modelo 102 y constituye uno de los casos singulares dentro de la intervención. La casa está construida como un armazón de madera sobre vigas de acero que salvan la luz de un puente bajo el cual se refugia el vehículo. Con este gesto la vivienda resuelve el problema de la pendiente, ubicando el acceso en el lado más elevado del solar y albergando en el extremo volado la parte privada del programa. Se trata de una pieza mucho más detallada que el resto de las viviendas, como pone de manifiesto el juego de texturas logrado con el aparejo de bloques de hormigón que protege los soportes.

La Mutual Housing Association fue la cooperativa moderna más exitosa de todas las que se promovieron en el Sur de California. El episodio arquitectónico despertó el interés de John Entenza, lo que aseguró su repercusión mediática. La revista Arts \& Architecture siguió de cerca el proyecto y su construcción, publicando artículos periódicamente que daban a conocer la marcha de los mismos a lo largo de los años 1948, 1949 y 1950.
MHA, modelo de vivienda 301 en construcción Fotografía de Julius Shulman, 1949

Página anterior arriba: MHA, casa tipo puente construida (vivienda de C. Buckner, antiguas oficinas de los arquitectos en la cooperativa). Fotografía del autor

Página anterior abajo: proceso de construcción de la vivienda puente. Fotografía de Emiel Becksy, 1949 


\section{Notas y referencias bibliográficas}

1. Merle Armitage citado por Victoria DAILEY en su capítulo "Naturally Modern", en Victoria DAILEY, Natalie SHIVERS y Michael DAWSON: LA's Early Moderns. Art/Architecture/ Photogra phy. Los Angeles: Balcony Press, 2003, p. 23

1. Como tantas otras poblaciones de la región, Pasadena mantiene su autonomía política, instituciones e identidad cultural. Bajo su influencia reúne a un conjunto de ciudades satélite que se agrupan sin solución de continuidad -entre ellas Altadena, La Cañada, San Marino o San Gabriel-y que constituyen una realidad urbana con personalidad propia dentro del área metropolitana de Los Ángeles.

3. Benjamin Wilson (1811-1878) fue una pieza fundamental en la colonización del Valle de San Gabriel, actuando de nexo entre los pioneros españoles, sus sucesores mexicanos y los norteamericanos. Procedente de Tenessee, Wilson se había casado con la hija de José Antonio Yorba, terrateniente catalán que había llegado a Los Angeles con la expedición de Gaspar de Portolá de 1769 . En su libro Ciudad de Cuarzo, Mike Davis relata con ironía (véase el apartado Yernos cal culadores) el papel que jugaron los matrimonios entre los herederos de los ranchos españoles y los colonos estadounidenses en la estructura de propiedad de la tierra en el Sur de California: "S en el norte de California los ejércitos de buscadores de oro sobrepasaron brutalmente a la sociedad autóctona, en el sur el arma favorita de conquista fue el matrimonio. Los viejos hacendados de la región de Los Ángeles, la gente de razón a la que hoy recordamos sobre todo por los pintorescos nombres de las calles (Pico, Figueroa, Sepúlveda, etc.) fueron desposeídos sin violencia por las ma quinaciones de sus propios yernos yanquis". Mike DAVIS: Ciudad de Cuarzo. Arqueología del futuro en Los Ángeles. Madrid: Lengua de Trapo, 2004 (primera edición City of Quartz: Excavating the Future in Los Angeles. London, New York: Verso, 1990), p. 81

4. Cfr. Charles MOORE et al.: Los Angeles. The City Observed. A Guide to its Architecture and Landscape. Santa Monica: Hennessey + Ingalls, 1998 (primera edición New York: Vintage Books, 1984), p. 309.

5. Publicada en 1884

6. Mike DAVIS: Op. cit., p. 10

7. Ibid., p. 9

8. "Devoto de la moda del desierto saludable, como Lummis -afirma Mike Davis (Op. cit., p. 12), G. W. James organizó el Arroyo Guild (Gremio del Arroyo), un breve pero importante punto de in tersección entre el romanticismo del mito misionero y la franquicia del Arts \& Crafts de Pasadena dominada por los hermanos Greene». Tratando de emular las publicaciones especializadas de Este, en octubre 1909 James sacó a la luz un único número de Arroyo Craftsman, una revista que de haber prosperado debía haberse convertido en la voz a escala nacional del movimiento artístico californiano.

9. Batchelder fue uno de los ceramistas más dotados de una tradición muy apreciada en el Sur de California. En su casa del Arroyo Seco puso en marcha un pequeño taller donde produjo azulejos decorativos y baldosas de terracota cuyos diseños llegaron a ser demandados por arquitectos como los propios hermanos Greene. Su paleta consitía en colores naturales, ocres y tierras combinados con veladuras grisáceas y azuladas. Aunque llegó a poseer una importante manufactura a finales de los años 20, la Batchelder-Wilson Tile Company, el artista continuó per feccionado diversas técnicas artesanales en su taller, creando obras que respondían a su filosofía de nunca dos piezas iguales. Algunas representaban los paisajes inventados de una California romantizada. Su naturalismo en el detalle permite reconocer especies vegetales autóctonas, como el roble; otras son cultivos importados como la vid, o evocaciones del mundo mediterrá- neo. Entre sus temas también estuvo presente el folklore indígena, las tramas históricas y los motivos heráldicos. La vivienda es propiedad del historiador Robert Winter desde 1972.

10. En los sleeping baskets de su vivienda-estudio de Kings Road.

11. Descendiente de artesanos alemanes, Gustav Stickley (1858-1942) y sus hermanos fundaron en la década de 1880 Stickley Brothers Furniture Company, un próspero taller familiar que les convertiría en un referente nacional en el campo del diseño y fabricación de mobiliario craftsman.

12. Los más de doscientos diseños e ilustraciones de fachadas e interiores de viviendas realizados para ser publicados en The Craftsman aparecieron recopilados en dos influyentes libros Craftsman Homes (1909) y More Craftsman Homes (1912)

13. Una de estas comunidades fue Rose Valley, fundada en 1901 en Moylan (Filadelfia). Su impulsor, el arquitecto William L. Price trató de ser fiel al espíritu de la novela utópica de William Morris News from Nowhere (1890), en la que se relataba la vida de un pequeño asentamiento agrario cohesionado por un principio de mutua solidaridad. La dimensión social del Arts \& Cra$\mathrm{fts}$ atrajo a un importante número de adeptos en los Estados Unidos, principalmente mujeres, que simpatizaron con sus ideales progresistas de emancipación a través del trabajo justo, la igualdad de sexos y la educación de las jóvenes. Probablemente, la más famosa de todas las comunidades fue Roycroft Community en East Aurora (Nueva York), una próspera amalgama de empresa colectiva y colonia de artistas que llegó a obtener importantes beneficios y que permaneció activa hasta 1938. Establecidas por Elbert G. Hubbart en 1895, las manufacturas de Roycrofters llegaron a dar empleo a más de cuatrocientos artesanos. Producían mobiliario de estilo misión; tenían una imprenta y un taller de encuadernación; también un importante centro de metalistería especializado en cobre, y hasta un hotel para visitantes y compradores que se acercaban hasta allí buscando tanto los productos de una marca registrada como el sabor de un lugar que el mismo Hubbart se encargó de promocionar con gran visión comercial. En este éxito relativo puede identificarse una de las principales diferencias entre el Arts \& Crafts británico y el estadounidense ya que el pragmatismo empresarial con el que nació el movimiento americano dirigió buena parte de sus esfuerzos a conseguir piezas de calidad a precios asequibles. Para ello, aunque el movimiento europeo proscribía el uso de maquinaria, los talleres americanos introdujeron un cierto grado de mecanización en las tareas preparatorias, siendo el artesano el responsable último de ensamblar y acabar a mano.

14. Robert WINTER: American Bungalow Style. Op. cit., p 9.

1 5. Ciertamente los hermanos Greene construyeron bungalows de gran calidad arquitectónica que sin pretenderlo proporcionaron imágenes de las que se nutrió el estilo comercial del bungalow. Sin embargo, a pesar de lo que se ha escrito habitualmente sobre una de sus obras maestras, la Gamble House, ésta no puede considerarse en absoluto un bungalow. No puede serlo ni por sus extraordinarias dimensiones, ni por sus tres plantas, ni por su generoso presupuesto ni, desde luego, por la complejidad de las ideas estéticas que hacen de ella una obra irrepetible.

16. Robert Winter es uno de los principales especialistas en esta materia. Entre sus numerosas publicaciones dedicadas al tema han sido consultadas para la redacción de este apartado: The California Bungalow, con prólogo de David Gebhard (Santa Monica: Hennessey + Ingalls, 1998, primera edición de 1980); American Bungalow Style (Op. cit.); y Craftsman Style (New York: Harry N. Abrams, 2004). Más recientemente Robert Winter ha publicado Architecture of Entertainment. LA in the Twenties (Salt Lake City: Gibbs Smith, 2006). Winter es editor y autor de algunos textos del libro Toward a Simpler Way of Life: the Arts \& Crafts Architects of California (Berkeley: University of California Press, 1997), uno de los trabajos más completos publicados hasta la fecha sobre el conjunto de arquitectos que desarrollaron su obra en California durante los años del 
cambio de siglo. En él se publicaban también dos artículos póstumos de David Gebhard, uno de los cuales estaba dedicado a Irving Gill y otro a Harwell Hamilton Harris.

17. La primera residencia norteamericana que recibió el calificativo de bungalow, quizás por su característica de casa de retiro estival, fue construida en 1879 por William G. Preston en la playa de Cape Cod, Massachussets. Se trataba, sin embargo, de una vivienda de dos plantas que, estrictamente, expresaba muy poco de la esencia del tipo. En California, una década después, e arquitecto A. Page Brown construyó el primer bungalow en la ciudad de San Francisco.

18. M. A. DARRACH: "Why Not a Bungalow? The Simplest, Most Economical and Attractive Type of Small Country House", en Country Life in America (1906). Artículo citado por Juan COLLBARREU: Construcción de los paisajes inventados. Los Ángeles doméstico 1900-1960. Barcelona: Arquithesis. Fundación Caja de Arquitectos, 2004, p. 47.

19. Entre ellos Artistic Bungalows (1908) de William A. Radford; el Bungalow Book (1911) de Henry H. Saylor; el Modern American Homes (1930) de H. V. Von Holst; el Craftsman Homes (1909) y el More Craftsman Homes (1913) de Gustav Stickley; o el manual del bungalow, ya más tardío, publicado en 1923 por Charles E. White.

20. Para Winter, por ejemplo, las reinterpretaciones del Craftsman Style son extremadamente abiertas y abarcan desde el medievalismo de Bernard Maybeck y el eclecticismo romántico de Julia Morgan a las fabulaciones arquitectónicas de los hermanos Greene, la inspiración prehis pánica de Frank Lloyd Wright o las diferentes corrientes centroeuropeas que sirvieron de inspiración al California bungalow.

21. Una interesante discusión acerca de estas razones puede encontrarse en el primer capítulo del libro de Gwendolyn Wright Building the Dream. La autora sostiene que, como resultado del peso de la herencia del puritanismo de los pioneros, la sociedad norteamericana desarrolló un ideal de perfección moral basado en la vivienda como prototipo de templo familiar, un lugar sagrado separado del resto del mundo y gestionado de manera patriarcal. En este sentido, las habitación colectiva estaría asociada desde el siglo XIX con un fracaso del proyecto de vida individual e, incluso, con comportamientos socialmente reprobables. Véase el capítulo "The Puritan Way of Life" en Gwendolyn WRIGHT: Building the Dream. A Social History of Housing in America. Cambridge, MA: The MIT Press, 1981,pp. 3-17. Por cierto, el título de este libro ha inspirado la denominación de este apartado introductorio.

22. Citado por Don PARSON: Making a Better World. Public Housing, the Red Scare and the Direction of Modern Los Angeles. Minneapolis, MN: University of Minnesota Press, 2005, pp. xvi, 1,51, y $163-187$

23. Catherine BAUER: Modern Housing. Boston, MA : Houghton Mifflin, 1934.

24. Wurster estaba sin duda bajo la esfera del pensamiento social de su pareja, Catherine Bauer, a quien había conocido en 1940 en la Universidad de Berkeley.

25. Aliso Village, construido por el Housing Group Architects, integrado por Ralph Flewelling, Lloyd Wright, George J. Adams, Lewis Eugene Wilson y Eugene Weston Jr., presenta uno de los diseños urbanos más logrados de todas estas actuaciones en el ámbito de la vivienda social. Organizado a partir de una estructura radial sobre escrita sobre la trama urbana anterior, permitía liberar el centro de la intervención para un parque y servicios comunitarios. El conjunto es uno de los ejemplos de procesos de erradicación del chabolismo en el centro de Los Ángeles más representativos de la época y evidencia la complejidad de la gestión de la propiedad del suelo y a cuyo análisis esá dedicado el capítulo "Provisional Places with Fugitive Plans: Aliso Village" en Dana CUFF: The Provisional City: Los Angeles Stories of Architecture and Urbanism. Cambridge, MA: The MIT Press, 2002 (primera edición 2000), pp. 129-169.
26. Cfr. Kevin STARR, Prólogo al libro de Don PARSON: Op. cit., p. xii.

27. Consistían concretamente en 60 unidades de un dormitorio, 378 de dos dormitorios y 192 de tres dormitorios.

28. "Design for Postwar Living", en California Arts \& Architecture, agosto 1943, p. 27.

29. La arquitectura de Gregory Ain fue sensible a los problemas de la vivienda destinada a familias con recursos limitados, y sus investigaciones con cerramientos semiprefabricados, desmontables e intercambiables tuvieron como resultado obras tan significativas como los apartamentos Dunsmuir (Los Ángeles, 1937).

30. Marc TREIB y Dorothée IMBERT: Garret Eckbo, Modern Landscapes for Living. Berkeley y Los Ángeles: University of California Press, 1997, p. 150.

31. Este apartado ha sido realizado con ayuda de la arquitecta e historiadora Cory Buckner, especialista en Quincy Jones -es autora de la monografía sobre el arquitecto publicada por Phaidon en 2002- e imprescindible guía en Crestwood Hills, donde es propietaria de una de las viviendas originales de la MHA. Buckner ha dedicado importantes esfuerzos a documentar, divulgar y defender este conjunto como uno de los enclaves más representativos del patrimonio moderno de la ciudad de Los Ángeles. En 1961 un incendio arrasó 60 de las casas construidas por Quincy Jones; otras han sido demolidas o transformadas por completo; en la actualidad sólo se conservan 31 de las que, gracias a la labor de Buckner, la Heritage Commission of the City of Los Angeles ha declarado 15 de ellas como edificios de interés histórico cultural.

32. Las pequeñas cooperativas de artistas o de profesionales liberales eran muy frecuentes en Los Ángeles. Por ejemplo, también hacia esa fecha, por encargo de los miembros de una asociación musical Gregory Ain construyó en Silver Lake un excelente grupo de viviendas conocido como Avenal Cooperative Housing Project (1947).

33. El proyecto de paisaje estaba en realidad firmado por Eckbo y sus dos asociados Royston y Williams.

34. Cfr. Dorothée IMBERT en Marc TREIB y Dorothée IMBERT: Op. cit., p. 164.

35. Ibid., p. 166.

36. Ibid., p. 168.

37. Aunque la estrecha colaboración entre todos ellos resultó muy provechosa, este equipo técnico sólo coincidió una vez más cuando, tras el éxito de la MHA, Whitney R. Smith volvió a trabajar con Quincy Jones y Edgardo Contini en la construcción de diversos pabellones para un albergue femenino en Griffith Park (1949). Smith, que había participado en 1945 en el programa de las Case Study Houses ( $\mathrm{CSH} n^{\circ} 5$ ), acabaría asociándose con Williams y abriendo despacho en Pasadena.

38. Etimológicamente tract significa porción de terreno. La expresión tract housing designa el tipo de promociones suburbanas basadas en la parcelación de grandes superficies de terreno para promover desarrollos inmobiliarios basados en lotes de viviendas, generalmente de bajo coste de construcción y alta rentabilidad. Para abaratar costes se recurre a la repetición de unas pocas tipologías, lo cual, unido al empleo de los mismos materiales, incide en la imagen de uniformidad del conjunto.

39. Citado por Cory BUCKNER: Quincy Jones; London: Phaidon Press, 2002, p. 8 
40. Irvine, que inició su desarrollo urbano en 1960 bajo la dirección de William Pereira es la ciudad más grande planificada por una empresa privada, la Irvine Company, propietaria de más de 25.000 hectáreas, un sexto de la superficie del Condado de Orange. Actualmente cuenta con numerosos centros tecnológicos donde trabajan más de 150.000 personas, varios campus universitarios y dos bases marítimas. La idea de la Irvine Company fue aprovechar la situación privilegiada de unos naranjales próximos al aeropuerto internacional John Wayne y situados a pocas millas del Parque Disney para llevar a cabo la idea de un gigantesco complejo residencial, comercial y de ocio cercano a la playa y elitista puerto deportivo de Newport Beach. Hoy día es uno de los municipios más ricos del país y, con un índice de criminalidad casi inexistente, el FBI la declaró en 2005 la ciudad más segura de los Estados Unidos.

41. En 1961, John Entenza se puso en contacto con Quincy Jones y Frederick Emmons animándoles a que seleccionaran entre su obra reciente aquel proyecto que, cumpliendo con las condiciones del Case Study House Program, pudiera aportar alguna novedad a la iniciativa difundida por su revista. El interés de la propuesta escogida por los arquitectos motivó que Entenza ampliara los planteamientos iniciales de su programa para dar cabida a una intervención de 260 viviendas en Chatsworth. Ésta formaba parte del desarrollo inmobiliario llevado a cabo por Joseph Eichler en el Valle de San Fernando. El citado promotor había reajustado la zonificación para reducir las parcelas de $1.500 \mathrm{~m} 2$ a $1.000 \mathrm{~m} 2$ y emplear la superficie así obtenida para crear un parque, cinturones verdes de separación entre las propiedades, una pequeña zona de tiendas de barrio y un edificio de usos múltiples para la comunidad. Emmons y Jones diseñaron cinco tipologías diferentes de viviendas, muy flexibles, pero sólo detallaron una de ellas. La casa piloto, de cuatro dormitorios, perseguía la privacidad a la vez que una relación directa con e exterior, y para logarlo aparecía semienterrada, minimizando también el impacto visual de las viviendas en el conjunto del paisaje proyectado. Su diseño incluía un novedoso planteamiento de arquitectura bioclimática avant la lettre, con un sistema hidráulico de refrigeración y un uso de la cubierta ajardinada y la vegetación como elemento de disipación del calor. La promoción fracasó y nada se realizó conforme había sido previsto ya que las presiones de los compradores acabaron bloqueando todo intento de construir o mantener espacios dotacionales a costa de la propiedad privada. A pesar de que no llegó a realizarse, este desarrollo inmobiliario, por su escala, diseño ejemplar y vocación comunitaria era el proyecto que mejor podría explicitar las ideas originales de proyección social del CSH Program de Arts \& Architecture y que pocas vivien das $\mathrm{o}$ arquitectos seleccionados por Entenza lograron transmitir en su supuesta condición de prototipos reproducibles.

42. Lugar conocido por ser el epicentro del seísmo que devastó el Valle de San Fernando en 1994

43. A. Quincy JONES; Frederick E. EMMONS y John CHAPMAN: Builders' Homes for Better Living. New York: Reinhold Publishing Corporation, 1957. El libro estaba dedicado a Joseph Eichler y recogía todos los pasos y consideraciones que debían tener en cuenta tanto arquitectos como clientes para construir casas coherentemente integradas en el seno de una comunidad. Abarcaba todo tipo de aspectos, desde la burocracia relativa a la compra de solar, la aprobación de créditos y la obtención de permisos, hasta recomendaciones sobre zonificación, instalaciones, dotaciones, tipologías, criterios de diseño, materiales y métodos constructivos. Por ejemplo, Quincy Jones prefería la utilización de la madera por su meno coste pero, consciente de las consecuencias de la sobreexplotación de los bosques, sugería también otros materiales como el acero. 


\section{DISCUSSIONS IN A GARDEN}

[ DE OLIVE HILL A KINGS ROAD

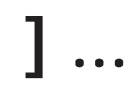

[ PAULINE GIBLING (SCHINDLER),

PROMOTORA DE LA MODERNIDAD CALIFORNIANA

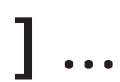

[ EDWARD WESTON EN LOS INICIOS DE LA

FOTOGRAFÍA DE ARQUITECTURA EN CALIFORNIA

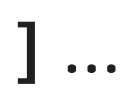

[RUDOLPH SCHINDLER Y LA FENOMENOLOGÍA

DEL ESPACIO MODERNO

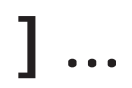


"Los pioneros de la modernidad de Los Ángeles afirmaron sus ideales a través de su trabajo como artistas y de un legado colectivo. Formaban parte de una comunidad alrededor de la cual gravitaban como satélites de expresión individual [...] Galka Scheyer, Walter y Louise Arensberg, Richard Neutra, Rudolph Schindler, Will Connell, Lloyd Wright, Edward Weston, John Cage, Jake Zeitlin, Merle Armitage, Harriet y Samuel Freeman y unas cuantas docenas de nombres más, constituían un auténtico círculo. Y, lo más importante, ese círculo trascendía los vínculos de meros conocidos ya que todos ellos se reunían como amigos y amantes, compartiendo el entusiasmo de estar abriendo una importante brecha en la tradición. De forma sencilla pero duradera cambiaron la modernidad para siempre. Su historia como grupo ha sido silenciada durante mucho tiempo pero esta situación, por fin, ha comenzado a cambiar. La historia de este Los Ángeles secreto que contemplaba con optimismo el nacimiento de una 'ciudad del futuro' diferente merece ser contada con mayor detalle ${ }^{{ }_{1}}$.

William Deverell

En 1994, el MAK Center for Art and Architecture instaló su sede en Los Ángeles. Se abrían al público sus dependencias en la casa-estudio que Rudolph M. Schindler había construido en el número 835 de North Kings Road a principios de los años 20. La institución ${ }^{2}$, de origen vienés como el propio arquitecto, iniciaba así en West Hollywood una emocionante aventura curatorial que convertía la vivienda, recién restaurada, en un centro de reflexión, sala de exposiciones, talleres y encuentros internacionales destinados a explorar la intersección entre el arte y la arquitectura contemporáneos. Una década más tarde, en 2004, con motivo de su décimo aniversario, el MAK Center de Los Ángeles propició la vivencia de la casa a través de una serie de conferencias sobre arte y política que denominó "Discussions in a Garden" (Conversaciones en el jardín). Aquel ciclo, a través del cuidado de detalles como el acondicionamiento del escenario original, los temas escogidos, el día de la semana en que se convocaban los debates (los domingos por la tarde) y, por supuesto, su título, fue planteado como una celebración del espíritu de las reuniones que, antes de la Segunda Guerra Mundial, Pauline Gibling Schindler organizaba cada domingo en ese mismo jardín.

También a modo de homenaje, esta sección recupera el título "Discussions in a Garden" para abordar el contexto arquitectónico y cultural de la modernidad californiana durante el periodo de entreguerras. Precisamente aquellas décadas en las que, en especial durante el boom inmobiliario de los años 20 , se reforzaron las campañas publicitarias dirigidas a vender los atractivos de California como el edén de Norteamérica. Miles de imágenes de sus paisajes inventados, idílicas postales, folletos promocionales y hasta etiquetas de frutas y mermeladas con escenas de huertos y misiones fabricaron el sueño de poseer una casa con jardín en aquel vergel mediterráneo con el que se asoció para siempre la identidad del Sur de California.

Frente a esta edulcorada -pero nada inocente- visión del jardín, los arquitectos y artistas modernos de Los Ángeles también hicieron suyo el mantra California Calls You aunque ellos, por el contrario, movidos por un afán de progreso, se vieron a sí mismos como agentes de cambio e instrumentos de acción para forjar con sus ideas los cimientos de una nueva ciudad-región. Apoyados por el trabajo de sus amigos escritores, políticos y clientes, aspiraron a rediseñar por completo su medio urbano como el escenario de una nueva vida contemporánea. $Y$ aunque no lo consiguieron, sí lograron dejar 
Abajo: Vivienda-estudio de Schindler en Kings Road, 1922, Dibujo del arquitecto

Página siguiente: Vista aérea del área de West Hollywood en 1922 . La vivienda de Kings Road se localiza hacia el centro de la fotografía, en la zona delimitada por el cambio de dirección del Boulevard de Santa Mónica. Fuente: Los Angeles Public Library Photography Collection

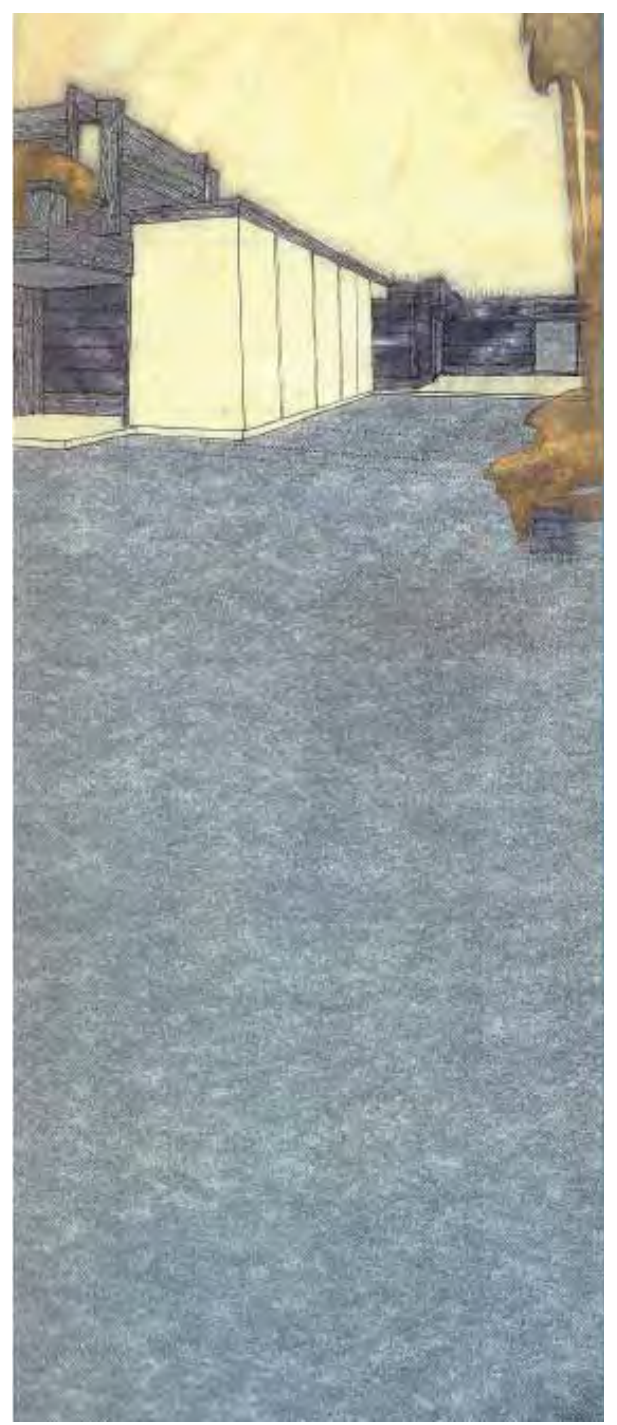

huella en algunas viviendas, fotografías y obras de arte memorables, así como en el diseño de mobiliario, objetos industriales, jardines, publicaciones, decorados de cine, etc.

Más allá de su significado arquitectónico, Kings Road fue una de las células germinales de aquel movimiento local, el lugar del que partieron o donde se cruzaron algunos de los itinerarios profesionales más originales o que más influyeron en la gestación de la arquitectura moderna californiana. Esta sección aborda varios episodios formativos de esa historia -aunque en rigor debiera decirse historias-y lo hace a través del hilo conductor de dos de sus protagonistas, Rudolph y Pauline Schindler.

Las biografías de ambos, y en especial la de Pauline, tienen la capacidad de expresar el espíritu de una época, de resumir las aspiraciones de una generación radical.

Su casa se convirtió en un laboratorio de ideas y estilos de vida progresistas, un salón imprescindible en la vida cultural de la ciudad, y sus jardines, en el escenario de todo tipo de eventos que reunían a algunos de los personajes más fascinantes de la época. Por allí pasaron el líder socialista Upton Sinclair3, promotor del histórico movimiento contra la pobreza en California y aspirante a Gobernador del estado en 1934, los escritores Max Eastman y Theodore Dreiser, mentor de Esther McCoy, los fotógrafos Edward Weston y Willard Morgan, los coleccionistas Walter y Louise Arensberg, la marchante de arte Galka Scheyer, el bailarín John Bovington, el músico John Cage, los patrones Philip y Leah Lovell -quienes además de encargar sus viviendas a Schindler y a Neutra les pusieron en contacto con otros clientes-, Jean Murray Bangs, amiga íntima de Pauline, y su marido Harwell Hamilton Harris, el dramaturgo y fundador del Chicago Little Theatre Maurice Browne, actores de Hollywood y un largo etcétera de modernos y militantes.

El sentido del título Discussions in a Garden sería, pues, doble. Por un lado, haría referencia al propio jardín de Kings Road donde tenían lugar aquellos eventos mientras que, al mismo tiempo, aludiría a la imaginación como jardín de paisaje del Sur de California.

Incidiendo en el plano metafórico, el jardín de los Schindler sería indisoluble de su condición de oasis. Las fotografías de Kings Road en 1922 muestran una vivienda aislada en el parcelario abstracto y aún sin desarrollar de West Hollywood, un jardín en mitad de un paraje semidesértico y apenas cultivado. Por otro lado, la excepcionalidad de la arquitectura y de la cultura desarrollada en aquel pequeño paraíso de la vanguardia, remitiría a su metáfora de oasis moderno, es decir, a la dificultad de recepción de sus planteamientos en una región urbanizada vertiginosamente a través de un ideario económico, político y social manifiestamente conservador. En efecto, a pesar de la extraordinaria riqueza del patrimonio moderno de Los Ángeles, en realidad aquél movimiento tuvo muy poco impacto en la mayoría de sus ciudadanos, que ignoraron por completo cualquier ruptura con la tradición. La obra de Schindler, como la de Neutra y demás arquitectos modernos, resultaba incomprensibles a casi todo el mundo. La mayoría de los propietarios de las casas de la ciudad prefirieron el confort de lo familiar, de los estilos reconocibles como Spanish Revival, Colonial o Tudor. Exceptuando su círculo de amistades, "muy pocos clientes supieron ver más allá de la trampa de sus propias ilusiones y aspiraciones y, por ello, casi nadie aceptó el sueño de la modernidad"4. 


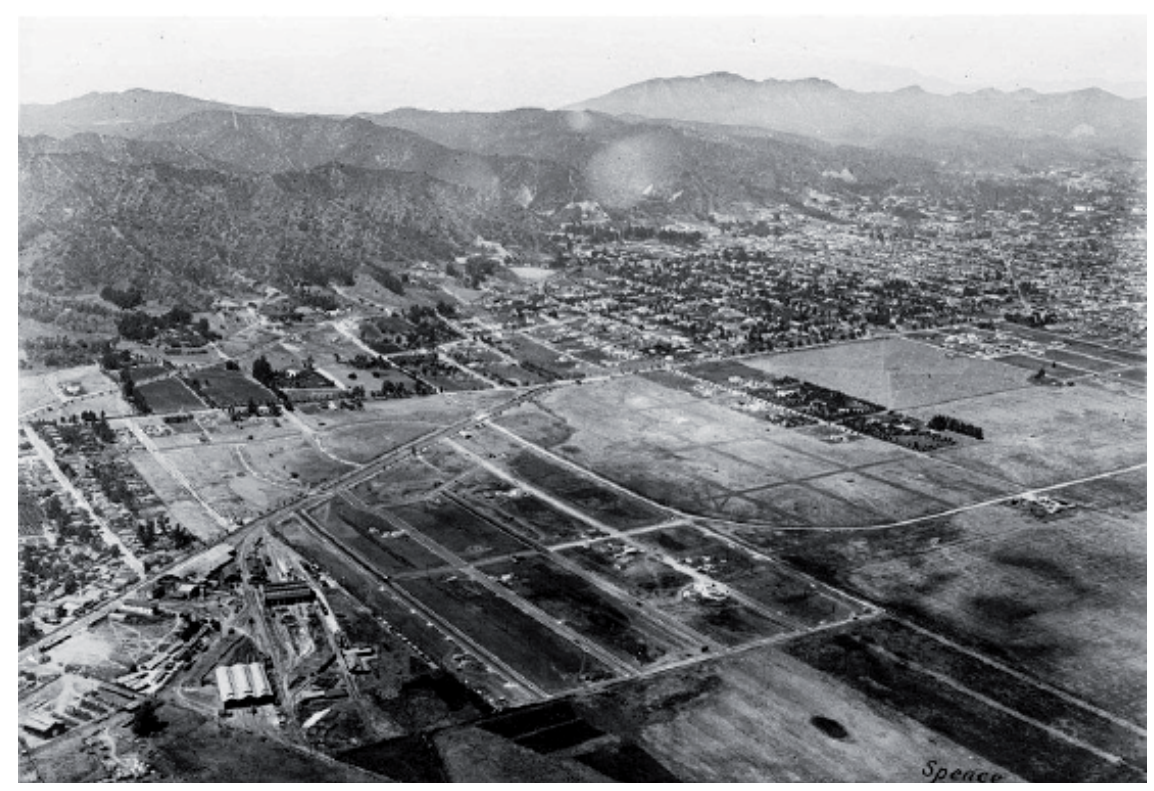

En otro orden de cosas, es necesario ubicar a Pauline Schindler como pieza imprescindible de un grupo de mujeres que fueron fundamentales para la historia de la arquitectura de Los Ángeles: Jennie Reeve y Adelaide Tichenor -clientes y mecenas de los hermanos Greene-, Aline Barnsdall, Leah Lovell, Jean Murray Bangs, Constance Perkins y tantas otras... Mujeres cultas y determinadas, comprometidas con sus ideas y que, sin embargo, apenas han sido estudiadas más allá de su condición de personajes secundarios. Ahora bien, sin su intervención, por ejemplo generando ellas mismas los encargos, algunas de las arquitecturas más meritorias de la ciudad no hubieran sido posibles.

A lo largo de toda su vida Pauline Schindler movilizó incansablemente a sus amigos y a todos aquellos cuyo trabajo consideraba valioso. Creó una red de arquitectos, artistas, clientes y editores sin cuya concurrencia las condiciones de partida de la modernidad californiana habrían sido otras muy distintas. Fue a través de ella como Rudolph Schindler contactó con algunos de los autores más relevantes del momento, brindándole experiencias artísticas de primer nivel, como la fotografía de Edward Weston. Pauline Schindler fue además una de las primeras personas que escribió sobre arquitectura moderna en Los Ángeles, precediendo incluso a Esther McCoy a quien, por cierto, consiguió que Schindler contratara como delineante influyendo así en su carrera posterior como historiadora de la arquitectura. Pauline fue también una de las primeras divulgadoras y promotoras de la obra de su amigo Harwell Hamilton Harris. Y, por supuesto, fue la responsable del encargo de dos de las obras más icónicas de la arquitectura del siglo XX: la Lovell Beach House, de manera directa e, indirectamente, de la Lovell Health House. 


\section{[ DE OLIVE HILL A KINGS ROAD ] ]...}

LPAULINE GIBLING (SCHINDLER),

PROMOTORA DE LA MODERNIDAD CALIFORNIANA

LEDWARD WESTON EN LOS INICIOS DE LA

FOTOGRAFÍA DE ARQUITECTURA EN CALIFORNIA

LRUDOLPH SCHINDLER Y LA FENOMENOLOGÍA

DEL ESPACIO MODERNO 
"Vine a vivir y a trabajar a California. Acampé bajo las estrellas, en sus bosques de secuoyas, en sus playas, en sus colinas y en el desierto. Testé su granito y también su cielo. Y después de reflexionar sobre cómo el hombre urbano podía enraizarse en este lugar-único y encantador-construí mi casa. Y a menos que haya fallado ésta debería ser tan californiana como el Partenón es griego y el Foro romano"s.

Rudolph Schindler, 1952

En 1916, casi todo en Los Ángeles estaba aún por hacer. La atmósfera de informalidad y de relativa libertad que se respiraba en el Sur de California atraía como un imán a intelectuales, bohemios y todo tipo de personalidades contestatarias incapaces de ajustarse a las rígidas normas sociales que imperaban en el resto del país. Sólo por esta razón, Los Ángeles era la ciudad perfecta para Aline Barnsdall.

Hija y nieta de magnates del petróleo, Barnsdall disfrutó de la autonomía que su fortuna le proporcionó para hacer siempre lo que quiso ${ }^{6}$. Mujer, culta, apasionada por los viajes, las artes escénicas y la arquitectura moderna, profundamente inconformista e inmensamente rica, rompió moldes para su tiempo. Fue madre soltera abiertamente en una época en la que esa opción era impensable. Ejerció como mecenas y como productora de teatro experimental. Simpatizante comunista, se rodeó de los personajes más variopintos: artistas, activistas políticos y radicales cuyas causas apoyó con generosidad. No porque creyera en todas ellas, sino porque detestaba toda forma de sumisión y de orden establecido, una rebeldía que le costó que se le revocase el pasaporte ${ }^{7}$ y que fuera incluida, especialmente por su amistad con la anarquista Emma Goldman, en la lista negra de John Edgar Hoover, quien durante años ordenó que el FBI vigilara de cerca todas sus actividades.

Pero si Aline Barnsdall está en los libros de historia es por ser la promotora de una de las principales obras de Frank Lloyd Wright: la Hollyhock House, nombre con el que se identifica la casa que éste le construyó en Olive Hill (Los Ángeles, 1919-21). Aunque el proyecto de esta vivienda es en general bien conocido ${ }^{8}$, representa sólo un episodio de la complicada relación profesional entre el arquitecto y su clienta, una vinculación que se prolongó durante toda una década (1914-24) y cuyo resultado fue el diseño de decenas de edificios y el tejido de una red de contactos interpersonales, encargos, amistades e influencias que, empezando por el hecho de llevar a Wright, Schindler y, más tarde, a Neutra a California, marcaron el curso de la arquitectura moderna de Los Ángeles.

El análisis más comprehensivo de la casa Barnsdall en el contexto del conjunto de proyectos para la colina de Olive Hill y otras localizaciones de la ciudad se debe a la historiadora Kathryn Smith, cuya monografía Frank Lloyd Wright, Hollyhock House and Olive Hill: buildings and projects for Aline Barnsdall , aborda pormenorizadamente el análisis de cada uno de esos edificios como arranque de su segundo y más largo periodo creativo.

En efecto, el periodo de 1914 a 1924 fue crucial en la carrera de Wright. Se inicia con la tragedia de Taliesin ${ }^{10} y$, por tanto, con su intento de recuperación de una profunda crisis personal, agravada por la necesidad de reinventarse profesionalmente tras ser abandonado por casi todos sus clientes. Dicha década está jalonada por dos encargos monumentales, el del Hotel 
Aline Barnsdall frente a su casa Hollyhock, Frank Lloyd Wright, Olive Hill, 1920-1921. Fuente: Security Pacific Collection/ Los Angeles Public Library

Página siguiente: The Little Review, portada del número de noviembre de 1915. Entre los colaboradores figura el escritor Theodore Dreiser, futuro vecino de los Schindler en Kings Road y mentor literario de Esther McCoy

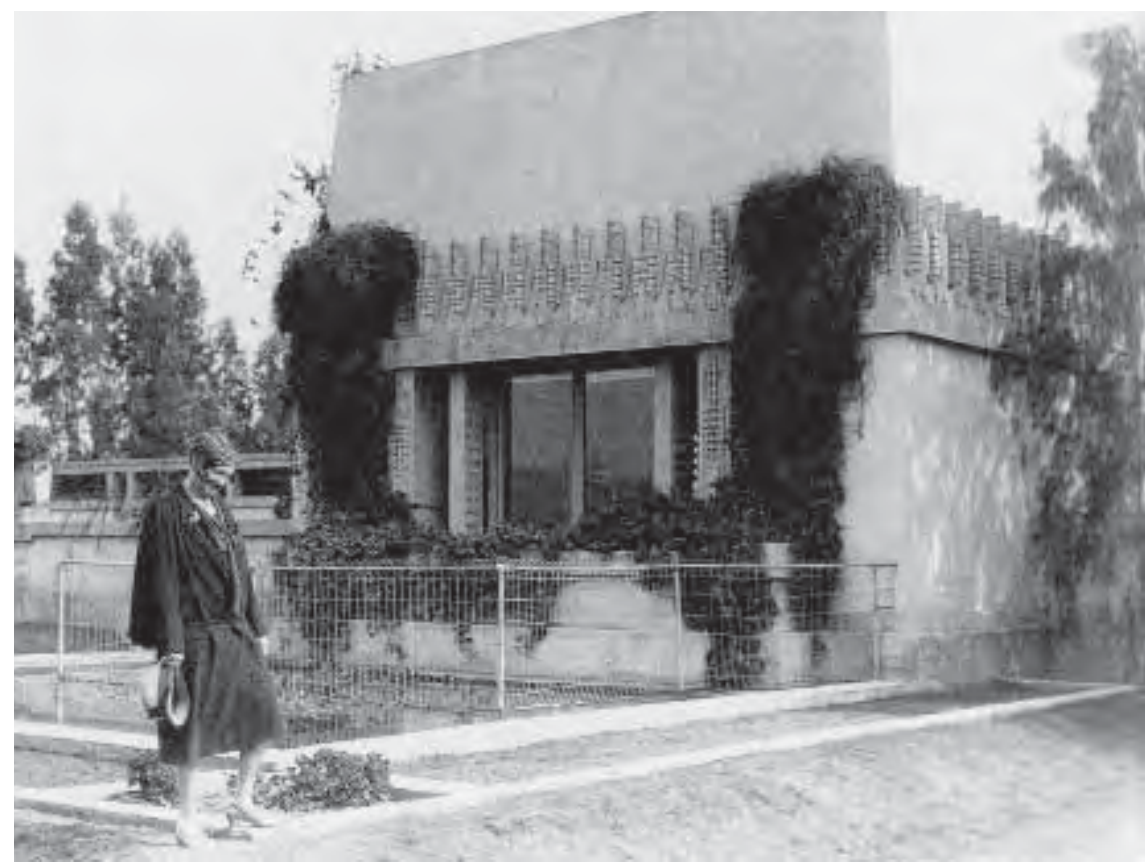

Imperial de Tokio y el proyecto de Barnsdall de edificar en Hollywood una comunidad de artistas y un complejo teatral compuesto por varios edificios diseminados en un parque con vocación pública. El primero marcó las prioridades de su agenda, mermó sus energías y consumió casi todo su tiempo entre 1917 y 1922 ya que Wright quiso supervisar personalmente su construcción. El segundo, que se vio perjudicado por esta circunstancia, fue aceptado -no sin pocos reparos- ante la insistencia de Aline Barnsdall. Seguramente porque en aquel momento de su vida no podía permitirse renunciar a sus cuantiosos honorarios y porque Los Ángeles presentaba la ventaja de ser una etapa ineludible del viaje entre Arizona y Japón.

Sin embargo, a pesar de la atención prestada al Hotel Imperial, el conjunto de encargos para Aline Barnsdall, a través de su diversidad de situaciones y de estrategias proyectuales, de las posibilidades de investigación formal y técnica -tanto en obras construidas como en hipótesis sobre el papel- revela con mayor intensidad la encrucijada personal y la evolución creativa de Wright desde la etapa de sus últimas casas de la pradera hasta la experimentación con sistemas industriales y el avance de nuevos temas como, por ejemplo, la prefiguración de la Casa de la Cascada en la idea de la Director's House presente en el primer masterplan de Olive Hill.

A lo largo de la década, Aline Barnsdall solicitó de Wright el diseño de 45 edificios. De éstos, dos eran teatros (uno para Chicago, otro para Olive Hill); otros dos sus residencias privadas (la Hollyhock House y una vivienda en Beverly Hills); 16 eran tiendas y locales comerciales; 21 eran casas unifamiliares y bloques de apartamentos; también estaban previstos un pabellón de entrada al parque, un cine y una escuela infantil; todo ello dispuesto según dos planes directores y sus correspondientes proyectos de paisajismo que organizaban las diferentes edificaciones de acuerdo con un planeamiento que anticipaba la teoría urbana desarrollada más tarde en Broadacre City ${ }^{11}$.

Las ausencias de Wright, traducidas en continuos retrasos, negligencias, parones en las obras, desplantes al cliente y disputas entre todas las partes implicadas fueron el principal motivo por el que se malogró el complejo de Olive Hill y la mayoría de sus edificios nunca llegó a salir del tablero de dibu- 
jo. Aunque no sería justo responsabilizar únicamente a Wright del curso que tomaron los acontecimientos. En parte, el proyecto también se frustró por el carácter a menudo caprichoso de su promotora. Su inconstancia y tendencia a idealizar a las personas que admiraba, sobre todo a Wright, así como la indefinición de aquello que quería construir realmente, es decir, su falta de previsión, más allá de la vaguedad de una idea o de su necesidad vital de crear algo importante para la comunidad y la cultura su tiempo, dejaron a la voluble Barnsdall demasiado expuesta a la personalidad egocéntrica, oportunista y despótica de su arquitecto ${ }^{12}$.

\section{Chicago, The Little Theatre}

Aline Barnsdall se había trasladado a Chicago a mediados de 1914 para dirigir obras de teatro independiente en la línea de los montajes a los que de joven había asistido como público en París. Temporalmente, fijó su cuartel general en el Fine Arts \& Architecture Building, donde alquiló el auditorio principal para las producciones teatrales de la Players Producing Company, compañía que codirigía junto a Arthur Bissell. Aquel edificio albergaba entonces buena parte de la actividad cultural de Chicago, una ciudad donde volvía a brotar la savia de la creatividad y poco a poco se recuperaba el pulso histórico que había desacompasado la Exposición Colombina de 1983.

El Fine Arts Building era entonces el epicentro de un efímero pero crucial movimiento de renovación artística, denominado más tarde como Chicago Renaissance. En sus dependencias estaba la sede de The Little Review, la revista de vanguardia literaria publicada entre 1914 y 1929 por Margaret Anderson y su socia Jean Heap -y a la que Wright contribuyó durante años prestando apoyo financiero y enviando diversos artículos. The Little Review dio a conocer una extraordinaria colección de textos inéditos de escritores estadounidenses, ingleses e irlandeses, entre los cuales, su mayor hito fue la publicación por entregas del Ulises de Joyce. También en Chicago, otra mujer de gran talento, Harriet Monroe, editora y crítica literaria había fundado en 1912 Poetry Magazine, gaceta desde la que se difundió la obra de algunos de los mejores poetas norteamericanos como T. S. Eliot, Ezra Pound o Carl Sandburg.

En ese ambiente, en algún momento hacia finales de 1914, el camino de Aline Barnsdall se cruzó con el de Frank Lloyd Wright. En 1908, el arquitecto había tenido un despacho en el Fine Arts Building y, de nuevo, de 1909 a 1910. Poco después, en la cuarta planta del edificio, en 1912, Maurice Browne y su mujer, la actriz Ellen Van Volkenburg, habían fundado el Chicago Little Theatre, uno de los primeros little theatres o teatros experimentales de los Estados Unidos y una de las iniciativas más influyentes para la escena independiente norteamericana de los años 20 y 30 . El Little Theatre se había interesado por la renovación plástica y literaria de las vanguardias europeas, enfocando su actividad hacia la representación de textos contemporáneos. Igualmente promovía representaciones modernas de los dramas griegos, creando sugerentes atmósferas cargadas de simbolismo. Entre los dramaturgos introducidos por el Little Theatre en América estaba Henrik Ibsen, uno de los autores más admirados por Emma Goldman, su principal valedora y quien, por su afición al teatro, había trabado amistad con el círculo de Browne, Van Volkenburg y la propia Barnsdall'13.

De origen ruso-judío, Emma Goldman había emigrado a los Estados Unidos con apenas quince años para evitar un matrimonio de conveniencia. Desde

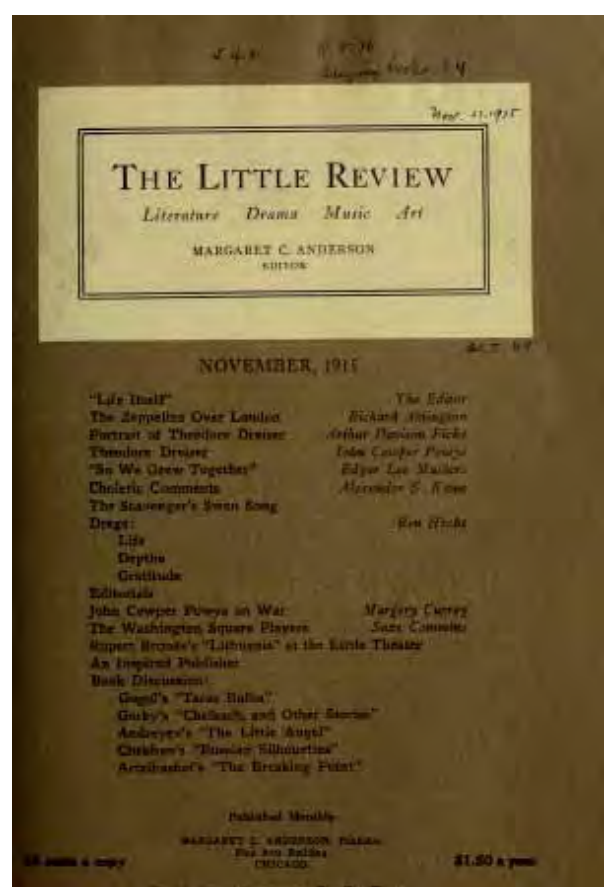




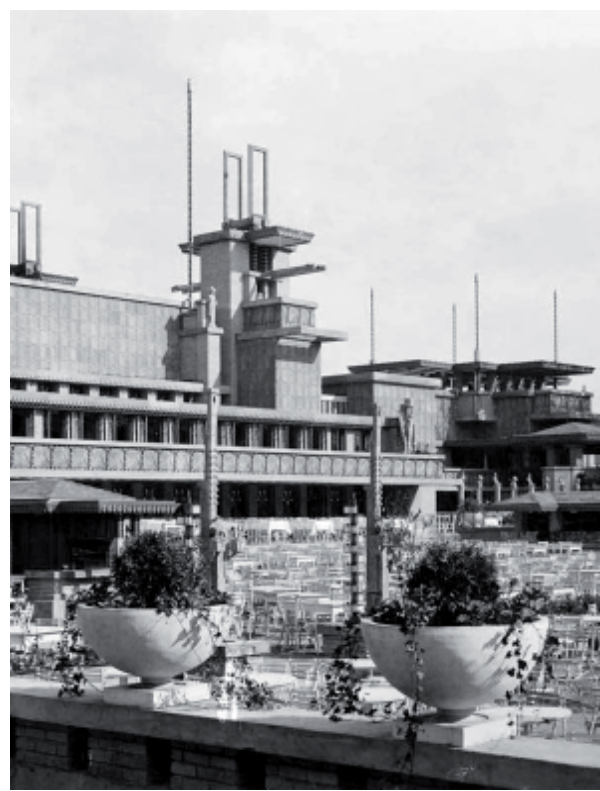

su llegada a Nueva York se convirtió en una de las más activas portavoces de la lucha por la emancipación de la mujer y en el símbolo de la rebelión cívica contra los abusos arbitraria y sistemáticamente ejercidos por el Estado y los poderes fácticos contra la libertad individual. En aquellos años, Goldman dio varias conferencias en el Fine Arts Building, aportando sus ideas al pensamiento social del movimiento de Chicago. Barnsdall se sintió fascinada por su personalidad y su entrega a las más diversas causas y trató de brindarle apoyo económico. Ambas mujeres compartían sus ideas feministas pero, sobre todo, estaban unidas por su rebeldía y su pasión por el teatro moderno ${ }^{14}$.

Por su parte, el Little Theatre contaba con el apoyo de la élite social e intelectual del Lake Shore Drive pero, debido al empeño de Browne por mantener precios asequibles con los que fomentar el interés por el teatro entre las clases más desfavorecidas, nunca tuvo entre sus metas el ser una empresa rentable. Barnsdall también se había entusiasmado con el trabajo de la pareja Browne-Van Volkenburg -a quienes había conocido hacia noviembre de $1914^{-}$y a quienes, por supuesto, también quiso ofrecerles ayuda para superar sus altibajos financieros, hasta el punto de proponer a sus amigos la construcción de una nueva sede para el Little Theatre, un teatro mayor y mucho más moderno cuyo proyecto decidió encargar a Wright.

En 1914, Wright había regresado a Chicago mientras llevaba a cabo la reconstrucción de Taliesin. El arquitecto atravesaba entonces un momento de dificultades económicas y su oficina se encontraba reducida a su mínima expresión, teniendo sólo en plantilla a un antiguo delineante del despacho de Oak Park y a sus hijos John y Lloyd -formándose junto a Irving Gill en California. Wright acababa de terminar los Midway Gardens (1913-14) que, desde su inauguración en el verano de 1914, se habían convertido en una de las principales atracciones de Chicago. Precisamente, este vasto complejo de casinos, restaurantes y salones de baile al aire libre impresionó tanto a Barndsall que, tras conocer la obra, quiso contactar con Wright para proponerle la construcción del teatro.

Es probable, -como relata Wright en su autobiografía ${ }^{15}{ }_{-}$, que fuera Henry Blackman Sell, futuro editor de Harper's Bazaar y entonces un joven reportero que trabajaba como publicista para el círculo de Maurice Browne y del Little Theatre, quien presentara a Barnsdall y a Wright hacia finales de 1914 o principios de 1915. De todos modos, en esa fecha, las relaciones de éstos y sus amigos en común eran ya eran suficientes como para que ambos hubieran coincidido antes. Aunque Wright se refirió a un teatro en Los Ángeles como el motivo de su encuentro con Barndsdall, lo cierto es que, de acuerdo con el relato de Nelly van Volkenburg, ella misma, su marido, Barnsdall y Wright, llegaron a reunirse para hablar de ese teatro de Chicago, del que Smith afirma haber encontrado un croquis en los archivos de la Fundación Wright ${ }^{16}$.

Sea como fuere, Barnsdall abandonó pronto la idea de construir un nuevo teatro en la ciudad. Uno de los rasgos más definitorios de la personalidad de Aline Barnsdall era su inconstancia, la necesidad de cambiar continuamente de lugar en busca de nuevos estímulos. Durante los meses de primavera y verano de 1915 Barnsdall estuvo recorriendo California con ocasión de las dos grandes ferias internacionales que celebraban la apertura del canal de Panamá, la Panama-California Exposition de San Diego y la Panama-Pacific International Exposition de San Francisco. A su regreso a Chicago y antes de que el proyecto para el Chicago Little Theatre fuera más allá, comunicó a Wright su intención de establecerse en San Francisco y 


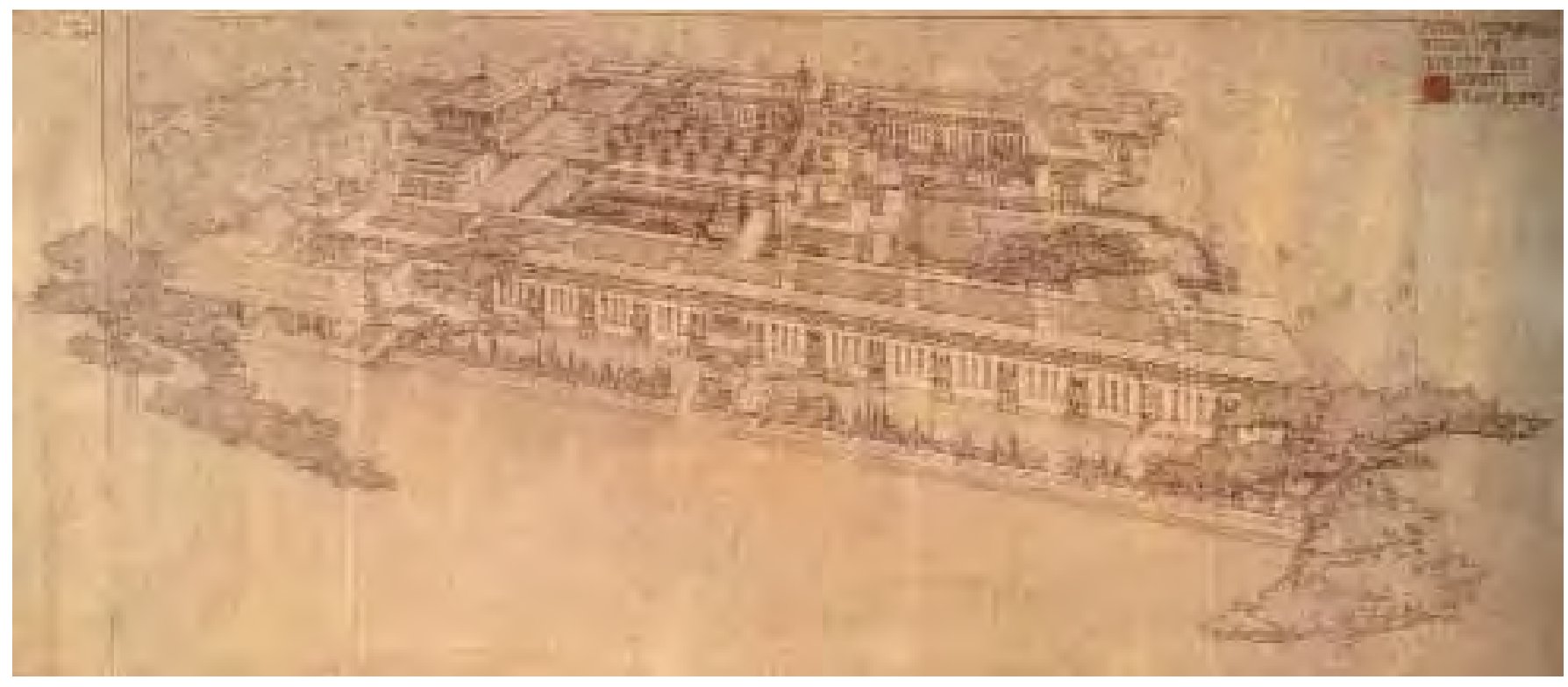

fundar allí su propia compañía itinerante. A principios de 1916 extendió su invitación a Maurice Browne y a Nellie van Volk, pero estos declinaron su oferta. En aquel momento, Chicago comenzaba a declinar de nuevo como centro de vanguardia y el movimiento acabaría disolviéndose definitivamente poco después de la Primera Guerra Mundial ${ }^{17}$.

A pesar de no tener una localización física concreta ni una compañía todavía organizada, Barnsdall pidió a Wright que se reuniera con ella para comenzar a trabajar en el proyecto de un nuevo teatro para San Francisco. Ambos se vieron varias veces en Chicago a principios de 1916, justo antes de que ella se marchase a California en febrero. Desde el principio, la oportunidad de diseñar un teatro se reveló como un reto atractivo para Wright, aunque muy pronto su atención se desvió hacia otro proyecto que trasladó su interés por el teatro a un segundo plano. La casualidad quiso que, coincidiendo con la partida de Barnsdall, Aisaku Ayashi, el director del Hotel Imperial visitara Taliesin y, tras entrevistarse con el arquitecto unos días, formalizó su encargo. En diciembre de 1916 Wright se embarcó para Japón. Sería el primero de seis viajes que le mantendrían prácticamente fuera del país hasta 1922.

\section{Una acrópolis para Los Ángeles}

Nada más llegar a California, Barnsdall replanteó su relación con el teatro, abandonó la dirección y centró sus esfuerzos en una labor empresarial como productora de obras independientes. Tras pasar algunos meses en San Francisco sin encontrar un emplazamiento convincente para su nuevo teatro, en el verano de 1916 se mudó a Los Ángeles, donde alquiló la Egan Dramatic School a la que rebautizó como Los Angeles Little Theatre. Meses antes había contactado con Norman Bel Geddes, entonces todavía un joven desconocido, a quien ofreció unirse a su compañía. El futuro dramaturgo y visionario diseñador industrial accedió y se trasladó a Los Ángeles para convertirse en su escenógrafo y director artístico. Pero para Barnsdall, 1916-1917 fue su primera temporada teatral en la ciudad y también la última ${ }^{18}$. Había remodelado el teatro en la intersección de las calles 9 y Figueroa, mantenido el nombre de Players Producing Company y contratado a Richard Ordynski como actory director teatral. Sin embargo, a pesar de las buenas críticas recibidas ${ }^{19}$, meses más tarde, a principios de 1917, despedía a todo el mundo y clausuraba
Frank Lloyd Wright : Hotel Imperal, Tokio, 1917-1922. Fuente: Robert McCarter, Frank Lloyd Wright Architect, Phaidon

Página anterior: Frank Lloyd Wright : Midway Gardens, Chicago, 1913-14. Fuente: Robert McCarter, Frank Lloyd Wright Architect, Phaidon 


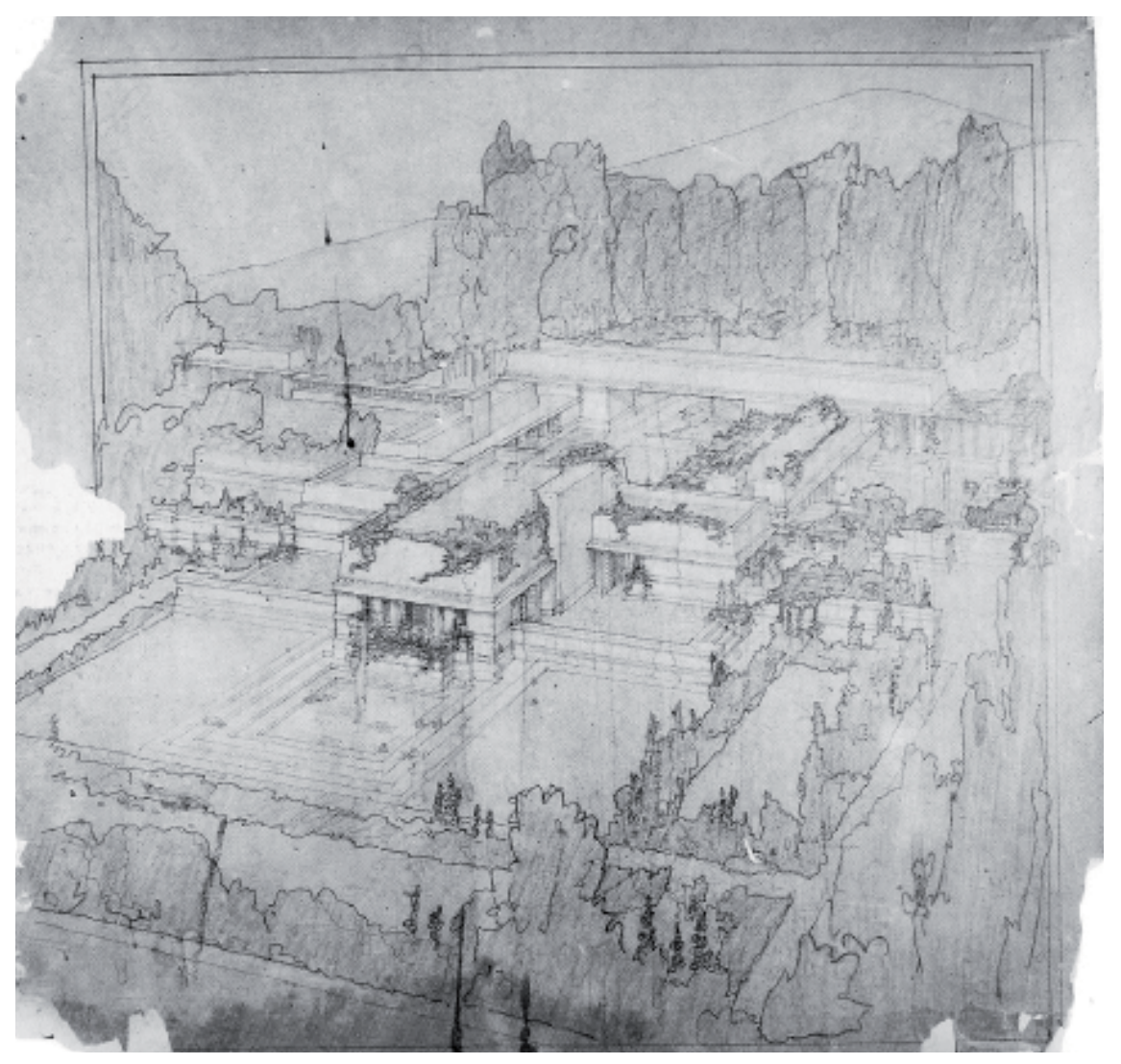

su compañía por razones personales. En primer lugar, la muerte de su padre en febrero de 1917 requirió toda su atención para proceder al reparto legal con su hermana de la multimillonaria herencia recibida. Por otro lado, su inesperado embarazo -del que señaló a Ordinsky como responsable-y el nacimiento de su hija Betty (familiarmente "Sugar Top") en agosto de ese año, forzaron a Barnsdall a posponer sus planes de tener su propio teatro.

Durante meses, Barnsdall se dedicó viajar, su principal afición por encima incluso del teatro. No obstante, a pesar de sus largas temporadas fuera de la ciudad, Barnsdall había descubierto ya el potencial de Los Ángeles y quería instalarse allí definitivamente. De nuevo carecía de compañía, pero quiso seguir adelante con su sueño de construir un teatro, una idea que fue complejizando con la posibilidad de asociar al teatro un centro de interpretación y a una comunidad de artistas que gravitasen alrededor de su propia residencia. A principios de 1918 volvió a escribir a Wright. Éste, apenas había tenido tiempo para desarrollar los bocetos del teatro y ella había pospuesto su decisión una y otra vez. No queriendo retrasarlo más, el 4 de enero envió un cheque de 2.500 dólares a Wright, instándole a que se pusiera a trabajar urgentemente en su proyecto de un complejo teatral para Los Ángeles.

Entre 1917 y 1919, a falta todavía de un solar definitivo, con Wright en Japón y Barnsdall viajando constantemente alrededor del mundo, el arquitecto planteó de manera teórica algunas ideas de partida que, en su formalización más avanzada de 1919, contienen ya las bases conceptuales del diseño de ambos edificios, sobre todo en el caso de la vivienda, como se puede apreciar en los dibujos realizados en esas fecha y que, una vez se decidió el emplazamiento, Wright trasladó literalmente a las condiciones reales de la parcela.

Coincidiendo con la adquisición de los terrenos para su casa, en el verano de 1919, Barnsdall inició una de las etapas más sedentarias de su vida. El 
23 de junio hizo efectiva la compra de Olive Hill, un colina de Hollywood de 36 acres (alrededor de $145.000 \mathrm{~m}^{2}$ ), englobada en una supermanzana cuadrada de 380 metros de lado, definida por la intersección de los bulevares de Hollywood (al norte) y Sunset (al sur) con Vermont Avenue (por el este) y Edgemont Street (en el oeste).

En 1919, el nombre de Olive Hill no podía ser más descriptivo. En el límite de la llanura de la ciudad, su silueta era reconocible desde lejos. La suave colina, que había sido plantada con una retícula de centenares de olivos, alcanzaba los 30 metros de altura sobre el nivel de las calles cercanas, muchas de ellas aún sin urbanizar. Desde su cima se disfrutaba de un privilegiado panorama de las montañas de Santa Mónica y de San Gabriel y, en días claros, podía distinguirse hasta el océano. Aquella visión paradisíaca de Los Ángeles sería también la primera que tendría Rudolph Schindler de la ciudad, y la que le dejó completamente fascinado cuando, en 1920, fue enviado por Wright a Los Ángeles para dirigir las obras del complejo Barnsdall.

A pesar de sus reticencias a gastar más de lo estrictamente necesario, algo que recalcaría una y otra vez a Wright -aunque sin mucho éxito, por cierto-, Barnsdall invirtió en su nueva propiedad una enorme suma de dinero para la época ${ }^{20}$. En efecto, tras varios años tratando de edificar un proyecto para el que no existía emplazamiento, finalmente adquirió un lugar cuyas espectaculares dimensiones y valores paisajísticos superaban con creces cualquier idea sobre la que ni ella ni Wright se hubieran atrevido a soñar. Sin duda, aquel lugar tuvo que despertar de nuevo el interés de Wright por el proyecto de Barnsdall.

Hasta ese momento, ambos únicamente habían discutido acerca del teatro y de su propia casa, pero las posibilidades de Olive Hill animaron a Barnsdall a proponer a Wright el diseño de nuevos edificios que completaran el conjunto. Entusiasmada con su adquisición, Barnsdall estaba deseando empezar a construir. Si bien, con Wright en Asia hasta finales de verano y un proyecto en estado embrionario poco podía avanzarse, para desesperación de su clienta, que llegó a plantearse viajar a Japón e, incluso, cambiar de arquitectos, algo de lo que, persuadida por Wright, acabó desistiendo.

Ansiosa por comenzar, y plenamente consciente de la representatividad y potencial inmobiliario de la operación, Barnsdall desveló inmediatamente sus intenciones a la prensa. Hizo público que había contratado a Frank Lloyd Wright para desarrollar un plan de urbanización de la colina que daría cabida a un teatro, un centro de interpretación y una escuela de danza de referencia nacional, y que este complejo destinado a las artes escénicas sería mucho más ambicioso de lo que ella había discutido con Wright en los meses anteriores puesto que, además del teatro y de su vivienda particular ya mencionados, incluiría edificios de apartamentos, locales comerciales y una serie de residencias secundarias. Barnsdall anunció también que su casa presidiría la cima de la colina y que el teatro se ubicaría en la ladera este, asegurando que ya disponía de los primeros dibujos de estas piezas y que, en breve, serían materializadas en un proyecto de conjunto.

Los periódicos locales se mostraron encantados con la noticia, a la que dieron amplia cobertura, destacando la idea de que los ciudadanos de Los Ángeles pronto disfrutarían de un parque accesible al público y de un teatro diseñado por Wright, al que podrían llegar paseando entre olivos y lagos artificiales. Sobre el teatro, se afirmaba:

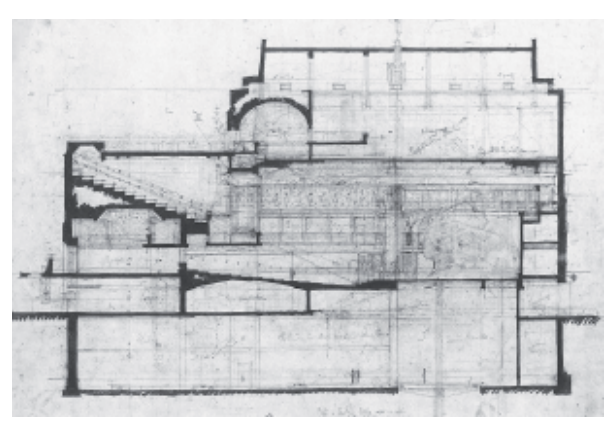

Frank Lloyd Wright : Sección del Teatro para Aline Barnsdall, 1918. Fuente Kathryn Smith, Hollyhock House \& Olive Hill, Hennesey + Ingalls, en adelante simplemente Smith

Página anterior arriba: Hollyhock House, dibujo hacia 1917-1918. Fuente: City of Los Angeles Departments of Recreations \& Parks and Cultural Affairs

Página anterior abajo: Olive Hill, abril 1921, Fuente: Department of Geography, UCLA 

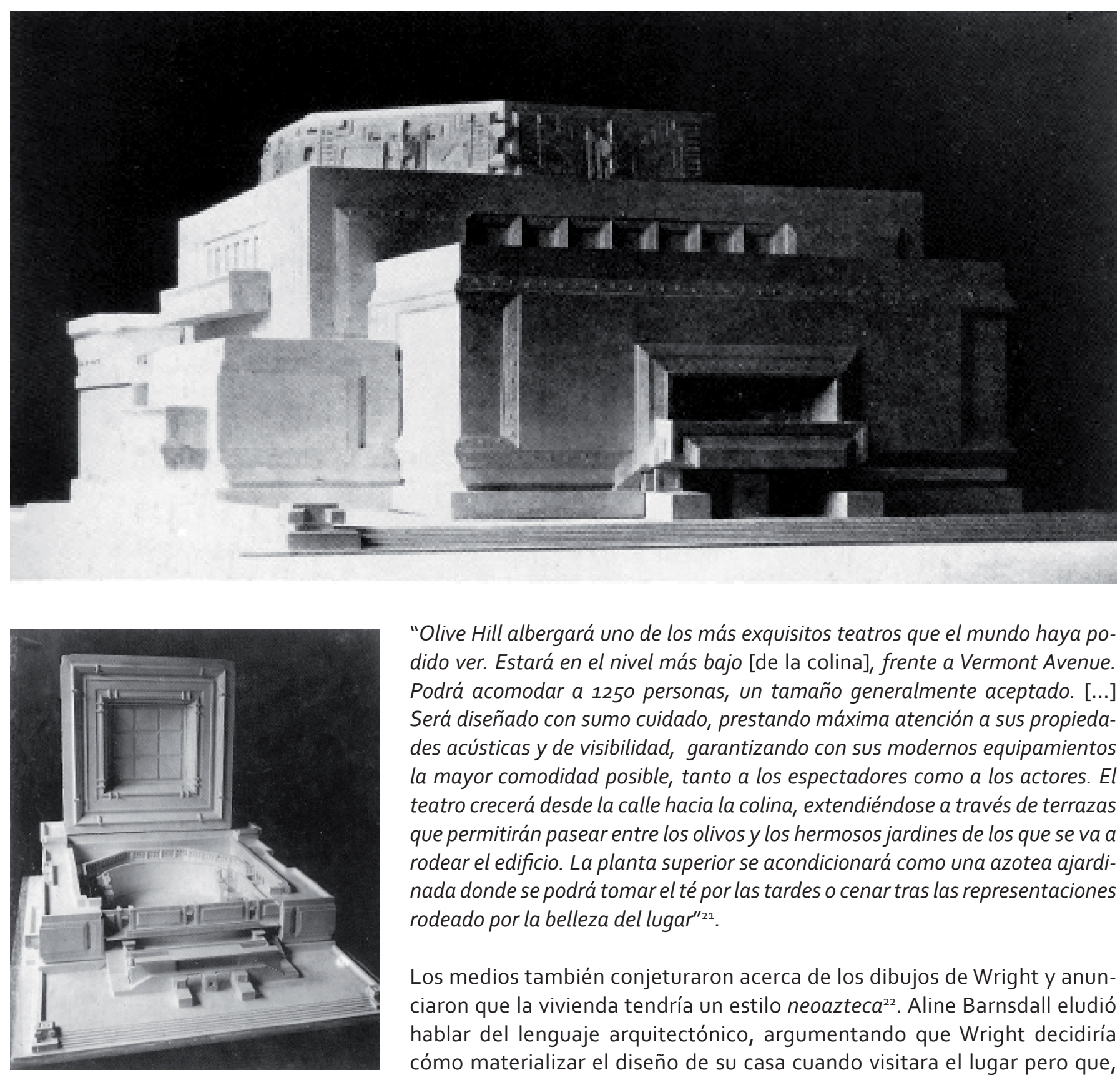

"Olive Hill albergará uno de los más exquisitos teatros que el mundo haya podido ver. Estará en el nivel más bajo [de la colina], frente a Vermont Avenue. Podrá acomodar a 1250 personas, un tamaño generalmente aceptado. [...] Será diseñado con sumo cuidado, prestando máxima atención a sus propiedades acústicas y de visibilidad, garantizando con sus modernos equipamientos la mayor comodidad posible, tanto a los espectadores como a los actores. El teatro crecerá desde la calle hacia la colina, extendiéndose a través de terrazas que permitirán pasear entre los olivos y los hermosos jardines de los que se va a rodear el edificio. La planta superior se acondicionará como una azotea ajardinada donde se podrá tomar el té por las tardes o cenar tras las representaciones rodeado por la belleza del lugar"21.

Los medios también conjeturaron acerca de los dibujos de Wright y anunciaron que la vivienda tendría un estilo neoazteca ${ }^{22}$. Aline Barnsdall eludió hablar del lenguaje arquitectónico, argumentando que Wright decidiría cómo materializar el diseño de su casa cuando visitara el lugar pero que, seguramente, crearía un nuevo tipo de arquitectura acorde con la región de Los Ángeles, sin necesidad de recrear los estilos de otros lugares. Sin embargo, es revelador el hecho de que sí enfatizase que, independientemente de la forma final de la vivienda, Wright consideraba que un hogar californiano debía ser mitad casa y mitad jardín ${ }^{23}$, lo que denota que las intenciones del arquitecto y su voluntad de asumir el imaginario y la cultura local, en este sentido, estaban ya claras antes incluso de disponer de un emplazamiento.

Finalmente, sincerándose ante la prensa, Barnsdall relataba sus conflictos internos, quizás, de manera demasiado explícita. Exponiendo públicamente su misión de crear algo útil y bello para la ciudad, hablaba de una responsabilidad ineludible que asumía resignada, puesto que se vería obligada a permanecer atada a ese lugar. Ese sentimiento contradictorio de querer $y$, al mismo tiempo, tener que construir Olive Hill explicaría el choque de personalidades cliente-arquitecto que, sumado al comportamiento interesado y, en ocasiones, poco profesional de Wright-desbordado por los acontecimientos-, acabarían por frustrar el proyecto. En sus propias palabras, Barnsdall confesaba: 


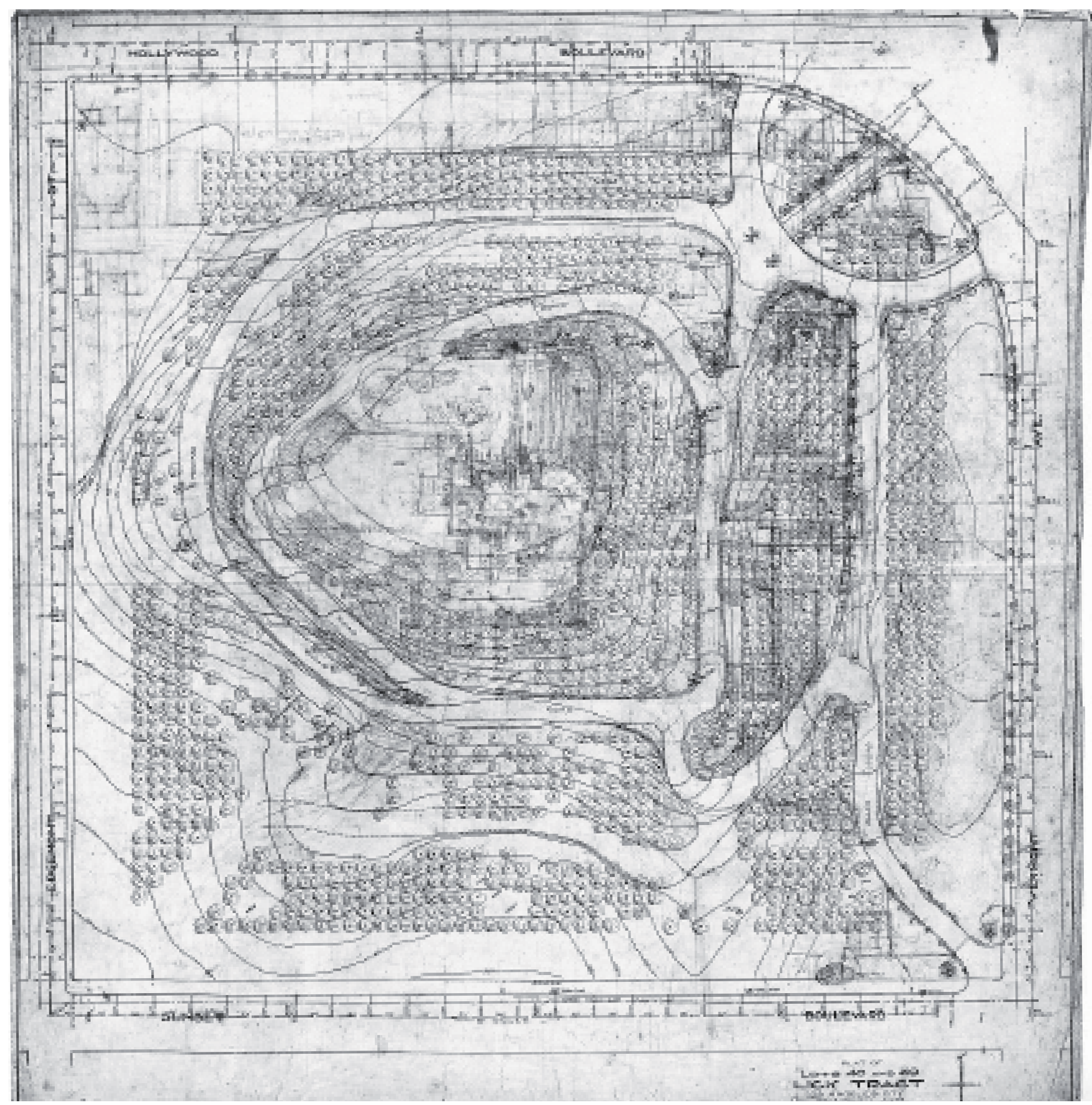

"Mis jardines estarán siempre abiertos al público [...] y a todas las personas que amen la belleza y deseen contemplar los amaneceres, las puestas de sol y otros espectáculos de la naturaleza visibles en pocos otros lugares en el centro de la ciudad [...] Sé que requerirá tiempo, una constante lucha conmigo misma y sacrificar la libertad que mi espíritu anhela pero es algo que, simplemente, debo hacer [...] aunque personalmente preferiría errar por el mundo divirtiéndome en compañía de mis amigos"24.

Tras diez meses fuera del país, Wright desembarcó en Seattle en septiembre de 1919 y en lugar de continuar viaje hasta Taliesin, se desvió a Los Ángeles para encontrarse con una airada clienta que le exigió comenzar a construir en enero y terminar las obras de su casa antes de que finalizara 1921. Barnsdall le detalló sus ideas acerca de simultanear usos públicos y privados, por lo que, además del teatro y de su propia casa, le solicitó una residencia para el director de la compañía -aún sin contratar-y un edificio de apartamentos para actores cuyo alquiler funcionase como fuente de ingresos. El coste para
Frank Lloyd Wright : Mapa topográfico de Olive Hill con la primera versión del Plan Director, julio 1919. Fuente: Smith. FLW Foundation

Página anterior arriba y abajo: Segunda versión del Teatro para Aline Barnsdall, maquetas, 1918. Fuente: Smith 
Frank Lloyd Wright : Tercera versión del Teatro para Aline Barnsdall, 1919. Fuente: Smith

Página siguiente arriba: Olive Hill, perspectiva aérea, 1919. Fuente: Architectural Drawing Collection, University of California Santa Barabara

Página siguiente abajo: Casa del Director, redibujado. Fuente: Smith

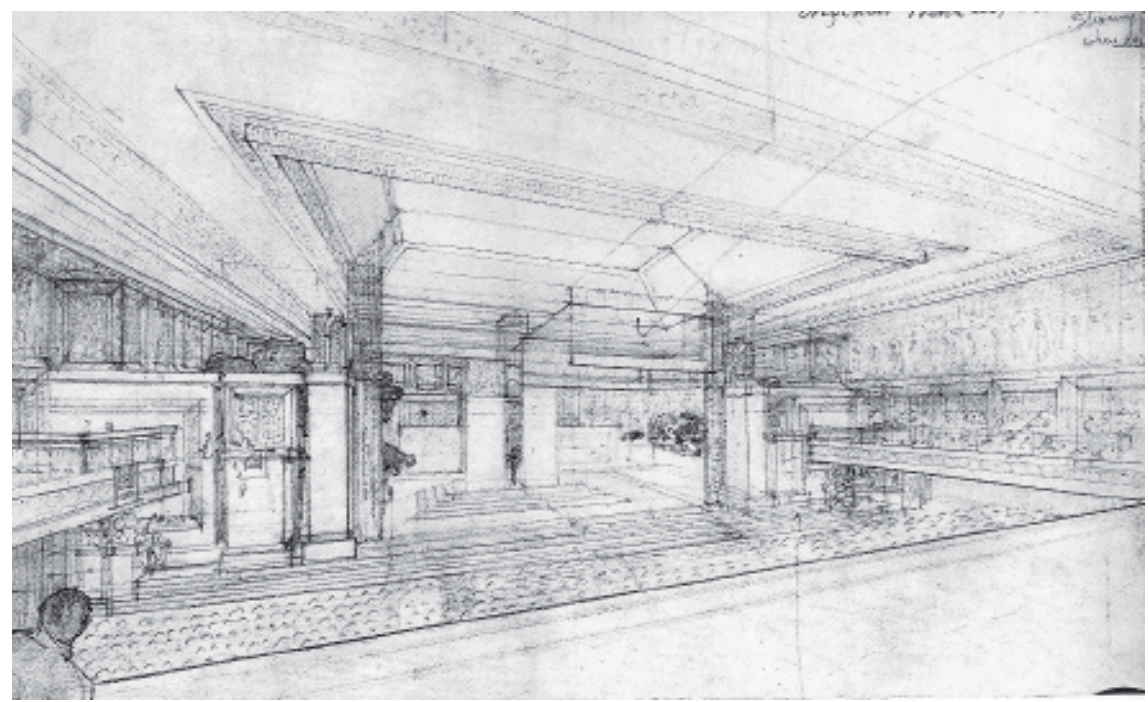

todos esos edificios, incluyendo la urbanización y el proyecto paisajístico de Olive Hill, así como los honorarios del arquitecto, no podría superar los 375.000 dólares.

Desde 1918 Wright tenía ya los dibujos preparatorios de una primera versión del teatro. Inspirado por algunas obras de Sullivan (como el cubo rematado por una semiesfera de su Wainright Tomb de 1892), el edificio evolucionaba a gran escala el diseño de tambor octogonal que el propio Wright había pensado como remate de su estudio de Oak Park. El teatro, en cuyo exterior también podría ser reconocible la influencia del protorracionalismo del Sezessionstil vienés, recurría a las técnicas de construcción con hormigón armado ensayadas en el Templo Unitario una década antes.

Atendiendo a los requerimientos de Barnsdall, Wright había previsto una gran sala para 1250 espectadores sobre la cual, alojada en el tambor, se disponía otra más pequeña destinada a teatro experimental. El innovador planteamiento del auditorio principal que, situando bajo la misma cubierta a público e intérpretes, eliminaba la tradicional barrera física del proscenio no acabó de convencer a Bel Geddes quien, por un lado, consideraba que Wright le había robado sus ideas para producir un diseño plagado de errores en la concepción del escenario y de la iluminación y, por otro, llevaba tiempo alertando a Barnsdall sobre la falta de familiaridad de Wright con esta tipología. Por su parte, Wright, que no estaba dispuesto a dejarse aconsejar por nadie, se disgustó por lo que consideraba una nueva intromisión del entorno de Barnsdall en su trabajo, incidiendo en viejas disputas que se vieron agravadas por el hecho de que la maqueta desmontable de escayola que había prometido se rompió durante el viaje de vuelta de Japón, pudiendo enseñar sólo las fotografías que había tomado de ella en Tokio.

Para forzar aún más la situación, durante semanas siguió mostrando los mismos dibujos sin apenas avances, lo que llevó al límite la paciencia de su clienta. Tratando de asegurarse de que Barnsdall no cambiara de opinión y le retirara el encargo, Wright envió a su hijo Lloyd a supervisar el acondicionamiento de la colina y propuso iniciar las obras de la vivienda sin haber terminado los planos del teatro. Barnsdall tuvo que acceder de mala gana, pero amenazó con abandonar la idea del proyecto si continuaban los retrasos. Los esfuerzos de Wright se concentraron entonces en el diseño de la casa, cuyas obras se iniciaron como estaba previsto y concluyeron, tras un nuevo cúmulo de desencuentros, a finales de 1921. 


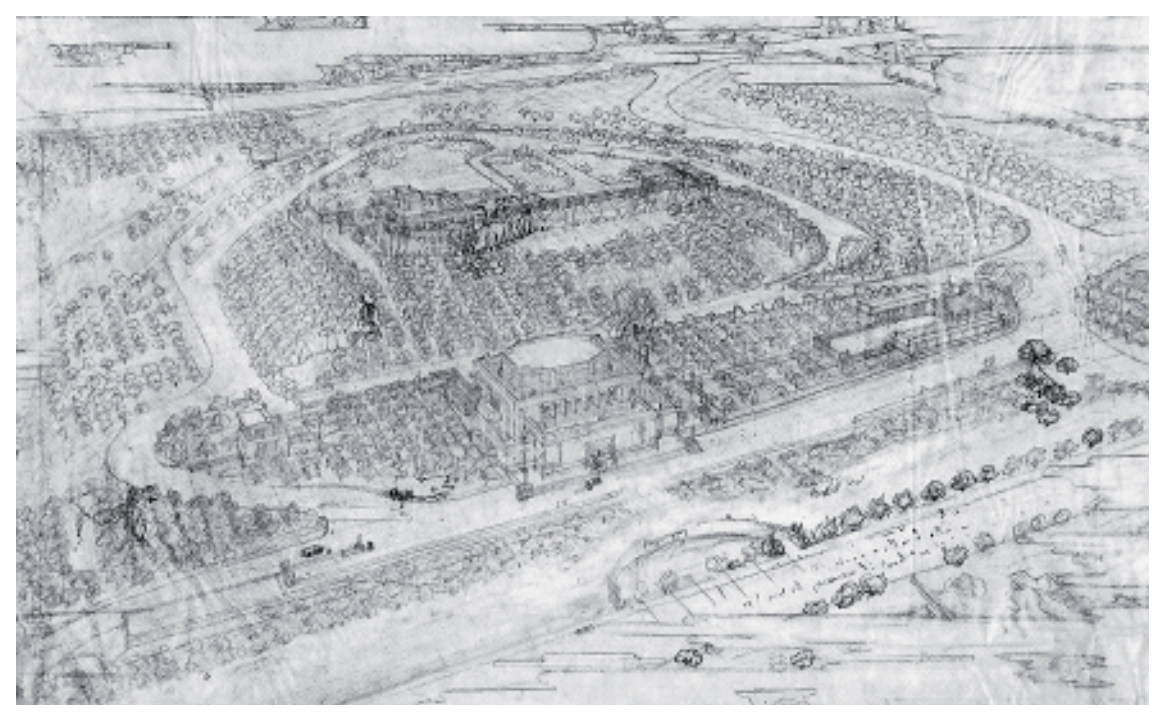

\section{Olive Hill, media década de proyectos}

En líneas generales puede hablarse de la existencia de dos planes directores para la colina. El primer masterplan, que estuvo listo a finales del otoño de 1919, preveía ya las dos piezas más importantes del complejo en su posición definitiva: el teatro, cuyo proyecto teórico Wright apenas tuvo tiempo de readaptar a la topografía de Olive Hill y la casa Hollyhock, que presidiría el conjunto desde su cima. Un año más tarde, en 1920, una segunda ordenación modificaba algunas de las edificaciones previstas, como la residencia de actores y completaba, sobre todo, el límite norte de la propiedad que hasta ese segundo masterplan había quedado prácticamente sin desarrollar.

Ambos planes directores asumían como condición de partida la plantación de olivos que daba nombre a la colina. El arquitecto quiso incorporar al proyecto de paisajismo la estructura de árboles preexistentes que, plantados a una distancia variable de 18 a 20 pies (alrededor de 6 metros), conformaban una conspicua malla ortogonal a la que adaptó los nuevos caminos, la posición de los edificios y la distribución del resto de especies vegetales 25 . Los dos accesos a Olive Hill se situaban en los extremos noreste y sureste, manteniendo así su localización original. Wright dividió la inmensa parcela en cuatro cuadrantes iguales delimitados por la intersección de dos ejes esteoeste y norte-sur que, cortándose en jardín de la casa Barnsdall, bisecaban la planta sutilmente asimétrica de la vivienda. De acuerdo con los deseos de su clienta, ubicó la residencia principal en la cota más elevada de Olive Hill que coincidía además con la zona más plana y con mejores vistas del promontorio. De este modo, la implantación, axialidad y centralidad de la casa denotaban organizativa y simbólicamente la importancia de esta pieza y de su propietaria como vértice focal de aquella acrópolis moderna.

En el planeamiento de Olive Hill de 1919, además de la residencia principal y del teatro, aparecían también diversos edificios de apoyo al funcionamiento del conjunto, de los cuales la estructura más inspirada era la vivienda del director teatral. Situada al sureste de la Hollyhock House, muy próxima al teatro, esta estructura tampoco se construyó. Surge asociada al primer masterplan y desaparece en la versión definitiva del mismo pero es reseñable porque avanza ideas elaboradas años más tarde por Wright, como la de plantear una casa sobre una cascada.

Desde de la ordenación de 1919 el eje este-oeste aparece como principal sistema estructurador de la parcela, divide longitudinalmente la residen-

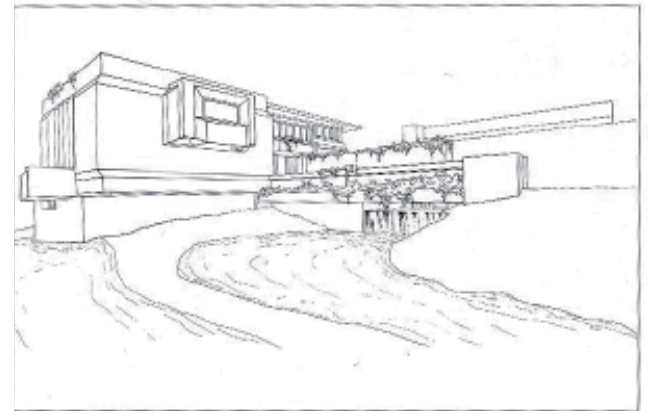




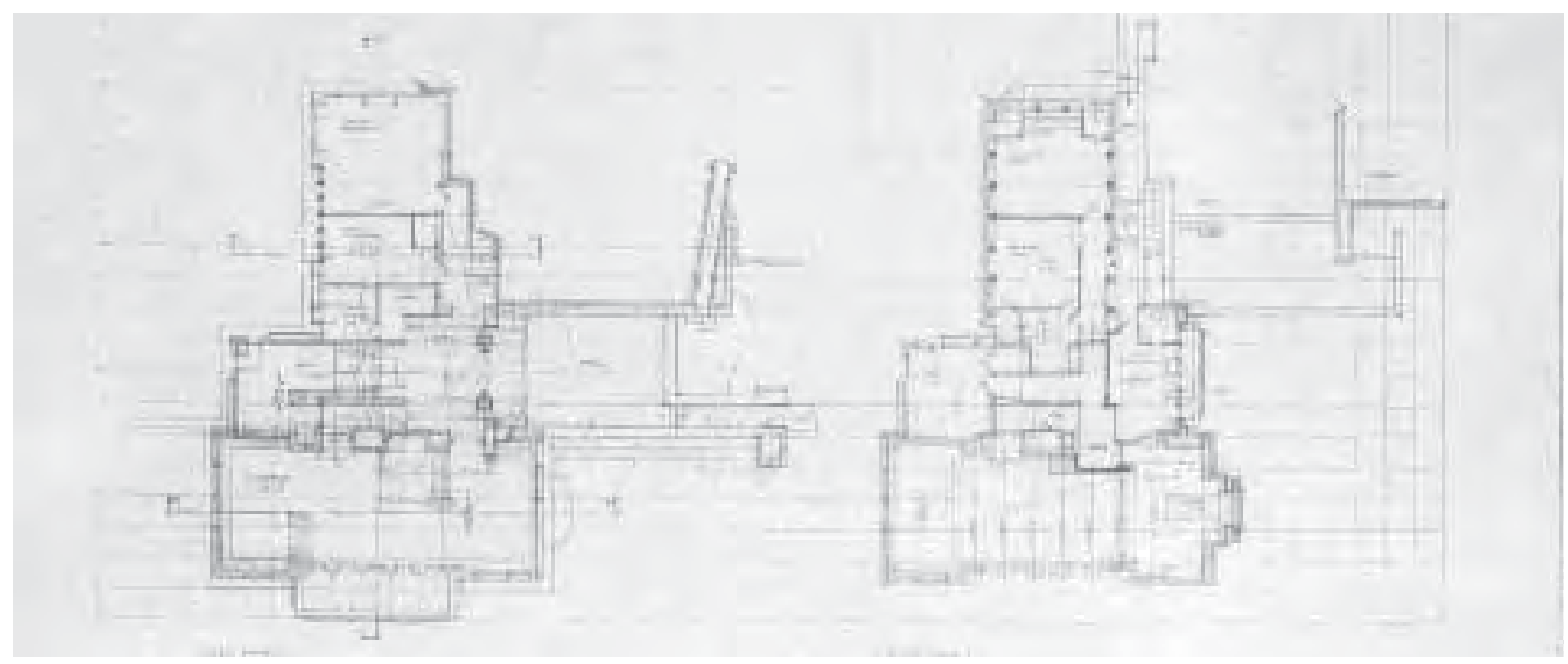

Frank Lloyd Wright: Casa del Director, planta de acceso (izda) y planta superior (dcha), versión de enero de 1920. Fuente: Architectural Drawing Collection, University of California Santa Barbara

Página siguiente arriba: Vista aérea de la casa Hollyhock y Olive Hill hacia 1923-1924. Fuente: Security Pacific Photograph Collection/ Los Angeles Public Library

Página siguiente abajo: Frank Lloyd Wright: Residencia A, alzados, versión de septiembre de 1920, FLW Foundation cia principal por la mitad de la sala de estar y del patio de la casa, y vincula axialmente la vivienda con el teatro. El eje norte-sur, sin embargo, aparece desplazado lateralmente hacia Vermont Avenue para conectar la residencia de actores con la vivienda del director a través del teatro que, como la casa, ocupa una posición central en mitad de esta línea imaginaria.

La vivienda para el director teatral fue ofrecida a Wright como residencia mientras durara la construcción del complejo, probablemente en un intento de Barnsdall de retener al arquitecto en Los Ángeles. Quizás por ello Wright se dedicó a este proyecto con un mayor esmero, aunque nunca se llegó a materializar ni Wright residió en Olive Hill hasta su regreso definitivo de Japón en 1922 cuando, paradójicamente, sus principales intereses en la ciudad ya no sólo tenían que ver con los encargos de Barnsdall.

La casa del director puede considerarse un precedente de la Falling Water House en Pennsylvania. Estaba planteada en la esquina de la colina frente a Sunset y Vermont, justo por debajo de la cota de Hollyhock House y por encima del nivel del teatro, edificio con el que se conectaba a través de un puente que servía de acceso peatonal a la vivienda y de una doble cascada creada mediante un curso de agua artificial. La idea de incorporar un recurso tan escenográfico al proyecto no era nueva para Wright. La cascada estaba presente ya en la casa McCormick, y también en el paisajismo de Taliesin, donde el trazado del arroyo tampoco era natural. Sin embargo, el curso de agua de Olive Hill, dibujado a mano para darle una apariencia lo más natural posible y cayendo en una cascada que se fundía con la arquitectura de la casa, era el elemento más lírico propuesto por Wright hasta la fecha ${ }^{26}$.

El arquitecto plasmó esta visión en diferentes bocetos que apenas tenían en cuenta el emplazamiento exacto de la vivienda y fue Schindler quien se ocupó de acomodar las ideas abstractas de Wright a la topografía real de la parcela.

La Director's House estaba distribuida en dos plantas sobre el nivel del garaje y una cubierta ajardinada practicable a la que se accedería a través de una caja de escaleras cuyo volumen recorría toda la casa equilibrando las masas de la composición. La planta tenía una forma de $T$ en la que las estancias privadas ocupaban su trazo largo y los espacios públicos su trazo corto. Esta misma planta sería reutilizada más tarde para la Residencia A y su idea de 


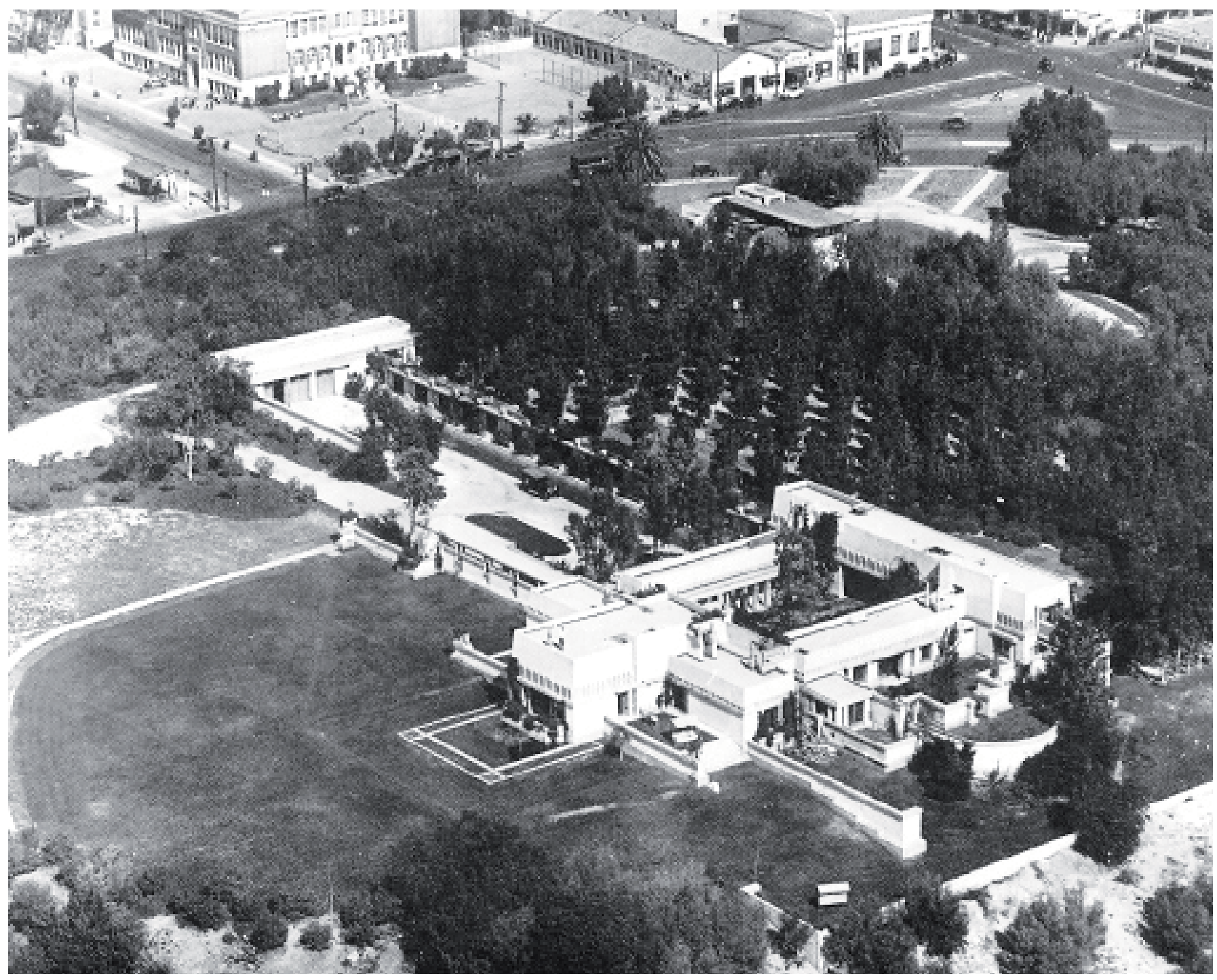

estar-comedor a doble altura presidido por la chimenea también en la Residencia B del segundo masterplan.

El acceso a la Director's House se producía a través de una generosa explanada a la que se llegaba atravesando un puente. Éste separaba las dos cascadas por las que el agua debería fluir a través del jardín de la casa rodeando otro lago cuyo reflejo duplicaba virtualmente la fachada sur de la vivienda. La primera cascada era un estrecho chorro de agua de no más de un pie, cuya presencia indicaba la posición de la puerta de entrada. Bajo el puente, el agua se recogía en un estanque que se precipitaba en una segunda cascada mucho más ancha pero sólo apreciable a cierta distancia. De este modo, el sugerente efecto de una cascada cuya sonoridad se amplificaba por ruido de otra cascada invisible y de mayor dimensión anticipaba el dramatismo de la Falling Water House, construida dos décadas más tarde.

Como en Taliesin, el recurso del agua en Olive Hill tenía para Wright implicaciones profundas. Simbolizaba la vida y el dinamismo de su ciclo natural: el renacer, la metáfora perfecta para un centro de artistas fundado en un ciudad joven y llena de energía, una comunidad de la que Barnsdall sería el corazón y el director teatral su cabeza visible. Ambos órganos, representados por sus respectivas residencias -estructuras masivas e inertes-, quedarían conectados y activados por un curso de agua en movimiento que arrancaba del estanque cuadrado frente a la Hollyhock House; continuaba rodeando

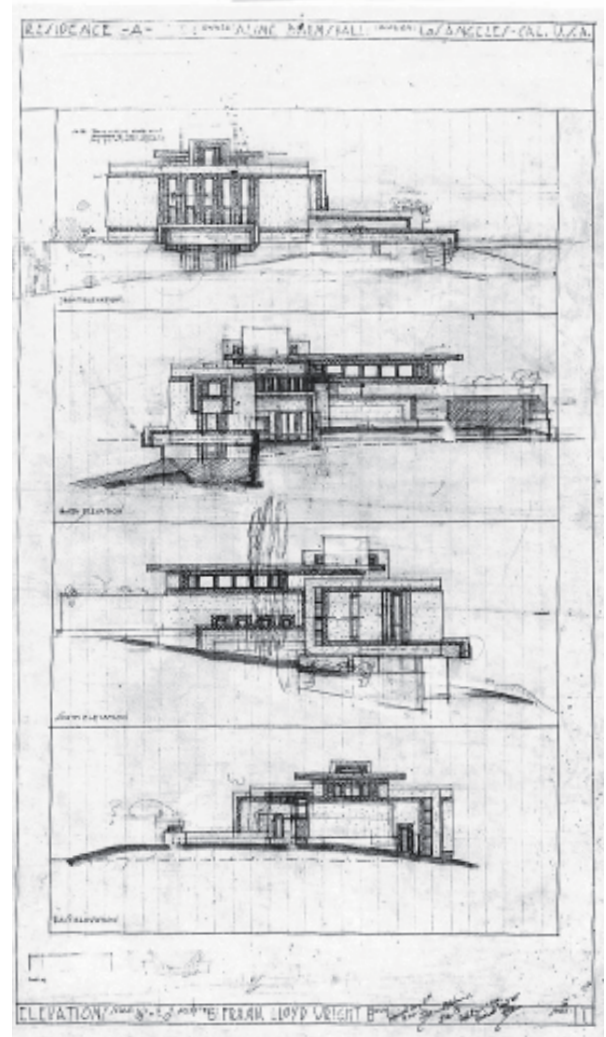



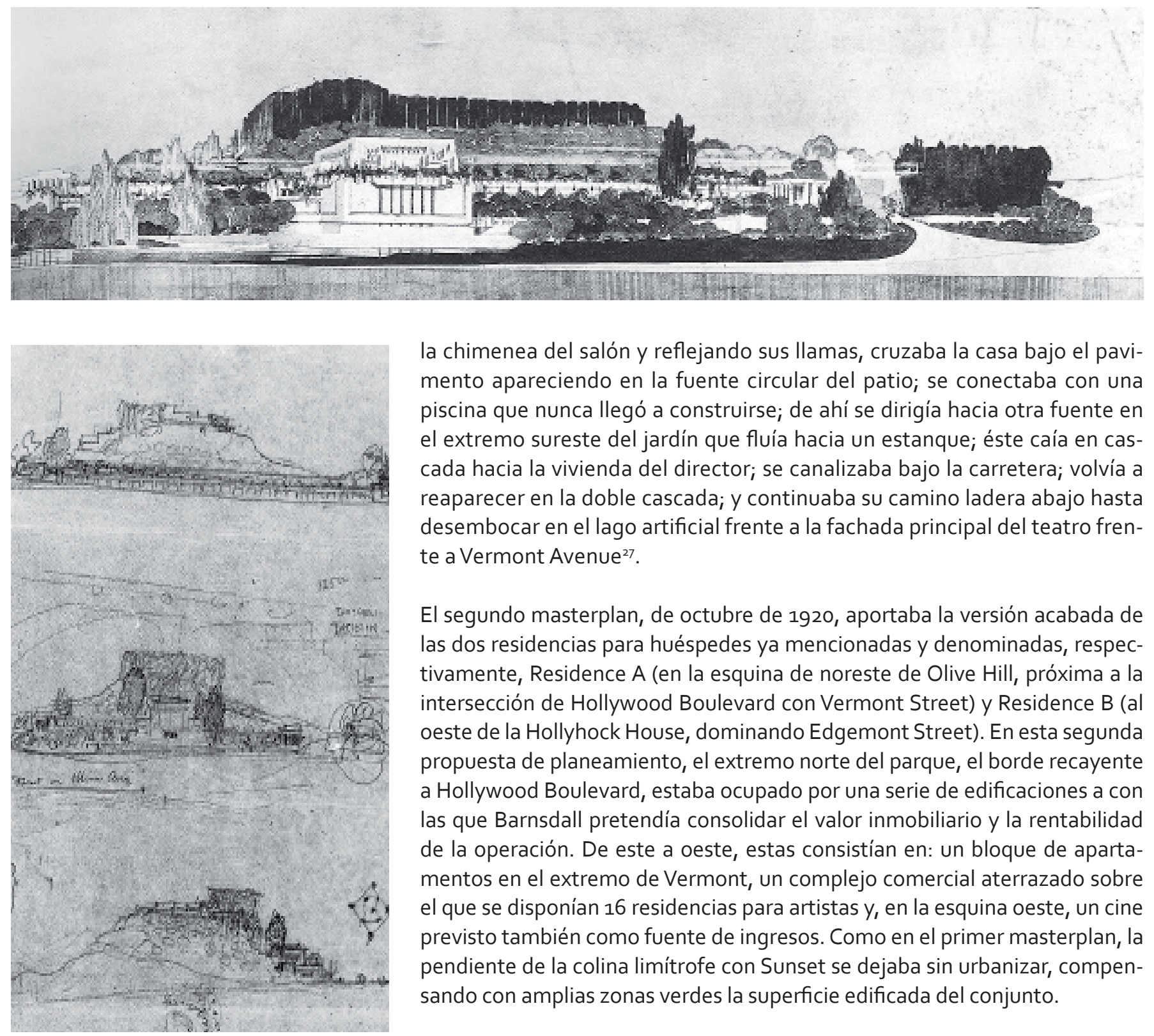

la chimenea del salón y reflejando sus llamas, cruzaba la casa bajo el pavimento apareciendo en la fuente circular del patio; se conectaba con una piscina que nunca llegó a construirse; de ahí se dirigía hacia otra fuente en el extremo sureste del jardín que fluía hacia un estanque; éste caía en cascada hacia la vivienda del director; se canalizaba bajo la carretera; volvía a reaparecer en la doble cascada; y continuaba su camino ladera abajo hasta desembocar en el lago artificial frente a la fachada principal del teatro frente a Vermont Avenue ${ }^{27}$.

El segundo masterplan, de octubre de 1920, aportaba la versión acabada de las dos residencias para huéspedes ya mencionadas y denominadas, respectivamente, Residence $A$ (en la esquina de noreste de Olive Hill, próxima a la intersección de Hollywood Boulevard con Vermont Street) y Residence B (al oeste de la Hollyhock House, dominando Edgemont Street). En esta segunda propuesta de planeamiento, el extremo norte del parque, el borde recayente a Hollywood Boulevard, estaba ocupado por una serie de edificaciones a con las que Barnsdall pretendía consolidar el valor inmobiliario y la rentabilidad de la operación. De este a oeste, estas consistían en: un bloque de apartamentos en el extremo de Vermont, un complejo comercial aterrazado sobre el que se disponían 16 residencias para artistas $y$, en la esquina oeste, un cine previsto también como fuente de ingresos. Como en el primer masterplan, la pendiente de la colina limítrofe con Sunset se dejaba sin urbanizar, compensando con amplias zonas verdes la superficie edificada del conjunto.

Uno de los aspectos más reseñables de la propuesta de Wright para Olive Hill es el planteamiento romántico de su intervención paisajística. Los primeros dibujos a mano alzada muestran ya un esquema básico de relaciones figurafondo que se mantendrá hasta 1920, tal como se aprecia comparando los tres bocetos iniciales con los alzados y perspectivas aéreas del segundo plan director. De modo similar a como había procedido para el acondicionamiento del entorno de su casa-estudio de Wisconsin -por cierto, otra comunidad de artistas en la cima de una ladera-, el arquitecto enfatizó el carácter rural y exótico de la colina de Barnsdall. La propuesta paisajística reforzaba la presencia de los olivos superponiendo capas sucesivas de vegetación destinadas a ser contempladas a cierta distancia. Tras la casa y el teatro se disponía una alineación de pinos sobre los que sobresalían masas de eucaliptos de mayor altura, conformando el fondo natural sobre el que se recortaban los edificios. Por último, una serie de cipreses salpicaban puntualmente el parque en una clara alusión -también romántica-al pasado mediterráneo de la región.

El otoño de 1920 fue un periodo de trabajo frenético para el estudio de Wright que, antes de embarcarse de nuevo a Japón, tenía que readaptar el teatro a la topografía real de Olive Hill, diseñar los nuevos edificios y redactar un plan director para la totalidad colina. Bajo la coordinación de Schindler 


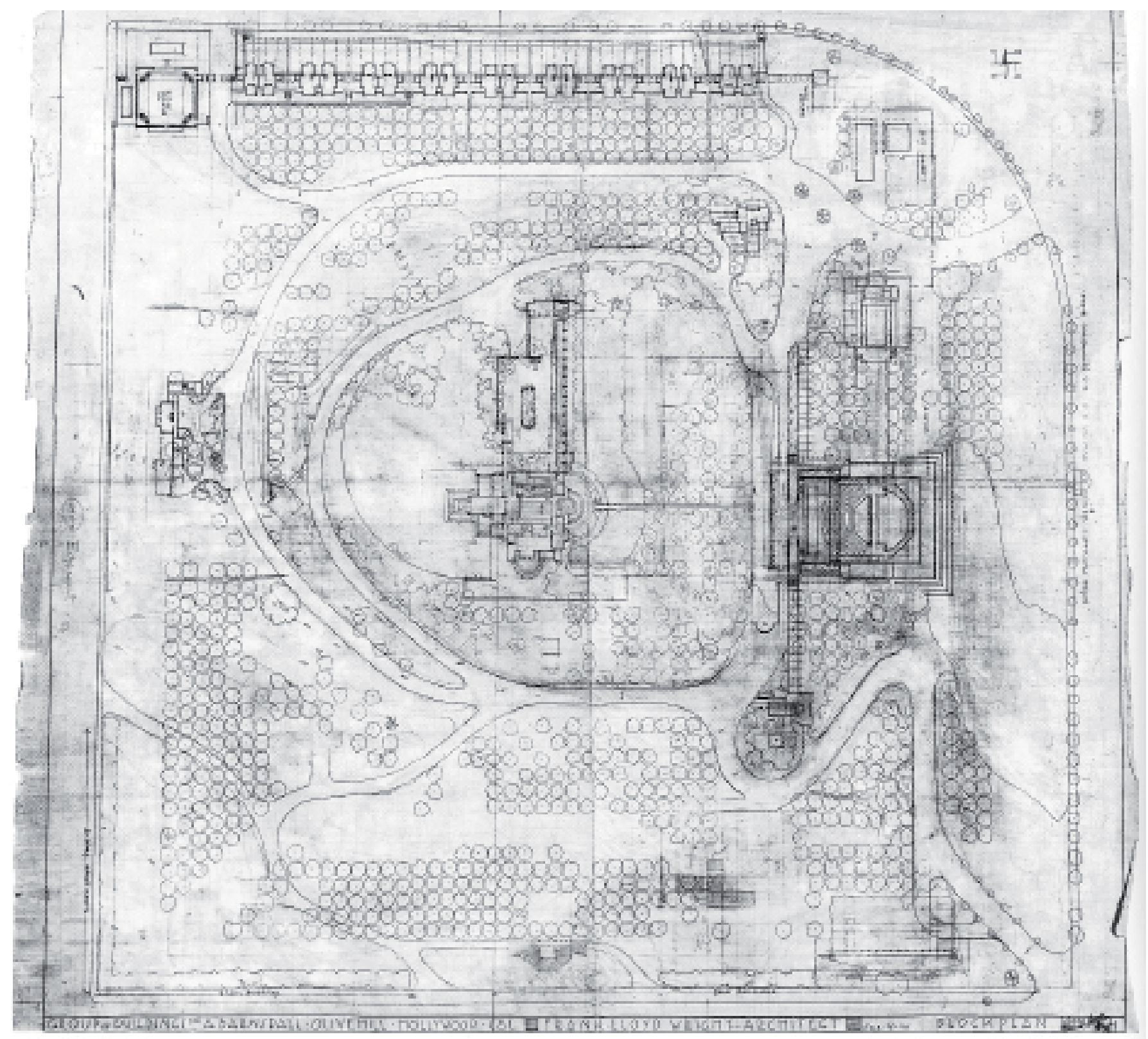

y gracias al esfuerzo de todo el equipo de Taliesin que se entregó a fondo para terminar el proyecto, incluida su mujer Pauline -que colaboró pasando a tinta pasando numerosos dibujos-, el segundo masterplan, con todos sus edificios, estuvo listo antes de que Wright partiera de nuevo para Japón en octubre de 1920.

Si bien, durante ese mes, los acontecimientos se complicaron una vez más y Wright se vio obligado a retrasar su viaje hasta final de año. Justo cuando se había completado el planeamiento y los proyectos de los edificios más representativos estaban prácticamente listos - de hecho las residencias A y B obtuvieron licencia municipal en diciembre de ese mismo año-, en el momento en que se estaba ejecutando la estructura de la Hollyhock House, Barnsdall decidió parar las obras de su casa ante la falta de dibujos y detalles constructivos necesarios para seguir adelante, tal como ella misma informaba en un telegrama enviado a Wright a Taliesin desde Los Ángeles el 22 de octubre de $1920^{28}$. Obviamente, el hecho de que Barnsdall detuviese la construcción de su casa era una medida de presión sobre Wright para que éste atajara una situación de conflicto prolongado y agravado por sus continuas ausencias. Sin los planos oportunos y una dirección insuficiente-
Frank Lloyd Wright : Olive Hill, segundo Plan Director, agosto 1920. Fuente: Smith

Página anterior arriba: Olive Hill, perspectiva desde Vermont Street, 1921. Fuente: City of Los Angeles Departments of Recreations \& Parks and Cultural Affairs

Página anterior abajo: Olive Hill, esquemas de implantación de las piezas principales del conjunto en la colina, hacia 1920. Fuente: City of Los Angeles Departments of Recreations \& Parks and Cultural Affairs 

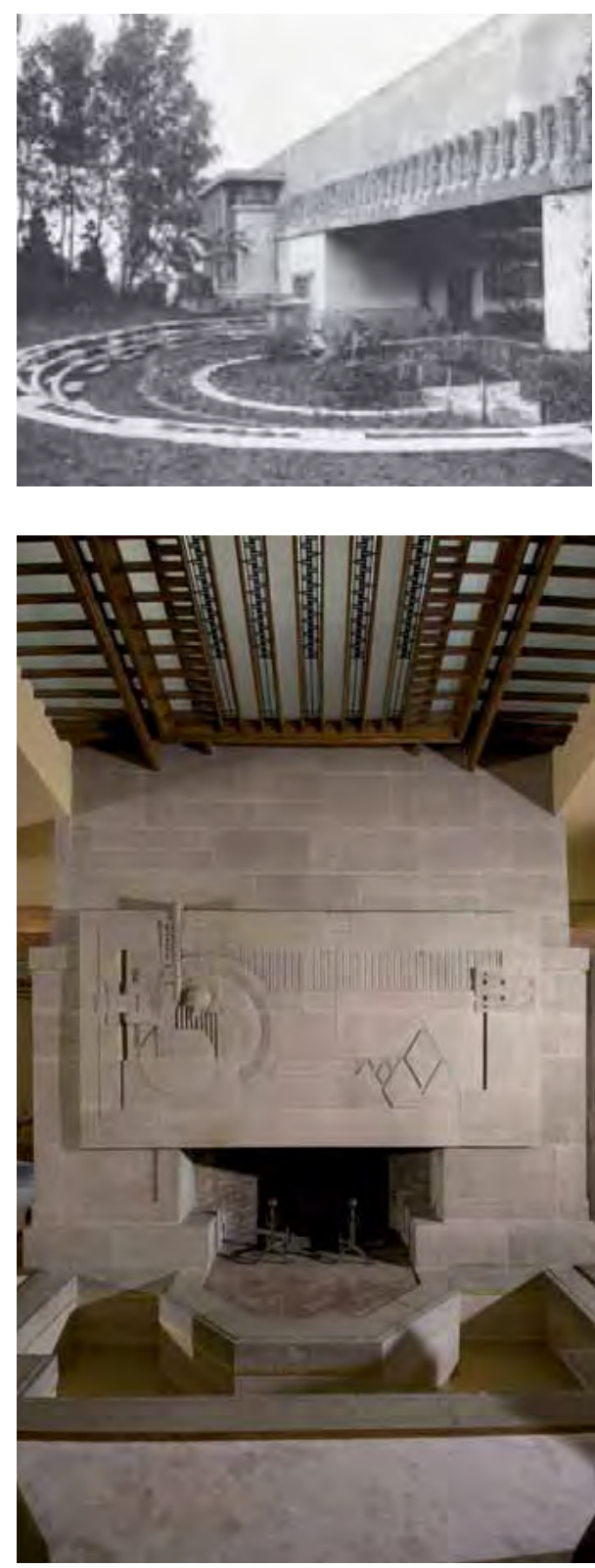

mente enérgica por parte de Lloyd Wright, a quien Barnsdall consideraba demasiado inexperto, las disputas entre el arquitecto director; el contratista, S. G. H. Robertson, poco hábil para adaptarse a los métodos de ejecución propuestos por Wright; y el administrador y hombre de confianza de Barnsdall, Clarence Thomas, quien se temía que su patrona estaba siendo engañada por ambos, Barnsdall se sentía abrumada por los problemas de la obra y requería una solución urgente por parte de Wright, a quien instó a que destituyera a su hijo.

Durante algún tiempo Wright se mostró reacio y trató de persuadirla proponiéndole, en lugar de ello, despedir a su contratista. Finalmente, ante la inminencia de su viaje y el disgusto de su clienta, no le quedó otra opción que acceder a sus presiones y remplazar a su hijo Lloyd por Rudolph Schindler, a quien informó de que, en cuanto tuviera listos todos los detalles y las nuevas modificaciones del proyecto, debía partir sin dilación para Los Ángeles. Aunque nunca lo admitiese, en el fondo Wright debía saber que Schindler era la persona más valiosa de su estudio, y el único capaz de reconducir aquella penosa situación. A principios de diciembre de 1920, Rudolph y Pauline Schindler, tomaron el tren rumbo a California. Aquella misión se acabaría revelando pronto como el inicio del fin de la relación profesional -y personal-entre ambos arquitectos.

Durante su etapa de estudiante de Wagner en Viena, Schindler había quedado tan impresionado por el Wasmuth Portfolio de 1910 que, en 1914, había emigrado a los Estados Unidos, aceptando un puesto en la firma de Chicago Ottenheimer, Stern \& Reichter, con la esperanza de poder coincidir allí con Wright y que, eventualmente, éste quisiera admitirle como colaborador en su estudio. Lo había intentado en diversas ocasiones, la primera de ellas en 1916. Ante las reiteradas negativas de Wright había pensado regresar a Europa pero la entrada de los Estados Unidos en la Primera Guerra Mundial complicó sus planes hasta el punto de verse obligado a permanecer en América. Sin nada que perder, volvió a dirigirse de nuevo a Wright, a quien insistió hasta que, finalmente, el arquitecto accedió. Wright no le contrató sino que le permitió trabajar con él y, de hecho, no le asignó un salario hasta que formalizó el encargo y comenzó a cobrar los honorarios del Hotel Imperial y de la casa Barnsdall. Wright mantenía todavía una oficina en Chicago y Schindler acudía regularmente a Taliesin, adonde fue por primera vez en febrero de 1918 para trabajar en el proyecto del Hotel junto a los dos arquitectos japoneses que avanzaban los dibujos de la obra en el despacho de Wright. Como ha apuntado David Gebhard, "lo que inclinó la balanza a favor de Schindler fue su formación como ingeniero, ya que Wright necesitaba a alguien que le ayudase a completar los detalles del Hotel Imperial en Tokio, en particular a desarrollar la complicada cimentación flotante. Schindler, como otros [...] que habian trabajado para Wright con anterioridad, terminó haciendo no sólo de ingeniero de estructuras, sino también de contable, de director de obras y diseñador, al tiempo de participar en la vida cotidiana de Taliesin. Es difícil determinar la forma en que Wright reaccionó frente a Schindler durante estos años, pero es de suponer que sintió un cierto respeto por sus dotes, ya que de otra forma no le hubiera confiado la finalización de diseños o la dirección de obra de un proyecto de la importancia de la casa Hollyhock"29.

Tanto el programa doméstico de la vivienda, como su propia formalización y la idea misma de Olive Hill era monumental y, en este aspecto, es donde Wright más se alejó del estilo de vida desenfadado ${ }^{30}$ que se estaba populari- 


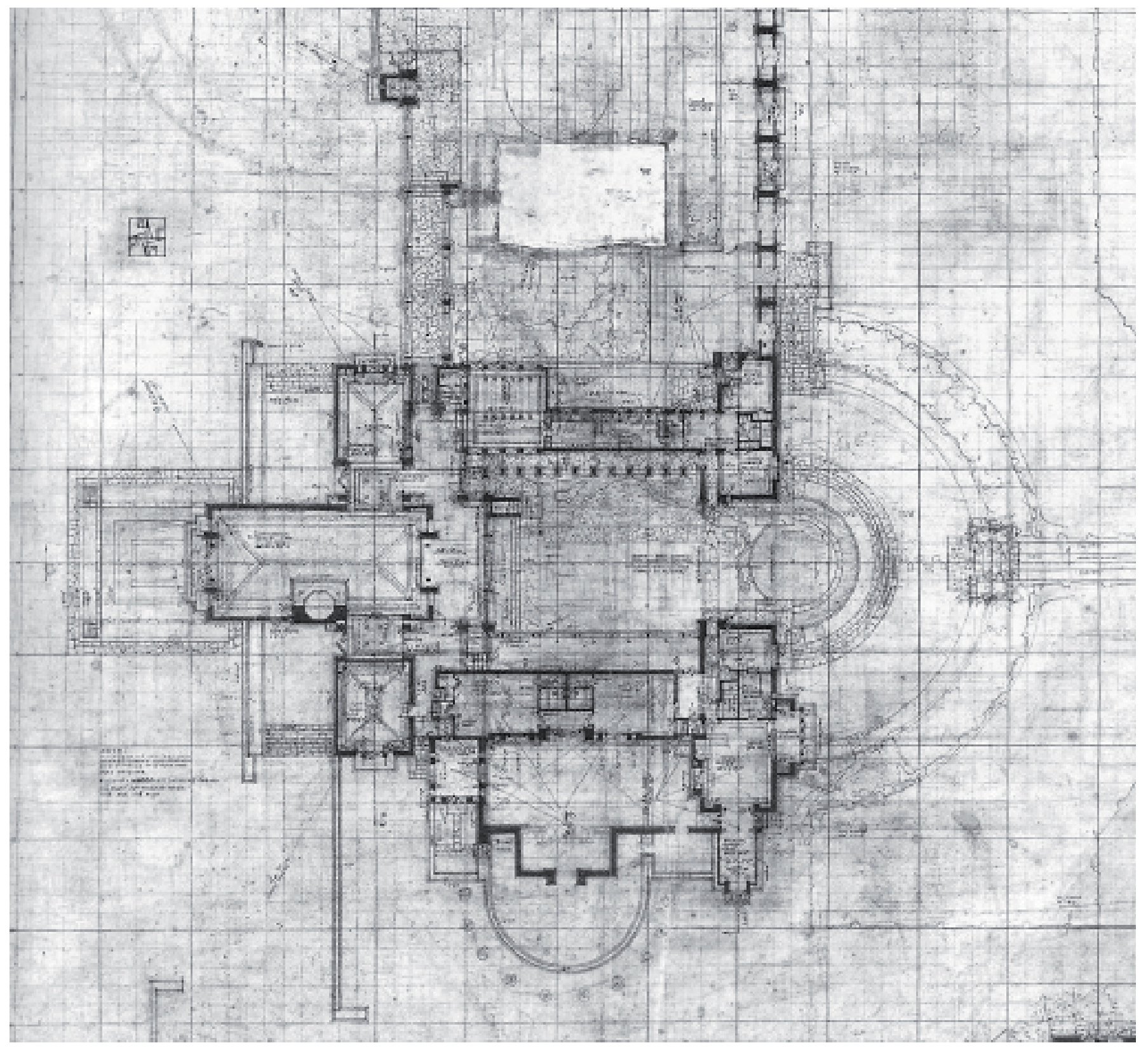

zando como filosofía común al conjunto de prácticas arquitectónicas que en aquellos años se estaban gestando en la región.

En planta, la casa de Aline Barnsdall está formada por cuatro alas estructuradas en torno a un patio que se abre hacia Vermont Avenue, hacia el lugar destinado al emplazamiento del teatro. Dos cuerpos auxiliares se prolongan hacia el norte: uno es una crujía de acceso porticada que conduce a cubierto desde el garaje y la garita del chófer hasta la puerta de la residencia; el otro es una especie de menagerie constituida por las perreras y las jaulas de los animales de su hija Betty.

El ala de poniente alberga la parte pública de la casa, con el volumen principal a doble altura del salón avanzando hacia el oeste, hacia el jardín. Está flanqueado por la biblioteca y por la sala de música, una metáfora del papel central de Barnsdall como mecenas de las artes. El ala norte contiene el comedor, la cocina y espacios de servicio. El ala sur da cabida a los dormitorios de invitados. El ala este, interrumpida por la presencia del puente que abre el jardín, recoge los dormitorios de servicio, el cuarto de las niñeras y la sala
Frank Lloyd Wright : Hollyhock House, planta de la primera versión de la casa, enero 1920, Fuente: Smith. FLW Foundation

Página anterior arriba: Hollyhock House, fotografía de 1928, vista hacia los sleeping porches de Aline Barnsdall. FLW Foundation Página anterior abajo: Hollyhock House, chimenea del salón principal. Fuente: Barnsdall Residence official site 
Frank Lloyd Wright : Hollyhock House, dibujos preliminares, hacia 1917-1918, alzado principal. Fuente: City of Los Angeles Departments of Recreations \& Parks and Cultural Affairs

Página siuiente: Frank Lloyd Wright : Hollyhock House, dibujos preliminares, hacia 19171918, alzado principal evolucionado hacia su formalización definitiva. Fuente: City of Los Angeles Departments of Recreations \& Parks and Cultural Affairs

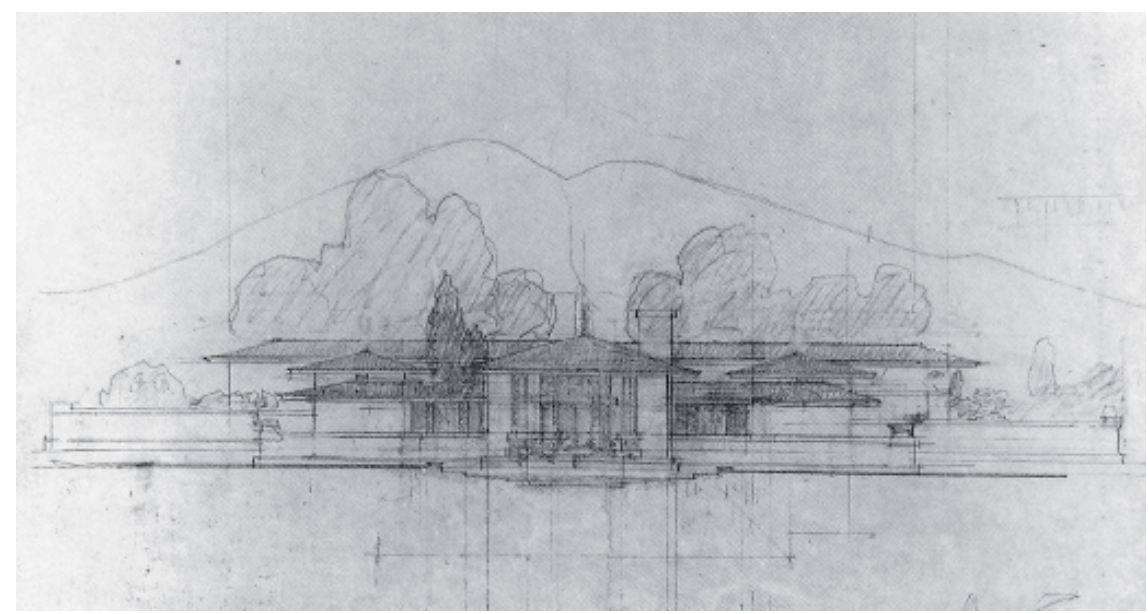

de juegos. Por último, las estancias privadas de Barnsdall y su hija se ubican en la primera planta, con el dormitorio principal avanzando en una terraza abierta hacia el sur.

Diseñada al final de la etapa de las Prairie Houses, la Hollyhock House conserva aún algunos rasgos distintivos de esa época, como su marcada axialidad, pero plantea diferencias importantes. Por un lado, en planta, los ejes ya no se cortan en una posición central que ponga de manifiesto las jerarquías del programa doméstico; en su lugar se potencian fugas y relaciones tangenciales entre los espacios que, deslizando unos sobre otros, determinan los puntos de referencia de la geometría que ordena la casa. Ésta, más allá de detenerse en los muros de la casa, se expande hacia los límites de la propiedad, asumiendo la retícula misma de la ciudad de Los Ángeles.

Resulta fácil identificar claramente cada uno de los tres ejes que estructuran la vivienda. Un eje principal este-oeste divide la casa en dos mitades y conecta el estar con el patio y el jardín, prolongándose hacia el eventual teatro. Los dos ejes secundarios norte-sur aportan otra diferencia sustancial con el diseño de las Prairie Houses. En aquellas sólo había dos ejes perpendiculares, que intersectaban en la chimenea, foco de la vida familiar. En este caso, al existir dos ejes perpendiculares al eje principal, uno a cada lado del patio, Wright parecer haber querido enfatizar la centralidad de este elemento en un esfuerzo por subrayar su papel organizativo y simbólico dentro de la tradición californiana. Así, mediante la incorporación al proyecto de las particularidades del clima de la región, el arquitecto evidenciaba también las diferencias entre la arquitectura propia de Los Ángeles y la del Medio Oeste ${ }^{31}$.

La doble axialidad y la configuración en $\mathrm{U}$ de la planta remiten a proyectos precedentes, como la McCormick House de 1907 y los Midway Gardens y, también, a la experiencia contemporánea del Hotel Imperial. En efecto, como revelan los estudios de Smith, la casa Hollyhock guarda relación con numerosos proyectos anteriores de Wright, como puede comprobarse en la evolución de los alzados de la casa, analizada con detalle por esta historiadora en su monografía sobre Olive Hill ${ }^{32}$. En los primeros bocetos, previos a la compra de Olive Hill, entre 1916 y 1918, la vivienda asume una fachada similar a la de la Brigham en Glencoe, Illinois (1915) y, aunque todavía evoca el perfil de las Prairie Houses, en sucesivos dibujos, poco a poco varía la inclinación de la cubierta e incorpora nuevas abstracciones de motivos precolombinos hasta una formalización muy próxima a su materialización definitiva; lo que demuestra que, en 1918, antes incluso de disponer de una ubicación real, Wright ya tenía clara la imagen final de la casa. 


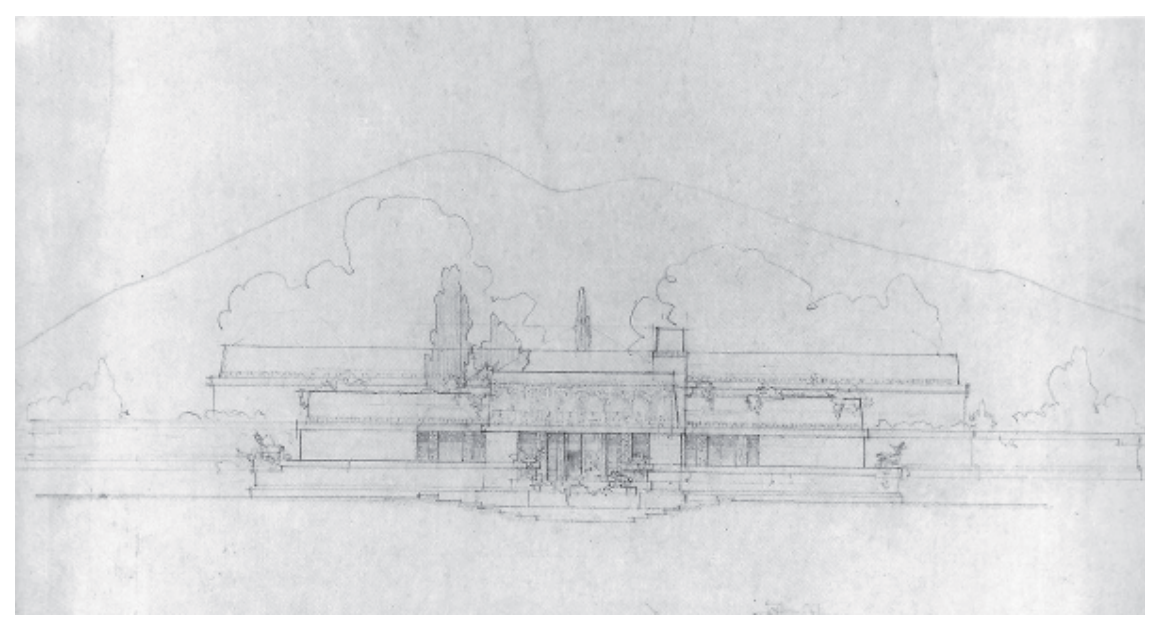

\section{California Romanza}

La vivienda para Aline Barnsdall no fue el primer proyecto ${ }^{33}$ de Wright en el área de Los Angeles, aunque sí su primer intento por establecer un estilo local. A través de los sucesivos proyectos para esta obra, cuyos primeros bocetos están planteados sin tener todavía un emplazamiento físico, el arquitecto inició una personal exploración artística en busca de un nuevo lenguaje acorde con la realidad cultural del Sur de California. A él se refirió como California Romanza, una alegoría sobre la virginidad estética de una región proclive a la libertad creativa y las licencias estéticas. En este sentido, la visión romántica de Wright participa del espíritu de los pioneros californianos en su intento de formalizar el sueño de una arcadia del oeste, de fundar una nueva tradición arquitectónica en un lugar desprovisto aún de códigos dominantes.

Aunque Wright trajo consigo algunas ideas de Chicago, en cuanto contempló la colina, la dimensión doméstica del programa se diluyó en favor de su carga simbólica. El propio emplazamiento le sugirió la necesidad de enfatizar el carácter de un templo en la cima de aquella futura acrópolis dedicada a las artes. Buscó inspiración en la arquitectura precolombina, en la articulación de volúmenes de los primitivos asentamientos de los pueblos indígenas de los estados del sur, así como en sus propias investigaciones espaciales de las décadas anteriores para crear algo diferente a partir de todo aquello.

Incluso, además de las referencias mesoamericanas predominantes en la imagen del conjunto, diferentes historiadores han encontrado otras influencias en el lenguaje arquitectónico que Wright creó para esta casa. Thomas Hines, por ejemplo, habla de las "deudas indirectas que su diseño tiene con los arquitectos austriacos Otto Wagner, Joseph Olbrich y Josef Hoffman, artífices del Sezessionstil de la Wagnershule de la Viena fin de siglo"34, una afirmación apoyada en la tesis del historiador Anthony Alofsin 35 de que Wright no sólo habría tenido oportunidad de estudiar la obra de estos arquitectos en persona durante su viaje a Europa en 1910, sino mucho antes de acudir a Viena, ya que el arquitecto había conocido los pabellones de Austria y Alemania durante su visita a la Feria Internacional de Saint Louis de 1904. Y, también de acuerdo con Hines $^{36}$, el crítico Colin Rowe defendió la influencia austríaca en detrimento de la evocación maya cuando visitó Olive Hill por primera vez en 1974.

En cualquier caso, las formas y los relieves decorativos de la casa construi$\mathrm{da}$, con el remate de sus paramentos sutilmente inclinados a 85 grados, recuerdan la arquitectura maya -a la que, por cierto, Wright nunca se refirió directamente-, pero no la copian. Su evocación no es literal y sin embargo 


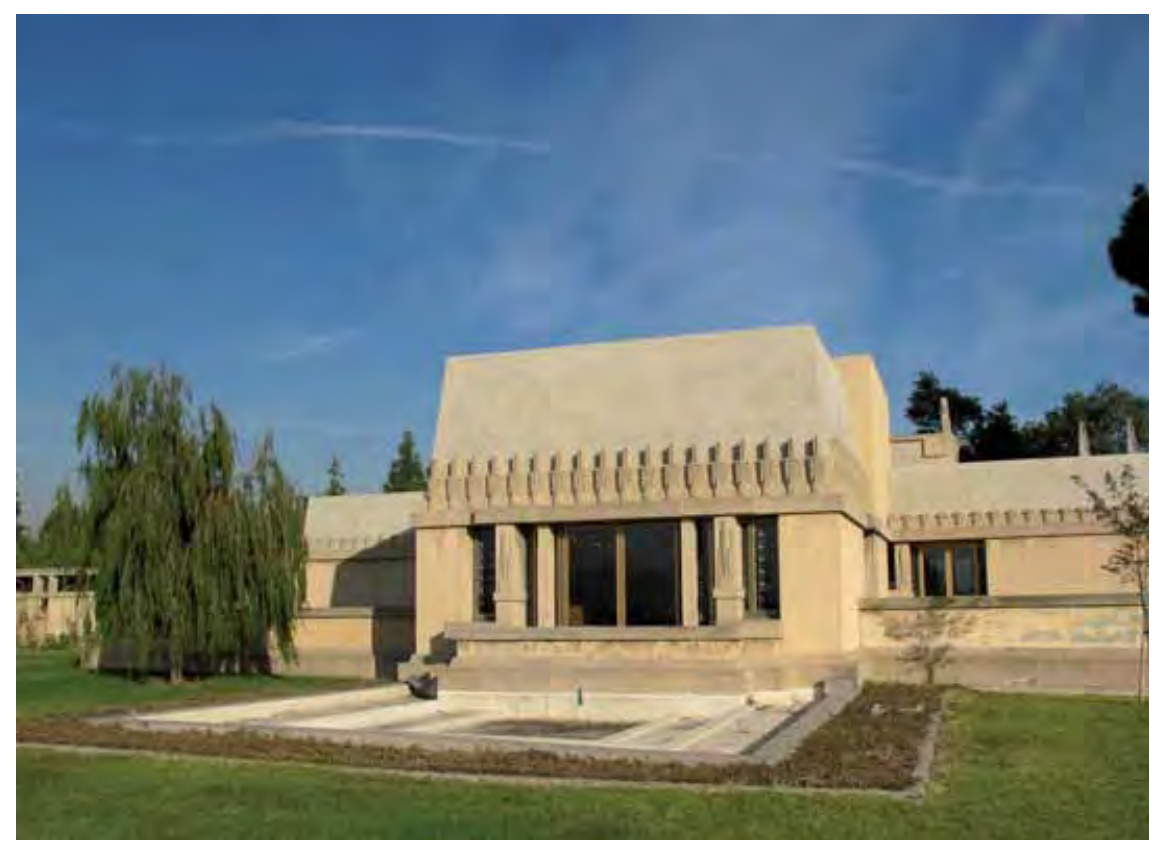

transmite toda la solemnidad de sus complejos ceremoniales, como se aprecia en las perspectivas aéreas, los imponentes alzados y el proyecto de paisajismo del conjunto de la colina. Así, la casa Hollyhock por un lado vehicula la elevada función espiritual que Wright había previsto para Olive Hill y, por otro, remite a un pasado idealizado, a una cultura inventada a la vez próxima y lejana y que, aunque puede ser reconocible como otra cosa, realmente no pertenece a ningún lugar, excepto a California.

A través de la invención de su propia realidad, más allá de las referencias precolombinas o vienesas, la Hollyhock House, sobre todo, entraba en resonancia con el universo fantástico de la recién creada industria del cine. Muy cerca de la vivienda, los estudios de Hollywood, sus fastuosos escenarios y las extravagantes mansiones de sus primeras estrellas, desplegaban una influencia a la que, aunque de modo inconsciente, es prácticamente imposible que Wright hubiera podido sustraerse. En efecto, como recuerda Hines ${ }^{37}$, el más célebre de todos aquellos decorados, la grandilocuente recreación de Babilonia para la película de D. W. Griffith Intolerancia (1916), aún permanecía en pie a pocas manzanas de Hollywood cuando comenzó a edificarse la casa. En palabras del historiador Neil Levine, aunque "pocas casas modernas han sido diseñadas con un propósito tan monumental como la Hollyhock House [...] los fabulosos y efímeros monumentos de la industria cinematográfica 'establecieron un contexto' que Wright dificilmente hubiera podido ignorar, especialmente teniendo a Nabucodonosor como vecino de al lado". En la casa Barnsdall "el lujo del decorado, la sofisticada belleza de

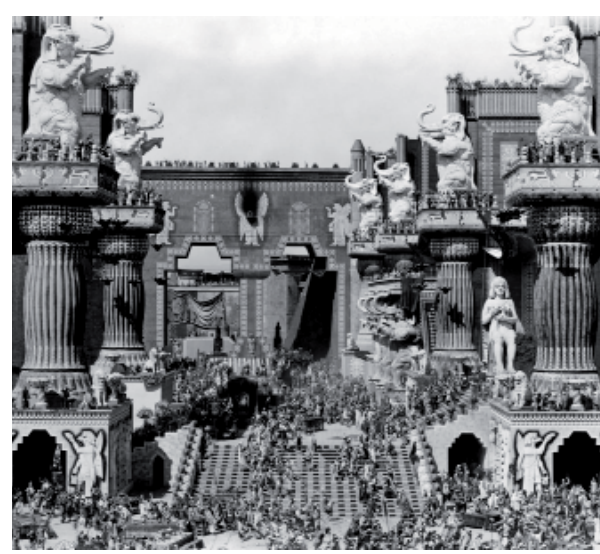
las formas y el sentido de encantamiento proporciona una experiencia visual que, más que cualquier otra obra seria de arquitectura, habla del ambiente romántico que representa el mundo de Hollywood de finales de los años 10 y principios de los $20^{\prime \prime 3}{ }^{3}$.

Por otra parte, en su afán de establecer un estilo regional, Wright intentó adecuarse también a la realidad física del medio californiano y, por ello, a pesar de la introspección y de la idea de fortaleza que sugiere la composición de la Hollyhock House, la casa es una combinación de volúmenes compactos y de jardines organizados a través de un patio abierto. Además, la estrategia de terrazas al aire libre que Wright había ensayado previamente en sus Midway Gardens (1913-14), cobraba todo el sentido en el clima templado y seco 


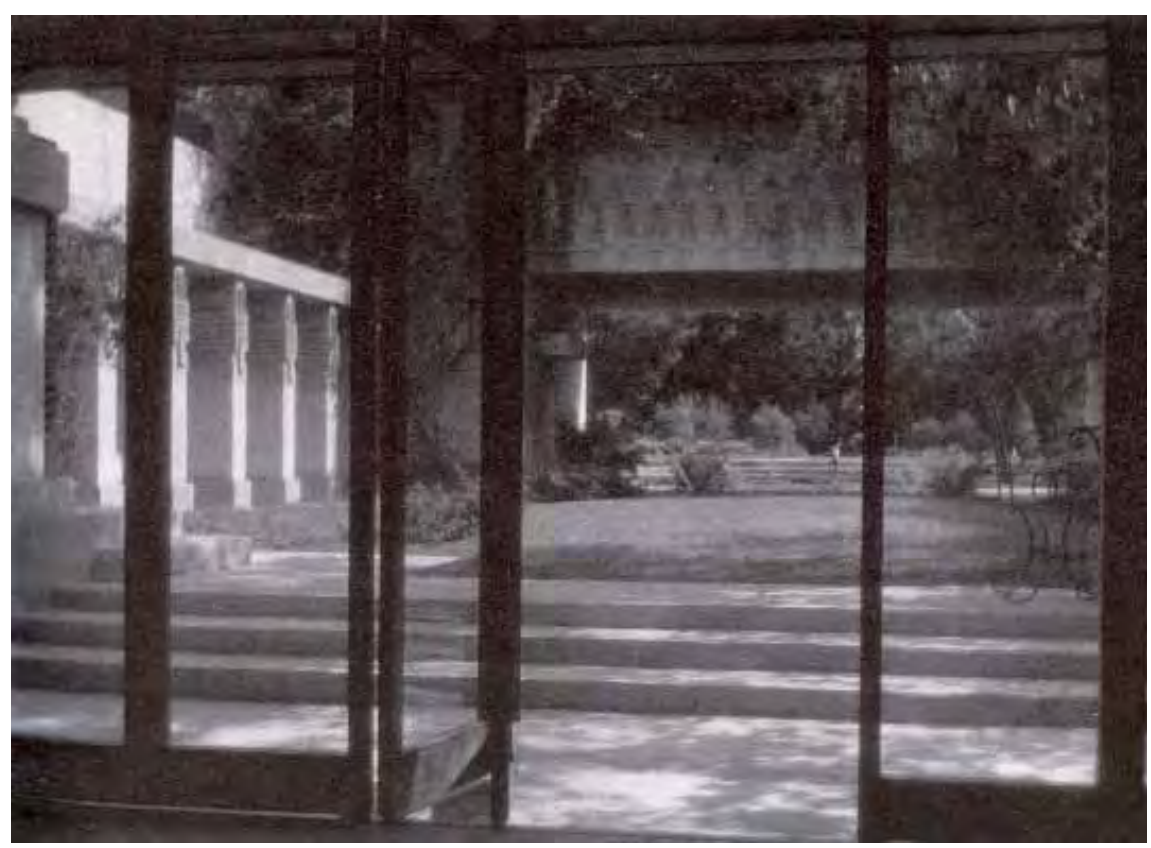

de Los Ángeles. Así, aunque la vivienda desde fuera es impenetrable a la mirada, sus principales espacios interiores están resueltos como continuación de un espacio exterior equivalente con el que cada uno de ellos se vincula a través dispositivos arquitectónicos de diferente transparencia, como puertas de vidrio, loggias, o pórticos de pilares en función de las necesidades de privacidad 39 .

La posibilidad de disfrutar de la vida al aire libre que permitía el clima californiano encontró su correspondencia más directa en el proyecto de un pequeño teatro para funciones privadas en el extremo oriental del jardín de la Hollyhock House. Éste constituye uno de los elementos más ingeniosos de la casa, dada su dualidad como residencia y centro de la vida de una comunidad actores y artistas ${ }^{40}$. De inspiración clásica, este teatro está conformado por plataformas semicirculares que rodean la exedra y el estanque que cierra el patio de la vivienda. La originalidad del teatro estriba en su doble orientación y, por tanto, en la doble utilización que se permite del mismo. Mirando desde el patio hacia el exterior, las terrazas actúan como palcos en sus tres lados, mientras que su superficie puede acondicionarse como auditorio. El puente que contiene los servicios de las estancias privadas de la primera planta configuraría en este caso el proscenio, enmarcando un escenario situado tras el estanque, ligeramente elevado tres escalones y resguardado naturalmente por masas de vegetación. De este modo, las galerías sobre las que se apoya el puente esconderían las salidas y entradas de actores. Separando el escenario del auditorio, una fuente accionada eléctricamente proporcionaría una cortina de agua que haría las veces de telón, un recurso tan hollywoodiano como la iluminación, pensada para potenciar el efecto cinematográfico de una arquitectura que haría las veces de decorado y que se integraría en la representación, enriqueciéndola con el fondo donde se proyectan los crepúsculos, los árboles mecidos por el viento o el paso de las nubes. Y, a la inversa, el teatro podría orientarse desde el exterior hacia la vivienda. En este caso, el público se dispondría en el graderío del jardín y los actores en el patio de la casa.

La imagen monolítica de la Hollyhock House revela las intenciones de Wright de trabajar con un material continuo. En este sentido, es lógico pensar que se tratase de hormigón, un material con el que el arquitecto estaba
Hollyhock House, imagen del jardín hacia 1925. Fotografía de Viroque Baker

Página anterior arriba: Hollyhock House, exterior, imagen actual. Fuente: Barnsdall Residence official site

Página anterior abajo: Recreación fantástica de Babilonia. Fotograma de la película Intolerancia (1916) de D. W. Griffith 


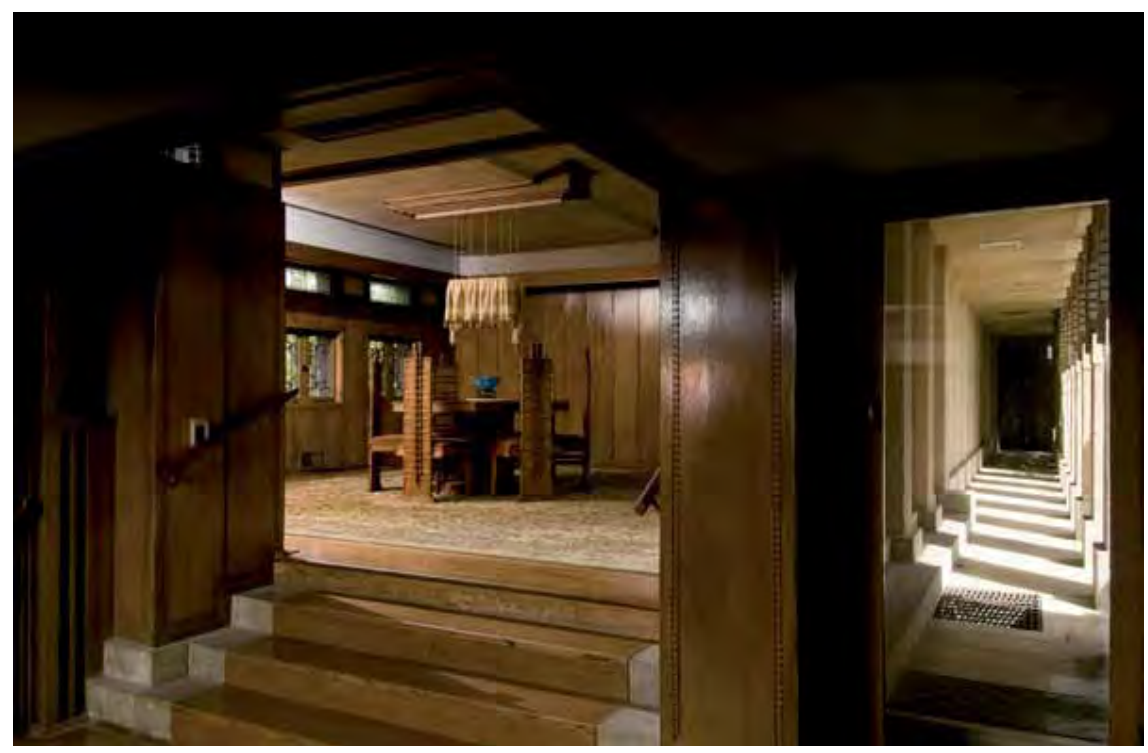

familiarizado desde principios de siglo, y cuya característica de ser un material pétreo y fluido Wright consideraba esencial para conseguir la continuidad de las superficies sugerida por las primeras perspectivas de la casa. No obstante, ante las dificultades para dirigir él mismo la obra y su falta de confianza en la pericia del contratista, desechó esta posibilidad en favor de otra con la que éste pudiera estar familiarizado. Pero también porque, ante los continuos descuadres del presupuesto y las presiones de su clienta, no tuvo más opción que abaratar costes recurriendo a una solución económicamente más viable. El sistema constructivo elegido como alternativa al hormigón in situ fue el de muros de ladrillo cerámico hueco posteriormente enfoscados y cuya apariencia terrosa, inevitablemente, hace pensar en los paramentos de adobe con los que, en los años 20, estaba asociada la imagen romántica de la California española.

La estructura de la vivienda permanece oculta. Los muros cerámicos están atados en su cabeza por un zuncho perimetral de hormigón donde descansan las vigas o las cerchas de madera que sustentan la cubierta y que, como en el salón central, salvan luces de hasta 12 metros, permitiendo un techo falsamente abovedado muy expresivo. Los pilares tienen misión portante y sus capiteles, decorados con la flor emblema del parque, fueron materializados con piedra artificial, una versión primitiva del hormigón prefabricado que Wright comenzaría a experimentar a mayor escala algunos meses más tarde. Dos vigas de acero con perfiles en I sustentan el puente que cierra el patio, el único empleo de este material en esta obra.

La austeridad de los muros exteriores se acentúa por contraste con la riqueza y exotismo de los acabados del interior de la vivienda. Las superficies de los paramentos están revestidas con un estucado continuo en tonos claros que recuerdan el color del desierto. Predomina la madera de roble. Éste recorre todas las estancias principales subrayando dinteles y configurando una moldura continua. Nada en el interior se ha dejado al azar, sino que es fruto de un programa decorativo integral que incluye la ideación de alfombras, mobiliario y piezas de arte ${ }^{41}$, como corresponde con la filosofía de trabajo wrightiana, con la estela del Arts \& Crafts, y con la tradición del mejor diseño californiano de la época -cuyos representantes más sobresalientes serían, por supuesto, los hermanos Greene, aunque en 1920 su práctica comenzaba a declinar tras el periodo de esplendor de las dos décadas anteriores. En el interior de la sala de estar todos los elemen- 


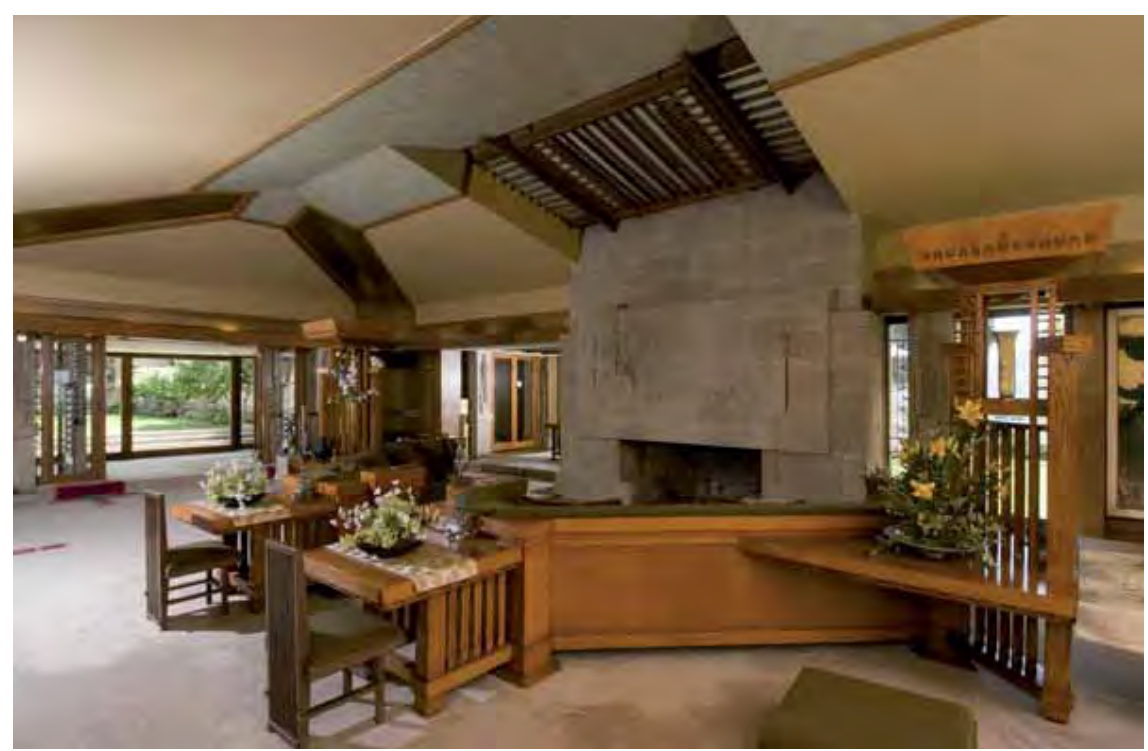

tos, desde las particiones de los techos, hasta la disposición simétrica de las mesas y el singular sofá hexagonal, focalizan la composición hacia la monumental chimenea de piedra. En ésta, un relieve escultórico retoma el tema del desierto a través de una alegoría abstracta que recopila todos los motivos geométricos usados en la casa: el círculo, el cuadrado, el diamante y la malvarrosa. En el panel${ }^{42}$, uno de los mejores trabajos artísticos de Wright, su hijo Lloyd afirmó 43 que su padre había querido rendir un homenaje a Aline Barnsdall representándola como sacerdotisa del desierto, recostada mientras contemplaba el crepúsculo. De nuevo, Wright incidía en el simbolismo del proyecto de Olive Hill, como revela la importancia que el arquitecto quiso conceder a los elementos de la naturaleza en una sala presidida por el fuego de la chimenea, a su vez rodeada de agua y protegida por poderosos muros de tierra, emplazada en lo alto de una colina expuesta al viento y desde la que, perfectamente orientada hacia el oeste, cada tarde se podía contemplar la puesta de sol sobre las montañas de esa nueva arcadia con la que los pioneros de la arquitectura moderna identificaron el paisaje de California.

Desde el momento en que puso un pie en Los Ángeles, Schindler se mostró disconforme con el proyecto de Wright, que encontraba demasiado retóri$\mathrm{co}$, grandilocuente y falto de luz natural. Por ello, trató de efectuar algunas correcciones en la vivienda que, sin contradecir las ideas originales, solventaran sus errores; a veces motu proprio, otras a instancias de Barnsdall que quería, ante todo, una casa en la que poder vivir cómodamente. Pero debía enviar los planos a Japón para que Wright diera su aprobación, algo que no siempre se producía, por lo que en no pocas ocasiones, antes las imposiciones de Wright, tuvo que asistir atónito al desafortunado rumbo que tomaban los acontecimientos, comenzando por el hecho de que, a finales de 1920, el presupuesto inicial de 50.000 dólares previsto para la vivienda, se había disparado superando el tope de 75.000 dólares fijado por Barnsdall, una cantidad que, en aquel momento, tampoco parecía ser muy realista. Para empeorar aún más las cosas, la vivienda pronto reveló tener goteras, fallos estructurales y problemas de fisuración. Su ineficiente respuesta frente a los esfuerzos laterales inducidos por los terremotos de la región y sus frecuentes inundaciones por falta de previsión de un sistema de drenaje adecuado para las Iluvias torrenciales del Sur de California, obligaron a Barnsdall desde el principio a gastar considerables sumas de dinero en operaciones de mantenimiento y continuas reparaciones ${ }^{44}$.
Hollyhock House, imagen actual del salón Fuente: Barnsdall Residence official site

Página anterior: Hollyhock House, vista del comedor y de la loggia de acceso al patio, imagen actual. Fuente: Barnsdall Residence official site 


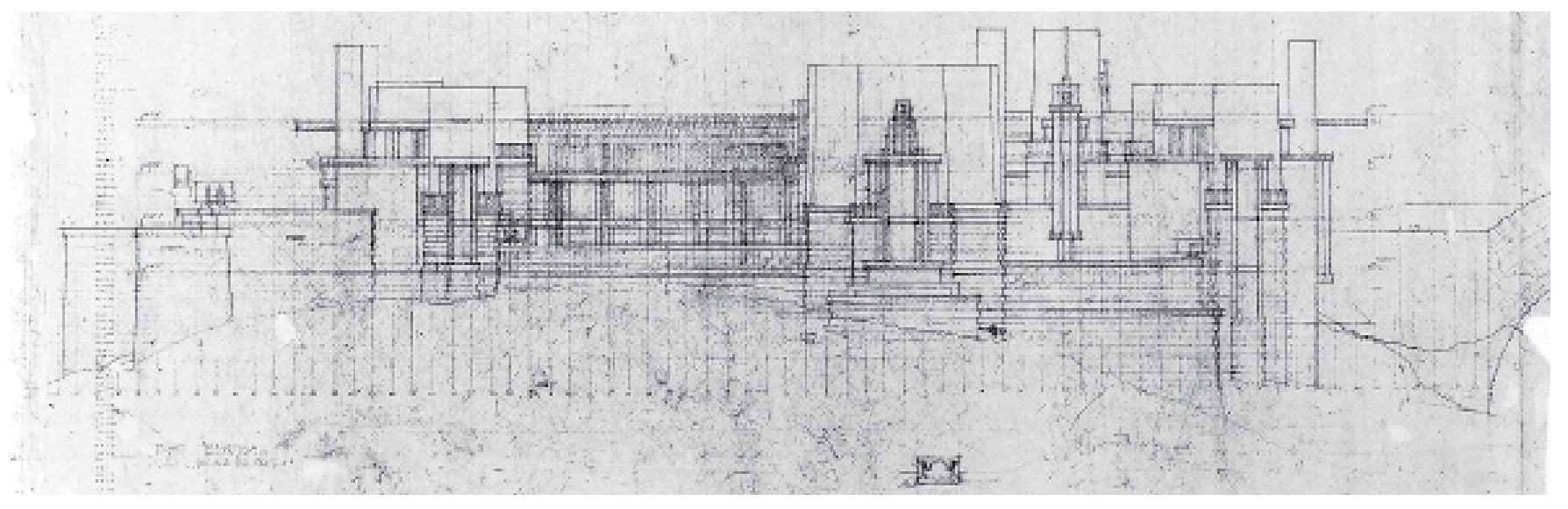

La relación de Schindler y Wright se fue haciendo cada vez más tensa. Schindler era objeto de implacables críticas por parte de Wright mientras que, en Los Ángeles, él se veía obligado a paliar sus faltas y a dar la cara ante su clienta. También sentía que estaba mal pagado para la responsabilidad y la cantidad de trabajo que Wright había depositado en él ya que Schindler, además de encargarse de los proyectos y de la dirección de la obra de Olive Hill, llevaba los asuntos económicos del despacho durante las ausencia de Wright, entre ellos, pagar nóminas, alquileres, atender facturas y gestionar la pensión vitalicia que Wright había asignado a Sullivan.

Por su parte, Wright siempre culpó a Schindler del resultado final de la obra. Consideraba que la inexperiencia e ineptitud de su ayudante habían malogrado el proyecto de Olive Hill. Probablemente Schindler careciera de la experiencia necesaria para dirigir un encargo de semejante relevancia pero los reproches de Wright son injustos y fácilmente rebatibles a partir de los hechos. David Gebhard, en su biografía de Schindler, defendió el trabajo del arquitecto desde su complicada posición frente a Wright, expresando que si "Wright no estuvo satisfecho con la vivienda una vez terminada es seguro, pero si pensó en 1920 (como haría en los años treinta) que fue la ineptitud de Schindler lo que la había estropeado, es cuestión de opinión. Es fácil imaginar las dificultades que se presentaron, particularmente las derivadas de las personalidades, y que afectaron el proyecto de Olive Hill. Schindler se encontró en la incómoda posición de estar en el centro de un triunvirato compuesto por Wright, Aline Barnsdall y el contratista. [...] Con Wright en Japón, Schindler tuvo que tomar decisiones que hubieran debido ser tomadas por el propio Wright. A fin de contener el coste del edificio, que se había disparado, y al mismo tiempo como expresión de su propia filosofía de diseño, eliminó y simplificó numerosos detalles. Miss Barnsdall tenía la furtiva sospecha de que Wright la estaba timando, ya que creía que el gran genio hubiera debido mostrar el suficiente interés en el proyecto como para estar presente durante su construcción. Y a medida que la casa progresaba se encontró, al igual que muchos otros clientes de Wright, con que el coste del proyecto seguía subiendo, tanto debido a dificultades constructivas imprevistas, como debido a los cambios que ella insistía en introducir. Aline Barnsdall quería una casa que funcionara realmente bien y en consecuencia introdujo cambios que aseguraran su habitabilidad. Al igual que otros clientes [...] su reacción frente al edificio que crecía en su colina de Hollywood era doble: deseaba la notoriedad de poseer un edificio de Wright, pero al mismo tiempo no estaba segura de querer vivir en un monumento. [...] Schindler trató, de la mejor manera que pudo, los a veces ultrajados sentimientos de la clienta, y fue tal su éxito que no sólo llegó a terminar la vivienda principal, sino que Miss Barnsdall se convirtió en amiga personal y, más tarde, en una de sus clientas más importantes" 45 . 


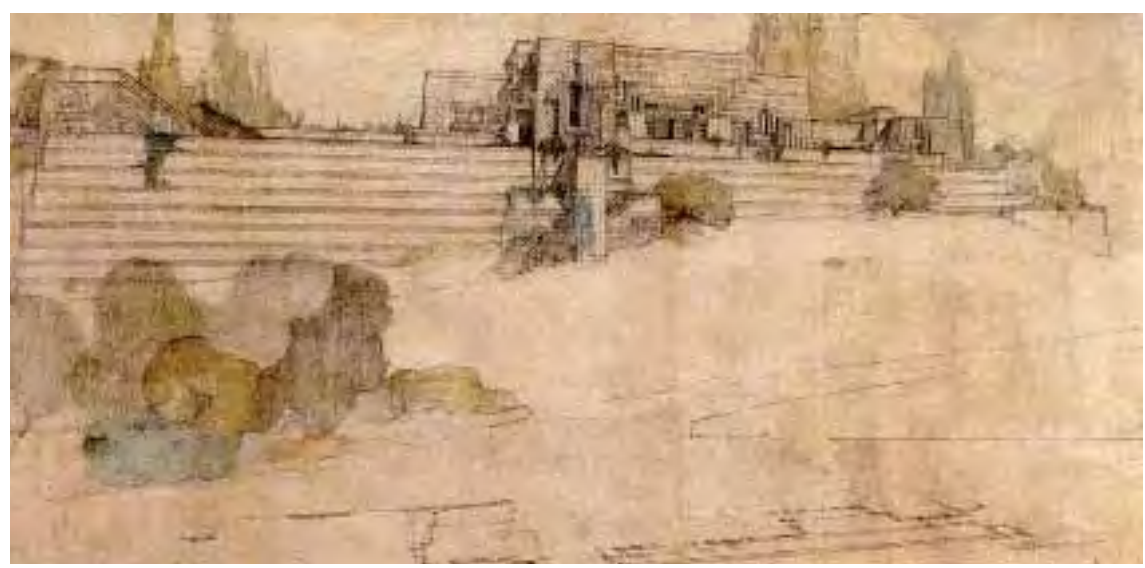

\section{Wright en Beverly Hills, visiones de una nueva arquitectura}

La información acerca de la vida en Olive Hill es escasa $4^{4}$. Aline Barnsdall habitó la Hollyhock House durante muy pocos meses, probablemente el tiempo suficiente para confirmar sus sospechas de que no le gustaría vivir en ella. Al igual que Schindler, Barnsdall pensaba que sus interiores eran excesivamente solemnes, demasiado oscuros, casi opresivos.

En 1922, volcada en la educación de su hija y con su mirada puesta en otros negocios inmobiliarios, sus prioridades habían cambiado. Por otra parte, después de los desengaños de su experiencia profesional con Wright, se sentía sin fuerzas para seguir impulsando la construcción y la gestión de un proyecto de la envergadura de un teatro y una comunidad autosuficiente de artistas.

Quizás por esta razón, aunque en su fuero interno experimentaba la necesidad de dejar un legado como el de su padre, su lucha para ver terminada la casa tras los constantes retrasos y variaciones presupuestarias y su desilusión con el teatro tras asumir que Wright sería incapaz de construirlo desde Japón, hicieron que para ella la idea de completar la colina se convirtiese en una pesada carga. En agosto de 1921 concluyeron los trabajos en su vivienda y en las dos residencias secundarias (de las que sólo ha sobrevivido la Residencia A). Sin embargo, dado que desde el inicio de las obras de su casa había desistido de sus planes para inaugurar el teatro en la temporada de 1921, Barnsdall fue perdiendo interés por este edificio para prestar más atención a otros que, como el bloque de apartamentos, podrían aportarle mayores beneficios económicos. Consideró entones la posibilidad de reducir las dimensiones y el aforo del teatro a menos de la mitad y, en lugar de formar de nuevo su propia compañía, entregar la gestión del edificio al Hollywood Community Theater, otra idea que abandonó pronto pues, finalmente, tomó la decisión de no completar el proyecto de Olive Hill.

Curiosamente, esto ocurría justo cuando, una vez finalizado el Hotel Imperial de Tokio, Wright regresaba definitivamente a los Estados Unidos en agosto de 1922. Sin perspectivas de trabajo en el Medio Oeste ni apenas relación con sus clientes en Chicago tras años fuera del país la actividad profesional de Wright se resentía. Y también su popularidad. Sus prolongadas ausencias le habían alejado del público, de la crítica y de los medios en general -tanto en Europa como en América-, mermando su capacidad para influir en ellos. Una vez más Wright necesitaba reinventarse y Los Ángeles, una ciudad sin una tradición arquitectónica imperante, abierta al eclecticismo y receptiva a la experimentación, parecía el lugar idóneo para un nuevo comienzo. Por ello, ese mismo verano tomó la decisión de instalarse de manera permanente en California.
Frank Lloyd Wright : Casa Ennis, Los Ángeles, 1923-24, dibujo, FLW Foundation

Página anterior: Frank Lloyd Wright : Casa para Aline Barnsdall en Beverly Hills, 1923, alzado principal a la colina. Fuente: City of Los Angeles Departments of Recreations \& Parks and Cultural Affairs 


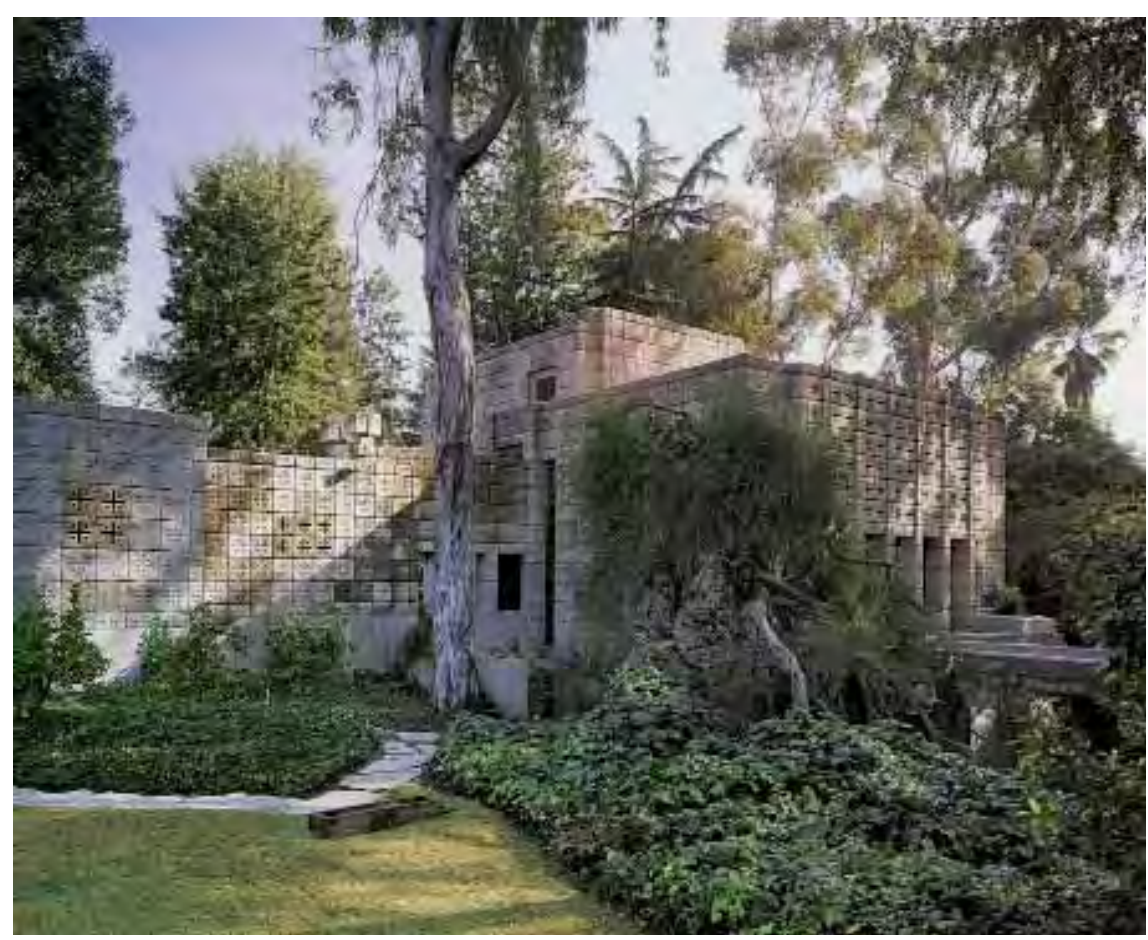

En enero de 1923 alquiló un estudio en el 8228 de Fountain Ave, apenas a unas seis manzanas de distancia de la casa que los Schindler acababan de construirse y ocupar en Kings Road. Allí, con ayuda de su hijo Lloyd, Wright comenzó a trabajar en un nuevo proyecto residencial para Aline Barnsdall, una casa en Beverly Hills que, de acuerdo con Robert Sweeney ${ }^{47}$, puede considerarse el arranque del periodo de bloque textil que se extenderá durante toda la primera mitad de la década de los años 20 -culminando con el ciclo de sus cuatro conocidas viviendas de Los Ángeles: las casas Millard (La Miniatura, 1923), Ennis-Brown (1923-24), Storer (1923-24), y Freeman (1924-25).

También a principios de 1923, Wright redactó un nuevo artículo de la serie In the Cause of Architecture que envió a la revista Wendingen ${ }^{48} \mathrm{y}$ al que dio el significativo título de La tercera dimensión. Con él se remontaba a algunas de sus obras más reconocidas internacionalmente (el Edificio Larkin o el Templo Unitario), presentándolas como antecesoras de una determinada manera de entender, literal y metafóricamente, el espacio arquitectónico en tres dimensiones, un argumento que le servía como hilo conductor para presentar su evolución posterior y anunciar que había comenzado a trabajar en un nuevo sistema estructural basado en bloques prismáticos de hormigón gracias al cual, por fin, podía materializar su aspiración de construir de forma simplificada a partir de plantas modulares y elementos prefabricados. Adoptando - con una clara estrategia publicitaria- la postura de un arquitecto interesado en los procesos industriales y defendiendo la utilidad de la máquina como instrumento para lograr estandarización y repetición, Wright describía la invención del bloque textil remontando sus precedentes a los elementos decorativos del Hotel Imperial (realizados en piedra volcánica-Oya o lava block) y de la propia Hollyhock House, de cuyos motivos escultóricos como la estilización de la flor preferida de Barnsdall (la malvarrosa o hollyhock en inglés), de donde procede el nombre de la casa ${ }^{49}$. Afirmaba: "Se fabrica con la grava del granito disgregado de las colinas, muy fácil de obtener, y se mezcla con cemento y arena en moldes adecuados para conseguir masas sólidas y compactas que pueden emplearse como pequeños bloques, elementos monolíticos o combinaciones de ambos. Supone el inicio de un 


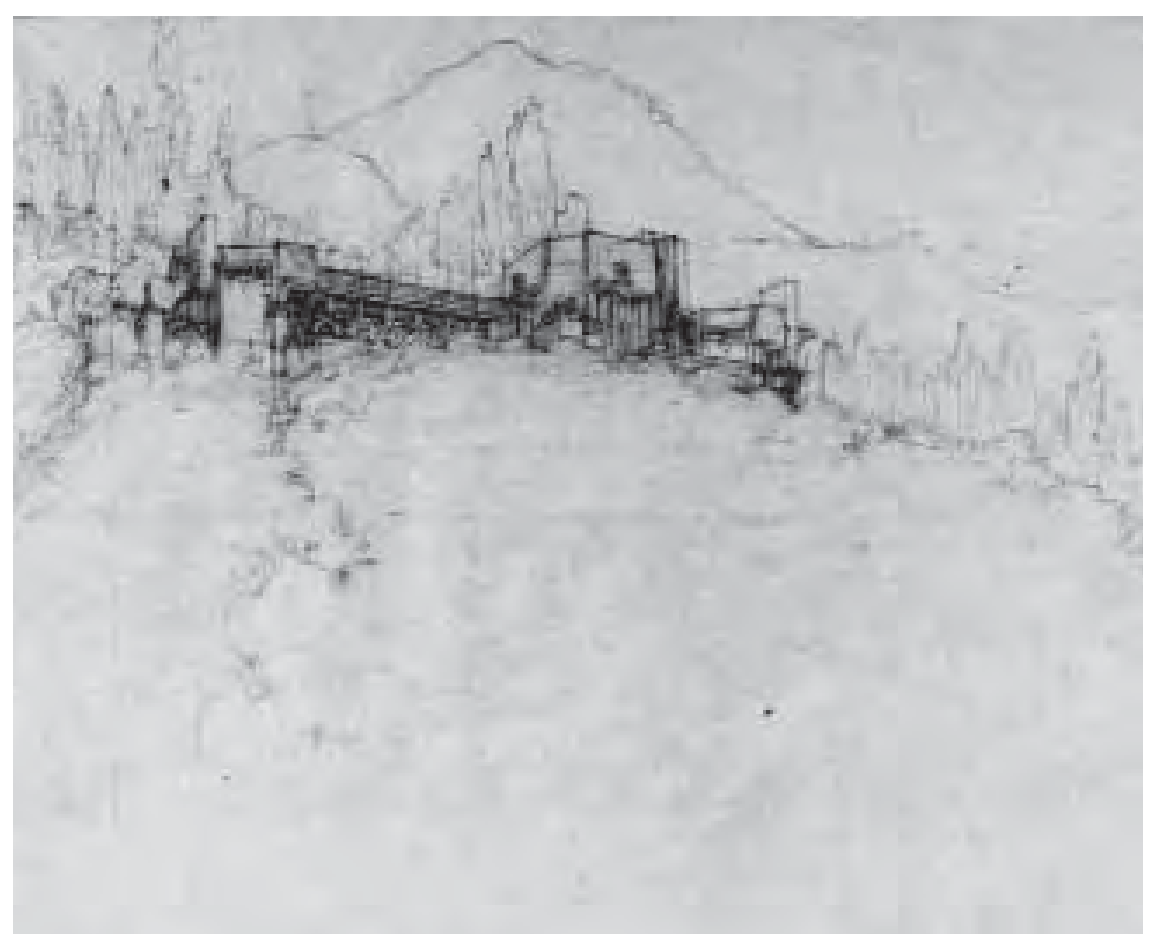

esfuerzo para producir piezas que satisfagan las necesidades de estandarización y repetición de unidades constructivas. [...] Deberían ser empleados como elementos constructivos en cualquier arquitectura proyectada desde la tercera dimensión". También en este artículo, tras defender la casa Hollyhock como paradigma de adecuación al medio californiano, Wright señalaba a la vivienda como paso previo de la técnica del bloque textil, pues éste ya se ensayaba parcialmente para realizar determinados elementos decorativos, como los estilizados capiteles florales de hormigón, sosteniendo además que todo ello respondía a un mismo "esfuerzo para producir una arquitectura integral y apropiada a las necesidades climáticas de California".

En cualquier caso, a pesar de la consideración por parte de Wright de la casa Hollyhock como precedente y teniendo en cuenta el hecho de que la casa Millard (terminada en febrero de 1923) es la primera obra enteramente construida con bloque textil, los dos principales proyectos en los que Wright experimentó -al menos teóricamente- con las posibilidades técnicas y expresivas de este sistema fueron dos nuevos encargos de Aline Barnsdall no realizados y contemporáneos de La Miniatura: la referida casa en Beverly Hills y otra obra de la que se tratará en el siguiente apartado de este mismo capítulo, la escuela comunitaria para el Parque Barnsdall o Little Dipper. Ambos proyectos datan de principios de 1923.

La vivienda de Beverly Hill respondía a un intento de Aline Barnsdall de alejarse del entorno de Olive Hill y, en cierto modo, podría entenderse como una especie de compensación a Wright por haber frustrado sus planes de completar el conjunto de obras previstas para la colina. Barnsdall previó su ubicación en una aatractiva parcela de 24 acres en un cañón situado justo al norte de "Pickfair", la propiedad que las estrellas del cine mudo Douglas Fairbanks y Mary Pickford poseían en Beverly Hills y que, durante los años 20, se había convertido en el centro de relación más importante para la alta sociedad de Hollywood.

A pesar del deseo de Barnsdall de huir de la monumentalidad de la casa Hollyhock, el proyecto de esta nueva residencia comparte con aquella la com-
Frank Lloyd Wright : Millard House, 1923, Pasadena, Fuente Robert McCArter, Phaidon

Página anterior: Frank Lloyd Wright : Casa para Aline Barnsdall en Beverly Hills, 1923, perspectiva de conjunto. Fuente: City of Los Angeles Departments of Recreations \& Parks and Cultural Affairs 


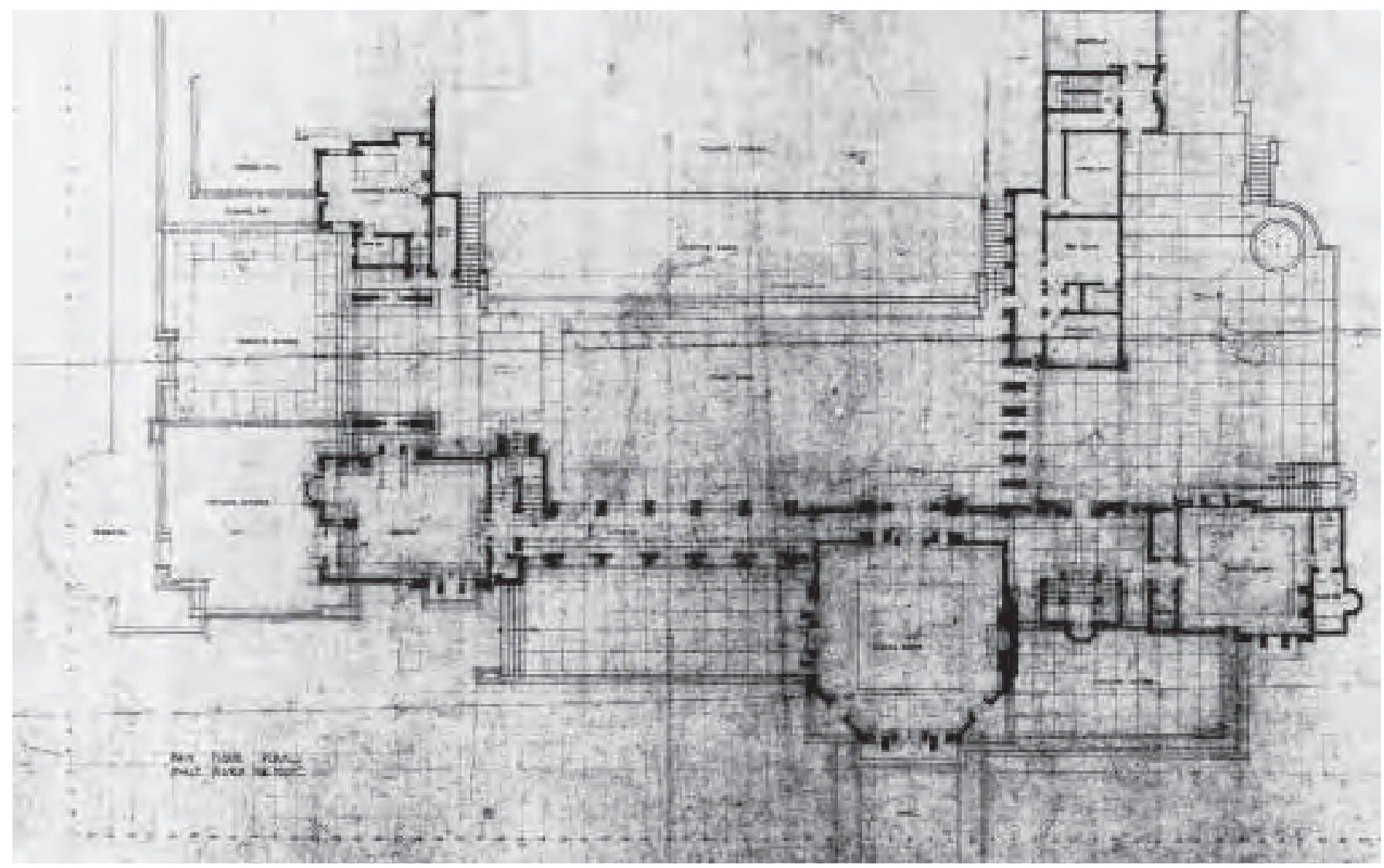

Frank Lloyd Wright : Frank Lloyd Wright : Casa para Aline Barnsdall en Beverly Hills, 1923, planta de acceso. Fuente: City of Los Angeles Departments of Recreations \& Parks and Cultural Affairs

Página siguiente izquierda: Barnsdall House en Beverly Hills, 1923, plano de implantación. Fuente: City of Los Angeles Departments of Recreations \& Parks and Cultural Affairs

Página siguiente derecha arriba: Olive Hill, Residencia B. Fotografía de Kameki Tsuchiura, 1923

Página siguiente derecha abajo: Olive Hill, Residencia B. Fuente: City of Los Angeles Departments of Recreations \& Parks and Cultural Affairs plejidad y dimensiones del programa, su carácter representativo y su condición de referente paisajístico, pues de haberse construido estaba destinada a convertirse en otra acrópolis sobre las colinas del oeste de Los Ángeles. Los alzados de la vivienda que se han conservado trasmiten una idea de fortaleza inexpugnable muy similar a la de su futura casa Ennis en Los Feliz, con la que su imagen guarda muchas semejanzas.

El programa de la vivienda se dividía en cuatro grandes funciones que Barnsdall estableció de su puño y letra emulando, curiosamente, las cuatro alas existentes en la casa de Olive Hill50: estancias de invitados, área social, zona de servicio y dependencias particulares. En el proyecto de Beverly Hills, a partir de una planta ${ }^{11}$ con forma de $U$, cada una de estas funciones se corresponde con un volumen, de modo que la casa puede entenderse como una serie de pabellones articulados en torno a un gran patio abierto. No obstante, la principal novedad organizativa frente a la vivienda de Hollywood es la introducción de ejes diagonales que tensionan las circulaciones entre los recintos principales de la vivienda: el dormitorio de Aline Barnsdall y el espacio del comedor, dispuestos en las esquinas del primer piso y entre los que se ubica, de manera asimétrica, el volumen a doble altura del salón, orientado a sur. Desde su emplazamiento en lo alto de la colina, la espectacular sala de estar, rodeada de terrazas y conectada por una loggia con la biblioteca, hubiera disfrutado de una de las mejores vistas sobre la llanura de la ciudad en línea recta hasta el Pacífico.

En su intento por subrayar y presentar las posibilidades de repetición un sistema constructivo de naturaleza industrial, Wright compuso tanto la planta como los alzados de la vivienda a partir de una retícula, cuyo módulo base se correspondía con las dimensiones del bloque. Todos los dibujos de esta casa se realizaron en un papel cuadriculado, como también se hizo con los de la es- 


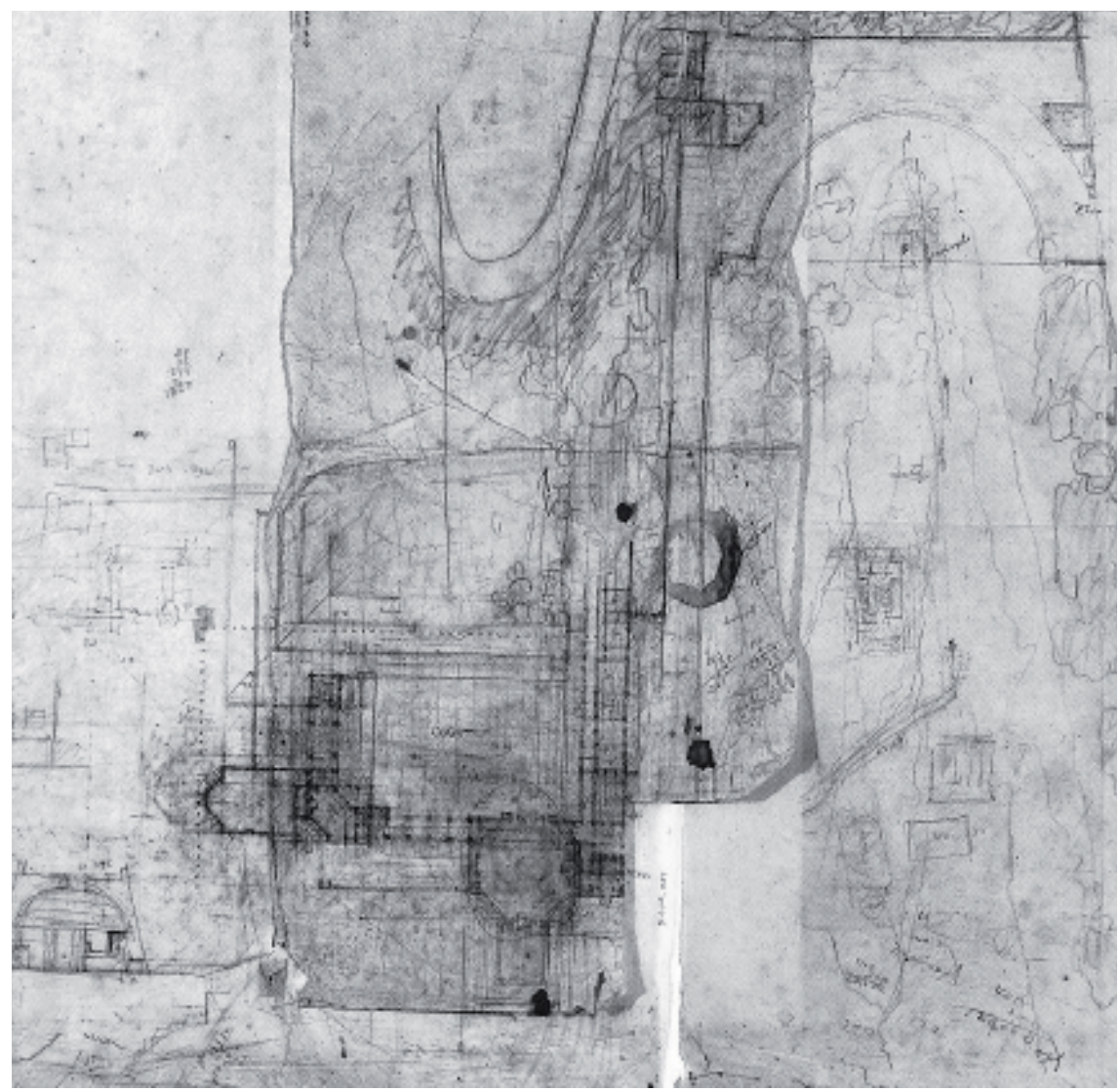

cuela comunitaria, un proyecto realizado casi simultáneamente y con el que esta vivienda tiene también en común su ensayo de geometrías hexagonales.

El proyecto estuvo listo a principios de mayo de 1923. Wright había completado las plantas secciones y alzados de los tres niveles de la vivienda cuando el periódico local Holly Leaves, anunció en un artículo fechado el 18 de mayo que Barnsdall había cerrado la adquisición de su nueva propiedad por 60.000 dólares y que en breve iniciaría la construcción de una vivienda cuyo coste se estimaba en otros 150.000 dólares más ${ }^{52}$. Pero las negociaciones debieron fallar, pues la compra nunca llegó a realizarse, frustrándose así la posibilidad de esta obra. Sin embargo, por primera, vez la relación entre ambos terminó amigablemente. Ella pagó de inmediato los honorarios del proyecto y, al poco tiempo, previamente a iniciar un nuevo viaje a Europa, ofreció a Wright la oportunidad de mudarse a su Residencia B para trabajar desde allí en un último encargo.

En ese momento, Aline Barsndall ya tenía claro que no quería seguir viviendo en la Hollyhock House. Se debatía entre vender su propiedad, embolsándose una considerable suma de dinero ${ }^{53}$ y mantenerse fiel a su idea de convertir Olive Hill en un centro cultural abierto al público. Por fin, en julio de ese mismo año 1923, justo antes de partir, halló una solución que le permitiría cumplir con su destino filantrópico y, a la vez, liberarse de la obligación que para ella suponía la casa, el pago de sus impuestos y sus costosos gastos de mantenimiento. Su decisión fue donar la vivienda a la ciudad de Los Ángeles para que se destinase a centro de arte y biblioteca y, junto a ella, cedería 10 acres de su jardín para crear un parque en memoria de su padre, Theodore Barnsdall. Con el propósito de adecuar la casa a su nueva función, Barnsdall solicitó a Wright la remodelación de algunas estancias y el acondicionamiento para ella de la casa de huéspedes en la que el arquitecto se acababa de instalar.
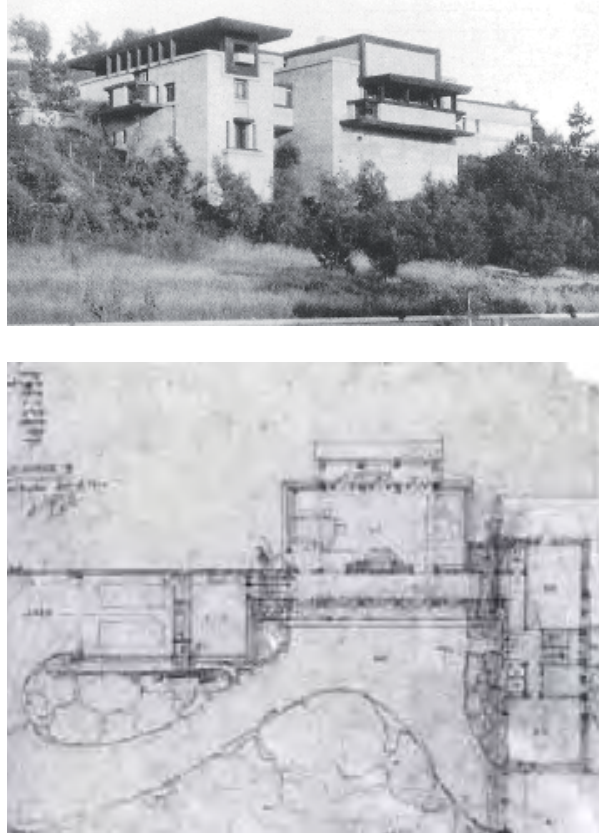


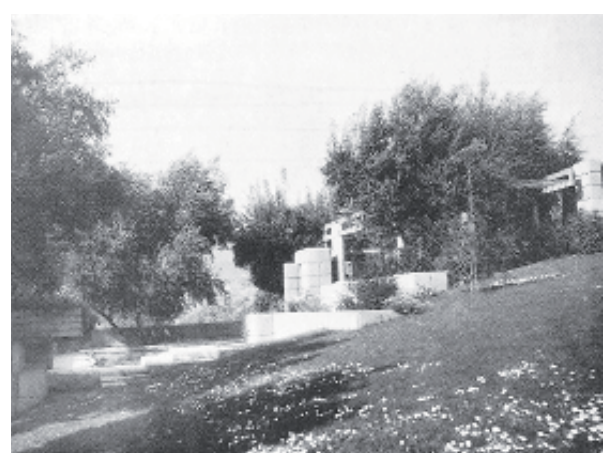

\section{El parque Barnsdall, jardín de trayectorias que se bifurcan}

Defensora de la enseñanza moderna y de proporcionar una formación artística desde la infancia, Barnsdall había fundado, junto a su amiga la pedagoga Leah Lovell, una escuela de orientación progresista donde educar a su hija Betty y a un pequeño grupo de niños procedentes de su círculo de amistades, artistas o intelectuales militantes. Su interés por estos temas le llevó a encargar a Wright que completara el programa de equipamientos culturales previsto en su donación con una escuela comunitaria que debería ubicarse entre la Hollyhock House y la Residencia B, en el lado de la colina recayente a Edgemont Street.

Durante el verano de 1923, Wright estuvo trabajando en el diseño de esta escuela comunitaria que planteó de nuevo como un experimento focalizado en el sistema de construcción con bloque textil. La escuela, cuyas notas iniciales apuntaban una capacidad para 20 alumnos, debía albergar, además, un espacio de juegos y un teatro para niños (Community Playhouse), cuyo programa tenía mucho en común con otro proyecto anterior del arquitecto, el Playhouse para la casa Coonley de 1912 y que, como en este caso, tampoco llegó a ver la luz. El conjunto de escuela, parque infantil y pequeño teatro denominado "The Little Dipper", La Osa Menor-porque su planta recordaba la forma de esta constelación-es, junto con la casa del Director del primer masterplan, otro de los proyectos no construidos más interesantes del complejo de Olive Hill.

En su versión definitiva, la planta es un cuadrado deformado que se prolonga en una especie de mango alargado. En ella pueden reconocerse dos hexágonos superpuestos: uno, más pequeño, configura la entrada; el otro, de mayor dimensión está flanqueado por dos triángulos desiguales generando una sala de doble altura que da acceso a un teatro al aire libre cuyo graderío está resuelto, como en el jardín de la casa Hollyhock, con plataformas circulares. La compleja combinación de geometrías triangular, hexagonal, y circular planteada por Wright en este proyecto experimental inauguraba una investigación espacial destinada a producir convincentes resultados en las décadas siguientes.

Al mismo tiempo que desarrollaba este proyecto, Wright dirigía las obras de la casa Millard, en las que trabajaba con el mismo contratista que llevaba a cabo la remodelación de la Residencia $\mathrm{B}$. Con dos meses de retraso sobre la fecha que había prometido a Barnsdall antes de su partida -y con ésta todavía fuera del país-, Wright obtuvo los permisos municipales a principios de noviembre de 1923, iniciando la construcción de la escuela poco después. En aquella ocasión, Barnsdall tenía a Wright trabajando y viviendo en Olive Hill por lo que, ingenuamente, pensó que no se repetirían los errores del pasado. Confiando en el criterio de su arquitecto y tratando de evitar nuevos desencuentros, Barnsdall -que con casi total certeza no llegó a ver ningún boceto del proyecto antes de embarcarse para Europa-concedió a Wright plena libertad y todo tipo de facilidades a condición de que Little Dipper estuviera terminado a la mayor brevedad posible pues, como ella le insistía en sus cartas, "sugiero que aceleres tu genialidad porque la reputación de mi escuela se resiente al no disponer a estas alturas de instalaciones permanentes" 54 . A pesar de todo, una vez más, Wright no cumplió su cometido; en parte, porque durante la ausencia de Aline Barnsdall había preferido centrarse en la reforma55 de la Residencia $B$, contraviniendo así los deseos de su clienta que le había instado a posponerla para priorizar la ejecución de la escuela. 


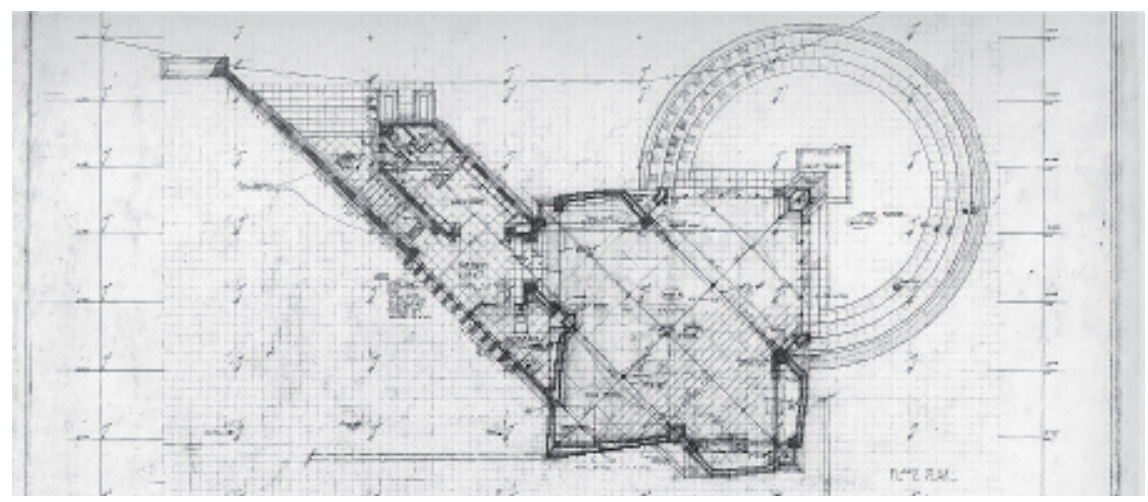

En diciembre de 1923 Barnsdall regresó a California e inmediatamente hizo oficial su donación de la Hollychock House a la ciudad de Los Ángeles. Si bien, no coincidió con Wright quien, semanas antes y sin terminar las obras, se había marchado a Taliesin para celebrar su nuevo matrimonio con Miriam Noel. Molesta por los cambios no autorizados en la Residencia B pero, sobre todo, con su actitud y con el retraso en la construcción de la escuela, en enero de 1924, decidió parar su construcción y dar por terminada para siempre su relación contractual con Wright ${ }^{56}$.

Cuando poco después, en marzo de 1924 la ciudad rechazó los términos de la donación, Barnsdall optó por remodelar la obra-cuyos primeros muros ya se habían ejecutado por encima de los cimientos- $y$, para disgusto de Wright ${ }^{57}$, que lo consideró una traición de su antiguo ayudante, encargó a Schindler aprovechar los materiales existentes para crear en ese emplazamiento un jardín de acceso público.

Schindler reutilizó los bloques prefabricados de hormigón para crear una pérgola y una piscina de chapoteo para niños al norte de Little Dipper, el lugar donde Wright había previsto una terraza. Conservó los muros existentes ya construidos para contener el terreno y transformó la escuela con pequeños cambios, añadiendo un parterre monumental sobre la pared oeste y convirtiendo la pista de juegos de arena en una fuente y la terraza en un estanque. El proyecto y la obra consumieron varios meses, de abril de $1924 \mathrm{a}$ marzo de 1925. Por su experiencia como arquitecto paisajista, para la versión definitiva de 1925, Schindler incorporó como colaborador ${ }^{58}$ a Richard Neutra, quien había llegado a la ciudad en febrero de ese año y se había instalado con Schindler en Kings Road ${ }^{59}$. Esta obra, concluida poco después, fue el primer proyecto construido en el que participó Richard Neutra en Los Ángeles, por lo que, también, su trayectoria profesional en California fue otra de tantas que, en uno u otro sentido, tuvieron el parque Barnsdall como punto de partida.

En efecto, en torno a la persona de Aline Barnsdall se forjaron decisivos vínculos entre artistas, arquitectos y clientes. En 1921, Barnsdall había presentado a dos de sus amigas radicales, Pauline Schindler y Leah Lovell -cuyo apellido de soltera era Press- proponiéndole a Pauline que ayudara a Leah en la dirección de su escuela. Barnsdall quería educar allí a su hija Betty junto a otros niños seleccionados ${ }^{60}$ entre las familias más progresistas de Los Ángeles, entre ellos Neil y Cole Weston, los hijos menores de Edward Weston.

Con casi total seguridad, la amistad de Pauline Schindler y Aline Barnsdall se había iniciado en Chicago, y más concretamente en el círculo del Little Theatre de Browne y Van Volkenberg, ya que ellos habían colaborado inten-

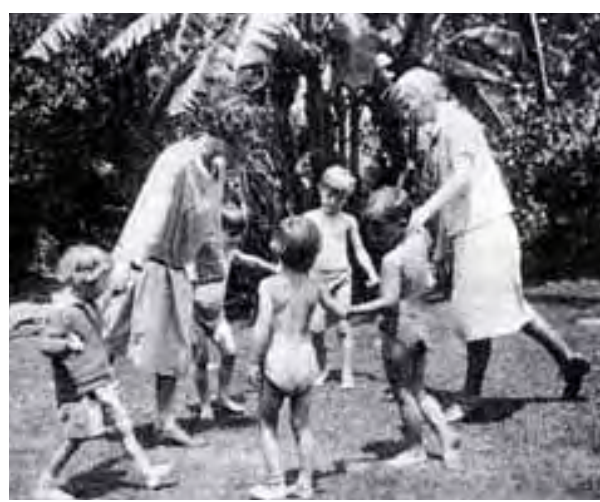

Izquierda: Frank Lloyd Wright : The Little Dipper, Community Playhouse, escuela para Aline Barnsdall en Olive Hill, planta, 1923. Fuente: City of Los Angeles Departments of Recreations \& Parks and Cultural Affairs Derecha: Pauline Schindler (izda) y Leah Lovell en el jardín de su escuela en Argile Avenue, Hollywood, 1923. En la fotografía aparecen los dos hijos pequeños de Edward Weston, Neil y Cole Weston. Fuente Esther McCoy, Vienna to Los Angeles

Página anterior: Schindler y Neutra, pérgola y piscina de chapoteo en el Parque Barnsdall, 1925. Fuente: Archivo de Schindler, Architectural Drawing Collection, University Art Museum, UCSB (en adelante ADC/UCSB) 


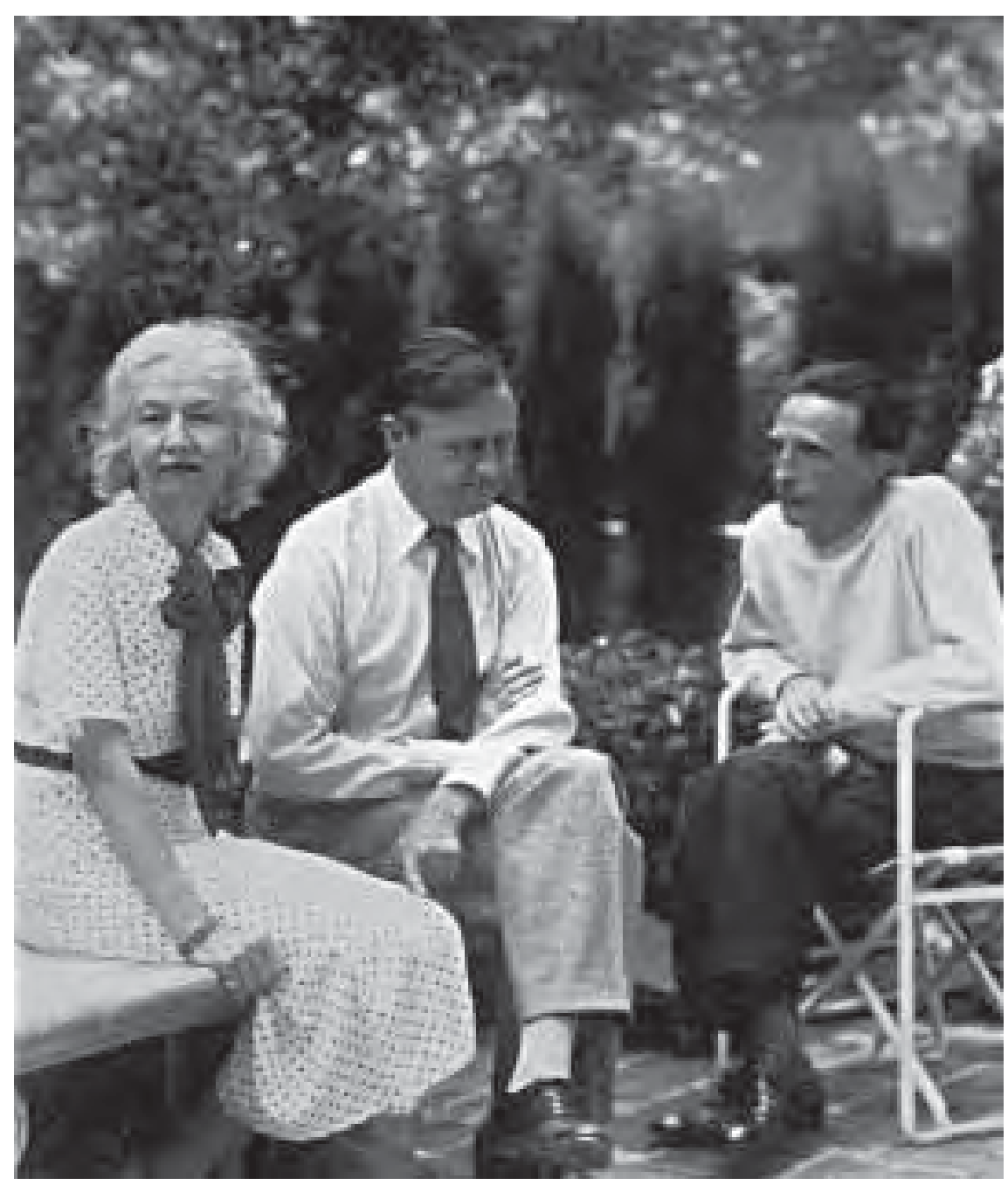

samente con su mentora, Jane Addams y la Hull House -un episodio de la vida de Pauline del que se tratará más adelante- para producir una gira nacional de Las Troyanas de Eurípides, una pieza teatral que promovieron por su alegato pacifista en plena Primera Guerra Mundial.

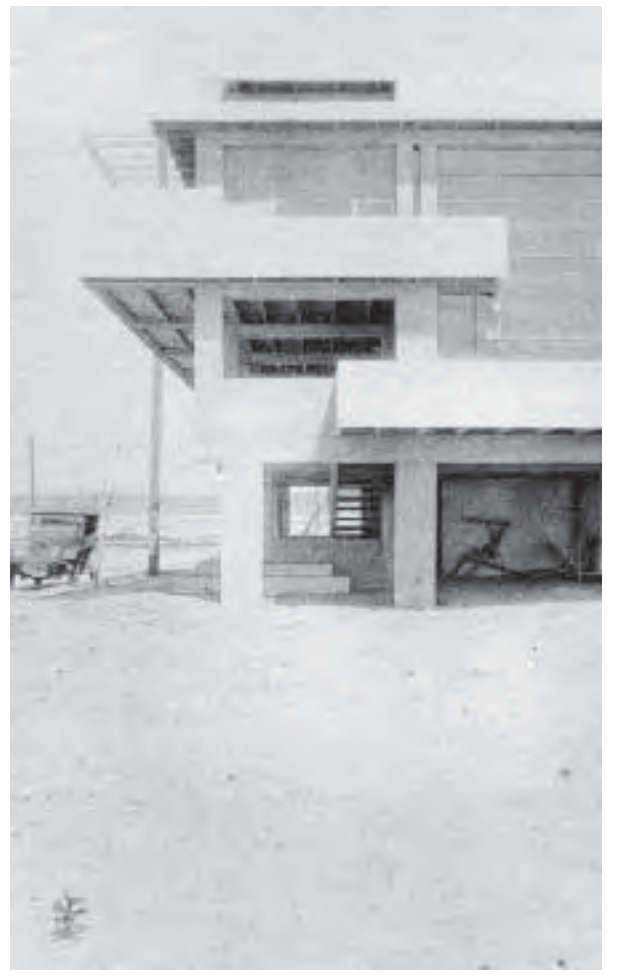

A través de Leah Press Lovell, Pauline conoció a la hermana de ésta, Harriet Press Freeman. Leah, como Pauline, era educadora y Harriet bailarina. Leah y Harriet Press estaban casadas, respectivamente, con Philip Lovell, médico y reputado columnista de Los Angeles Times, y con Samuel Freeman que, como su cuñado, era otro valedor de las corrientes modernas de la ciudad y anfitrión de otro de sus salones más activos. De este modo, por medio de la conexión de Pauline Schindler con Aline Barnsdall y de ésta con las hermanas Press, Schindler se convertiría tanto en el arquitecto de los Lovell como de los Freeman. Para los primeros, realizaría tres edificios a partir de 1922: una cabaña, una pequeña casa rural y una vivienda pionera de la arquitectura moderna, la Lovell Beach House en la playa de Balboa, Newport, que terminó en 1926. Para los segundos, Schindler diseñó diversas piezas de mobiliario y la reforma de su casa en East Hollywood, la última de las obras del ciclo del bloque textil de Frank Lloyd Wright.

Los Freeman habían conocido a Wright en casa de Aline Barnsdall. Dado que tras la experiencia de su amiga en Olive Hill conocían las dificultades del arquitecto para prever y controlar coste de sus obras, estipularon por contrato que Wright debería hacerse cargo del pago de toda cantidad que superase los 10.000 dólares del presupuesto pactado a cambio de una participación 


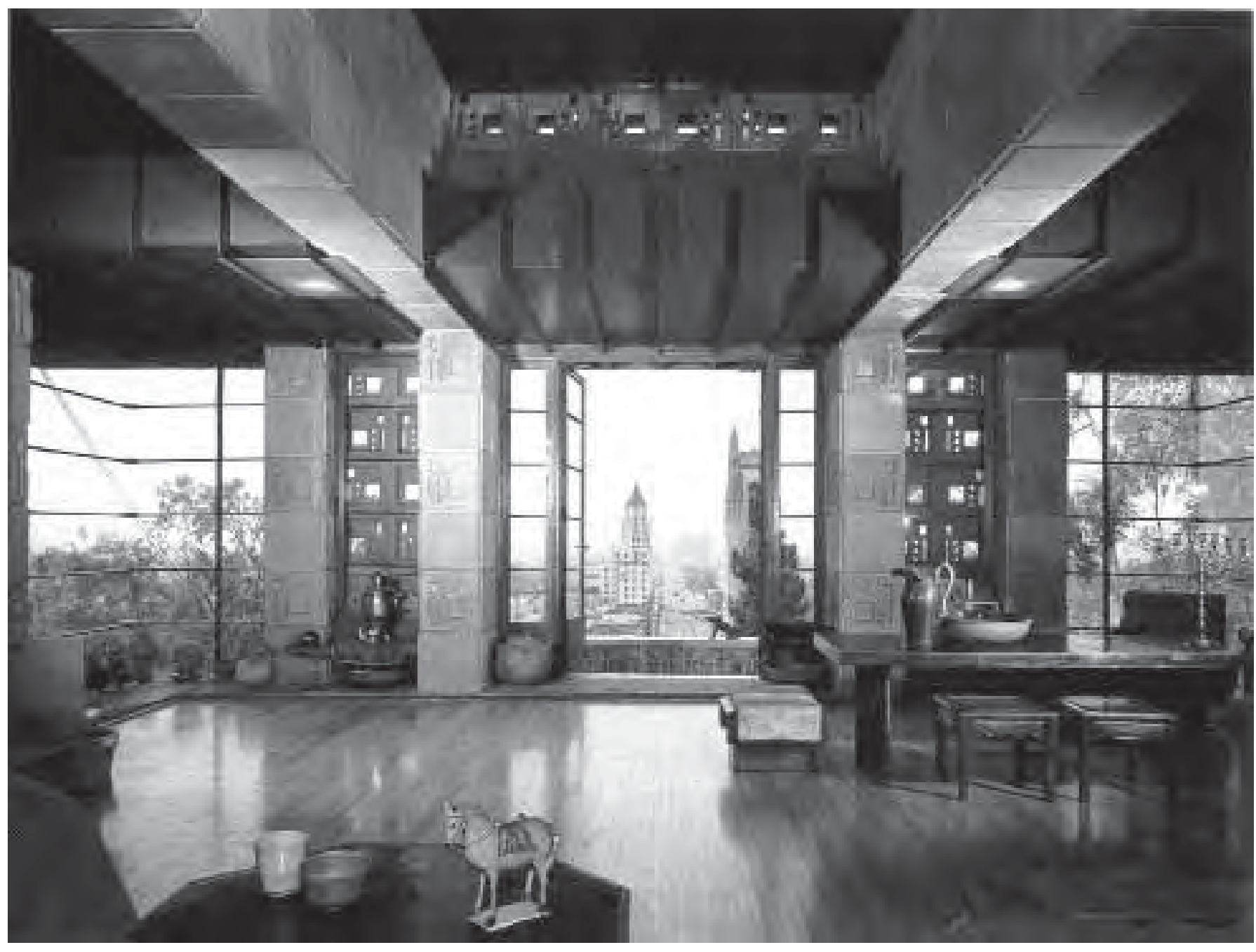

en la propiedad de la vivienda. El coste final fue de 22.000 dólares, pero se desconoce si Wright sufragó o no la diferencia ${ }^{61}$. Samuel Freeman poseía una joyería en el Downtown de Los Ángeles y su mujer, Harriet, era profesora de danza en varias escuelas de la ciudad y, una vez que se terminó su nueva residencia, comenzó a dar clases en su propia sala de estar. En ella se reunía también una de las comunidades de artistas, librepensadores, actores y músicos más heterogéneas y divertidas de Hollywood. Entre sus miembros estaban el cineasta Jean Negulesco, los fotógrafos (y amantes) Edward Weston y Margrethe Mather, el coreógrafo Lester Horton, mecenas y coleccionistas como los Arensberg, la marchante de arte Galka Scheyer, el galerista y librero Jake Zeitlin, los actores Clark Gable y Albert van Dekker (futuro cliente de Schindler), el músico Xavier Cugat y, por supuesto, Pauline y Rudolph Schindler y también Lloyd Wright.

Por su parte, este último, que después de que su padre le retirara del proyecto de Olive Hill, se había convertido en un asiduo de los salones de Barnsdall, había conocido por medio de ésta a Elaine Hyman (Kira Markham), una de las principales actrices del Chicago Little Theatre, que se había unido a la compañía de Barnsdall, viajando con ella a California en 1916. Ambos se casaron en 1917 y, aunque su matrimonio duró poco, Lloyd decidió permanecer en Los Ángeles, abriendo un despacho propio que llegaría a ser uno de los focos de producción más representativos del Art Déco de la ciudad.

Hasta el final de sus días, Barnsdall mantuvo a Schindler como arquitecto, encargándole trabajos de remodelación de todas sus residencias en Olive
Frank Lloyd Wright : Freeman House. Fotografía de Julius Schulman

Página anterior arriba: Louise y Walter Arensberg en su casa de Hollywood con Marcel Duchamp, agosto de 1936. Fotografía de Beatrice Wood

Página anterior abajo: Rudolph Schindler, Lovell Beach House en Newport, 1925-26. Fotografía de J. R. Davidson. Fuente, Esther McCoy Papers, Archives of American Art, Smithsonian Institution 


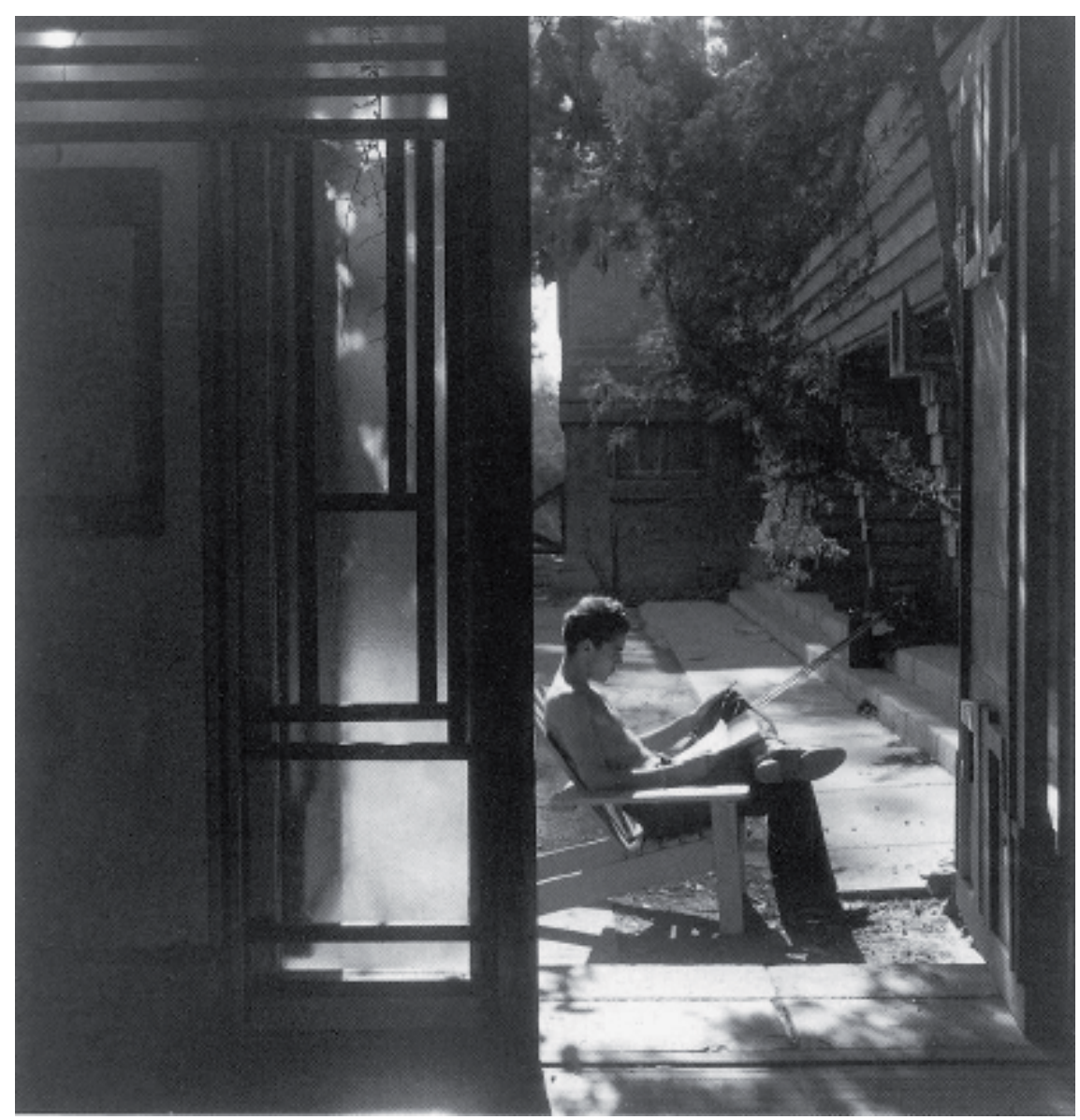

Hill. En 1927, la ciudad de Los Ángeles aceptó finalmente los términos de la donación y la casa Hollyhock pasó a ser durante 15 años la sede del California Art Club. Cuando esta concesión expiró en 1942, el Ayuntamiento entregó la vivienda y el parque a diferentes fundaciones privadas que alteraron su organización y la trataron descuidadamente, hasta el punto de que, desde los años 70, el deterioro de la obra ha exigido importantes labores de restauración, cada vez más rigurosas, para devolverla a su estado original ${ }^{62}$.

Barnsdall se aseguró de conservar mientras viviera la Residencia B. Como pasaba largas temporadas fuera de la ciudad, y además disponía de otros domicilios, ofreció esta casa a diversos amigos, convirtiéndose en cuartel general para diversas personalidades del mundo del arte. Entre sus huéspedes más destacados estuvieron Walter Conrad y Louise Arensberg, que, curiosamente, coincidieron con Wright en la casa ${ }^{63}$ antes de instalarse definitivamente en Los Ángeles en 1927. El matrimonio de coleccionistas, íntimos amigos de Marcel Duchamp, atesoraba una impresionante muestra de las primeras vanguardias europeas. Habían llegado a Los Ángeles procedentes de Nueva York y habrían de ejercer también su actividad protectora sobre el arte de la región. Con ellos habían traído parte de su colección de dadaístas, fauvistas y cubistas. Cuadros y esculturas de Picasso, Braque, Brancusi, Gris y Matise que, entre otros autores, desfilaron por las estancias de la Residencia B a mediados de los años 20.

Uno de los últimos protegidos de Barnsdall fue Edmund Teske ${ }^{64}$, artista y fotógrafo formado como actor y escenógrafo en el círculo de la Hull House en Chicago y, más tarde, en Nueva York, donde su obra se vio influida por la de sus contemporáneos Berenice Abbott, Paul Strand, Eward Weston, László Moholy-Nagy, y, sobre todo, Alfred Stieglitz y su mujer la artista 
Georgia O'Keeffe. A mediados de los años 30 viajó a Taliesin para conocer a Frank Lloyd Wright, quien sería determinante en su forma de entender el arte y de quien se convirtió en uno de sus fotógrafos habituales. En 1943, Teske se había trasladado a Hollywood, donde dio a sus fotomontajes un giro decisivo a raíz de su experimentación en el cuarto oscuro con diferentes concentraciones de productos químicos y exposiciones desiguales sobre papel de alto contraste para crear expresivas manchas de color. Como resultado, sus imágenes parecen envueltas en niebla, adquiriendo un aspecto más de pintura que de fotografía. Interesada por su trabajo, Aline Barnsdall le permitió vivir en su Residencia B, a cambio de cuidara de la casa para ella. Teske colaborabó con los estudios de fotografía de la Paramount Pictures y, paralelamente, trabajaba en su estudio de Olive Hill, donde los edificios de Wright -en continua transformación-y los retratos de los operarios que los alteraban, se convirtieron en algunos de sus temas favoritos. Fue precisamente en la Residencia B donde Teske fue presentado a Man Ray, uno de los fotógrafos a los que más admiraba y cuyas solarizaciones habían influido decisivamente en su producción. Las fotografías de Olive Hill tomadas por Teske en aquella época constituyen algunos de los principales documentos para conocer el ambiente de la colina y sus arquitecturas ${ }^{65}$, que el fotógrafo plasmó en el estado de decadencia en que se hallaban poco antes de la muerte de Barnsdall en 1946.

Barnsdall compaginó su labor de mecenazgo privado y sus contribuciones a instituciones públicas, como el Hollywood Bowl ${ }^{66}$, con la promoción de causas sociales y políticas a las que, para enfado de sus vecinos que la consideraban una activista bolchevique ${ }^{67}$, dio visibilidad en Olive Hill. Así, protestó enérgicamente contra la desidia con la que el Ayuntamiento estaba tratando su donación; apoyó la candidatura del socialista Upton Sinclair para Gobernador; erigió paneles pidiendo justicia para los inmigrantes italianos Sacco y Vanzetti, encarcelados por un asesinato que no habían cometido; $Y$, también desde allí, continuó la labor iniciada años antes por su amiga Emma Goldman de exigir la liberación del líder sindical Tom Mooney, acusado de colocar una bomba en San Francisco en 1916 y que pasaría 23 años de su vida en prisión hasta que, finalmente, se demostró su inocencia. Durante ese tiempo, Barnsdall sufragó buena parte de los gastos de la defensa, manteniendo vivo el proceso mediante campañas de apoyo a Mooney que materializó rodeando su propiedad por enormes carteles cuyo diseño realizó Lloyd Wright en 1932.

A finales de los años 30, después de visitar la casa que Neutra había construido al director de cine Josef von Sternberg en el Valle de San Fernando, Barnsdall se dirigió al arquitecto, a quien ya le unía una larga amistad, para encargarle una vivienda similar, recalcando que quería una casa al menos tan moderna como la que había proyectado para el cineasta. En su carta enviada en febrero de 1939, Aline Barnsdall escribió a Richard Neutra expresándose con elocuencia, no sólo acerca de sus intenciones, sino también por extensión, acerca de sus sentimientos hacia Olive Hill: "Me temo que te estarás preguntando por qué no te he dicho nada todavía sobre la vivienda. Hay demasiadas razones que sería largo explicarte por escrito, pero el motivo principal de mi carta es éste: quiero construir una casa más, que sea un hogar, el definitivo. Esta vez quiero tiempo para pensar todo lo que tiene que tener, para que sea lo que realmente necesito, y no más, y quiero estar segura de que éste sea el lugar en el que quiero pasar el resto de mi vida. Una de las razones por las que dejé Olive Hill es porque allí siempre me sentí cansada y falta de vida. Quiero que veas mi propiedad de Palos Verdes, y quiero una

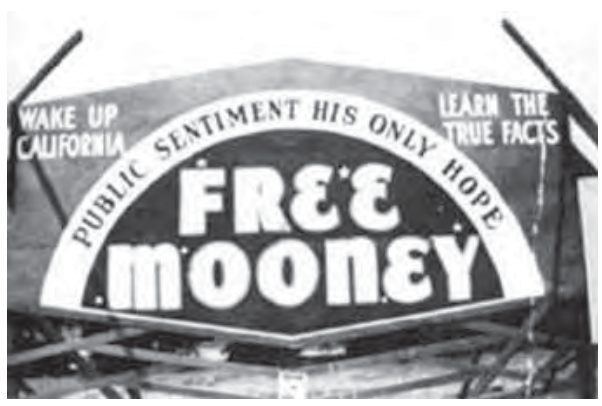

Olive Hill, Cartel solicitando la libertad para Tom Monney. LA Public Library

Página anterior arriba: Olive Hill, Residencia $B$ fotografiada por Edmund Teske, 1945 Página anterior abajo: Casa Hollyhock, detalle fotografiado por Edmund Teske, 1944 


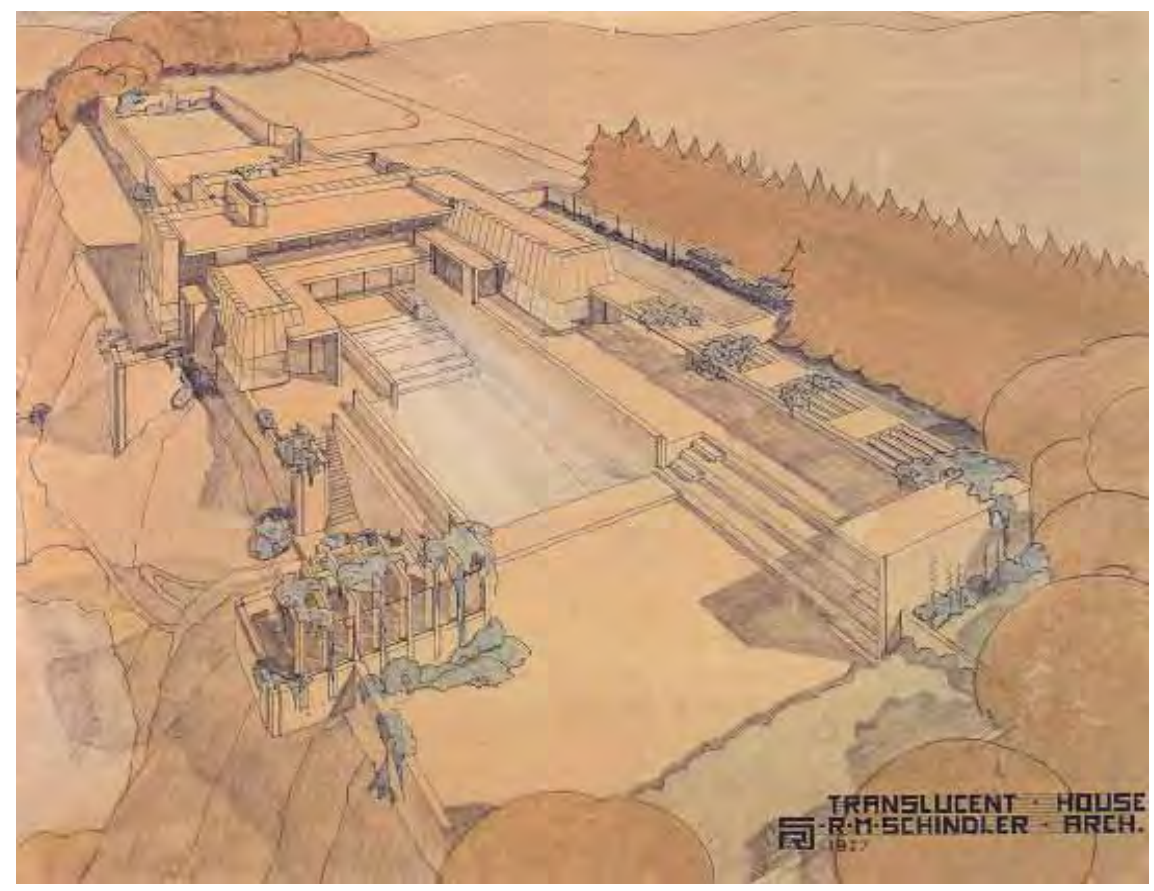

casa como la de von Sternberg. Hace poco, hablando con Wright, le decía que si sus casas son como San Bernardos [...] la tuya para von Sternberg es como un galgo. Aprendímucho en los pocos minutos que pasé en ella. He descubierto todo un nuevo mundo de depuración y de limpieza y muchas otras cosas... No quiero decir que quiera una copia de la casa, sino su esencia, el acero, el aluminio, su simplicidad, hasta incluso la vegetación. Asíque tendrás noticias mías en cuanto esté lista para empezar" ${ }^{\prime \prime 68}$.

Sin embargo, poco después, con el estallido de la Segunda Guerra Mundial y el paulatino deterioro de su salud,Aline Barnsdall abandonó la idea y Neutra nunca pudo trabajar en esta vivienda que, como ella le proponía en su carta, habría construido en la propiedad que poseía en la península de Palos Verdes, al sur de Los Ángeles. Éste era el mismo emplazamiento al borde un acantilado frente al océano donde, una década antes, en 1927, Schindler había intentado otra casa para ella de la que sí llegó a realizar un anteproyecto.

La casa de Rudolph Schindler para Aline Barnsdall en Palos Verdes, conocida como Traslucent House, era otro proyecto monumental, una condición que, como se desprende de los encargos anteriores, iba con la personalidad de la clienta. Sin embargo, a diferencia de Olive Hill, la idea de partida surgía como una respuesta específica a las particularidades climáticas de la península que, por su condición de gran roca avanzando hacia el Pacífico dividiendo la costa de Los Ángeles en dos líneas que cambian de dirección en este accidente natural, recibe constantemente el frío húmedo de las nieblas y los fuertes vientos procedentes del océano. Schindler debía por tanto resolver una casa emplazada en un clima con máximas de $15^{\circ}$ a $25^{\circ}$ y expuesta al viento, como enfatizó David Gebhard: "Los dos elementos necesarios para contrarrestar las adversas características del clima son: resgurado de los vientos, e introducción de la máxima cantidad posible de luz en el interior. Schindler solucionó fácilmente el primer problema orientando el patio en forma de $U$, de manera que la parte de atrás estuviera expuesta a los vientos dominantes [...] Como solución al problema de la luz utilizó cristal traslúcido en la parte superior de las paredes exteriores [de ahí el nombre de la casa], doblando los paneles de manera que formaran el primer medio metro 


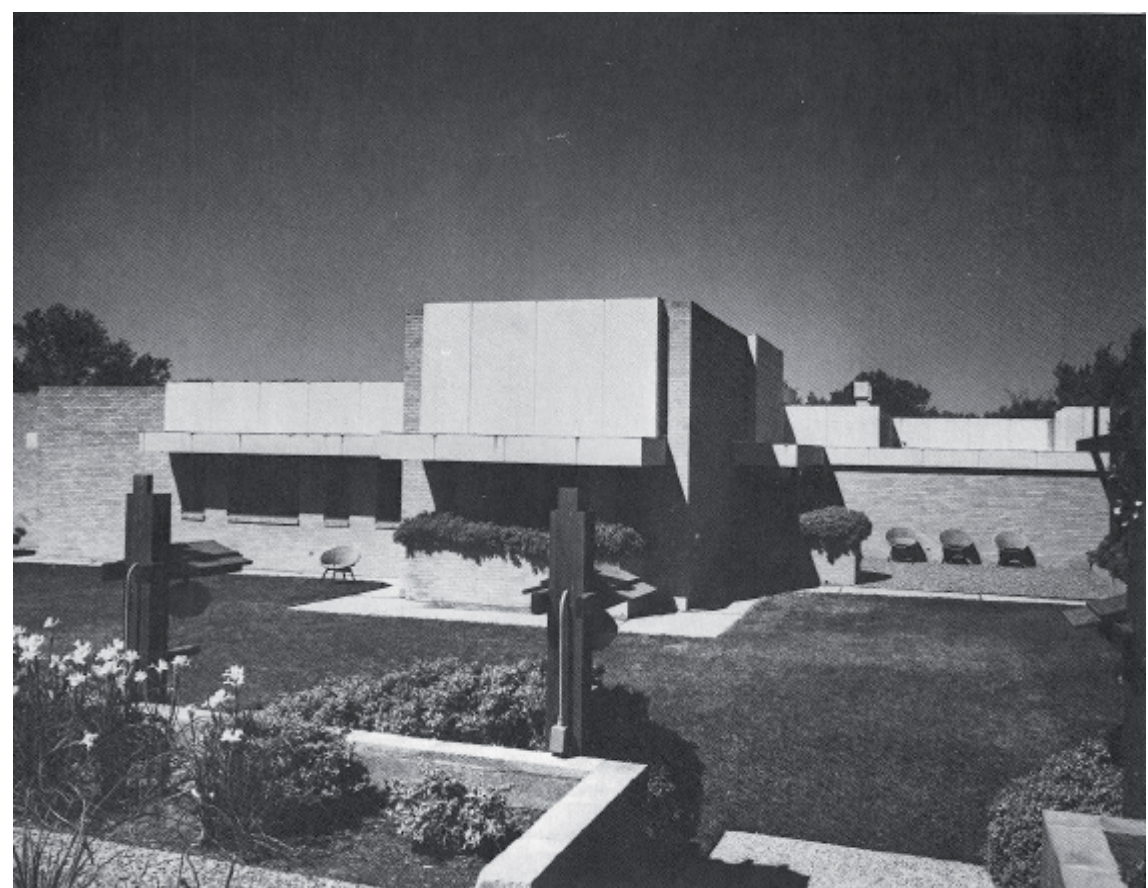

de la cubierta"69. De este modo parecería que el plano de cubierta flotaba sobre el vidrio. Por otra parte, a pesar de la cantidad de materiales -como el metal, la madera o el vidrio -, Schindler se las ingenió para que un diseño de apariencia tan innovadora pudiera ser resuelto, con pocos detalles, pero muy claros, a partir de los medios y recursos disponibles con la tecnología de la época. No obstante, la indecisión de su clienta y las condiciones de la Gran Depresión impidieron su ejecución, pasando así a engrosar la lista de visiones arquitectónicas frustradas de Aline Barnsdall.

Por todos estos edificios y encargos residenciales, desde el conjunto de proyectos realizados por Wright para Olive Hill, hasta la última vivienda intentada por Schindler, Aline Barnsdall puede considerarse la gran figura tutelar de la primera arquitectura moderna del Sur de California. Fue la supervisión de las obras de la Hollyhock House la razón por la que Rudolph Schindler se trasladó a Los Ángeles y no regresó a Europa. Fue también en su círculo de amistades, concretamente a través de una red formada por mujeres con ideales progresistas, como Schindler y, por medio de él, Neutra, conocieron al cliente de sus casas Lovell, dos de las obras fundacionales de la modernidad norteamericana.

Y, extendiendo su influencia más allá, hasta la segunda generación, fue también el descubrimiento de la Hollyhock House el motivo por el que Harwell Hamilton Harris decidió abandonar su carrera de escultor para convertirse en arquitecto, iniciándose así otra de las trayectorias más singulares de la arquitectura californiana. Tras su visita a la casa en 1925, el joven Harris quedó fascinado por sus valores plásticos como generadores de espacio arquitectónico; por el modo en que Wright había resuelto una vivienda a partir de una escultura monumental en diálogo con la naturaleza.

Treinta años más tarde, una vez ya había abandonado California, Harris rendiría un elocuente tributo a su admirado Wright en su ambicioso proyecto de residencia para otra mujer: su Ruth Carter Stevenson House ${ }^{70}$ en Fort Worth (Texas, 1955-56), una casa cuya planta, distribución de volúmenes y hasta imagen de conjunto guarda apreciables semejanzas con la Hollyhock House.

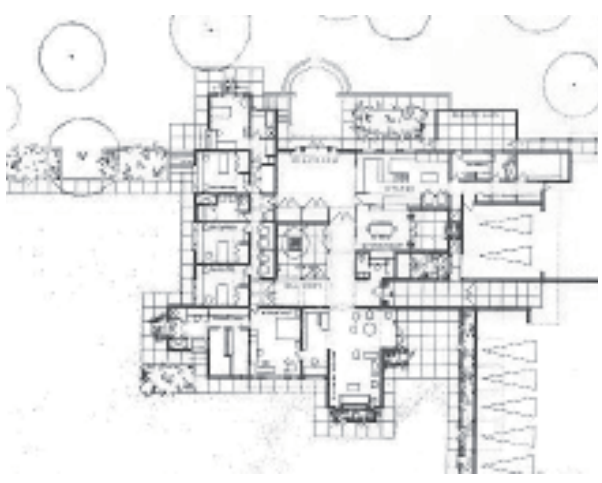

Izda: Harwell Hamilton Harris: Ruth Carter Stevenson House, Forth Worth, Texas, 1955. Fuente: Esther McCoy, The Second Generation Dcha: Harris: Carter Stevenson House, planta

Página anterior arriba: Rudolph Schindler, Traslucent House para Aline Barnsdall, 1927 Página anterior abajo: Schindler: Diseño expositivo, exhibición de pósters de la vanguardia europea en la Casa Barnsdall, 1927 


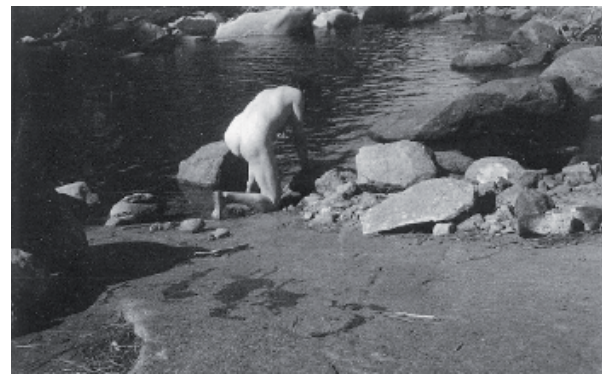

\section{Kings Road, y el ideal de California}

A su llegada a Los Ángeles, Schindler sintió que su paso por la ciudad sería provisional. Sus cartas de mediados de 1921 testimonian su deseo de regresar a Europa e, incluso, de acudir a Japón para asistir a Wright con la obra del Hotel Imperial una vez hubiera terminado su cometido en Olive Hill. Sin embargo, tras el deterioro de su relación con Wright, en el verano de 1921, Schindler se planteó por primera vez la posibilidad de iniciar una carrera como arquitecto independiente en América, una decisión que pospuso hasta la vuelta de unas vacaciones que llevaba años esperando. Después de varias semanas recorriendo California en un coche descapotable y de acampar en los espectaculares bosques de Yosemite, Schindler volvió a sopesar con intriga las oportunidades de reinvención profesional que podría tener un arquitecto en un medio urbano tan atípico como el de Los Ángeles, entonces inmerso en un proceso de transformación territorial sin precedentes. A su regreso en otoño, la poderosa impresión que le habían causado los paisajes que había descubierto en el norte del estado terminó de despejar sus dudas y el arquitecto se dispuso a abrir su propio despacho en la ciudad.

Su vivienda-estudio, localizada en el 835 de North Kings Road, en West Hollywood, fue su primera obra en solitario. Con ayuda de los padres de Pauline, que aportaron 3.000 dólares para comprar el solar y avalaron un préstamo bancario por valor de 5.000 dólares más, Shindler pudo construir la casa en la que permanecería hasta su muerte en 1953. A ella dedicó un considerable esfuerzo intelectual y físico -más que a ningún otro proyecto posterior- que consumió la mayor parte de su tiempo hasta que estuvo terminada en junio de 1922. En apenas nueve meses había proyectado y construido algo completamente nuevo, un lugar donde vivir, trabajar y relacionarse socialmente. De hecho, su diseño era tan insólito, que el Building Department expidió un permiso temporal, advirtiendo que podría revocarse la licencia en cualquier momento.

Su primera obra supuso una declaración de intenciones con la que demostraba que una casa contemporánea no podía ser "sólo una nueva variación de estilo, sino una concepción radicalmente diferente ${ }^{\prime \prime 71}$. Sin duda, bajo la influencia de Pauline, Kings Road fue, ante todo, un manifiesto radical: la propuesta de un nuevo modo de vida a partir de la versatilidad de usos de una casa entendida simultáneamente como contenedor de funciones privadas y públicas.

Esta casa iba más mucho allá de cualquier innovación que se hubiera planteado hasta la fecha en un programa doméstico. Ponía en cuestión la idea misma de domesticidad, privacidad y unidad familiar sacralizadas por la tradición americana; empezando por el hecho de que, bajo una consideración liberal de la familia que primaba la individualidad de sus miembros, la casa fue concebida -en palabras de Schindler- como "una vivienda cooperativa para dos jóvenes parejas"72. Para ahorrar costes, minimizar el im-

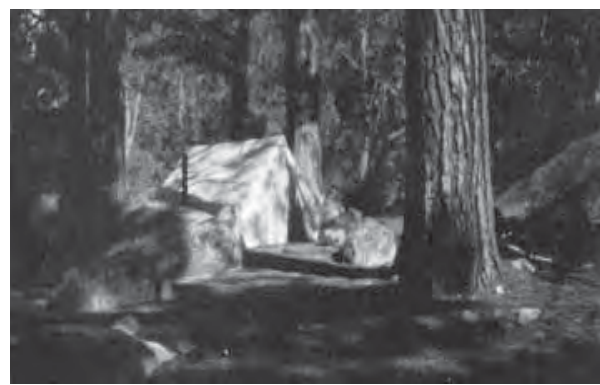
pacto de las instalaciones ${ }^{73}$ y fomentar una vida en común, los Schindler dividieron la vivienda en cuatro estudios que compartieron con Marian y Clyde Chace, a quienes habían conocido en Chicago a través de Pauline ya que Marian también era educadora y activista social. Su marido, contratista, colaboró también en la ejecución de la casa, donde residieron junto a los Schindler hasta que, en julio de 1924, se trasladaron a Florida. Mediante un contrato privado, las dos parejas establecieron el marco jurídico de su 


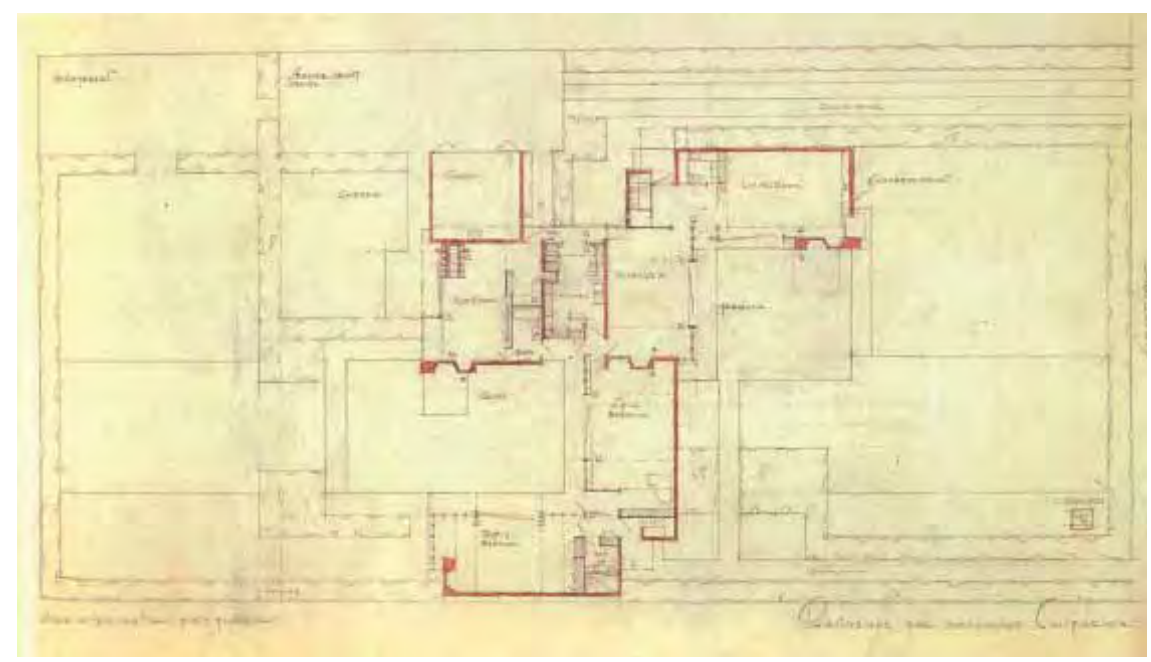

convivencia, comprometiéndose al mantenimiento y pago conjunto de los gastos de la vivienda.

Situada en mitad de un solar rectangular de $100 \times 200$ pies (30 $\mathrm{m} \times 60 \mathrm{~m}$ ), la casa funcionaba como un sistema de patios-jardín delimitados por estancias habitables que se abrían a ellos por completo a través de puertas correderas y paños de vidrio. Dos alas enfrentadas en forma de $L$ (una por pareja) albergaban cada una de ellas dos de estos estudios semiindependientes. Describiendo el giro de un esquema helicoidal, la planta se completaba con un tercer brazo ocupado por un garaje y un pabellón de huéspedes dotado de su propia cocina y que sería alquilado para obtener algunos ingresos extras con los que ayudar a la comprometida economía, casi de subsistencia, de sus caseros. Schindler describía así la organización de este programa tan poco convencional: "Se ha abandonado la habitual disposición de estancias especializadas según funciones propias de una casa. En lugar de ello, cada persona posee un estudio privado; y cada pareja su propia entrada y un baño común. Los porches abiertos de la cubierta hacen las veces de dormitorio. Un patio privativo para cada pareja, con una chimenea exterior, cumple con todas las funciones de una sala de estar tradicional"74.

La actividad doméstica en Kings Road estaba orientada hacia el disfrute de la vida al aire libre, hasta el punto de que gran parte de la vida diaria se realizaba en el exterior. Los días de buen tiempo -la mayoría de los mesesno sólo se comía fuera sino que, incluso, usando a las chimeneas exteriores también se preparaban y cocinaban los alimentos en el jardín.

Los jardines eran una estancia más de la casa, quizás la más importante. Resultaban esenciales para las reuniones de amigos, eventos culturales y concurridas fiestas que, habitualmente, organizaban los Schindler y que convirtieron su vivienda en lo más parecido a un centro cultural de vanguardia. En sus veladas de los domingos, cuando el número de invitados era considerable, se retiraban las carpinterías para convertir la vivienda y el jardín en un único recinto que podía dar cabida a más de 200 personas. El interior de los estudios funcionaba entonces como un gran porche o pabellón, un espacio de sombra o al resguardo de la lluvia, la mejor expresión de la idea de casa cabaña-cueva, preconizada por Schindler.

La vida en la casa era un reflejo de las inquietudes y de la personalidad de sus propietarios. Influenciados desde su llegada a la ciudad por las ideas de sus amigos Leah y Philip Lovell, redactor de la influyente columna Care
Arriba: Rudolph M. Schindler: Planta de Kings Road, 1921. Fuente: ADC/UCSB

Abajo: Kings Road, montaje de las losas de hormigón, 1921 ADC/UCSB

Página anterior arriba: Schindler en Yosemite National Park, octubre 1921. Fotografía de Pauline Schindler. ACD/UCSB

Página anterior arriba: Campamento de los Schindler en Yosemite. Fotografía Rudolph $M$. Schindler (en adelante RMS), ADC/UCSB

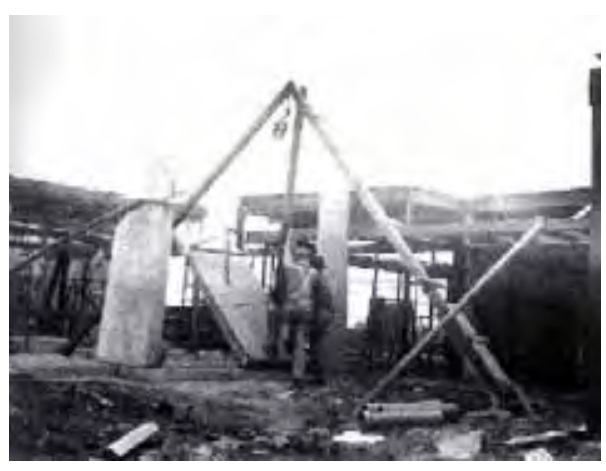




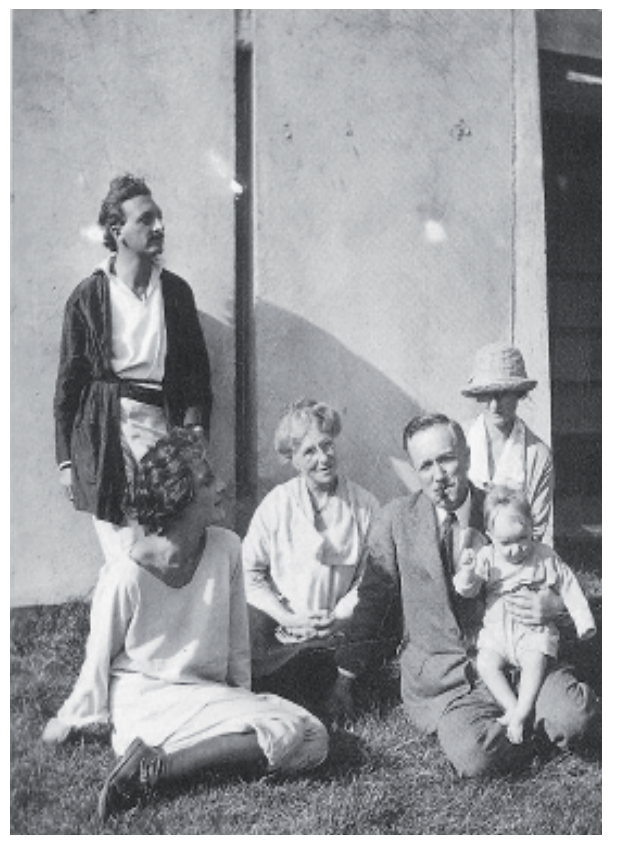

of the Body, los Schindler eran partidarios de observar preceptos de vida saludable como la práctica de ejercicio al aire libre y la alimentación con productos naturales; tal como este médico naturópata defendía apasionadamente desde páginas del dominical de Los Angeles Times, semanario al que Schindler también contribuiría con diversos artículos, publicados entre marzo y mayo de 1926, y que versaban sobre la importancia de determinadas condiciones del proyecto, instalaciones y habitabilidad de una casa moderna.

Aunque Pauline y Rudolph Schindler compartían muchos de sus intereses, como la fotografía contemporánea, casi siempre es posible identificar a uno u otro miembro de la pareja en la procedencia de las ideas que explican la singularidad de la vida en Kings Road. Por ejemplo, su preocupación por mantener a su hijo al margen de las retrógradas instituciones de enseñanza del país, apostando por una educación libre de convencionalismos, así como el contenido político y artístico de las veladas de los domingos (con especial énfasis en el teatro, la literatura y la música) respondían a la formación intelectual de Pauline. También, muy a menudo, la temática de sus celebraciones públicas respondía más a las preferencias de Pauline, mientras que su ambientación al modo en que su marido entendía el carácter desenfadado de la etiqueta y del diseño californianos. Los Schindler también asimilaron muchas de las inquietudes de los diferentes inquilinos que, a lo largo de los años, fueron desfilando por la casa. Algunos, como Richard y Dione Neutra, les trasmitieron su pasión por el psicoanálisis y la psiquiatría moderna; otros, como Galka Scheyer, representante del grupo Die Blave Vier (Los Cuatro Azules), su experiencia como galerista y su conocimiento de los pintores Kandinsky, Klee, Feininger y Jawlensky, cuya obra trataba de difundir y vender América.

En junio de 1922, cuando los Schindler se mudaron a su nueva casa, West Hollywood era un lugar apartado y semidesierto en el camino de los grandes boulevares que, recién asfaltados, recorrían la ciudad desde el Downtown hacia el océano atravesando en su camino huertos de naranjos y campos de judías. En las fotografías tomadas antes y durante la construcción de la vivienda, las colinas que delimitaban esta área de Los Ángeles aparecían aún despobladas. En la inmensidad de los solares vacíos, la única excepción era 
la vecina Dodge House de Irving Gill que, desde 1916, exhibía su elegante urbanidad $^{75}$ en mitad de aquel paraje rural. Alejada geográfica e ideológicamente de los reaccionarios ambientes afines a la élite socioeconómica que gobernaba la región, la casa-estudio de Kings Road constituía por tanto un oasis en aquel paraje rural, y la hospitalidad de su jardín, destino obligado de la intelligentsia de izquierdas, la mejor metáfora de la intensidad con la que, a pesar de su aislamiento y carácter minoritario, comenzaron a activarse las conexiones entre las células germinales de la cultura más transgresora de la ciudad.

Kings Road era mucho más que una casa-estudio: una reflexión sobre nuevas formas de habitar propias de la época moderna, un intento por establecer una profunda relación con el lugar, un laboratorio donde experimentar una materialidad arquitectónica diferente a partir de nuevas técnicas constructivas, un entorno donde ejercer la libertad creativa $y$, en suma, un dispositivo híbrido capaz de producir la realidad familiar, el espacio social y la imagen pública de los Schindler.

Al poco tiempo de haberse instalado en su vivienda, Schindler envió una carta a Neutra-que todavía aguardaba en Europa su oportunidad para viajar a América- relatándole lo siguiente: "[la casa] está concluida, es decir, ya vivo y trabajo en su interior. El dinero se ha acabado antes de finalizar las obras, así que yo mismo estoy terminando lo que falta"776. La misiva resumía perfectamente el espíritu de su obra: trabajar con los medios disponibles, en general escasos, plegándose a las condiciones materiales existentes, hasta el punto de terminar el mismo claveteando si así era necesario. El arquitecto continuaba, entre resignado y optimista: "Además, estoy trabajando en el diseño de dos casitas y de un hotel en el desierto. Este último será muy interesante si se llega a construir y quizás me ayude económicamente" ${ }^{\prime \prime 7}$. Sobre la naturaleza de su vivienda relataba a Neutra el sistema constructivo del que, se trasluce su satisfacción: "Mi casa es un interesante y exitoso experimento. Los muros se han construido por secciones, vertiendo el hormigón en la losa de hormigón y después levantándolos. He llamado a esta construcción 'tilt-slab' [losa giratoria] -y parece ser efectiva. Elimina el coste del encofrado. He colocado vidrio entre los paneles, y como resultado, la repetición de ranuras de 3 pulgadas crean un ritmo decorativo. Gracias a este la pared de la casa produce una nueva sensación $n^{178}$.

Como pionero de la tradición californiana más experimental, Schindler materializó por primera vez en esta obra sus ideas acerca de la relación entre la estructura y el espacio, sobre la indisolubilidad de la forma, la luz y los materiales; un modo de entender la arquitectura sobre el que, más tarde, en 1934, reflexionaría por escrito en Space Architecture ${ }^{79}$, uno de sus textos más importantes.

Como Irving Gill ya había hecho con su vivienda en la década anterior y Richard Neutra haría diez años más tarde en su casa VDL en Silver Lake, y después de ellos también Harwell Harris, en 1935, y Gordon Drake, en 1946, discípulos y maestros, uno tras otro, todos estos arquitectos californianos consideraron su propia casa como un laboratorio de ideas, un lugar donde testar libremente su particular concepción de la arquitectura y llevar algunos temas hasta su formulación más arriesgada. Ahora bien, frente a la distancia científica interpuesta por la modernidad europea entre sujeto y objeto, este linaje de arquitectos californianos asoció su implicación personal con el proyecto con un ideal de buena vida californiana del que, por supuesto, las casas

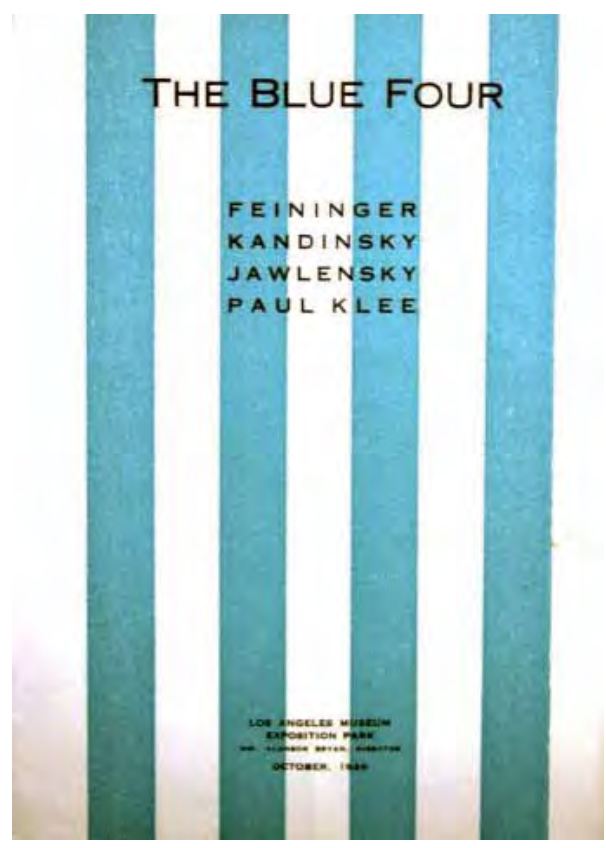

Galka Scheyer: Catálogo de la exposición itinerante The Blue Four, UCLA, 1926. Fuente: Getty Research Institute

Página anterior idza: RMS con Pauline y los padres de ésta en Kings Road, 1923. Fuente Robert Sweeney, Schindler Family Collection, Friends of the Schindler House

Página anterior dcha: Solar de Kings Road antes de iniciarse la construcción de la casa, West Hollywood, 1922. Fotografía RMS, ADC/ UCSB 


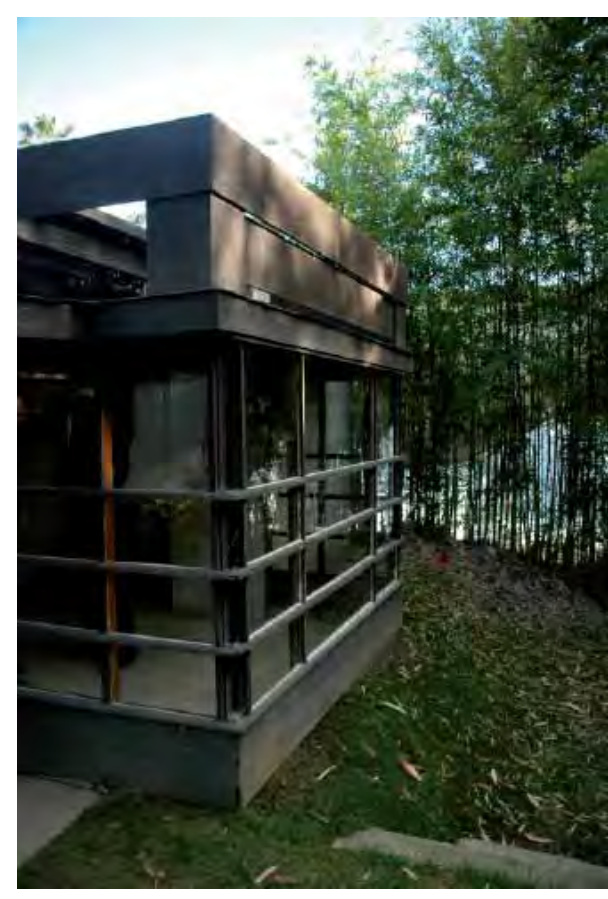

RMS: Kings Road en la actualidad. Fotografías del autor

Página siguiente: Irving Gill, Women's Club, La Jolla, 1913. ADC/UCSB

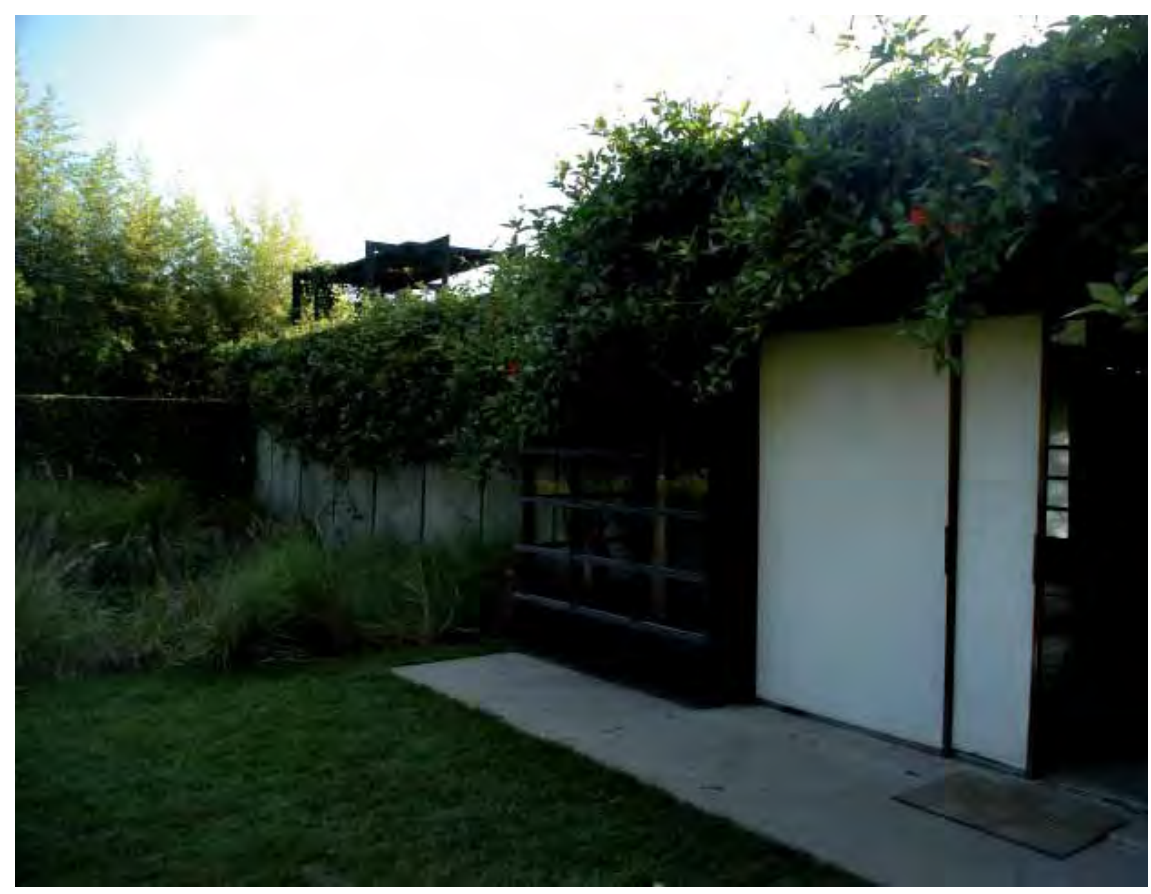

Eames (1949), la vivienda de Ray Kappe (1967) e incluso, la Gehry House en Santa Mónica (1978), serían otros de sus principales exponentes.

En Kings Road, como en la práctica totalidad de sus realizaciones ${ }^{80}$, Schindler fue el contratista de la obra, lo que le permitió experimentar en con diseño y controlar su ejecución hasta el mínimo detalle. El diseño total del proyecto y el ejercicio de ese control sitúan su obra en una esfera de producción artesanal de herencia wrightiana y bajo influencia de la corriente Arts \& Crafts, inevitable en el arranque de la tradición arquitectónica del Sur de California. En una oportuna -aunque algo simplificada- comparación de la forma de trabajo Richard Neutra con la de Rudolph Schindler, Charles Moore quiso ver "al primero como un arquitecto que comenzaba con una idea abstracta y que, al final, casi a regañadientes la construía (aunque Neutra construyera mucho), frente al ejemplo del segundo como un arquitecto que empezaba por el acto mismo de construir y todo el placer ligado al mismo y, después, evolucionaba de manera dialéctica planteándose por qué hacer las cosas de una determinada manera y no de otra" ${ }^{\prime \prime 1}$.

La lógica de la construcción estuvo presente desde el principio en la definición del proyecto. Concentrando su atención en la ideación del espacio de la vivienda a partir de la resolución del detalle y de la elección del sistema de montaje, Schindler fue capaz de iniciar las obras el 15 de febrero de 1922 y de terminar el grueso de las mismas en poco más de cuatro meses.

El proceso partía de la ejecución de una solera de hormigón pulido sobre la que pre-fabricar in situ las losas de los muros y que, después, haría las veces de pavimento de la vivienda. El acabado directo, tanto del suelo como de los paneles, abarataba costes y simplificaba su mantenimiento. Las piezas se hormigonaron sobre una lona cuyos pliegues, al quedar impresos en su superficie, aportan textura a los paramentos. Dichos paneles tenían $10 \mathrm{~cm}$ de espesor y, como el propio Schindler explicaba a Neutra, fueron izados después hasta su posición definitiva.

Uno de los documentos visuales de la casa más conocidos es la serie de fotografías que muestran el proceso de su construcción ${ }^{82} y$, en concreto, el 


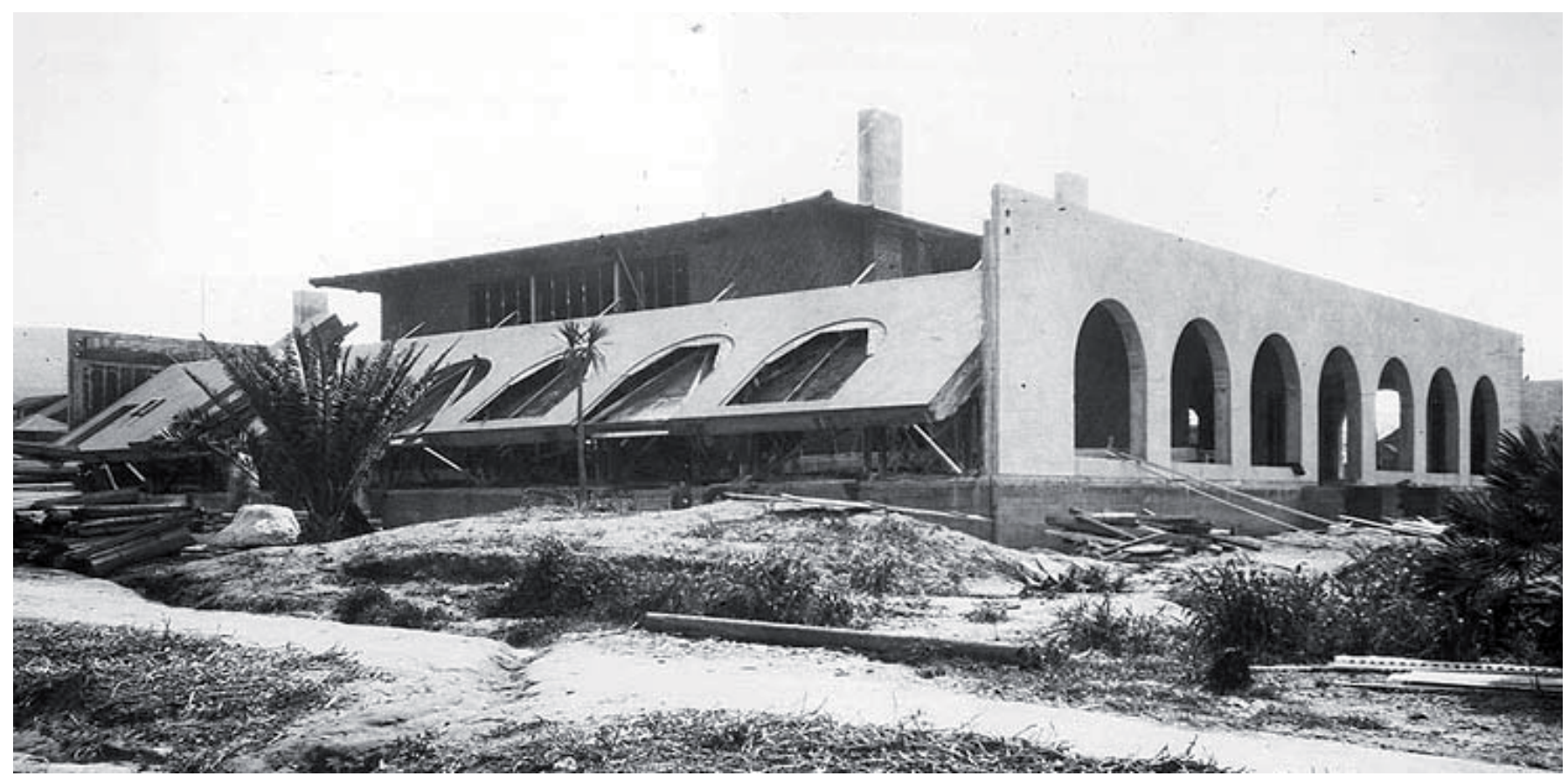

modo en que las losas de hormigón se ejecutaron en el suelo y se elevaron luego mediante un sencillo trípode con polea que podía ser accionado por tres operarios y que recordaba la construcción de los muros del Women's Club de Irving Gill en La Jolla, patentado ${ }^{83}$ por el arquitecto en 1913. Una vez fijadas verticalmente en el suelo se hormigonaba un nervio de atado en coronación.

Las rasgaduras de vidrio, de las que también hablaba Schindler en su carta a Neutra, son consecuencia del proceso constructivo que requería juntas entre las piezas para disponer los encofrados. La existencia de estos huecos entre los paneles de hormigón producía una repetición de aperturas hacia el espacio trasero de cada estancia que, sin interferir en la privacidad de la otra pareja, permitía una serie de vistas muy acotadas sobre el jardín, complejizando así la relación interior-exterior.

Otra herencia wrightiana, la esquina de vidrio, fue empleada en la solución de acristalamiento del estudio de Schindler. Dicha solución favorecía un sugerente juego de relaciones visuales pues, desde la mesa de trabajo, mirando hacia el jardín por encima de los patios hundidos, se tenía la sensación de estar en una caja transparente completamente rodeado de vegetación.

Además del hormigón de la solera y de los muros, los materiales empleados fueron vigas y tableros de madera, vidrios, telas y paneles de insulite que, también como las losas, respondían a un sistema modular y fueron definidos previamente.

Dada su limitación presupuestaria, Schindler puso un especial cuidado en el tratamiento de los materiales hasta el punto de que, haciendo de la necesidad virtud, logró una inteligente y novedosa combinación de acabados. El suave pulido del hormigón gris claro, la trasparencia de los vidrios y la traslucidez de los tejidos de las pantallas de lona, el color tostado y la aspereza del insulite, y el reconocible tono rojizo de la madera de redwood que Schindler cepilló para acentuar su brillo, son las cualidades de las que, en última instancia, depende la reconocible imagen de la casa 


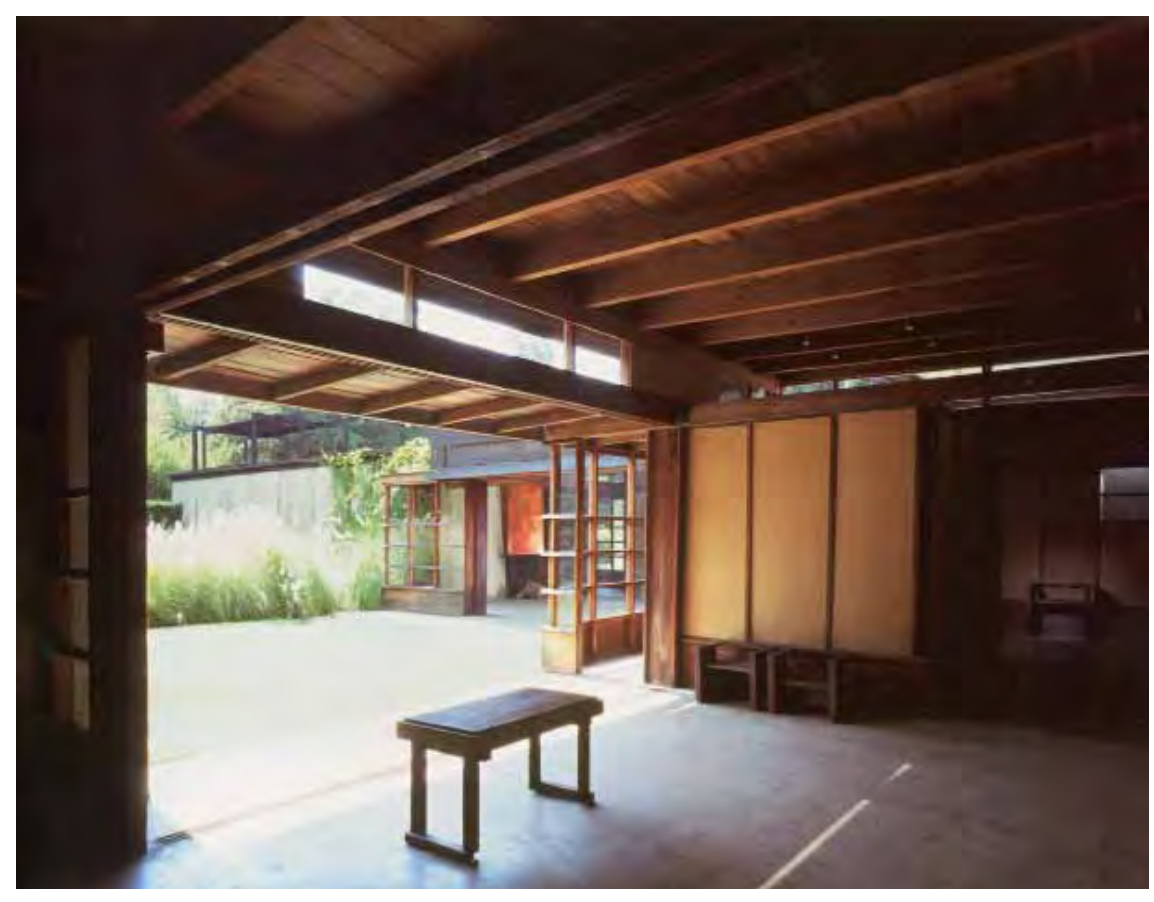

RMS: Kings Road, estudio del arquitecto. Fotografías Grant Mudford (arriba) y del autor (abajo)

Página siguiente: Pauline Schindler con su hijo Mark en Kings Road, 1923. Fuente Robert Sweeney

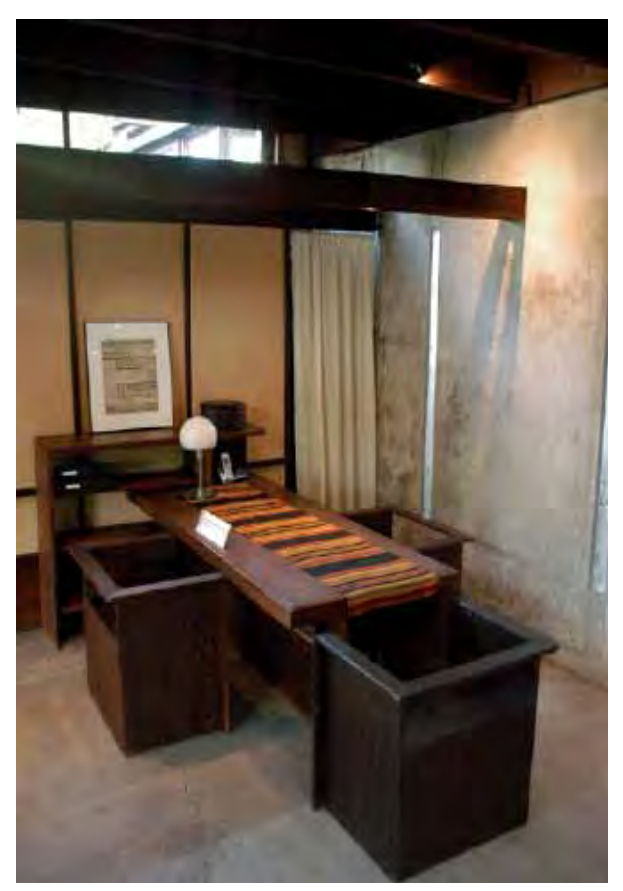

La verdad constructiva, la identificación de la estructura y la expresión de los materiales a través del énfasis en su color y textura naturales, fue una obsesión para Schindler en estos primeros años de su carrera. Durante esa etapa el arquitecto atacó la lógica de la arquitectura premoderna por esconder su sistema portante bajo capas de elementos decorativos y revestimientos innecesarios. Más adelante, sin embargo, su trabajo evolucionaría hacia una investigación espacial mucho más abstracta que relegó a un segundo plano la importancia concedida anteriormente a la expresión de las cualidades materiales de su arquitectura.

Otra de las características más destacadas de sus primeras obras y que mantuvo a lo largo de su vida, es la combinación de materiales naturales con productos de la industria y su predilección por soluciones baratas utilizadas de manera imaginativa. Harwell Hamilton Harris, a pesar de no llegar a trabajar para Schindler, heredaría de él esta actitud hacia los materiales convirtiéndola también en uno de los recursos proyectuales más reconocibles de su arquitectura. Éste sería por ejemplo el caso de paneles de insulite, un compuesto de silicato cálcico hidratado -muy novedoso para la época-, al que Schindler recurrió por su capacidad aislante, por su ligereza y porque permitía resolver las particiones con espesores mínimos de una pulgada.

La cubierta y su estructura sustentante estaban ejecutadas en madera de secuoya local (redwood), siguiendo una modulación de 100 × 200 pies. Los pilares, también de madera, estaban trabados con un entramado dispuesto a unos $70 \mathrm{~cm}$ bajo el techo. Éste se prolongaba hacia el exterior en un voladizo que protegía el interior de los estudios del soleamiento directo. Se generaba así un único recinto de $2,64 \mathrm{~cm}$ de altura, bajo el cual, las vigas de atado delimitaban virtualmente un segundo espacio de 1,90 cm de altura. Estas vigas de madera apoyaban también la diversidad de configuraciones espaciales de cada estancia, soportando las guías de las particiones interiores móviles. El reflejo de esta subestructura en la franja perimetral de huevos altos y las divisiones de los cerramientos, en la que se puede reconocer la influencia japonesa, sería una de las soluciones más recurrentes de la arquitectura californiana que siguió la estela de esta tradición, como ocurre en las obras Harwell Harris y de Gordon Drake. La lectura de esta línea de dintel continua, la compensa- 
ción del deslumbramiento por la presencia de una franja de vidrio a mayor altura en la pared opuesta, y la posibilidad de reducir la dimensión de las puertas correderas de vidrio conservando un fijo por encima de las ellas, fueron algunas de razones por las que, sobre todo a partir de Kings Road, se popularizó esta solución en las viviendas modernas californianas.

Las vigas también conducían el cableado eléctrico, ya que sobre ellas discurrían ocultos unos carriles electrificados que permitían mover las luminarias según las necesidades de cada distribución. Además, las lámparas estaban dotadas de un sistema de regulación que permitía variar la intensidad y que había ideado el propio Schindler.

Schindler también concedió una gran importancia a la iluminación del jardín, que podía variar según el tipo de evento con pequeños dispositivos móviles. Las líneas y racimos de bombillas distribuidas entre los árboles complementaban la fuente de luz -y calor- principal procedente del fuego de las chimeneas de cada patio. De este modo, al ponerse el sol, los jardines transformaban su carácter pero seguían siendo el principal escenario de la vida nocturna de la casa. En este sentido, la casa-estudio de Kings Road, en opinión de Reyner Banham "el espacio doméstico más sencillamente disfrutable que se haya construido Los Ángeles"84, es la primera vivienda que responde de un modo inequívocamente moderno a las particularidades del clima y de la cultura del Sur de California.

En su planteamiento más extremo, la propuesta de dormir en la azotea bajo las estrellas, protegidos sólo por una cubierta ligera debe entenderse en la genealogía californiana de los sleeping porches (evolucionados en Kings Road hasta sleeping baskets -cestas para dormir-), un elemento que no era invención de Schindler, ni de Greene \& Greene, como se ha afirmado, sino que estaba asociado a la visión romántica de California de principios del siglo XX y a la suavidad del clima y, por tanto, ya había sido incorporado en muchos bungalows craftsman como distintivo tipológico. Schindler había ensayado incluso una formulación previa en Olive Hill, modificando el diseño de Wright para enfatizar el acristalamiento de los dormitorios de la Residencia B y la posibilidad de su completa apertura al exterior. En Kings Road, sin embargo, la experiencia de Yosemite estaba muy reciente y Schindler continuaba fascinado con la idea de poder acampar cada noche bajo el cielo -todavía libre de contaminación- de la ciudad, por lo que llevó la propuesta de los sleeping porches hasta sus últimas consecuencias. Una de las cestas se sostenía con cuatro soportes laterales, mientras que la otra además estaba cerrada por cinco apoyos en su extremo; ambas sólo estaban cubiertas parcialmente, pero su estructura podría cubrirse con telas en caso de lluvia. En su versión primitiva, accediendo a la cubierta por una escalera exterior, estos espacios, muy próximos a las copas de los árboles, remitían al sueño infantil de dormir en una cabaña en un árbol; un tema recurrente en la producción posterior de Schindler $y$, en general, muy presente en la tradición romántica californiana ${ }^{85}$. Poco tiempo después, se revelaría su ineficacia durante pues, incluso para austriaco acostumbrado a los rigores del clima de Chicago, las noches de Los Ángeles no eran tan cálidas como había supuesto para dormir a la intemperie.

El recuerdo de Yosemite influyó tanto en la manera de entender el proyecto de la casa y el uso de sus espacio que Schindler afirmó que ésta debía responder esencialmente a las cuatro necesidades básicas de la estructura de un campamento: "protección por la espalda, un frente abierto, un lugar para el fuego y un techo" ${ }^{\prime 86}$.

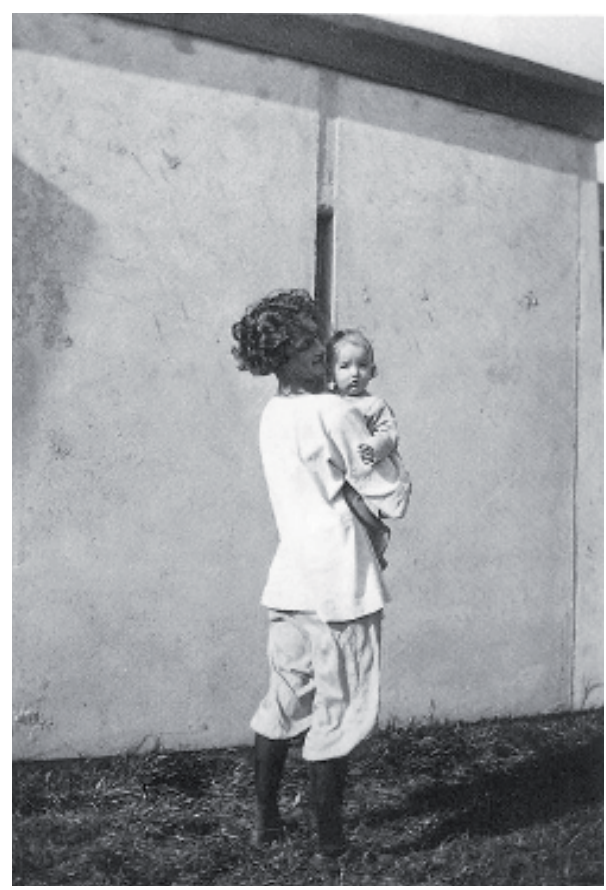




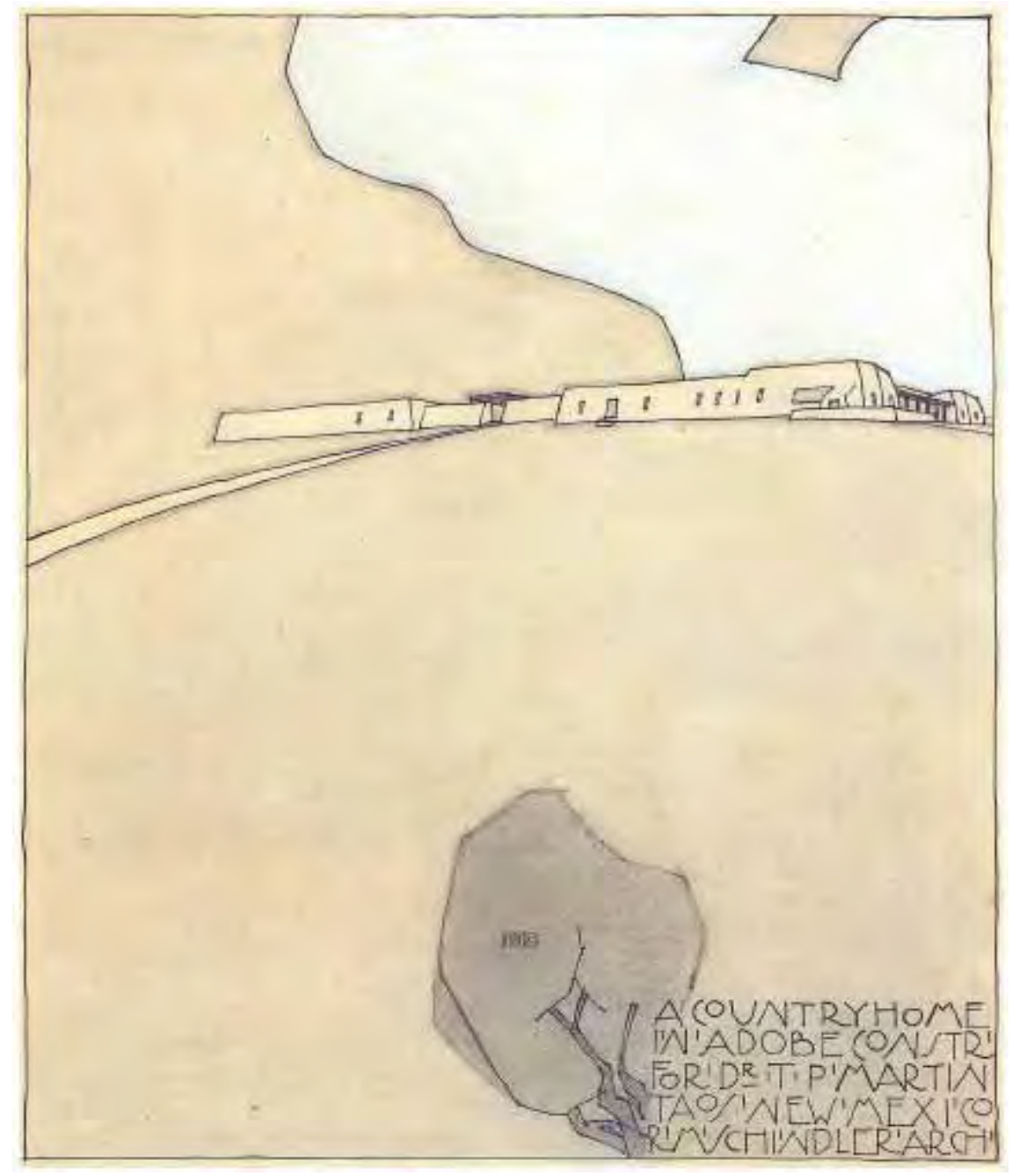

RMS: Thomas Paul Martin House, dibujo para el proyecto de una vivienda en Taos, Nuevo México, 1915, ADC/UCSB

Página siguiente arriba: Edificios de adobe, Taos, Nuevo México. Fotografía de RMS

Página siguiente abajo: RMS: Log House, proyecto, hacia 1916-1918
Así, los muros de hormigón cerrando la vivienda a la calle y a las propiedades vecinas, la apertura de las estancias a los jardines mediante el filtro ligero de vidrios y lonas que incluso pueden retirarse (hasta el punto de que las fronteras interior-interior se han diluido por completo), la presencia de las chimeneas exteriores recreando el fuego del campamento, y la cubierta ligera de madera, permitiendo que la luz y el aire inundaran la casa, constataban la herencia emocional de este proyecto con la experiencia de los bosques del Norte de California. En su recreación mixta del arquetipo de la cueva y de la cabaña, entendidos desde un sentido profundamente individualista, la casa representaba uno de los ideales fundamentales de la arquitectura moderna genuinamente californiana: que el hombre moderno podía restaurar un vínculo roto con la naturaleza.

Por otra parte, el historiador Michel Darling, ha analizado el interés del primer Schindler por las tradiciones vernáculas del suroeste de los Estados Unidos; un interés que se había despertado ya durante un viaje al oeste realizado con anterioridad a su colaboración con Wright. Darling -junto con Elizabeth A. T. Smith-, uno de los dos comisarios de la exposición sobre el arquitecto organizada por el MoCA en 2001, en el catálogo de aquella muestra monográfica hacía la siguiente reflexión: "La casa es interesante por la riqueza de su historia social, por la innovación de sus ideas acerca de un hábitat comunitario y por su experimentación de novedosas técnicas constructivas, pero es su deriva desde las propicias experiencias de Schindler en la naturaleza salvaje de California, lo que la conecta con sus primeras reflexiones sobre la especificidad del lugar" ${ }^{\prime \prime 7}$. 


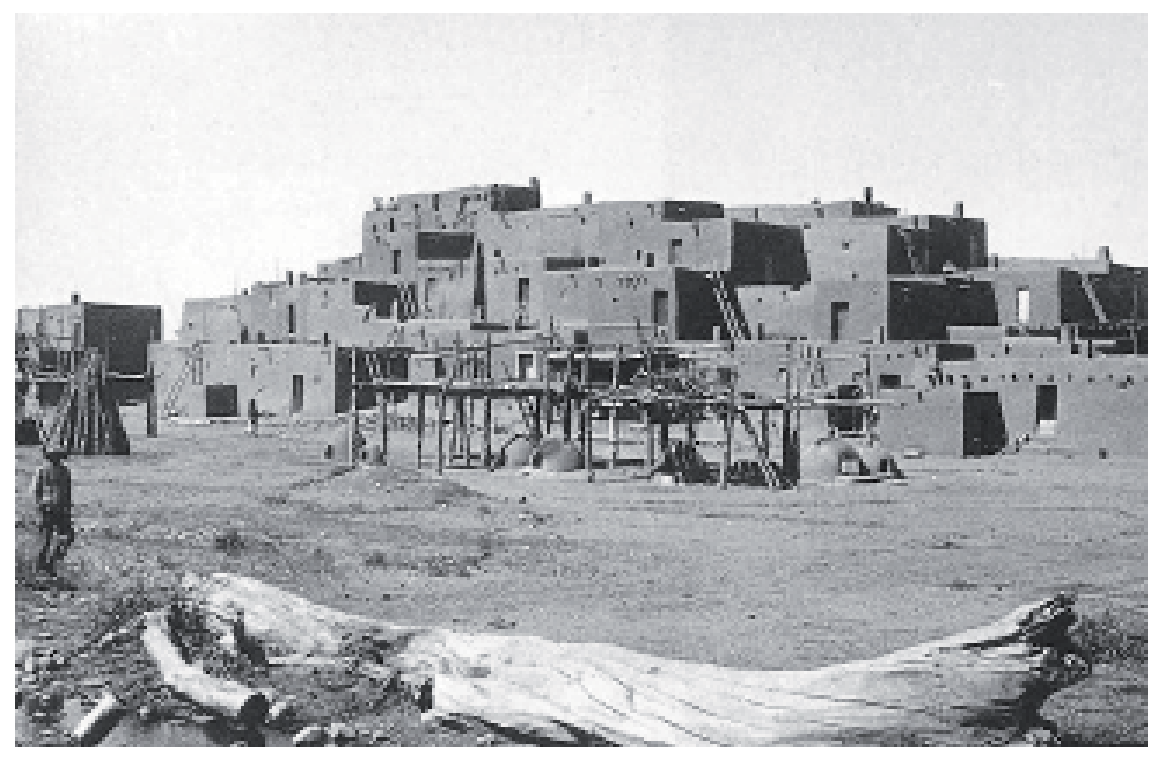

Estas reflexiones sobre la naturaleza de la arquitectura vernácula a las que aludía Darling son aquellas que Schindler comenzó a plantearse tras su descubrimiento de los asentamientos indígenas que visitó en Nuevo México. Siete años antes de construir su casa en Los Ángeles, Schindler ya había realizado un viaje a California con ocasión de la Exposición Panamericana de San Diego de 1915; un viaje en el que, por cierto, había podido conocer la arquitectura de Irving Gill de primera mano. En aquella ocasión Schindler había emprendido viaje a California vía Denver, Salt Lake City y Taos (Nuevo México), y había visitado también el Gran Cañón. A su regreso a Chicago propuso un proyecto para el Dr. Thomas Paul Martin en Taos, que no llegó a realizarse. Se trataba de una casa de campo construida en adobe. Ésta ponía de manifiesto el interés que había despertado en él la arquitectura indígena de los indios Pueblo, los únicos cuyas construcciones vernáculas, a diferencia de los asentamientos efímeros de los indios de las praderas, habían dejado testimonio de la relación histórica entre el hombre y el medio natural en Norteamérica, como él mismo escribía a Neutra en una carta sin fechar, probablemente de finales de 1920 o principios de 1921: "Los únicos edificios que hablan del apego profundo por la tierra en la que se asientan son los construidos en adobe secado al sol por los primeros pueblos de inmigrantes y sus sucesores-los españoles y mexicanos-que colonizaron más tarde el suroeste del pais"

Kings Road establecía una relación similar con el medio californiano a partir de una hibridación de modernos sistemas constructivos (la prefabricación) con técnicas tradicionales (la carpintería) que rendía tributo a la arquitectura vernácula. Los muros de hormigón de la casa garantizaban la protección y adecuación climática proporcionada históricamente por el adobe $y$, al mismo tiempo, recordaban la rusticidad de este material, trasmitiendo así un sentimiento de pertenencia al lugar.

Sin bien, las arquitecturas de adobe del suroeste del país que habían interesado a Schindler no eran la única tradición vernácula evocada por su casa. Ciertamente, gracias a sus muros de hormigón, la vivienda de Kings Road re-producía una sensación de seguridad propia de un refugio sólido, o de una cueva; pero también su entramado de madera aludía a las estructuras de troncos de una cabaña en el bosque; sus tabiquerías móviles y pantallas de tela a un pabellón japonés; y la construcción ligera de los sleeping baskets a la idea de tienda desmontable como la que había instalado en Yosemite.

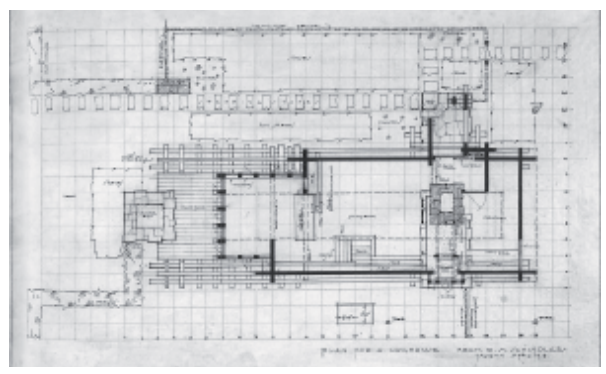




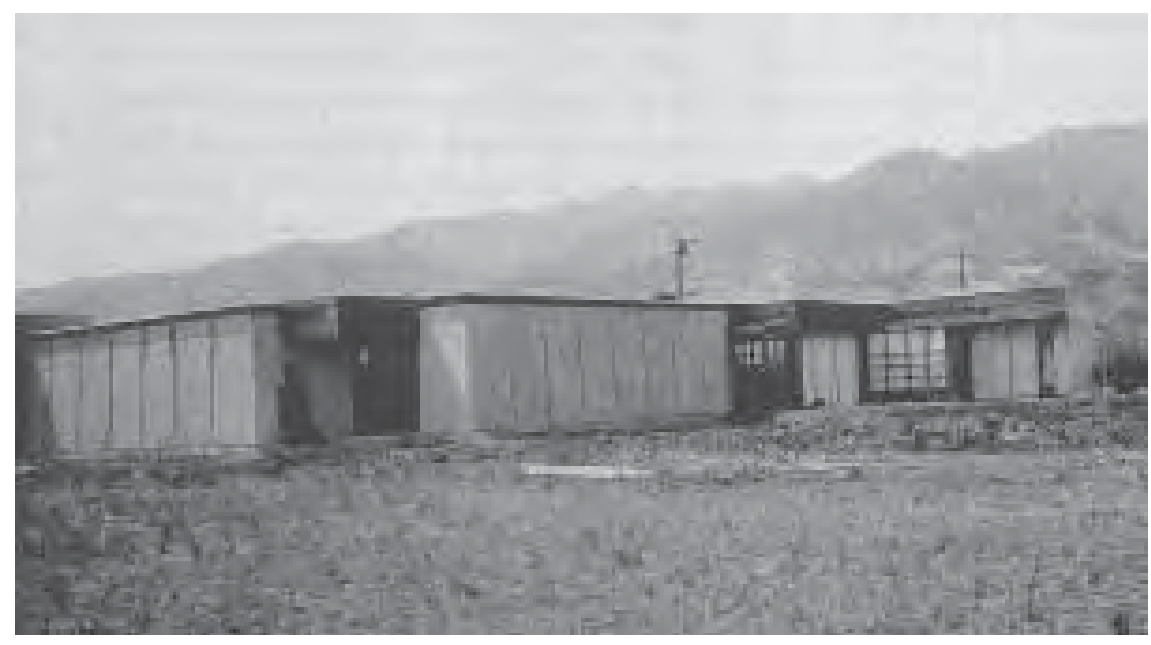

Como Wright en Olive Hill -y antes que él los hermanos Greene-, en Kings Road, Schindler se afirmó como arquitecto californiano al re-inventar un nuevo paradigma doméstico que desplegaba su originalidad a través de la fusión de múltiples referencias culturales. Pero a diferencia de Wright, la reelaboración cultural de Schindler no era de naturaleza fundamentalmente estilística, sino constructiva. Schindler no recurrió a arquitecturas exóticas ni tradiciones lejanas sino a las formulaciones vernáculas de arquetipos culturales (la cueva, la cabaña, la tienda) que las tradiciones constructivas locales habían generado en entornos vecinos como respuesta a las particularidades del clima de la región.

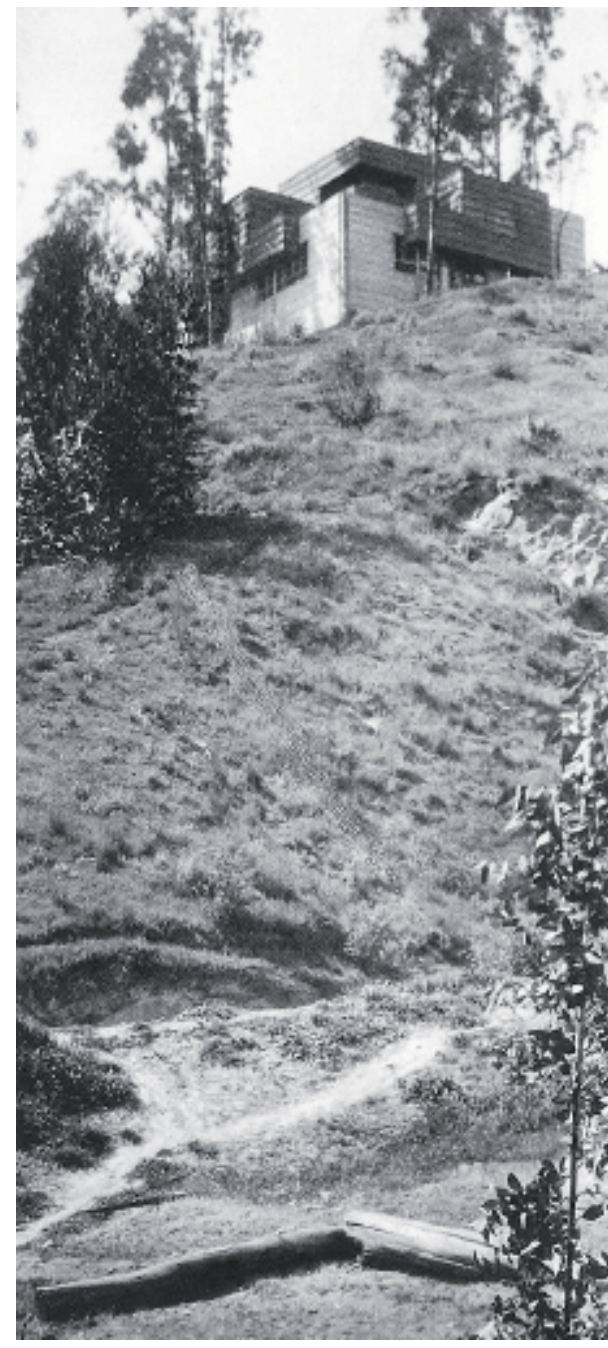

Ahora bien, si la búsqueda de una respuesta arquitectónica genuinamente californiana encontró en Schindler una expresión más contemporánea que la de Wright, es evidente que ambos planteamientos tenían en común la idealización romántica de California. En este sentido pintoresco, volviendo a las reflexiones de Schindler sobre la especificidad del medio apuntadas por Michel Darling, es importante subrayar que Kings Road, antes que ser una respuesta al sitio, era el resultado directo de trasladar al proyecto las condiciones de una noción idealizada sobre el medio californiano ${ }^{89}$.

California ofrece un microcosmos de climas y paisajes, de playas de arena, de abruptos acantilados, frondosos bosques, áridos valles y cadenas montañas con algunas de las cumbres más elevadas del país, como Schindler pudo comprobar en 1915 y, más tarde, a partir de 1920. Solo en la región del Sur de California la diferencia de temperatura y de condiciones de humedad varía drásticamente a partir de los $30 \mathrm{~km}$ tierra adentro, cuando las brisas frescas del Pacífico quedan obstaculizadas por la cordillera costera y el clima mediterráneo desaparece bruscamente para dejar paso al desierto.

A lo largo de su carrera Schindler experimentó diversas tipologías residenciales que respondían específicamente a diferentes situaciones topográficas y microclimas del estado: cabañas de alta montaña en las Sierras, casas de playa, refugios en el desierto de California y viviendas en múltiples entornos suburbanos con todo tipo de pendientes. Pero también afrontó proyectos en emplazamientos idealizados como la referida vivienda para Thomas Paul Martin en Taos (Nuevo México, 1915) y casas sin una localización conocida, como la Log House (1916-18), una cabaña geometrizada de piedra y madera cuya rigurosa modulación influirá decisivamente en los despieces y transiciones de materiales en bandas paralelas de la casa How en Silver Lake (Los Ángeles, 1925). 
La cabaña, tanto en su conceptualización arquetípica como en su formalización práctica, fue un tema recurrente para los arquitectos modernos californianos conscientes, entre otras cosas, de la traslación operada por el imaginario popular norteamericano de sus valores románticos (la autenticidad de la vida los pioneros) a una tipología residencial asociada con el retiro de fin de semana y el disfrute de la naturaleza. Schindler primero, como después Harris -en el proyecto de su propia casa en Los Ángeles- $y$, por supuesto, Drake -con sus proyectos didácticos de cabañas para Sunset Magazine-, exploraron pronto los programas, lenguajes y sistemas constructivos tradicionales propios de esta tipología para reelaborar soluciones arquitectónicas con las que proponer una solución arquitectónica a la especificidad de las condiciones del medio local. En el caso de Schindler, su mente abierta y permeable a múltiples influencias le permitió descubrir en la cabaña de troncos de los bosques americanos "una oportunidad para investigar la historia cultural de la arquitectura vernácula y para abordar una aproximación modular" ${ }^{\prime \prime}$ a la construcción residencial de importantes consecuencias en obras posteriores que el arquitecto resolvería brillantemente; algunas de modo directo como la cabaña para Gisela Bennati (Lake Arrowhead, 1934-37), otras en cambio, como la casa de Ellen Janson (Los Ángeles, 1949) o la casa para Maryon Toole (Palm Springs, 1948), con soluciones nada habituales, incluso exóticas o aparentemente gratuitas pero cuyo sentido último puede rastrearse en el primer interés del arquitecto por escrutar libremente la tradición californiana en busca de inspiración para sus respuestas arquitectónicas al lugar.

Varias de sus tempranas experiencias con viviendas en climas extremos parecen inspiradas por las fotografías que el propio arquitecto tomó en Taos de edificaciones tradicionales de adobe. Se trataba de construcciones masivas formadas a partir del apilamiento en altura de volúmenes cúbicos desiguales. El proyecto para Thomas Paul Martin en Taos y la casa de fin de semana en el desierto para Paul Popene en Coachella Valley recordaban esas arquitecturas adaptadas a los rigores del medio, de las que Kings Road extraía parte de su imagen sin tener que responder a esa misma condición climática. Otros ejemplos de referencias vernáculas manejadas por Schindler que prueban el carácter local que quería imprimir a sus primeras arquitecturas es la proyección al exterior de la estructura de madera que también sucede en Kings Road. Así, en los precedentes de la vivienda no realizada de Taos o en la Log House, Schindler exageró la proyección de las vigas de madera que, evocando los troncos de los porches de las antiguas misiones o de las cabañas de troncos, significaban las posibilidades expresivas de trasladar la lógica constructiva de un material tradicional a un proyecto contemporáneo.

Con sus aciertos (e inevitables desajustes inherentes a un proceso experimental), el esfuerzo intelectual de Schindler en Kings Road consistió en condensar la proteica realidad geográfica y cultural de California en una noción idealizada a la que responder históricamente desde su personal filosofía arquitectónica y desde su propia memoria emocional. Lógicamente, para potenciar la abstracción de los conceptos, Schindler tuvo que soslayar determinadas particularidades del sitio. Este esfuerzo sincrético es especialmente visible en los primeros croquis de su vivienda, donde el entorno banal e inexpresivo de los suburbios de West Hollywood es obviado en favor de la representación romántica de un paraje natural en el que se implanta la casa; es como si ésta emergiese en mitad del bosque, probablemente Yosemite, cuyo recuerdo se quiere recrear en el jardín.

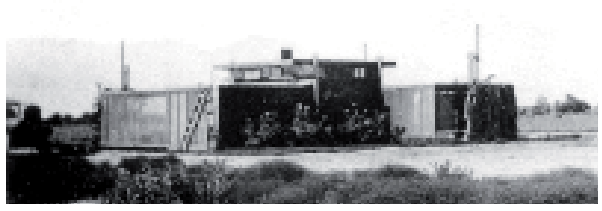

RMS: Paul Popenoe Desert House, Coachella Valley, 1923. ADC/UCS

Página anterior izda: RMS: How House, Los Ángeles 1925-1926. Fotografía de Viroque Baker Página anterior dcha: Kings Road, 1922. Fotografía RMS. Fuente: McCoy Papers, Smithsonian Institution 
RMS: Kings Road, croquis inicial, 1921, $A D C / U C S B$

Página siguiente: RMS: Fotografías del proceso de construcción de los aparamentos Pueblo Ribera, La Jolla, 1923-1925. Fotografía de RMS

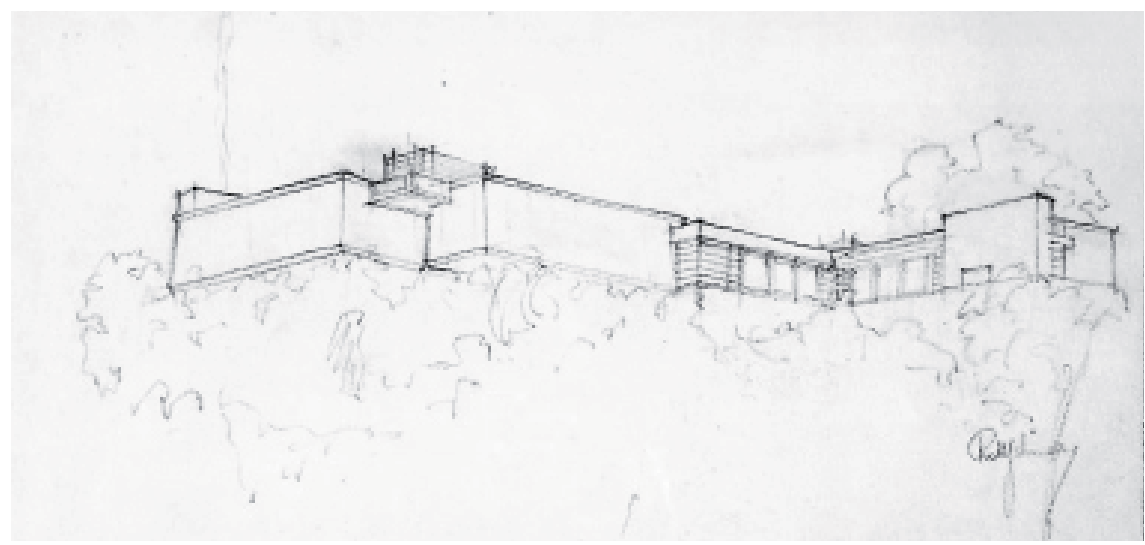

Yosemite fue una de las principales experiencias que marcaron el inicio de la trayectoria profesional de Schindler. Según el arquitecto relató a Neutra en una de sus cartas, aquellos paisajes son "uno de los lugares más prodigiosos de América. Acampo en la orilla del Tenaya, duermo en una cama de agujas de abeto bajo un cielo limpio y me baño en el agua helada procedente de las cascadas de la montaña ${ }^{\prime \prime 1}$. Schindler había visitado Yosemite a finales de verano, una de las mejores épocas para pernoctar en el parque por la benignidad de la estación -ya que el clima de alta montaña lo hubiera hecho imposible durante el invierno. Además, se había retirado al bosque para descansar después de cerrar una etapa profesional marcada por los desencuentros con Wright; la visita ocurrió pues un momento propicio de su vida, con un estado de ánimo propenso al optimismo y al disfrute del lugar. Seguramente por ello retuvo e idealizó la vivencia de la acampada como su auténtico descubrimiento de California. Aquel episodio biográfico "fue instrumental en el aprecio del clima, el paisaje y el modo de vida que parecía exclusivo de California"92, hasta el punto de forjar una imagen arquetípica a la que recurriría hasta el final de su vida para explicar el sentido último del proyecto de su casa.

David Gebhard vio en la casa de Kings Road una extraña mezcla de tradiciones culturales de los siglos XIX y XX: "El deseo romántico de vivir al aire libre (la necesidad de exponer el cuerpo a los rigores de la naturaleza) es una idea del más puro Arts \& Crafts, en la línea del vigor masculino de exponentes americanos de este movimiento tales como Elber Hubard y Gustav Stickley (y, en la Costa Oeste, de Bernard Maybeck y los hermanos Charles y Henry Greene). Pero la visión que Schindler tenía de la vida al aire libre era europea. Su entorno 'natural' no era la agreste naturaleza de la frontera occidental, sino un entorno urbano, pequeño y estrictamente controlado"93.

La distancia a los centros de abastecimiento más próximos y el modo de vida de los Schindler propiciaron un acondicionamiento de la parcela como un entorno cuidadosamente controlado. En él, los jardines de cada estudio quedaban definidos por líneas de setos que separaban áreas de juegos a distinta cota, patios privados, parterres de flores, árboles frutales y huertos de hortalizas con los que llevar una existencia comunitaria casi autosuficiente.

Pero el enclave rural de Kings Road, ya en 1922, a pesar de ser todavía una extensión infinita de solares vacios atravesada por caminos polvorientos, estaba lejos de ser natural; más bien, era el resultado de una gigantesca operación de lotización e incorporación urbana trazada a escuadra y cartabón por una de tantas compañía inmobiliarias de la ciudad. Afrontando la inminencia de una colonización de estilos historicistas como toda la ciudad de Los Ángeles estaba experimentando en ese momento, la condición de oasis intelec- 
tual de Kings Road parece todavía más evidente. Es más, el esfuerzo de abstracción de este proyecto se hace insoslayable pues, aun siendo consciente del destino previsto para su vecindario, Schindler abordó el proyecto de su casa desde la consideración idealizada de su entorno como sublimación de los valores del paisaje, del clima y de la cultura californiana.

Gebhard fue especialmente crítico con la consideración excesivamente ingenua -y no menos romántica por parte Schindler- de las bondades climatológicas de Los Ángeles. Aunque para muchos recién llegados de Europa o del Medio Oeste -y que, como Schindler, encontraron en la realidad de Los Ángeles lo más parecido a un paraíso mediterráneo-pequeñas deviaciones de temperatura y humedad sobre la media eran soportables, y a pesar de que Gebhard fue también uno de los primeros valedores históricos del arquitecto, el historiador se mostró implacable con Schindler en esta cuestión, afirmando: "En más de un aspecto la casa de Kings Road es retrógrada para los años veinte, especialmente por su indiferencia hacia los medios mecánicos de calefacción, que por entonces ya se habían convertido en parte esencial de la vivienda americana [...] aunque el clima del sur de California sea ciertamente templado, tienes sus más y sus menos de frío, humedad y calor. Schindler aplicó la norma, ignoró los extremos, y en el proceso comprometió por completo la habitabilidad del entorno. [...] La diáfana suavidad del clima habitual, en el que era realmente posible la vida al aire libre, le hizo encogerse de hombros y mirar con indiferencia a los extremos: noches frías, días incómodamente calurosos, vientos de Santa Ana intensos como un horno, lluvias torrenciales, y días y semanas de niebla húmeda que hiela los huesos. Los clientes de Schindler estaban dispuestos a aguantar ese laissez-faire del clima en sus casas de verano $y$ de fin de semana, pero no en donde residían durante todo el año. Para el final de los años veinte se había convencido, o por lo menos forzado, a aceptar la calefacción y la refrigeración mecánicas"94.

Por su puesto, analizados desde parámetros de la crítica actual, la reflexión de Gebhard cuestionando el desinterés de Schindler por los sistemas mecánicos de acondicionamiento térmico es discutible. Aunque el historiador escribía desde un posicionamiento intelectual previo al nuevo paradigma energético surgido tras la crisis del petróleo -la primera edición de su monografía sobre Schindler fue publicada en 1971-, es obvio que su intrépida defensa de estos sistemas llega a resultar trivial, especialmente teniendo en cuenta que hasta después de la Segunda Guerra Mundial la calefacción eléctrica y el aire acondicionado no fueron instalaciones habituales en la mayoría de los proyectos modernos y que, incluso, obras tan emblemáticas de posguerra en California como la casa Eames, carecía de ellos. Así, aunque es lógica su discusión del fracaso de los sleeping baskets, resulta chocante que Gebhard plantee la reivindicación de los sistemas mecánicos en fecha tan temprana como 1922 para desautorizar la respuesta al clima californiano de las obras de Schindler. Además, Gebhard no tuvo en cuenta que en un proyecto de mínimos como Kings Road, Schindler no pudo ni plantearse invertir un dinero del que no disponía en las instalaciones de su casa que no fueran estrictamente necesarias. Curiosamente, en 1971, Banham había escrito en su Los Angeles. The Architecture of Four Ecologies un alegato a favor de la casa como brillante ejercicio de interpretación de las relaciones interior-exterior y de la sencillez de la tecnología local para resolver las necesidades y las posibilidades de su medio95.

Hasta el final de la década Schindler estuvo desarrollando las ideas presentes en su casa en diferentes proyectos encargados por clientes progresistas
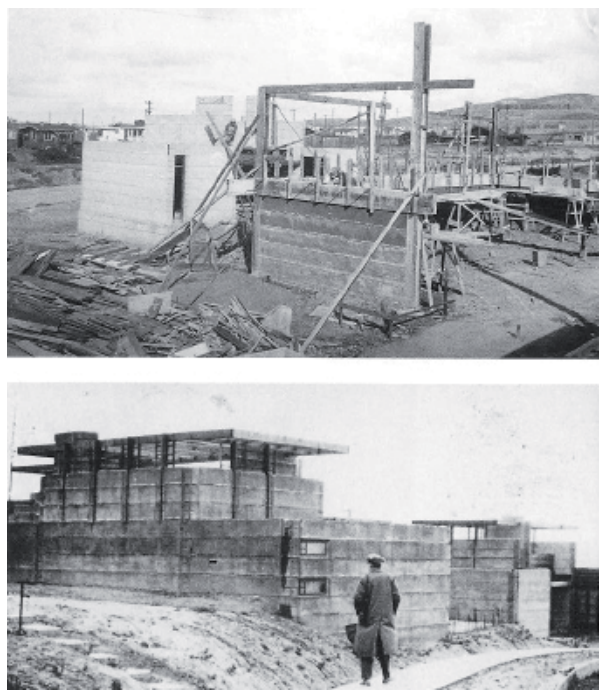


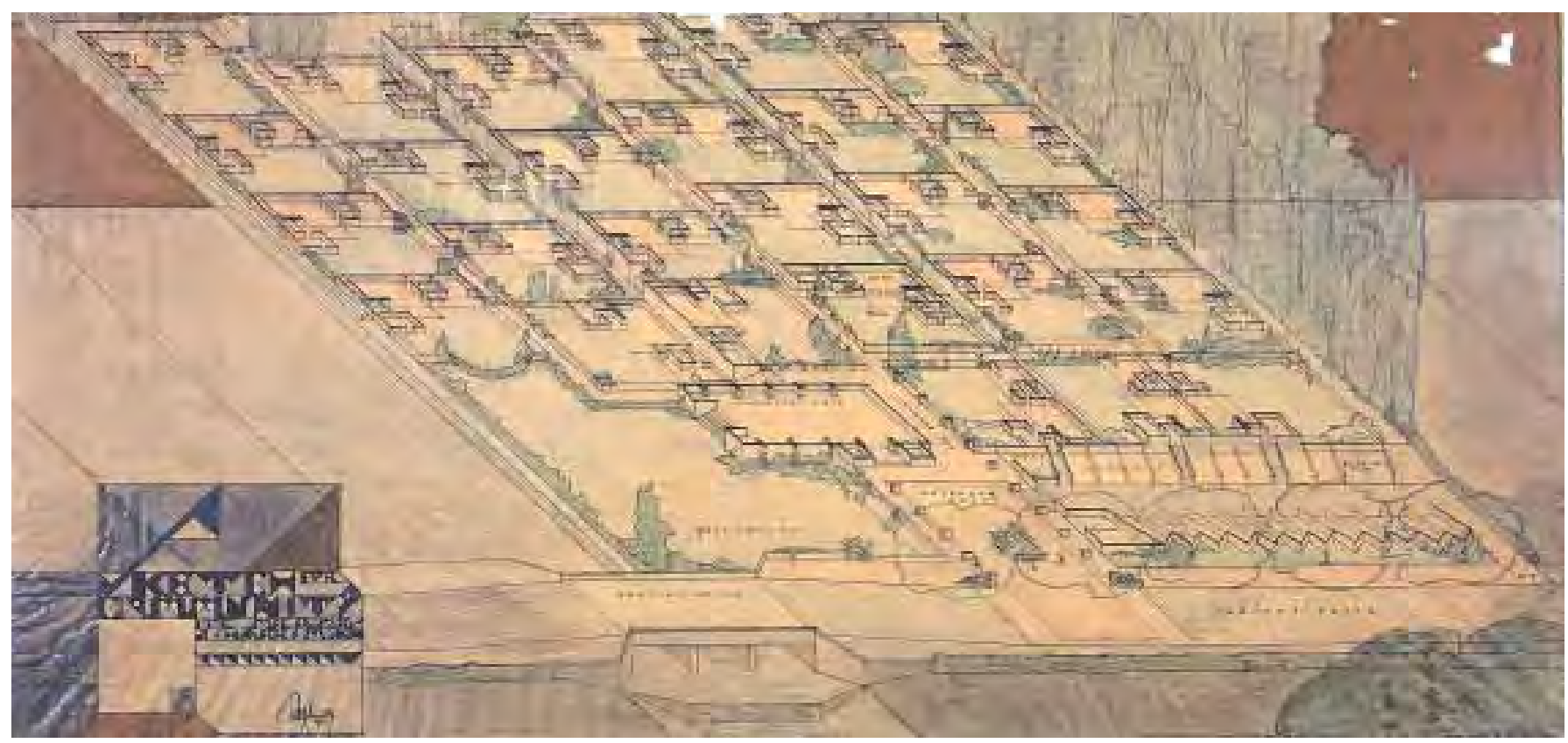

como los Packard (John Cooper Packard era abogado, Rose Marie, su mujer, maestra, y ambos fundadores en 1920 de la American Civil Liberties Union), a quienes construyó su casa en Pasadena en 1924; el doctor James Eads How (How Residence, Los Ángeles, 1925-26); o Charles y Ethel Wolfe (Catalina Island, 1928-31), propietarios de una escuela de diseño de moda y a quienes Schindler había conocido a través de los Lovell. Aunque, exceptuando la casa Lovell en Newport Beach (1926), el resto de estas obras está lejos de la radicalidad de Kings Road, la progresiva complejidad espacial de estos proyectos deriva de sus respuestas a condicionantes específicos del medio, como la espectacular tensión diagonal de la casa How, consecuencia de la necesidad de garantizar vistas lejanas; o la precisa sección escalonada de la Wolfe House como respuesta a la escarpada pendiente de su emplazamiento desde el que domina la bahía de Avalon. A pesar de su riqueza y complejidad espacial, en todas ellas es posible reconocer de inmediato la lógica del proyecto, ya que el rigor geométrico con el que han sido concebidas facilita su lectura.

En paralelo, Schindler trató de ensayar las técnicas constructivas de su vivienda en proyectos de vivienda colectiva para llevar a la práctica sus ideas de viviendas económicas realizadas a partir de elementos prefabricados de hormigón, lo que demostró convincentemente en el complejo de 12 unidades residenciales Pueblo Ribera Courts en La Jolla, al norte de San Diego, ejecutado entre 1923 y 1925. Durante esos mismos años Schindler trabajó en dos proyectos no construidos de vivienda obrera donde aplicaba los sistemas ensayados en Pueblo Ribera a una mayor escala: la colonias de trabajadores Gould \& Bandini Workmen's Colony y la Harriman's Colony. Este último es un proyecto teórico concebido para el idealista y carismático abogado Job Harriman, fundador de la colonia socialista Llano del Rio ${ }^{96}$, a quien Schindler admiraba y con quien intercambió correspondencia durante 1924 .

Sin embargo, a pesar de todas estas experiencias y del interés local que la arquitectura de Schindler había comenzado a despertar en los años 30, su obra fue deliberadamente excluida de la primera exposición internacional de arquitectura moderna, organizada por el Museo de Arte Contemporáneo de Nueva York en 1932 y, por consiguiente, del catálogo The International Style: Architecture Since 1922, editado por Henry-Russell Hitchcock y Philip Johnson. La correspondencia cruzada entre Schindler y Johnson es revelado- 


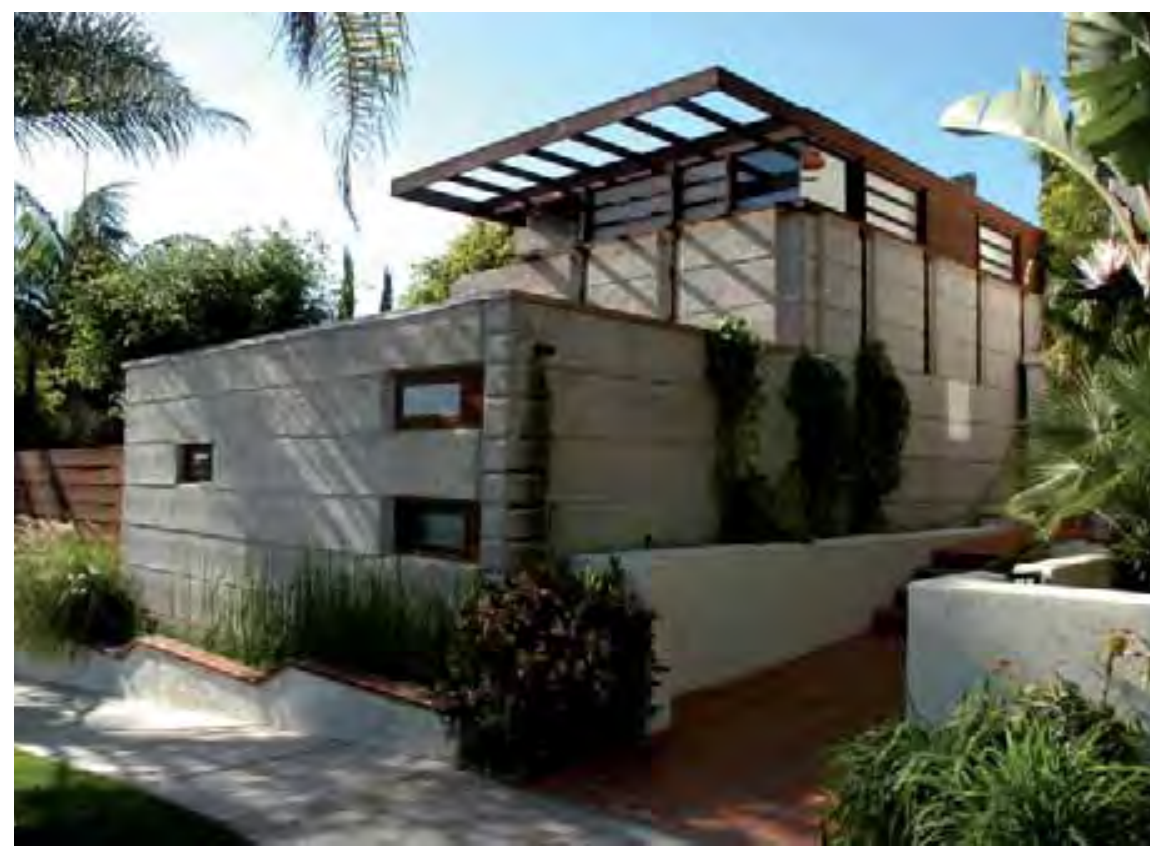

ra del desdén con el que sus comisarios trataron la vivienda-estudio de Kings Road (precisamente de 1922) y cuya modernidad la crítica del Este se esforzó por no ver. Schindler escribió hasta tres cartas solicitando ser incluido, a lo queJohnson se negó aduciendo que "por lo que conozco de su obra, mi opinión más sincera es que en esta exposición no hay sitio para su obra"97.

Es obvio que la casa, sencillamente, no encajaba en el vocabulario que Johnson pretendía codificar y publicitar como moderno y que, por tanto, su exclusión se debió al énfasis que los comisarios pusieron en presentar todas las obras seleccionadas como exponentes de un nuevo estilo del que, por cuestiones mediáticas, no era posible disentir. Este énfasis publicitario fue tal que, según ha reparado Beatriz Colomina el lenguaje del catálogo tuvo incluso una retórica militar: "Los principales arquitectos del acontecimiento mediático-Barr, Johnson y Hitchcock-entendieron su campaña publicitaria como una campaña militar. Hay a lo largo del libro un despliegue de retórica miliar: 'Los nacionalistas europeos se opondrán al Estilo como si fuera otra invasión europea [...] No obstante, el Estilo Internacional ya ha obtenido varias victorias importantes en Estados Unidos [...] en Europa también [...] Peter Behrens [...] y Mandelsohn [...] se han pasado al Estilo Internacional'. El libro fue concebido como arma publicitaria para difundir la arquitectura moderna en los Estados Unidos. Las imágenes se usan como municiones. El texto está completamente subordinado a la imagen"98.

En este contexto, en el que el medio era el mensaje, la imagen de la obra era determinante para ser o no incluida en la muestra y la vivienda de Schindler -que Charles Moore calificó con ironía de "monumento extraordinario y monumental jaleo"99_ difícilmente podía ajustarse a ninguno de los códigos normalizados como modernos. Esta consideración epidérmica de la modernidad pasó por alto todos los valores de la casa. De hecho, el revolucionario programa doméstico de Kings Road era más moderno que el de cualquiera de las viviendas seleccionadas para representar esta tipología que, por cierto -y de manera en absoluto casual-integraba el grueso de la exposición. Más aún, la radical innovación en la organización de los espacios de la casa de acuerdo con una consideración igualitaria de sus usuarios y -hasta cierto punto- libre de prejuicios culturales era mucho más avanzada socialmente que la estricta asignación de roles de género y códigos de conducta del suburbio americano
Arriba: RMS: Pueblo Ribera Apartments, La Jolla, 1923-25. Fotografía del autor Abajo: RMS: Propuesta para la Publicidad de automóbiles Collier, 1936, comparativa de dos anuncios utilizando las casas Buck de Schindler en Los Ángeles, 1934 (arriba) y VDL de Neutra, 1932 (abajo). Fuente: Catálogo The Architecture of RM Shindler, MoCA, 2001

Página anterior: RMS: Propuesta para la Harriman's Colony, Valle de San Gabriel 1924
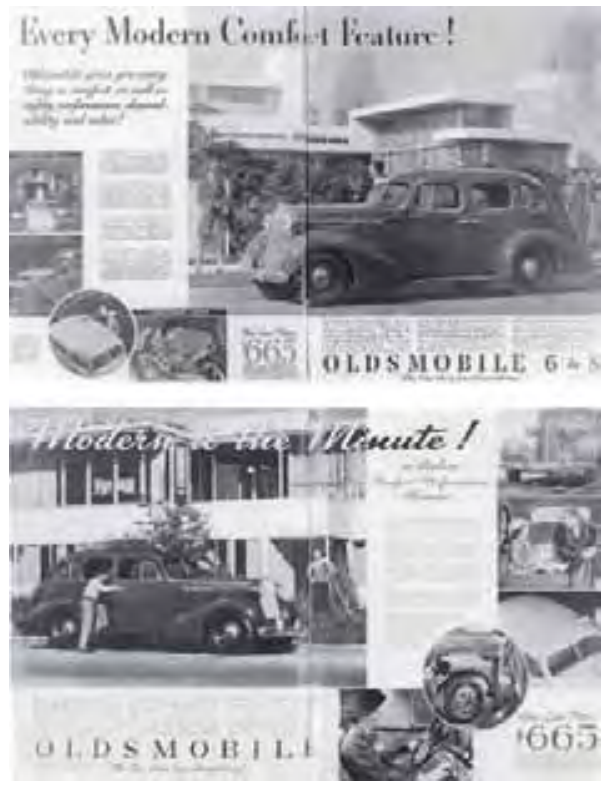


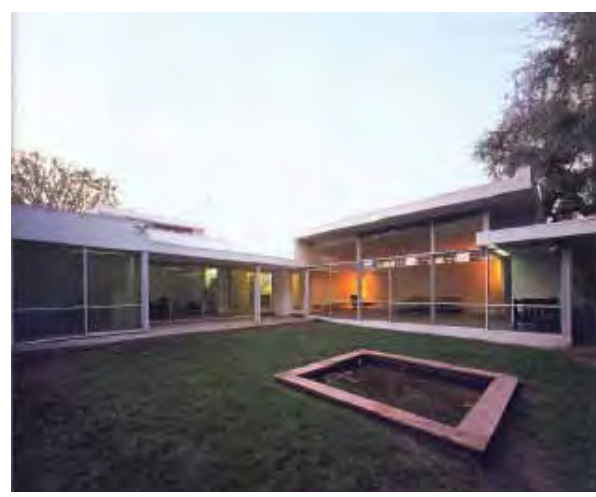

RMS: Casa Buck en la actualidad, Los Ángeles, 1934. Fotografía de Grant Mudford de posguerra, un paradigma patriarcal y sexista que incorporaron sin cuestionar a su diseño moderno los prototipos modernos del CSH Program.

Ahora bien, aunque la idiosincrasia de Schindler fue una de las razones por las que permaneció al margen de determinados círculos poco proclives a aceptar la heterogenia y fue apartado de dos de los episodios publicitarios más influyentes de la modernidad americana, la Exposición del MoMA de 1932 y el programa de John Entenza, el arquitecto no fue nunca una figura aislada. Por ejemplo, poco después de su primer rechazo en Nueva York, fue incluido en la exposición del MoMA Contemporary Architecture in California y sus escritos y obras publicados en importantes revistas nacionales e internacionales ${ }^{100}$ como Pencil Points, Architectural Record o Architectural Forum, aunque, por supuesto, sin la frecuencia e impacto de Richard Neutra.

En cualquier caso, el malestar de Schindler por esta significativa exclusión duró el resto de su vida y sus textos revelan un especial interés en que sus ideas fueran comprendidas. Quizás por ello, por su necesidad de ser reconocido es por lo que algunas de sus obras de los años 30 muestran una mayor afinidad con los códigos visuales del Estilo Internacional, a veces incluso a costa de pequeños desajustes con su propia lógica arquitectónica interna. No obstante, este periodo reconocible en sus casa Oliver (Los Ángeles, 193334) o Buck (Los Ángeles, 1934) fue breve y pronto retomó su personal exploración sobre el espacio y la especificidad y singularidad del lugar que le llevaría a producir sus obras más sorprendentes de la siguiente década. En una carta enviada en 1943 a Elizabeth Mock (Directora del Departamento de Arquitectura y Diseño Industrial del MoMA durante los años de la guerra), tratando de explicar por qué se había alejado de cualquier estilo para poder desarrollar sus investigaciones en torno al espacio como su medio creativo, Schindler enfatizaba que su obra, frente a la de otros autores del Estilo Internacional, había sido mucho más moderna y que en fecha tan temprana como 1922, a pesar de que muchos no lo supieron ver, había sido capaz de crear una vivienda perfectamente integrada técnica, social y culturalmente en el lugar y en el tiempo en que fue construida, y que no se trataba en absoluto de una pose, como la de "la mayoría de los arquitectos contemporáneos que buscan sobre todo conseguir un efecto moderno"101.

En abril de 1952, pocos meses antes de morir, Schindler escribía una carta Arthur Drexler, entonces Conservador y Director del Departamento de Arquitectura del MoMA. En ella, una vez más insistía sobre la originalidad de su vivienda con la que, según recalcaba, a diferencia de los retóricos, superficiales e inadecuados intentos de Frank Lloyd Wright y de la fallida importación del Estilo Internacional por parte de Richard Neutra, él sí había logrado desarrollar una expresión arquitectónica genuinamente californiana, coherente con el clima, los valores históricos y el contexto cultural de la región. En dicha misiva, la última de tantas que escribiría al MoMA solicitando adhesión a sus ideas, Schindler volvía a su propia vivienda para explicar los principales conceptos en los que se apoyaba su visión de la arquitectura y del lugar cuando dio forma a esta obra: "En 1921, con el impacto que me causó California todavía muy presente, construí mi propia casa, intentando responder al carácter local. Introduje algunos aspectos que parecían ser fundamentales para la vida en California; planta libre, cubierta plana, exteriores habitables, muros de vidrio, muros traslúcidos, amplias puertas correderas, franjas de ventanas altas, pérgolas y cubiertas ligeras con voladizos de protección. Todas estas características ya han sido ampliamente aceptadas y constituyen las bases de la casa californiana contemporánea"102. 
[DEOLIVEHILLAKINGSROAD_ ] W.

[ PAULINE GIBLING (SCHINDLER),

PROMOTORA DE LA MODERNIDAD CALIFORNIANA

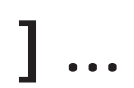

LEDWARD WESTON EN LOS INICIOS DE LA

FOTOGRAFÍA DE ARQUITECTURA EN CALIFORNIA

$\square \square$

RUDOLPH SCHINDLER Y LA FENOMENOLOGÍA

DEL ESPACIO MODERNO 
"Uno de mis sueños, madre, es tener algún día el pequeño placer de un bungalow en la frontera entre un bosque y las montañas cerca de una populosa ciudad. La casa estaría abierta tal como los corazones de las personas están abiertos a los amigos de toda clase y condición. Sería un lugar de encuentro tan democrático como la Hull House, donde millonarios y trabajadores, profesores e iletrados, lo espléndido y lo innoble se encontraran constantemente ${ }^{\prime \prime 103}$.

Pauline Gibling, 1916

Desde la recuperación histórica de Rudolph Schindler, a través de un proceso de paulatina apreciación y aceptación de su arquitectura que requirió varias décadas y que culminó, a mediados de los años 9o, con la restauración y apertura al público de su vivienda-estudio de Kings Road, la casa ha sido objeto de innumerables análisis arquitectónicos, artículos de difusión y nuevas monografías con imágenes a todo color que demuestran el renovado interés que existe por esta obra en la actualidad. Sin embargo, la historia cultural de la casa, es decir, el relato social y político y una investigación en profundidad sobre las implicaciones artísticas del salón de los Schindler, es todavía una cuestión abierta. Y, en este sentido, la reivindicación del papel fundamental de Pauline en esa y otras historias próximas se revela como la tarea más urgente.

Por ejemplo, en su narración ${ }^{104}$ de los avatares de la fortuna histórica de la obra de Schindler, la investigadora Margaret Crawford minimizaba todavía a finales de los años go la figura de Pauline Schindler, reduciendo su presencia en dicha narración a la de un personaje marginal. Es cierto que el argumento de Crawford arrancaba de la muerte de Schindler, pero las referencias a la figura de Pauline son anecdóticas, presentándola en los años 60 y 70 como la viuda que recibía y atendía amablemente a los jóvenes arquitectos europeos que, como Reyner Banham o Hans Hollein acudían a Kings Road atraídos por el enigmático maestro. Crawford no tuvo en cuenta el hecho de que, en vida de Schindler, Pauline fue la primera difusora de la obra de su marido, y que escribió sobre él y muchos otros arquitectos antes de que lo hiciera Esther McCoy. Incluso, llegó a afirmar que Pauline "era más convencional de lo que creía" y que, por ello, "en 1927, cada vez más distanciada de Schindler a causa de las infidelidades de su marido, abandonó la ciudad junto a su hijo Mark"105.

Dos años después del artículo de Crawford, la publicación del catálogo de la exposición The Architecture of R. M. Schindler, organizada por el Museum of Contemporary Art de Los Ángeles en 2001, incluía el ensayo -ya citado ${ }^{106}$ del arquitecto e historiador Robert L. Sweeney ${ }^{107}$, Life at Kings Road: As It Was 1920-1940 donde, por primera vez, se presentaba a Pauline como el personaje central alrededor del cual gravitaba toda la vida en la casa. Sweeney se basaba en la copiosa correspondencia dejada por Pauline Gibling Schindler para afirmar que había sido ella, y no su marido, quien había establecido el tono del salón de Kings Road y que, por supuesto, también había proporcionado a Schindler todo el apoyo social e intelectual que necesitaba para asumir los riesgos que el arquitecto afrontó en sus primeras obras.

En su breve recorrido por la vida de esta mujer fascinante, Sweeney comenzaba a desplegar el conjunto de relaciones personales -casi todas procedentes de los círculos de Pauline- que convirtieron Kings Road en uno de los centros de creación más intensos de la vanguardia de Los Ángeles durante el periodo de entreguerras. También, aunque quizás de manera más inconsciente, al poner el foco en las idas y venidas de Pauline a su vivienda
Pauline Gibling Schindler (PGS) en 1919. Fuente: Esther McCoy, Vienna to Los Angeles

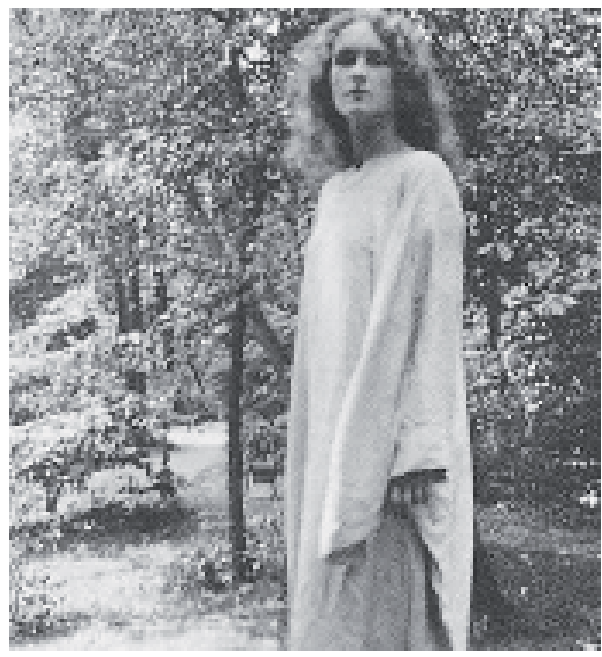


de Kings Road tras su ruptura con Schindler en 1927, Sweeney apuntaba el trabajo como escritora, editora y agitadora cultural que Pauline había desempeñado mientras recorría California en la década de los años 30. Aunque Sweeney no desarrollaba esta faceta, sí ampliaba la información facilitada por Esther McCoy en Vienna to Los Angeles ${ }^{108}$, donde la historiadora ya había reparado en los méritos literarios de Pauline durante sus años de existencia nómada. Después de ella, Thomas Hines también había comentado ${ }^{109}$ algunas de sus contribuciones a la divulgación de las primeras obras de Schindler y de Neutra, entre otros arquitectos. No obstante, ha sido el historiador John Crosse ${ }^{110}$, quien ha comenzado por fin a desentrañar todo el tapiz de relaciones modernas tejido por Pauline antes y después de su vida de pareja junto a Rudolph Schindler para explicar, a partir de su red de amistades y contactos profesionales, cuáles fueron las condiciones que hicieron posible su labor como agente difusora de la modernidad californiana. Aún así, todavía es necesario ahondar más en esta labor en la que con toda seguridad incidirá un previsible estudio monográfico de Sweeney, ya que es este autor quien custodia buena parte de los fondos del archivo personal de Pauline. En cualquier caso, sirva por ahora este intento crítico para valorar el alcance de la actividad catalizadora del personaje y, por supuesto, el reconocimiento a Pauline Gibling Schindler por su incansable promoción de la mejor arquitectura moderna californiana. Fue precisamente ella una de las principales defensoras de la obra del joven Harwell Hamilton Harris a quien le consiguió, entre otras oportunidades, su primera aparición en la revista California Arts \& Architecture (CA\&A)en 1935.

\section{De nuevo Chicago, ciudad de intercambio}

Pauline Gibling, de padre inglés y madre alemana, había nacido en Minneapolis en 1893. Pertenecía a una familia industriosa, relativamente acomodada y con ideas muy avanzadas. Sus padres ${ }^{111}$ le proporcionaron una selecta formación intelectual y la educaron, como a su hermana Dorothy, en el convencimiento de que la mujer debía ser parte activa de la vida pública.

De joven había cursado estudios superiores de Música en el Smith College, una universidad privada femenina de Northampton, Massachusetts. En 1915, después de graduarse junto a su íntima amiga Marian Da Camara (futura Marian Chace), Pauline se trasladó a Chicago donde, entre 1916 y1919, ambas dieron clases de música en la Hull House ${ }^{112}$ y en una escuela de Ravinia, un suburbio obrero de la ciudad. La Hull House era una institución liberal dedicada a la acogida de inmigrantes y a la enseñanza a jóvenes sin recursos. Su sede se había convertido en centro de reunión de intelectuales y militantes defensores de reformas sociales. Su fundadora, la socióloga y feminista Jane Addams -que en 1931 se convertiría en la primera mujer norteamericana en ser galardonada con el Premio Nobel de la Paz- fue una firme opositora de la entrada de su país en la Primera Guerra Mundial, creando en 1915 la Women's International League for Peace and Freedom de la que Sophie Gibling, la madre de Pauline, llegó a ser Tesorera y miembro activo hasta su muerte. Curiosamente, Richard Neutra, tras su llegada a Chicago procedente de Nueva York a principios de marzo de 1924, aconsejado por Pauline, también pasaría algunas semanas alojado en la Hull House, donde trabajó como profesor de dibujo para ganar algún dinero ${ }^{113}$.

La Hull House fomentaba la implicación de sus residentes en actividades sociales. Para poder disfrutar de sus instalaciones era necesario cooperar de 
algún modo, generalmente impartiendo clases. Pauline enseñó en la Hull House junto a su amiga Edith Gutterson, que trabajaba en el Art Institute como asistente curatorial de fotografía y cuyo marido, Karl Howenstein, antiguo empleado de Sullivan, era amigo de Rudolph Schindler.

Entre las grandes pasiones de Pauline estaban la música y el teatro. A través de la Hull House entró en contacto con varios de los protagonistas de la corriente de renovación artística del Chicago Renaissance. Allí entabló amistad con Maurice Browne quien -como se ha visto en el apartado anterior-, por esos años se había planteado a iniciativa de Aline Barnsdall la posibilidad de encargar a Wright la construcción de una nueva sede para su Little Theatre. Browne se convertiría en uno de sus mejores amigos y apoyos $y$, aunque después de abandonar Chicago, Browne se trasladó a Seattle para abrir una escuela de interpretación, cuando acudía a Los Ángeles solía visitar a Pauline e, incluso, era invitado como orador en Kings Road (1926).

En Chicago, en aquel momento en que se daban los primeros pasos conducentes a la creación del Partido Comunista Americano, en 1919, Pauline se involucró en los movimientos políticos más radicales de la ciudad. Por ejemplo, allí conoció a Emma Goldman, una de sus heroínas y de cuyas charlas y escritos, como la publicación anarquista Mother Earth, se hizo seguidora.

Pauline Gibling era una ávida lectora y admiraba el trabajo de Margaret Anderson y su Little Review. Algunos de sus colaboradores, como los escritores Alexander Kaun, Theodore Dreiser (futuro mentor de Esther McCoy y vecino en West Hollywood) o el propio Maurice Browne, llegaron a ser buenos amigos de Pauline $y$, en uno u otro momento, pasaron por Kings Road, tanto en calidad de conferenciantes como de huéspedes.

De aquella época de formación política y literaria, o incluso antes - de su etapa en el Smith College-, procede el interés de Pauline por autores como el escritor, poeta y activista Max Eastman, defensor, como Goldman, del sufragismo femenino o del control de la natalidad. Eastman, doctorado por Columbia y uno de los líderes del Harlem Renainassence, había asumido en 1913 la dirección de la revista socialista The Masses, clausurada por sedición en 1917 y de la que Pauline era suscriptora. En esta publicación Max Eastman escribió con finura intelectual sobre diversos temas, entre ellos: literatura, filosofía, psicología, educación y reformas sociales. Algunos de sus colaboradores fueron John Reed, Lovise Bryant, Carl Sandburg o Upton Sinclair, todos ellos, como el propio Eastman, figuras de referencia en la gestación del pensamiento político de Pauline y, por extensión, de Rudolph Schindler. Su ideario estaba perfectamente resumido en los créditos de la revista donde, a propuesta de Reed, Eastman proclamó: "The Masses es una revista revolucionaria y no una revista reformista: una revista con sentido del humor y sin respeto alguno por lo respetable. Franca, arrogante, impertinente, interesada por la verdad, dirigida contra toda forma de intolerancia o de dogma [...] Una revista cuya política final es hacer, tanto si gusta como si no, sin preocuparse ni siquiera por la opinión de sus lectores".

Pauline Gibling y Rudolph Shindler coincidieron por primera vez en Chicago en 1919. Detenerse en el modo en que se conocieron podría parecer un aspecto anecdótico pero es representativo de su personalidad, marcada por un impulso romántico de abrazar la modernidad, tanto en el arte como en su propia vida. Tal como ella habría narrado a Thomas Hines ${ }^{114}$, ambos habían acudido por separado al Chicago's Orchestra Hall para asistir
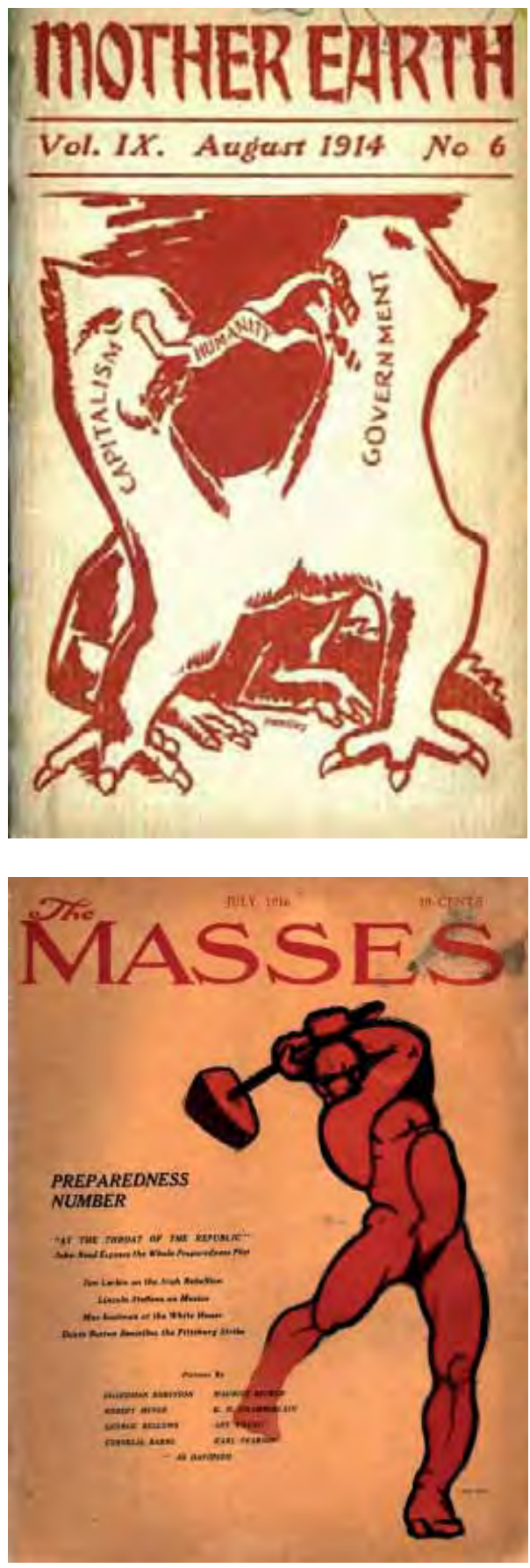

Arriba: Portada de Mother Earth, agosto 1916 diseñada por Man Ray

Abajo: The Masses, julio 1916

Página anterior: Hull House, Chicago. Fuente: Jane Addams Hull House Museum 
a un programa doble cuya primera parte ofrecía la première americana de la Suite Escita de Sergei Prokofiev, una composición originalmente pensada para los Ballets Rusos de Diaghilev pero que acabó siendo reescrita como suite orquestal y estrenada con gran escándalo en San Petersburgo en 1916. Tratándose de una de las obras más violentas del compositor, la pieza les entusiasmó tanto que, según relató Pauline, los dos tuvieron la misma idea de abandonar la sala de conciertos al término de su interpretación para que el recuerdo de aquella novedosa experiencia sonora no se viera empañado por el clasicismo de la música de Carl Maria von Weber, que constituía la segunda parte del programa. En el vestíbulo del edificio Pauline se detuvo a saludar a su compañera de la Hull House Edith Gutterson, quien conversaba con Rudolph Schindler y quien presentó a la futura pareja. De acuerdo con Esther McCoy, el arquitecto quedó impresionado por la oratoria de Pauline, por sus conocimientos de música y por el modo en que criticaba abiertamente el creciente militarismo de los Estados Unidos tras su intervención en la Primera Guerra Mundial115. Al parecer la fascinación por las ideas del otro fue mutua y, como diría la propia Pauline, bajo el hechizo de aquel momento conectaron inmediatamente ${ }^{116}$. Contrajeron matrimonio en agosto de 1919 y poco después se trasladaron a Taliesin. Un año más tarde Wright envió a Schindler a Los Ángeles para que pusiera fin al caos de las obras de Olive Hill. Los Schindler llegaron a la ciudad el 3 de diciembre de 1920. Pocos meses después les siguieron los Chace.

\section{Focos de militancia: LosÁngeles (1920) y la gestación del salón Gibling-Schindler}

Con su "innato sentido de la urgencia" ${ }^{117}$, Pauline comenzó a frecuentar todos aquellos ambientes en los que consideraba que podía coincidir con personas interesantes o recabar información sobre los acontecimientos más relevantes que estaban ocurriendo en Los Ángeles. El líder socialista Upton Sinclair fue uno de sus primeros contactos. Se hicieron amigos después de que Pauline le persiguiera por toda la ciudad hasta ser recibida. A través de Sinclair, los Schindler tuvieron acceso a diferentes círculos como el Gaylord Whilsire, un acaudalado promotor que, sin embargo, compartía con ellos su ideología de izquierdas y que años antes había lanzado la revista Wilshire's Magazine, la publicación de orientación socialista de mayor tirada de la época.

En pleno auge inmobiliario, el boom del petróleo y el triunfo de los estudios de Hollywood, hacia 1920, el edén de Los Ángeles era el escenario de los más descarnados conflictos ${ }^{118}$ políticos y sociales -sobre los que el cine y la literatura han dejado inolvidables relatos de género negro. Las compañías ferroviarias propietarias de buena parte del suelo -y que habían conseguido despertar el deseo de América por aquel paraíso promocionado mediante todo tipo de reclamos publicitarios-, las agendas los principales promotores inmobiliarios, y la hegemonía de las antiguas familias industriales comandadas por los herederos de Harrison Gray Otis (con Harry Chandler al frente de Los Angeles Times), regían con firmeza militar los destinos de la región. Con el fin de eliminar cualquier obstáculo que se interpusiera en sus intereses empresariales, habían intentado exterminar violentamente toda forma de sindicalismo o de protesta ciudadana que cuestionara la precariedad de los salarios o las duras condiciones laborales de los trabajadores, en especial, las de una población inmigrante cada vez más numerosa. 
Como reacción a este régimen de control oligárquico, intelectuales, políticos progresistas y artistas comprometidos se movilizaron para plantarle batalla en diversos frentes, desde los que defendieron una visión más justa de aquel modelo de desarrollo económico. A través de una arriesgada proclama de sus ideales, activistas y reformadores sociales lograron pocas, pero efectivas, victorias que contuvieron momentáneamente la presión de las grandes compañías privadas. A pesar de que se trató de episodios puntuales, algunos de ellos resultaron determinantes para plantear los límites -al menos moral y conceptualmente- a las dinámicas capitalistas que estaban moldeando la realidad territorial y el imaginario de la futura metrópolis.

Desconectados unos de otros hasta la unificación de múltiples causas bajo la plataforma End Poverty in California de Upton Sinclair (EPIC) en 1934 ya durante la Gran Depresión-, entre aquellos episodios que inauguraron la tradición de lucha por los derechos civiles en el Sur de California pueden mencionarse: el apoyo popular a las dos candidaturas del abogado socialista Job Harriman a la Alcaldía de Los Ángeles (1911 y 1913), perdiendo por un escaso margen de votos a pesar de las maniobras de sus enemigos políticos; la consecución del voto femenino ${ }^{119}$ en 1911 -una década antes que en el resto del país; la fundación en mayo de 1923 del American Civil Liberties Union of Southern California por Upton Sinclair, como consecuencia de una brutal persecución a los huelguistas del puerto de San Pedro y de varios miembros del Industrial Workers of the World, incluido el propio Sinclair, que fue detenido; o la emergencia de un movimiento popular que reunió a escritores, periodistas, arquitectos, planificadores urbanos y líderes vecinales para intentar preservar las cualidades ambientes de inmensas áreas de la ciudad que estaban siendo devastadas por la presión de la actividad inmobiliaria y las prospecciones petrolíferas. Centros históricos como $\mathrm{Pa}$ sadena, emplazamientos pintorescos como Venice o lugares frecuentados por artistas y bohemios como el campus del Occidental College en Boyle Heights, restaurantes de Hollywood, la librería de Jake Zeitlin en el Downtown de Los Ángeles o la Walt Whitman School en Boyle Heigths, fueron algunos de los focos de esta resistencia. En este sentido, la ignorada visión del Plan Olmsted-Bartholomew de 1930, considerando la región de Los Ángeles como una red coherente de playas, áreas recreativas, parques y zonas verdes conectadas entre sí y con los principales parajes naturales, debe entenderse como una lúcida contrapropuesta a la expansión desregulada y sin estructura que estaba imponiendo el crecimiento suburbano de la ciudad.

La Walt Whitman School era una escuela progresista vinculada a los principios de la Modern School. Iniciada en Nueva York en 1911, esta corriente ${ }^{121}$ promovía la enseñanza laica en centros educativos mixtos. Su ideología fue articulada, entre otros, por Emma Goldman y su discípulo William T. Brown -director de esta institución en Los Ángeles- quienes, en la estela de la Escuela Moderna de Francesc Ferrer, defendían la educación para las clases sociales más desfavorecidas y la formación de los niños en valores como la igualdad, el respeto, el cuidado de la salud y la educación sexual, además del desarrollo de las capacidades de cada estudiante al margen de los prejuicios, la hipocresía y la coacción de la enseñanza puritana. A través de Pauline, Rudolph Schindler -a quien ella por entonces denominaba su camarada- participó activamente en diversas iniciativas de la Walt Whitman School de la que ambos eran miembros de su consejo de dirección. Schindler, concretamente, reformó su biblioteca y preparó un proyecto para una nueva sede del colegio en la ciudad que finalmente no llegó a construirse.
Lloyd Wright: Zeitlin Books, Fuente: Special Collections, Charles E. Young Research Libary, Univeristy California Los Angeles (en adelante UCLA)

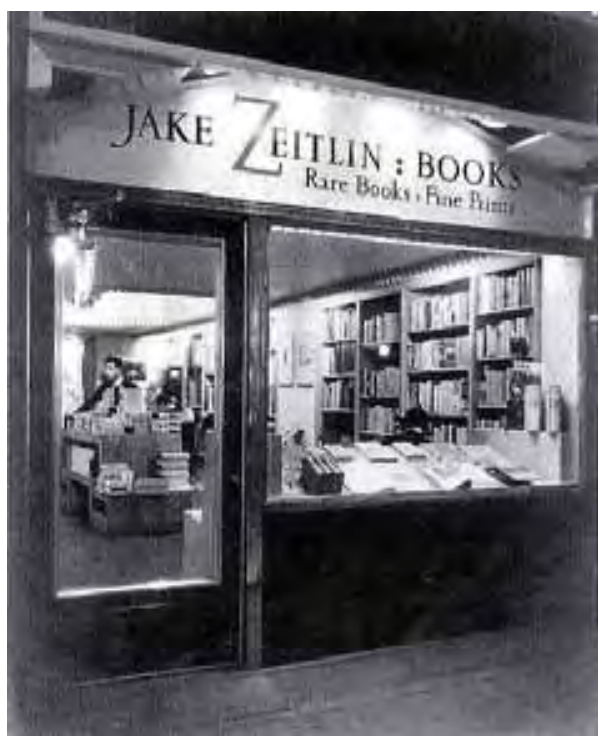




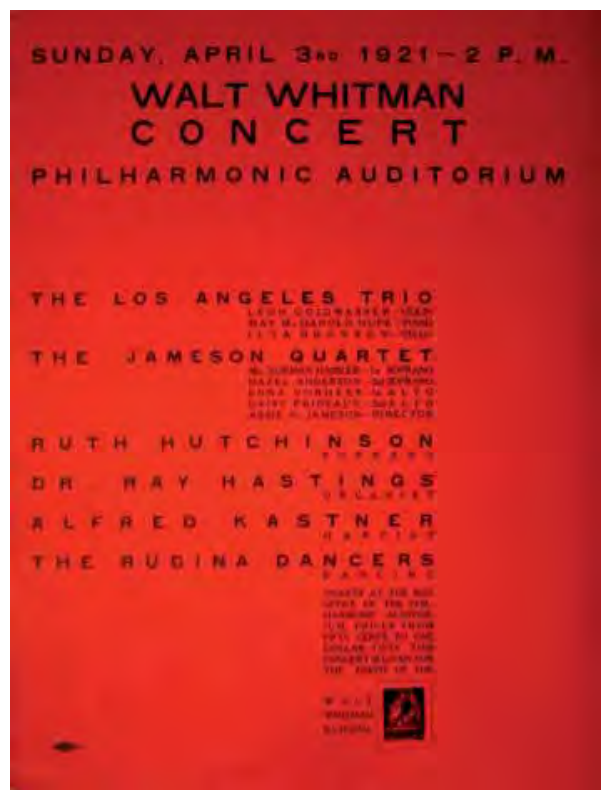

Como lugar de encuentro de la militancia de izquierdas, la experiencia de la Walt Whitman School supuso para los Schindler una fuente de contactos de gran importancia posterior en sus respectivas carreras como arquitecto y escritora. Entre las relaciones iniciadas en Boyle Heights, la más significativa fue su amistad de por vida con la familia Weston. En 1921, Chandler y Brett, los hijos mayores Edward Weston estudiaban en la Walt Whitman School, tal como Pauline Schindler relató en The Carmelite en un artículo ${ }^{122}$ de 1928 en el que elogiaba el talento artístico del joven Brett sobre el que afirmaba que era ya reseñable cuando le conoció como alumno en Boyle Heights. Dos años más tarde, en 1923, Pauline sería profesora junto con Leah Lovell de los dos hijos menores del fotógrafo, Neil y Cole que asistían a la escuela de Aline Barnsdall.

En junio de 1921, seis meses después de su llegada a Los Ángeles, en una carta sin destinatario identificado, Pauline relataba la intensidad de todas sus primeras actividades como militante: "Nos hemos involucrado tanto en el movimiento radical que apenas pasamos una sola noche en casa [...] Reuniones del Committee for the Worker's Defence [sic., Comité de Trabajadores], asambleas para la Walt Whitman School -más o menos concurridas-; cenas en los lugares más inverosímiles con los tipos más raros que nos facilitan una información de primera mano que de otro modo sería imposible tener; conferencias; charlas en las cuales apenas tenemos tiempo para detenernos y hacer un comunicado antes de ir a la siguiente o pasar por el impresor para revisar las pruebas de los materiales para la escuela; viajes con el coche para entrevistarnos con miembros de una comisión, un médico, un abogado y y [sic.] un psiquiatra [alienist], idas y venidas al hospital para visitar a un IWW [miembro de la Industrial Workers of the World], que ha pasado un mes en la cárcel esperando el juicio y que había sido tratado con tanta brutalidad por las autoridades y quien, además de sus heridas, está muy afectado mentalmente [...] Y con todo, en la vorágine del día, hemos ido corriendo a Pasadena a casa de un millonario radical [...] para escuchar a Max Eastman [...]. Todo el mundo estaba allíy tuvimos una estupenda conversación después de la conferencia [...] Upton Sinclair aprovechó para presentarme a su mujer [...] Fue una velada fantástica [...] En general, mucho mejor que cualquier ocasión en las que hay oportunidad de pasarlo bien en Chicago ${ }^{\prime \prime 23}$.

Aunque en su carta Pauline se refería tanto a su propia implicación como a la de Rudolph Schindler en todas estas iniciativas, no es difícil comprobar que su entusiasmo por ser parte activa el movimiento radical era mayor que el de su marido. Como apunta ${ }^{124}$ Robert Sweeney, su participación en la organización de comités y piquetes obreros (en Chicago había sido arrestada en 1915 por instigar a una huelga) y su enérgico apoyo a las actividades de la Worker's Defense League, dedicada a asistir a sindicalistas perseguidos políticamente, prueban sobradamente el celo militante de Pauline frente a los intereses, eminentemente artísticos, de Rudolph Schindler.

Por su parte, éste había entrado a formar parte de la Hollywood Art Association $^{125}$. Creada en 1920, esta agrupación tenía entre sus objetivos impulsar la construcción de un museo de arte en Hollywood. Schindler promovió e impartió diversas charlas en este foro, fundamentalmente sobre arquitectura y urbanismo. También con el apoyo de la Hollywood Art Association escribió un artículo para el rotativo local Holly Leaves en el que criticaba el modo en que gigantescas operaciones especuladoras estaban consumiendo territorio de Los Ángeles. Schindler fue, de hecho, uno de los primeros arquitectos en denunciar la destrucción de los valores paisajísticos de la región ${ }^{126}$. 


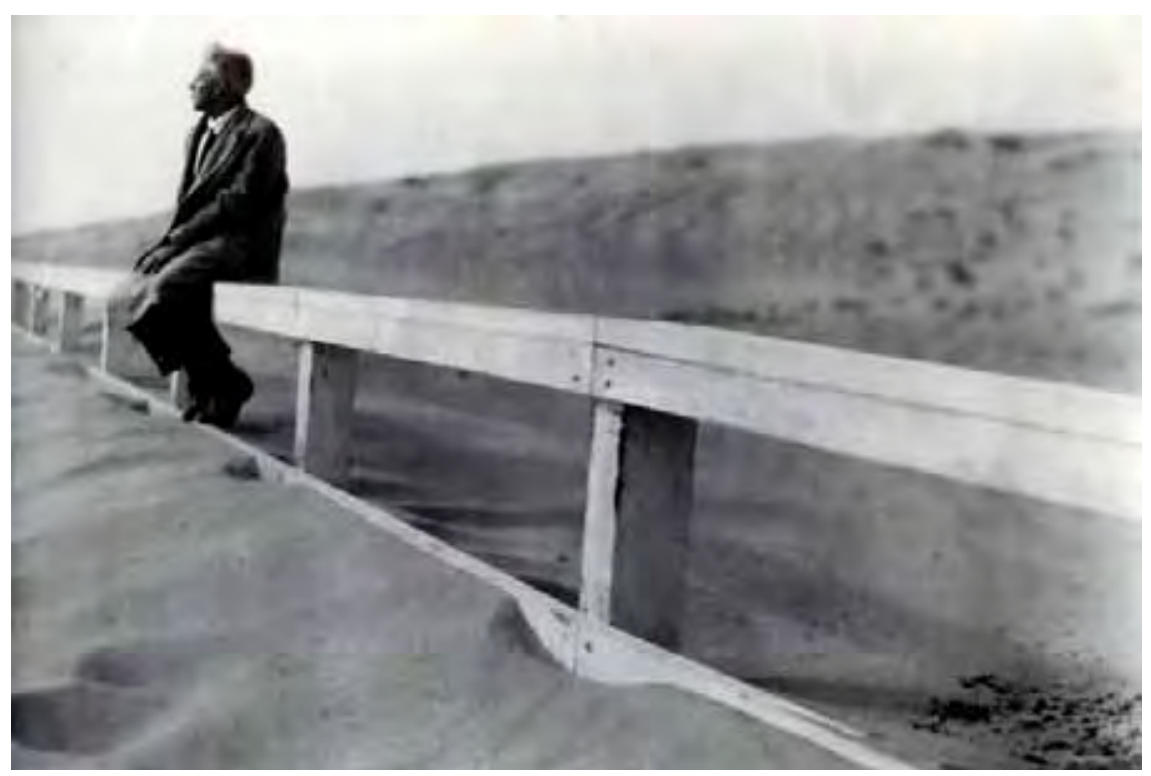

En octubre de 1922, Pauline mencionaba que su marido estaba siendo "muy activo en media docena de comités", aunque matizaba: "disfruta mucho con ello, pero creo que sería una pérdida de tiempo si no fuera por la cantidad de buenos contactos que supone ${ }^{1127}$. Con Schindler absorbido plenamente por las obras de Olive Hill y sus ratos libres dedicados a diferentes comisiones de cultura, Pauline consagraba buena parte de su tiempo a cultivar y extender su círculo de nuevas amistades. Sus cartas de la época dan testimonio de su frenética actividad diaria. Es evidente que, desde su llegada a la ciudad, Pauline estaba decidida a forjar una red de contactos personales a través de la cual poder participar en diferentes causas. Pero, sobre todo, quería asegurarse su imbricación en un tejido de relaciones donde ambos pudieran desarrollar sus intereses profesionales. Meses antes, ella misma había expresado: "de momento queremos un periodo de tiempo para conocer y disfrutar de la gente interesante con la que nos estamos relacionando [...] aunque, por supuesto, pronto querremos crear también nuestro propio ambiente $^{1128}$. En apenas un año y medio, Pauline consiguió cumplir su sueño de tener su propio salón.

\section{Pauline en Kings Road, 1922-27}

Harwell Hamilton Harris dijo en una ocasión sobre la vibrante atmósfera de Kings Road: "aquella gente no se estaba rebelando contra las viejas formas de vida, sencillamente no las tenían en cuenta para nada"129. Según Harris, los miembros del círculo de Pauline eran ante todo "aventureros que perseguían nuevos horizontes [...] Poetas, dramaturgos, bailarines, fotógrafos y músicos [...] Socialistas, reformadores e intelectuales de diversa procedencia eran también asiduos. Las reuniones no eran simples charlas amigables, sino que se discutía de ideas revolucionarias en todos los campos. Lo más Nuevo [sic], lo más Avanzado [sic]. No había enfrentamientos porque los participantes eran gente culta $y$, en lo fundamental, todos estaban de acuerdo. La mayoría vivían en la ciudad, otros eran visitantes esporádicos que iban y venían. Y todo el mundo podía traer libremente a quien quisiera con tal de que fuera interesante ${ }^{\prime \prime 130}$.

El modo de vida propiciado por la casa de Kings Road reflejaba los ideales de Pauline, sus ambiciones artísticas y sus convicciones sociales. Punto por punto, su recién estrenada vivienda respondía al contenido de aquella carta
Max Eastman fotografiado por Margrethe Mather y Edward Weston, 1921

Página anterior: Programa-anuncio de un concierto en la Walt Whitman School diseñado por Pauline Gibling Schindler (PGS) 
Edward Weston: Retrato de su amigo Ramiel McGehee, 1920. Fuente: Center for Creative Photography. University of Arizona

Página siguiente: Kings Road, Fotografía de Dorothy Gibling, 1923. Fuente: R. Sweeney

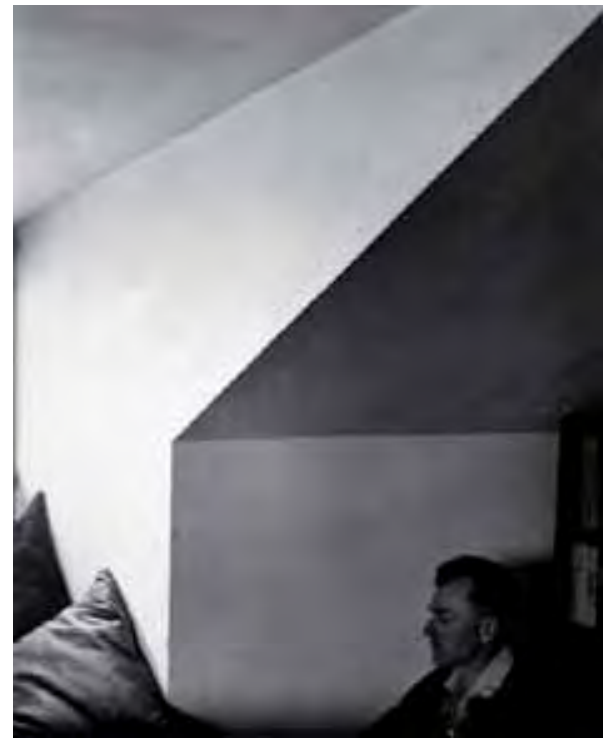

que Pauline había escrito a sus padres desde Chicago en 1916, cuando aún no había conocido a Schindler. Desde entonces ella aspiraba tener algo así como una cabaña a medio camino entre la naturaleza y la ciudad, una casa abierta "a los amigos de toda clase y condición [...] un lugar de encuentro tan democrático como la Hull House, donde millonarios y trabajadores, profesores e iletrados, lo espléndido y lo innoble se encontraran constantemente ${ }^{\prime \prime 131}$.

El mérito de Schindler fue condensar y representar este ideal en una innovadora forma arquitectónica ${ }^{132}$. Propuso una vivienda cuya concepción material, organizativa y espacial expresaba a los valores de una nueva arquitectura que se nutría de la esencia de California, un lugar tan especial que permitía, por fin, que el modo de vida ansiado por Pauline se hiciera realidad. Podría decirse por tanto que si la arquitectura era de Rudolph Schindler, la casa lo era de Pauline Gibling.

En octubre de 1921 los Schindler habían tomado la decisión de permanecer en la ciudad. En noviembre ya existía un primer encaje del proyecto y en enero estuvo listo para empezar a construir inmediatamente. A mediados de febrero se iniciaron las obras por el ala norte, la de los estudios de los Chace. Ésta fue la primera que se completó. Los Chace se mudaron el 12 de mayo, cinco días después Marian dio a luz a una niña. A la semana siguiente, sin gas ni electricidad, los Schindler llegaron a Kings Road. La vivienda se terminó con ellos dentro. Exceptuando el piano de Pauline, carecían de mobiliario. Aún así, ella escribía ${ }^{133}$ a sus padres que, desde la primera noche, con la única luz de las chimeneas, la casa era un hervidero de gente que pasaba a saludar; eran invitados de Schindler que acudían a conocer la obra o simplemente amigos que se presentaban de improviso y se quedaban a cenar con ellos en el jardín. Como su amiga Marian, Pauline también entró en la casa embarazada de casi nueve meses. Su único hijo, Mark, nació el 20 de julio de 1922. Pero la estresante actividad de la casa apenas se detuvo. Al contrario, tras las primeras fiestas, tertulias literarias y algunos comités de la Modern School, en pocas semanas, Kings Road se había consolidado como uno de los centros de reunión alternativos más concurridos de Los Ángeles, materializando así el sueño de Pauline.

Uno de los primeros visitantes de la casa fue Edward Weston quien, por entonces, era ya uno de los mejores amigos que la pareja tenía en la ciudad. Aunque Robert Sweeney sitúa la aparición de Weston en las vidas de los Schindler a partir de su llegada a Kings Road, éstos ya se habían conocido unos meses antes, en la Walt Whitman School. A través de Pauline, Rudolph Schindler y, después, Richard Neutra entablaron amistad con la familia Weston. Su relación personal se tradujo en diversas colaboraciones profesionales entre el fotógrafo, su hijo Brett y ambos arquitectos, un episodio aún insuficiente conocido y sobre el que se incidirá más adelante.

Una carta de Pauline Schindler a sus padres relata las circunstancias en las que Edward Weston visitó la residencia de Kings Road en el verano de 1922. Invitado por la propia Pauline a una improvisada velada musical en su casa, el fotógrafo había acudido a la cita como colofón a una serie de fiestas y encuentros en casas de otros artistas que él y el matrimonio Schindler habían encadenado a lo largo de una tarde de domingo: "El domingo quisimos pasar un buen rato y llamamos al señor Weston, un artista del que nos habían hablado mucho y cuya personalidad nos había gustado desde que le oímos dar una conferencia y vimos sus fotografías. Es una persona extremadamente interesante y, cómo no, respondió atentamente a RMS enseñándonos sus obras. 


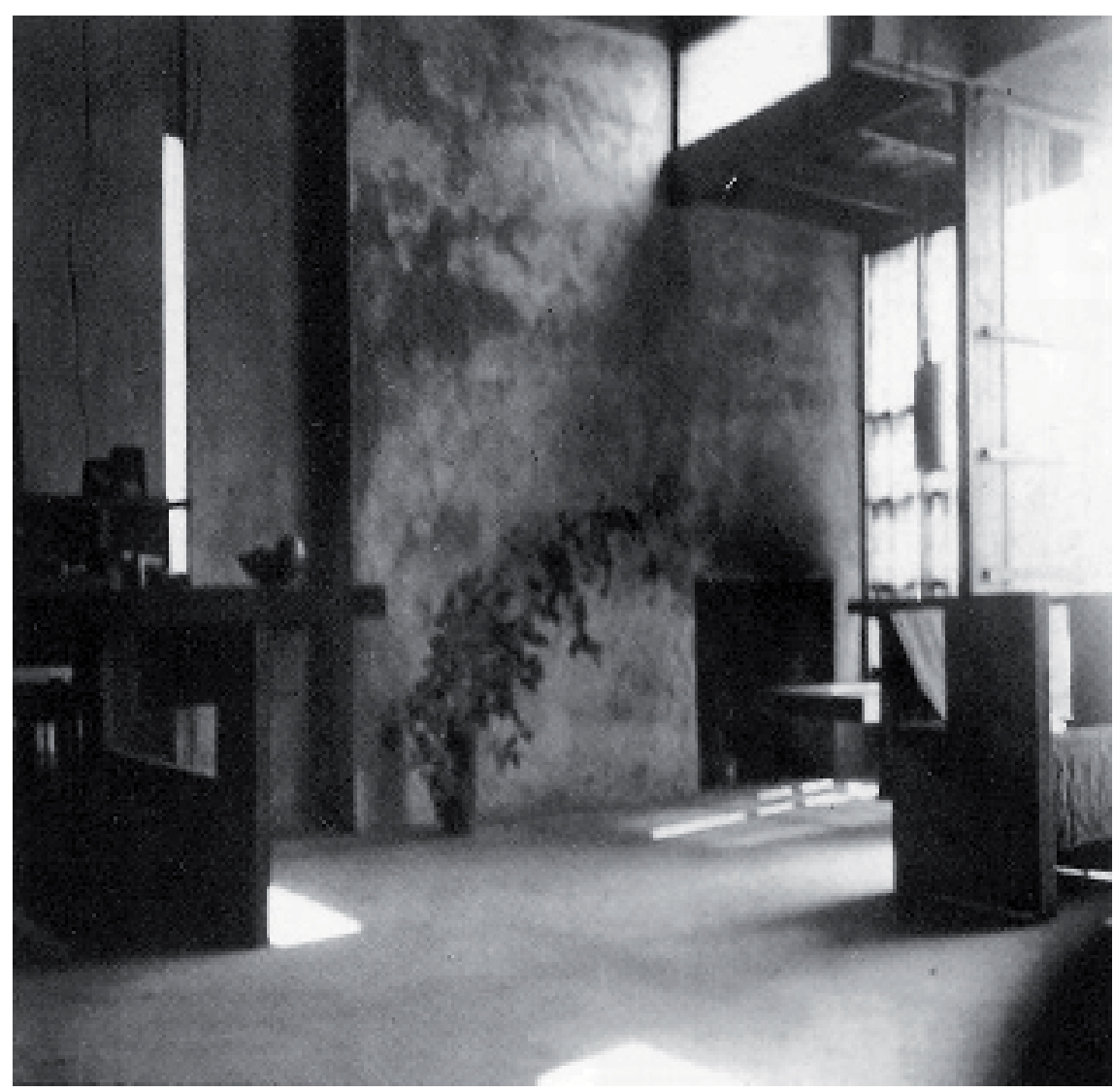

Más tarde, cuando surgió el momento, nos llevó a la casa de una pianista muy brillante que pertenece a su círculo de amigos. De un modo muy natural nos dispersamos por su estudio y nos sentamos en el suelo a escucharla tocar. Es realmente brillante -podría decir que la mejor intérprete del repertorio modero francés de la Costa Oeste [...]. Poco antes de la media noche sugerí que nos trasladáramos a nuestra casa para probar el Steinway [...]. El señor Weston, por supuesto, se mostró entusiasmado con la casa y dijo que estaba deseando verla a la luz del día. Fue una noche increíblemente estimulante [...]. RMS y yo apenas pudimos dormir con la excitación de la música y las fotografías del señor Weston"134. De acuerdo con el contenido de esta carta, Edward Weston habría estado por primera vez en Kings Road el 9 de julio de 1922, es decir, apenas un mes después de su inauguración.

Lloyd Wright también figura en las cartas de Pauline como otro de los primeros visitantes de la casa. Como más tarde haría Dione Neutra, el arquitecto tocaba el violoncelo y, a veces, acompañado por Pauline al piano, compartía con ella el improvisado escenario de conciertos en los que se convertía su estudio cuando se retiraban las puertas para que el público se acomodara en el jardín.

La hermana de Pauline, Dorothy Gibling, profesora en la University of California, llegó a Kings Road poco después del nacimiento de su sobrino y ocupó el pabellón de invitados durante algunas semanas ${ }^{135}$. Las descripciones de la casa y las fotografías tomadas por Dorothy Gibling constituyen algunos de los primeros testimonios escritos y documentos gráficos sobre la vida en Kings Road. Fue precisamente la hermana de Pauline quien desmontó por primera vez el mito de los sleeping baskets, asegurando que desde el principio los Schindler dormían en sus estudios de planta baja. Aunque ni sus padres ni su hermana Dorothy tenían unas ideas tan radicales como Pauline aprobaban e, incluso, aplaudían su insólito y "delicioso estilo de vida". ${ }^{136}$ 

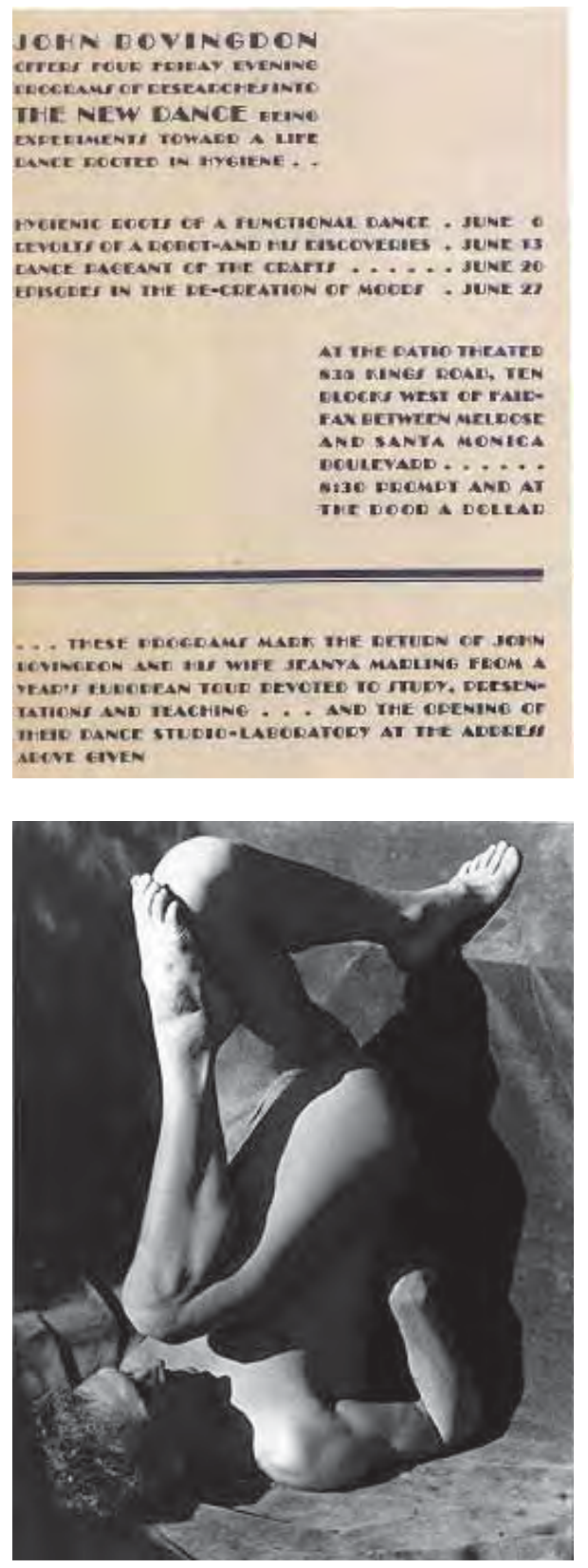

De acuerdo con Robert Sweeney ${ }^{137}$ y con las cartas que Dorothy Gibling envió a varios de sus amigos, sus tempranos recuentos de las actividades de la casa arrojan luz sobre determinados comportamientos. Por ejemplo, que los quehaceres domésticos recaían en Marian Chace. Ésta se encargaba de las comidas, asistida por su madre y por la niñera de su hija, que también vivían en Kings Road. Según la hermana de Pauline, los alimentos se preparaban en la cocina y se llevaban en bandejas hasta el jardín, donde se comía junto a la chimenea. El menú solía consistir en ensaladas, verduras y piezas de fruta, una dieta eminentemente vegetariana, tal como disponían los Schindler.

Frente al papel más convencional asumido por Marian, Pauline promovía las actividades culturales, organizaba los eventos y ejercía de anfitriona, un cometido por el que siempre fue celebrada tanto por la calidad de sus atenciones como por el interés de su conversación ${ }^{138}$.

El arquitecto vienés $A$. R. Brandner, otro de los huéspedes de los Schindler e inquilino durante algún tiempo en Kings Road, relató: "Pauline era quien organizaba aquellas reuniones, aunque era Schindler el que más las disfrutaba. Aquellas fiestas eran tiempos felices, encuentros únicos que reunían tanto a intelligentsia como a personajes desesperados. Pauline prefería veladas serias, pero entonces Schindler y Sadakichi Hartmann intervenían para hacerlas gloriosamente divertidas"139. El propio Harwell Hamilton Harris afirmó: "Los Schindler eran tan poco convencionales como su casa. RMS -genial, amistoso, siempre proclive a disfrutar de la vida, escondiendo su carácter serio tras sus formas jocosas- llevaba el pelo largo y ondulado hasta el borde de la camisa, blanca y abierta siempre muy por debajo del cuello. Sus pantalones anchos blancos, faja y sandalias mexicanas le permitían distinguirse de sus contemporáneos" ${ }^{\prime 140}$. La puesta en escena era para Schindler tan importante como el contenido para Pauline. La decoración de las improvisadas mesas, las luces en los árboles, las ramas distribuidas por toda la casa, las telas desplegadas por el jardín y los fuegos encendidos en cada rincón del patio convertían cada domingo por la noche en una experiencia inolvidable.

Cuando, en octubre de 1925, el dramaturgo Maurice Browne, fundador del Chicago Little Theatre y antiguo colaborador de Aline Barnsdall, pasó una temporada en la ciudad, su amiga Pauline le invitó a dar una conferencia en Kings Road y organizó una gran fiesta en su honor. Según ella sería la mayor celebrada hasta ese momento, como anunciaba a su madre con gran excitación: "[la fiesta] va a ser enorme. Nunca hemos tenido más de cien invitados a la vez, pero esta vez será algo desbordante ${ }^{\prime \prime 141}$. Años más tarde, Browne escribiría sobre su anfitriona "Pauline Schindler, brillante, apasionada, sarcástica, intentaba crear un salón con todos los malditos de Hollywood"142.

Sophie Gibling, quien visitaba regularmente Los Ángeles para pasar temporadas con su hija y cuidar de ella y de su nieto, incidió también el carácter único de las veladas de Kings Road"143: "cuando aparecen sus invitados [Pauline] es la más fascinante de las anfitrionas. El domingo por la noche volví a quedar impresionada por el ambiente y el carácter irrepetible de sus fiestas, así como por el interés de toda la gente a la que es capaz de convocar" ${ }^{144 .}$

En otra ocasión, en una carta escrita en septiembre de 1926 y enviada desde Los Ángeles a su marido Edmund J. Gibling, Sophie describía otro de los acontecimientos artísticos recurrentes de la casa, las performances del bailarín John Bovingdon: "[Se trataba de] una especie de fiesta. Los Neutra y John [Bovingdon] estaban presentes, la cena se servía en el jardín, en torno 


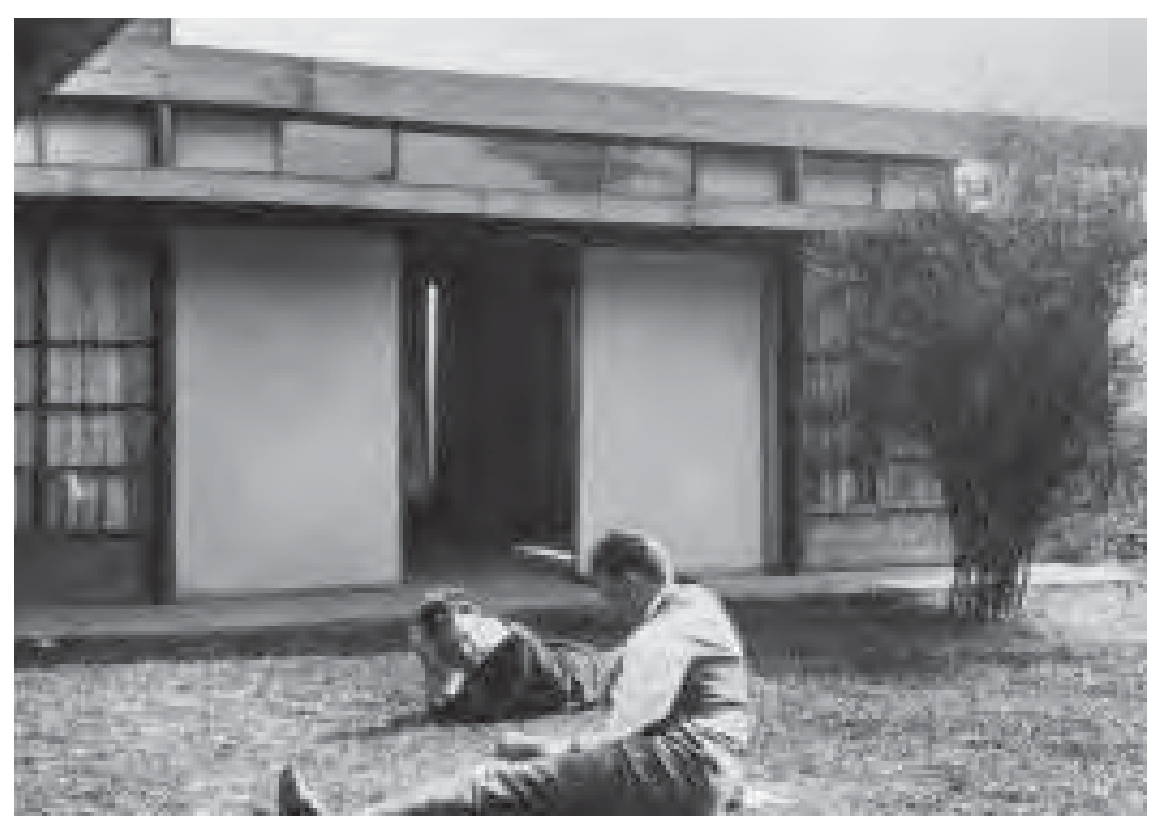

a la chimenea al aire libre, en una casi total oscuridad. Habían sacado el gran sofá y todo resultaba muy efectivo... John lucía un fantástico atuendo de seda [...] Entre otras cosas, discutimos la posibilidad de que bailara una danza cinematográfica. R. M. [sic.] sugirió entonces que partiera de su tema más básico, 'Breath [Aliento]' desarrollándolo en sus relaciones con la vida, el universo, la alegría, el amor, el miedo, etc." ${ }^{145}$. Por su parte, Dione Neutra, testigo -como afirmaba Sophie Gibling- de las coreografías de Bovingdon y de su compañera Jeanya Marling, también narró alguna de aquellas exóticas escenas: "Bailaban prácticamente desnudos, lo cual, en aquella época era todo un acontecimiento en Hollywood. Era de noche, el jardín estaba iluminado y colgando de algunas cuerdas había varios gongs que golpeaban alternativamente para producir los sonidos de su propia música. Recuerdo una danza que denominaba La Ascensión del Hombre. Primero, él se arrastraba, y poco a poco se iba incorporando desplazándose a cuatro patas para, después, muy despacio, adoptar una posición erecta y echar a andar sobre sus piernas hasta que comenzaba a bailar. Era algo muy emocionante ${ }^{1146}$.

Durante los veranos de 1925 y 1926 Kings Road fue una explosión de actividades culturales y de ocio. Según Dione Neutra, la gente acudía a la casa porque entonces tenía fama de que ser una auténtica locura ${ }^{147}$. Cobrando un módico precio por la entrada a algunos de los eventos más multitudinarios, Pauline aprovechaba el reclamo de sus invitados para obtener pequeños ingresos extras con los que contribuía al mantenimiento de la casa y, por supuesto, a sufragar nuevas iniciativas. Gracias a su habilidad como diseñadora gráfica, ella misma creaba muchos de los carteles y folletos que anunciaban los actos de carácter público. Sus conocimientos de dibujo y tipografía, adquiridos de joven y ejercitados a través de su colaboración con Schindler -a quien ayudó puntualmente a producir y rotular planos-, o con revistas literarias y asociaciones políticas, le resultarían de gran utilidad en su labor editorial posterior. De hecho, en numerosas ocasiones Pauline fue responsable del diseño y maquetación de sus artículos o de las publicaciones que dirigió personalmente e, incluso, entre 1931 y 1932, ella misma impartió clases de tipografía y diseño editorial en la Universidad del Sur de California ${ }^{148}$.

Con independencia del espíritu progresista de Kings Road, para los Schindler cualquier evento constituía una oportunidad para reunir a los amigos más
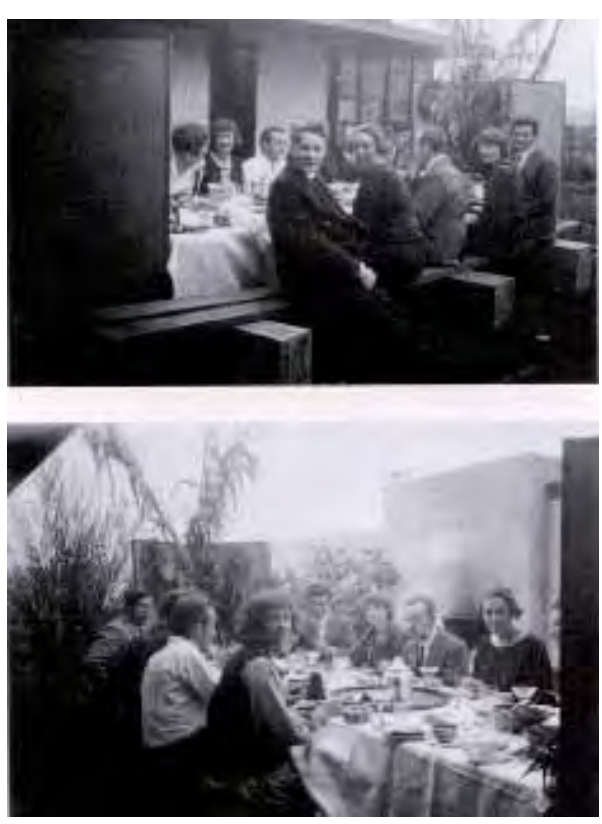

Izquierda: Rudolph Schindler y el arquitecto Werner Moser en Kings Road, abril 1924. Fuente: Sweeney

Derecha: Comida de Acción de Gracias en Kings Road, 1924. Fuente: Sweeney

Pagina anterior arriba: Anuncio de diversas actuaciones de John Bovingdon en Kings Road, junio 1930

Pagina anterior abajo: John Bovingdon fotografiado por Imogen Cunningham, 1928 


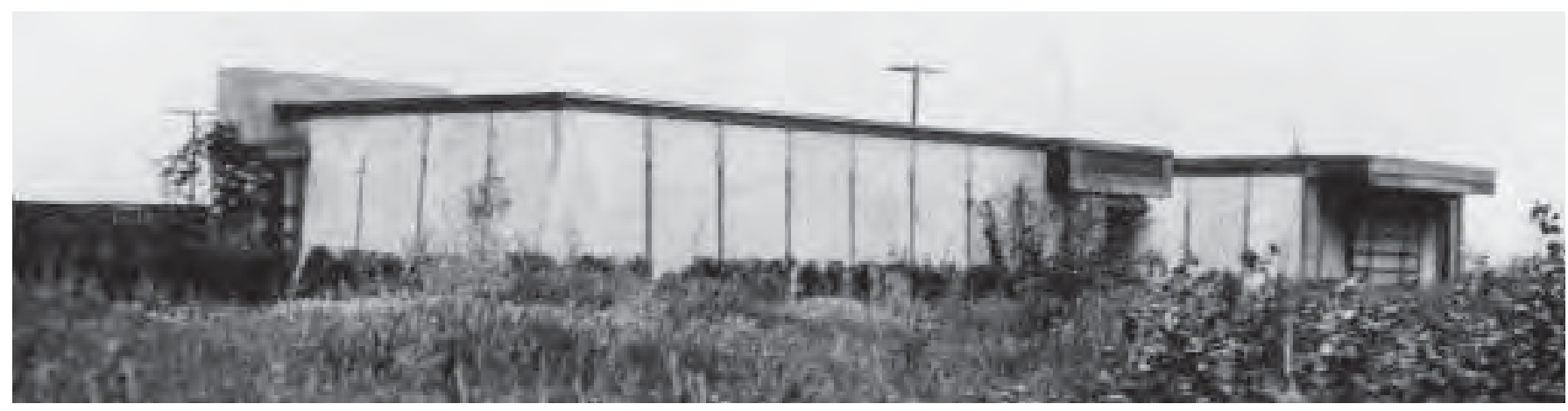

Kings Road en 1924 fotografiado por Werner Moser

Página siguiente: Dione y Richard Neutra con su hijo mayor, Frank, en Kings Road, 1925. Fuente: Sweeney cercanos de su círculo, incluso las festividades más tradicionales, como Navidad y Acción de Gracias, que Pauline organizó hasta 1924. En una imagen de la comida de Acción de Gracias de 1923 proporcionada por Robert Sweeney, sentados a la mesa en improvisados bancos, se puede distinguir, entre otros invitados, a Dorothy Gibling; al artista Herman Sachs, futuro cliente de Schindler y que había colaborado con Pauline en la Hull House; así como a Karl ${ }^{149}$ y Edith Howenstein, amigos desde Chicago de los Schindler -recuérdese que ella fue quien presentó a la pareja-y huéspedes durante dos años (1922-24) de su pabellón de invitados.

Para Sweeney, la participación de Clyde y Marian Chace en la vida social de la casa no parece estar clara ${ }^{150}$. Por un lado, entre 1922 y 1923 el matrimonio pasó varias temporadas fuera de la ciudad, por otro, de la correspondencia de Pauline se desprende que su implicación en la creación del ambiente de Kings Road no fue notoria o, al menos, que los Chace no tuvieron un papel tan activo como habían tenido en la construcción de la vivienda. Seguramente, la diferencia de caracteres entre ambas parejas hizo que los Chace vivieran la casa de manera menos apasionada que los Schindler. Después de haber habitado en Kings Road de manera intermitente durante dos años, en julio de 1924, los Chace rescindieron su contrato con los Schindler y abandonaron la ciudad para instalarse en Florida -de donde procedía Marian y donde Clyde fundó con su suegro la empresa Da Camara-Chace Company en West Palm Beach.

En cualquier caso, la relación profesional entre Rudolph Schindler como arquitecto y Clyde Chace como contratista fue fructífera, como atestigua su colaboración en algunas de las obras más significativas llevadas a cabo por Schindler durante los años que la pareja permaneció en Los Ángeles, entre ellas, la cabaña Popenoe en Coachella (1922) y los apartamentos Pueblo Ribera en La Jolla (1923-25). Esta relación continuó aún durante los años 30, siendo Clyde contratista de algunas obras del arquitecto. Sin embargo, Pauline y su amiga Marian dejaron de escribirse, lo que induce a pensar en una confrontación de tipo personal entre ambas ${ }^{151}$.

Tras la marcha de los Chace, sus dos estudios quedaron disponibles como vivienda de alquiler. El ala norte de la casa fue habitado sucesivamente por numerosos inquilinos de variada procedencia, aunque no todos se hicieron fácilmente al modo de vida de los Schindler. Los primeros fueron Arthur Rankin, un actor de cine mudo de cierta fama, y su mujer Ruth. En los casi dos años que residieron en Kings Road, Arthur realizó nueve películas y consolidó los contactos de los Schindler con el mundo de Hollywood ${ }^{152}$. De hecho, mientras ellos residían en las antiguas dependencias de los Chace, otro actor, George O'Hara, se mudó al apartamento de invitados ${ }^{153}$. Cuando O’Hara dejó libre el pabellón de huéspedes a principios de 1925, casi sin 
solución de continuidad, este pequeño estudio independiente pasó a ser ocupado los Neutra.

Dando por finalizada una breve estancia en Taliesin, Richard y Dione Neutra llegaron a California en febrero de 1925 junto con su hijo mayor, Frank, a quien habían llamado así precisamente en honor de Wright. Pocos meses antes, en el verano de 1924, Schindler y Neutra habían coincidido en Nueva York mientras éste aguardaba que su mujer desembarcara en América para ir a Wisconsin, donde Wright les había invitado a vivir y trabajar. Fue el primer encuentro entre los dos compatriotas después de diez años de correspondencia. Seguramente, las conversaciones con Schindler en Nueva York y su relato en primera persona de sus logros en Kings Road hicieron que Neutra desistiese de permanecer más tiempo que el de una mera estancia de cortesía con Wright y que, ante las expectativas de aquella tierra de oportunidades, resolviera abandonar las comodidades de Taliesin para labrarse un futuro en California. Un par de años antes, Schindler, siempre optimista, había escrito a su antiguo camarada: "¿Tienes una idea clara de lo que es el Oeste? 0 , como ocurre con la mayoría, ¿se trata de una necesidad romántica? En cualquier caso seguro que podrás ganarte la vida tan bien aquí como en Chicago $y$, siendo extranjero, posiblemente mejor. Estaré encantado de recibirte y de ayudarte con las dificultades iniciales. Y mientras esté en mi mano, no nos moriremos de hambre" ${ }^{154}$. Schindler fue a recogerlos a la estación y les acomodó en el apartamento de huéspedes de su casa, donde residieron hasta final de año ${ }^{155}$, cuando se instalaron en los dos estudios del ala norte. Permanecerían en Kings Road durante cinco años más hasta que, en 1931, Richard Neutra regresó a Los Ángeles después de su gira por medio mundo promocionando la Lovell House (1927-29).

Dione Neutra relató que llegaron a Los Ángeles bajo una intensa lluvia ${ }^{156}$, por lo que su primera impresión de la casa fue que ésta era demasiado oscura. No obstante, pocos días despúes escribió a su amiga Frances Toplitz: "Schindler nos esperaba en Los Ángeles y nos condujo a su extraña casa en Hollywood, la cual posee su propia belleza, considerando la falta de medios económicos de Schindler. Vivimos en un apartamento de invitados, una habitación espaciosa con su cocina y su propio baño que posee una entrada independiente. La señora Schindler trata siempre de ayudar y ambos nos demuestran su gran amistad y apoyo [...] Si Schindler y Richard van a trabajar juntos está todavía por decidir. Por desgracia, Schindler tiene muy pocos proyectos"157. A pesar de su amistad, las relaciones entre ambas parejas pronto se revelarían complicadas.

Por un lado, profesionalmente, los intereses arquitectónicos y el método de trabajo de Schindler diferían sensiblemente de las opiniones y del carácter de Neutra. A pesar de ello, en un primer momento, ambos trataron de colaborar en algunas obras. Lógicamente, sin contactos en la ciudad, Neutra dependía de los encargos de Schindler y no tenía más opción que familiarizarse con su entorno. En una carta de Richard Neutra enviada a la madre de Dione, el arquitecto escribía: "Estoy trabajando en un jardín para Schindler cerca de Griffith Park, para Miss Barnsdall en Olive Hill. Me levanto a las 5.00 de la mañana para poder disponer de dos horas para mi propio trabajo [Neutra trabajaba entonces en la redacción del texto de Wie Baut Amerika?]. Por eso me gustaría estar en la cama antes de las 10.00 de la noche, lo cual es dificil dado que Schindler y sus amigos rara vez lo hacen antes de las 2.00 de la mañana. Eso, desde luego, no es para mí. Pasar la noche entre bocanadas de humo no tiene tanto interés para mí como tener la cabeza fresca por la mañana ${ }^{\prime \prime 25}$.

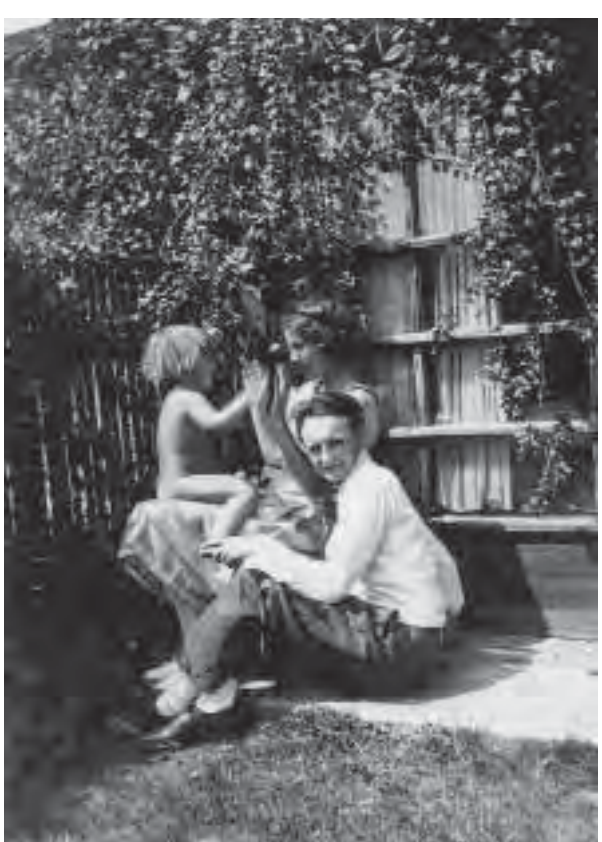




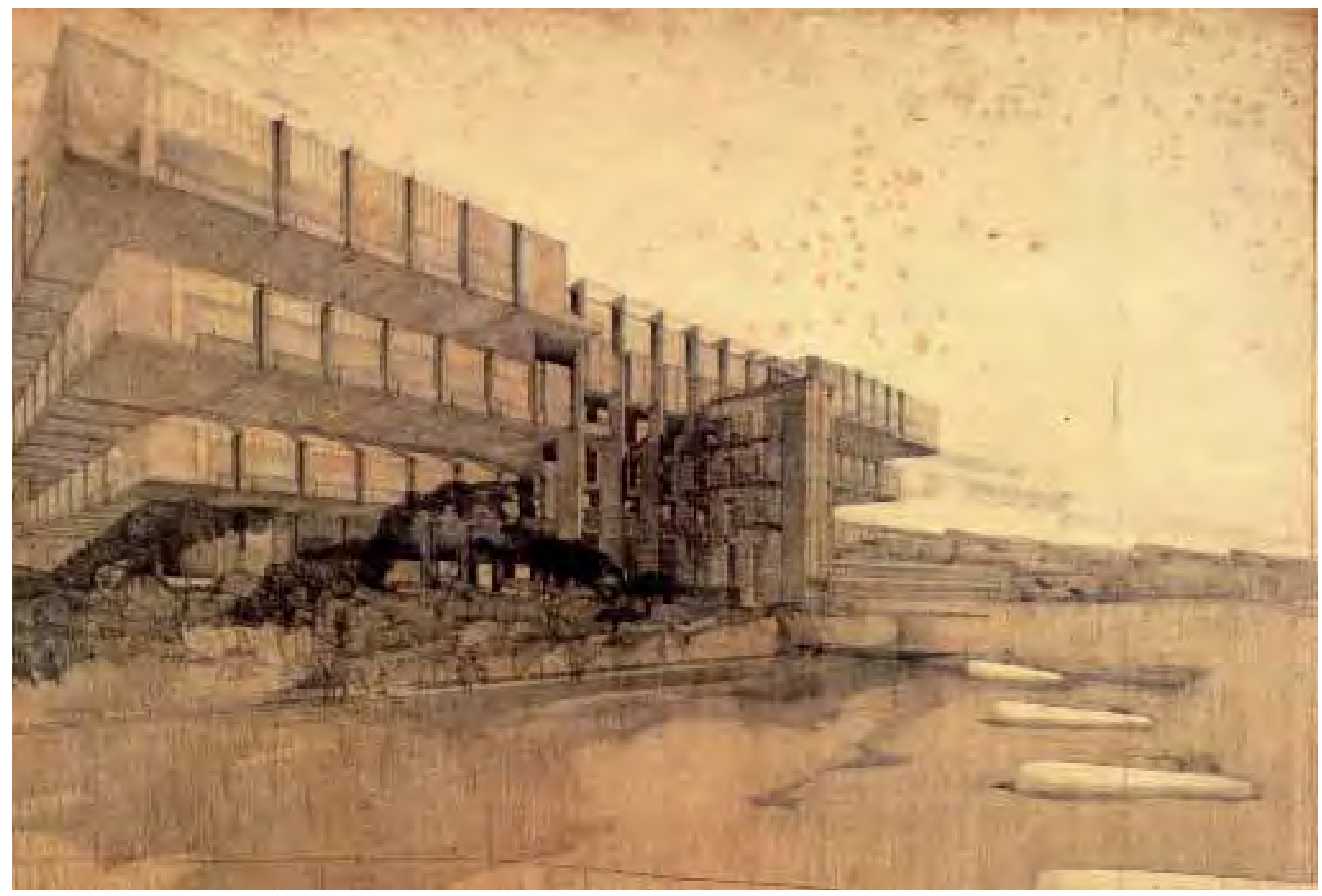

Rudolph Schindler y Richard Neutra: Propuesta de edificio para la Socieda de Naciones, Ginebra, 1926 Fuente: Sweeney

Página siguiente: Galka Scheyer en Kings Road, hacia 1930. Fuente Robert Sweeney
Además de su implicación en el diseño de la pérgola y piscina de chapoteo para el Parque Barnsdall, los primeros trabajos de Richard Neutra en California consistieron en el paisajismo de viviendas de Schindler como la casa How (1925) o la Lovell Beach House (1925-26). Con estos proyectos apenas obtenía ingresos por lo que tuvo que buscar empleo en diferentes despachos de la ciudad para hacer frente a sus gastos. Neutra trabajaba durante el día para otros arquitectos y por la tarde, al llegar a casa, extendía su jornada para colaborar con Schindler.

Conforme Neutra consolidaba sus propios contactos y su dependencia de Schindler se iba diluyendo, su asociación profesional fue siendo cada vez más abierta. Además, Neutra aprobó los exámenes estatales para poder ejercer como arquitecto en California a principios de 1926. Schindler sin embargo no obtuvo su licencia hasta 1931 por lo que, a partir del momento en que Neutra dejó su estatus de diseñador para ser oficialmente arquitecto, los papeles comenzaron a invertirse ya que no precisaba la firma de ningún otro técnico para validar su trabajo. Por su habilidad para captar clientes, Neutra comenzó a conseguir mayores encargos fuera de la tipología residencial mientras que el círculo de clientes de Schindler continuaba centrado en las relaciones de Pauline, en su mayoría profesionales liberales, bohemios e intelectuales de izquierdas cuya demanda eran principalmente viviendas privadas y pequeñas reformas.

Esta situación se formalizó en 1926 cuando, tras ganar su licencia y pensando en metas profesionales más ambiciosas, Neutra propuso los términos de un sistema de colaboración flexible en el marco de una sociedad entre ambos y el urbanista Carol Aronovici que, con sede en Kings Road, denominaron Architectural Group for Industry and Commerce (AGIC). Entre 1926 y 
1930 AGIC centró sus esfuerzos en proyectos de mayor envergadura como edificios comerciales, un club social, cafés, pequeños hoteles, un grupo de viviendas y un auditorio y centro cívico cerca de Richmond. Ambos supervisaban todos los proyectos, aunque la autoría era siempre más de uno que de otro arquitecto. Schindler abordó principalmente proyectos no construidos y Neutra los apartamentos Jardinette (1927), el primer edificio Estilo Internacional de Los Ángeles y su obra de mayor relevancia hasta esa fecha.

Pero las primeras desavenencias no tardaron en producirse, algunas de ellas importantes, como la del concurso para la nueva sede de la Sociedad de Naciones en Ginebra, fallado en 1927. Aunque ambos habían concurrido en equipo, Alfred Niedermann, el padre de Dione, que había quedado encargado de coordinar la entrega del proyecto en Europa, omitió por descuido el nombre de Schindler y éste, a pesar de las reiteradas disculpas e intentos de reparación por parte de Neutra, acabó disgustado con su amigo. No obstante, ni su disparidad de criterios, ni desencuentros como el de Ginebra, ni otros episodios como el la asignación de los encargos Lovell afectaron tanto la relación profesional entre ambos arquitectos como para que terminase en ruptura, como generalmente se piensa y como se tratará más adelante.

Por otro lado, en el terreno personal y como se desprende de citada carta de Richard Neutra a su suegra en Europa, la pareja encontró algunas dificultades para adaptarse al particular modo de vida de la casa. Sobre todo Dione Neutra, quien solía ser blanco de las críticas de Pauline por sus ideas más convencionales ${ }^{159}$. Dione pensaba que Pauline la consideraba una mojigata y que, por esa razón, se burlaba de ella. En el momento en que llegaron a Kings Road, Pauline atravesaba una etapa muy difícil en su relación emocional con Schindler, lo cual extremó la variabilidad de su carácter. Thomas Hines lo expresó escribiendo que la "vólatil esposa de Schindler [...], alternativa e impredeciblemente, intrigaba, atraía, desconcertaba y se ganaba la antipatía de los Neutra"160.

En 1983, un año después de la publicación de la monografía de Hines sobre su marido, Dione confirmó al historiador al confesar en su entrevista con Lawrence Weschler para el Oral History Program de la Universidad de California en Los Ángeles que, en realidad, la razón para aquel comportamiento era que Pauline proyectaba habitualmente sobre ellos su frustración con Schindler: "Me llevó tiempo darme cuenta de su inestabilidad, de su carácter cambiante, de su infelicidad como ser humano y de su desdichada relación con Schindler"161, decía. Parece claro que la amistad de Pauline Schindler con Dione y Richard Neutra era sincera, pero también que, durante aquellos años, inevitablemente se vio empañada por las dificultades de su convivencia diaria.

Hay que recordar que Pauline ya había favorecido al matrimonio Neutra antes incluso de que se instalaran en su casa. Como ciudadana americana, había avalado su solicitud de inmigración, cuya petición había sido denegada en diversas ocasiones por el Departamento de Estado, por lo que, en última instancia, al ayudar a la expedición de su visado, fue ella quien propició el acceso de Neutra a los Estados Unidos ${ }^{162}$. Después, por unas u otras razones, Pauline no dejó nunca de beneficiar a Neutra; ya fuera presentándole a futuros clientes; o a políticos y funcionarios de izquierdas como su amigo Frank Wilkinson ${ }^{163}$ que facilitaron sus encargos de viviendas sociales; o de organizarle conferencias promocionales; o de escribir fervientemente sobre su trabajo en casi todas las revistas especializadas para las que trabajó desde finales de los años 20.

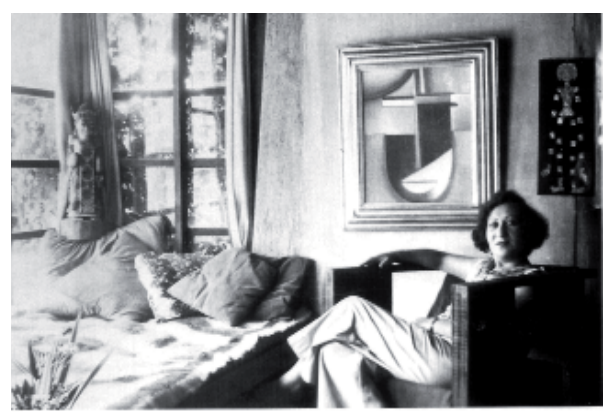




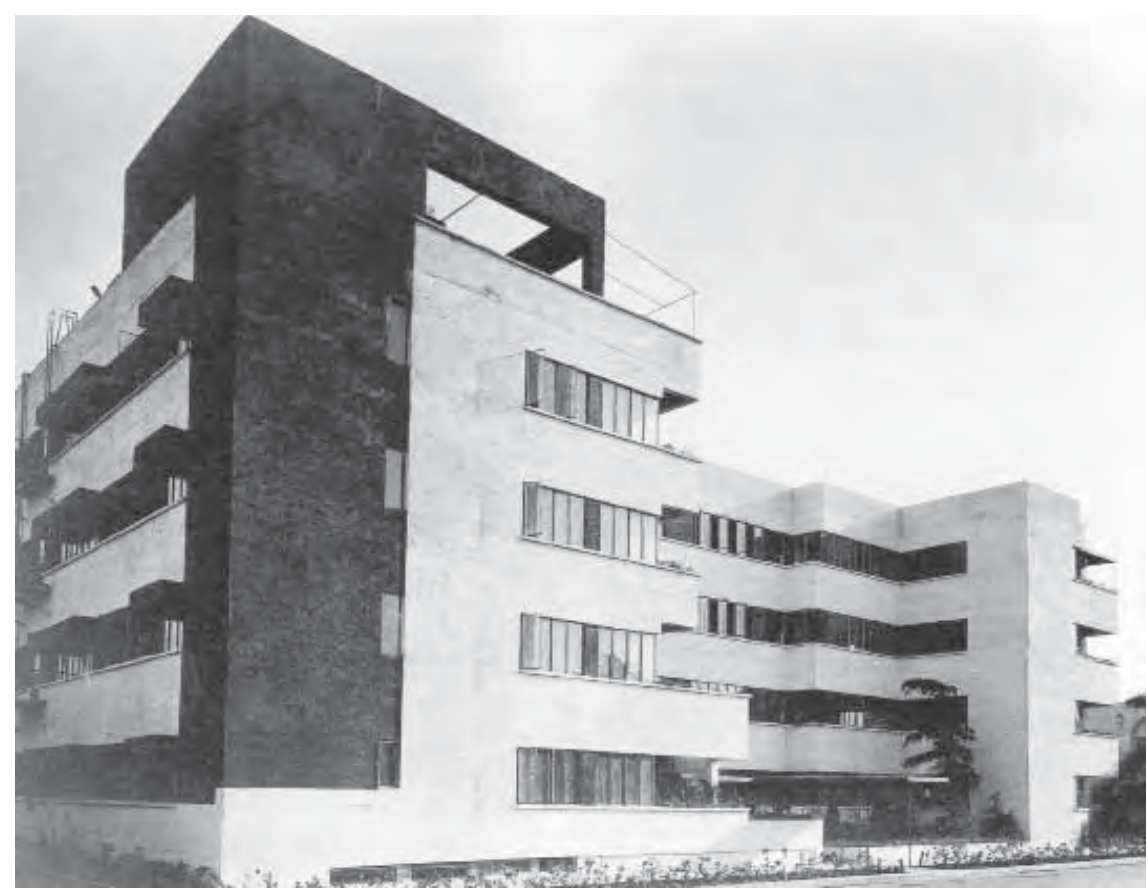

Richard Neutra: Jardinette Aparments Building, Los Ángeles, 1927. Fotógrafo desconocido, probablemente el propio Neutra

Página siguiente: Johan Hagemeyer: Fotografía de Point Lobos, 1925. Fuente. Metropolitan Museum of Art
Por ello, a pesar de sus diferencias, Dione hablaba con respeto de Pauline. Solía decir de ella que era una de las mujeres más inteligentes y con mayor don de palabra que había conocido ${ }^{164}$. También de manera retrospectiva afirmó que los años que pasaron en Kings Road, a pesar de tratarse de un modo de vida totalmente desacostumbrado, fue una etapa feliz de su vida y que, en términos generales, siempre se sintieron muy cómodos en la casa. Y, por supuesto, reconoció toda la ayuda que les había prestado al promocionar la obra de su marido: "[Pauline] era muy intelectual [...] disfrutaba discutiendo y por ello era difícil hablar con ella. Pero siempre le interesó mucho la obra de Mr. Neutra, y también le ayudó mucho. Por ejemplo, fue ella quien organizó su primera conferencia en América, en la Hollywood Art Association. Aunque también creo que si le ayudó tanto fue para disgustar a Schindler ${ }^{\prime \prime 165}$.

En 1927, Pauline era ya incapaz de sobrellevar las cada vez más frecuentes infidelidades de su marido. Sus crisis de ansiedad se habían ido agravando y se producían casi a diario. Richard y Dione Neutra, y también Galka Scheyer, que ese verano se había instalado en el apartamento de huéspedes $^{166}$, fueron testigos de la tensión entre los miembros de la pareja. El distanciamiento entre ambos había comenzado en junio de $1924^{167}$, tras el intento de suicidio de Pauline mientras su marido estaba en Connneticut trabajando para Helena Rubinstein. Desde entonces su salud mental se había resentido considerablemente, aunque experimentó épocas de cierta mejoría. Él se quejaba del carácter irascible de su mujer, mientras que ella, aunque consideraba el matrimonio un mero formalismo para contentar la única demanda que le había exigido su familia para sufragar su estilo de vida, no podía tolerar la situación. Despúes de tres años en los que se sucedieron periodos de tensos enfrentamientos con temporadas de relativa calma (o, al menos, "de menor violencia" -en palabras del propio arquitecto ${ }^{168}-$ ), su ruptura definitiva se produjo en el verano de 1927. Todo apunta ${ }^{169}$ a que en ese momento, Schindler mantenía una relación con su amiga y clienta Leah Lovell -y probablemente también con su hermana Harriet-, un affaire de importantes consecuencias para la historia de la arquitectura, como se abordará más adelante. Una noche de agosto, en secreto para no provocar una nueva pelea ${ }^{170}$, Pauline se marchó de Kings Road llevándose a su hijo Mark. 


\section{El círculo de Carmel, The Carmelite}

A partir de ese momento, el trato entre Pauline Gibling y Rudolph Schindler fue sólo profesional y su forma de comunicación estrictamente epistolar. No obstante, Pauline nunca dejó de considerarle un genio y a pesar de su separación y de su enfrentamiento personal siguió divulgando y defendiendo enérgicamente su trabajo, hasta el punto de convertirse en su más elocuente panfletista.

Durante aproximadamente una década, Pauline vagó por toda California. Recaló en diversas ciudades como Carmel, Ojai, San Francisco o Los Ángeles, ciudad a la que regresaba intermitentemente. Su primer destino fue Halcyon, una pequeña comunidad utópica de artistas y escritores bohemios fundada en 1903 por adeptos de la mística teosófica al sur de San Luis Obispo.

Su amiga la escritora Ellen Janson ${ }^{171}$, quien curiosamente sería una de las últimas clientas de Schindler y la mujer con la que el arquitecto terminó sus días $^{172}$, le brindó asilo en su casa de la costa. Janson era por aquel entonces pareja sentimental de Maurice Browne -con quien la poetisa había iniciado una relación en 1924 tras el divorcio del dramaturgo de Ellen Van Volkenberg, cofundadora del Chicago Little Theatre ${ }^{173}$. Janson y Browne propusieron a Pauline Schindler que pasara el invierno en Halcyon, disfrutando de la tranquilidad de aquel paraje virgen, pero a pesar del ofrecimiento, el clima de extraña religiosidad de Halcyon no convenció del todo a Pauline en su primera visita al lugar ${ }^{174}$ y decidió continuar su viaje hacia el norte.

A mediados de octubre de 1927 Pauline se instaló en Carmel, al sur de la Bahía de Monterrey, otro enclave costero de singulares cualidades paisajísticas donde pasaría los dos siguientes años de su vida. Inmediatamente se integró en el día a día de esta pequeña localidad formada también por poetas, escritores y artistas y cuya vida social gravitaba alrededor de las tertulias literarias, conciertos y estrenos teatrales del Carmel Playhouse y del Theatre of the Golden Bough. Carmel fue para ella un nuevo comienzo, y supuso su despegue profesional como escritora y editora por cuenta propia.

Antes de finalizar el año ya era colaboradora habitual de la revista Carmel Pine Cone, donde tenía su propia columna, "The Black Sheep", que, entre noviembre de 1927 y marzo de 1928, fue publicada en once ocasiones. Aunque su cometido principal era la crónica de eventos locales, Pauline se centró en la crítica musical. Poco después, fue invitada como crítica de teatro desde Carmel por el rotativo Christian Science Monitor y, aún más importante, fue durante esa época cuando Pauline comenzó su fructífera relación con la revista The Carmelite ${ }^{175}$.

The Carmelite era un semanario autopublicado de tendencias progresistas que daba cobertura a la vida cultural de la ciudad. Pauline inició su asociación con la revista escribiendo dos columnas, "Stage and Screen" y "With the Women" que, junto con otros artículos sobre temas diversos, aparecieron a principios de 1928. Pronto fue nombrada asistente de dirección, haciéndose cargo de la revista como directora en abril de ese mismo año. No obstante, durante las negociaciones del traspaso, un editorial aparecido en mayo anunciaba la desaparición de la publicación tras la marcha de Stephen A. Reynolds, propietario de la misma durante sus dieciséis primeras semanas de vida, a no ser que, según se afirmaba, "otras manos más capaces decidieran asumir esa carga" ${ }^{1176}$. Rápidamente Pauline consiguió aglutinar en torno a ella un equipo de confianza $y$, tras formalizarse

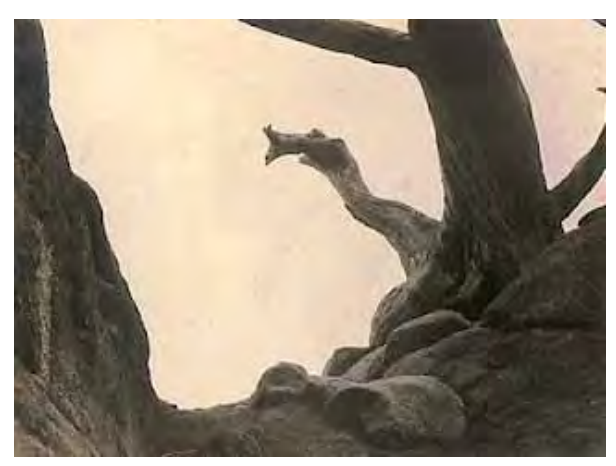


su compra, emprendió una arriesgada aventura editorial en la que se involucró personalmente al invertir en la revista casi todo el dinero que recibía de su familia.

A partir de ese momento, los principales intereses de la revista fueron políticos y artísticos. Bajo la dirección de Pauline Gibling Schindler, The Carmelite se convirtió en un boletín de izquierdas, en cuyas páginas el periodista político y cronista de la Revolución Mexicana Lincoln Steffens o el poeta Robinson Jeffers siempre tenían cabida. Pauline se sirvió de la revista para expresar sus propias ideas, dejando claros sus puntos de vista sobre determinados aspectos de la vida de la comunidad -como cuando se opuso, por ejemplo, a la propuesta de una tasa para la biblioteca ${ }^{177}$ o se manifestaba sobre los problemas del crecimiento y del tráfico de Carmel ${ }^{178}$.

La música y el teatro eran dos de sus principales focos de atención. Ella misma escribía las críticas sobre los conciertos y representaciones que tenían lugar en Carmel y, además, enriquecía el tono de sus crónicas sociales -cometido original de la revista- contextualizando el significado de los artistas que recalaban en la ciudad. La trayectoria biográfica y política de Pauline explica muchas de sus decisiones, tanto respecto a los temas de sus artículos en particular como, en general, al nuevo carácter que supo imprimir a The Carmelite. Así, la relevancia concedida a la noticia de la visita a Carmel de Jane Addams, reseñada como un acontecimiento en primera página, o la frecuencia con la que se incluían fotografías de Edward Weston (especialmente en portada), no pueden entenderse sin el paso de Pauline por la Hull House de Chicago o la amistad que le unía al fotógrafo desde los tiempos de la Walt Whitman School y de Kings Road. También en este sentido, la recurrente publicación de los poemas de Robinson Jeffers y de Ellen Janson o de las ilustraciones de Virginia Tooker -otra de las primeras asiduas a las veladas de Kings Road ${ }^{179}$-, debe explicarse tanto por su afinidad política e intelectual como por una cuestión de afectos.

A principios de 1929, cansado de la vida cada vez más trepidante de Los Ángeles, Edward Weston se instaló en Carmel, un movimiento ${ }^{180}$ que Pauline anunció con entusiasmo en el último número de diciembre de 1928 de la revista. Weston se convirtió en la mano derecha de su amiga Pauline y ésta en su introductora en los círculos de la ciudad ${ }^{181}$. Además, con Weston en Carmel, Pauline se ejercitó en su faceta de representante artística y editora freelance al seleccionar sus fotografías y ponerle en contacto con revistas como Vogue para que publicaran su trabajo ${ }^{182}$.

Junto con la galería de sus amigos Dene Denny y Hazel Watrous, la casa y el estudio de Edward Weston pronto se convirtieron en los más destacados centros de reuniones de la élite local. Las conferencias, tertulias y fiestas celebradas por el fotógrafo eran narradas por Pauline en la revista y por el propio Weston en sus diarios. De acuerdo con lo escrito en ellos, a pesar de su retiro a Carmel, en 1929, Edward Weston llevó una ajetreada vida social, recibiendo continuas visitas, entre ellas: sus hijos Brett, Neil y Cole; sus amantes -simultáneas- la intérprete alemana y redactora de sus diarios Christel Gang y la fotógrafa Sonya Noskowiak (futuro miembro del grupo f/64); Galka Scheyer en sus continuos viajes entre Los Ángeles y San Francisco para organizar exposiciones y vender la obra de los artistas que representaba en California; el pintor Peter Krasnow -otro asiduo de Kings Road-; o su médico personal el Dr. Philip Lovell y su mujer Leah que llegaron a Carmel el 27 de octubre de 1929, es decir, la misma semana en la que 
se les había concedido la licencia de ocupación de su nueva casa de Los Ángeles, la Lovell Health House.

Firmando como Pauline G. Schindler, a partir del último número de mayo de 1928, ella figuraba en los créditos de The Carmelite como principal responsable ("editor") de la revista. Como miembros del consejo de dirección ("contributing editors"), Pauline incluyó, entre otras personas de su confiaza procedentes de diversos campos, a la poetisa Dora Hagemeyer -la mujer del fotógrafo Johan Hagemeyer-, al urbanista Carol Aronovici, a Richard Neutra y, por supuesto, a su inseparable Edward Weston.

Aunque Weston era su fotógrafo preferido, lógicamente, Pauline publicó también obras de Johan Hagemeyer quien, por cierto, era otro visitante ocasional de Kings Road. Los Schindler le habían conocido en Los Ángeles a través de Edward Weston, y por medio de Hagemeyer el arquitecto había conseguido el encargo del productor agrícola Paul Popenoe ${ }^{183}$ de su cabaña en Coachella Valley, una de las primeras obras de Schindler, como se ha comentado. Otro de los fotógrafos publicados por The Carmelite fue Ansel Adams, otro amigo de Weston y futuro miembro del grupo $\mathrm{f} / 64$. Sus fascinantes imágenes de paisajes de la Sierra Nevada de California no dejaron indiferente a Pauline, quien utilizó sus fotografías como portada de los números de 10 de octubre y 21 de noviembre de 1928.

Los artistas plásticos californianos -aunque en realidad casi ninguno había nacido en el estado- tenían otro lugar destacado en la revista, como el pintor de origen ucraniano Peter Krasnow o la canadiense Henrietta Shore, uno de cuyos óleos fue portada del número de 25 de julio de 1928. En el terreno de la crítica de arte, es destacable el nivel y la cobertura de Pauline a los eventos más significativos no sólo de Carmel sino de toda el Área de la Bahía, ya que solía asistir con regularidad a conciertos, recitales de poesía y exposiciones en San Francisco, como la nueva edición en la muestra itinerante "The Blue Four", organizada por Galka Scheyer en el Museo de Berkeley en 1928.

Pauline preparaba personalmente más de la mitad de los artículos que se publicaban The Carmelite a pesar de que, como ella misma informó a su padre, muchos de ellos aparecieran sin firmar ${ }^{184}$. Intervenía en su maquetación y era responsable de su diseño editorial, tanto de la propia revista como de todos los soportes gráficos, incluidos los anuncios, que aparecían asociados a la misma.

La intensidad de los editoriales, la defensa de la modernidad y el interés por la divulgación arquitectura producida en California marcaron la etapa de Pauline Gibling Schindler al frente de la revista. En el número de The Carmelite de 28 de noviembre de 1928, Pauline anunciaba una conferencia de Richard Neutra en la ciudad, un evento que ella misma había organizado en la galería Denny-Watrous el siguiente domingo 2 de diciembre. En su celebración del trabajo de su amigo, escribía que Neutra era uno de los únicamente dos o tres arquitectos que podían ser considerados "dignos herederos del linaje Sullivan-Wright, para quienes la arquitectura no era sólo una mera expresión de cada civilización sino un poderoso agente capaz de conformar el futuro" ${ }^{\prime 185}$.

En el siguiente número de la revista, fechado el 5 de diciembre de 1928, Pauline publicaba su propia crítica de la conferencia de Neutra. En su artículo, titulado Richard Neutra Renders Modern Architecture Intelligible, elogiaba los

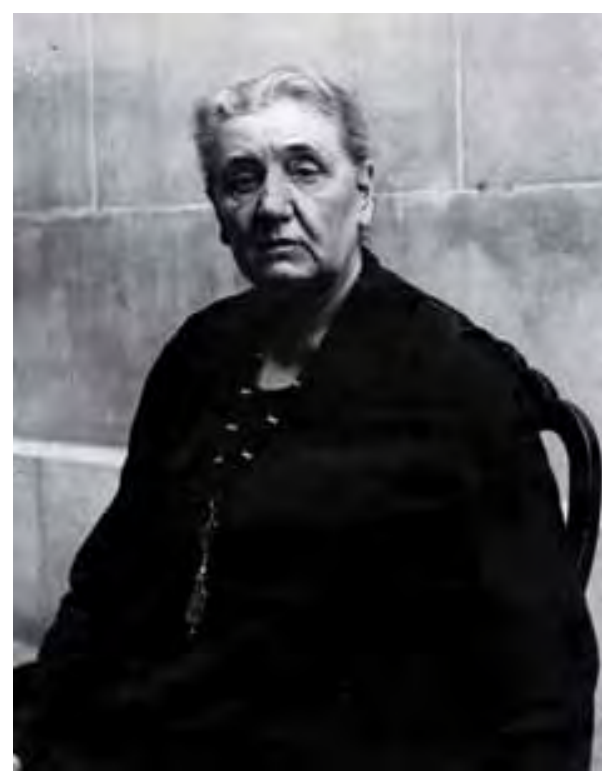

Jane Addams. Fotografía de George W. Haley, 1928. Fuente: Los Angeles Public Library

Página anterior: The Carmelite, portada del número del 4 de julio de 1928 ilustrado con una fotografía del bailarín John Bovingdon 

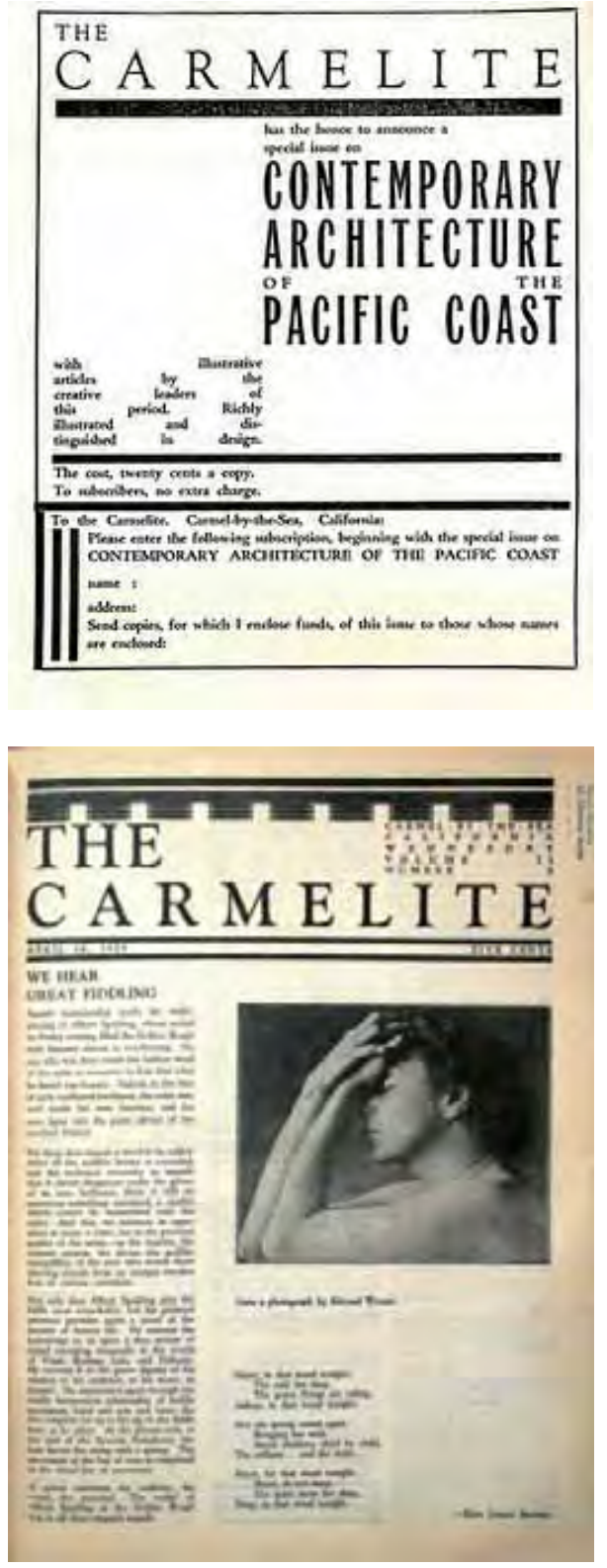

logros de Neutra, en especial, sus dotes de publicista. Pauline enfatizaba las dotes comunicativas del arquitecto y su habilidad para ilustrar convincentemente su charla mediante fotografías distribuidas por toda la sala, de modo que "Mr. Neutra no sólo consiguió con su intervención que los asistentes escucharan atentamente su extraordinaria exposición de principios modernos, sino que consiguió fascinar al público con las imágenes de arquitectura moderna, la mayoría obras suyas, que colgaban de las paredes de la galería"186.

Pauline también invitó a Rudolph Schindler a Carmel ${ }^{187}$. La sala DennyWatrous se había convertido en un espacio expositivo clave para difundir la obra de los arquitectos (Neutra), artistas (Weston) o creadores representados por Galka Scheyer, todos ellos procedentes del núcleo de amistades consolidado en Kings Road. La intervención de Schindler tuvo lugar el 6 de septiembre de 1929, es decir, casi un año después de Neutra y en su anuncio de la conferencia de su marido, Pauline afirmaba en The Carmelite: "de los tres arquitectos [Wright, Neutra y Schindler] éste es el más creativo de los genios $^{\prime 188}$. En ese número, fechado el 4 de septiembre, un dibujo del proyecto de la casa Wolfe de Schindler en Catalina Island (1928-1931) ocupaba buena parte de la portada.

Algunos meses antes, en marzo de ese mismo año, Pauline había escrito a Schindler a Kings Road en calidad de editora de la revista. Le solicitaba material de obras recientes para divulgar en The Carmelite. Más adelante se reproducirá el contenido de esta carta ${ }^{189}$, ya que Pauline comentaba que disponía de fotografías de Edward Weston de la Lovell Beach House de Newport que iban a ser incluidas en un número especial. Dicho número no llegó a publicarse pero debía haber sido un monográfico sobre arquitectura moderna en California que, según afirmaba la editora en un anuncio aparecido en marzo de 1929, se habría llamado Contemporary Architecture of the Pacific Coast. La fecha es significativa porque indica que en ese momento tan temprano para un territorio periférico -la casa Lovell de Neutra aún estaba en construcción y la Exposición de Johnson y Hitchcock en el MoMA aún no había tenido lugar-, Pauline Schindler ya consideraba que había suficiente obra de calidad como para ser necesaria una publicación específica que diera cuenta de la versatilidad y originalidad de la modernidad californiana. Sin embargo, aunque el número no llegó a ver la luz, la idea del mismo debe entenderse como el germen de dos proyectos curatoriales llevados a cabo por Pauline a principios de los años 30: uno de ellos expositivo, la muestra Contemporary Architecture in California (1930); y el otro editorial, el número monográfico de la revista California Arts \& Architecture aparecido en enero de 1935 y consagrado por completo a la producción reciente de los arquitectos modernos más representativos de la región.

La razón por la que Contemporary Architecture of the Pacific Coast no salió adelante fue la pérdida de la dirección de la publicación a finales del verano de 1929. Dadas las dificultades financieras de The Carmelite, el escritor Lincoln Steffens y su mujer Ella Winter, usaron las facturas impagadas de la revista para denunciar la ineficacia de Pauline como mujer de negocios. Pauline convocó entonces una reunión de su consejo editorial para estudiar un plan de viabilidad económica pero, en lugar de obtener el apoyo de la mayoría de los miembros, se encontró con una calculada maniobra que forzó su destitución. El matrimonio Steffens sufragó parte de los gastos pendientes y asumió el control de la revista el 16 de septiembre de 1929. Aun así, durante algún tiempo ella siguió colaborando de manera desinteresada, hasta que, a finales de 1929, resolvió abandonar Carmel. 


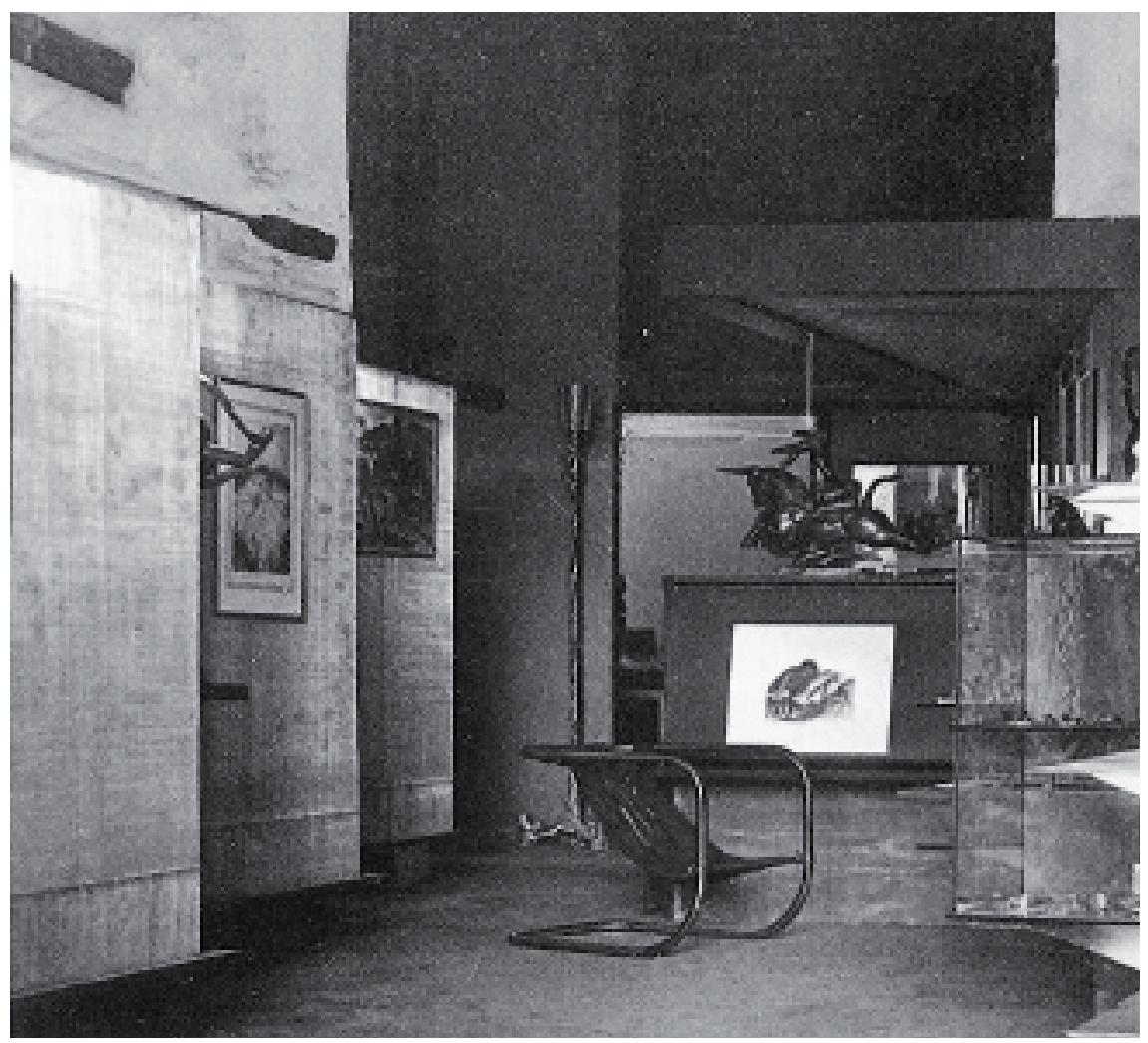

\section{Contemporary Creative Architecture in California, una exposición inaugural (1930)}

A principios de 1930, Pauline volvió temporalmente a Los Ángeles y se instaló en una de las residencias de bloque textil de Wright, la Storer House (1923). A cambio de ejercer de cuidadora de la casa, consiguió un alquiler muy barato que, de nuevo, pudo sufragar con ayuda de su padre. Pauline utilizó esta vivienda -por cierto muy próxima a Kings Road-como oficina para escribir $y$ actuar de agente de algunos arquitectos ${ }^{190}$ y artistas. Uno de ellos fue su amigo y antiguo estudiante, el fotógrafo Brett Weston quien, junto con Galka Scheyer, también se sirvió durante algún tiempo de sus dependencias ${ }^{191}$. Gracias a Pauline Schindler, las conexiones de Galka Scheyer y el patronazgo de Merle Armitage, la obra del segundo hijo de Weston fue expuesta en la Braxton Gallery ${ }^{192}$ y Brett comenzó a recibir encargos importantes, no sólo como retratista, sino también como ilustrador de revistas y libros de arte y cinematografía. Y también por mediación de Pauline, meses más tarde, Rudolph Schindler encargaría a Brett las fotografías de su Wolfe House en la isla de Catalina.

Desde sus improvisadas oficinas en la Storer House, Pauline comenzó a desarrollar su idea de organizar una exposición sobre arquitectura moderna californiana. Dos años antes, en 1928, su amiga la pintora Annita Delano, profesora en UCLA y en el Otis Art Institute, y además miembro del círculo de Kings Road y estudiante de Richard Neutra, había organizado una exposición sobre artistas contemporáneos locales en los primitivos almacenes Bullock's en su sede del Downtown de Los Ángeles. La muestra, titulada Decorative and Fine Arts of Today, había puesto el foco en realizaciones Art Déco, pero incluyó determinadas obras de arquitectos modernos como Richard Neutra y Rudolph Schindler, además de fotografías de Edward Weston. John Crosse apunta a que éste podría haber sido el germen de la idea de Pauline, aunque también es lógico pensar que la influencia fuera recíproca, es decir, que el interés de Delano, una artista, por extender la exposición a los arquitectos

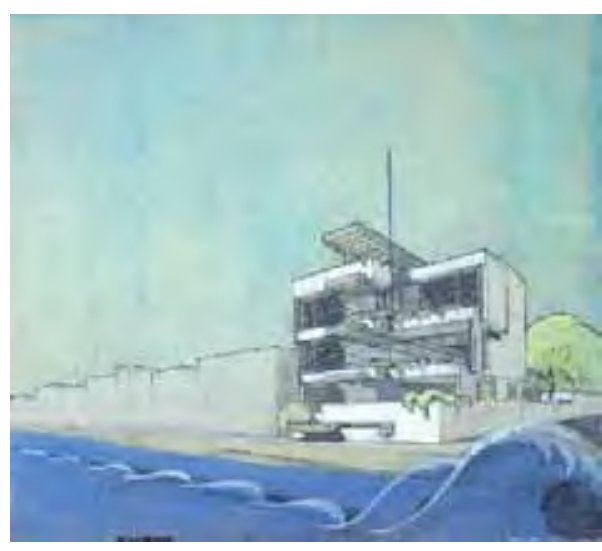

Izda: RMS: Braxton Gallery, 1928-29, ADC/ UCSB Library

Dcha: RMS: Braxton-Shore Residence, Venice Beach, 1926, ADC/UCSB Library

Página anterior arriba: Anuncio de marzo de 1929 del número especial de The Carmelite dedicado a Contemporary Architecture of the Pacific Coast. Fuente: John Crosse

Página anterior abajo: The Carmelite, portada del número de 10 de abril de 1929 con fotografía de Edward Weston y poema de Ellen Janson. Diseño y maquetación de PGS 


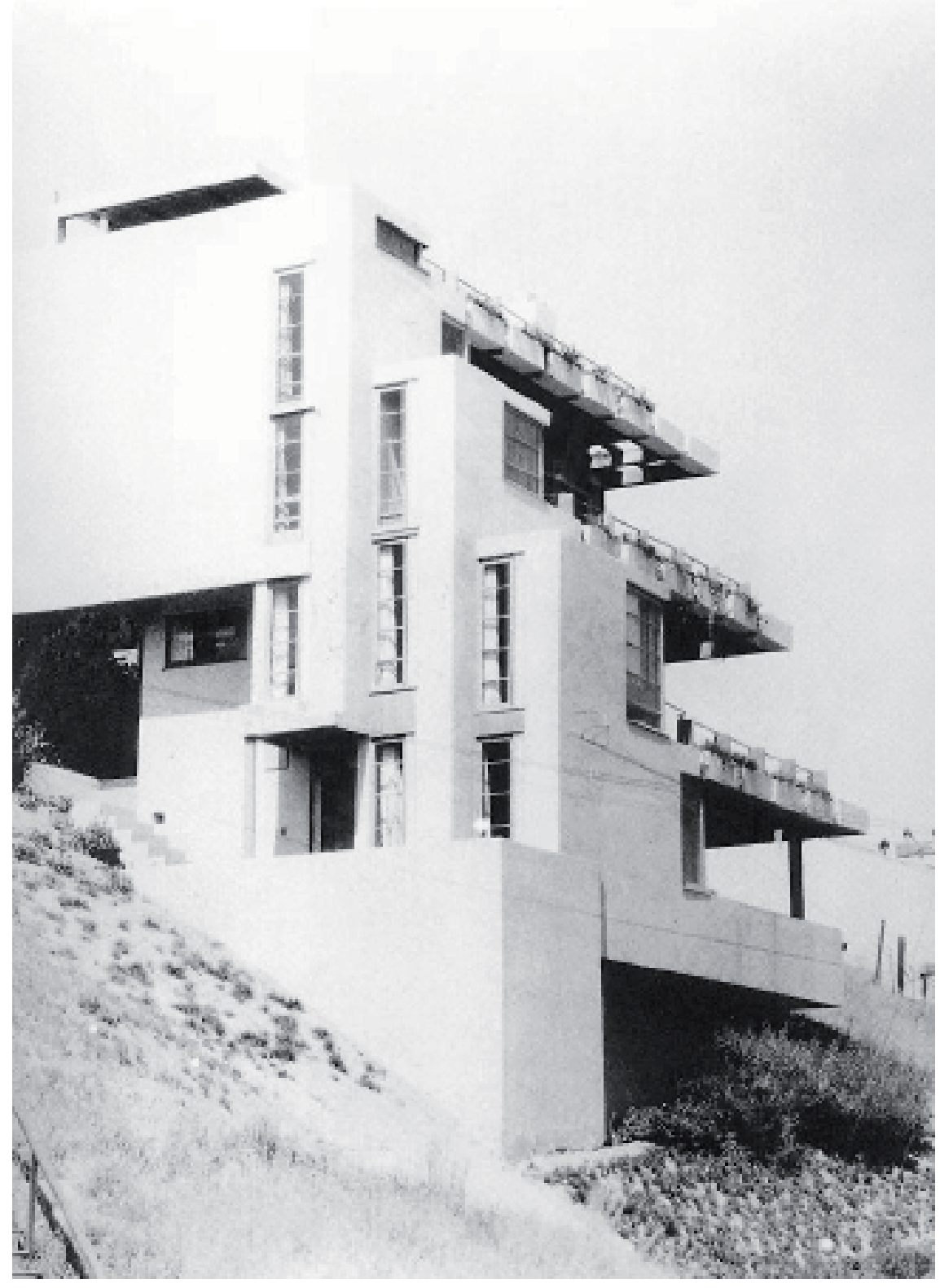

del núcleo de Pauline se debiera a su paso por Kings Road, donde conoció a Neutra. De hecho, su participación en el curso de arquitectura moderna impartido por éste en 1929 no se entiende sin su vinculación con el salón de los Schindler.

En cualquier caso, la oportunidad temática, y su coherencia en la elección de los arquitectos, fue mérito de Pauline Schindler, que seleccionó personalmente obras de Frank Lloyd Wright, Richard Neutra, Rudolph Schindler, Jock D. Peters, John Weber, Kem Weber y J. R. Davison.

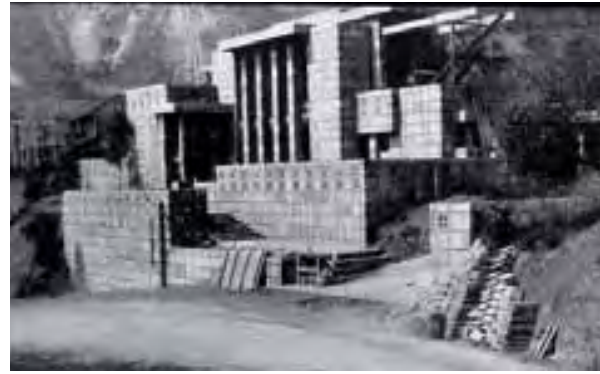

Dos semanas antes de la inauguración, Wright escribió a Pauline exigiéndole que retirara su nombre de la exposición y renunciando participar en ella ${ }^{193}$. Al parecer, su hijo Lloyd, que en principio había preferido mantenerse al margen pero que después acabaría sustituyendo a su padre, le había informado del papel preeminente que jugaban Rudolph Schindler y Richard Neutra en el evento y Wright, cuyas relaciones personales con sus antiguos ayudantes, especialmente con Schindler, estaban prácticamente rotas ${ }^{194}$, decidió finalmente no acudir, sin tiempo para rehacer los carteles y folletos anunciadores de la exposición. 
Contemporary Creative Architecture in California contó con la asistencia de Galka Scheyer para el catálogo, publicidad y planificación de la itinerantica de la muestra. Scheyer llevaba desde su llegada a Los Ángeles en 1924 organizando exposiciones y contactando galeristas por toda California para poder dar a conocer y vender la obra de los pintores europeos que representaba (Kandinsky, Jawlensky, Feininger y Paul Klee). Sus habilidades como publicista fueron de gran ayuda para Pauline, así como la participación de Delano, que también brindó su colaboración ${ }^{195}$ al implicar al Departamento de su Universidad.

Contemporary Creative Architecture in California se inauguró el 21 de abril de 1930 en la Universidad de California en Los Ángeles (UCLA) bajo los auspicios de su Art Department. La exposición, pionera en su género en los Estados Unidos, fue anterior incluso a la muestra del MoMA de 1932, exhibiendo dos años antes la Lovell House de Neutra. Por otra parte, cuando en 1935 el MoMA consagró una exposición monográfica a la arquitectura californiana, tuvo que resultar difícil para los responsables del museo obviar este trabajo previo Pauline Schindler, hasta el punto de que, como se verá más adelante, la exposición inaugurada en el Museo de Arte Moderno de Nueva York en septiembre de 1935 se denominó Contemporary Architecture in California.

En 1930, Pauline actuó como agente de los arquitectos que integraban su exposición, firmando con ellos un documento contractual para realizar acciones publicitarias, entre las cuales figuraba, acordar conferencias en su nombre por toda la ciudad. En este sentido, la exposición se benefició de la experiencia previa de Pauline Schindler como gestora cultural adquirida en la organización de los eventos de Kings Road y, de manera más profesional, de su labor en Carmel.

Uno de los mayores aciertos de la muestra fue la organización de un debate abierto entre tres de los arquitectos (-diseñadores) presentes en la misma: Richard Neutra, Rudolph Schindler y Kem Weber, tres autores modernos pero con posiciones claramente distintas. De este modo, los asistentes tenían la oportunidad de recibir y contrastar comparativamente información de primera mano sobre las novedosas obras expuestas $y$, por su parte, los autores disfrutaban de una acción comercial que les permitía dar a conocer su trabajo a una audiencia de potenciales de clientes. El simposio se celebró el domingo 27 de abril de 1929, tal como figura en el cartel del acto maquetado con la reconocible tipografía de Pauline Schindler.

El influyente crítico de arte de Los Angeles Times durante los años 20 y 30, Arthur Millier -por cierto, otro visitante de Kings Road-, enfatizó la pluralidad de las obras seleccionadas como uno de los aspectos más reseñables de la muestra: "[...] esta exposición en UCLA no trata sobre una escuela de arquitectura moderna, sino que representa el trabajo de varios artistas que tratan, cada uno de ellos, de proyectar creativamente para la época presente ${ }^{1196}$, escribió. Más allá de sus diferencias, para Millier, todos los autores representados tenían en común su valentía para aportar soluciones contemporáneas alejadas de los estilos que dominaban el panorama arquitectónico de una ciudad que, según decía, "[...] es todavía un lugar donde estos esforzados arquitectos han de ejercer como pioneros. Hasta la fecha, en este país el público ni demanda viviendas modernas ni tiene interés por nada que no se nutra de los estilos del pasado"197.

Su puesta en valor de la diversidad de la exposición -y más si se considera que abordaba la arquitectura producida en un único territorio- no podía es-

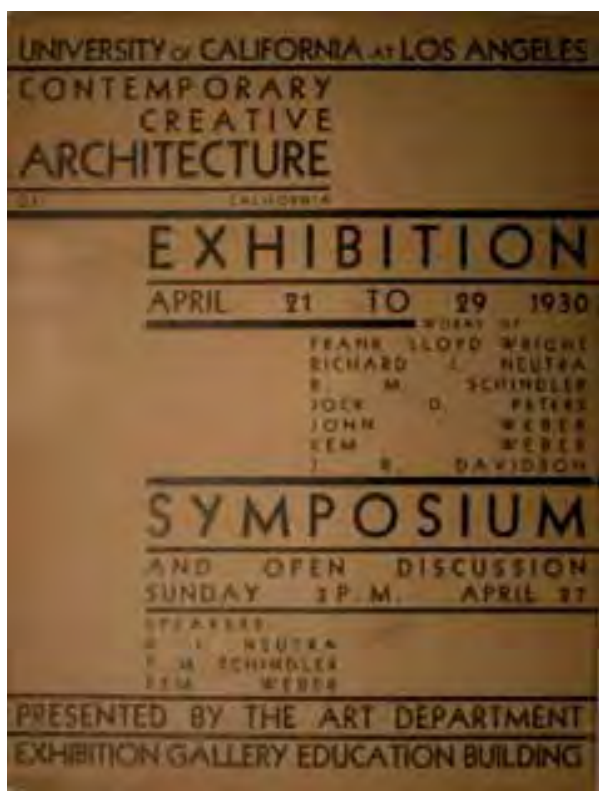

PGS: Contemporaty Creative Architecture in California, Cartel anunciador de la exposición y el ciclo de conferencias que tuvo lugar en la Exhibition Gallery, Education Building de UCLA

Página anterior izda: Frank Lloyd Wright: Storer House (1924) en Hollywood Blvd. Residencia y oficina de Pauline Schindler y Brett Weston en 1930. Fotografía de RMS incluida en el libro de Richard Neutra Wie Baut Amerika? Página anterior dcha: RMS: Wolfe House, 1928-1931, Avalon, Catalina Island. Fotografía de Brett Weston, ADC/UCSB 


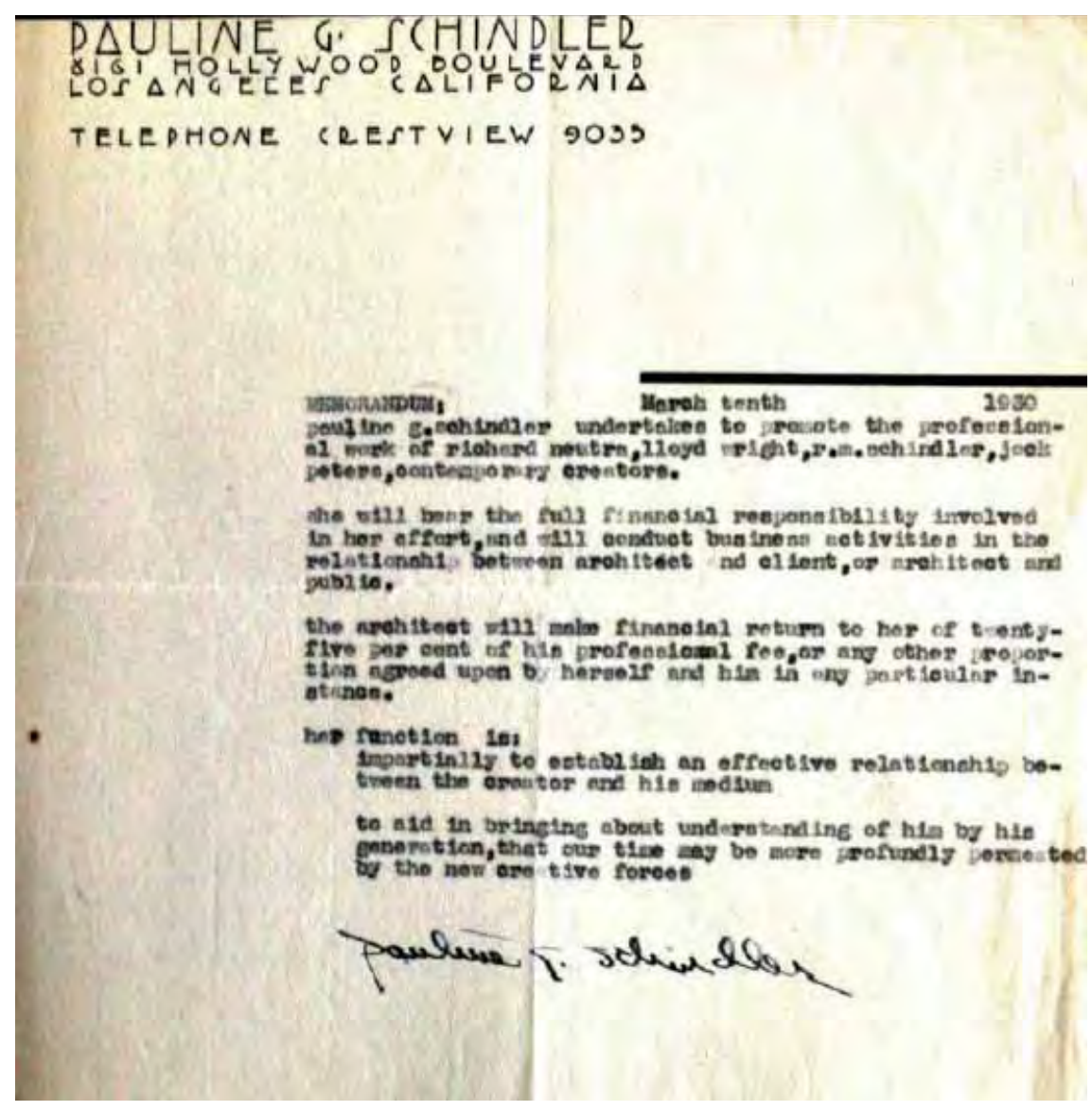

PGS: Contrato con los arquitectos representados en la exposición para contratar conferencias y eventos promocionales en su nombre, marzo 1930, ADC/UCSB

Página siguiente: PGS: Díptico promocional de la obra de RMS. La fotografía del arquitecto es un retrato de Edward Weston, $A D C / U C S B$ tar más alejada del criterio de coincidencia estilística perseguido para todo el planeta por los comisarios de Modern Architecture: International Exhibition, y en base al cual se excluiría la obra de Schindler de la convocatoria del MoMA de 1932. De hecho, a pesar de que posteriormente diversos críticos - entre ellos el propio Hitchcock ${ }^{198}$ - denostarían la heterogeneidad de California, el artículo de Millier considerando positivamente el carácter proteiforme de su arquitectura es revelador porque, anticipándose sin proponérselo a la profusión de etiquetas de las décadas siguientes para explicar diferentes sensibilidades (international, steel modern, bay region, mid-century, etc.), reconocía la multiplicidad de identidades modernas como distintivo de la región. Incluso, esta diversidad era celebrada desde el título mismo de la exposición donde el adjetivo Creative no era en absoluto casual.

Otro de los aciertos de Contemporary Creative Architecture in California-aunque respondiera en parte a una contingencia- fue que no se exhibiera sólo en una institución académica, sino que tuviera distintas sedes en la misma ciudad de Los Ángeles, llegando así a diferentes públicos. Tras su inauguración en UCLA, la exposición pudo visitarse en junio en las instalaciones del California Art Club en Olive Hill. De allí viajó a la Honolulu Academy of Fine Arts, a la Universidad de Washington en Seattle, a la Portland Art Association y, finalmente, volvió a California para ser instalada en la San Diego Fine Arts Gallery ${ }^{199}$. Una versión expandida de la exposición fue inaugurada en octubre de 1931 en el Plaza Art Center de Los Ángeles, incluyendo mobiliario y diseños industriales. Meses antes, otra variación de la misma había sido expuesta en abril en la Architectural League de Nueva York.

La versión extendida del Plaza Art Center es significativa porque en ella, por primera vez, figuraba Harwell Hamilton Harris como arquitecto. En ese momento, Harris era aún colaborador en el estudio de Neutra y aún no había 
construido una obra en solitario, pero sí realizado algunos proyectos, una vivienda multifamiliar para Arthur Jensen y una casa-estudio para Lewis Gaffney, ambas en Los Ángeles. Pauline incluyó estas experiencias previas en la muestra y señaló su nombre como diseñador independiente ${ }^{200}$.

Harris había conocido a Pauline como estudiante de Neutra, con quien había comenzado su relación profesional en 1928. Aunque Harris había llegado a Kings Road después de la marcha de Pauline, ésta había vuelto puntualmente a su casa tras regresar a la ciudad y, especialmente durante la primera mitad de 1930, tuvo un intenso trato con Neutra con motivo de la preparación de Contemporary Creative Architecture in California. Con toda seguridad, Harris tuvo que haber colaborado de una u otra forma en la preparación de la exposición ya que era él quien se ocupaba de asistir a Neutra en las tareas de promoción de su oficina. En 1930 su despacho estaba todavía en Kings Road y, cuando Neutra se embarcó en su gira internacional a finales de mayo, Harris quedó al frente del estudio hasta el regreso de su jefe a Los Ángeles en abril de 1931. Durante esa época, el contacto de Pauline con el despacho de Neutra fue a través de su discípulo. También durante esa época en la que Neutra estuvo fuera de la ciudad, Harris conoció a su futura mujer, Jean Murray Bangs, amiga de Pauline y habitual de Kings Road en su primera etapa, como se verá más adelante. A partir de ese momento, Pauline Schindler y Harwell Hamilton Harris cimentaron una amistad de por vida. Pauline se convirtió también en la primera protectora y difusora de su obra, antes incluso de Jean Murray Bangs, como demuestra el hecho de que se interesara por incluir a un joven arquitecto sin ninguna experiencia en una exposición junto a sus maestros.

Ejerciendo de agente de los arquitectos incluidos en la muestra de 1930, incluido Lloyd Wright, Pauline escribió diversos artículos sobre sus obras que fueron enviados a Lawrence Kocher, editor de Architectural Record y, gracias a la reciente amistad de ésta con su asistente de dirección, Douglas Haskell ${ }^{201}, 15$ de ellos fueron publicados por la revista entre principios de 1930 y 1931. Gracias a los esfuerzos de promoción de Pauline y del fotógrafo Willard Morgan, la Lovell Health House de Richard Neutra fue publicada enfáticamente en el número de mayo de $1930^{202}$.

Su labor de promoción, estipulada en el contrato firmado en marzo de 1930, se extendió más allá de la duración y coincidencia temporal de las diferentes ediciones de Contemporary Creative Architecture in California. A cambio de un porcentaje en torno al $25 \%$-negociable según la ocasión- sobre los honorarios de la conferencia o de la acción publicitaria que se tratase, Pauline se comprometía a poner a los arquitectos en contacto con editores, público en general e, incluso, clientes. Concretamente, según las dos cláusulas del citado contrato, su función consistía en: "[1] establecer de manera imparcial una efectiva relación entre el creador y su medio; [2] ayudar a facilitar la comprensión de su obra por parte de su generación, de tal modo que nuestro tiempo pueda ser afectado más profundamente por las nuevas fuerzas creativas".

En su esfuerzo por divulgar y hacer inteligible la obra de estos arquitectos, Pauline Schindler escribió docenas de cartas a las asociaciones culturales más activas del área de Los Ángeles, como el Hollywood Women's Club, Los Angeles City Club o el Engineers Club, a los que ofreció albergar conferencias de sus representados. Diseñado por Pauline, el díptico ${ }^{203}$ que anunciaba la intervención de Rudolph Schindler tenía también un claro propósito didáctico. En su texto introductorio Pauline presentaba el concepto de arquitectura del espacio (Space Architecture) y enfatizaba la novedad de las ideas derivadas del 


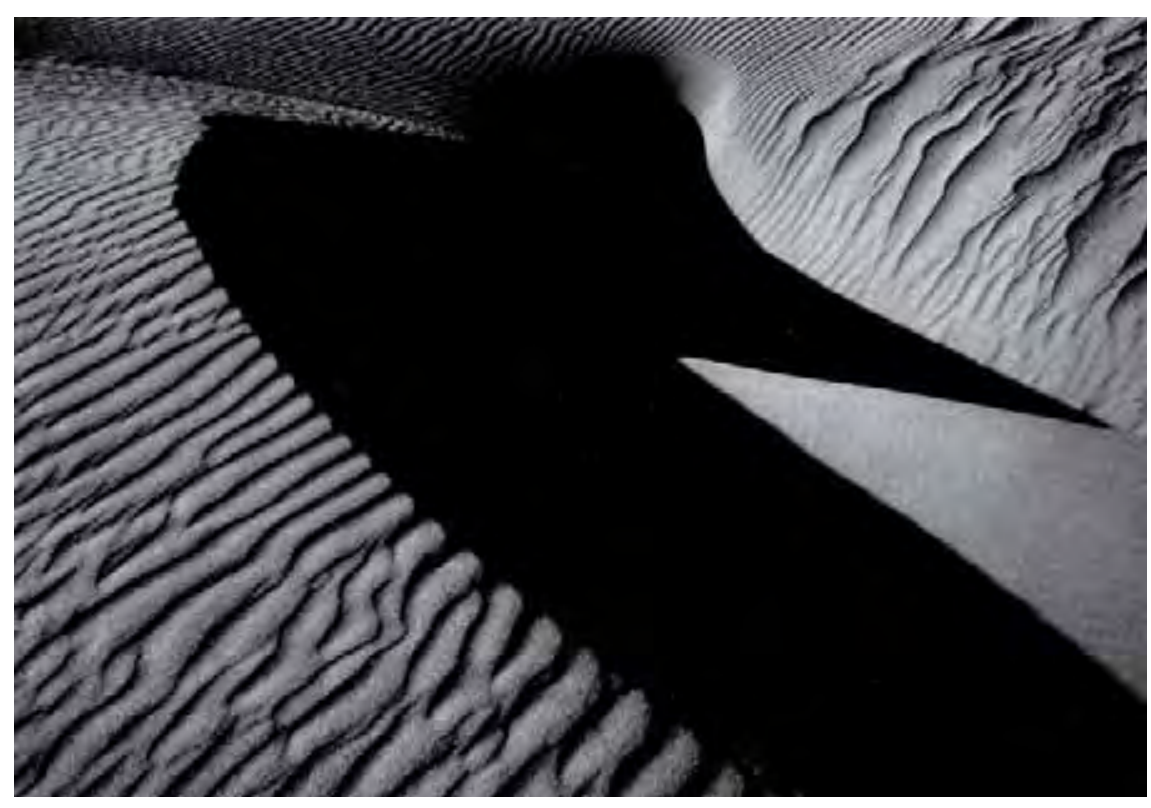

Arriba: Brett Weston: Paisaje de Oceano, California, 1933

Abajo: Moy Mell hacia 1934. Fuente: Schindler Familiy Collection. Sweeney

Página siguiente: Dune Forum: Contributors Number (arriba) y Suscribers Number (abajo)

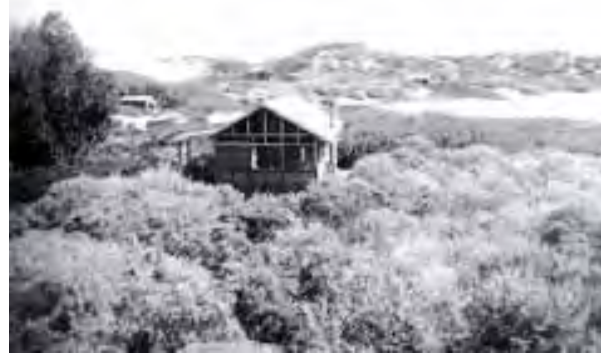

mismo, esforzándose por distinguir la auténtica modernidad de la obra de Schindler de la profusión de estilos más o menos históricos que estaban colonizando el Sur de California. En el tarjetón promocional de la conferencia de su marido escribía: "Una nueva arquitectura ha acontecido en nuestro tiempo y está evolucionando hacia su plena realización [...] Esta arquitectura no puede ser considerada con viejos criterios, tiene su propias formas y su propio vocabulario, responde a un tipo de vida completamente nuevo. No se trata de un nuevo estilo. Está profundamente enraizada. Por ello es necesario comprender sus fundamentos para no confundirla con una mera imitación [...] Los edificios de Schindler son organismos tridimensionales soberbiamente concebidos y construidos a partir de una revolucionaria concepción de la arquitectura y de la vida" ${ }^{\prime 204}$.

Resulta irónico que, dos años más tarde, Schindler se viera apartado de la exposición del MoMA por su originalidad mientras que Neutra, el otro gran beneficiado de la actividad publicitaria de Pauline, era celebrado en Nueva York como uno de los principales representantes de un nuevo estilo.

Por supuesto, en 1932, Neutra tenía plenamente desarrolladas sus dotes para la autopromoción y apenas requería ya de las relaciones personales de Pauline Schindler. Para entonces, él mismo había creado una red de contactos mucho más extensa e influyente que la de su amiga. Hacia esa época, Pauline comentaba a su padre que Neutra se había convertido en "la principal figura de la arquitectura moderna de Los Ángeles [...] mientras que Schindler continúa siendo el misterioso y romántico 'michael' [sic.]"205. Por su parte, Schindler, que en aquel momento aún no había asimilado su exclusión del MoMA -en realidad nunca llegó a superarla del todo-, hizo de aquel episodio un escollo en su aprecio profesional a Neutra y, de hecho, fue la principal causa de su distanciamiento (no así el concurso de Ginebra o el encargo de la casa Lovell, como se ha escrito). Schindler conocía de cerca las estrategias propagandísticas de Neutra y, por ello, llegó a recriminar a Pauline su ingenuidad al considerar a Neutra un genio: "no son celos hacia Neutra, sino oposición a todo lo que él defiende. Podría entender que fueras al fin del mundo por Frank Lloyd Wright o por Mies van der Rohe, sin embargo, la estéril actitud empresarial de Neutra, cuya principal habilidad es su inteligente entendimiento del mercado de la publicidad, es veneno para cualquier forma auténtica de arte. Él es esencialmente un mafioso y no puedes ser tan inocente como para no darte cuenta"206. 


\section{Dune Forum, la mística de las dunas}

La pequeña población de Ojai, a pocas millas al este de Santa Bárbara, fue otro de los destinos habituales de Pauline Schindler durante la primera mitad de la década de los 30. Su hijo Mark estuvo internado en el Ojai Valley School de octubre de 1932 a junio de 1935. Ella le visitó con frecuencia y pasó algunas temporadas en la ciudad en compañía de John Cage, con quien la escritora mantuvo una relación sentimental ${ }^{207}$ entre 1934 y 1935 . Desde Ojai, Pauline solía viajar a Halcyon, y desde allí a Oceano, una pequeña población de la costa Central de California enclavada en un paraje virgen.

Apartadas de toda civilización, las espectaculares dunas de Oceano se habían convertido en un lugar iniciático, una especie de santuario para artistas y buscadores de una nueva espiritualidad que, entre los primeros años 30 y el inicio de la Segunda Guerra Mundial, acogió a "una extraña comunidad de solitarios $^{\prime 208}$, de gente que, como ella, erraba entre diferentes destinos. Alli, durante el otoño de 1933, Pauline se involucró en un nuevo proyecto editorial como directora adjunta de Dune Forum, una de las revistas autopublicadas más interesantes del panorama literario norteamericano de la primera mitad del siglo $x x$.

Dune Forum era una revista mensual sobre arte y literatura con un trasfondo político que, desde posiciones intelectuales de diversa orientación pero sobre todo radicales y de izquierdas, abordaba temas tan progresistas como el nudismo o la libertad sexual. La escasa tirada y condición ultraperiférica de Dune Forum garantizaron su originalidad y su completa independencia.

La revista nació en el seno de la colonia bohemia de Moy Mell, fundada por el escritor Gavin Arthur cerca de Oceano, justo a mitad de camino entre Los Ángeles y San Francisco. Moy Mell reunía a artistas, escritores, filósofos, místicos teosóficos e incluso eremitas, conocidos como "dunitas", que vivían en la playa de Oceano en cabañas construidas con maderas del bosque y los materiales que devolvía el mar.

Chester Alan (Gavin) Arthur aspiraba a ofrecer puntos de vista poco convencionales, a ser la voz de una nueva sensibilidad ligada a un modo de vida genuino de la costa del Pacífico y que expresara "el pensamiento creativo de una América que ya no mira a Europa, sino al oeste"209.

Nieto de Chester Alan Arthur, vigésimo primer presidente de los Estados Unidos (1881-85), Gavin Arthur pertenecía a una de las familias más ricas e influyentes de San Francisco, aunque había preferido leer, viajar y desempeñar los más variopintos oficios (como marino mercante o repartidor de periódicos), antes que plegarse a las comodidades de una vida burguesa. Interesado por el ocultismo y las corrientes espiritualistas, había estudiado astrología y también todo lo referente a las investigaciones en ciernes sobre la biología y psicología de los comportamientos sexuales del ser humano, siendo amigo, entre otros pioneros de la sexología de Alfred Kinsey. Su fascinación por el ocultismo y sus reflexiones acerca de la homosexualidad fueron expuestas en su principal trabajo, The Circle of Sex. Siendo uno de los primeros activistas pro-derechos de la todavía invisible población gay de San Francisco, Gavin Arthur defendía que había que separar completamente la sexualidad de la procreación, algo que, de acuerdo con sus argumentos, liberaría a los heterosexuales de la carga social del matrimonio, permitiendo a su vez la aceptación de otros comportamientos sexuales como la homosexualidad, la bisexualidad e, incluso, la normalización de las identidades transgénero. Ar-
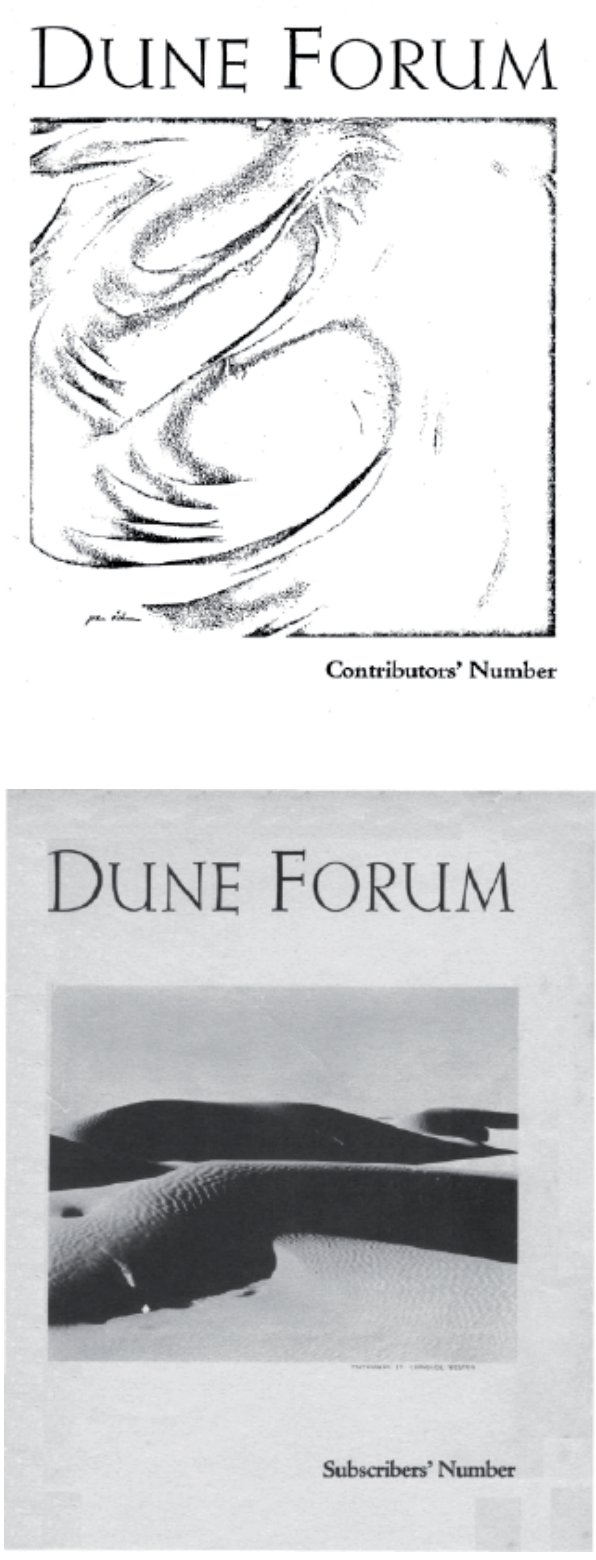
Dune Forum: número 1, enero 1934 (arriba) y número 2, febrero 1934 (abajo)

Página siguiente arriba: California Arts \& Architecture, portada del número de agosto de 1934 a partir de la fotografía de Brett Weston de las dunas de Oceano

Página siguiente abajo: Edward Weston: Retrato de su hijo Brett con 16 años. San Francisco Museum of Modern Art

\section{DUNE FORUM}

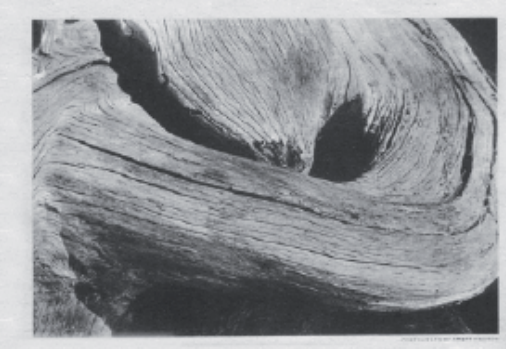

Number One Dise 30 cons

\section{DUNE FORUM}

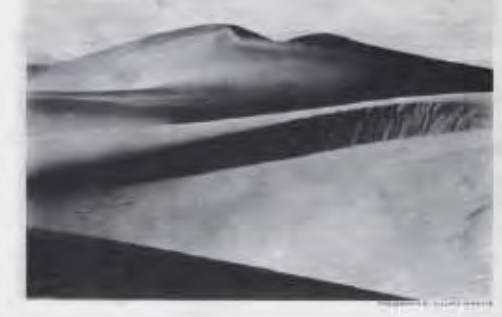

Vol.I. No. 2 Fehnauy 15, 193 Price 30 Cents thur era por tanto buen conocedor y seguidor de muchos de los movimientos contraculturales de la época, en los que habría que enmarcar su labor al frente de Dune Forum una revista que, de acuerdo con el editorial del primer número sería de "cultura y controversia".

La revista fue fundada en el verano de 1933. El primer número, Contributors' Number, apareció sin fechar pero fue publicado presumiblemente en el mes de agosto. Poco después, por invitación de su amiga la escritora Ellen Janson, directora adjunta desde ese primer número, Pauline viajó a Moy Mell para conocer a Gavin Arthur y su participación en la revista se inició semanas más tarde. De hecho, fue incluida en los créditos del segundo número (Subscribers' Number), aparecido en otoño y al que contribuyó con un artículo titulado Note on the Contemporary Art.

En total se publicaron siete números, aunque estrictamente fueron cinco, ya que los dos primeros, Contributors' Number y Suscribers' Number, si bien incluyeron algunos artículos y textos literarios, estuvieron destinados a presentar los objetivos de la revista en sendos editoriales, así como a adelantar futuros contenidos y, en el caso del Suscribers' Number, a relacionar a todos aquellos suscriptores con los que Dune Forum se había puesto en contacto directamente y habían aceptado participar en ella de uno $u$ otro modo.

En este segundo número de presentación, destinado a captar suscriptores, se anunciaba la aparición del primer número oficial en enero de 1934, y en él se declaraba: "queremos huir de cualquier estereotipo, política editorial al uso o rigurosos requerimientos exigidos por la típica revista americana. Queremos lanzar una especial invitación a los creadores de cualquier campo, y no sólo escritores, que deseen unirse a nuestra conversación como si estuvieran sentados alrededor de nuestro propio fuego: arquitectos, músicos, científicos, bailarines y todos aquellos que muy rara vez tienen tiempo para escribir un artículo formal ${ }^{\prime \prime 210}$. Entre los suscriptores y futuros colaboradores ya confirmados se enumeraba a los poetas Countee Cullen y Robinson Jeffers; los músicos John Cage, Henry Cowell y Leopold Stowkowski; el filósofo y sexólogo Havelock Ellis; el pintor John O'Shea, la bailarina y coreógrafa Martha Graham; la controvertida abogada y fenimista Margaret Sanger; el fundador de IBM Thomas Watson; o el propio Richard Neutra.

Otra de las colaboradoras enumeradas en la lista publicada por Dune Forum era la poetisa celta Ella Young, exiliada irlandesa expulsada de su país por apoyar la República. Esta escritora, especializada en la mitología y el folklore irlandés pasó sus últimos años en la colonia de Moy Mell. Además de Young, varios colaboradores de la revista eran visitantes frecuentes de Oceano, o actuaban como nexos artísticos entre las comunidades teosóficas de Carmel, Ojai y Halcyon-Oceano, como los Weston quienes, gracias a Pauline Schindler, descubrieron el lugar e inmediatamente quedaron tan fascinados que convirtieron sus dunas en uno de sus temas preferidos de la época.

De las series de paisajes dunares realizadas por Edward y Brett Weston, varias ilustraron los números de Dune Forum, e incluso de otras revistas como California Arts \& Architecture, cuyo número de agosto de 1934 recurrió a una fotografía de Brett para la portada.

La portada del Contributors' Number consistió en un dibujo de las dunas de John O'Shea. A partir del Suscribers's Number, las portadas de Dune Forum incluyeron una fotografía a toda página que, en esta ocasión, a instancias 
de Pauline, se trataba de una imagen de Chandler Weston, el miembro más joven de esta dinastía de fotógrafos californianos.

El primer número oficial, de enero de 1934, con portada de Brett Weston publicó un artículo de Pauline, North-South ${ }^{211}$, donde, aludiendo a la obra de Richard Neutra, defendía el diseño arquitectónico moderno para las escuelas, de manera que un entorno adecuado favoreciera la educación de los niños. A partir del primer número, Dune Forum siguió una numeración consecutiva que continuaba ejemplar tras ejemplar.

El segundo número, aparecido el 15 de febrero de 1934, estaba ilustrado con una fotografía de las dunas de Willard van Dick, amigo de Edward Weston y miembro también del grupo $\mathrm{f} / 64$. El tercer número volvía a utilizar una obra pictórica de John O'Shea. En la cuarta entrega de la revista (abril de 1934) una fotografía de las dunas tomada por el propio Edward Weston protagonizaba la portada de Dune Forum. El quinto y último número recurría a una instantánea de Amsel Adams, otro de los líderes del grupo f/64.

Escrito en plena Depresión, el editorial del número de febrero de 1934, todo un alegato político en favor de la campaña del líder socialista Upton Sinclair y su lucha contra la pobreza en California, podría verse como un precedente aún más avanzado y radical de las célebres Notes in Passing con las que, una década más tarde, John Entenza comenzó a introducir los números de Arts \& Architecture.

Asimismo, por influencia de Pauline, la música fue otro de los temas centrales de este segundo número en el que se publicaron dos artículos sobre música contemporánea, uno de ellos de John Cage. De joven, ella había considerado incluso la posibilidad de ser compositora, siendo fácil contrastar su excelente formación musical en las diferentes reseñas o artículos publicados en The Carmelite o Dune Forum, en los que escribió sobre compositores modernos como Henry Cowell, Edgar Varèse y el mexicano Carlos Chávez. O en la correspondencia ${ }^{212}$ mantenida con John Cage, quien hacía partícipe a Pauline de sus análisis y preocupaciones musicales e, incluso, del contenido de sus clases con Arnold Schoenberg en Los Ángeles.

También por mediación de Pauline, el segundo número de Dune Forum publicó el texto de Rudolph Schindler Space Architecture ${ }^{213}$, lo que supuso la contribución más significativa de esta revista al ámbito de la cultura arquitectónica. En este ensayo teórico, Schindler exponía sus principales ideas sobre arquitectura, explicitaba las premisas de sus proyectos anteriores y sentaba las bases de su posterior exploración espacial. En su texto, fundamental para entender el sentido último del trabajo del arquitecto, Schindler distinguía el espacio derivado de una investigación plástica o escultórica, o el espacio consecuencia de una necesidad estructural (ejemplificado con la Dimaxion House de Buckmister Fuller), de lo que él consideraba el auténtico resultado de la creación espacial: el espacio arquitectónico. Space Architecture comenzaba con la siguiente declaración: "Si nos detenemos a analizar las diferentes proclamas de grupos o individuos que desean encabezar el movimiento arquitectónico moderno, no encentramos en ellas el menor atisbo de una auténtica comprensión del problema del espacio". En aquel momento, tras su frustración por el rechazo a su obra por parte del MoMA dos años antes, Schindler se debatía entre una necesidad personal de reconocimiento a su trabajo, por lo que -como se ha explicado anteriormente-sus obras de mediados de los años 30 exhiben un lenguaje más reconocible como modernidad internacio-
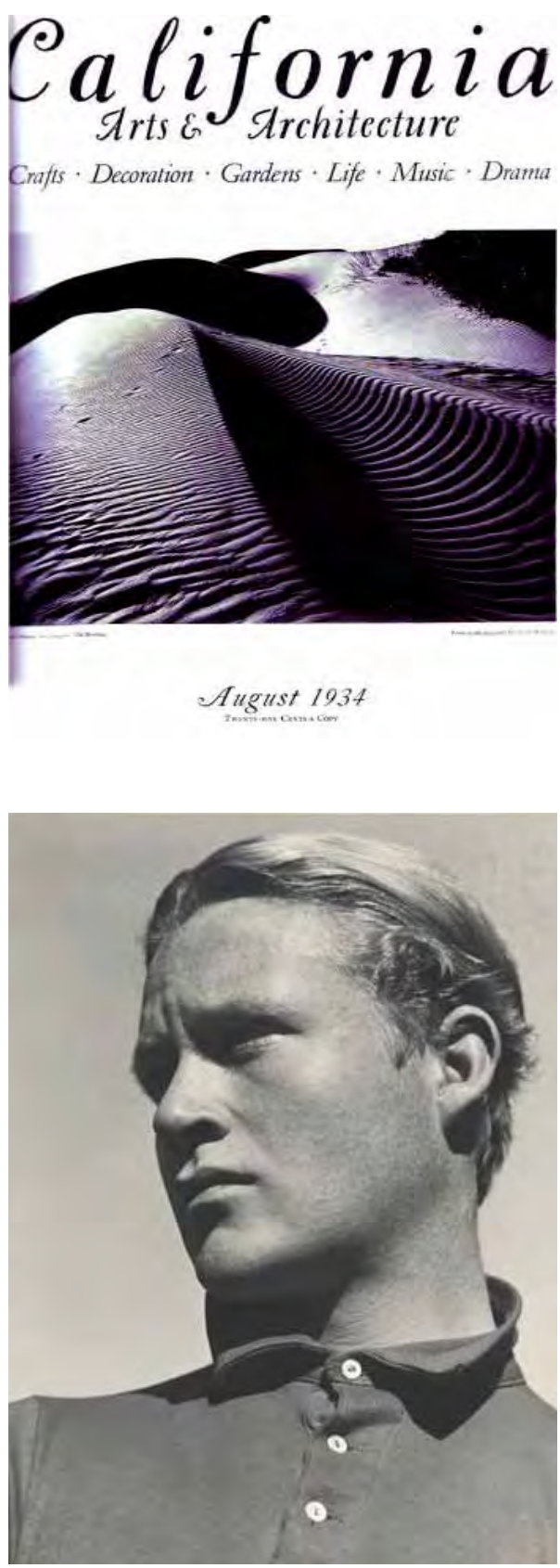
Dune Forum: número 3, marzo 1934 (arriba) y número 4, abril 1934 (abajo)

Página siguiente: Dune Forum, quinto y último número, mayo 1934

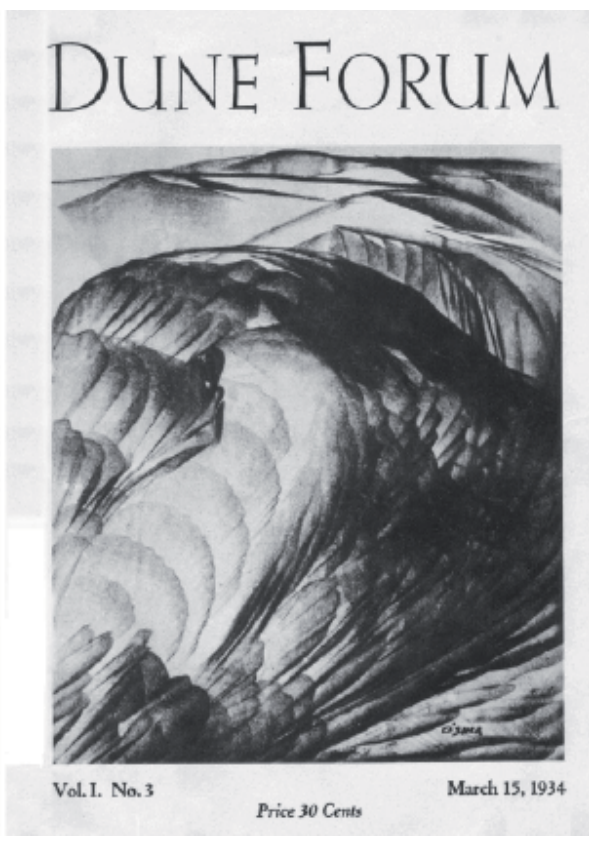

\section{DUNE FORUM}

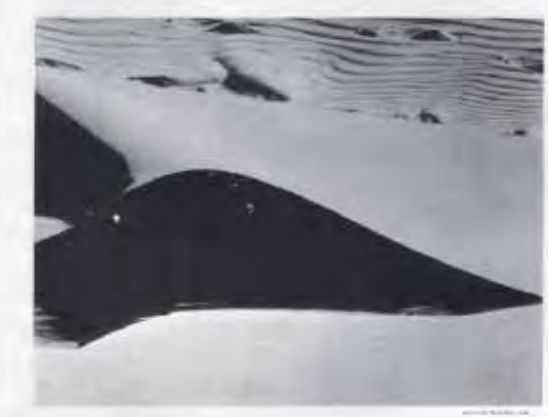

Vol.1. No,4

Price 30 Cents nal, y una voluntad profesional de seguir defendiendo enérgicamente sus convicciones. Esta encrucijada explicaría la rivalidad implícita en sus textos de la época y la beligerancia de sus ataques a la actitud de algunos de sus contemporáneos, proyectados en la figura de Richard Neutra y en "todo lo que él defiende". Por ello, desmitificando la metáfora de la máquina como estrategia publicitaria de un nuevo estilo, Schindler afirmaba: "[...] Para acaparar la atención pública un grupo de funcionalistas ha dado nombre a su especie: Estilo Internacional [...] El ideal de perfección de los nuevos creadores de eslóganes es la máquina, sin reparar en el hecho de que la máquina es un conjunto de partes que trabajan, pero no es en absoluto un organismo [...] La mayoría de los edificios de Le Corbusier y de sus seguidores se nos presentan como 'máquinas para habitar' [... pero las máquinas] son meros instrumentos de producción y no pueden servir nunca como marco de vida [...] La fábrica debe seguir sirviendo al hombre. Y si una casa 'hecha a máquina' debe emerger de ella alguna vez, tendrá que cumplir con los requisitos de nuestra imaginación, y no ser meramente un producto de los medios de producción del momento [...] La arquitectura moderna no puede desarrollarse con un simple intercambio de esloganes. No depende del ingeniero, del experto en eficiencia, del maquinista, o del economista. Se está desarrollando en las mentes de los artistas que pueden entender el espacio y las formas espaciales como un nuevo medio de expresión humana". Un año después, Pauline volvería a publicar este ensayo contextualizado con la obra de su marido en el número de enero de 1935 de la revista California Arts \& Architecture $(C A \& A)^{214}$.

En la última entrega de Dune Forum, un texto de Richard Neutra defendía la necesidad de recurrir a procesos industriales en la producción de viviendas sin dejar de lado la dimensión artística del arquitecto, cuya obligación, según argumentaba, era utilizar de manera creativa los medios a su alcance para actuar como puente entre las aspiraciones de su cliente -ya fuera uno o cientos de consumidores (sic.)- y las fuerzas de producción. El equilibrio, afirmaba Neutra, sería distinto en cada época porque distinto era el grado de desarrollo tecnológico, pero no así la misma actitud moral de sinceridad para extraer todas las posibilidades que permitieran las condiciones del presente o del futuro. Un posicionamiento que expresaba hábilmente desde el propio título del artículo, Equilibrando dos condicionantes de la creación ${ }^{215}$, y que podría entenderse como una contestación a la visión romántica de Schindler y a su cada vez más acusado desinterés por la técnica.

\section{Otros hitos editoriales. CA\&A (1935) y la influencia sobre Esther McCoy}

En noviembre de 1934, siete años después de su salida de Kings Road, Pauline Schindler admitió a sus padres que su matrimonio era insalvable y, que a pesar de la opinión de éstos, que trataron de evitar una ruptura legal, ya no había posibilidad de reconciliación -de hecho, a finales de 1937, se iniciaron los trámites de un divorcio que les fue concedido a principios de $1940^{216}$. Una vez aceptada esa situación fue cuando la autora pudo plantearse regresar de manera permanente a su antiguo hogar.

Poco antes de hacerlo, en julio de 1935 Pauline había vivido junto con su hijo Mark una de las experiencias personales más gratificantes de su vida, su estancia durante algunas semanas en el Commonwealth College de Mena, Arkansas. Esta institución, creada 1923 y activa hasta 1940, adquirió pleno sentido en el momento en que comenzaban a organizarse en los Estados 
Unidos los primeros movimientos sociales, sindicatos obreros y asociaciones agrícolas para defender los derechos de los trabadores, en su mayoría inmigrantes sin recursos que sufrían las implacables condiciones laborales impuestas por sus patronos, especialmente en el medio rural y durante los años de la Gran Depresión.

Vigilada de cerca por el FBI y considerada por muchos como una institución bolchevique y subversiva, el Commonwealth College tenía como principal cometido reclutar y formar líderes laborales capaces de pelear legalmente y dirigir procesos de cambio conducentes a sentar las bases de una nueva sociedad más justa. En Palabras de Pauline, en Commonwealth "se tiene la impresión de que la revolución está siendo preparada de manera científca y práctica, y que es inevitable. La mayoría de los estudiantes este verano son jóvenes comunistas recién graduados, algunos de los cuales han sido muy activos en iniciativas radicales llevadas a cabo en sus universidades y están preparándose concienzudamente para liderar la revolución" ${ }^{217}$.

Pauline escribió diversas cartas a su familia relatándoles su aprendizaje en Arkansas, contaba que ella disfrutaba especialmente las reuniones informales que tenían lugar por la tarde con los estudiantes y en las que "se discutían distintos aspectos de la doctrina marxista concernientes al materialismo dialéctico o se organizaban lecturas del Manifiesto Comunista"212. Aunque terminó su estancia convencida de que ella todavía no se sentía comunista en sentido estricto, tenía claro que, si como afirmaban sus compañeros en Commonwealth, "realmente la única forma de derrotar al capitalismo es plantearle una batalla frontal"219, cuando llegara ese momento, ella "lucharía del lado de los trabajadores" ${ }^{\prime 220}$.

Como consecuencia de su paso por el Commonwealth College, las ideas socialistas de Pauline Schindler experimentaron una progresiva deriva hacia las tesis del partido comunista. En opinión de Robert Sweeney ${ }^{221}$, su evolución ideológica habría empezado incluso antes y, en ésta, tuvo que haber influido muy probablemente el reconocimiento de la Unión Soviética por parte de los Estados Unidos en 1933. El argumento de Sweeney explicaría, por ejemplo, el sentido de los editoriales de Dune Forum, cada vez más radicales. Lo cierto es que, ya en diciembre de ese año, ella recomendaba a su madre una subscripción al Daily Worker, "un periódico comunista" 222 y que, dos años después, Pauline estaba escribiendo para el Western Worker, la publicación oficial del órgano en la Costa Oeste del Partido Comunista de los Estados Unidos. Una década más tarde, en 1946, Pauline entró a formar parte oficialmente del Partido Comunista, un paso que Schindler nunca daría y por el que, durante la Caza de Brujas, fue citada a declarar por el Comité de Actividades Antiamericanas.

Tras la experiencia de Arkansas, Pauline regresó definitivamente a Los Ángeles para residir de nuevo en Kings Road. En una carta enviada a su padre el 31 de octubre de 1931, Pauline ya exponía su intención de volver a Kings Road con su hijo Mark, aunque no consideraba todavía instalarse de modo permanente. Ese año, Schindler había reconocido sus derechos sobre la casa firmando un título de propiedad a su nombre. El arquitecto le solicitó tiempo para encontrar una nueva residencia para él pero nunca llegó a mudarse. En julio de 1932, escribía: "nunca dejamos de sentir que Kings Road es nuestra casa y es allí donde Mark y yo vamos a regresar para hacerla de nuevo nuestro hogar [...] No me gusta Los Ángeles, pero Mark y yo amamos realmente esa casa ${ }^{\prime \prime 223}$. Desde entonces, como legítima dueña de la mitad de

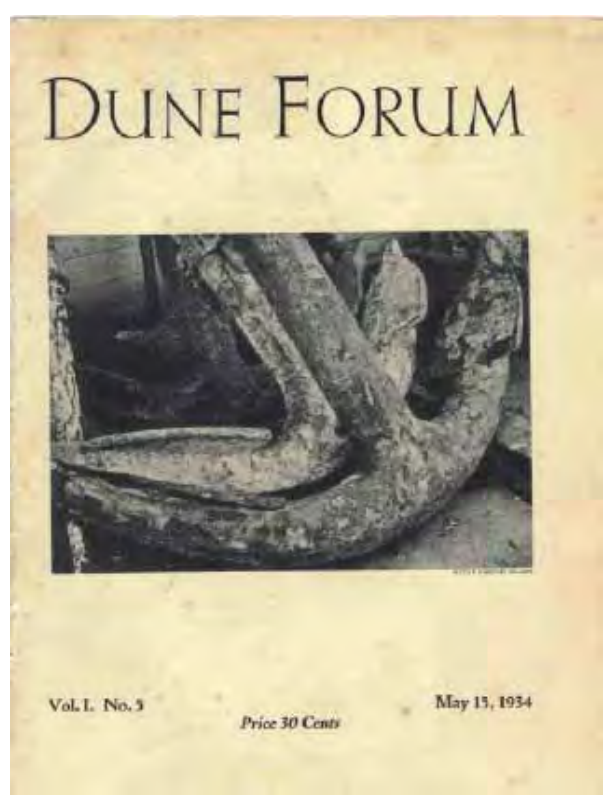



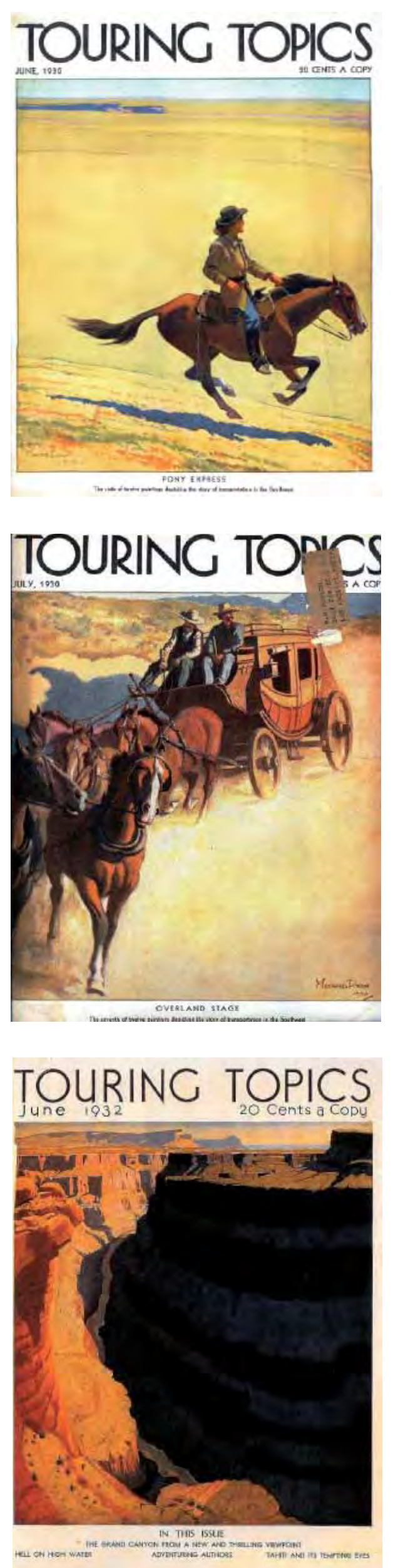

la vivienda, había visitado ocasionalmente Kings Road pernocando, bien en el apartamento de huéspedes, bien en los antiguos estudios de los Chace, donde terminó instalándose y permanecería hasta el final de su vida ${ }^{224} \mathrm{co}-$ municándose principalmente por escrito con su ex marido hasta la muerte de éste en 1953.

Durante la década de 1930, la producción escrita de Pauline Schindler fue notable. Antes de su marcha de Kings Road ya había publicado una entusiasta crítica ${ }^{225}$ del libro de Neutra Wie Bau Amerika?, a cuya redacción había asistido en su propia casa.

Por otro lado, hay que recordar la campaña promocional de Pauline para conseguir que la obra de arquitectos modernos californianos tuviera difusión en medios nacionales e, incluso, en revistas de alcance internacional como Architectural Record. Una iniciativa que tuvo sus frutos a principios de la década de los 30, sobre todo con la publicación de la casa Lovell de Neutra en el número de mayo de 1930. No obstante, el criterio de los editores del Este se regía por estrictos códigos visuales que facilitaran la inteligibilidad de las obras publicadas a un público muy amplio y heterogéneo de suscriptores. Esto explicaría, por ejemplo, que el Art Déco de la casa Samue ${ }^{226}$ de Lloyd Wright, fuera publicado en el número siguiente de junio de 1930, mientras que se vetó el acceso a la documentación enviada por Pauline de su casa de Kings Road. Una vez más hay que insistir, es significativo que la extraña casa de los Schindler no fuera publicada hasta diez años después de su terminación, cuando la revista de Filadelfia $T$-Square la dio a conocer en febrero de $1932^{227}$.

Pauline Schindler fue colaboradora habitual de prácticamente todas las revistas californianas que, en los años 30, durante su etapa de mayor actividad como escritora, trataron de manera especializada sobre temas relacionados con el arte y la arquitectura. Hay que destacar, sobre todo, la publicación de San Francisco Architect and Engineer y dos revistas de Los Ángeles, Touring Topics y California Arts \& Architecture, las más avanzadas en su defensa de la modernidad arquitectónica gracias al nivel intelectual de sus sucesivos editores y colaboradores, comprometidos ya con esa causa varios años antes de la llegada de John Entenza a la dirección de esta última.

Touring Topics era la publicación del Automobile Club of Southern California y, por tanto, había surgido vinculada al coche y a la movilidad, la esencia de la cultura californiana. Su primer número había aparecido en 1909, pero lejos de centrarse en los automóviles, había apostado por enfatizar la parte lúdica del viaje, el placer del descubrimiento, los atractivos turísticos de los paisajes del Oeste y las posibilidades de la buena vida californiana. En 1927, siendo una de las publicaciones más leídas del sur del estado, la dirección de la revista fue asumida por el escritor Phil Townsend Hanna, antiguo editor nocturno de Los Angeles Times. Hanna estaba conectado con la vanguardia artística y literaria de la ciudad, teniendo una estrecha relación personal con el librero Jake Zeitlin y el empresario y coleccionista Merle Armitage -con los que solía polemizar porque sus ideas eran más conservadoras que las de sus amigos ${ }^{228}$.

Bajo la dirección de Hanna, los artículos de Touring Topics destacaron por su documentación y por la profundidad de sus discusiones. Por ejemplo, la revista comenzó a publicar los textos críticos de Carey McWilliams sobre la historia de California, distanciándose así de otras revistas locales que aún seguían en la órbita romántica y publicitaria de los mitos de la región. 


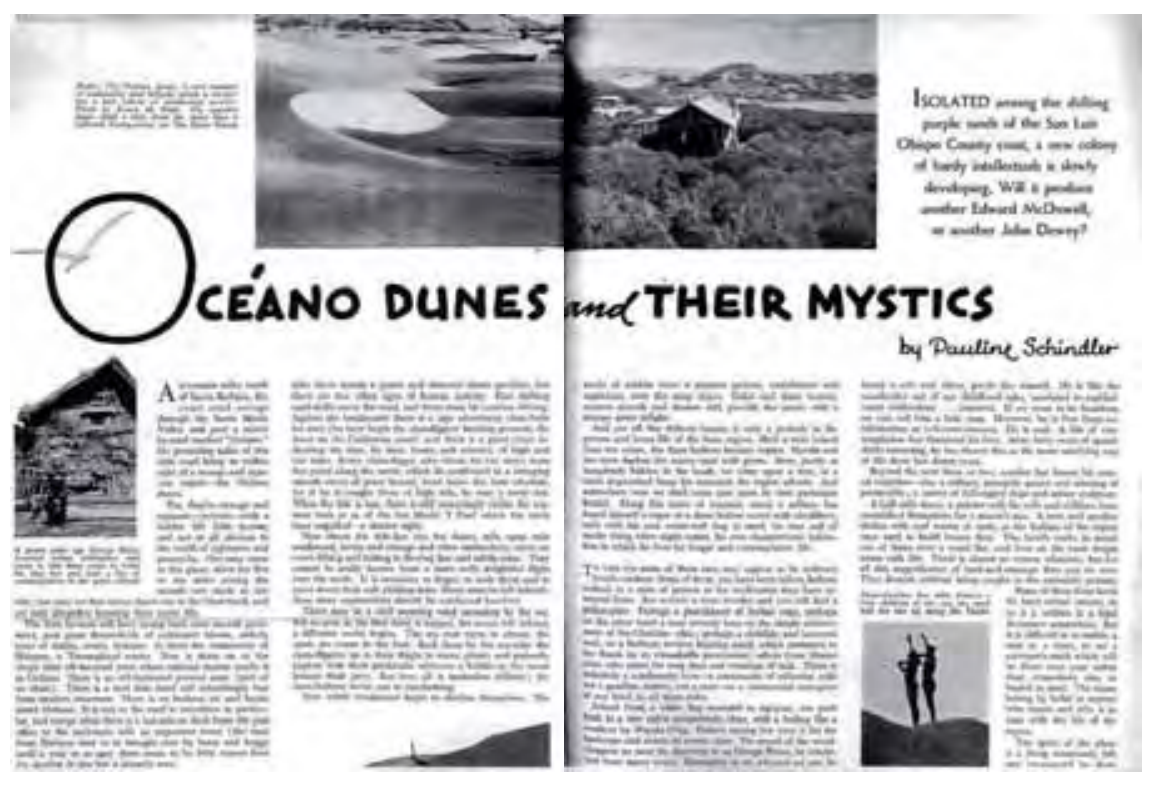

La nueva etapa de Phil Townsend Hanna se caracterizó igualmente por una actualización de de la imagen de la revista, apostando por un diseño gráfico de indiscutible calidad. Touring Topics se esforzó en divulgar la obra de algunos de los artistas modernos más relevantes del Sur de California, como la pintora Henrietta Shore o los fotógrafos Will Connell y Edward Weston, de quien publicó un artículo de ocho páginas en el número de junio de 1930 escrito por Merle Armitage, futuro editor de Weston. Por cierto, la revista dio a conocer también una de las primeras imágenes de Julius Shulman que por entonces iniciaba su carrera como fotógrafo de arquitectura y, muy poco antes, había tomado la fotografía de las dunas que se incluyó en el número de enero de $1937^{229}$.

Phil Townsend Hanna buscó a los mejores cartelistas para que diseñaran sus portadas: Maynard Dixon, a quien Hanna había conocido en una exposición de sus trabajos en la galería Zeitlin Books, fue contratado para ilustrar todas las del año 1930 con una serie dedicada a la historia de los medios de transporte en California; Carl Oscar Borg hizo lo propio en 1931 con los hitos de la exploración del Oeste; y Grace Marion Brown optó por identificar con composiciones abstractas algunos de los números más rompedores de 1932. El pintor Conrand Buff, uno de los primeros clientes de Richard Neutra y asiduo de los círculos de Kings Road y Jake Zeitlin realizó el número de junio de 1932; y, en 1933, Alvin Lustig, futuro diseñador y responsable de la nueva imagen de Arts \& Architecture durante la etapa de John Entenza, produjo la divertida portada del número de mayo de 1933.

Cuando, en febrero de 1934, Pauline Schindler publicó su artículo Oceano Dunes and Their Mystics ${ }^{230}$ sobre la comunidad de artistas de Oceano con objeto de promocionar el lanzamiento de Dune Forum, la revista de Phil Townsend Hanna acababa de cambiar su nombre por el de Westways, denominación bajo la cual se ha continuado editando hasta la actualidad.

Por su parte, California Arts \& Architecture -una revista en cuya historia se incidirá más adelante al tratar de las relaciones entre John Entenza y Harwell Hamilton Harris-, había surgido en 1929 como fusión de dos publicaciones especializadas en arquitectura, mobiliario y diseño de interiores. Su propietario tras la refundición, el arquitecto de San Francisco Harris Allen, y su directora de contenidos (managing editor) Mabel Urmey Seares, habían

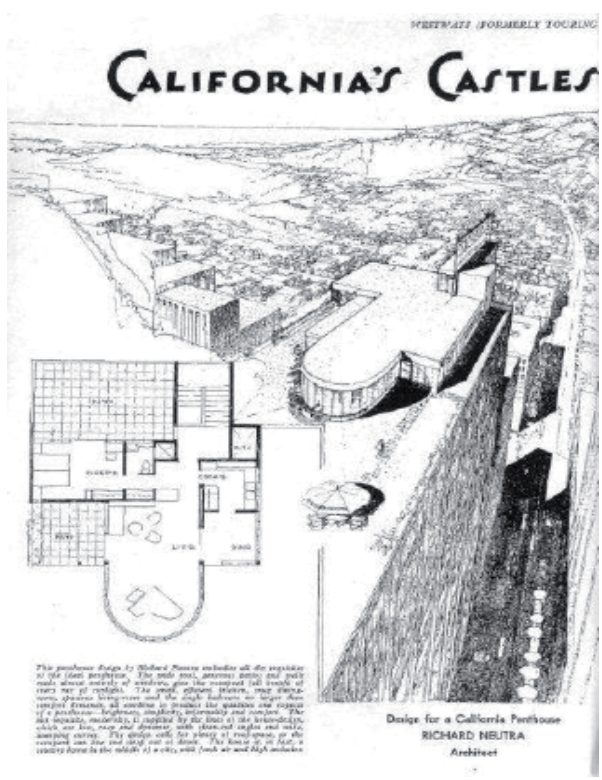

Izquierda: Touring Topics (Westways): PGS: "Oceano Dunes and Their Mystics", artículo aparecido en febrero de 1934

Derecha: Touring Topics (Westways): Richard Neutra: "California Castle's in the Air", articulo sobre un proyecto de ático aparecido en febrero de 1934. Fuente: John Crosse

Página siguiente arriba y centro: Touring Topics: Portadas de los números de junio (arriba) y julio (centro) de 1930 diseñadas por Maynard Dixon

Página siguiente abajo: Touring Topics: Portada del número de junio de 1932 diseñado por Conrand Buff 

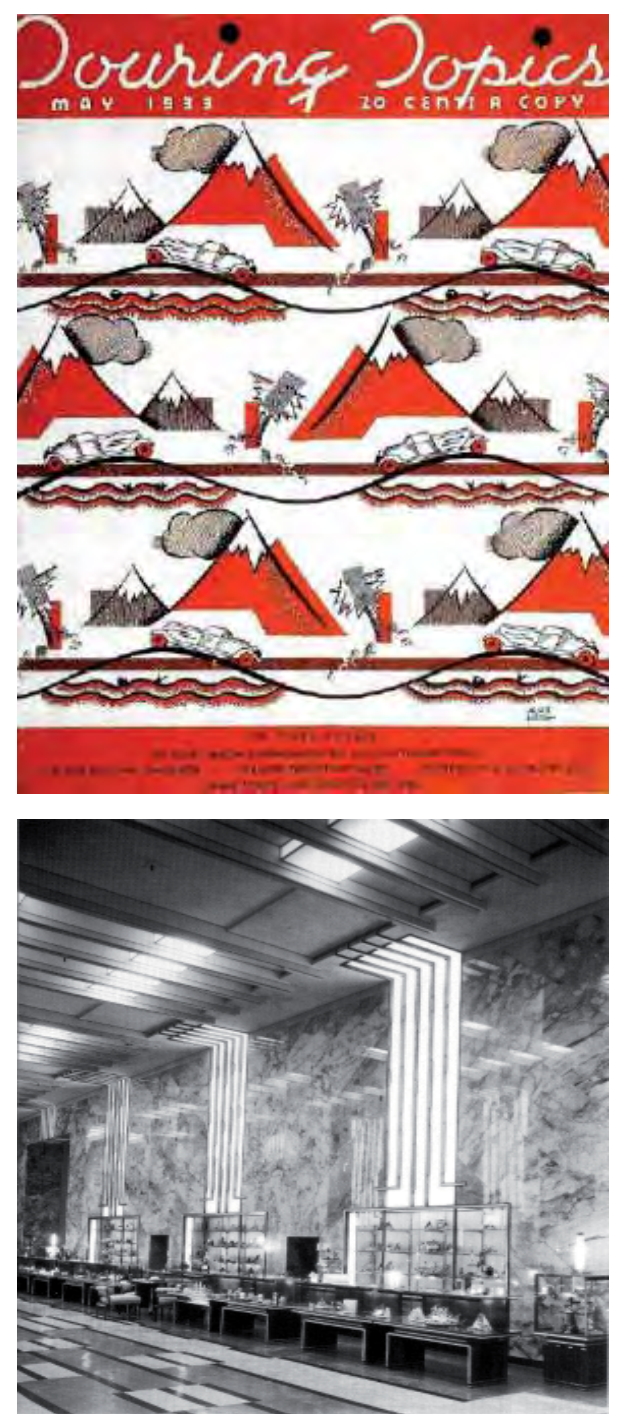

Izquierda arriba: Touring Topics: Portada de mayo de 1933 diseñada por Alvin Lustig Izquierda abajo: Jock Peters: Departamento de perfumería. Almacenes Bullock's Wilshire Derecha: Almacenes Bullock's en Wilshire Boulevard, 1929. Los Angeles Public Library Photo Collection

Página siguiente arriba: Richard Neutra: Articulo sobre la exhibición en Bullock's Wilshire de la exposición del Estilo Internacional publicado en el número de julio de 1932 de CA\&A Página siguiente abajo: CA\&A tras la fusión de las revistas Pacific Coast Architect y California Southland, marzo 1929

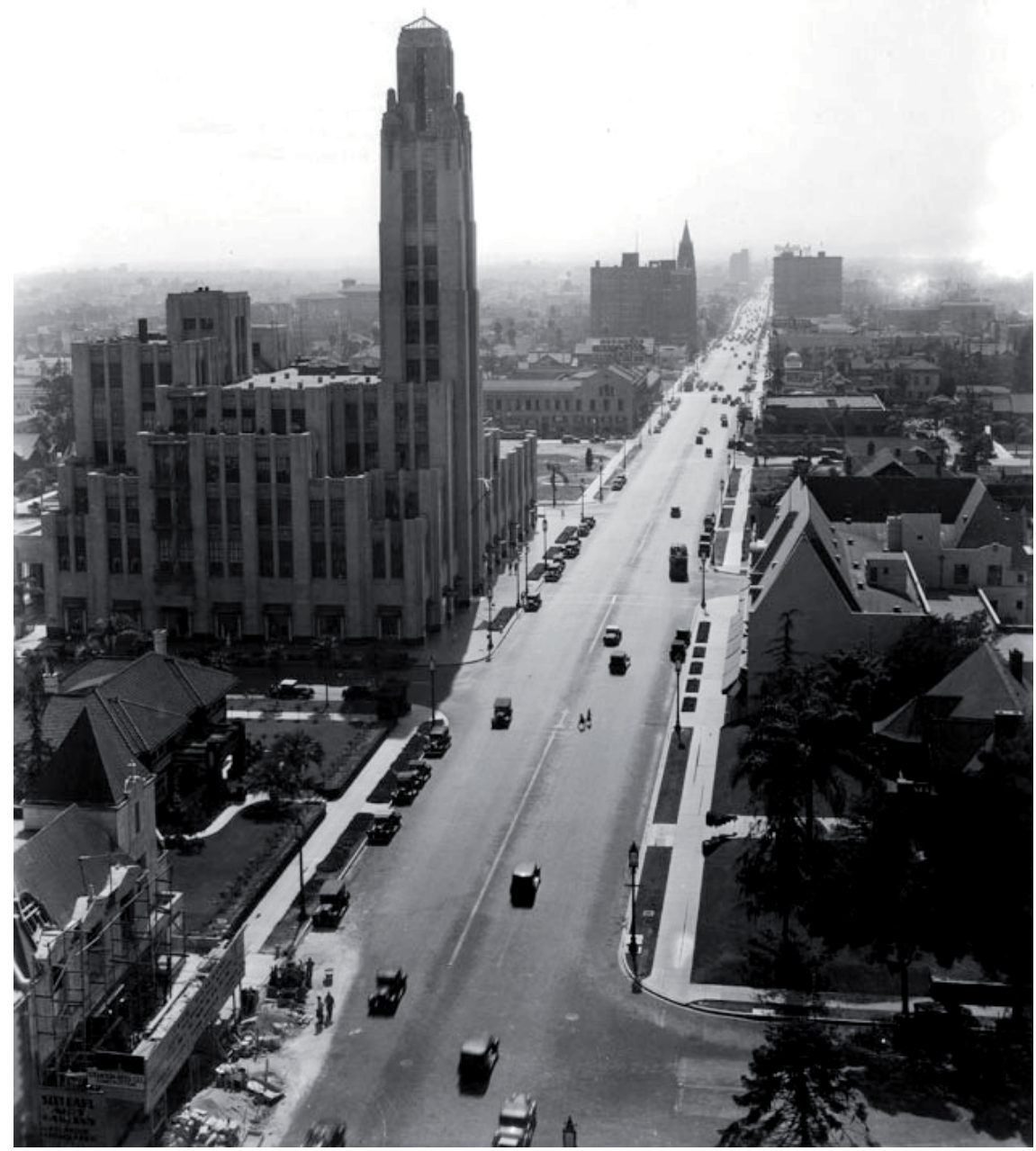

comenzado a cubrir las agendas de las principales galerías y salas de exposiciones de Los Ángeles con el fin de dar cuenta en la nueva revista de las principales actividades del panorama artístico de la ciudad. De este modo, California Arts \& Architecture inició su andadura como revista mensual de arte y arquitectura, dando también cabida a temas de moda y decoración.

Frente a Touring Topics, destinada a un público diverso y mucho más numeroso, los suscriptores de California Arts \& Architecture eran profesionales de la arquitectura o acomodados residentes del Sur de California con aficiones artísticas y gusto por el diseño y la arquitectura. Las fuentes de ingresos de las dos revistas procedían en buena medida de la publicidad. Pero mientras que los anunciantes de Touring Topics eran sobre todo empresas de productos relacionados con los automóviles, talleres, compañías de seguros, hoteles y restaurantes, los de California Arts \& Architecture procedían de los negocios inmobiliarios, fabricantes de materiales de construcción y profesionales del sector como decoradores, fabricantes de muebles o galerías de arte.

Aunque, por la inercia de las tendencias anteriores a la fusión, las primeras arquitecturas publicadas por California Arts \& Architecture, en general, fueron obras historicistas o viviendas Arts \& Crafts, esta situación no se prolongó mucho tiempo ya que la nueva dirección de la revista pronto empezó a interesarse por realizaciones modernas, tanto en el campo del arte como de la arquitectura. De hecho, aunque la revista mantuvo su lado conservador 
hasta mediados de los años 30, el cambio de dirección ocurrió antes de lo que se cree y aunque, hasta principios de 1935 , no hubo un número dedicado exclusivamente a arquitectura moderna, la aparición esporádica de artículos sobre determinadas obras o eventos relacionados con la modernidad pone de manifiesto la existencia de movimientos internos en su consejo editorial.

Entre estos, cabe destacar el inicio en 1932 de la colaboración de Merle Armitage con $C A \& A$, aunque su nombre no figura en los créditos como miembro de su consejo editorial hasta $1933^{231}$. La defensa a ultranza de la modernidad por parte de Armitage tuvo seguramente entre sus primeros frutos la publicación, en el número de julio-agosto de 1932, de un crítica a doble página de Richard Neutra sobre la inauguración en la ciudad, coincidente con los Juegos Olímpicos de Los Ángeles, de la exposición del Estilo Internacional del MoMA en los Almacenes Bullock's Wilshire, un artículo que el arquitecto aprovechó hábilmente para publicitar una vez más su Lovell Health House.

Desde sus inicios hasta 1934, California Arts \& Architecture compitió con Touring Topics por atraer lectores, como prueba el hecho de que ambas revistas cubrían las obras de los mismos artistas locales. Las fotografías de Edward Weston aparecieron en el número de junio de Touring Topics, concretamente en la citada crítica de Merle Armitage y cinco meses más tarde, en noviembre de 1931, en un artículo de CA\&A publicado sobre él'232. De nuevo, en marzo de 1934 Touring Topics incidía en la obra del fotógrafo. Y ese mismo año, en agosto, CA\&A recurría a una fotografía de su hijo Brett para ilustrar su portada con una imagen de las dunas de Oceano que había llegado a la redacción de la revista a través de la influencia ejercida por Pauline Schindler como directora adjunta de la recientemente clausurada Dune Forum.

En esa época, los temas, diseño y tipografía de California Arts \& Architecture habían evolucionado paulatinamente hacia las posiciones y gustos de los miembros más avanzados de su diseño editorial. Poco antes de completar su giro definitivo hacia la promoción de la modernidad local con la llegada de Mark Daniels al frente de su consejo editorial, George Oyer, responsable de los contenidos revista entre la etapa de Allen y la siguiente de Daniels, ofreció a Pauline Schindler la oportunidad de seleccionar, en calidad de directora invitada, los contenidos del primer número de 1935.

La primera colaboración de Pauline Schindler con California Arts \& Architecture había tenido lugar en 1930. Ésta había consistido en su elogiosa crítica233 del interiorismo ${ }^{234}$ del nuevo edificio de los grandes almacenes Bullock's en Wilshire Boulevard, publicado a continuación de otro artículo sobre la misma obra escrito por el editor de la revista Harris Allen.

El número de enero de 1935 de California Arts \& Architecture, dirigido en solitario por Pauline Schindler, es relevante desde el punto de vista histórico por varias razones. Por un lado, fue el primer número que esta publicación dedicó monográficamente a la arquitectura moderna producida en California; por tanto, supuso la constatación más evidente del cambio de rumbo que había ido experimentando la revista. Por otro lado, confirmaba el papel de agente promotora de la modernidad de Pauline Schindler en su triple faceta de divulgadora, crítica y precursora de los primeros cronistas de la región, ya que la mayoría de arquitectos escogidos -exceptuando la significativa incorporación de Harwell Hamilton Harris- ya habían sido objeto de sus escritos anteriores por lo que, al incidir en la idea de grupo, indirectamente Pauline se estaba anticipando a las narraciones de Esther McCoy sobre las diferentes
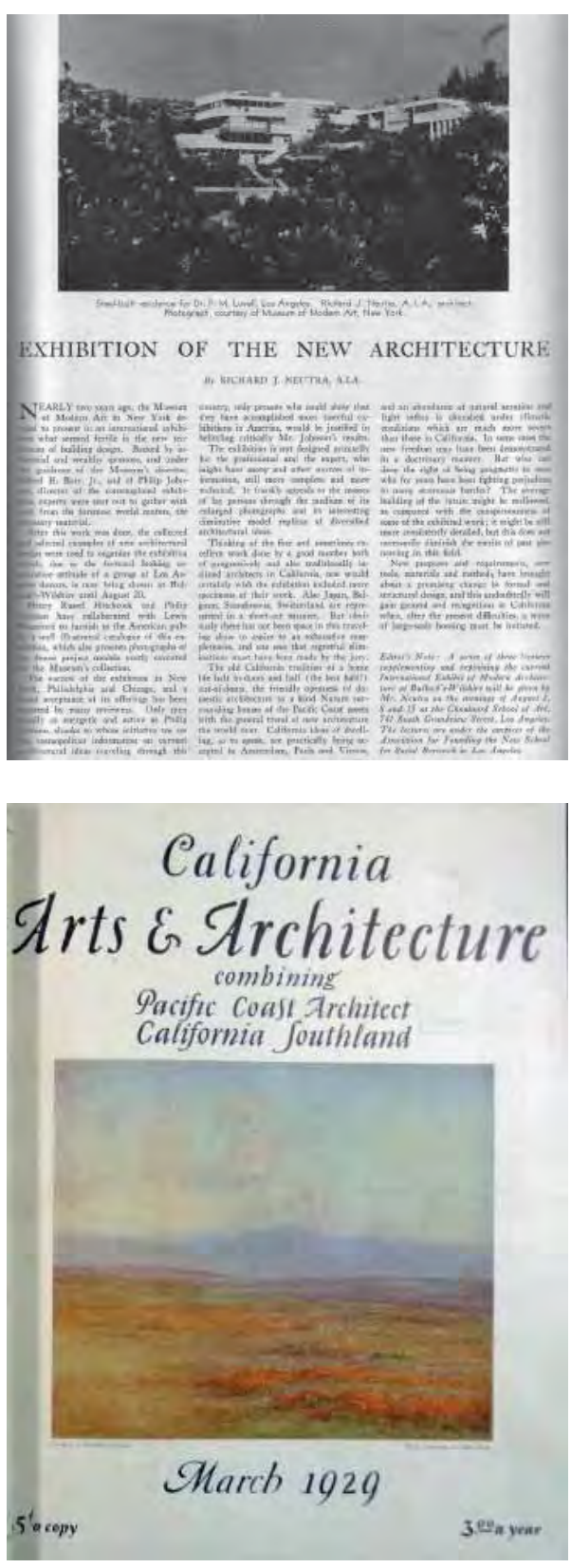

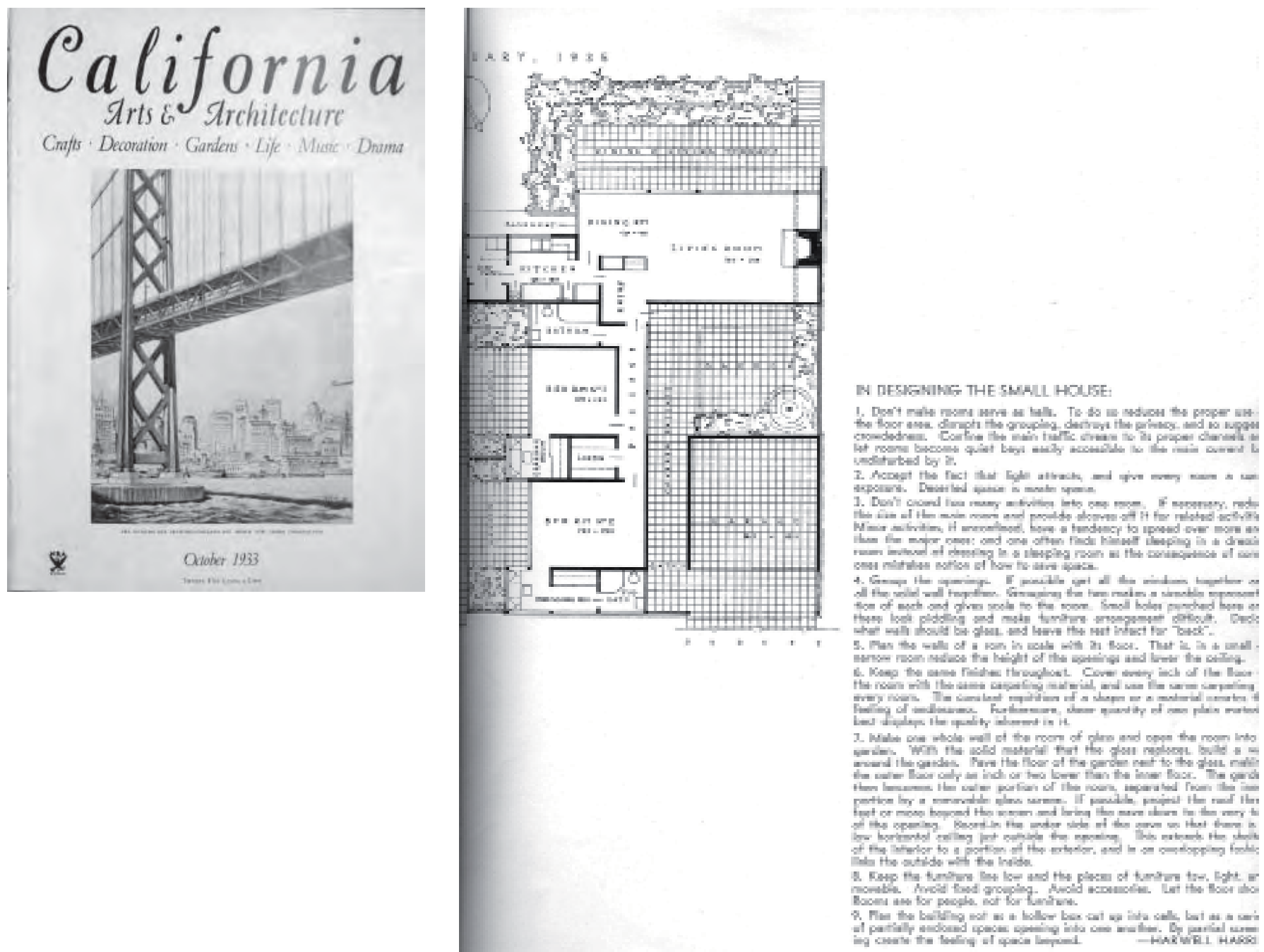

generaciones de arquitectos californianos. Por último, este primer número de 1935 de California Arts \& Architecture confirmaba el debut de Harris como arquitecto independiente.

Mediante la selección de los textos y de las obras que integraban su índice, Pauline Schindler ponía una vez más el foco en la diversidad y originalidad de la vanguardia californiana. Entre otros, los arquitectos protagonistas de este número eran: Richard Neutra, Rudolph Schindler, J. R. Davidson, Kem Weber, Lloyd Wright, Jock Peters, Morrow \& Morrow y Harwell Hamilton Harris.

Entre las obras de Richard Neutra, Pauline escogió la Lovell Health, la vivienda del arquitecto en Silver Lake (VDL Research House) y las residencias Koblick, Mosk, Beard y Sten-Frenke; de Rudolph Schindler las casas Oliver, Wolf y Gibling -la vivienda de sus padres en Westwood-; por último, de Harwell Hamilton Harris publicó la casa para Pauline Lowe en Altadena, una casa recién terminada y que poco antes había aparecido la revista House Beautiful en su número de octubre de 1934, es decir, un mes antes de la primera reseña de Richard Neutra en esta popular revista. Además de publicar su primera obra construida, Pauline pidió a su amigo Harris un artículo para este número monográfico de CA\&A, y éste envió su texto In Designing the Small House (Para diseñar una casa pequeña), una relación de criterios y recomendaciones de diseño que, como se verá más adelante, contenían el resumen de un ideario arquitectónico al que Harris se mantuvo fiel el resto de su vida. 
Dado que Frank Lloyd Wright había rehusado participar en la exposición organizada por Pauline en 1930, en este caso, ella prefirió escribir un artículo sobre él en lugar de solicitar de nuevo su participación. Dicho artículo fue planteado como un panegírico de su obra titulado Modern Architecture Acknowledges the Light Which Kindled It (La arquitectura moderna reconoce la luz que la alumbró).

Sintomáticamente, la portada de este número estaba ilustrada con una litografía de William Woolett de la construcción de la presa Boulder -futura presa Hoover-en el río Colorado, una infraestructura terminada en 1936, dos años antes de lo previsto, y que junto con el Golden Gate Bridge y el Bay Bridge de san Francisco se convirtió en uno de los símbolos nacionales de la superación de la Gran Depresión.

En su editorial, Pauline Schindler reflexionaba sobre la efervescencia creativa y sobre las condiciones únicas de libertad para experimentar que se daban en Los Ángeles y en otros asentamientos costeros californianos. También incidía en la reunión de tantos y nuevos talentos en la región -todos vinculados a su círculo de Kings Road-, así como valoraba muy positivamente la determinación de la revista para reconocer y apostar por un nuevo movimiento artístico que ella misma, aun prefiriendo denominarlo contemporáneo, aceptaba calificar como moderno, no sin antes matizar: "Este número de California Arts \& Architecture tiene como tema central el movimiento de arquitectura contemporánea que se ha dado en llamar 'moderna'. [...] Aunque los artífices de la nueva arquitectura están preocupados por la resolución de problemas funcionales y de simplificación técnica, es el espíritu de los tiempos el que dirige su trabajo. Están provocando un vocabulario formal para una civilización nueva que aún está por venir. [...] Pero 'moderno' (modern) y de 'estilo moderno' (modernistic) no hacen referencia a la misma arquitectura. El estilo moderno es algo superficial, una moda de vacía geometrización, por fortuna ya superada y comparable al 'art nouveau' del periodo victoriano. La auténtica y creativa arquitectura contemporánea, la cual, a falta de un calificativo más adecuado, denominamos como 'moderna' es orgánica y está basada en los principios de la estructura y de un espíritu de profunda realización. Entre el estilo moderno y la modernidad hay la misma distancia que separa al eco distorsionado de la auténtica $v_{0 z}{ }^{\prime 235}$. Aunque es reconocible la influencia de Neutra y, por supuesto, de Schindler en sus ideas, sus palabras suponían toda declaración para 1935, realizada además por una mujer y desde un territorio periférico.

El propio editor de la revista, George Oyer, reconoció el mérito de su directora invitada cuando en su texto introductorio, California, As Wee See it (California tal como la vemos), escribió: "Desde hace varios meses venimos considerando la conveniencia de registrar una muestra representativa del trabajo de nuestros diseñadores californianos modernos. Para el profano, el término moderno se aplica a cualquier casa o edificio donde dominan las líneas horizontales y verticales, a cualquier fachada con paneles de aluminio pulido o revestimientos de bronce. El término moderno aplicado a la arquitectura y al diseño de interiores tiene por tanto todavía un significado impreciso [...] Es imposible mostrar toda la producción más distintiva de estos arquitectos modernos californianos. Por ello, tanto si resulta o no del agrado de ustedes, estamos en deuda con la señorita [sic.] Pauline Schindler por su inestimable ayuda en la selección de fotografías y artículos. Vaya desde aquí nuestro agradecimiento".

En su capítulo del libro The Second Generation dedicado a Harwell Hamilton Harris, Esther McCoy aludió a la importancia de este número concreto de

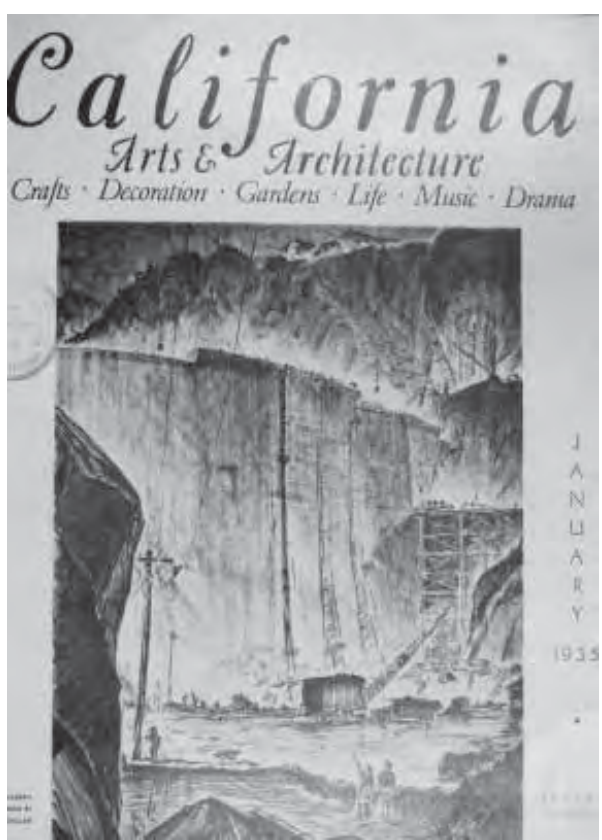

CA\&A, portada de enero de 1935 con el dibujo de la construcción de la presa Hoover Los temas abordados por la revista, tal como aparece en su encabezado son: Crafts, Decoration, Gardens, Life, Music, Drama

Página anterior izda: CA\&A, portada de octubre de 1933 ilustrada con un dibujo del Bay Bridge, San Francisco

Página anterior dcha: Harris, "In Designing the Small House", artículo aparecido en CA\&A, enero de 1935 ilustrado con la planta de la Pauline Lowe House, 1934. 


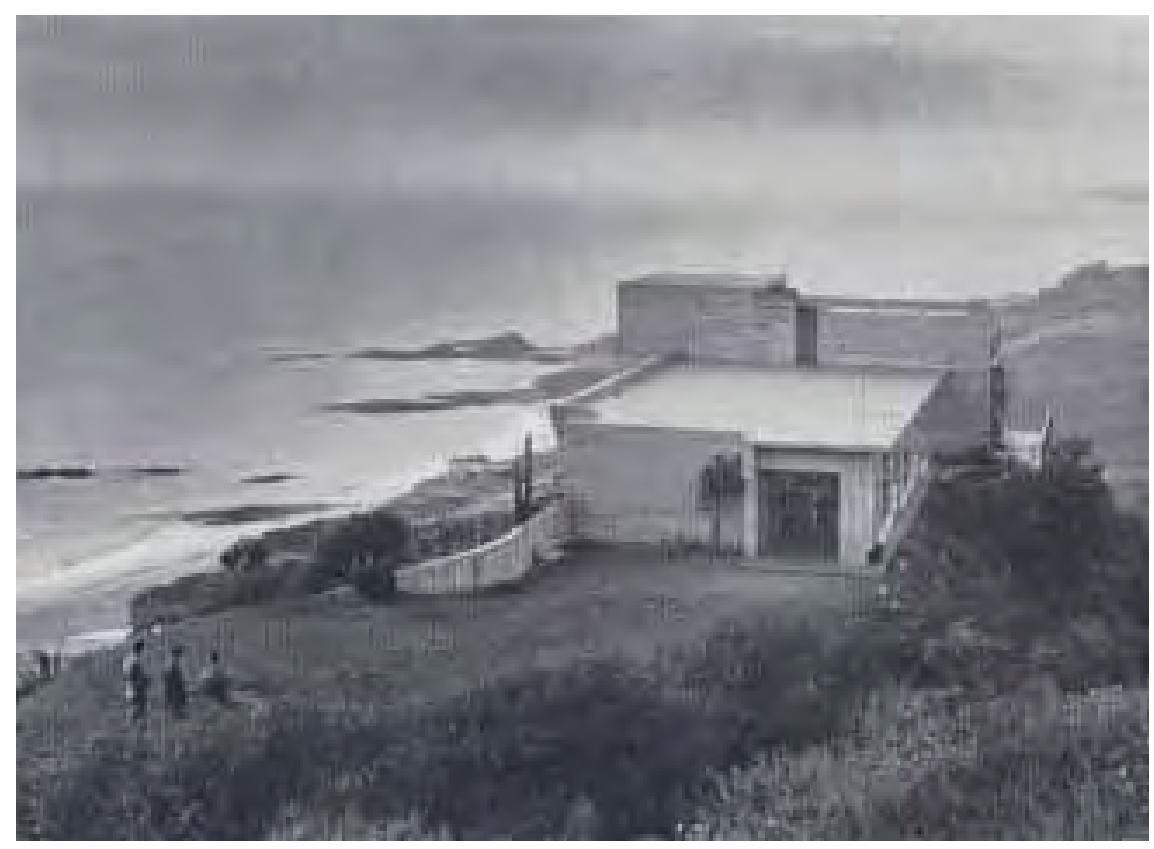

CA\&A comentando que aquella " pequeña banda de modernos fue afortunada al tener una revista como California Arts \& Architecture donde publicar sus obras $^{\prime 236}$. La discusión sobre su relevancia fue indirecta, ya que la historiadora recurrió al caso concreto de este número para referir la oposición que los trabajos de estos arquitectos encontraban en la otra costa del país. En concreto, McCoy sostenía que "el número de enero de 1935 dedicado a la modernidad de California se topó de frente con la crítica del Este" ${ }^{\prime \prime 237}$. Y citaba, como ejemplo del desdén con el que fue recibido en determinados círculos de opinión, el caso del arquitecto $\mathrm{H}$. Van Buren Magonigle quien, en el número de marzo de 1935 de la revista neoyorquina Pencil Points, ridiculizaba el movimiento californiano calificándolo de una moda inconsistente ${ }^{238}$. En cualquier caso, es llamativo que Esther McCoy no nombrase a Pauline como responsable última de este número de $C A \& A$, un dato que, sin duda, debía conocer por su estrecha amistad con los dos Schindler y que avanzaría el argumento sobre el que se volverá más adelante acerca de la facilidad con la que McCoy se olvidaba de citar sus fuentes.

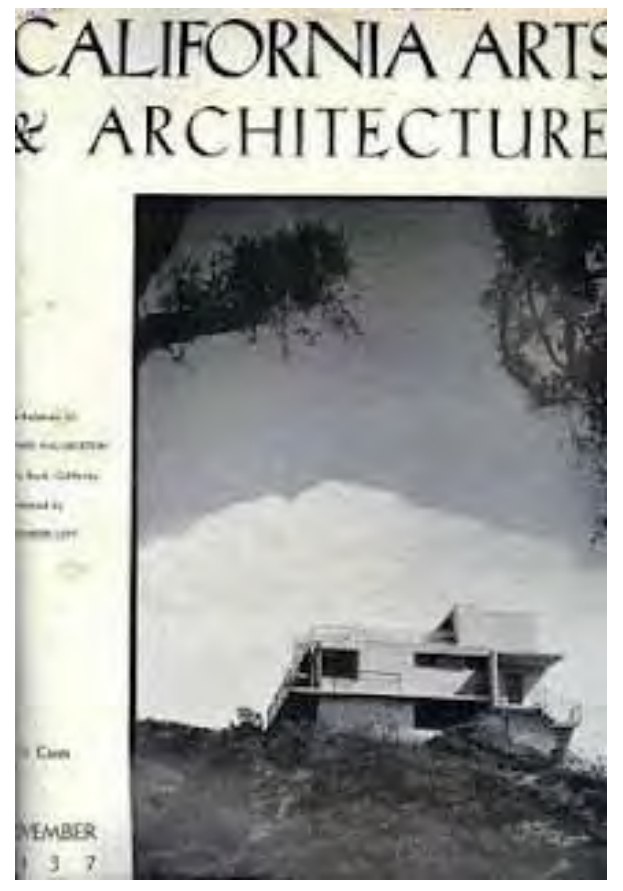

Otro de los importantes trabajos editoriales que contaron con la colaboración de Pauline Gibling Schindler fue el número de diciembre de 1935 de Architect \& Engineer dedicado a "The Modern Movement in Architecture" y realizado poco después de la clausura de la exposición en el Museo de Arte Moderno de Nueva York Contemporary Architecture in California que pudo visitarse del 30 de septiembre al 24 de octubre de 1935. En ella, por fin, después de tres años de la muestra del Estilo Internacional, el MoMA reconocía la importancia del conjunto de una producción arquitectónica moderna que, además de Richard Neutra y Frank Lloyd Wright, incluía obras de Schindler y William W. Wurster, entre otros. Es de suponer que, en el caso de esta nueva exposición, el MoMA tuvo que tener en cuenta los anteriores trabajos críticos de Pauline Schindler, no pudiendo obviar por más tiempo ni la citada exposición Contemporary Creative Architecture in California de 1930, ni el número de enero de 1935 de California Arts \& Architecture que ella había dirigido personalmente.

Es importante subrayar de nuevo el hecho de que, en 1935, eran precisamente los editores del Este los primeros que leían las pequeñas revistas de California para estar informados de cualquier novedad aunque, paradójica- 
mente, por aquellos años ellos todavía no consideraran el Oeste como un auténtico centro de producción arquitectónica.

Respecto a este trasvase entre las revistas minoritarias del Oeste y las publicaciones de gran tirada del Este, pueden citarse varios ejemplos. Uno de ellos lo constituye el caso de la enigmática vivienda de William Alexander Levy para el escritor y aventurero Richard Halliburton, su amante y editor Paul Mooney y el propio arquitecto e íntimo amigo de ambos. La vivienda, construida en Laguna Beach en 1937, es extraña a la tradición californiana por estar realizada enteramente en hormigón, quizás por esta razón, debido a su imagen más reconocible como internacional fue publicada con gran atención por Architectural Record -en octubre de $1938^{239-}$ menos de un año después de que apareciera a toda página y en portada en el número de septiembre de 1937 de California Arts \& Architecture.

Otro ejemplo es el del concurso General Electric Small Houses de 1934 donde, como se verá en la segunda parte, dos arquitectos de Chicago ganaron el primer premio con una propuesta que copiaba literalmente la planta de la Lowe House de Harwell Hamilton Harris en Altadena. Cuando el proyecto galardonado fue ampliamente difundido por la revista Time en abril de 1935, el editor de California Arts \& Architecture, George Oyer, publicó un artículo comparando la propuesta ganadora con la solución de Harris para poner en evidencia la coincidencia y denunciar el plagio. Este artículo, titulado Concernings Competitions, apareció en el número de mayo de 1935 de CA\&A, intrigando tanto a los editores de Architectural Forum que la revista de Boston lo reprodujo en su número de junio ${ }^{240}$. Sin embargo, Pauline Schindler, siempre atenta lo que sucedía a su alrededor, ya había publicado un artículo sobre el tema meses antes en el número de enero de la revista Aperitifif ${ }^{241}$, defendiendo a su amigo e iniciando para él toda aquella publicidad gratuita.

De todos los arquitectos promocionados por Pauline Schindler, indudablemente, la obra de su marido fue la que más dedicación requirió por su parte. En primer lugar, porque le exigió un gran esfuerzo para mantener su vida privada al margen de su relación profesional. A pesar de la cuidadosa educación progresista y del apoyo recibido por sus padres, seguramente, las infidelidades de su marido y la necesidad afectiva y económica de su familia incidieron en sus estados de ánimo, determinando así la evolución de su trabajo. Como ha señalado Robert Sweeney, sus aspiraciones de alta cultura y su idealismo chocaban frecuentemente con su propia realidad personal ya que, en muy pocas ocasiones, Pauline fue capaz de compaginar satisfactoriamente su anhelo de estar siempre al frente del pensamiento más progresista del momento con su necesidad de alcanzar una auténtica independencia emocional y financiera ${ }^{242}$. También porque, aunque era una mujer inteligente, con innumerables inquietudes y grandes ambiciones intelectuales, tenía tendencia a subestimar la calidad de su propia producción ${ }^{243}$ mientras que idealizaba la de sus compañeros y amigos, lo que dificultó aún más su labor crítica.

Pauline nunca dejó de considerar a Schindler como "el más brillante de todos los arquitectos modernos ${ }^{\prime 244}$. Por ello, tampoco puede pasarse por alto el hecho de que sus habituales cumplidos dificultan su propio discurso, por lo que éste no siempre resulta claro en la exposición de la originalidad y del

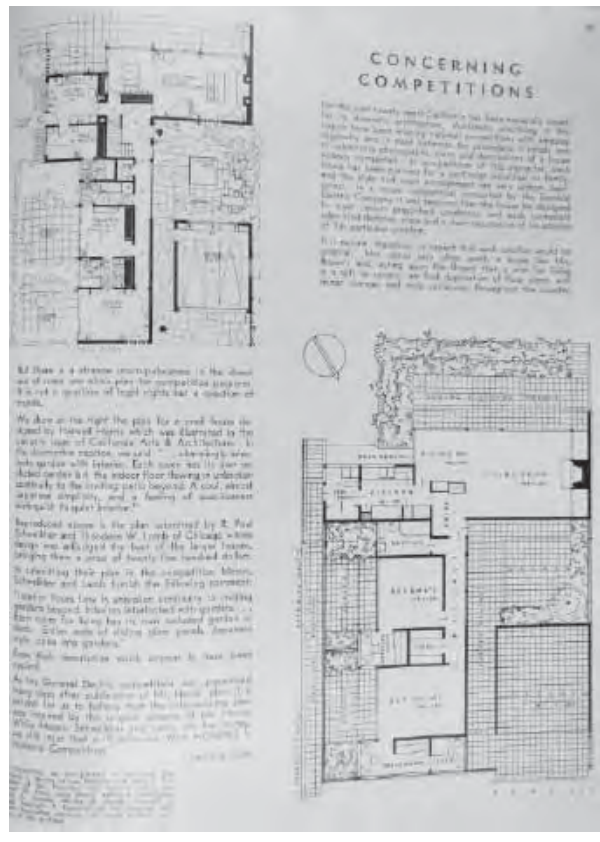

CA\&A, número de mayo de 1935 comparando la plabta de la Lowe House de Harris (derecha) con la propuesta ganadora del primer premio del Small House Competition organizado por General Electric en 1934

Página anterior izda: Alexander Levy: Richard Halliburton House en Laguna Beach, 1937, publicada por C\&A en septiembre de 1937 Página anterior abajo: Imagen de la Halliburton House publicada por Architectural Record en octubre de 1938 


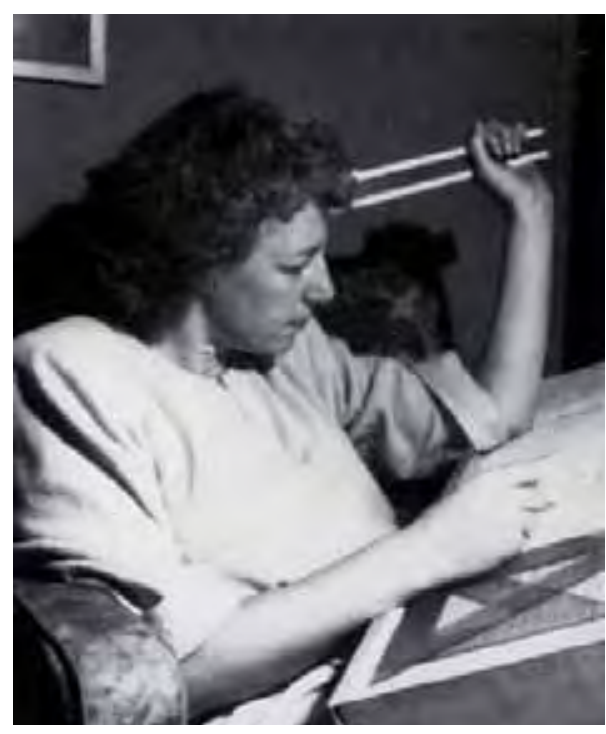

Esther McCoy en su mesa de dibujo, 1940. Fuente: Susan Morgan, Sympathetic Seeing Página siguiente: Direction, portada del número de otoño de 1945 significado de la arquitectura de Rudolph Schindler frente a la del resto de sus contemporáneos. En otras ocasiones, Pauline recurre a la paráfrasis del propio arquitecto para explicar su obra.

En un artículo publicado en la revista Creative Art en 1932, Pauline sostenía: "El trabajo de Schindler procede de una visión revolucionaria del mundo que difiere por completo de una consideración mecanicista de la vida a la que, quizás de manera abyecta, sirve el nuevo funcionalismo [...] Schindler considera la forma arquitectónica como el espacio mismo que crea, y no como las superficies planas de las paredes que lo delimitan. La percepción de las formas de este modo es radicalmente diferente del planteamiento inverso y añade una nueva dimensión a la experiencia del espacio. Las viviendas de Schindler están intimamente relacionadas con la tierra. Lo que quiere decir que la vida fluye libremente desde la casa y se prolonga puertas afuera, mientras que al mismo tiempo logra mantener una intensa privacidad. Las viviendas están interconectadas con sus jardines, y los jardines mismos se convierten en estancias" ${ }^{\prime 245}$.

En este artículo Pauline empleó directamente las tesis del propio Schindler sin mediación crítica $y$, por este motivo, aun describiendo características esenciales de su obra, incurrió en una generalidad aplicable a otros arquitectos tan californianos como Harrris, cuya producción arquitectónica, a pesar de haber sido influida por Schindler difiere notablemente de la de éste. La utilización promocional de los argumentos de su marido por parte de Pauline resulta aún más evidente cuando, para seguir con el ejemplo de este mismo artículo, describe el trabajo de Schindler como lírico y orgánico frente al funcionalismo de Neutra. Esta oposición era muy habitual en los textos del arquitecto y, además-como se ha visto-Schindler solía enfatizarla para poner en valor su trabajo frente al de Neutra.

Es innegable que, como escritora, Pauline también debió percibir el atractivo literario de la polaridad entre ambos autores. Una dualidad que, por supuesto, fue Esther McCoy quien supo explotar en todo el dramatismo de su confrontación personal.

La historiadora fue una de las últimas beneficiadas por la red de contactos y el apoyo brindado por Pauline a sus amigos. De acuerdo con Esther McCoy, ella y su marido, Berk Tobey habían visto por primera vez Kings Road en 1941, quedando sorprendida por aquella vivienda que le resultaba del todo extraña e incomprensible. Su mentor literario, el escritor Theodore Dreiser, vecino en la misma calle de los Schinlder y habitual de su salón, fue quien les llevó a conocer a Pauline. Respecto a aquella presentación McCoy escribió hacia el final de su vida: "No entendía nada, todo en ella era curioso y desconcertante. Pauline hablaba de su casa de un modo poético pero para una persona como yo, que últimamente había estado sólo pendiente del metal Alclad y de cómo se ensamblaban piezas en la Douglas, Kings Road era un mundo opaco. En el apartamento de Pauline miraba las ventanas altas, mi ojo seguía la transferencia de cargas de una a otra viga, la transición entre la cubierta más alta y el techo más bajo. Intentaba averiguar cómo había sido construido, intentaba pensar cómo había sido concebido e, incluso, intentaba tener claro cómo había sido dibujado. Dejé de hacerle preguntas a Pauline porque me di cuenta de que el tipo de cuestiones que planteaba estaban poniendo en evidencia que la estructura no era el camino para comprender la arquitectura de Schindler. Más tarde, un día Pauline me dijo que el único delineante de Schindler había sido llamado a filas y que yo debía entrevistarme con él para el puesto vacante ${ }^{\prime \prime 246}$. 
En realidad, McCoy no empezó a trabajar en la Douglas Aircraft hasta 1942, por lo que, o bien el dato de la fecha de su encuentro con Pauline no era un recuerdo exacto o bien -y esta segunda hipótesis parece más plausible dada la tendencia de la historiadora a alterar determinadas situaciones para hacer más convincente su discurso- McCoy evocó sus experiencias en la industria aeronáutica para enfatizar el contraste entre la fascinación que los materiales y la tecnología de la guerra ejercían sobre determinados arquitectos y el romanticismo de aquella case inexplicable. Muy seguramente se trate de una de sus habituales licencias literarias pero, en cualquier caso, tanto este texto como su entrevista ${ }^{247}$ con Joseph Giovannini, ambos documentos de 1987, McCoy afirmaba que fue a través de Pauline como conoció a su Schindler y comenzó a trabajar para éste.

Durante el tiempo que trabajó en Kings Road como delineante de Schindler (1944-1947), Esther McCoy cultivó una gran amistad con ambos, incluso es probable que-dado el carácter de Schindler-el arquitecto tuviera algún tipo de acercamiento sentimental con ella como apuntaron, entre algunos personajes próximos a la pareja, Dione Neutra ${ }^{248}$. Lo cierto es que, a partir de esa relación personal y del conocimiento directo de la obra de Schindler, a cuya producción ella misma ayudó dibujando, entre otras, las casas Kallis, Toole y Pressburger ${ }^{249}$, la historiadora desarrolló un considerable aprecio por su obra. Es más, coincidiendo con la estancia en su estudio, McCoy escribió su primer texto sobre arquitectura precisamente sobre él, Schindler, Space Architect $^{250}$ que, por mediación de Dreiser, apareció publicado en el número de otoño de 1945 de Direction, una revista de la Costa Este "dedicada a las artes y a las letras de izquierdas".

En mayo de 1953, dos meses antes de la muerte de Schindler, Pauline le envió su última carta. En ella se sinceraba escribiendo: "Estoy en deuda contigo, RMS, por todo lo que en todo este tiempo ha supuesto tu contribución a la arquitectura. Siempre que he logrado dejar al margen mis sentimientos personales, he sabido reaccionar plenamente a tu obra, sentir y apreciar su riqueza e, incluso, a veces, darme cuenta de su significado. Gregory Ain habla con frecuencia de la casa de Kings Road como una especie de milagro-que podría equipararse en arquitectura a lo que en música supuso la revolución creativa de La Consagración de la Primavera. Conforme veía tu trabajo a lo largo de estos años, me daba cuenta de cómo tu preocupación central era la evocación de una idea que todavía no había sido concebida, una especie de desvelamiento de las dimensiones en el espacio. Puedo reconocer aquellas cosas importantes que hacen que esta vida sea valiosa $y$, ahora [...], ya por fin, estoy lista para darte las gracias por ello"251.

Esther McCoy insinuó que Schindler no quiso ver a Pauline después de que fuera diagnosticado de cáncer y que tampoco llegó a leer nunca esta carta. Thomas Hines, sin embargo, opina que esta información no es correcta y que McCoy exageró la ruptura de las relaciones verbales entre ambos hacia el final de su vida ${ }^{252}$. Reparando en la pericia de McCoy para proporcionar información sesgada ${ }^{253}$, es probable que los recuerdos de Hines sean verídicos, sobre todo teniendo en cuenta que el historiador estuvo estrechamente vinculado a Pauline por una amistad que se mantuvo hasta la muerte de ésta en 1977.

Durante los últimos meses de la enfermedad del arquitecto, éste intercambió numerosa correspondencia con Esther McCoy. Del contenido de estas cartas se desprende que McCoy estaba recabando toda la información po-

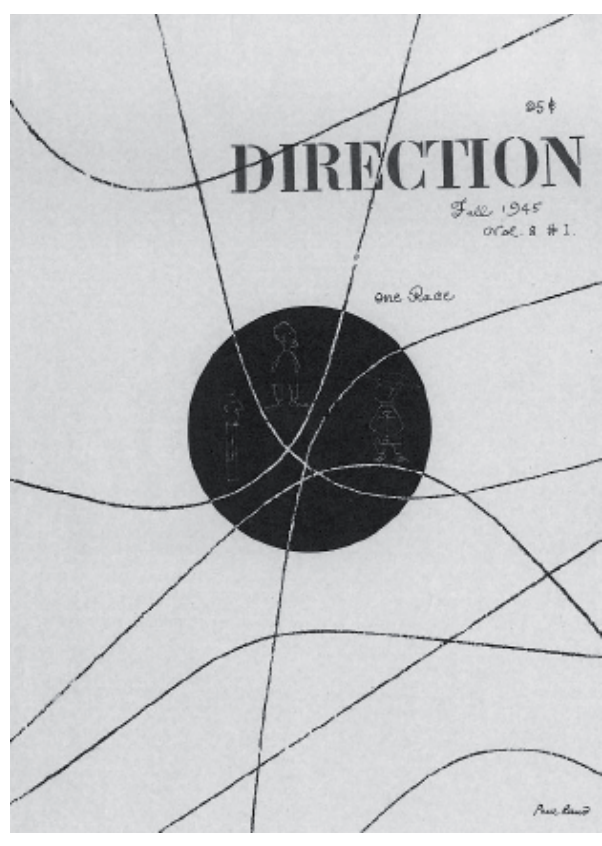

$182 \mid 183$ 
Pauline Schindler en Kings Road en 1941. Fuente: Schindler House Archives, Sweeney

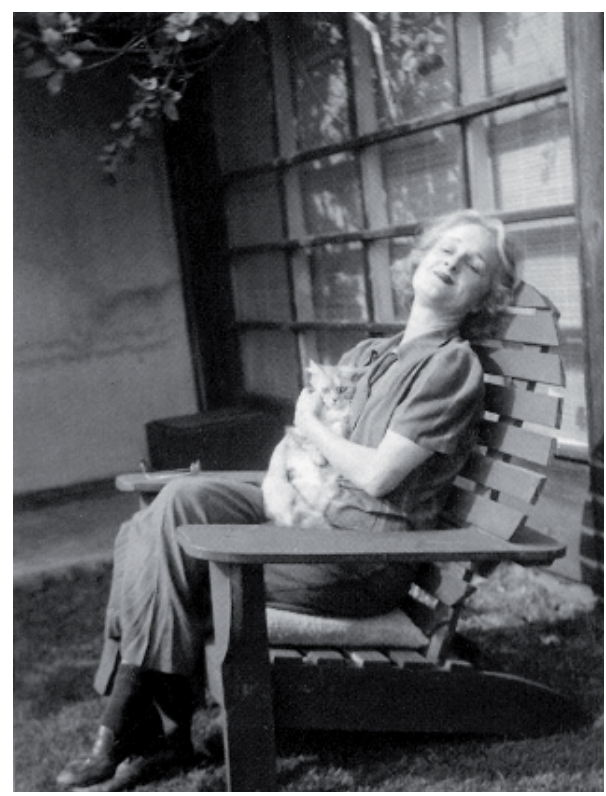

sible sobre las raíces del pensamiento arquitectónico de Schindler. La historiadora estaba entonces intrigada por el reciente descubrimiento de Greene \& Greene, llevado a cabo por el matrimonio Harris -sobre el que se tratará en la segunda parte de esta tesis- y trataba de establecer lazos entre la obra del Schindler y los orígenes de la tradición californiana representada por los hermanos Greene. En una carta enviada a Esther McCoy en marzo de 1952, Schindler comparaba la esencia californiana de su arquitectura ("Californiarooted architecture") con el "romanticismo insustancial" de Wright y la "forzada importación del Estilo Internacional" de Neutra, actitudes que cuestionaba con el fin de distinguirse a sí mismo como el autor que había producido la respuesta arquitectónica al medio californiano más sincera y original.

Es importante señalar dos aspectos sobre esta carta. En primer lugar, que fue escrita en el momento en que Schindler coincidió con su antiguo socio en el hospital durante una semana; aunque ambos arquitectos departieron amistosamente y recordaron momentos pasados, parece evidente que el contacto de nuevo con Neutra (entonces en la cima de su reconocimiento internacional frente a su discreto segundo plano), le movió en ese momento final de su vida a hacer un último esfuerzo por aclarar el sentido histórico de su arquitectura. Por otro lado, esta teoría se refuerza por el hecho de que, pocas semanas más tarde, en abril Schindler envió a Arthur Drexler al MoMA una carta -ya citada 254 al final del apartado anterior- cuyo contenido reproducía con insistencia las mismas ideas trasmitidas a McCoy en el mes de marzo. Probablemente por las explicaciones de Schindler a McCoy en las que se distanciaba contundentemente de los planteamientos de Wright y de Neutra, enfatizando la expresión "arquitectura enraizada en California", la historiadora agrupó a Schindler con los hermanos Greene, Maybeck y Gill en su primer libro de historia, Five California Architects, publicado siete años después de la muerte de Schindler.

La presencia en este trabajo de los hermanos Greene y de Bernard Maybeck se debía a la labor de recuperación iniciada por Jean Murray Bangs y Harwell Hamilton Harris, en la que McCoy basó su estudio de los hermanos. Por su parte, la decisión de incluir a Irving Gil probablemente surgiera a partir de los comentarios de Schindler a McCoy, como ella misma reconoció implícitamente en Five California Architects al afirmar que: "A lo largo de sus últimos años Schindler habló en numerosas ocasiones de la carrera interrumpida de Gill. El declive de la popularidad de Gill había sido para él como un viento helado que había golpeado muy cerca de su propia puerta. Schindler [me] dijo en una ocasión que, sobre todo, lo que él más temía era terminar sus días como arquitecto haciendo menudencias como le ocurrió a Gill"255.

En este sentido, no es aventurado pensar que el contacto con el arquitecto durante aquellos últimos meses influyó de manera determinante en la idea del libro y, por extensión, en el inicio de la carrera de McCoy como historiadora. 


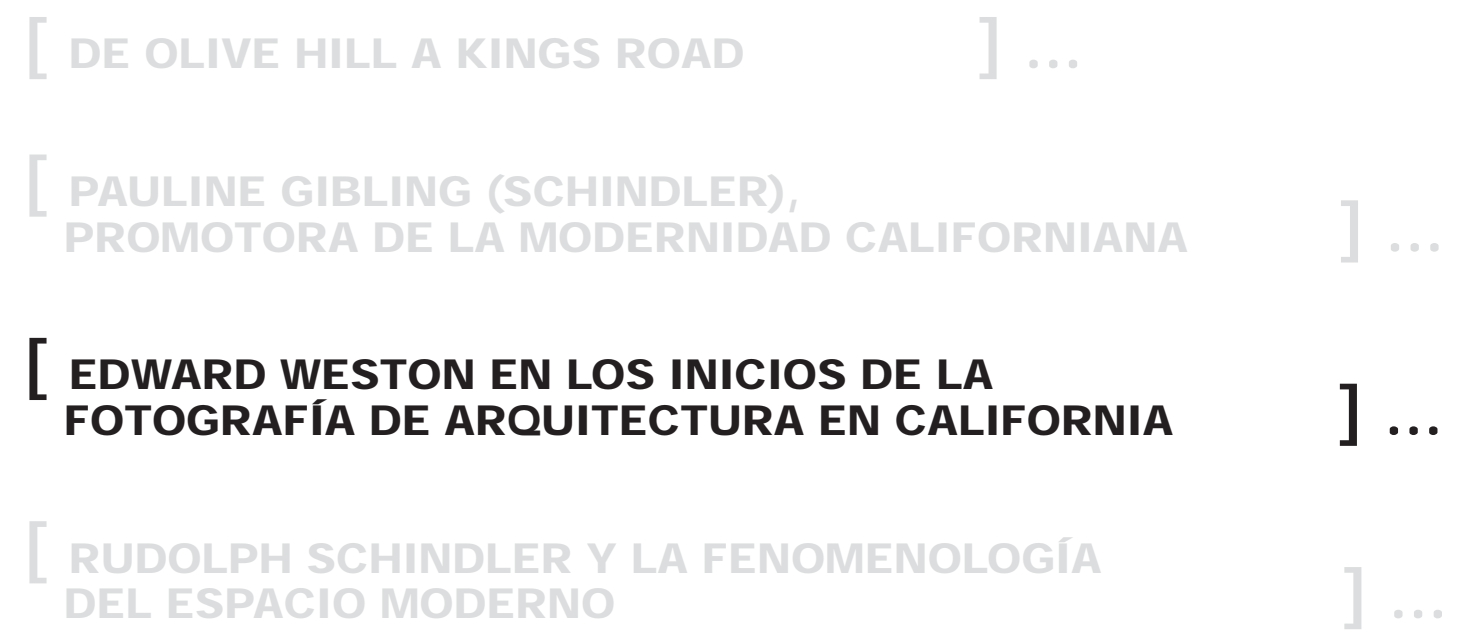




\section{Un nuevo paisaje creativo: artistas, amigos y amantes}

Con apenas 20 años, Edward Weston llegó a California en 1906, pocos días después del terremoto de San Francisco. Fue para trabajar como documentalista de algunas de las grandes infraestructuras que se estaban construyendo en el estado, como el puerto de San Pedro y la línea férrea del Salt Lake Railroad.

Weston Había nacido en Highland Park, Illinois. Comenzó a fotografiar a la edad de 16 años, con una cámara Kodak Bulls-eye regalo de su padre con la que tomaba instantáneas de la ciudad de Chicago y de la granja familiar. En 1906, el mismo año que viajó a California, había publicado su primera fotografía en la revista Camera and Darkroom. Durante sus primeros meses en Los Ángeles se ganó la vida como fotógrafo itinerante, yendo de casa en casa para retratar niños, bodas y funerales. Necesitando completar su formación regresó a Illinois durante una temporada para seguir estudios de fotografía en el College of Photography de Effingham, Illinois, donde completó los cursos en la mitad de tiempo para regresar cuanto antes a Los Ángeles. Durante dos años trabajó en los estudios de algunos fotógrafos de la ciudad hasta que, en 1911, abrió el suyo propio en Tropico (Glendale) a pocas millas del Downtown. Lo denominó The Little Studio y fue su base de operaciones durante casi dos décadas.

Durante ese tiempo Edward Weston trabajó solo, realizando fotografías de amigos, de su mujer, Flora, y de sus dos hijos mayores ${ }^{256}$, Chandler y Brett, nacidos, respectivamente, en 1910 y 1911 . Desde los inicios de su carrera el retrato fue uno de sus géneros preferidos. Esta disciplina le permitió ejercer una actividad profesional remunerada y, al mismo tiempo, desarrollar sus intereses artísticos como fotógrafo.

En esos primeros años el fotógrafo participó del pictorialismo, una corriente romántica influida por el impresionismo y el simbolismo literario y que estaba muy en boga por aquel momento en Norteamérica. Sus imágenes de este periodo introducen al espectador en ambientes vaporosos, son fotografías en tonos grises y beiges, deliberadamente difuminadas y con un enfoque sentimental acorde con el gusto de la época. Weston captó de inmediato la atención de sus contemporáneos, logró varios premios y sus obras, junto con sus artículos, comenzaron a ser publicados en revistas como PhotoEra, American Photography y Photo-Miniature.

Edward Weston, como muchos de sus amigos -pertenecientes al círculo de los Schindler-, evitó las convenciones de la vida familiar llevando una existencia libre de ataduras. Aunque, lógicamente, a costa de que su mujer permaneciera en casa al cuidado de sus cuatro hijos. Ella era hogareña, convencional, disciplinada y puritana; él, un incansable viajero, un creador radical, innovador y voluptuoso que mantuvo diversas relaciones con algunas de las mujeres más interesantes de su época.

Una de sus primeras compañeras, la fotógrafa Margrethe Mather visitó a Edward Weston en su estudio por primera vez en 1912 atraída por su creciente reputación. Bisexual y bohemia, era una artista notable cuyo trabajo y modo de vida, completamente opuesto al de su mujer Flora, debió fascinar a Weston. Mather se convirtió en su asistente y permaneció con él durante casi una década. Durante ese tiempo firmaron individualmente sus fotografías, aunque solían participar en la producción del otro e, incluso, realizaron algunos trabajos de manera conjunta. Muchos son retratos de personajes afines
Brett Weston: Retrato de su padre, Edward Weston, 1929. Fuente: Brett Weston Archive, Ocklahoma City

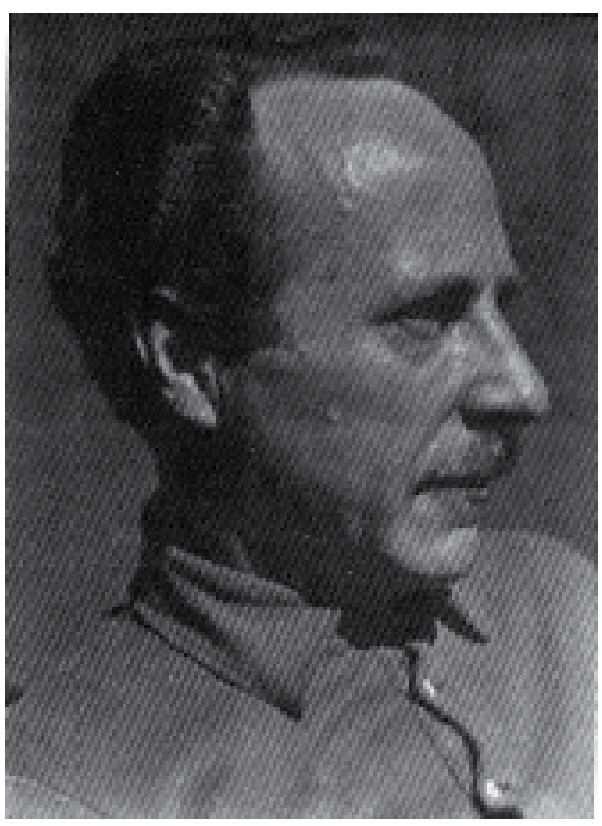




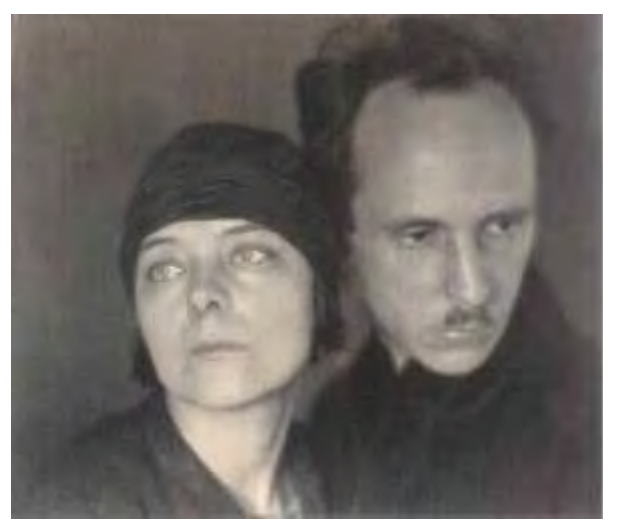

Imogen Cunningham: Retrato de Margrethe Mather y Edward Weston, 1922. Center for Creative Photography, University of Arizona.

Página siguiente izda: Edward Weston: Armco Steel Plant, Ohio, 1922. Georges Eastman House, Rochester, NY

Página siguiente dcha: Edward Weston: Epilogue, 1919. Center for Creative Photography, University of Arizona. a las ideas políticas de ambos, como el escritor Carl Sandburg y el también escritor y activista Max Eastman. Profesionalmente, Weston trató siempre a Mather como su igual y, de hecho, ésta fue la única etapa de su vida en la que el fotógrafo compartió los créditos de varias de sus obras.

Mather fue su musa, su colaboradora y su amante. Ella no sólo estimuló su creatividad, sino que ejerció con sus fotografías una decisiva influencia en la evolución del estilo de Weston, a quien proporcionó toda una serie de temas y de enfoques por los que el fotógrafo más tarde desarrollaría predilección. Fue Mather y no Weston quien, por primera vez, fijó su objetivo en partes del cuerpo o pequeños objetos, como manos, huevos, flores, frutas, alas de pájaro, accesorios de baño o conchas marinas, algunos de los cuales se convertirían en los principales motivos de la fotografía de Weston durante los años $20^{257}$.

Hacia finales de la década, después del nacimiento de su tercer hijo en diciembre de 1916, Weston conoció al fotógrafo Johan Hagemeyer, a quien brindó protección y a quien animó en los inicios de su carrera profesional. Weston prestó a Hagemayer su estudio en numerosas ocasiones, favor que éste le devolvería dejándole usar su estudio de Carmel cuando Weston regresó de México. No obstante, a pesar de la amistad entre ambos, Weston y Hagemayer tuvieron diversos desencuentros profesionales, especialmente cuando, tras la formación del Group f/64 a principios de los años 30, Hagemayer criticó duramente la fotografía directa que entonces defendían Edward Weston y Ansel Adams -entre otros-y se negó a formar parte del movimiento, una razón, probablemente, por la que su obra no alcanzó la difusión de la de sus amigos.

En 1919, su fotografía Epilogue marcó el inicio del progresivo alejamiento del fotógrafo de la temática y del estilo del pictorialismo. Ese mismo año, tras el nacimiento de Cole, su hijo menor, Weston se distanció aún más de su mujer, prácticamente relegada ya por éste al papel de madre. A pesar de ello, a partir de 1920, cuando Weston comenzó a fotografiar desnudos, Flora fue su primera modelo. Poco después fotografió a Mather, a cuyos desnudos siguieron otros, como los de Tina Modotti que, en esa época se convirtió en su nueva modelo y principal amante.

Weston había conocido a Modotti258 en 1921 y pronto su colaboración profesional derivó también en una relación sentimental, hecho que la pareja de ésta, el poeta y miembro de la bohemia de Los Ángeles Roubaix de l'Abrie Richey (Robo), no sólo toleró sino que, incluso, invitaría a Weston a compartir su estudio en México y promocionaría su obra en aquél país por medio de una exposición celebrada en 1923 y que incluía varios desnudos de Modotti.

Un año antes, en 1922, Weston había viajado a Middeltown, Ohio, para visitar a su hermana. Durante ese viaje realizó una serie de fotografías de la American Rolling Mill Compnay (ARMCO). Las imágenes tomadas en la planta de aceros ARMCO suponen un cambio en la manera de fotografiar de Weston. Al posar su mirada en los ambientes fabriles del Medio Oeste el artista abandonó la estética del pictorialismo. Weston se centró en los objetos fotografiados, reproduciéndolos con extraordinaria nitidez y precisión.

En ARMCO, Weston jugó por primera vez con las formas. Destacó las líneas rectas que atraviesan verticalmente la fotografía y los elementos curvos que cruzan la imagen en horizontal. El punto de vista bajo, la omisión del plano 


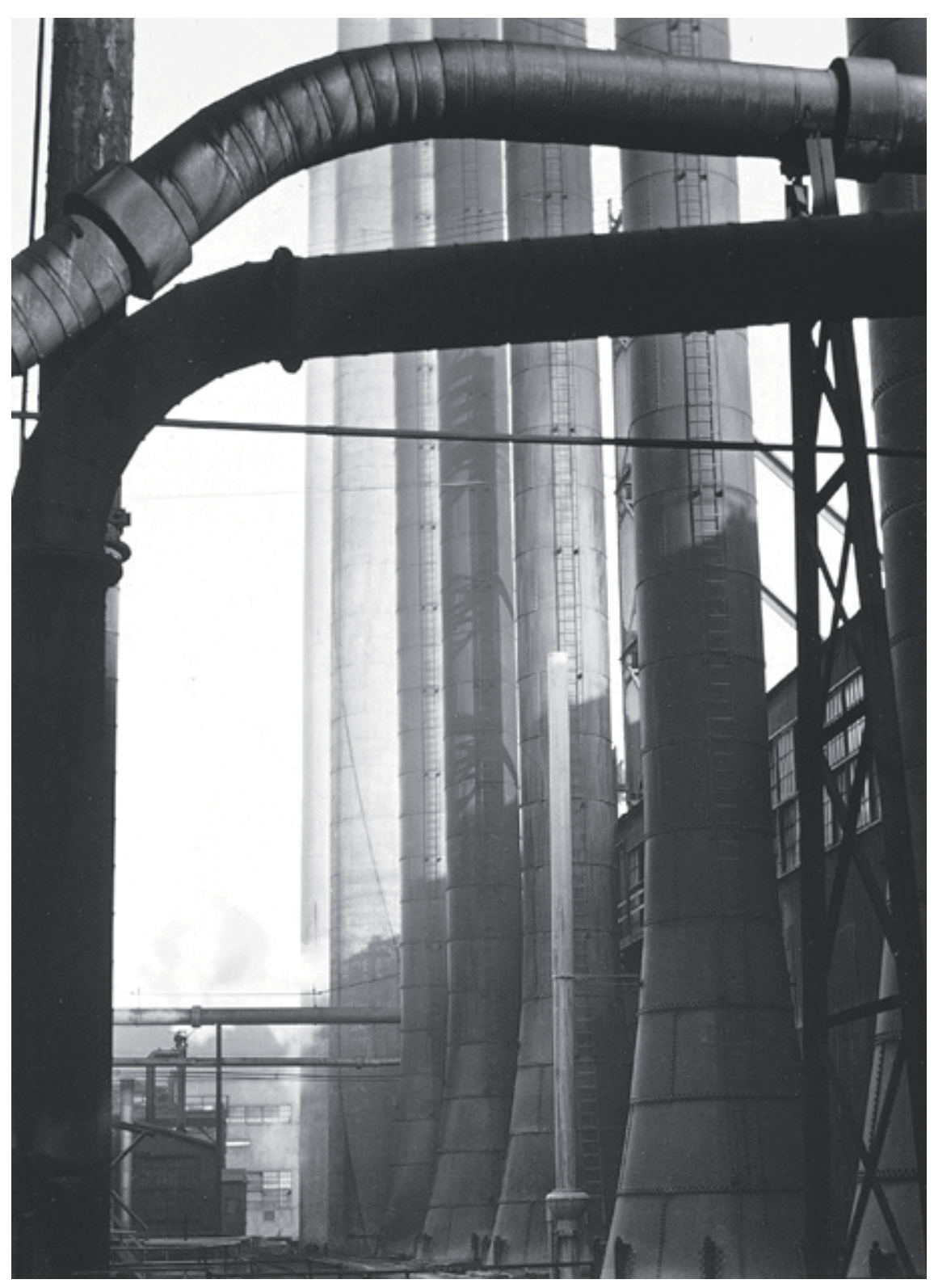

del suelo, el ritmo y la altura sin acotar de las chimeneas inciden en la carga plástica de los artefactos, poniendo de manifiesto toda la potencia de los paisajes de la industria norteamericana. Él mismo reconocería en sus diarios que "la visita a Middletown fue memorable, sobre todo, mi sesión fotográfica en ARMCO. Aquél día hice grandes fotografías... incluso, el propio Stieglitz admitiría su importancia".

Desde Ohio Weston continuó viaje a Nueva York, donde pasó los meses de octubre y noviembre con la intención de poder entrevistarse con Alfred Stieglitz, la figura más importante en aquel momento de la fotografía norteamericana. Además de Stieglitz, a quien reconoció como maestro, Edward Weston tuvo contacto con Charles Sheeler, Paul Strand, Clarence H. White, Gertrude Kasebier y Georgia O'Keefe. Todos estos artistas influyeron decisivamente en su producción posterior. Nueva York fue un punto de no retorno para la fotografía de Weston, que inició un periodo de transición y depuración a través del autoanálisis y la autodisciplina.

Esta evolución culminó en 1923, cuando el fotógrafo, acompañado por Chandler, el mayor de sus hijos, y por Tina Modotti (bajo el pretexto de ser sus asistente y traductora), a finales de julio iniciaron un viaje de varios años por

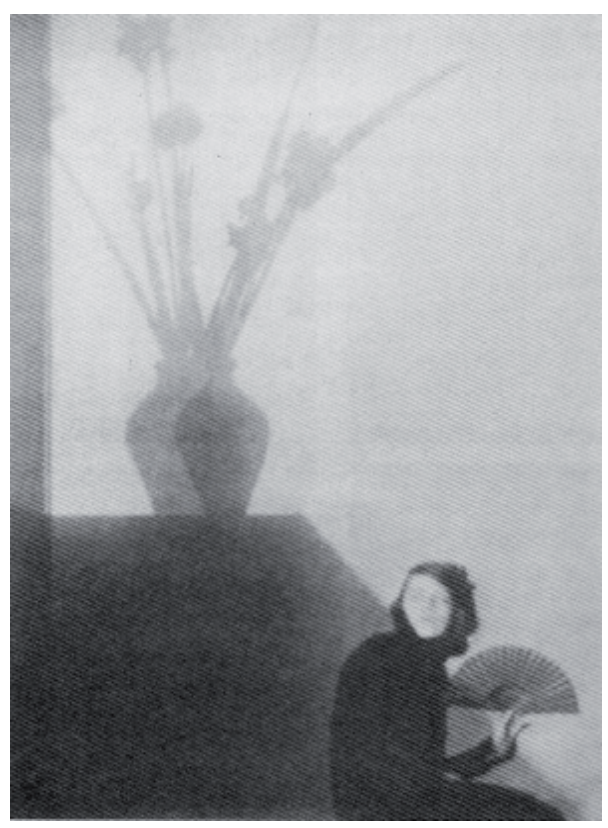




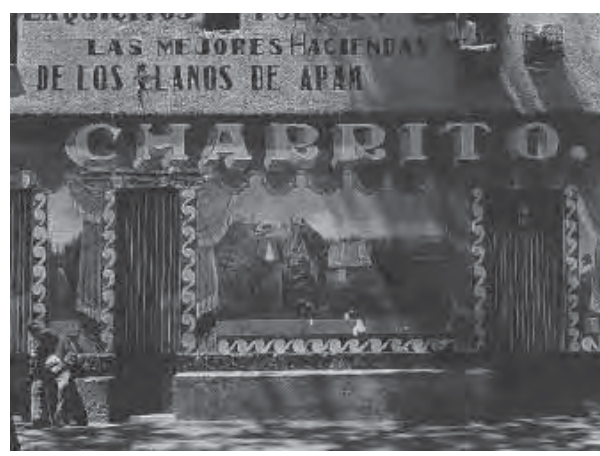

Edward Weston: Pulqueria, México, 1926. Georges Eastman House, Rochester, NY

Página siguiente arriba: Edward Weston \& Merle Armitage: Edward Weston, 1932 Página siguiente centro y arriba: Westways, agosto 1937, número dedicado a los paisajes de California fotografiados por Weston ("Seeing California with Edward Weston")
México ${ }^{259}$. Durante su estancia en este país, que se prolongaría hasta 1926, Weston reaccionó inmediatamente ante la intensidad del lugar, la fuerza de sus paisajes y la vitalidad de sus gentes, que retrató como criaturas rebosantes de energía saboreando la vida hasta sus últimas consecuencias. Allí trabó amistad con diversos fotógrafos y pintores de la vanguardia mexicana, entre ellos Diego Rivera, José Clemente Orozco y David Alfano Siqueiros, quienes fortalecieron sus ideas comunistas e influyeron en su producción artística. Fue entonces cuando Weston radicalizó el purismo de la técnica que le hizo famoso, abrazó definitivamente el realismo fotográfico y abrió su personal exploración de la veracidad a nuevos horizontes creativos. Los retratos mexi$\operatorname{canos}^{260}$ ilustran la máxima que Weston había aprendido de Alfred Stieglitz: el máximo detalle con la mayor simplificación.

De vuelta en California, entre 1926 y 1932, el fotógrafo vivió un periodo de gran producción en el que se inscriben buena parte de sus trabajos más representativos. Weston regresó a Los Ángeles con un estilo diametralmente opuesto al pictorialismo. Continuó realizando retratos y fotografías del cuerpo humano pero comenzó a trabajar en una serie de estudios sobre vegetales, coles, pimientos, calabazas, formaciones rocosas, dunas, cactus, árboles doblados por el viento y conchas marinas. Todos estos objetos se fotografían con una atención casi obsesiva por el detalle de sus texturas. Utilizando una cámara de placas de $8 \times 10$ pulgadas y empleado tiempos de exposición de más de cuatro horas, los contrastes entre el blanco y el negro se extreman, los contornos se vuelven nítidos, las formas radiantes y sensuales. Su técnica directa (straight fotography), sin filtros, utilizando siempre luz natural, producía efectos sorprendentes que transformaban la realidad del objeto en algo insólito y de gran valor plástico. Como el propio Weston escribiría en su diario: "la cámara debería usarse para representar la sustancia y la esencia de las cosas mismas, tanto si se trata de acero pulido como de carne palpitante".

Hacia 1915, Weston había comenzado a escribir sus diarios. En ellos plasmaba regularmente sus impresiones sobre su trabajo, sus citas profesionales, sus relaciones con su familia, sus encuentros con amigos y hasta su vida sentimental. Sus day books, o anotaciones de sus actividades e ideas son una fuente imprescindible para acercarse al pensamiento artístico de Edward Weston. En 1928 publicó una serie de escritos seleccionados entre los materiales procedentes de sus diarios (From My Day Books), aunque el grueso de ellos se publicó tras la muerte del fotógrafo en $195^{261}$. En sus diarios, Weston se presenta en repetidas ocasiones como un intermediario, enfatizando la idea de que no se trata tanto de que el artista se exprese individualmente a través de su lectura de la realidad, como de que el fotógrafo, en cuanto sujeto, identificándose con sus objetos, se convierta en un medio, un canal a través del cual pueda revelarse la verdad profunda que se oculta en cada cosa.

En 1930 Weston expuso por primera vez en Nueva York, donde exhibió su trabajo en la Alma Reed Gallery (Delphic Studios) y también en la Harvard Society of Contemporary Arts, donde su obra fue mostrada junto a la de Eugène Atget, Walker Evans, Charles Sheeler, Alfred Stieglitz y la propia Tina Modotti, entre otros artistas.

Un año antes, en 1929, el fotógrafo se había instalado en Carmel para disfrutar una vida más tranquila. Después de su viaje al país vecino, Weston prefirió los entornos naturales y los asentamientos poco poblados, tanto para vivir como para trabajar. Desplazándose por la costa central de California foto- 
grafió las playas de rocas, los acantilados y los cipreses de la reserva marina de Point Lobos, uno de los lugares de mayor interés paisajístico y significado para los habitantes de la zona. Casi al mismo tiempo descubría el desierto de Mojave y las dunas de Oceano que, como se ha adelantado en el capítulo anterior, convirtió en uno de sus principales temas.

Su interés por fotografiar la naturaleza afianzaría su amistad con el fotógrafo de paisajes Ansel Adams, a quien había conocido años antes y con quien, en 1932, fundó el Group f/64 cuyos miembros, además de Weston, Adams fueron Paul Edwards, Henry Swift, Willard van Dyke y las fotógrafas Imogen Cunningham, Consuelo Kanaga y Sonya Noskowiak.

El grupo se caracterizó por su defensa de la fotografía directa, contraria a la manipulación de la imagen, tanto en el revelado como durante el proceso de impresión, realizado directamente a partir del negativo. El nombre mismo del grupo expresaba sus principios. La denominación procedía de la unidad de apertura de diafragma que distinguía su trabajo, $\mathrm{f} / 64$, con la que obtenían una mayor profundidad de campo y un enfoque más amplio, asegurándose el detalle en el conjunto de la imagen, tanto para el fondo como para la figura.

Tras regresar de su viaje a México en 1926, Edward Weston afianzó su amistad con Merle Armitage, uno de sus principales valedores y fuente de contactos durante los años 30. Armitage había llegado a Los Ángeles a principios de la década anterior y se había convertido en una figura imprescindible para la cultura moderna de la ciudad. Editor, mecenas y coleccionista, ejercía una gran influencia sobre los artistas del Sur de California, a quienes promovía y defendía frente a los sectores más reaccionarios de la región. El nutrido grupo de amigos de Armitage, entre ellos, Walter Arensberg o Cedric Gibbons fueron de los primeros en apreciar la obra del fotógrafo fuera del círculo de Kings Road.

Weston y Armitage habían sido presentados en la fiesta de despedida que el crítico Arthur Millier había organizada en honor del fotógrafo poco antes de que éste partiera por primera vez a México. Millier había invitado también a Merle Armitage y ambos conectaron inmediatamente, como recordaría el propio Armitage: "Edward y yo nos acercamos a mi galería, donde pudo ver por primera vez piezas étnicas y dibujos de Picasso. [...] Estaba absolutamente fascinado. Durante nuestras idas y venidas de la fiesta a la galería pude darme cuenta de su calidad como artista y le pedí que me escribiera para seguir en contacto nada más regresara de México"262. La relación profesional entre ambos culminó diez años más tarde con la publicación, en 1932, de la primera monografía sobre el fotógrafo bajo la dirección de Armitage, quien la tituló simplemente Edward Weston. Este proyecto, reproduciendo algunas de las mejores obras de Weston constituye un hito en la historia de la fotografía en los Estados Unidos porque se trata del primer trabajo comprehensivo publicado sobre un fotógrafo norteamericano moderno. La publicación fue concebida, diseñada e impresa enteramente en Los Ángeles ${ }^{263}$.

A pesar de la importancia de este proyecto editorial como hito en la historia de las publicaciones de fotografía, apenas si tuvo difusión. Weston y Armitage lograron vender sólo 100 de las 500 copias impresas y después de algún tiempo, se vieron obligados rebajar el precio hasta la mitad de su coste de impresión para recuperar parte del dinero invertido. Durante años, Weston
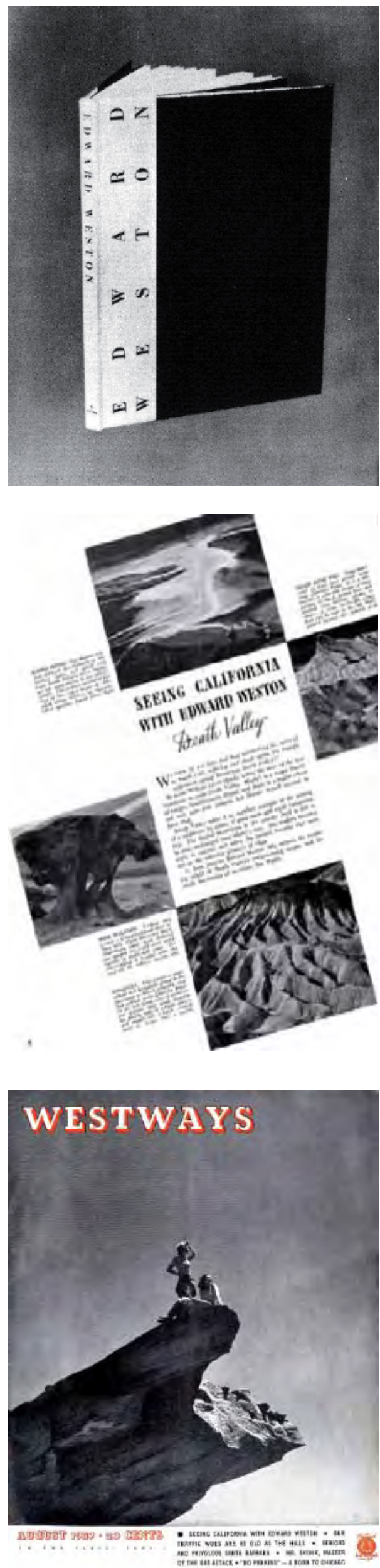

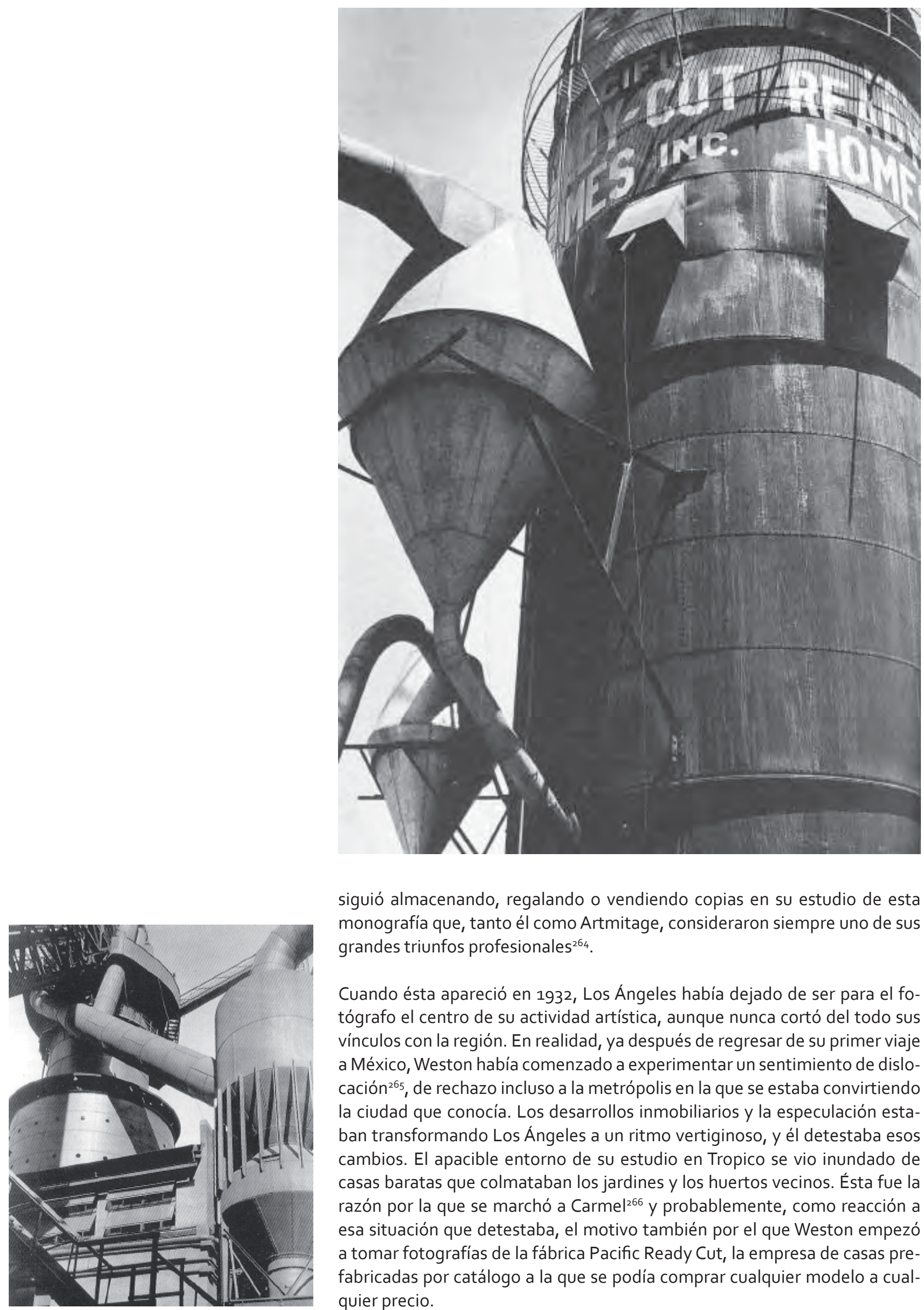

siguió almacenando, regalando o vendiendo copias en su estudio de esta monografía que, tanto él como Artmitage, consideraron siempre uno de sus grandes triunfos profesionales ${ }^{264}$.

Cuando ésta apareció en 1932, Los Ángeles había dejado de ser para el fotógrafo el centro de su actividad artística, aunque nunca cortó del todo sus vínculos con la región. En realidad, ya después de regresar de su primer viaje a México, Weston había comenzado a experimentar un sentimiento de dislocación ${ }^{265}$, de rechazo incluso a la metrópolis en la que se estaba convirtiendo la ciudad que conocía. Los desarrollos inmobiliarios y la especulación estaban transformando Los Ángeles a un ritmo vertiginoso, y él detestaba esos cambios. El apacible entorno de su estudio en Tropico se vio inundado de casas baratas que colmataban los jardines y los huertos vecinos. Ésta fue la razón por la que se marchó a Carmel ${ }^{266}$ y probablemente, como reacción a esa situación que detestaba, el motivo también por el que Weston empezó a tomar fotografías de la fábrica Pacific Ready Cut, la empresa de casas prefabricadas por catálogo a la que se podía comprar cualquier modelo a cualquier precio. 


\section{Los encargos Lovell, algunas hipótesis. Edward Weston en Newport Beach}

Leah y Philip Lovell fueron de las primeras personas a quienes los Schindler invitaron a su casa de Kings Road. En Los Ángeles frecuentaban los mismos círculos que sus amigos, con quienes se reunían también en otros salones como el de sus parientes Freeman o la bohemia de Echo Park, a los que solía acudir Edward Weston.

Todos ellos compartían un visible interés por cuestiones relacionadas con la salud, una inquietud vinculada a los incipientes movimientos de culto al cuerpo que se estaban popularizando en la excéntrica sociedad californiana de los años 20. Schindler y Weston coincidían plenamente con las teorías del doctor Lovell acerca de derribar tabúes y de vivir de acuerdo con una nueva época de regeneración a la que abocaban el clima, las conquistas sociales y los avances tecnológicos.

Lovell era un formidable relaciones públicas y su consulta médica pronto adquirió notoriedad por toda la ciudad, tanto entre las viejas familias del Downtown, como en los liberales ambientes de Hollywood y del Westside. Uno de sus más devotos pacientes fue el millonario Harry Chandler, propietario Los Angeles Times y principal gestor de su maquinaria de propaganda. A través de éste, Lovell accedió a las páginas del periódico donde no sólo pudo dar a conocer su práctica médica sino, sobre todo, difundir su filosofía de vida saludable. Chandler contrató al doctor Lovell para continuar la columna que, oportunamente titulada Care of the body (El cuidado del cuerpo) Harry Ellington Brook ${ }^{267}$ llevaba publicando en el dominical del Times desde 1899.

Tras la jubilación de su anterior responsable en 1924, Philip Lovell se sirvió de esta plataforma para trasmitir sus avanzadas ideas acerca de procurarse cuidados naturales. Entre otras cuestiones, defendía las ventajas de practicar ejercicio físico, los masajes, los baños en el océano, la conveniencia de exponer el cuerpo al sol e, incluso, de dormir al aire libre. Asimismo, Lovell fue uno de los primeros partidarios de observar una dieta principalmente vegetariana y de renunciar al tabaco y al alcohol.

Convertido en un gurú de la salud, sus teorías se extendían también al ámbito de la sexualidad y de la educación. En este último campo Philip Lovell estaba claramente influido por su mujer. Discípula de Angelo Patri, Leah Lovell era partidaria de aplicar una novedosa pedagogía basada en la psicología infantil y en el desarrollo de las capacidades individuales de cada niño.

Por su parte, Edward Weston sentía un auténtico desprecio por la enseñanza tradicional. La consideraba una tortura y por ello envió a sus hijos a más de una docena de escuelas diferentes tratando de evitar que éstos recibiesen algo parecido a una educación formal. Sus dos hijos mayores asistieron a clase en la Modern School mientras que los dos más jóvenes fueron alumnos de Pauline Schindler y de Leah Lovell en la escuela de Aline Barnsdall, ambas especializadas en dar atención personalizada. No obstante, los continuos cambios de centro para huir de todo convencionalismo generó problemas de disciplina en sus hijos, especialmente en Brett, quien más tarde confesaría que aquella situación fue muy estresante para él y que de niño afectó a las relaciones con sus padres y de ellos entre sí: "Mi padre odiaba las escuelas, y por eso se casó con una maestra de escuela. Para superar su fobia nos envió a docenas de colegios diferentes. Pasé mi infancia de escuela en escuela. Creo que es un milagro que mis padres pudieran estar juntos tanto tiempo, incluso aún es más sorprendente que Cole llegara a nacer"268.
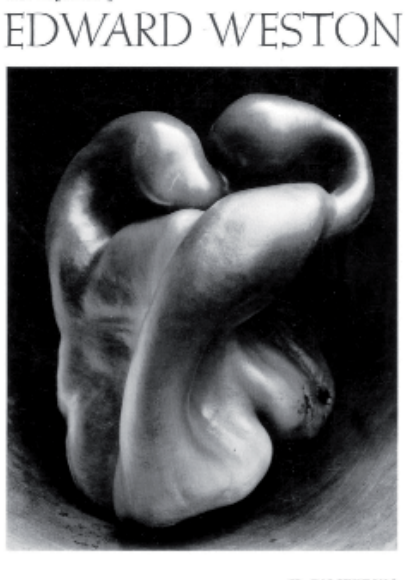

Edward Weston: Diarios, vol. 2 California, editado en 1961

Página. anterior arriba: Edward Weston: Ready-Cut Homes Factory, 1925. Fuente. LA's Early Modern

Página anterior abajo: Charles Sheeler, Pulverizadora, Ford Plant, Detroit, 1927. Boston Museum of Fine Arts, Boston 

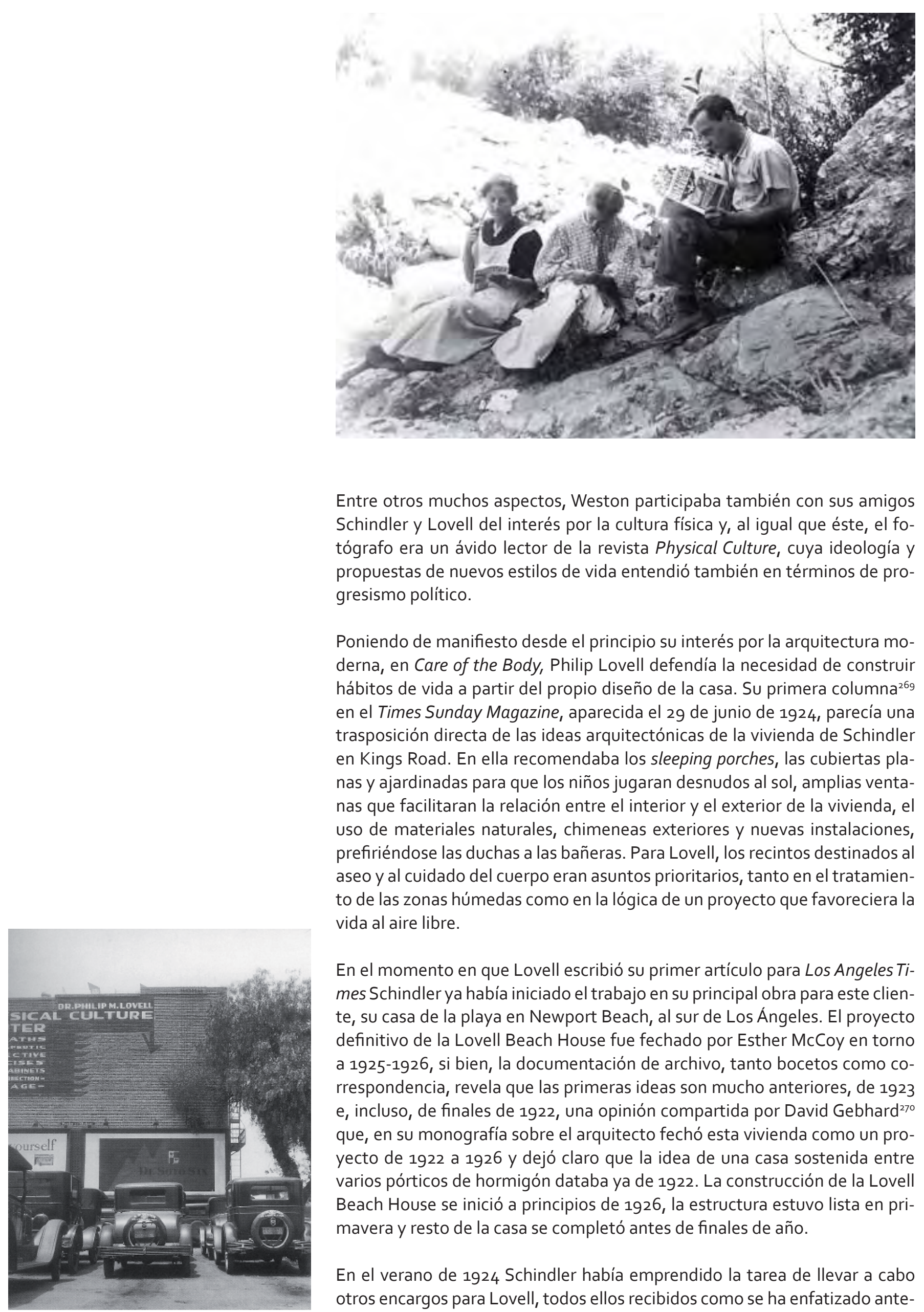

Entre otros muchos aspectos, Weston participaba también con sus amigos Schindler y Lovell del interés por la cultura física $y$, al igual que éste, el fotógrafo era un ávido lector de la revista Physical Culture, cuya ideología y propuestas de nuevos estilos de vida entendió también en términos de progresismo político.

Poniendo de manifiesto desde el principio su interés por la arquitectura moderna, en Care of the Body, Philip Lovell defendía la necesidad de construir hábitos de vida a partir del propio diseño de la casa. Su primera columna ${ }^{269}$ en el Times Sunday Magazine, aparecida el 29 de junio de 1924, parecía una trasposición directa de las ideas arquitectónicas de la vivienda de Schindler en Kings Road. En ella recomendaba los sleeping porches, las cubiertas planas y ajardinadas para que los niños jugaran desnudos al sol, amplias ventanas que facilitaran la relación entre el interior y el exterior de la vivienda, el uso de materiales naturales, chimeneas exteriores y nuevas instalaciones, prefiriéndose las duchas a las bañeras. Para Lovell, los recintos destinados al aseo y al cuidado del cuerpo eran asuntos prioritarios, tanto en el tratamiento de las zonas húmedas como en la lógica de un proyecto que favoreciera la vida al aire libre.

En el momento en que Lovell escribió su primer artículo para Los Angeles Times Schindler ya había iniciado el trabajo en su principal obra para este cliente, su casa de la playa en Newport Beach, al sur de Los Ángeles. El proyecto definitivo de la Lovell Beach House fue fechado por Esther McCoy en torno a 1925-1926, si bien, la documentación de archivo, tanto bocetos como correspondencia, revela que las primeras ideas son mucho anteriores, de 1923 e, incluso, de finales de 1922, una opinión compartida por David Gebhard270 que, en su monografía sobre el arquitecto fechó esta vivienda como un proyecto de 1922 a 1926 y dejó claro que la idea de una casa sostenida entre varios pórticos de hormigón databa ya de 1922. La construcción de la Lovell Beach House se inició a principios de 1926, la estructura estuvo lista en primavera y resto de la casa se completó antes de finales de año.

En el verano de 1924 Schindler había emprendido la tarea de llevar a cabo otros encargos para Lovell, todos ellos recibidos como se ha enfatizado ante- 


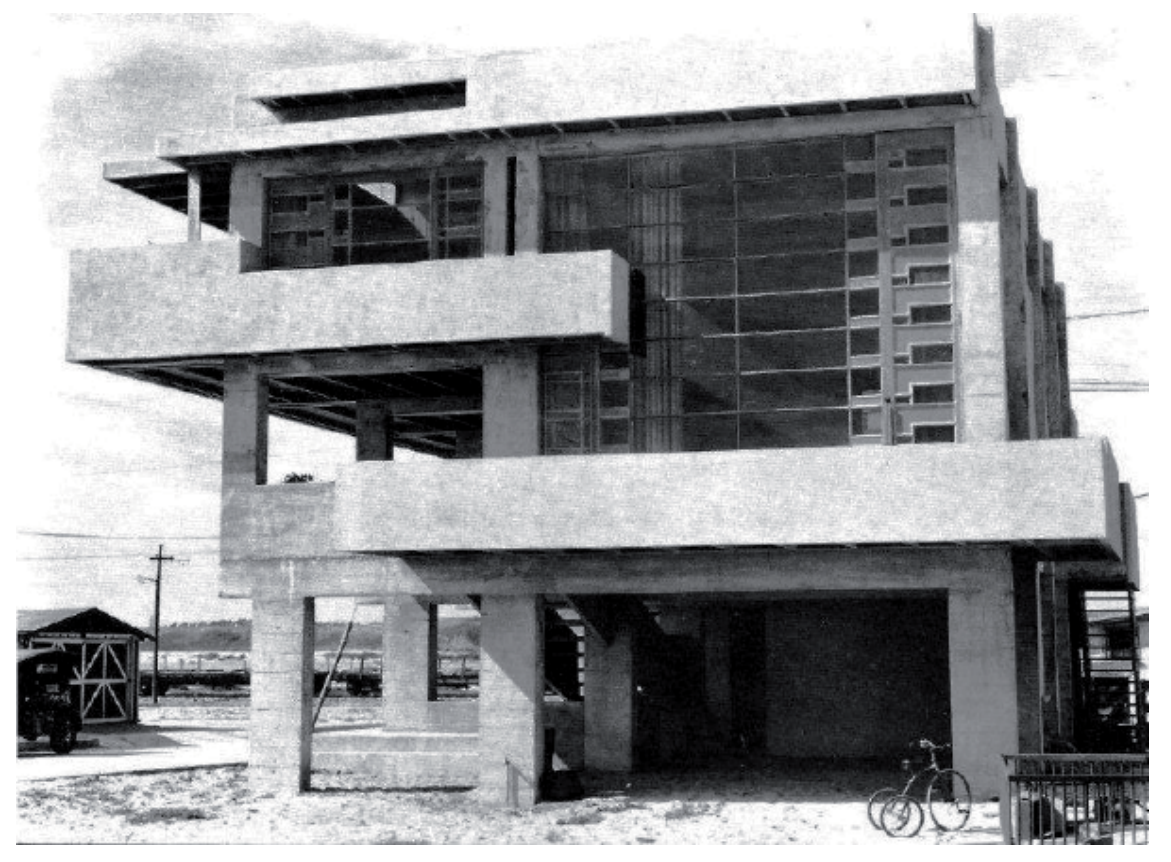

riormente, a través de la temprana amistad de Pauline con Leah, una relación que convirtió a los Lovell en dos de los principales patrones de la arquitectura moderna del Sur de California; primero a través de Schindler y más tarde de Neutra, con quien Philip compartía además su fascinación por la tecnología.

Además de la Beach House en Newport, Lovell encargó a Schindler la reforma de su casa en Mount Washington, un pequeño rancho en Fallbrook -cerca de San Diego- (1924-1925) y una cabaña en Wrightwood, en las montañas de San Gabriel (1926). En 1927 pidió a Neutra que adaptase un edificio comercial de 500 metros cuadrados de planta en un centro de salud, gimnasio y consultorio médico, su Lovell Physical Culture Center, que sería la antesala del encargo de su nueva casa en la ciudad, la Demostration Health House (1927-29). Ambos arquitectos materializaron las ideas de Philip Lovell con diferentes planteamientos.

La vida al aire libre era el tema central de la Lovell Beach House. Para asegurar la privacidad y garantizar vistas lejanas del océano, Schindler elevó la casa sobre pilares de hormigón armado. Además de la estructura de pórticos, la casa consistía en una caja de madera sostenida por éstos a la que se llegaba por una escalera doble que partía directamente desde la arena. De este modo, la playa llegaba hasta la base misma de la vivienda. Neutra colaboró con Schindler en el diseño de un paisajismo de mínimos que acondicionaba el acceso al tiempo que permitía que el ecosistema costero se fundiera con el patio de la casa, concebido como una terraza exterior a la sombra acondicionada con su propia chimenea. La cocina fue especialmente equipada con las más modernas instalaciones y los baños diseñados de acuerdo con los requerimientos sanitarios del cliente. Exceptuando el patio exterior, el único espacio público de la casa consistía en una gran sala para que la familia y sus amigos se reunieran de manera informal. Como reparó Gebhard, en una residencia de playa Schindler aún podía encontrar más razones para eliminar los dormitorios que en una vivienda en la ciudad ${ }^{271}$, limitándose a proyectar un vestidor privado por estancia frente a un porche abierto para dormir. Un corredor recayente a la doble altura del espacio principal de la vivienda distribuía los accesos a los sleeping porches. El hueco ${ }^{272}$ a doble altura orientado al sur, permitía disfrutar del panorama del Pacífico.

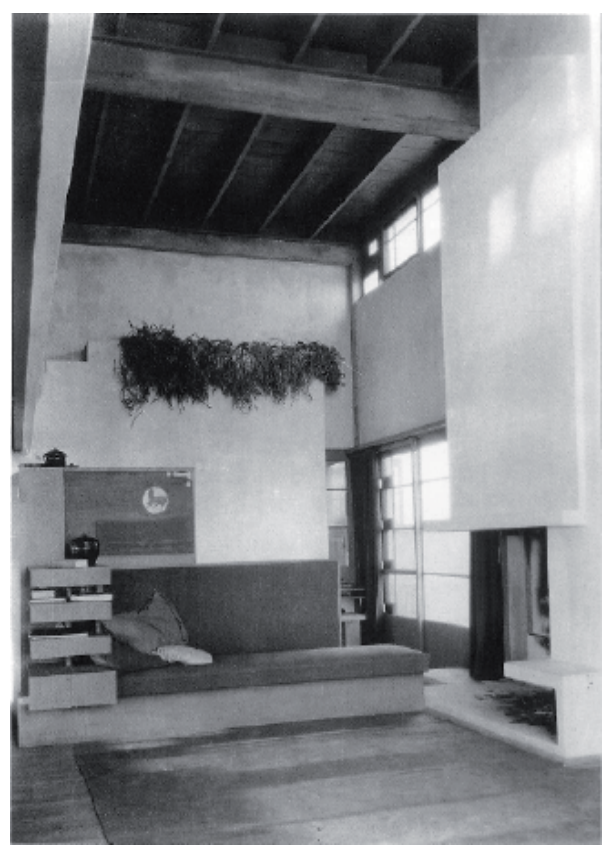

Izquierda: RMS: Lovell Beach House, fachada sur, Newport Beach, 1925-1926. Fotografía de Edward Weston, 1927 (FOTOGRAFÍA EXT. NÚMERO 1). ADC/UCSB

Derecha: RMS: Lovell Beach House, interior Fotografía de Edward Weston, 1927 (FOTOGRAFÍA INT. NÚMERO 1). ADC/UCSB

Página. anterior arriba: Edward Weston y Flora Weston leyendo Physical Culture, 1907. Center for Creative Photography, University of Arizona.

Página anterior abajo: Lovell Physical Center, Los Ángeles, fotografía de Willard Morgan 

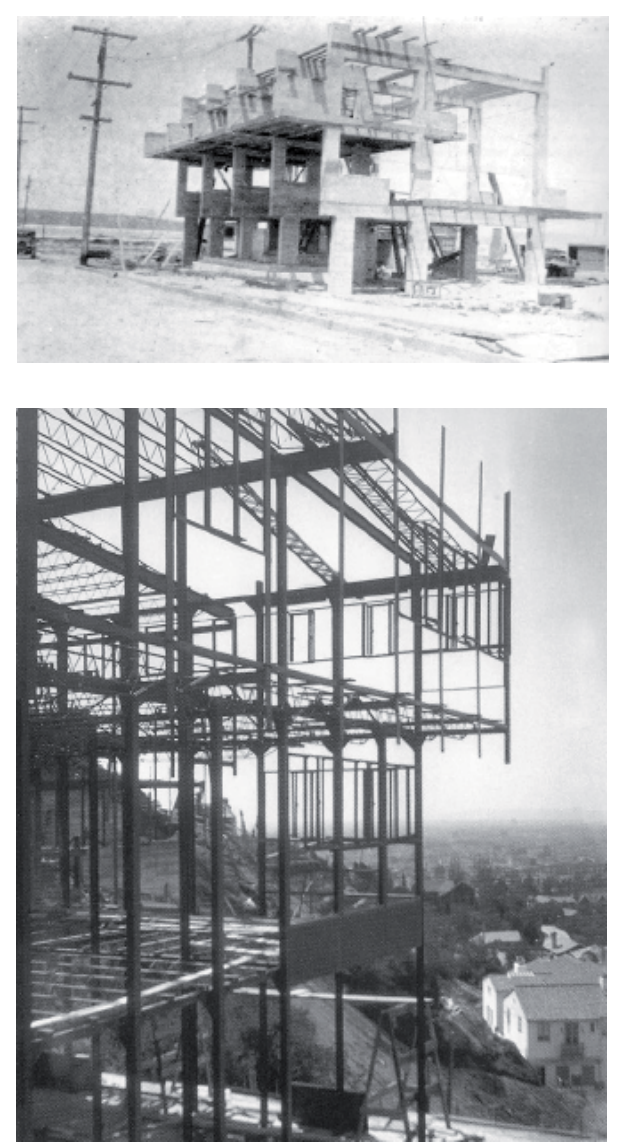

Durante la construcción de su casa de la playa, Lovell encargó a Schindler varios textos que fueron publicados en su columna dominical, fueron seis artículos que aparecieron entre marzo y mayo de 1926: Ventilación; Fontanería y salud; Calefacción; Acerca de la iluminación; Sobre el mobiliario; y, Morada o patio de juegos. En éste último, fechado del 2 de mayo de 1926, como si describiera su propia casa, el arquitecto afirmaba: "El progreso material nos permite controlar nuestras condiciones de vida. Los nuevos conocimientos sobre nuestro propio organismo nos liberan de los lastres del pasado. La Naturaleza se convierte en amiga [...] Las habitaciones descenderán hasta el nivel del suelo, y el jardín será parte integrante de la vivienda. La distinción entre dentro y fuera desaparecerá. Las paredes serán pocas, delgadas y móviles. Todas las estancias serán parte de una unidad orgánica, en lugar de permanecer como recintos estancos apenas conectados por unos cuantos agujeros [...] La vivienda dejará de ser un conjunto de madrigueras, destinadas las de mayor tamaño a impresionar socialmente, y las más pequeñas (dormitorios) a albergar la manada familiar. Cada individuo deseará una habitación privada que sirva de fondo a su vida, pero dormirá al aire libre. Un estudio-sala de juegos satisfará, junto con el jardín, las necesidades del grupo. El baño podrá convertirse en un gimnasio que haga las veces de centro social"273.

El hecho de anunciar la construcción de su propia vivienda en el periódico, de explicitar los conceptos de su diseño, de involucrar a su arquitecto en la redacción de su columna y, como ocurrirá con la Lovell Health House de Neutra, de abrir incluso las puertas de su casa a sus lectores, iba más allá de una necesidad de ejemplarizar con su estilo de vida el mensaje de modernidad que Philip Lovell estaba trasmitiendo a través de sus escritos y de su ejercicio profesional. En este sentido, el desplazamiento de la domesticidad a la esfera de lo público, la transferencia de los valores del espacio privado y familiar hacia el espacio de los medios de comunicación, su visibilización en tanto que representación de un ideal de vida publicitable, sitúa las arquitecturas concebidas para el doctor Lovell en un espacio moderno y postdoméstico, al mismo nivel que los casos estudiados por las profesoras Colomina y Preciado para arquitectos como Le Corbusier y Mies van der Rohe, respectivamente ${ }^{274}$.

Tanto en la Lovell House de Neutra como la Beach House de Schindler, las fotografías de las dos viviendas Lovell fueron publicadas antes de la compleción de las obras. Las impactantes imágenes del esqueleto de la casa de Neutra en construcción tomadas por Willard Morgan fueron aclamadas internacionalmente como epítome de la tecnología norteamericana. La estructura de hormigón de Schindler, fotografiada por él mismo, sin embargo, se asimiló a los pilotis de Le Corbusier -el propio Gebhard contribuyó a ello ${ }^{275}$ - cuando ni sus ideas ni la fecha en que fueron concebidas respondían a ese planteamiento. En cualquier caso, es evidente que la difusión de las fotografías del proceso de construcción -una tradición por cierto iniciada por Irving Gill en California- respondía a una estrategia publicitaria por parte tanto del promotor como de sus arquitectos.

En el caso de Neutra, la exitosa campaña de comunicación fue orquestada por el propio arquitecto y contó con la total entrega de su cliente y de sus fotógrafos, como se tratará más adelante. En el de Schindler, a pesar del alcance y celebración internacional de la obra -en parte debido a la difusión de Neutra-sus intentos de divulgación no fueron tan certeros, como demuestra el hecho, por ejemplo, de que las fotografías de la casa de Newport fueron publicadas de forma anónima y, posteriormente, ni McCoy (Five Califor- 


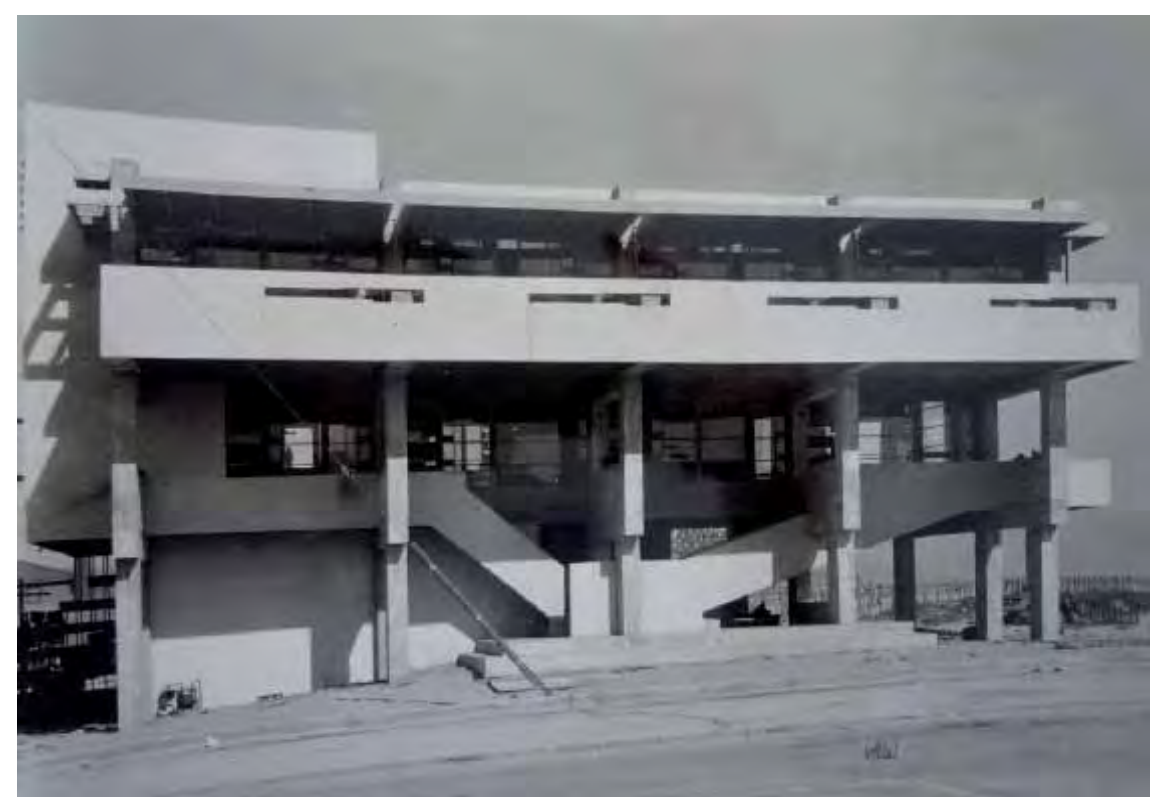

nia Architects) ni Gebhard (Schindler) trataron de esclarecer en sus libros la autoría de las imágenes.

Schindler realizó personalmente las fotografías del proceso de construcción de la vivienda y tomó también algunas instantáneas de la casa acabada. Ésta apareció por primera vez en el número de junio de 1927 de la revista Popular Mechanics Magazine, curiosamente, una publicación sobre automóviles, ocio y tecnología a cuyos editores debieron intrigar las imágenes enviadas por el propio arquitecto. En general, sobre todo a partir del catálogo de la exposición monográfica sobre Schindler del MoCA en 2001, dichas fotografías aparecen acreditadas. Incluso, Esther McCoy, en Vienna to Los Angeles, trató de identificar a Schindler como autor. Sin embargo, las mejores fotografías históricas de la Lovell Beach House continúan aún siendo anónimas.

Del contenido de la correspondencia de Pauline se deduce que tanto ella como Schindler encargaron diversas fotografías a los Weston, fundamentalmente a Edward, pero también a su hijo Brett, y en menor medida a Chandler. Se trataría sobre todo de retratos o de imágenes que, como editora y agente freelance, Pauline necesitaba para ilustrar sus artículos o promover la obra de su amigo Weston. Pero también y, al menos, hubo dos encargos para fotografiar obras de arquitectura.

En una de sus cartas, Pauline Schindler escribióp a su marido afirmando que disponía de imágenes de la casa Lovell de Newport realizadas por Edward Weston y que quería incluirlas en el frustrado número Contemporary Architecture of the Pacific Coast que estaba preparando para The Carmelite. En dicha carta, fechada el 14 de marzo de 1929, conservada en el archivo del arquitecto en la Universidad de California en Santa Bárbara y cuyo texto se reproduce traducido al castellano, Pauline se expresaba en los siguientes términos:

"The Carmelite está a punto de publicar un número especial dedicado a la arquitectura contemporánea de la Costa Oeste y queremos incluir en dicho número algunos de tus trabajos. Disponemos ya de una fotografía de Weston de la casa Lovell en Balboa, pero nos gustaría publicar al menos un trabajo más -a ser posible un dibujo. Éste no tendría por qué estar especialmente

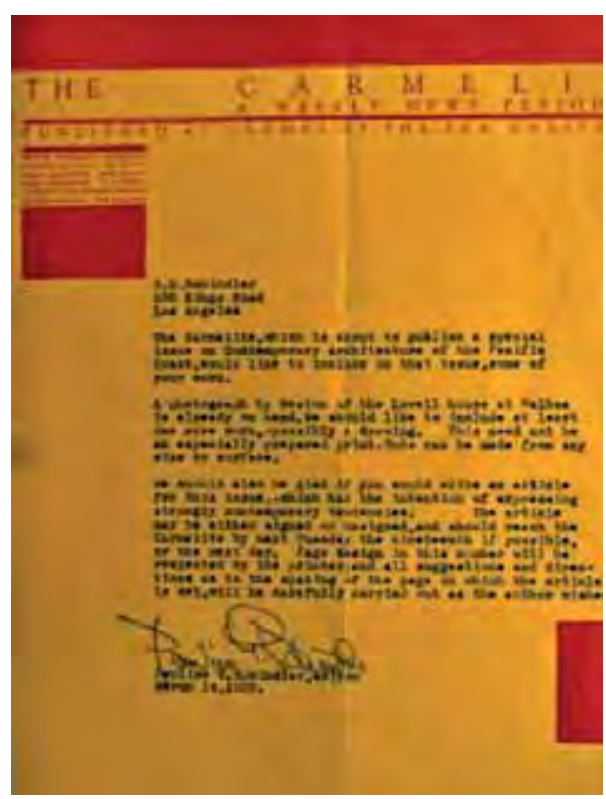

Izda: RMS: Lovell Beach House, fachada oeste. Fotografía de Edward Weston o de RMS (FOTOGRAFÍA EXT. NÚMERO 2). ADC/UCSB

Dcha: PGS, Carta a RMS solicitando documementación para publicar en The Carmelite, marzo 1929. ADC/UCSB

Página anterior arriba: RMS: Lovell Beach House en construcción. Fotografía de RMS. $A D C / U C S B$

Página anterior abajo: Richard Neutra: Lovell Health House en construcción. Fotografía de Willard Morgan 


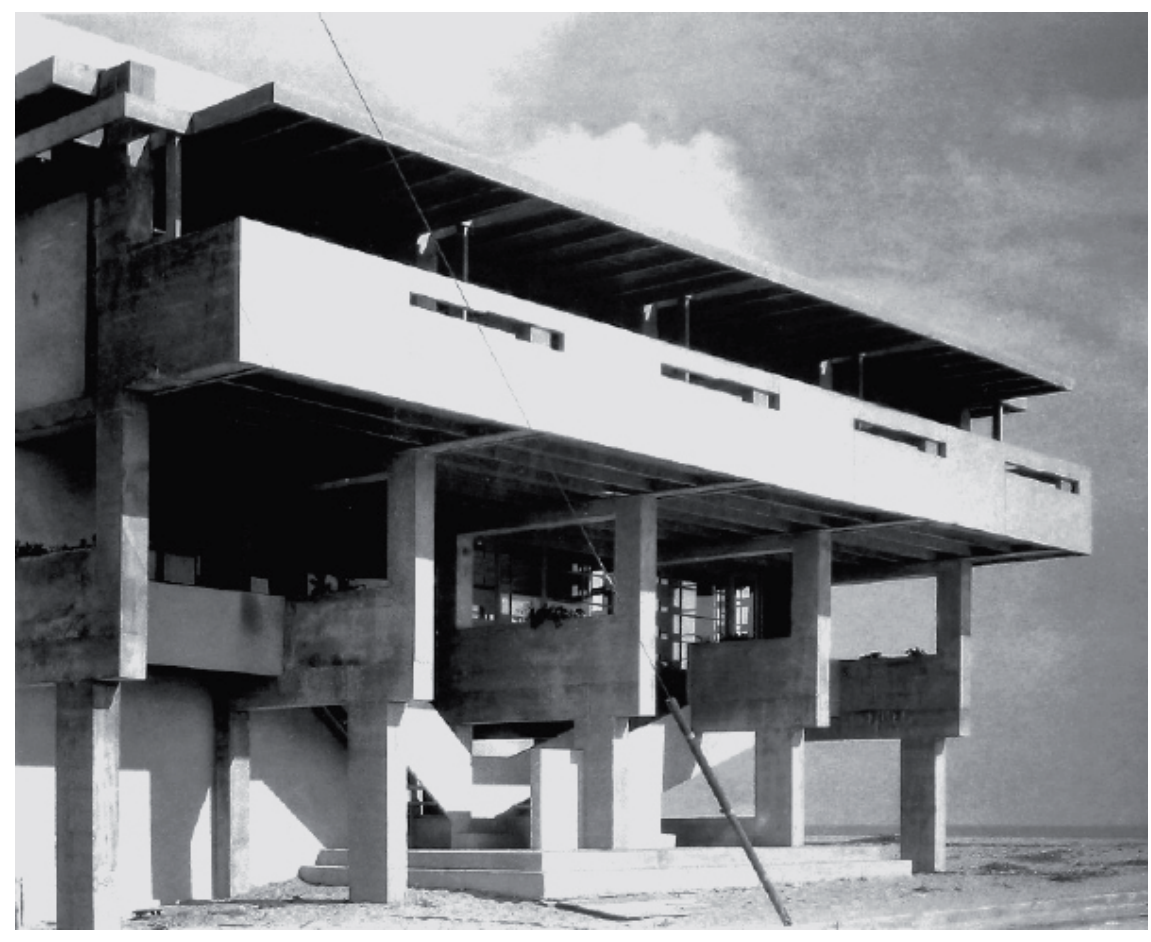

maquetado, podemos adaptarlo desde cualquier formato o soporte. También estaríamos encantados si pudieras escribir un artículo para este número-cuya intención es exponer claramente las tendencias contemporáneas. El artículo podría estar o no firmado y deberíamos tenerlo en nuestras oficinas antes de próximo martes 19, o como muy tarde al día siguiente. El diseño de cada página será respetado por el impresor, de modo que cualquier sugerencia o instrucción respecto a cómo maquetar los artículo será seguida cumplidamente según los deseos de cada autor ${ }^{\prime \prime 276}$.

La segunda obra, la Wolfe House en Avalon, Catalina Island, fue fotografiada por su hijo Brett 277 en 1931 y constituyó la portada del libro Five California Architects aunque Esther McCoy tampoco acreditó su autoría.

De acuerdo con la información del archivo de Schindler en la Universidad de Santa Barbara y la discusión mantenida con el historiador John Crosse, hay referencias a un mínimo de seis imágenes de la Lovell Beach House realizadas por Edward Weston. El propio Weston hace alusión a esos seis negativos

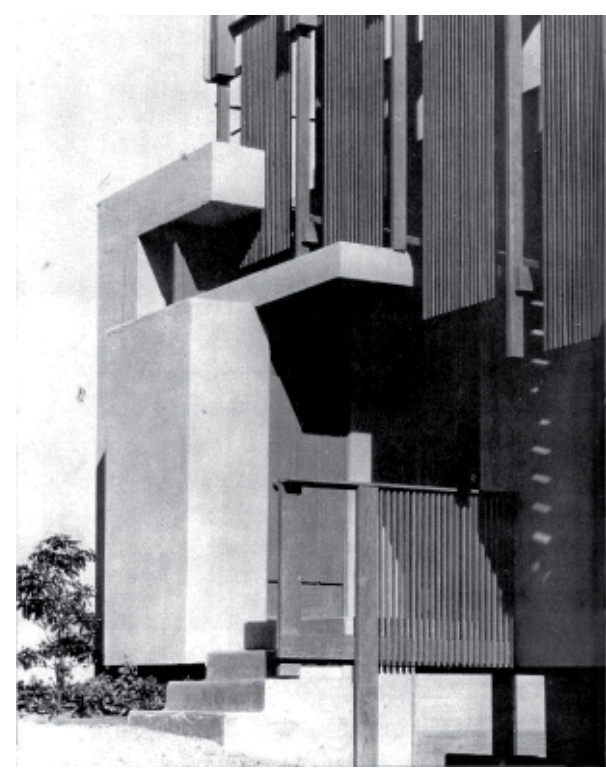
en una nota manuscrita enviada a Schindler el 27 de abril de 1928:

"Querido Schindler. Tengo listos tus retratos, pero esperaré a que respondas a mi nota sobre las impresiones de la casa de la playa para enviártelo todo junto. Para repetir, ¿quieres devolver las que te envié de urgencia y que te haga un nuevo set? Las que te envié son de Pauline. Has de saber que tengo seis negativos de la casa. ¿Quieres que te haga copia de los seis? ¿Tienes ya o necesitas una vista del lado contrario de la habitación? Mis mejores deseos. Edward W." ${ }^{\prime 27}$.

Dos de los cuatro negativos corresponden a fotografías del interior de la vivienda identificadas en el archivo de Schindler. Una de ellas apareció en Die Neue Raumkuntz in Europa und Amerika 279 , editado en 1930 por Julius Hoffmann quien, a instancias de Richard Neutra y Willard Morgan incluyó también un interior suyo de la Lovell Health House. La misma imagen del estar de la Beach House publicada en Sttutgart fue utilizada por McCoy en Five California Architects; y por David Gebhard, que empleó las dos fotografías del 


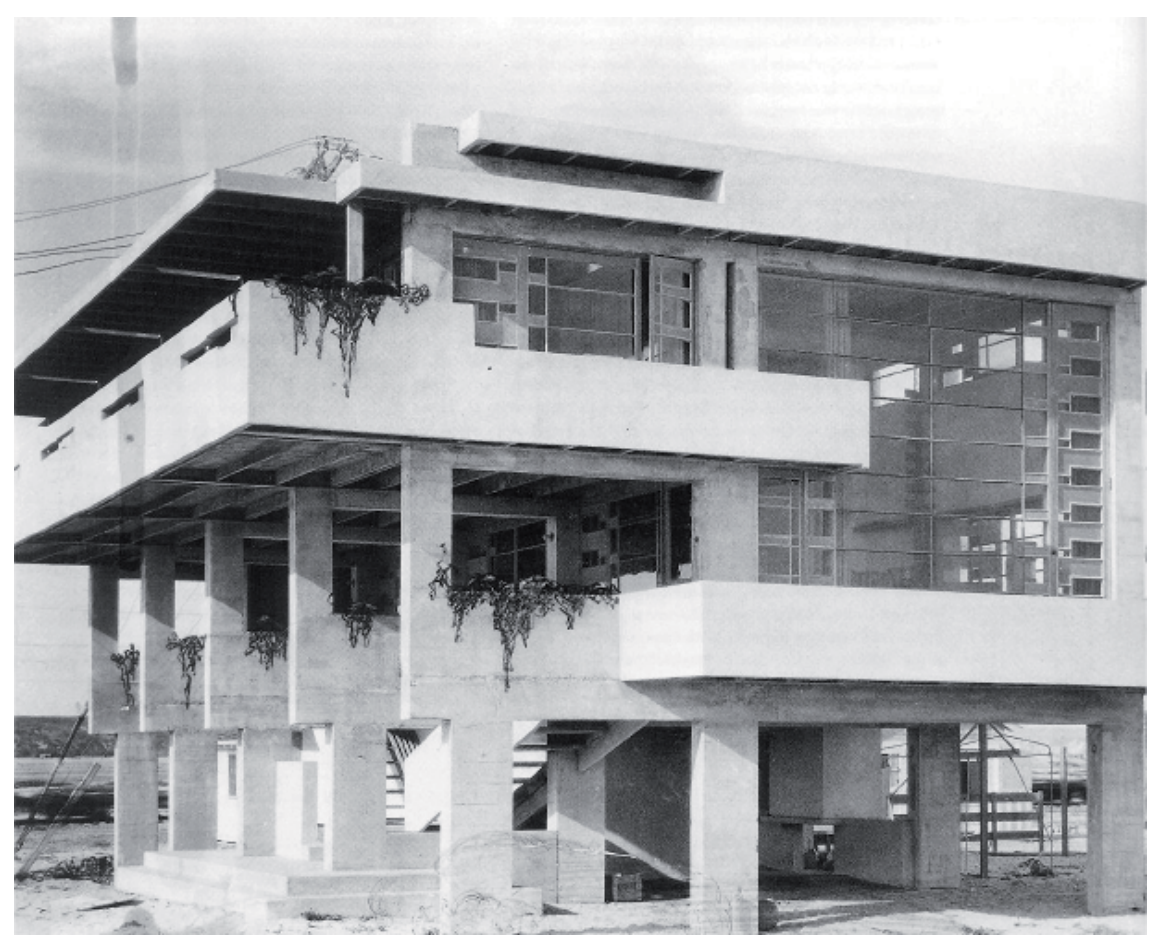

salón tomadas por Weston para ilustrar su monografía sobre Schindler. En todas estas ocasiones las imágenes se usaron de forma anónima. Por cierto que el propio Richard Neutra realizó también una fotografía de esta estancia-generalmente tampoco acreditada-donde aparecían Samuel y Harriet Freeman sentados junto a Dione Neutra en el sofá y Rudolph Shindler de pie en la galería superior de acceso a los sleeping porches.

Respecto a las fotografías del exterior de la Lovell Beach, hay constancia por anotaciones sobre los negativos referidos de que Weston estuvo fotografiando en Newport el 2 de agosto de 1927. Si bien, no es posible una identificación tan directa de estas imágenes como ocurre con los interiores. Tomando cuatro de las fotografías del exterior más recurrentemente publicadas desde los años 20 de forma anónima, cabría por tanto plantear la hipótesis de su autoría en base a la certeza de la existencia de al menos cuatro imágenes, así como a partir de un análisis de las mismas planteado desde la suposición de que podrían haber sido realizadas por Edward Weston.

En todas ellas las sombras están muy acusadas y su disposición apunta a que, tratándose de agosto las fotografías fueron tomadas hacia las cuatro la tarde, cuando el sol genera una ángulo de $45^{\circ}$ sobre las horizontales. La fachada de acceso (oeste) y la fachada orientada hacia el océano (sur) están iluminadas por igual en todas ellas.

Se trata de fotografías de gran detalle, conseguidas con aperturas de diafragma muy pequeñas y grandes tiempos de exposición; reveladas de forma convencional, sin manipulación química; y las impresiones por contacto obtenidas directamente del negativo, sin necesidad de ampliación.

Los diafragmas cerrados permiten exposiciones más largas del negativo, favoreciendo la creación de una amplia gama de grises. Esta gradación también podría haberse obtenido mediante el revelado posterior del negativo, utilizando una temperatura baja y aumentando el tiempo de revelado, con lo que se habría ganado, además de matices de grises, una mayor finura del grano del negativo y, por tanto, más resolución.

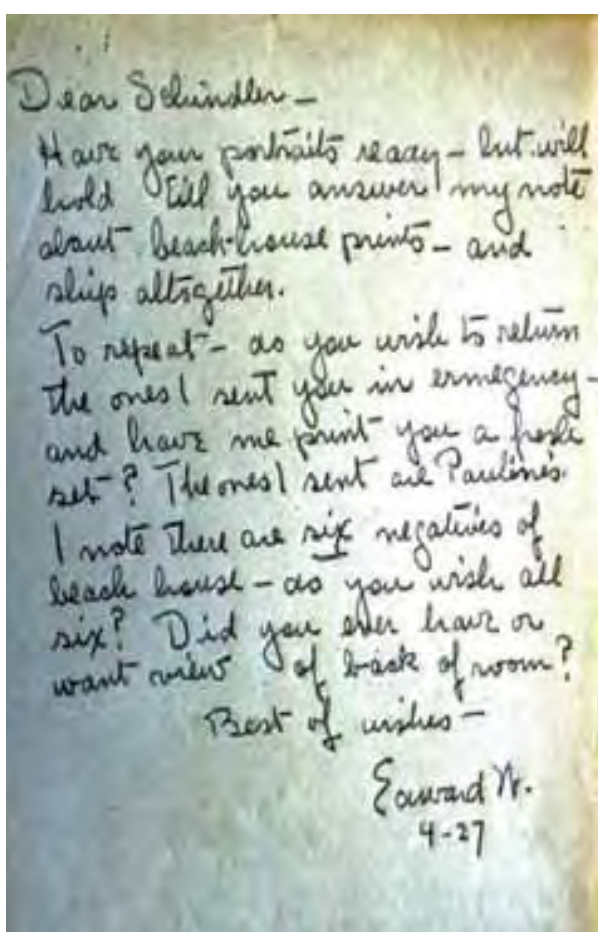

Izda: RMS: Lovell Beach House. Fotografía de Edward Weston (FOTOGRAFÍA EXT. NÚMERO 4). $A D C / U C S B$

Dcha: Edward Weston: carta a RMS, 27 abril 1928. Fuente: John Crosse. ADC/UCSB

Página anterior arriba: RMS: Lovell Beach House. Fotografía de Edward Weston (FOTOGRAFÍA EXT. NÚMERO 3). ADC/UCSB

Página anterior abajo: Brett Weston: Fotografía de la Wolfe House, imagen de portada del libro de E. McCoy Five California Architects 


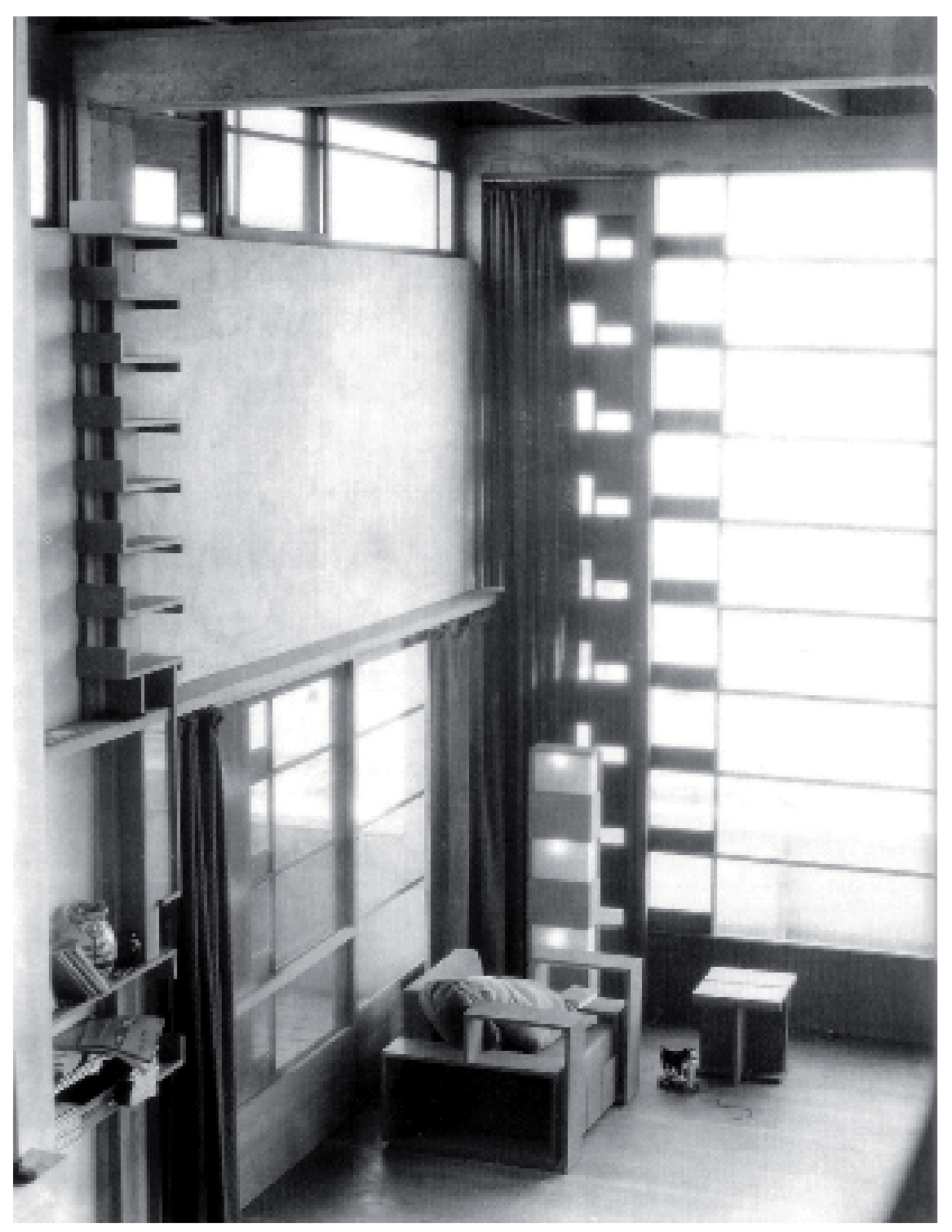

RMS: Lovell Beach House, fachada sur, Newport Beach, 1925-1926. Fotografía de Edward Weston, 1927 (FOTOGRAFÍA INT. NÚMERO 2). ADC/UCSB

Página siguiente: Richard Neutra: Wie Baut Amerika? . Julius Hoffmann, Stuttgart, 1927
Por su cercanía a la propiedad vecina, la fachada del acceso no permitía ser fotografiada desde lejos. Todas estas imágenes acentúan las líneas rectas verticales de los pórticos, por lo que habrían sido realizadas con una cámara de placas grande y una óptica con una distancia focal de $250 \mathrm{~mm}$ en adelante. Weston fotografiaba con una cámara de placas de 8xio pulgadas que habría permitido corregir mediante el movimiento del respaldo las líneas de fuga. Una cámara de estas características habría sido muy pesada, requiriendo el empleo de trípode para asegurar su estabilidad y, por tanto, movimientos lentos y una cuidadosa planificación previa de la perspectiva.

La fotografía denominada $\mathrm{n}^{\circ} 3$ sería la más limpia, exceptuando el inevitable el cable telegráfico, que fue eliminado en reproducciones posteriores. Mientras que con el resto de las imágenes hay dudas razonables, con mucha seguridad podría afirmarse que ésta se trata de una obra de Weston. De hecho, es la imagen donde más enfatiza la presencia de la arena y del océano, mostrando muy expresivamente la relación de la vivienda con su medio natural.

La fotografía denominada $\mathrm{n}^{\circ} 2$ presenta aberraciones de perspectiva y acusadas líneas de fuga en comparación con las otras. En este caso parece estar realizada con una cámara de formato medio o incluso más bajo, con una óptica angular más propia de la cámara portátil con la que Schindler fotografió la casa. 
En contra de la autoría de Weston, en el resto de las imágenes, podría argumentarse la proliferación de elementos como la bicicleta, las maletas o el coche que, aun siendo necesarios para aportar escala a la fotografía de arquitectura, parecen ajenos al estilo abstracto del artista.

Pauline Schindler envió estas imágenes a la redacción de Architectural Record que dio salida a un reportaje sobre la vivienda con un texto sin firmar pero escrito probablemente por ella -o a partir de éste-en su número de septiembre de $1929^{280}$. Se trató de la primera publicación de repercusión internacional de la casa en un medio norteamericano ya que, como se verá a continuación, Neutra consiguió que ésta apareciera un año y medio antes en Europa.

\section{Neutra y la familia Weston, una colaboración de vanguardia}

Tras la inclusión de su propuesta -erróneamente atribuida- para el edificio de la Sociedad de Naciones en la exposición del Werkbund de 1927 en Sttutgart, y la publicación ese mismo año de Wie Baut Amerika?, también en Sttutgart, Neutra afianzó su prestigio ante la vanguardia internacional. El arquitecto había logrado seducir a sus lectores europeos con su personal aproximación al paradigma tecnológico norteamericano. Dando cuenta de los avanzados medios de gestión y producción de arquitectura y de obra civil en los Estados Unidos, Neutra mostraba el milagro industrial del país como la auténtica realización de las utopías modernas del otro lado del Atlántico. Indirectamente, al informar puntualmente de todo lo que estaba ocurriendo en el Nuevo Mundo, ponía en valor su privilegiada posición como nexo entre los dos continentes y se presentaba así mismo como uno de los arquitectos más destacados de Norteamérica.

Esta faceta mediática no dejó indiferente a las publicaciones europeas, en especial a las revistas alemanas como la influyente Das Neve Frankfurt, con la que Neutra inició su labor de corresponsal en abril de 1928. Sobre el interés mutuo de esta colaboración, Rubén Alcolea ha escrito: "Es obvio que el propio Neutra, sumido en una intensa labor propagandística, había encontrado en la revista alemana un espléndido cómplice. A su vez, Das Neue Frankfurt conseguía, a través de este tipo de colaboraciones periódicas desde el continente americano, ofrecer una perspectiva mucho más amplia que sus lectores, entusiasmados con la internacionalización de las vanguardias, seguramente apreciarían ${ }^{\prime \prime 281}$.

Precisamente, para consolidar su autoridad como arquitecto y cronista americano, Neutra tuvo claro que debía construir un relato fascinante del panorama creativo californiano en el que estaba inmerso. No sólo necesitaba sorprender con nuevas obras a sus lectores sino, sobre todo, vender la originalidad de Los Ángeles como centro incontestable de vanguardia. Por ello, junto a sus obras -como los apartamentos Jardinette o el proyecto de la casa Lovell-comenzó a publicar las de sus contemporáneos, tanto en sus propios libros, como en los artículos que demandaban sus editores europeos.

En su segunda contribución a Das Neve Frankfurt, en el número de mayo de 1928, Neutra dio a conocer sus primeras ideas para la casa Lovell. El artículo, titulado Amerika. Körperübung und gegenwärtige Bauarbait ${ }^{22}$ (América. El ejercicio del cuerpo y la arquitectura actual) incluía una perspectiva de conjunto y el plano de implantación de la primera versión de la casa. Junto a estos croquis, contextualizando el sentido de su proyecto y la ideología de su clien-

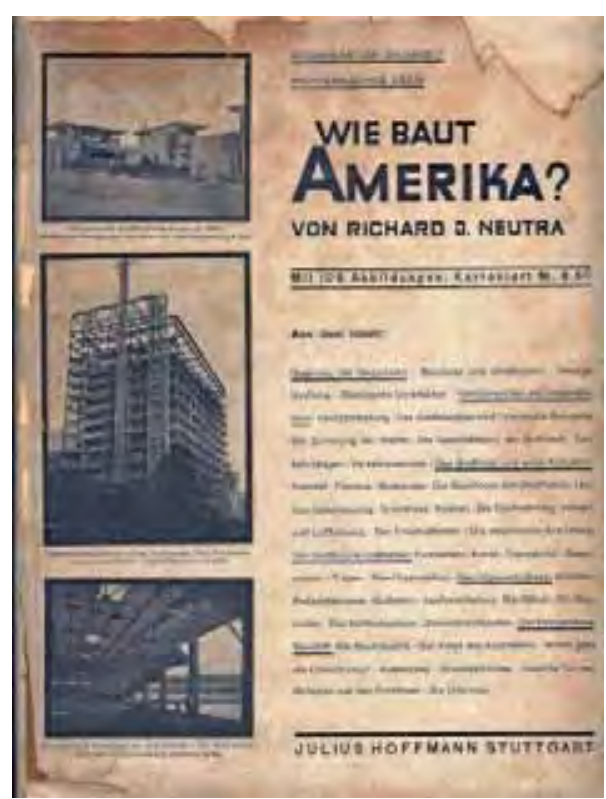



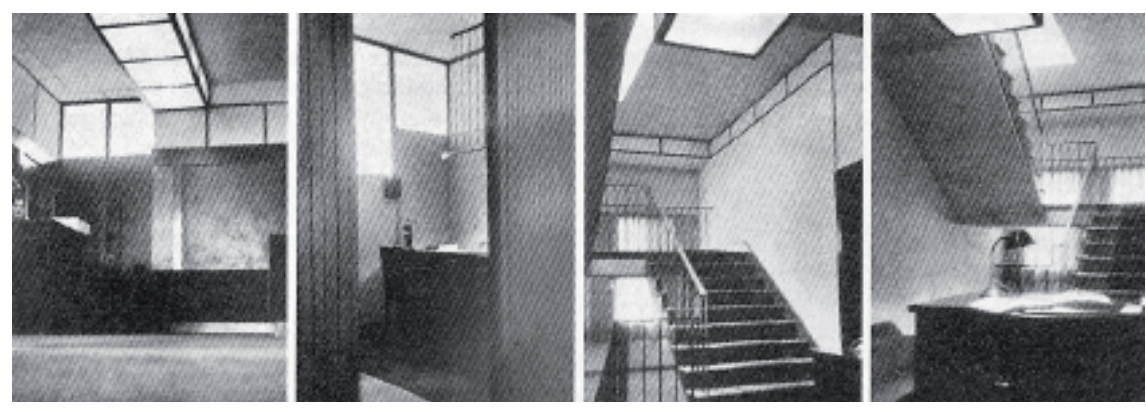

te, Neutra aportó dos edificios previos de Philip Lovell. Uno de ellos realizado por él mismo -de hecho fue el primer encargo que Neutra recibió de Lovell y su primera obra oficialmente en solitario- y consistía en la reforma recién terminada de su centro de salud o Lovell Physical Culture Center (1927) en Los Ángeles. Las fotografías que explicaban este espacio, eran del acceso, las escaleras y una vista sesgada de las oficinas. La tercera y última obra del artículo no era de Neutra, sino de Schindler, la casa de los Lovell en Newport Beach. Las imágenes del interior y exterior de la vivienda, publicadas anónimamente, podrían haber sido realizadas por el propio Neutra quien, como se ha apuntado, fotografió esta casa de Schindler alrededor de 1927.

Rubén Alcolea sostiene, sin embargo, que Willard Morgan, el primer fotógrafo con el Neutra estableció una estrecha relación profesional y principal responsable de las fotografías con las que el arquitecto divulgó su Lovell Health House, habría sido el autor estas imágenes de la casa de la playa publicadas por Das Neve Frankfurt. No obstante, Alcolea no aclara de qué información dispone para afirmar que Morgan desempeñó una importante labor como fotógrafo en esta vivienda: "Sus imágenes de la Lovell Beach House no fueron muchas, pero han sido prácticamente las únicas aparecidas en las publicaciones que hicieron referencia a esta emblemática obra. La aparición de la Lovell Beach House en el número de septiembre de 1929 de Architectural Record constituyó otro momento decisivo. La aparición a toda página de la fotografía del salón, así como de la representativa instantánea del exterior de la vivienda en la que ésta aparecía como una estructura maquinista habitable, hizo que la vivienda diera la vuelta al mundo, llegando a convertirse en la obra más representativa de la trayectoria profesional de Schindler" ${ }^{\prime 283}$. Su argumento es atractivo por diversas razones.

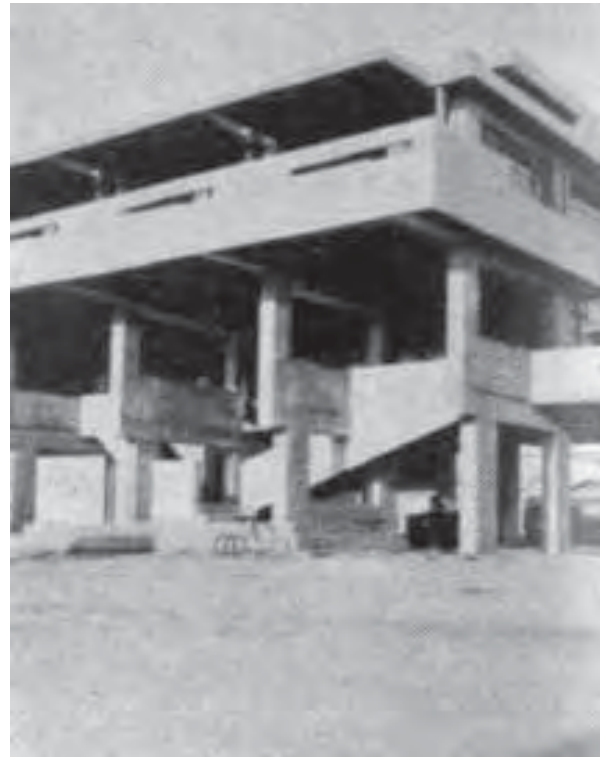

Por un lado apunta la posibilidad de que Morgan, reconocido por sus fotografías de la segunda casa Lovell, hubiera fotografiado también la vivienda de la playa. Esta eventualidad ha sido discutida con John Crosse ${ }^{284}$, quien también encuentra factible el hecho de que Willard Morgan hubiese retratado las dos casas Lovell, especialmente dada su amistad con Schindler, ya que él y su mujer, Barbara Morgan, eran también habituales de Kings Road. No obstante, Crosse afirma no haber podido encontrar ninguna prueba al respecto, aunque no es descartable que existan datos en el archivo del fotógrafo cuya donación a UCLA tramitan en la actualidad sus herederos y podrán ser consultados en pocos meses.

Por otro lado, Alcolea ha reparado en la existencia de unas imágenes recurrentemente publicadas que él atribuye a Morgan pero cuya autoría, independientemente del caso de Das Neve Frankfurt, se ha intentado probar en este capítulo que correspondería a Edward Weston. Es más, contrariamente a lo que opina Alcolea, existen dudas razonables en cuanto a los créditos de las mismas en la revista alemana, y hasta parece lógico conjeturar que las fo- 

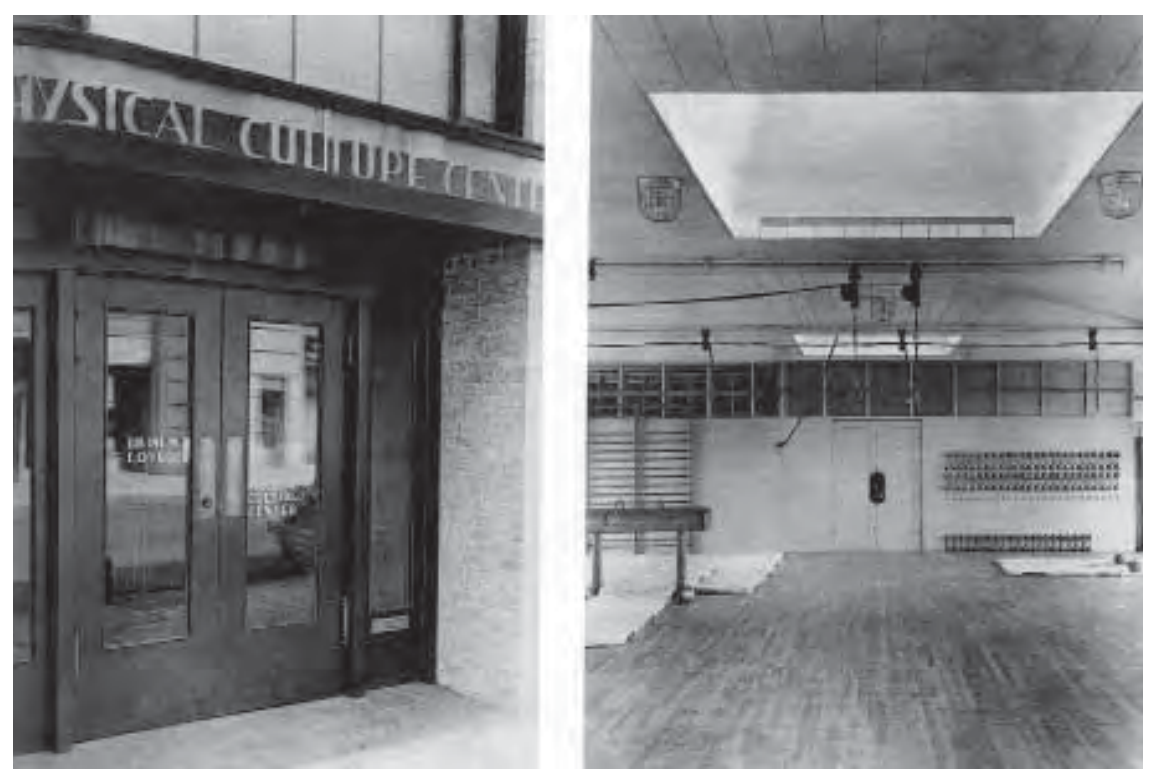

tografías aparecidas en Architectural Record habrían sido de Weston. Sobre todo teniendo en cuenta que fue Pauline Schindler ${ }^{285}$ quien las envió y que ella poseía las copias realizadas por el propio Weston. Dada esta circunstancia demostrada anteriormente, es poco probable que Pauline enviara fotografías de Willard Morgan teniendo las de su íntimo amigo con quien además vivía por entonces en Carmel y, en cualquier caso, la imagen del interior a la que se refiere Morgan fue realizada por Weston.

Por último y como hipótesis derivada de los párrafos anteriores, cabría la opción de pensar que el exterior de la casa Lovell de Newport publicada por Das Neue Frankfurt fuese una fotografía de Edward Weston. Aunque, si se compara con las imágenes discutidas anteriormente, ni la elección del punto de vista (muy bajo) ni las sombras concuerdan con aquellas. Además, frente al interés por narrar la relación de la casa con el entorno de la playa mostrado por las imágenes las imágenes presumiblemente de Weston, esta otra incide en la calidad espacial del recinto exterior que la vivienda genera bajo los pórticos. Es decir, el autor subraya el objeto mismo arquitectónico aunque para ello haya tenido que descontextualizar la obra, una actitud que, como se comentará más adelante, caracteriza muchas de las fotografías de la serie que, por encargo de Neutra, Morgan realizó de la segunda casa Lovell.

Respecto a las fotografías del centro de salud de Lovell aparecidas en Das Neue Frankfurt, Rubén Alcolea las atribuye igualmente a Willard Morgan, afirmando que "las obras en el Lovell Physical Culture Center se presentan sin planos, utilizando únicamente cinco imágenes de la serie realizada por Willard Morgan" 286 .

En efecto, Morgan fotografió el Lovell Physical Culture Center en una serie de imágenes de gran calidad y sentido arquitectónico. Las instantáneas han sido acreditadas correctamente en diferentes estudios y monografías sobre el arquitecto, como la de Thomas Hines, cuyo libro sobre Neutra reproduce tres de ellas: el acceso, el gimnasio y la oficina ${ }^{287}$. Sin embargo, surgen algunas dudas razonables sobre la autoría de las imágenes que ilustraban este artículo de Das Neue Frankfurt dedicado por Neutra a los encargos Lovell.

Por un lado, el hecho de que fotografías como las de Weston no estén autentificadas. Por otro, la diferente técnica fotográfica, encuadres $y$, hasta

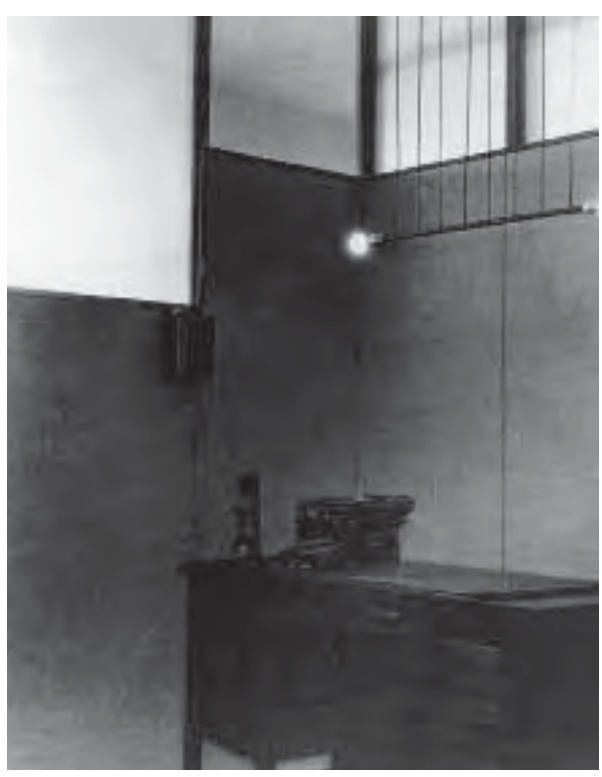

Richard Neutra: Imágenes del Lovell Physical Center, 1927, tomadas por Willard Morgan. Fuente: Thomas Hines, Richard Neutra

Página anterior arriba: Imágenes del Lovell Physical Center, aparecidas en el número de mayo de 1928 de Das Neue Frankfurt Página anterior abajo: Imagen de la Lovell Beach House publicada en ese mismo número de la revista alemana 


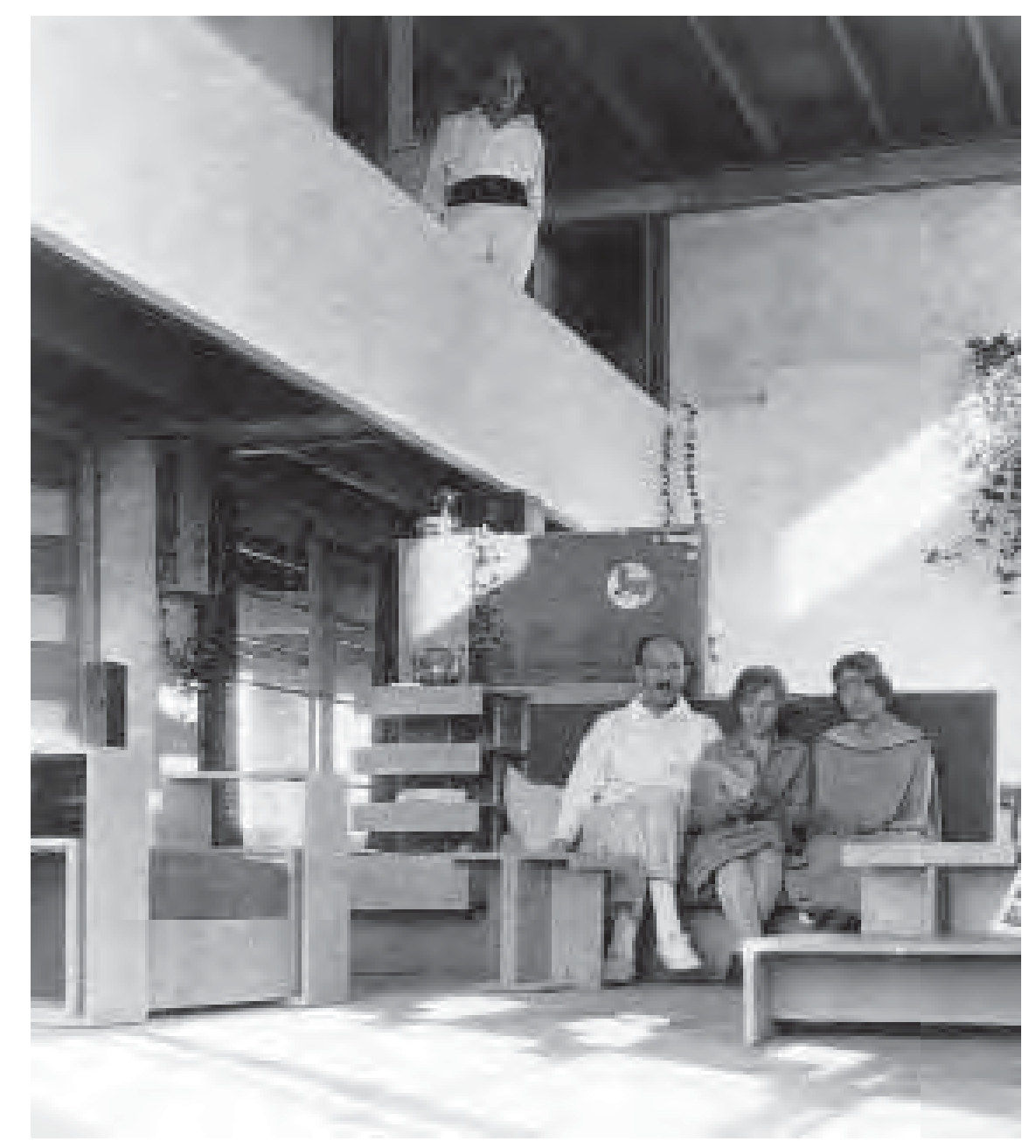

amueblamiento de los interiores entre unas y otras instantáneas. Por último, porque en una carta ${ }^{288}$, escrita por Weston a su entonces compañera Christel Gang y fechada el 20 de marzo de 1928, éste afirmaba que estaba trabajando en un encargo del doctor Lovell, consistente en producir 40 negativos $8 \times 10$ de su Lovell Physical Culture Center, en pago por sus servicios médicos ${ }^{289}$.

El precedente del anonimato de sus fotografías de la Lovell Beach House y la estrecha relación personal existente durante esos años entre los Schindler, los Lovell, los Neutra y la familia Weston, inducen a pensar que, independientemente de la autoría de las imágenes que Alcolea atribuye a Morgan, en esa época Edward Weston, podría haber fotografiado más de un edificio, bien fuera por encargo de uno $u$ otro arquitecto $\mathrm{o}$, incluso, del propio cliente, su amigo Philip Lovell. Asimismo, Raymond Neutra piensa que Edward Weston probablemente tomase alguna fotografía de la Lovell Health House aunque afirma que los archivos de Weston en el Center for Creative Photography de la Universidad de Arizona no contienen ninguna referencia a su padre. Por su parte, John Crosse apunta otro interesante descubrimiento en la relación profesional entre Edward Weston y Richard Neutra, cuando afirma que el arquitecto intentó que Josef von Sternberg encargase a Weston un mural fotográfico de $5 \times 40$ pies para su casa impreso no sobre papel, sino INTERNATIONALE AUSSTELLUNG

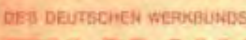
sobre aluminio, tal como el artista escribía sorprendido pidiendo consejo a su amigo Ansel Adams en una carta ${ }^{290}$ de 1935.

Richard Neutra y Edward Weston eran amigos desde la llegada del arquitecto a Los Ángeles. Pruebas de su amistad y mutua admiración profesional se encuentran en los diarios del fotógrafo donde, por ejemplo, en una entrada 
del 6 de junio de 1928, éste escribe acerca de invitar a Schindler y-por extensión a los Neutra a cenar-: "Telefoneé a Schindler para que viniera [...] pero fue Neutra quien respondió al teléfono, lo cual supuso invitarle también a él y a su mujer, pero me pareció bien porque les tengo aprecio a ambos" ${ }^{\prime 291}$.

Rubén Alcolea sostiene que el descubrimiento por parte de Neutra de la producción artística de Edward Weston tuvo que deberse a la colaboración del arquitecto con el fotógrafo Willard Morgan, afirmando: "[...] es difícil imaginar que Neutra hubiera conocido la obra de Weston sin la necesaria intervención de Morgan ya que, aunque el arquitecto estaba muy bien relacionado socialmente gracias a su amistad con Schindler, los círculos arquitectónicos y fotográficos no coincidían exactamente y, además, Weston ya se había trasladado por aquel entonces a San Francisco" ${ }^{\prime 292}$.

Alcolea basa su razonamiento en el hecho de que el matrimonio Morgan había entablado amistad con Edward Weston a raíz de la exposición sobre el fotógrafo que su mujer, Barbara Morgan, comisarió con Annita Delano en la Universidad de California en Los Angeles en 1927 -y en la que, por cierto, también se exponía la obra de su hijo Brett. No obstante, Alcolea no ha tenido en cuenta que Weston era amigo de los Schindler y un habitual de Kings Road, y que tuvo que ser allí, al regreso del viaje del fotógrafo a México en 1926, cuando forzosamente Neutra, que aún vivía en la casa, tuvo que conocerle ${ }^{293}$.

Más allá de cualquier especulación, es evidente que Richard Neutra trataba de beneficiar a Edward Weston, como prueba el hecho de que el arquitecto facilitara el acceso de su amigo al comisariado de la histórica exposición Film und Foto.

Organizada por el Werkbund alemán e inaugurada en Stuttgart en 1929, Film und Foto supuso la primera exposición comprehensiva de la fotografía moderna europea y norteamericana. En principio, esta muestra itinerante ${ }^{294}$ había sido había sido planteada como plataforma de difusión de las artes visuales vinculadas a los planteamientos de la Bauhaus y de la Nueva Objetividad. Sin embargo, terminó extendiendo sus contenidos y su ámbito geográfico más allá de la Nueva Visión ${ }^{295}$ para dar cabida a 1.200 obras de 191 artistas de los dos continentes cuya producción, a través de su relación con la fotografía, pudiera ser definida por su dimensión experimentalista. A través de los artistas representados, Film und Foto exploraba los límites de la técnica fotográfica y ponía en valor lo insólito de sus experiencias para romper definitivamente con cualquier tradición fotográfica anterior.

La exposición exploraba el potencial de los nuevos lenguajes visuales abstractos como aproximación estructural y crítica a la realidad. Ponía en valor el trabajo de cineastas, fotógrafos, arquitectos y diseñadores y presentaba de una muy manera sistemática los logros del cine y de la fotografía a través de diferentes disciplinas como el arte, la publicidad, la propaganda y los media. A pesar de lo temprano de su fecha, la exposición reconocía la influencia que el cine y la fotografía habían comenzado a ejercer en la cultura popular ya que nunca antes ni el arte ni ningún otro medio habían logrado poner en circulación tal cantidad de imágenes.

Film und Foto facilitaba la comprensión de los materiales expuestos a través de una didáctica correlación entre temas y técnicas. Bajo este aspecto, se concedía la misma importancia a las obras de arte expuestas que a las escenografías y estrategias de comunicación de la propia exhibición. Aunque
Film und Foto, póster de la exposición a partir de una fotografía de Willi Ruge

Página anterior arriba: RMS: Lovell Beach House, imagen del interior tomada por Richard Neutra, 1927. En el corredor de acceso aparece RMS, abajo, sentados en el sofá Samuel y Harriet Freeman junto a Dione Neutra (dcha) Página anterior abajo: Film und Foto, catálogo de la exposición de 1929. Portada diseñada por El Lissitzky

\section{INTERNATIONALE AUSSTELIUNG DES DEUTSCHEN WERKBUNDS}

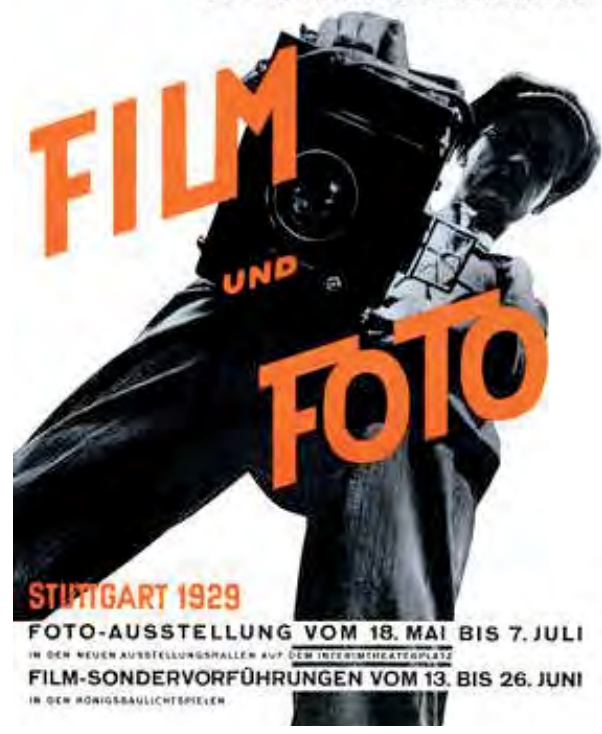




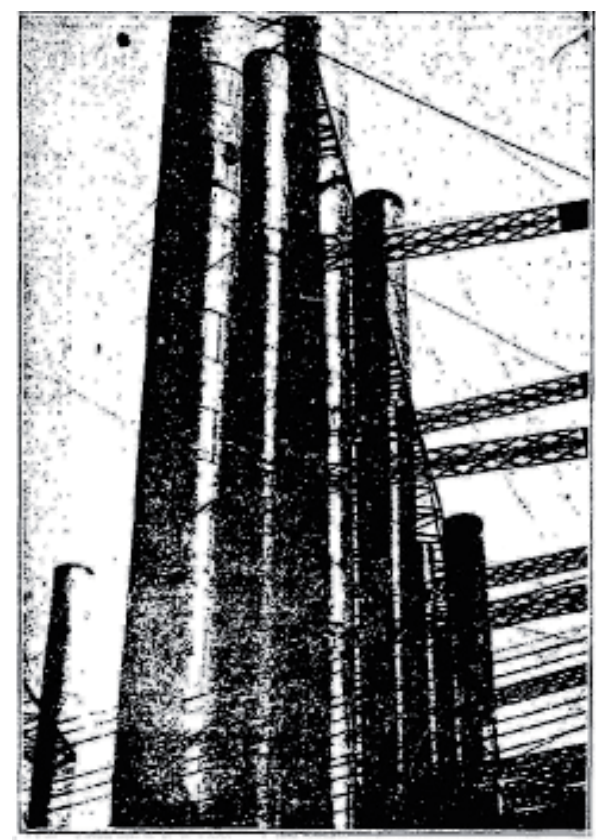

Stacks" Fram the Plototragh by Brett Weeton

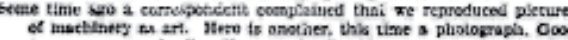

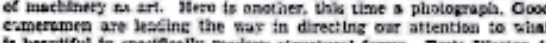

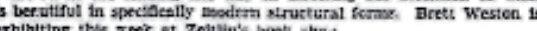

Arthur Millier: "Photographs for Himself," artículo sobre la exposición de Brett Weston en la gelería de Jake Zeitlin, Los Angeles Times, 25 julio 1930. Fotografía de Brett Weston de una fábrica en Los Ángeles

Página siguiente: Richard Neutra: Amerika, portada realizada a partir de un fotomontaje de El Lissistzky de la imagen de Brett Weston la exposición mostraba géneros clásicos como el retrato, enfatizaba nuevos campos de acción como el reportaje periodístico, la fotografía científica, el documental, los estudios de luces, el fotomontaje y el collage fotográfico.

Además, los trabajos de artistas desconocidos se mezclaban con los de autores consagrados o de otros que muy pronto alcanzarían renombre internacional como figuras imprescindibles en su disciplina. La propuesta de artistas europeos recayó en Moholy-Nagy quien, entre otros, incluyó a Eugène Atget, Willi Baumeister, Marcel Duchamp, Hannah Höch, Alexander Rodtshenko y Willi Ruge. Edward Weston estuvo a cargo de seleccionar representantes norteamericanos como Berenice Abbott, Imogen Cunningham, Paul Outerbridge, Man Ray, Edward Steichen, Charles Sheeler o su propio hijo, Brett Weston.

El 12 de junio de 1929, Weston refirió en su diario una cena con "Paul" -uno de los diferentes nombres que inventaba familiarmente para referirse a Pauline Shindler. Escribió sobre la conversación que ambos habían mantenido esa noche acerca de cómo enfocar la dirección de The Carmelite, sobre nuevos contenidos para la revista y sobre algunos de los asuntos que le habían ocupado recientemente, entre ellos, el comisariado de Film und Foto. Weston afirmaba textualmente: "Como parte del consejo editorial, me quedé hasta que después de media noche me venció el sueño discutiendo cuestiones que habíamos tratado durante todo el día. Los cotilleos de la ciudad acerca del divorcio de Lincoln Steffens y Ella Winter. Una carta de Una Jeffers, escrita en el tren, expresándome de nuevo su satisfacción por sus retratos. Y el catálogo de Film und Foto-Stuttgart donde se reproducía mi cabeza de Galvan, se publicaba mi artículo y se colgaron 18 fotografías de Brett y otras 20 mías, de las 20 de cada uno de nosotros que yo les había hecho llegar".

Fue Neutra quien, gracias a sus contactos europos, logró que Giedion y Moholy-Nagy aceptasen la labor de comisariado de Edward Weston ampliando así el foco de la exposición a los Estados Unidos. Desde finales de 1928, los contactos entre Neutra y los líderes del Movimiento Moderno en Europa, se habían intensificado con motivo de la preparación del CIAM de Frankfurt de 1929, al que Neutra no pudo asistir pero en el que aparecía acreditado como delegado norteamericano ${ }^{296}$. Por otra parte, también desde finales de 1928, con el inicio de las obras de la casa Lovell, el arquitecto tenía en mente un viaje promocional a Europa una vez que éstas terminasen y dedicó considerables esfuerzos a su planificación, consiguiendo entre otros hitos que, en 1930, se le invitase durante un mes a impartir clases en la Bauhaus. Mucho antes incluso, en 1925, cuando apenas había comenzado a trabajar en California, Neutra ya se había fijado el objetivo de entablar una relación personal con los principales responsables de los canales de comunicación de la modernidad en Europa, como bien aleccionaba por carta a sus suegros que habían quedado allí al frente de sus intereses: "Tened en cuenta" -advertía"que actualmente, Walter Gropius, Sigfried Giedion y Das Neue Frankfurt son los únicos que publican las revistas más sinceras y de mayor reputación"297. Y, precisamente, había sido desde su incorporación a la plantilla de colaboradores de Das Neue Frankfurt como Neutra había conseguido difundir sus primeras obras en Europa, Ilamando la atención, entre otros del propio Walter Gropius quien, durante su visita a Los Ángeles en 1928, se había mostrado entusiasmado ${ }^{298}$ con sus apartamentos Jardinette.

La propuesta de Edward Weston por parte de Neutra como comisario de la sección norteamericana de la exposición no fue casual. Por un lado, el ar- 
quitecto contribuía al prestigio internacional de uno de los mejores amigos de su principal cliente. Por otro, fortalecía su relación profesional con un artista imprescindible y de cuya obra pronto se serviría para ilustrar algunas de las ideas de su segundo libro, Amerika. Y, por supuesto, mostrando ante la vanguardia europea la calidad de los artistas seleccionados por Weston, varios de ellos californianos como el propio fotógrafo, su hijo Brett o la futura integrante del grupo f/64 Imogen Cunningham, él mismo se beneficiaba del hecho de que la crítica y el público fueran conscientes en Europa de la intensidad e interés del medio creativo en el que estaba desarrollando su obra y, por supuesto, de su envidiable posición como el arquitecto que estaba en el lugar adecuado en el momento adecuado. En este sentido, no es aventurado suponer que mientras veía avanzar su Lovell House, Neutra tenía clara ya su estrategia y preparaba el camino para su siguiente golpe de efecto mediático.

El propio Edward Weston, en una entrada de principios de 1929 escribía sobre su cometido al frente de la selección de artistas estadounidenses: "Neutra, como siempre, es extremadamente perspicaz, y sabe muy bien de lo que habla. Como representante en América de una importante exposición de fotografía que tendrá lugar este verano en Alemania, ha sido él quien me ha dado plena libertad para escoger los autores cuyas obras yo considere que deben formar parte de la muestra, así como la tarea de escribir en el catálogo sobre los artistas norteamericanos..." 299 .

En su texto introductorio al catálogo de la exposición, titulado America and Photography, Edward Weston defendía las principales ideas que resumían su obra como fotógrafo y, por extensión, la intencionalidad de su elección: "He escrito sobre fotografía como un medio directo, honesto, sin concesiones, y así lo es cuando se utiliza en toda su pureza, cuando el fotógrafo es igualmente sincero en su comprensión, selección y presentación. Entonces tiene todo el poder de conmover al espectador. No puede haber mentira en esta fotografía". El catálogo de la exposición fue diseñado por El Lissitzky, quien también fue responsable de la litografía de la portada del segundo libro de Richard Neutra, Amerika.

Publicado por Anton Schroll en Viena en 1930, Amerika estaba presidio por un fotomontaje realizado por el artista ruso a partir de una instantánea de Brett Weston tomada en una fábrica de Los Ángeles. Duplicada especularmente, la imagen de los artefactos industriales de Brett Weston y el fondo de rascacielos aportado por El Lissitzky condensaban las dos principales visiones que la vanguardia europea más admiraba de la construcción en América y a la que Neutra había dedicado su primer número.

La fotografía de Brett Weston había sido realizada en 1927 y utilizada también para ilustrar una crítica de Arthur Millier para Los Angeles Times sobre la exposición que Jake Zeitlin ${ }^{300}$ había organizado al fotógrafo en su galería de Los Ángeles.

Amerika supuso para Brett Weston su primera portada. Todos los hijos de Edward Weston habian aprendido a fotografiar de la mano de su padre, aunque fue Brett quien más había colaborado con él y quien heredó su interés por los temas cotidianos, su precisión técnica y la sinceridad de su objetivo. Como ya se ha indicado, Brett comenzó a fotografiar muy joven y aunque pronto desarrolló un estilo propio, en ocasiones, es difícil atribuir la autoría de determinadas imágenes a uno u otro Weston.

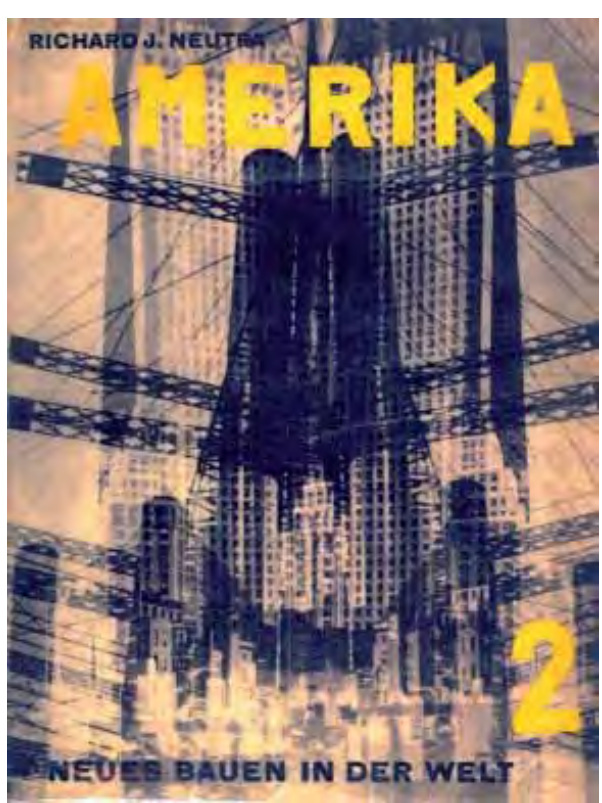


Quizás, por esta razón, Rubén Alcolea ha defendido equivocadamente que, en el caso de la portada de Amerika, Neutra atribuyó por error a Brett Weston la base del fotomontaje de El Lissitzky cuando, en realidad, se trataba de una fotografía de la serie ARMCO realizada por su padre en 1922. Sin embargo, Neutra estaba en lo cierto y acreditó correctamente al segundo hijo de Weston como autor, tal como figuraba en los créditos de la exposición de Zeitlin Books y en el citado artículo de Arthur Millier de 1930. No obstante, esta confusión es fácil ya que la instantánea de 1927 estaba claramente influida por el trabajo de su padre en Ohio, pero no fue Edward sino Brett Weston quien prestó su trabajo a Neutra para la portada de este segundo libro ${ }^{301}$.

Sí lo hizo sin embargo en el interior, donde Neutra se sirvió de algunas obras de Edward Weston, como Pulqueria, una fotografía realizada en México en 1926 o la instantánea de una carpa de circo, cuya ligereza estructural no dejó indiferente al arquitecto que la rotuló como lámina y cuerdas de tracción. $Y$, ciertamente, es sintomático el uso por parte de Neutra de todo tipo de imágenes para ilustrar Amerika.

El arquitecto recurrió a fotografías de sus obras y las de sus contemporáneos como Schindler, a reproducciones de otros libros de arquitectura e, incluso, a obras de artistas como los Weston que ponen de manifiesto el interés de Neutra por tender puentes entre la arquitectura y la fotografía modernas. Como ha reparado Rubén Alcolea ${ }^{302}$, en su segundo libro, Neutra explotó aún más las posibilidades de la fotografía de lo que lo había hecho en Wie Baut Amerika? Tanto es así que "el hecho de pasar de las cien imágenes contenidas en éste a las doscientas sesenta publicadas en aquél da fe de la importancia atribuida por el arquitecto austriaco a la edición de libros capaces de expresarse no sólo mediante texto sino también a través de las imágenes" ${ }^{1303 .}$

Es evidente pues que la producción artística de Weston había interesado a Neutra y que éste, fotógrafo aficionado y profesional atento a la producción de los creadores que le rodeaban, supo apreciar la técnica fotográfica de su amigo, aunque su relación posterior con la fotografía de arquitectura se moviera por diferentes derroteros. Aún así, Neutra extrajo importantes lecciones para el futuro al reconocer en el estilo abstracto y directo de Weston todo el potencial expresivo que encerraba la representación del detalle. 
[DE OLIVEHILLA KINGS ROAD ] ]..

LPAULINE GIBLING (SCHINDLER),

PROMOTORA DE LA MODERNIDAD CALIFORNIANA

LEDWARD WESTON EN LOS INICIOS DE LA

FOTOGRAFÍA DE ARQUITECTURA EN CALIFORNIA

[RUDOLPH SCHINDLER Y LA FENOMENOLOGÍA DEL ESPACIO MODERNO

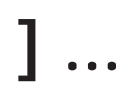




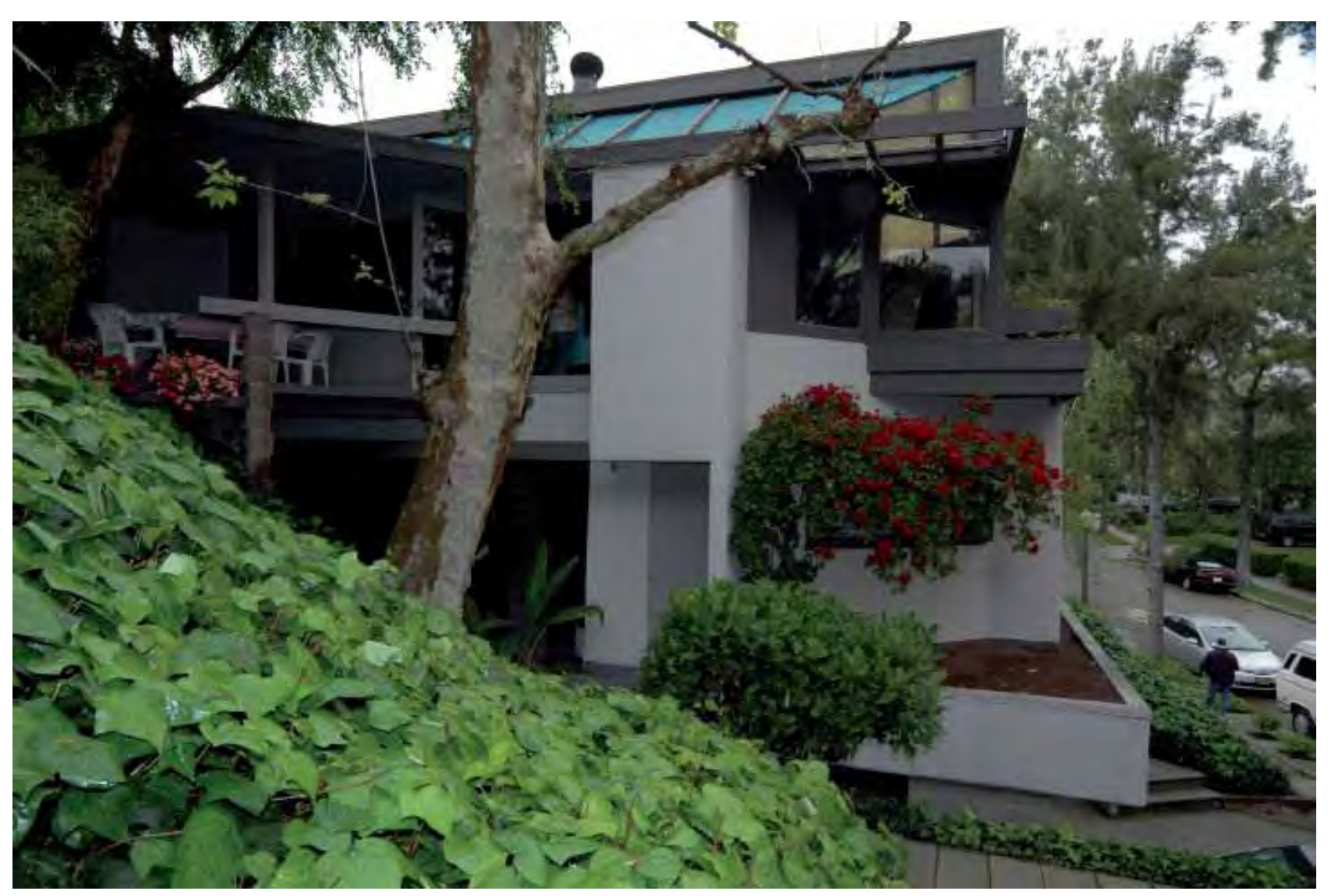

Greenfield Avenue ${ }^{304}$ es una amplia calle residencial próxima a Veteran Avenue, la arteria principal del barrio que, conectando los bulevares de Sunset y RMS: Tischler House (1949-1950) y vista parWilshire, bordea el Cementerio Militar y el campus de UCLA en Westwood. Esta área del oeste de la ciudad de Los Ángeles comenzó a ser desarrollada en los años 20 a través de importantes operaciones inmobiliarias que tuvieron mucho que ver con el asentamiento del nuevo complejo de la Universidad de California en Los Ángeles. Hacia finales de la década, las comunidades surgidas alrededor de UCLA se habían consolidado como respetables vecindarios de clase media alta. Según lo acostumbrado en estos casos, el distrito se conformó por agrupaciones de viviendas unifamiliares de cuidados jardines y las calles, profusas en arbolado y pintorescamente trazadas sobre las colinas, fueron poblándose con variadas muestras de todos los historicismos. Los promotores prefirieron la evocación mediterránea pero también hubo lugar para el eclecticismo colonial, el Spanish Revival, los medievalismos sajones o el estilo Regencia305. A pesar de que comités de artistas velaban por mantener una imagen de inspiración romántica, antes de la Segunda Guerra Mundial determinados arquitectos habían logrado ya incorporar el Estilo Internacional al repertorio de lenguajes. Los apartamentos Strathmore o Landfair, ambos de 1937 y ambos firmados por Richard Neutra, abrieron el camino a posteriores realizaciones como la Case Study House construida por Craig Ellwod en Bel Air (1952-53). A diferencia de estos ejemplos, en Westwood la introducción de las heterodoxias modernas fue más tardía y su aceptación bastante desigual, como atestigua el llamativo conjunto de apartamentos Sheets (L'Horizon, 1948) de John Lautner. En el caso de Schindler la asimilación de su trabajo resultó un proceso especialmente complicado ya que ni el gusto del público ni los parámetros de la crítica parecían dispuestos a aceptar las extrañas formas de la vivienda ${ }^{306}$ que, en 1949, construyó para el matrimonio Tischler (1949-50). 


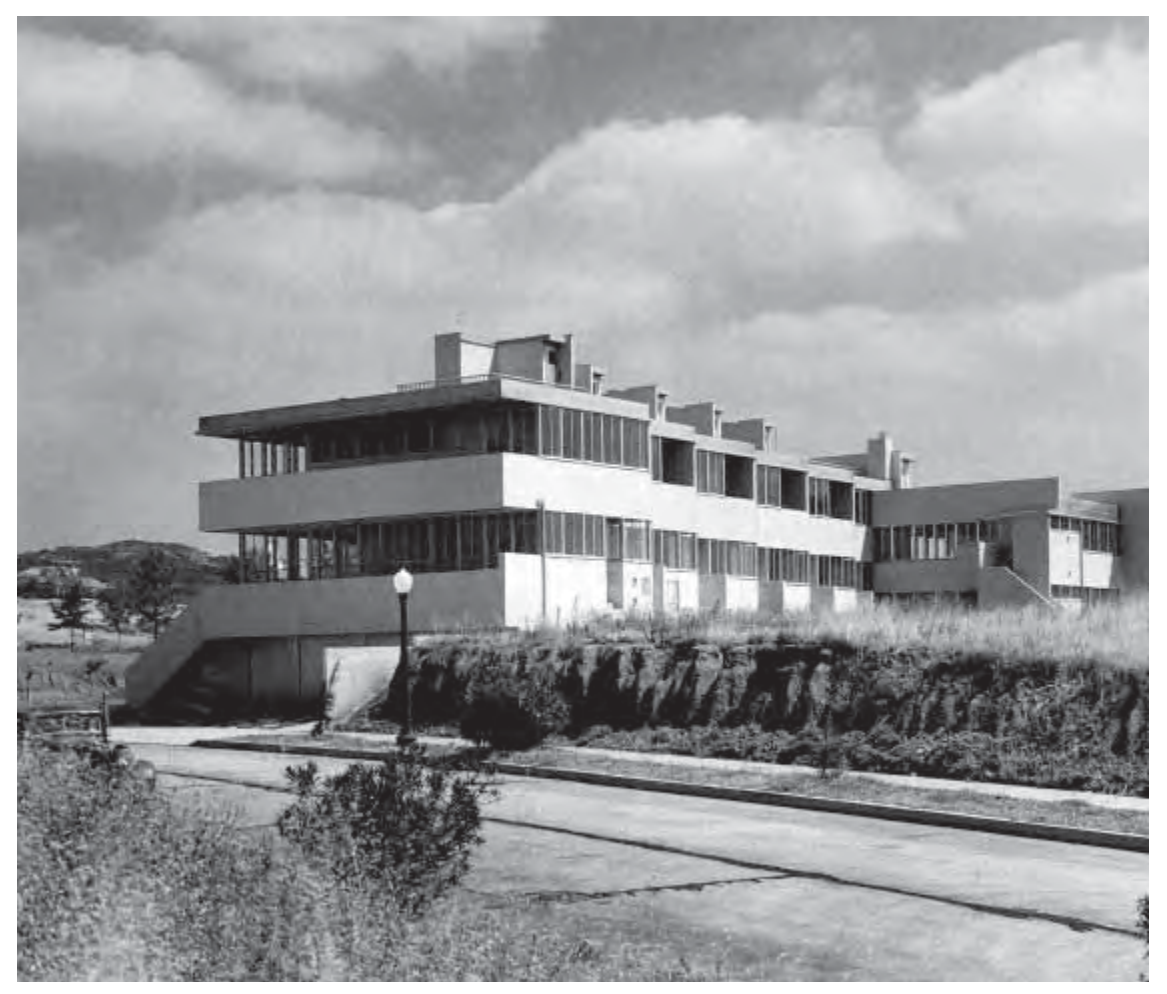

La casa Tischler, una de sus últimas actuaciones, ilustra de manera paradigmática la arquitectura espacial de Schindler. Las viviendas ejecutadas en este periodo, que se extiende desde mediados de los años 40 hasta poco antes de su muerte en 1953, tienen en común una trasgresora reflexión sobre el espacio doméstico. En principio, estas obras vuelven a poner de relieve las constantes que recorren su producción arquitectónica desde su viviendaestudio de 1922. En Kings Road ya aparecían temas como la ambigüedad de los interiores, la exploración de sus límites, sus posibilidades como contenedores, o lo cambiante de su percepción según la manera de usarlos. Después de la guerra, Schindler llevó hasta casi sus últimas consecuencias todas estas líneas de investigación, haciéndolas confluir en una revolucionaria continuidad material que engloba estructura, cerramientos, mobiliario y objetos en la envolvente que delimita el espacio. Schindler logró tal grado de integración que, frecuentemente, en sus casas de aquella época los conceptos de contenedor y contenido llegan a ser intercambiables.

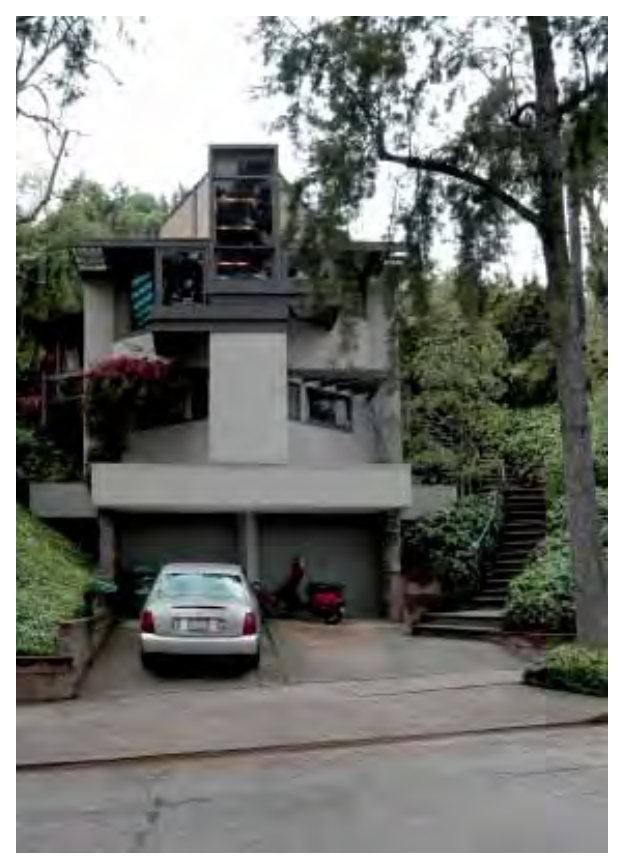

Entre los nuevos temas planteados, las casas Tischler, Janson o Skolnik, abordan la experiencia sensorial derivada de propiedades del mundo físico tales como la permeabilidad o la translucidez ${ }^{307}$. Estas cualidades son manipuladas de un modo muy abstracto, tanto que el arquitecto consigue minimizar la presencia misma de los materiales concretos de los que depende el efecto arquitectónico deseado. Uno de los casos más extremos sería el de la cubierta de la Tischer House, donde Schindler recurrió a un material de reciente aplicación, la fibra de vidrio traslúcido, escogiendo un tono azul intenso que crea bajo su superficie una atmósfera tan perturbadora como evanescente. Aunque el efecto de irrealidad perseguido requería la concurrencia de una cualidad específica y también de un color determinado para el tipo de plástico empleado, a Schindler no le interesó potenciar su singularidad ni dirigir la atención hacia el propio material como hubieran preferido, por ejemplo, los hermanos Greene con la textura de la madera o Richard Neutra con el acero. Su intención fue la de expresar el carácter de un espacio a través de sus límites más allá de poner en valor la sustancia con la que éstos estaban construidos. Tampoco se molestó en explicar cómo se 


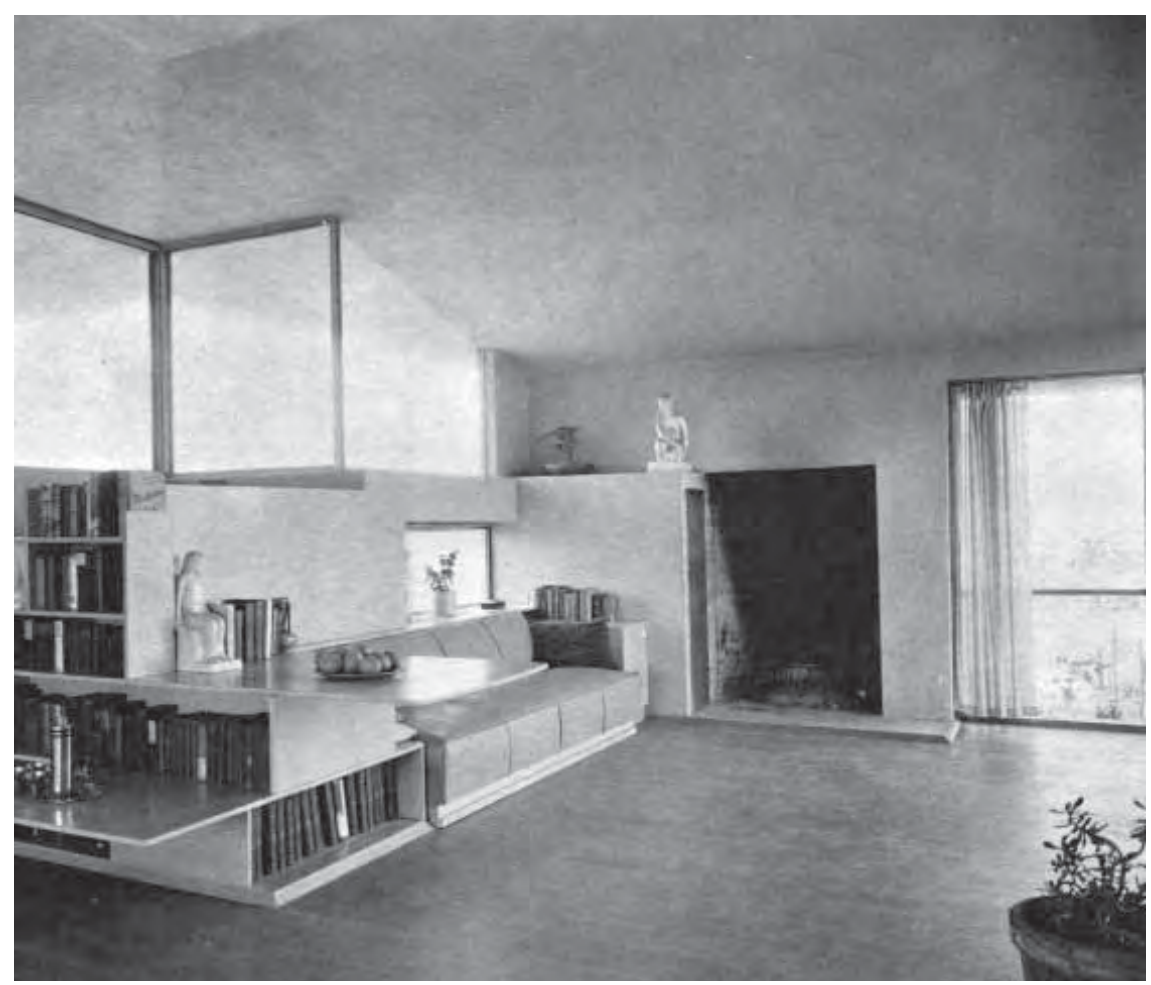

sostenía todo aquel dispositivo, es más, desmaterializó el sistema portante de la cubierta pintándolo de negro y plata. Una acción profundamente anticlásica pues con ella desposeía a la estructura de su papel como referente en la definición del espacio.

Schindler había ido abandonando el empleo de materiales de mayor pregnancia como la secuoya roja, con la que se identifican muchos de sus primeros trabajos, y se había interesado por el contrachapado; paulatinamente había dejado de lado la experimentación con el hormigón y terminó recurriendo, cada vez más, al tradicional armazón de madera revestido de estuco $^{308}$. En este sistema tan extendido en California encontró una solución constructiva lo suficientemente flexible y, sobre todo, barata ${ }^{309}$ para moldear las formas que originaban sus espacios. Este posicionamiento de Schindler frente a la técnica, evolucionando en sentido contrario al que parecía dictar el espíritu de los tiempos, le condujo a adoptar posiciones aún más alejadas tanto de las tesis ideológicas más canónicas como de las aspiraciones estéticas y de las imágenes más recurrentes de las vanguardias de acero y vidrio preconizadas por determinados medios de la época.

Aunque, en realidad, Schindler había iniciado este camino mucho antes de la guerra. Según apunta la propia Esther McCoy, después de concluir la Lovell Beach House, Schindler comenzó a perder el interés por la tecnología y a centrar los temas de su arquitectura en la investigación sobre la forma arquitectónica. En 1928 había escrito en su cuaderno de notas: "Técnica = tipo basado en las leyes humanas. Arte = variación producida a través de la mente humana ${ }^{310 "}$. Schindler pensaba que ni los materiales ni los métodos constructivos debían cobrar tanta importancia como para prevalecer sobre la manera en que las personas habitan sus hogares. En sentido estricto, sólo reconocía el espacio, el clima, la luz y el carácter como condiciones para la forma, y su interacción como causa última del hecho arquitectónico.

Bajo las citadas premisas de flexibilidad y economía estimaba oportuno incorporar todos aquellos elementos que pudieran contribuir a materializar

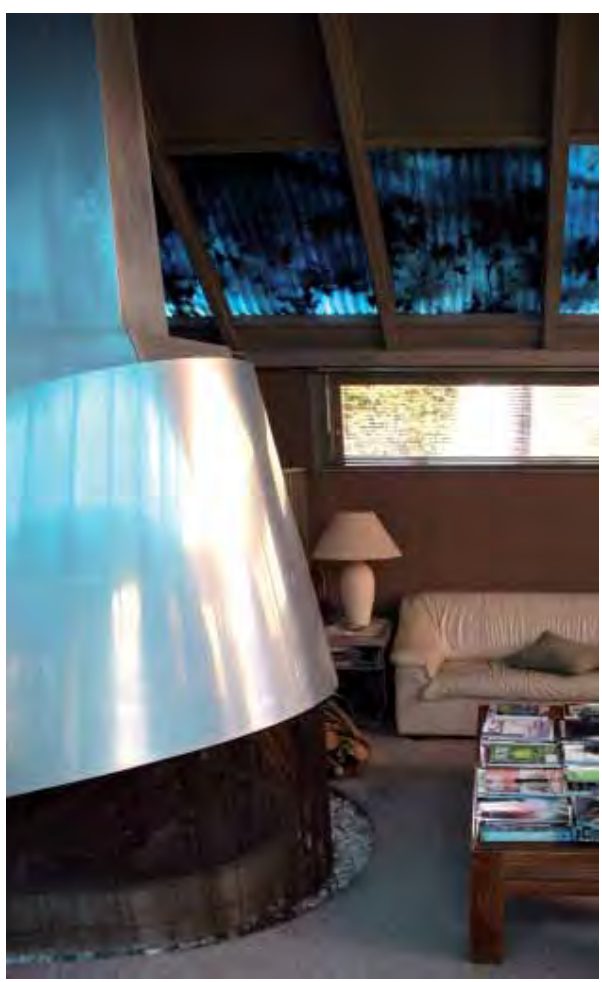

Izda: Schindler: Oliver House, 1933. ADC/UCSB Dcha: Tischler House, interior, detalle de la chimenea. Fotografía del autor

Página anterior arriba: Neutra: Landfair Apartments, Los Ángeles, 1937. Fotografía de Julius Shulman

Página anterior abajo: RMS: Tischler House. Fotografía del autor 
nuevas relaciones espaciales o a mejorar aspectos de la vida cotidiana, sin importarle demasiado la naturaleza efímera ${ }^{311}$ de algunos de ellos. También esta actitud, aparentemente ecléctica o arbitraria, es fruto de una coherente evolución creativa que desafortunadamente no fue intuida hasta varios años después de la desaparición del arquitecto ${ }^{312}$.

Harwell Hamilton Harris escribió sobre él: "El proceder de Schindler era diferente dependiendo de cada encargo. Consideraba que sus respuestas, para cada caso concreto, tenían que ser distintas porque también eran distintos el cliente, el programa, el lugar y el presupuesto. La variabilidad de problemas $y_{1}$ en especial, los presupuestarios, en vez de desanimarle alentaban su creatividad, y parecían liberarle del recurso a soluciones obvias" ${ }^{\prime 3_{13}}$. Acometiendo cada proyecto desde su especificidad, Schindler priorizaba la faceta experimental de su trabajo, ensayando nuevas soluciones en lugar de asegurarse el éxito recurriendo a la repetición de fórmulas probadamente satisfactorias.

Al abrir nuevos caminos, sus viviendas crecieron en complejidad, se enriquecieron espacialmente y adoptaron lenguajes poco identificables, hasta el punto de que Schindler, con mayor o menor propósito, acabó confundiendo la opinión de sus contemporáneos. En sus casas construidas en la década de los años cuarenta, con la desaparición de los revestimientos de madera, se han ido desdibujando las referencias vernáculas asociadas con la obra de arquitectos como Hamilton Harris cuyo trabajo de esos años reinventaba la sensibilidad regionalista a través de su descubrimiento de Greene \& Greene. Por otro lado, las influencias wrightianas se han integrado en un vocabulario formal tan personal como desconcertante; y la libertad para seleccionar criterios compositivos, superponer referencias y cometer transgresiones sintácticas (como la indiferenciación de estructura y cerramiento) ponen en evidencia el conflicto de la obra de Schindler con muchas de las convenciones modernas. Conforme avanza la cronología se hace cada vez más difícil reconocer elementos de imagen que vinculen su obra con la herencia europea, con las tradiciones americanas $y$, mucho menos, con las sofisticadas residencias de acero y cristal con las que Richard Neutra había marcado las pautas de un estilo internacional convenientemente aclimatado a la modernidad californiana.

A pesar de que no le importó discrepar abiertamente con el establishment americano y dentro de su círculo de clientes casi siempre pudo ingeniárselas para realizar el tipo de arquitectura que le interesaba investigar, a Schindler le molestaba profundamente el trato recibido por parte de algunos de sus contemporáneos. Como se ha visto en los capítulos anteriores, sentía la necesidad de justificar su trayectoria frente a la incomprensión de determinados círculos de opinión y, aunque principalmente trataba de defenderse de los reproches acerca de lo inclasificable de su obra, también se esforzaba en explicar sus ideas porque consideraba injusto no poder acceder a encargos de mayor envergadura, reservados a los arquitectos más gratos a los medios. En no pocas ocasiones, denunció con vehemencia lo que él consideraba la reducción de la modernidad a un estilo como cuando, disgustado por su exclusión del MoMA en 1932, escribió a Philip Johnson: "Considero que, en lugar de mostrar los últimos avances de la arquitectura más creativa la Exposición se ha concentrado en el llamado Estilo Internacional y por ello mis obras no tienen cabida. No soy un funcionalista, no me interesan los estilos y menos los eslóganes. Cada uno de mis edificios afronta y resuelve un problema arquitectónico diferente, cuya existencia parece haber sido olvidada en este periodo de mecanización racional. La cuestión sobre 


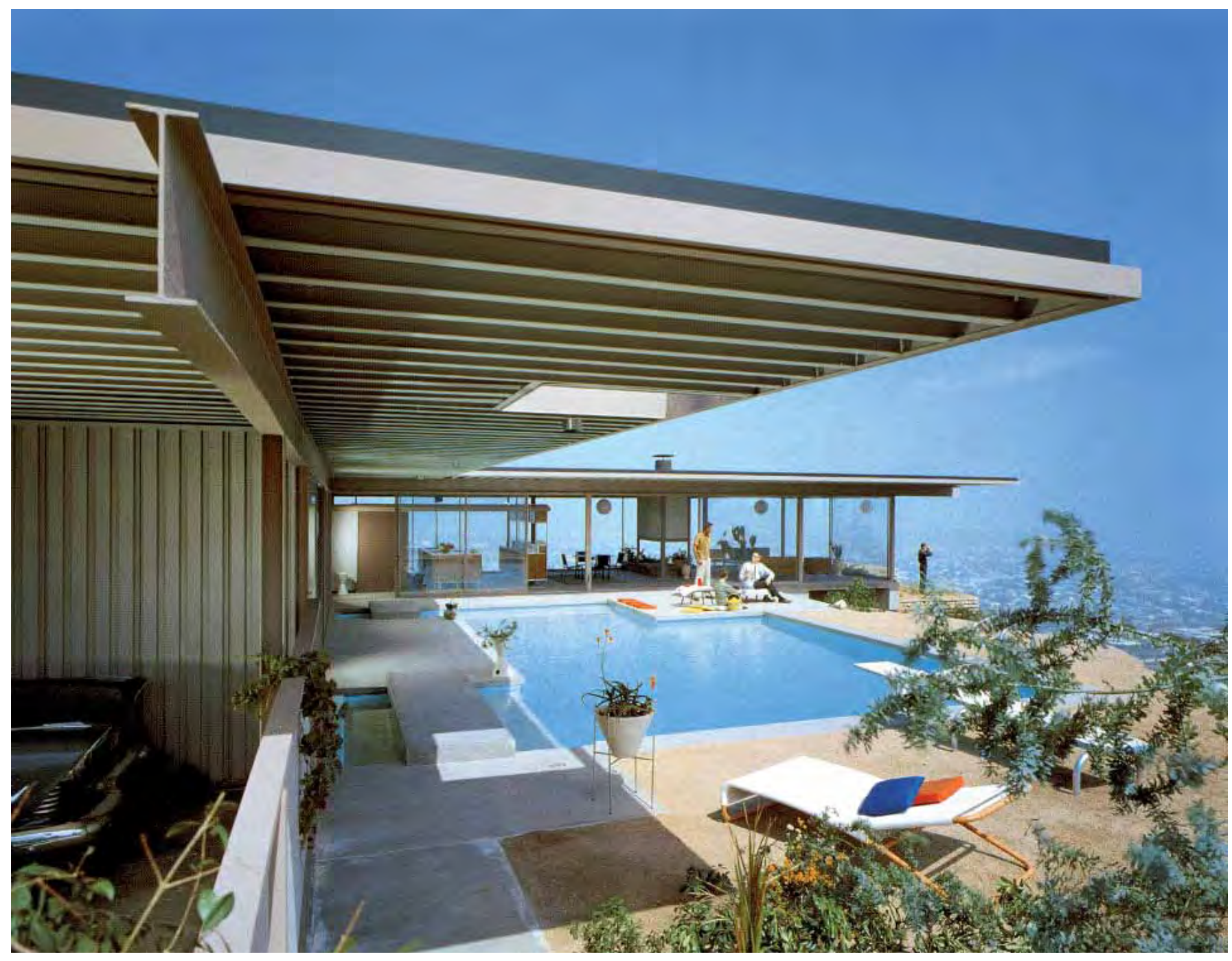

qué es verdaderamente una casa me importa mucho más que el hecho de si está construida con acero, cristal, masilla o palabrería"314.

P. Koenig: Stahl House, CSH \#22, 1959-60. Fotografía de Julius Shulman

Ser moderno para Schindler, como para Harris, era una actitud. Consistía en dar respuesta a las necesidades de un cliente, un lugar y de un modo de vida determinados y traducir en formas las investigaciones espaciales derivadas de un programa concreto. Bajo este enfoque parece lógico suponer que sus formas estuvieran destinadas a ser únicas.

Paradójicamente, lo que la modernidad parecía necesitar era una cierta convención para hacer llegar sus mensajes con la mayor claridad. Reconducir la confusión de estilos, evocaciones nostálgicas y visiones de todo signo instaladas en el inconsciente de la clase media no era tarea fácil en un lugar como California. Dado que muchos habían acudido allí en busca de fortuna, y casi siempre con una idea de casa soñada que solía asociar la extravagancia o la grandiosidad de su aspecto con el éxito personal, es hasta cierto punto comprensible que la cruzada moderna, tratando de transformar el gusto popular, concediera poco margen a las heterodoxias schindlerianas.

Los esfuerzos de Arts \& Architecture por difundir las aplicaciones domésticas de la tecnología surgida tras la guerra, más allá de su éxito mediático, apenas fructificaron en el paisaje residencial californiano y la originalidad de sus planteamientos iniciales acabó dando paso en las décadas siguientes a una codificación publicitaria de determinadas imágenes como reconociblemen- 


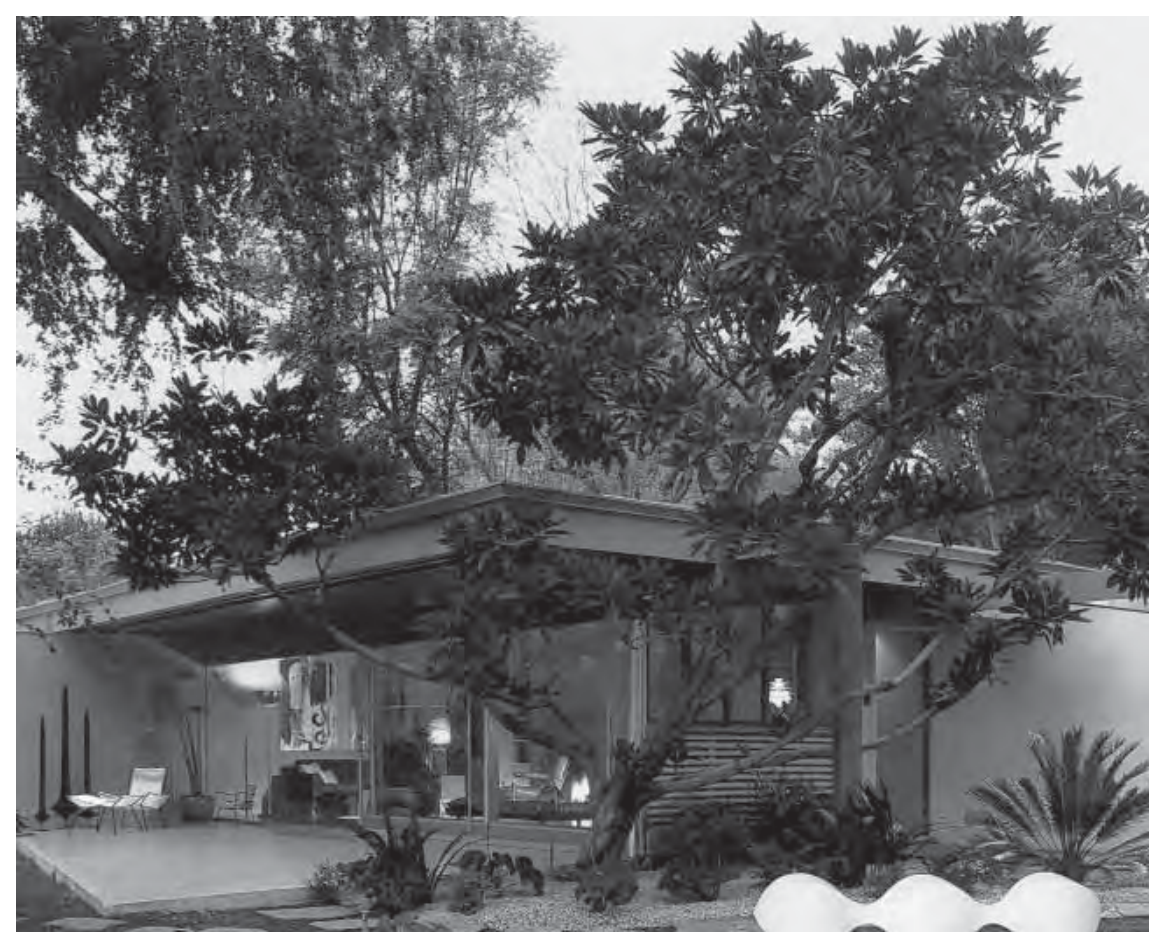

te modernas. $Y$ tampoco faltaron disidencias, polémicas ${ }^{315}$ y diversos casos que, como el de Schindler, ponen de manifiesto la poliédrica realidad arquitectónica del Sur de California a principios de los años 50.

Tómese como referencia el área metropolitana de Los Ángeles y el año del proyecto de la casa Tischler, 1949, el mismo en que Beatriz Colomina ${ }^{316}$ sitúa el punto culminante de la vanguardia americana por la coincidencia en esa fecha tanto de su consagración arquitectónica como del momento en que se habría iniciado su disolución. Ese preciso año los Eames se trasladaban a su casa de Pacific Palisades, donde también John Entenza veía finalizar su nueva residencia; Neutra, que meses antes había terminado dos de sus mejores obras, la Tremaine House en Montecito y la $\mathrm{CHS} \mathrm{n}{ }^{\circ} 20$, concluía la casa Wilkins en South Pasadena; Quincy Jones levantaba el conjunto de la Mutual Housing Association; John Lautner construía la casa Schaffer en el Valle de San Fernando; y Harwell Hamilton Harris afrontaba el proyecto de la English House en Beverly Hills, la casa con mayor presupuesto de toda su carrera. Todos estos ejemplos ilustran suficientemente la diversidad de las ideas modernas y el amplio margen de acción que concurrían en el paisaje residencial de Los Ángeles al iniciarse la segunda mitad del siglo.

Curiosamente, esta situación de ebullición arquitecónica y de incontestable potencial creativo fue atribuida por Henry-Russell Hitchcock al "extraño ambiente psicológico de la región" y fue la excusa que este reputado crítico e ideólogo del Estilo Internacional utilizó para arremeter contra Schindler cuando quiso ridiculizar su obra afirmando que "existe desde luego una gran vitalidad [en California...] pero esta vitalidad parece producir, en general, efectos arbitrarios y brutales" ${ }^{\prime 317}$.

Exceptuando descalificaciones infundadas como las de Hitchcock -por las cuales más tarde pediría disculpas ${ }^{318}$ - puede sostenerse que la incomprensión o el rechazo que encontraron las últimas viviendas de Schindler se debió a la inmediatez y al peso que, tras la guerra, todavía tenían las ideas de una modernidad importada a California, a pesar de lo que pueda creerse. Resulta por tanto sintomático que estas últimas obras de Schindlder, junto con Kings 


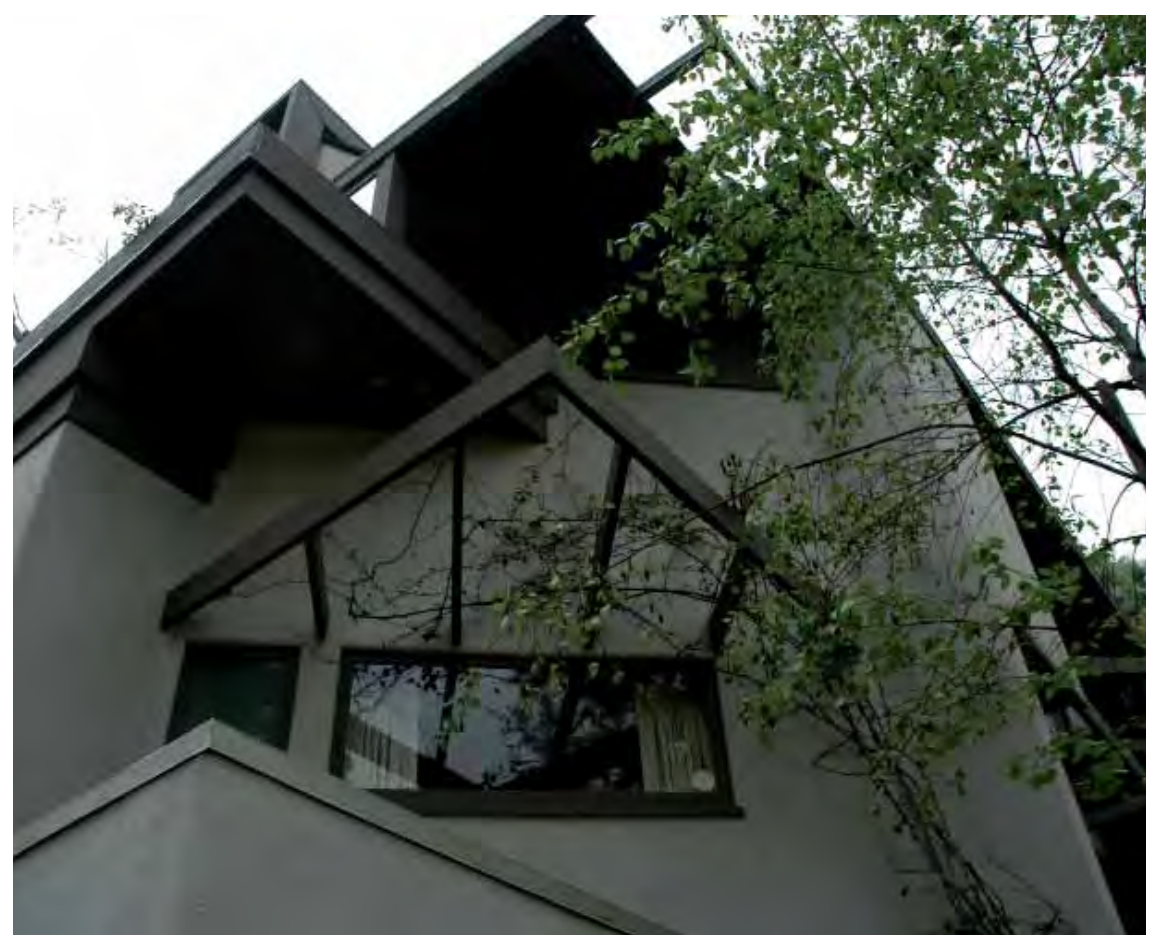

Road las más innovadoras de toda su carrera, absolutamente desprovistas de cualquier prejuicio, no fueran bien recibidas a pesar del relativo clima de libertad de California que acaba de mencionarse.

Incluso David Gebhard, el más importante artífice de la recuperación del arquitecto después de Esther McCoy, reconocía no haber entendido muchas de sus realizaciones postreras, afirmando no estar seguro de lo que Schindler había querido decir. En su monografía sobre el autor sostiene que casas como la Tischler y, en general, los proyectos realizados hacia el final de su vida son piezas discordantes, débiles e indecisas. Gebhard afirmó: "En el periodo de posguerra Schindler se adentró más aún en el terreno de las discordancias. Sus edificios dejaron de estar dominados por un único elemento, como habían sido sus volúmenes De Stijl de los años treinta. La atmósfera de disonancia y ambigüedad, en lugar de ser uno de los caminos para conseguir un fin, se convirtió para Schindler en finalidad"319. En un acertado comentario sobre estas opiniones, la historiadora Margaret Crawford dio la vuelta al argumento subrayando, desde el punto de vista de la crítica actual, que lo que en realidad estaba planteando Gebhard como recriminación ponía en valor, sin pretenderlo, las cualidades heterotópicas de la obra de Schindler, cuya sensibilidad era capaz de aceptar valores tan contemporáneos como la diferencia, la discontinuidad, la contigüidad y la disimilaridad ${ }^{320}$.

Hace más de una década, compartiendo foro con Crawford en el mismo número de la revista $2 \mathrm{G}$ consagrado a Schindler, otra de las especialistas en su obra, Judith Sheine, lamentaba la escasa atención que hasta el momento habían recibido las últimas viviendas de Schindler. En aquel momento la recuperación histórica del personaje que, se había producido muy tardíamente, estaba casi completada pero todavía se echaban en falta estudios especializados sobre proyectos concretos. Desde entonces estas carencias se han venido subsanando: la propia Sheine, que aportaba en aquel número de $2 G$ nuevos análisis y documentación gráfica -destacando el redibujado de planos y las excelentes fotografías de Grant Mudford-, ha continuado publicando (Phaidon, 2001); han aparecido textos de difusión popular como el de James Steele (Taschen, 1999); se ha reeditado una vez más la obra de

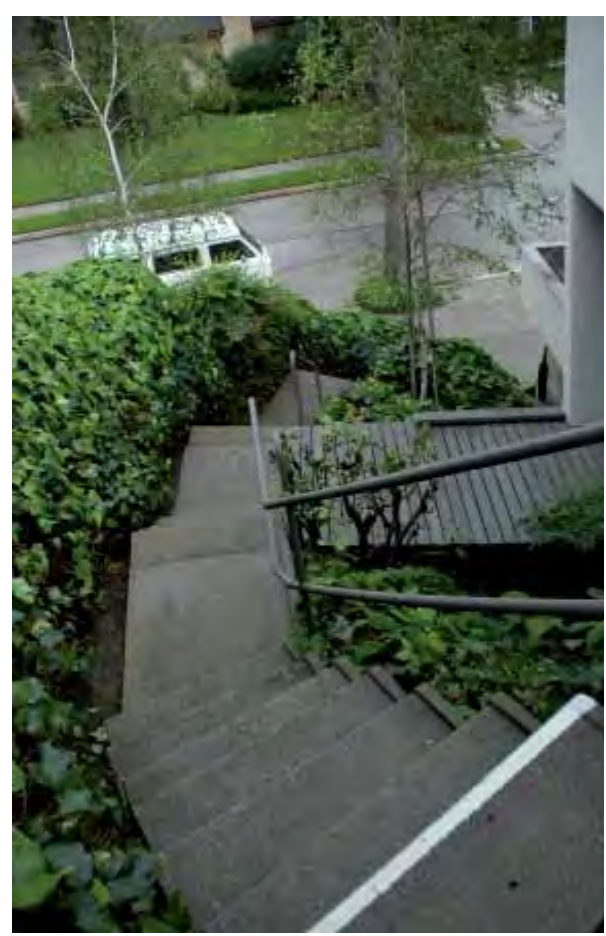

RMS: Tischler House, vistas del acceso a la vivienda (dcha e izda). Fotografías del autor

Página anterior arriba: Richard Neutra: Wilkins House, Pasadena, 1949. Fotografía de Julius Shulman

Página anterior abajo: John Lautner: Casa Schaffer, Montrose, 1949. Fotografía de Julius Shulman 


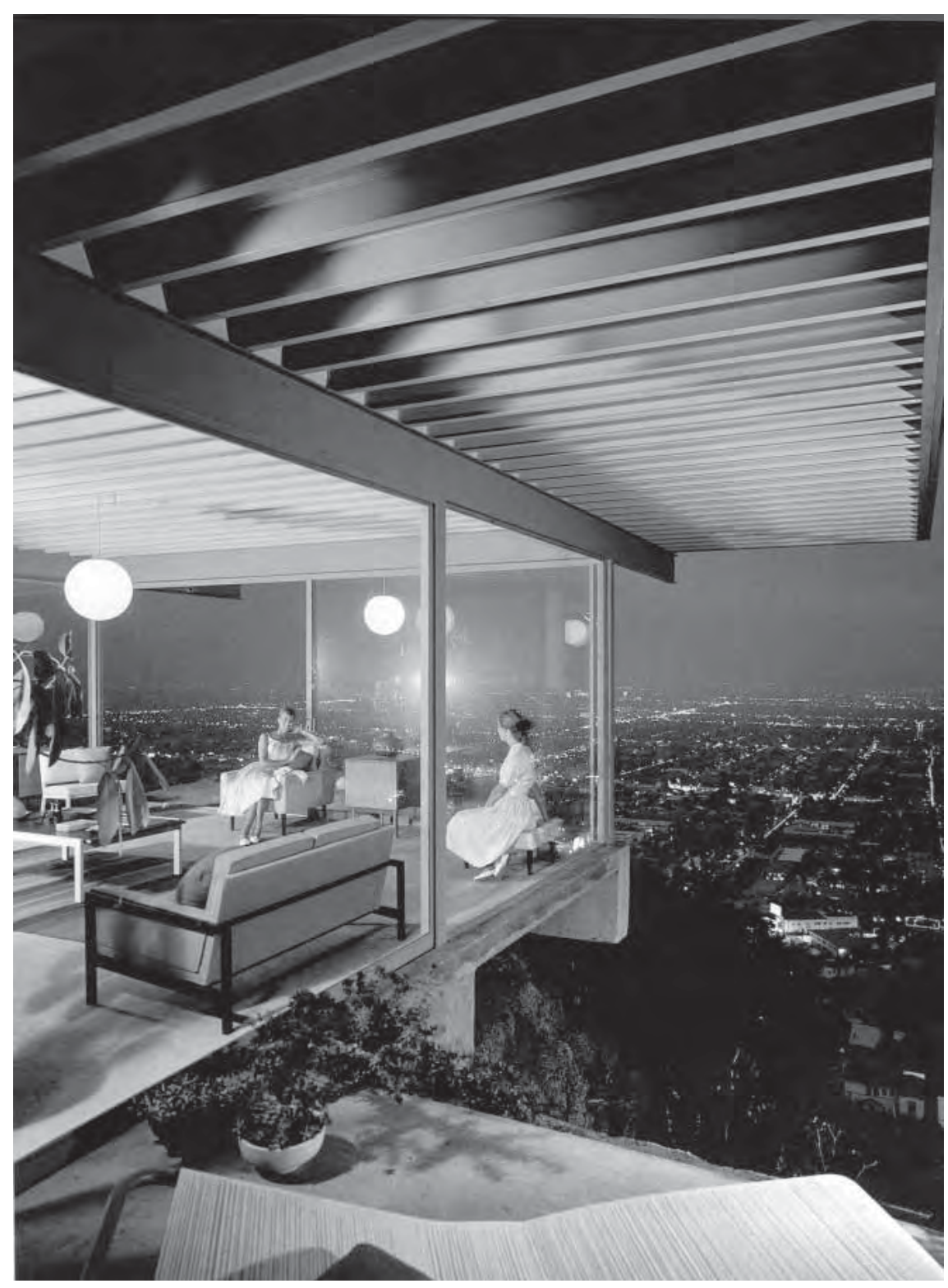

Gebhard (W. Stout, 2003); y ha tenido lugar una exposición antológica -y su consiguiente catálogo ${ }^{321}$ - organizada en el año 2001 por el Museum of Contemporary Art (MoCA) de Los Ángeles y de la que se hicieron eco diferentes medios como Architectural Record o Artforum a través de series de conferen-

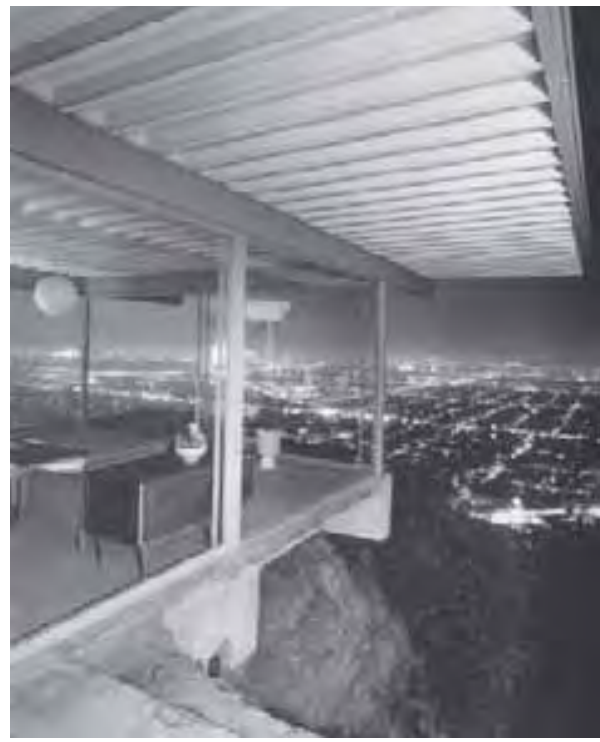
cias, artículos y debates que constataban el renovado interés por la figura de Schindler como autor de actualidad ${ }^{322}$.

Entre los escritos enumerados pueden destacarse dos sugerentes aproximaciones a la arquitectura del último Schindler. En primer lugar los textos de Sheine, que centran su atención en los hallazgos arquitectónicos como la justificación a sus experimentos de posguerra; $y$, en segundo lugar, la interpretación de Coll-Barreu que, sin restar importancia a la investigación espacial de Schindler, expone sus argumentos desde las implicaciones de la crisis ideológica provocada por la Segunda Guerra Mundial.

Ambos enfoques permiten contrastar las ideas que subyacen en los proyectos finales de Schindler con las motivaciones que cierran el ciclo histórico de las Case Study Houses, cuya conclusión representan las viviendas realizadas por los arquitectos de la llamada tercera generación: Craig Ellwood y Pierre Koenig, entre otros. Contraponiendo la Tischler House con, por ejemplo, la 
elegante Casa Stahl en West Hollywood (CSH no22) se aprecia inmediatamente la distancia conceptual que separa la obra de Schindler de la pieza de Koenig, construida tan sólo una década más tarde. Para empezar porque la primera, ignorada o rechazada por la crítica fue vista como una inexplicable anomalía mientras que la segunda, encumbrada por la cámara de Julius Shulman, se difundió internacionalmente como una de las imágenes publicitarias más efectivas de la modernidad de Los Ángeles, especialmente a través de aquella conocida fotografía en la que se presentaba a dos mujeres conversando de noche en el extremo de un voladizo suspendido sobre la trama iluminada de los bulevares de la ciudad y que pronto se convertiría en la más genuina representación del atractivo californiano.

En lo que se refiere a sus planteamientos arquitectónicos, la comparación entre ambas viviendas revela las mayores discrepancias: la Casa Tischler renuncia a un código formal establecido, se manifiesta hacia la calle con un lenguaje difícilmente descifrable. Por su parte, la Case Study House abraza un vocabulario prefijado y trata esencialmente de depurarlo, de reducir a la mínima expresión los principios de un único material, el acero. El proyecto de Koenig surge de la elaboración de los detalles, mientras que los estimulantes espacios de Schindler poseen tanta fuerza que, en el fondo, la finura con la que se ejecuten los detalles importa poco. Los volúmenes de la Tischler son el resultado de un proceso performativo que culmina en unas formas irrepetibles, por el contrario, el desarrollo de las formas de la Casa Stahl se encuentra autolimitado y el excesivo interés del arquitecto por exponer la precisión con la que se han ensamblado las piezas prefabricadas anuncia el amaneramiento con el que se cerrará el periodo. En definitiva, es lo que viene a señalar Judith Sheine cuando escribe: "El refinamiento de los detalles de las ventanas y las entregas de los pilares de tubo de acero a las vigas en I se convirtieron en la preocupación central $y$, al cabo de un tiempo, esta cuestión no condujo a ningún desarrollo interesante, frustrando las carreras de estos prometedores jóvenes arquitectos (Ellwood y Koenig). La arquitectura de Schindler, que no dependía de ningún sistema constructivo pero era lo suficientemente flexible para incorporar todo lo que fuera económico y útil, con su énfasis en el desarrollo espacial interior y en las secciones complejas más que en los sistemas o el estilo, nunca estuvo sujeta a esta frustración. Schindler no se limitó simplemente a repetir su trabajo con refinamientos de menor importancia. Cada proyecto era único y Schindler se enfrentaba a él como si fuera un nuevo problema arquitectónico, en el que podía inventar su respuesta" ${ }^{\prime 323 .}$

De hecho, la Stahl House de West Hollywood parece haber quedado atrapada por su celebridad y los comentarios anteriores demuestran que el análisis arquitectónico de la obra casi no se sostiene sin la referencia al significado histórico de su propia fama, en la medida que la enorme repercusión mediática alcanzada por la casa es uno de los mejores indicadores del pensamiento de la época. No obstante, con la perspectiva que permite el paso del tiempo, se descubre que el reduccionismo estetizante de Koenig carecía de la profundidad necesaria para aspirar a la sublimación miesiana de la técnica y que la vivienda, a pesar de su cautivadora imagen, tampoco pretendía ni podía ser revolucionaria porque evitaba el riesgo de la experimentación que desde ese mismo marco del programa de John Entenza habían asumido, por ejemplo, autores como Quincy Jones o los Eames. También se evidencia que, frente a la dimensión iconológica de la $\mathrm{CHS}$ n$^{\circ} 22$, la Tischler House, una obra olvidada, estaba proponiendo desde su iconoclasia, la versatilidad y la imaginación como alternativas al cansancio de la arquitectura más convencionalmente moderna.

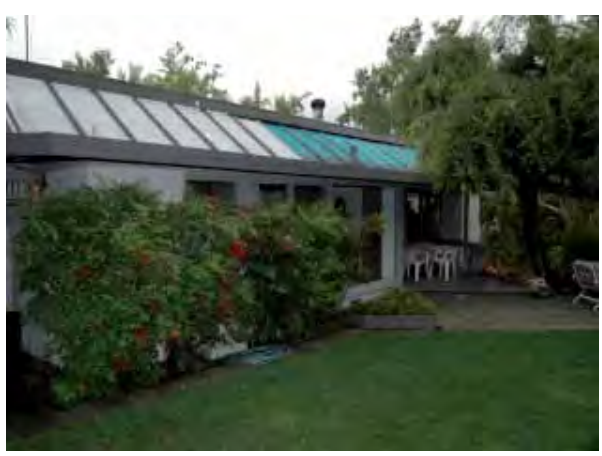

Tischler House, vista desde el jardín a cota de la planta principal. Fotografía del autor

Página anterior arriba: P. Koenig: Stahl House, CSH \#22, 1959-60. Fotografía: Julius Shulman Página anterior abajo: Stahl House, imagen de trabajo tomada por Shulman antes de preparar la ambientación de la fotografía 


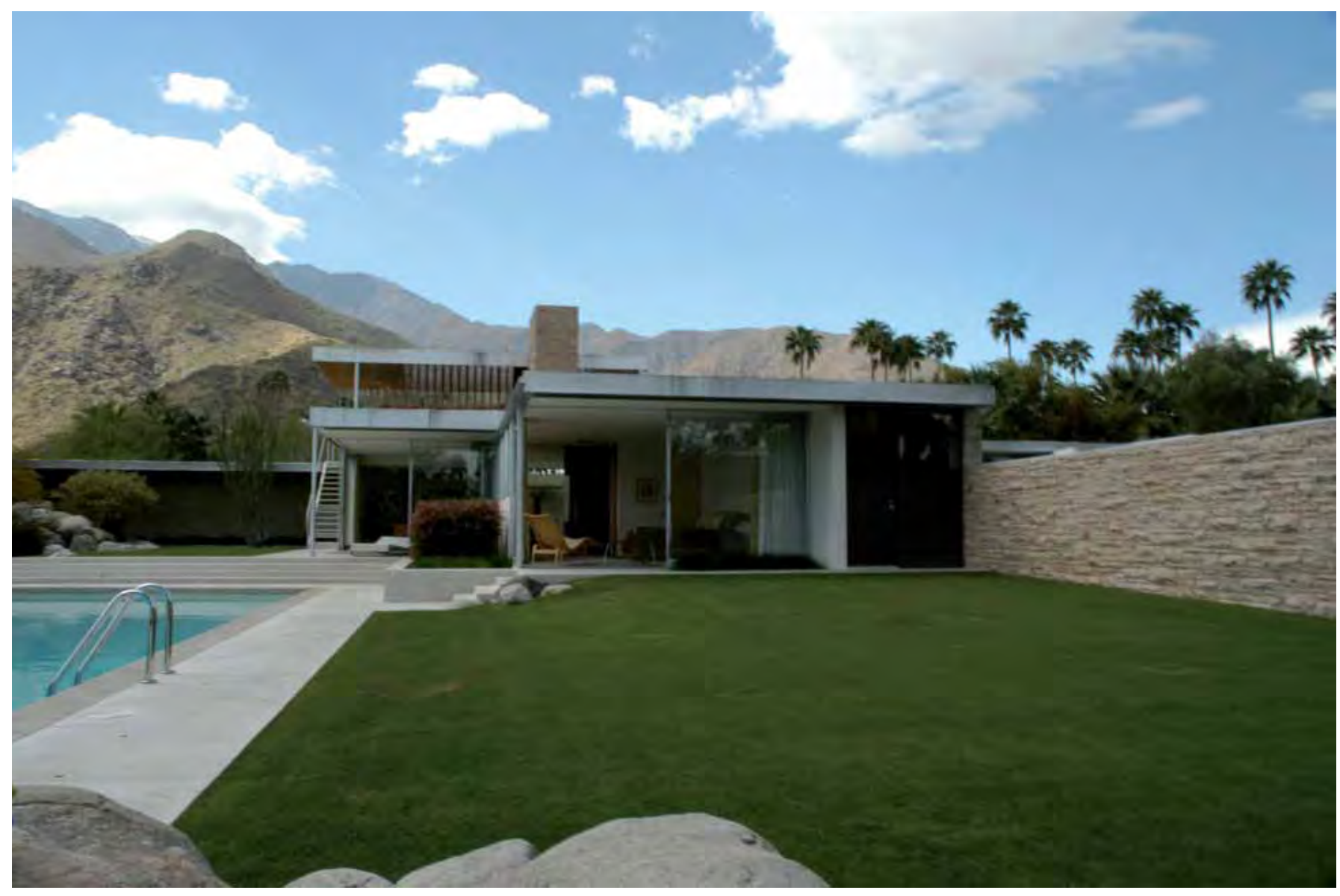

Richard Neutra: Kaufmann House en Palm Springs, 1946. Fotografía del autor

Página siguiente: Kallis House en Studio City, $R$. M. Schindler, 1946. ADC/ UCSB
Volviendo de nuevo a las afirmaciones de David Gebhard puede entenderse que, precisamente, por esa misma falta de perspectiva histórica -su monografía fue publicada en 1971- pudiera sostener teorías como la siguiente: "En 1940 era posible referirse inequívocamente a la nueva escuela de la California meridional de Schindler, Neutra, Ain, Soriano y Harris, y todo parecía indicar que después de la guerra la escuela seguiría desarrollándose con renovado vigor; pero no ocurrió así. El trabajo de estos arquitectos continuó siendo de calidad, pero sus ideas parecieron haberse agotado. Las nuevas ideas fueron suministradas, finalmente, por una fuerte y poderosa tradición local miesiana, adoptada de manera muy distinta por Charles Eames y, más tarde, por Craig Ellwood"324.

Antes de tomar en consideración esta última afirmación conviene puntualizar algunos aspectos. Primeramente, aclarar que por escuela entiende ámbito geográfico y no paralelismos en los discursos, de lo contrario estaría contradiciéndose ya que durante todo su libro se ha esforzado por alejar conceptualmente la arquitectura de Schindler de la de otros autores modernos. En segundo lugar, aunque arquitectos como Soriano o Harris abandonaran el Sur de California poco después de la guerra, tampoco es cierto que se resintiera el nivel de su producción; más bien al contrario pues en el caso de Harris varias de sus obras maestras están realizadas entre 1940 y 1950, como se verá en la segunda parte de este documento. Por último, nada tiene de local la tradición miesiana en California ya que los Eames como, es sabido, se apartaron premeditadamente del clasicismo industrial de Mies y Craig Ellwood, por su parte, lo adoptó como justificación estética de una evolución más heterogénea, insegura y sobre todo publicitaria de lo que pudiera parecer. Dicho esto, resta todavía cuestionar la aseveración de Gebhard de que la tradición miesiana vino a aportar nuevas ideas a la modernidad arqui- 
tectónica tras la guerra, para lo cual baste recordar que se trata de la tesis opuesta de la opinión que acaba de exponerse mediante la comparación entre la innovación de la arquitectura de Schindler y la reiteración sistemática de Koenig. En este sentido cabe recordar que esta tesis trata de argumentar que los episodios arquitectónicos más interesantes de la modernidad californiana tuvieron lugar en la primera mitad del siglo pasado. De todos modos, fue el propio Gebhard quien se dio cuenta de su limitación cuando, hacia el final de su libro, tratando de poner en valor el significado histórico de la obra de Schindler, aventuró una de sus más interesantes conclusiones: "en el momento presente sólo podemos ser parcialmente conscientes de lo que Schindler significó, ya que nuestras ataduras intelectuales y emocionales con el concepto de Estilo Internacional son todavía demasiado fuertes. A medida que nos demos cuenta que el estilo es el envase y nada más, las acciones de Schindler subirán más y más en la bolsa arquitectónica" ${ }^{325}$. En realidad, Gebhard estaba intuyendo más cosas de las que llegó a comprender.

Otro esclarecedor acercamiento a la trayectoria de Schindler es el que ofrece Juan Coll-Barreu en su texto La modernidad y la guerra: seducción y culpa, el cuarto de los capítulos que componen su reciente libro. El discurso de Coll-Barreu apunta hacia el dilema moral de la reconciliación entre técnica y sociedad planteado tras el trauma de la Segunda Guerra Mundial y se centra en este problema como una de las explicaciones más plausibles al desinterés de Schindler por la tecnología. Así, el desarraigo y la discordancia que acrecientan la complejidad de su arquitectura serían aún más valiosos en cuanto que obras como la Tischler House estarían anticipando la "aceptación artística de la ruptura que la guerra había provocado en la historia lineal de la modernidad"326.

La prosperidad californiana, el ascenso de la clase media y la democratización de un modo de vida deseado por todo el mundo habían ido de la mano con el desarrollo y la reconversión de una industria bélica sin precedentes. Mediante los mismos procesos con los que se fabricaban casas, mobiliario y electrodomésticos a gran escala se habían creado, entre otros mortíferos artefactos, los superbombarderos B-17 en las colosales plantas del sur de Los Ángeles. La misma tecnología que ahora garantizaba un futuro prometedor, colmando a los individuos de bienes de consumo, había sido responsable de la destrucción de medio continente europeo y de buena parte de las islas del Pacífico. Después de la guerra, en Estados Unidos y, especialmente en California, que conservó la hegemonía de las fuerzas de producción, tanto la victoria militar como el auge de su economía dificultaban la comprensión de la magnitud real de la tragedia. Este clima de optimismo nada tenía que ver con el hundimiento espiritual de Europa, donde la constatación del horror y el sentimiento de culpa motivaron que las reflexiones acerca de la relación entre el hombre y la técnica cobraran proporciones ontológicas.

Considerando la encrucijada social y cultural que suponía aquel momento histórico puede efectuarse otra interesante comparación a través del llamativo ejemplo de la casa Kaufmann en Palm Springs. En ella Richard Neutra, un año después de finalizar la guerra, continúa proclamando su fe incondicional en el progreso técnico y exhibe sus últimos adelantos en uno de los mayores aciertos compositivos de toda su carrera. Las fachadas de vidrio producidas en taller y trasportadas hasta el desierto, las novedosas lamas orientables de la terraza superior o la escalera exterior de acero remiten de nuevo a la metáfora de la máquina a través de una sutil elaboración de su imagen náutica. Por el contrario, la casa Tischler manifiesta una oposición

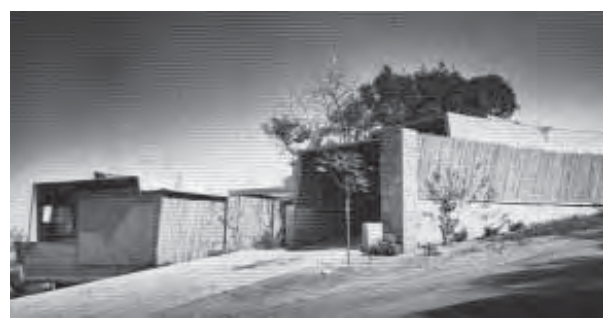




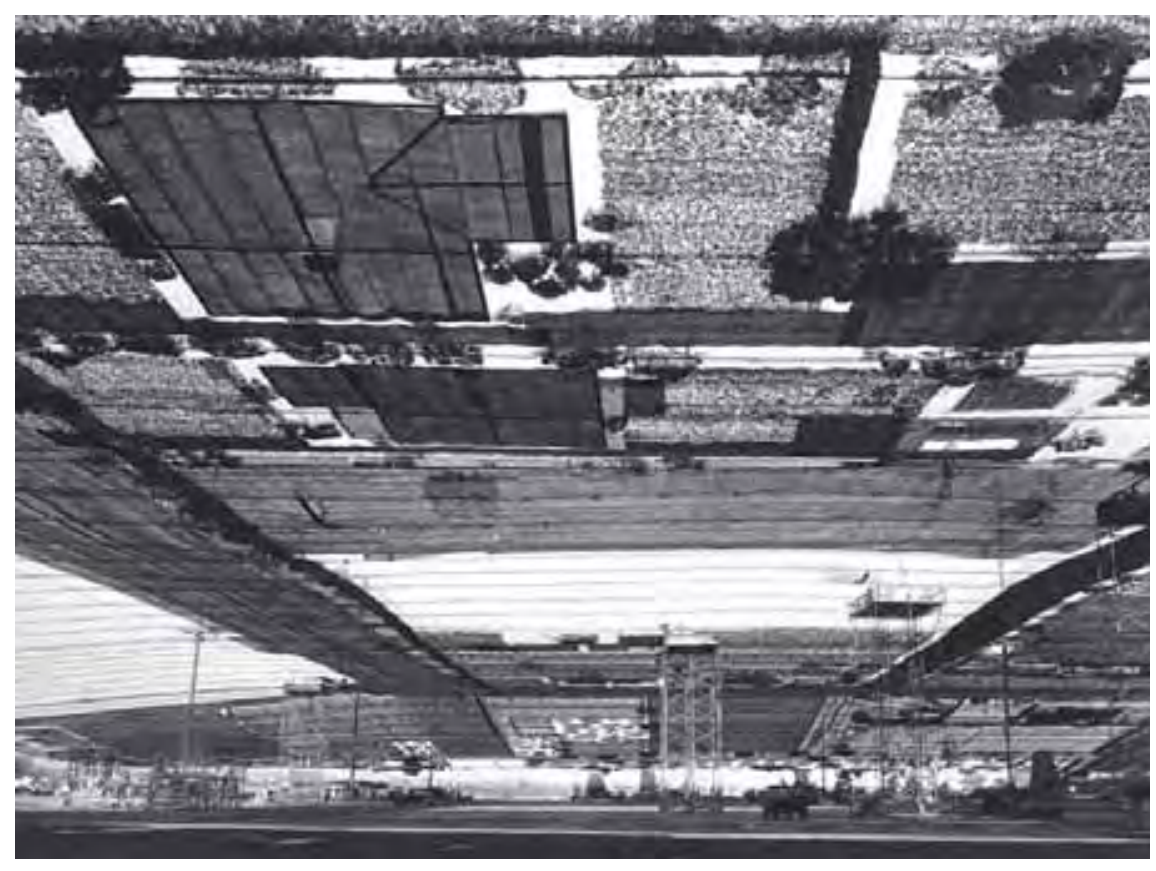

frontal hacia este tipo de actitudes. Hasta el momento, Schindler había obviado la estética maquinista rechazándola como abstracción pura, pero ahora parece repudiarla también por sus connotaciones violentas. En efecto, la necesidad de reconciliación en Schindler ha dado paso a un sentimiento de culpa que le lleva a renunciar a la utilización de la tecnología por sus vínculos con un pasado doloroso cuyas heridas aún permanecen abiertas, como si temiera más que nunca la modernidad racionalista proveniente de Europa e identificada con los odios de la guerra ${ }^{327}$. Schindler se posiciona ideológicamente interrogándose sobre qué tipo de arquitectura es posible después de semejante fracaso de la razón. Frente a sus contemporáneos, deslumbrados aún por las posibilidades del progreso, es Schindler quien parece comprender la necesidad de reformular la disciplina, entendiendo que lo terrible de la contienda bélica ha desenmascarado los peligros del desarrollo tecnológico y con ellos la relatividad de los principios modernos.

Una de las paradojas más ilustrativas de esta situación es el ejemplo extremo de los paisajes de la guerra que escenificaron las fábricas de aviones construidas por la Douglas Aircraft Company a principios de los años 40 en Long Beach o en Santa Monica. Se trataba de gigantescas estructuras de cientos de miles de metros cuadrados que, para evitar ser vistas desde el aire por el potencial enemigo que llegara a la ciudad desde el océano, se ocultaban entre el tejido residencial simulando barrios, calles, jardines e incluso, para dar verosimilitud al engaño, sobre ellas se edificaban viviendas de todos los estilos, incluido el moderno. De este modo, "los prismas de la modernidad se convertían en un estándar válido para la tematización. La pureza desornamentada, resultado del esfuerzo internacional de generaciones de arquitectos, se convertía en motivo ornamental de la no arquitectura plenipotenciaria que producía máquinas de destrucción [...] Sobre la realidad bélica de un paisaje colosal e inaudito, necesario para fabricar máquinas de guerra, se tendió la ficción de un paisaje habitual" ${ }^{228}$.

En efecto, el uso escenográfico de la arquitectura moderna significaba su normalización como código y la finalidad de este empleo anunciaba su arbitrariedad como sistema coherente. La guerra dinamitó los escasos puentes que aún permanecían tendidos entre la realidad y la ficción en los paisajes 
del Sur de California; había terminado por borrar sus límites. "Se interrumpía el significado de la palabra arquitectura. Tampoco eran ya aplicables los conceptos de lugar, función, adecuación constructiva y escala. Sin embargo las cajas de la arquitectura de la paz (las Case Study Houses) no distarán de las cajas que construían el paisaje inventado de la guerra. Así no es extraña la pregunta de Schindler sobre qué arquitectura moderna podía construirse a partir de ese momento"329.

La guerra había abierto muchas brechas pero aún así fue posible recomponer algunas de las verdades que tanto había costado formular. Era quizás pronto para hablar de crisis, y los ideales modernos pudieron encontrar en el fabuloso despliegue industrial y publicitario californiano un nuevo terreno abonado para su fructificación. La falta de distancia histórica dificultó comprender el alcance de la fractura y sólo unos pocos, entre ellos Schindler, vislumbraron en el episodio bélico el final de las certidumbres modernas. En cualquier caso, su agotamiento estaba cerca y apenas trascurrirían los años que separan la casa Tischler de la casa Stahl hasta que, en 1959, los CIAM se disolvieran en Otterloo. Entre tanto, los nuevos focos de la vanguardia arquitectónica internacional concedieron cada vez más importancia a sus interpretaciones regionales. California, uno de esos focos más activos, siguió también esta tendencia general, reafirmándose en su idiosincrasia, aunque todavía el Estilo Internacional mantendría su protagonismo mediático durante toda aquella década.

El conjunto de argumentos anteriores ha tratado de facilitar la aproximación conceptual a las últimas obras de Schindler, ayudando a determinar el significado de sus formas, para el cual, intentos de explicación como los de David Gebhard, habían resultado insuficientes. Gebhard probó con De Stijl, seguramente porque las composiciones de Theo Van Doesburg parecían influenciar sus plantas en $L$, doble $L$ o aspa, o porque las maclas de esta vanguardia podían aclarar parcialmente las interpenetraciones y el dinamismo de las soluciones de esquina presentes ya en las primeras viviendas de Schindler. En las sucesivas ediciones de su guía de arquitectura de Los Ángeles -escrita conjuntamente con Winter- sostuvo que la Tischler House "propone una composición tridimensional De Stijl como frontispicio de una cubierta inclinada" ${ }^{133^{\circ}}$. Un enunciado vago que podría rebatirse completando la inspiración sugerida por Gebhard con la enumeración de inverosímiles referencias más o menos reconocibles en la fachada de la casa: desde la abstracta plástica de Irving Gill a los artefactos vintage del cine fantástico de la época; desde las pérgolas wrightianas a las celosías del rancho californiano; o desde el colorido ambiente mediterráneo descrito por Hellen Hunt-evocado por los geranios de las jardineras y las buganvillas trepadoras- hasta el imprevisto objet trouvé que toma posesión del lugar. La lista podría alargarse, pero no aportaría mucho a la cuestión sobre el sentido del alzado que la Tischler House ofrece a Greenfield Avenue. En el fondo, su aspecto exterior dice poco sobre el asombroso espacio interior de la vivienda pues el volumen principal de la casa, perpendicular a la calle, permanece oculto entre la vegetación que cubre el escarpado solar, muy por encima de la altura de la vista.

La clave para interpretar la pieza reside en el brillante ejercicio de implantación con el que Schindler afrontó el proyecto. Cuando recibió el encargo de esta vivienda el arquitecto llevaba años construyendo en pendiente. Desde la casa Wolfe (1928-31), que domina la bahía de Avalon en la isla Catalina, había comenzado una personal exploración de las posibilidades arquitectónicas que ofrecía una topografía complicada, convirtiendo las diferentes

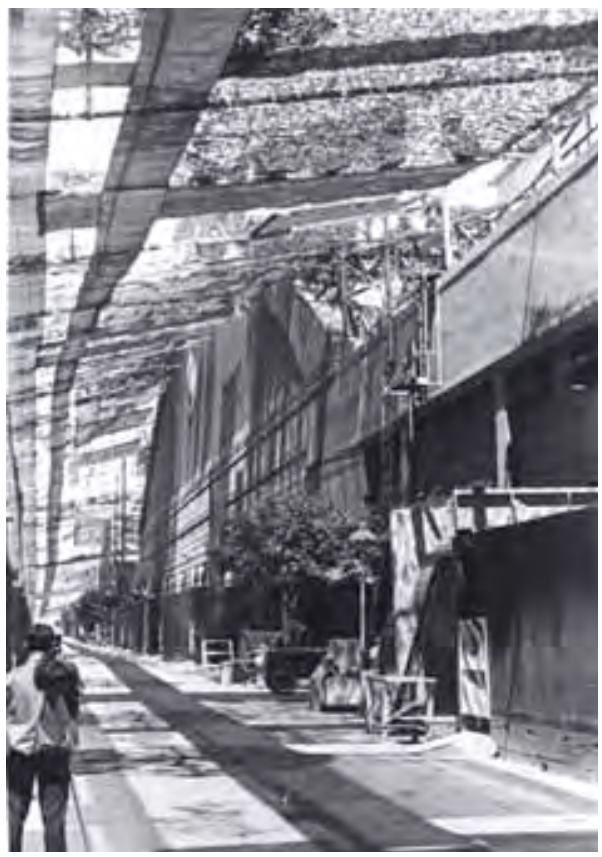

Arriba y página anterior: Camuflajes de la planta de producción de aviones de combate de la Douglas Aircrafts en Santa Mónica durante la Segunda Guerra Mundial. Fuente: Santa Monica Public Library 


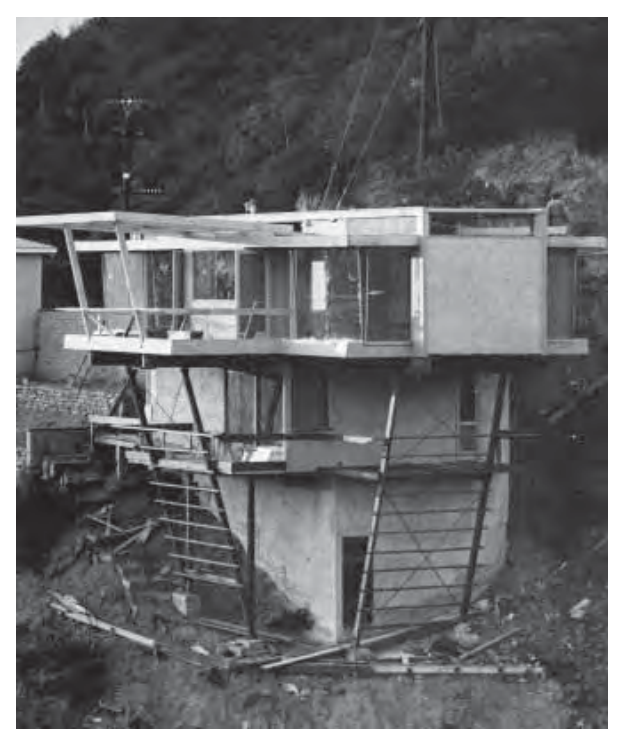

Schindler: Janson House, Los Ángeles, 1949, $A D C / U C S B$

Página siguiente: RMS: Tischler House, planta soluciones a este problema tan característico de Los Ángeles en señas de identidad de sus obras. El grado de implicación de sus viviendas con el suelo es tal que la manera en que se establece contacto resuelve buena parte del esquema organizativo y de la expresión de la arquitectura. Las casas de Schindler se apoyan sobre las laderas permitiendo que la montaña atraviese sus espacios (Elliot, 1930); descienden con la propia pendiente (Walker, 1936-41); se despegan mediante plataformas elevadas para que el terreno siga su curso (Janson, 1949); o lo hacen todo a la vez (Kallis, 1946-51). En cierto modo, esto también es lo que sucede con la Tischler House, en cuanto a que los espacios de la casa se generan simultáneamente excavando la ladera, retirándose de ella y posándose sobre ella como muestra la elocuente secuencia de secciones transversales.

A diferencia de las casas vecinas, paralelas a Greenfield Avenue, la dirección de la Tischler House es casi ortogonal al eje definido por el viario. Al girar la vivienda 90 grados, sus dos plantas inferiores se empotran en la pendiente mientras que la pieza superior, de aproximadamente la profundidad del solar, se coloca apoyada sobre la colina. Desplazando este volumen, casi hasta adosarlo al linde norte de la parcela, el arquitecto libera la máxima superficie de suelo para jardín. A su vez, al haber posicionado la vivienda perpendicularmente a la calle, Schindler asegura vistas diagonales que resuelven el problema de ver sin ser visto y ésta es la explicación a los giros a 45 grados que definen los retranqueos de fachada.

La Tischler House muestra su lado más corto hacia el espacio público del bulevar. Este alzado, prácticamente simétrico, es el único donde se percibe la totalidad de la altura ya que sus tres plantas sólo se superponen para producir el acceso. El nivel inferior corresponde al garaje, originalmente abierto aunque se cerró con dos puertas que dan a la calle y con planchas de policarbonato hacia el lado de la montaña; el nivel intermedio es un estudio-taller asociado a la casa; por último, el volumen más alto alberga el programa de la vivienda propiamente dicha. Éste se compone de un estar, una cocina, un dormitorio principal y dos estancias auxiliares ocupando una superficie aproximada de $150 \mathrm{~m}^{2}$ sobre los poco más de doscientos del total del edificio.

Una escalera circular adosada al límite septentrional de la parcela va desembarcando en cado uno de estos niveles mediante pasarelas que, al atravesarlas, ponen de manifiesto la independencia de la forma arquitectónica respecto del contorno del terreno excavado. Una segunda escalera desciende desde la zona superior de la casa hacia el estudio y a éste se llega bajo la protección del porche que conecta el pavimento del salón con el suelo del jardín y que desempeña una función análoga a la de las pasarelas.

Schindler solía simplificar en sus planos las formas más complejas antes de reunirse con sus clientes para que así pudieran captar las ideas importantes de su casa sin perderse en detalles que él desarrollaría posteriormente o, incluso, que terminaría por elaborar en obra ${ }^{331}$. Con esta actitud también facilitaba los trámites administrativos al evitar prejuicios por parte de quienes otorgaban licencias o concedían préstamos y que no siempre estaban dispuestos a tomarse el tiempo necesario para comprender las singularidades de sus proyectos. Algo parecido ocurrió con esta vivienda que primeramente Schindler explicó a los Tischler mediante un esquema de prismas rectos y que, más tarde, complicó seccionándolos para dar lugar a sus diagonales actuales. Curiosamente, aunque no alteró el concepto que rige 


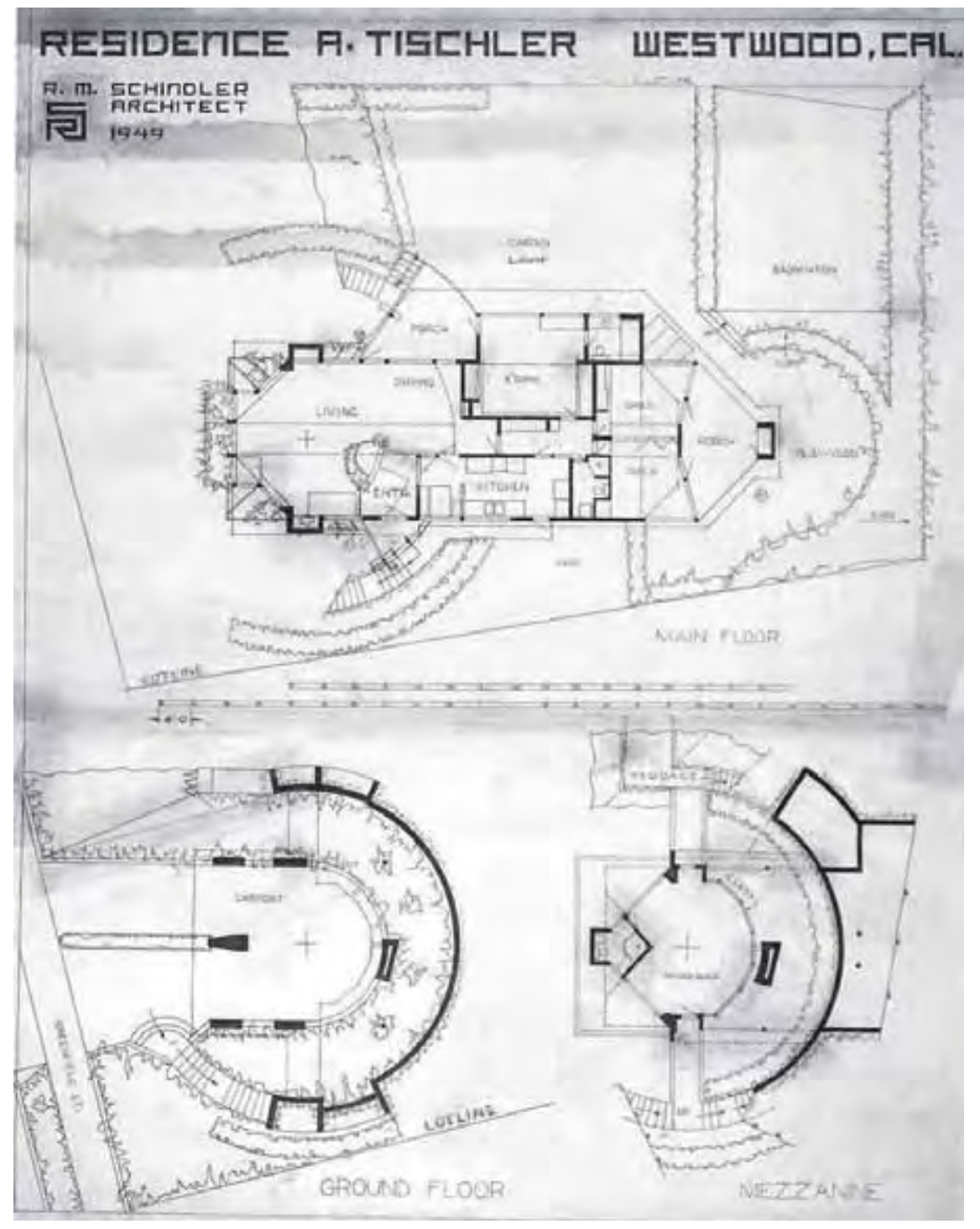

la implantación de la vivienda a través de su posición en el solar, sólo dejó esbozado el tratamiento de la pendiente, uno de los temas más complejos del proyecto, especialmente por sus consecuencias sobre el coste ${ }^{332}$ total de la vivienda.

El éxito de la Tischler reside en la manera en que la casa asume la topografía del solar. En el proceso de modificación de la misma Schindler jugó una de sus grandes bazas como arquitecto y también como constructor capacitado para manejarse con presupuestos restringidos. Habiendo estudiado todas las posibilidades del empotramiento en la ladera, Schindler optó por vaciados estratégicos ya que un desmonte complicado de la montaña, tanto por la consolidación del terreno como por la movilización de una cantidad considerable de material, hubiera comprometido la viabilidad económica del proyecto. De este modo, las ideas apuntadas inicialmente tuvieron que ser minuciosamente detalladas antes de proceder a la transformación de la parcela.

La operación comportaba dos acciones principales: en primer lugar, la excavación de un segmento de la colina y, en segundo lugar, el allanamiento de la explanada donde se asienta la casa en la cota más elevada de la parcela. El volumen excavado tiene planta circular y crea un recinto a modo de cuenco de sección variable. En él se introduce la pieza del estudio, opaca hacia la 

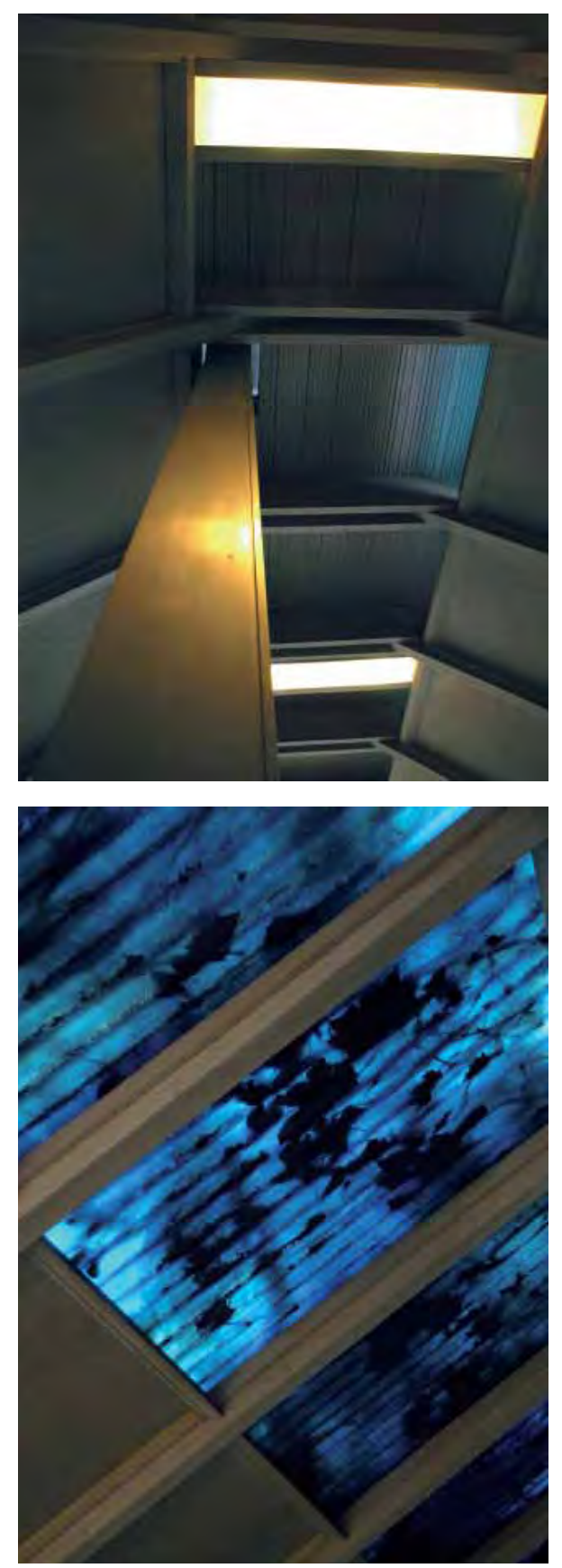

Tischler House, imágenes de efectos de la cubierta en distintas estancias de la casa. Fotografías del autor

Página siguiente arriba: $R$ MS: Cabaña Bennati en Lake Arrowhead, 1937. Fuente: Sweeney Página siguiente abajo: Tischler House, imágen del volumen a la calle antes del cierre del garaje. Fuente:ADC/UCSB

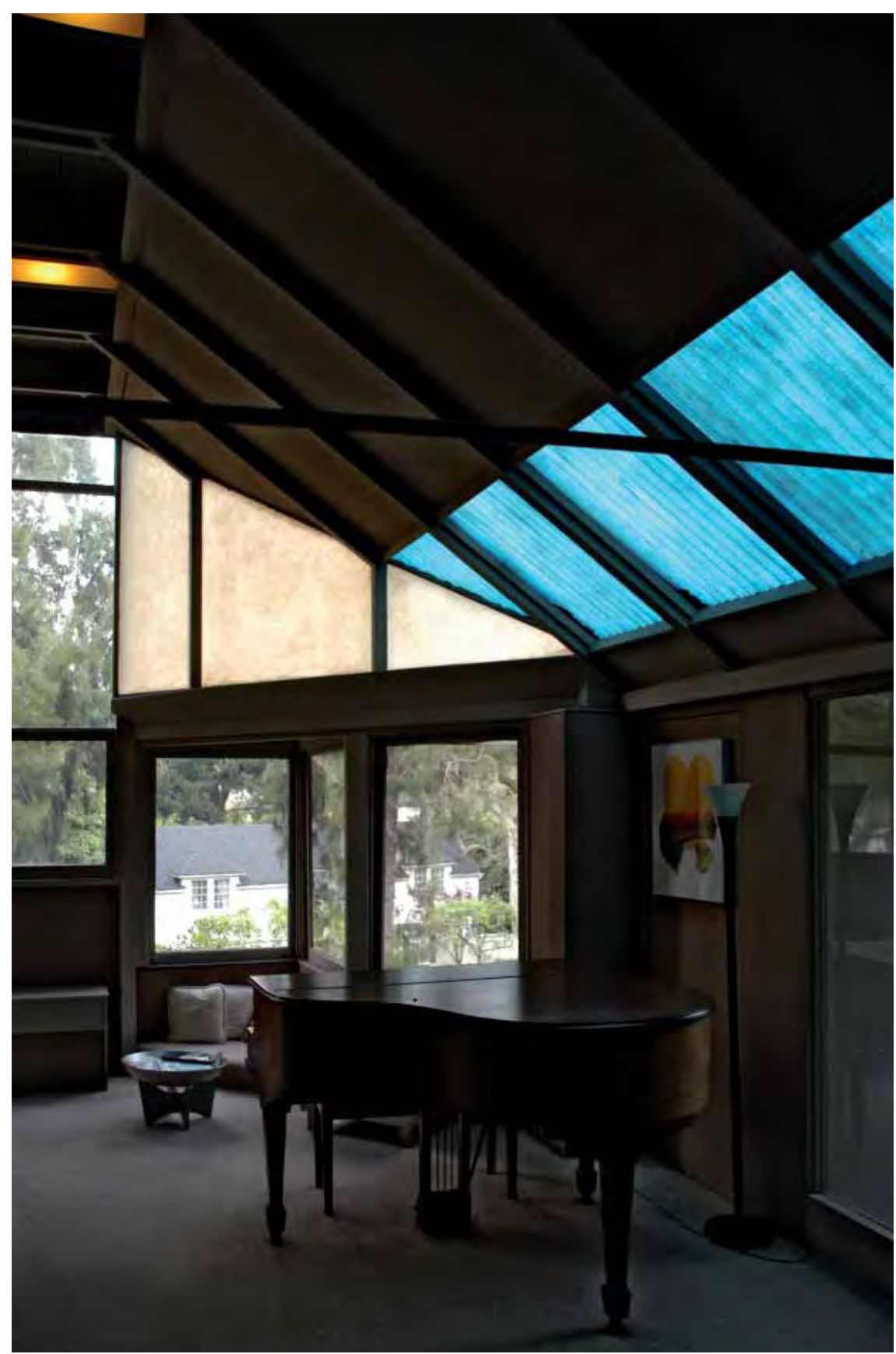

calle, transparente hacia la pendiente. Sobre el estudio, el resto de la casa se distribuye en una sola planta desde la que se accede a pie llano al jardín. El área exterior ha sido corregida hasta garantizar su horizontal y alberga, entre otros usos, una pista de bádminton. Bajo el estudio se sitúa el carport, un aparcamiento para dos vehículos que ocupa el espacio delimitado por un muro de bloques que contiene el arranque de la pendiente. Sobre ésta ha dejado crecer la hiedra, redibujado de un modo natural el contorno de la gruta que produce el paso de la montaña bajo la casa.

Del talud resultante brotan los cinco pilares y el machón de la chimenea que sostienen la vivienda. Todos ellos están construidos con fábrica de bloque de color rosáceo y aspecto terroso que, aparejados con un pequeño desfase de apenas una pulgada, subrayan el efecto natural que también persiguen los soportes. Existe una deliberada voluntad de resaltar la continuidad entre el terreno y el arranque de la estructura. 
La Casa Tischler propone diferentes aproximaciones al paisaje residencial donde se aproa su arquitectura, un barrio de clase media alta próximo a uno de los centros sociales más concurridos de la ciudad. Greenfield Avenue es, como las calles de las inmediaciones, una amable vía de cuidada vegetación, sin excesivo tráfico, pero de escasa personalidad. La vivienda atrae inmediatamente la atención por su imagen conspicua que interrumpe la serie de historicismos enlazados por las fachadas vecinas. Se produce, en primer lugar, una oposición formal; pero seguidamente la casa no establece con el terreno una relación de autonomía, por el contrario, mantiene una relación de continuidad, en la que tiene mucho que ver la manera de entender el papel de la pendiente en la configuración de la vivienda, introduciéndose en sus estancias y formando parte de sus límites; finalmente, el volumen sobre la colina crea un paisaje interior que incorpora las vistas de la calle pero que discrimina cualquier referencia que no proceda de su propio ámbito doméstico. En suma, el acercamiento desde el espacio público al interior de la casa comienza con la percepción de un contraste formal que da paso a una continuidad topológica que vuelve a conducir a un espacio autorreferencial: una sucesión de abstracción-contextualismo-abstracción con la que Schindler incide en el lugar manipulando su carácter.

Considerado otras obras de Schindler realizadas hacia la misma época, los volúmenes de la Tischler, aunque extraños, no son excesivamente complejos y el conjunto del proyecto, pese a lo elaborado de sus planteamientos, se comprende de inmediato al penetrar en el interior de la vivienda. Al traspasar el umbral de la puerta, un falso techo curvo comprime el acceso generando el vestíbulo que antecede al salón. Tanto la forma de este techo más bajo como el muro donde se apoya la chimenea recuperan la geometría del círculo con la que se ha realizado la excavación de la colina. La escultórica pieza de la chimenea se ha desplazado convenientemente con respecto al hipotético eje de simetría longitudinal para favorecer la presencia del vestíbulo y distinguir el estar del comedor, vinculado a la cocina. De la planta superior, casi rectangular, sólo sobresale el volumen del dormitorio principal que avanza hacia el jardín separando física y visualmente la zona pública del programa del ámbito más privado del resto de las habitaciones.

Todo ocurre bajo la ineludible presencia de la cubierta de plástico azul. Ésta se convierte en el elemento que unifica los espacios de la casa y facilita su lectura. Dichos espacios se encadenan a lo largo de un corredor que coincide con la proyección de la pieza plana donde se unen los nervios de la nave. Dado que las tabiquerías no llegan hasta el techo, Schindler resuelve estos encuentros con paños de vidrio, comunicando la visión desde el mirador de la calle hacia testero opuesto, también de vidrio y tras el cual se divisan los árboles del patio posterior. Buscando el material y el color necesarios para potenciar el efecto perseguido por la cubierta, Schindler acudió a una fábrica de plásticos de San Diego, la Allied Synthetics Company y consiguió que las placas traslúcidas, que desde hacía poco tiempo esta empresa venía produciendo y comercializando con el nombre de Alsynite, fueran también realizadas en el tono de azul más intenso posible.

Con la cubierta a dos aguas Schindler recurrió curiosamente a una forma consagrada por la historia, aunque su conocimiento de la misma le permitió manejar sus referencias a voluntad. Muchos años después, arquitectos posmodernos como Charles Moore quisieron ver en él un precursor de su libertad para citar episodios del pasado. No obstante, Schindler no estaba rememorando sino transformando: la Casa Tischler hace presentes la nave
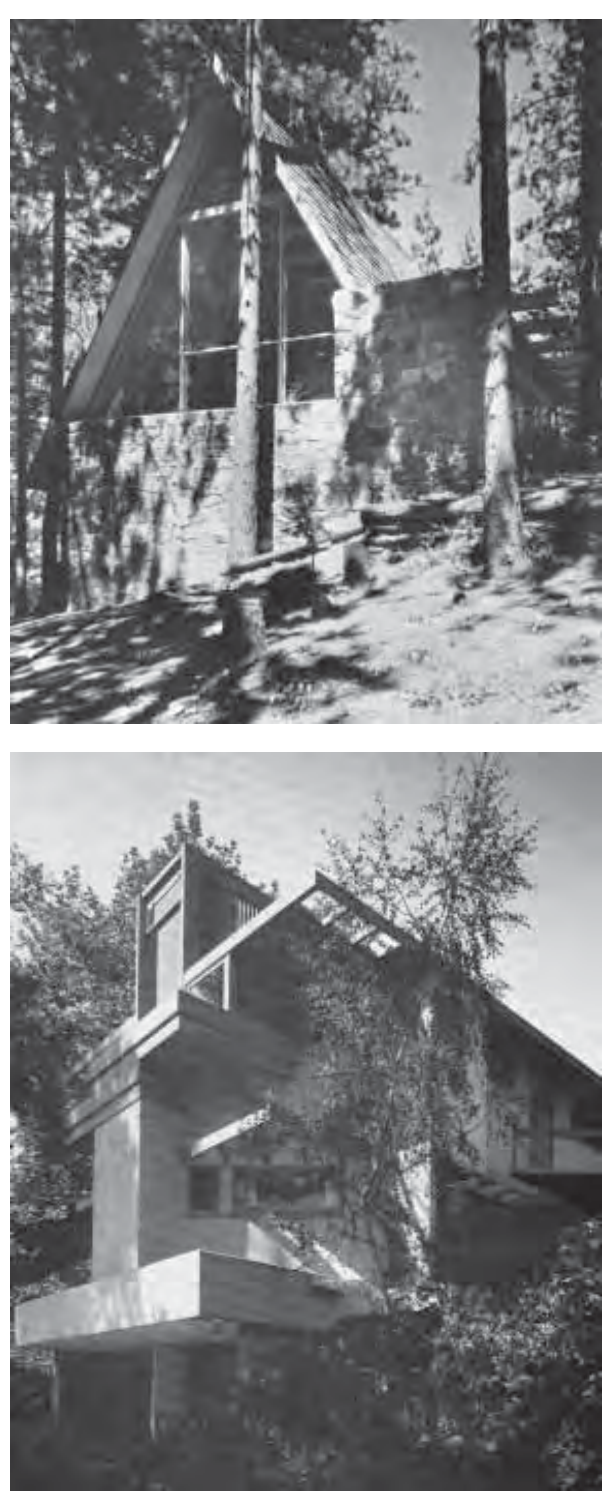


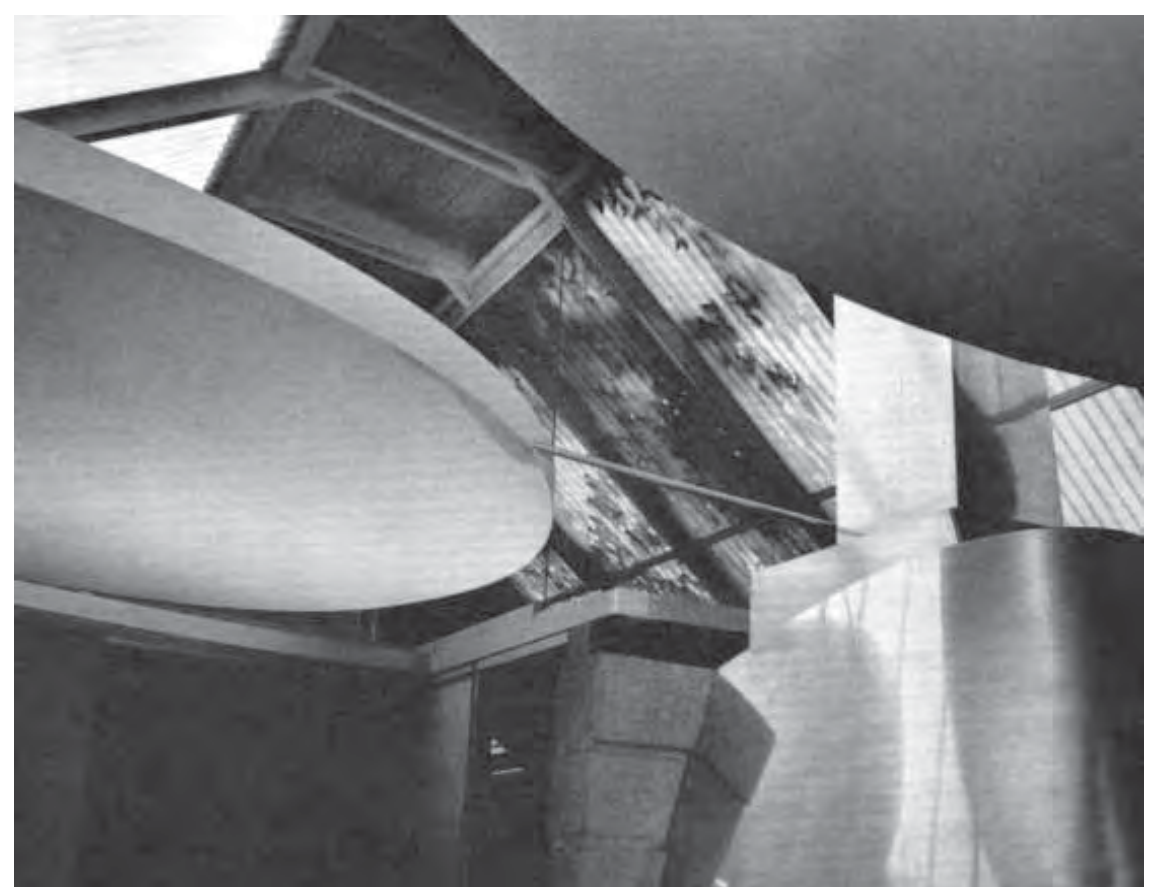

RMS: Tischler House, imagen del interior de la vivienda antes del cierre parcial de los paneles de minionda azul, ADC/UCSB

Página siguiente: Tischler House, imágenes del interior de la vivienda y detalles del efecto de la cubierta traslúcida de plástico azul. Fotografías del autor industrial, la planta basilical o la cabaña del bosque fundiendo en un espacio insólito la dimensión funcional, representativa y doméstica de todos ellos.

Es fácil reconocer en la cubierta inclinada la metáfora de una embarcación a la que físicamente se ha dado la vuelta. Sin embargo, lo más interesante es que la alegoría esté también invertida en su sentido histórico pues, en lugar de señalar hacia el imaginario náutico maquinista, Schindler prefirió recordar la imagen de un navío tradicional que deja expuestas sus cuadernas de madera. Incluso podría verse en la altura de los dinteles de ventanas y pasos, en los que se interrumpe deliberadamente la estructura, la evocación más onírica de la línea de flotación que dibuja el barco sobre el medio acuoso recreado por las ondulaciones del plástico azul.

También el recuerdo de la cabaña en el bosque podría ser otra explicación convincente. Si en 1934, en las inmediaciones de San Bernardino, Schindler ya había diseñado una cabaña real para Gisela Bennati junto al Lago Arrowhead ahora, en las colinas de Bel Air, planteaba una fantasía sobre el tema del refugio en las montañas aunque, esta vez, al elevar la casa dos plantas sobre el nivel de la calle y procurar su acceso a través de ligeras pasarelas se añadía una nueva componente lúdica: la idea de una cabaña que, como en los juegos infantiles, ha sido instalada entre las copas de los árboles.

La Tischler House ejemplifica, probablemente mejor que ninguna otra obra de Schindler, sus ideas acerca de la percepción de la arquitectura, tema crucial de esta última época y al que el autor dedicaría uno de sus últimos textos, Visual Technique, escrito en 1952. Por su investigación de propiedades como el color, la traslucidez, la permeabilidad o la reflexión de la luz, esta casa supone uno de sus más profundos acercamientos a la fenomenología del espacio. La sugerente atmósfera creada bajo la cubierta de la Tischler emana de la cualidad adquirida por la luz al ser filtrada por la lámina azul; una luz cambiante según la hora del día, la estación del año o las condiciones del cielo; una luz que modifican también las sombras arrojadas por las ramas de los árboles que mueve el viento; una luz alterada por las manchas oscuras de las hojas que caen sobre la cubierta y que, periódicamente, cuando son retiradas, devuelven la luminosidad al interior que reinicia un nuevo ciclo de 

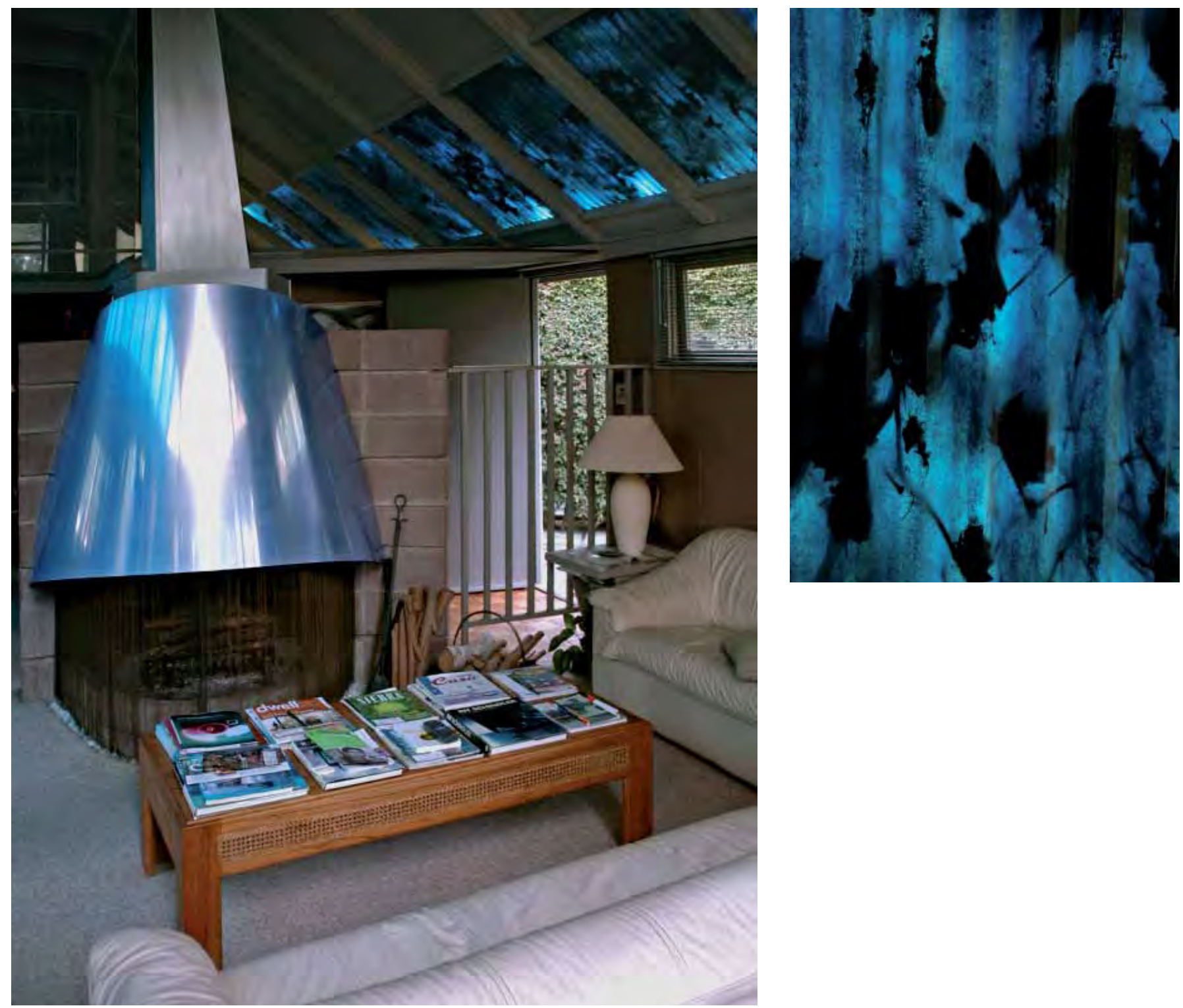

oscurecimiento progresivo; una luz que matizan los reflejos del cristal y los tonos verdes introducidos desde el jardín; y una luz que, intencionadamente, distorsionan los brillos plateados sobre la superficie metálica y convexa de la chimenea, en un claro guiño al oficio de platero del cliente.

La vivencia de este espacio es casi imposible de reproducir en fotografías. Ésta es una observación aplicable al conjunto de la producción schindleriana aunque no es necesario detenerse en ella. No obstante, puede contraponerse la relación entre la fotografía de la obra de Schindler y la de Neutra o con muchas de las viviendas del Case Study House Program. Estableciendo de nuevo la comparación con la casa Stahl de Koenig, es innegable que allí la visualidad de la fabulosa fotografía de Shulman tiene tanto peso que acaba por distorsionar completamente la relación del espectador con el espacio de la casa, recreado por completo a través de la imagen. En cambio, en el caso de la Tischler, ninguna fotografía llega a condicionar la percepción de sus espacios, tan poco fotogénicos. Es curioso, pero este mismo aspecto que dificultó la difusión de la obra de Schindler es ahora responsable de que su arquitectura cada vez parezca mejor, ya que el abismo que separa lo que se espera encontrar a juzgar por las imágenes disponibles y la riqueza de estímulos que proporcionan sus espacios hacen que la visita a Schindler sea siempre una experiencia inolvidable ${ }^{333}$. 


\section{Notas y referencias bibliográficas}

1. William DEVERELL (historiador y Profesor del California Institute of Technology): Introducción al libro de Victoria DAILEY, Natalie SHIVERS y Michael DAWSON:: LA's Early Moderns. Art/ Architecture/Photography. Los Angeles: Balcony Press, 2003, p. 13 y contraportada.

2. El MAK Center fue fundado en Viena en 1863 como Austrian Museum of Art and Industry. Actualmente es un innovador museo y espacio de experimentación -como la propia institución se define- en la interfaz del diseño, la arquitectura y el arte cuya finalidad es apoyar nuevos discursos en estos campos, potenciar la investigación interdisciplinar y fomentar el trabajo colaborativo sobre diferentes áreas de conocimiento relacionados con la sociedad y la cultura contemporáneas.

3. Sinclair había nacido en Baltimore, aunque se crió con su familia en Nueva York, donde se graduó en 1987 y estudió durante algún tiempo en la Universidad de Columbia antes de dedicarse a la literatura. Durante años trabajó duramente en los mataderos de Chicago para documentar su novela de denuncia social The Jungle, cuyo éxito de ventas le permitió obtener ingresos suficientes para dedicarse a la política y defender la causa de los trabajadores más desfavorecidos. En los años 20 se trasladó a California, donde fundó el capítulo estatal de la American Civil Liberties Union y trató sin éxito de obtener un escaño como congresista y, después, como senador por el partido socialista. En esa época fue muy activo en Los Ángeles, defendiendo y colaborando con diferentes asociaciones laborales que le granjearon la enemistad de muchos de sus detractores conservadores. En 1934, en plena Gran Depresión, obtuvo la nominación Demócrata y se presentó a la elección de Gobernador de California, perdiendo frente a su oponente republicano Frank Merriam, cuyo equipo le acusó de comunista por apoyar los derechos de los inmigrantes que llegaban masivamente a California procedentes en su mayoría de los estados del Sur, azotados entonces por la crisis económica, la sequía y las tormentas de polvo-episodio histórico inmortalizado por Steinbeck en sus Las uvas de la ira. No obstante, Sinclair obtuvo casi 900.000 votos gracias a su campaña basada en el movimiento para erradicar la pobreza, End Poverty in California (EPIC), una iniciativa apoyada por artistas e intelectuales de izquierdas, como los Schindler desde Kings Road, adonde también acudió como conferenciante.

4. Victoria DAILEY: "Naturally Modern", en Victoria DAILEY, Natalie SHIVERS y Michael DAWSON: Op. cit., p. 36

5. "I came to live and work in California. I camped under the open sky, in the redwoods, on the beach, the foothills and the desert. I tested its granite and its sky. And out of a carefully built up conception of how the human being could grow roots in this soil -unique and delightful- I built my house. And unless I failed it should be as Californian as the Pathenon is Greek and the Forum Roman". Rudolph SCHINDLER: Nota fechada el 18 de febrero de 1952. Archivo de Esther McCoy. Archives of American Art, Smithsonian Institution.

6. Aline Barnsdall había nacido en Bradford, Pennsylvania, en 1882. Su padre, Theodore Barnsdall, llegó a ser el principal productor independiente de petróleo del país. Su madre, profesora de música, murió cuando ella era pequeña, por esta razón, de joven viajó frecuentemente por Europa con su padre, lo que le permitió muy pronto entrar en contacto con las vanguardias artísticas.

7. Debido a su amistad con Emma Goldman, a la que en 1919 ayudó con un cheque por valor de 5.000 dólares tras ser ordenada su deportación, Barnsdall fue retenida en Nueva York en marzo de 1920 cuando, poco después del proceso contra Goldman, se disponía a viajar a Europa y se denegó el embarque para impedir que saliese del país.

8. Los materiales de proyecto más conocidos relacionados con el conjunto de encargos de Aline Barnsdall para su complejo de Hollywood son aquellos procedentes de la Frank Lloyd
Wright Foundation en Taliesin West, Scottdale, Arizona. Si bien, otras fuentes menos familiares, igualmente interesantes e, incluso, inéditas, son las procedentes de los archivos californianos que custodian cantidades ingentes de documentos relacionados con la historia de Olive Hill. Los Department of Parks and Recreation y el Municipal Art Department del Ayuntamiento de Los Ángeles conservan buena parte de los dibujos del planeamiento y del acondicionamiento paisajístico de la colina, así como planos de la casa y dibujos con diferente nivel de detalle de edificios previstos en los dos masterplan, bocetos de proyectos no construidos y todo tipo de informes. En los archivos de Rudolph Schindler en la Universidad de California en Santa Bárbara y de Richard Neutra en la Universidad de California en Los Ángeles pueden consultarse los trabajos desarrollados por ambos para Olive Hill una vez que Wright abandonó la tutela del proyecto, así como los dibujos y correspondencia relativa a los encargos que Aline Barnsdall efectuó a cada uno de estos arquitectos por separado.

9. Kathryn SMITH: Frank Lloyd Wright, Hollyhock House and Olive Hill: buildings and projects for Aline Barnsdall. Santa Monica, CA: Hennessey + Ingalls, 2006 (edición original New York: Rizzoli, 1992). El libro es resultado de un trabajo de investigación iniciado en 1977 y cuya primera publicación fue el artículo que contiene ya las principales ideas en las que profundiza la citada monografía. Véase: Kathryn SMITH: "Frank Lloyd Wright, Hollyhock House and Olive Hill, 19141924". Journal of the Society of Architectural Historians, vol. 38, no 1, marzo 1979, pp. 15-33 (en adelante citado como Kathryn SMITH: JASH).

10. En 1909, durante la construcción de la obra que culminaba su etapa de las casas de la pradera, la Robie House, Wright había iniciado una escandalosa relación sentimental con Mamah Cheney, la esposa de un cliente y vecino de Oak Park con la que, tras abandonar a su mujer, se marchó a Europa. El acontecimiento afectó gravemente a su reputación profesional y, probablemente, se desencadenó como consecuencia de la frustración que el arquitecto sentía ante el agotamiento de un periodo creativo y la falta de encargos relevantes. Wright aprovechó su estancia en Berlín para contactar con la casa editorial de Ernst Wasmuth, a quien convenció para publicar su obra en las 100 litografías que conforman los dos volúmenes del Wasmuth Portfolio, libro con el que dio a conocer su trabajo en Europa y a través del cual llegó su temprana influencia hasta los jóvenes Rudoph Schindler y Richard Neutra. A finales de 1910 la pareja regresó a los Estados Unidos y pocos meses más tarde, con la ayuda de su madre, Wright adquirió unas tierras en Wisconsin, próximas a las propiedades de su familia, donde estableció su residencia estudio de Taliesin. En agosto de 1914, coincidiendo con la fecha del estallido de la Primera Guerra Mundial, mientras Wright estaba en Chicago supervisando la construcción de los Midway Gardens, uno de sus sirvientes enloqueció e incendió Taliesin en el transcurso de una cena en la que asesinó a siete personas, entre ellas, Mamah Cheney, los dos hijos pequeños de ésta y personal del estudio. Wright, que por entonces estaba volviendo recuperar su notoriedad como artista y el estatus social perdido tras abandonar a su familia, volvió a saltar a los titulares con esta noticia.

11. Cfr. Kathryn SMITH: JASH. Op. cit., p. 15.

12. A pesar de la oportunidad brindada por Barnsdall e incapaz de reconocer sus errores, Wright acusó a su clienta de frustrar su visión de Olive Hill por no haber sabido estar a la altura de las circunstancias. Incluso, en su autobiografía, Wright habló de ella con desdén. En su relato de los hechos, Wright culpabilizó a todo el entorno de Barnsdall, en el que incluyó también a Schindler, considerando que su antiguo ayudante se había puesto de parte de su clienta hasta el punto de ver en ello indicios de conspiración. En cualquier caso, las continuas disputas, enfrentamientos y litigios entre Barndsall y Wright fueron superados con el paso del tiempo prevaleciendo entre ambos una relación cordial. Véase Frank Lloyd WRIGHT: An Autobiography. Edición consultada Petaluma, CA: Pomegranate Publishers, 2005 (reimpresión de la edición original de 1943, New York: Duell, Sloan and Pearce), p. 225-333 
13. Cfr. Alice T. FRIEDMAN: "No Ordinary House: Frank Lloyd Wright, Aline Barnsdall and Hollyhock House", en Women and the Making of the Modern House. A Social and Architectural History. New York: Harry N. Abrams, 1998, p. 34.

14. Durante algunos años, Emma Goldman se movió en los mismos círculos artísticos que frecuentaba Aline Barnsdall, especialmente el Little Theatre. Fue Goldman quien introdujo las obras de Ibsen en los Estados Unidos, dramas escandalosos para la época por su denuncia de la hipocresía victoriana y de la opresión moral sufrida por la mujer. En sintonía con las ideas del autor norvego, Goldman consideraba el teatro como un eficaz instrumento para el debate y la denuncia de las injusticias sociales. Ella misma había sufrido en su propia piel la brutalidad ejercida contra la clase obrera y sus implacables condiciones de vida ya que desde muy joven se había visto obligada a trabajar duramente para sobrevivir. Dotada de gran inteligencia natural Goldman leyó todo lo que cayó en su mano, principalmente textos filosóficos relacionados con el anarco-individualismo, adquiriendo de modo autodidacta una sólida formación intelectual que le permitió escribir numerosos manifiestos e impartir conferencias. La radicalidad de sus escritos, como el que difundió en 1916 en favor de la contracepción, le costaron la cárcel en repetidas ocasiones. Su activismo pacifista y sus protestas contra el servicio militar obligatorio y la intervención norteamericana en la Primera Guerra Mundial sobrepasaron los límites de libre expresión que el Estado estaba dispuesto a conceder a sus ciudadanos y, en 1919, se decretó su expulsión del país. El siempre controvertido J. Edgar Hoover, director durante casi medio siglo del FBI, fue el encargado de presidir la comisión que evaluaba su caso, y en ella adujo que se trataba de una de las mujeres más peligrosas de América. Debido a su amistad con Emma Goldman, el poco convencional mecenazgo de Aline Barnsdall quedó bajo sospecha y durante más de dos décadas estuvo vigilada por agentes federales que siguieron muy de cerca sus viajes, reuniones sociales y actividades más mundanas hasta que, finalmente, se llegó a la conclusión de que no se trataba de un personaje subversivo sino más bien de una millonaria excéntrica.

15. "Conocí a Miss Barnsdall poco después de la tragedia de Taliesin, cuando yo todavía estaba en Chicago [...] Henry Sell la trajo para que habláramos sobre el proyecto de un teatro en el que ella estaba interesada en Los Angeles". Frank Lloyd WRIGHT: An Autobiography. Op. cit., p. 224

16. Cfr. Kathryn SMITH: JASH. Op. cit., p. 18.

17. El hecho de que se tratase de un movimiento minoritario y de carácter regional no fue obstáculo para el desafío de sus metas artísticas y conexiones internacionales. Como la propia Emma Goldman denunció, a pesar de los esfuerzos de Maurice Browne y de sus logros, en realidad casi nadie en Chicago conocía la existencia de The Little Theatre. Cuando, en 1918, problemas legales y financieros obligaron a Browne a cerrar las puertas de su teatro, la desintegración de movimiento evidenció, precisamente, que éste había sido uno de sus pilares fundamentales. Un año antes, en marzo de 1917, Margaret Anderson y Jean Heap, siguiendo los consejos de Ezra Pound, habían trasladado la sede de The Little Magazine de Chicago a Nueva York, una ciudad mucho más propicia para la vanguardia artística.

18. Cfr. Kathryn SMITH: JASH. Op. cit., p. 19.

19. Entre el público que asistía a sus representaciones estaban actores y directores tan conocidos como Charles Chaplin, Cecil B. DeMille y Gloria Swanson. Cfr. Kathryn SMITH: Frank Lloyd Wright. Hollyhock House and Olive Hill. Op. cit., pp. 22.

20. El valor de la colina era difícil de cuantificar. Relativamente apartada del Downtown para que su desarrollo residencial suscitase interés y, también, alejada del incipiente centro de negocios del Westside como para prever la inmediata construcción de edificios administrativos o comerciales, hacía años que su propietaria, Mary Harrison Spires, tenía en venta Olive Hill pidiendo, sin mucho éxito, 360.000 dólares por sus 36 acres de terreno. Durante todo ese tiempo se permitió su uso comunitario como jardín y como lugar de celebración de servicios religiosos al aire libre, por lo que se rumoreaba, incluso, que la colina sería finalmente convertida en parque público. Cuando Aline Barnsdall rebajó esa cantidad, ofreciendo 300.000 dólares en metálico, la venta se hizo efectiva inmediatamente. Cuatro años después, en pleno boom inmobiliario de los años veinte, momento en que Barnsdall se planteaba la posibilidad de su donación, la propiedad valía 6 veces el precio pagado en 1919. Cfr. Kathryn SMITH: Frank Lloyd Wright. Hollyhock House and Olive Hill. Op. cit., pp. 49, 165, 217 y 221.

21. Florence Lawrence: "Eminence to Be Made Rare Beauty Spot". Los Angeles Examiner, 6 julio 1919. Citado por Kathryn SMITH: JASH. Op. cit., p. 20.

22. Cfr. Monroe Lathrop: "Olive Hill Playhouse, Woman's Fine Project". En Los Angeles Express, 5 julio 1919. Citado por Kathryn SMITH: Frank Lloyd Wright. Hollyhock House and Olive Hill. Op. cit., pp. 49-50

23. Cfr. Kathryn SMITH: Ibid., p.50.

24. Florence Lawrence: "Eminence to Be Made Rare Beauty Spot". Los Angeles Examiner, 6 julio 1919. Citado por Kathryn SMITH: Ibid., pp. 50 y 217.

25. En el primer proyecto de paisajismo Wright limitó sus primeras decisiones a eliminar estratégicamente algunos olivos, supliendo su ausencia con nuevas masas vegetales que aportaban interés al conjunto.

26. Cfr. Kathryn SMITH: Frank Lloyd Wright. Hollyhock House and Olive Hill. Op. cit., pp. 65

27. Cfr. Kathryn SMITH JASH. Op. cit., p. 23

28. Cfr. Kathryn SMITH: Frank Lloyd Wright. Hollyhock House and Olive Hill. Op. cit., pp. 111

29. David GEBHARD: Rudolph Schindler. Barcelona: Oikos-tau, 1979 (edición original: Schindler. Prefacio de Henry Russell Hitchcock. New York: Viking Press, 1971. Reeditado por William Stout, San Francisco, 2001), p. 43

30. Teniendo en cuenta que existían dos viviendas para invitados y que la residencia principal estaba sólo destinada a Barnsdall y a su hija, las 17 estancias y 7 cuartos de baño de la casa se plantearon para dar cabida a un excesivo número de sirvientes y niñeras, algo muy poco frecuente en la ciudad.

31. Cfr. Kathryn SMITH: JASH. Op. cit., p. 25

32. Sobre esta evolución véase el capítulo 4 de la monografía de Kathryn SMITH: Frank Lloyd Wright. Hollyhock House and Olive Hill. Op. cit., pp. 39-45.

33. Hollyhock House es su segunda residencia construida en California. La primera de ellas, prácticamente desconocida, data de 1909. Se trata de una vivienda para George C. Stewart en Montecito, Santa Bárbara. La casa estaba resuelta en madera de secuoya local, redwood, y fue finalizada antes de iniciar su importante viaje a Europa de 1910. El proyecto, redactado en el estudio de Oak Park, se ejecutó en pocos meses. La construcción, que no fue supervisada por Wright ni apenas por su despacho, alteró el diseño original y la obra sufrió importantes modificaciones que dejan formalmente el resultado final a medio camino entre el desenfado de un bungalow craftsman y la articulación en planta de una casa de la pradera, aunque en este caso trasplantada al clima del Sur de California. El proyecto, sin embargo, debió gustar a Wrigh, pues incluyó una perspectiva de la vivienda en el Wasmuth Portfolio. Cfr. David GEBHARD: California Romanza. The California Architecture of Frank Lloyd Wright. San Francisco: Chronicle Books, 1988., p. 9. 
34. Thomas S. HINES: Architecture of the Sun: Los Angeles Modernism 1900-1970. New York: Rizzoli, 2010, p. 138

35. Anthony ALOFSIN: Frank Lloyd Wright: The Lost Years (1910-1922). A Studie of Influence. Chicago: Chicago University Press, 1993, pp. 6-19.

36. Thomas S. HINES: Architecture of the Sun. Op. cit., p. 138

37. Ibid.

38. Neil LEVINE: The Architecture of Frank Lloyd Wright. New York: Princeton Architectural Press, 1996, p. $124-128$

39. La sala de estar se abre al patio mediante una loggia, un motivo que se repite también en las Residencias A y B. El comedor y la cocina se relacionan con el patio a través de una columnata abierta, un especio de sombra orientado a sur que remite al rancho como tipología histórica de la región. Finalmente, los dormitorios de invitados están separados del patio por un corredor cubierto a modo de pérgola y cerrado por una cristalera.

40. Ibid., p. 27

41. Wright compró también diversas telas y dibujos japoneses para Barnsdall. Durante sus es tancias en Tokio, Wright aprovechaba para comprar antigüedades y objetos de arte japonés que después vendía en América, actuando como marchante para obtener algunos ingresos extra con los que hacer frente a su complicada situación económica.

42. El historiador Neil Levine, ha querido ver en el relieve de la chimenea una versión wrightiana de la pieza escultórica, ya de por sí abstracta, La novia desnudada por sus solteros, incluso. El gran vidrio, una de las obras maestras de Marcel Duchamp en la que el artista estuvo trabajando entre 1915 Y 1923 . Véase Neil LEVINE: The Architecture of Frank Lloyd Wright. Op. cit., p. 142.

43. Thomas S. HINES: Architecture of the Sun. Op. cit., p. 135

44. Desde el punto de vista estructural, la casa siempre se ha comportado mal frente a los seís mos de la región, algo sorprendente si se considera el éxito de la construcción sismorresistente del Hotel Imperial de Japón, proyectado al mismo tiempo y que fue capaz de resistir el devastador terremoto de 1923. Por este motivo, parece lógico pensar que Wright sabía que el uso de hormigón armado hubiera solucionado los problemas de empujes horizontales del sismo y que la solución de muros adoptada, ineficaz a pesar de su grosor y de que éstos sólo debían aguantar el peso de una planta, se debió a razones presupuestarias. Wright tampoco tuvo en cuenta la particularidad del clima californiano, caracterizado por la alternancia periodos prolongados de sequía a los que siguen lluvias torrenciales y proyectó unas cubiertas incapaces de evacuar toda el agua que puede acumularse en un breve lapso de tiempo.

45. Ibid., p. 46 y 47

46. Kathryn Smith, su principal estudiosa, aporta muy pocos detalles sobre este episodio, como ella misma reconoce en su monografía.

47. Cfr. Robert SWEENEY: Wright in Hollywood: Visions of a new Architecture. New York: The Architectural History Foundation y Cambridge, MA: The MIT Press, 1994, p. 6.

48. Publicado en 1925 , dentro de la serie de siete números que la revista holandesa dedicó al arquitecto americano y que más tarde serían publicados como el libro The Life Work of the Ame rican Architect: Frank Lloyd Wright (edición holandesa de 1925: C.A. Mees Santpoort; edición americana de 1948: A. Kroch and Sons; y reeditado como Frank Lloyd Wright: The 1925 "Wendingen"Series. New York: Dover Books on Architecture, 1992).

49. Igualmente se inspiró en la estilizada silueta de esta flor para crear los motivos de todos los relieves murarios, los capiteles de los pilares y hasta los maceteros destinados a su vez a ser plantados de malvas. La flor reaparece obsesivamente en las particiones de las carpinterías exteriores, distintivamente wrightianas, y también en el diseño del mobiliario, de los tapices y de las alfombras que adornan los interiores.

50. En un programa manuscrito para Wright, Barnsdall subdividió por zonas las siguientes estancias: área de invitados (comedor de Sugar Top, salón, dormitorio, baño, estudio y zona de almacenaje); área social (salón, comedor, sala de música y dormitorio); área de servicio (cocina, office, comedor de servicio, estancia para el servicio, tres dormitorios, dos baños, zona de almacenaje, cuarto de lavado y perreras); estancias privadas de Barnsdall (dormitorio, bibliotecadespacho, gimnasio, baño, vestidor), y su hija (dormitorio y baño, dormitorio niñera y baño y sala de juegos).

51. A una escala mucho mayor, el esquema de la casa podría relacionarse con la disposición de los volúmenes de la Residencia B, cuya sala de estar a doble altura está articulada de manera similar con el resto de cuerpos que integran la vivienda y éstos a su vez con el patio abierto que sirve de acceso.

52. Cfr. Kathryn SMITH: Frank Lloyd Wright. Hollyhock House and Olive Hill. Op. cit., pp. 168-169.

53. Cada vez más codiciada por los promotores inmobiliarios, en junio de 1923, Olive Hill podría haberse vendido por 1.800 .000 dólares, de modo que descontando la suma pagada por el solar en 1919, el coste de las obras y el pago de los honorarios a Wright por sus diferentes proyectos, aún habría obtenido un beneficio neto de un millón de dólares. Por esta razón Barndall se reservó todavía la titularidad de 26 acres, compaginando así su faceta filantrópica con la de hábil mujer de negocios. Cfr. Kathryn SMITH: Frank Lloyd Wright. Hollyhock House and Olive Hill. Op. cit., $\mathrm{p} 165$

54. Aline BARNSDALL: Carta a Frank Lloyd Wright escrita desde Suiza el 19 de octubre de 1923 y citada por Kathryn SMITH: Frank Lloyd Wright. Hollyhock House and Olive Hill. Op. cit., pp. 186-187.

55. Fue el propio Wright quien, para hacer suya la casa, cerró los sleeping porches planteados en el proyecto y ejecutados como espacios abiertos, seguramente, a iniciativa de Schindler.

56. Wright abandonó Olive Hill y, a pesar de la actitud conciliadora de Barnsdall, éste inició una serie de disputas legales por los trabajos y honorarios inconclusos que atraparon a arquitecto, clienta y contratista en una maraña de demandas cruzadas que no se resolvió hasta que las partes llegaron a un acuerdo en 1927. El episodio está ampliamente documentado en el capítulo 16 "The Lawsuits and After" de la monografía de Kathryn SMITH: véase Ibid., pp. 193-195

57. Concluidas el resto de sus obras en la ciudad, meses después, Wright abandonaba definitivamente Los Ángeles en 1925

58. Curiosamente, Schindler tachó más tarde de los planos el nombre de Richard Neutra como coautor del proyecto. Quizás un año después y con motivo de su malestar porque su nombre fuera retirado por el padre de Dione Neutra del concurso para la sede de la Sociedad de Naciones y en cuya propuesta, galardonada con una mención, sólo figuraba el de Richard Neutra.

59. Gracias a la ayuda de Schindler -antiguo compañero en Viena- y de su mujer, Pauline, Neutra había llegado a América en noviembre de 1923. En abril de 1924 tuvo la oportunidad 
de conocer personalmente a Wright en el funeral de Sullivan y fue invitado a Taliesin, donde colaboró brevemente con Wright hasta que pudo dar el salto a California a principios de 1925. La correspondencia entre ambos arquitectos (1914-1924), publicada por Esther McCoy, recoge las impresiones que Schindler le trasmitía a Neutra desde su llegada a los Estados Unidos, incluidas sus experiencias en Los Ángeles trabajando para Wright en el proyecto de Olive Hill y en el de su propia casa. Véase Esther McCOY: Vienna to Los Angeles. Two Journeys. Letters Between $R$. M. Schindler y Richard Neutra. Prólogo de H. H. Harris. Santa Monica, CA: Arts + Architecture Press, 1979

6o. Thomas S. HINES: Architecture of the Sun. Op. cit., p. 142

61. Cfr. Natalie W. SHIVERS: "A New Creative Medium", en Victoria DAILEY, Natalie SHIVERS y Michael DAWSON: LA's Early Moderns. Art/Architecture/ Photography. Los Angeles: Balcony Press, 2003, p. 144

62. Muy afectada tras el terremoto de Northridge de 1994, Hollyhock House se abrió de nuevo al público en 2005 tras ser restaurada y provista de un sistema sismorresistente.

63. Cfr. Kathryn SMITH: JASH. Op. cit., p. 31

64. Sobre el trabajo de Teske como fotógrafo-cuyos principales fondos alberga el archivo de Getty Museum de Los Ángeles-y, más concretamente, sobre su etapa en Olive Hill (1944-49) puede consultarse el artículo de Thomas S. Hines: "Photography, Architecture, and the Coming to Oneself: Edmund Teske and Frank Lloyd Wright", en AA. VV., SALAS, Charles G. y ROTH, Michael S. (eds.): Looking for Los Angeles: Architecture, Film, Photography and the Urban Landscape. Los Angeles: The Getty Research Institute (Publication Program: Issues \& Debates), 2001

65. Aline Barnsdall ofreció a Teske instalarse en la Residencia B, que reacondicionó una vez más para que el artista viviera en ella cómodamente. Durante sus últimos años, Barnsdall apenas residía en Olive Hill pero mantenía la posibilidad de dormir de vez en cuando en esa residencia cuando se encontraba en la ciudad. Fue allí, precisamente en compañía de Teske, donde falleció de un ataque al corazón en 1946. Tras la muerte de su madre, Betty permitió al fotógrafo seguir habitando la casa hasta 1949 cuando, para evitar el pago de impuestos de la propiedad y ahorrarse los costes de su mantenimiento y restauración, decidió vender la Residencia B a un promotor que demolió la casa para construir un grupo de apartamentos.

66. El principal teatro y sala de conciertos al aire libre de la ciudad, en las colinas próximas a su residencia e institución de la que era una de sus principales patronas. Su contribución económica a las actividades del Hollywood Bowl le permitió influir en la elección de Lloyd Wright como proyectista de su primera concha acústica (1927-28).

67. Frank Lloyd WRIGHT: An Autobiography. Op. cit., p. 232

68. Aline BARNSDALL: Carta a Richard Neutra fechada el 15 de febrero de 1939 y citada por Thomas S. HINES: Richard Neutra and the Search for Modern Architecture: a Biography and His tory. New York: Rizzoli, 2006 (primera edición New York: Oxford University Press, 1982), p. 157.

69. David GEBHARD: Rudolph Schindler. Op. cit., pp. 117-118

70. Sobre esta obra puede consultarse Lisa GERMANY: Harwell Hamilton Harris. Prólogo de Kenneth Frampton e Introducción de Bruno Zevi. Berkeley, CA: University of California Press, 2000 (edición original Austin, TX: University of Texas Press, 1991), pp. 157-161. Y también puede consultarse Esther McCOY: The Second Generation. Salt Lake City, UT: Gibbs Smith Publisher, 1984, pp. 70-72. No obstante, McCoy se refiere a esta obra, encargada por Ruth Carter, la hija de una de las más prominentes fortunas de Fort Worth, como la J. Lee Johnson House. La vivienda funcionaba con una estructura jerárquica de patios inspirada en la planta de la Hollyhock House, pero a diferencia de ésta, Harris controlaba estrictamente las dimensiones de los mismos y las proporciones de los corredores para generar más espacios de sombra, imprescindibles en el clima extremo de Texas, tan distinto de las benignas condiciones de California. Por otra parte, Robert Winter y David Gebhard en su guía de arquitectura de Los Ángeles han sugerido también que la English House de Harris (Beverly Hills, 1949-50) es otra una obra claramente deudora de proyecto de Olive Hill, afirmando que podría considerarse la obra como el resultado de retirar los ornamentos de la casa Barnsdall. Cfr. David GEBHARD y Robert WINTER: An architectural Guidebook to Los Angeles. Salt Lake City, UT: Gibbs Smith Publisher, 2003 (edición revisada y ampliada de las guías de 1994, 1977 y 1965), p. 154

71. Cfr. Rudolph M. SCHINDLER: "Furniture and the Modern House: A Theory of Interior Design", en Architect and Engineer, diciembre 1935 (Part I), p. 21.

72. Texto del proyecto citado por Elizabeth A. T. SMITH: "R. M. Schindler: An Architecture of Invention and Intutition", en AA. VV., DARLING, Michael y SMITH, Elizabeth A. T. (eds.): The Architecture of R. M. Schindler. Op. cit., p.25.

73. Por razones presupuestarias, las instalaciones de fontanería de la vivienda se dejaron vistas, trasladando la lógica utilitaria de los contenedores industriales a la imagen de los cuartos de baño y produciendo de este modo una imagen doméstica insólita para la época.

74. Rudolph M. SCHINDLER: "A Cooperation Dwelling", en T-Square, febrero 1932, p. 20

75. Michael DARLING: "The Vulnerable Architecture of R. M. Schindler", en AA. VV., DARLING, Michael y SMITH, Elizabeth A. T. (eds.): The Architecture of R. M. Schindler. New York: Harry N. Abrams, 2001. (Catálogo de la exposición homónima, Museum of Contemporary Art, Los Angeles, 2001), p.192

76. Rudolph M. SCHINDLER: Carta a Richard Neutra fechada el 16 de junio de 1922. Recopilada por Esther McCOY: Vienna to Los Angeles. Two Journeys. Op. cit., pp. 139-140.

77. Ibid.

78. Ibid.

79. Rudolph M. SCHINDLER: "Space Architecture". Dune Forum (Oceano, California), febrero 1934, pp. 44-46.

80. Schindler proyectó alrededor de 400 obras, de las que construyó 150

81. Charles MOORE: Los Angeles. The City Observed. A Guide to its Architecture and Landscape. Santa Monica, CA: Hennessey + Ingalls, 1998 (edición original New York: Vintage Books, 1984), p. 235 .

82. El primer estudio ejecutado fue el correspondiente a Marian Chace, $y$ en sus paneles pueden percibirse los errores de las primeras tentativas, solventadas en la última estancia que se construyó, la del propio Schindler.

83. Sobre la ideación del sistema de prefabricados horizontales y la atribución de su autoría a Gill por parte de Esther McCoy en su libro de 1960 Five California Architects, donde la historiadora presenta a Schindler como continuador de éste, véase la tesis doctoral de Juan Coll Barreu donde discute tal origen, argumentando que su primera utilización, por parte del ejército norteamericano, se había llevado a cabo a gran escala en las construcciones militares bajo la tutela del coronel Robert H. Aiken quien, en 1907, ya habría desarrollado este procedimiento tal como 
lo emplearon primero Gill y después Schindler. Cfr. Juan COLL-BARREU: Construcción de los paisajes inventados. Los Ángeles doméstico 1900-1960. Barcelona: Arquithesis. Fundación Caja de Arquitectos, 2004, pp. 104-105

84. Reyner BANHAM: Los Angeles. The Architecture of Four Ecologies. Berkeley y Los Angeles: University of California Press, 2001 (primera edición: Baltimore, MD: Penguin Books Inc., 1971), p. 164

85. Como se verá en otros casos analizados más adelante en esta tesis.

86. Rudolph M. SCHINDLER: Architectural Scheme. Residence RMS, 1922. Schindler Archive. The Architecture \& Design Collection (ADC). University Art Museum. University of California, Santa Barbara (UCSB).

87. Michael DARLING: "The Vulnerable Architecture of R. M. Schindler", en AA. VV., DARLING, Michael y SMITH, Elizabeth A. T. (eds.): The Architecture of R. M. Schindler. Op. cit., p. 192

88. Rudolph M. SCHINDLER: Carta a Richard Neutra sin fechar, escrita probablemente en diciembre de 1920 o enero de 1922. Recopilada por Esther McCOY: Vienna to Los Angeles. Two Journeys. Op. cit., pp. 129.

89. Cfr. Michael DARLING: "The Vulnerable Architecture of R. M. Schindler", en AA. VV., DARLING, Michael y SMITH, Elizabeth A. T. (eds.): The Architecture of R. M. Schindler. Op. cit., p. 192

9o. Ibid.

91. Rudolph M. SCHINDLER: Carta a Richard Neutra fechada en octubre de 192. Recopilada por Esther McCOY: Vienna to Los Angeles. Two Journeys. Op. cit., p. 137.

92. Elizabeth A. T. SMITH: "R. M. Schindler: An Architecture of Invention and Intutition", en AA. VV., DARLING, Michael y SMITH, Elizabeth A. T. (eds.): The Architecture of R. M. Schindler. Op. cit., p.25.

93. David Gebhard: Rudolph Schindler. Op. cit., p 59

94. Ibid., pp. 60, 62-63.

95. Sobre la casa, Banham afirmó que era "the most remarkable design he was ever to produce [...]. Its system of interlocking garden-courts, flanked by living spaces that had opne glass fronts and almost fortified backs made of tilted-up concrete slabs, is a model exercise in the interpenetration of indoor and outdoor spaces, a brilliant adaptation of simple constructional technology to local environmental needs and possibilities, and perhaps the most unobtrusively enjoyable domestic habitat ever created in Los Angeles". Reyner BANHAM: Op. cit., p. 164

96. Situada 45 millas al norte de Los Ángeles, en Antelope Valley, este histórico asentamien to vio la luz durante los años de la Primera Guerra Mundial bajo los auspicios Job Harriman, frustrado aspirante socialista a la alcaldía de Los Ángeles. Instigado por el grupo de poder liderado por H. G. Otis, fundador la poderosa dinastía de Los Angeles Times que llegó a erradicar toda forma de sindicalismo en la región, Harriman se vio imposibilitado para llevar a cabo sus ansiadas reformas sociales y se trasladó al desierto de Mojave donde, en 1914, levantó Llano, una colonia socialista basada en una economía agraria de raíz cooperativista. Llano era también un gran centro docente y de intercambio de ideas. Poseía varias escuelas, una nutrida biblioteca y una orquesta ragtime. Los planos de la ciudad-jardín para la futura Ciudad Socialista en la que se iba a convertir fueron preparados por una mujer, Alice Constance Austin y eran, en opinión de Dolores Hayden, "rotundamente feministas y californianos". Aunque llegó a contar con una población de más de 1.000 colonos, a finales de 1917, disensiones internas y conspiraciones políticas llevaron a la pérdida de sus derechos sobre el agua y la colonia, de la que apenas quedan hoy sus ruinas, se trasladó a Louisiana donde acabó disolviéndose en 1939. El episodio, muy bien documentado, es rememorado por Mike Davis para contextualizar las luchas de clase en Los Ángeles con las que introduce su imprescindible City of Quartz (Op. cit., p. $x x \mathrm{I}$ ).

97. Philip JOHNSON: Carta a Rudolph Schindler fechada el 17 de marzo de 1932. Schinder Archive (ADC), University Art Museum de la University of California, Santa Barbara (UCSB).

98. Beatriz COLOMINA: Privacidad y publicidad. La arquitectura moderna como medio de comunicación de masas. Yaiza Hernández y José Parra (dirs.). Traducción Isabel Hortal, Beatriz Preciado, Yaiza Hernández y José Parra. Murcia: CENDEAC, COAMU, OBS, 2010, p. 145 (edición original Privacy and Publicity. Modern Architecture as Mass Media. Cambridge, MA: The MIT Press, 1994)

99. Charles MOORE: Op. cit., p. 233. El comentario ingenioso del autor se ha traducido libremente para tratar de reproducir su sentido en castellano, empleándose la palabra "jaleo" para el término inglés "mess".

100. Schindler publicó sus primeros textos de madurez en los años 30, en concreto, Space Architecture, fue publicado por Dune Forum en febrero de 1934, California Arts \& Architecture en enero de 1935, y Atelier (Sidney) en noviembre de 1951.

101. Rudolph M. SCHINDLER: Carta a Elizabeth Mock, fechada el 10 de agosto de 1943. Schinder Archive (ADC), University Art Museum de la University of California, Santa Barbara (UCSB).

102. Rudolph M. SCHINDLER: Carta a Arthur Drexler, fechada el 15 de abril de 1952. Schinder Archive (ADC), University Art Museum de la University of California, Santa Barbara (UCSB). Carta citada parcialmente por Michael DARLING: Op. cit., p. 175.

103. "One of my dreams, Mother, is to have, some day, a little joy of a bungalow, on the edge of the woods and mountains near a crowded city, which shall be open just as some people's hearts are open, to friends of all classes and types. I should like it to be as democratic a meeting-place as Hull House where millionaires and laborers, professors and illiterates, the splendid and the ignoble, meet constantly together". Pauline GIBLING: Carta a su madre Sophie S. Gibling fechada el 9 de mayo de 1916. Nótese que en el momento en que fue escrita esta carta Pauline Gibling aún no había conocido a Rudolph Schindler.

104. Sobre este proceso puede consultarse el ensayo de Margaret CRAWFORD "Olvidando y recordando a Schindler: la historia arquitectónica de una reputación arquitectónica", en $2 \mathrm{G}$ n 7, Schindler, 1998, pp. 129-143.

105. Ibid., p.132

106. Robert SWEENEY: "Life at Kings Raod: As It Was 1920-1940", en AA. VV., DARLING, Michael y SMITH, Elizabeth A. T. (eds.): The Architecture of R. M. Schindler. Op. cit., (en adelante sólo Robert SWEENEY).

107. Robert Sweeney es Presidente desde 1982 de la asociación Friends of the Schindler House y miembro del Comité de Gobierno del MAK Center L.A. Este arquitecto e historiador fue uno de los principales responsables que impulsaron la restauración y preservación de la vivienda de Kings Road tras la muerte de Pauline en 1977 
108. Esther McCOY: Vienna To Los Angeles. Op. cit., principalmente pp. 58-61. McCoy sitúa la fecha del abandono de Kings Road en 1928, cuando en realidad, Pauline dejó Los Ángeles en agostos de 1927, esta fecha ha sido asumida por diversos autores anteriores a la publicación de Sweeney como, por ejemplo, Margaret Crawford.

109. En su monografía Richard Neutra (Op. cit., principalmente pp. 76-77, 84-85, 87-88, 96-98 y 252) y más recientemente en su Architecture of the Sun (Op. cit., principalmente pp. 213-214, $244-246,264-265,292-293$, y $325-327)$.

110. John Crosse ha sido una de las principales fuentes de este capítulo, proporcionando valiosos documentos originales, guiándo la búsqueda en archivos locales y discutiendo, tanto por correo electónico como en su estudio de Playa del Rey los aspectos más controvertidos de esta investigación.

111. De acuerdo con McCoy (Vienna To Los Angeles. Op. cit., p. 32), su padre, Edmund J. Gibling, había nacido en Inglaterra y fue responsable en Chicago de la oficina del Sweet's Catalog Service, catálogos de productos y equipamientos industriales para construcción y que, lanzados en 1906 por la Architectural Record Company, Richard Neutra llegaría a considerar como la Biblia del arquitecto, según testimonio de Harwell Hamilton Harris.

112. La Hull House fue la primera casa de acogida de inmigrantes de Chicago. En ella, cada semana, alrededor de 2.000 personas, sobre todo jóvenes desfavorecidos, recibían formación y asistencia social. Esta institución privada proporcionaba, entre otros servicios públicos, guardería, clases para niños, talleres de artesanía para los chicos mayores, formación musical y artística para todo el mundo, escuela nocturna para adultos, así como conferencias y debates. Contaba además con un comedor social, con gimnasio y piscina y daba cabida a asociaciones culturales, grupos de teatro y hasta un servicio de búsqueda de empleo. Dada la formación e intereses de su fundadora, Jane Addam, así como su experiencia de campo, la Hull House era también una institución sociológica orientada a la mujer, así como un centro de reunión de reformadores sociales y defensores de los derechos civiles. Jane Addam, que durante toda su vida mantuvo una relación de pareja con Mary Rozet Smith, fue una feminista, sufragista y antimilitarista declarada. En 1915, fundó junto con Emily Green Balch la Women's International League for Peace and Freedom y presidió el Congreso Internacional de Mujeres por la Paz en La Haya. Fue además cofundadora de la American Civil Liberties Union y la National Association for the Advancement of Colored People. Fue miembro también de la American Anti-Imperialist League y de la American Sociology Association. Jane Addam y Emily Green Balch fueron galardonas por separado con e Premio Nobel de la Paz en 1961 y 1946, respectivamente.

113. Cfr. Dione NEUTRA (Compiladora y ed.): Richard Neutra. Promise and Fulfillment, 1919 1932. Selections from the Letters and Diaries of Richard and Dione Neutra. Carbondale, IL: Southern Illinois University Press, 1986, p. 116. Esta información también la proporciona Thomas S. HINES: Richard Neutra and the Search for Modern Architecture. Op. cit, p. 67

114. Cfr. Thomas S. HINES: Richard Neutra and the Search for Modern Architecture. Op. cit., p. 76 (en adelante simplemente Thomas S. HINES: Richard Neutra).

115. Cfr. Esther McCOY: Vienna to Los Angeles: Two Journeys. Op. cit., p. 31. McCoy relata la impresión de Rudolph Schindler ante la enérgica condena de la guerra por parte de Pauline dado que, como comenta la historiadora, por su condición de emigrante procedente de un país enemigo, llevaba años guardando en silencio sus opiniones políticas por miedo a ser deportado.

116. Entrevistas de Pauline Schindler con Thomas S. Hines, realizadas en 1972 y 1976. Véase Thomas S. HINES: Richard Neutra... Op. cit. p. 77 y p. 85, n. 35 .

117. Robert SWEENEY: Op. cit., p. 88.
118. El relato de la gestación de Los Ángeles como escenario de conflicto es abordado con lucidez por Mike Davis en los dos primeros capítulos de su ya clásico City of Quartz, (Ciudad de Cuarzo. Op. cit.).

119. Un mérito de varias agrupaciones de mujeres como la Women's Trade Union League of Los Angeles, el Friday Morning Club of Los Angeles, la Women's Socialist League of California y la California Federation of Women's Clubs. Entre otros logros pioneros de estas asociaciones estuvieron la aprobación de leyes estatales protectoras para la mujer como la jornada laboral de ocho horas y el salario mínimo.

120. Pauline GIBLING SCHINDLER: Carta a Emsa, fechada el 25 de junio de 1933. Citada por Robert SWEENEY: Op. cit., p. 91

121. El primer centro, abierto en Nueva York, fue denominado Ferrer Center y contó con nueve alumnos, uno de los cuales fue Man Ray.

122. Pauline GIBLING SCHINDLER: "Edward Weston on the Way", en The Carmelite, 26 diciembre 1928 , p. 2

123. Pauline GIBILING SCHINDLER: Carta fechada en junio de 1921. No existe fecha exacta $n$ destinatario conocido. Schindler Archive. Schinder Archive (ADC), University Art Museum de la University of California, Santa Barbara (UCSB), en adelante: ADC/UCSB.

124. Cfr. Robert SWEENEY: Op. cit., p. 91

125. Ibid.

126. Cfr. Rudolph SCHINDLER: "Who will save Hollywood?", en Holly Leaves, noviembre 1922, p. 32

127. Pauline GIBLING SCHINDLER: Carta a su madre Sophie S. Gibling fechada el 26 de octubre de 1922. Citada por Robert SWEENEY: Op. cit., p. 91

128. Pauline GIBLING SCHINDLER: Carta a sus padres fechada el 2 de marzo de 1921. ADC/ UCSB.

129. "These people weren 't rebelling against the old; they were disregarding it". Harwell Hamilton HARRIS: Prólogo al libro de Esther MCCOY: Vienna to Los Angeles. Op. cit., p. 13.

130. Ibid.

131. Pauline GIBLING: Carta a su madre escrita desde Chicago y fechada el 9 de mayo de 1916.

132. Cfr. SWEENEY: Op. cit., p. 87 .

133. Cfr. Pauline GIBLING SCHINDLER: Carta a sus padres y a su hermana Dorothy escrita el 16 de julio de 1922.

134. Pauline GIBLING SCHINLDER: Carta a sus padres, Sophie y Edmund J. Gibling, fechada el 16 de julio de 1922. Extractos citados por Beth G. WARREN: Artful Lives: Edward Weston, Margrethe Mather and the Bohemians of Los Angeles. Los Angeles: The J. Paul Getty Museum, 2011, p. 253

135. Aunque volvería en diversas ocasiones para cuidar de Pauline durante las frecuentes crisis nerviosas que sufría su hermana como consecuencia de las infidelidades de su marido. 
136. Cfr. Robert SWEENEY: Op. cit., p. 94

137. "Poets, playwrights, dancers, photographers and musicians were not the only visitors on these occasions. Socialists, reformers and intellectuals of all varieties were there. The talk was not chit-chat but about revolutionary ideas in all fields. The New, the Advanced. There were no fights because the participants, too, were advanced and so in fundamental agreement with one another. Most were locals; some were habitues; others were ones who came and went. Everyone felt free to bring a friend if he were interesting; it was a way to entertain". Ibid.

138. Esther McCoy afirmó: "Su costumbre de mirar directamente a los ojos de las personas hacía que una conversación con ella adquiriera siempre una particular intimidad". Esther McCOY: Vienna to Los Angeles: Two Journeys. Op. cit., p.32.

139. A. R. BRANDNER citado por Esther McCOY en Vienna to Los Angeles. Op. cit, p. 41. (Sadakichi Hartmann, actor, artista y crítico había participado, entre otras películas de la etapa dorada del cine mudo de Hollywood en El ladrón de Bagdad, dirigida en 1924 por Raoul Walsh y protagonizada por Douglas Fairbanks).

140. "The Schindlers were as unconventional as their house. RMS - genial, friendly, accommodating, enjoying life, hiding a serious nature behind a joking manner- let his hair curl over the back of his collar and his white shirt remain open at the throat. White duck trousers, a cummerbund and Mexican huarachis further set him apart from his contemporaries". Harwell Hamilton HARRIS Introducción al libro de Esther McCOY Vienna to Los Angeles: Op. cit., p. 13.

141. Pauline GIBLING SCHINDLER: Carta a su madre fechada en octubre de 1925 citada por Robert SWEENEY: Op. cit., p. 96.

142. Maurice BROWNE: Too Late to Lament (Autobiografía). Fragmento citado por Robert SWEENEY: Op. cit., p. 96.

143. Cfr. Robert SWEENEY: Op. cit., p. 104. De acuerdo con Robert SWEENY, entre 1923 y 1928, Sophie Gibling viajó a la ciudad en al menos cinco ocasiones.

144. Sophie GIBLING: Carta a Edmund J. Gibling, diciembre 1926. Citada por Robert SWEENY Op. cit., pp. 103-104.

145. Sophie GIBLING: Carta a Edmund J. Gibling, septiembre 1926. Citada por Robert SWEENY: Op. cit., p. 103.

146. Dione NEUTRA: Carta citada en To Tell the Truth. Entrevista con Lawrence Weschler (abril, julio y agosto 1982). Los Angeles: Oral History Program, University of California Los Angeles (UCLA), 1983, p. 110 (en adelante simplemente Dione NEUTRA: Oral History Program, UCLA).

147. Ibid.

148. Información proporcionada por John Crosse.

149. Karl Howenstein había trabajado en el Art Institute de Chicago antes de trasladarse a Los Ángeles, donde llegaría a ser Director del Otis Art Institute.

150. Ibid., p. 97.

151. Sweeney se plantea si la salida de la casa de los Chace y su marcha a Florida tuvo que ver sólo con razones profesionales. Según este autor, Schindler habría comentado en abril de 1924 que, con el nacimiento de su hijo Thomas ese mismo mes, los Chace fueron conscientes de sus dificultades económicas y decidieron hacer una apuesta profesional más segura regresando junto a los padres de Marian. No es probable que las dos parejas terminaran enfrentadas, ya que Clayde Chace y Rudolph Schindler continuaron colaborando todavía en alguna de las casas realizadas por el arquitecto en los años 30 . No obstante, sí parece plausible la teoría del distanciamiento personal entre las dos mujeres. De acuerdo con Sweeney, los Chace dejaron la casa inmediatamente después del intento de suicidio de Pauline, lo que sugeriría que su situación emocional se les hizo insoportable. Sea como fuere, la realidad es que a pesar de que sus maridos mantuvieron una relación fluida, Marian y Pauline, dos amigas íntimas que habían compartido los años de Universidad en el Smith College, el trabajo en la Hull House y en Ravinia y, por último, la vida en Kings Road, interrumpieron prácticamente su contacto durante años. Véase Ibid., p. 99.

152. En 1925, los Rankin encargaron una vivienda a Schindler, de la que nada se sabe aunque, más tarde, trataron de comprar la casa que el arquitecto había construido para su suegro Edmund J. Gibling en Westwood (1925-28). Ninguna de estas operaciones salió adelante por las dificultades económicas de la pareja.

153. Ibid., p. 99

154. Rudolph SCHINDLER: Carta a Richard Neutra fechada el 22 de noviembre de 1922. Citada por Thomas HINES: Thomas S. HINES: Richard Neutra and the Search for Modern Architecture: a Biography and History. Op. cit. p 157 (en adelante simplemente: Thomas S. HINES: Richard Neutra).

155. Encadenando uno tras otro, la vivienda de huéspedes alojó entonces al bailarín John Bovingdon quien residió durante un año en Kings Road junto a su compañera Jeayna Marling

156. Simplemente, a modo de curiosidad, es significativo que en el relato de tantos arquitectos, historiadores y críticos que fueron a trabajar o a escribir sobre Los Ángeles, su fascinación por la ciudad comienza con la experiencia misma de su descubrimiento un espléndido día de sol, excepto Richard Neutra, que llegó a ciudad bajo la lluvia.

157. Dione NEUTRA: Carta a Frances Toplitz fechada en febrero de 1925. Recopilada en En Dione NEUTRA ( ed.): Richard Neutra. Promise and Fulfillment, 1919-1932. Selections from the Letters and Diaries of Richard and Dione Neutra. Op. cit, pp. 136-137 (en adelante simplemente Dione NEUTRA (ed.): Op. cit.).

158. Richard NEUTRA: Carta a Lilly Niedermann (Mutterli), escrita en Los Ángeles y fechada el 25 de abril de 1925. Ibid., p. 139.

159. En realidad, Según Thomas Hines, a pesar de que Dione desempeñó un papel eminente mente de esposa y apoyo doméstico a la carrera profesional de Richard Neutra, desde el punto de vista de sus ideas políticas, ella era más avanzada que su marido. Incluso, en algunas ocasiones, Neutra se mostró ambiguo en sus posicionamientos cuando se trataba de acceder a determinados puestos de responsabilidad, amistades o encargos, por lo que su ideología, antes que social o política, habría sido arquitectónica. Es decir, habría cedido en algunas de sus convicciones para tener la posibilidad de producir arquitectura. Uno de los hechos que más apoyan esta teoría es su apoyo al comité olímpico norteamericano en su decisión de acudir en 1936 a los juegos organizados por los nazis, en contra de la opinión de buena parte del país. Pauline Schindler escribió inmediatamente al arquitecto y le reprendió con dureza por su comportamiento, que consideraba injustificable e inmoral. En su carta, decía: "Mi más querido richard [sic.], ¿cómo puedes estar tan dormido? [...] colaborar, del modo que sea, en la promoción de los Juegos Olímpicos este año en Alemania, es simplemente ser cómplice de la colosal limpieza étnica que están llevando a cabo. Sería decirle al mundo que está bien lo que pasa en Alemania, que todo es felicidad, libertad, salud y diversión; los cánticos de los himnos que sonarán en los juegos acallarán los gritos de los 
torturados, ocultarán el sufrimiento, los suicidios, la brutalidad, el sadismo [...] No soy judía, pero soy un ser humano y si tú dejas que tu nombre aparezca en el comité olímpico en cualquier forma de colaboración tendré que pensar que no lo eres. Pídeles que retiren tu nombre, richard [sic.]. Cometiste un espantoso error al aceptar. ghibbeline". (La firma, Gibbeline, era uno de los nombres por el que la llamaban familiarmente sus amigos más íntimos. Richard Neutra, al parecer, no retiró su nombre). Pauline GIBLING SCHINDLER: Carta a Richard Neutra sin fecha exacta (1936), documento en posesión de Hines y citado en Thomas S. HINES: Richard Neutra. Op., cit., p. 207.

16o. Thomas S. HINES: Richard Neutra. Op. cit., p. 76 .

161. Dione NEUTRA: Carta citada en Oral History Program, UCLA, p. 107.

162. Cfr. Thomas S. HINES: Richard Neutra. Op. cit., pp. 58-59

163. Frank Wilkinson, viejo amigo de Pauline y cliente de Neutra, era Secretario del Citizens Housing Council y Director de Información de la CHA (Housing Authority of the City of Los Angeles), la oficina responsable de las obras de vivienda social en la ciudad y que, durante los años previos e iniciales de la Segunda Guerra Mundial, llevó a cabo ambiciosos planes de vivienda pública en la ciudad bajo los auspicios de los programas federales del New Deal. Wilkinson era un idealista de izquierdas, un técnico reformador y un inteligente relaciones públicas que du rante más de 10 años favoreció del desarrollo de dichos programas en Los Ángeles, defendiendo la integración racial y la gestión comunitaria de las obras. Por ejemplo, en 1950, fue nombrado negociador oficial entre la CHA y el partido comunista para mediar y convencer a los residentes de Chavez Ravine de las ventajas del proyecto Elysian Park Heights de Richard Neutra y Robert Alexander, una actuación frustrada por la compleja situación política durante la Caza de Brujas. En 1952, en el momento álgido del macartismo, Wilkinson fue procesado, destituido y represaliado por el Comité de Actividades Antiamericanas. Cfr. Don PARSON: Making a Better World. Public Housing, the Red Scare and the Direction of Modern Los Angeles. Minneapolis, MN University of Minnesota Press, 2005, pp xvi, 1, 51, y $163-187$

164. Cfr. Dione NEUTRA: Oral History Program, UCLA, pp. 108 y 487 , entre otras.

165. Ibid., pp. 108-109.

166. Despúes Galka Scheyer residiría temporalmente en casa de los Freeman. En 1931 regresó a Kings Road y se instaló durante dos años en el ala de los Chace.

167. Atendiendo a la correspondencia de su hermana Dorothy, las crisis de ansiedad de Pauline habían comenzado a manifestarse antes, probablemente hacia noviembre de 1922 y de nuevo en 1923, coincidiendo con el estrés de las celebraciones de Acción de Gracias.

168. Al parecer, una apreciación de Rudolph Schindler a su suegra, Sophie Gibling, y referida por carta a su marido Edmund Gibling en noviembre de 1926. Carta en posesión de Robert Sweeney y citada por éste en Robert SWEENEY: Op. cit., p. 104.

169. Así lo afirma, por ejemplo, Raymond Neutra, como se expondrá más adelante.

170. Dione NEUTRA: Carta a su madre Lilly Niedermann fechada en agosto de 1927 y reproducida en Dione Neutra (ed.): Op. cit., p. 167.

171. Pauline y Rudolph Schindler habrían conocido a Ellen Janson en el círculo de Aline Barnsdall en 1920. Cfr. Judith SHEINE: R. M. Schindler. London: Phaidon Press, 2001, nota 27, p. 283

172. De hecho, Schindler murió en su casa de Los Ángeles, la Janson House (1949) en abril de 1953.
173. Tras el cierre del Chicago Little Theatre y una breve singladura teatral por ciudades como Washington y Nueva York, Browne y Van Volkenberg, se habían trasladado a Seattle en 1921 por invitación de Nellie Cornish, a quien les propuso ser profesores de su escuela de artes escénicas en esta ciudad (la Cornish School tendría entre otros docentes a Martha Graham y John Cage, y entre sus alumnos a Cole Weston, el hijo menor de Edward Weston). Despúes de su divorcio, Browne y Van Volkenberg continuaron su asociación profesional, trabajando conjuntamente en diferentes producciones teatrales que, durante los años 20 les llevaron de gira por California.

174. Años más tarde, en el número de 6 de marzo de 1929 de la revista The Carmelite, Pauline describiría Halcyon como un pequeño y extraño asentamiento dotado -según sus propias palabras- de una asombrosa calidad, tan extraordinaria y universal como la luz, un lugar donde huir de la civilización para encontrarse con personas de mente y gustos cultivados, "quizás sea el clima el que cause todo esto, la radiación en Halcyon de fuerzas telúricas que producen un tipo humano de inusual harmonía y serenidad, del mismo modo que el clima de Carmel, por contraste, crea en sus habitantes sobre-estimulación cerebral y destellos de inteligencia colectiva". Pauline GIBLING SCHINDLER: "Utopia Found", en The Carmelite, 6 marzo 1929.

175. Cfr. Robert SWEENEY: Op. cit., pp. 104-105.

176. "The Swan Song of S.A.R", en The Carmelite, zo mayo 1928.

177. Véase Pauline GIBLING SCHINDLER: "Tooth-Gnashing over the Library Tax", en The Carmelite, 9 enero 1929.

178. Véase Pauline GIBLING SCHINDLER: "Our Road Hazard", en The Carmelite, 17 abril 1929

179. Cfr. Robert SWEENEY: Op. cit., p. 105

180. Previamente a su mudanza a Carmel, Weston había pasado una breve temporada en la casa de su amigo y antiguo estudiante el fotógrafo Johan Hagemeyer en San Francisco y después, durante algún tiempo, se alojó en el estudio que éste tenía en Carmel antes de trasladarse al Seven Arts Building, la misma sede de las oficinas de The Carmelite.

181. Según las últimas investigaciones de John Crosse en la correspondencia de Pauline Gibling Schindler, cada vez parece más evidente que ambos tuvieron una relación sentimental.

182. Tal como figura en la entrada de los diarios de Weston correspondiente al 20 de Septiembre de 1929: "Up at 4:00 and in my darkroom straightening prints from work of yesterday and the day before: work which was strenuous enough to put me to bed at 8:30. At last I have been printing the peppers. I had to have an excuse to do them for conscience's sake, for orders are still behind: the excuse was Pauline's request for several prints for Vogue. But I notice that instead of printing just one, I found it necessary to print five, - for selection! Well, they are gorgeous, - the strongest things I have done, outside of some portraits... "

183. Información facilitada por John Crosse.

184. Cfr. Pauline GIBLING SCHINDLER: Carta a su padre fechada el 7 de mayo de 1928. Citada por Robert SWEENEY: Op. cit., p. 105

185. Pauline GIBLING SCHINDLER: "The Architecture of the Future", en The Carmelite, 28 noviembre 1928, p. 11

186. Pauline GIBLING SCHINDLER: "Richard Neutra Renders Modern Architecture Intelligible", en The Carmelite, 5 diciembre 1928, p. 4. 
187. Pauline Schindler tardó mucho tiempo en poder afrontar una relación profesional con su marido. De hecho, a pesar de la admiración que le profesaba, sus comentarios sobre Schindler traslucen el momento concreto que atravesaba su relación, bien fuera como amantes, amigos, padres, socios o creadores. Durante años Pauline experimentó serias dificultades para separar el plano personal del plano laboral, pero aún así continuó promocionando a su ex pareja. De su correspondencia se desprende cómo durante el final de 1927, poco después de abandonar Kings Road, Pauline trataba de recuperarse "del shock y del dolor de aquél verano", o cómo ya, a principios de los años 30 , ella era ya capaz de expresar "un enorme respeto y reconocimiento hacia la personalidad de RMS", pudiendo de nuevo trabajar con él siempre y cuando "logremos mantener las cosas en un terreno completamente impersonal". En marzo de 1930 Pauline escribía a su madre: "[RMS] es un hombre muy extraño: un gran artista cuy a persona va a contracorriente de las normas establecidas, como suele ocurrir con los genios". Dos años más tarde, en febrero de 1933, afirmaba en una carta dirigida también a su madre "[RMS] es un grandísimo mentiroso sin ningún tipo de escrúpulos" $y$, dos semanas después, en otra carta enviada a su padre le definía como "una persona inconsciente y poco considerada, un hombre de gran talento, cautivador encanto y falta de responsabilidad que miente con la misma facilidad que dice la verdad". Fragmentos de cartas de Pauline GIBLING SCHINDLER a destinatarios diversos, fechadas en 1927 y 1930 y citadas por Sweeney. Véase Robert SWEENEY: Op. cit., p. 112, 113 y 115.

188. Pauline GIBLING SCHINDLER: "Schindler Modern Speaks on Architecture", en The Carmelite, 4 septiembre 1929, p. 4

189. Carta de Pauline G. Schindler (tal como figura en la firma) a Rudolph Schindler fechada el 14 de marzo de 1929. Una copia de la carta, descubierta en el Archivo de Schindler en la Universidad de California en Santa Bárbara fue facilitada por John Crosse en julio de 2011.

190. Robert SWEENEY: Wright in Hollywood: Visions of a New Architecture. Op. cit., p. 24

191. Información proporcionada por John Crosse.

192. La Braxton Gallery, en Hollywood, fue inaugurada en septiembre de 1929. El encargo de este espacio expositivo había recaído en Schindler gracias a la amistad de la marchante de arte Galka Scheyer y de Edward Weston con el galerista Henry Braxton, con quien tanto Scheyer como Schindler colaboraron estrechamente durante la realización del proyecto. Posteriormente Henry Braxton encargó también a Schindler su casa con Viola B. Shore en Venice Beach, un proyecto que no llegó a construirse porque Braxton y Shore se mudaron poco después a Nueva York.

193. De acuerdo con McCoy, las nuevas fotografías de sus obras, realizadas por Roger Sturtevant no habrían sido del agrado de Wright (Cfr. Esther McCOY: Vienna to Los Angeles. Op. cit., p. 58). Judith Sheine reproduce parte del contenido de la correspondencia intercambiada por Pauline Schindler y Frank Lloyd Wright (Véase Judith SHEINE: Op. cit., p.42).

194. También de acuerdo con McCoy, Wright, que habría estado en Kings Road en 1923, habría vuelto por segunda vez después de que Pauline regresara a finales de los años 30 para visitar a su amiga y tratar de formalizar una reconciliación con Schindler. En esta segunda ocasión, Schindler no estuvo presente y rehusó además devolverle su llamada. McCOY: Vienna to Los Angeles. Op. cit., p. 60.

195. De acuerdo con John Crosse, hay evidencias de que Pauline asistió a Galka Scheyer en el montaje de las cuatro exposiciones consecutivas sobre los Cuatro Azules que la Braxton Gallery albergó entre marzo y mayo de 1930, por lo que esta colaboración coincidente con el montaje de Contemporary Creative Architecture in California debió ser muy útil para Pauline a la hora de adquirir experiencia.
196. Arthur MILLIER: "Building for Our Age: California Designers of Modern Style Architecture Distinguished from Those Who Imitate", en Los Angeles Times, 27 abril 1930. Entre otras imágenes, el artículo estaba ilustrado con fotografías de Will Connell, Brett Weston y Willard Morgan.

197. Ibid.

198. Véase el artículo de Henry-Russell HITCHCOCK: "An Eastern Critic Looks at Western Architecture", en California Arts \& Architecture, diciembre 1940, pp. 221-223

199. Cfr. Judith SHEINE: Op. cit., p. 256

200. Información proporcionada, discutida y verificada por John Crosse a partir de la correspondencia de Pauline Gibling Schindler.

201 Haskell era miembro del consejo editorial de la revista neoyorkina Creative Art y, entre 1929 y 1930 fue ayudante de dirección de Architectural Record, un puesto al que regresaría de nuevo en 1943 y donde continuó hasta que, en 1949, se convirtió en editor de Architectural Forum. Fue uno de los primeros promotores de la arquitectura moderna en los Estados Unidos desde los años 20 y, también, un enérgico defensor de la planificación urbana desde planteamientos socialmente avanzados, siendo amigo, entre otros urbanistas y críticos de Clarence Stein, Catherine Bauer, Lewis Mumford o Jane Jacobs, a quien contrató como editora asociada de Architectural Forum en 1952

202. Es decir, antes de que el arquitecto regresara a Nueva York de su gira europea en noviembre de ese mismo año.

203. Las copias de dichos panfletos han sido proporcionadas por John Crosse. La fotografía de Schindler que aparecía en el díptico era un retrato realizado por Edward Weston.

204. Pauline GIBLING SCHINDLER: Panfleto anunciador de una conferencia de Rudolph Schindler en el marco de la exposición Contemporary Creative Architcture in California, 1930.

205. Pauline GIBLING SCHINDLER: Carta a su padre fechada el 11 de octubre de 1932. Citada por Robert SWEENEY: Op. cit., p. 103

206. Rudolph SCHINDLER: Carta a Pauline Gibling Schindler sellada el 2 de diciembre de 1935 Ibid

207. Pauline Schindler y John Cage se habían conocido en Kings Road y aunque su relación sentimental duro poco -probablemente porque la diferencia de edad (ella era 20 años mayor) y la bisexualidad del compositor debieron influir en su ruptura- ambos continuaron siendo amigos durante toda su vida. Cfr. Thomas S. HINES: Architecture of the Sun: Op. cit., p. 325

208. Pauline GIBLING SCHINDLER: "Oceano Dunes and Their Mystics", en Westways n 26, febrero 1934, pp.12-13

209. Véase Gavin ARTHUR: Dune Forum, "Subscribers' Number", otoño de 1933

210. "Notes and Names", en Dune Forum, Suscribers' Number, otoño 1933, p. 19

211. En ese mismo artículo, la escritora hacía alusión a la visita a Ojai del místico hindú y gurú de la época Jiddu Krishnamurti, a quien por cierto, ya había conocido en California J. J. (Koos) van der Leeuw, convencido teosófico y hermano del empresario holandés que financió el proyecto y las obras de la propia casa VDL de Neutra en Silver Lake. 
212. Cfr. John CAGE: Carta a Pauline Gibling, fechada el 11 de enero de 1935 en Los Ángeles. Transcrita por Maureen MARY en Letters: The Brief Love of John Cage for Pauline Schindler, 19341935. Fuente disponible online en http//: www.ex-tempore.org/ExTemporeg6/cageg6.htm. De acuerdo con Maureen Mary, Pauline debió conocer a John Cage antes de 1934. La primera carta enviada por Cage a Pauline fue como directora asociada de la revista Dune Forum, a la que envió material para el artículo "Counterpoint" en respuesta a otro del director y violinista Roderick White, ambos publicados en el número de febrero y al que, por su parte, contestó el compositor y editor de la revista New Music Henry Cowell en el número de marzo de 1934 de Dune Forum.

213. Rudolph SHINDLER: "Space Architecture", en Dune Forum nº 2, febrero 1934, pp. 44-46.

214. Rudolph M. SCHINDLER: "Space Architecture". California Arts \& Architecture, enero 1935 pp. 18-19.

215. Richard NEUTRA: "Balancing the Two Determinates of Creation", en Dune Forum no 5 , mayo 1934, pp. 136-139

216. Las vidas de los Schindler tuvieron en ocasiones tintes verdaderamente cinematográficos. De acuerdo con John Crosse, y la correspondencia existente en el Archivo de Schindler en la Universidad de California en Santa Bárnara, la abogada de Rudolph Schindler durante su proceso de divorcio fue Ana Zacsek, amiga de Edward Weston y miembro también del círculo de Kings Road. Zacsek había sido actriz de Hollywood bajo el nombre artístico de Olga Gray, habiendo participado en películas como El nacimiento de una nación a las órdenes de D. W. Griffith. Zacsek fue además clienta de Schindler, que construyó su casa en Playa del Rey (1936-1938), justamente durante el propio proceso de divorcio. Por otra parte, el abogado de Pauline, Morris E. Cohn, era como ella compositor aficionado y también había sido visitante de Kings Road.

217. Pauline GIBLING SCHINDLER: Carta a su hermana Dorothy fechada el 11 de julio de 1935 Citada por Robert SWEENEY: Op. cit., p. 112.

218. Pauline GIBLING SCHINDLER: Carta a su padre fechada el 13 de julio de 1935

219. Ibid.

220. Ibid

221. Cfr. Robert SWEENEY: Op. cit., p. 111.

222. Pauline GIBLING SCHINDLER: Carta a su madre fechada el 13 de diciembre de 1933. Citad por Robert SWEENEY: Op. cit., p. 111.

223. Pauline GIBLING SCHINDLER: Carta de Pauline Schindler a su padre, Edmund J. Gibling fechada el 14 de julio de 1932. Citada por Robert SWEENEY: Op. cit., p. 111

224. Aunque ella se quejó del estado en el que Rudolph Schindler había dejado Kings Road tras su partida -Reyner Banham encontró seductora la maleza que colonizaba la casa-y lamentara el poco mantenimiento al que había sido sometida la vivienda, Pauline fue responsable de numerosas alteraciones como operaciones de repintado y compartimentación interior que debieron ser revertidas tras la exhaustiva restauración a la que fue sometida la vivienda de Kings Road en 1987 cuando, basándose en fotografías de época, se devolvió a su estado original después de que, en 1980, un grupo de entusiastas liderado por Robert Sweeney (FOSH: Friends of the Schindler House) adquiriera la propiedad y garantizara su preservación.

225. Pauline GIBLING SCHINDLER [publicado de manera anónima]: "Wie Bau Amerika? Book Review". Los Angeles City Club Bolletin, 30 julio-6 agosto 1927.
226. "The Samuel House- Architect Lloyd Wright", en Architectural Record, junio 1930, pp. 525 y $528-530$.

227. Rudolph M. SCHINDLER: "A Cooperation Dwelling", en T-Square, febrero 1932, p. 20

228. Victoria DAILEY: "Naturally Modern", en Victoria DAILEY, Natalie SHIVERS y Michael DAWSON: Op. cit., p. 57

229. Información proporcionada por John Crosse.

230. Pauline GIBLING SCHINDLER: "Oceano Dunes and Their Mystics", en Westways n 26, febrero 1934, pp.12-13.

231. Armitage perteneció al mismo hasta 1938

232. Victoria DAILEY: "Naturally Modern", en Victoria DAILEY, Natalie SHIVERS y Michael DAWSON: Op. cit., p. 58.

233. Pauline GIBGLING SCHINDLER: "A Significant to Culture. The Interior of a Great California Store as an Interpretation of Modern Life", en California Arts \& Architecture, enero 1930, pp. $23-28$ y 74 .

234. El diseño de interiores había sido realizado por Jock Peters, John Weber y Kem Weber.

235. Pauline GIBLING SCHINDLER: Texto de presentación como directora invitada del número de la revista. Página de créditos. California Arts \& Architecture, enero de 1935, p.11. Con este ataque al estilo moderno lanzado desde la propia página de créditos de la revista, Pauline Gibling Schindler estaba apuntando claramente a la reciente Exposición The International Style donde, como se ha indicado, Philip Johnson sólo había accedido a incluir la casa Lovell de Neutra como representante de la modernidad californiana, obviando, a pesar de las reiteradas cartas de Schindler, su propia casa de Kings Road. Una actitud reduccionista que Pauline Schindler quiso evitar a toda costa en su trabajo de selección poniendo en valor una cuidada muestra de la diversidad de manifestaciones arquitectónicas que estaban dando forma a una modernidad californiana que ya había alcanzado entonces unas incuestionables cotas de madurez.

236. Esther McCOY: The Second Generation. Salt Lake City, UT: Gibbs Smith Publisher, 1984, p. 42

237. Ibid.

238. El crítico empleó la palabra "flurry", que aunque puede traducirse como oleada o rágafa, tiene aquí el significado de algo pasajero, por lo que se ha traducido libremente en su sentido más peyorativo.

239. "A House for Writer Affords Privacy and Spectacular View. Alexander Levy, Designer", en Architectural Record, octubre 1938, pp. 47-51.

240. "California Charges", en Architectural Forum, junio 1935, p. 42.

241. Pauline GIBLING SCHINDLER: "What Constitutes Plagarism?", en Aperitif, enero 1935 Referencia bibliográfica facilitada por John Crosse.

242. Cfr. Robert SWEENEY: Op. cit., p. 112. 
243. NEUTRA, Dione: Oral History Program, UCLA, pp. 107-108.

244. Pauline GIBLING SCHINDLER: Carta a su madre fechada el 2 de mayo de 1936 .En aquella época, Pauline trataba de publicar una monografía sobre la obra de Rudolph Schindler en un momento en el que, después de tanto tiempo parecía que, según ella misma afirmaba "por fin, él está listo para esta tarea".

245. Pauline GIBLING SCHINDLER: "Modern California Architects", en Creative Art, febrero 1932 , p. 113

246. Esther McCOY: "Schindler: A Personal Reminiscence", en L.A. Architect, noviembre 1987, P. 5

247. ESTHER McCOY: Entrevista con Joseph Giovannini. Oral History Interview with Esther McCoy, 7 junio-14 noviembre 1987, Archives of American Art, Smithsonian Institution, p.35.

248. Dione Neutra, en su entrevista para la Universidad de California en Los Ángeles, llegó a referirse a Esther McCoy como "la novia de Schindler". Véase Dione NEUTRA: Oral History Program, UCLA, p. 443.

249. Cfr. Susan MORGAN y Kimberli MEYER (ed): Sympathetic Seeing: Esther McCoy and the Heart of American Modernist Architecture and Design. Los Angeles: MAK Center, 2011, p. 41.

250. Esther McCOY: "Schindler, Space Architect", en Direction n 8, otoño 1945, pp. 14-15.

251. "I am grateful to you, RMS [...] for what you have given to architecture all these years, while forbidding myself personal feeling, $i$ (sic) have been free nevertheless to respond fully to your work, to feel and know its richness and perhaps even sometimes its meaning. Gregory Ain speaks sometimes of the house at Kings Road as though it were a sort of miracle, -bringing to architecture the same miraculous freshness of creation which the Sacre du Printemps does to music As I have seen your work over the many years it seemed to me that your central preoccupation was the evocation of that which had never before imagined. A sort of uncoiling of dimensions in space. I recognize the elements of greatness in this life; and now [... I ] am at last ready to acknowledge it to you freely". Pauline GIBLING SCHINDLER: Carta a Rudolph Schindler, fechada el 9 de julio de 1953.

252. Opiniones discutidas mediante correo electrónico con John Crosse y Raymond Neutra octubre y noviembre 2011

253. En su libro Vienna to Los Angeles, la historiadora dio a entender la ruptura de Schindler y Neutra con motivo del encargo de la casa Lovell, una cuestión sobre la que se discutirá en próximos capítulos. Y probablemente, McCoy también mitificó la supuesta reconciliación entre Schindler y Neutra, que relató en Five California Architects como la coincidencia de ambos en la misma habitación del hospital donde el primero había sido intervenido de cáncer y el segundo se recuperaba de un ataque al corazón.

254. Rudolph M. SCHINDLER: Carta a Arthur Drexler, fechada el 15 de abril de 1952. Schinde Archive (ADC), University Art Museum de la University of California, Santa Barbara (UCSB).

255. Esther McCOY: Five California Architects. Santa Monica, CA: Hennessey + Ingalls, 2004 (edición original New York: Reinhold Pub. Corporation, 1960), p. 192.

256. Su primer hijo, Chandler (Edward Chandler Weston), nació en abril de 1910. En diciembre de 1911 nació Brett, el más conocido de los hijos de Edward Weston que, como su padre, también se dedicaron a la fotografía. El tercero de los hermanos Weston, Laurence Neil nació en 1916 y el menor de todos ellos, Cole, también fotógrafo, en 1919
257. En sus diarios de esa época, una vez rota la relación con ella, Weston describiría a Mather como "la primera persona realmente importante en mi vida y, quizás, ahora que ha desaparecido todo contacto, puedo decir que la más importante".

258. Tina Modotti, una de las mujeres más fascinantes de la primera mitad del siglo XX, italiana afincada en California y en México, comunista, políglota, actriz de cine mudo en Hollywood, fotógrafa y musa de artistas como Weston, desarrolló una carrera como creadora a la altura de los hombres que fueron sus amigos y mentores. Vivió en el turbulento México de los años veinte, un país que pugnaba por abrirse al mundo a la vez que reunía algunos de los focos de las artes y la política más efervescentes y radicales del momento. Modotti compartía las aspiraciones de libertad espiritual y sexual con los artistas e intelectuales con los que se relacionaba. Personalidades alimentadas por la pasión y los ideales que inspiraron las revoluciones de principios de siglo: Frida Kahlo, Diego Rivera -fue precisamente ella quien presentó a la pareja-, los muralistas José Clemente Orozco y David Alfaro Siqueiros, el propio Edward Weston o su también amante Julio Antonio Mella, líder estudiantil cubano tiroteado -presumiblemente por orden del dictador Machado- cuando ambos paseaban juntos en 1929. Poco después, como resultado de una campaña anticomunista llevada a cabo por el gobierno mexicano, Modotti fue expulsada de México en febrero de 1930 y embarcada rumbo a Rotterdam. Aunque el gobierno italiano había solicitado su extradición, logró evadir la cárcel y pudo viajar a Berlín y a Suiza, donde trató de unirse a la resistencia antifascista. El deterioro de la situación política en Alemania la impulsó a viajar a Moscú en 1931. A lo largo de los siguientes años participaría en diferentes misiones vinculadas a organizaciones dependientes de la Internacional Comunista. En 1936, tras el estallido de la Guerra Civil, Modotti viajó a España, donde permaneció hasta 1939 cuando, tras la caida de la República, regresó a México. Murió súbitamente en 1943 en el Distrito Federal, precisamente cuando regresaba de visitar en casa a su buen amigo y antiguo director de la Bauhaus Hans Meyer. Tenía 45 años.

259. La semana antes de partir hacia México, el fotógrafo tuvo un rápido encuentro con Mather, de la que tomó varios desnudos en la playa de Redondo Beach. Las fotografías, centradas en mostrar la relación directa del cuerpo con el medio que lo acoge, constituyen un hito en los estudios de desnudo de Weston.

26o. Varias de las fotografías realizadas por Weston y Modotti en México fueron incluidas y discutidas en el imprescindible ensayo de Anita Brenner sobre la iconografía mexicana Idols behind the Altars, publicado en 1929

261. Edward WESTON y Nancy NEWHALL(ed.): The Daybooks of Edward Weston. Volume 1: Mexico \& Volume 2: California. Rochester, NY: George Eastman House, 1961.

262. Merle ARMITAGE, citado por Arthur MILLER: "Photos by Weston in Japan Art Club", en Los Angeles Times, septiembre 1927. Artículo a su vez citado en Victoria DALLEY, Natalie SHIVERS y Michael DAWSON: LA's Early Moderns. Art/Architecture/ Photography. Los Angeles: Balcony Press, 2003, p. 253.

263. Tras las primeras discusiones acerca del formato y del contenido, Edward Weston y Merle Armitage seleccionaron los negativos que debían formar parte del libro. Weston temía que la impresión mecánica de sus fotografías restara calidad a las imágenes e insistió en que la publicación tuviese una calidad similar al del revelado en papel fotográfico. El editor aceptó este reto, prácticamente imposible fuera de los talleres especializados de Nueva York. Armitage depositó su confianza en Lynton Kistler, el único impresor de la ciudad a quien creyó capacitado para reproducir las fotografías de Weston con unas dimensiones y con una tirada que nadie en Los Ángeles había intentado antes. Los tres trabajaron estrechamente para resolver los numerosos problemas que se plantearon durante el proceso de producción, comenzando por el papel escogido por Weston. Se trataba de un papel brillante y de gran gramaje importado de Alemania pero cuya superficie satinada impedía la fijación de la tinta. Para solventar esta dificultad un 
ayudante de Kistler tuvo la ocurrencia de verter gasolina sobre las planchas de impresión y prender fuego para que éstas se calentaran y la tinta quedase fijada al papel por el calor. Otro de los problemas fue la financiación. Armitage trató de conseguir diversos patrocinios para esta empresa llevada a cabo en plena Depresión. Consiguió sufragar parte del proyecto vendiendo 40 subscripciones básicas del libro a un precio base de 10 dólares. Pero su mayor éxito fue conseguir el pago de 500 dólares por parte de Alice Rohrer, mecenas y admiradora del trabajo de Weston a quien el editor consideró oportuno dedicar el libro. Con este dinero Armitage pudo asegurarse la impresión y, una vez terminado la obra, vendió 50 copias al editor de Nueva York Erhard Weyhe a cambio de que su nombre figurara ostensiblemente en los títulos de crédito. Cfr. Michael DAWSON: "South of Point Lobos", en Victoria DALLEY, Natalie SHIVERS y Michael DAWSON: Op. cit., p. 256.

264. Armitage siguió promocionando incansablemente la obra de su amigo, tratando de hacer ver a todo el mundo la importancia de su trabajo como fotógrafo. La admiración de Armitage por Weston se materializó en dos libros más: 50 Photographs: Edward Weston (1947) y la monografía que, en 1956, dedicó a su hijo Brett, a quien conocía desde finales de los años 20 y que, emulando a la de su padre, quiso titular también simplemente Brett Weston.

265. Cfr. Michael DAWSON: "South of Point Lobos", en Victoria DALLEY, Natalie SHIVERS y Michael DAWSON: Op. cit., p. 249

266. Weston realizó su última fotografía en 1948. Dos años antes, en 1946, el Museo de Arte Moderno de Nueva York presentó una exposición retrospectiva de su obra. Bajo su supervisión, en 1952, tres décadas después de su primera monografía, su hijo Brett comenzó a preparar un segundo proyecto monográfico que incluía más de 800 impresiones a partir de los negativos $8 \times 10$ de las fotografías que el artista escogió como las mejores de su vida. Murió en Carmel en 1958.

267. Harry Chandler, que en 1917 había sucedido a su suegro el coronel Otis al frente de Los Angeles Times y sus negocios familiares, se había mudado precisamente a California desde New Hampshire para curar sus problemas respiratorios. Trasladando su personal preocupación por la salud a los contenidos del periódico, había encargado a Harry Ellington Brook una columna sobre formas de vida saludable y disfrute del medio californiano la cual, además de tratar sobre cuestiones relacionadas con la higiene o la alimentación, servía para también para promocionar las bondades del clima y la geografía de la región. Después de la llegada de Chandler a la direc ción del Times, alrededor de 1920, éste se había convertido ya en el medio de comunicación más influyente de todo el Oeste.

268. John Charles WOODS: A Restless Eye: A Biography of Photographer Brett Weston. Richmond, MO: Erica Weston Editions, 2010, p .27.

269. Philip LOVELL: "Building Homes for Health", en Care of the Body. Los Angeles Times, (Sunday magazine section), 29 junio 1924, pp. 25-26.

270. David GEBHARD: Rudolph Schindler. Op. cit., p. 100

271. Ibid

272. Su fenestración es el elemento donde la influencia wrightiana resulta más reconocible.

273. Rudolph SCHINDLER: "Shelter or Playground", en Care of the Body. Los Angeles Times, (Sunday magazine section), 2 mayo 1926, pp. 26-27

274. Véase: Beatriz COLOMINA: Privacidad y publicidad. La arquitectura moderna como medio de comunicación de masas. Traducción Isabel Hortal, Beatriz Preciado, Yaiza Hernández y José
Parra. Murcia: CENDEAC, COAMU, OBS, 2010 (edición original Privacy and Publicity. Modern Architecture as Mass Media. Cambridge, MA: The MIT Press, 1994); y véase también: Beatriz PRECIADO: "Mies-conception: La casa Farnsworth y el misterio del armario transparente", en Zehar: revista de Arteleku-ko aldizkaria $\mathrm{n}^{\circ} 44,2000, \mathrm{pp} .23-32$.

275. Sobre esta discusión véase también Agust E. SARNITZ.: "Proportion and Beauty-The Lovell Beach House by Rudolph Michael Schindler, Newport Beach, 1922-1926", en Journal of the Society of Architectural Historians, vol. 45, diciembre 1986, pp. 347-388.

276. "The Carmelite, which is about to publish a special issue on Contemporary Architecture of the West Coast, would like to include in that issue, some of your work. A photography by Weston of the Lovell house at Balboa is already on hand. We should like to include at least one more work,-possibly a drawing. This need not be an especially prepared print. Cut can be made from any size or surface.We should also be glad if you would write an article for this issue, -which has the intention of expressing strongly contemporary tendencies. The article may be either signed or unsigned, and should reach the Carmelite by next Tuesday the nineteenth if possible or the next day. Page design in this number will be respected by the printer; and all suggestions and directions as to the spacing of the page on which the article is set, will be carefully carried out as the author whishes". Carta inédita de Pauline GIBILING SCHINDLER como editora de The Carmelite a R. M. Schindler fechada el 14 de marzo de 1929: ADC/ UCSB. Una copia de la carta fue proporcionada por John Crosse y su contenido discutido en su casa de Playa de Rey, California, en julio de 2011 y verificada en el archivo de Schindler en la Universidad de Santa Bárbara en agosto de ese año.

277. Información facilitada también por John Crosse. El fotógrafo rondaba entonces los 20 años. Una biografía de Brett Weston ha sido recientemente publicada por su hija, Erica Weston, por cierto, compañera de clase de Raymond Neutra en el Happy Valley School. Véase John Charles WOODS: A Restless Eye: A Biography of Photographer Brett Weston. Richmond, MO: Erica Weston Editions, 2010.

278. "Dear Schindler. Have your prints ready- but I will hold till you answer my note about beach house prints and ship altogether. To repeat- do you wish to return the ones I sent you in emergency and have me print a fresh set? The ones I sent are Pauline's. I note there are six negatives of beach house- do you wish all six? Did you ever have or want view of back of room? Best of wishes. Edward W.". Nota manuscrita de Edward WESTON a RM Schindler, fechada el 27 de abril de 1928: $\mathrm{ADC} / \mathrm{UCSB}$

279. Información proporcionada por John Crosse. Existe documentación sobre la publicación en $A D C / U C S B$.

280. (¿Pauline GIBLING SHINDLER?:) "A Lovell Beach House for Dr. P. Lovell at Newport Beach, California", en Architectural Record, septiembre 1929, pp. 257-261.

281. Rubén A. ALCOLEA: Picnic de Pioneros: Arquitectura, fotografía y el mito de la industria Valencia: Ediciones Generales de la Construcción, 2009, p. 175

282. Richard NEUTRA: "Amerika. Körperübung und gegenwärtige Bauarbait", en Das Neue Frankfurt, mayo 1928, p.91.

283. Rubén A. ALCOLEA: Op. cit. p. 257

284. Mediante intercambio de correos electrónicos con este historiador, septiembre de 2011.

285. Por cierto que Alcolea atribuye a Schindler la autoría del artículo sobre la Lovell Beach House aparecido en Architectural Record en 1929. Seguramente no ha tenido en cuenta el he- 
cho de que fue Pauline quien preparó todos los materiales para publicar y los envió a su amigo Douglas Haskell a redacción de la revista junto con un texto sin firmar que, como se ha visto en anteriores apartados, era su procedimiento habitual.

286. Rubén A. ALCOLEA: Op. cit. p. 179

287. Thomas S. HINES: Richard Neutra. Op. cit., p. 99.

288. Información facilitada por John Crosse.

289. Weston y sus amigos solían intercambiar servicios, como consultas, visitas al dentista, etc. por retratos y fotografías.

290. Información facilitada por John Crosse a través de Susan Morgan. Carta procedente de archivo de Edward Weston en el Center for Creative Photography de la Universidad de Arizona.

291. Edward WESTON y Nancy NEWHALL(ed.): The Daybooks of Edward Weston. Op. cit., p. 60.

292. Ibid., p. 251.

293. Weston no se instaló en Carmel hasta 1929, aunque pocos meses antes, en 1928, viajara a San Francisco.

294. Esta exposición recorrió ese mismo año 1929las ciudades de Zürich, Berlín, Danzig y Viena y, en 1931, viajó a Tokio y Osaka.

295. De hecho, pocos meses antes de su inauguración, sus dos comisarios principales, László Moholy-Nagy y Siegfried Giedion, variaron sensiblemente la programación de la sala principal para convertir gran parte de la exposición en un escaparate de la Nueva Visión.

296. Según el relato de Dione Neutra (Oral History Program, UCLA, p. 146), Richard Neutra se había convertido en delegado americano de los CIAM a por su amistad con Karl Moser, con quien había trabajado en Zurich, y con su hijo Werner Moser, con quien había coincidido en Taliesin en el otoño de 1924 cuando éste visitaba a Wright -por cierto, tras haber visitado antes a Schindle en Kings Road. Giedion y Karl Moser eran amigos y, también de acuerdo con Dione Neutra, Werner Moser medió ante ellos en la designación de Neutra para el cargo.

297. Richard NEUTRA: Carta a sus suegros Alfred y Lilly Niedermann fechada el 25 de dicimebre de 1925 y compilada por Dione NEUTRA (ed.): Op. cit., p. 114. Por cierto que, en esa misma carta en la que informaba a la familia de su mujer de la escasez de trabajo en Los Ángeles, Neutra les rogaba que el relato de sus dificultades en América no traspasase el umbral de la más absoluta intimidad de modo que nadie en Europa se enterase de ello.

298. Cfr. Dione NEUTRA: Oral History Program, UCLA, pp. 140-141. Los Jardinette Apartments fueron publicados por Das Neue Frankfurt en abril de 1928 y, poco después, junto al edificio de apartamentos de Ernst May en Frankfurt, en julio de 1928 por la revista berlinesa Baugilde.

299. Edward WESTON: Entrada de sus diarios del 3 de enero de 1929, en Edward WESTON Y Nancy NEWHALL(ed.): The Daybooks of Edward Weston. Op. cit., pp. 102-3.

300. Cfr. Arthur MILLIER:"Photographs for Himself", en Los Angeles Times, 25 julio 1930, pp.iii-12.

301. Por otra parte, Rubén Alcolea, sostiene también que Brett Weston comenzó a fotografiar a la edad de 13 años en México, cuando acompañó a su padre y a Tina Modotti en el primer viaje del fotógrafo. Si bien, no fue Brett, sino Chandler quien siguió a su padre a México.
302. Rubén A. ALCOLEA: Op. cit. p. 243.

303. Ibid.

304. Greenfield Avenue está localizada en Westwood, uno de los distritos del Westside de Los Ángeles, concretamente, se halla en el área residencial situada en el extremo noroeste de la porción de la ciudad encerrada por la autopista San Diego Freeway y las grandes vías de Wilshire y Sunset a su paso por las inmediaciones de la Universidad de California en Los Ángeles. Siendo la frontera que establece los límites entre Westwood y la demarcación de Bel Air, el trazado de Sunset Boulevard emprende en este lugar su recorrido serpenteante por las colinas de Brentwood, haciendo visible cómo la trama ortogonal de la planicie comienza a deformarse para ir ascendiendo por las Montañas de Santa Mónica.

305. Cfr. David GEBHARD y Robert WINTER: Los Angeles. An architectural guide. Salt Lake City Gibbs Smith Publisher, 1994 (o en su reedición del año 2003, An architectural Guidebook to Los Angeles.Salt Lake City: Gibbs Smith Publisher, 2003), p. 105. En estas guías se ofrece una breve historia de la formación de Westwood y una evocación del ambiente arquitectónico del barrio.

306. La casa Tischler está ubicada en el 175 de Greenfield Avenue.

307. En realidad, Schindler había iniciado estas investigaciones mucho antes, en el proyecto no construido de la Translucent House para Aline Barnsdall (1927-28) donde experimentaba con recintos iluminados de manera natural sin necesidad de que tuvieran vistas exteriores. Habiendo comprendido las posibilidades de aquellos materiales que dejando pasar la luz garantizaban la privacidad, en sus últimas obras volvería a explorar este tema con mayor profundidad.

308. Gebhard dedica uno de los capítulos de su monografía sobre Schindler a analizar su relación con la madera y la evolución de sus ideas acerca de su utilización como material de revestimiento. Apunta que, habiendo dejado ya de emplearla en exteriores a principios de los años treinta y estando entonces ya más interesado por el contrachapado y los revestimientos de estuco, había criticado su uso en fachada. Sostenía que era improcedente en el Sur de California ya que durante nueve meses no llovía prácticamente nada y que luego, a finales de invierno, los niveles de humedad con las lluvias torrenciales aumentaban bruscamente, resultando esta variación nefasta para la madera. En cualquier caso, a finales de la década, Schindler volvió a recurrir a ella como revestimiento para abandonarla, otra vez, después de la guerra. Gebhard sugiere incluso la influencia de la obra de Harwell Hamilton Harris, pero entiende el cambio de opinión, sobre todo, como reacción a los lenguajes wrightianos, precisamente en el momento en que las Usonian Houses, comenzaban a ser conocidas. Cfr. David GEBHARD: Rudolph Schindler. Op. cit., pp. 195-201.

309. Por su rapidez y economía, aún en la actualidad, el sistema de armazón de madera o de tableros de OSB revocados y pintados sigue siendo la forma de construir más barata y habitua en muchos estados del país, incluido California.

310. Esther MCCOY: Five California Architects. Op. cit., 1960, p. 167

311. Muchos de ellos, como telas o papeles, no han llegado hasta nuestros días. Esto dificulta abordar la restauración de las obras de Schindler puesto que el proceso implica, necesariamente, un alto grado de reconstrucción. Por otra parte, un problema añadido a la conservación de dichas obras de es que, después de sucesivas alteraciones y una vez desaparecidos estos materiales, su identificación se hace extremadamente compleja por la escasez de información a respecto. A diferencia de los exhaustivos planos de detalle de Richard Neutra, la documentación gráfica de los proyectos de Schindler es muy limitada ya que muchos de sus interiores fueron casi improvisados sobre la marcha a base de explicaciones en obra, dibujos en las paredes o croquis que eran destruidos una vez que cumplían su cometido. 
312. Margaret Crawford ha apuntado que la casa de Frank Gehry, acabada en 1978, revelaba toda una serie de similitudes con la obra de Schindler, entre ellas, el interés por la construcción con madera y técnicas locales, materiales baratos, corrientes y desacostumbrados como las mallas metálicas o las chapas onduladas, los tableros de contrachapado sin barnizar, etc. "Tal como había sucedido previamente con Schindler, los críticos consideraron el uso de materiales evocativos y fuertemente táctiles de Gehry, así como sus formas aparentemente arbitrarias, como una forma muy personal de expresionismo. No obstante, en cierto modo, ambos arquitectos mantienen una relación parecida con el paisaje urbano de Los Ángeles, celebrando lo que otros rechazan como banal. Ambos miran la ciudad con nuevos ojos, tomando información visual del entorno urbano y recomponiéndolo en su arquitectura [...] lo que capta a la perfección el aura insustancial de la ciudad y la convierte en arte" (Margaret CRAWFORD "Olvidando y recordando a Schindler: la historia arquitectónica de una reputación arquitectónica", en 2G, nº 7 . Revista Internacional de Arquitectura: Schindler. Barcelona: Gustavo Gili, 1998, p. 137.) Gehry, como todos los arquitectos formados en torno a la denominada L.A. School, entre ellos Rotondi, Mayne, etc., han defendido siempre la figura de Schinder, tanto en sus obras como a través de sus escritos.

313. Harwell Hamilton HARRIS: Prólogo al libro de Esther McCoy: Vienna to Los Angeles. Op. cit. p. 11.

314. Rudolph M. SHINDLER: Carta a Philip Johnson, citada por David GEBHARD: Rudolph Schindler. Op. cit., pp. 132-133.

315. Entre las voces más críticas con la mitificación del Estilo Internacional y su "autoproclamada élite" se encontraba la revista House Beautiful que, especialmente durante los años en los que Elizabeth Gordon estuvo al frente de la publicación, se reveló como alter ego de Arts \& Architecture. Desde este foro su directora opinaba: "ciertos museos, ciertas revistas de arquitectura y ciertos diseñadores no se cansan de ensalzar [...] una arquitectura de aspecto frí, falta de rigor científico, irracional, y nada económica. [...] Ahí reside el peligro, en que si nos dejamos convencer aceptando a dictadores en materia de gustos sobre cómo debemos organizar nuestros hogares, nuestra mente acabará pronto aceptando las imposiciones en muchos otros aspectos de nuestra vida". Elizabeth GORDON: "The Threat to the Next America", en House Beautiful, abril 1953, pp. $126-130$

316. Cfr. Beatriz COLOMINA: 1949, en AA. VV: Robert E. SOMOL (ed.): Autonomy and Ideology. Positioning an Avant-Garde in America. New York: The Monacelli Press, 1997, pp. 321-322. El libro es consecuencia de un importante ciclo de conferencias acerca de la originalidad y autonomía de la vanguardia arquitectónica americana. Tuvo lugar en Nueva York en febrero de 1997. Estuvo organizado por la Graduate School of Architecture de la Universidad de Columbia, el Canadian Centre for Architecture y el MoMA. En él participaron, entre otros, Philip Johnson, Colin Rowe, Peter Eisenman, Francesco Dal Co y Rem Koolhaas. En su artículo "1949", publicado más tarde en castellano (La domesticidad en guerra, Barcelona: Actar, 2006) Beatriz Colomina sostiene que desde el punto de vista de la cronología ésta es la fecha clave en la vanguardia americana, su momento culminante. Si a obras de referencia por su radicalidad construidas, en 1949, en los Estados Unidos como la Glass House de Philip Johnson en New Canaan o la Eames House en Santa Mónica se añaden otras como la vivienda experimen tal que Marcel Brever instaló ese mismo año en el patio del MoMA, se entiende el sentido de las siguientes palabras de Colomina cuando afirmaba que 1949 fue el año en que realmente empezaron a suceder cosas en los Estados Unidos: "nunca más América necesitaría fijarse en Europa, más bien lo contrario. Y no sólo Europa, sino el resto del mundo, desde los confines del mapa-Australia, Nueva Zelanda, Sudáfrica, etc.-, de repente, todas las miradas apuntaban en esa dirección. Si esto es lo que significa estar a la vanguardia, entonces podría argumentarse que 1949 o, en cualquier caso, los años que siguieron al final de la guerra, coinciden con el inicio de una vanguardia arquitectónica americana [...] O, quizás, es el principio del fin: 1949 es el compendio de lo que ocurría en la arquitectura de Estados Unidos durante la posguerra pero que pronto cambiaría completamente de rumbo".

317. Henry-Russell HITCHCOCK: "An Eastern Critic Looks at Western Architecture", en California Arts \& Architecture, diciembre 1940, p. 222.

318. Justamente en el prólogo al libro sobre Schindler publicado por David Gebhard en 1971. Op. cit., p.9.

319. Ibid., p. 204

320. Cfr. Margaret CRAWFORD: "Olvidando y recordando a Schindler: la historia arquitectónica de una reputación arquitectónica", en 2G, nº 7 . Revista Internacional de Arquitectura: Schindler. Op. cit., pp. 136-137.

321. The Architecture of R. M. Schindler. Museum of Contemporary Art, Los Ángeles, exposición monográfica sobre el arquitecto, febrero-junio de 2001, comisariada por Elizabeth A. T. Smith y Michael Darling. (Catálogo homónimo por Michael DARLING y Elizabeth A. T. SMITH (eds.): Op. cit.).Exhibida posteriormente en Washington y Viena ha sido hasta el momento la muestra más completa sobre el trabajo del arquitecto. La exposición recopilaba dibujos originales, fotografías actuales y de archivo, maquetas, y piezas de mobiliario presentadas según un montaje inspirado en los propios interiores de Schindler. Como en éstos, se procuró emplear materiales económicos (laminados, cartones, papeles, plásticos corrugados, etc.) que envolvían el espacio recorriendo de manera continua techos y paredes, conformando esquinas, prolongándose para formar asientos, etc.

322. En España, la citada tesis doctoral de Juan Coll-Barreu, publicada en 2004, ha prestado una especial atención a los últimos proyectos del arquitecto, haciendo precisamente de la casa Tischler el motivo conductor de uno de los cinco capítulos que conforman su trabajo. Véase Juan COLL-BARREU: Op. cit., pp. 209-233.

323. Judith SHEINE: R. M. Schindler 1887-1953. En 2G, $\mathrm{n}^{\circ} 7$, Schindler. Op. cit., p. 23. 324. David GEBHARD: Rudolph Schindler. Op. cit., p.204 325. Ibid., p. 219 326. Juan COLL-BARREU: Op. cit., p. 255 327. Ibid., p. 251 328. Ibid., p. 253 329. Ibid., pp. 254-255. 330. David GEBHARD y Robert WINTER: Los Angeles. An architectural guide. Op. cit., p. 109 331. Cfr. Esther McCoy: Five California Architects. Op. cit., p. 168.

332. El coste total, incluyendo los honorarios del arquitecto, ascendió a 16.000 dólares, habiéndose incrementado muy poco sobre el presupuesto inicialmente previsto. También en esta casa, como era habitual para Schindler, él mismo se ocupó del proyecto, del cálculo de estructuras, de la gestión de permisos y préstamos y de la contratación de la obra. Procediendo de este modo, Schindler ahorraba dinero a sus clientes evitándoles intermediarios y, a su vez, él obtenía un dinero extra, siempre necesario para compensar sus limitados ingresos. 
333. Desde su conclusión en 1950 el estado de la casa ha variado muy poco, especialmente si se tiene en cuenta que sus propietarios originales llevan ocupándola desde hace seis décadas. El cierre del garaje puede ser quizás lo más evidente junto con las modificaciones introducidas en los paneles de cubrición. Inicialmente, buscando el efecto pictórico de las sombras de los árboles arrojadas sobre la cubierta traslúcida, y también para que éstas evitaran la exposición directa de las planchas al sol, Schindler pensó plantar dos filas de eucaliptos paralelas a la casa. El diseño del jardín ni se completó como estaba previsto, ni resultó ser suficiente, por lo que los Tischler ocultaron parte del techo con paneles de madera para mitigar el efecto invernadero que producía el calor retenido por el plástico. El matrimonio, cansado del perturbador efecto de la estructura negra con sus líneas ribeteadas en plata, también terminó pintando la madera en tonos claros. Sin embargo, lejos de plantear quejas -como tantos casos conocidos de clientes que denunciaron a sus arquitectos modernos por goteras, falta de aislamiento o problemas de privacidad- los Tischler asumieron tranquilamente todas estas alteraciones considerándolas simplemente como inevitables reajustes. Durante la entrevista mantenida en su casa con Adolph Tischler éste -platero y orfebre de profesión- habló con veneración de Schindler, de quien afirmó "Después de tanto tiempo me doy cuenta del acierto de haber escogido a Schindler como arquitecto. Mi mujer y yo hemos vivido tan bien aquí que puedo afirmar que, en mi caso, construirme esta vivienda ha sido una de las dos o tres decisiones más acertadas que he tomado en mi vida". 


\section{Discípulos Y MAESTROS}

[ RICHARD NEUTRA Y LA IDEALIZACIÓN PUBLICITARIA DE LA TECNOLOGía EN AMÉRICA

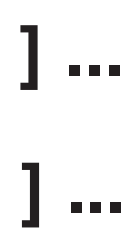

[ HARWELL HAMILTON HARRIS EN CALIFORNIA I.

[ GORDON DRAKE: NO MAN IS AN ISLAND ] ... 
"Mi asociación con Neutra fue sobre todo para aprender. Aprendí trabajando en sus proyectos. Niguno de los proyectos en los que participé, exceptuando la casa Lovell [...] fue nunca construido. Aquellos proyectos teóricos me enseñaron mucho más de lo que podría haber aprendido detallando planos de obra para edificios reales. Fueron el Concurso para el Lehigh Portland Cement Airport, el proyecto Rush City Reformed, la Ring Plan School y los CIAM. Greg Ain era el otro asociado en aquellos proyectos (Neutra nos llamaba 'colaboradores') [...] De todas las lecciones que aprendí de Neutra la integración fue la más importante [...] cómo una cosa lleva a otra, cómo dos cosas producen otra distinta, todo estaba ahí..."

Harwell Hamilton Harris sobre Richard Neutra

"Conocía Gordon cuando era estudiante. De hecho, era uno de los doce que, en 1940, asistían a mis clases en la Universidad del Sur de California [...] Realmente, no recuerdo que fuera capaz de terminar ninguno de sus dibujos. Una vez se sentía satisfecho con el trabajo realizado, encontrando que no había nada más que descubrir [...] lo abandonaba y se centraba en otro problema. Sabiendo esa faceta suya aún me sorprende que le permitiera venir a trabajar conmigo el otoño siguiente. [...] Fue impaciente con el final de la guerra. Fue también impaciente con su propia lentitud pero, sobre todo, con la falta de voluntad de los demás para tratar de comprenderle. Estaba seguro de que la arquitectura era el camino: confiaba en que en el momento en que alcanzara la simplicidad, la unidad y el auténtico significado de su arquitectura también lograría ser dueño de su propia vida [...] Apenas había empezado cuando murió"

Harwell Hamilton Harris sobre Gordon Drake

Harwell Hamilton Harris tenía 25 años cuando llegó al estudio de Richard Neutra en 1928. Neutra residía todavía en Kings Road y ultimaba los planos de ejecución de la Lovell Health House. Su principal colaborador hasta ese momento, Gregory Ain, había sido el responsable de redibujar casi todo el proyecto. Harris ayudó durante la última semana previa al inicio de las obras, asistiendo a su amigo en la elaboración de los detalles pendientes de la que habría de convertirse en una de las viviendas más mediáticas de todo el siglo Xx.

Durante la construcción de la Lovell House, Neutra impartió clases de arquitectura moderna a un selecto grupo de alumnos que le acompañaron a las obras de la casa en diversas ocasiones. El arquitecto se retrató rodeado de ellos, haciendo ver que aquella obra fundacional era más que un edificio, era toda una escuela donde él, como maestro, estaba formando a la siguiente generación de arquitectos modernos californianos.

Harris asistió a aquellas clases donde no sólo disfrutó únicamente de la oportunidad de aprender a proyectar de la mano de Neutra. Se vio inmerso en una nueva metodología de trabajo y en un pensamiento moderno que entendía la arquitectura no sólo desde el potencial de su nueva relación con los medios de comunicación sino -por utilizar una expresión de Beatriz Colomina-a ella misma como un medio más de comunicación. El propio Bruno Zevi, el primer crítico que consagró un libro enteramente a Neutra afirmó que "mientras otros inventaron la arquitectura moderna Neutra se dedicó a hacerla prestigiosa"3. 


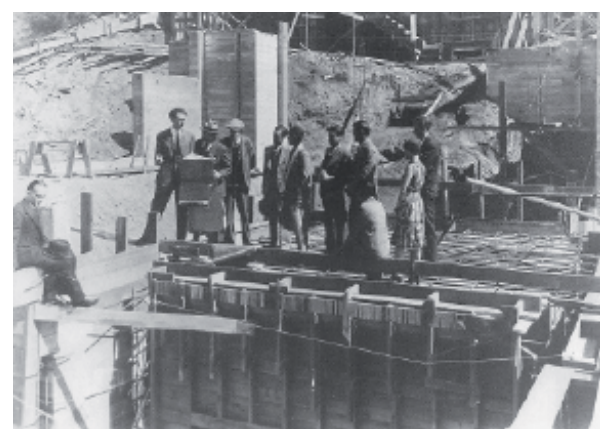

Richard Neutra: Lovell Health House en construcción. Clase y visita de obra a sus discípulos de la Academy of Modern Art, 1929. Fotografía de Willard Morgan. Harris es el quinto personaje por la izquierda.
Durante el tiempo que duró su asociación con Neutra, Harris asistió a la orquestación por parte de su mentor de una formidable campaña publicitaria para promocionar la casa Lovell como representación de su ideal arquitectónico, para dar a conocer la exposición del MoMA fuera de los círculos del museo y, por supuesto, para fabricarse una reputación a escala internacional.

Harris entendió perfectamente el alcance público de lo doméstico y por ello se movió de manera sobresaliente en ambas dimensiones. Recurriendo de nuevo a las tesis de Colomina podría decirse que, a través de Neutra, Harris aprendió que la era de la publicidad había cambiado para siempre el estatus de lo privado. La arquitectura moderna estaba transformando la relación tradicional entre lo público y lo privado de un modo que alteraría profundamente la experiencia del espacio. Pruebas de la pericia de Harris para moverse en la difusa línea entre lo público y lo privado serían: la exitosa experiencia de su colaboración con John Entenza en su vivienda de Santa Mónica; la discreta gestión de sus desencuentros profesionales con el futuro editor de Arts \& Architecture; o el episodio arquitectónico y editorial de la Weston Havens House, una de las casas modernas con mayor difusión en los medios de la época y que, gracias al celo del arquitecto por salvaguardar la intimidad de su cliente, la publicidad garantizó su privacidad al poner a la vista de todo el mundo aquellas formas de vida que, precisamente, se pretendían ocultar.

Cuando Drake fue admitido en el estudio de Harris tenía también aproximadamente la misma edad con la que éste había conoció a Neutra. Comenzó trabajando en la Weston Havens House, concluida pocas semanas antes de la entrada de los Estados Unidos en la Segunda Guerra Mundial. En cierto modo era un ciclo que se cerraba pues, si aquél había asistido a la casa que había construido la fama de Richard Neutra, Gordon Drake participaba también de la obra más célebre de Harwell Hamilton Harris. Asimismo, como su maestro había hecho durante su estancia en la oficina de Neutra, Drake aprendió de Harris los entresijos de los medios de comunicación. Si Harris había podido ver desfilar un elenco de fotógrafos por la Lovell House, Drake presenció las infinitas pruebas de imagen realizadas en esta obra hasta que Harris estuvo satisfecho con una determinada forma de mostrar su arquitectura. Por su afinidad de caracteres, Drake entabló amistad con Julius Shulman, el fotógrafo más mediático de posguerra y el más hábil publicista de la arquitectura de Los Ángeles exceptuando a los propios arquitectos. Las imágenes que Shulman tomó de la casa de Drake en Los Ángeles, terminada en 1946, catapultaron a una joven promesa con la que inmediatamente se entusiasmaron las redacciones de algunas de las revistas de arquitectura más prestigiosas de la época (aunque en la actualidad sea difícil recordar el nombre de Gordon Drake fuera de círculos muy especializados de California). De la decena de viviendas unifamiliares construidas por Drake, apenas un par son reconocibles en el presente; el resto, sencillamente han desaparecido. De tal modo que, si el objetivo de Shulman no se hubiera detenido en sus obras, el rastro de Gordon Drake habría desaparecido de la historia de la arquitectura4. 
[ RICHARD NEUTRA Y LA IDEALIZACIÓN PUBLICITARIA DE LA TECNOLOGía EN AMÉRICA

] ...

HARWELL HAMILTON HARRIS EN CALIFORNIA

[ GORDON DRAKE\# NO MAN IS AN ISLAND] "." 


\section{¿Cómo se construye en California?}

Los primeros cinco años de Richard Neutra en Los Ángeles (1925-1930) representan un corto espacio de tiempo en su dilatada carrera de más de cuatro décadas, si bien, resultaron cruciales en la evolución posterior de su trayectoria como arquitecto. Se trata de un periodo de reflexión muy fecundo, primero en solitario y, después, a partir de finales de 1928, en compañía de sus discípulos y colaboradores Gregory Ain y Harwell Hamilton Harris, con quienes trabajó en sus dos proyectos más significativos del momento: la casa Lovell (1928-29) y el desarrollo de su modelo urbano Rush City Reformed (1925-30). Como argumenta Marc Boutin, ambos constituyen "diseños seminales y significantes del siglo $x x$, en cuanto que vehiculaban todo el potencial de la tecnología y la planificación americanas en una manifestación arquitectónica y urbana. Ambos atestiguaban y, de hecho, simbolizaban la culminación de la idealización de la tecnología como arquitectura moderna"s.

En el ámbito del urbanismo, el proyecto teórico Rush City Reformed supuso la contribución de Neutra a los modelos urbanos planteados por otros maestros modernos durante los años 20. Pero a diferencia de propuestas como La Ville Contemporaine o Broadacre City, el de Neutra no es estrictamente un modelo utópico, sino que se trata, más bien, del análisis de las macro tendencias de la ciudad norteamericana, de un ensayo teórico de soluciones basadas en datos y hechos objetivos, como la técnicas de planificación y los sistemas de transporte existentes en los Estados Unidos, cuyos resultados podrían extrapolarse a la evolución futura de las nuevas metrópolis.

Respecto a la casa Lovell, ésta puede entenderse como la cristalización de sus esfuerzos iniciales por hacer realidad su visión de una arquitectura basada en las prácticas constructivas que había encontrado en los Estados Unidos y a cuya descripción consagró su primer libro Wie Baut Amerika? (¿Cómo construye América?). En efecto, Neutra entendió este encargo como una oportunidad para lograr una expresión arquitectónica universal a partir del paradigma industrial norteamericano en cuya conceptualización llevaba trabajando desde su llegada al país.

Gracias a la perseverancia de Neutra y de sus suegros, Alfred y Lilly Niedermann, que actuaban como representantes suyos en Europa, Wie Baut Amerika? fue publicado en enero de 1927 por Julius Hoffmann en Stuttgart. El libro, ilustrado con alrededor de 100 imágenes tuvo una tirada inicial de 4.400 copias y fue el primer número de una importante colección ${ }^{6}$ que continuó con los textos de Ludwig Hilberseimer?.

Pocas semanas antes de abandonar Kings Road, Pauline Schindler escribió una apasionada crítica sobre Wie Baut Amerika? que apareció publicada de manera anónima a principios de agosto de 1927 en Los Angeles City Bulletin ${ }^{8}$. Neutra había terminado la redacción del texto en casa de los Schindler por lo que, muy probablemente, Pauline habría discutido con él su manuscrito obteniendo numerosas explicaciones que le habrían resultado de gran utilidad para su artículo. Por esta razón, Thomas Hines ${ }^{9}$ sostiene que Pauline consiguió trasmitir el mensaje de Neutra mejor que ninguna otra reseña contemporánea sobre el libro.

Pauline Schindler argumentaba que Wie Baut Amerika? era una auténtica expresión arquitectónica de la modernidad, una afirmación del aprecio de Neutra por la civilización y la arquitectura norteamericanas. Resumiendo en muy pocos párrafos la ideología de su autor, Pauline escribía: "La edificación y el 


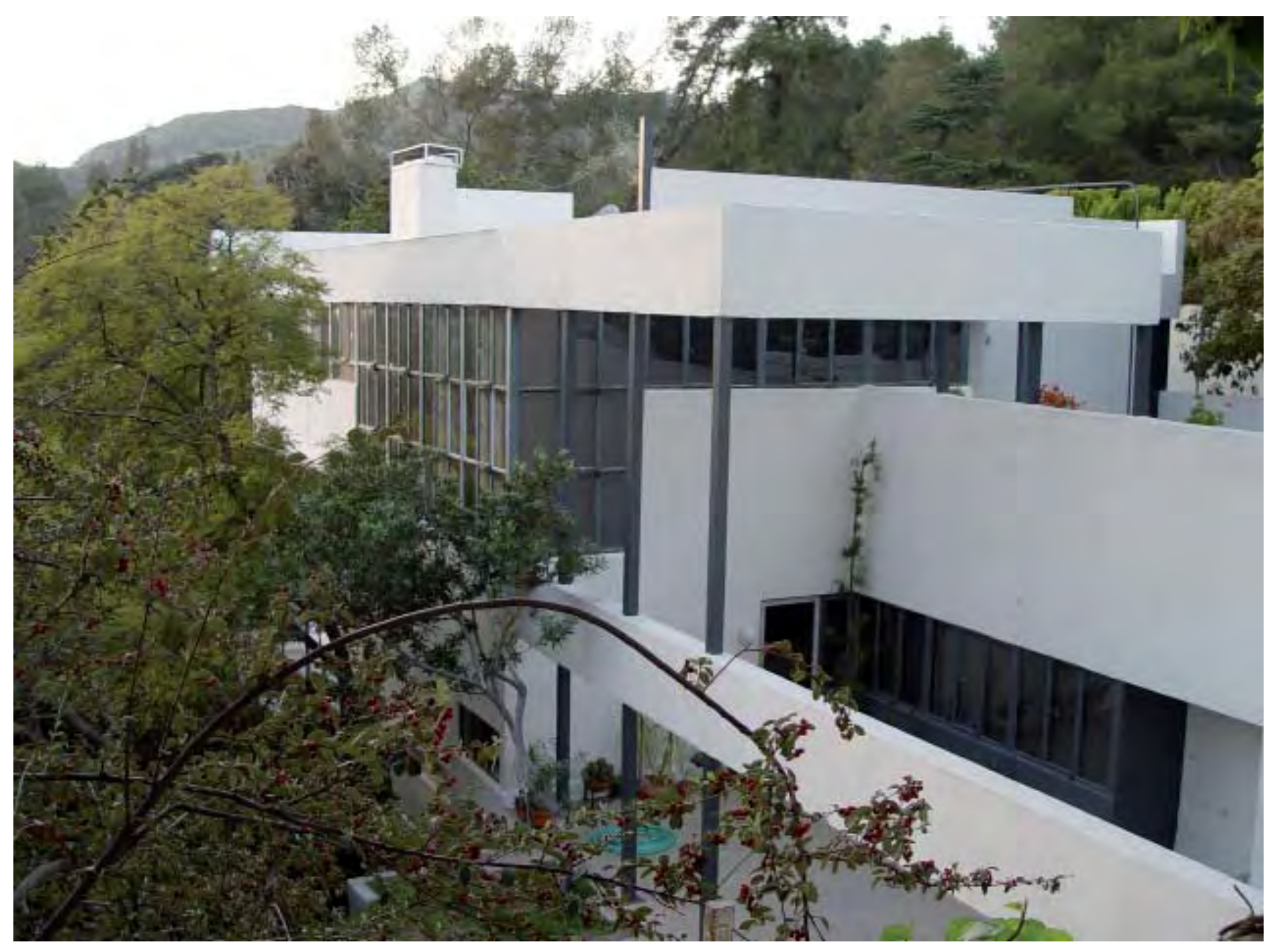

Richard Neutra: Lovell Health House, 1927-29. Estado actual, fotografía del autor

Página siguiente arriba y abajo: Páginas de Wie Baut Amerika? Proceso de construcción del Palmer Hotel House, 1927 planeamiento urbano no deberían tener que ver sólo con la decoración superficial y el diseño ornamental [...] Los viejos símbolos ya no tienen sentido. Rápidos cambios sociales y económicos están transformando nuestra manera de vivir. La imparable industrialización y acumulación de población hacen urgente la necesidad de viviendas para la clase trabajadora, reajustes en los transportes y en el tráfico [...] en esta época descrita en términos artísticos como árida, una nueva arquitectura está tomando forma a partir de estos problemas impelidos, por un lado, por las fuerzas e intereses que modelan las ciudades $y$, por otro, por el mercado inmobiliario [...] esta nueva arquitectura ya no puede ser creada sólo por los arquitectos sino por las diferentes especialidades y productores de la nueva industria de la edificación [...] estos factores, supliendo y controlando la demanda nacional de vivienda requieren de la producción en masa, de la prefabricación que mejore los resultados, eleve los estándares y cree un nuevo tipo de calidad"10.

Casi un año más tarde, en junio de 1928, Henry-Russell Hitchcock respaldaba a Neutra con una nueva reseña sobre Wie Baut Amerika? publicada en Architectural Record. Hitchcok se mostraba entusiasmado por haber encontrado un joven relevo a Wright, una nueva voz en su país que por fin celebraba la realidad tecnológica norteamericana como el escenario más propicio para la nueva arquitectura. El crítico elevaba las reflexiones de Neutra a la altura de las teorías de arquitectos europeos del prestigio de Corbusier, Gropius, Mies y Oud y, obviando por completo -e incluso menospreciando implícitamente la figura de Schindler- afirmaba sin titubeos que Neutra era: "[...] uno de escasísimos arquitectos que trabajan en este país -exceptuando a Wright, de 
quien es el único discípulo formado en el extranjero que merece la pena- que están plenamente convencidos, como los líderes de la arquitectura francesa, alemana y holandesa, de la relación esencial entre el diseño moderno y los medios y materiales de los que éste se vale. Tanto para el arquitecto de 'Rush City', como para los arquitectos de Pessac, Dessau, o de Rotterdam, la arquitectura es la cristalización estética de las soluciones ingenieriles a los problemas de la edificación. De nuevo, la creación, como en los tiempos de las grandes arquitecturas estructurales del pasado es una posibilidad, que en ningún otro sitio se hace tan real como en América $^{\prime \prime 11}$. Esa posibilidad era precisamente el núcleo del discurso de Wie Baut Amerika?

Neutra descubrió en la tecnología norteamericana de su tiempo las ideas que habían sido proyectadas hacia el futuro por la modernidad europea. Es decir, mientras que las vanguardias trataban de anticipar el futuro en el presente, Neutra actuó en el sentido contrario al proponer el presente de la tecnología de su país de adopción como el futuro de la arquitectura internacional y, por tanto, la universalidad de una nueva práctica.

Éste es uno de los argumentos de Marc Boutin quien, en su tesis sobre el arquitecto y su idealización de la tecnología en América sostenía que el mensaje de Wie Baut Amerika? derivaba del "compromiso de Neutra por determinar lo factual y lo universal en las condiciones existentes en América ${ }^{112}$ y, a partir de ahí proponer una arquitectura inseparable de esas condiciones y que evolucionara en paralelo a ellas.

En su monografía sobre el arquitecto, Esther McCoy señaló que Neutra había podido comprobar cómo los grandes despachos de arquitectura e ingeniería estadounidenses se habían convertido en exitosas máquinas de gestión cuyo funcionamiento bordeaba o dejaba de lado el hecho arquitectónico ${ }^{13}$. Neutra se había dado cuenta de que, precisamente por ello, las salas de dibujo de estos despachos no podían ser mejores como campos de entrenamiento para los futuros arquitectos. A partir de su inmersión en esta realidad Wie Baut Amerika? no sólo reflexionaba sobre el paradigma industrial norteamericano sino que, además, construía todo un discurso legitimador de la misión de su autor de establecer las bases para una nueva arquitectura.

Neutra concibió las ideas de su primer libro a mediados de 1924, poco después de su llegada a Chicago. Durante casi un año colaboró en la oficina de Holabird \& Roche. En esa época, la firma ultimaba el proyecto del nuevo Palmer House Hotel, que debía albergar 2.400 habitaciones. El arquitecto fue asignado a pie de obra a controlar los detalles de la ejecución. En un primer momento, su tarea consistió en detallar los huecos de ascensores para, poco después, actuar de enlace entre los diseñadores y todos los departamentos relacionados con los diferentes oficios. Este trabajo supuso para él su primera oportunidad de observar desde la primera línea de acción el modo en que se organizaba la construcción de un gran edificio en Norteamérica. Durante los meses que duró su ejecución Neutra tomó notas de todo el proceso, documentando por escrito y sacando fotografías de cualquier acontecimiento que tenía lugar en obra. Dichas notas, una vez elaboradas y convenientemente ilustradas, constituyen el núcleo de Wie Baut Amerika?

El libro tuvo una gran acogida en Europa, especialmente tras la favorable reseña de Henry-Russell Hitchcock en Architectural Record, siendo sobre todo los críticos alemanes quienes elogiaron el modo en que "su estilo pretendidamente científico se alejaba [...] del lirismo utópico de Le Corbusier" ${ }^{\prime \prime 14}$.
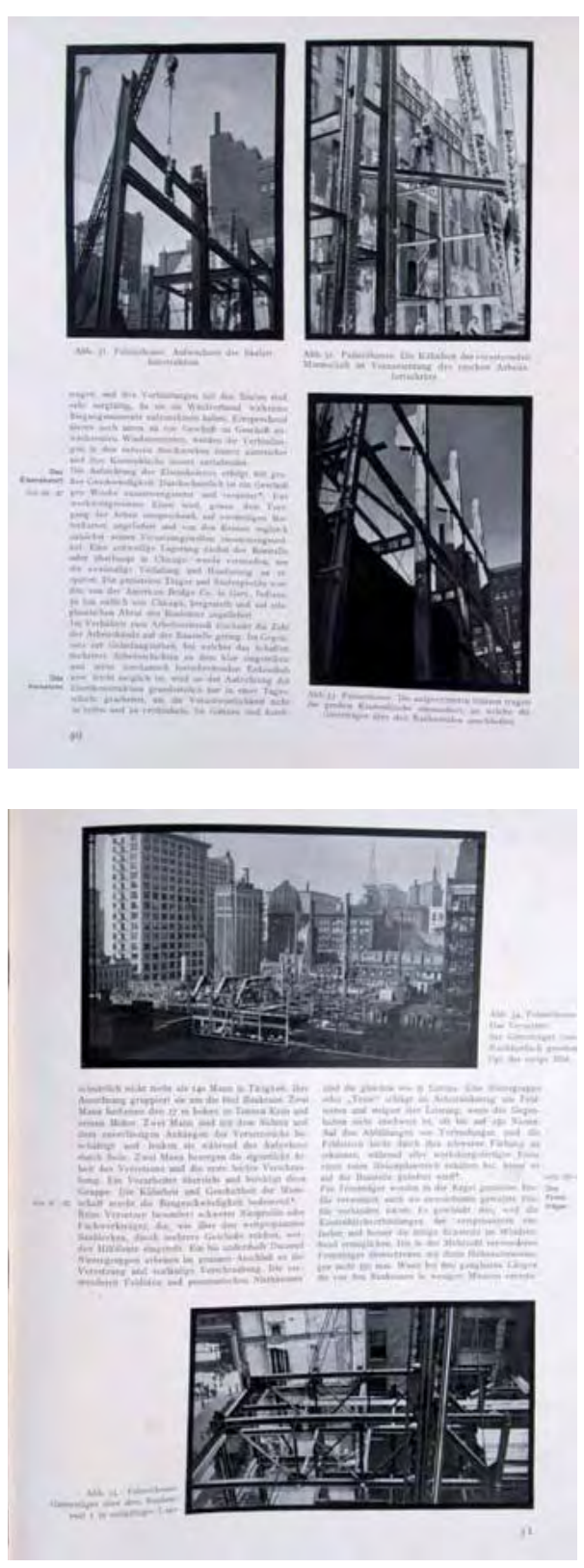
Wie Baut Amerika? Proceso de construcción del Palmer Hotel House, 1927

Página siguiente arriba: Montaje de la estructura de acero de la Lovell House. Fotografía de Willard Morgan, 1929

Página siguiente centro: Proyección del hormigón en la solera de la Lovell House. Fotografía de Willard Morgan, 1929

Página siguiente abajo: Imagen de conjunto de la obra de la Lovell House. Fotografía de Willard Morgan, 1929
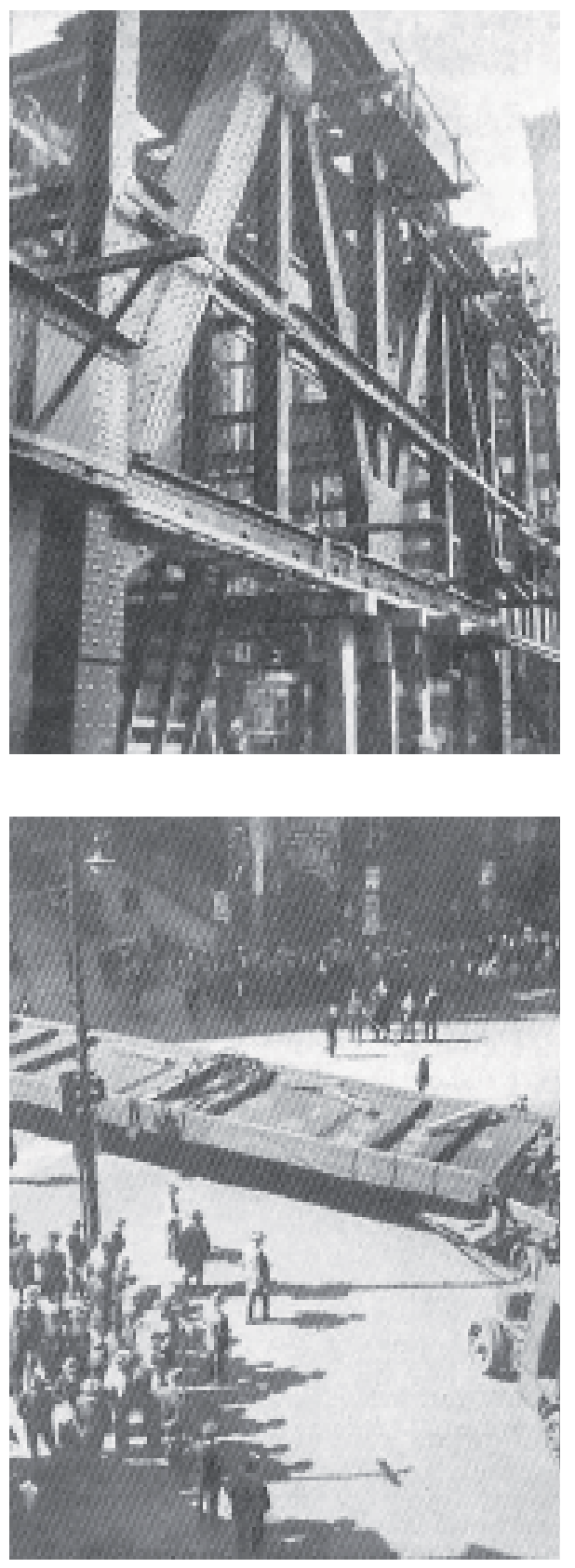

De hecho, antes incluso de la asociación establecida por Hitchcock entre el trabajo de Neutra y el de Le Corbusier, las publicaciones europeas habían realizado también la inevitable comparación entre las diferentes aproximaciones de ambos arquitectos a la tecnología. Por ejemplo, la revista suiza Magazine for Politics and Culture en su reseña de Wie Baut Amerika? distinguía claramente entre la carga utópica y literaria de los manifiestos de Le Corbusier y el pragmatismo de las ideas de Richard Neutra afirmando, entre otras cuestiones, que este libro debería ser del "[...] interés de todos aquellos lectores preocupados por las nuevas condiciones económicas y sociales del presente"15 así como que Neutra, "un hombre que procede desde la más impecable lógica, es un trabajador que dice sólo lo que puede probar, que proyecta únicamente lo que es capaz de construir"16.

Incidiendo en esta oposición, Thomas Hines sostenía que, durante la participación de ambos arquitectos en el CIAM III de Bruselas (1930): "Le Corbusier remitió a muchas de las intuiciones expresadas en Vers une Architecture (1923) y en sus últimos escritos sobre la Ville Radieuse. Por su parte, la propuesta de Richard Neutra, menos visionaria, más pragmática, hizo alusión a los planteamientos de Wie Baut Amerika? Tanto en su libro como en la conferencia de Bruselas, Neutra conquistó a la audiencia con sus descripciones de lo que entonces todavía se consideraba el nuevo y sorprendente fenómeno de la gran escala y a gran altura de la construcción civil y la edificación americana"17.

Wie Baut Amerika? es un compendio de textos en los que se abordan múltiples cuestiones. Neutra escribió sobre los innovadores métodos de construcción empleados en Chicago, enfatizando el nivel de desarrollo de la industria norteamericana; incluyó análisis de edificios de otros arquitectos; y deslizó propuestas teóricas suyas, cuyas imágenes a veces eran lo suficientemente ambiguas como para que el lector pudiera tener la impresión de que podían tener algún viso de materialidad. Una mezcla deliberadamente confusa en la que, como en sus artículos enviados a Europa, primaba el objetivo publicitario de presentarse a sí mismo desde una envidiable posición de testigo y actor del escenario que relataba.

El libro estaba estructurado en tres partes que corresponden, aproximadamente, con un tercio del mismo cada una.

La primera de ellas se ocupa de la descripción de la realidad de la ciudad norteamericana, sus dinámicas y su problemática. América era para los arquitectos europeos el país de los rascacielos, las fábricas y los automóviles. Los rascacielos ocupan buena parte de esta primera sección, sus normativas técnicas, las disposiciones sobre sus retranqueos en Nueva York y diferentes ejemplos de esta tipología en Manhattan y en el centro de Chicago. La producción industrial y los sistemas de transporte eran otro de los intereses de Neutra en este apartado, pues de ellos dependía la planificación urbana y la colonización del territorio. Imágenes de las infraestructuras del transporte, estaciones e intercambiadores pueblan esta primera parte, donde Neutra mezcla con destreza fotografías de edificios reales con las imágenes producidas para su proyecto de urbanismo teórico Rush City.

La segunda parte de Wie Baut Amerika?, la más significativa, está dedicada enteramente al proyecto y al proceso de construcción del Palmer House Hotel. En esta sección, Neutra manejó los datos con la destreza de un gestor y la astucia de un publicista. A partir de la información recopilada armó una crónica de las obras que entusiasmó a sus destinatarios europeos por 
la heroicidad de sus cifras, convenientemente administradas a lo largo de las páginas del libro. La cantidad de material, el número de operarios o los tiempos de montaje del Palmer House Hotel revelaban el prodigio de la tecnología norteamericana. Según informaba a sus lectores, en aquel edificio se habían empleado 17.000 toneladas de acero en perfiles prefabricados y atornillados directamente en obra por 140 operarios que manejaban 5 grúas simultáneamente ${ }^{18}$. Aunque sobre todo el arquitecto cargó las tintas en la gestión de las obras, enfatizando su logística y su eficacia dignas de una cadena de montaje de Henry Ford: el hotel crecía al ritmo de una planta por semana; el hormigón se vertía diariamente en dos momentos, uno por la mañana y otro por la noche; y para evitar acopios innecesarios la estructura se producía y enviaba directamente desde fábrica cada domingo según una ruta y unos horarios perfectamente planificados para no interferir con el tráfico de la ciudad.

En esta parte del libro son impactantes las imágenes de las secciones de acero transportadas por las avenidas de Chicago hasta su emplazamiento definitivo. El propio Neutra fotografió ese despliegue de medios y presentó la evolución de las obras del hotel de una manera casi cinematográfica, creciendo, como la ciudad norteamericana, a un ritmo trepidante. Reparando en esas instantáneas se adivina ya el mismo sentido del drama con el que, más tarde, el arquitecto haría fotografiar a Willard Morgan la ejecución de la estructura de acero de la Lovell Health House.

El libro vio la luz poco antes de que concluyese la construcción del edificio. La fecha de la publicación y la ausencia de imágenes de la obra terminada no son una casualidad. Neutra quería dejar claro que no le interesaba el resultado final; un edificio de estructura metálica revestido con una fachada beauxartiana, absolutamente ajena a la innovación tecnológica y a la complejidad organizativa de la obra.

Finalmente, la tercera sección del libro se centraba en el contexto de California. Esta última parte estaba ilustrada con imágenes que Neutra, como fotógrafo amateur, había tomado en sus continuos desplazamientos por la región. Fascinado con sus paisajes y armado con su pequeña cámara portátil tomó instantáneas "del océano, los bosques, el desierto, la nieve, las palmeras [...] todo en tres horas conduciendo"199 $\mathrm{El}$ arquitecto fotografió y reprodujo en su libro las arquitecturas californianas que consideró más representativas de los avanzados métodos constructivos empleados en California, como las viviendas de bloque textil Wright (1923-25) y los apartamentos Pueblo Ribera de Schindler en La Jolla (1923).

El interés de Neutra por dar a conocer en Europa a los pioneros de la arquitectura californiana continuó durante los meses siguientes a la publicación de Wie Baut Amerika? Así, en el número de septiembre de 1928 de Das Neue Frankfurt, el arquitecto publicó un artículo ${ }^{20}$ donde planteaba una genealogía de los arquitectos norteamericanos de Sullivan a Irving Gill pasando por la figura de Wright. Neutra situó a Irving Gill en el arranque de la tradición moderna de California y utilizó su obra para explicar aspectos de su propio trabajo y dar a conocer la originalidad del movimiento local, sus aportaciones constructivas y sus relaciones con la modernidad internacional.

Se ha tratado con cierta frecuencia acerca de la aparente similitud entre Irving Gill y Adolf Loos, una semejanza recurrente para explicar determinados aspectos de la obra del arquitecto californiano. Sin embargo, el parecido en-
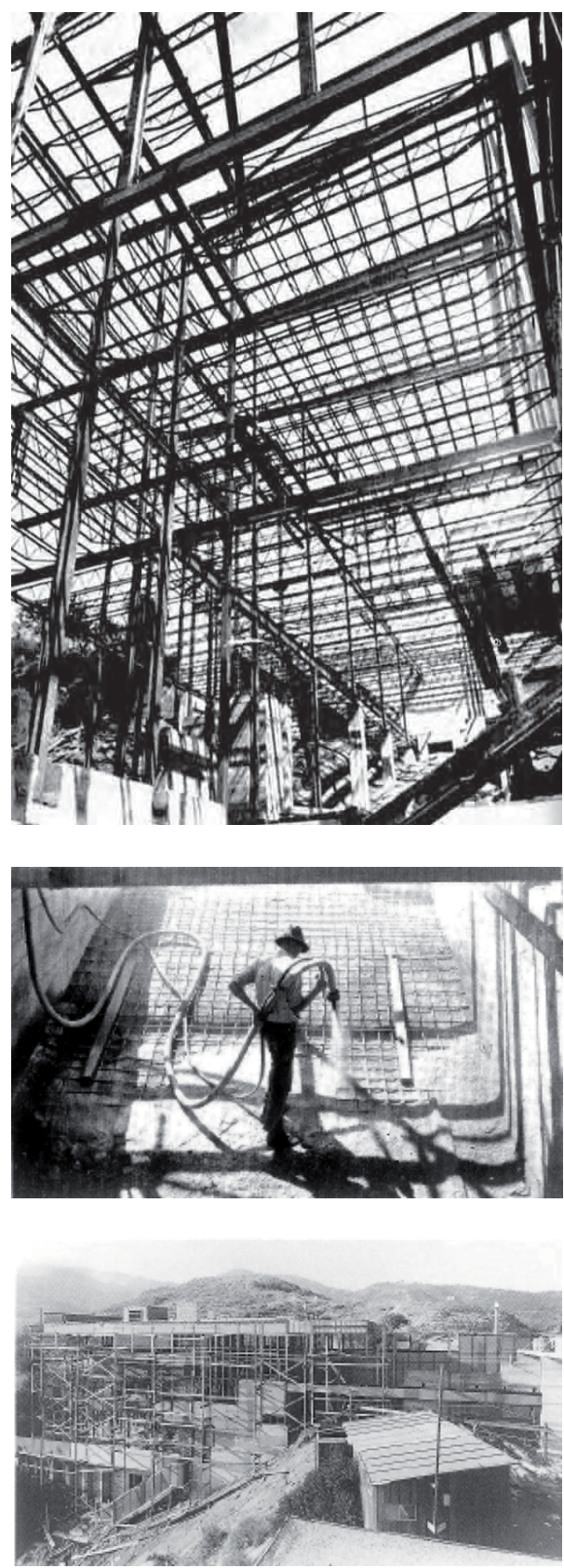

aspectos de la obra delarquitecto californiano. Sin embargo, el parecido en- 
Arriba: Richard Neutra: Lovell Health House, primer dibujo de conjunto, hacia finales 1927. Fuente: Thomas Hines

Abajo: Irving Gill: Dodge House en Kings Road, West Hollywood, 1916. Fuente: Esther McCoy, Five California Architects

Página siguiente: Fotografía de Willard Morgan de la estructura de acero de la casa Lovell, 1929. Fuente: Barbara Lamprecht

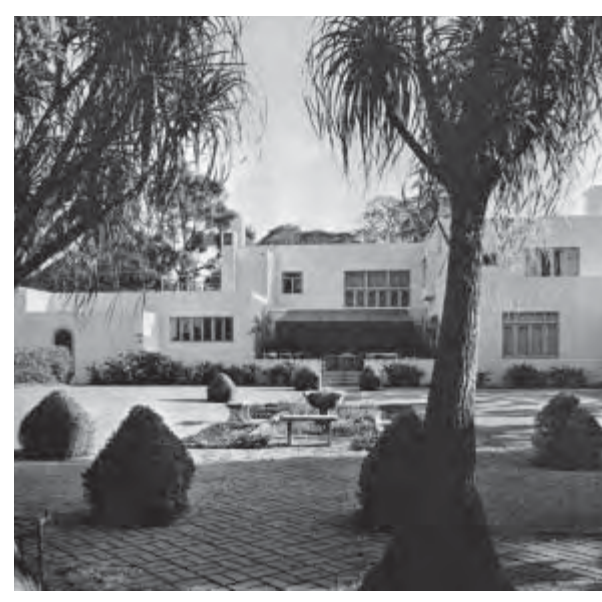

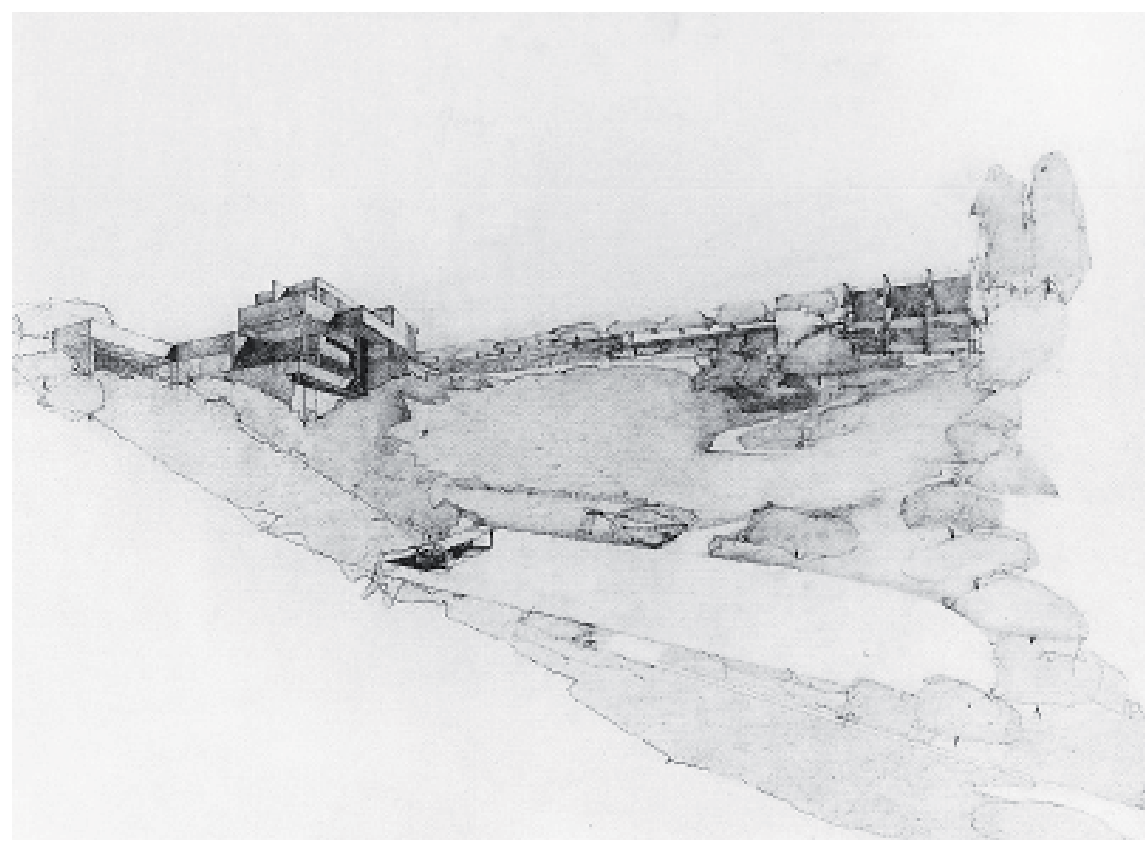

tre uno y otro no debe ser considerado más allá de una mera anécdota visual. Las fachadas abstractas de las casas de Loos responden a su obsesión por huir del exhibicionismo y por evitar cualquier posibilidad de proyección pública de la vida privada de sus habitantes. En el caso de Gill, la desornamentación de sus exteriores es consecuencia de un sistema constructivo que, por razones prácticas, requería la simplificación -probablemente del estilo que tenía más próximo, el Spanish Revival. El interés de Irving Gill reside en lo novedoso de su tecnología y no en sus espacios. Incluso en su obra maestra, la Dodge House de 1916, las plantas son poco satisfactorias y los detalles torpes, produciendo un resultado diametralmente opuesto a la extraordinaria complejidad y finura de los interiores de Adolf Loos.

Neutra por supuesto no cayó en esa trampa y recurrió a Irving Gill para demostrar la capacidad de invención de la arquitectura californiana. Le interesaba poner en valor el contexto cultural de California, un lugar que había propiciado por un camino eminentemente tecnológico soluciones próximas a las utopías de la modernidad europea -y, al mismo tiempo, presentarse a sí mismo como partícipe de esa lógica arquitectónica.

Al margen de señalar una vez más las estrategias publicitarias de Richard Neutra, es importante señalar algunas de las paradojas que supuso la traslación directa de las ideas de Wie Baut Amerika? al diseño de la obra que pretendía ser su enunciado práctico, la Lovell Health House.

Por un lado, mientras que Wie Baut Amerika? exploraba de forma especulativa la relación entre arquitectura y tecnología, la casa Lovell tuvo que abordar dicha relación desde un salto cualitativo a la especificidad de las condiciones socioeconómicas del medio californiano. Para empezar, Neutra quiso trasladar al caso concreto de una única vivienda una tecnología concebida para la producción a gran escala. La estructura de acero descrita en el libro como solución universal no era en absoluto un sistema constructivo disponible para esa tipología residencial en 1929. Y mucho menos económico ya que sólo ésta costó 37.000 dólares ${ }^{21}$, más de la mitad del presupuesto total de la vivienda. De hecho, hasta después de la guerra no estuvo lista con precios asequibles y aun así, nunca fue una forma de construcción habitual en California, donde la madera y los derivados industriales de este 


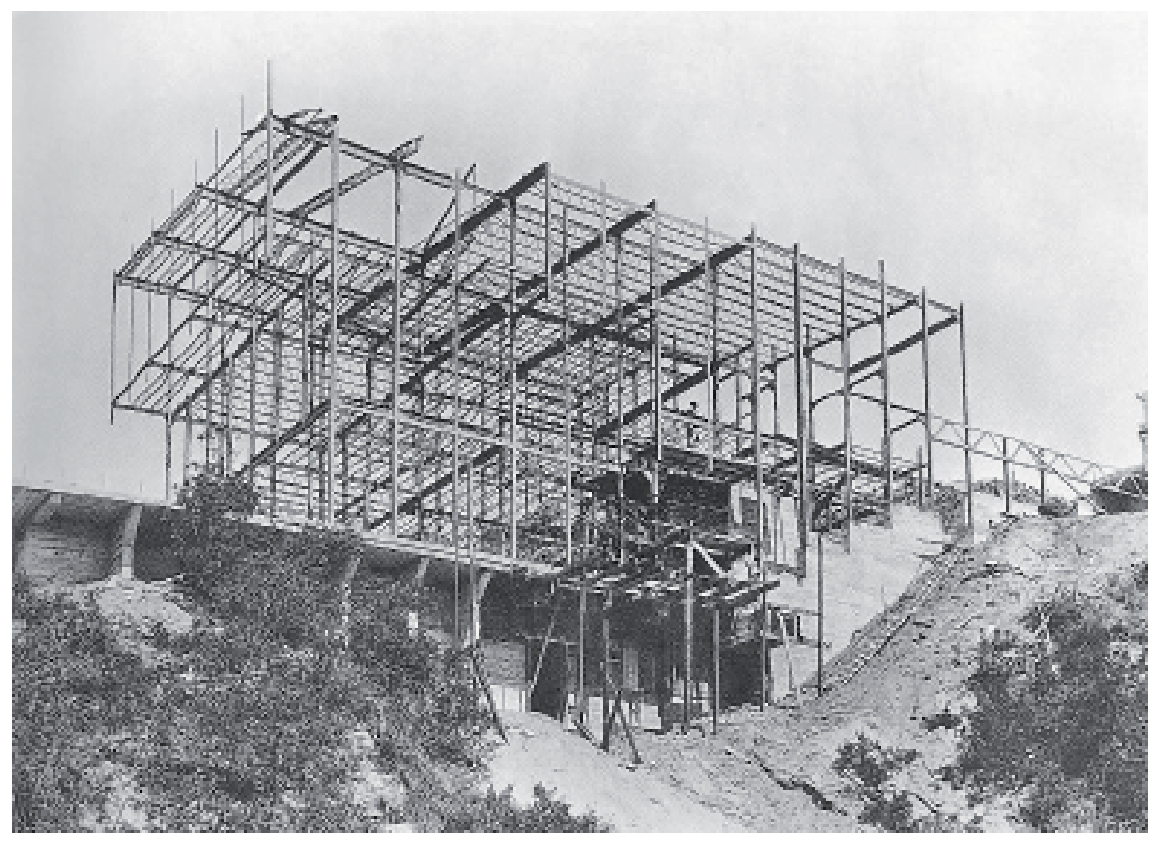

material dominaban el mercado de la vivienda desde hacía décadas, desde los entramados de madera para revestir a las estructuras post-and-beam, o incluso las fachadas prefabricadas de los bungalows.

Por otro lado, desde el punto de vista de su dimensión significante, al convertir la casa en la máxima expresión de su filosofía arquitectónica y de las aspiraciones de su cliente de publicitar un particular modo de vida californiano, Neutra revelaba inconscientemente la conflictiva fusión de dos tradiciones modernas, el idealismo europeo que romantizaba la máquina como símbolo de progreso y el pragmatismo norteamericano o, para decirlo en palabras de Alan Colquhoun "si los edificios han de retener su singularidad como símbolos, ¿cómo pueden ser a la vez el resultado último de un proceso industrial cuyo propósito es encontrar soluciones generales?"22.

En la segunda parte de Wie Baut Amerika? A través del ejemplo de la construcción del Palmer House Hotel, Neutra había argumentado la existencia de una belleza (Sachlichkeit im Baven ${ }^{23}$ ) que emergía del potencial de la estructura de acero ${ }^{24}$. En base a ese potencial proponía su empleo en todo tipo de edificaciones, incluidas las viviendas. Neutra consideraba la estructura de acero como el grado cero de una nueva práctica arquitectónica de carácter universal, que integraría racionalmente a partir de su esqueleto metálico tridimensional (Skelettkonstruktion) los nuevos materiales y sistemas tecnológicos posibilitados por la industria de su tiempo.

Durante el proceso de redacción del libro Neutra había ensayado sus ideas en proyectos y ejercicios teóricos que había incorporado al mismo, como el diseño de una vivienda modular de paneles prefabricados (1926) en la que exploraba la lógica organizativa de la estructura y la flexibilidad compositiva de los elementos de cerramiento, poniendo en evidencia tanto el orden subyacente en el sistema como, por supuesto, la belleza objetiva del acabado del material en crudo. Esta objetividad fue paradigmática en la definición de Neutra de una nueva belleza, en este caso una transparencia conceptual consistente en la "expresión natural" 25 del proceso constructivo y de los materiales que formaban parte de ese proceso ${ }^{26}$. Esta transparencia, es decir, la expresión del orden estructural de la Skelettkonstruktion fue precisamente la idea que presidió la conceptualización y construcción de la 


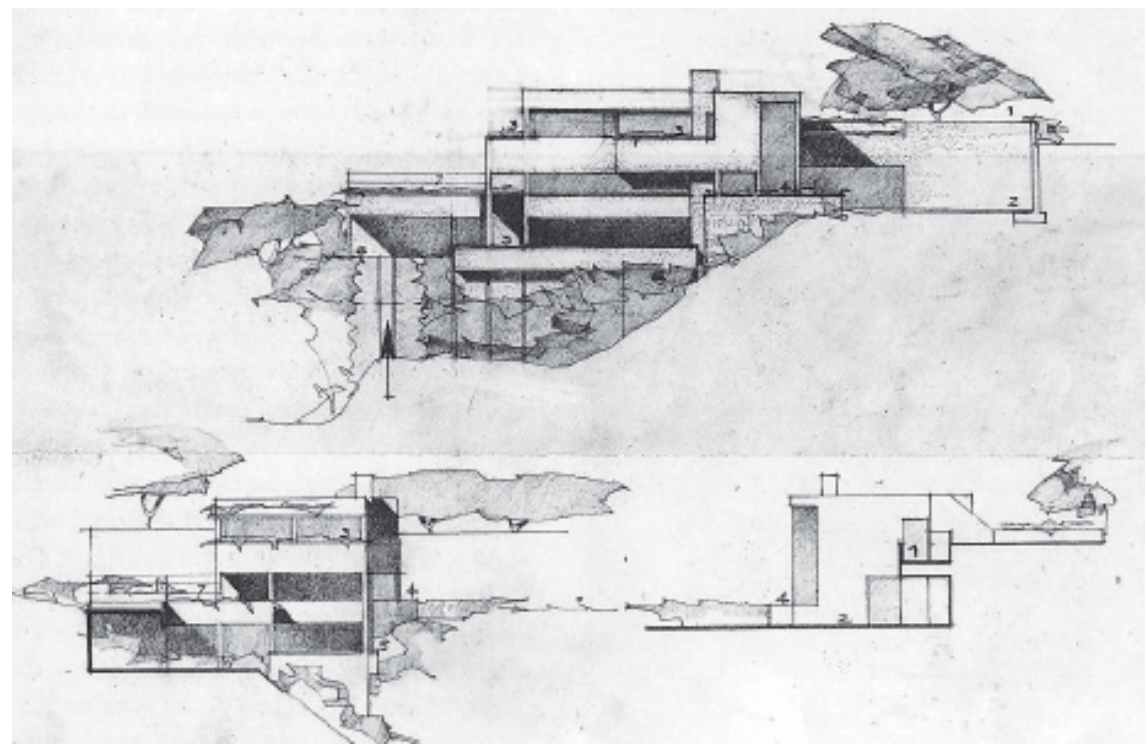

casa Lovell, la primera vivienda realizada enteramente con estructura de acero en los Estados Unidos ${ }^{27}$.

En la ideación de este edificio pueden distinguirse dos fases. Una primera, entre finales de 1927 y principios de 1928, cuya solución más elaborada recogen los dibujos en alzado y sección reproducidos por Thomas Hines ${ }^{28}$. Y una segunda propuesta definitiva, ratificada en abril de 1928, y que fue la que desarrolló el proyecto de ejecución al que se otorgó licencia en noviembre de 1928.

Tanto en los croquis de partida como en la versión construida de la casa es fácil reconocer los mismos criterios de implantación y relación con la pronunciada pendiente que define parcela adquirida por los Lovell en las colinas de Hollywood -justo debajo de Griffth Park. El modo de acceso desde el cul de sac de Dundee Drive y la posición de la vivienda en perpendicular a la ladera noreste es prácticamente la misma en ambas propuestas. Asimismo la interpretación de las estancias principales de la casa y su relación con el exterior de acuerdo con el programa de vida al aire libre perseguido por el cliente; e, incluso, la disposición de los sleeping porches es también muy similar.

Sin embargo, la solución formal de la vivienda, en un determinado momento, experimentó un giro de $180^{\circ}$ como resultado de su incorporación a la lógica constructiva del proyecto. La razón para ello fue la definición clara del papel de la estructura de acero, no sólo como sistema portante sino como matriz espacial y organizativa de todo el edificio.

A partir del análisis de los primeros dibujos puede deducirse que los alzados han sido compuestos de forma aditiva $y$, de hecho, a pesar de su imagen de modernidad revelan una metodología de trabajo tradicional. En esta primera versión la forma y la estructura parecen separadas. Por el contrario, los alzados de la versión construida son el resultado de una aproximación al diseño de la casa a partir de la malla tridimensional de la estructura de acero que, en este caso, se convierte en la auténtica generadora de sus espacios. "La estructura era la casa; la casa era la estructura. Estructural y estéticamente le daba todo su significado" ${ }^{29}$, escribió Thomas Hines. Se trataría por tanto de transparencia, es decir, de un sistema de proyección de dentro afuera responsable también de las fachadas de la casa como el arquitecto había argumentado en Wie Baut Amerika? 


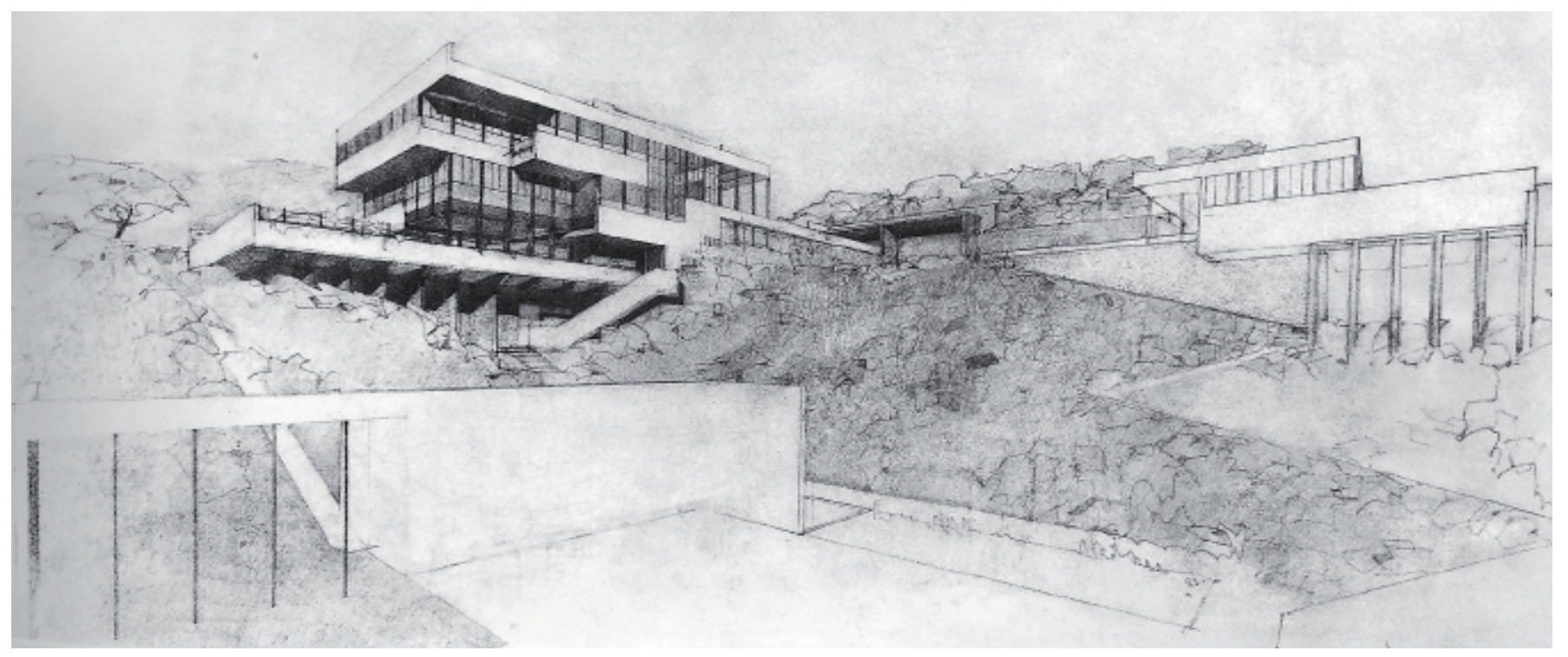

Así, mientras que en el primer diseño afrontaba independientemente las particularidades del sitio y del programa ${ }^{30}$ con respecto a la lógica espacial y constructiva del steel-frame, en el proyecto definitivo de la casa Lovell Neutra procesó y racionalizó estas condiciones acomodándolas a la modularidad inherente a la estructura de acero y a los elementos prefabricados, como reflejan tanto las plantas como los alzados definitivos de la vivienda. En este sentido, frente al método de trabajo habitual de abordar la complejidad en un proyecto de arquitectura, también frente al individualismo de Wright y a las formas espaciales de Schindler, Neutra se movió del tipo al objeto arquitectónico o, por decirlo de otro modo, de un sistema general -con pretensión de universalidad-a lo particular ${ }^{31}$.

No obstante, a pesar de la defensa de Neutra de la racionalidad constructiva, la casa Lovell era, como ha razonado Neil Jackson un manifiesto retórico sobre el empleo del acero. "[La casa] estaba claramente sobrediseñada: de hecho si hubiera sido proyectada teniendo en cuenta toda la economía de medios que permitía la construcción en acero, la estructura podría haberse erigido en menos de las cuarenta horas que se tardó. La casa era tanto una demostración de la construcción en acero como un ensayo sobre arquitectura moderna europea"32.

A pesar de ello, el argumento de Neutra de una traslación directa del paradigma tecnológico a la práctica de la arquitectura garantizó un reconocimiento inmediato para su obra. Y las circunstancias históricas no podían haber sido más propicias. Se trataba de un momento en la gestación de la arquitectura moderna en la que la estética de la máquina primaba como representación del ideal tecnológico de las vanguardias europeas. Las fotografías de la flamante estructura metálica de la casa Lovell en construcción no podían expresar mejor aquellos principios y el extraordinario esfuerzo publicitario por parte de Neutra fue dirigido precisamente a potenciar esas imágenes, las mismas que sus lectores estaban esperando.

Sin embargo, poco después de su celebración en la exposición del MoMA de 1932, el nuevo contexto de la Gran Depresión -la casa recibió el final de obra el día anterior al hundimiento de la bolsa de Nueva York-y la aparición de las primeras voces críticas que cuestionaban el valor proyectual de los principios asociados a la estética de la máquina, pusieron en evidencia los desajustes de esta experiencia que Neutra no pudo volver a repetir con la intensidad y
Richard Neutra: Lovell Health House, perspectiva de la versión definitiva, 1928. Fuente: Thomas Hines

Página anterior arriba: Lovell Health House, primer dibujo, alzados, hacia finales de 1927. Fuente: Thomas Hines

Página anterior abajo: Lovell Health House, maqueta para la exposición del MoMA de 1932. Harris participó en la construcción de la misma. Fuente: Barbara Lamprecht 


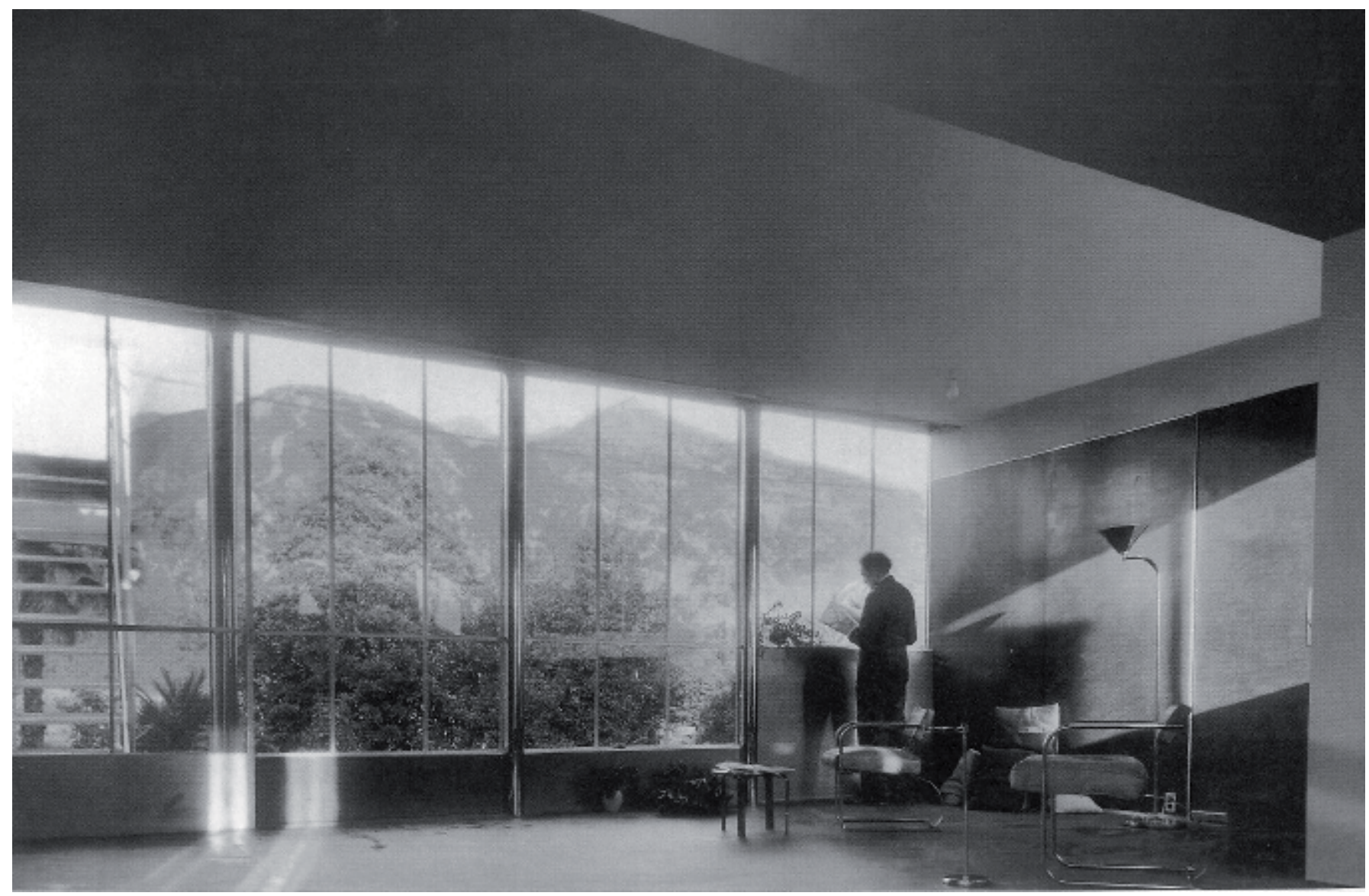

Richard Neutra: Bear House, Altadena, 1934. Fotografía de Arthur Luckhaus. El propio arquitecto aparece de espaldas en la imagen. Fuente: Barbara Lamprecht

Página siguiente arriba: Lovell Health House, maqueta. Fuente: Thomas Hines

Página siguiente abajo: Richard Neutra: Beard House, Altadena. Fotografía del autor literalidad de la casa Lovell y que, incluso, dificultó o, al menos retasó alrededor de una década, su interés por repensar de manera crítica el papel de la tecnología en la sociedad moderna.

Neutra siguió discutiendo y promocionando el uso del acero en la construcción de viviendas durante los años 30, no obstante, muy pronto se dio cuenta de que los procedimientos industriales en California pasaban por el empleo de la madera y no del acero, una solución que siempre terminaba revelándose antieconómica. No por ello renunció a este material, pero sólo consiguió resultados reseñables en un puñado de viviendas decididamente experimentales; como la casa para William y Melba Beard en Altadena (1934), un sofisticado profesor de ingeniería del Institute of Technology de Pasadena y una audaz pionera de la aviación dispuestos asumir riesgos y que se mostraron encantados con su estructura tecnológica "toda de metal revestida con paneles celulares [...] capaces de autorregular la temperatura de los cerramientos"

Neutra continuó enfatizando una estética derivada del uso del acero que no siempre estaba en correspondencia con la verdad constructiva. Su casa VDL Research House, a pesar de las apariencias, estaba realizada con una estructura de madera. En otros casos Neutra comenzó a plantear los pilares de madera con secciones similares a las del acero y también a pintar la madera de color plata para simular acabados metálicos. Sobre esta actitud de su maestro, Harwell Hamilton Harris escribió que en varias ocasiones, él y Gregory Ain estuvieron tentados de preguntarle con malicia: "Señor Neutra, ¿cuál es el mejor material para construir una casa de acero?"34. Pero también de acuerdo con Harris, la respuesta de Neutra hubiera sido la misma con la que siempre justificaba esta práctica educativa, ya que se trataba de formar el gusto de la gente, de acostumbrar al público a las imágenes del futuro. 


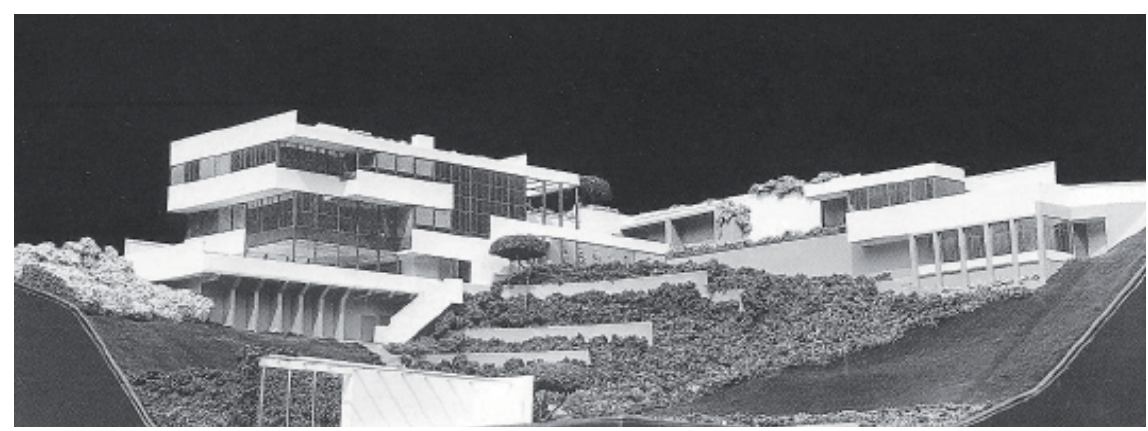

\section{Más hipótesis en torno a Lovell. La versión de Esther McCoy}

En abril de 1928, Dione Neutra trataba de explicar por carta a su madre la delicada posición en la que se había visto su marido tras aceptar el encargo de construir una nueva casa para Philip Lovell. Ella apuntaba la existencia de un triángulo de intereses y afectos personales entre el cliente, la familia de éste y Richard Neutra derivados de sus relaciones con Rudolph Schindler, a quien cargaba indirectamente con la responsabilidad de una situación ajena a la arquitectura pero que estaba determinando el curso de los acontecimientos. Dione se quejaba asimismo de que las diferentes motivaciones de cada uno de los implicados estaban perjudicando a Neutra y, aunque no llegaba a exponer las razones últimas que habían llevado a aquel escenario de conflicto, era posible leerlas entre líneas. En aquella carta, en la que por cierto ya se mencionaba la fecha de los primeros planos de la Lovell Health House, Dione relataba los hechos del siguiente modo:

"Déjame que te exponga brevemente en qué consisten estas dificultades. Schindler construyó una casa para Lovell en la playa. Durante su construcción los ánimos estuvieron soliviantados. Las razones que lo explicarían son mucho más profundas que eso. De hecho, la irritación de Lovell no tenía que ver con la marcha de las obras sino más bien con el carácter de Schindler. Probablemente se trataba de celos. Resumiendo, la cuestión es que a partir de ahora [Lovell] ya no quiere tener ningún trato con él.

Richard ha estado rechazando continuamente asumir el diseño de esta nueva casa por deferencia a Schindler, a quien defiende como perfectamente capaz de ello. Ha tenido que aparecer en escena la señora Scheyer diciendo que la postura de Richard era ridícula. Ella ha estado mediando entre Schindler, Lovell y Richard $y$, finalmente, se ha llegado a un preacuerdo. Richard quería trabajar con Schindler, pretendía involucrarle en el proyecto pero no ha sido posible.

La hermana de la señora Lovell [Harriet Freeman] tiene una casa35 de Wright. Ella detesta a su cuñado y trata de crear tanta discordia como puede en el matrimonio Lovell. Es muy amiga de Schindler y está furiosa por el hecho de que se le haya apartado de este encargo. Ayer Lovell pasó varias horas con nosotros mirando los planos y discutiendo esta situación [...] Ahora hay un enfrentamiento permanente entre las dos hermanas. Y cualquier cosa que Richard hace es criticada y se le ridiculiza a sus espaldas porque Schindler podría haberlo hecho mucho mejor. Richard sin embargo pone buena cara y se muestra prudente.

Lovell ha decidido no hacerle caso a su mujer porque es él quien ha tomado la decisión. Además, cuanto más le ataca su cuñada más se ratifica en ella [...] Desde luego es una atmósfera poco propicia para la creación. Todas estas cuestiones son muy delicadas y sólo puede entenderlas quien sepa realmente todo lo qué está pasando. No se puede hablar de ello, pero es un lío propio de una trama de Dostoyevsky"136.

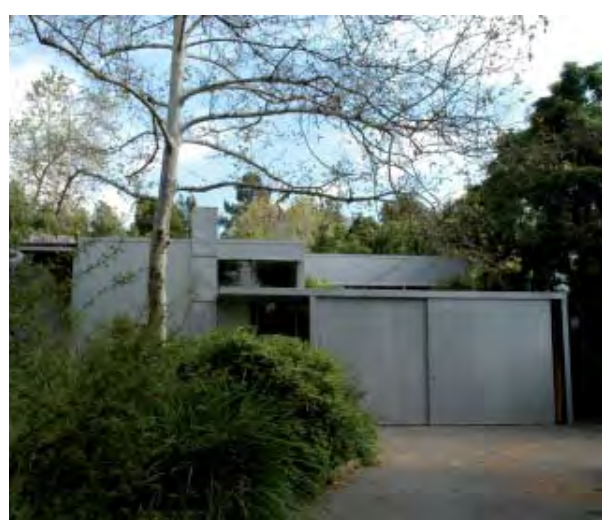




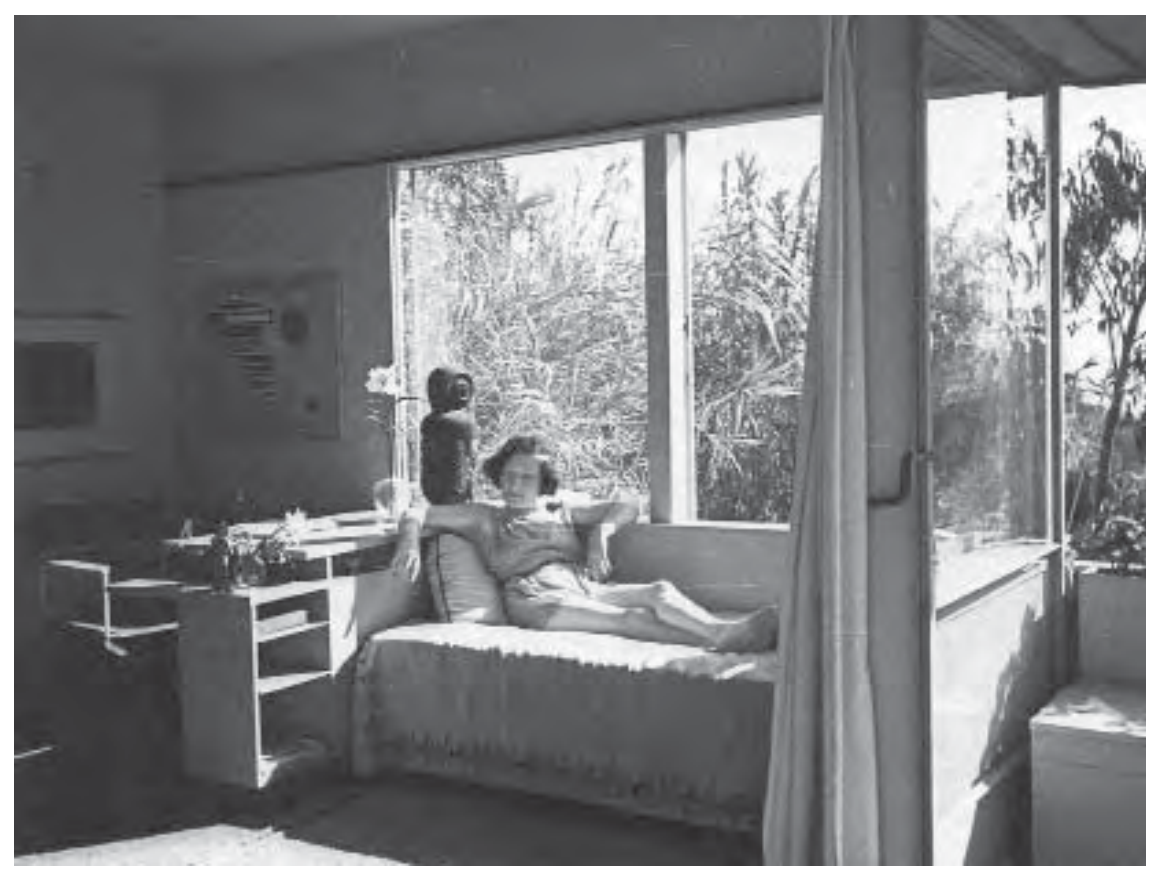

Galka Scheyer en su casa de Los Ángeles construida por Richard Neutra y Gregory Ain, 1934-35. Fuente: Tino Hammid
Esther McCoy ${ }^{37}$ y Thomas Hines ${ }^{38}$ coinciden al señalar que Schindler y Lovell llegaron a tratar sobre el diseño de una segunda casa en Los Ángeles y que incluso el arquitecto habría realizado algunos dibujos preliminares. No obstante, algo sucedido en el verano de 1927, alrededor de la misma fecha en que Pauline abandonó Kings Road, motivó que Schindler fuera retirado del proyecto y sustituido por Richard Neutra39. Al parecer, al principio éste se habría mostrado reticente, después habría intentado que Schindler apareciera como colaborador hasta que, finalmente, convencido por Galka Scheyer ${ }^{40}$ de que si no aceptaba el encargo otro arquitecto acabaría construyendo la casa, Neutra terminó al frente del mismo.

Por otro lado, como consecuencia de los comentarios ${ }^{41}$ de Esther McCoy en Vienna to Los Angeles, asegurando que para Schindler la pérdida del trabajo a manos de su amigo fue un duro golpe, una de las creencias más extendidas es que Schindler y Neutra rompieron su relación profesional tras el episodio de la casa Lovell. Pero esta teoría no se sostiene.

Al margen de otros datos que se aportarán más adelante en esta discusión, el hecho de que los Neutra siguieran viviendo y trabajando en Kings Road hasta el inicio de su viaje alrededor del mundo en 1930 e, incluso, la constatación ${ }^{42}$ de que ambos arquitectos impartieron juntos un curso de arquitectura moderna en el Chouinard Art Institute en otoño de 1931 desmienten esta posibilidad de una ruptura personal hacia 1928 ó 1929. Lo cierto sin embargo es que, en 1932, ambos arquitectos ya estaban separados definitivamente en el plano profesional 43 , algo que se ha apuntado en varias ocasiones en esta tesis. Como también que, con mucha seguridad, la principal causa para su distanciamiento fue la exclusión de Schindler de la exposición del MoMA de 1932 y todo lo que ésta suponía de reconocimiento internacional de la obra de Neutra y, al mismo tiempo, de rechazo hacia su propio trabajo ${ }^{44}$.

Desde ese momento, la frustración y, muy probablemente, los celos de Schindler, explicarían la beligerancia de sus ataques a la arquitectura de Neutra e, incluso, la circunstancia de que, años después, su malestar le llevara a decir injustamente que Richard Neutra le había arrebatado el proyecto. Su influencia sobre Esther McCoy habría ayudado a que la historiadora 
aceptase esa visión de los hechos y por ello, en Vienna to Los Angeles, ésta reprodujo la entrevista que había mantenido con los Lovell en 1958 de una forma que daba veracidad a su versión de la historia.

Regresando al verano de 1927, una de las razones que se han argumentado para el descontento de Lovell hacia Schindler fueron los diversos problemas constructivos que se dieron simultáneamente en sus diferentes casas. Tomando como base el relato de Dione Neutra ${ }^{45}$, Lovell culpó a Schindler del colapso del techo de Celotex en su cabaña en la sierra, de la rapidez con la que se propagó el fuego durante el incendio de su rancho de Fallbrook y de la inundación de los sleeping porches de su vivienda de la playa. Al parecer, de acuerdo con esta versión, el enfado de Lovell y la actitud huidiza de Schindler quien, según Dione Neutra, evitaba sus llamadas, habrían motivado que Richard Neutra fuera considerado para el encargo de la Lovell Health House. Por su parte, tras conversaciones privadas de Thomas Hines con Dione Neutra acerca de la marcha de Pauline de Kings Road y de los celos de Lovell, el historiador escribió que "a pesar del progresismo de Philip Lovell en materia de comportamiento sexual, se sentía profundamente disgustado por el encaprichamiento de Schindler con Leah Lovell" ${ }^{66}$ y que fue una combinación de ambos factores (los problemas constructivos de sus casas y sus asuntos personales) lo que motivó que el promotor buscase un reemplazo para su arquitecto.

Cuando convencido por Galka Scheyer Neutra aceptó el encargo, el arquitecto trató de que Schindler quedara vinculado a él de algún modo, probablemente como ayudante. En la entrevista realizada por Esther McCoy a los Lovell en 1958, Leah sostenía ${ }^{47}$ que ella accedió a que su marido contratara a Neutra porque creía que Schindler colaboraría con él en este cometido y que no fue hasta poco después de ver los primeros planos de la casa en abril de 1928 cuando se dio cuenta de que no había sido así y que Neutra estaba llevando adelante el proyecto en solitario. Quizás Lovell, para contentar a su mujer y a su cuñada, les hizo creer que Schindler continuaba trabajando para él, lo que justificaría la carta que, en agosto de 1927, nada más recibir el encargo de la Lovell Health House, Richard Neutra envió a Dione -de vacaciones en Ojai- relatándole que había llegado a un preacuerdo con Lovell para realizar el proyecto de su nueva vivienda. En aquella carta Neutra hacía alusión a que ya le había presentado un borrador de contrato y que el cliente se había mostrado dispuesto firmarlo con unos cuantos ajustes menores: "[Lovell] quiere que lo pasemos a limpio incorporando algunos cambios. Pero en cualquier caso ya me ha adelantado un pago de los honorarios. He estado hablando con él y parece que no guarda ningún rencor personal a Schindler y que tampoco tiene nada en contra de que él participe en el diseño. Pero para estar seguro quiere que yo sea responsable de todo..." ${ }^{48}$.

Muchos años después, hacia finales de los 60 -antes incluso de la aparición de Vienna to Los Angeles- Richard Neutra sentía que con el tiempo se había extendido el rumor de que él le había arrebatado el encargo a Schindler. Probablemente por este motivo, el arquitecto escribió una carta a Philip Lovell solicitándole que aclarase aquel episodio ya que, según decía, "he sido víctima de esa sospecha durante toda mi vida" ${ }^{49}$. Thomas Hines, en su apéndice a la última edición de su monografía sobre Neutra reprodujo el contenido de la correspondencia cruzada que mantuvieron los Neutra y los Lovell entre finales de 1968 y principios de 1969. Meses antes de morir, el propio Neutra envió esas cartas a Esther McCoy en un intento de que la historiadora corroborara su versión. Sin embargo, McCoy hizo mención al contenido de aque- 


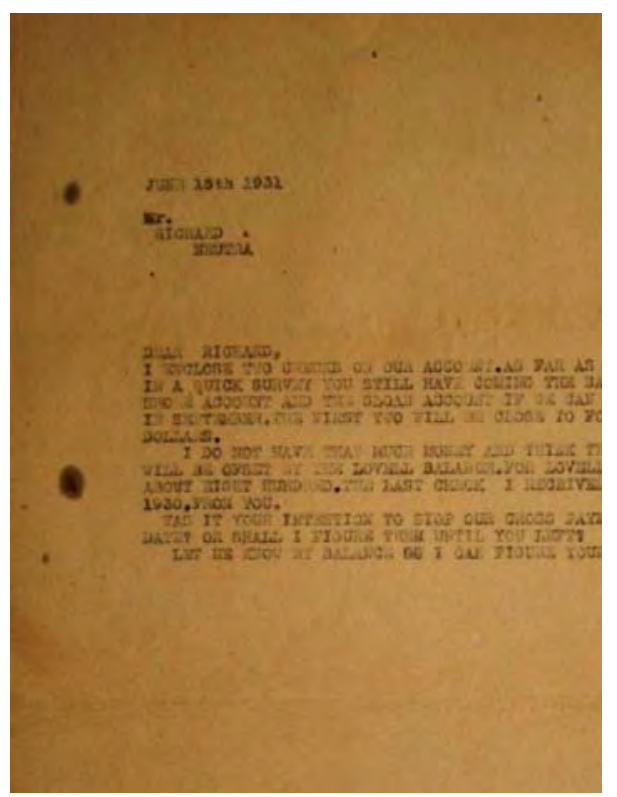

Rudolph Schindler: Carta a Richard Neutra tratado cuestiones relativas a sus pagos cruzados, 15 junio 1931. Fuente: John Crosse, $A C / U C S B$
Ila correspondencia en Vienna to Los Angeles ${ }^{50}$, pero de un modo sesgado en el que daba a entender que Neutra había escrito una versión inexacta de los hechos y que los Lovell la confirmaban porque se trataba de dar la razón a un hombre anciano y enfermo sobre algo que ya pertenecía al pasado.

Tanto de la lectura del conjunto de aquellas cartas como de su interpretación a partir en un artículo inédito de Raymond Neutra ${ }^{51}$ se deduce que Philip Lovell dio versiones contradictorias. Por ejemplo, a Esther McCoy le dijo que había encargado el proyecto a Neutra porque le consideraba un hombre de negocios más capaz que Schindler de ajustar un presupuesto $5^{22}$ y Leah, presente en aquella entrevista de 1958, confirmó su argumento diciendo que ella pensaba que era una buena idea porque creía que Schindler (el artista) y Neutra (el gestor) trabajarían juntos en el proyecto o, al menos, que eso fue lo que le hicieron creer ${ }^{53}$.

Si bien, como respuesta a la carta enviada por Richard Neutra, Philip Lovell afirmó que le había encargado el proyecto de su nueva casa porque la envergadura de ésta correspondía a las otras tres obras que anteriormente Schindler había realizado para él y quería beneficiar por igual a ambos arquitectos ${ }^{54}$. Poco después, incidiendo en que su marido había enviado aquella carta sin consultarle, Leah escribió a los Neutra disculpándose por si, en algún momento, "hubiera dicho o hecho algo que les podría haber causado algún tipo de infortunio" 55 . Leah agradecía asimismo a Richard Neutra su contribución a la historia de la arquitectura -aunque, curiosamente, a Esther McCoy le había confesado que le había desagradado profundamente vivir en aquel usseo $^{56}$.

Raymond Neutra sostiene que la inocencia de su padre parece segura, así como que los relatos de Philip Lovell variaron según su destinatario. Además, defiende también la consistencia de las versiones de Leah Lovell entre 1958 -su entrevista con McCoy- y su carta de 1969. Para Raymond Neutra, quizás, Leah se dirigía a sus padres pidiendo perdón por haber hecho pública - ¿a McCoy?- demasiada información. No obstante, considerando fundamentada esta opinión de Raymond Neutra, también podría argumentarse que el texto de la carta era lo suficientemente ambiguo como para pensar que Leah Lovell no se refería a 1958 sino a hechos mucho más antiguos, es decir, a su apoyo incondicional a Schindler en 1927. Y, en cualquier caso, atendiendo a sus palabras, es cierto que Leah Lovell no cambió tampoco su testimonio acerca de que no le había gustado su casa de Los Ángeles ya que, a diferencia de su marido, evitaba con mucho tacto dar las gracias a Richard Neutra por la Lovell Health House. En lugar de ello, Leah simplemente se limitaba a reconocer su talento como arquitecto de una forma muy general.

De todo esto puede deducirse que Esther McCoy utilizó la versión de Leah Lovell y el relato tendencioso de Schindler para construir su propia narración de los hechos. Es importante insistir por tanto en que la lectura de Esther McCoy no siempre puede hacerse de manera directa, ni en éste ni en otros muchos casos en los que hay que tener la precaución de recordar que ella misma era parte de la historia.

Probablemente, basándose también en el relato de Esther McCoy, Judith Sheine, concluyó que la colaboración profesional entre ambos arquitectos había terminado tras el encargo de la Lovell Health House a Richard Neutra, asegurando además que no era posible que Schindler hubiera trabajado en este proyecto ${ }^{57}$. 
Sin embargo, hay algunas dudas razonables para objetar lo contrario. Documentos recientes localizados en el archivo de Rudolph Schindler en la Universidad de California en Santa Bárbara permiten plantear la hipótesis de una colaboración del arquitecto con Richard Neutra en esta segunda casa Lovell, una participación que, de haberse producido, es evidente que por las razones expuestas anteriormente, habría habido interés en que se mantuviese dentro de una estricta confidencialidad.

John Crosse ha aportado la evidencia de una carta enviada por Schindler a Neutra en junio de 1931 y en la que el primero le daba cuenta de los honorarios pendientes por su participación en el "proyecto Lovell". Este documento implicaría que Schinlder tuvo que colaborar de algún modo con Neutra en esta casa, como se deduce de sus palabras: "He ingresado dos cheques en tu cuenta. Por lo que deduzco de un vistazo rápido aún te debería parte de tus honorarios por los proyectos de Barnsdall, Shore y Sloan, y debemos llegar a una decisión en septiembre. Los dos primeros rondarían los 400 dólares. No dispongo de esa cantidad de dinero, por lo que podríamos compensarlo por lo que tú aún me debes de Lovell. Por [el proyecto] Lovell he recibido cerca de 800 dólares. El último cheque que me enviaste era de enero de 1930. ¿Era tu intención finalizar nuestros pagos cruzados en esa fecha? ¿O debo entender que cuando te fuiste? Dime por favor mi saldo contigo para que pueda hacer cuentas" $" 5$.

El contenido de esta carta da a entender que a mediados de 1931 Schindler y Neutra mantenían todavía abiertas sus cuentas por colaboraciones anteriores. De acuerdo con lo que el propio arquitecto exponía, en esa fecha Neutra estaba pagando a Schindler su asistencia en el proyecto conforme él facturaba a Lovell. Hasta ese momento, Schindler afirmaba haber recibido 800 dólares a cuenta de sus honorarios totales, que Neutra le había hecho llegar en enero de 1930. Es decir, poco después de concluirse la casa en octubre de 1929, lo que supondría que Schindler podría haber trabajado con Neutra hasta una fase tardía de la obra, quizás controlando detalles de ejecución en el despacho. También de acuerdo con lo que Schindler alegaba, por su parte, él le debía más de 400 dólares a Neutra y, dado que -según decía- no disponía de ellos, pensaba compensárselos con el dinero que su antiguo socio aún debía pagarle por su ayuda en la Lovell House. Es difícil precisar cuánto dinero sería éste pero, suponiendo que fuera como mínimo esa deuda, esto querría decir que Schindler habría ganado al menos 1.200 dólares por su participación en el proyecto de Neutra. Teniendo en cuenta que Neutra cobró alrededor de 6.500 dólares en total59, 1.200 dólares serían aproximadamente el $20 \%$ de sus honorarios. Además, trasladada esta cantidad a valores actuales, podría deducirse que Schindler como mínimo habría cobrado unos 15.000 dólares por su colaboración en la segunda casa Lovell y, por tanto, que ésta no debió ser desdeñable ${ }^{60}$.

Quizás, podría lanzarse la hipótesis de que Schindler asistiera a Neutra en el diseño de la estructura de acero o durante su contrata. Es una hipótesis arriesgada y difícilmente comprobable, especialmente porque los planos consultados en archivo son todos originales de Neutra y no aportan ningún indicio gráfico que haga pensar en la mano de Schindler. Harwell Hamilton Harris tampoco hizo ninguna mención al posible trabajo de Schindler en la segunda casa Lovell. Es cierto que cuando él llegó al proyecto éste ya se encontraba en un estado avanzado, pero si esta participación hubiera tenido lugar, el hecho de no tener información podría apuntar a que Neutra habría preferido no compartir esta circunstancia ni siquiera con sus colaboradores más allegados. En cualquier caso, hay algunos hechos que deben ser considerados. 


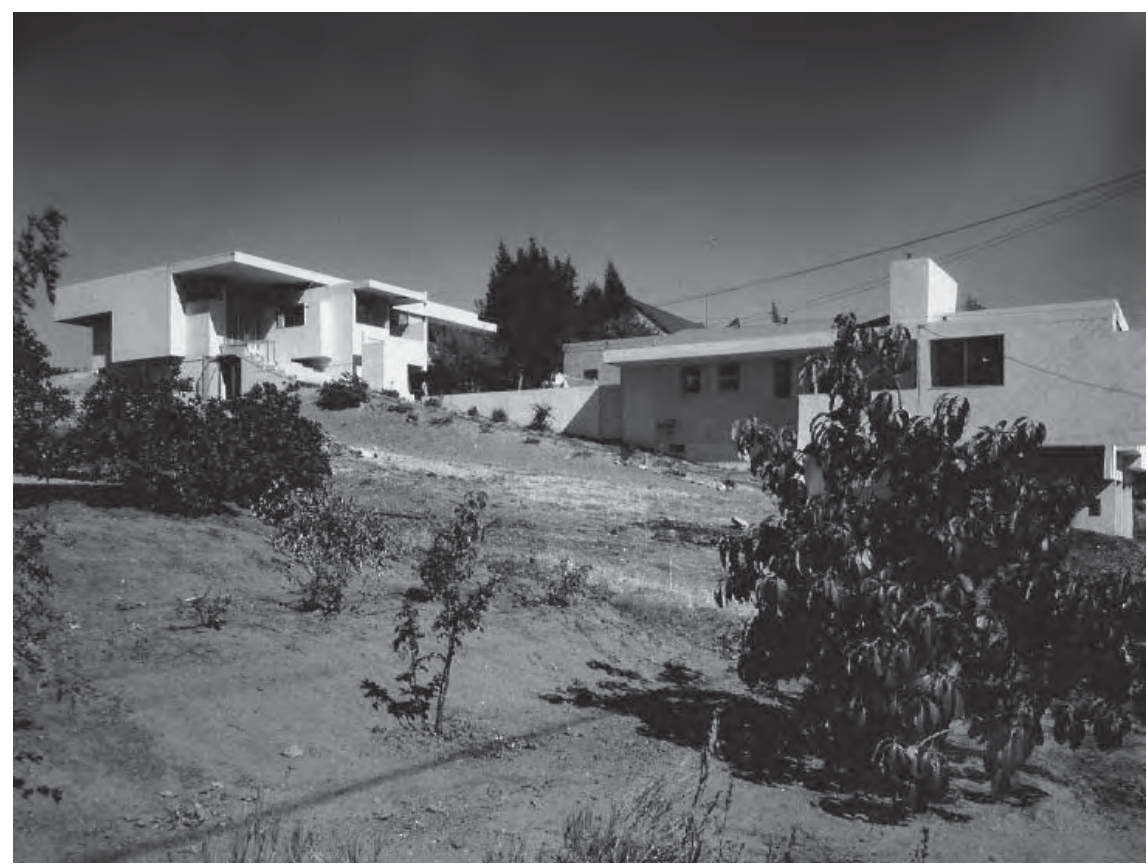

Rudolph Schindler: McAlmond House, Los Ángeles, 1934. Fotografía de Julius Shulman

Página siguiente: Lovell Health House, fotografía del autor
Por un lado, Richard Neutra se vio influenciado por los primeros trabajos de Schindler, en especial por las técnicas de prefabricación de hormigón (tilt-slab concrete construction) empleadas en Kings Road y en otros proyectos como los apartamentos Pueblo Ribera en la Jolla, cuyas fotografías del proceso de construcción Neutra incluyó en Wie Baut Amerika? Aunque no podría afirmarse que fue este aspecto lo único que interesó a Neutra del Pueblo Ribera ya que, analizando esta obra con detalle existen algunas similitudes espaciales entre ésta y los primeros bocetos de la Lovell Health House. Y en un sentido contrario, existen también apreciables semejanzas entre los primeros dibujos de la Lovell House de Neutra y algunas de las viviendas que Schindler construyó a mediados de los años 30, como las casas McAlmon y Buck, ambas de 1934

Por otro lado, dado lo insólito del proyecto de la Lovell Health House, el hecho de que Neutra no encontrase una empresa constructora suficientemente fiable para asumir la ejecución de la vivienda, le llevó a tomar la decisión de ejercer él mismo como contratista y jefe de obra de todos los oficios, incluida la estructura de acero donde contó con la supervisión de la Bethlehem Steel Coorporation. Él mismo escribió: "cada mañana antes de que saliera el sol ya estaba revisando cada uno de los miles de tornillos que se iban a remachar"61. Fue sin duda una enorme responsabilidad, por lo que no sería descartable que, dada su experiencia como constructor, Schindler pudiera haberle asistido de algún modo en esta tarea.

Además hay que tener en cuenta que antes de graduarse como arquitecto, Schindler había recibido también instrucción como ingeniero en el Instituto Politécnico Imperial de Viena, adquiriendo mayores conocimientos técnicos que Richard Neutra. Precisamente, su formación ingenieril había sido la razón por la que Frank Lloyd Wright le había permitido trabajar con él en su despecho de Chicago cuando necesitaba un colaborador cualificado que le ayudase con los planos de la estructura del Hotel Imperial.

Schindler había dado pruebas de pericia constructiva y gestión de obra desde su llegada a Los Ángeles: había dirigido en solitario los edificios de Olive Hill, había desarrollado una técnica innovadora en su casa de Kings Road y había 
producido una experiencia a mayor escala de ese sistema de prefabricados de hormigón para el complejo de apartamentos Pueblo Ribera. Neutra, sin embargo había mostrado sobre todo sus dotes en el ámbito de la publicidad, una disciplina que ya le había interesado de joven en Europa y que explotaría hasta sus últimas consecuencias en América, hasta el punto de llegar a ser portada $^{62}$ de la revista Time en agosto de 1949.

Seguramente por su entendimiento cada vez más profundo de la lógica de los medios, Richard Neutra se sirvió de Wie Baut Amerika? para describir su paso por el Palmer House Hotel y, después, de las revistas europeas para promocionarse en todo el mundo como un pionero en el campos de las estructuras de acero. Es decir, mientras que Schindler poseía más conocimientos técnicos, dominaba la construcción y tenía una mayor trayectoria de obras, incluidas las estructuras de acero que ya había ensayado en Chicago en el Buena Shores Club y en el Chicago Elks Club -cuyo esqueleto de acero él mismo diseñó-, Neutra compensó su falta de experiencia en este campo a través de un encomiable esfuerzo editorial.

En esta faceta Neutra se mostró tan convincente que, incluso Esther McCoy, una de sus más duras críticas, especialmente tras su experiencia con él durante la preparación de su monografía para Braziller, escribió: "La casa Lovell [...] es a menudo considerada como un trabajo aislado, aunque debe entenderse en el marco de una paciente exploración de la que es imposible separar. Esta vivienda tuvo en Los Ángeles en 1929 una importancia comparable a la de los primeros edificios de hierro o a los pabellones de acero y cristal de las exposiciones europeas $y$, de hecho, fue gracias a ella cómo se conoció por primera vez y de un modo generalizado la arquitectura de Los Ángeles en Europa. La genialidad de la idea estructural no hubiera podido pasar del proyecto sin la familiaridad de Neutra con los métodos de construcción y su destreza con las contratas adquirida a través de su trabajo con Holabird and Roche ${ }^{\prime \prime 63}$.

El malestar de Esther McCoy con Richard Neutra era comprensible ya que el arquitecto trató de confundirla sobre la cronología de la casa Lovell, dando a entender que la fecha de la vivienda era la de su encargo, 1927, en lugar de la de su proyecto o construcción. Con objeto de que la obra pareciera aún más meritoria al haberse adelantado a la Villa Savoie, el arquitecto jugó con esta ambigüedad durante toda su vida y cuando, en 1960, tuvo la oportunidad de utilizar a McCoy para oficializar su argumento, no dudó igualmente en despistar a la historiadora durante la preparación de su libro. Ésta sin embargo descubrió la maniobra y, sintiéndose engañada, expresó su disgusto haciendo público que Neutra había intentado manipularla. Por ello, en su monografía sobre Neutra, McCoy quiso dejar bien claro que los planos de la Lovell House y las fechas en que fueron solicitados los permisos revelaban que la versión definitiva de la casa no estuvo lista hasta abril de 1928.

A pesar de todo, McCoy elogió la dimensión pionera de esta obra y, como se ha visto, puso de manifiesto la vinculación de Neutra con el mundo de la tecnología y su familiaridad con los procesos industriales, enfatizando que la casa era la culminación de un sólido proceso de investigación iniciado por el arquitecto muchos años antes. Parece lógico pensar que, dada la estrecha relación de la historiadora con Schindler y su toma de partido por éste en Vienna to Los Angeles, si Esther McCoy hubiera tenido alguna sospecha de la posible participación de Schindler en el proyecto de la casa Lovell, difícilmente hubiera guardado silencio.

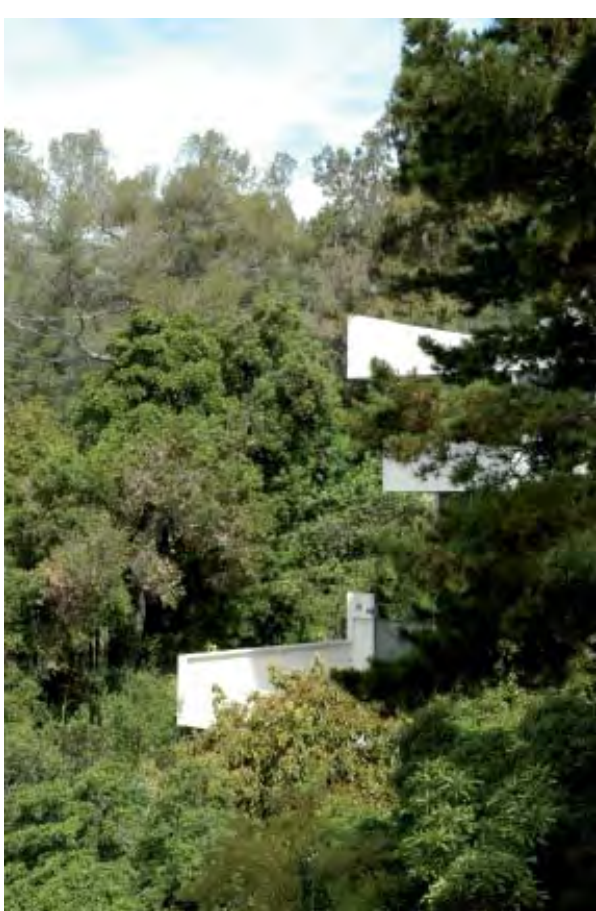




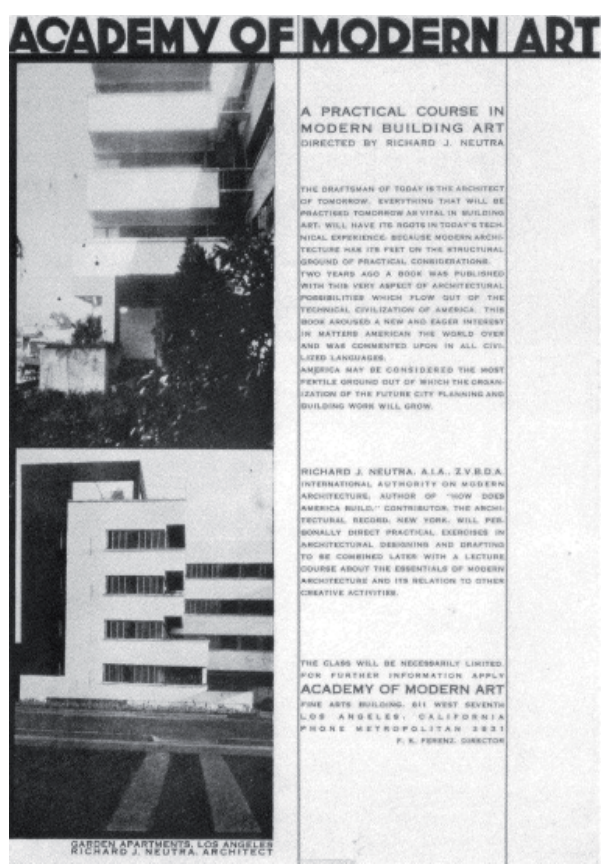

Academy of Modern Art, anuncio del Curso de 1929 ilustrado con imégenes de los apartamentos Jardinette de Richard Neutra. Fuente: Dione Neutra: RIchard Neutra, Promise and Fulfillement

Página siguiente: Harwell Hamilton Harris, proyecto para la clase de Neutra, 1929

\section{Academy of Modern Art, clase del 29}

Franz K. Ferenz, llegó a los Estados Unidos procedente de Austria en 1914, prácticamente al mismo tiempo que Schindler. Instalándose primero en Nueva York, había iniciado una exitosa actividad como librero, galerista y marchante de arte industrial antes de instalarse definitivamente en California en 1927. Ferenz estaba muy interesado en todo lo relacionado con el arte moderno, la fotografía y las vanguardias europeas por lo que, una vez en Los Ángeles, decidió fundar en 1928 la Academy of Modern Art, que concibió como un centro de reunión, debates y de seminarios sobre estos temas ${ }^{64}$.

Ferenz entabló pronto amistad con sus compatriotas Rudolph Schindler y Richard Neutra, con quienes coincidió en diferentes actos en la ciudad ${ }^{65}$. En el otoño de 1928, coincidiendo con el inicio de la obras de la casa Lovell de Neutra, Ferenz invitó al arquitecto a impartir una serie de conferencias en su recién inaugurada Academy of Modern Art. Entre los asistentes estaban Harwell Hamilton Harris y Gregory Ain quienes, entusiamados con las enseñanzas de Neutra, instaron a Ferenz a contratar a Neutra para un curso de mayor duración y que, bajo el nombre $A$ Practical Course in Modern Building Art, se inició el 29 de enero de 1929 y continuó hasta el 29 de mayo de ese mismo año.

De acuerdo con el propio Harris, el inicio de su colaboración profesional en el estudio de Neutra se inició precisamente durante el periodo de tiempo entre el primer ciclo de conferencias y el inicio del curso del 29, como él mismo relató en su entrevista para el Oral History Program de la University of California Los Angeles (UCLA):

"[...] hubo una serie de conferencias impartidas por Neutra en la nueva Academy of Modern Art -ésta tenía dos sedes, una en la vieja Chouinard Art School, en English Street, cerca de Westlake Park y la otra en el nuevo Fine Arts Building más abajo en la calle 7, cerca de Flower Street. Estoy tratando de recordar el nombre de la persona que las fundó -Ferenz, F. K. Ferenz. Recibí un anuncio de estas conferencias $y$, por supuesto, asistí. Disfruté mucho porque se trataba de una introducción a las ideas básicas de la arquitectura moderna tal como Neutra la entendía y afectaba tanto a los nuevos procesos tecnológicos de la edificación como a la planificación urbana y a otras cuestiones relacionadas con la tecnología. Allí conocía Greg Ain, que también asistía como público. Un poco más tarde, cuando hubo concluido esta serie de conferencias, Greg Ain, yo y dos o tres estudiantes más que seguimos las conferencias (aunque ninguno tan interesado como nosotros dos), nos matriculamos en otro curso en la Academy of Modern Art. Cada uno de nosotros nos centramos individualmente el diseño de un proyecto concreto. [...] Creo que Neutra nos sugirió los temas. Yo había estado siguiendo el progreso del proyecto de la Lovell House -Acabo de cometer un error en la cronología de los hechos. En el breve espacio entre el final de las conferencias y el inicio del curso yo había comenzado a trabajar ya en el estudio de Neutra"66.

El curso del 29 en la Academy of Modern Art fue un compendio de lecciones teórico prácticas acerca de todos los temas relacionados con la tecnología moderna que centraban el interés de las investigaciones de Neutra en esos años. El mismo anuncio del curso hacía énfasis en el mensaje de su primer libro. Una vez más, el arquitecto incidía en las posibilidades de una nueva arquitectura basada en el potencial de la tecnología norteamericana. El folleto de presentación, "A PRACTICAL COURSE IN MODERN BUILDING ART. Directed by J. Richard Neutra", estaba ilustrado con dos imágenes 
de los apartamentos Jardinette y en él se afirmaba: "El delineante de hoy es el arquitecto de mañana. Todo aquello que será esencial para la edificación del futuro tiene sus raíces en la experiencia de la tecnología actual ya que la arquitectura moderna se apoya en el campo estructural de las consideraciones prácticas. Hace dos años se publicó un libro que abordaba precisamente las posibilidades de una arquitectura fundamentada en la civilización tecnológica americana. Este libro despertó en todo el mundo un nuevo y entusiasta interés sobre cuestiones concernientes a la técnica norteamericana que fue discutido y traducido en todas las lenguas civilizadas. América puede ser considerada el terreno más fértil del que surgirán las prácticas de planeamiento y edificación del futuro".

La referencia a Wie Baut Amerika? era doble, por un lado como parte de la exposición de la temática de las clases y, por otro, como uno de los trabajos esenciales que determinaban el currículo del director del curso. Neutra no dejó escapar la ocasión para promocionarse, resaltando en la primera línea de su breve reseña biográfica su condición de arquitecto con licencia estatal (AIA) y su reconocimiento más allá de las fronteras de los Estados Unidos: "Richard Neutra. AlA. Autoridad internacional en arquitectura moderna. Autor de ¿Cómo construye América? Colaborador de la revista Architectural Record. Nueva York".

Esta información fue difundida por Los Angeles Times, donde no sólo se informaba de las sesiones teóricas del seminario sino que, además, el crítico Arthur Miller había publicado una reseña ${ }^{67}$ biográfica acerca Neutra, la relevancia de su trabajo y la pertinencia de unas conferencias de estas características en la ciudad de Los Ángeles.

En el folleto del curso se hacía mención al número limitado de plazas disponibles. De hecho, la clase de 1929 contó con 12 estudiantes. Se trataba de un curso muy personalizado, más bien de un taller donde los alumnos matriculados debían poner en práctica las lecciones aprendidas en el desarrollo de ejercicios individuales y proyectos colectivos.

De acuerdo con Harris ${ }^{68}$, Neutra hablaba de prefabricación todo el tiempo y-según refería su discípulo- afirmaba en clase que éste sería el único medio de producción de la arquitectura del futuro, independientemente de la tipología. Tambien de acuerdo con Harris, sólo él y Gregory Ain (quien trabajó en el diseño de una penitenciaría) desarrollaron sus trabajos individuales más allá del final del curso ya que, cuando éste terminó, ambos continuaron en el estudio de Neutra mientras que el resto de sus estudiantes regresaron a sus actividades diarias. Respecto a su propio ejercicio de curso, Harris escribió:

"Cada uno elegíamos un proyecto de manera individual. Dado que yo había estado trabajando en la casa Lovell, estaba particularmente interesado en el tema de la vivienda y, en especial, en los métodos de construcción que se habían utilizado allí. Asíque propuse el diseño de un edificio con una estructura de vigas y pilares. Tenía dos plantas de alto. Sin embargo, la estructura no era de acero sino de hormigón armado. La propuesta estaba claramente influenciada por el diseño de la Lovell, aunque quizás también por el de los apartamentos Jardinette. Éste era el primer edificio de Neutra que yo había conocido aunque, en un principio había pensado que se trataba de Schindler cuando, en realidad, era todo prácticamente de Neutra, de lo cual me hubiera dado cuenta inmediatamente si por aquel entonces yo hubiera sabido algo de Neutra"69. 
Richard Neutra, visita de obra y clase en la Lovell House, 1929. Fotografía de Willard Morgan. Harris es el segundo personaje por la derecha

Página siguiente arriba: Arthur Miller: "A New Art", en Los Angeles Times, 2 enero 1929 Página siguiente abajo: Richard Neutra: "From Terminals? - Transfer!", artículo sobre movilidad y redes de transporte en la ciudad moderna publicado en Architectural Record, agosto 1930

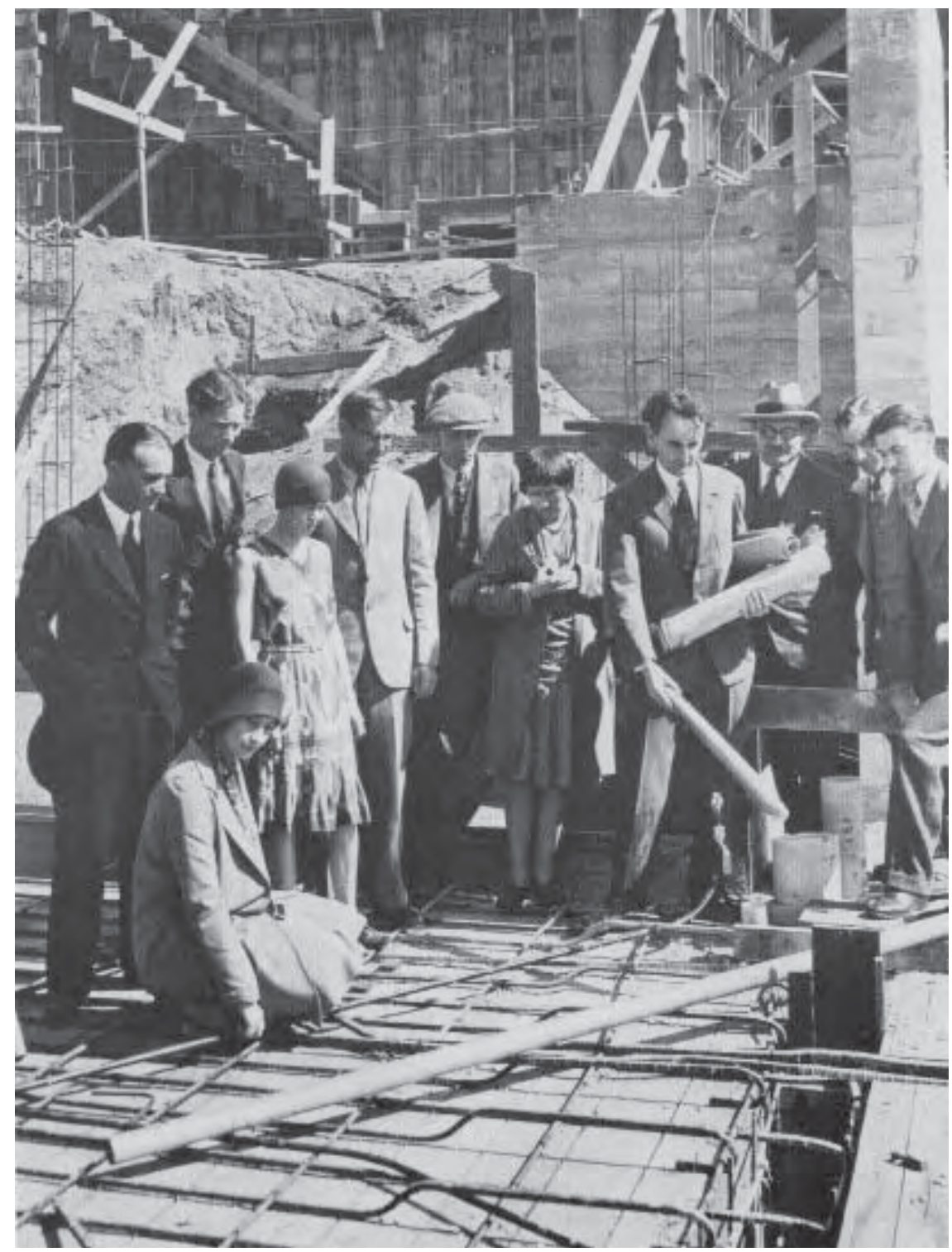

Dado que el inicio del curso coincidió con el arranque de las obras de la casa Lovell, Neutra consideró la experiencia de esta vivienda como el mejor caso de estudio al que podía enfrentar a sus discípulos. Organizándoles visitas periódicas para examinar con ellos el progreso de las mismas, junto a sus clases teóricas, Neutra les brindó una oportunidad única para aprender las técnicas constructivas y la metodología del proyecto moderno directamente sobre su primer campo de pruebas.

Aunque Harris colaboró con Neutra en la realización de los planos de obra de la Lovell House, su participación fue requerida hacia el final de la misma, siendo Ain quien trabajó durante más tiempo en el proyecto. De hecho, la implicación de éste último fue tal que hasta donó los dos faros de su Ford Model A que aparecen en las escaleras de la vivienda ${ }^{70}$ y que Neutra, más allá de su estética maquinista, probablemente quiso incorporar como un guiño a la estrecha relación entre la vivienda y el automóvil que en aquel momento se forjaba en la ciudad de Los Ángeles.

Como refirió el propio Harris, Neutra estaba especialmente interesado en tener discípulos. Pretendía transmitir sus ideas e iniciar una escuela de arquitectos modernos en California. Quizás viéndose a sí mismo como fundador de la auténtica modernidad de Los Ángeles e, incluso, tratando de ser reco- 
nocido por ello, le gustaba fotografiarse con sus discípulos dando explicaciones a pie de obra.

Una de las más célebres fotografías de la casa durante su ejecución muestra a Neutra rodeado de sus estudiantes. Él señala algunos detalles del encofrado con los planos de la vivienda mientras estos escuchan sus comentarios distribuidos por el forjado de la planta sótano, a punto de ser hormigonado. Toda una metáfora sobre los cimientos de un nuevo futuro de optimismo tecnológico.

En la fotografía, de izquierda a derecha se reconocen: en primer término, arrodillada, Bárbara (Johnson) Morgan y, tras ella Franz Ferenz, director de la Academy of Modern Art; junto a él David Giffen y su mujer (Ragenhilde Liljedahl); dos estudiantes sin identificar; Annita Delano; Richard Neutra; un tercer personaje sin identificar; Harwell Hamilton Harris y, en el extremo derecho de la imagen, Gregory Ain. La imagen fue tomada por Willard Morgan hacia finales de enero de $1929^{71}$.

Uno de los proyectos afrontados de manera colaborativa fue Rush City Reformed. Evolucionado a partir de las ideas de Rush City, la propuesta fue desarrollada por Neutra y algunos de sus discípulos de la Academy of Modern Art, en concreto Harris, Ain y el matrimonio Giffen quienes, tras el final de las clases se quedaban en el aula discutiendo y trabajando con su maestro en el desarrollo y dibujo de las ideas de su modelo teórico. Aunque esta tesis no es el lugar para abordar el interés de muchos de sus planteamientos, conviene señalar el énfasis del proyecto en la movilidad, los transportes y equipamientos urbanos o el análisis de nuevas formas de vida y de usar la ciudad por parte de distintos segmentos de población, o su preocupación por abordar los problemas de los grupos sociales más desfavorecidos, adelantándose una realidad a la que el arquitecto aportó memorables soluciones durante los años 40 cuando, como se ha comentado en las notas introductorias, formó parte de algunos de los programas de vivienda pública de mayor envergadura del Sur de California.

Casi todos los alumnos de la Academy of Modern Art gravitaban también en otros círculos artísticos relacionados con la modernidad de Los Ángeles, especialmente Kings Road. Procedían en su mayoría del mundo del arte y su participación en el curso del 29 se debió a su interés por adquirir conocimientos de arquitectura moderna de la mano de uno de sus más enérgicos defensores, Richard Neutra ${ }^{72}$. Annita Delano, docente en el Departamento de Arte de UCLA había sido comisaria de exposiciones sobre arte y arquitectura moderna en la ciudad (como se vio en la primera parte de esta tesis) y responsable de una muestra sobre la fotografía de los Weston en la misma Universidad en 1927 junto con Barbara Morgan, la mujer de Willard Morgan. Por su parte, Barbara Morgan, impartía clases de arte en la Universidad del Sur de California. Morgan y Delano eran amigas de los Schindler y habían formado parte con estos del un grupo artístico de breve duración, el Modern Art Workers Group ${ }^{73}$. Tanto Annita Delano como los Morgan habían colaborado con Galka Scheyer en las dos exposiciones organizadas en Los Ángeles sobre los Cuatro Azules en 1926. Meses antes de matricularse en las clases de la Academy of Modern Art, en el verano de 1928, Scheyer y Delano realizaron una importante labor promocional de Neutra en Europa, donde se entrevistaron con algunos de los principales artistas modernos y llevaron cartas de recomendación del arquitecto a la Bauhaus, informando de los progresos del diseño de su amigo en la casa Lovell.
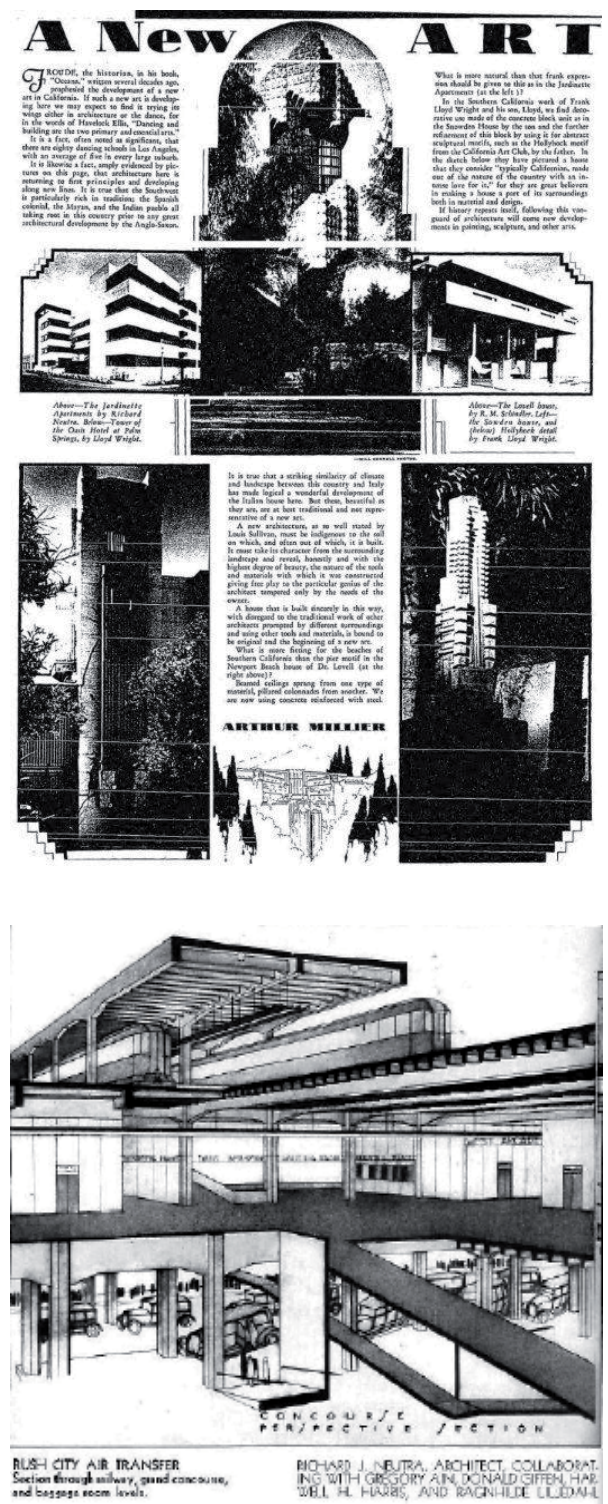


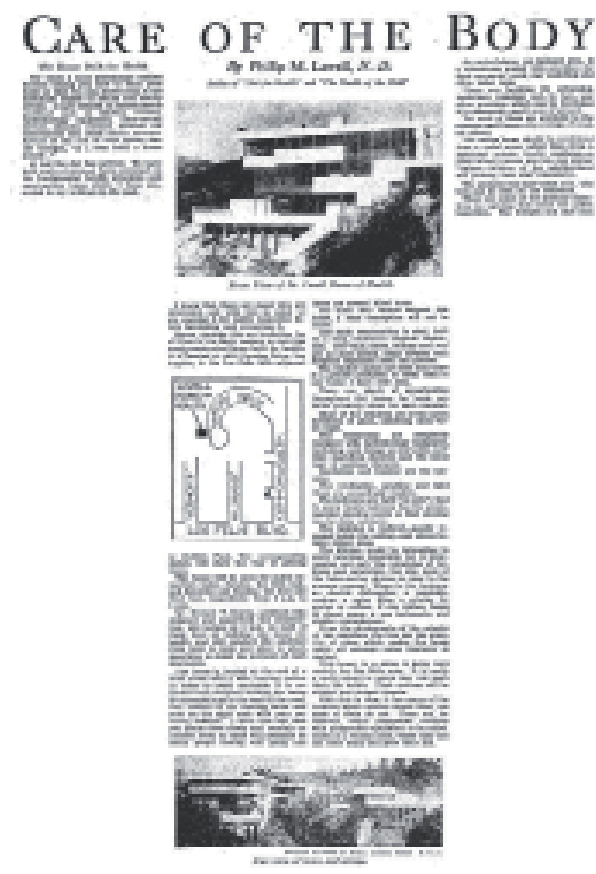

Izda: Care of The Body: Invitación de Philip Lovell a los lectores de su columna a visitar su casa. Los Angeles Times, 15 diciembre 1929 Dcha: Richard Neutra: Rush City Reformed, vista de conjunto de la propuesta, dibujo de 1929. Fuente: Thomas Hines. Department of Special Collections, Charles E. Young Research Library, UCLA

Página siguiente arriba: Lovell Health House, detalle de la estructura de acero fotografiada desde abajo. Fotografía de Willard Morgan, 1929. Thomas Hines

Página anterior centro: Willard Morgan: Barbara Morgan dibujando en el Cañón del Colorado, 1928. Collection of the Haggerty Museum of Art, Marquette University Página anterior abajo: Barbara Morgan: Frontier, fotografía de Martha Graham, 1935 Collection of the Haggerty Museum of Art, Marquette University

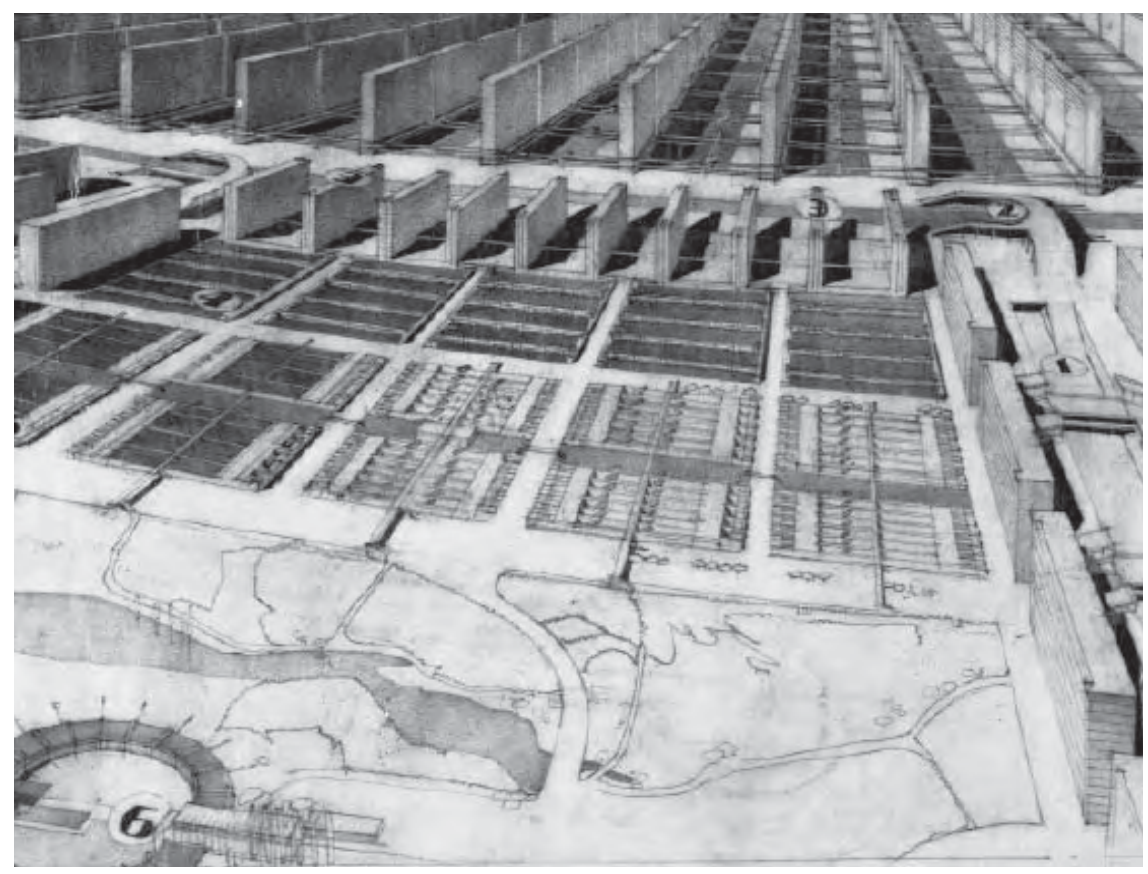

\section{Demostration Health House: fotografiando en Dundee Drive}

El doctor Lovell era un genuino producto del Sur del California y es difícil imaginar que su personaje pudiera haber sido creado o que hubiera tenido tanto éxito en otro lugar. Su columna en Los Angeles Times ejercía una influencia que iba mucho más allá del cuidado del cuerpo. Alimentaba una filosofía de vida que no tardaría en ser identificada con el hedonismo de la cultura californiana. David Gebhard ya reparó en ello cuando afirmó: "[Lovell] era, y quería ser considerado, progresista, ya fuera en cultura física, educación permisiva o arquitectura. Al igual que las nacientes estrellas de Hollywood de los años veinte, su vida era completamente pública. Su vida familiar, o por lo menos la imagen de la misma, emitía su mensaje tanto como sus escritos y su vida profesional; su casa, por consiguiente, tenía que ser expresión de cómo deseaba ser visto. No debía demostrar únicamente de forma directa la gran prioridad que daba a la función, sino que debía estar presentada en un envoltorio de deslumbrante novedad; y disponía del dinero necesario para ello"74.

Lovell dio completa libertad a sus arquitectos, tanto a Schindler como a Neutra para proponer y desarrollar el diseño que consideraran más adecuado. Y, aunque en ambos casos refirió la construcción de sus casas en su columna, en éste último, invitó a sus lectores a comprobar por ellos mismos el alcance de su obra: "Durante años he escrito artículos aconsejándoles periódicamente cómo construir una casa de la que se derive el máximo de salud, utilidad y belleza. He tratado sobre diferentes cuestiones relacionadas con iluminación, calefacción, instalaciones de hidroterapia, dispositivos que ahorren trabajo, sleeping porches, materiales de construcción y muchos más asuntos. Siempre terminaba mi columna diciendo, 'es lo que yo haría si algún día me construyera una casa'. Pues bien, ese día ya ha llegado. Hemos construido esa casa a partir de todos estos principios relacionados con la salud y de las ideas de arquitectura de las que les he estado hablando en el pasado. Sabemos que hay muchas personas interesadas en esta casa y por ello quiero comunicarles que vamos a abrir la misma para su inspección antes de que sea amueblada y ocupada. Por tanto, consideren esto como una invitación para todos los lectores de Care of the Body y vengan a visitar esta innovadora construcción para la salud localizada en el 4616 de Dundee Drive" ${ }^{\prime \prime 7}$. 
Rotulada en los planos de proyecto por el propio Neutra como Demostration Health House, la casa estuvo abierta de 8.00 a 17.00 horas el domingo 15 de diciembre de 1929 y el sábado y el domingo del siguiente fin de semana. Según diversas fuentes ${ }^{76}$, alrededor de 15.000 personas visitaron la vivienda. El éxito de la convocatoria fue tal que cada fin de semana tenían lugar verdaderos problemas de circulación en las inmediaciones de Griffith Park, requiriendo un auténtico despliegue de la policía de tráfico de Los Ángeles. Neutra participó en la iniciativa de su cliente, asistiéndole en la organización de las visitas y guiándolas él mismo cada día a las tres de la tarde. La prensa nacional se hizo también eco de la noticia y el arquitecto sumó a esta oleada de popularidad sus propios esfuerzos publicitarios, iniciados casi desde el arranque mismo del proyecto.

Realizado el replanteo de la vivienda en el solar, a principios de diciembre de 1928, el ritmo de las obras fue trepidante, tanto que la casa estuvo lista en apenas un año. Uno de los momentos de mayor intensidad de su construcción fue el montaje de la estructura metálica, la principal seña de identidad de la vivienda. Como escribió Esther McCoy: "El esqueleto estructural, en el cual se integraban los marcos estandarizados de acero de ventanas de tres particiones, fue ejecutado en secciones y transportado en camión hasta la empinada colina donde se levantaba la obra. Las viguetas ligeras prefabricadas fueron unidas mediante soldadura eléctrica. La precisión del trabajo de taller, con una tolerancia mínima77, evitó el coste de posibles desajustes de obra y, como resultado, el armazón de acero se erigió en tan solo 40 horas, demasiado rápido incluso para que las distintas fases del montaje pudieran ser documentadas fotográficamente ${ }^{1778}$.

El proceso fue registrado cuidadosamente por Willard Morgan, cuyas fotografías transmiten toda la excitación de aquellos días. Como fotógrafo y estudiante Neutra, Morgan recorrió la estructura con su cámara en busca de puntos de vista sorprendentes. En ocasiones se trata de imágenes de la pieza completa tomada desde abajo; otras veces de detalles de gran valor plástico, $\mathrm{e}$, incluso, de diferentes planos y contrapicados captados desde el interior de la jaula metálica.

Willard Morgan había llegado muy joven a California, donde transcurrió su adolescencia. En 1925 se casó con Barbara Brooks Johnson, pintora y profesora de arte a quien inició pronto en la fotografía. Ésta se convertiría más tarde en una de las principales fotógrafas de danza, retratando entre otros artistas del círculo de los Weston y de John Cage, a Martha Graham y Merce Cunningham. Por su parte, su marido llegaría a ser uno de los más influyentes editores de fotografía del país. Fue adjunto a la dirección de la revista Life, publicó diversos libros sobre técnicas fotográficas y comisarió exposiciones tan significativas como la muestra de fotografía documental sobre las condiciones de vida de los agricultores de la Farm Security Administration durante la Gran Depresión que se exhibió79 en Nueva York en 1938. Willard Morgan fue el introductor, en 1928, de la cámara Leica de $35 \mathrm{~mm}$ en los estados Unidos, a la que también dedicó un tratado, Leica Manual. En 1943, Morgan fue nombrado Director de Fotografía del Museo de Arte Moderno de Nueva York, siendo el primero en ocupar ese cargo.

En capítulos anteriores se ha tratado acerca de la estrecha relación entre los Schindler, los Weston, los Morgan y los Neutra, concretamente, a través de sus vínculos con Kings Road ${ }^{80}$. Sin embargo, Willard Morgan sintió más afinidad por el trabajo de Richard Neutra con quien, más allá de fotografiar para
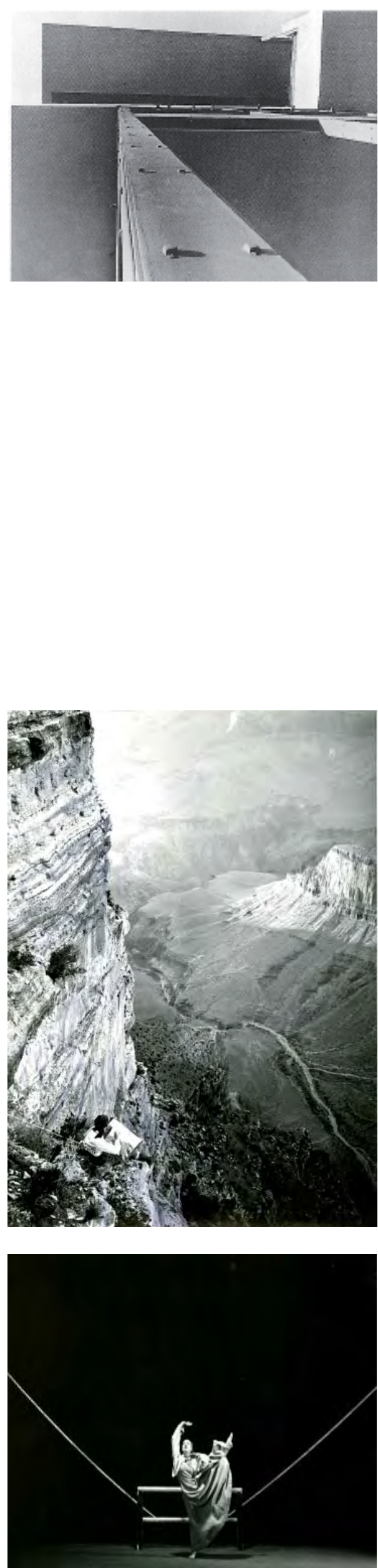


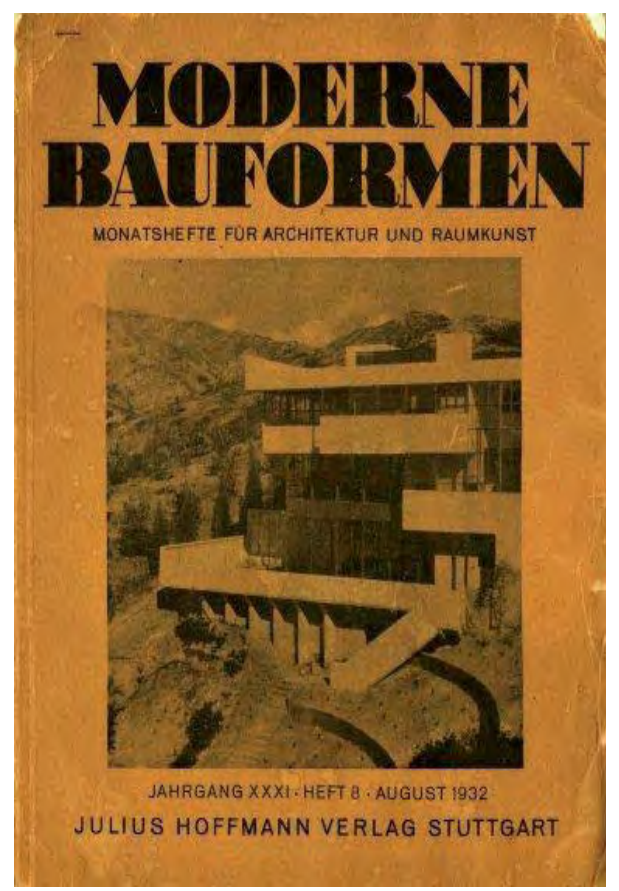

él, colaboró en diversos proyectos editoriales y mantuvo una amistad hasta el final de su vida. Morgan y Neutra compartían su interés por los medios de comunicación, demostrando ambos gran capacidad para relacionarse con sus editores y conseguir publicar sus artículos, generalmente relacionados con cuestiones tecnológicas.

Uno de los temas que más fascinaba a Morgan por aquel entonces era el de la movilidad, las infraestructuras y los equipamientos específicos para el coche que se estaban implementando en California como consecuencia del desarrollo vertiginoso de la industria y de la cultura del automóvil que estaba condicionando de manera determinante los modos de vida de la región. La movilidad era también otro de los ejes del modelo teórico Rush City Reformed en el que Neutra trabajaba en aquellos momentos. En septiembre de 1928, por ejemplo, Willard Morgan había publicado un artículo ${ }^{81}$ sobre supermercados destinados a automovilistas en los que era posible realizar la compra sin bajar del coche (California Drive-In Markets, aparecido en la revista Chain Store Review). En dicho artículo, Morgan trataba sobre un proyecto de estas características de Richard Neutra que no llegó a construirse. El fotógrafo y el arquitecto compartían su entusiasmo por todas estas novedades $y$, de hecho, Morgan seguiría publicando artículos al respecto y Neutra, en las dos décadas siguientes, llegaría a ser uno de los arquitectos que más influenció el diseño comercial de la ciudad de Los Ángeles.

A partir de su colaboración para estos artículos y las fotografías de sus primeras obras, como los apartamentos Jardinette o el Lovell Physical Center, ambos intensificaron su relación profesional que culminó, precisamente, durante la construcción de la Lovell House.

Entre otros medios, las imágenes del proceso de montaje de la estructura, firmadas por Willard Morgan, fueron publicadas en el número ${ }^{82}$ de mayo de 1930 de Architectural Record, en el segundo libro de Neutra, Amerika, aparecido en Viena ese mismo año e, incluso, en un artículo sobre la casa escrito por el propio fotógrafo y que Morgan envió en julio a la revista Sheet Metal Worker bajo el título An Architect's Warm-Air Heated Health House ${ }^{83}$. Estas imágenes, seguramente más que las de la obra terminada, fueron las que contribuyeron a que la casa se convirtiera en un mito. Las fotografías 


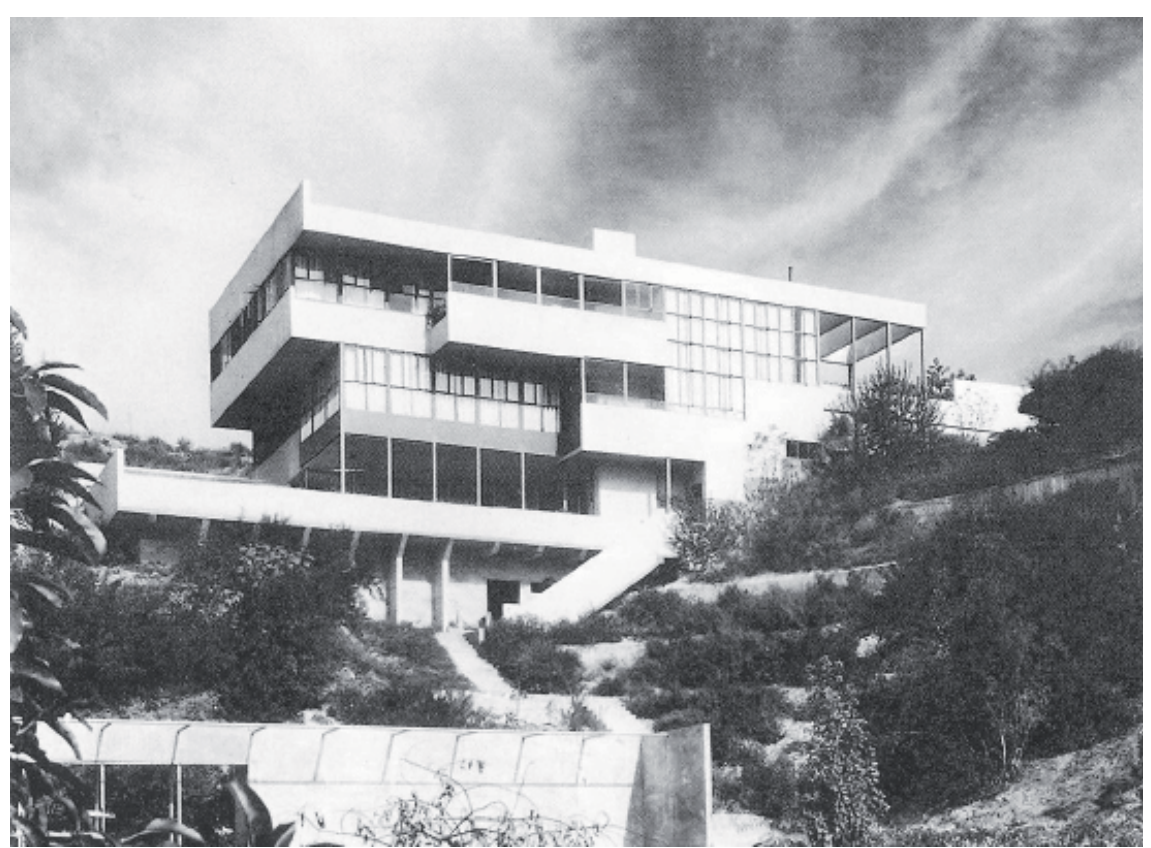

transmitían la idea de construcción de un artefacto. El montaje podía ser el de un silo, o el de una fábrica, o incluso un barco, tipologías asociadas al ideario de la máquina que las fotografías de Willard Morgan se esforzaban en representar.

Dichas imágenes exhibían al mundo el nivel de precisión logrado por la tecnología americana, un grado de exactitud sólo comparable al de las máquinas y, en este sentido," las fotografías de máquinas realizadas por Evans, Weston o Sheeler [...] no son muy distintas de algunas de estas instantáneas" ${ }^{\prime \prime 4}$, como ha señalado Ruben Alcolea. Al impacto de aquellas fotografías Neutra sumó el de las prolijas descripciones de todos los adelantos con los que contaba la casa: "un sistema de riego automático para la cubierta, las jardineras y toda la parcela [...] un incinerador a gas para la basura; ventiladores giratorios; lavaplatos [...] interfono [...] altavoces dinámicos por control remoto; sistema de calefacción por aire controlado por termostato [...] puertas hidráulicas de garaje [...] tanque para combustible y surtidor de gasolina [...] vidrios con protección de rayos ultravioletas" ${ }^{\prime \prime 5}$ y una larga lista de novedosos materiales como linóleos, papeles lavables, cerrajería cromada, encimeras de bakelita, etc. La asociación entre las imágenes del esqueleto de acero y todo este catálogo de construcción inaccesible a la mayoría de los arquitectos del mundo no podía ser más reveladora del interés de Neutra por reclamar para sí mismo una posición destacada entre los líderes de la vanguardia internacional.

Gracias a esas fotografías, mostradas una y otra vez durante sus conferencias por todo el mundo, desde Tokio a la Bauhaus, Neutra fue recibido como un mago de la tecnología ${ }^{86}$-por usar las palabras de Esther McCoy. Aunque, a pesar de ello, coincidiendo con su regreso a la Coste Este, entre finales de 1930 y 1931, Richard Neutra y Willard Morgan trataron sin éxito encontrar un editor en Norteamérica que quisiera publicar un libro monográfico dedicado a la Lovell House ${ }^{87}$.

Tras el objetivo de Morgan, el siguiente fotógrafo en proyectar su mirada sobre la casa fue Arthur Luckhaus, a quien muy probablemente puso en contacto con Neutra el propio Willard Morgan antes de marcharse a Nueva York con la intención de consolidar allí su carrera editorial ${ }^{88}$.
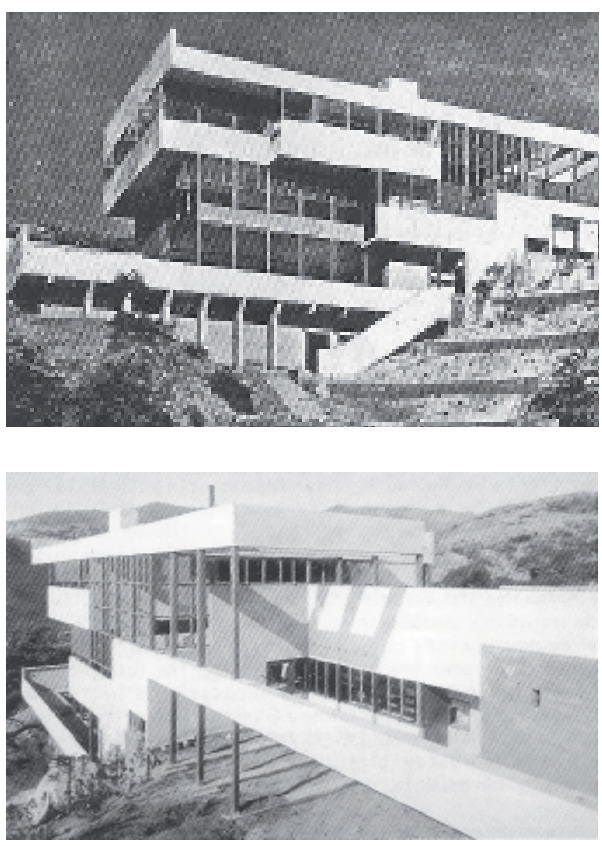

Arthur Luckhaus: Imagenes exteriores de la Lovell House tomadas en momentos diferentes a lo largo de los últimos meses de 1929. Fuente: Thomas Hines

Página anterior izda: Portada de Moderne Bauformen, Julius Hoffmann, Sttutgart, agosto 1932, con una imagen de la casa Lovell de Arthur Luckhaus

Página anterior dcha: Richard Neutra: Dibujo de Drive-in Market, hacia 1928-29. 

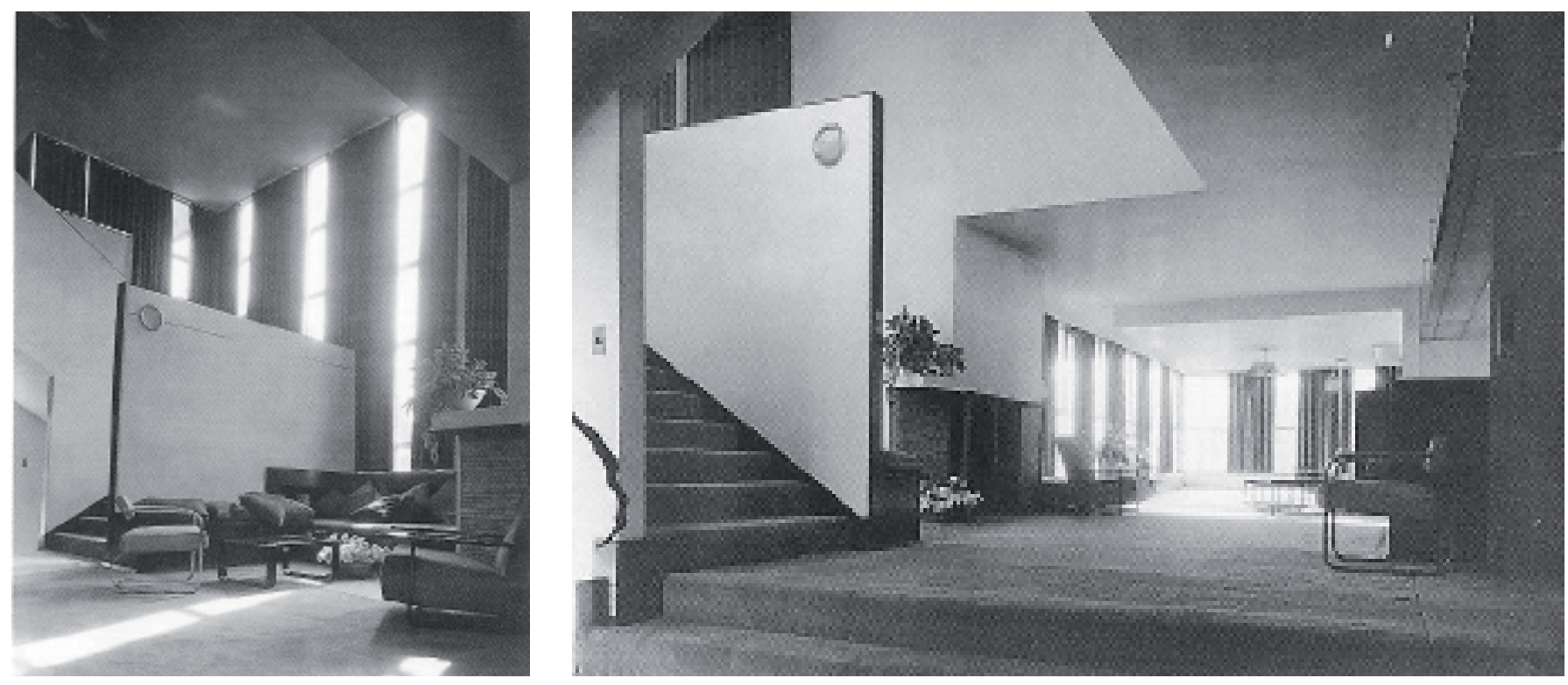

Luckhaus llevaba trabajando como fotógrafo comercial en Los Ángeles desde principios de los años 20. Aunque sin las aspiraciones artísticas de Shulman, Luckhaus realizó una obra de una gran corrección. Como autor posee el interés de ser el documentalista urbano de algunos de los principales episodios de la ciudad, como los programas de vivienda pública de la City Housing Authority, agencia para la que fotografió el proceso de intervención en The Flats, desde los estudios de campo hasta su concreción en el proyecto de Aliso Village (1940-1942). A partir de su encargo de retratar la casa Lovell, Luckhaus se convirtió en el fotógrafo de Neutra hasta la aparición en escena de Julius Shulman en 1936, pero compartió todavía el favor de Neutra hasta principios de los años 40. Luckhaus realizó casi todas las imágenes con las que el arquitecto dio a conocer obras tan emblemáticas como sus viviendas Beard, Koblik, Scheyer, VDL y von Sternberg, todas ellas construidas entre 1932 y 1935.

La aproximación de Luckhaus a los espacios de Neutra es metódica, aséptica y de una austeridad diametralmente opuesta a la creación de ambientes de Julius Shulman. En muy pocos interiores fotografiados por Luckhaus aparecen personas y apenas hay trazas de actividad humana excepto, muy ocasionalmente, el propio arquitecto, que suele aparecer posando en la distancia, a veces mirando por una ventana, otras sentado ojeando un libro y generalmente de espaldas a la cámara, como si quisiera dejar claro que simplemente está de paso. El propio Shulman se refería probablemente a ello cuando escribió sobre él: "Había muy buenos fotógrafos comerciales aquí [en Los Ángeles], incluyendo a un hombre que respondía al nombre de Woodcock ${ }^{89}$ y que era estupendo. Realizó fotos de Schindler y de Harwell Harris. Y antes que él había otro fotógrafo de origen alemán llamado Luckhaus que trabajó para Neutra. Luckhaus fue un pionero de la fotografía... hizo muy buenas fotos comerciales, aunque no eran (y no me gusta usar este témino) 'obras de arte'go".

Luckhaus fotografió la Lovell House poco después de su terminación en 1929. Lo hizo en dos momentos distintos separados por un intervalo de pocos meses. El tiempo suficiente para que hubiera crecido la vegetación y las terrazas del jardín comenzaran a cobrar vida. Los puntos de vista en ambas series son muy similares, perspectivas lejanas que, a pesar del encuadre que incluye buena parte de la parcela, no logran trasmitir una imagen del lugar y ni tampoco aproximarse a la compleja relación que la casa establece con su 
entorno. Luckhaus centró su mirada en el objeto arquitectónico, aislándolo y presentándolo en la rotundidad de sus volúmenes, como si de una escultura abstracta se tratase.

El fotógrafo se esforzó por reproducir el mismo punto de vista con que se habían retratado las maquetas. Se trataba, por un lado de poner de manifiesto la exactitud con la que se había ejecutado la obra, es decir, de subrayar la precisión de un diseño industrial capaz de materializar sin error alguno el salto de escala desde el modelo del objeto a su realidad construida. Por otro, la fotografía tomada desde la cota más baja de la parcela, con la cámara enfocando hacia arriba -a vista de gusano- era ciertamente espectacular, magnificaba las dimensiones reales del proyecto y hacía creer que la casa era mayor de lo que era.

Las fotografías de Luckaus revelan sin embargo algunas de las contradicciones internas del proyecto de la Lovell House. Por ejemplo, mientras que Neutra había proclamado la transparencia de una metodología de trabajo consistente en trasladar de dentro afuera la lógica organizativa de la estructura, la voluntad compositiva de los planos blancos de hormigón gunitado destacándose sobre la malla metálica y, en especial, los remates verticales de los antepechos, evidenciaban un énfasis en el diseño ajeno a dicha lógica.

Los interiores de la primera serie, apenas amueblados, sin la presencia de ninguna persona en la fotografía, ponen en valor la estructura de acero y las superficies que delimitan los recintos. Luckhaus incorpora en la misma proporción, casi de forma simétrica, el plano del suelo y el plano del techo, algo especialmente evidente en las instantáneas de la escalera, uno de los espacios más estimulantes del repertorio moderno, en opinión de Thomas Hines ${ }^{91}$, y donde el fotógrafo enfatizó las líneas verticales de las franjas de luz interrumpidas dramáticamente por las sombras de las cortinas. Los fondos quemados de Luckhaus aplanan la imagen, evitan que la mirada escape del interior de la casa, concediendo tanto protagonismo a éste que parece imposible todo intento de diálogo con el exterior.

Si Morgan había fotografiado la Lovell como un artefacto fabril y Luckhaus había descontextualizado la casa para poner en valor su carga objetual, fue Shulman quien plasmó finalmente la calidad de sus espacios y la capacidad de la arquitectura para dialogar con su medio natural.

En la primera parte de esta tesis se ha especulado con la posibilidad de que Richard Neutra también hubiera trabajado con Edward Weston como fotógrafo en la Lovell Health House. Al margen de que esta hipótesis pudiera ser o no comprobada, parece claro que la forma de fotografiar del artista no fue del agrado del arquitecto para quien, a veces, la extrema definición de Weston en el detalle de los objetos representados debió resultar distorsionadora, como el mismo Neutra se encargó de precisar: "Mi querido amigo -ya desaparecido-Edward Weston (al que estoy muy feliz y orgulloso de haber promocionado con una exposición itinerante desde Munich [sic.] y por toda Europa cuando casi nadie le conocía) ino era en absoluto un fotógrafo de arquitectura! Weston sencillamente podía enamorarse de la textura y de las grietas de la escayola. Sus extraordinarias fotografías podrían haber servido como evidencia en un juicio contra el constructor. Pero la fotografía de arquitectura es un arte aplicado. Los fotógrafos de arquitectura como Julius Shulman se aplican al arte de sus amigos arquitectos. Deben seleccionar las imágenes que se aproximan más a la esencia de la obra"92.
Abajo y página anterior (izda y dcha): Interiores de la Lovell Health House. Fotografías de Arthur Luckhaus, 1929

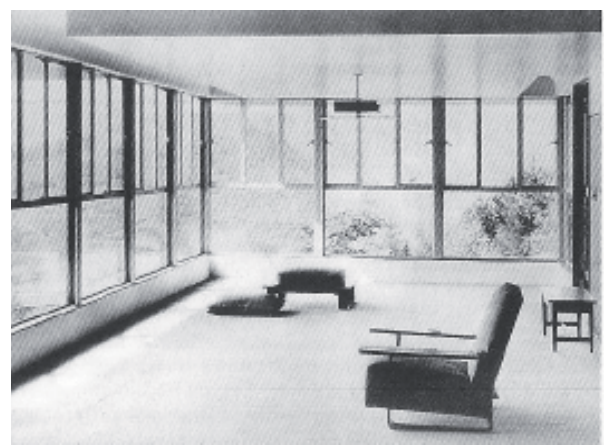




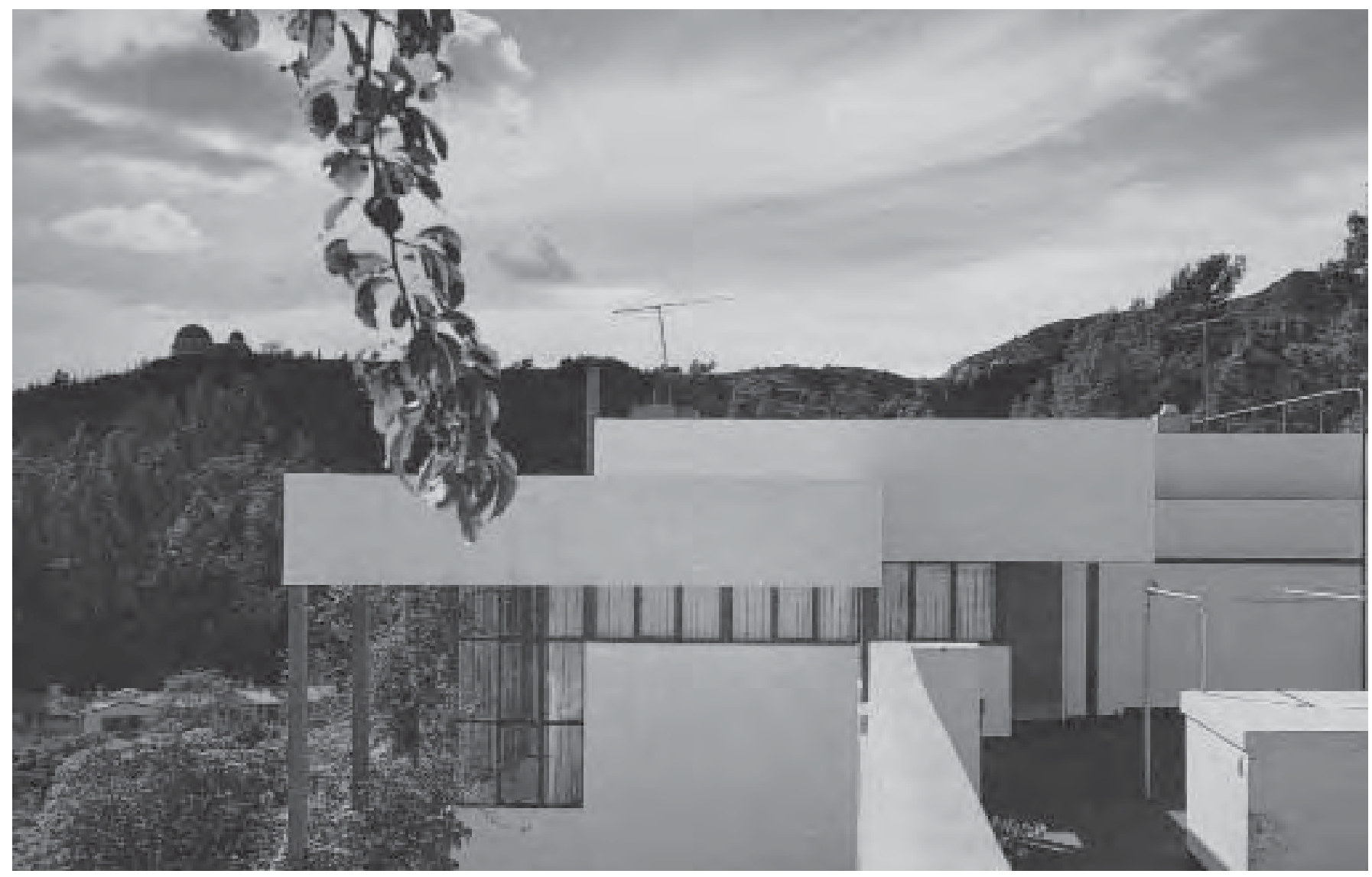

La afirmación de Neutra formaba parte de su introducción al libro de Julius Shulman Photographing Architecture and Interiors, la primera publicación que el fotógrafo dedicó a explicar su técnica. Es revelador que hasta ese momento de su texto (aproximadamente dos tercios del mismo) el arquitecto ha estado tratando sobre cuestiones relacionadas con la fotografía de arquitectura sin nombrar directamente a Julius Shulman, a quien introduce en el mismo párrafo en el que se ha referido a Weston. Es decir, por oposición a Shulman, Neutra utilizó a Weston como ejemplo antitético de lo que debería ser un fotógrafo de arquitectura.

La estrecha relación profesional entre Richard Neutra y Julius Shulman es conocida. El fotógrafo narró en numerosas ocasiones los detalles de su encuentro con el arquitecto en marzo de 1936 y cómo, tras enseñarle una serie de imágenes tomadas con su Vest Pocket Kodak de la casa Kun que Shulman había realizado por iniciativa propia, Neutra se mostró tan satisfecho que comenzó a encargarle fotografías de sus obras. A partir de 1936 Neutra influyó decisivamente la fotografía de Shulman quien, bajo su tutela, entró en contacto con las ideas de la modernidad arquitectónica, aprendió a representar sus edificios y dejó de ser un fotógrafo comercial para convertirse en fotógrafo de arquitectura. De acuerdo con Shulman, Neutra fue la persona que más peso ejerció en su formación visual y en su manera de entender el espacio arquitectónico moderno93. Al año siguiente, Shulman fotografiaba ya para todos los arquitectos del entorno de Neutra (Schindler, Gregory Ain, Rapahel Soriano y J. R. Davidson, etc.), exceptuando a Harwell Hamilton Harris.

Formalmente, su técnica fotográfica es prodigiosa. Shulman sabía bien que la luz era la principal responsable del carácter de la arquitectura y sacó todo el partido a la luz tan especial y matizada del Sur de California. El fotógrafo desarrolló una paleta extrema de blancos y negros, sirviéndose del contras- 
te entre zonas iluminadas, áreas en sombra y sombras arrojadas para producir profundidad. Él mismo escribió: "Una sombra en una fotografía es algo casi subliminal [...] es un eco de los elementos del diseño de los que reproduce o refleja su estructura misma dotándolos de carácter" ${ }^{\prime \prime 4}$. Igualmente, de noche, se valía de los reflejos de las luminarias los vidrios para dirigir la mirada del espectador desde el primer plano de la fotografía hasta un fondo infinito. Shulman usó formatos de cámara de $4 \times 5^{\prime \prime}$ y, en menor medida, $8 \times 10^{\prime \prime}$, así como diversos tipos de lentes con los que enfatizar la profundidad de sus imágenes. Su control de las técnicas de revelado, variando las exposiciones de partes de la fotografía para manipular-por ejemplo- las nubes y los cielos, incidía también en esa sensación de profundidad que transmiten todas sus instantáneas. En general, sus meticulosas composiciones responden a una jerarquía visual que el artista se permitía desequilibrar por medio de sutiles asimetrías.

Shulman demostró un talento instintivo para orquestar escenas: "para fotografiar arquitectura hay que tener una mente abierta, ser capaz de imaginarse una situación y narrarla" ${ }^{\prime 95}$. El fotógrafo se concedía diversas licencias artísticas, como sugerentes posiciones de cámara, iluminaciones arbitrarias y montajes de ambientaciones con modelos, accesorios, plantas, y hasta ramas sostenidas mediante trípodes para recalcar la íntima relación de la arquitectura con el medio natural.

La fotografía que Shulman realizó del acceso de la casa Lovell muestra una estructura blanca emergiendo entre los árboles. A diferencia de las imágenes de fotógrafos anteriores, casi no hay interés por contar de qué material está hecha la vivienda, o cuáles son sus auténticas proporciones porque, como ocurre en la realidad, la exuberante vegetación del jardín apenas permite adivinar el modo en que la casa desciende por la parcela. En lugar de ello, Shulman repara en los planos del antepecho que conduce hasta la entrada, en la secuencia de terrazas que confieren escala doméstica, en las líneas horizontales de la cubierta enmarcando la vista de las colinas del parque, y en la inconfundible silueta del Observatorio Griffith en la esquina superior izquierda de la fotografía. Shulman logra transmitir la misma sensación que tiene el visitante que llega a la Lovell House por primera vez y percibe la casa como una privilegiada atalaya dominando uno de los mejores panoramas de Hollywood Hills.

La comparación con la sobriedad de las fotografías de Luckhaus resulta inevitable. La condición estática del primero es remplazada por las perspectivas dinámicas y llenas de vida de Shulman. Mientras que las imágenes de Luckhaus recuerdan las asépticas aproximaciones de los fotógrafos de entreguerras a las máquinas de la modernidad europea, Shulman, más allá de fotografiar arquitectura, celebraba el estilo de vida californiano con el que se identifica su ciudad y su época.

Aunque Shulman fotografió todo tipo de estilos y construcciones, sus imágenes de mediados del siglo pasado mostraron al mundo que la arquitectura moderna de Los Ángeles, mejor que ninguna otra, condensaba todos los valores de buena vida asociados al imaginario del Sur de California. La fotografía de Shulman no sólo representaba una realidad, producía una nueva realidad. O, como ha afirmado Ted Wells, en las "agudas composiciones de Julius Shulman, hombres interesantes y elegantes mujeres son captados en mitad de una estimulante conversación mientras beben cocktails, se relajan en el jardín o emergen de un baño nocturno en la piscina [...] Las fotografías de
Julius Shulman preparando el encuadre y la ambientación de una fotografía de una casa de Cliff May, 1954

Página anterior: Lovell Health House, acceso a la vivienda fotografiado por Julius Shulman

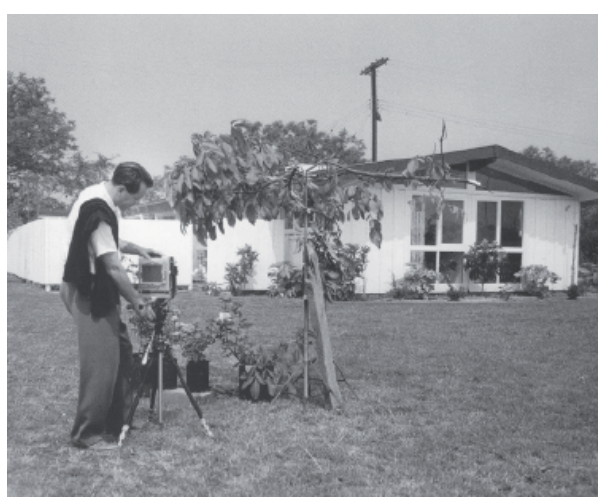




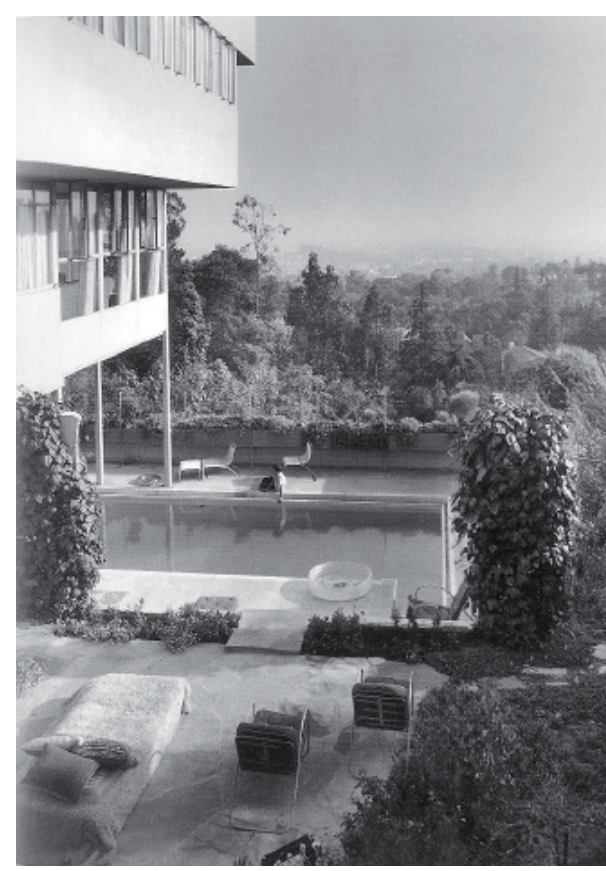

Lovell Health House, vista de la piscina. Fotografía de Julius Shulman

Página siguiente: Richard Neutra y Harwell Hamilton Harris: Propuesta para el Concurso del Observatorio de Griffith Park publicada en T-Square magazine, febrero 1932
Shulman otorgaban las dos cosas que una obra necesita para la inmortalidad: respetabilidad y deseabilidad [...] Se trataría de visiones de un futuro en el que todo el mundo vive en casa modernas con mobiliario de firma. Más de un siglo después [esas imágenes intemporales] tienen el poder de recordarnos el futuro de nuestro pasado"96.

En efecto, si hay un rasgo distintivo que deba señalarse del trabajo de Shulman es su capacidad de seducción. El fotógrafo consigue llevar inmediatamente al espectador a su terreno, haciéndole desear ser partícipe de las escenas que describe. Las imágenes de Shulman captan la esencia de las arquitecturas retratadas y proyectan sobre ellas toda la fantasía asociada al Sur de California. Y por esta razón resultaron tan atractivas tanto para los arquitectos, como para los editores y para el público en general.

La relación de Richard Neutra y Julius Shulman fue bidireccional. Si el primero marcó la orientación de la carrera profesional del fotógrafo, hasta el punto de que éste afirmó que la persona de la que más aprendió a fotografiar arquitectura fue de Neutra97, el arquitecto también se vio influido por la mirada que Shulman proyectaba sobre sus obras. Shulman relató su particular lucha con Neutra para conseguir que le dejase incluir más elementos de mobiliario, objetos y modelos en sus composiciones, a lo cual al principio el arquitecto se mostró reticente ${ }^{98}$. La incorporación del paisaje a la fotografía y la introducción de personas e, incluso de niños, humanizando sus arquitecturas, favoreció la progresiva apertura de Neutra hacia la naturaleza y, aunque Shulman no fue la única razón para ello, a partir de la década de 1940, las viviendas de Neutra se prefiguran como dispositivos que se proyectan hacia el exterior, estableciendo cada vez más transiciones hacia el lugar donde acaban disolviéndose.

\section{Harris y las lecciones de Neutra}

Interrogado en una entrevista acerca de qué arquitecto le había despertado mayor interés durante su etapa formativa, si Schindler o Neutra, Harwell Hamilton Harris contestó de forma muy gráfica: "Bueno, en realidad, fue más cosa de Neutra, porque fue él quien mostró interés por tenerme a mí. Él quería tener algunos discípulos y por ello me dedicó muchísima atención. Schindler era muy amable pero nunca me propuso nada. Y yo ya había asistido a varias conferencias de Neutra y había quedado impresionado por la sugerente influencia de la tecnología en el diseño, así como por el uso de la tecnología como medio de producción. Esos fueron mis comienzos. Además había comenzado a trabajar con Neutra [...] sus ideas dominaban por entonces mi pensamiento. $Y$ aunque contibuaba fijándome y aprendiendo del trabajo de Schindler [...] fue Neutra quien marcó mi camino"99.

Como se tratará en el capítulo siguiente, en esa misma entrevista y en otras ocasiones, Harris habló del impacto que la casa de Shindler había supuesto para él, pero insistió siempre en que fue de Neutra de quien verdaderamente comenzó a aprender arquitectura.

En efecto, aunque la obra de Schindler ejerció una notable influencia sobre la arquitectura de Harris a lo largo de los años, fue Richard Neutra quien se encargó personalmente de reorientar el rumbo de su carrera. De hecho, cuando -con 25 años- fue a visitar por primera vez a Schindler y Neutra a Kings Road pensando en iniciar sus estudios como arquitecto, Harris estaba 
dispuesto a marcharse a San Francisco tras su aceptación en la Universidad de Berkeley, pero Neutra le convenció para que desistiese de ello, asegurándole que aprendería mucho más sobre arquitectura moderna si se quedaba en Los Ángeles trabajando para él y asistiendo de noche a algunos cursos de ingeniería con los que complementar su formación. Harris aceptó inmediatamente la propuesta de Richard Neutra y éste le encomendó, como primera tarea, la delineación de los últimos planos de obra de la Lovell Health House.

Entre 1928 y 1932, durante los aproximadamente cinco años que estuvo colaborando con Richard Neutra, Harris tuvo la oportunidad de seguir de cerca la evolución creativa de su mentor, desde la experiencia de la casa Lovell, en cuya filosofía arquitectónica pudo profundizar a pie de obra y en las clases de la Academy of Modern Art, hasta sus primeras obras de los años 30.

En esa etapa formativa y de relación profesional con Neutra, el aprendizaje de Harris puede establecerse en dos ámbitos. Por un lado, desde el punto de vista disciplinar, Neutra le transmitió los ideales del proyecto moderno y, a través de su relación con los CIAM, propició el contacto del joven arquitecto con la vanguardia internacional -por mediación de Neutra, Harris se convirtió en el secretario del American Chapter para los CIAM. Por otro lado, con respecto a la publicidad de su trabajo, Harris tuvo como maestro a uno de los arquitectos de su tiempo más dotados para la autopromoción.

El paso de Harris por la oficina de Richard Neutra fue determinante para él en muchos aspectos. Exceptuando la Lovell House, Harris no trabajó en ningún otro proyecto que acabase siendo construido, por lo que, aunque tuvo un contacto indirecto con las obras de Neutra -a cuyo cargo estaba Gregory Ain-, su principal ámbito de acción fue el proyecto arquitectónico y la reflexión teórica. Dado que dedicó buena parte de su tiempo a asistir a Neutra en el planteamiento de concursos, presentaciones teóricas y modelos urbanos (como los proyectos para los CIAM o Rush City Reformed), Harris tuvo la ocasión de abordar propuestas experimentales mucho más avanzadas de las que podría haber desarrollado en obras construidas; tanto en lo referido a nuevos programas, producción industrial de la arquitectura y análisis de macrotendencias en la sociedad moderna, como también en lo relativo a técnicas gráficas, estrategias publicitarias, etc.

Los concursos en los que Harris participó con Neutra fueron proyectos de considerable escala. Éstos tuvieron lugar en los primeros meses de 1930, antes del viaje de Neutra alrededor del mundo. El primero de ellos fue el diseño del edificio para el Observatorio y Planetario de Griffith Park. Neutra se presentó en colaboración con Harris y el arquitecto Addison Mehr. Su rotundo y elegante edificio puente avanzando perpendicular a la pendiente de la montaña fue relegado en favor de la propuesta Art Déco más convencional de John Austin, cuyo conocido diseño fue construido en 1935.

El otro concurso emblemático de ese momento al que concurrieron juntos fue la convocatoria nacional para el Lehigh Portland Cement Airpot. Harris la calificó ${ }^{100}$ como su gran experiencia formativa con Neutra, dada la complejidad del programa y su necesidad de documentarse acerca de esta novedosa tipología para 1930, viéndose obligado a aprender acerca de todo tipo de cuestiones, desde dimensiones de pistas y hangares, hasta el funcionamiento de una terminal, redes de movilidad, sistemas de transporte asociados, etc. El concurso supuso para ambos una oportunidad para aplicar las tesis de diseño urbano de Rush City Reformed a una propuesta real.

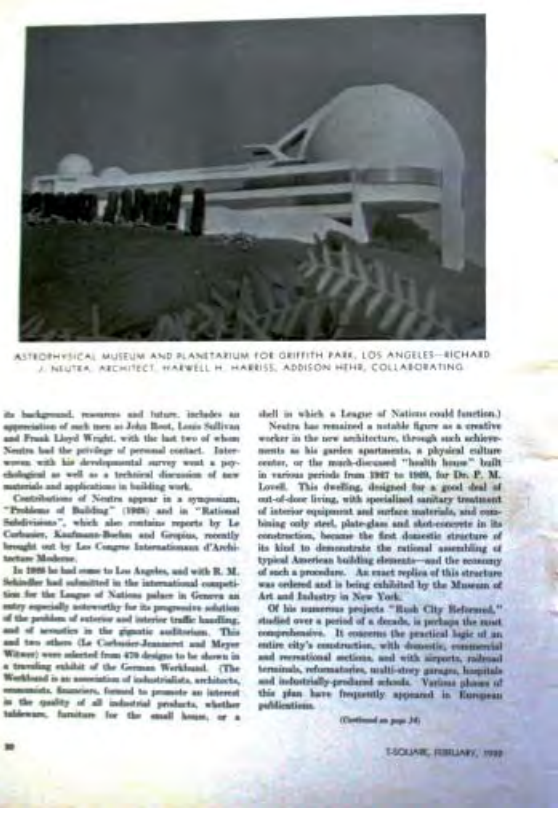

\section{(1)}




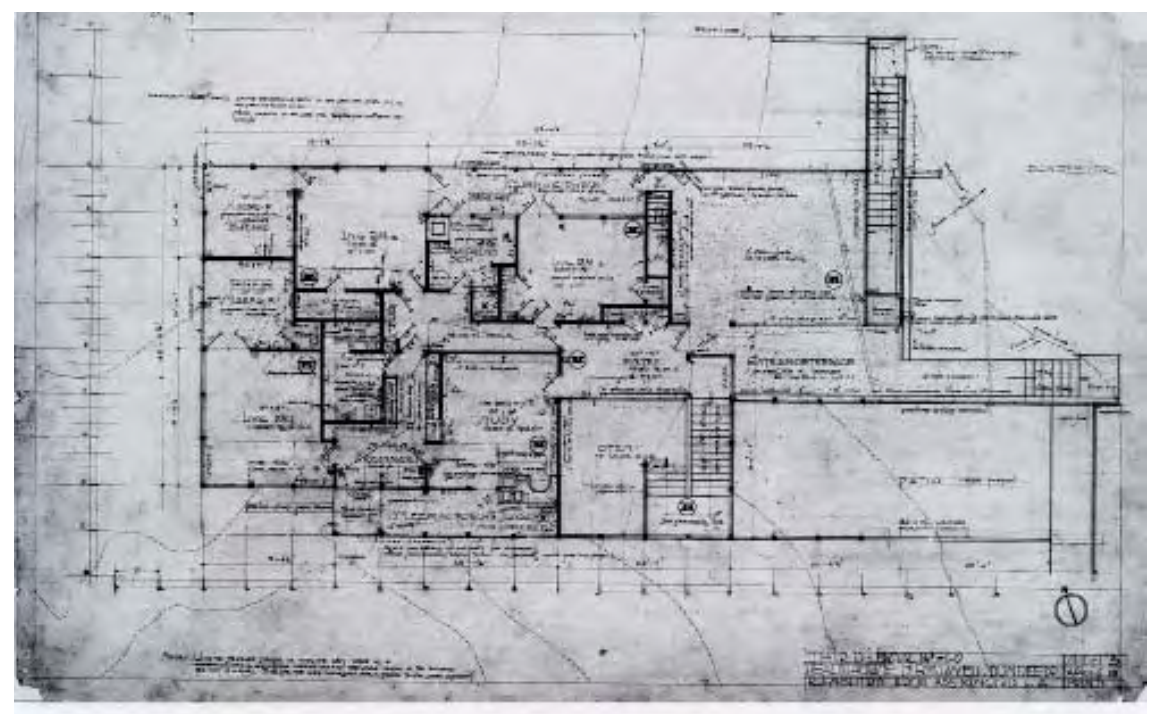

Lovell Health House, platas moduladas de la vivienda. Plantas de acceso y dormitorios (arriba) y nivel inferior con las estancias más públicas de la casa (abajo). Richard Neutra Papers. UCLA Library Special Collections

Página siguiente: Richard Neutra: Entrada y garaje del estudio de Conrand Buff publicado en Architectural Record, noviembre 1930

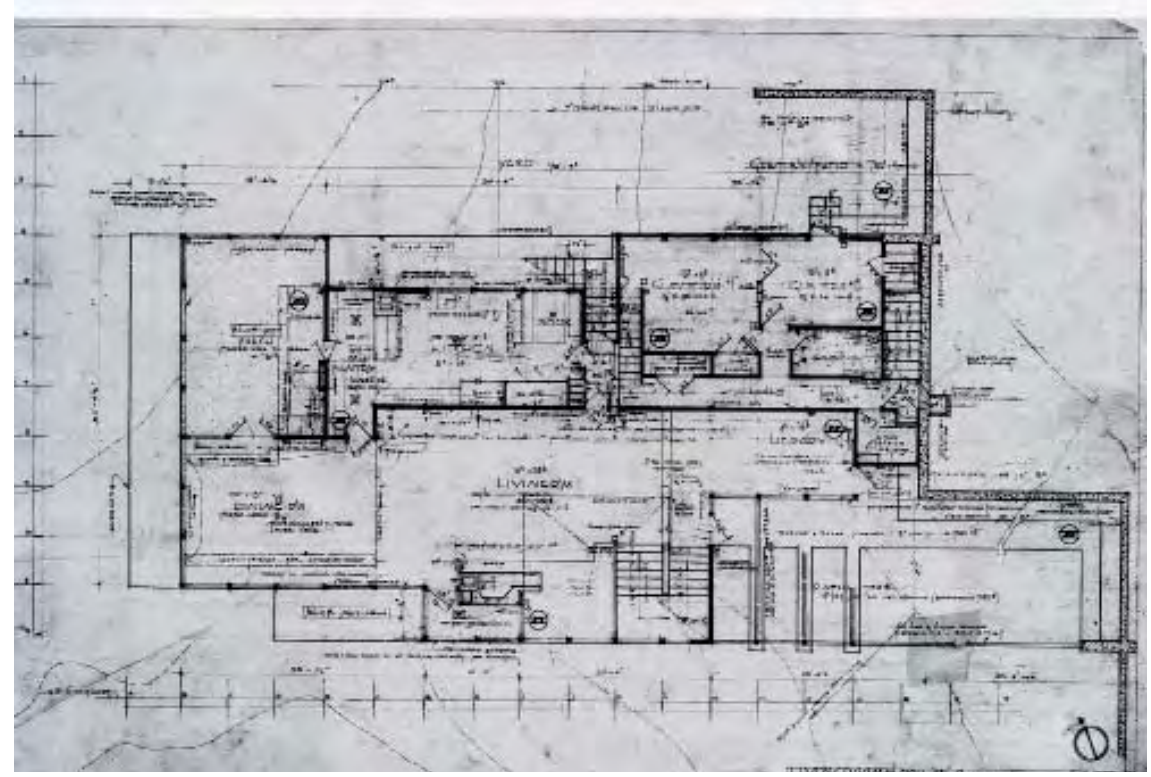

Trabajando codo con codo con Neutra, Harris llegó a conocer muy de cerca la personalidad y los intereses de su maestro, e intentó comprender las razones últimas que sustentaban su fascinación por el mundo de la industria americana. Harris se dio cuenta muy pronto de las diferencias culturales que separaban la mentalidad de los arquitectos europeos de la de los norteamericanos. Y sobre esto escribió:

"Para Neutra, Henry Ford simbolizaba el auténtico fenómeno americano: estandarización y la producción en masa. El 'Henry Fordismo' había cautivado las mentes europeas acostumbradas al orden y que, ante el malestar de un pasado reciente, desilusionadas por el fracaso del viejo orden, necesitaban encontrar pronto una nueva autoridad. La máquina podía ser esa nueva autoridad. Para los americanos, las máquinas podían ser herramientas o juguetes, pero nunca una autoridad. Los americanos nunca hemos reconocido autoridad alguna, con la única excepción, quizás, de la Biblia [...] En los años que pasé junto a Neutra, nunca dejó de maravillarse con el Sweet's Catalogue, para él su auténtica Biblia. Estaba convencido de que podría construir un edificio entero echando mano sólo de los productos de ese catálogo (que por entonces se publicaba en un solo volumen). Mientras Le Corbusier estaba fascinado por las imágenes de las máquinas americanas y los elevadores de grano, Neutra estaba absorto por los problemas y las oportunidades de una nueva civilización tecnológica. Ha- 
blaba de que todo edificio podría proyectarse como el producto de una producción industrial, o al menos un prototipo de uno. Afirmaba que pronto las casas se producirían en las fábricas como los coches; y no solo las casas, también las escuelas, los hospitales, las cárceles. Por supuesto, todos los proyectos que realicé por mi cuenta en aquella época tenían la prefabricación inoculada en su torrente sanguíneo ${ }^{\prime \prime 101}$.

Bajo la tutela de Neutra, Harris aprendió la conveniencia de estandarizar los componentes de la arquitectura y las ventajas constructivas de la precisión de los elementos producidos en serie. En este sentido, aunque la obra de Harris está asociada al uso de la madera más o menos procesada industrialmente, su gusto por emplear también otros materiales nuevos, en general prefabricados de bajo coste, procede de esta etapa.

La intercambiabilidad de las partes en un diseño modular y la idea de orden derivada de este sistema de trabajo fueron algunas de las enseñanzas que más calaron en su discípulo. Y la importancia que Harris concedería a la modulación de las plantas lo largo de toda su vida no se entiende tampoco sin la intervención directa de Richard Neutra.

En cuanto a los medios de comunicación, coincidiendo con la época en la que Harris llegó a su oficina, Neutra se dio cuenta rápidamente de que el mercado norteamericano demandaba y respondía muy bien a una inteligente y vigorosa autopromoción, de modo que "cuanta más fama él y su trabajo alcanzaran, mayor sería el impacto de sus ideas" ${ }^{\prime \prime 102}$. Por ello, desde la publicación de Wie Bau Amerika? sus estrategias publicitarias se habían hecho cada vez más agresivas.

En abril de 1928, por ejemplo, cuando Neutra apareció por primera vez en Das Neve Frankfurt, el arquitecto apenas había construido nada todavía, pero ya había obtenido su licencia en California y exhibió visiblemente su pertenencia al American Institute of Architects en la firma de su primer artículo. En éste, titulado Um die neue Gestaltung ${ }^{103}$ (Para una nueva formalización), la revista alemana incluía además una pequeña biografía en la que situaba al arquitecto en la tradición de Sullivan y Wright, una genealogía en la que, seguramente el propio Neutra había insistido para ser reconocido en la tradición de arquitectos norteamericanos que sus compatriotas europeos más admiraban ${ }^{104} \mathrm{Y}$ por supuesto, la reciente publicación de Wie Bau Amerika? era convenientemente puesta en valor en su reseña biográfica. El artículo se ilustraba con imágenes de la construcción y el proyecto de sus Jardinette Apartments, uno de los pocos edificios que, por entonces, había podido llevar a cabo.

Precisamente, por esa falta de obra construida en el número de septiembre de 1928 de la revista alemana, Neutra presentó una pequeña reforma en la vivienda-estudio del pintor de origen suizo Conrand Buff ${ }^{105} \mathrm{Como}$ si se tratase de una casa realizada bajo su entera responsabilidad. Conrand y Mary Buff frecuentaban los círculos de Jake Zeitlin y de Kings Road, donde habían conocido a Neutra. Éste les había construido en 1927 un pequeño garaje para su residencia de Eagle Rock, al oeste de Pasadena y, aunque Neutra no había actuado más que en elementos puntuales y en la reforma del jardín, presentó la vivienda de manera que confundía deliberadamente sobre el verdadero alcance de su intervención. El título del artículo, Richard Neutra: Casa Buff en Los Ángeles, permitía interpretar que él era el arquitecto de toda la obra $y$, por tanto, que tenía una probada trayectoria cuando apenas había podido
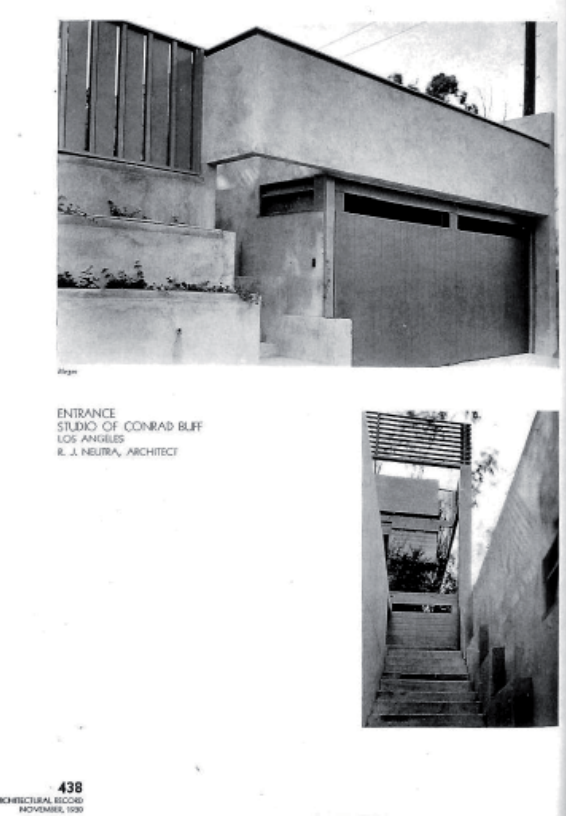


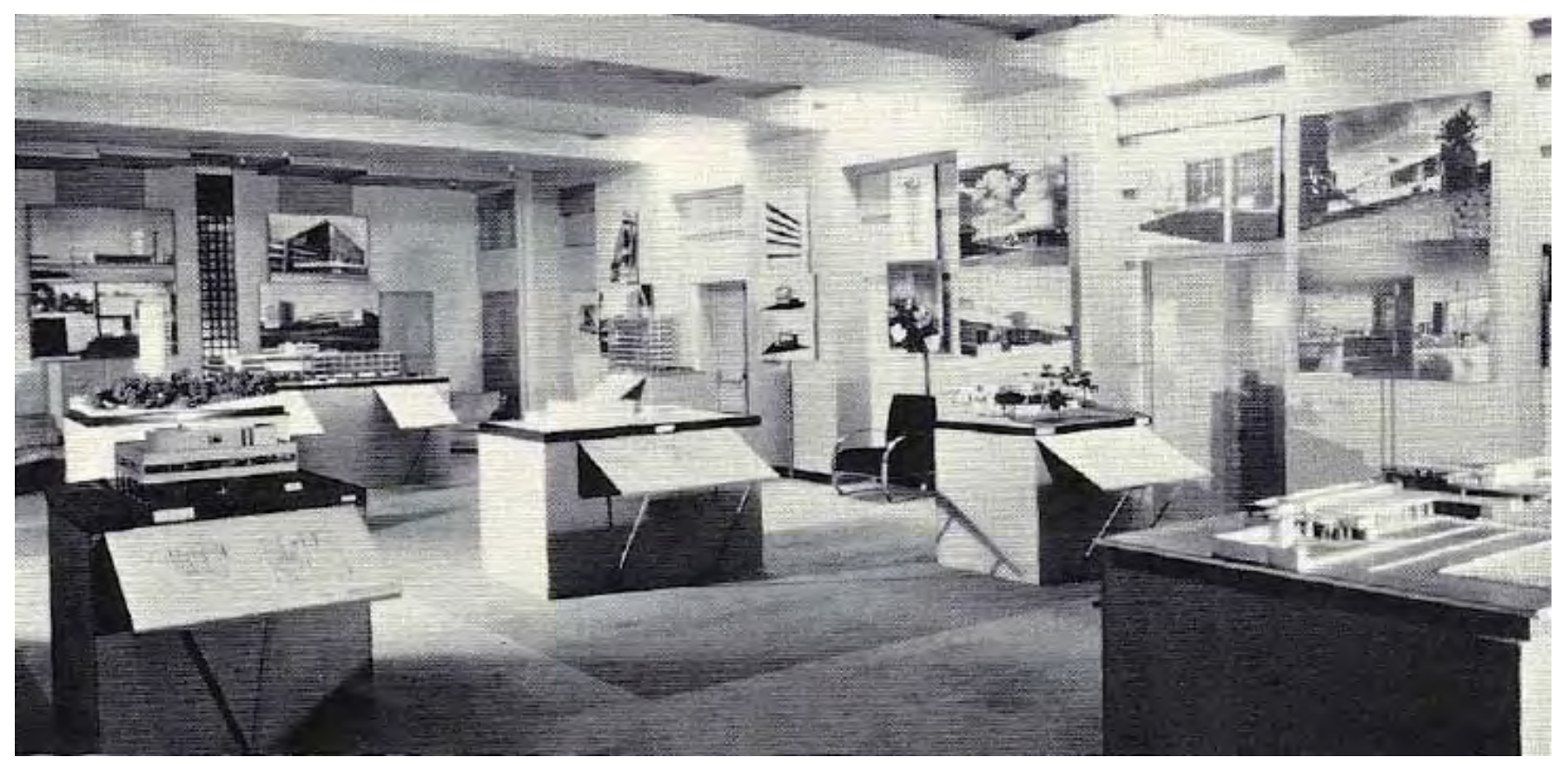

Exposición del MoMA de 1932 "Modern Architecture: International Exhibition", en su exhibición en julio-agosto de 1932 en los grandes almacenes Bullock's en Wilshire. Fuente: MoMA. La coordinación de su traslado a Los Ángeles y el seguimiento de su montaje fue realizado por $\mathrm{H}$. H. Harris, quien también buscó patrocinio.

Página siguiente: Anuncio de la exposición en Los Angeles Times, 24 julio de 1932. En las imágenes de arquitectura internacional que ilustran el artículo, junto a la casa Lovell y la Fábrica Van Nelle en Rotterdam, al incluir una fotografía de la maqueta del proyecto de su Ring School, Neutra procuró que, dado que era el único arquitecto del Oeste representado en la muestra, hubiera más obras suyas en el Times que de ningún otro autor empezar a construir, una estrategia que en la que también insistió dos años después en la publicación de esta obra en Architectural Record ${ }^{106}$.

Esta tendencia a la ambigüedad, e incluso a la exageración, explicaría también la elección del nombre de su sociedad con Schindler y Aronovici, AGIC, Architectural Group for Industry and Commerce. Bajo esta denominación empresarial, Neutra -que no Schindler- sugería un alcance corporativo de gran despacho de arquitectos e ingenieros que, en absoluto, se correspondía con las limitadas capacidades y el ámbito exclusivamente arquitectónico de su pequeño estudio de Kings Road. Pensado para impresionar, las siglas de AGIC, sin embargo, a veces llegaban a resultar intimidantes, como expresó Thomas Hines ${ }^{107}$.

El propio Harris relató que tenía instrucciones muy claras por parte de Neutra de contestar al teléfono usando exclusivamente el nombre oficial de la firma: "El primer día en su estudio, Neutra me dijo que si alguien llamaba por teléfono y él estaba fuera debía contestar diciendo 'Architectural Group for Industry and Commerce'. Para que no se me olvidara me lo escribí justo delante de mi teléfono y practiqué un poco, así que la primera vez que éste sonó respondí perfectamente. Durante un momento no hubo respuesta; entonces alguien al otro lado del teléfono dijo 'Oh, lo siento, pensaba que estaba llamando a un despacho de arquitectura' y colgó" ${ }^{108}$.

Tras el concurso del aeropuerto de Portland, Neutra inició su gira promocional por Asia y Europa. Dado que desde 1929 Harris era el Secretario del Capítulo Americano de los CIAM, él contactó directamente con Giedion y se ocupó de asistir a Neutra en la organización de su intervención en el CIAM III de Bruselas, donde presentó Rush City Reformed con los planos preparados por Harris.

Durante los meses que Neutra estuvo fuera de la ciudad, Harris fue la cara de su estudio y él mismo fue a recogerle a la estación a su regreso a Los Ángeles al año siguiente. En ese tiempo el arquitecto compaginó su labor en la oficina de Neutra con el inicio de su propia práctica profesional, abordando algunos diseños en solitario que no llegaron a construirse. 


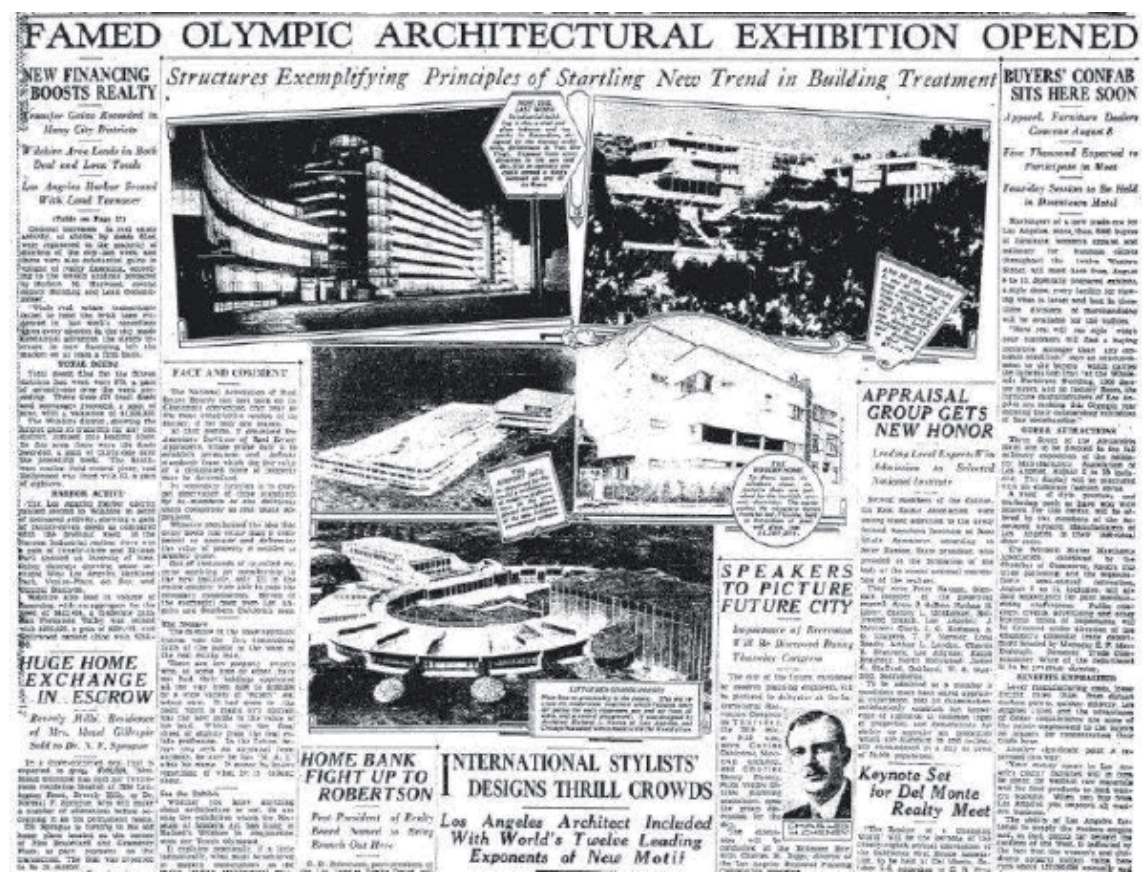

Con Neutra de vuelta en Los Ángeles -y ya fuera de Kings Road-, hacia el final de su colaboración con él, Harris fue asignado a otra iniciativa publicitaria de gran alcance, la exhibición en Los Ángeles de la exposición del MoMA Modern Architecture: International Exhibition tras su clausura en Nueva York en marzo de 1932. Neutra era el único autor del Oeste representado en la muestra, por lo que su intento para llevar la exposición a California no fue secundado por otros arquitectos y todas las gestiones se llevaron a cabo desde su oficina particular. En aquel momento Neutra estaba inmerso en la construcción de su casa VDL en Silver Lake y pidió a Harris que, con la ayuda de Ain, se hiciera cargo de la logística del traslado.

Ante la negativa de la Universidad de California de albergar la exposición, Harris llamó personalmente a John G. Bullock ${ }^{109}$, un próspero comerciante interesado en el arte moderno. Bullock sufragó buena parte de los gastos de la misma y accedió a que se exhibiera en sus Almacenes de Wilshire Boulevard, donde también se celebraron las conferencias de Johnson y Hitchcock. De este modo, gracias a Harris "de la misma forma en la que Le Corbusier había involucrado a través de L'Esprit Nouveau a los grandes almacenes franceses en su lucha por la modernización de la casa, Johnson y Hitchcock [lograron] penetrar en el mercado extremadamente conservador de la clase media del hogar"110.

En paralelo con la celebración de las Olimpiadas en la ciudad, la muestra abrió sus puertas en la quinta planta de este centro comercial, acondicionado como museo del Estilo Internacional, el 24 de julio de 1932 y fue clausurada el 30 de agosto. El evento también coincidió con otro hito histórico en el país, el vuelo en solitario de Amelia Earhart, de Los Ángeles a Newark, Nueva Jersey, que la convirtió en la primera mujer en completar un viaje sin escalas entre las dos costas del país ${ }^{111}$.

Durante el mes de agosto Neutra impartió tres conferencias en la ciudad a cerca de la exposición ${ }^{112}$. Y, gracias al empeño de Neutra, la exposición fue cubierta con más de 20 artículos en Los Angeles Times. Neutra publicó también una reseña de la exposición a doble página en el número de julio-agosto de 1932 de California Arts \& Architecture, como se apuntó en la primera parte de esta tesis. 
Cuando Harris dejó definitivamente el despacho de Neutra a principios de 1933 para iniciar su ejercicio profesional en solitario, Neutra había conseguido ya publicar más de 250 artículos y reseñas sobre sus obras construidas, proyectos, libros o actividad como conferenciante, incluso había escrito algunos bajo el nombre de Harris, como el artículo sobre el concurso para el aeropuerto de Portland que apareció en el número de abril de 1930 de la revista Die Form.

Todo aquel esfuerzo publicitario marcó la formación como arquitecto de Harris. De Richard Neutra aprendió que la fotografía era el instrumento de representación gráfica más poderoso para dar a conocer una obra de arquitectura y explicar sus intenciones. Neutra, en lugar de insistir en los dibujos, planos o detalles trató de fascinar mediante el impacto visual que las imágenes causaban en la mente de sus lectores. Y Harris heredó de su maestro la obsesión por la fotografía, hasta el punto que no cejó nunca en su empeño de encontrar al fotógrafo capaz de poner en valor las cualidades más reseñables de sus arquitecturas.

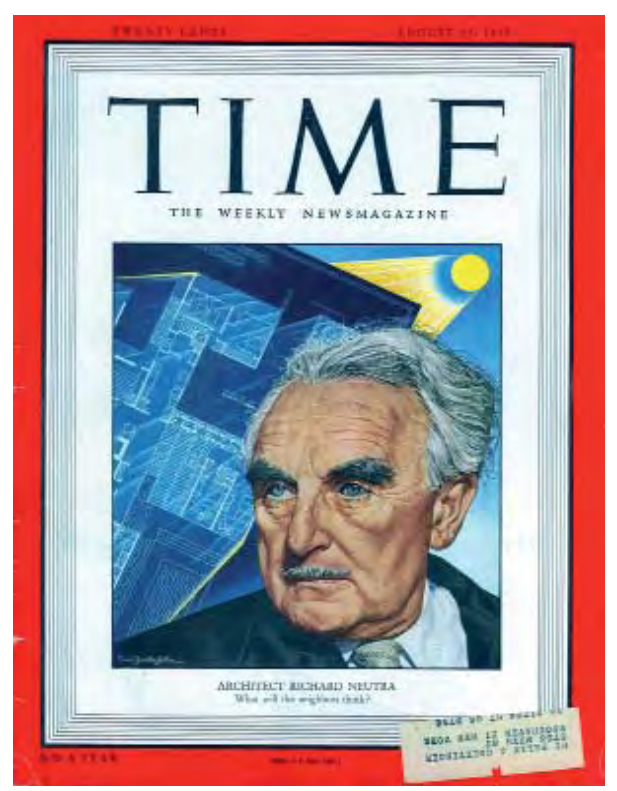




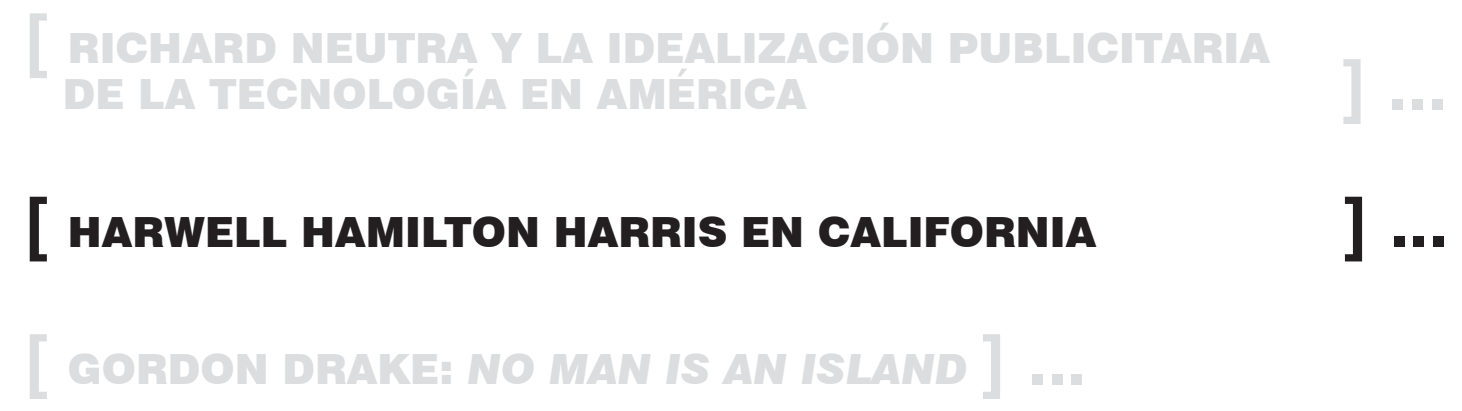




\section{Mi América realmente es California ${ }^{113}$}

Harwell Hamilton Harris es un arquitecto tan incuestionablemente moderno como californiano. Sus raíces culturales, confundiéndose con las de su propio árbol genealógico, se remontan hasta los primeros colonos anglosajones llegados al estado ${ }^{114}$. A diferencia de muchos de sus contemporáneos Harris había nacido en California, como también lo habían hecho sus padres. $Y$, aunque pasó los últimos 40 años de su vida fuera de California, siempre se sintió californiano. Su fascinación por la región alimentó un pensamiento arquitectónico permeable a múltiples referencias internacionales, pero que evolucionó remitiendo siempre a una profunda reflexión sobre el lugar y el modo de vida californianos.

La obra de Harris aglutina diversas tradiciones, desde la temprana influencia de su padre, un arquitecto forjado en los estilos fin de siglo, Craftsman y Mission Revival, hasta las enseñanzas de su mentor, Richard Neutra, quien conectó a Harris con la vanguardia europea y con los focos americanos del Estilo Internacional. Harris heredó también una concepción espacial mediada por el peso que desde finales del siglo XIX Japón había tenido en la cultura arquitectónica californiana, tal como pone de manifiesto la asimilación por parte de arquitectos tan admirados por Harris como los hermanos Greene, Rudolph Schindler y, por supuesto, Frank Lloyd Wright, de las tradiciones orientales. Incluso, su obra, sin tener una relación directa con las realizaciones del área de San Francisco aglutinadas bajo las controvertidas denominaciones "woodsy"115 (por su empleo de la madera) o "Bay Region Style" (por su énfasis en las tradiciones constructivas locales), podría analizarse bajo algunas de las mismas claves que permiten abordar el trabajo de arquitectos contemporáneos como Charles Warren Callister, Joseph Escherick o William W. Wurster.

Nacido en 1903 en Redlands, en el condado de San Bernardino, limítrofe con la ciudad de Los Ángeles, Harwell Hamilton Harris había crecido en el entorno rural del Imperial Valley. Aunque era hijo de un reconocido arquitecto local, Fred Harris, no mostró un verdadero interés por la arquitectura hasta muchos años después, una vez había iniciado su formación en otros campos artísticos como la literatura o la música en los que su madre le había iniciado desde pequeño. Su formación como arquitecto fue del todo inusual. Comenzó sus estudios universitarios en el Pomona College, institución que abandonó cuando, en 1923, se trasladó a Los Angeles para estudiar escultura en el Otis Art Institute, matriculándose, en 1925, en los cursos de dibujo y pintura que impartía Stanton Macdonald-Wright en el Art Students League.

La influencia de éste fue importante en el uso que más adelante Harris haría del color. Stanton Macdonald teorizó acerca de las sensaciones transmitidas por el color y su relación con la fisiología. Para Macdonald, el uso decorativo del color era un error, una teoría que Harris aplicó en su arquitectura. De acuerdo con sus enseñanzas, la percepción de los colores y las sensaciones que éstos transmiten se corresponden con la percepción que el ojo hace de la naturaleza. Así, por ejemplo, el amarillo sería responsable de las luces más brillantes y los violetas producirían las sombras más expresivas, dado que el ojo percibe amarillos y naranjas en un primer plano mientras que la visión profunda tiende a confundir formas y colores en tonos azul-violáceos. Por este motivo, también de acuerdo con este pintor, el color amarillo en las superficies de los muros los aproximaría al espectador, mientras que los colores azules o tonos próximos a ese color en puertas o ventanas los alejaría dando sensación de profundidad. Aunque Harris no utilizaría colores puros,
H. H. Harris en el Museo de Arte Moderno de Nueva York en 1945. Fotografía de Y. Karsh

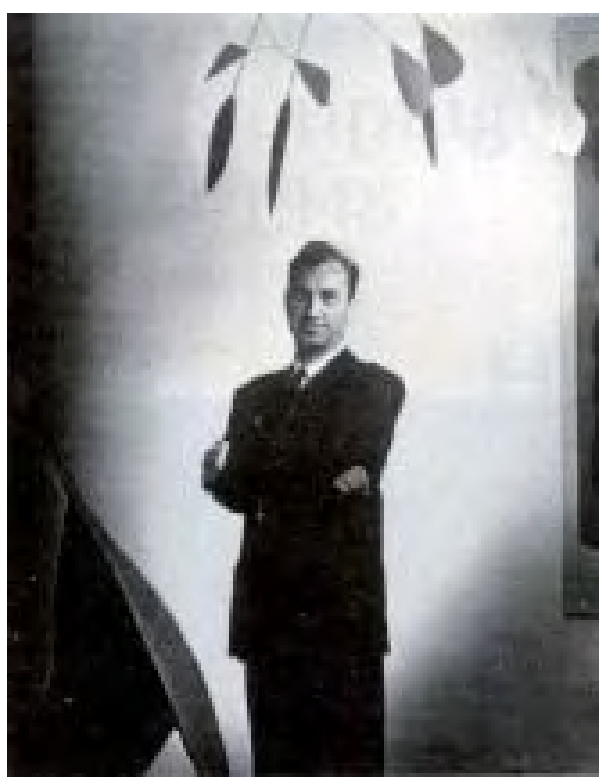




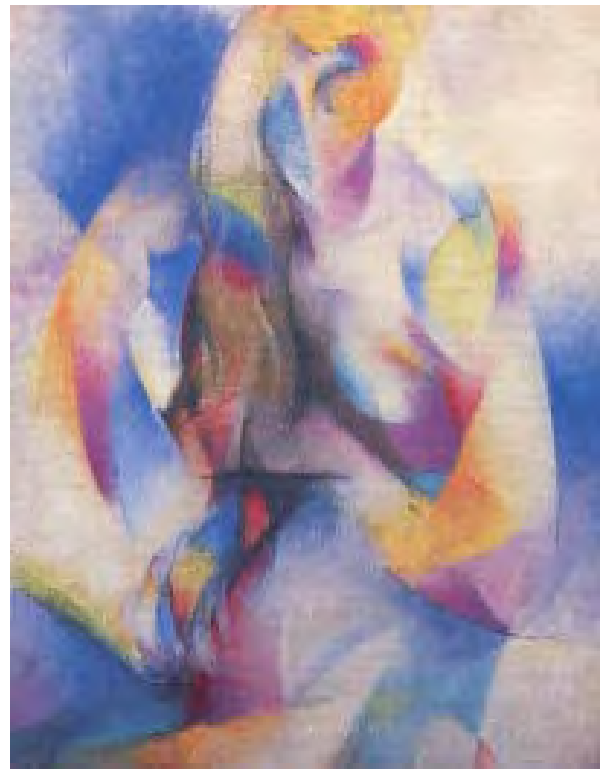

Stanton Macdonald: Synchromy in Purple Minor, 1918. Huntington Art Gallery, University of Texas at Austin

Página siguiente: Harwell Hamilton Harris: Vivienda el arquitecto en Fellowship Park (Echo Park), Los Ángeles, 1935. Fotografía de Fred Dapprich, una de las escasas imágenes de este fotógrafo en color. Fuente: Lisa Germany sino naturales, aplicaría con sutileza estas consideraciones aprendidas del mundo de la pintura. Su uso de los colores mostazas y del verde aceituna en determinados planos, incluso del bermellón en los cerramientos interiores de su propia casa de Fellowship Park, respondía a esta filosofía cromática ${ }^{116}$.

Durante su estancia en el Otis Art Institute, Harris sintió por primera vez su vocación como arquitecto tras visitar, a instancias de una compañera de cla$\mathrm{se}^{117}$, la casa Hollyhock que Wright había construido en Hollywood cinco años antes-y donde, por cierto, Aline Barnsdall aún seguía viviendo en 1925 cuando Harris se presentó de improviso en sus jardines ${ }^{118}$. Como ya se adelantó, lo primero que llamó la atención de Harris de esta casa no fueron sus espacios, sino el hecho de que se trataba de una gigantesca escultura que demostraba como, ningún otro edificio que hubiera conocido antes, las posibilidades plásticas de la arquitectura. Descubrió en ella todo el potencial de un objeto escultórico que podía habitarse y, al mismo tiempo, entablar un diálogo con el medio natural en el que se espacializaba.

Harris escribió acerca de su descubrimiento de aquella obra, relatando poéticamente su decisivo encuentro con la Romanza Californiana de Wright: "Era la última hora de la tarde y el sol estaba ya muy bajo [...] la luz dorada de la puesta de sol lo inundaba todo. El edificio era muy horizontal y tenía alas que venían hacia ti o se alejaban de ti, además, el movimiento de esas alas era paralelo a las bandas ornamentales repetitivas. Sencillamente no me podía estar quieto, necesitaba avanzar y conforme el edificio se movía yo debía moverme... Este edificio era algo que yo ni había visto ni había sido capaz de imaginarme antes ${ }^{\prime 119}$.

Curiosamente, Schindler había hablado prácticamente en los mismos términos pero desde otro enfoque de esta obra de Wright cuando, en 1920, nada más Ilegar a Los Ángeles para trabajar en la ejecución del proyecto, escribió a Richard Neutra, entonces en Viena, afirmando: "[Wright] es el primer arquitecto que ha logrado realmente lo que yo perseguía y defendía en la Escuela de Wagner; su arte es espacial en el auténtico sentido de la palabra pues se ha despojado de las características de la escultura que toda arquitectura del pasado poseía. Sus edificios son organismos en los que cada parte o miembro encuentra su expresión natural, son composiciones en los que cada forma resuena a través del todo"120.

Fascinado con la casa, Harris quiso conocer más cosas sobre Wright y acudió a la Biblioteca de Los Ángeles para consultar un ejemplar del Wasmuth Portfolio. El libro supuso para él una auténtica epifanía y, según McCoy, "como tantos otros jóvenes en todo el mundo, se convirtió inmediatamente en uno de sus discípulos"121. Más tarde, decidido a ser arquitecto, se matricularía de algunos cursos de construcción en la Frank Wiggins Trade School, solicitando también ser admitido en la Facultad de Arquitectura de la Universidad de Berkeley.

Durante ese periodo, Harris se había comenzado a interesar por los nuevos edificios modernos que se construían en la ciudad de Los Ángeles de modo que, cuando otro compañero de clase -un estudiante japonés del Otis Art Institute- le habló de los Apartamentos Jardinette (1927-28), un bloque de hormigón y vidrio entonces en fase de construcción, no dudó en visitar la obra e indagar acerca de sus arquitectos. Se le informó de que eran Rudolph Schindler y Richard Neutra -aunque en realidad el edificio era sólo de este último. Harris localizó la dirección de West Hollywood en el listín telefónico 


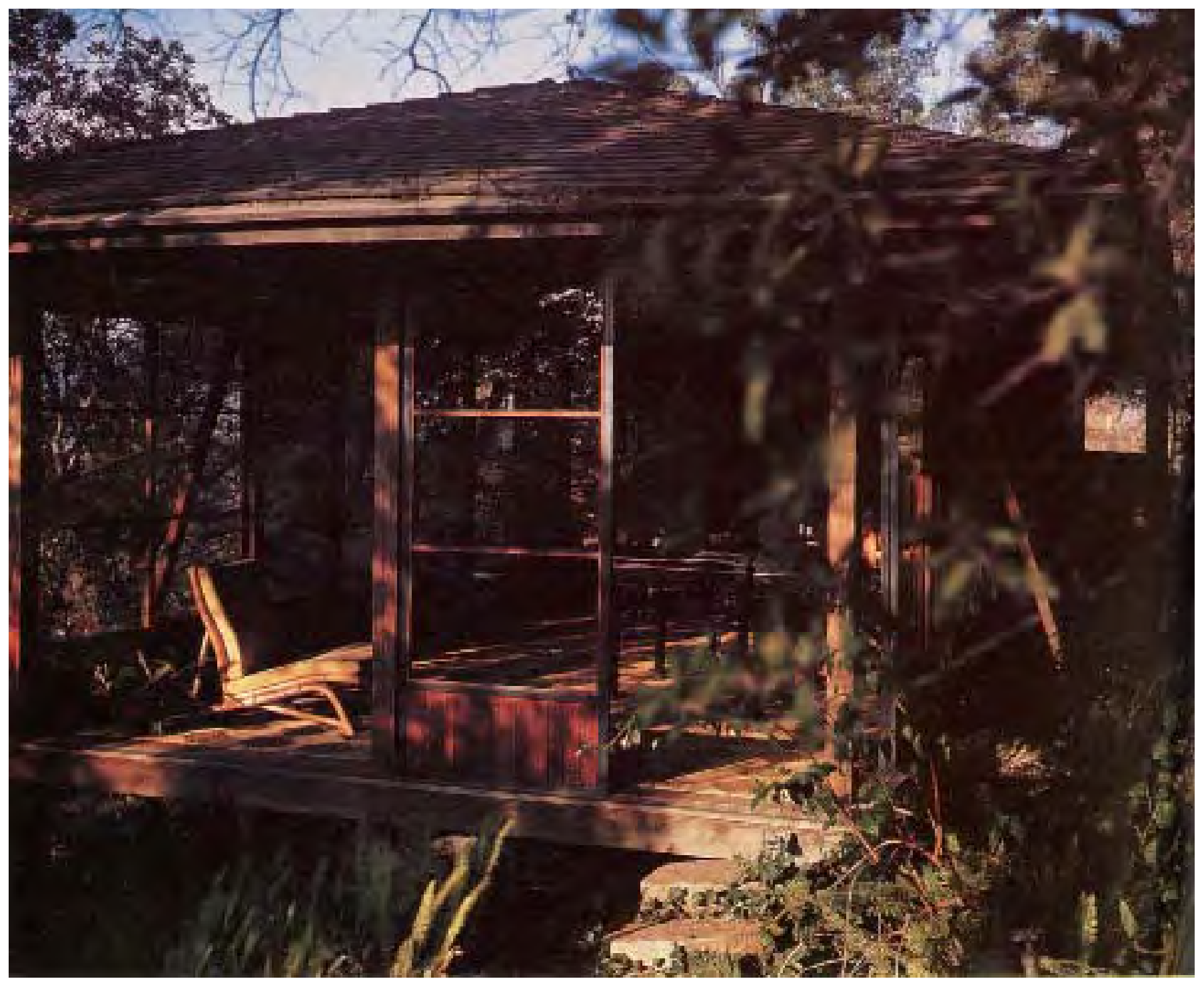

e, intrigado por aquella nueva arquitectura decidió, acudir a Kings Road en busca de sus autores.

Cuando Harris llegó a Kings Road en el verano de 1928, Neutra todavía residía en casa de Schindler. En aquel momento, Neutra y su familia ya habían abandonado el pabellón de huéspedes instalándose en la misma residencia que, hasta 1925, habían ocupado los Chace. Schindler y Neutra llevaban prácticas independientes, pero colaboraban puntualmente en determinadas obras y, como se ha comentado en el capítulo precedente, de un modo más estrecho del que tradicionalmente se ha venido afirmando. El joven arquitecto pudo comprobar el modo de trabajo de ambos, conocer sus proyectos individuales $y$, por supuesto, familiarizarse con las ideas y las personalidades tan diferentes de uno y de otro. Barbara Lamprecht, biógrafa de Neutra expresó con elocuencia esta oposición de caracteres que tanto sedujo a Harris: "Schindler, dionisíaco, frente a un Neutra apolíneo; el primero un hippy intelectual el segundo un arribista prolijo; uno vistiendo chanclas y camisas abiertas, el otro traje y corbata; Schindler un arquitecto del espacio, Neutra un arquitecto de sistemas; Schindler encontrando el paraíso, Neutra creando la utopía ${ }^{1122}$.

Harris apenas habló con Schindler el día de su encuentro, sino que pasó casi toda la tarde conversando con Neutra. Por la noche, antes de regresar a su casa, Neutra ya le había ofrecido un trabajo, aunque no comenzó a 


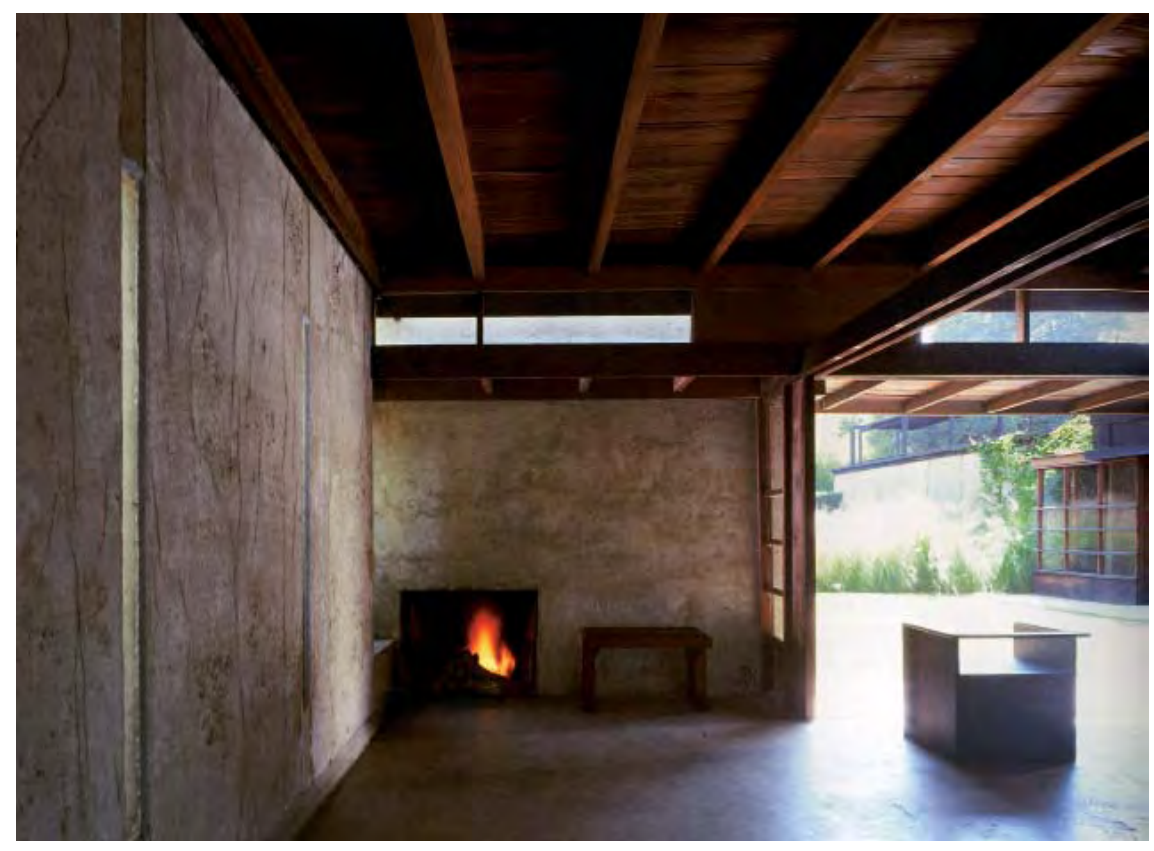

colaborar con él hasta algunas semanas más tarde. Dada la precariedad de medios con los que contaban en aquel momento, Neutra le invitó a que se fabricase su propia mesa de dibujo, usando como asiento un tronco que encontró en el jardín.

Además del propio Neutra, el marco de Kings Road fue otra revelación para Harris. Sobre esta obra, muchos años después, el arquitecto escribiría en una carta a Pauline Schindler la impresión que aquella primera visita le había causado: "Si algún edificio puede encender simultáneamente una auténtica pasión por un modo de vida sencillo y un elevado pensamiento es esta casa"123. Absolutamente radical en todos sus planteamientos programáticos, con sus espacios abiertos al jardín para vivir y trabajar en una íntima relación con la naturaleza, para ser compartidos en la intimidad o disfrutados públicamente, la vivienda-estudio de Kings Road fue uno de los primeros referentes arquitectónicos de Harris, quien describió la casa en los siguientes términos:

"El interior era tan sencillo como el de una vivienda japonesa, y transmitía su mismo espíritu, a pesar de que los muros y el suelo estuvieran realizados en hormigón. La planeidad de las superficies y el ritmo marcado por la modulación de los paneles eran responsables de esta sensación. El efecto era reforzado por la naturalidad de las texturas y colores de los acabados: el gris del cemento, la madera y los tableros de fibra sin tratar, el cobre naturalmente oxidado, las ramas grises y verdes de los eucaliptos. Los vidrios llegaban hasta el suelo y la planta se hallaba despojada de mobiliario. Había muy pocos muebles $y$, exceptuando el piano de cola, todos eran bajos, de madera de secuoya natural y tan adecuados al carácter del edificio que parecían ser una consecuencia lógica del mismo [...] Por la noche había otro material más: la luz artificial. Las luminarias estaban escondidas. Y como no se sabía con certeza de dónde procedía la luz, al reflejarla, el techo y las paredes parecían tener su propio resplandor. Otras veces la luz surgía de un grupo de hojas de eucalipto. Se cortaban unas cuantas ramas y, casi como sugiriendo que aún colgaban del los árboles, se suspendían de las vigas que ocultaban los focos. Esta iluminación general, asegurada por varias fuentes de luz difusa, se completaba con focos de luz directa, como el fuego de las chimeneas. Una llama en cada estancia y otra hoguera en el jardín establecían su propio diálogo, una fusión completa de interior-exterior. Un organismo de espacios, una estructura de ritmos, un aire 


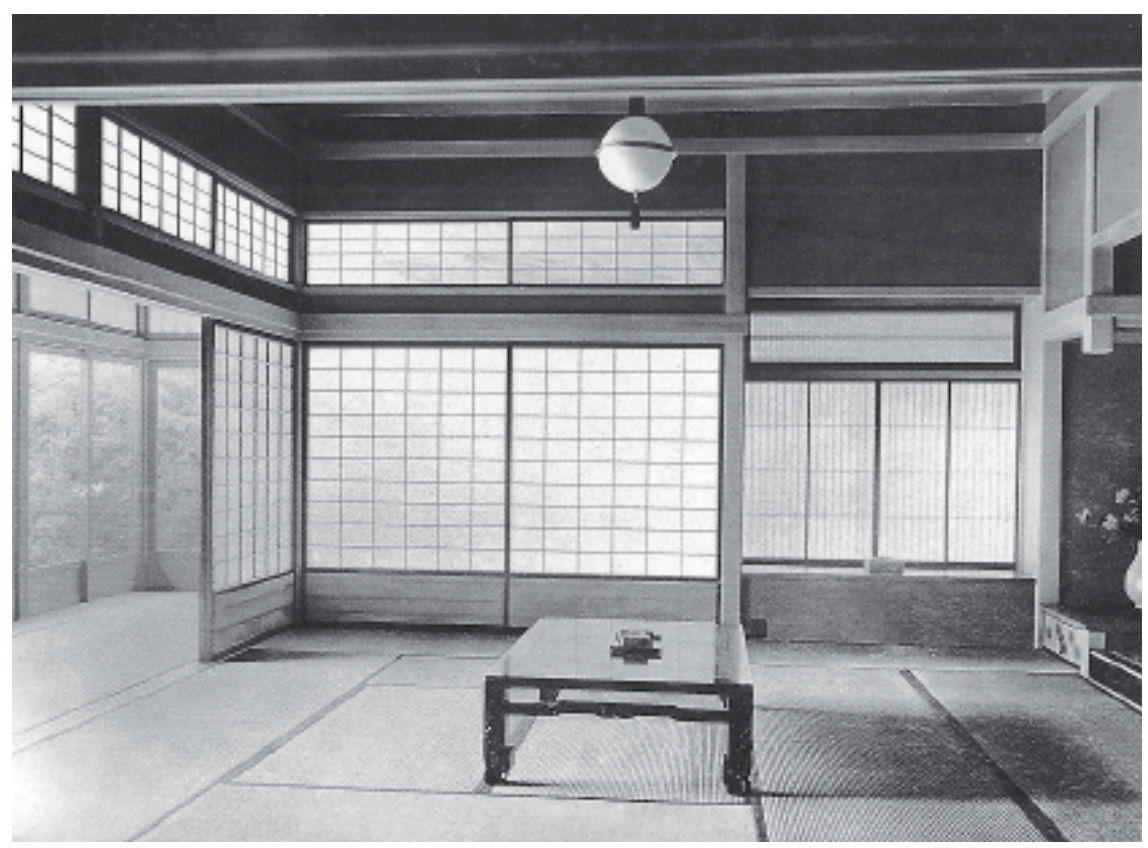

de encantamiento, de irrealidad: iCamelot! -debían pensar los invitados que acudian por primera vez a una fiesta en Kings Road"124.

La vivienda-estudio de Kings Road dejó una huella profunda en el pensamiento arquitectónico de Harris y, aunque nunca llegó a colaborar con Schindler, siempre tuvo muy presente su trabajo. Como puede comprobarse en el análisis de las viviendas examinadas en esta tesis, Harris fue uno de los primeros arquitectos californianos que interpretó de manera personal muchos de los novedosos planteamientos del proyecto de Kings Road: la efectiva relación interior-exterior; el tratamiento de los muros como cerramientos ciegos, translúcidos o transparentes y la inversión de estas relaciones mediante paneles móviles y puertas correderas; el uso de diferentes planos horizontales definidos por la propia estructura acotando sin compartimentar un mismo espacio de mayor dimensión y altura; el uso de materiales perecederos; la inspiración japonesa en la ligereza de las superficies que delimitan los diferentes recintos; el expresivo empleo de la madera en contraste con otros materiales; el recurso del color; el tratamiento de la iluminación natural combinando huecos grandes con franjas lineales de huecos altos; el planteamiento de la iluminación artificial indirecta asociada a otros elementos del proyecto; el diseño de un mobiliario con múltiples funciones aunque vinculado al carácter de un determinado espacio -incluso, su afición a elementos de mobiliario fijo también sería herencia de Schindler-, etc.

Harris fue también uno de los primeros en denunciar la injusticia histórica del olvido por parte de la crítica de la obra de Schindler, así como los esquemas preconcebidos con los que las instituciones culturales de la otra costa del país entendían la arquitectura producida en California, como demuestran estas palabras escritas a finales de los años 70: "Estos proyectos [de Schindler] tienen un nivel de ingenio como pocas obras del Estilo Internacional han logrado [...] Por tanto, me pregunto, ¿cómo cuentan realmente esta inteligencia y la evidente falta de ella en muchas obras del Estilo Internacional cuando la crítica y el público valoran tan negativamente a Schindler y siguen prefiriendo una arquitectura basada en la repetición de las fórmulas aceptadas por el Estilo Internacional? Imagino que las camisas abiertas con amplios cuellos que vestía Schindler, sus sandalias de huarachi y sus amigos bohemios le debieron costar la pérdida de clientes locales, pero no serían una razón para justificar la falta
Sutemi Origuchi: residencia Okada, Tokio, 1933. Fuente: Barbara Lamprecht

Página anterior arriba: RMS: Kings Road, imagen actual de la vienda estudio de los Schindler. Fotografía de Grant Mudford Página anterior abajo: Harris: Vivienda del arquitecto en Fellowship Park, 1935. Fotografía de Fred Dapprich 
Arriba: Craig Ellwood: Kubly House, Pasadena, 1964-65. Fotografía del autor

Abajo: Frank O. Gehry: Steeves House, Brentwood, 1959. Fotografía de Julius Shulman

Página siguiente: Jack Hillmer: Ludekens House, 1951. Fotografía de Roy Flamm. Fuente: Pierluigi Serraino, NorCalMod

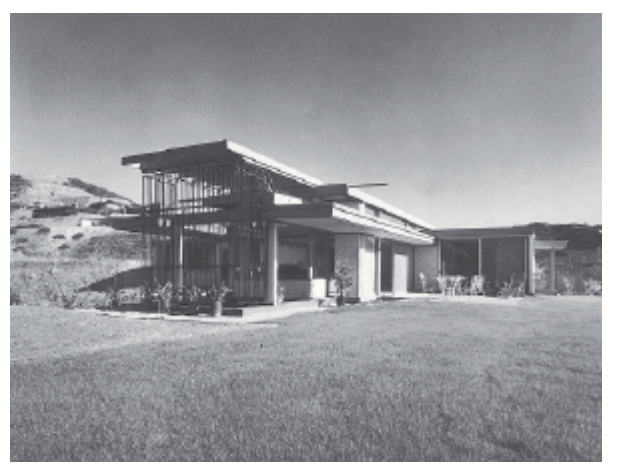

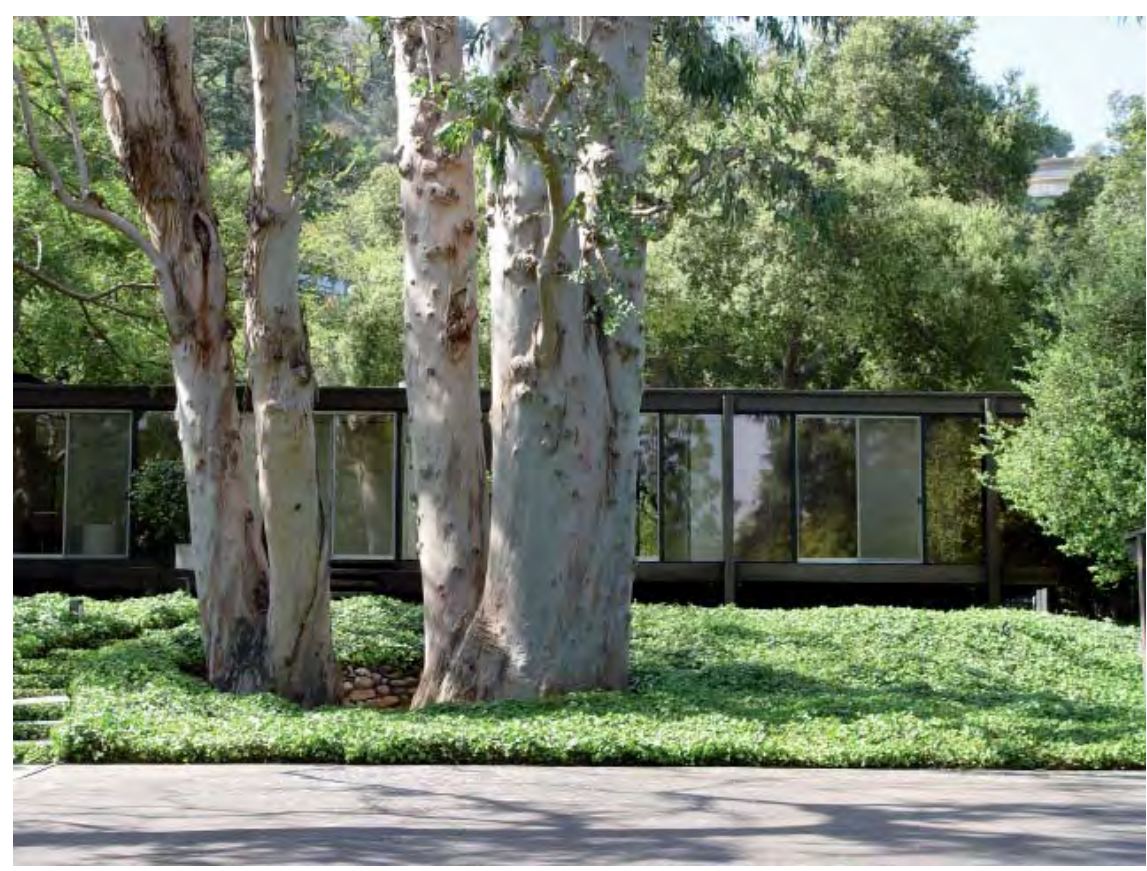

de aprecio hacia su obra por parte de los críticos especializados, del MoMA y del público cuyo gusto formaban. Algo más subyacía en este rechazo ${ }^{\prime \prime 25}$.

Precisamente, este conflicto entre el Este y el Oeste, su diferencia de criterios y la disparidad de sus referencias, conformó la identidad de Harwell Hamilton Harris, así como su modo de entender la arquitectura. Forjado entre varias culturas, desde el individualismo de la tradición anglosajona y el Arts \& Crafts, hasta las enseñanzas y vocación internacional de Neutra, Harris se opuso a los códigos estilísticos impuestos por la interpretación eurocéntrica de la modernidad imperante en el Este. Como sostiene Ted Wells: "A diferencia de aquellos que vieron en la máquina la solución a los problemas colectivos, él sintió que la arquitectura moderna debía ser una expresión individual de los lugares naturales, de la libertad, de las experiencias propias y de la exploración del mundo a través de la psique de cada arquitecto"126. Por esta razón sintió una especial conexión no sólo con la obra de Neutra, sino con la de Greene \& Greene, Schindler y Wright, sobre quien afirmó que representaba perfectamente "la época, el lugar, los ideales y los mitos que también me han formado a mi"127.

La referencia para la arquitectura de Harris no era la máquina sino la naturaleza, el elemento dominante en la imaginación de los arquitectos californianos. Para Harris, frente a la uniformidad de la máquina, la naturaleza ofrecía "una excitante variedad y riqueza de expresiones [...] la idea de la que parten y evolucionan las formas"128 ya que mientras que "la razón puede ser restrictiva, la naturaleza siempre es liberadora"1229.

(A modo de inciso, dado que los textos se citan traducidos al castellano para agilizar su lectura, es imprescindible señalar las dificultades de traducir el estilo de Harris ya que, a diferencia de otros arquitectos, era un excelente escritor y cualquier traducción lógicamente implica la pérdida de las sutilezas de su prosa irónica y elegante)

En la obra y en los escritos de Harris, el término naturaleza (como el adjetivo natural) tiene varios significados: se trataría, por un lado, de un diseño acorde con las cualidades propias de los materiales; de la relación del edificio con 


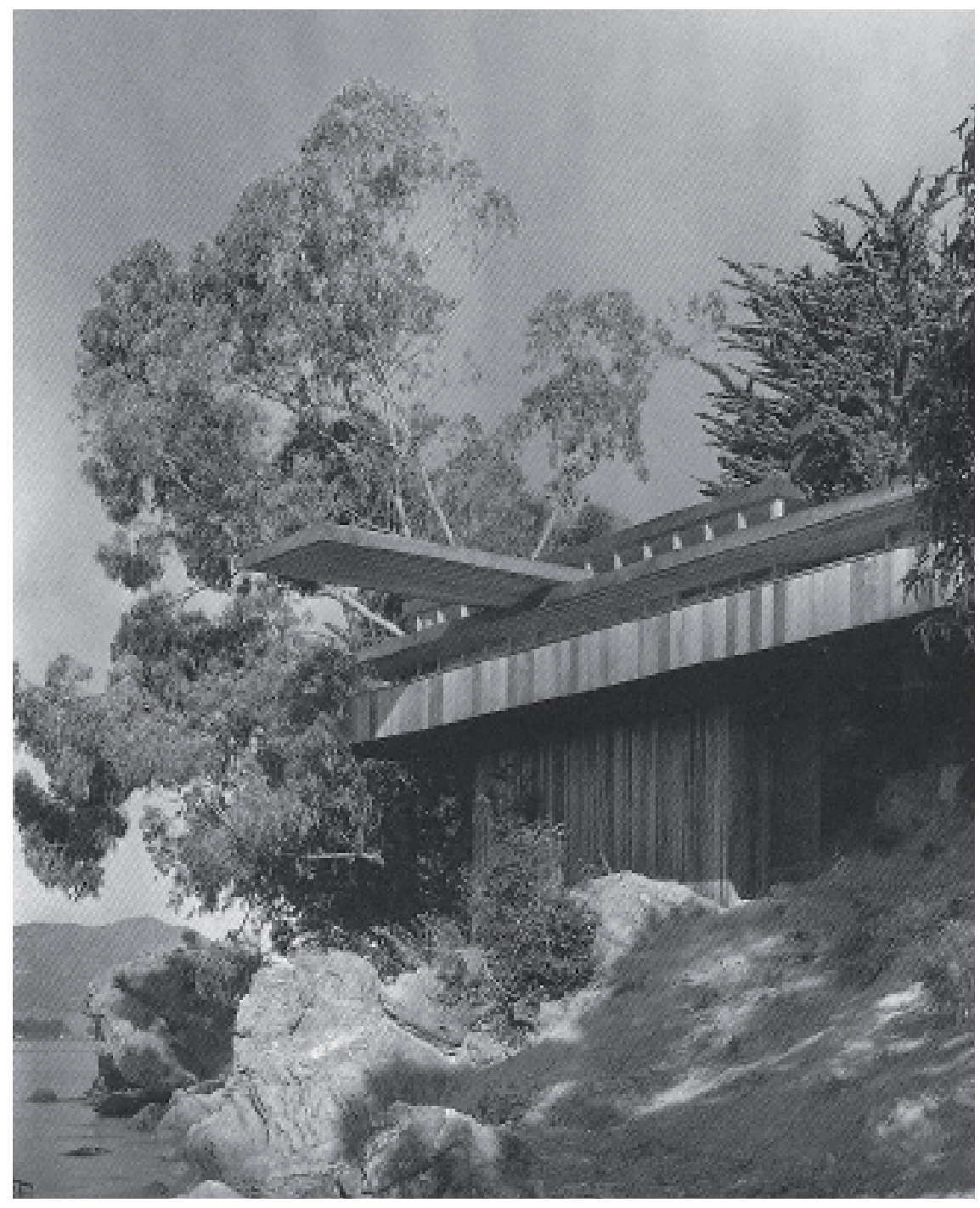

su entorno; de la economía en la adecuación de los medios a los fines; de la forma en la que un proyecto crece o evoluciona con el tiempo. Dadas estas consideraciones íntimamente relacionadas con las premisas de la arquitectura orgánica, es fácil entender el interés de Bruno Zevi por la obra de Harris y el hecho de que, junto a Kenneth Frampton, prologaran la monografía de Lisa Germany sobre el arquitecto. Pero también, por otro lado, en palabras de Ted Wells "lo natural, para Harris era una forma de pensamiento. Como artista, estaba preocupado por el proceso natural de creación, el cual ofrecía infinitas posibilidades aunque correspondía al individuo descubrir la fuente de su inspiración" ${ }^{130}$. Harris consideraba que, para el creador, los significados de la naturaleza eran varios y que dichos significados, debidamente interpretados eran "sugerencias y no diseños cerrados"131.

Su familiaridad con los procedimientos metodológicos de Richard Neutra y su relación personal con los miembros de los CIAM (a través de su posición como secretario del American Chapter y de sus encuentros posteriores en Nueva York o en las instituciones académicas del Este donde impartió clases) ratificaron a Harris en su visión de una modernidad intransigente frente a posturas, como la suya, consideradas heterodoxas. Más adelante se desarrollará esta cuestión pero es importante avanzar que las disputas, por las diferentes maneras de entender la arquitectura moderna, entre el Este y el Oeste, terminaron por desarrollar en él una actitud defensiva y, en ocasiones, beligerante, como también había ocurrido con Schinlder. En el caso de Harris, 
esta necesidad de luchar para defender sus ideas afectó tanto a su dimensión pública como a su foro interno ya que, como ha sugerido Ted Wells, muchas veces se forzaba a sí mismo a ser más radical de lo que podía ${ }^{132}$.

Para varios críticos de la época, la versión de Harris de la modernidad resultaba demasiado romántica e, incluso, poco rigurosa intelectualmente, entendiendo que estaba realizada más con el corazón que con la cabeza ${ }^{133}$. Es obvio que se trataba de una crítica superficial y poco argumentada más allá de cuestiones estilísticas, en general fruto del desinterés que muchos comisarios, historiadores y críticos del Este mostraron por esta otra tradición moderna genuinamente californiana -como así se pondría de manifiesto en los debates del MoMA de 1948 celebrados tras la polémica exaltación de Lewis Mumford de una sensibilidad regional. En cualquier caso, probablemente, lo que más podía incomodar de Harris, entre otros al propio Entenza, no era su uso de la madera sino su enfática celebración de sus todas sus cualidades expresivas.

De hecho, uno de los mitos modernos más extendidos de la región es que la revista Arts \& Architecture privilegió la publicación de viviendas construidas en acero frente a las que usaban madera. En realidad, salvo los casos más icónicos de la casa Eames, las viviendas de Koenig y algunas más, buena parte de las Case Study Houses estaban realizadas en madera, el material local más abundante y barato. Incluso, algunos de los arquitectos preferidos por Entenza, como Craig Ellwood, también por razones de economía, trasladaron directamente la lógica de las viviendas de estructura de acero a construcciones en madera, como la casa Kubly en Pasadena (1964-65). No obstante, la adopción publicitaria por parte de Ellwood del canon miesiano hizo que fueran perfectamente reconocibles como modernas, a diferencia de las obras de Harris que no todo el mundo aceptó como tales.

Otros autores, entre ellos el propio Thomas Hines, han aludido al viaje de vuelta de Harris desde la modernidad de las ideas de Neutra y el impacto que éstas tuvieron en su pensamiento hacia la tradición "de los primeros trabajos de Wright, Maybeck y Greene \& Greene y del ethos del bosque [woodsy] de la arquitectura de mitad de siglo de William Wurster y la escuela de la Bahía de San Francisco ${ }^{\prime \prime 34}$.

Ahora bien, este viaje de vuelta no debe entenderse como regresión, sino como un posicionamiento claro con el que, a mitad de los años 30, Harris se adelantaba alrededor de una década a tantos arquitectos modernos que, tras la Segunda Guerra Mundial, examinaron de manera crítica sus tradiciones locales. Más adelante Harris hablaría de regionalismo para argumentar su actitud, concretamente de un regionalismo liberador: "para que una arquitectura sea realmente buena debe expresar la variedad, libertad, energía expansiva y amor por el medio físico del que es producto el mejor regionalismo, el regionalismo de la liberación"135.

Desde los inicios de su actividad profesional en solitario, Harris reclamó su libertad creativa; reconoció con agradecimiento todo lo aprendido de Neutra pero, como Schindler, se mostró decidido a trazar su propio camino a través de su personal visión del paisaje, los materiales, el clima, el pensamiento y los modos de vida de California, que cómo él mismo subrayaba no eran compartidos por todos los americanos:

"Vi América a través de mis ojos californianos.

Mi América es realmente California". 


\section{Jean Murray Bangs (Harris)}

"[Fui a Nueva York] para trabajar en cualquier fábrica en la que se emplearan mujeres con la intención de documentar mi tesis doctoral 'Las mujeres en la industria'. Abandoné esta idea para intentar ayudar a aliviar el sufrimiento de los seres humanos, luchar contra la pobreza y la opresión. Al final consideré que era un mal empleo y regresé a casa a Los Ángeles"136.

Jean Murray Bangs

Harwell Hamilton Harris se casó con Jean Murray Bangs en 1937. Se habían conocido en una fiesta en 1931 a la que ambos habían llegado los primeros e inmediatamente conectaron hablando de arte y arquitectura. Jean era diez años mayor ${ }^{137}$ que él, una persona culta y extraordinariamente bien conectada. Ella colaboraba, por ejemplo, con la revista California Arts \& Architecture $y$, tras la salida de Harris del estudio de Neutra, coincidieron profesionalmente en diversas ocasiones, sobre todo a partir de 1934, cuando comenzó a publicarse la primera obra del arquitecto.

Desde finales de los años 20 Jean Murray Bangs frecuentaba los círculos políticos y editoriales más progresistas de Los Ángeles. Se había instalado en la ciudad tras una estancia en Nueva York, donde había acudido en 1919 tras graduarse en Economía por la Universidad de Berkeley para iniciar su investigación doctoral y documentarse sobre movimientos sindicales. Uno de sus primeros objetivos había sido aspirar a la Secretaría de Trabajo, tratando de ser la primera mujer en ocupar este puesto, algo que finalmente no logrón ${ }^{138}$. Si bien, en Nueva York pudo conocer Emma Goldman, Max Eastman, John Reed y Katherine Anne Porter ${ }^{139}$, algunos de los ídolos de Pauline Schindler. Tras divorciarse de su primer marido, el líder laboral Abe Plotkin a quien siguió a Los Ángeles en 1921, comenzó a trabajar para Los Angeles County Welfare Department, la oficina responsable de los servicios sociales del condado. Allí entabló gran amistad con Pauline a través de amigos activistas que ambas tenían en común. Bangs se convirtió pronto en una asidua de Kings Road donde, antes que Harris, se encontró con Schindler y también con Neutra, a quien conoció nada más llegar a la ciudad en 1925. De hecho, las primeras fotografías de la pareja Richard y Dione Neutra en California fueron tomadas por Jean Murray Bangs -se trata de unas instantáneas muy difundidas que, sin embargo, nunca se han acreditado ${ }^{140}$.

Cuando Harris entró en Kings Road Pauline ya no vivía allí. Sin embargo, en su introducción al libro de Esther McCoy Vienna to Los Angeles, el arquitecto recurrió a sus propios recuerdos del lugar y, seguramente, a lo que había oído contar a Pauline Schindler y a su propia mujer, para narrar algunos episodios de la época dorada de la casa. Este prólogo aporta un valioso testimonio escrito sobre el carácter de aquellas celebraciones y de algunos de sus invitados más destacables, tal como se reproduce en los siguientes fragmentos del texto de Harris:

"Los Schindler abrían su casa cada domingo por la tarde y en ella se reunían todos los artistas e intelectuales de la primera posguerra mundial. [...] Hollywood los atraía como un imán.

Alli estaba Robert Nichols, un joven poeta inglés que había regresado a Los Ángeles tras su estancia de un año enseñando en Japón [...] Y Maurice Brown
Jean Murray Bangs Harris en 1937. Fuente: Lisa Gemany

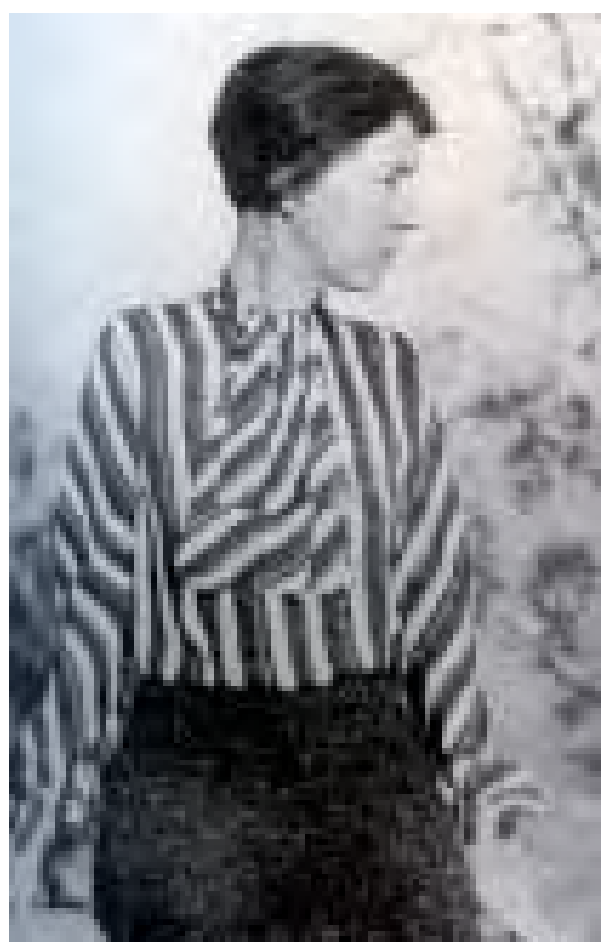


(sic), un dramaturgo y actor británico conocido por el trabajo que él y su mujer habían realizado en el Little Theater (sic), en Chicago. Brown (sic) y Nichols son recordados por sus discusiones sobre arte. Estaba también John Bovignton, un aventurero que vivía de su ingenio y que se había curado a sí mismo bailando, observando dieta y llevando una vida ociosa. Había aprendido a bailar casualmente en Bali y coreografiaba su propia danza que denominaba 'Danza de la evolución'. Comenzaba con su compañera femenina con los senos desnudos representando la agitación de un protoplasma primigenio sobre la hierba del patio y consistía en la representación de varias formas de animales inferiores que iban desarrollándose a través de estadios evolutivos sucesivos que culminaban en el ser humano.

Edward Weston era otro de los amigos que acudian a la casa y solía llevar impresiones de negaivos de $8 \times 10^{\prime \prime}$ realizadas con una disciplina insólita. Objetos comunes aparecían en sus fotografías de un modo nunca visto antes. La mirada de Weston, su sensibilidad y sus retratos realizados con medios directos revolucionaron el concepto de la fotografía como arte.

Doris Levings, una joven pianista que más tarde se casó con John Pennington, primer violín del London String Quartet, tenía alquilado el ala de invitados de los Schindler [...] Cuando llegaron los Neutra, Dione, cantando y tocando el cello se convirtió en otra de los participantes en estas veladas musicales de las noches de los domingos.

[...] No todas las reuniones implicaban grupos. A veces se trataba sólo de una pareja invitada. Si era para cenar, ellos se organizaban para sentarse a ras de suelo y comer, tanto carne como vegetales, servidos sobre una hoja. Pauline servía cada plato separadamente en una gran bandeja de mimbre que depositaba sobre un marco de madera de secuoya. La bandeja hacía las veces de tablero de la mesa descansando sobre unos soportes muy bajos de secuoya y se cambiaba con cada plato. Los asientos eran taburetes también bajos de secuoya. Tanto si el grupo era grande, necesitando ambos estudios y el jardín, como si era pequeño y se restringía a una sola estancia o el patio, todo el lugar se hacía comunitario, más allá de los propios espacios comunes de la casa. El lugar [a través de sus diferentes reconfiguraciones] potenciaba la libre expresión de cada cual. Ésta era una habilidad que Pauline y RMS desplegaban imaginativamente, $y$ asi merece ser recordado ${ }^{1141}$.

Harris llegó a Kings Road en el verano de 1928, como se ha indicado. Era ya una época tardía, por lo que no pudo asistir a ninguna de sus fiestas anteriores al verano de $1927 \mathrm{y}$, aunque, sus conversaciones posteriores con Pauline Schindler le ayudaran a reconstruir los hechos descritos es obvio que el texto estuvo influido por el relato de primera mano de Jean Murray Bangs, quien estuvo presente en la casa desde mediados de los años 20. Por cierto, en ese mismo texto Harris dedicaba unas elogiosas palabras a su amiga Pauline, por quien sentía gran admiración y a quien siempre agradeció su apoyo en los inicios de su carrera. Harris la consideraba una persona inteligente y apasionada, describiéndola como una persona "entusiasta, ardiente, siempre dispuesta para cualquier idea nueva en cualquier campo, ella convertía cualquier cosa en una experiencia inolvidable y la saboreaba hasta sus últimas consecuencias. [...] Había gente a quien [Pauline] no caía bien y decían que todo en ella era pose, lo cual era injusto. Trabajó duro y consiguió casi todo lo que una mujer querría lograr pero que muy pocas en su posición consiguen alcanzar ${ }^{\prime \prime 142}$. Bangs demostró ser -como también su marido- una excelente escritora. Estaba interesada en el periodismo, el arte, la arquitectura y los libros; además 


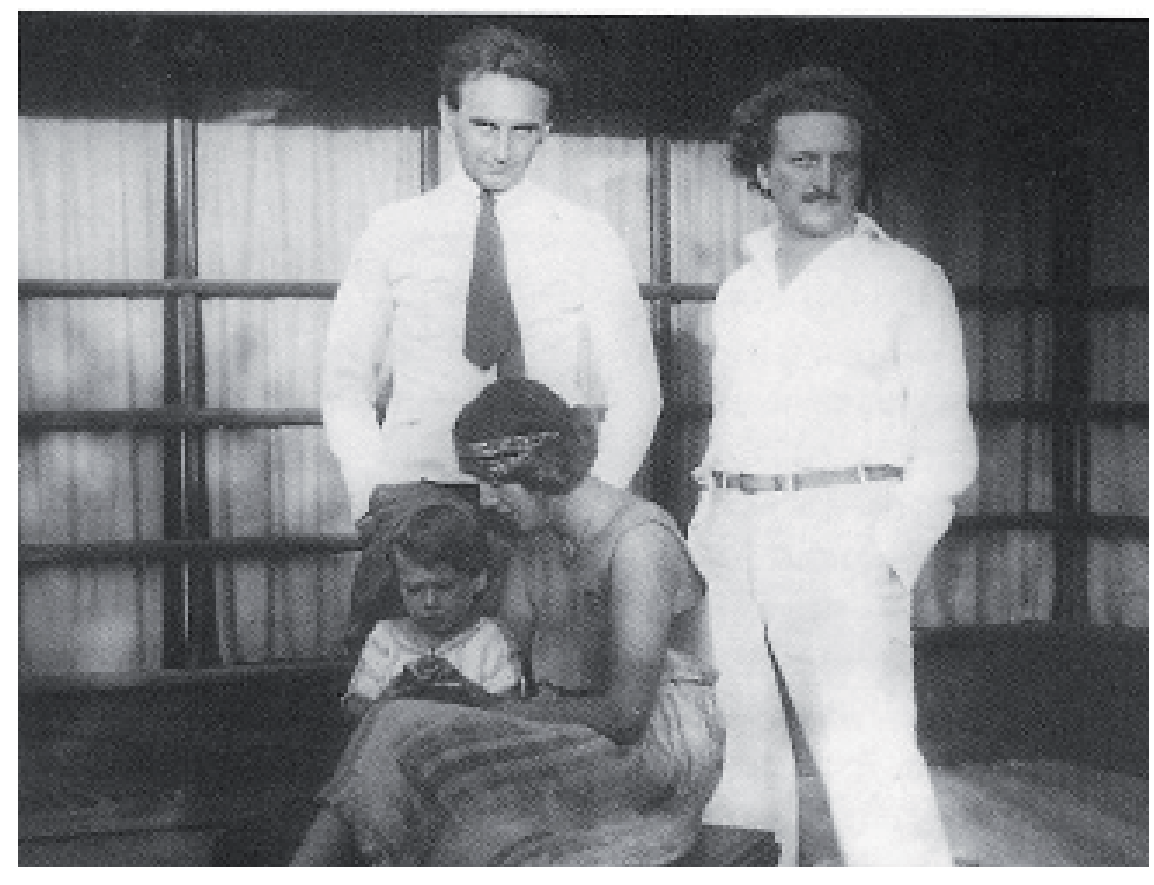

era gourmet y colaboraba como crítica gastronómica para la revista House Beautiful. Ella ejerció una influencia decisiva sobre Harris, presentándole clientes, poniéndole en contacto con instituciones académicas, círculos de prensa y, sobre todo, a través de sus investigaciones históricas. Como crítica y divulgadora de arquitectura, Jean Harris se adelantó algunos años a la labor de Esther McCoy de reivindicar figuras marginadas. Como ocurrió en los años cuarenta cuando, como resultado de sus investigaciones, Bangs descubrió la obra de los pioneros de la arquitectura californiana Bernard Maybeck ${ }^{143}$ y los hermanos Greene. Gracias a sus escritos ${ }^{144}$-en los que más tarde se basaría McCoy- la mujer de Harris desencadenó el proceso de recuperación histórica de estos arquitectos, entonces completamente olvidados, y cuya obra resultó crucial en la evolución posterior de la carrera de su marido.

Jean Murray Bangs fue responsable de buena parte de la fama de Harris. Ella tenía amistad y era estrecha colaboradora de algunos de los personajes más influyentes del panorama norteamericano de los medios de comunicación de su tiempo, como el crítico de arquitectura Talbot Hamlin o la activa y polémica editora de House Beautiful Elizabeth Gordon. Esta última se había interesado por los conocimientos culinarios de Jean Harris y, después de publicar algunos de sus artículos sobre arquitectura y mantenerla durante algún tiempo como colaboradora habitual, la incluyó en el consejo de redacción de House Beautiful en 1950.

Por su parte, Harris había conocido a Elizabeth Gordon en 1943, aunque su obra ya le había llamado la atención varios años antes, probablemente a través de James Marston Fitch ${ }^{145}$. Su obra más significativa, la casa Weston Havens apareció en el número de agosto de 1944 de House Beautiful, ciertamente con algunos años de retraso, pero la demora se había debido al cambio de prioridades impuestas por la contienda bélica. Poco después, a través de su mujer, Harris tuvo acceso continuado a la popular revista de Elizabeth Gordon, una de las más leídas en los Estados Unidos. Y también por mediación de ella se convirtió en 1955 -ya durante su etapa texana- en uno de los arquitectos seleccionados para el Pace Setter House Program, la iniciativa que Gordon lanzó en 1946 como réplica al programa auspiciado por John Entenza desde las páginas de Arts \& Architecture.
Jean Murray Bangs: Fotografía de RMS con Dione, Dione y Richard Neutra en Kings Road, 1928. Fuente: Thomas Hines. La fotografía aparece sin acreditar 


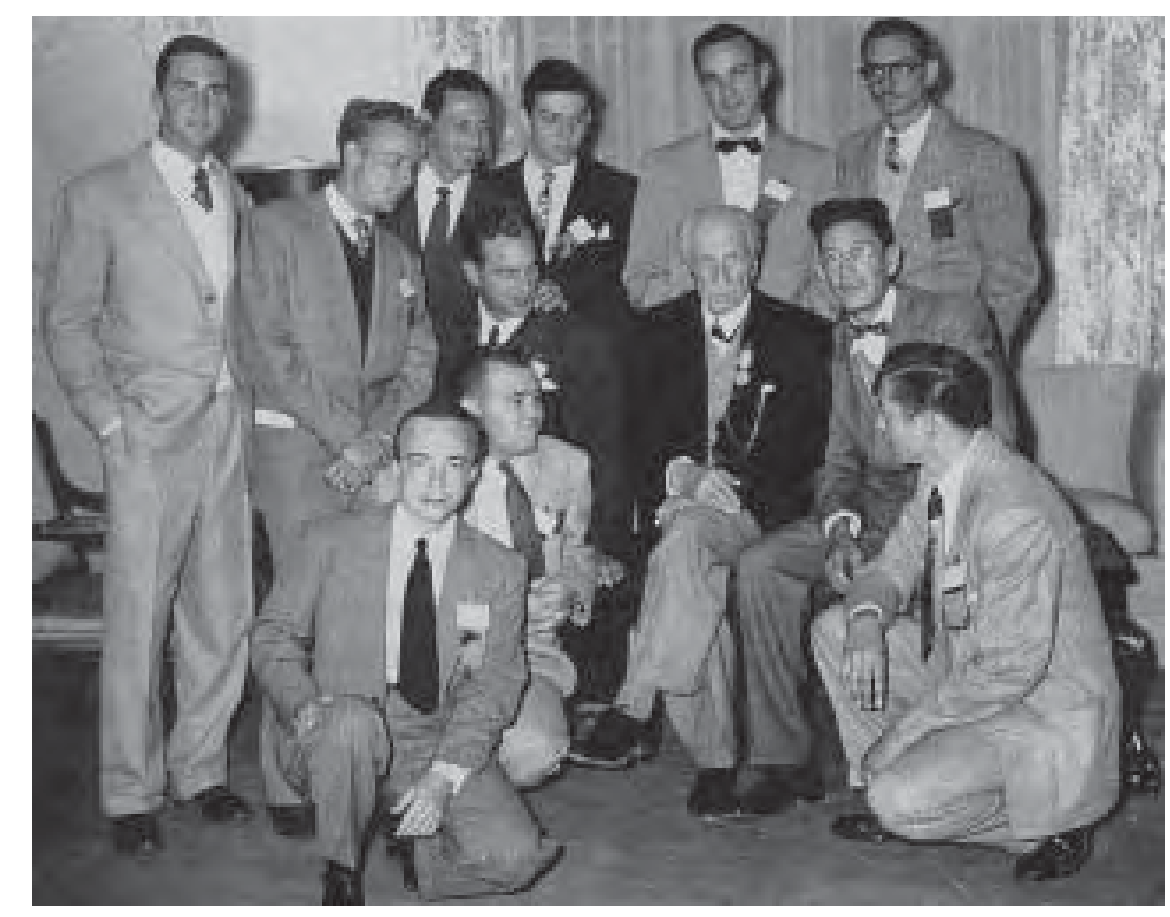

Harris y sus estudiantes de la University of Texas en un encuentro con F. L. Wright en Ciudad de México en 1952. Fuente: Lisa Germany

Página siguiente: Harris: Pauline Lowe House, 1934, imágenes de la vivienda fotografiada por F. Dapprich y publicadas en el número de enero de CA\&A
Las 17 casas modelo de Gordon, construidas por todo el territorio nacional, defendían una idea de modernidad vivible y democrática, alternativa a la ficción tecnológica de los prototipos de la revista californiana. Rechazando abiertamente la filosofía del Case Study House Program de viviendas universales a partir de elementos prefabricados, las Pace Setter Houses proponían soluciones en las que el edificio respondiera al clima, las diferentes culturas regionales y la expresión individual y artística de sus arquitectos y usuarios. En la disputa entre ambos programas por imponer su visión de una arquitectura doméstica destinada a la emergente clase media, puede leerse uno de los grandes debates arquitectónicos de posguerra: "la tensión entre lo específico y lo general, lo regional y lo internacional, lo individual y lo colectivo"146.

No obstante, a pesar de todo el apoyo inicial que Harris recibió por parte de los contactos de Jean, según Wells ${ }^{147}$, también fue ella quien, debido a su carácter irascible y sus celos profesionales -que tarde o temprano la llevaron enemistarse con casi todo el mundo-, en última instancia, fue responsable si no de arruinar la carrera de su marido, al menos de que se le apartase de numerosos círculos. Colin Rowe ofrece en las memorias de su etapa en Texas con Harris un curioso relato ${ }^{148}$ sobre la pareja, describiendo, con todo lujo de detalles y anécdotas sobre las camarillas de la Universidad, los enfrentamientos provocados por la actitud conflictiva de Jean en el claustro de profesores, así como su comportamiento sobreprotector-casi de esposa y madre- hacia su marido. De acuerdo con la divertida narración de Rowe, fue "la zarina" quien forzó a Harris a aceptar su puesto en Austin, quien decidía a qué profesores debía contratar y quien manejaba los hilos de su labor directiva.Según con Colin Rowe ${ }^{149}$, Jean Murray Bangs deseaba para Harris un puesto de responsabilidad académica a la altura del de William Wurster en Berkeley, donde era Director de la Escuela de Arquitectura. También según Rowe, tanto por celos hacia la mujer de éste, Catherine Baver, como por lo que representaba el nombre de la escuela del Área de la Bahía en el reconocimiento por parte de la crítica de una tradición regional basada en la madera, ella ansiaba para su marido una posición de prestigio como la de Austin, desde la que se visibilizaría por fin su liderazgo al frente de una corriente arquitectónica análoga en el Sur de California. 


\section{Los años 30, casas con buenos modales}

Cuando Harris abrió su propio despacho en Los Ángeles, sus primeros encargos consistieron en pequeñas residencias para algunos amigos y antiguos compañeros de estudios, como la casa que construyó en 1934 para Pauline Lowe en Altadena. En estas primeras obras, Harris comenzó a poner en práctica las enseñanzas de Neutra: ejercitó diferentes sistemas modulares y experimentó con algunos de los primeros materiales industriales disponibles en el mercado, sobre todo tableros prefabricados de madera, aislantes, elementos de cubierta y chapas metálicas. No obstante, el resultado de estos primeros trabajos permite ver una orientación muy distinta al enfoque de Neutra. Harris hizo suyos también aspectos que le habían interesado de la obra de Wright y de Schindler, como algunos de sus recursos plásticos o su voluntad de crear una arquitectura específicamente californiana y, muy pronto, manifestó su propia personalidad.

La casa Lowe fue publicada en el número de enero de 1935 de California Arts \& Architecture, el número que había sido dirigido por Pauline Schindler y dedicado por completo a la arquitectura moderna californiana ${ }^{150}$. El artículo apareció en dos páginas, incluyendo uno de los primeros textos teóricos de Harris, In Designing the Small House. En él, dando algunos consejos de proyecto, exponía de forma clara las bases de su trabajo. La casa le valió una temprana celebridad porque, tras ser plagiada por otros arquitectos y presentada a un concurso de ámbito nacional, revistas como Architectural Forum, atendieron la denuncia de California Arts \& Architecture, investigaron los hechos y se hicieron eco de la noticia identificando a Harris y reivindicando su proyecto original ${ }^{151}$. En palabras de David Gebhard, la primera realización de Harris tras abandonar la oficina de Richard Neutra, "publicada recurrentemente, atrajo de inmediato sobre Harris el interés nacional, siendo, sorprendentemente, su primer edificio construido y la obra que lo situaba sin titubeos en la tradición del Arts \& Crafts ${ }^{152 "}$.

Poco después, su propia casa construida en Fellowship Park en 1935 fue galardonada con el primer premio en la convocatoria Beautiful Small House Competition. Promovido por la revista House Beautiful, el éxito de Harris en este concurso confirmó su reconocimiento por parte de los medios, así como su conexión con el gusto de la clase media norteamericana. La Fellowship Park House era apenas un escueto pabellón de madera cuyo espacio, retirando las puertas correderas, podía abrirse completamente su entorno natural. La descripción de esta obra puede abordarse bajo varias lecturas. Por un lado, parece lógico pensar en la referencia de la cabaña refugio en el bosque, un arquetipo norteamericano asociado con la libertad, el individualismo y la autenticidad de los pioneros y compartido también con Schindler; asimismo podría entenderse como una personal interpretación del recinto del ceremonial del té japonés; o como una proyección del deseo infantil de la casita en el árbol. Pero Fellowship Park es, ante todo, una declaración de intenciones sobre la propia manera de Harris de entender la arquitectura: living simple, high thinking, lema a través del cual el arquitecto, más allá de su visión de las formas, los oficios o los materiales locales, conectaba filosóficamente con la tradición cultural del Arts \& Crafts a la que se refería la cita de Gebhard sobre la Lowe House.

Como se ha apuntado en el apartado de fuentes, los textos disponibles hasta la fecha sobre Harris, ya sea la monografía de Lisa Germany (1991 y 2000), como los capítulos de los libros publicados por Esther Mccoy (The Second Generation, 1984) o por Robert Winter (Towards a Simper Way of Life,
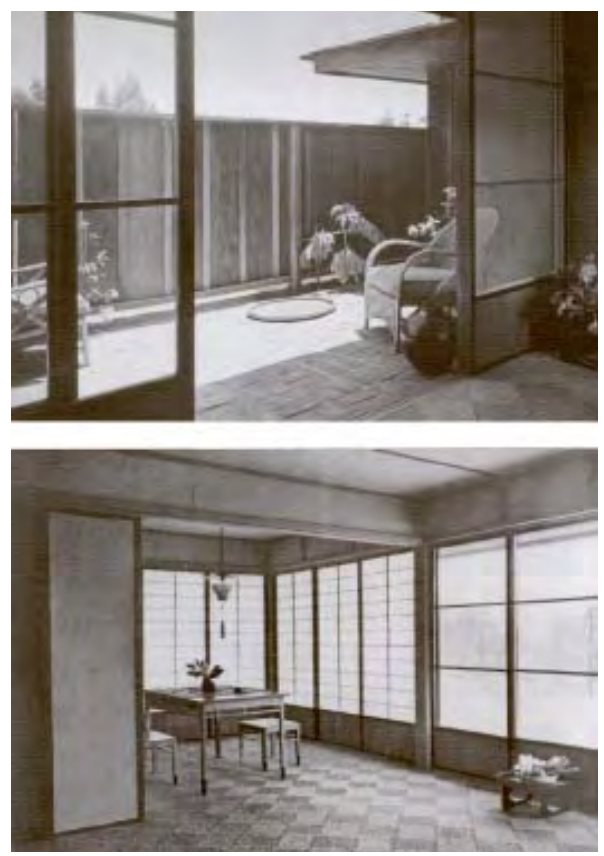
Harwell Hamilton Harris: Houso in Fellowship Park, 2311 Fellowship Parkway, Los Angeles, California, 1935

A capacious low-hipped roof shelters a tiny hillside house of extraordinary freshness and charm. The designer was also the client, and he and his wife wanted only the bare bones of domesticity - isst a large space for living and sleeping. a bathroom and a hitchen. But the appecrance of simplicity is deceptive, as it is the product of refinement rather than of primitivity.

The wooded hill is scarcely disturbed, for cutting and filling were avoided by the use of concrete pier foundations. The roof rests on a series of widely spaced posts, braced by ingenious flying buttresses of wood and iron. Between the posts slide doors glazed alternctely with clear and frosted gloss, In good weather the doors are removed on three sides and the living room becomes an open pavilion, confronting ferns and oak trees and the distant view of mountains.
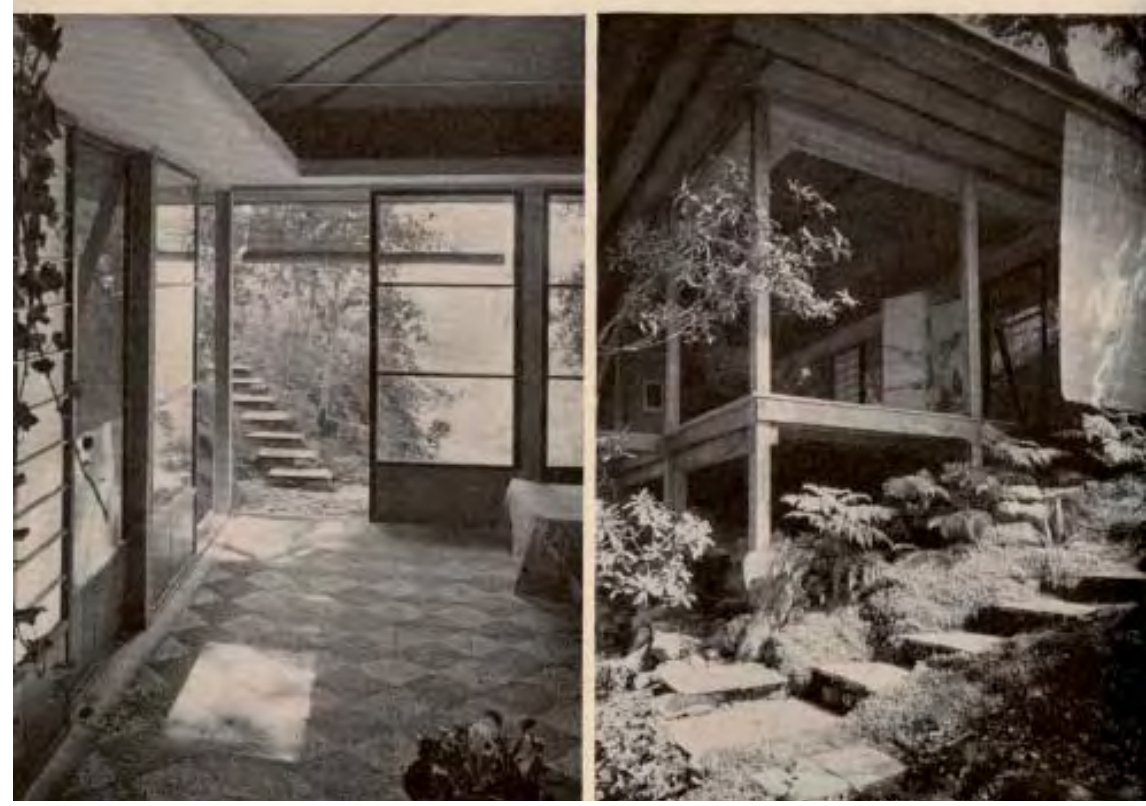

Harris: Residencia del arquitecto en Fellowship Park, Los Ángeles, 1935. Fotografía de Fred Dapprich. Páginas de "Built in USA 19321944". Catálogo de Exposición del MoMA, 1944
1997), están lejos de ser estudios conclusivos sobre el arquitecto. Ni siquiera puede suponerse que estas publicaciones dan por terminada la tarea de documentación del conjunto de la producción de Harris. Prueba de ello son las pequeñas viviendas localizadas en revistas y artículos de periódicos de la época que no aparecen mencionados en ninguno de los textos citados anteriormente.

Éste sería, por ejemplo, el caso de la Otto Hermle House en La Cañada, Los Ángeles, obra que no aparece reseñada ni en el listado de obras del arquitecto aportado por Germany ni en la relación de los fondos del archivo de Harris en la Universidad de Texas en Austin. Resulta especialmente llamativa esta omisión ya que la Hermle House fue publicada en el suplemento de vivienda de Los Angeles Times ${ }^{153}$ el 6 de mayo de 1945, muy bien ilustrada con dibujos de plantas y con fotografías de Fred Dapprich, el fotógrafo preferido de Harris durante los años 30. Bajo el título Preview of Tomorrow's House, la casa Hermle House, era presentada por el Times como un modelo de vivienda de futuro $y$, más específicamente, como un caso ejemplarizante de vivienda de posguerra, aun cuando la casa, con casi total seguridad, habría sido diseñada por Harris algunos años antes de la guerra. Esta circunstancia 


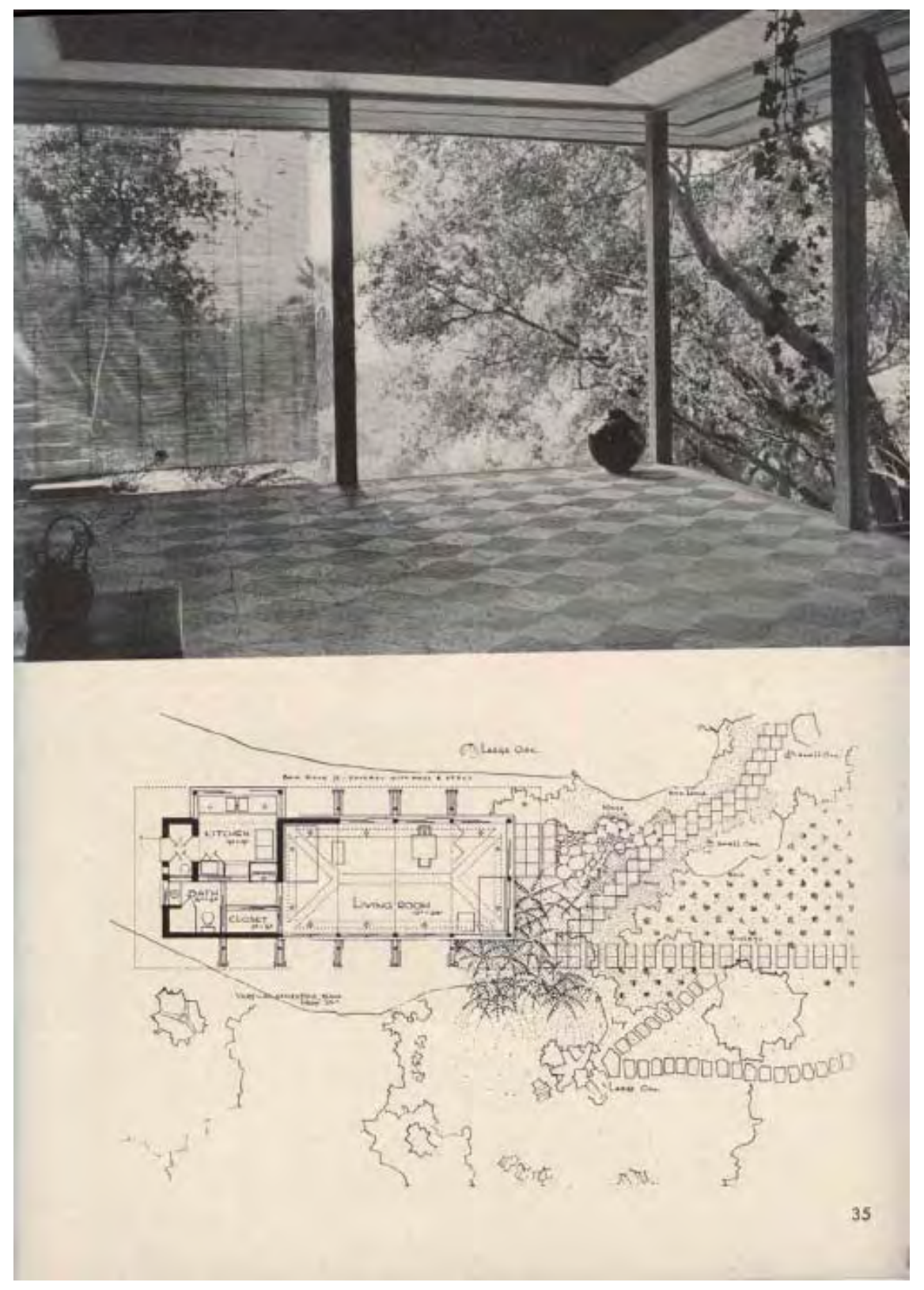

era puesta en valor por la propia revista que reconocía la visión de futuro de Harris cuando afirmaba: "Como tantos americanos, estamos tan entusiasmados ante las deslumbrantes promesas de mejoras que vendrán con nuestras casas de posguerra que a veces perdemos la noción de la realidad respecto a lo que razonablemente deberíamos esperar. A aquellos que afirmen ver en las casas de posguerra unas formas, tamaños y funciones inéditos hasta la fecha, les sugerimos que las mejores realizaciones de preguerra son el mejor indicador de lo que podremos esperar como los auténticos logros de la casa del mañana. En este sentido, muchas de las promesas de la casa del futuro ya se encuentran en este proyecto para Otto B. Hermle en La Cañada. La vivienda fue diseñada por Harwell $H$. Harris desde la premisa de obtener todas las ventajas de su implantación en una colina, disfrutando de las magníficas vistas de las montañas y del valle. Puertas correderas y amplias ventanas constituyen gran parte de los cerramientos, abriéndose a unas terrazas que actúan como prolongaciones de las estancias interiores [...] El acabado exterior de los muros es de redwood [...] y el interior de contrachapado de redwood natural. Dormitorios, baños y cocina han sido enfoscados y pintados. Los techos están cubiertos con tableros de fibra aislantes que se han dejado en su color natural. El estar tiene una cubierta inclinada que gana altura para abrir unos huecos altos practicables a 

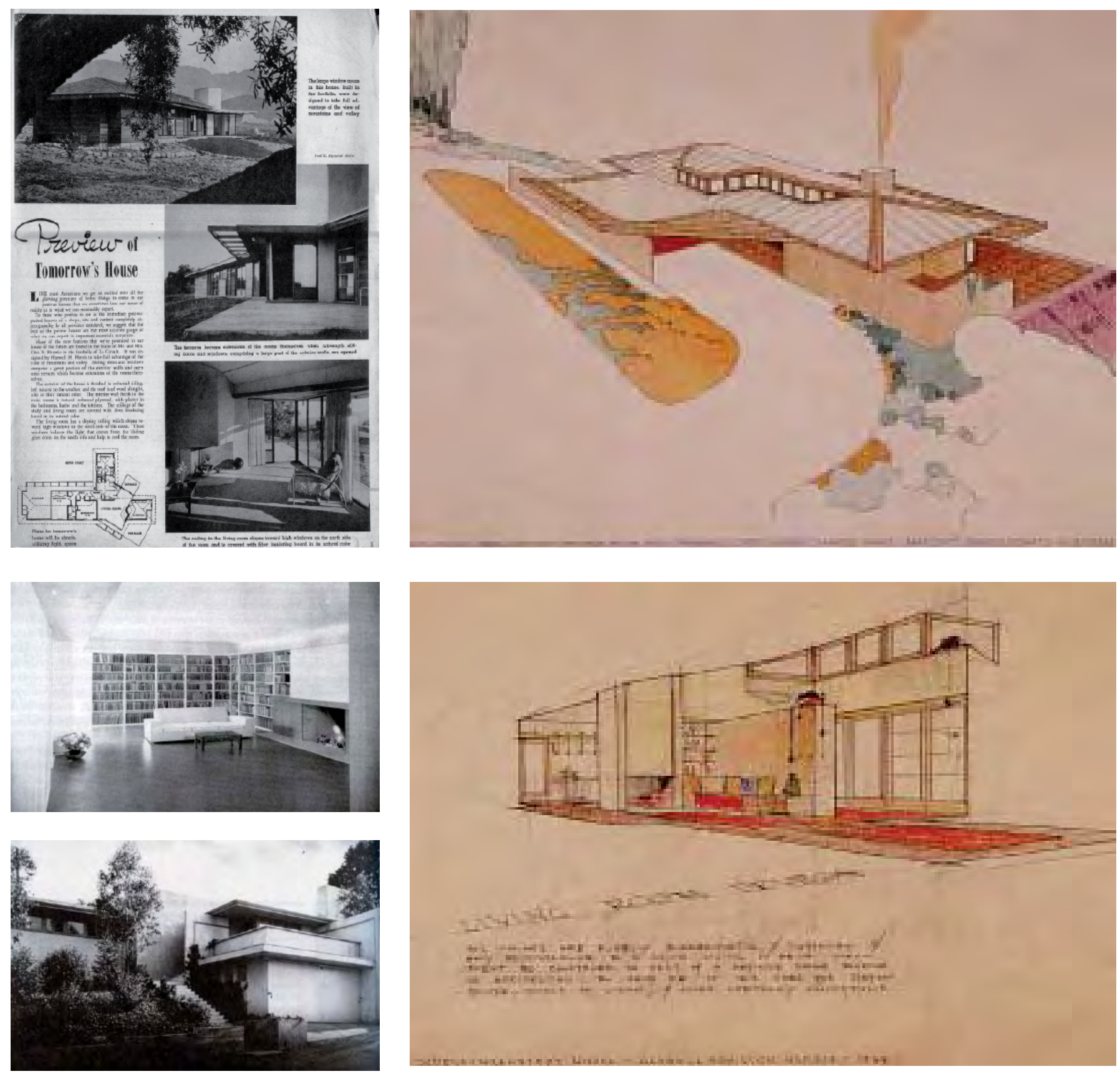

norte. Esta línea de ventanas elevadas equilibra la luz que viene de los grandes huecos al sur y ayuda a generar ventilación cruzada"154.

Este sistema de grandes huecos a sur, practicables a modo de puertas correderas de suelo a techo y enfrentados a líneas de ventanas altas, también practicables pero orientadas a norte (para compensar el deslumbramiento y ventilar los espacios principales), venía siendo una constante en las viviendas de Harris realizadas en la década de los treinta, como las casas Lowe, Laing - De Steiguer. No obstante, la casa con la que más similitudes mantiene la Hermle House, repitiendo muchas de sus estrategias y soluciones formales -y que por lo tanto podrían ayudar a fechar este proyecto hacia esa misma época- es la Greta Granstedt House ${ }^{155}$ de 1938 en Hollywood Hills.

Entusiasmado por algunas de estas obras, John Entenza, recién llegado a Los Ángeles para iniciar una carrera literaria y que por entonces colaboraba con los estudios MGM, fue a visitar a Harris convencido de que, de un modo 


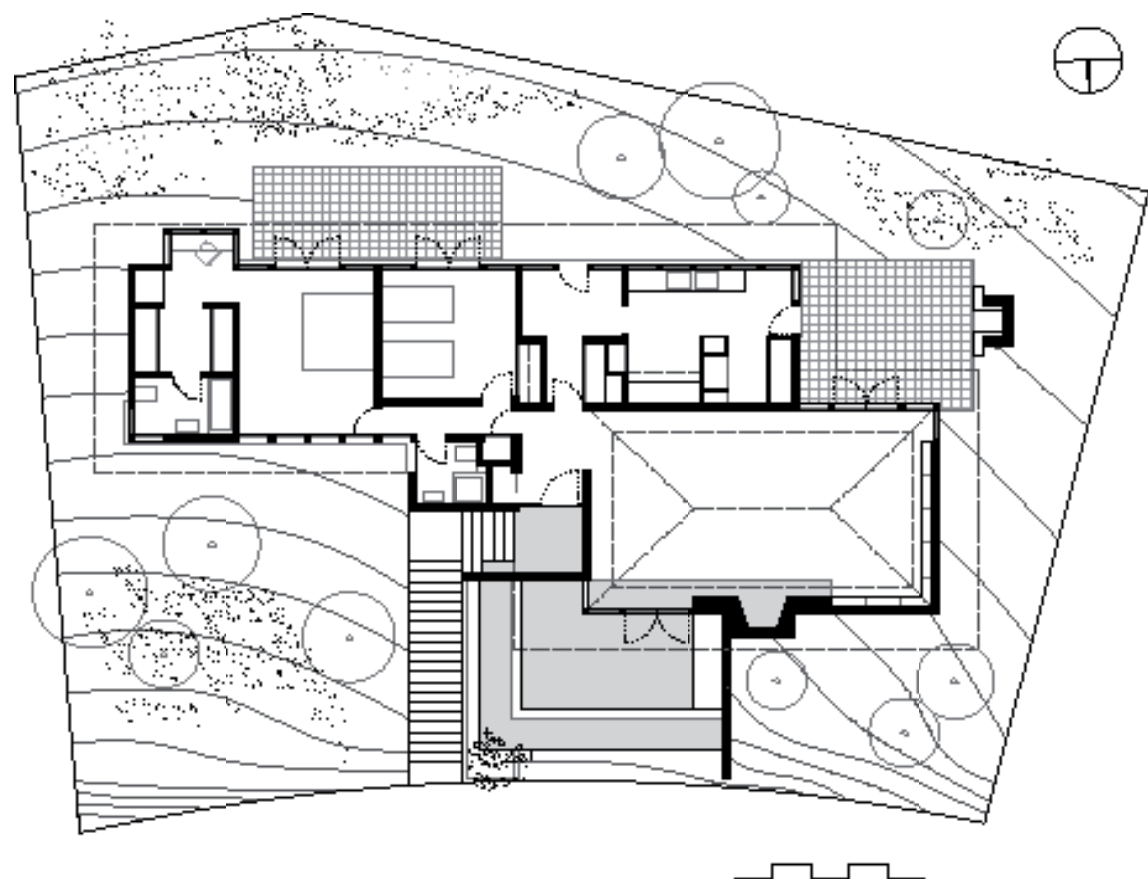

u otro, ambos deberían hacer cosas juntos. De su relación surgió, en 1937, el encargo de su casa en Santa Mónica, la única que, por expreso deseo de Entenza, Harris realizó en un lenguaje próximo al Estilo Internacional.

A finales de los años treinta, Harris se había labrado una reputación como arquitecto de casas modernas para artistas, intelectuales y profesionales liberales del área de Los Ángeles. Todas ellas eran construcciones realizadas a partir de plantas modulares herencia de Neutra, con cubiertas inclinadas de inspiración wrightiana y huecos altos que complejizan las franjas de vidrio de Schindler. Se trataba de viviendas donde la comodidad, privacidad y el disfrute del medio primaban sobre cualquier otra decisión de proyecto; casas en suma, al igual que sus propietarios, reconocibles -como diría Lisa Germany- por sus buenos modales.

Eran viviendas discretas, de medianas dimensiones, prácticas y acogedoras, donde el arquitecto había logrado combinar el gusto por la plástica escultórica que admiraba de Wright con el uso de materiales industriales como el contrachapado o los paneles sintéticos, que había aprendido de Rudolph Schindler y de Richard Neutra. Harris incorporó además las tradiciones constructivas y los materiales locales. La madera no sólo era barata sino que, a diferencia del acero de Neutra, estaba asociada en la psique norteamericana con la idea de confort. Harris supo combinarla con otros materiales, potenció sus cualidades constructivas y expresivas, y celebró su presencia en los detalles, en el diseño de mobiliario, en despieces de carpinterías interiores, elementos de iluminación artificial, etc.

Hacia 1940, la evolución profesional de Harris vino marcada por el encargo, proyecto y construcción de la Weston Havens House (1939-41) en las colinas de Berkeley, su obra más representativa y su vivienda más significativa antes del parón impuesto por la Segunda Guerra Mundial. En ella, el arquitecto recurrió a una inteligente solución de cubiertas inclinadas a partir de prismas triangulares invertidos con los que respondía con un desacostumbrado dramatismo a su espectacular emplazamiento frente a la Bahía de San Francisco, tal como muestran las fotografías con las que Man Ray inmortalizó la obra.
Harris: Laing House, Pasadena, 1935. Redibujado del autor

Página anterior izquierda arriba: Harris: Hermle House publicada en Los Angeles Times Home magazine, mayo 1945

Página anterior izquierda centro y abajo: $\mathrm{Ha}$ rris: Laing House, Pasadena, 1935. Imágenes del interior y exterior de la vivienda. Fotografias de F. Dapprich

Página anterior derecha: Harris: Dibujos de la Granstedt House, 1938. University of Texas Archives 

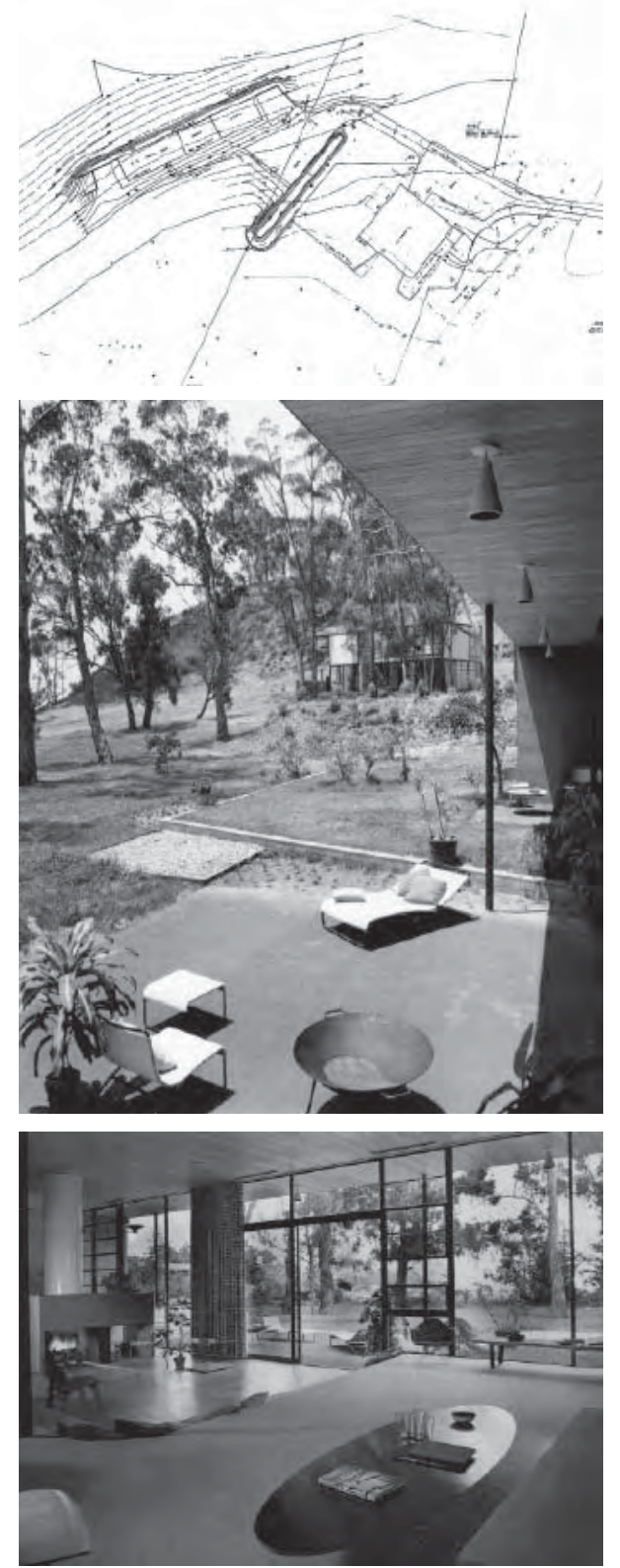

\section{Una vivienda para John Entenza}

Desde 1938 hasta el día en que se mudó a su nueva vivienda de Pacific Palisades, la $\mathrm{CSH} n^{\circ} 9$ - proyectada en 1945 y edificada cuatro años más tarde en la propiedad colindante con la de los Eames-, John Entenza había residido durante más de una década en esta pequeña casa de apenas 6 o metros cuadrados, enclavada en una de las laderas del cañón de Santa Mónica ${ }^{156}$ y desde la que aún hoy se tienen impresionantes vistas con el océano Pacífico de fondo.

En línea recta, las dos casas que John Entenza se hizo construir en Los Angeles están separadas por menos de una milla de distancia $y$, aunque ambas siguen denominándose por el apellido de su propietario original, esta última, la Entenza House de Santa Mónica, recientemente restaurada tras años deteriorándose, sigue siendo todavía - especialmente en Europa- una pieza poco conocida en comparación con su homónima de Pacific Palisades. Aún así, y a pesar de sus notables diferencias, las dos comparten un singular destino. Si la casa firmada por Charles Eames y Eero Saarinen tiene la peculiaridad de ser una de las primeras Case Study Houses, la vivienda realizada por Harwell Hamilton Harris donde John Entenza habitó entre 1938 y 1949, tiene el valor histórico de ser el detonante del proceso que le llevó a acceder a la dirección de la revista y, una vez bajo su control, el lugar donde comenzó a gestar las ideas que impulsaron su célebre programa residencial de posguerra.

Con poco más de treinta años, los caminos de Harwell Hamilton Harris y de John Entenza se cruzaron por primera vez en esta vivienda. La casa de Santa Mónica podría considerarse como el primer éxito mediático Entenza quien estableció personalmente las condiciones para su programa iconográfico, logrando que Harris, aun discrepando profundamente de las mismas, aceptara el encargo. Después de aquel momento, $y$ a partir del desencuentro personal que motivó la forma -para Harris muy poco honesta-como Entenza adquirió la revista California Arts \& Architecture, sus historias se separaron destinadas a cristalizar en algunos de los episodios más notables de la arquitectura norteamericana del siglo pasado, y a la que cada uno contribuyó desde su propio campo de acción y desde su particular y divergente visión de la modernidad.

John Entenza se había interesado por la obra de Harris a raíz del escándalo del concurso Small House, convocado por General Electric en 1934. Poco después de haberse fallado, California Arts \& Architecture denunció que el equipo ganador, integrado por los arquitectos de Chicago R. P. Schweikher y T. W. Lamb, había copiado una vivienda que Harris acababa de terminar ese mismo año en Altadena. Publicando los planos del proyecto ganador y comparándolos con el diseño original de la Pauline Lowe House de Harris, la revista demostraba que la reproducción casi literal de su planta había sido algo más que una mera coincidencia. Aunque los arquitectos se vieron forzados a admitir que sabían de la existencia de la casa, el incidente no tuvo mayores consecuencias y los imputados, que negaron la acusación de plagio, conservaron el premio. No obstante, la repercusión del episodio puso en valor el trabajo de Harris quien logró una inesperada y favorable publicidad a escala nacional, principalmente cuando otras revistas de gran tirada en el conjunto del país se hicieron eco de la noticia. Intrigado por la calidad de la obra plagiada, John Entenza contactó ${ }^{157}$ con Harris y pudo conocer de primera mano la trayectoria recientemente emprendida por este antiguo estudiante y colaborador de Richard Neutra. 


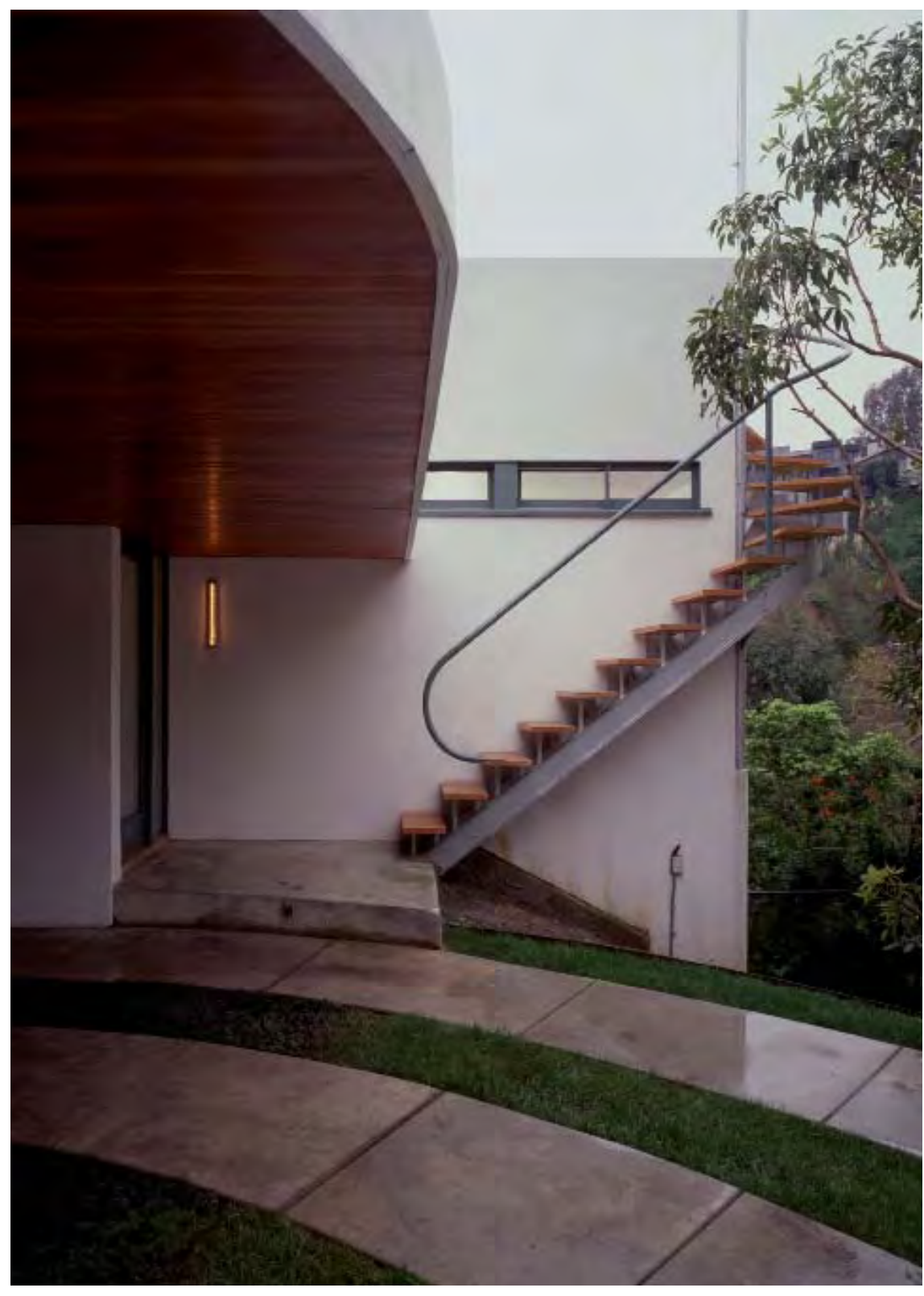

En esa época, Harris había consolidado su prestigio como arquitecto, ganándose el respeto de la profesión y la fidelidad de una clientela de clase media, discreta, culta y amante de la naturaleza.

Por su parte, en aquel momento Entenza era un joven escritor de Michigan, formado en la Universidad de Virginia que se había establecido en California en 1932 con la intención de fomentar sus inquietudes estéticas, entre las que destacaba una inusitada fascinación por el cine ${ }^{158}$, el diseño y la arquitectura moderna. Harwell Hamilton Harris y, sobre todo su mujer, Jean Murray Bangs, gozaban de numerosas amistades en Los Ángeles e introdujeron a Entenza en los círculos artísticos de la ciudad, ayudándole también a establecerse profesionalmente. El matrimonio Harris le proporcionó varios contactos en el mundo de la cultura ${ }^{159}$ y fue a través de ellos como John Entenza consiguió su puesto en el consejo editorial de California Arts \& Architecture, publicación que acabaría transformando en Arts \& Architecture.

En 1937, una vez afianzada la amistad entre ambos y aproximadamente un año y medio después del incidente de la Small House Competition, Entenza pidió a su amigo Harris que realizase el proyecto de su vivienda, proponién-
Harris: Entenza House, Santa Mónica, 1937. Vista desde el acceso a la vivienda desde Mesa Road, 2006. Cortesía de Michael Folonis, arquitecto responsable de la restauración de la obra

Página anterior arriba: Charles Eames \& Eero Saarinen, Entenza House (CSH \#9), Pacific Palisades, 1949: Plano de implantación conjunto con la Eames House (CSH \#8)

Página anterior centro: $\mathrm{CSH}$ \#9. Vista desde el jardín hacia la Eames House

Página anterior abajo: CSH \#9. Vista del estar de la vivienda

Fotografias de Julius Shulman 


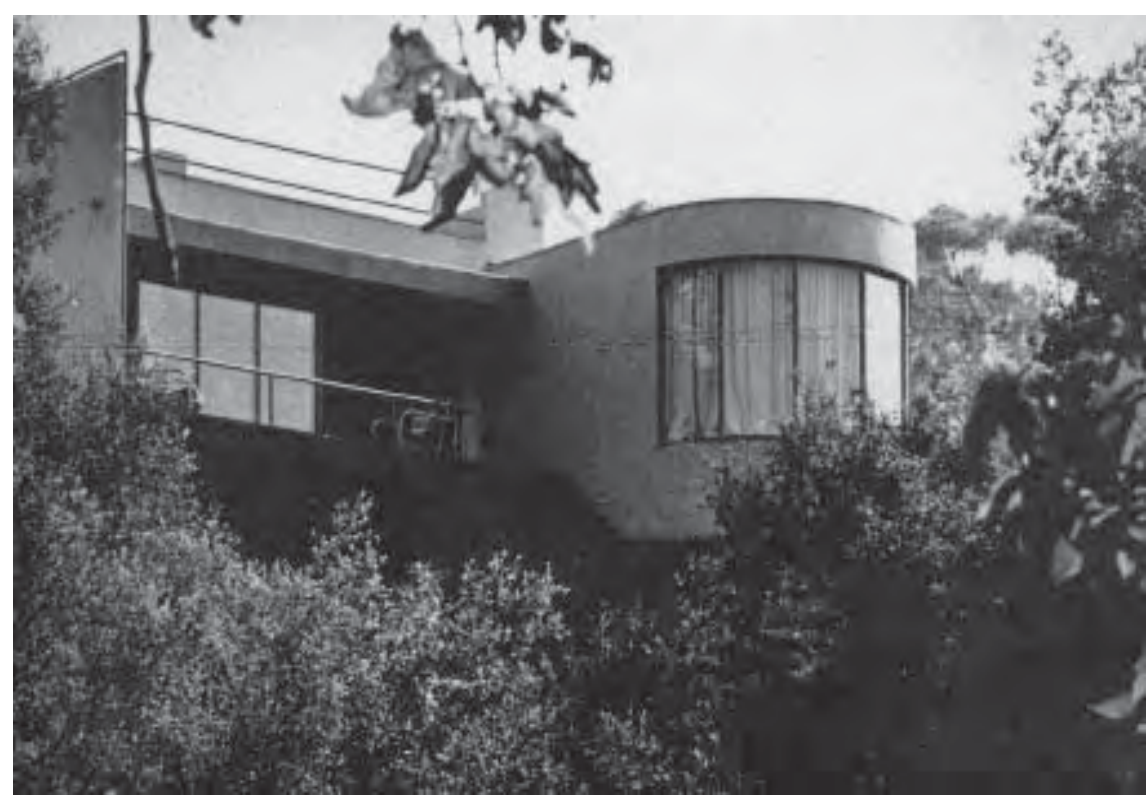

dole un pequeño solar estratégicamente situado sobre uno de los barrancos de las Montañas de Santa Mónica.

Confiando en la capacidad del arquitecto para desenvolverse en diferentes registros, aunque discrepando de su particular concepción de la arquitectura, Entenza dejó muy claro que conocía la casa tan sui generis que Harris se había construido en Fellowship Park en 1935 y que no quería, bajo ningún concepto, que su nueva residencia se pareciera ella. $Y$, seguramente porque varios de sus clientes anteriores habían sido mujeres, como Pauline Lowe o Helene Kerschner, y porque Entenza debió encontrar en sus respectivas viviendas de madera con cubiertas inclinadas y en sus acogedores interiores una versión suavizada de lo que él consideraba que tenía que ser una casa moderna, el escritor exigió también que el resultado final tuviese un aspecto decididamente "masculino"160. Como bien explica Lisa Germany ${ }^{161}$, dado el carácter reflexivo de Harris, poco propenso a exteriorizar gestos, el arquitecto no se preocupó demasiado por esta petición, como tampoco lo hizo cuando fue elogiado por California Arts \& Architecture, que difundió la vivienda comentando que se trataba del "hogar de un hombre hasta el último de sus rincones" y que la casa aparecía "elegantemente, como el nuevo modelo de coche de la más reciente temporada"162.

De lo que sí se preocupó Harris fue de encontrar una repuesta arquitectónica a la intencionalidad de los requerimientos de Entenza que, en el fondo, le estaba pidiendo una obra que expresara su firme adhesión a la modernidad internacional. Los comentarios de la revista son significativos porque, al aplaudir con entusiasmo la novedosa imagen de la vivienda, constatan el éxito de Harris para satisfacer las demandas de John Entenza para quien, no bastando con que su casa fuera moderna, tenía además que parecerlo.

En la medida en que Harris asumió que la clave del proyecto residía en el empleo enfático de un determinado lenguaje, el sentido histórico de su aproximación al mismo desvela importantes discontinuidades en la evolución de la modernidad californiana, así como un trasvase de influencias mucho más complejo que la linealidad que tradicionalmente se ha venido presuponiendo.

Dejando al margen las colaboraciones en el estudio de Richard Neutra, la Entenza House fue la primera y la única vivienda que Harwell Hamilton Harris 

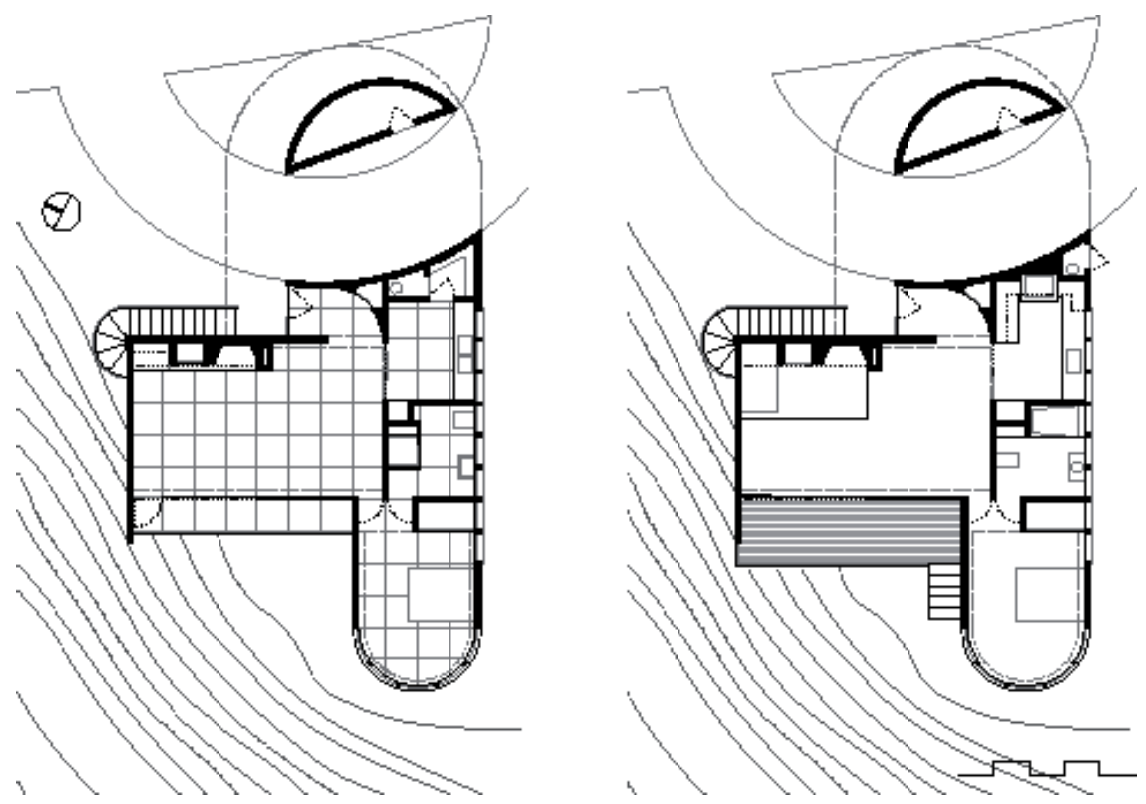

construyó empleando un vocabulario oficialmente moderno. Las casas de Harris eran modernas porque estaban planteadas de una manera moderna pero nunca sintieron la necesidad de exhibir conflictos ni de defender ideales, como tampoco de recurrir a una imagen que justificara su contemporaneidad. El caso de la Entenza House supone una excepción porque a través de ella tuvo que anunciar, por expreso deseo del cliente, a unas convicciones que no eran del todo las suyas.

Resulta irónico que en la casa del mayor agitador cultural del momento y el más firme defensor del Estilo Internacional en California, un arquitecto profundamente regionalista como Harris anticipara, casi sin proponérselo, una de las cuestiones más ampliamente debatidas por la crítica durante la segunda mitad del siglo xx: que la modernidad europea, tras la Exposición del MoMA de 1932, había cruzado el océano sintetizada en el germen de un nuevo estilo ${ }^{163}$.

Esta modernidad importada carecía del sentido épico con el que Richard Neutra había construido su visionaria casa Lovell (1927-29). Después de aquel acto fundacional en la Arcadia del Oeste, se ralentizó el proceso de asimilación de lo europeo, en gran medida porque durante la Gran Depresión disposiciones gubernamentales prohibían levantar toda construcción que no fuera absolutamente imprescindible.

Exceptuando los experimentos de Richard Neutra u otras obras innovadoras por su dimensión social como las de Gregory Ain -en aquella época se produjeron algunos de los mejores grupos y edificios de apartamentos modernos de Los Angeles- en general, durante los años centrales de la década de los treinta buena parte de la arquitectura más cercana a la ortodoxia internacional, a pesar del clima de optimismo reinante, atravesó por un impasse creativo hasta que obtuvo el determinante empuje de las fuerzas de producción. Todavía sin el respaldo de la tecnología surgida de la industria bélica, su capacidad de transformación social estaba limitada. Por ello, muchas de las ideas más novedosas se quedaron en proyectos que no llegaron a materializarse, y los años comprendidos entre los inicios de la era Roosevelt y el estaIlido de la guerra pueden identificarse como un periodo de menor actividad constructora privada que trascurre en paralelo con un fortalecimiento de los códigos como el más efectivo recurso publicitario para la nueva arquitectura.

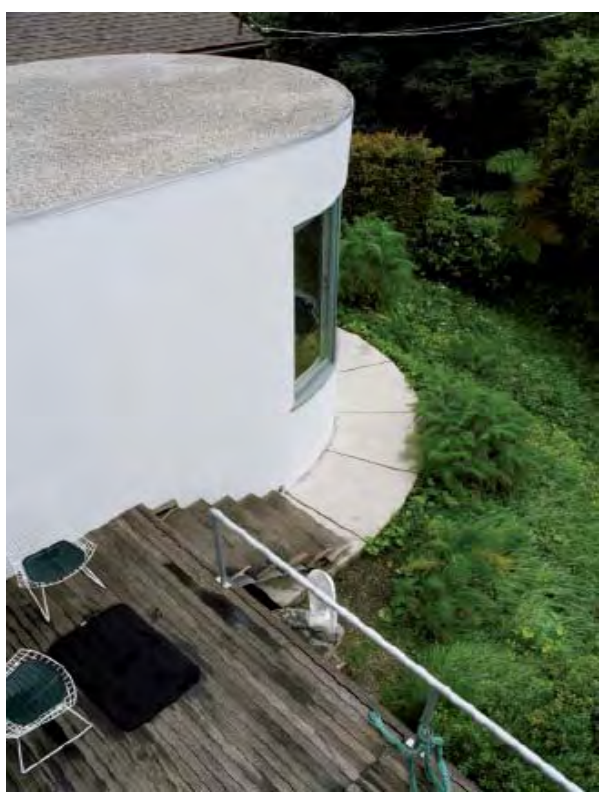

Izquierda: Planta original de la casa (izqda) y planta tras la restauración (derecha) Redibujado del autor a partir de la documentación proporcionada por M. Folonis

Derecha: Vista actual desde la azotea Fotografía del autor

Página anterior arriba: Fachada al cañón de Santa Mónica, 1938 (F. Dapprich)

Página anterior abajo: Richard Neutra: Prototipo de vivienda prefabricada, principios de los años 20. Fuente: Thomas Hines 

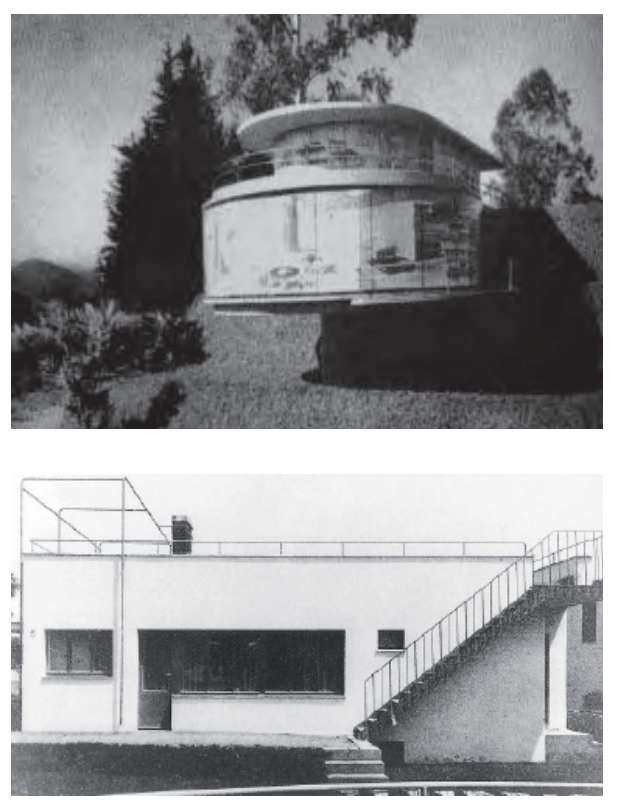

Izquierda arriba: Paul Laszló: Proyecto de vivienda en Los Ángeles, 1937. Fuente: David Gebhard, Los Angeles in the Thirties Izquierda abajo: Richard Neutra: Vivienda experimental para la Exposición del Werkbund Austríaco, Viena, 1932. Fuente Thomas HinesDerecha: Richard Neutra: Casa von Sternberg, 1934. Fotografía Julius Shulman

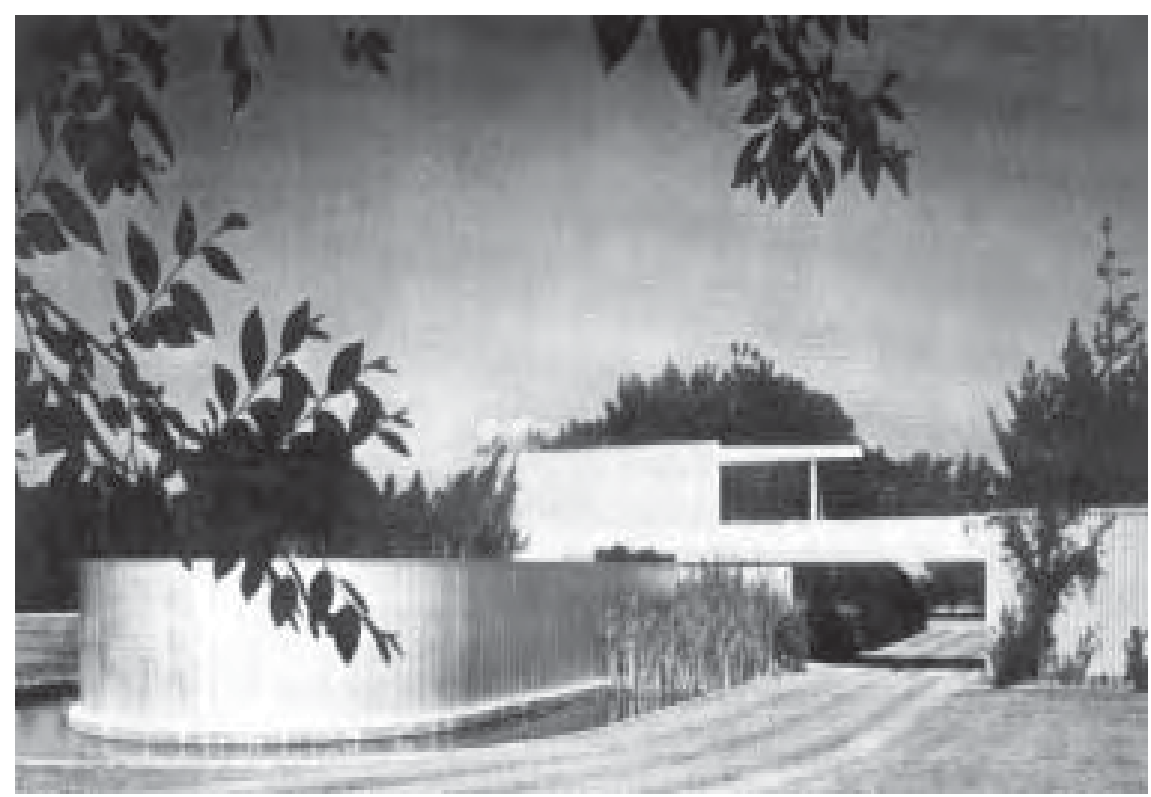

Precisamente, fue uno de estos códigos, el streamline moderne, por su pregnancia y aparente radicalidad formal, el lenguaje que escogió Hamilton Harris para llevar a cabo el precoz ejercicio de estilo que constituye su Entenza House.

La plástica streamline (literalmente racionalizado, eficiente, aerodinámico), con sus contundentes curvas y prolongadas líneas horizontales subrayadas por cubiertas planas y ventanas corridas, es heredera de las vanguardias racionalistas europeas. Mediante su evocación -a veces casi literal- de la imagen arquetípica del paquebote supone una de las más directas formulaciones de la estética maquinista. Sin embargo, en Norteamérica, durante los años de su mayor esplendor (1936-38) coexistió con una serie de corrientes afines que eclosionaron como interpretaciones tardías del movimiento Art Déco, sobre todo en tipologías asociadas al ocio como teatros, cines y auditorios donde es fácil comprobar cómo el angst europeo había sido sustituido definitivamente por el fun californiano.

Una de las muestras más satisfactorias y puristas de esta genuina expresión arquitectónica de la década de los treinta es la casa que Raphael Soriano construyó para la familia Lipetz en Silver Lake (1935-36). En ella la geometría semicircular se reservó para la estancia más emblemática, una sala de música destinada a dar recitales de piano y cuya dirección apunta, como la mirada del público asistente a las veladas, hacia el paisaje próximo.

Neutra realizó diversas incursiones en este estilo, como su prototipo de casa modelo prefabricada con el que Harris había coincidido en su estudio o como la casa para la estrella de Hollywood Anna Sten en Santa Mónica. Si bien, probablemente, el mayor paradigma doméstico de la escenografía streamline de la época sea la residencia que este arquitecto construyó a Josef von Sternberg ${ }^{164}$ en el Valle de San Fernando (1934-35). En este caso, para resaltar su contraste con el ambiente rural de la campiña, la estructura y los cerramientos estaban realizados en acero. El muro curvo del patio, revestido de aluminio y rodeado por un doble estanque, marcaba el recorrido del vehículo en una versión estilizada del garaje de la Villa Savoie, y adquiría toda su dimensión teatral cuando se aproximaba el Rolls Royce del director. 


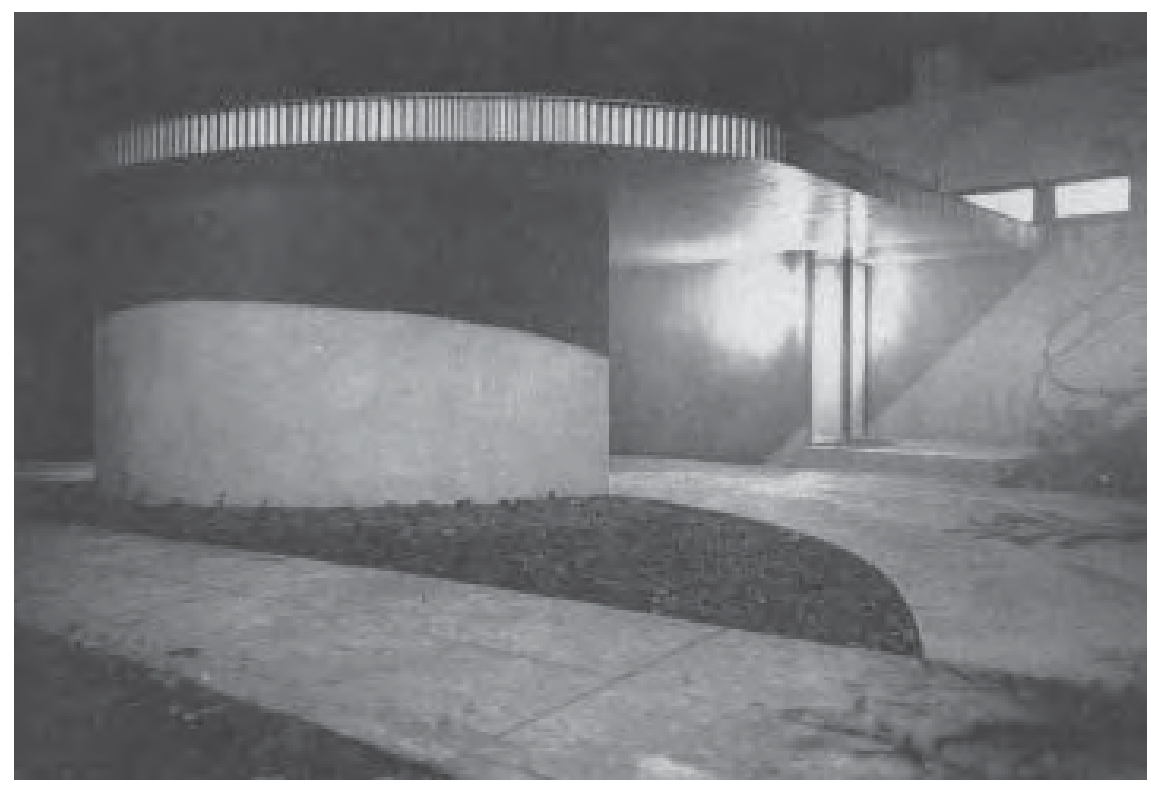

La obra de Neutra proporcionó diversas referencias léxicas que Harris quiso citar en esta vivienda, adoptando una actitud ambigua entre el homenaje, la crítica velada y el guiño cómplice. La interesante relación entre ambos personajes tratada en el capítulo anterior ha sido aún poco estudiada fuera de los Estados Unidos. En algunas de las escasas reseñas que sobre Harris publicaron las revistas especializadas europeas como L'Architecture d'Aujourd'hui, el arquitecto aparece frecuentemente vinculado a la figura tutelar de Richard Neutra y suele presentarse como un discípulo que evolucionó después de haber compartido sus ideas. Esta consideración no es exacta ya que Harris siempre tomó distancia con el trabajo de su mentor. Admiró y reconoció públicamente ${ }^{165}$ la obra de Neutra pero nunca siguió sus pautas. Una vez más hay que insistir, mientras trabajó para él, y aun sin estar de acuerdo con sus planteamientos, proyectó ajustándose a sus directrices pero, cuando a partir de 1933 inició su trayectoria en solitario, su admiración por Wright, su fascinación por la arquitectura japonesa, su predilección por la madera vernácula y su gusto por las tradiciones domésticas de la región (que descubrió en el Schindler de Kings Road y, más tarde, en el trabajo de Greene \& Greene) apartaron definitivamente a Harris del camino trazado por Richard Neutra.

La única excepción fue esta vivienda donde es fácil adivinar en qué medida las lecciones de su maestro debieron resultarle de la mayor utilidad. Por ejemplo, cuando John Entenza hizo saber a Harris que un amigo industrial había decidido regalarle una partida de acero procedente de su fábrica, el arquitecto le sugirió elaborar un detalle singular ${ }^{166}$ para la fachada e ideó la escalerilla desde la que se accede a la terraza superior de la casa. Este elemento metálico, recortándose sobre el muro blanco, está directamente inspirado en la obra de Richard Neutra y, más concretamente, en el prototipo de vivienda para la Exposición del Werkbund austriaco celebrada en Viena en 1932. Harris conocía bien este proyecto puesto que había sido desarrollado hacia el final de su estancia en el estudio de Neutra quien, por su parte, volvería a recurrir a este diseño ${ }^{167}$ de una escala exterior en edificios posteriores y composiciones cada vez más refinadas como la de su Casa Beard de 1934.

Otra pieza representativa, desaparecida en la actualidad aunque está prevista su reconstrucción ${ }^{168}$, era una chapa ondulada que ribeteaba la curva del porche. Con una actitud más propia de Richard Neutra en la casa de Jo-
Izquierda: Harris: Entenza House. Fotografía de Fred Dapprich, 1938. Fuente: California Arts \& Architecture. En la fotografía se aprecia la chapa corrugada de acero original de la vivienda

Derecha arriba: Raphael Soriano: Lipetz House en Silver Lake, 1935. Fotografía Julius Shulman Fuente: Thomas Hines: Architecture of the Sun Derecha abajo R. Soriano: Lipetz House, sala de música. Fotografía Julius Shulman Fuente: Thomas Hines: Architecture of the Sun
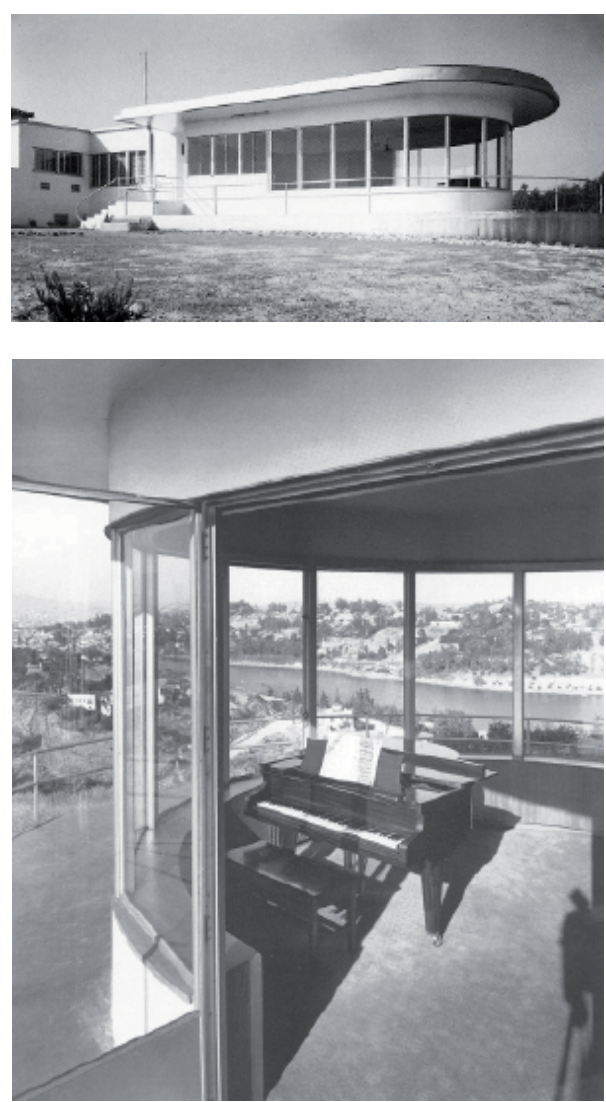

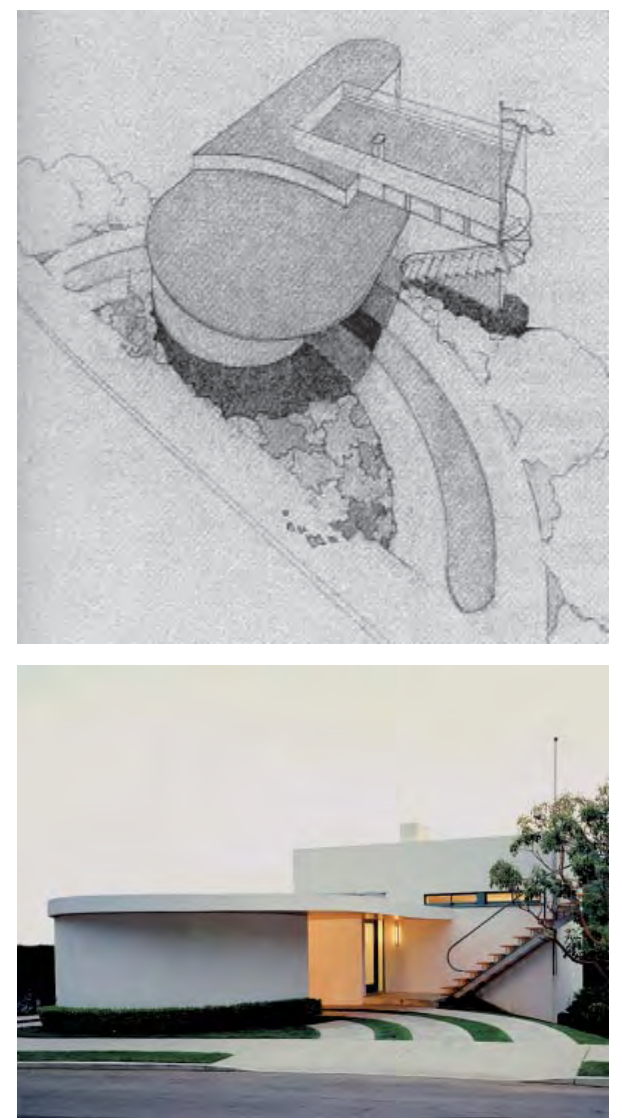

sef von Sternberg ${ }^{169}$, el elegante remate de acero, brillando sobre el lugar destinado al automóvil, adquiría un grado de visualidad insólito en la obra de Harris. El protagonismo de este acabado mecanizado y exacto parecía más destinado a recordar el vínculo existente entre el estilo recreado y los impetuosos eslóganes maquinistas de la época.

En este sentido, un detalle anecdótico más, casi de pabellón ferial, es la bandera que figura en los dibujos originales. Este mástil (recuperado tras la restauración), la citada escalera de acero y la barandilla que da la vuelta por la cubierta rememoraban de una manera lúdica, como si Harris se divirtiera haciéndolo, todas las metáforas náuticas tan de moda en Europa a principios de los años treinta.

No obstante, era en la propia geometría de la planta donde resonaban con mayor fuerza las referencias al mundo de la máquina. Por un lado, funcionalmente, el trazado del carport, facilitando la circulación y el estacionamiento frente a la casa, aportaba una de las primeras soluciones al habitual problema en las colinas de Los Angeles de dar la vuelta con el coche sin necesidad de avanzar marcha atrás en pendiente. Por otro lado, en lo que se refiere a cuestiones de imagen, recurriendo a un gestualidad sin parangón en toda su obra posterior, Harris convirtió esta ingeniosa solución en el elemento más expresivo del proyecto.

La escultórica fachada del acceso, con el brazo del garaje adelantado hacia la calle, fue ideada como una puesta en escena para que el automóvil, sobre todo en movimiento, completara su sentido. Harris había pensado la pérgola y el jardín exterior tomando como base las dimensiones del modelo del Ford de Entenza de 1925. La ligereza de aquel coche nada tiene que ver con el tamaño del SUV de Mike Deasy, propietario actual de la vivienda. Resulta conspicua la distorsión de escala que produce la presencia de este gran vehículo, poniendo de relieve el mesurado acuerdo que existía entre la máquina de transporte y la máquina de habitar proyectada en 1937. Ambas facetas, connaturales a la realidad doméstica de Los Angeles, se presentaban en esta casa perfectamente equilibradas, tal vez como un reflejo idealizado de una ciudad que aún permanecía en un incipiente estadio de crecimiento pero que, muy pronto, sufriría las radicales transformaciones que la cultura del automóvil iba a operar en la geografía urbana del Sur de California.

Uno de los logros más reseñables de Harris en esta casa es el hecho de que, aun trabajando desde el condicionante retórico impuesto por John Entenza, el arquitecto consiguiera satisfacer las exigencias de imagen de su cliente sin dejar de ser fiel a sus propias convicciones.

La Entenza House es el resultado de la implicación del mejor Harris en la búsqueda del ajuste entre una arquitectura hasta cierto punto programática y el modo de vida real del usuario. Pese a su retórica moderna, la vivienda trasluce la sensibilidad del arquitecto y esto ocurre fundamentalmente en sus espacios interiores donde, lógicamente, al pasar la propaganda a un segundo plano, Harris recondujo el proyecto hacia planteamientos más personales, haciendo prevalecer la privacidad, el confort, y la relación con el lugar. Así, al traspasar el umbral de la casa se van descubriendo varios de los temas que esta vivienda comparte con el resto de la producción del arquitecto. Por ejemplo, su preocupación por salvaguardar la privacidad justificaría la anteposición de un pequeño vestíbulo. Este recinto, cuya misión es impedir la visión del interior desde la puerta de acceso, se conver- 


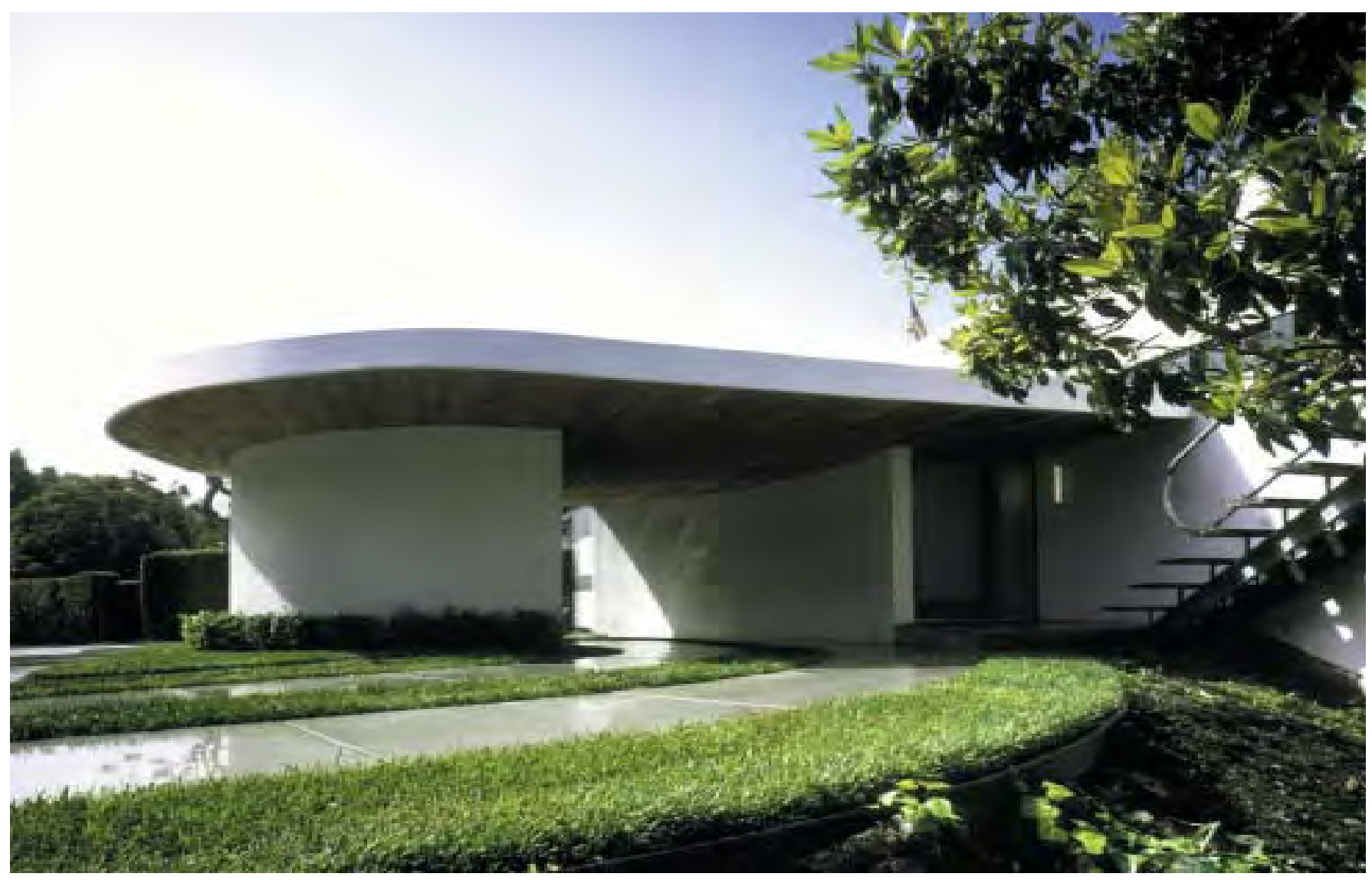

tirá en uno de los elementos más distintivos de su obra. Otra constante de la misma es su atención a los más pequeños problemas del día a día, entre ellos, la necesidad de almacenaje que Harris resolvió perfectamente al prever para esta función un espacio suficiente y distribuido de tal forma que no alterase la lectura de la planta.

Obviando la geometría circular, la planta responde a una sencilla disposición que agrupa tanto los espacios sirvientes (cocina, baño) como el dormitorio en una banda adosada al espacio más público del estar. En dicha estancia, Harris compensó lo reducido de sus dimensiones organizando eficazmente el mobiliario fijo en torno a la chimenea como un apoyo para futuras piezas. A su vez, mediante dos puertas correderas de vidrio, abrió completamente la pared opuesta posibilitando así las vistas panorámicas sobre el cañón de Santa Mónica.

Aprovechando que el emplazamiento elevado de la casa dificultaba las vistas directas hacia su interior desde las propiedades vecinas, el gran acristalamiento de la fachada sureste apoyaba la implantación de la vivienda al introducir en ella los árboles la parcela. Dado que éstos han acabado fundiéndose con la exuberante vegetación de las laderas circundantes, desde el estar de la vivienda se tiene una idea de mayor amplitud al disponer de toda la profundidad de las perspectivas del barranco.

El efecto resulta particularmente interesante en el diminuto dormitorio cuyo mirador semicircular avanza decidido hacia el jardín. Harris aprovechó la pendiente para hacer descender la cota de las circulaciones frente a estas ventanas y de este modo, la falta de visión del plano del suelo exterior y la presencia del verde como telón de fondo, inducen una sensación de hallarse suspendido en el lugar $y$, por ende, de permanecer en un espacio mayor de lo
Arriba y abajo: Imágenes tras la restauración, Cortesía de Michael Folonis

Página anterior: Entenza House, dibujo del proyecto original, 1937 

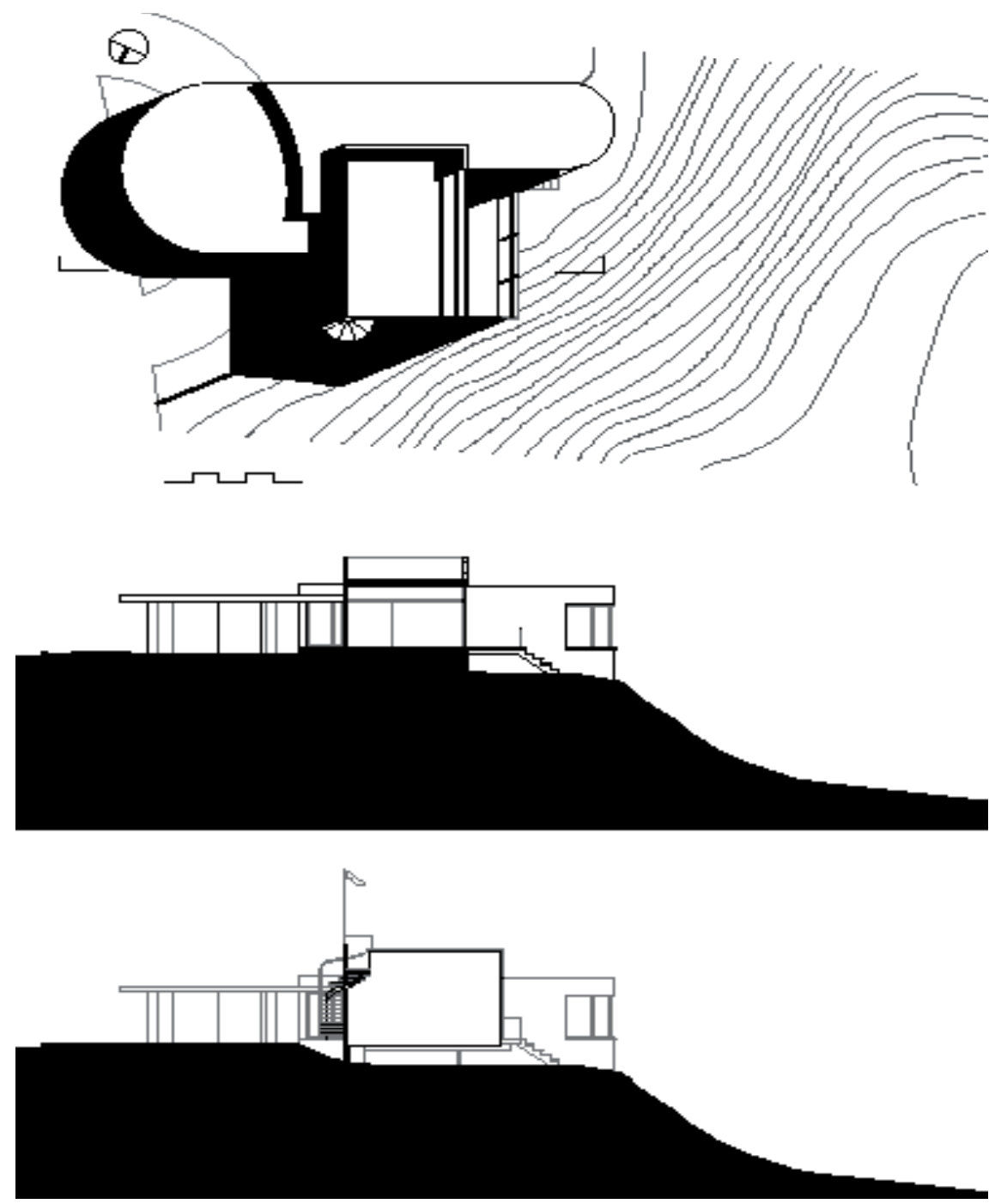

Planta de cubiertas y secciones trasversales de la vivienda. Redibujado del autor

Página anterior izda arriba y abajo: Vistas interiores desde el estar. Fotografías del autor, Página anterior dcha arriba y abajo: Harris: Pumphrey House, Santa Mónica, 1937. Exterior e interior. Fotografías actuales. Cortesía de Michael Folonis que en realidad es. Finalmente, la mirada puede recrearse libremente desde la terraza superior que, tratando también de suplir las limitaciones de espacio, se concibió como una atalaya desde la que dominar el paisaje.

Por razones presupuestarias la casa fue realizada con entramado de madera, revocado y pintado de blanco que, por su impermeabilidad, eficacia como aislamiento y rapidez de montaje, era una de las soluciones constructivas más habituales en California, por ejemplo en las viviendas estilo misión. Aunque Richard Neutra rechazaba estos sistemas tradicionales, en cierto modo se trataba del mismo proceder incoherente de pintar la madera color plata. Y Harris, al igual que venía haciendo Schindler en sus casas de los años treinta, no dudó en recurrir a un sistema constructivo tradicional para materializar unas formas insólitas y completar luego la composición con unas cuantas piezas de acero destinadas a enfatizar el aspecto moderno pretendido por Entenza.

Gracias a la restauración llevada a cabo en 1998 por el estudio de Santa Mónica Michael W. Folonis \& Associates ${ }^{170}$, pueden descubrirse aún más analogías entre la Entenza House y otros proyectos de Harris, ya que ahora es posible admirar detalles que el deteriorado estado de la vivienda impedía percibir con nitidez. Uno de ellos es el cuidadoso planteamiento de la iluminación artificial. Procurando siempre luces indirectas, Harris dispuso una banda de madera para esconder las luminarias. Este elemento, a modo de remate, rodea todas las estancias de la casa a una altura aproximada de unos cuarenta centímetros por debajo del techo (18 pulgadas). Dispositivos similares 

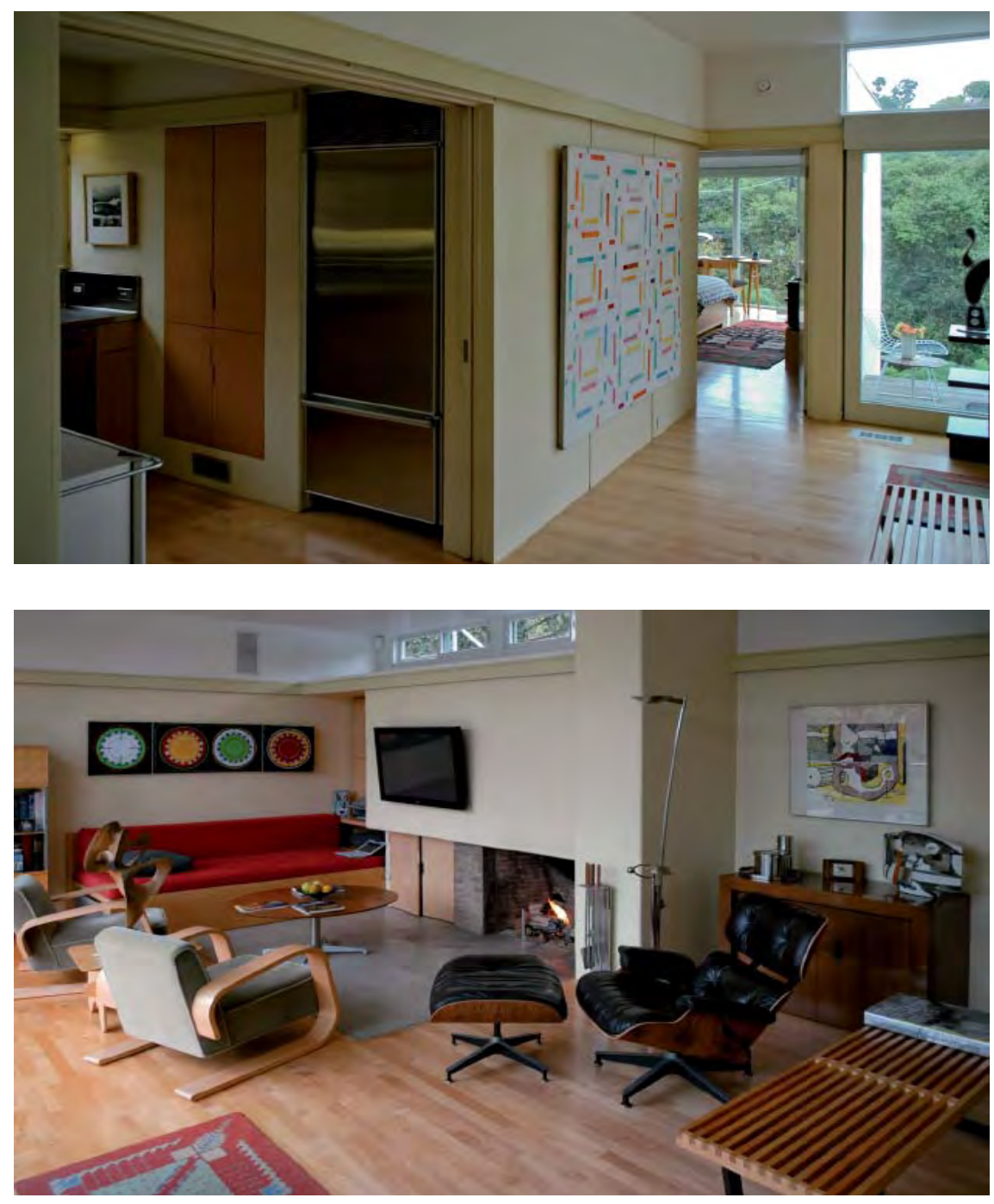

de luces ocultas bañando las superficies interiores fueron dando lugar a una serie de diseños recurrentes en el conjunto de su obra -como los que se comentarán más adelante en el capítulo dedicado a la Hanson House en Silver Lake- y que, como el propio Harris reconoció en más de una ocasión, estaban directamente inspirados en el tipo de iluminación artificial que Schindler había inventado en su casa-estudio de Kings Road y a la que el arquitecto se había referido en diversos escritos ${ }^{171}$.

También en la vivienda de John Entenza el arquitecto pudo utilizar su particular gama de colores naturales, reservando el blanco para el techo y pintando las paredes en un tono crema que oscureció ligeramente en la banda de madera donde había escondido los focos. Para potenciar la luminosidad procedente de esta pieza, así como la luz natural que penetra por los característicos huecos altos de Harris, dispuestos según orientaciones enfrentadas este-oeste, la franja superior de los paramentos comprendida entre el borde del panel perimetral y el techo también se pintó de blanco. La paleta de colores se completaba con el bermellón de las losas cerámicas, los tonos rojizos de la madera y el verde grisáceo con el que estaban pintadas las carpinterías exteriores, todo de acuerdo con su asimilación de las enseñanzas de Stanton Macdonald.

En definitiva, en lo referente a cuestiones de imagen, el arquitecto satisfizo ampliamente las expectativas de Entenza construyéndole una vivienda funcional, sencilla y elegante donde, aparentemente, no había ninguna conce-
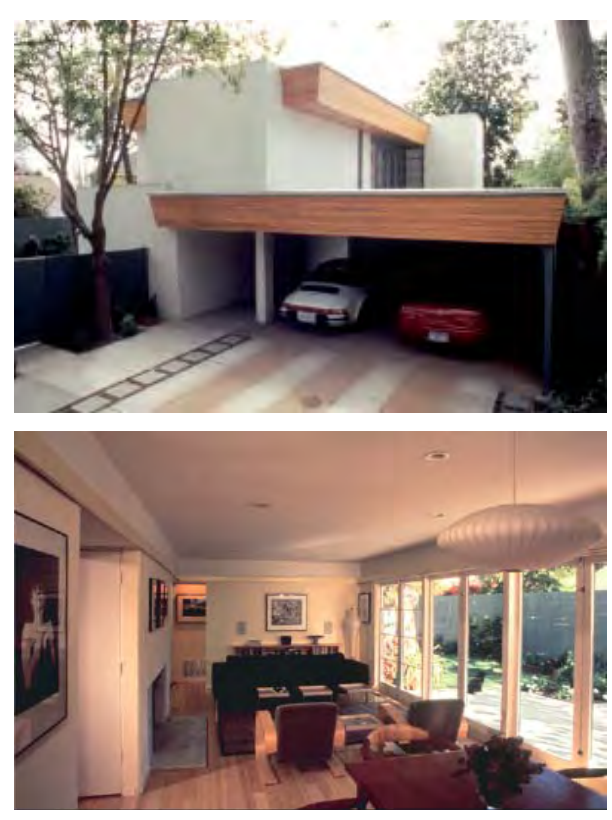


\section{A L I F ARTS \& ARCHITEC}
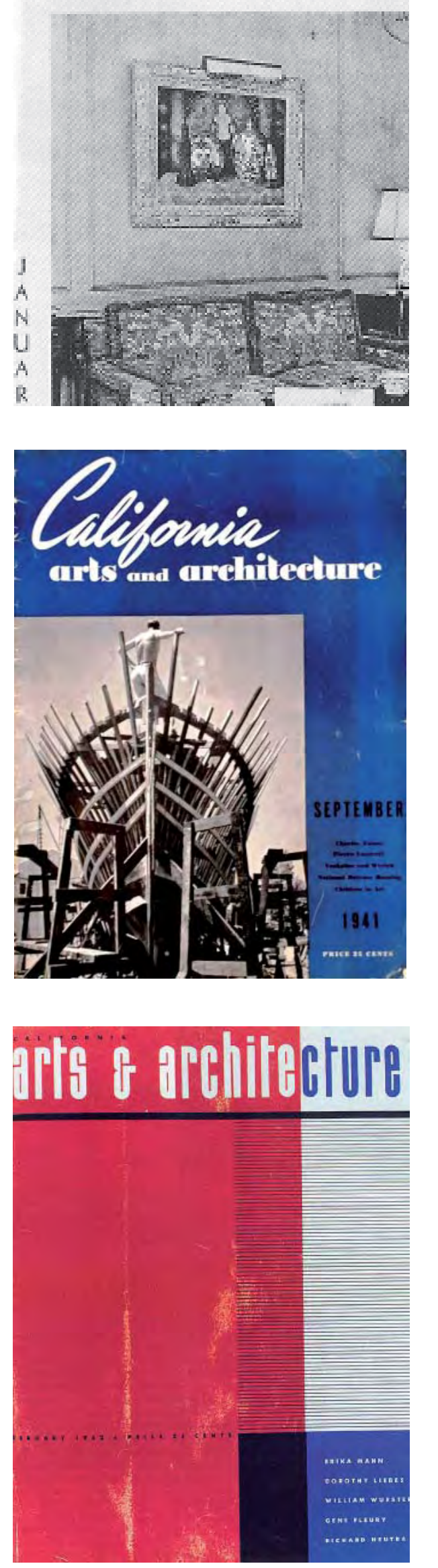

sión regional; aunque en lo referente al espíritu de obra, Harris logró compatibilizar un lenguaje internacional con sus ideas sobre el hogar californiano, haciendo valer su propia manera de entender la arquitectura.

Tras esta coincidencia sus caminos se separaron. El de Entenza estuvo fijado por la dirección editorial y la difusión de su personal modo de entender el estilo moderno californiano, consecuencia de las aplicaciones residenciales de la tecnología industrial mientras. Harris, por su parte, continuó cimentando su carrera en la investigación fenomenológica del espacio donde transcurre la vida doméstica. Desde entonces la relación entre ambos fue complicada y sus discrepancias profesionales entraron incluso en el terreno de lo personal cuando John Entenza compró la revista California Arts \& Architecture.

Ésta había sido fundada en 1929 como resultado de la unión de dos boletines sobre vivienda circunscritos al ámbito de la Costa Oeste, Pacific Coast Architect y Southland, lanzados, respectivamente, en 1911 y 1918. La nueva publicación daba cabida a residencias de estilos tan variados como el Regencia, el Mediterráneo, el Colonial o el ubicuo Spanish Revival. Si bien, después de la fusión fue despertándose el interés de la revista por propuestas más novedosas. A principios de la década de 1930 se incorporó el movimiento Art Déco y poco a poco aparecieron realizaciones modernas sin desatender nunca sus particularidades locales. En esos años aumentó el número de páginas hasta una media de 70-75 y gracias a la publicidad crecieron también sus ingresos. Tanto Harris Allen, su primer editor, como George Oyer, que le siguió al frente de la dirección, se esforzaron por contratar a críticos y escritores solventes, consiguiendo que la revista iniciase un momento de esplendor cultural que se prologaría de 1935 a 1940, momento de la entrada en escena de John Entenza. En ocasiones California Arts \& Architecture suministraba información a revistas de tirada nacional como Architectural Record o Architectural Forum, sobre las que llegó a ejercer una cierta influencia a la hora de seleccionar los ejemplos de vivienda californiana que se publicarían en el resto del país.

Resulta por tanto sorprendente que David Travers, quien sucedió a John Entenza al frente de Arts \& Architecture en 1962 y acabó arruinando una publicación extraordinaria tras su desafortunada gestión al frente de la misma, haya escrito en su texto introductorio a la ambiciosa reedición facsímil de la revista llevada a cabo por Taschen hace un par de años que, cuando Entenza se hizo con el control de California Arts \& Architecturea en 1938, debido a las consecuencias económicas de la Gran Depresión, esta publicación se encontraba al borde de la quiebra ${ }^{172}$. Éste es uno de los grandes mitos sobre la revista que se han perpetuado, a pesar de su falsedad.

Por supuesto, un mito más es el de la fecha de su adquisición de por parte de Entenza. Ésta se produjo en 1940, y no en 1938, como se encarga de enfatizar el propio Travers reiterando un error iniciado en 1962 por Esther McCoy ${ }^{173}$, continuado por Barbara Goldstein ${ }^{174}$ e, incluso, perpetuado por investigadores como Elizabeth Smith ${ }^{175}$, o la propia Lisa Germany en su monografía sobre Harris. La acumulación de errores e inexactitudes históricas, motivada por la trasmisión de información sin contrastar de unos a otros historiadores es especialmente llamativa en el trabajo de Elizabeth A. T. Smith, comisaria, coautora y editora del catálogo publicado en 1989 con motivo de la exposición sobre el programa Case Study Houses organizada por Museo de Arte Contemporáneo de Los Ángeles. En su texto ${ }^{176}$ para este libro -por otra parte imprescindible- Smith ensalza la figura John Entenza hasta el punto de que, más allá de celebrar sus indiscutibles méritos como ideólogo 
del programa, magnifica también su papel como el único responsable de la completa transformación de los contenidos, objetivos y repercusión de la revista California Arts \& Architecture. Ésta, es presentada en su evolución desde una publicación local sin importancia hasta convertirse en un icono cultural de la vanguardia norteamericana de la segunda mitad del siglo xx. Smith otorga todo el protagonismo de este proceso a John Entenza, sin tener en cuenta que la revista ya era un referente de modernidad antes de su llegada. En su capítulo "Arts \& Architecture and the Los Angeles Vanguard", Smith se aventura a comparar dos portadas: una de California Arts \& Architecture (enero de 1938) y otra de Arts \& Architecture (febrero de 1942) diseñada por Alvin Lustig. La elección del número de enero de 1938 de California Arts \& Architecture no es en absoluto inocente. No sólo porque Smith escogió una de las portadas menos afortunadas de la publicación para confrontarla con un magnífico diseño gráfico de Lustig, sino porque, confundiendo la fecha de asunción del control de la revista por parte de Entenza dos años, la historiadora atribuía erróneamente al editor todos los méritos de California Arts \& Architecture logrados entre 1938 y 1939.

Otro de los mitos acerca de la revista es, por tanto, que ésta no se había interesado por la modernidad hasta la llegada de John Entenza, primero como editor adjunto y más tarde como propietario a partir desde mediados de 1940. Es suficiente consultar los índices de la publicación a partir de enero 1935 e incluso mucho antes, en algunos números de mediados de 1932 -con la intervención de Neutra-, para caer en la cuenta de todo lo contrario. Más aún, la exploración de la modernidad llevada a cabo por California Arts \& Architecture en esos años es un episodio tan interesante y desconocido que resulta imprescindible detenerse en él para comentar algunos aspectos.

Su acercamiento a la modernidad se había iniciado entre 1933 y 1935, cuando California Arts \& Architecture comenzó a consolidarse como la fuente más fiable de difusión de las ideas de la modernidad arquitectónica californiana gracias al esfuerzo colectivo de un grupo de individuos entre los que habría que destacar a Harris Allen, responsable de la fusión, y a George Oyers, editores a los que seguirían Mark Daniels en 1935 y a éste, a su vez, Jere Johnson en 1938. El fotógrafo Edward Weston, el proteico Merle Armitage que ayudó a Daniels a rediseñar y actualizar la revista definitivamente en 1936, Pauline Shindler, Richard Neutra o el propio matrimonio Harris serían algunos de los personajes que, como grupo, trataron de influir en la sociedad, el arte y la arquitectura de su tiempo través de las páginas de esta revista.

En este sentido es imprescindible señalar una vez más el número de enero de 1935, dirigido por Pauline Gibling Schindler por invitación de George Oyer y que supuso el primero número de la revista California Arts \& Architecture dedicado por completo a arquitectura moderna. Concretamente, a través de su selección de los textos y las obras que integraban el mismo, Pauline Schindler fue la primera en poner el foco en el conjunto de la pluralidad y la originalidad de la vanguardia arquitectónica de la ciudad de Los Ángeles. El número supuso la constatación definitiva del cambio de rumbo que había ido poco a poco materializándose en la revista y fue la primera ocasión en la que Harris fue publicado por la revista. Por su parte, la primera mención a John Entenza en las páginas de California Arts \& Architecture se produjo en julio de 1937. Se trataba de la publicación del proyecto de su casa de Santa Mónica. Su siguiente aparición tuvo lugar en mayo de 1938, con un reportaje dedicado a la obra de Harris ya construida.
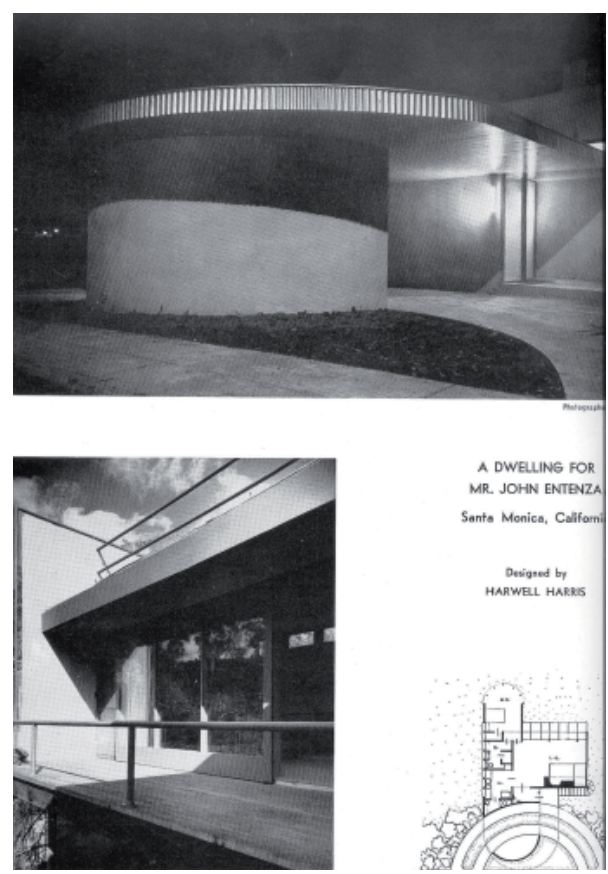

A DWELING FOR MR. JOHN ENTENZ sonto Monice, Calfion Devigeed by

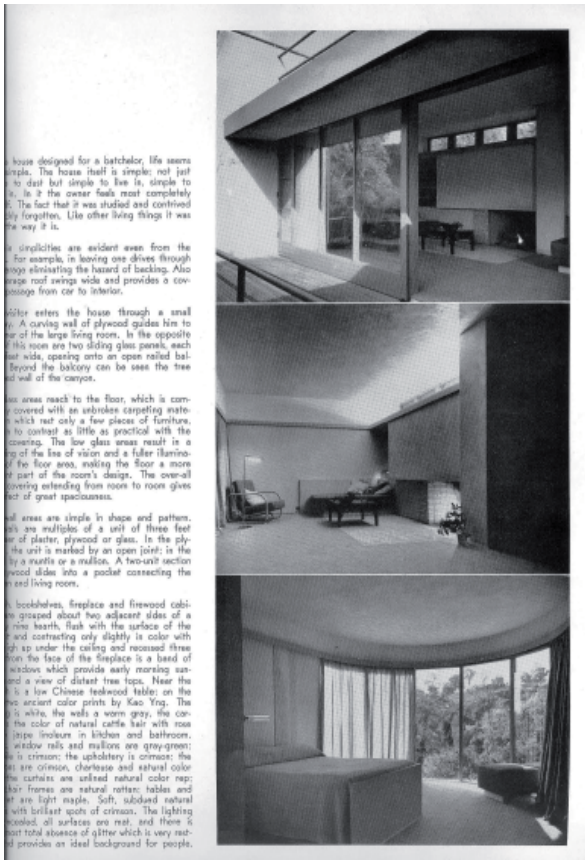

California Arts \& Architecture, mayo 1938 Imágenes de la Entenza House construida

Página anterior: Portadas de California Arts \& Architecture. De arriba abajo: enero 1938, febrero 1937 (con fotografía de portada de Edward Weston) y septiembre 1942.

En esta última, diseñada por Alvin Lustig, la palabra 'California' ha reducido considerablemente su tamaño hasta casi desaparecer. 


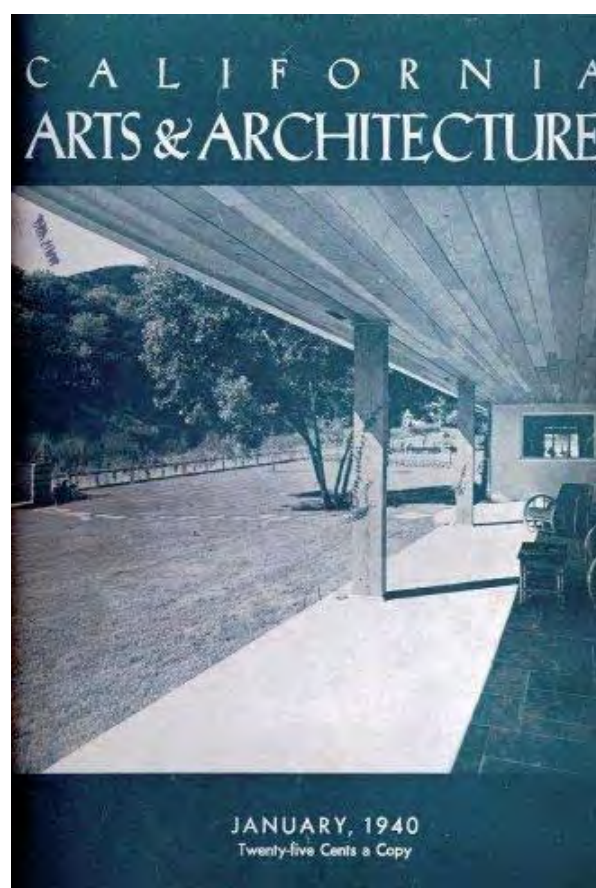

California Arts \& Architecture, enero 1940 Imagen de portada: Rosenson House de Paul Laszló fotografiada por J. Shulman

Página siguiente: California Arts \& Architecture, marzo 1940. Imagen de portada: Havens House (H. Harris) Portada propuesta por John Entenza
En aquel momento Jere Johnson, muy cercana a Hamilton Harris y a su mujer Jean Murray Bangs, era la editora y propietaria de la publicación. De hecho, las oficinas de la revista se encontraban en el mismo edificio donde Harris tenía su despacho. En 1939, cuando éste entró a formar parte del consejo editorial de la revista, Johnson estaba embarazada y precisaba de alguien que la sustituyera durante algunos meses tras el nacimiento de su hijo. Cuando consultó los Harris sobre la persona idónea para desempeñar esta tarea, éstos no dudaron en recomendarle a John Entenza. Johnson le puso inmediatamente a cargo de su equipo, pero una vez que hubo asumido sus responsabilidades plenamente, en 1940, Entenza decidió comprar la revista y consiguió hacerlo por muy poco dinero.

En una carta enviada a Esther McCoy en 1989, Harris relataba los hechos del siguiente modo: "Jean y yo éramos buenos amigos de Jere Johnson, la dueña y editora de CA\&A. Mi despacho y las oficinas de la revista estaban en el mismo piso del 2404 Oeste de la Calle Séptima (frente a parque Westlake, (más tarde McArthur Park), y cada una de mis casas se publicó en CA\&A antes de que apareciera en ninguna otra parte. Un día Jere le dijo a Jean que estaba esperando un bebé y que no sabía a quién dejar al frente de la revista mientras ella estuviese fuera. Sabiendo que John podía escribir y probablemente editar, nosotros se lo sugerimos para el trabajo. En aquel momento John sabía muy poco sobre arquitectura, por lo que su única contribución al principio eran las 'Notes in Passing'. John se hizo con la revista y Jere ya no pudo recuperarla. Nunca llegamos a saber todos los detalles de la adquisición. Supongo que Jere estaba demasiado disgustada por su ingenuidad para querer hablar de ello. Stella [Gramer] era muy astuta $y$, sin duda, dirigió maniobras de John. Esto terminó con nuestra amistad con John"177.

La forma en la que se convirtió en el nuevo editor de California Arts \& Architecture disgustó profundamente al matrimonio Harris pues pensaban que su amiga había salido perjudicada y que tanto el padre abogado de Entenza como su socia, Stella Gramer, la habían presionado abusivamente hasta que se había decidido a vender. En palabras de Harris:"[Entenza] compró [CA\&A] por muy poco dinero, al igual que logró construir su casa por muy poco dinero. Sobre todo por la presión ejercida por su padre y, particularmente por la socia de su padre, una joven cuyo nombre he olvidado ahora mismo [Stella Gramer] y a quien yo le diseñé una casa que no llegó a realizarse a partir de un diseño de casa experimental que había construido Neutra. En cualquier caso, todos ellos eran muy dados a presionar a todo el mundo, ya fuera para construir una casa para John o para comprar una revista para John. Nuestra sensación es que habían engañado a Jere. Esto causó nuestra rupture con John. Cuando, más tarde, él inició su Case Study program y me pidió diseñar una casa para la revista, yo decliné su invitación ${ }^{178 "}$.

El número de enero de 1940 es muy significativo ya que epitomiza el legado de Johnson y su última portada como editora en solitario de California Arts \& Architecture. Lleva en su cubierta una imagen de la Rosenson House de Paul Laszló en Bel Air, que supuso la primera portada de Julius Shulman como fotógrafo. Dos meses más tarde, en marzo, recurriendo a la documentación pendiente de ser publicada, John Entenza asumía su responsabilidad como coeditor de la revista produciendo una brillante portada que reproducía la sección de la Weston Havens House de Harris en Berkeley, aún en proceso de construcción.En este número de marzo, Entenza llevó a cabo un cambio topográfico en el título de la revista, la cual se mantuvo con este nuevo encabezado hasta que, en abril de 1942 contrató a Alvin Lustig como diseña- 
dor gráfico y éste propuso la característica tipografía asociada con Arts \& Architecture. En el número intermedio de febrero de 1940, Entenza introdujo por primera vez su célebre columna de opinión política Notes in Passing, su primer cometido en la revista. Dos importantes gestos en menos de un mes que demostraban la prisa de Entenza, aun actuando todavía como editor adjunto, por realizar profundos cambios en la revista y que éstos se asociaran con su persona.

Todo parece apuntar a que estaba realmente ansioso por adquirir la revista cuya compra logró formalizar en mayo de 1940. Al mes siguiente, en el número doble de junio-julio, Entenza eliminó el nombre de Johnson de cualquier crédito de la publicación. Su alejamiento definitivo de las posiciones de la etapa anterior fue escenificado en agosto de ese mismo año mediante la distancia física impuesta al reubicar las oficinas de la revista en la ciudad. Éstas fueron trasladadas desde la misma planta donde se encontraba el despacho de Harris en el Elk's Club Building, en el número 2404 de West Seventh Street, al 3305 de Wilshire Boulevard, donde permanecieron hasta 1962, cuando John Entenza vendió la revista a David Travers y abandonó Los Ángeles para trasladarse a Chicago como flamante nuevo director de la Graham Foundation.

El encabezado California se eliminó de la portada en septiembre de 1943. En el número del mes siguiente volvió a aparecer, alimentando la leyenda de que se había tratado de un error de impresión ${ }^{179}$. Sea como fuere, la palabra California se suprimió definitivamente y sin ninguna explicación en febrero de 1944. Como consultor de la revista, Harris lamentó que con la desaparición de una parte del nombre original desaparecieran también las referencias a las particularidades locales y todo intento de documentar una sensibilidad distintiva de algunas de las mejores viviendas californianas. El nuevo rumbo emprendido por Entenza agravó su distanciamiento. Sin negar el encomiable esfuerzo realizado por Entenza para dar cabida a los contenidos sociales y al paradigma de la construcción de viviendas en serie, Harris consideraba un error la homogeneización de las lecturas modernas y discrepó con él por el hecho de que casi toda interpretación regionalista -al menos hasta 1949fuera erradicada, por sospechosa, de las páginas de la revista.

Harris y Entenza pusieron fin a casi todos sus vínculos, aunque no de forma inmediata. El arquitecto, que era miembro del consejo editorial de California Arts \& Architecture desde octubre de 1939 y prefería publicar primero sus obras en esta revista, dejó de suministrar información a Entenza, rehusando también participar en el programa Case Study Houses. De hecho, podría causar extrañeza que después de haber construido una casa con la que Entenza quedara tan satisfecho, Harris no proyectase ninguna de las Case Study Houses promovidas por su antiguo cliente. Habitualmente esta circunstancia se ha atribuido exclusivamente a John Entenza, como si la diferencia de posiciones entre ambos -cada vez más evidente- hubiera motivado el que el editor le retirara su apoyo. Sin dejar de ser cierto, el caso es que Harris fue uno de los primeros arquitectos llamados a participar en el programa pero declinó la invitación porque no se mostró de acuerdo con la forma en la que Entenza había asumido el control de la revista. En cualquier caso y aunque por decisión propia no quiso publicar en Arts \& Architecture, Harris se mantuvo vinculado a la revista todavía unos meses más hasta que, tras rechazar de nuevo su invitación para construir una casa modelo, en abril de 1946, abandonó definitivamente su puesto en el consejo a petición de John Entenza y apenas volvieron a hablarse ${ }^{180}$.
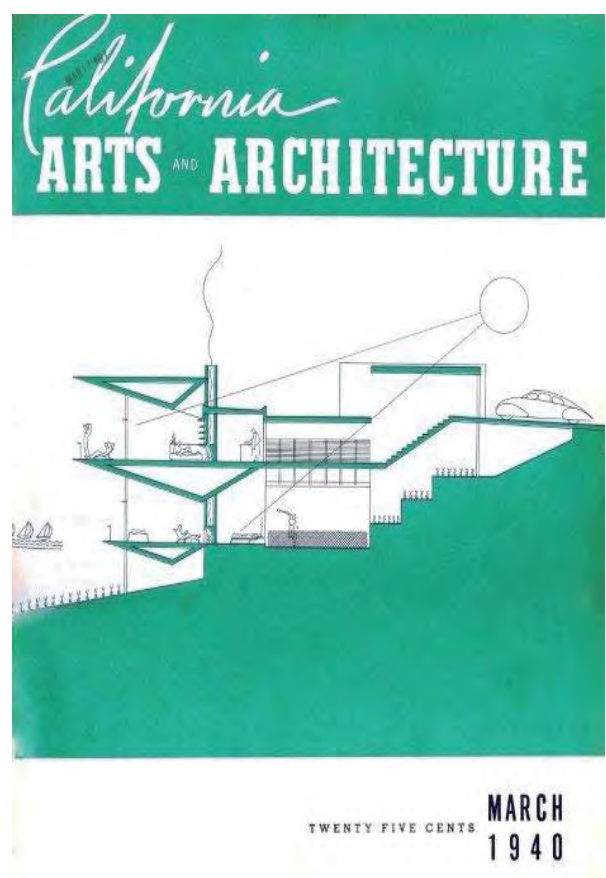


\section{Weston Havens House, la arquitectura y sus fotógrafos}

Entre la espesa vegetación que puebla las colinas ${ }^{181}$ del campus de la Universidad de Berkeley, dominando discretamente desde su privilegiado mirador el horizonte de la Bahía de San Francisco, permanece semioculta la casa Havens, una de las cimas de la arquitectura doméstica norteamericana y, sin embargo, una de las realizaciones más olvidadas por la historiografía reciente. $\mathrm{O}$, al menos, esto es lo que sucedía hasta hace muy poco tiempo, cuando, tras la muerte de su propietario, la casa fue donada a la Universidad de California en Berkeley que ha emprendido su restauración para devolver la pieza a un estado próximo a lo que debió ser hace setenta años.

El tránsito de los años 30 a 40, coincidiendo con la madurez de su etapa californiana, es la etapa más fructífera de la carrera de Harris, tanto en lo que se refiere a la cantidad como a la calidad de sus obras. El episodio de la Weston Havens House es absolutamente central en este periodo de transición que redefinió por completo el resto de su producción arquitectónica, así como su relación con los medios de comunicación. No sólo porque supuso el final de la íntima colaboración de Harris con la revista California Arts \& Architecture sino porque, a partir de esta obra, el arquitecto ganó acceso al panorama editorial internacional.

Sobre ese periodo, Esther McCoy escribió, "hacia 1941, los californianos creíamos saber qué podíamos esperar de Harris pero esta casa en Berkeley fue todo un shock. Esperábamos complejos juegos de cubiertas pero no triángulos invertidos. Él ya había construido en terrenos escarpados pero la Havens House fue un tour de force ${ }^{\prime \prime 182}$.

Terminada pocas semanas antes del ataque japonés a Pearl Harbor, la difusión de la obra tuvo que hacer frente a los reajustes que, con motivo de la entrada en la guerra, sufrieron las líneas editoriales del país, aún así captó la atención de los medios y consiguió un reconocimiento que perduró hasta los años cincuenta $y$, a partir de entonces, su fama fue diluyéndose. De hecho, una prueba del prestigio que Harris logró con esta casa hace cincuenta años es el hecho de que cuando, en 1956, el American Institute of Architects, con motivo de su centenario, hizo pública una lista de las mejores realizaciones de sus cien años de existencia, la Havens House, hoy incomparablemente menos conocida que la Lovell Health House de Neutra o la Casa de la Cascada de Wrigth, aparecía entre estas dos obras formando parte de una relación de edificios que incluía tan sólo catorce viviendas unifamiliares. Y entre estas catorce casas escogidas para representar un siglo de arquitectura americana, la Havens estaba empatada, al mismo nivel que la casa Lovell, ocupando la novena posición.

Su promotor, John Weston Havens Jr., era un joven heredero de una antigua fortuna familiar que se remontaba a uno de los principales terratenientes y fundadores de ciudad de Berkeley. Dedicaba su vida a la administración de su patrimonio y a determinadas causas filantrópicas. Aunque existe una cierta controversia al respecto ya que era una persona reservada de la que apenas se conocen datos de su vida, salvo los relacionados con determinados acontecimientos de la sociedad de Berkeley, a la que pertenecía por su posición como mecenas de varias instituciones culturales y académicas. Sí está claro, sin embargo, que le interesaban la arquitectura y el arte modernos y que había hecho del coleccionismo una de sus principales ocupaciones. Buscando modelos en los que inspirarse para construir su propia casa, en 1938, un año antes de encargar esta vivienda, había viajado a Europa para visitar 


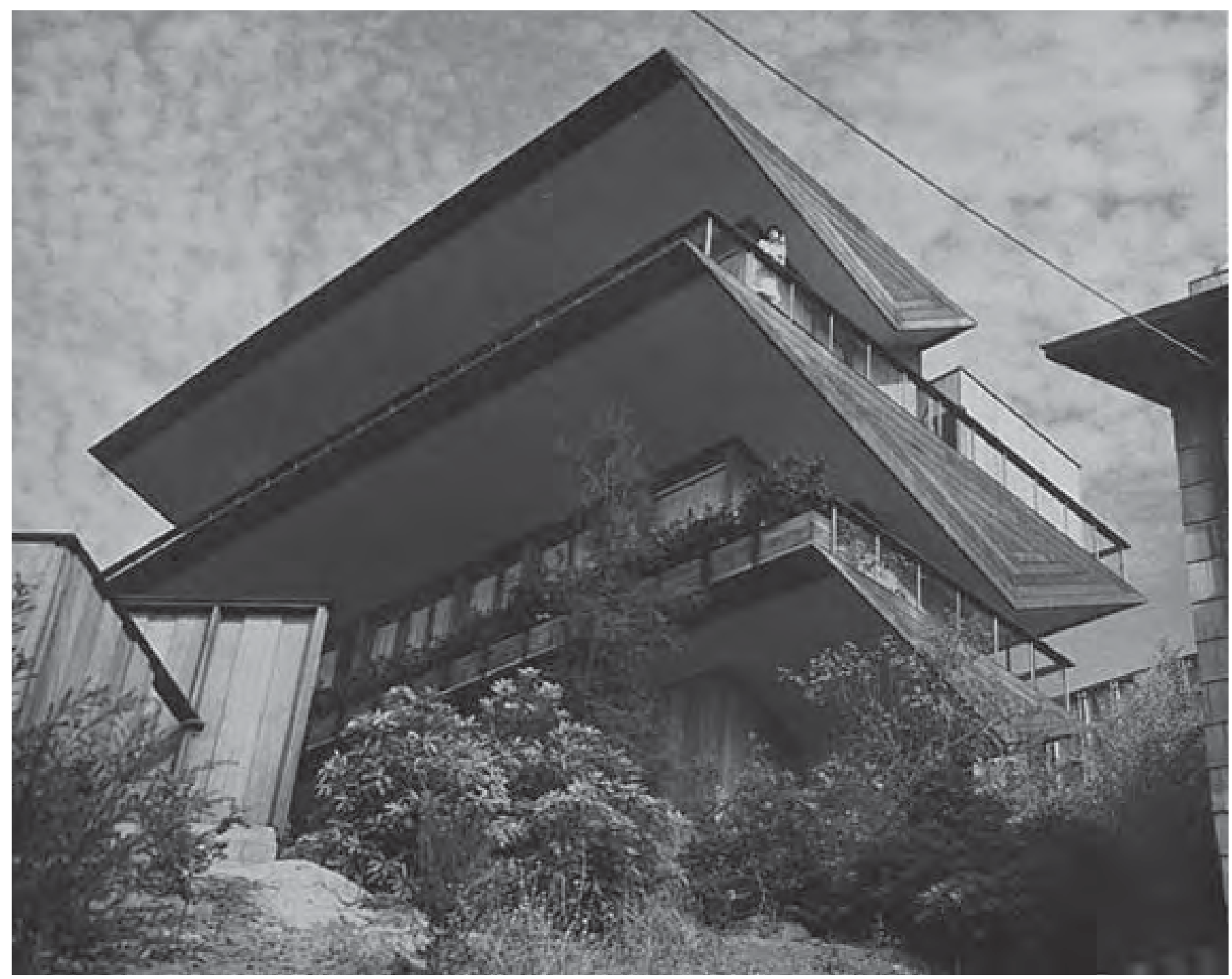

algunas de las últimas realizaciones de maestros del Movimiento Moderno como Le Corbusier y Alvar Aalto, con quien llegó a coincidir. A su regreso a los Estados Unidos adquirió esta propiedad en las colinas de Berkeley de la que debió atraerle sobre todo la impresionante panorámica de toda la Bahía y la ciudad de San Francisco.

John Weston Havens tenía pues los recursos, el lugar y la voluntad de construirse una casa magnífica. Sólo le faltaba el arquitecto que canalizara su visión de crear una obra de arte en la que poder vivir tranquilamente rodeado de algunas de sus piezas más apreciadas. Quería un arquitecto moderno, pero también a alguien con un punto de vista inconfundiblemente californiano $y$, en este sentido, Harwell Hamilton Harris era el hombre que buscaba. Como Harris, Havens consideraba que la arquitectura moderna californiana debía ser una expresión contemporánea pero también un eco de los condicionantes más genuinamente locales. En este sentido, precisamente en ese vecindario, las tradiciones arquitectónicas del Arts \& Crafts y del Bay Region Style cristalizadas en las viviendas construidas en Berkeley por autores como Maybeck, Howard, Mullgardt, Coxhead y William Wurster, ejercían un peso considerable en la formación del gusto de sus futuros habitantes.

Comenzando por el hecho de que Havens y Harris eran exactamente de la misma edad -habían nacido en 1903-, ambos tenían mucho en común, lo que favoreció no sólo su mutuo entendimiento sino que, habiéndose conocido con

Imagen desde la cota inferior de la parcela. Fotografía tomada por Man Ray en 1941

Página anterior arriba: Harris: Havens House, axonometría, lápiz de color. University of Texas Archives

Página anterior abajo: Acceso a la vivienda. Fotografía de Man Ray, 1941 


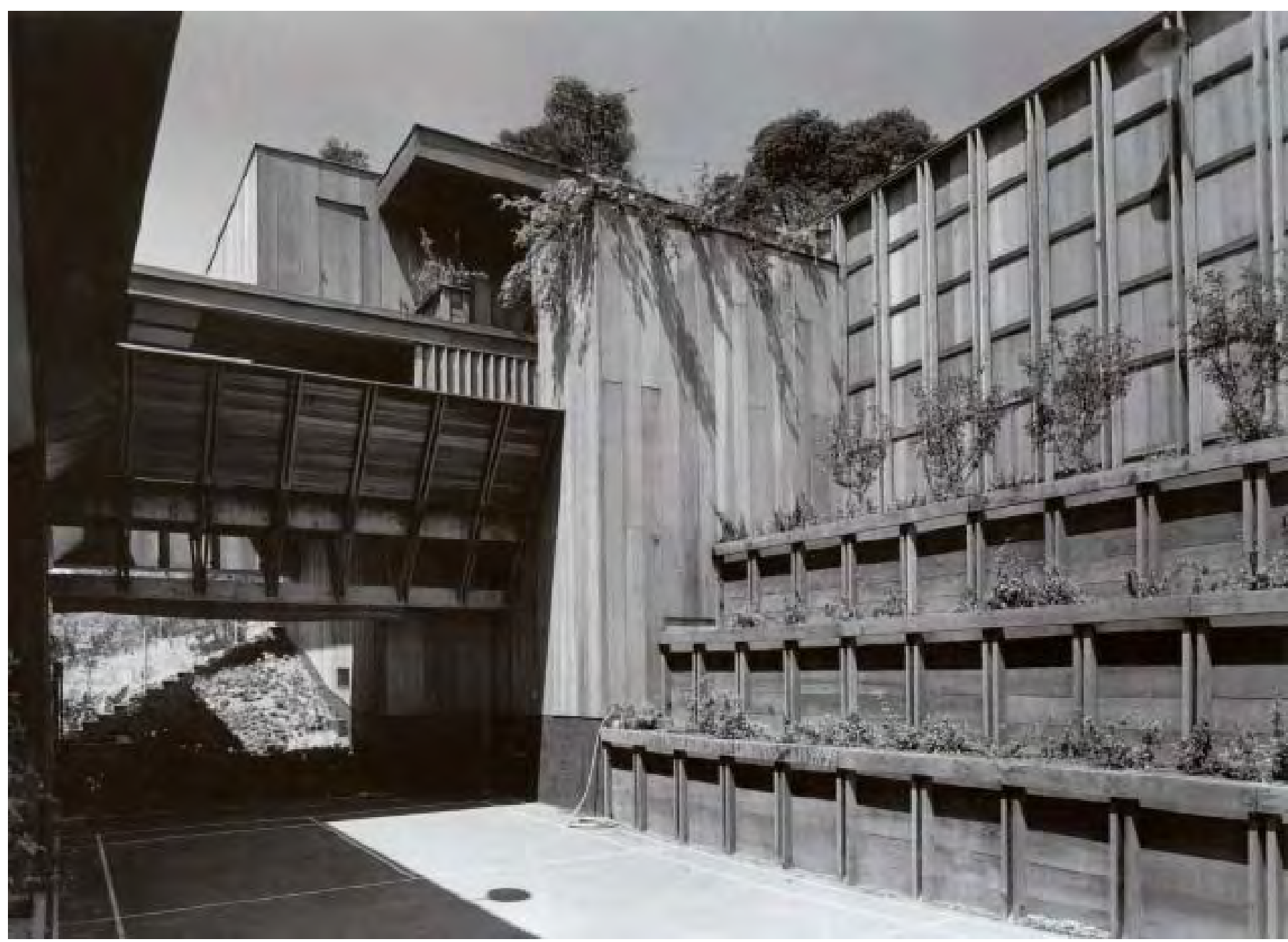

Imagen del patio con el puente de acceso al fondo y la pista de juegos en primer término. Fotografía de Roger Sturtevant, 1941

Página siguiente arriba: Planta de acceso (izqda), planta inferior (derecha) y sección por el patio de juegos. Fuente: Esther McCoy, The Second Generation

Página siguiente abajo: Dibujo explicativo del puente como elemento de acceso a la vivienda y dispositivo de control que impide las vistas hacia la planta de los dormitorios. Esquema publicado en Architectural Record, septiembre 1943 ocasión del encargo de la casa, cliente y arquitecto cimentaran una amistad que perduraría hasta el final de sus vidas. Aunque Havens en el norte y Harris en el sur del estado, ambos se habían educado en el seno de familias anglosajonas de pioneros. Su mentalidad se había forjado en la tradición del individualismo y del pragmatismo norteamericanos. Y ambos eran hombres cultos, amantes de naturaleza y de la vida sencilla que compartían una misma visión de California, cuyos valores están presentes en cada rincón de esta obra.

La originalidad de la misma se explica fácilmente en sección. El planteamiento de la casa es una consecuencia de su estrategia de implantación. La vivienda podría entenderse como dos volúmenes separados por un vaciado de la colina y conectados por un puente. En lo alto del promontorio, un volumen directamente vinculado a la calle alberga el garaje y, en una cota más baja, un pequeño apartamento para el servicio independiente de la casa. El segundo volumen, la vivienda propiamente dicha, surge como superposición de tres prismas triangulares bajo los cuales se organizan sus principales espacios. David Gebhard, en su guía de arquitectura del Área de la Bahía, definió la casa como "una pila de prismas invertidos a punto de abalanzarse sobre la asombrosa vista que contemplan ${ }^{183 "}$.

A la vivienda se accede desde la cota más elevada de la parcela, desde la carretera que bordea la colina. Una valla opaca de madera de redwood de más de dos metros de altura y parcialmente cubierta de hiedra dificulta la visión de la vivienda desde la calle, ocultando cualquier pista sobre el insólito paisaje construido que se esconde tras el muro. Éste gira para provocar la aparición del volumen cubierto y retrasado del garaje, apenas perceptible 

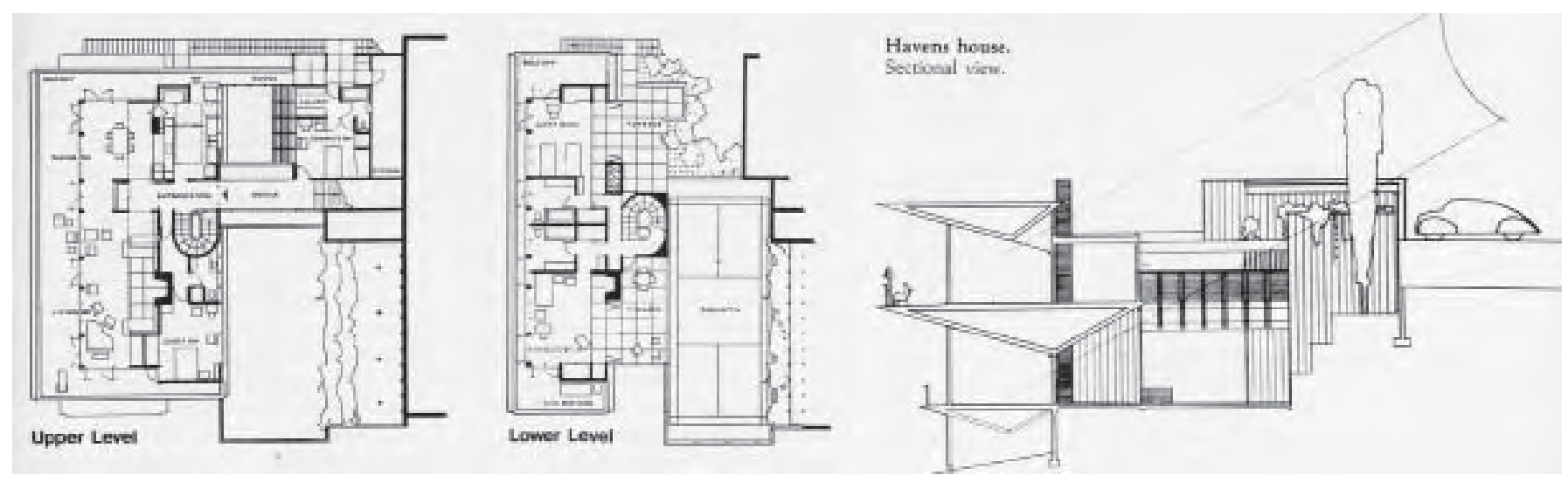

cuando está cerrado. Tampoco es fácil intuir la entrada principal a la vivienda, cuya puerta se sitúa precisamente en el hueco que queda entre ambos planos paralelos. Sólo se percibe -si se presta mucha atención- la estrecha escalera de servicio que desciende hasta la cocina y que ocupa el espacio de retranqueo con la vivienda colindante. A través de esta cesura, el peatón que ocasionalmente se aventurara a mirar hacia el interior de la propiedad únicamente tendría una fugaz visión de uno de los testeros, adivinando apenas cómo la casa desciende con el terreno.

Una vez traspasada la valla, una escalera obliga a bajar hasta el puente que conecta la colina con la planta principal de la vivienda. Este elemento, tratado como una especie de invernadero, desorienta al visitante para que se dirija directamente hacia la puerta de la vivienda y no se detenga a asomarse hacia los lados. Por si así fuera, está protegido por una estructura en forma de $V$ que, revestida de lamas de madera, impide la visión hacia abajo, hacia la terraza de la planta de dormitorios; más bien al contrario, sus aberturas, estratégicamente situadas, distraen la atención hacia el cielo.

Superado el umbral de la vivienda, un vestíbulo tratado como una pieza interpuesta, impide toda vista al interior de la vivienda mediante un armario ropero situado frente a la puerta y que, además de barrera visual, hace las veces de distribuidor hacia los espacios de cocina y dormitorios. Una escalera en espiral conduce al piso inferior donde el arquitecto ha dispuesto dos estancias de dormitorios y zonas de estar, únicamente accesibles al propietario de la vivienda y a sus invitados más íntimos. Estas piezas, prácticamente independientes una de la otra, abren directamente al patio hundido en la colina, cuya excavación se ha contenido por medio de un elaborado dispositivo de paños verticales construidos en madera y que integran amplias jardineras plantadas con flora autóctona. Este patio de juegos, donde a petición del cliente se acondicionó una pista de bádminton, independiza completamente el volumen de la vivienda de la falda de la montaña. Se crean así una serie de recintos cuyas transiciones entre la luz y la sombra redundan en la riqueza espacial de la vivienda.

Por su parte, la planta principal, la más pública de la casa, alberga la cocina, un dormitorio de invitados y un estar comedor cuyo espacio se abre directamente a una terraza mediante un paño de vidrio vertical continuo que asume toda la longitud de la vivienda alcanzando los 12 pies de altura. El efecto expansivo del estar se ve indudablemente reforzado cuando, al final de la promenade architecurale descrita, tras la compresión impuesta por el vestíbulo, la altura de este espacio crece rápidamente con la inclinación de la cubierta para integrar una impactante vista de Berkeley en primer término, la Bahía

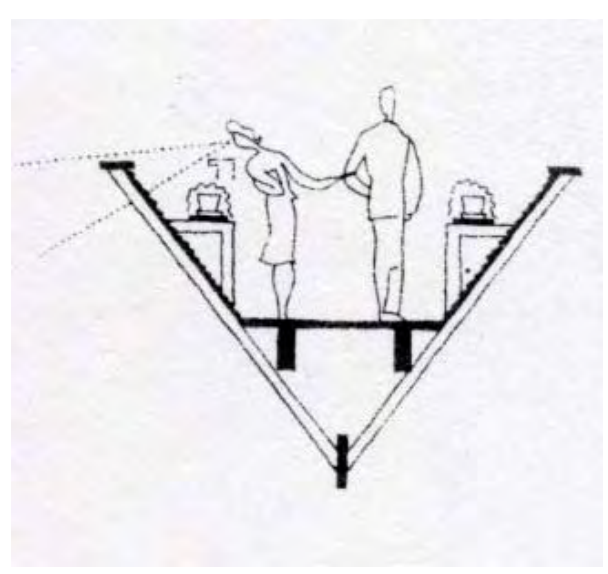




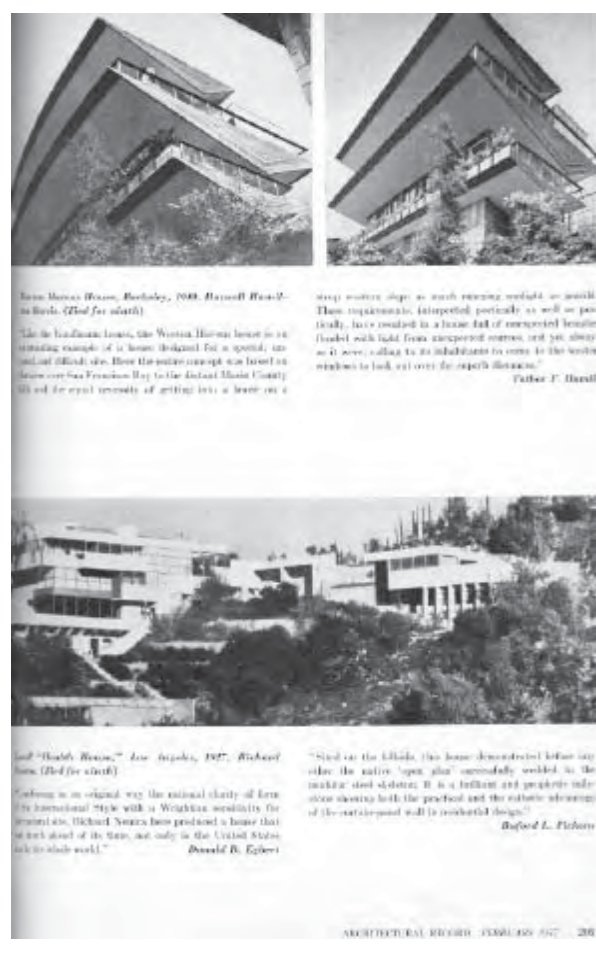

Publicación en Architectural Record (febrero 1957) de la relación de obras seleccionadas por el AIA. Talbot Hamlin escribe sobre la Havens House, publicada con imágenes de Man Ray (sup. izda) y Roger Sturtevant (sup. dcha). La casa de Harris comparte página con la Lovell House de Neutra

Página siguiente: Interior de la vivienda, estar. Fotografía Henry Bowles. Fuente Lisa Germany y la ciudad de San Francisco al fondo y, cerrando la perspectiva, el mítico puente Golden Gate, inaugurado tan sólo tres años antes que esta casa.

Para Harris, la casa no enmarcaba la panorámica, más bien se proyectaba hacia ella. Las vistas no constituyen un mero fondo que se perciba a través de determinados huecos. En lugar de ello forman parte de la casa, son una extensión de sus espacios, del cielo, del agua y de las colinas que rodean la vivienda.

Frente a la contundencia de la sección pudiera parecer que la planta es un sistema de generación de orden secundario. Esto no es del todo exacto, lo que ocurre es que la aparente facilidad con la que ha sido resuelta la hace pasar a un discreto segundo plano, como si la planta fuese una capa de orden subyacente destinada a potenciar las relaciones más orgánicas del proyecto. Debido a un riguroso diseño estructural y a la aplicación de una cuadrícula que Harris extiende a toda la propiedad, incluido el patio ajardinado, todo encaja cómodamente en su sitio. La planta surge a partir de una retícula basada en un módulo de 3 pies que ayuda a resolver sutilmente todos los encuentros entre las piezas y sus detalles más básicos.

La casa puede ser leída también a través del contraste entre las escalas de cada uno de los recintos, un recurso muy habitual en Harris, que aprovechaba las diferencias de cota generadas por la inclinación de las cubiertas para ajustar la altura de cada espacio de acuerdo con la función encomendada. El área de la entrada, la cocina, los baños y los dormitorios tienen una altura considerablemente más baja pero que crece con la inclinación de la cubierta hasta los 15 pies del extremo del voladizo.

En el encuentro de los triángulos de las cubiertas con el cerramiento del área del estar, la diferencia de altura de casi un metro entre la fachada a la Bahía y el paramento recayente al patio se absorbe con una banda continua de lucernarios dispuestos en el plano inclinado de la propia cubierta. El resto de esa superficie está resuelta con paneles de Celotex (composite de partículas de madera y cemento), cuyo acabado gris rosáceo muy claro, en conjunción con el resto de revestimientos de madera, contribuye a difundir una luz cálida.

La madera es el principal material de la casa. La estructura de la vivienda, incluidas las cerchas triangulares que dan forma a sus cubiertas invertidas es de madera de abeto Douglas mientras que los revestimientos de fachada, las carpinterías, los muros escalonados del patio, el puente y buena parte de los armarios, estanterías y paneles interiores son de madera de secuoya local o redwood, en sintonía con la tradición constructiva y material del Área de la Bahía. La secuoya se trata principalmente con un acabado natural, siendo el material responsable de la imagen de la vivienda, sobre todo al exterior, donde los explícitos testeros revelan la geometría triangular de la cubierta materializada en un despiece de tableros paralelos. Los suelos de roble y la escalera espiral realizada en abedul, complementan la paleta dominante del redwood. Un mural de suelo a techo ocupa toda la superficie de las dos puertas que separan la cocina del comedor y que, cerradas, dejan ver un mapa del mundo que deliberadamente no incluye fronteras políticas, sólo accidentes geográficos.

Las juntas de los paneles del revestimiento interior de las cubiertas a están resueltas con latón. Los herrajes de los armarios están ocultos y reducidos a su mínima expresión para que las puertas puedan abrirse completamente y 


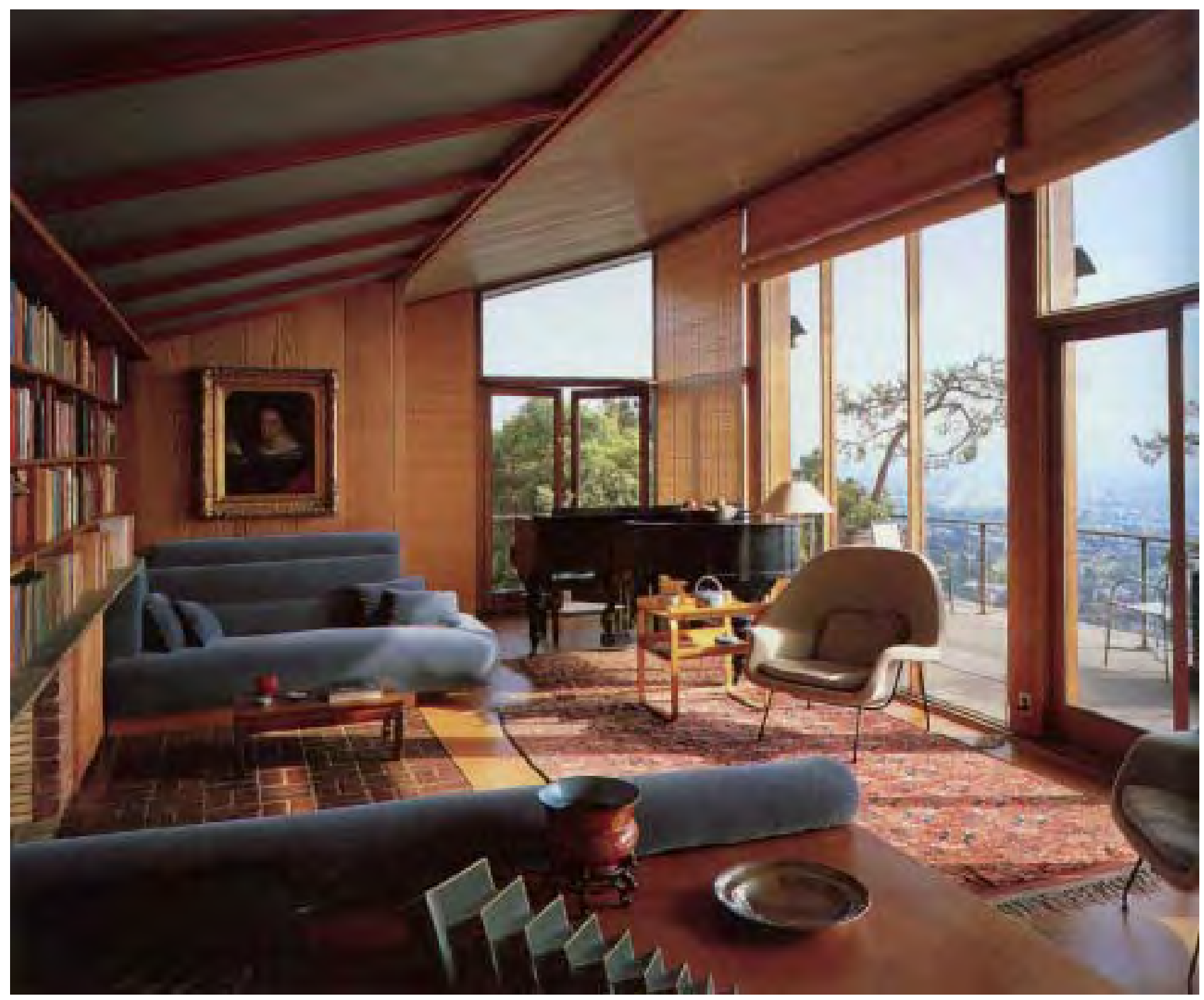

que, cuando permanezcan cerradas se confundan con el paneleado del paramento. Como en casi todos sus proyectos Harris recurre al diseño del mobiliario fijo, los sofás a ambos lados de la chimenea del estar están tapizados en un terciopelo azul cuyo tono fue escogido por el propio Harris. Al exterior, todos los remates metálicos, encuentros, tapajuntas y canalones vistos están realizados en cobre que, una vez oxidado en la actualidad, ha adquirido un tono verdoso muy natural que se confunde entre las sombras y brumas de la vegetación circundante ${ }^{184}$.

Havens pidió a Harris que tuviera en cuenta el almacenaje de su amplia colección de libros. En lugar de proyectar un recinto cerrado que hiciera las veces de biblioteca, el arquitecto decidió destinar toda la superficie posible de paramentos verticales a estanterías. De este modo, la pared continua del estar opuesta al plano de vidrio que se abre a las vistas de la Bahía aparece completamente forrada de libros a partir de la cota superior del hueco de la chimenea, proporcionando así una textura que contribuye a la confortable tactilidad que caracteriza el conjunto de la casa. Justo en frente, las pesadas cortinas colocadas para proteger la vivienda de la luz de oeste fueron poco después sustituidas por persianas de cañizo enrollables, muy económicas, que permiten oscurecer el oeste, mientas que los lucernarios enfrentados ayudan a compensar el deslumbramiento. 


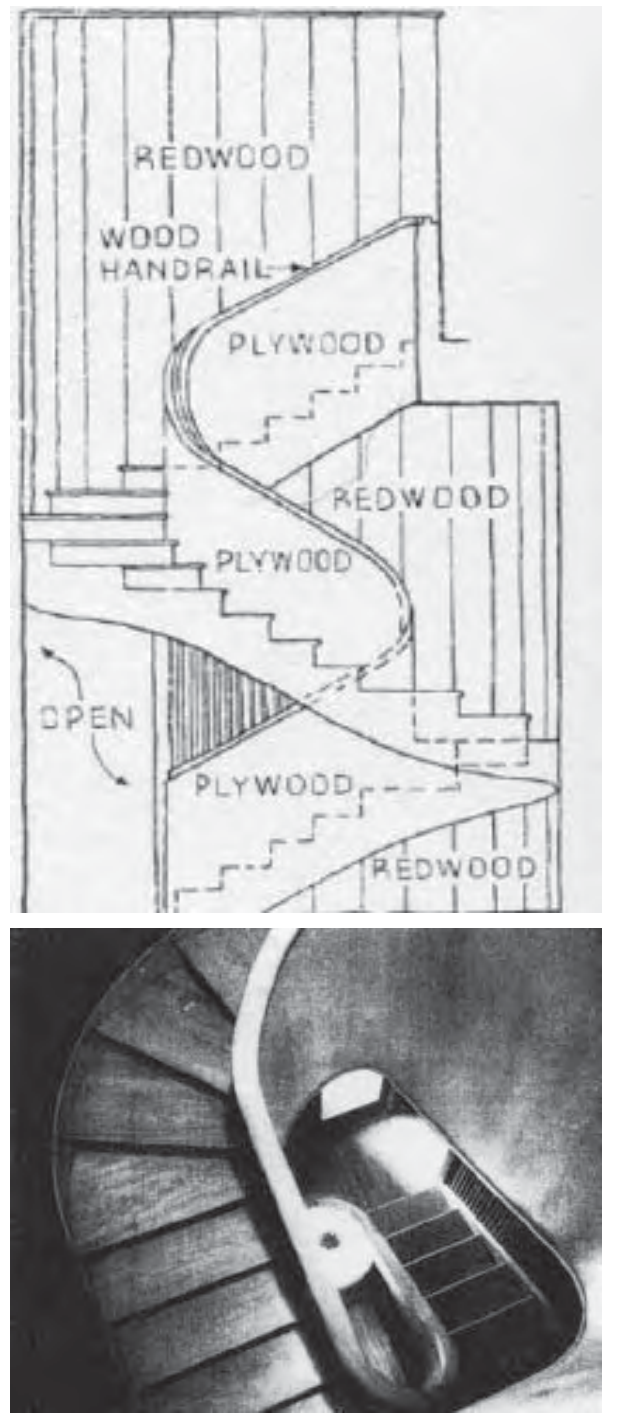

La chimenea, otro elemento fundamental en la casa, no sólo es un generador de orden, al ayudar a configurar el recinto del hogar, sino también la responsable del sistema de calefacción de la vivienda. Las cubiertas, huecas, albergan las instalaciones y funcionan como plénum, por lo que a través de ellas el calor de la chimenea es canalizado por toda la casa.

La vivienda conserva la mayor parte de las piezas de su mobiliario original. Muchas de ellas fueron compradas en Europa durante el viaje que realizó Weston Havens en 1938. Por ejemplo, las sillas y la mesa de comedor extensible son de Alvar Aalto. También hay piezas de Bernhard Mathesson y de otros diseñadores escandinavos que evidencian el gusto del arquitecto y de su cliente por la madera y las fibras naturales. Especialmente al atardecer, todos estos elementos, iluminados por el sol de poniente y recortados sobre el fondo color mandarina de la Bahía de San Francisco, envuelven al visitante en un ambiente doméstico de una excepcional calidez a la que nunca renunciaron los arquitectos modernos del Norte de California.

Quizás pueda pensarse que el recurso a la madera por parte de arquitectos californianos como Harris, afines a una sensibilidad regional, tendría que ver con un gusto sólo orientado hacia materiales tradicionales. Nada más lejos de la realidad. A lo largo de su trayectoria, Harris fue incorporando muchos de los materiales más novedosos del mercado, principalmente por razones económicas. Así, tratando de reducir costes de obra, Harris empleó tanto la madera para estructura y revestimientos como, cuando las circunstancias lo requerían, los enfoscados sobre paneles industriales e, incluso, otros materiales más innovadores. Un ejemplo en esta casa sería el uso de paneles de fibra de madera prensada que evocan la ligereza del panel shoji japonés.

Otro ejemplo de reutilización de materiales procedentes de otros ámbitos sería el llamativo y desenfadado recurso de Harris a la malla de simple torsión con el que resuelve los antepechos de esta vivienda (¡de 1940!) destinada a un coleccionista de arte procedente de la alta burguesía. Con una decisión poco convencional y difícilmente justificable por razones económicas, Harris se anticipó casi tres décadas a Frank Gehry cuando empleó este material asociado con los vallados industriales en su casa de Santa Mónica.

La portada del número de marzo de 1940 de California Arts \& Architecture, reproduciendo a toda página la inspirada sección transversal de la casa supuso para Harris un punto de inflexión en su carrera; un hito que, como se ha apuntado en el apartado anterior, también lo fue para John Entenza. Para Harris supuso el final de su estrecha relación con California Arts \& Architectu$r e$, la revista que había encumbrado su obra a la escena arquitectónica norteamericana. Al contrario, para Entenza -entonces en su segundo mes como editor adjunto- fue su primera portada y la gran oportunidad que estaba esperando para darse a conocer. La casa había sido previamente seleccionada por Jere Johnson para ser incluida en la revista en cuanto fuera posible. La casualidad quiso que ese momento llegase justo cuando Entenza asumió sus responsabilidades de editor sustituto durante la baja maternal de ésta. John Entenza vio inmediatamente el potencial publicitario de la obra y sintiendo la necesidad de dar un golpe de efecto que pusiera en valor su labor al frente de la revista, realizó una extraordinaria portada que no dejaba lugar a dudas sobre su talento como editor. Despegaba así una larga y prolíica carrera editorial que pasaba por asumir -aunque todavía no de un modo oficial- el control de esta revista en la que había estado evolucionando en sus tareas 


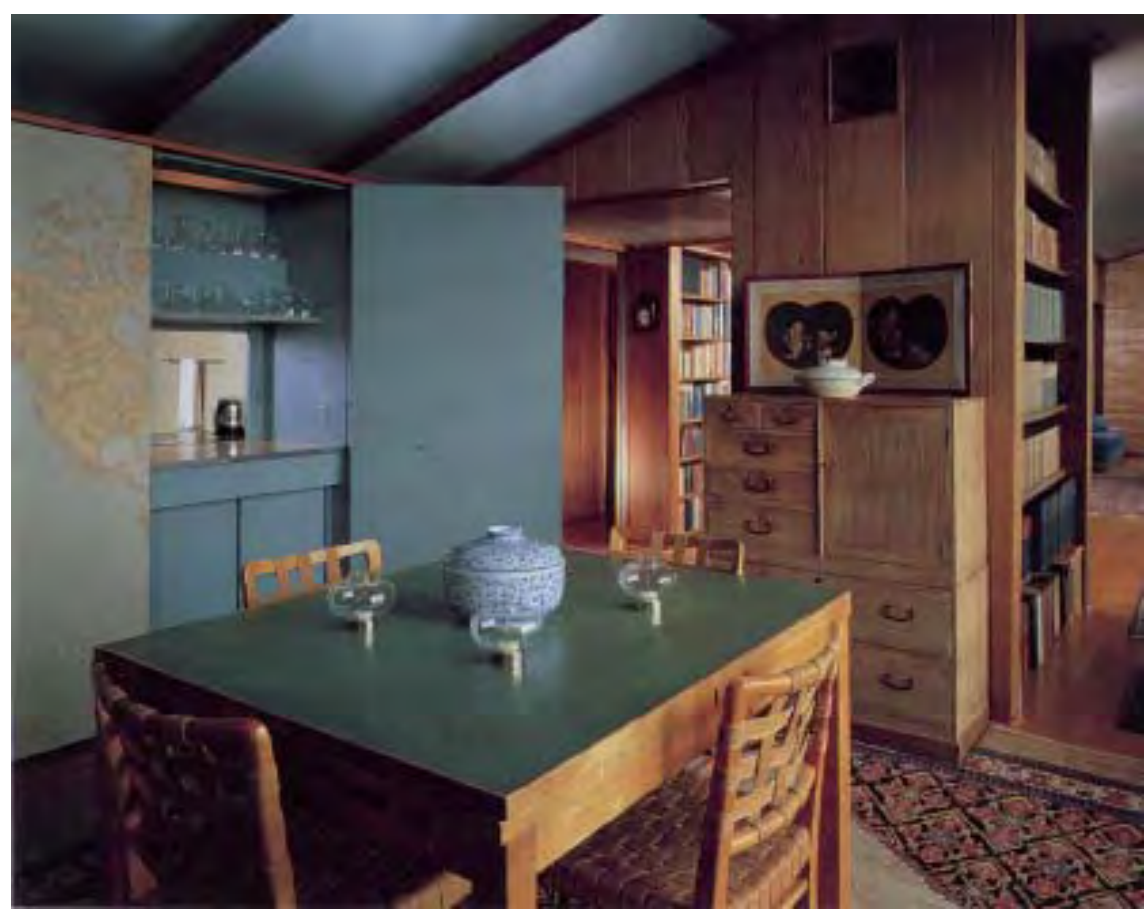

de escritor, comisario, director adjunto temporal y, finalmente, a partir de mayo de 1940, editor y propietario absoluto.

Harris, molesto por la forma en la que Entenza había obrado a espaldas de su amiga Johnson para quedarse con la publicación, decidió dejar de suministrar material a California Arts \& Architecture y, exceptuando una reseña ${ }^{185}$ sobre su restaurante en Chinatown inaugurado en 1940, nunca más volvió a aparecer en las páginas de la revista. Sin embargo, asegurada su posición ante los medios tras años de relación con los anteriores editores de California Arts \& Architecture (George Oyer, Mark Daniels y Jere Johnson) su fama no sólo no se vio disminuida sino que salió reforzada por la fascinación que su Havens House ejerció en los más importantes círculos arquitectónicos de la época que convirtieron al arquitecto, hasta finales de los años cincuenta, en una de las figuras de referencia del panorama editorial del país, apareciendo entre otros medios en: Architectural Forum, Architectural Record, AIA Journal, Magazine of Art, American Builder, Architectural Design, House Beautiful, House \& Home, Revista de Arquitectura, Nuestra Arquitectura, Byggmastaren, Studio, Pageant, Time, Life Magazine y muchas otras más ${ }^{186}$.

Aprovechando su celebridad y el interés que tras su publicación en California Arts \& Architecture había despertado la Havens House en muchos de los editores del país, Harris desplegó una de las campañas publicitarias más importantes de su carrera con esta casa que sintió como su mejor realización hasta el momento. Esta satisfacción personal, evidente incluso antes de haber iniciado la construcción de la obra, explicaría su doble empeño tanto por promocionar la casa Havens como en difundir este trabajo al margen de la revista recién adquirida por Entenza. Para ello recurrió a las estrategias publicitarias de Richard Neutra, maestro absoluto -tan solo comparable a Philip Johnson- en el dominio de los medios de comunicación y de difusión arquitectónica.

En 1941, poco después de haber completado este "tour-de-force de cubiertas invertidas" -tal como McCoy definiría la casa-, Harris comenzó a planificar diferentes sesiones de fotos para enviar a todos los editores de revistas a

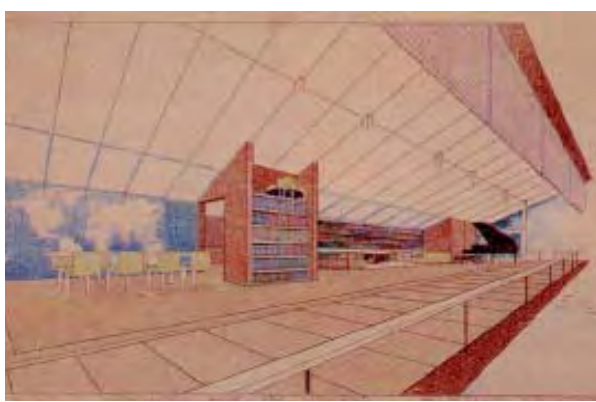

Izda: Vista del estar con los paneles de separación de la cocina semiabiertos. Fotografía de Henry Bowles. Fuente Lisa Germany

Dcha: Perspectiva de la terraza con el comedor en primer término. El mapamundi en los paneles que separan la cocina del comedor aparece completo. University of Texas Archives

Página anterior arriba: Dibujo explicativo de los difertentes tipos de madera de la escalera, Architectural Record, septiembre 1943 Página anerior abajo: Man Ray: Fotografía de la escalera, 1941 


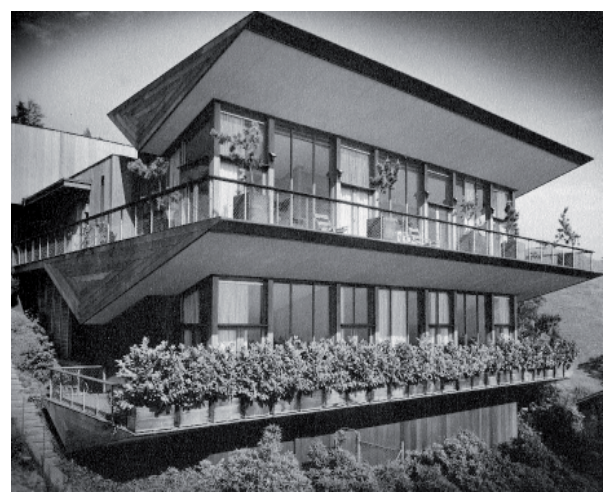

quienes había escrito informando sobre esta obra. Gordon Drake, que entonces trabajaba como asistente de Harris y viajaba a San Francisco para supervisar las obras de la casa, fue testigo de ese proceso de promoción, aprendiendo como antes Harris había hecho de Neutra, la importancia de la fotografía de arquitectura para comunicar los valores de una obra.

El celo con el que Harris atendía los más mínimos detalles de su trabajo se extendía también a la fotografía de sus obras. Como a Neutra, a Harris le obsesionaba estar presente en las sesiones fotográficas para controlar todos los aspectos relacionados con la narración de sus espacios. A pesar de no ser un arquitecto especialmente interesado en la autopromoción, sí que le preocupaba mucho el modo en que los medios de comunicación transmitían las principales ideas de su arquitectura y, por tanto, la calidad de su difusión editorial. Quizás el hecho de que muchos de sus espacios, auténticos santuarios de la vida doméstica, estuvieran animados por cualidades difícilmente reproducibles por medio de la fotografía, llevará a Harris a escoger cuidadosamente sus fotógrafos. El arquitecto buscaba en cada caso al profesional más capacitado para transmitir determinados valores muy concretos de sus obras, prefiriendo en general fotógrafos más proclives a interpretar la arquitectura de un modo personal y artístico antes que a otros que, dotados de una depurada técnica, pudiesen ofrecer fieles descripciones espaciales.

En este sentido, como la propia Esther McCoy afirmó en una ocasión, en el Sur de California, "el énfasis puesto en los detalles arquitectónicos, desarrolló una temprana y extraordinaria tradición de fotografía arquitectónica ${ }^{187 " . ~ L a ~}$ relación de Harris con los fotógrafos fue siempre muy estrecha y, a pesar de que en ocasiones discrepara con ellos o no quedara satisfecho de su trabajo, el grado de implicación y complicidad con algunos de ellos, especialmente con Fred Dapprich, llegó a ser comparable al del célebre tándem que Julius Shulman y Richard Neutra habían iniciado también por aquellos años.

Dapprich había fotografiado las primeras obras del arquitecto, entre ellas la Entenza House en Santa Mónica y la propia vivienda de Harris en Fellowship Park de 1935, donde se ofreció a trabajar gratis para promocionar la obra de su amigo. Cuando, poco después, Architectural Forum invitó a Harris a enviarle imágenes de su producción más reciente, ambos volvieron a plani-

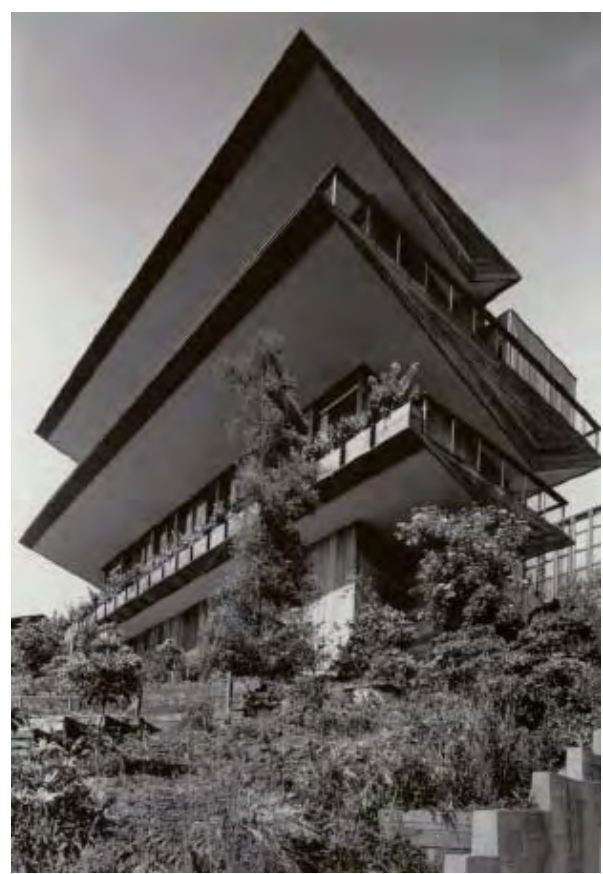
ficar una nueva sesión de fotografías manipulando al máximo los encuadres en su minúsculo espacio para recrear una sensación de amplitud que la casa producía in situ pero que la fotografía apenas transmitía. Para ello descolgaron puertas, retiraron muebles y Dapprich enfatizó el patrón de los cuadros de la alfombra de esparto tanto para forzar la perspectiva como para poner en valor la estrategia modular del proyecto.

Por su parte, apenas si existió un trato profesional entre el arquitecto y Julius Shulman, quien sólo fotografió dos de las obras de Harris, la Clarence H. Wyle House en Ojai, terminada en 1948, y la Mulvihill House en Sierra Madre, también de ese mismo año 1948. Éste es un tema sobre el que se ha discutido con personas cercanas al entorno de Julius Shulman, incluido el propio fotógrafo. No deja de ser llamativo ya que, tanto Shulman como Harris, casi de la misma edad, se habían formado ambos junto a Richard Neutra, aprendiendo de su talento para la promoción publicitaria por medio de la fotografía y las revistas de arquitectura. Aunque más tarde llegaría a apreciar enormemente el trabajo de Harris, Shulman confesaba ${ }^{188}$ que, en un primer momento, no entendió bien la obra de este arquitecto, probablemente porque su primer contacto con él fue en una etapa muy 


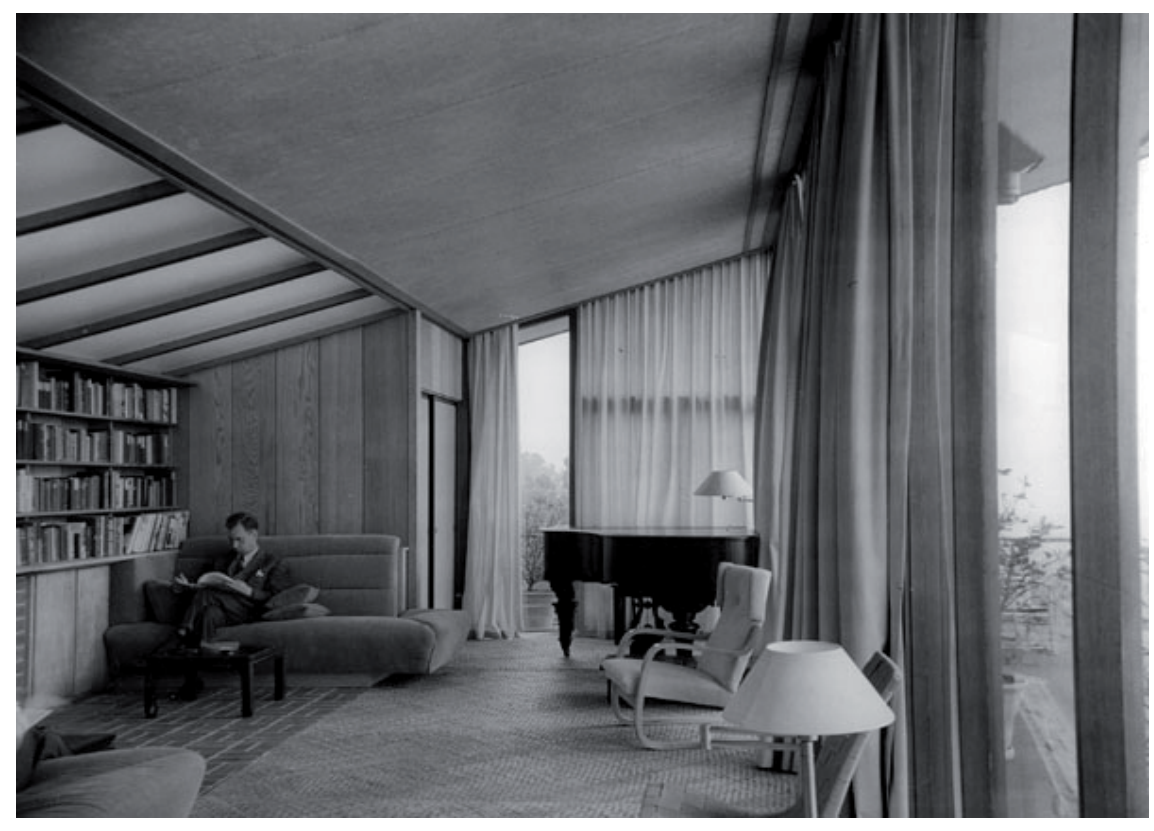

temprana de su carrera, mientras depuraba su propia técnica de la fotografía de arquitectura de la mano de Richard Neutra. En este sentido, su exposición a la modernidad internacional de Neutra le llevó a considerar a Harris como un autor poco moderno, como reconoció el propio Shulman ${ }^{189}$. Por su parte, Ted Wells también sostiene ${ }^{190}$ la sospecha de que, al principio, Harris no debió tampoco admirar mucho el trabajo de Shulman por considerarlo en aquella época todavía demasiado literal. La obra californiana de Harris abarca los años 30 y 40 mientras que la etapa de madurez de Shulman, con brillantes excepciones como la de Gordon Drake, tuvo lugar alrededor de los años 50, aunque este periodo podría ampliarse un poco hacia los últimos 40 y primeros 50. Frente a esa literalidad, Harris habría preferido la fotografía de artistas más interpretativos.

En el caso concreto de la casa Havens Harris ensayó diferentes aproximaciones a su obra, tantas como fotógrafos distintos contrató para que aportaran su mirada más personal. Respectivamente, Harris intentó ver la casa a través de la fotografía de un especialista en arquitectura moderna, de un artista y de un fotógrafo dedicado a retratar estilos de vida y tendencias de mercado. En efecto, probó primero con el fotógrafo local Roger Sturtevant, cuyo trabajo no le acabó de satisfacer por su impecable exactitud -al parecer, la fotografía de la casa desde abajo no cumplió con las expectativas de Harris, ya que al arquitecto no le gustó el hecho de que se hubieran corregido las fugas verticales, alterando de este modo las proporciones de la obra, ni tampoco que la vivienda fuera tomada a contraluz. Después llegó Man Ray y, finalmente, Maynard Parker, obteniendo con ellos diferentes resultados que el arquitecto fue enviando a sus editores en función de lo que éstos anduvieran buscando.

Las imágenes que más contribuyeron a la celebridad de Harwell Hamilton Harris $y$, desde luego, una medida del prestigio que, por aquella época, había alcanzado el arquitecto fueron fotografías tomadas por Man Ray entre 1941 y 1942. El artista fotografió tres de las viviendas más recientes de Harris, incluyendo la casa Havens en Berkeley. Las otras dos eran la Casa Pumphrey en Santa Mónica y la Birtcher House en Los Ángeles. Esta serie fotografías constituye la única incursión de Man Ray en el ámbito de la fotografía de arquitectura.
John Weston Havens fotografiado en su salón por Maynard Parker, 1942

Página anterior arriba y abajo: Havens House, fotografías del exterior de la casa tomadas por Roger Sturtevant en 1941 


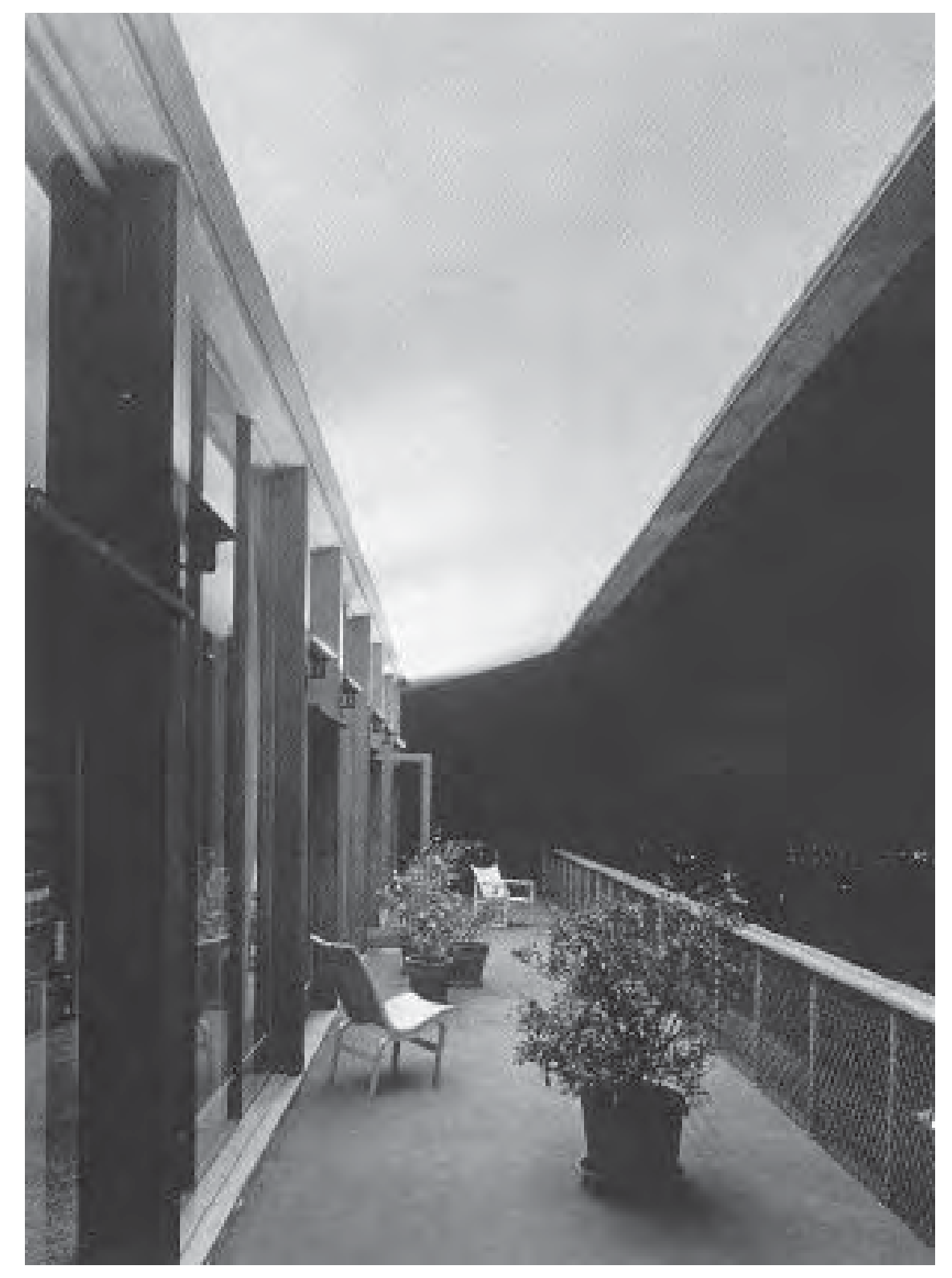

Havens House. Fotografía nocturna de la terraza realizada por Roger Sturtevant, 1941

Página siguiente izda: Harris: Birtcher House, Los Ángeles. Fotografía tomada por Man Ray en 1942

Página siguiente dcha: Havens House. Fotografía de la terraza, Man Ray, 1941
Man Ray, que permanecería en California hasta su regreso definitivo a Francia en 1951, había abandonado París huyendo de los nazis. En 1941 se encontraba en San Francisco, donde había llegado conduciendo desde Los Ángeles para asistir a la apertura de una exposición que ese mismo año le dedicaba el M. H. DeYoung Memorial Museum. Coincidió justamente con Harris cuando éste andaba buscando con cierta urgencia un nuevo fotógrafo pues sentía que ninguna de las fotografías realizadas anteriormente por Roger Sturtevant de la casa había logrado captar su esencia. Aunque conocía bien la producción de las vanguardias europeas, Harris quedó fascinado por la extraordinaria personalidad de este artista. En el escenario cultural de una América prebélica, con toda la tensión de un país que se preparaba para la guerra, la audacia creativa de Man Ray no era algo que se viera todos los días. El arquitecto quería una nueva mirada sobre su trabajo y en seguida debió intuir que, en aquel momento, quizás sólo el surrealista Man Ray podría proporcionarle esa frescura que tanto deseaba.

Cuando Man Ray y él se conocieron, el arquitecto le preguntó si alguna vez había fotografiado una casa, al contestarle que no, Harris le replicó: "entonces eres justo el hombre que necesito" ${ }^{191}$ y el fotógrafo, que andaba justo de fondos, aceptó el encargo. 


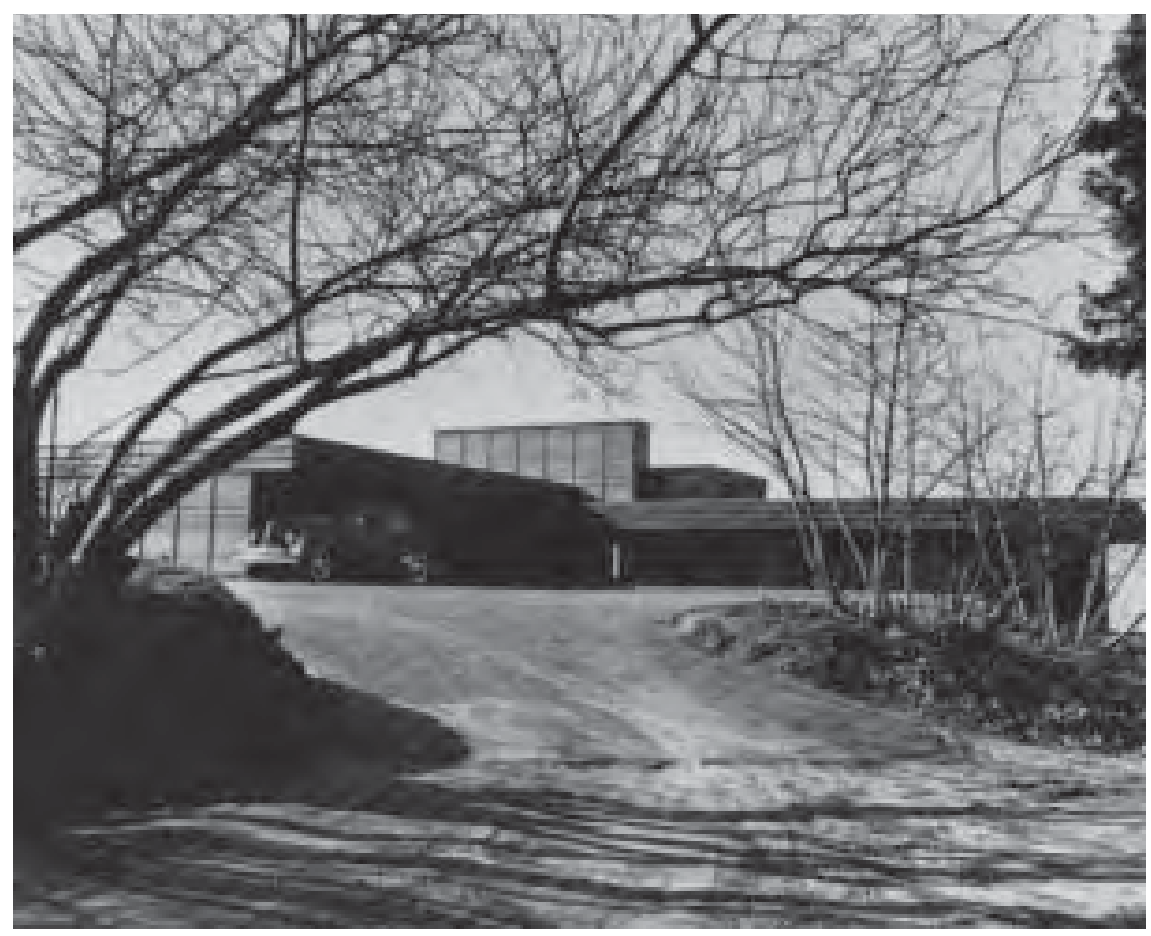

Si había un fotógrafo absolutamente libre de prejuicios y que se reinventara continuamente ése era Man Ray. Como él mismo decía, sólo la búsqueda del placer y de la libertad atravesaban su obra, que se movió incesantemente entre el dibujo, la pintura, la invención de objetos, las rayografías, la solarización de la fotografía, la experimentación con técnicas mixtas, el cine o la poesía. Como artista Dadá -o, mejor, como anti-artista- Man Ray era un provocador que atacaba radicalmente los buenos modales de la burguesía, por lo que no deja de sorprender que un personaje tan subversivo como él se entendiera tan bien con Harwell Hamilton Harris, uno de los arquitectos más elegantes ${ }^{192}$ de California, admirado, sobre todo, por sus impecables maneras ${ }^{193}$.

Las fotografías de la Havens House eran completamente diferentes de cualquier otra cosa que Harris hubiera visto anteriormente. La penetrante mirada artística de Man Ray supo descubrir inmediatamente, sin ningún tipo de indicación por parte del arquitecto, aquellos elementos de la vivienda que Harris quería enfatizar ${ }^{194}$, transmitiendo una sensación de ligereza, de ingravidez, y capturando por primera vez toda la excitación que la casa inspiraba al ser contemplada desde abajo.

Aunque el fotógrafo realizó varias instantáneas, tanto del exterior como de los interiores de la vivienda que fueron publicadas en diversas revistas de arquitectura de la época, fue la fotografía tomada desde la cota más baja del jardín la que habría de convertirse en la imagen icónica de la casa. Man Ray hizo varias pruebas desde abajo y pronto debió darse cuenta de que las fotografías resultaban mucho más sugerentes cuando la vivienda no aparecía completa, sino que se cortaba buena parte de la parcela. En efecto, la imagen que mejor plasmó la dramática respuesta de la casa al lugar fue aquella en la que fotógrafo prescindió a propósito de toda referencia al plano del suelo, omitiéndose incluso el arranque de la estructura. Sirviéndose de la elipsis, Man Ray fue capaz de transmitir toda la tensión del edificio en su encuentro con el terreno, precisamente, al obligar al espectador a imaginarse cómo debía ser de pronunciada la pendiente de la colina para entender el sentido de una fotografía deliberadamente incompleta.

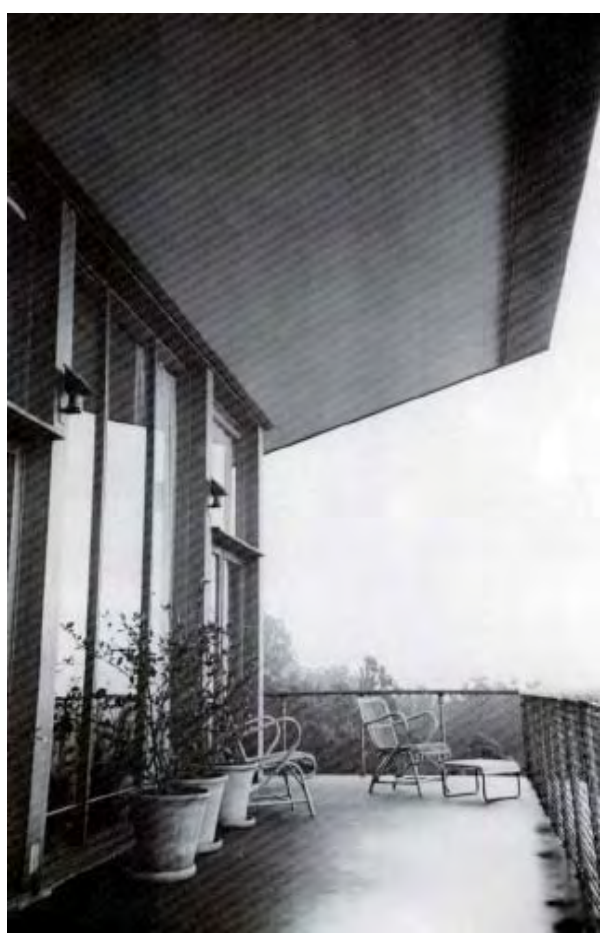




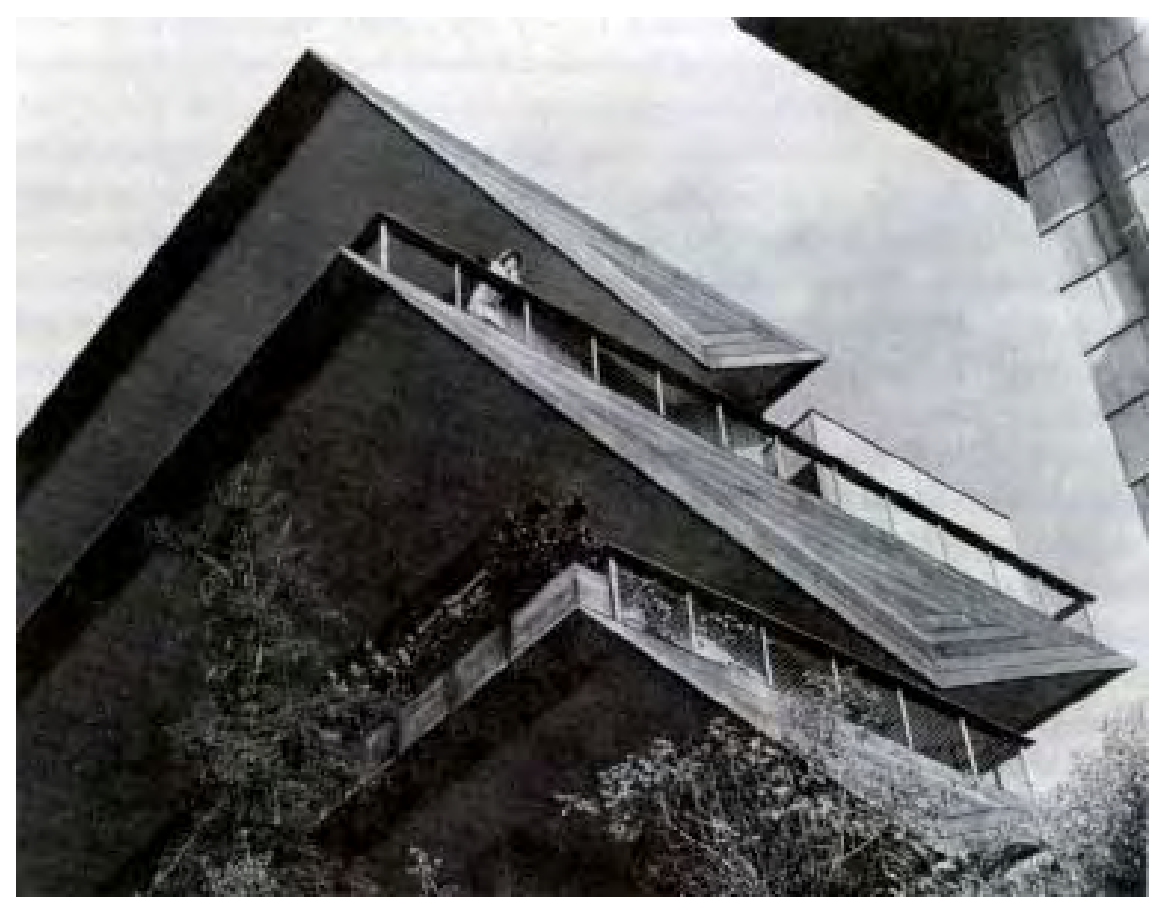

Imagen desde la cota inferior de la parcela. Fotografía tomada por Man Ray en 1941

Página siguiente: Interior de la vivienda, la mujer sentada es Juliet Browner. Fotografía de Man Ray, 1941
La supresión del plano del suelo ponía también en valor las cubiertas de la vivienda de las que, hábilmente, el fotógrafo enfatizó sus testeros revestidos de listones de madera concéntricos como el elemento más reconocible de su geometría. El triángulo inferior, semioculto por las copas de los árboles recién plantados, tampoco aparece completo, justamente para evitar contar cómo se apoya en el suelo e introducir así una componente de misterio.

La composición está dominada por una diagonal que cruza la imagen desde la esquina superior izquierda, hasta la esquina inferior derecha, dividiendo la imagen en dos zonas, una oscura y otra más clara. En sombra quedan los planos de los techos inclinados, por oposición, los testeros triangulares aparecen resaltados como las superficies iluminadas cuya dimensión es enfatizada además por la verticalidad de la perspectiva. Man Ray introduce un elemento externo a la Havens House, se trata de parte de la vivienda vecina. Este elemento, ajeno a la composición, pudo introducirse por dos razones, una obligada por la falta de espacio para la colocación de la cámara y otra de carácter estético, para compensar el peso visual y la ausencia de motivos en la parte superior derecha de la fotografía. El punto de vista se ha forzado para que la arista del sofito resulte paralela a las líneas de fuga de los planos superiores de las cubiertas. De este modo, por contraste, al deformar la visión de la vivienda contigua, que parece bascular hacia el espectador -y que también habría que imaginarse-, se consigue que la percepción de la casa Havens, a pesar de lo difícil del punto de vista escogido, resulte lo más natural posible.

Podría decirse que no se trata de fotografía estrictamente arquitectónica. Más bien es una fotografía artística. Más allá de la descripción de los volúmenes arquitectónicos, Man Ray manipula el punto de vista, enfatiza las líneas responsables de la composición y utiliza la presencia del elemento humano como un recurso emocional para el fotógrafo.

La diminuta figura femenina apoyada en el parapeto de la terraza superior es Juliet Browner, musa, modelo y futura esposa de Man Ray-se casarían en 1946- a quien el artista había conocido pocas semanas antes de abandonar 
Francia. Su aparición no es casual y sirve al fotógrafo para dar a la vivienda una escala mayor de la que en realidad tiene. $Y$ lo mismo ocurre con la casa vecina, un bungalow tradicional, como tantos en la Bahía, revestido de tablillas claveteadas de madera (shingles) y cuyo contraste con la casa Havens pone en valor la innovación de la plástica de Harris aun utilizando el mismo material.

En realidad, es la pequeña porción de esta casa vecina la que dota de un contexto a la fotografía, confirma su encuadre y permite al espectador introducirse en ella para tener el mismo punto de vista del fotógrafo. Con toda intención, Man Ray ha escogido un forzado plano contrapicado que obliga al espectador adoptar una posición de inferioridad respecto a la vivienda, haciéndole parte de su misterio, obligándole a imaginarse qué sentiría estando bajo sus cubiertas, hasta tal punto que, como escribió Lisa Germany, "tan arriesgada y dramática era la imagen que capturó, tan próxima e imponente, que la Casa Havens parecía planear sobre la cabeza del espectador. He ahí un fotógrafo capaz de causar una contractura en el cuello, incluso, hasta al observador más casual ${ }^{195}$ ".

Como buen surrealista a Man Ray le atraía lo irracional; quería que sus obras alimentaran el enigma, que dejaran fluir la belleza, que despertaran la imaginación del público. Le interesaba, sobre todo, el impacto causado por la imagen, y no tanto suscitar preguntas aburridas acerca de las intenciones del artista o de su técnica, por depurada que ésta fuera ${ }^{196}$.

Todo en esta imagen está perfectamente controlado, como el uso de la luz, fundamental para transmitir el carácter de la casa, esa cualidad atmosférica a la que se refería Germany. Man Ray tomó la fotografía en una hora cercana al medio día, cuando el sol iluminaba completamente los testeros de madera de la fachada sur y la sombra creada bajo los planos inclinados de las cubiertas hacía parecer que flotaban en el aire. De nuevo se trataba de provocar sensaciones, de crear una atmósfera de ingravidez, como si esos prismas apilados fueran a comportarse como un fuelle, desplegándose hacia el cielo. No en vano Harris solía decir de la vivienda que no era una casa de tierra (an earth house) sino, más bien, una casa de aire (a sky house) y su mujer, Jean Murray Bangs solía referirse a ella con un juego de palabras de difícil traducción al castellano: Havens Above. Hoy, sin embargo, esa visión de la obra que proponía la fotografía de Man Ray es imposible porque la vegetación ha crecido tanto que ha terminado ocultándola por completo.

A pesar de la buena acogida que tuvo la obra, la guerra ralentizó el flujo de información y la casa no sería publicada tan rápido como hubiera sido de esperar a juzgar por el impacto que el proyecto había causado en revistas como Architectural Forum o Pencil Points, cuyos editores quedaron fascinados ante la sugerente sección de la portada publicada por Entenza casi un año antes de finalizarse las obras. Por otra parte, con Harris en Nueva York desde 1943 implicado en la docencia y en proyectos experimentales vinculados con las aplicaciones de la futura reconversión de la industria bélica en industria de la domesticidad tal como exigían los tiempos, las revistas de arquitectura aparcaron durante esos años su prioridad de publicar residencias particulares. No obstante, aunque la casa no apareció nuevamente hasta septiembre de 1943 en Architectural Forum, la popularidad de Harris gozaba entonces de sus niveles más altos, como demuestran las exposiciones colectivas en las que participó en aquellos años, destacando Five California Houses (1942) y Built in USA, 1932-1944 (1944), ambas en el Museo de Arte Moderno de Nue-

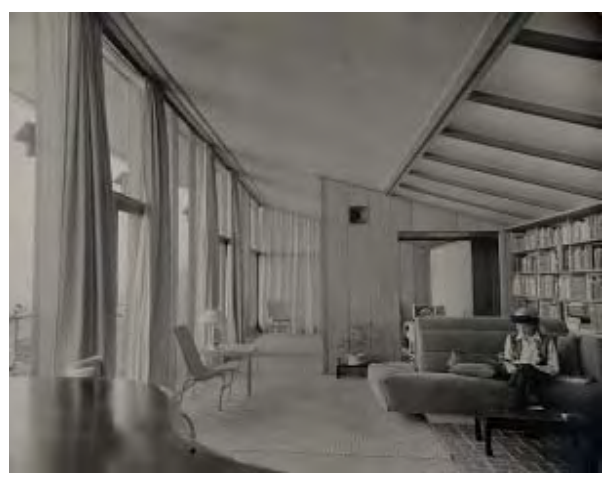


Domestic Architecture of the San Francisco Bay Region: Portada del catálogo de la exposición organizada por el Museo de Arte Moderno de San Francisco en 1949. La muestra fue una consecuencia directa de los debates del MoMA de 1948 celebrados en respuesta al artículo de Mumford publicado un año antes en The New Yorker. La exposición se centró en las reinterpretaciones modernas del Bay Region Style descrito por Mumford. Curiosamente, a pesar de que Jean Harris fue colaboradora en esta exposición, la casa Havens de su marido no aparecía en ella. ¿Habría sido Harris considerado un arquitecto surcaliforniano y por ello exluido de esta exposición sobre la arquitectura del norte? Si así fue, ¿suponía esto el reconocimiento de las particularidades de dos tradiciones arquitectónicas diferenciadas?

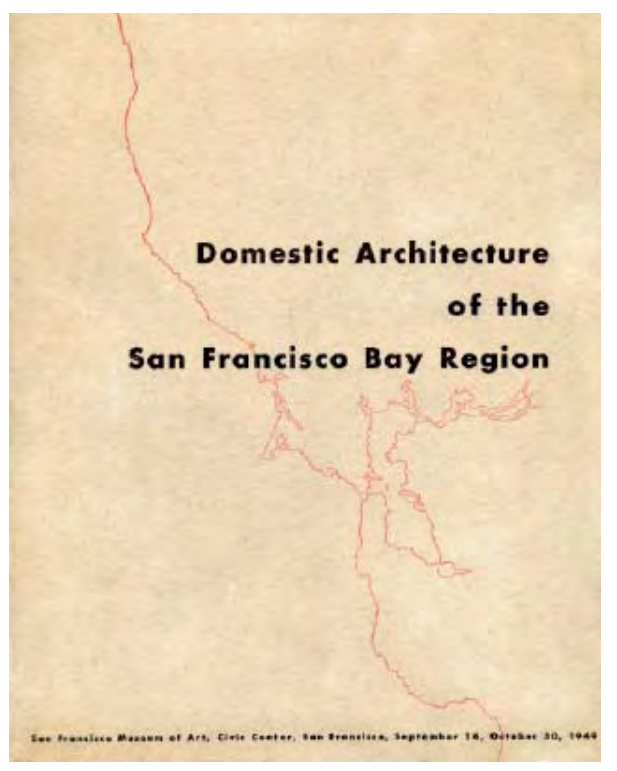

va York, o su inclusión en el especial "New California Architecture", publicado en abril de 1942 por la revista Time.

Del mismo modo, las revistas populares, aunque algo tardíamente, se hicieron eco de la casa Havens, entre ellas House \& Garden en enero de 1944 y House Beautiful en agosto 1944 . Y, como puede comprobarse en el capítulo de bibliografía específica sobre Harris de este trabajo, también fue muy bien acogida en publicaciones latinoamericanas como Revista de Arquitectura de Buenos Aires (agosto 1944), con la que Harris había entablado contactos tras el paso de Neutra por la ciudad. Si bien, las precarias circunstancias del panorama editorial europeo durante la guerra, con revistas como L'Architecture d'Aujord'hui cerradas en aquellos años dificultaron su recepción en Europa, que prácticamente se perdió esta obra.

Por otra parte, apenas se tiene información del tipo de vida que se desarrollaba en el interior de la casa. Tan sólo se sabe que Havens solía organizar algunas fiestas y reuniones muy privadas para un reducidísimo núcleo de amigos. Fue tal su preocupación por salvaguardar su intimidad que, seguramente, el hecho de haber limitado considerablemente el acceso y las fotografías de los espacios de la vivienda una vez ocupada ésta, tuvo que incidir en su paulatino olvido tras el reconocimiento inicial que la obra había alcanzado con su difusión en medios internacionales.

El planteamiento esencial de la misma, materializado en el juego de cubiertas invertidas que funden el espacio interior de la vivienda con la espectacular vista de la Bahía, surge con la condición de ver sin ser visto. Mientras sus ocupantes pueden disfrutar de la vista lejana de la ciudad, la casa Havens está completamente blindada a las miradas del exterior. Todos los dispositivos de la vivienda están destinados a impedir cualquier mínimo atisbo de su interior. Si Harris siempre se había caracterizado por su celo en salvaguardar la intimidad de sus clientes, en el caso de esta vivienda el celo se convierte en obsesión, produciéndose una total escisión entre lo público y lo privado. Por ejemplo, es llamativa la importancia concedida a la secuencia de espacios de transición entre el exterior y el interior de la vivienda para una casa relativamente pequeña: la puerta de la calle, el descenso por una escalera, el acceso a travesando un puente, el hall de entrada y el armario frente a la misma ocultando la vista de una sala de modestas dimensiones.

Probablemente, esta obsesión por mantener la privacidad de la vivienda tiene que ver con el hecho de que su propietario, John Weston Havens fuera homosexual. Havens permaneció soltero durante toda su vida y en el vecindario nadie conocía apenas detalles de su vida, excepto su desahogada posición económica y su pasión por el arte, los viajes, la gastronomía, y el mobiliario de diseño. Al menos, esto es lo que asegura Anthony Bruce, Director de la Berkeley Architectural Heritage Association y vecino puerta con puerta de Havens durante casi más de 50 años y para quien, Havens, una persona extraordinariamente reservada y cordial, siempre fue todo un misterio. En efecto, desde las fotografías encargadas por Harris, el interior de la casa apenas volvió a ser expuesto públicamente hasta la muerte de su propietario.

La casa daba forma al tipo de vida deseado por Havens: su biblioteca, su comedor para cocinar y cenar con sus amigos, su cancha de juegos oculta a las miradas del exterior, grandes terrazas privadas para tomar el sol, en suma, su reducto de libertad en una vivienda con la que debía negociar constantemente su posición en una sociedad donde cuestiones como el género, la 


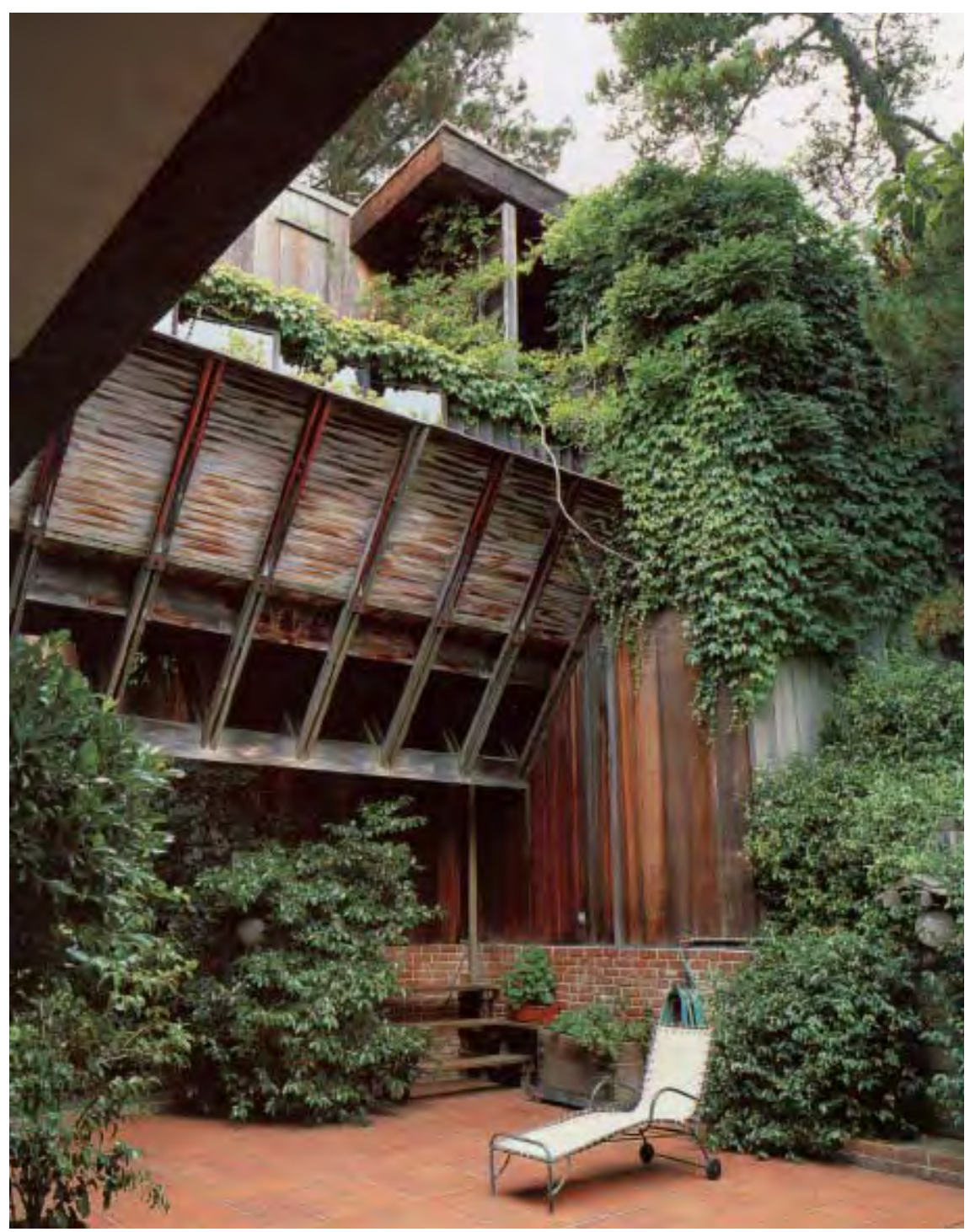

orientación sexual, la raza o la edad eran roles inamovibles ${ }^{197}$ y donde determinados comportamientos estaban forzados a la invisibilidad. En este sentido, si se compara esta casa con otras obras de Harris destinadas personas solteras, lo cierto es que, todas las estancias de esta vivienda, y en especial los dormitorios de la planta baja, se ocultan con absoluta paranoia.

En definitiva, puede afirmarse que tras el énfasis publicitario de los primeros años, la casa fue poco a poco relegada a un discreto segundo plano. Hasta el final de su vida y durante casi sesenta años, John Weston Havens Jr. habitó en esta casa, esforzándose por conservarla prácticamente inalterada mientras asistía a la disolución de su fama arquitectónica ${ }^{198}$. Por deseo de su propietario, que falleció en octubre de 2001 a los 97 años de edad, la vivienda fue donada a la Universidad de California, Berkeley. En 2005, tras un complicado proceso legal, la casa pasó a formar parte de las instalaciones del College of Environmental Design como residencia de profesores invitados, permitiéndose desde entonces algunas visitas muy controladas. Devuelta parcialmente a su esplendor original, la vivienda recupera lentamente su reconocimiento histórico $y$, mientras, algunas de sus incógnitas van siendo poco a poco desveladas. Habiendo permanecido en silencio todo ese tiempo, la desaparición progresiva de la vivienda entre los árboles que han ido cubriendo las laderas de Panoramic Hill sería tal vez la mejor metáfora de su injusto destino histórico.
Patio de la casa Havens. Fotografía de Henry Bowles. Fuente: Lisa Germany 


\section{A house with a future}
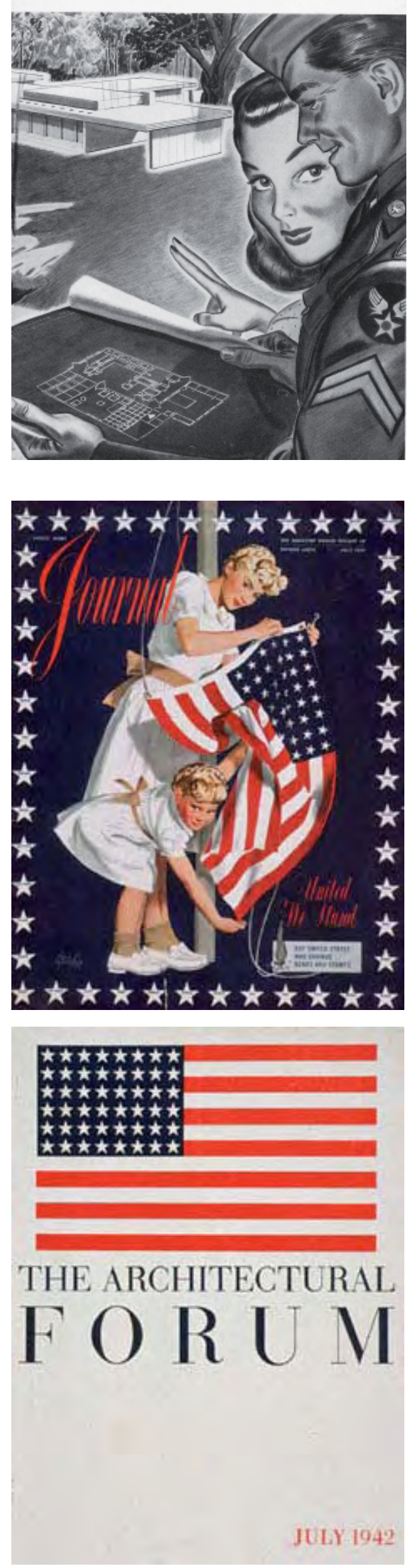

Nueva York: What is Happening to Modern Architecture?

Con la entrada de los Estados Unidos en la Segunda Guerra Mundial, la industria bélica movilizó la mayoría de los medios con los que contaba la construcción civil y cesaron los encargos. Fue el tiempo de la reflexión sobre el papel de los nuevos medios productivos y sobre las necesidades de la sociedad surgida tras el futuro restablecimiento de un nuevo orden socioeconómico y político global. Harris se involucró entonces en el proyecto de varias viviendas experimentales, proponiendo ideas sobre el hogar de posguerra que dejaron constancia de su visión de futuro ante los cambios que estaba experimentando el mundo.

Un ejemplo de su implicación en el contexto de reinvención de la propia disciplina y del papel del arquitecto como agente activo durante esta época fue su trabajo para la Revere Copper and Brass Corporation, proyectando en 1942: la Segmental House, una vivienda modular destinada a facilitar la adición de nuevas estancias a las familias de los veteranos regresados del frente. Una imagen $3 \mathrm{D}$ y la planta de un módulo tipo para esta vivienda se presentaban en la cubierta de un folleto publicitario, cuya portada, diseñada a modo de cómic, estaba protagonizada por una joven pareja de patriotas americanos que desplegaban encantados los planos de su futura casa. Las apenas doce páginas de este pequeño catálogo ofrecían todo tipo de explicaciones sobre los sistemas ampliación de esta vivienda experimental muy barata que, según se reiteraba, podía pasar de tener una sola estancia a albergar seis dormitorios y cuatro baños, creciendo en número de habitaciones conforme a las futuras (y deseables) nuevas necesidades de espacio por parte de sus habitantes.

En su fase inicial, la Segmental House consistía en una vivienda de un dormitorio cuyo coste no debía superar los 3.350 dólares. Con el tiempo, la casa iría ampliándose para alojar hijos, nietos o servicio doméstico según un plan preestablecido que valoraba las extensiones hasta el estado final en 10.340 dólares. Se trataba de un concepto eficiente, económico e incluso sostenible que influiría decisivamente en Gordon Drake, cuya Unit House en San Francisco debe mucho a este proyecto teórico de su maestro.

Esta casa modelo, que no llegó a construirse, fue publicada también como The New House $194 X$ en el número 77 (septiembre de 1942) de Architectural Forum. Las razones para ello, seguramente, tuvieron que ver con el hecho de que, tras la guerra, el masivo fenómeno de colonización suburbana en Norteamérica tendió a lotizaciones cada vez más pequeñas para minimizar el coste del suelo por parte de los promotores con lo que, sin una parcela de dimensiones suficientes, un prototipo como la Segmental House no podría crecer. En realidad, en plena contienda, se trataba menos de llevar a cabo la realización de proyectos teóricos como éste que de dirigir la atención del público hacia las posibilidades de la tecnología desarrollada para la guerra y su potencial reconversión en una industria del consumo doméstico. Como ha afirmado Ted Wells sobre este proyecto, al fin y al cabo, no importaban tanto las soluciones concretas como el hecho de vender sueños ${ }^{199}$.

En efecto, la condición teórica del proyecto de esta vivienda quedaba enfatizada desde el propio folleto publicitario de la misma, en el que se manifestaba que era imposible ejecutarla durante la contienda aunque "sin embargo, podría ser construido muy rápidamente después de la guerra, cuando los nuevos materiales y las instalaciones para su fabricación puedan ser destinadas a elevar nuestro nivel de vida" ${ }^{\prime 200}$. No deja de ser llamativo el hecho de que esta 

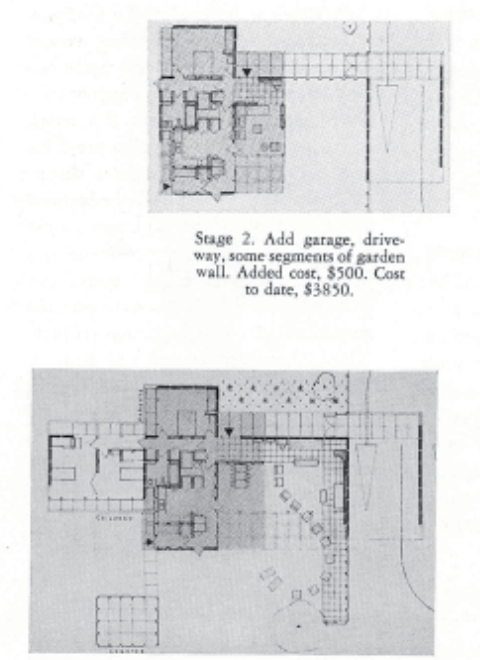

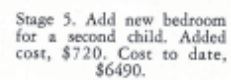

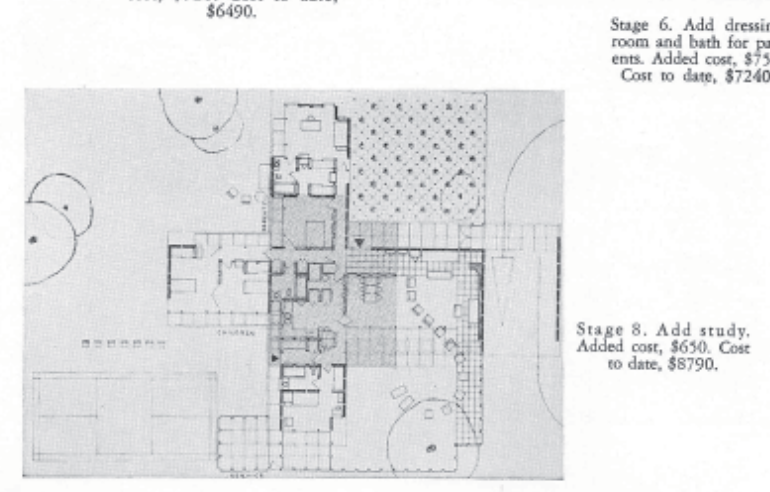

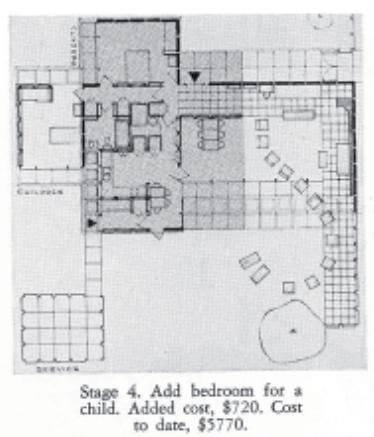

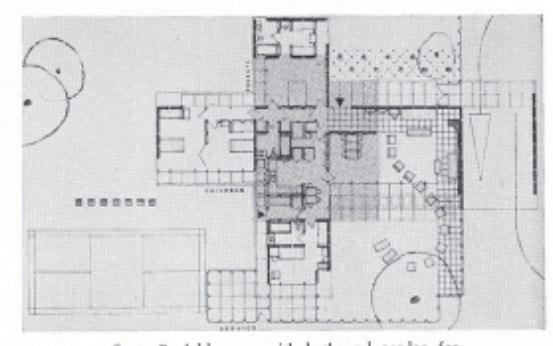

Stage 7. Add room with bath and garden for
servant; extend wall of liviag room garden Added cost, $\$ 900$. Cost to date, $\$ 8140$.

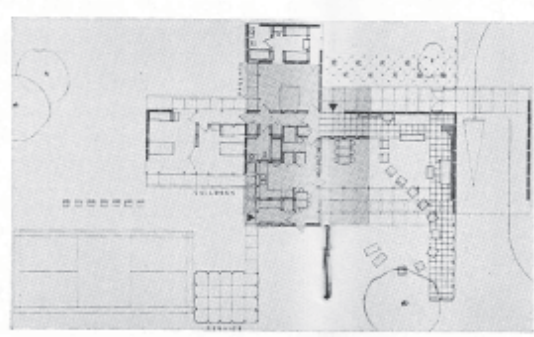

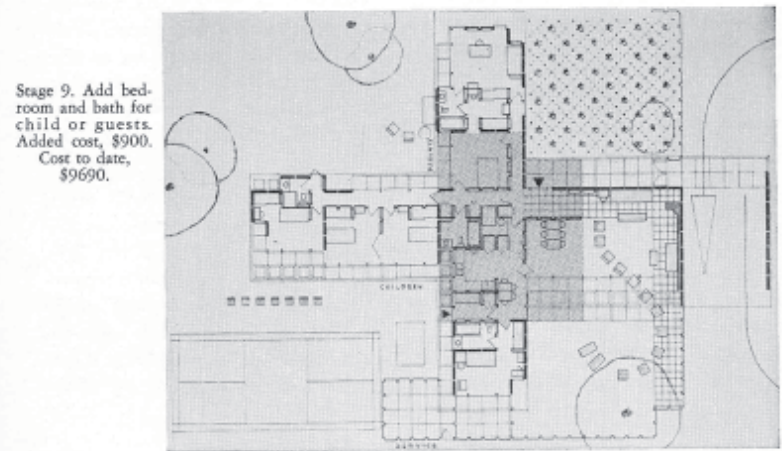

declaración se realizase a principios de 1943, es decir, que dos años antes del final de la guerra se tuviera claro que, tras el triunfo, todo el esfuerzo bélico se iba a trasladar a la industria de la vivienda y al consumo de masas. Es más, desde el verano de 1942, coincidiendo con el 4 de julio, todos los medios impresos del país habían lanzado una campaña patriótica, United We Stand $y$, exhibiendo en portada este lema y la bandera estadounidense, daban por sentada la victoria y llamaban a todos los ciudadanos a movilizarse en pro de nuevas formas de vida acordes con una nueva era ${ }^{201}$.

Imbuido del espíritu de unos tiempos marcados por el clima de colaboración entre arquitectos e industriales, Harris trabajó en el diseño de módulos de cocinas y baños como el Ingersoll Utiliy Unit junto con el diseñador Donald Deskey, con quien desarrolló este prototipo producido por la Borg-Warner Corportation en Chicago en 1945 y comercializado en 1946. A su vez, de las diferentes propuestas de arquitectura residencial de posguerra avanzadas por Harris en aquella época, varias resultaron premiadas, como la vivienda ganadora -justo por delante de la de Richard Neutra- del concurso patrocinado, en 1946, por la Libbey-Owens Glass Company. Esta empresa perseguía ejemplarizar sus productos con nuevos prototipos de viviendas energéticamente eficientes basadas tanto en nuevos criterios de diseño espacial como en el empleo de los nuevos materiales, en este caso vidrios, cuya tecnología había sido desarrollada por la investigación militar. Los prototipos premiados fueron recogidos en un catálogo editado por Maron J. Simon y titulado Your Solar House.
Folleto publicitario de la Segmental House de Harris proyectada en 1942 para la Revere Copper \& Brass Inc. Folleto de 1943. En la página reproducida se muestran posibilidades de crecimiento de la vivienda por adición de módulos habitables. Se aporta también una previsión de los futuros costes de ampliación según fase y necesidades. La portada del folleto ('A House with a Future'), publicado dentro del esfuerzo publicitario de futuros estilos de vida que supuso la Segunda Guerra Mundial en los Estados Unuidos, incide en el hecho de que él es un veterano de guerra mientras que ella, sutilmente, hace con dos dedos el signo de la victoria idos años antes del final de la contienda!

Página anterior arriba: Portada del catálogo de la Segmetal House

Página anterior centro y abajo: Portadas de Ladies' Home Journal y Architectural Forum de juio de 1942. Campaña patriótica United We Stand 


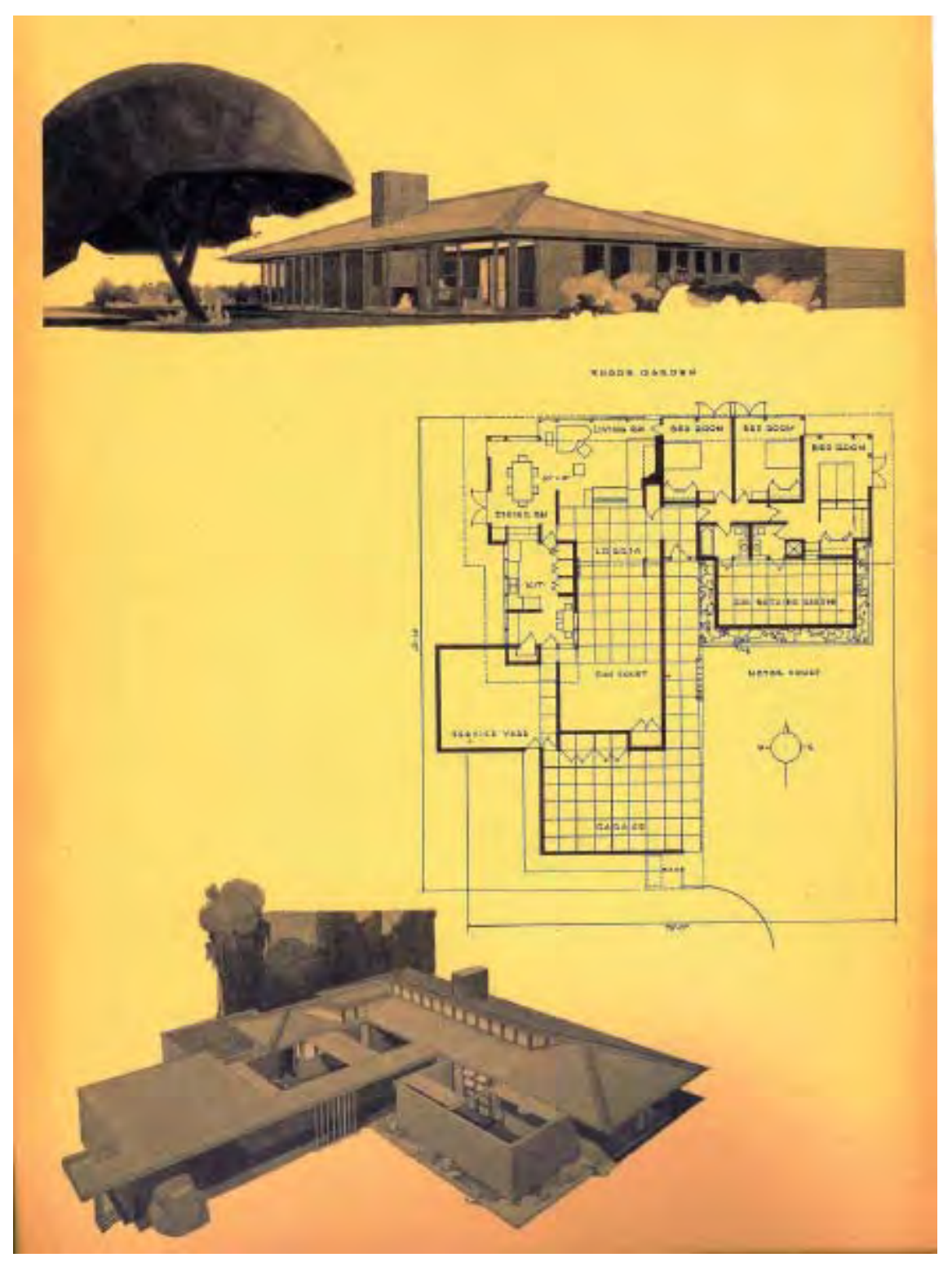

Harris: prototipo de vivienda, catálogo Your Solar House, 1946

Página siguiente: Ralph Johnson House, 1948, publicada en el catálogo de la exposición del MoMa Built in USA: Post-war Architecture 1944-1952, de 1952. Fotografías de Fred Dapprich
En dicho catálogo se alababa la vivienda propuesta por Harris destacándose de la misma: "Gracias al vidrio, tanto la luz como el espacio se han convertido en elementos flexibles del diseño arquitectónico. Como consecuencia, no sólo se ha conseguido llevar el exterior al interior de la vivienda y elevar su nivel de iluminación sino que, además, se ha transformado completamente el carácter de esos espacios interiores y su cualidad atmosférica. Quizás esto sea más fácil de conseguir en California, donde es posible abrir huecos a norte sin pérdida de calor. [...] De hecho es lo que sucede en esta casa solar pensada para California, donde la iluminación se garantiza a través de la cubierta. La luz solar penetra en cada estancia mediante bandas continuas de ventanas abiertas en el techo en las orientaciones sur y este. [...] De este modo, las vistas principales quedan del lado en sombra de la casa. El sol entra por la espalda, en lugar de hacerlo de frente. También así se mejora la iluminación. La luz cenital ilumina la superficie del techo, la parte superior de los objetos descendiendo suavemente por todas sus caras. Las ventanas a la altura de los ojos ya no tienen por qué ser también fuentes de luz, ahora son, principalmente, huecos abiertos para enmarcar las mejores vistas. [...] En el exterior de la vivienda el proyecto prevé espacios en sombra, agradables terrazas asoleadas y jardines privados para los baños. En el lado sur de la logia se ha dispuesto un luminoso patio delimitado por muros. Protegido del viento, permite ser utilizado durante los soleados días de invierno. 
Una línea de paneles horizontales, como prolongando la estructura de listones de madera de la cubierta de la casa, conectan y cierran los patios recorriendo su perímetro para crear una pérgola que tanto protege los paramentos de vidrio del soleamiento directo como arroja algo de sombra al jardín" ${ }^{\prime 202}$.

Asimismo, durante el periodo de posguerra, tanto las viviendas construidas por Harris en Los Ángeles poco antes del estallido de la contienda como sus proyectos de viviendas experimentales fueron publicados recurrentemente en revistas y libros cuyos autores o compiladores, en lugar de aventurar hipótesis de futuros diseños, volvían la mirada a los años previos a la guerra para encontrar referentes válidos. Sin que el arquitecto tuviera que esforzarse lo más mínimo para ello, más bien todo lo contrario, Harris despertó durante toda esa década el interés de casi todos los editores del país, que no quisieron dejar pasar la oportunidad de publicar algunos de sus mejores proyectos en alguna de las numerosas revisiones críticas y catálogos temáticos sobre los temas más candentes de la arquitectura del momento.

Una prueba irrefutable de la celebridad de Harris durante esos años es el hecho de que las viviendas del arquitecto ocuparan las páginas de publicaciones profesionales, revistas populares, manuales ${ }^{203}$ prácticos de construcción y algunos de los catálogos de las exposiciones más significativas de la época. Éste sería el caso de las dos muestras Built in the USA, organizadas por el Museo de Arte Moderno de Nueva York y que barren el periodo comprendido entre la exposición de 1932 y el final de la posguerra (Built in the USA, 19321944, de 1944, y Built in USA: Post-War Architecture, de 195220.

Entre 1943 y 1944 los Harris pasaron una temporada larga en Nueva York, donde Harwell había sido invitado a impartir clases en la Universidad de Columbia. Durante esa etapa, Jean comenzó a interesarse por la historia de la arquitectura moderna, la crítica arquitectónica y el periodismo. Alejado de su estudio de Los Ángeles, Harris pudo colaborar más intensamente con los CIAM, involucrándose en el Chapter for Relief and Postwar Planning. Allí coincidió con los emigrados europeos Gropius, Brever, Giedion, Sert, etc. Pero sus encuentros con ellos, con el telón de fondo de la guerra y teniendo que asistir a fuertes disputas internas sobre el futuro de los CIAM no resultaron una grata experiencia para una persona tan afable y poco acostumbrada a discutir como Harris -no así su mujer, que mantuvo algunos enfrentamientos con Giedion ${ }^{205}$. Como ha apuntado Lisa Germany, él, que había pasado varios años con Neutra, respetaba profundamente sus ideas de reformas sociales y las creía sinceras, pero le disgustó tener que asistir a una lucha de egos bajo el pretexto de una unidad de acción. Harris vio a aquellos arquitectos internacionales como hombres de negocios más preocupados "por presentar un nuevo producto que vender y llevarse el mérito por ello"206.

En las postrimerías de la guerra, el debate ideológico sobre la modernidad comenzó a polarizarse en los Estados Unidos, agudizando el enfrentamiento entre diferentes facciones. Por un lado, como ya había ocurrido con la exposición del MoMA de 1932 y el libro de Hitchcock y Johnson The International Style, una nueva campaña publicitaria estaba siendo orquestada desde los partidarios de la modernidad europea, representada ahora por los propios emigrados recién llegados a las prestigiosas universidades del Este. Algunas de ellas, con el apoyo del Museo de Arte Moderno de Nueva York, comenzaban a presentarlos como los auténticos salvadores de la arquitectura americana pues, viniendo al otro lado del océano, habían evitado que ésta siguiera peregrinando por más tiempo en la oscuridad del

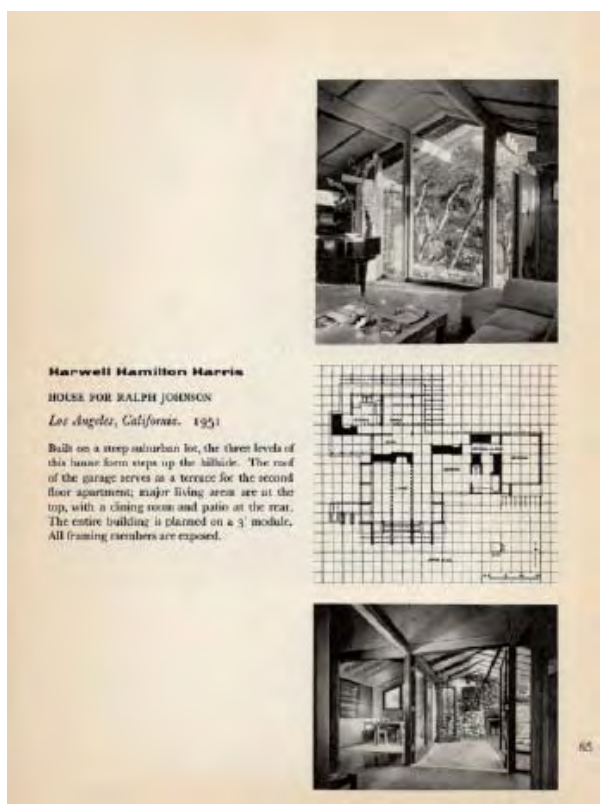


eclecticismo. Para otros autores, críticos e historiadores, la resurrección de esta mitología moderna era un gravísimo error que denostaba el interés de la arquitectura producida en los años previos a la guerra. El debate alcanzó todos los medios, desde las publicaciones más cultas hasta las revistas populares como House Beautiful, cuya dirección, tras la etapa de James Marston Fitch (amigo del matrimonio Harris) acababa de asumir Elizabeth Gordon, sobre la que ya se ha referido su vigorosa cruzada en defensa de los valores del hogar norteamericano.

Precisamente, fue en aquella época cuando Lewis Mumford publicó su polémico artículo Status $Q u 0^{207}$, defendiendo la existencia de una auténtica escuela americana en el Área de la Bahía y cuando, a raíz del debate suscitado, un año más tarde, en 1948, el MoMA convocó el histórico simposio What is Happening to Modern Architecture?200, donde se discutió acerca de la existencia, originalidad, autonomía o no de una auténtica vanguardia norteamericana.

\section{El descubrimiento de Greene \& Greene}

Los años 40 supusieron una vuelta de tuerca en la producción de los arquitectos norteamericanos, manifestándose como no había ocurrido hasta entonces, el cruce de influencias entre las diferentes generaciones. Por ejemplo, David Gebhard sostiene ${ }^{209}$ que el renovado interés de Schindler por las estructuras de madera vista a principios de los 40, tras haberlas evitado durante años, prefiriendo en su lugar las superficies uniformes de enfoscados continuos, tendría que ver tanto con la popularidad alcanzada por las viviendas de madera de Harris, como con las obras realizadas en el Área de la Bahía y, por supuesto, con la aparición de las casas usonianas de Wright, casi todas ellas realizadas en madera ${ }^{210}$. En este sentido, la obra de Harris se habría mantenido hasta ese momento conectada a la propia evolución de la obra de Wright, pero no a través de la experimentación con la madera sino, más bien, a través de las ideas de integración de la vivienda con el paisaje reiteradas por las casas usonianas que Harris ya había aprendido en la Hollyhock House.

No obstante, en los años 40, Harris pudo descubrir directamente en el trabajo de los hermanos Greene un precedente de esa relación interior-exterior previa a la obra de Schindler y a las primeras casas angelinas de Wright -a las que se adelantaron en más de una década- $y$, sobre todo, la principal fuente de la tradición de construcción con madera del Sur de California. De este modo, llevando más allá el argumento de Gebhard, se podría afirmar que la transformación de la obra de Harris tras su contacto con la arquitectura de Greene \& Greene llegó a atraer incluso la atención de Schindler sobre esta tradición en la que, tarde o temprano, todos estos arquitectos californianos se habían visto involucrados por las condiciones de una región que parecía expresarse a través de ellos mediante un proceso de escritura automática.

Los Harris habían regresado a Los Ángeles a finales de 1944. Fue entonces cuando Jean, que había comenzado a interesarse por la obra de Greene \& Greene, se dedicó a investigar sobre estos arquitectos olvidados. No debió resultarle fácil, ya que apenas quedaba rastro de ellos en la ciudad. Se desconocía incluso si todavía podían estar vivos pues sus nombres no aparecían ni en los nuevos ni en los viejos listines telefónicos, ni siquiera en los registros del American Institute of Architects, institución de la que se habían dado de baja hacía 30 años. Jean consiguió localizar finalmente la dirección de la hija 


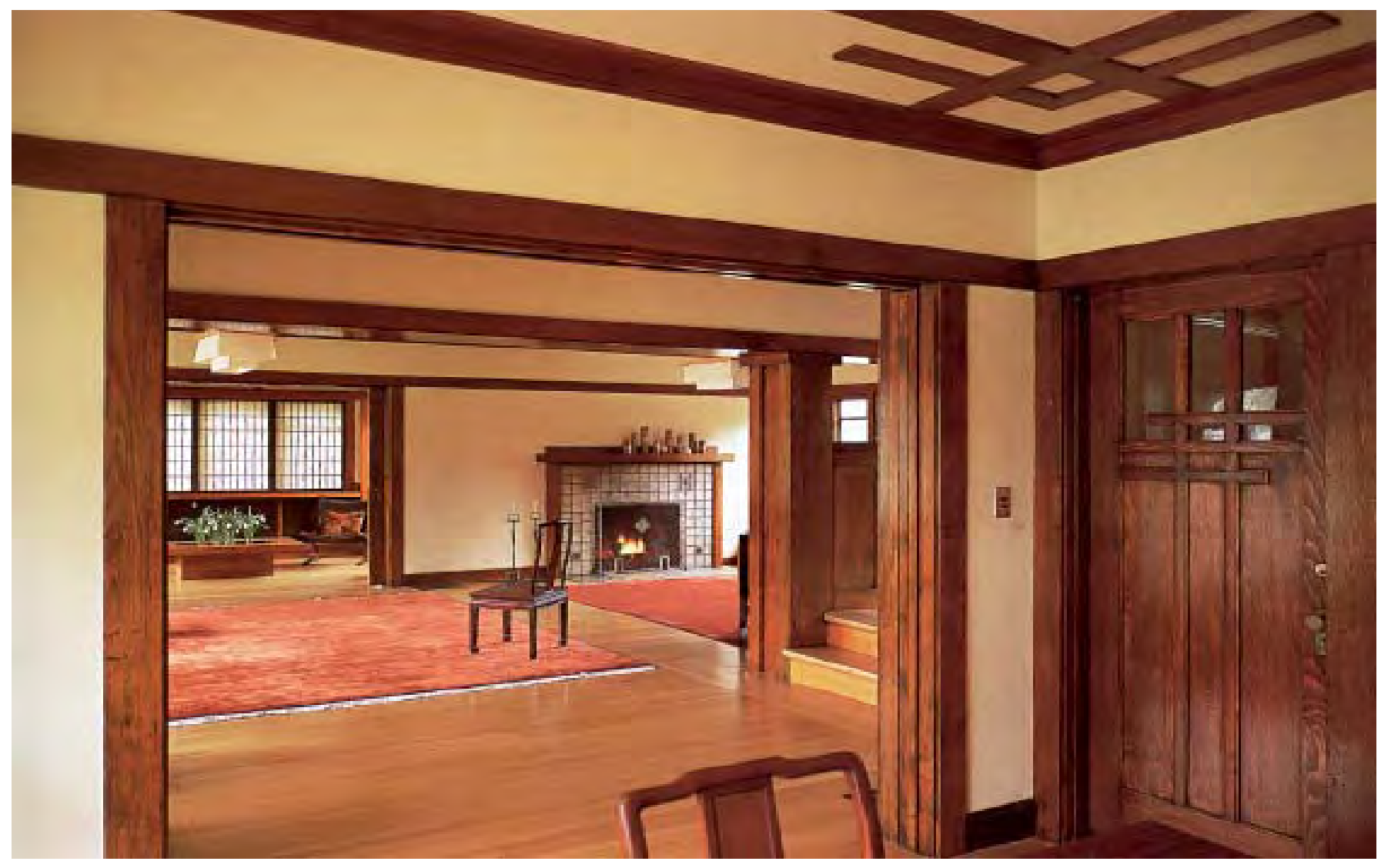

de Henry Greene, adonde el arquitecto se había mudado a vivir tiempo atrás. Su hermano Charles hacía años que residía en Carmel. Ambos rondaban los ochenta años de edad y nadie se acordaba ya de ellos. Henry Mather Greene comentó a los Harris que había dejado su archivo de planos en el garaje de su antigua casa y éstos, tras recuperar la documentación, decidieron donarla a UCLA, institución que, al igual que las demás universidades en California a las que les fue ofrecida, rechazó el legado que finalmente fue depositado en la Avery Library de la Universidad de Columbia.

Entre 1947 y 1951 los Harris entablaron una estrecha relación con los hermanos Greene. Jean trató de recopilar todo tipo de información sobre ellos para sus artículos, mientras que el arquitecto solía llevar a Henry Mather Greene a sus visitas de obra ${ }^{211}$. Entre las obras que Harris visitó con el menor de los hermanos Greene pidiéndole consejo estaban las viviendas Wyle Hosue en Ojai (1948), Ralph Johnson House en Los Ángeles (1948), Mulvihill House en Sierra Madre (1948), English House en Beverly Hills (1949), la casa de la playa para Rex Hardy en Palos Verdes (1950) y la Hanson House en Silver Lake (1950) que se tratará en el último apartado de este capítulo.

Tanto Jean como Harwell H. Harris dedicaron importantes esfuerzos para dar a conocer la obra de Greene \& Greene. Reunieron a ambos en el estudio de Henry en Carmel y encargaron a Cole Weston ${ }^{212}$, el menor de los hijos de Edward Weston, que tomara fotografías de ellos, las mismas que ilustraron muchos de los artículo de Jean Murray Bangs. Además, a través de algunos amigos, pudieron financiar también un reportaje fotográfico de varias de sus casas con el que organizaron una pequeña exposición itinerante.

Jean, por su parte, recurrió a sus contactos en Architectural Forum para que uno de sus editores, Howard Myers, de paso en la ciudad, la acompañara a vi- 
Artículo de Architectural Review, octubre 1948, sobre los debates celebrados en el MoMA en el mes de febrero de ese mismo año. Se discutía también sobre el papel que el descubrimiento de Greene \& Greene por parte del matrimonio Harris y los escritos de Jean M. Bangs habían tenido en la recuperación de una tradición doméstica original de California

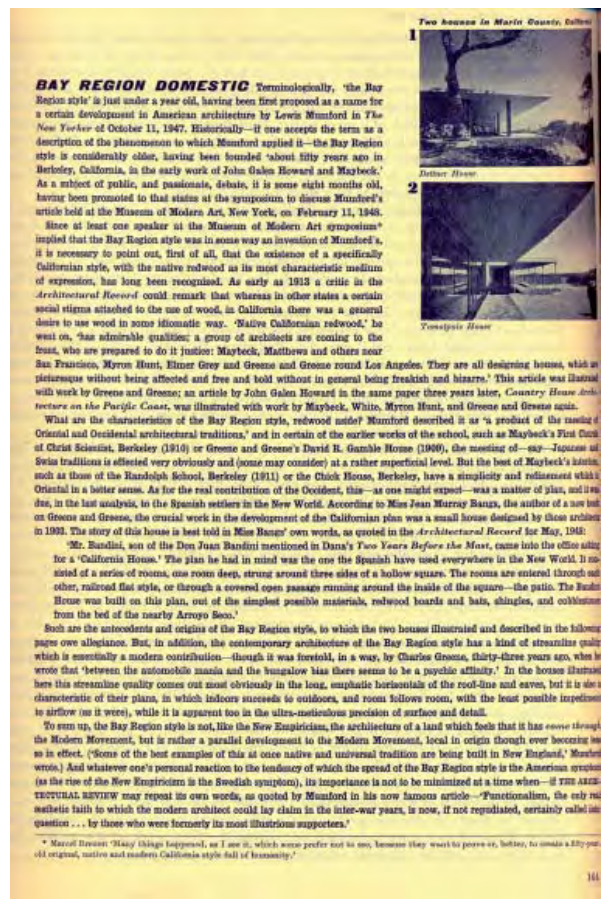

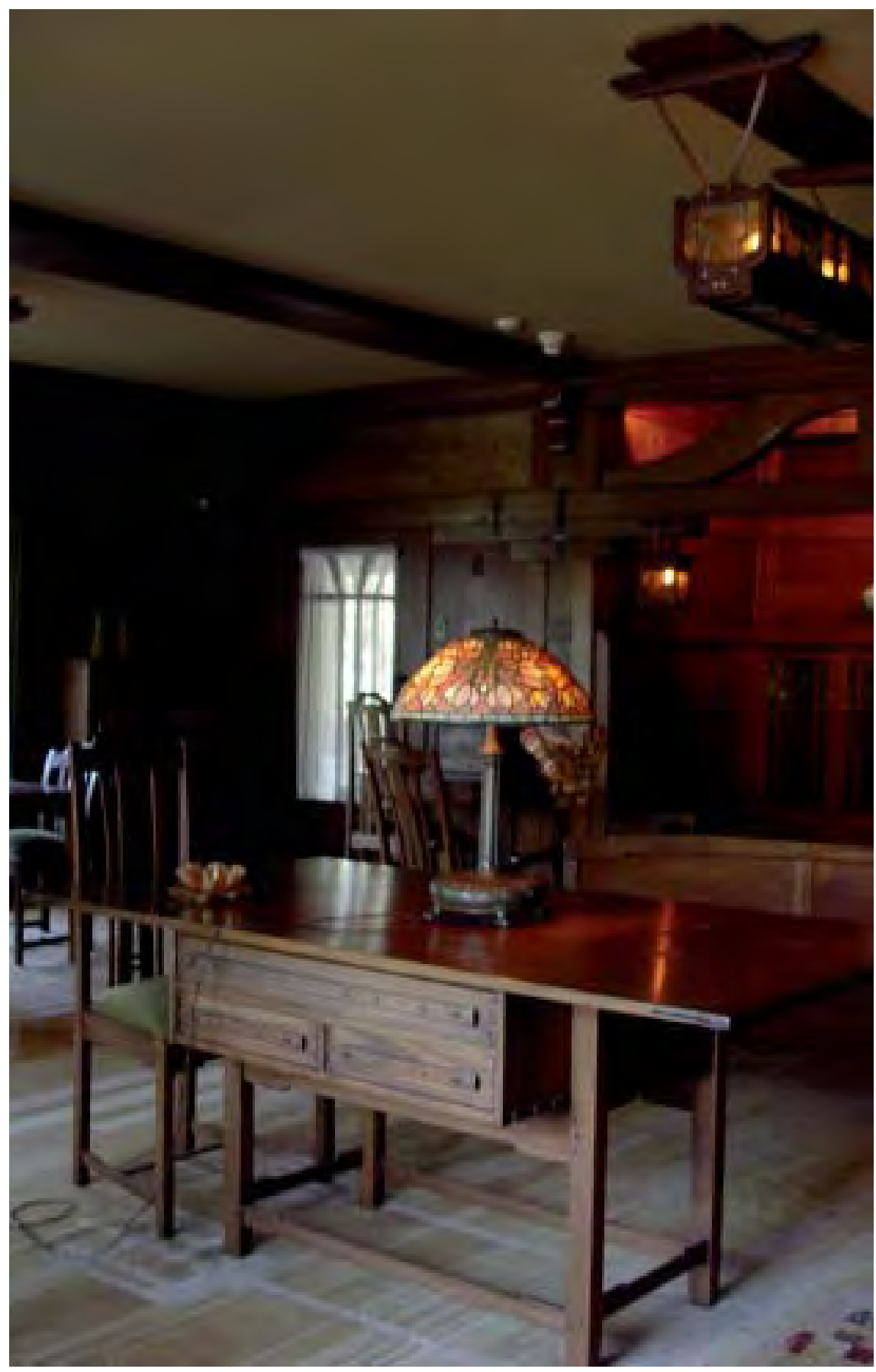

sitar una selección de las mejores residencias de estos arquitectos en Los Ángeles. La revista se interesó por el descubrimiento y en su número de octubre de 1948, Jean Harris publicó un artículo monográfico gracias al cual Greene \& Greene fueron dados a conocer en todo el país. En él documentaba su vida, escribía sobre algunas viviendas $y$, reivindicando la originalidad del trabajo de los Greene, exponía sus ideas en el contexto de la cultura arquitectónica de la época ${ }^{213}$. A raíz de esta tarea de documentación y divulgación llevada a cabo por los Harris, el AIA decidió conceder, en 1952, la medalla de honor como distinción por el conjunto de su obra a Henry y Charles Greene que, de este modo, tras décadas de olvido, obtuvieron el reconocimiento de la profesión pocos años antes de su muerte, respectivamente, en 1954 y 1957.

Harwell Hamilton Harris reconoció inmediatamente en la producción de los hermanos Greene toda su importancia como pioneros de una corriente arquitectónica genuinamente californiana. Charles y Henry Greene se basaron 
en el clima y en el uso de materiales locales para crear obras únicas donde lo elaborado del diseño y la perfección de la ejecución, en lugar de abrumar, contribuyen a generar atmósferas de apacible intimidad doméstica.

Los interiores de Greene \& Greene se expresan a través de los materiales empleados. En sus obras la madera asume el protagonismo, siendo explotada en todas sus posibilidades para crear espacios repletos de estímu$\operatorname{los}^{214}$. Sus viviendas de madurez expresan la devoción que los arquitectos sentían por este material. Una pasión evidenciada tanto en el cuidado con el que han sido seleccionadas sus diferentes variedades como en el deleite que produce mostrarlas todas juntas. La perfecta materialización de los encuentros, previendo hasta el más mínimo movimiento de la madera, las cuidadas transiciones de tono o los efectivos contrastes de textura y color entre diferentes especies utilizadas, conectaría el trabajo de los Greene con las tradiciones europeas de la madera, en concreto con las tradiciones escandinavas, antes incluso que con el Arts \& Crafts americano, corriente en la que se suele inscribir su trabajo, pero cuyos principales representantes, como Gustav Stickley, nunca lograron una obra de la originalidad y calidad alcanzada por los Greene.

Historiadores como Gebhard o Banham han coincidido al señalar que las plantas de las viviendas de los Greene aportaban en realidad pocas novedades. De hecho, pueden resultar convencionales si se comparan con las plantas de Maybeck o con los esquemas organizativos de las Prairie Houses de Wright, contemporáneas de la casa Gamble. No obstante, esta supuesta rigidez planimétrica parece diluirse en la naturalidad con que se relacionan los espacios interiores de los Greene. En efecto, en sus casas, las estancias públicas no renuncian a su representatividad pero las circulaciones están planteadas con un desenfado -impensable, por ejemplo, en Nueva Inglaterra -y los ambientes, manteniendo su autonomía, se conectan visualmente a través de grandes aperturas o se enlazan mediante vestíbulos de transición. En este sentido, la importancia de las tradiciones arquitectónicas japonesas en el ideario de los Greene es responsable de la fluidez de estas relaciones. Los techos son bajos y hay pocas variaciones altimétricas, sin embargo, provocan una efectiva tensión horizontal y los espacios parecen expandirse continuamente, variando sus escalas conforme se recorren.

La influencia de la arquitectura oriental queda patente también en el modo en que los Greene resuelven en muchos de sus interiores el encuentro de los paramentos verticales con los techos a través de dinteles y zunchos de atado inspirados en el nageshi ${ }^{215}$ japonés, elemento que también resulta evidente en la vivienda de Schindler en Kings Road y que será evocado por Harris de manera recurrente en las franjas acristaladas altas características de sus viviendas de los años 30 y 40.

El mobiliario es otra de las claves para entender la complejidad de los proyectos realizados por los hermanos Greene. Como obra de arte total, todos sus aspectos se encuentran interconectados dentro de un plan general de diseño que desciende progresivamente de escala. Pero el férreo control ejercido sobre todas las etapas del proyecto, sobre cada elemento, cada pequeño detalle nunca es de naturaleza impositiva. Los objetos diseñados por Greene \& Greene son obras de arte, pero no pretenden deslumbrar, su finalidad es apoyar las tareas del habitar. Como en la arquitectura japonesa, cada acción posible ha sido prevista y encuentra su correspondencia en un objeto a cuyo cometido sirve con precisión.
Greene \& Greene: A. Tichenor House, Long Beach, CA, 1905. Fuente Ted Bosely

Página anterior: Greene \& Greene: Gamble House, Los Ángeles 1909, salón. Fotografía del autor

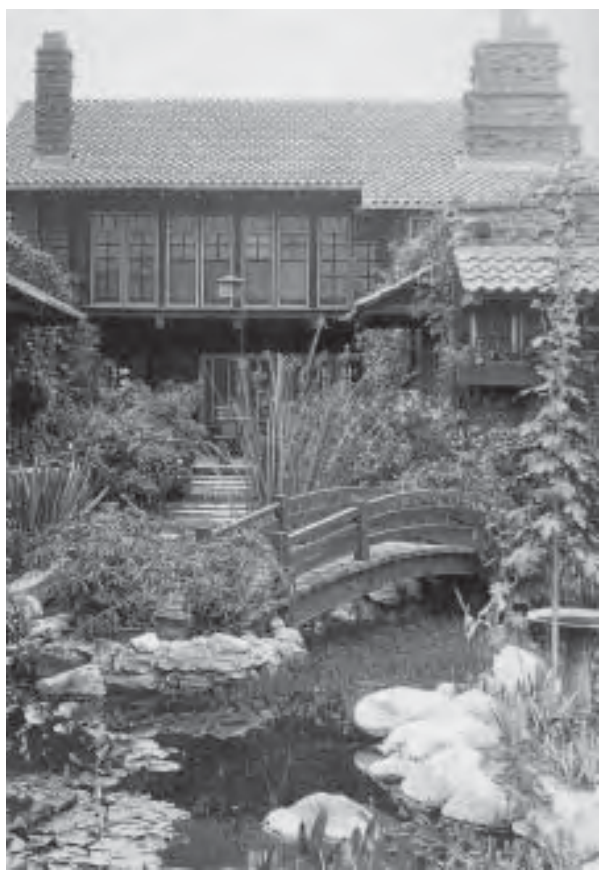



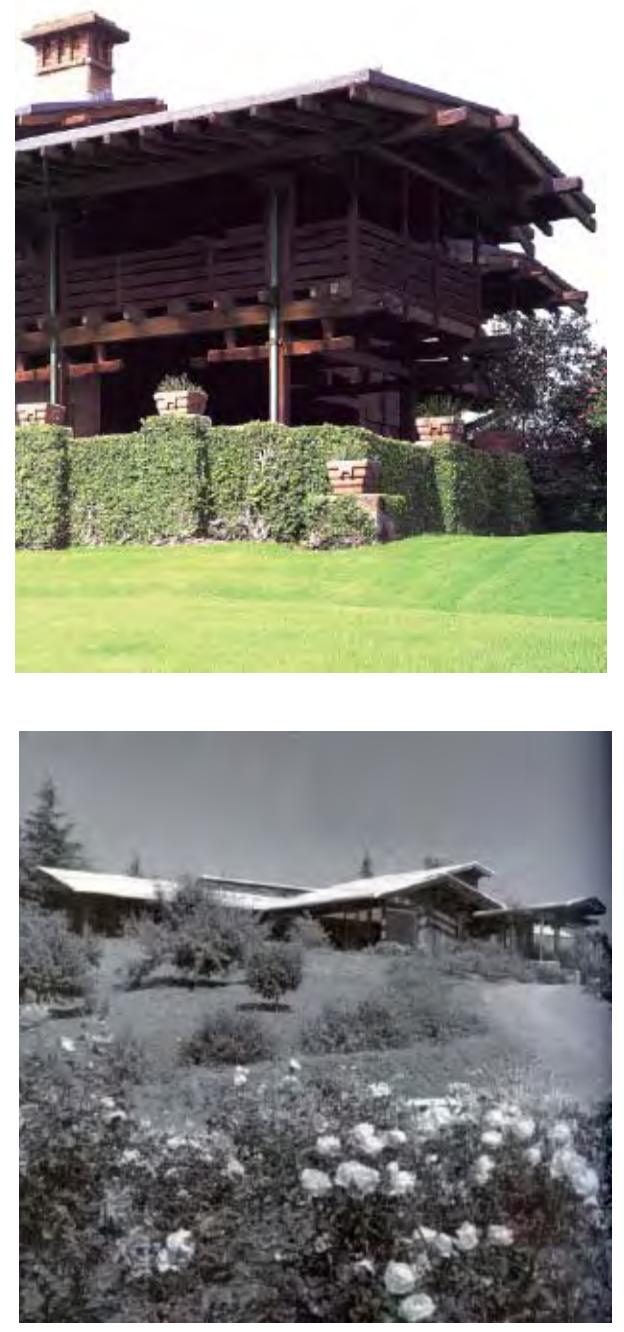

Izquierda arriba: Greene \& Greene, Gamble House, Pasadena, 1909. Fotografía del autor Izquierda abajo: Harris: Wyle House, 1948. Fotografía de Julius Shulman

Derecha: Harris: Ralph Johnson House, 1948. Fotografía de Fred Dapprich

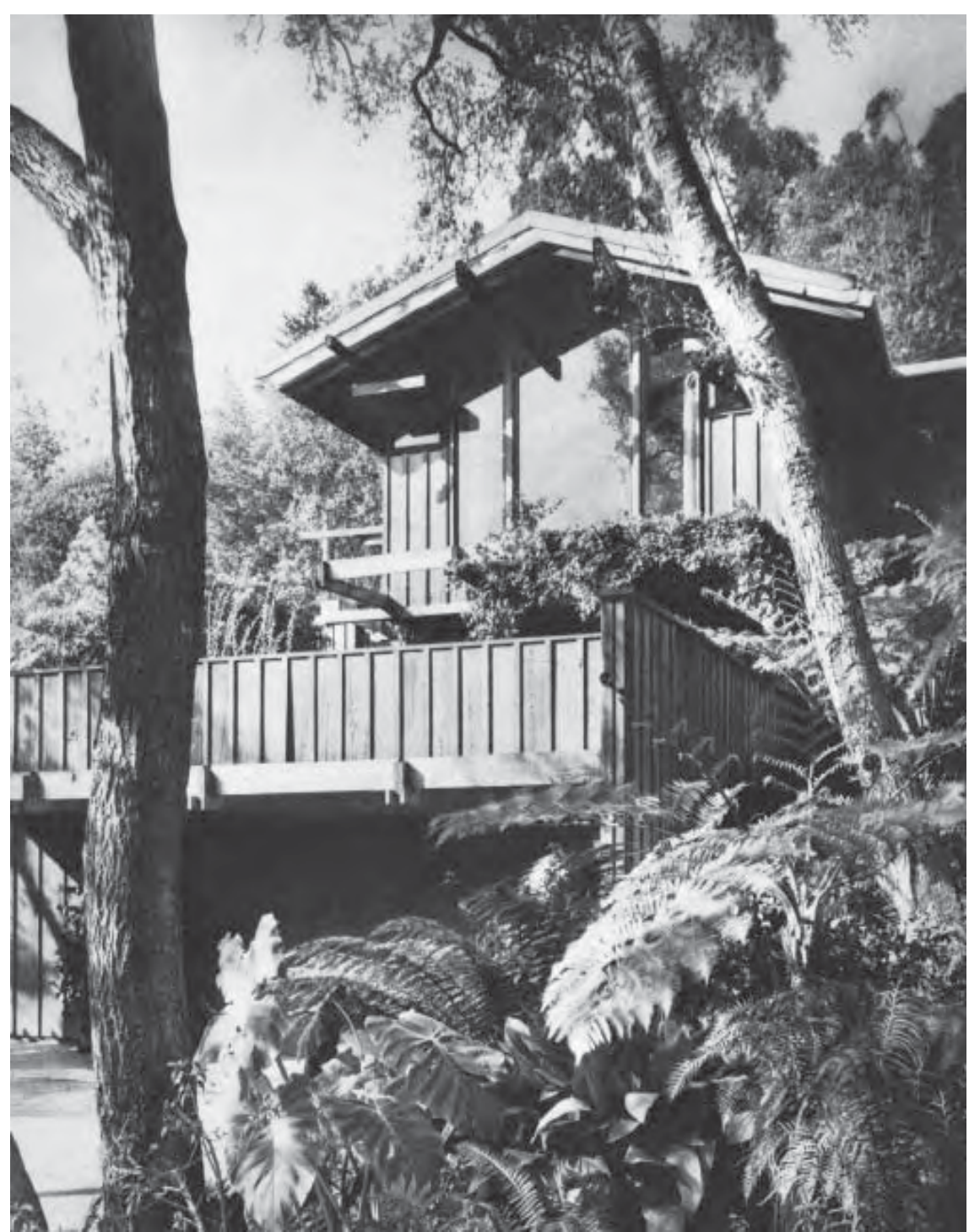

La arquitectura de los Greene sentó las bases conceptuales de la tradición arquitectónica de la región. La serie de influencias espacial y temporalmente deslocalizadas que atraviesan su trabajo se entremezclan para crear algo absolutamente nuevo y original. La Gamble House, por ejemplo, constituye el primer hito de una tradición cultural tan extraña a su contexto físico como genuinamente californiana. Conocedores y admiradores de las tradiciones constructivas de la California española, la tierra, el adobe, las superficies encaladas, la casa rancho de muros masivos, huecos pequeños y porches de teja como dispositivos de protección solar, los hermanos Greene, no podían haberse alejado más de esta arquitectura convencionalmente asociada con el entorno californiano. Las casas de madurez de los Greene asumen referencias extrañas en el tiempo y en la distancia, hay ecos de civilizaciones lejanas que se funden en una unión casi imposible. La cabaña nórdica y la terraza mediterránea, el granero del oeste americano, los balcones coloniales de las selvas subtropicales de Birmania, el bungalow, la pagoda china, el palacio y el jardín japonés. No es una obra ecléctica, ni un revival, nada en ella remite a estilos codificados. Se trata sobre todo de una arquitectura inventada que, como ocurría en la casa Hollyhock, surge de la ensoñación de paisajes y edificios exóticos para crear una forma nueva donde todos ellos son reconocibles en su evocación pero ninguno en su literalidad. En este sentido, La Gamble House inaugura esta convivencia sin la cual no puede entenderse la arquitectura californiana: arquitecturas inventadas en un paisaje soñado ${ }^{216}$. 
Para Harris, su contacto con Greene \& Greene fue clave en la reinvención de su propio lenguaje, siendo evidente en el nuevo tratamiento que concedió a los materiales locales y en su redescubrimiento de Japón a través de la visión de la obra de estos arquitectos. La influencia recibida de los hermanos Greene encontró su expresión más clara en algunas de las obras californianas construidas por Harris a finales de la década de 1940, como la vivienda para Ralph Johnson (1947-48) en Los Ángeles, o la Clarence Wyle House (1946-48) en Ojai, todo un homenaje a las cubiertas y vigas enfáticamente proyectadas al exterior tan características de los Greene.

En las viviendas de madurez de Geene \& Greene la estructura de la casa no se oculta, todo lo contrario, se despliega hasta convertirse en uno de los elementos más presentes, tanto en el exterior como en el interior de la arquitectura. Las dos viviendas mencionadas de Harris abrazan el lugar prolongándose al exterior a través de cubiertas y aleros expansivos que parecen querer dar la bienvenida. A pesar de los gestos no exentos de dramatismo de las cubiertas, la facilidad y naturalidad con la que estas obras de Harris se relacionan con el medio es otro de los rasgos distintivos que su trabajo comparte con el de los hermanos de Pasadena. También, al igual que ocurre con las obras de los Greene, las casas de Harris tampoco se ofrecen a un rápido escrutinio, menos aún a una fotografía. Es necesario recorrerlas sin prisa, ver, tocar sus superficies, sentarse tranquilamente junto a la chimenea o distraerse en el jardín para descubrir todo lo que la obra realmente encierra. En las casas de Harris la vida cotidiana se ve recompensada desde la propia arquitectura, apoyada por detalles que permanecen invisibles hasta que un pequeño gesto o una inesperada necesidad hacen que se revelen en toda su importancia.

\section{Un regionalismo liberador}

"El regionalismo es un estado mental, propio de personas cosmopolitas e imaginativas que tienen la vista puesta en el futuro" 217 .

Harwell Hamilton Harris

A finales de los años 40, en pleno debate ideológico de la modernidad, la cuestión del regionalismo se convirtió en un tema central en el pensamiento de Harris. Su interés por lo vernáculo, que en los inicios de su carrera respondía a una lógica proyectual o a cuestiones económicas y de facilidad de acceso a determinados materiales y sistemas constructivos locales, pasó a convertirse tras su paso por los círculos académicos de Nueva York en una actitud de defensa de los valores de una cultura regional, a cuya formulación teórica contribuiría de manera decisiva. De hecho, Harris se adelantó a Kenneth Frampton al referirse a su propia obra como regionalismo, un término que, por primera vez en el sentido dado por el crítico británico ${ }^{218}$, él mismo aplicó a la arquitectura. El propio Frampton, en dos de sus textos más representativos, Regionalismo crítico, arquitectura moderna e identidad cultural y Hacia un regionalismo crítico: Seis puntos para una arquitectura de resistencia, citó una conferencia de Harris que consideraba fundamental en la definición de este concepto:

"Quizás nadie haya expresado con más fuerza la idea de un regionalismo crítico que Harris en su Regionalismo y Nacionalismo, una conferencia que leyó por 
primera vez ante el Consejo Regional del Noroeste de la AIA en Eugene, Oregón, en 1954. En esta ocasión se adelantó por primera vez con su feliz distinción entre regionalismo de la restricción y regionalismo de la liberación".

(Frampton: Regionalismo crítico, arquitectura moderna e identidad cultura ${ }^{229}$ ).

"Que el regionalismo crítico no puede basarse simplemente en las formas autóctonas de una región específica fue bien expresado por el arquitecto californiano Hamilton Harwell Harris cuando escribió, hace ahora casi treinta años".

(Frampton: Hacia un regionalismo crítico: Seis puntos para una arquitectura de resistencia $\left.{ }^{220}\right)$.

El texto de la conferencia de Harris citado en ambas ocasiones por Frampton era el siguiente:

"Opuesto al regionalismo de la restricción hay otro tipo de regionalismo, el de la liberación. Éste consiste en la manifestación de una región que está especialmente en armonía con el pensamiento emergente de la época. Llamamos a esa manifestación 'regional' sólo porque todavía no ha emergido en todas partes. Es mérito de esta región estar más alerta de lo ordinario y ser más libre de lo común. Ha logrado además que esta manifestación tenga un significado para el resto del mundo. Para poder expresar este regionalismo arquitectónicamente es necesario que en un momento dado haya construcción -preferentemente mucha construcción. Sólo asípuede ser la expresión lo suficientemente general, variada y potente como para cautivar la imaginación de las gentes y aportar un clima favorable durante el tiempo suficiente como para que se desarrolle una nueva escuela de diseño.

San Francisco fue hecha para Maybeck. Pasadena fue hecha para Greene \& Greene. Ninguno de ellos podría haber logrado lo que logró en otro tiempo o lugar. Cada uno utilizó los materiales del lugar; pero no son los materiales los que distinguen su obra.

[...] Una región puede desarrollar ideas. Una región puede aceptar ideas. La imaginación y la inteligencia son necesarias para ambas. En California, a finales de los años veinte y en los treinta, las ideas europeas se encontraron con un regionalismo aún en desarrollo". Por otro lado, en Nueva Inglaterra, la modernidad europea se encontró un regionalismo rígido y restrictivo que primero presentó resistencia y luego se rindió. Nueva Inglaterra aceptó el conjunto de la modernidad europea porque su propio regionalismo se había reducido a una colección de restricciones".

En sintonía con el discurso de Lewis Mumford, quien tras su citado artículo Status Quo de 1947 había defendido en el MoMA en 1948 que el Bay Region Style había nutrido las bases culturales de una auténtica modernidad norteamericana, Harris describía la tensión que él mismo había percibido en la Costa Este entre los partidarios de la modernidad europea y los defensores de una sensibilidad regional para argumentar que este enfrentamiento no se había producido en la Costa Oeste. Para Harris, los arquitectos del Este, debido a la rigidez de sus ideas y formas regionales, veían un dualismo insuperable moderno-regional. Sin embargo, los arquitectos californianos, por tener una actitud más abierta y compartir una sensibilidad regional plural, permeable a múltiples influencias y todavía en gestación a principios de 


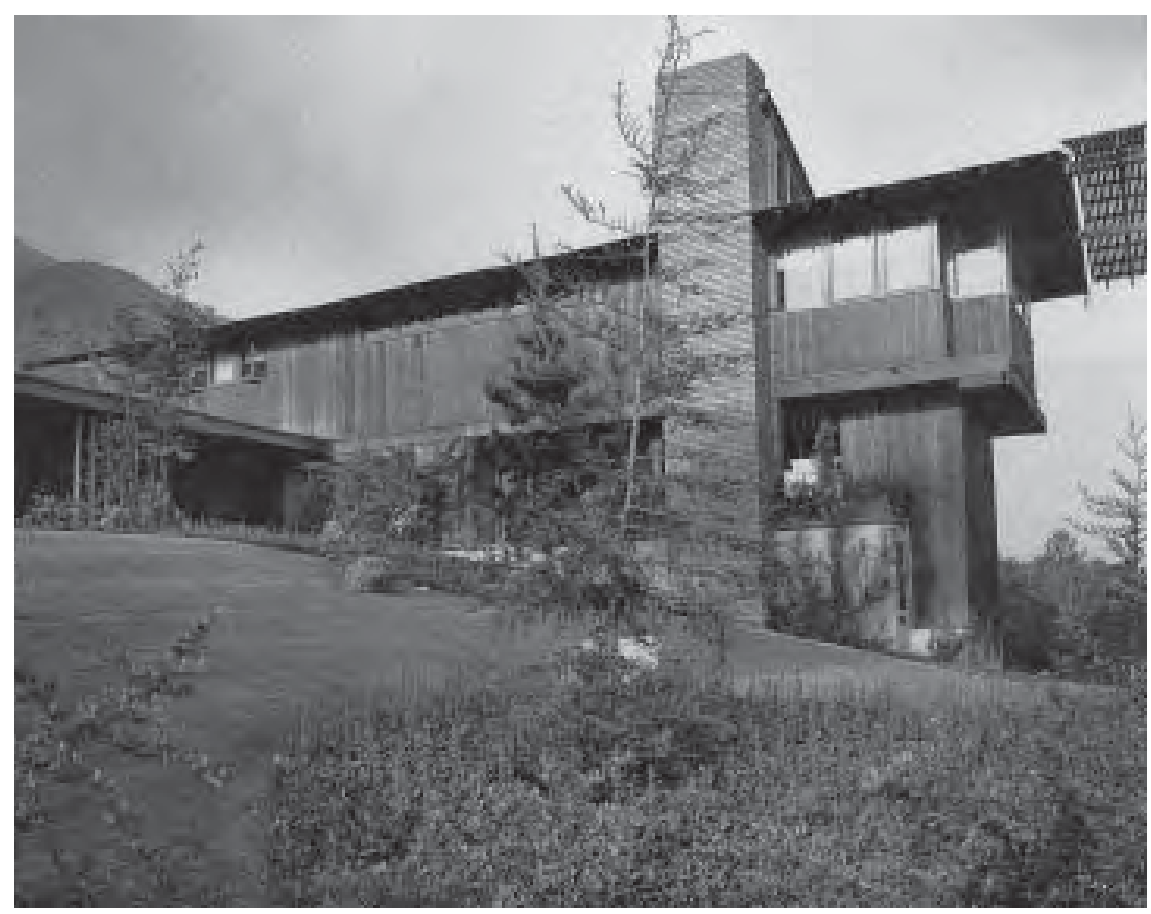

los años 20, los principios modernos llegados de Europa, principalmente a través de las figuras de los dos emigrados vieneses, Schindler y Neutra, que fueron sus maestros, no sólo no entraron en conflicto con el pensamiento arquitectónico de la época, sino que resultaron decisivos en su evolución.

Harris reivindicaba en este texto el papel de California como germen de una modernidad arquitectónica norteamericana, un papel que no comenzó a ser reconocido, precisamente hasta después de la Segunda Guerra Mundial, cuando los editores europeos comenzaron a prestar atención a lo que había ocurrido en la Costa Oeste, sin pasar por el filtro de los críticos del Este, quienes, en el fondo, siempre vieron la arquitectura californiana como una extraña anomalía regional que tarde o temprano acabaría por aceptar el canon moderno.

Pero, como tantos otros arquitectos californianos, Harris nunca aceptó la modernidad dogmática, menos aún entendida como un repertorio de formas o técnicas, todo lo contrario, abrió su investigación a una exploración desde la especificidad de lo local a lo universal. La vanguardia de Harris es reconocible en la audacia de sus respuestas al lugar, en lo innovador de sus premisas de implantación, en la simplificación de la complejidad del programa doméstico, en la acertada manipulación de la luz natural para definir el carácter de los espacios o en su impecable diseño estructural y, en conjunto, su obra, reticente a los códigos formales, trata de huir de gestos $u$ alardes compositivos que pudieran acabar interfiriendo en la vida del usuario, el auténtico protagonista de su arquitectura.

Para el carácter contemplativo de Harris, el boom económico de la posguerra y la transformación del paisaje del Sur de California en un proceso de expansión suburbana descontrolado debió resultar una realidad incómoda. Los rápidos cambios socioeconómicos y del gusto operados por una cultura de masas dificultaron su acceso a una clientela que ya no compartía los mismos ideales de antes de la guerra. En 1951, aun siendo una celebridad, forzado en parte por la complicación de sus circunstancias laborales, siguió los consejos de su mujer y aceptó el cargo de Director de la Escuela de Ar-
Harris: Mulvihill House en Sierra Madre, California, 1948. Fotografía de Julius Shulman 
quitectura de la Universidad de Texas en Austin, recién escindida de del College of Engineering.

Harris nunca había recibido una enseñanza académica reglada como arquitecto. Cabe recordar que, tras ser admitido en la Universidad de Berkeley en 1928, Richard Neutra le convenció para que desistiera en su idea recibir una formación universitaria y que, en lugar de ello, permaneciera trabajando y aprendiendo junto a él en su estudio. Durante el primer año de su colaboración en el despacho de Neutra, Harris había asistido a clases nocturnas de ingeniería civil en la Frank Wiggins Trade School en Los Ángeles y después de ello no volvió a pisar una institución académica hasta que fue contratado como profesor.

Harris comenzó a enseñar arquitectura en fecha tan temprana como 1933, es decir, pocos meses después de iniciar su práctica profesional en solitario. Desde entonces impartió clases durante más de cuatro décadas en diferentes centros universitarios por todo el país: Los Angeles College of Architecture and Engineering (profesor ayudante, 1933); Chouinard Art Institute (profesor de 1938 a 1940 y en 1944); University of Southern California School of Architecture (cursos de verano de 1940 y 1942 y profesor de 1946 a 1951); UCLA (1942 y 1945); Yale University (profesor visitante, 1951-52); University of Texas, Austin (Director, School of Architecture, 1951-55); Columbia University (profesor adjunto 1960-1962); University of Minnesota (profesor visitante en 1956) critic, 1956); Ball State University (profesor visitante en 1967); y finalmente North Carolina State University, Raleigh (profesor, 1962-75).

En Texas, Harris propuso novedosos programas de estudios con los que trasmitió lo mejor de sí mismo a sus estudiantes. Les brindó su experiencia involucrándose directamente con ellos en proyectos experimentales como, por ejemplo, el de la House Beautiful Pace Setter House, mostrada en la Texas State Fair de 1954. La labor de Harris al frente de la Escuela de Arquitectura se destacó por su contratación de un profesorado cualificado cuyas ideas chocaron frontalmente con el academicismo heredado de Beaux-Arts que aún imperaba en Texas.

Conocido más tarde como el grupo de los Texas Rangers, entre estos profesores se encontraban Colin Rowe, John Hejduk, Robert Slutsky, Werner Seligmann, y Herbert Hirsche. Sus teorías y modos de enseñanza, así como la intervención de Jean Murray Bangs Harris, acabaron generando tantas tensiones que, incluso, interfirieron en su propia práctica profesional y Harris decidió dimitir en el verano de 1955. Se trasladó entonces a Dallas donde continuó trabajando y adaptando brillantemente su arquitectura californiana a la dureza del clima de Texas. Resultado de estos esfuerzos son sus casas tejanas como la J. Lee Johnson House (1955-56) en Fort Worth; la Ruth Carter Stevenson House (1956); la Seymour Eisenberg House (1957-58) en Dallas; o edificios como el Greenwood Mausoleum en Fort Worth (1956), claramente influido por su trabajo de restauración del National Farmers Bank de Louis Sullivan en Minnesota ese mismo año; el Dallas Trade Mart Court(1958-60); o la First Unitarian Church (1961-63) en Dallas, que dejaron su impacto sobre una generación de jóvenes arquitectos tejanos.

En 1962 Harris aceptó una plaza de profesor en la Universidad de Carolina del Norte en Raleigh, ciudad donde continuó enseñando hasta su retiro en 1973 y donde mantuvo abierto su estudio profesional hasta $1975^{221}$. 


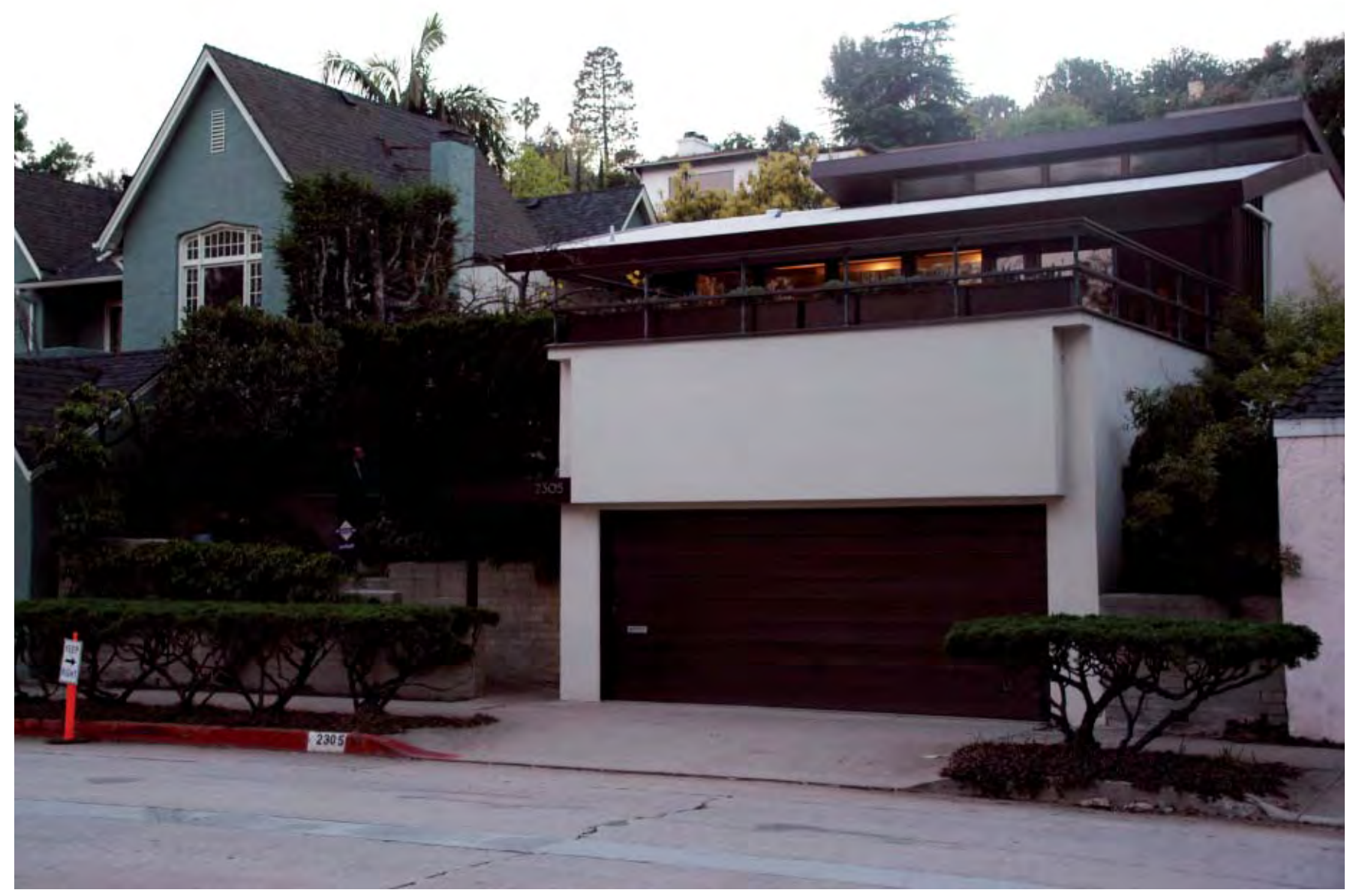

\section{Silver Lake, a modo de recapitulación}

Surgido alrededor de una reserva artificial de agua que da nombre al barrio, Silver Lake es uno de los distritos con mayor personalidad urbana de la ciudad de Los Ángeles. Su núcleo está definido por el área de las colinas que, formando una cubeta natural, descienden hasta el plano del lago. Una atmósfera de particular serenidad domina este enclave habitado, principalmente, por profesionales liberales, artistas, una importante comunidad homosexual $y$, en general, familias de rentas elevadas que integran un vecindario social y culturalmente activo muy consciente del interés e importancia histórica de muchas de las viviendas que salpican sus colinas. De hecho, Silver Lake, junto con los cañones del oeste de la ciudad, Santa Mónica y West Hollywood, alberga una de las principales concentraciones ${ }^{222}$ del patrimonio arquitectónico moderno del área metropolitana de Los Ángeles.

En el verano de 2004, un artículo aparecido en la sección de arquitectura de Los Angeles Times ${ }^{223}$ se hacía eco de una curiosa iniciativa llevada a cabo en este mismo barrio. La experiencia, descrita por el diario angelino -y probablemente sólo imaginable en California-, consistía en un encuentro privado con una excusa arquitectónica que bien podría haber encajado en el guión de alguna de las exitosas series para formato televisivo rodadas en la ciudad. Su artífice, Kirk Nozaki, un joven diseñador de ropa tecnológica deportiva había decidido recorrer diversos barrios de Los Ángeles Ilamando a 31 domicilios diferentes, puerta por puerta, para invitar a sus propietarios, completos desconocidos, a cenar en su casa de Silver Lake. Para su sorpresa -pues temía despertar las más raras sospechas en sus interlocutores-, casi todos ellos, entre los que se encontraban todo tipo de personas, desde jóvenes profesio-
Harris: Hanson House, vista desde la calle Fotografía del autor 


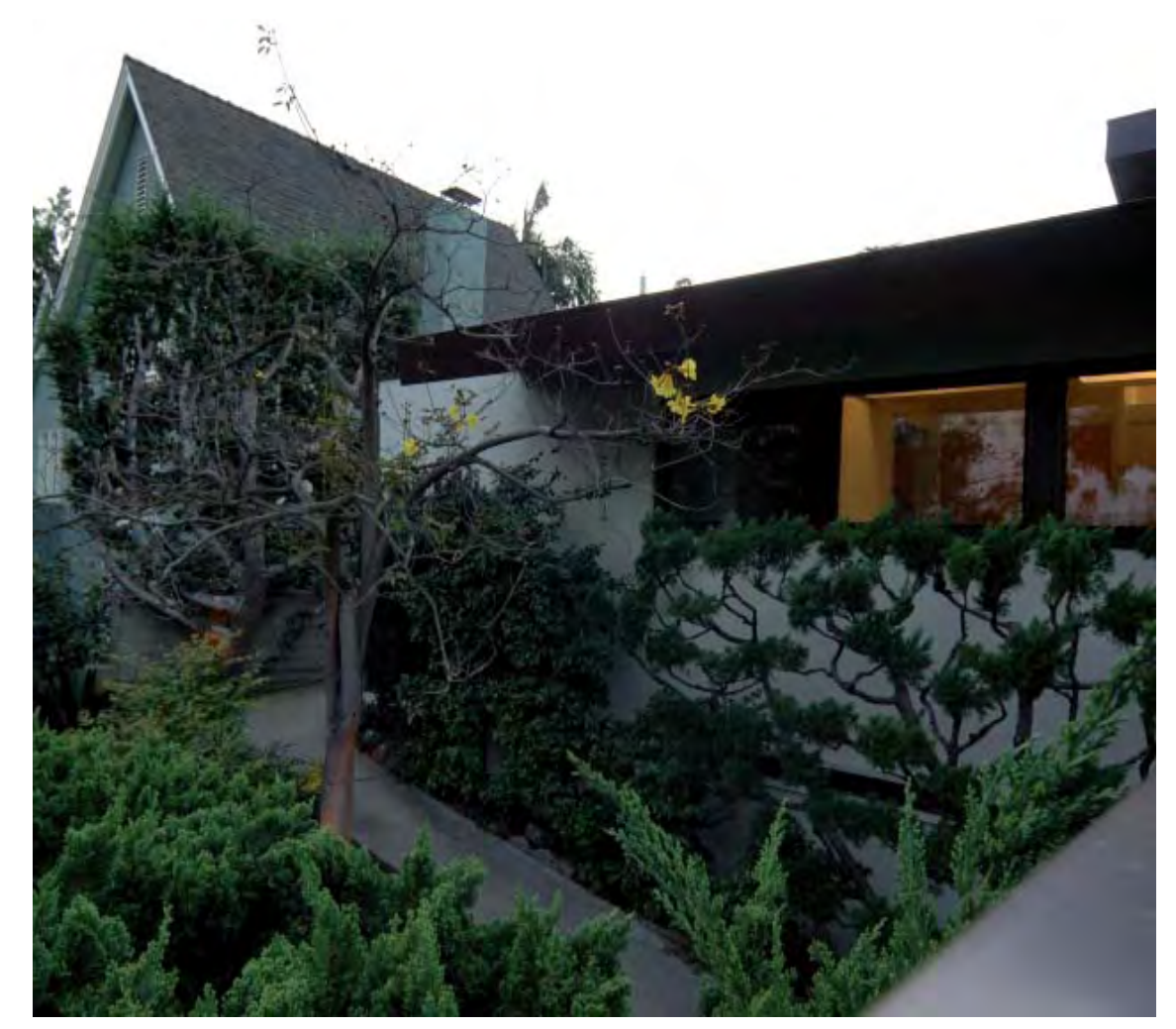

nales solteros, amas de casa, jubilados, un prestigioso juez de San Marino, y así hasta 24 personas más, decidieron aceptar la invitación de Nozaki y acudir a la velada que éste había preparado en su propia casa. Los asistentes a la reunión llevaban etiquetas con sus nombres ya que nunca se habían visto anteriormente. Para romper el hielo, mientras cenaban en la terraza de su casa, el anfitrión sugirió que comenzaran presentándose y hablando de cómo eran sus casas y de cómo vivían en ellas. La idea funcionó y los invitados conectaron inmediatamente porque todos ellos, aunque no lo sabían, compartían al menos una cosa: vivían en casas construidas por Harwell Hamilton Harris.

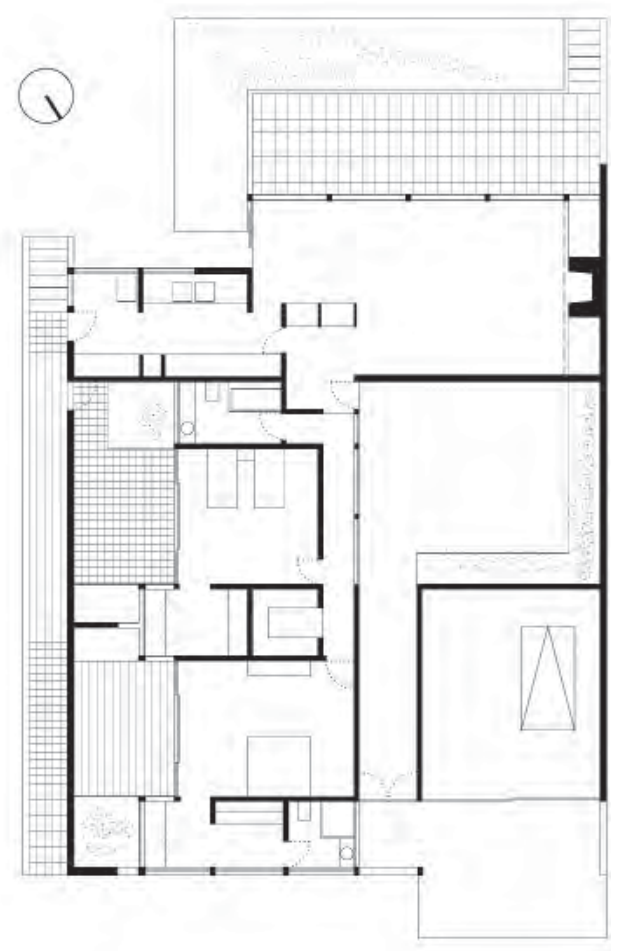

Excepto los clientes originales, muy pocos de ellos habían oído hablar sobre este arquitecto o apenas tenían información sobre su trabajo. Sencillamente habían comprado sus casas porque algo en ellas les había gustado y desde entonces se habían sentido enormemente satisfechos con su decisión.

Kirk Nozaki 224 , norteamericano de ascendencia japonesa, es el propietario actual de la casa Hanson, construida por Harris a principios de los años 50 en el borde occidental del lago, justo enfrente de la VDL House de Richard Neutra, situada en la orilla opuesta. En 1992, antes de comprar la casa, Nozaki no sabía nada sobre arquitectura, mucho menos sobre el arquitecto que cuatro décadas atrás había construido la que sería su futura casa. Adquirió esta vivienda porque le gustaban sus vistas sobre el lago pero, también, porque había algo en sus espacios que le era familiar o, como él mismo diría, que le recordaba a la intimidad de la vivienda y al jardín de sus abuelos en Japón ${ }^{225}$.

La casa Hanson ${ }^{226}$ (1950-51) es una de las últimas residencias particulares que Harris construyó en Los Ángeles poco antes de iniciar el éxodo académico que marcó las últimas décadas de su carrera. Muchas de las actitudes presentes en sus proyectos de los años zo perviven al completarse este ciclo, pero han experimentado una evolución que define el legado del mejor Ha$\square \sqsubset$ rris. Es por tanto una obra de madurez, muy representativa del tipo de arqui- 

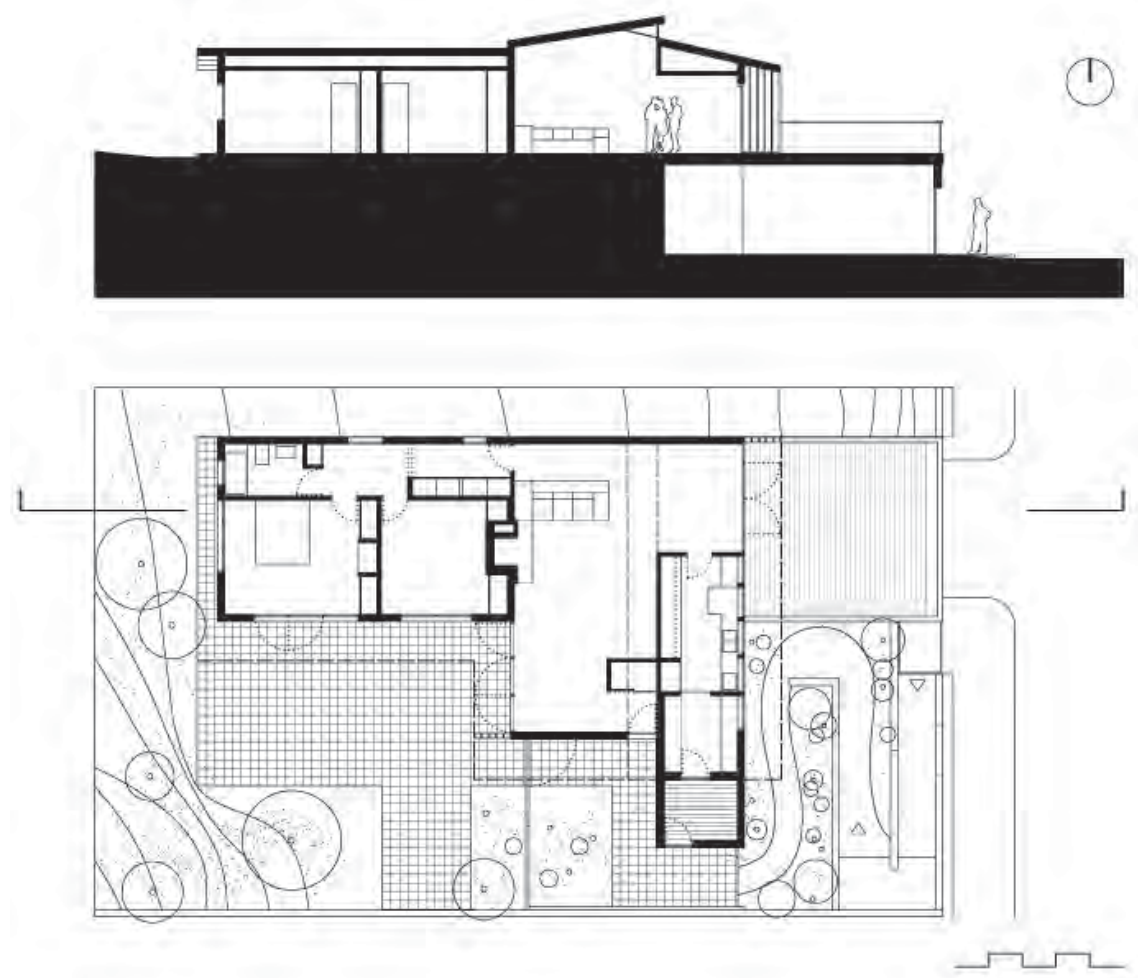

tectura que éste realizaba hacia el final de su etapa californiana: una vivienda modesta, amable y llena de aciertos.

Sin embargo, la casa es una de las viviendas menos conocidas del arquitecto. De hecho, Lisa Germany, únicamente la cita en el listado general de obras con el que cierra su monografía. Charles Moore también la cita en su guía ${ }^{227}$ de arquitectura de Los Ángeles, pero más que tratar sobre la casa, describe brevemente su aspecto exterior, tomando la obra como excusa para ilustrar al lector sobre algunos aspectos muy generales de la arquitectura de Harris. La casa no ha sido todavía suficientemente documentada y junto con la presente recopilación de información, fotografías y documentación gráfica se aportan también planos dibujados a partir de la toma de datos in situ.

Proyectada en 1950 y terminada en 1951, sus propietarios originales, Endicott y Alice Hanson residieron en la casa hasta su muerte a principios de los años 9o, es decir, cuarenta años a lo largo de los cuales apenas si hicieron mínimas reformas. Construida en la primera hilera de viviendas Cottage Revival que bordean la orilla oeste Silver Lake, la casa pasa prácticamente desapercibida, sobre todo porque gran parte de la vivienda permanece oculta tras la vegetación que la protege de las miradas del exterior. Unos planos de estuco blanco, unas bandas de madera oscura y una cuidada tipografía con el número de la vivienda son algunas de las escasas pistas que ofrece la obra desde la calle.

Harris planteó una casa en una sola planta que, elevada sobre la cota de acceso a la parcela, dificulta la visión desde la calle a la vez que consigue altura suficiente para disfrutar de la vista de las colinas al fondo de la orilla oriental del lago. La implantación de la vivienda recuerda la estrategia de proyecto con la que Schindler resolvía la casa Tischler en Bel Air, terminada ese mismo año. Situada en un solar rectangular entre dos propiedades contiguas y caracterizado por un importante desnivel, la casa se ubica perpendicularmente a la pendiente y a la calle. Esta decisión obedece al interés por liberar

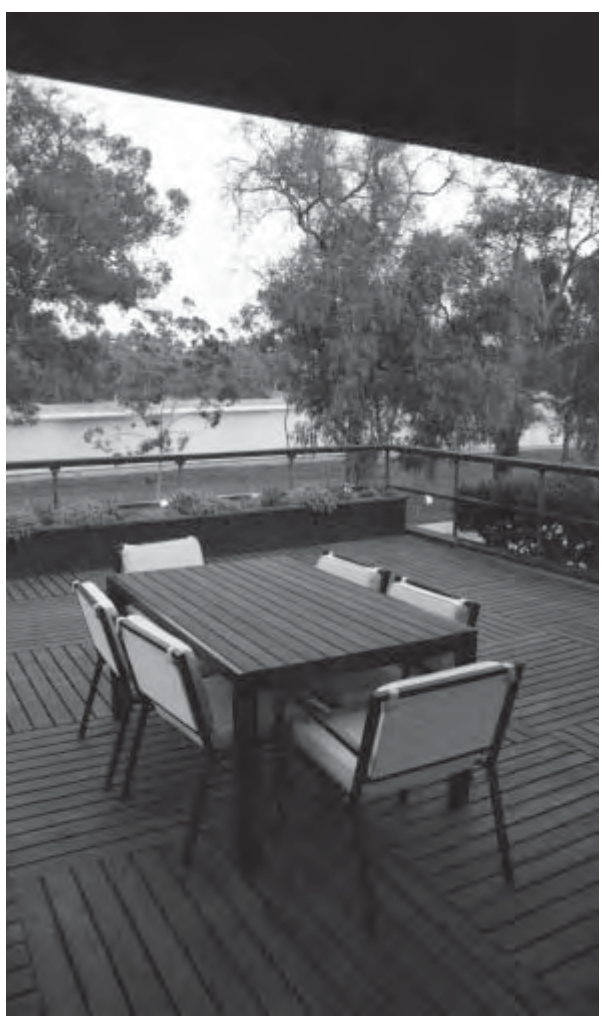

Izda: Hanson House, planta y sección longitudinal. Levantamiento del autor

Decha Hanson House, vista del lago desde la terrazas del estar. Fotografía del autor

Página anterior izda: Harris: planta de la casa para Pauline Lowe, 1934

Página anterior dcha: Hansen House, vista desdel jardín de acceso desde la terraza del estar. Fotografía del autor 

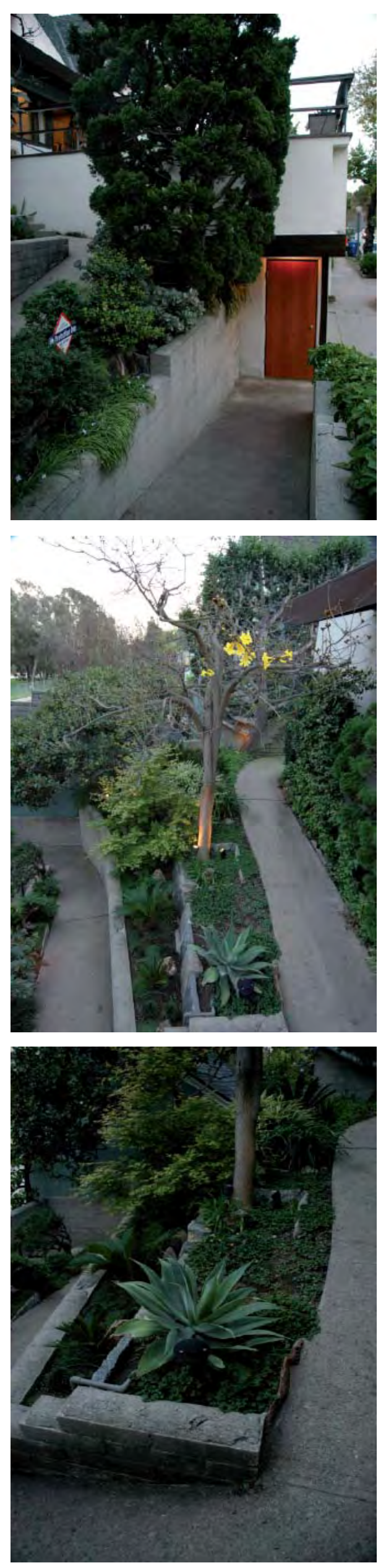

gran parte de la parcela para procurar recintos ajardinados que garanticen la intimidad de las estancias más privadas. A su vez, la vivienda se adosa a la propiedad norte - de la que sólo se separa mediante una estrecha banda ajardinada- permitiendo que los dormitorios disfruten plenamente de la orientación sur.

Desde la carretera que bordea el lago, la casa apenas existe y sólo es identificable el volumen prismático del garaje. Esta pieza es una caja empotrada en la ladera cuya cubierta sirve al arquitecto para generar una amplia terraza frente al lago a la misma cota que el resto de la vivienda. Delimitado por la caja de estuco blanco del garaje y el muro de la propiedad vecina, el resto del frente de la parcela está ocupado por una rampa que asciende zigzagueando hasta el acceso mismo a la vivienda, cuidadosamente oculto desde la calle.

El ingreso en la casa Hanson constituye uno de los accesos más escenográficos de toda la obra de Harris. Recrea el ascenso serpenteante por un exótico jardín japonés que conduce al visitante desde la calle hasta el último filtro previo a la entrada de la vivienda.

Para Harris, escenificar arquitectónicamente la distancia entre la privacidad y la publicidad, entre la intimidad de la vida familiar, la casa, y el exterior, la calle, requería algo más que un muro, un grosor o, incluso, un espacio como el del jardín. Requería tiempo. Como en la arquitectura japonesa, no son los muros los que protegen el interior de exterior, más bien al contrario, se trata de una distancia mental asumida a través de ritos que otorgan a los lugares un sentido diferente. En la casa Hanson el recorrido serpenteante a través del jardín en rampa atravesando las diferentes capas de setos paralelos forma parte de una estudiada secuencia que requiere invertir un cierto tiempo; el necesario para descubrir el arranque del estrecho sendero que conduce al porche de la casa, ascender caminando y, una vez completado el ascenso, rodear la prolongación de la pieza de servicio para encontrarse ante un nuevo patio donde aguardar a ser invitado a entrar.

Este recinto, mitad mineral, mitad vegetal, a medio camino entre lo natural y lo artificial, indefinido también respecto a su condición de interior o exterior a la vivienda, está separado del jardín de los dormitorios por una valla de madera lo suficientemente alta para impedir la visión pero que deja ver las copas de los árboles para enfatizar la sensación de hallarse rodeado completamente por la vegetación. Un último filtro aguarda al visitante tras cruzar el umbral de la puerta, un armario ropero que, como en tantas viviendas de Harris, impide cualquier posibilidad de mirar directamente hacia el interior.

Desde el exterior al interior de la parcela, la claridad de la planta permite explicar la casa como cuatro bandas paralelas a partir de la calle: el jardín en rampa coincidente con la pieza del garaje; la banda integrada por comedorcocina-patio de servicio; el estar propiamente dicho; y, por último, la pieza de los dormitorios que disfruta de su propio jardín. De nuevo todo el sistema de organización deriva del empleo de una cuadrícula basada en el característico módulo 3 pies. Por razones presupuestarias ya argumentadas, esta casa también se construyó con estructura y cerramientos de paneles de madera, material que sólo queda expuesto en los encuentros de la cubierta y en determinados elementos singulares como las carpinterías. Todos los paramentos fueron enfoscados y pintados de blanco. 


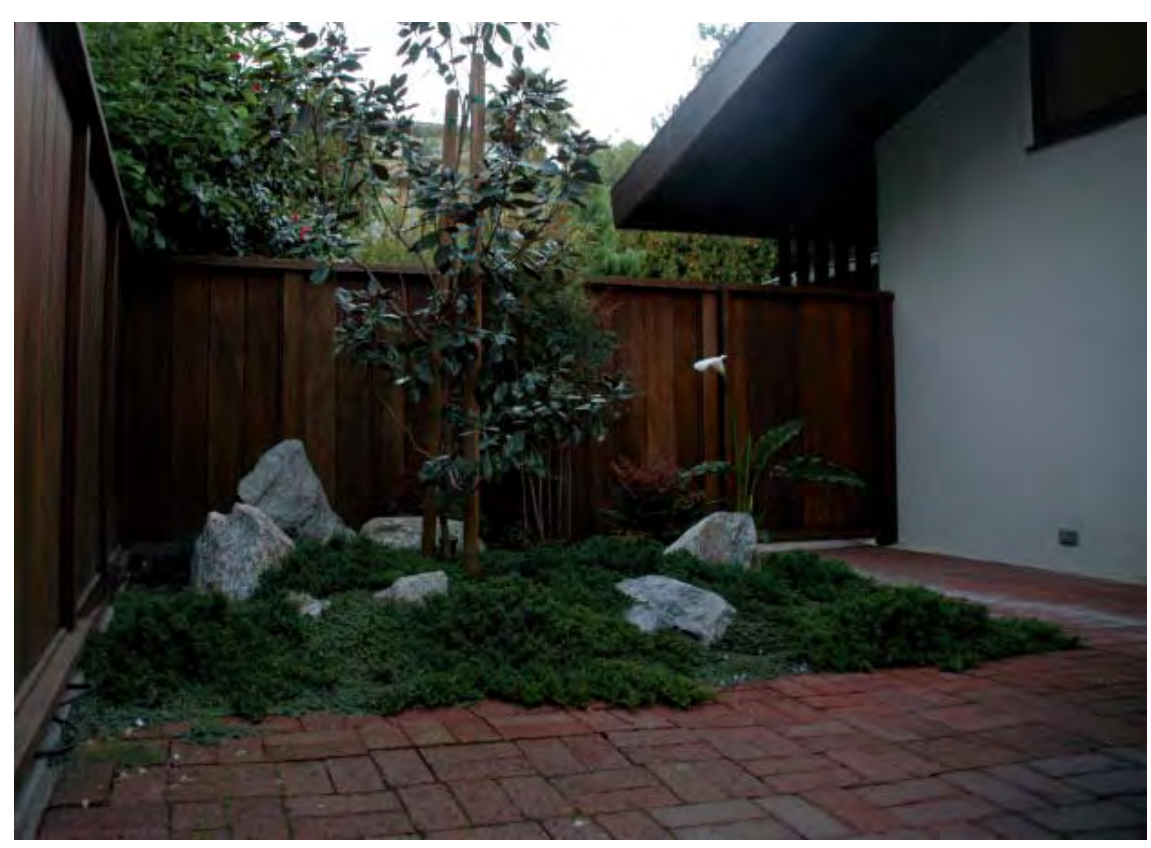

Nozaki se ha esforzado por mantener los acabados originales, tanto en el exterior como en el interior de la vivienda, donde ha restaurado tanto el linóleo del suelo como la encimera de plástico laminado de la cocina, dos de los materiales con los que más le gustaba experimentar a Harris hacia finales de la década de los 40. También los colores de la casa han sido recuperados a partir de la misma paleta de tonos naturales de Harris: blanco al exterior y colores cremas, rosáceos y marrones al interior.

A pesar de ser una de las últimas obras de su etapa californiana, resulta muy ilustrativo comprobar cómo esta casa cumple uno por uno con los nueve puntos de Designing the Small House, el artículo publicado en el número de enero de 1935 de California Arts \& Architecture ${ }^{228}$ y en el que, como se indicó, Harris había enunciado los conceptos básicos de su arquitectura que, en aquel momento, ilustraba igualmente bien su primera vivienda, la casa Lowe:

1. Las estancias no deben servir como vestíbulos. La elaboración de los espacios ajardinados como transición desde la calle hasta la puerta de la vivienda encuentra continuidad tras haber traspasado este umbral. En todas sus casas singulariza la pieza de acceso. En ocasiones se trata de recintos más bajos, incluso de minúsculas cajas, que provocan una compresión espacial previa al ingreso en el área de estar. En el caso de la Hanson House es un elemento interpuesto, el armario ropero, que impide la visión directa del interior desde la entrada de la casa. Harris sostenía que es mejor destinar un poco de superficie a un vestíbulo autónomo que proyectar una sala mayor y acceder a través de ella. Argumentaba que prescindir del vestíbulo era una mala solución que dificulta el uso del espacio interfiriendo en las agrupaciones, suscitaba incómodas afluencias que interrumpían las actividades de la casa y, sobre todo, comprometía la privacidad de sus habitantes.

En este orden de cosas también defendía que dormitorios, estudios o lugares de trabajo tenían que ser fácilmente accesibles desde las zonas comunes de reunión, aunque debían mantenerse desvinculadas de las circulaciones principales para que éstas no perturbaran ni el descanso ni la concentración.

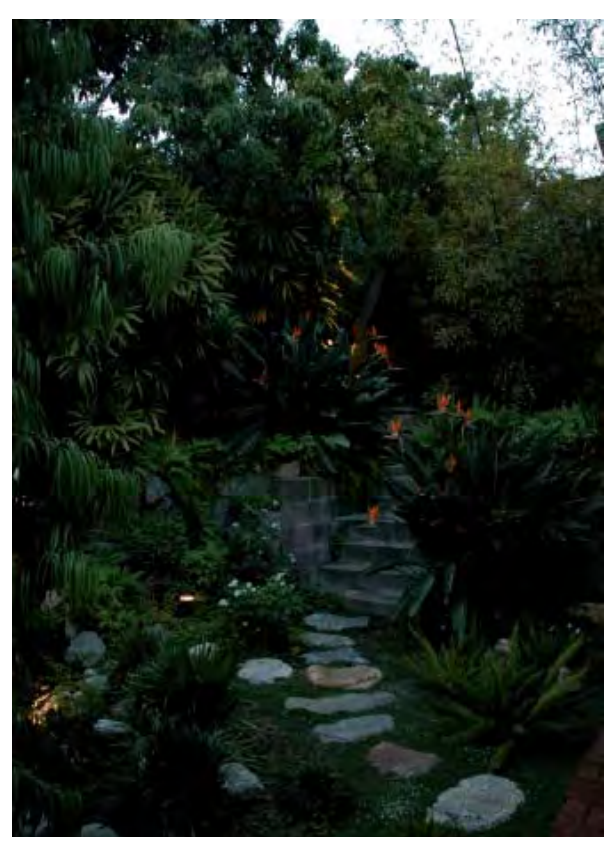

Arriba (izda y dcha) y página anterior: Harris: Hanson House, secuencia de vistas recorriendo la rampa del jardín de acceso a la vivienda. Fotografías del autor 


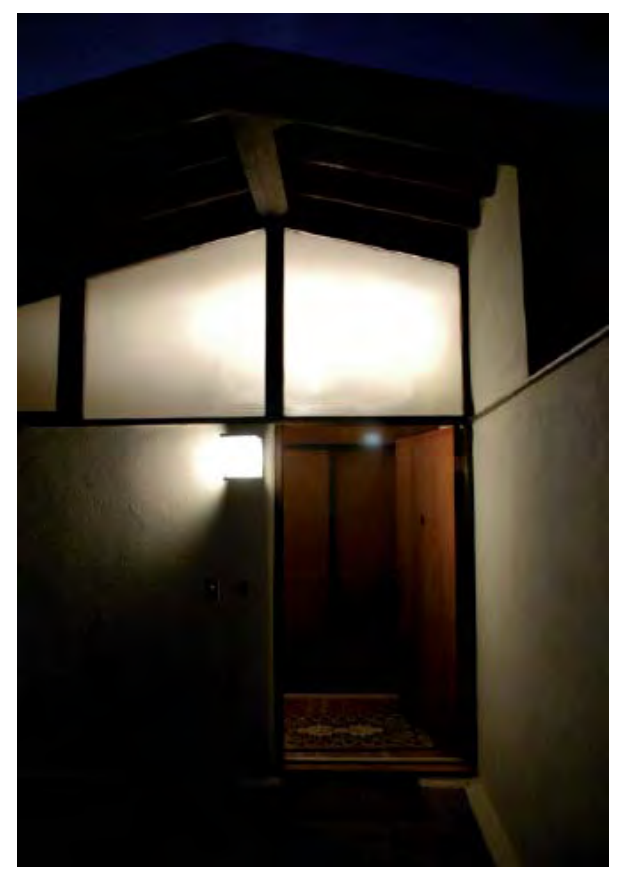

Izquierda: Harris: Hanson House, puerta de acceso a la vivienda.

Centro: Cocina con la vista del lago

Derecha: Distribuidor de los dormitorios con la luminaria oculta. Fotografías del autor

Página siguiente: Detalle de luminaria oculta en las vigas que apoyan las particiones interiores en la vivienda de RMS en Kings Road. Fotografía del autor
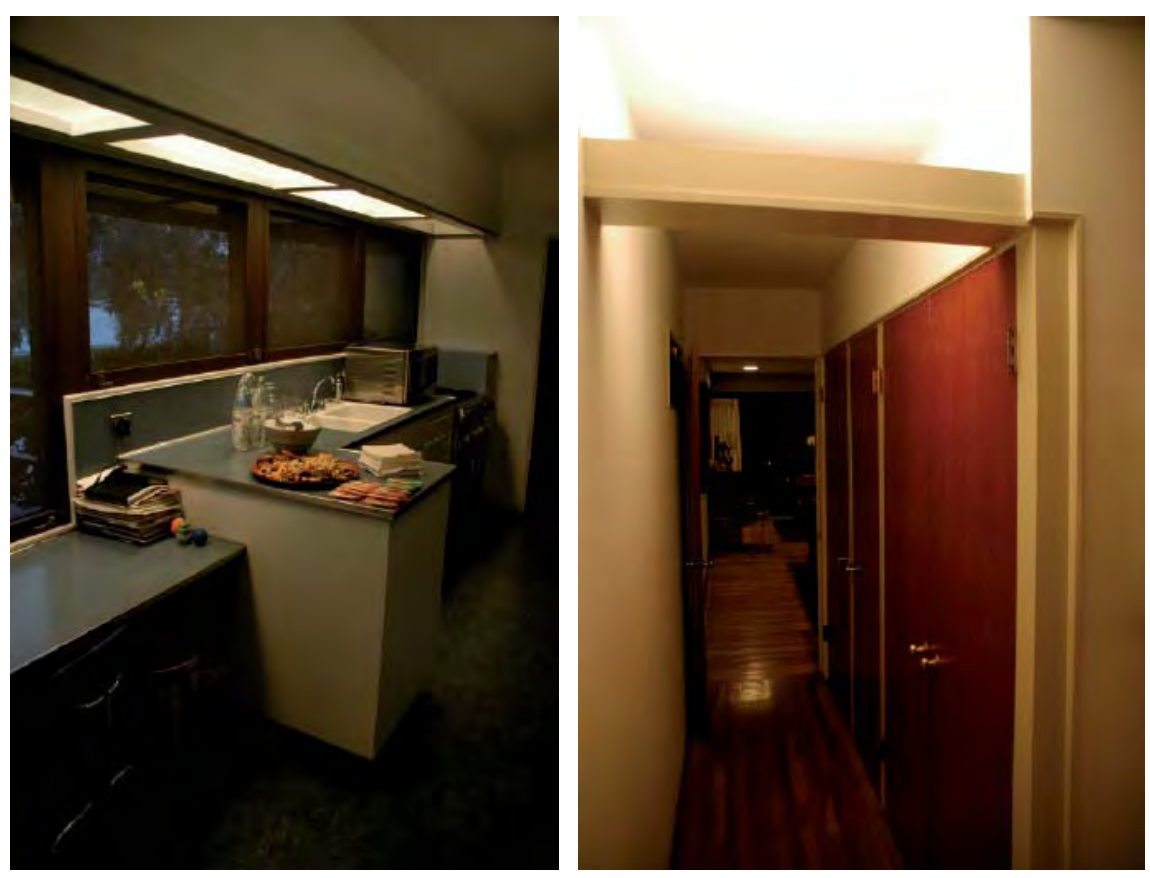

La diferenciación sin concesiones entre el ámbito de lo privado y la dimensión social del programa fue hasta cierto punto consecuencia del carácter introspectivo de Harris. La privacidad se convirtió en una exigencia de todos sus proyectos y sus obras reflejan como una constante su empeño por salvaguardar la intimidad de la vida familiar.

2. Las fuentes de luz generan atracción, especialmente la luz natural. Esta máxima es una consecuencia de su formación artística. El análisis del tipo de iluminación que precisaba cada función se traducía en la adecuada respuesta de los espacios al soleamiento requerido y Harris, con mecanismos muy sencillos, lograba siempre que sus casas disfrutaran relajadamente de la vibrante luz de California.

En la Hanson House, el estar y la cocina se orientan a este, recreándose en las vistas del lago. Los huecos altos de vidrio traslúcido, situados sobre la puerta de acceso, permiten que la luz del sur bañe rasante los techos y se difunda con la inclinación de éstos por el espacio más importante de la casa.

Desde el salón se accede a dos habitaciones atravesando un distribuidor que recibe las tenues luces del norte. A su vez, la geometría de este segundo vestíbulo está apoyada por la iluminación artificial. Escondido en la viga que delimita el paso, un reflector proyecta la luz hacia el plano del techo que el arquitecto libera de lámparas para no complicar la lectura de un recinto tan pequeño. Este recurso, frecuentemente empleado por Harris, es heredero de la estructura de guías y luminarias ocultas ideada por Schindler en Kings Road para flexibilizar las particiones del espacio de su vivienda y, en el caso de la casa Hanson, recordaba también los mismos dispositivos empleados por Gregory Ain en la Orans House de 1941.

El dormitorio y el estudio, sumergidos en la vegetación que aísla de la propiedad vecina se enfrentan al sur y juegan con la ambivalente cualidad de esta orientación. El voladizo de la cubierta protege con su sombra del rigor estival y la franja pavimentada retira convenientemente el jardín de la casa, abriendo camino a la luz del invierno. 


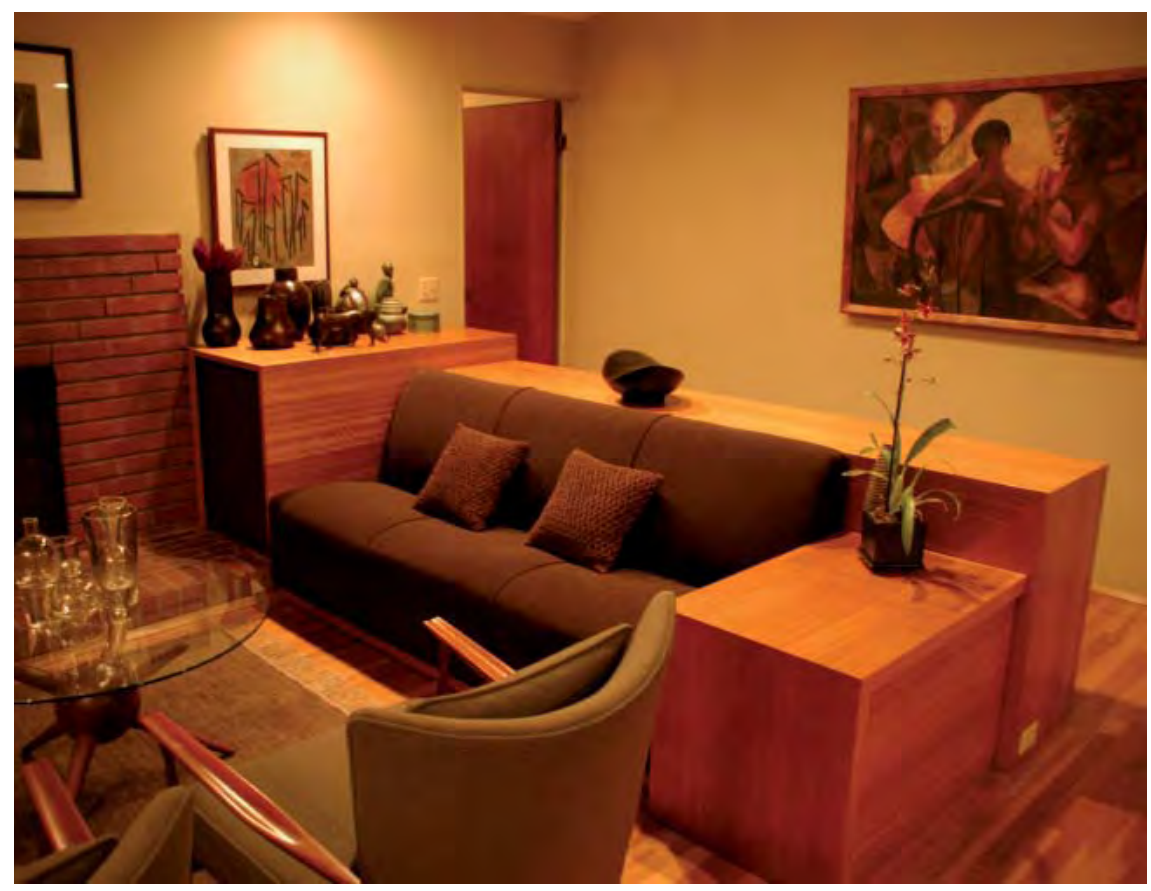

3. No agrupar demasiadas actividades distintas en una misma habitación. Para Harris era preferible reducir el tamaño de un dormitorio y anexionarle espacios diferentes más pequeños como el vestidor, un vestíbulo frente al aseo, etc., ya que, según decía, las relaciones que se establecen entre ellos generan una sensación de expansión mucho más efectiva que si todos estos usos se concentraran en un único espacio.

4. Agrupar todos los huecos. Harris insiste en diferenciar los planos de vidrio de los muros ciegos. Esta máxima tiene que ver con la claridad compositiva, pero su enunciado encierra otra preocupación del arquitecto: el uso óptimo de los espacios cuando se garantiza su facilidad de amueblamiento al disponer de amplias superficies libres donde apoyar enseres.

5. Proyectar los paramentos de cada estancia en función de su superficie. Expresa la necesidad de proporcionar la dimensión de las aberturas y la cota de los techos de acuerdo con el tamaño de cada recinto. En la casa Hanson, la inclinación de la cubierta aumenta la altura del salón significándolo como núcleo social de la vivienda. Luego desciende progresivamente, por un lado hasta el acceso a las habitaciones $y$, en el plano opuesto, hasta el comedor donde el techo más bajo está indicando el espacio que debe ocupar la mesa.

6. Emplear los mismos acabados en todo el proyecto. Por ejemplo, utilizando el mismo pavimento en todas las estancias de la casa. Para Harris, la constante repetición de formas y materiales contribuye a crear un efecto de crecimiento ilimitado, una aparente ausencia de fin que psicológicamente se asocia a una mayor dimensión. En cualquier caso, el empleo de pocos acabados permite abaratar costes $y$, sobre todo, poner en valor las cualidades intrínsecas de cada material.

7. Procurar que las habitaciones tengan al menos una pared completa de vidrio abierta a un jardín. Como si estuviese describiendo la casa Hanson, Harris recomienda que este cerramiento pueda abrirse o incluso retirarse completamente, que el área ajardinada se pavimente en su encuentro con el vidrio, que la cubierta vuele cobijando una distancia de tres pies medidos desde del

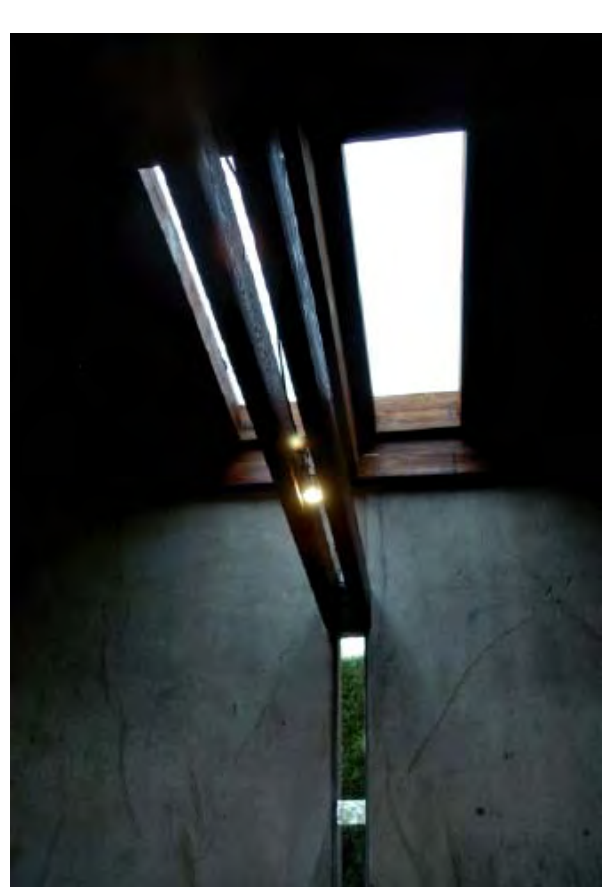




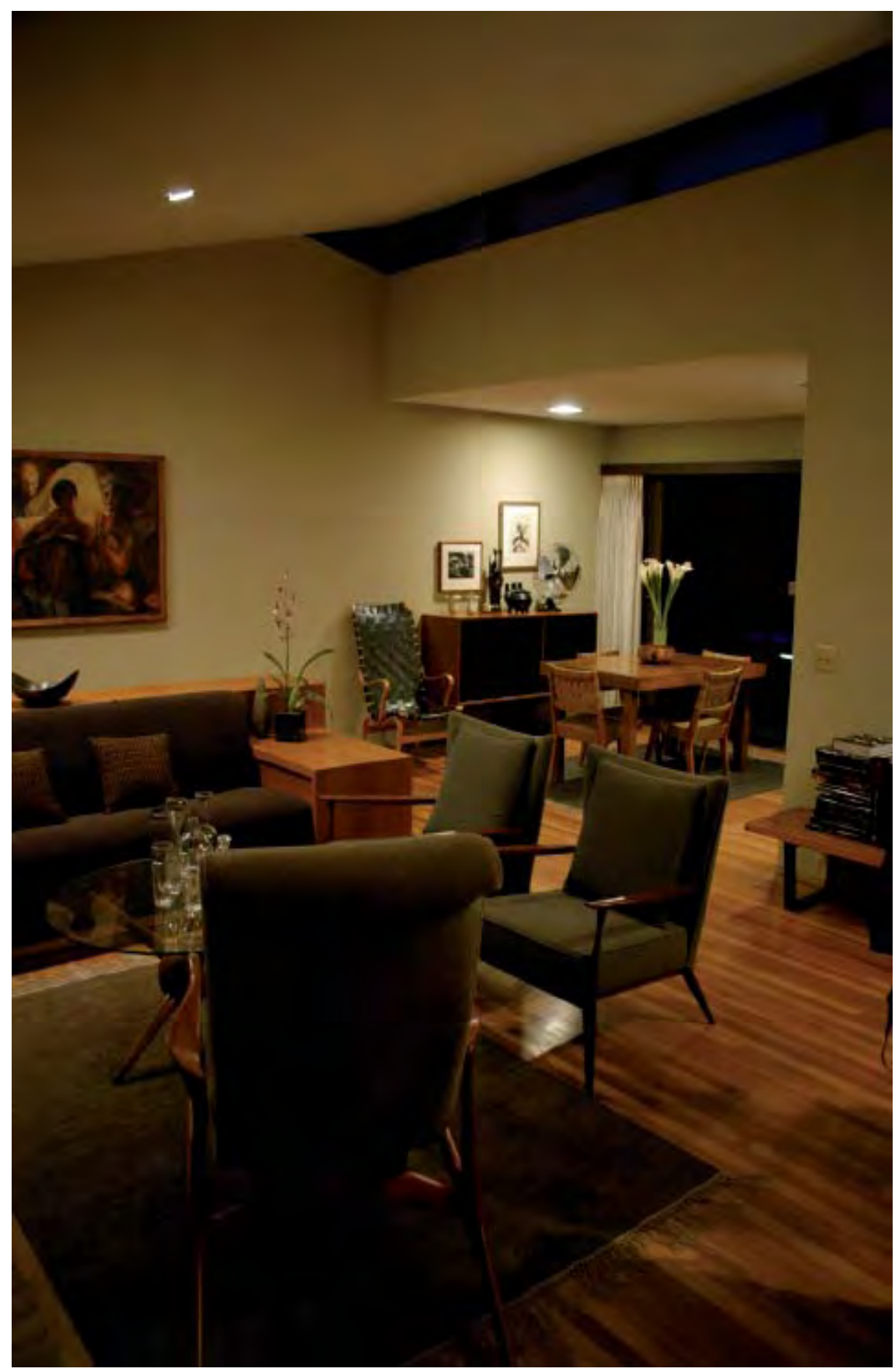

Harris: Hanson House, salón comedor Fotografía del autor

Página siguiente: Vista de la casa desde la terraza del estar. Fotografía del autor muro y que descienda hasta la cota superior de la carpintería para representar que interior y exterior forman parte del mismo espacio.

8. Mantener la línea del mobiliario lo más baja posible. Con esta recomendación, aprendida de Schindler, pretende que los muebles fijos, como librerías o bancos, no obstaculicen la visión del espacio desde una posición sentado.

En esta vivienda, un volumen de madera que incorpora mesas y asientos gravita junto a la chimenea posicionando el hogar, el fireplace. El sistema de un mobiliario más o menos permanente para delimitar el hogar se encuantra en numerosos proyectos de Harris como las casas Birtcher en Los Ángeles o Lodewijk en La Jolla, ambas de 1941. Con este diseño el arquitecto propone una organización eficiente del espacio y da pistas a los futuros usuarios de la vivienda a los que sugiere introducir pocas piezas, ligeras y fáciles de desplazar, recordando que los espacios son para las personas y no para los muebles. 


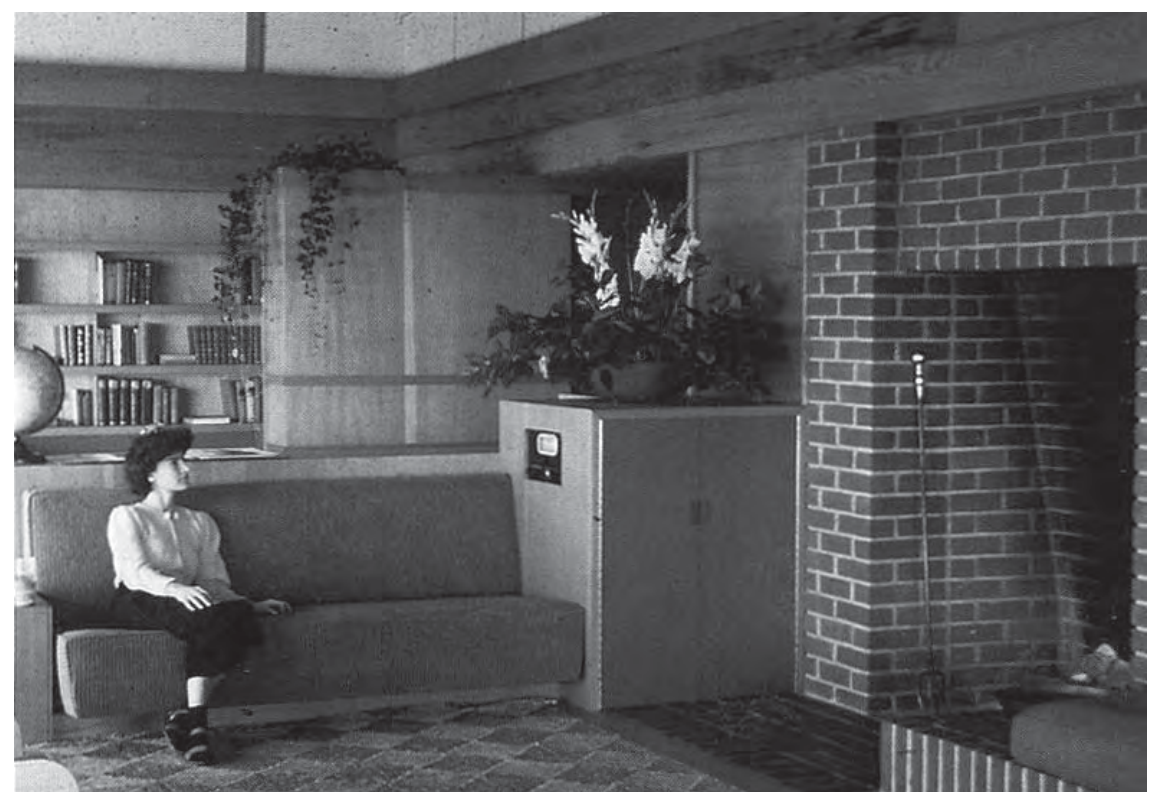

9. No proyectar la casa como una caja que se ha dividido en compartimentos distintos sino, todo lo contrario, como un añadido de espacios parcialmente autónomos que pueden ir abriéndose unos sobre otros. Este último punto incide en su defensa del diseño modular y de las estrategias de crecimiento aditivo que se han comentado a lo largo de este capítulo. Por otra parte, con esta declaración Harris estaba criticando implícitamente la carga objetual de muchas viviendas del estilo internacional que, por concepto, prescindían de un sistema de crecimiento orgánico.

Precisamente, es en esta organicidad de la obra de Harris en la que articula Bruno Zevi su defensa del arquitecto cuando, en el prólogo al libro de Lisa Germany, enunciaba como sus principales valores: "la supremacía del espacio; la fragmentación de volúmenes; la emancipación de las reglas; la especificidad de cada proyecto; y la mutabilidad y conflictos de su arquitectura" ${ }^{\prime 22}$.

En definitiva, frente al objeto formal y acabado de la primera modernidad internacional, el arquitecto propone un sistema de relaciones espaciales y fenomenológicas complejo que permita la adaptabilidad del proyecto a la vida que acontece en el interior: un crecimiento de dentro a fuera, resolviendo problemas cotidianos y despreocupado de su carácter representativo. Para Harris, la arquitectura debe sustentar, facilitar la vida, sugerir modos de apropiación del espacio a sus habitantes, nunca imponerse a ellos.

Harris tomó lo mejor de la modernidad europea, pero la hizo comprensible al público americano. El logro de Harris es haber asimilado en su obra muchas de las herramientas proyectuales de Neutra como los trazados modulares, la información acerca de la última tecnología disponible, el paisajismo, etc. y haberlos incorporado a la herencia de las tradiciones californianas relativas a una concepción orgánica del espacio y a una vinculación a determinados materiales locales.

Y, por supuesto, como los hermanos Greene, Wrigth, Schindler y, en general, tantos otros arquitectos californianos de su generación, Harris sentía auténtica fascinación por todo lo japonés. Su obra se nutrió, maduró y fue haciéndose cada vez más personal a través de la reinterpretación de todo tipo de influencias de la arquitectura japonesa: la simplicidad y delicadeza de sus estructuras de madera, la sutileza y contención de sus relaciones

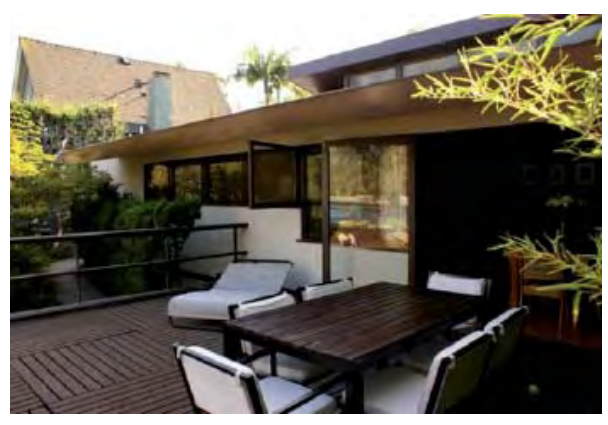




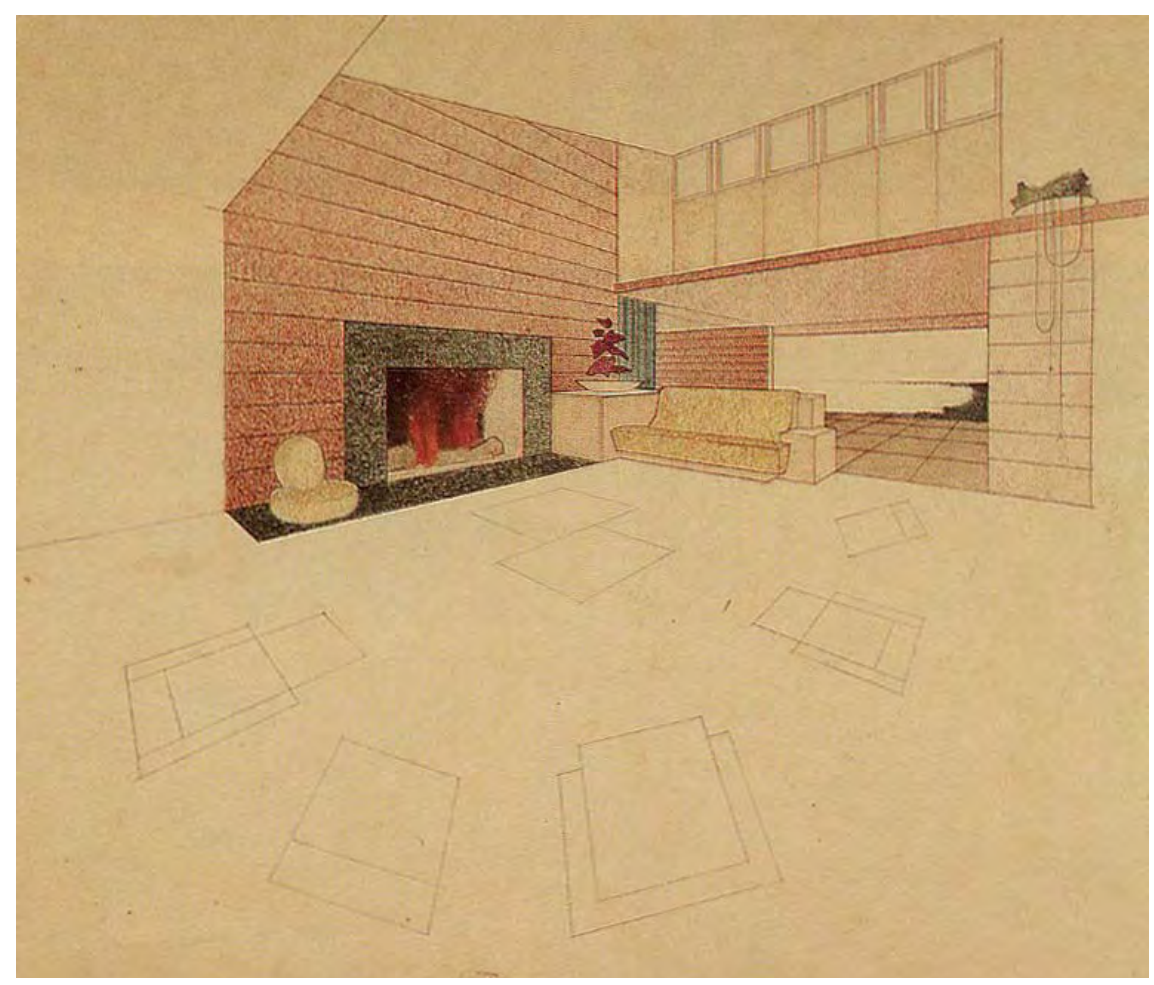

espaciales, la sensibilidad paisajística, la importancia funcional y casi ceremonial del mobiliario y de los objetos (como puede apreciarse en el tratamiento de los suelos o de los paramentos verticales del hogar, inspirados, respectivamente en el tatami y el tokonoma japoneses ${ }^{230}$ ), etc.

Autores como Robert Winter, David Gebhard o Charles Moore, coinciden con Germany al afirmar que Harris entendió el uso de la madera en la arquitectura japonesa mucho mejor que ningún otro arquitectos californiano a excepción de los hermanos Greene. Winter y Gebhard, por su parte, sostienen también que, como consecuencia de su entendimiento de las tradiciones arquitectónicas japonesas, Harris dominó los sistemas modulares mejor incluso que Frank Lloyd Wright.

La interpretación de Harris de la modernidad está llena de matices que, aunque en ocasiones dificultaran la instantánea publicitaria, la imagen fácil de empaquetar, reproducir y vender, sin embargo, resultaron extraordinariamente efectivos a la hora de facilitar la vida a sus clientes. Los valores de la obra de Harris a los que hacía referencia Zevi (supremacía del espacio, libertad frente a las reglas, especificidad de cada proyecto, mutabilidad...) resultaron claves ante la necesidad de resolver cualquier contingencia sin que por ello sus obras perdieran interés. Por ejemplo, cuando los bancos o las normativas locales impedían la financiación o las licencias a sus viviendas por considerar algunas propuestas, acabados o detalles demasiado arriesgados -algo muy habitual en los años 30 y 40 en California, donde tanto las compañías de crédito, las aseguradoras y las administraciones públicas miraban con auténtico recelo la arquitectura moderna-, Harris podía cambiar la forma de una cubierta, su inclinación o el acabado de un determinado elemento del proyecto sin alterar por ello su esencia ${ }^{231}$. Como él mismo bromeaba acerca de su Pauline Lowe House, los revestimientos de madera de secuoya fueron elección del cliente, la cubierta inclinada le vino impuesta por el banco, las circulaciones eran herencia directa de Frank Lloyd Wright, el sistema de fenestración una influencia de la arquitectura japonesa, y la geometría en forma de $L$ de la planta una decisión suya ${ }^{232}$. 


\footnotetext{
[ RICHARD NEUTRA Y LA IDEALIZACIÓN PUBLICITARIA DE LA TECNOLOGIA EN AMERICA

CHARWELL HAMILTON HARRIS EN CALIFORNIA

[ GORDON DRAKE: NO MAN IS AN ISLAND ] ...
} 


\section{Una estrella fugaz (1946-1952)}

Al terminar la Segunda Guerra Mundial, en los apenas siete años que duró su actividad profesional tras regresar del frente, Gordon Drake apenas construyó una decena de obras, de las cuales, la última, ni siquiera pudo verla terminada. No obstante, la obtención de dos galardones en convocatorias nacionales promovidas por dos de las revistas de arquitectura más leídas del momento -tanto en la esfera de la cultura arquitectónica, Progressive Architecture (P/A), como en la de la cultura popular House and Gardens (H\&G)- le valieron el suficiente reconocimiento público para que, gracias una inteligente y efectiva campaña de difusión internacional orquestada por el propio Julius Shulman, su obra quedara fijada en el imaginario arquitectónico de posguerra.

Hoy Gordon Drake es una de las figuras olvidadas de su generación, pero su prolífica carrera como arquitecto, a pesar de su brevedad, dejó una profunda huella en el trabajo de muchos de sus contemporáneos, como puede apreciarse en el espíritu de muchas de las realizaciones de Quincy Jones de principios de los años 50 o, como varias de las casas de Craig Ellwood, planteadas alrededor de patios y jardines delimitados por una combinación de elementos modulares y masas vegetales.

En 1996, en uno de los escasos textos críticos publicados sobre Drake desde su prematura desaparición, el crítico británico Neil Jackson afirmaba en las páginas de Architectural Review "Si Gordon Drake no hubiera muerto a la edad de 35 años mientras esquiaba en Sierra Mountains habría llegado a ser uno de los grandes nombres de la arquitectura californiana de posguerra" ${ }^{\prime 233}$.

Pese a su juventud y al hecho de que ni siquiera hubiera tenido tiempo para obtener el título oficial de arquitecto ${ }^{234}$, la confluencia en la obra de Drake de un inusitado interés por la dimensión social de la arquitectura, la tecnología y los medios de comunicación de posguerra, así como de un amplio conocimiento de las particularidades del paisaje, la cultura material y el estilo de vida californianos, cimentaron la promesa de una carrera brillante cuyas posibilidades quedaron frustradas un fatal accidente que acabó con su vida a principios de 1952 .

Nacido en Childress, Texas, en marzo de 1917, justo tres semanas antes de que su país entrara en la Primera Guerra Mundial, su padre fue destinado al frente y su madre se trasladó con el resto de la familia a Fresno, California. Más tarde volverían a mudarse a Los Ángeles y San Diego. Su hermano Max, diez años mayor, se había alistado en la marina y, estando destinado en Hawaii, Gordon pasó varios meses con él tras terminar el instituto. Allí, con 19 años, decidió seguir la tradición familiar de entrar en el ejército y, al mismo tiempo, compaginar esta vocación con el estudio de una carrera técnica.

En 1937 Drake se matriculó en la Escuela de Arquitectura de la Universidad del Sur de California (USC), donde estudió bajo la dirección del arquitecto sueco Carl Troedsson, con quien también colaboró en su oficina. Ese mismo año proyectó ya una casa para su hermano Max en Coronado, San Diego, que sería construida poco más tarde. La obra ("House in Coronado") consiguió una mención en la convocatoria anual Art Appoliad de su Universidad y fue exhibida en la Fisher Gallery del Campus de la USC, justo antes de conocer a Harwell Hamilton Harris en los cursos de verano de la Escuela de Arquitectura 235 .
Gordon Drake en 1946. Fotografía de Julius Shulman

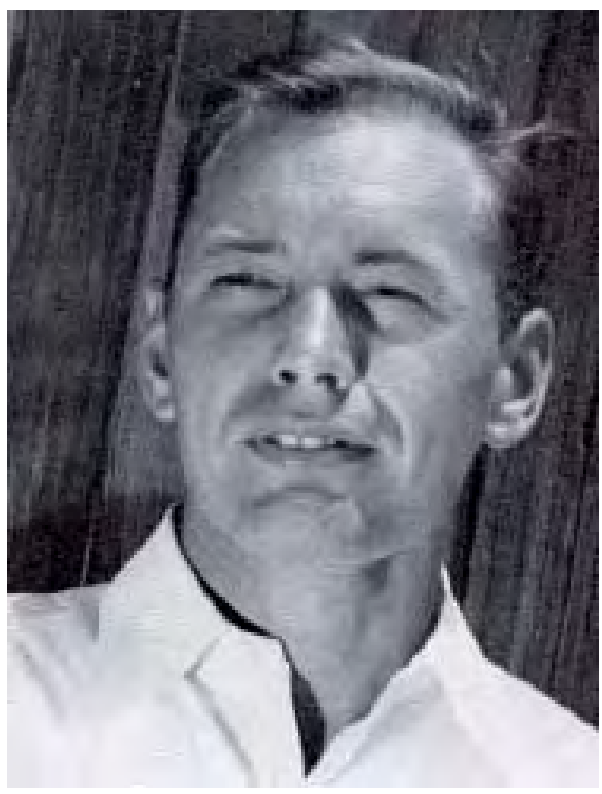




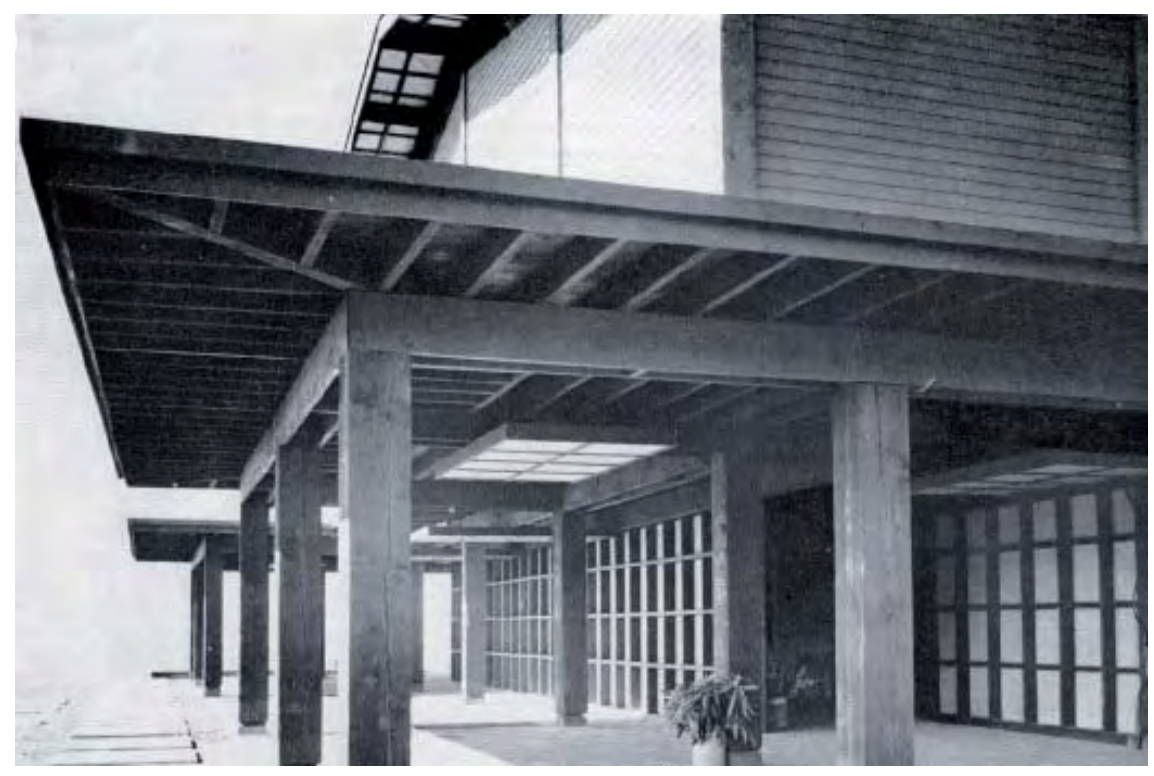

El descubrimiento del trabajo de Harris, en cuyo despacho estuvo colaborando durante los meses anteriores y posteriores a la Segunda Guerra Mundial, fue toda una revelación para Drake. Harris le introdujo en la esfera de la modernidad internacional y, al mismo tiempo, le descubrió la esencia de un pensamiento local, libre de prejuicios, vinculado al paisaje y estilo de vida californianos y capaz de asimilar e incorporar lo mejor de las diferentes tradiciones arquitectónicas que, desde Europa a Japón, habían ido dejando su impronta en California.

Como apuntaba el propio Gordon Drake en uno de sus escritos más tempranos, el principal hecho en la formación y desarrollo de la arquitectura doméstica californiana fue la ausencia de una estricta tradición formal ${ }^{236}$. Es sintomático que su aseveración, casi palabra por palabra, fuera suscrita completamente por su mentor cuando, como se ha visto en el capítulo dedicado a Harris, pocos años más tarde, en 1954, éste definiera el concepto de regionalismo de la liberación ${ }^{237}$ por oposición al academicismo y a la ortodoxia de la Costa Este, afirmando, como Drake, que el rasgo más distintivo de la auténtica arquitectura moderna californiana era el haber calado en un lugar donde la falta de una estricta tradición formal y la existencia de un regionalismo en formación permitió a las ideas europeas ser asimiladas sin prejuicios y reinterpretadas con libertad creando una idiosincrática modernidad local.

En 1941 Drake contrajo matrimonio y, pocos meses después de la entrada de los Estados Unidos en la contienda mundial fue movilizado en San Diego y, más tarde en Hawaii, en una unidad de ingenieros de la marina. Durante su etapa en el frente conoció a Louis Soltanoff, un ingeniero y comandante de aproximadamente su edad con quien hizo amistad y con quien se asociaría años después en Los Ángeles para construir y firmar sus viviendas. El interludio de la guerra le hizo sentir como nunca antes su vocación como arqui-

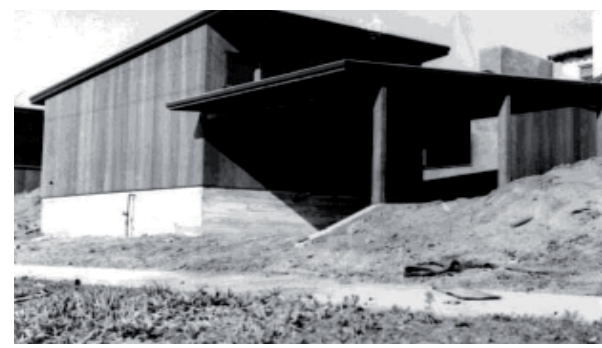
tecto. En Hawaii, Drake y Soltanoff organizaron un grupo de marines para construir barracones y edificios militares. La rapidez, precisión y economía de medios impuesta por el ejército en las estructuras que les fueron encomendadas entrenaron las habilidades de Drake como proyectista, ejecutor y project manager. Su versatilidad y talento en la gestión de recursos materiales y humanos tuvo como prueba de fuego, pocos meses antes de regresar a Los Ángeles, la construcción de un teatro y centro de ocio para los soldados destacados en la isla de Maui. La marina puso a disposición de Drake tantos 


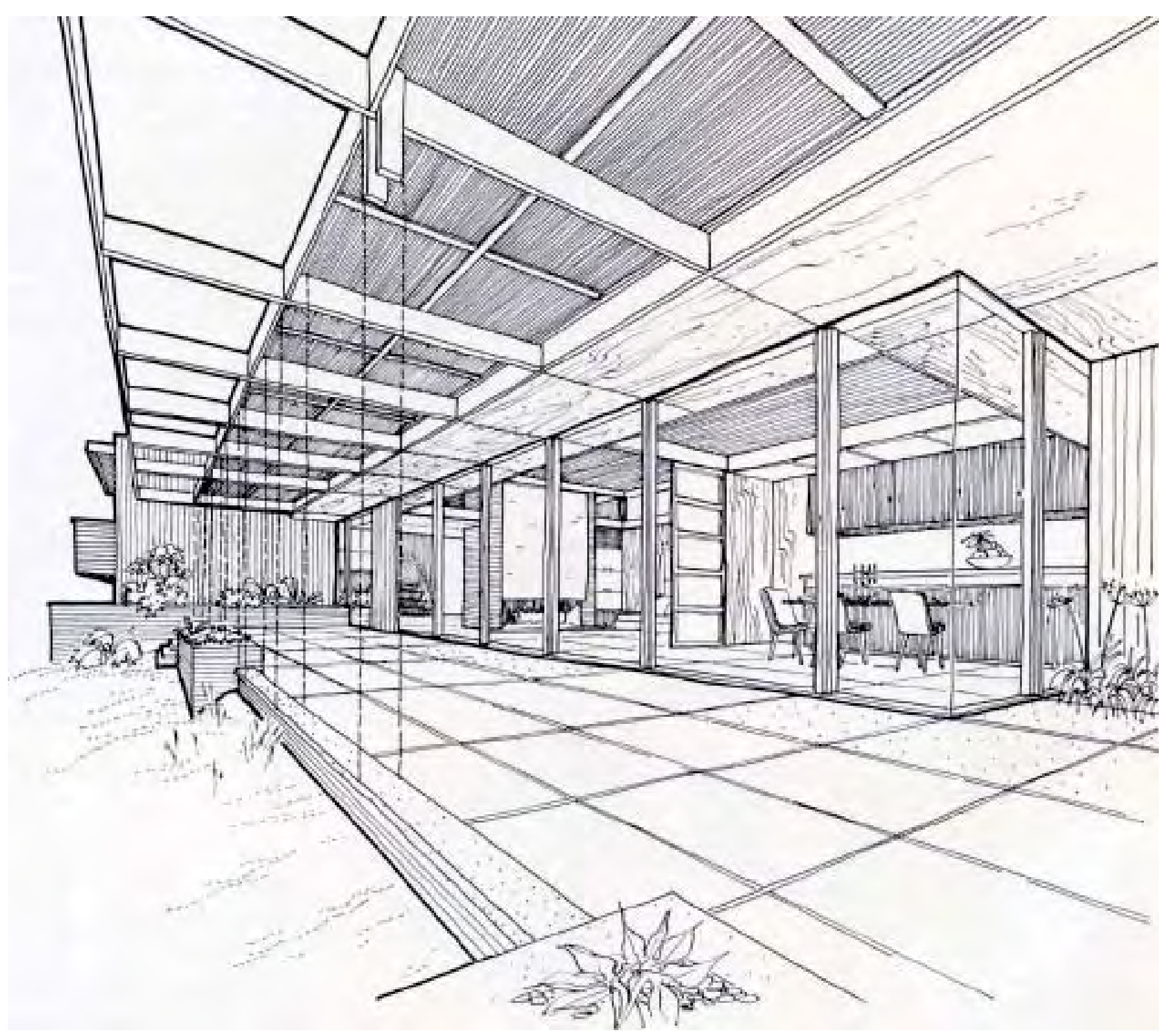

hombres y maquinaria como fuera necesario. La única condición era que el proyecto y la obra debían realizarse en un tiempo record. Veintiún días exactamente después del encargo, el teatro fue abierto al público.

Durante los años que duró la contienda, en mitad del Pacífico, su deseo de regresar a Los Ángeles fue acrecentándose, como atestiguan las cartas a su familia y a su mentor localizadas en el archivo de la Universidad de Berkeley. Los años destinado en las islas le hicieron reflexionar acerca de la idea del hogar y sobre las cualidades del paisaje que había dejado atrás, una añoranza que tuvo que resultar decisiva en el entendimiento del medio físico, pero también del contexto socioeconómico, al que regresaba. Con el final de la guerra, Drake sentía que el principal reto al que debía hacer frente la arquitectura era el alojamiento de los cientos de jóvenes y veteranos que regresaban del frente. Muchos de aquellos jóvenes irían en busca de trabajo a California, el paraíso de las oportunidades, y ciudades como Los Ángeles o San Diego debían prepararse para este nuevo fenómeno migratorio. Tras servir en primera línea, el deseo de forjar un hogar en aquel lugar donde abundaba el trabajo fue una necesidad que él, como soldado, experimentó en primera persona.

Gordon Drake, dibujos para una vivienda en el Medio Oeste realizados por encargo de un arquitecto de Michigan durante su etapa de estudiante. La precisión en la definición estructural apunta el futuro interés de Drake por las estructuras de madera. Douglas y Mary Baylis Papers, California Houses of Gordon Drake, University of Berkeley Archives (en adelante Baylis).

Página anterior arriba: Drake: Teatro y sala multiusos para los marines destacados en Hawaii, Maui, 1944. Baylis

Página anterior abajo: Drake: Vivienda en Coronado, San Diego, para su hermano, 1939. Cortesía de Gordon Converse H. Drake, sobrino nieto del arquitecto 


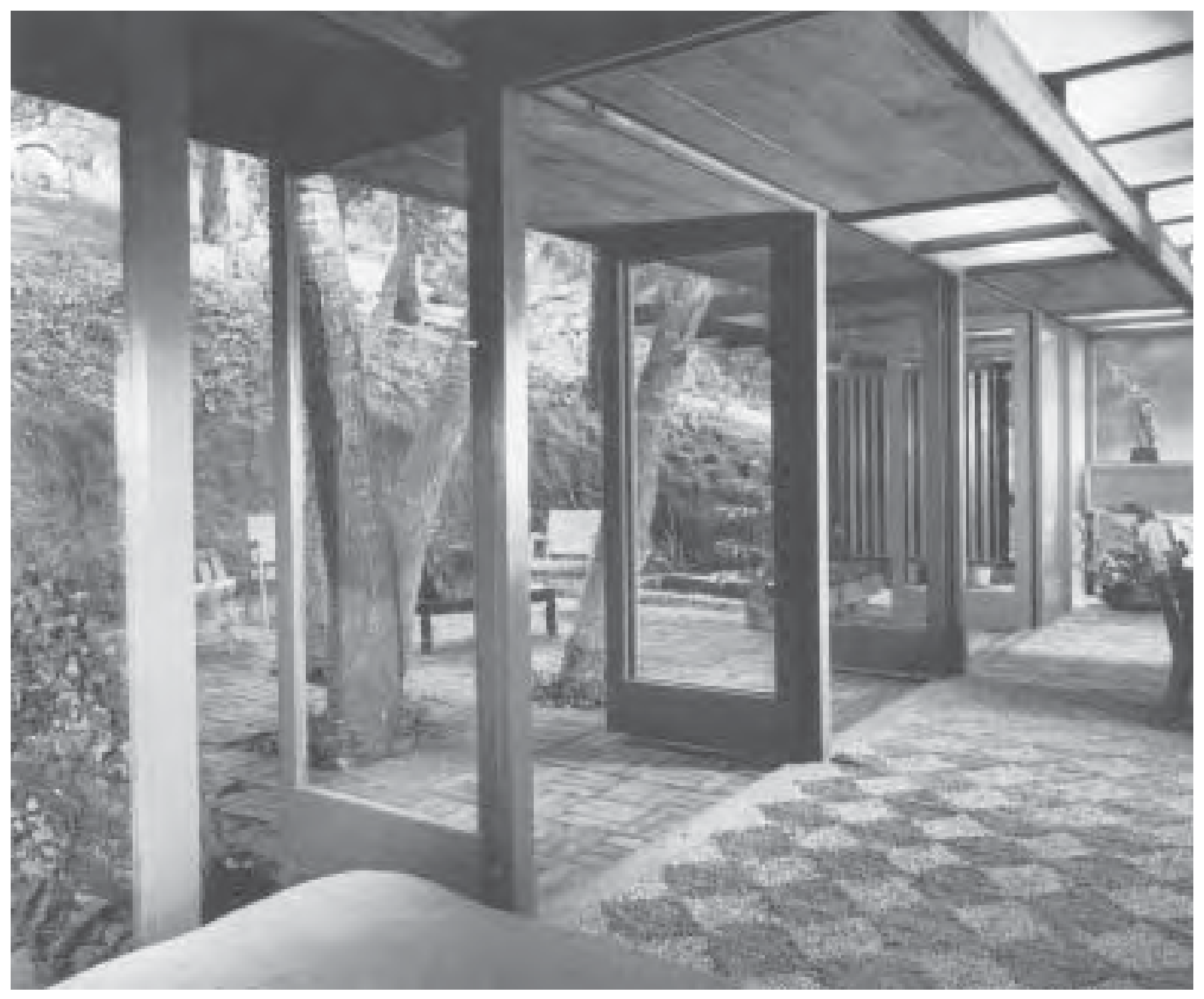

En una de esas cartas enviada a su madre en 1941 el joven e idealista Drake afirmaba: "De algún modo siento que algún día seré un buen arquitecto y que, gracias a mi trabajo, mucha gente pasará de malvivir en tristes suburbios a disfrutar del verdor de la hierba bajo el sol, la sombra de los árboles, la brisa fresca y el azul de un cielo perfecto... siento que llegará mi momento, que un día escribiré libros y tendré discípulos". Tenía entonces sólo diez años por delante para cumplir su sueño.

Hablar de Gordon Drake implica necesariamente retomar una de las cuestiones sobre las que se ha tratado en esta tesis: la celebridad de los arquitectos, los procesos, avatares, y razones por las que algunos autores alcanzan mayor notoriedad y capacidad de influenciar a otros. En el caso de Drake, su fama fue considerable y el hecho que su obra haya sido olvidada estaría más relacionada con su repentina desaparición que con cambios de criterios o de gusto en las políticas editoriales.

Gordon Drake experimentó en primera persona las ventajas y desventajas de haber alcanzado una temprana fama, atrayendo sobre él todo el interés de los medios de la época. En 1946, ganó con su propia casa el Primer Premio del concurso de proyectos convocado por la revista Progressive Architecture (Progressive Architecture's First Annual Award). Un año después, con sus dos siguientes obras, obtuvo el segundo de los Premios de Arquitectura conce- 
didos por la revista House \& Gardens y una Mención en la segunda de las convocatorias anuales de Progressive Architecture (Progressive Architecture's Second Annual Award). Fotografiada con destreza por Julius Shulman y publicitada incesantemente en algunas de las revistas más prestigiosas y de mayor tirada en los Estados Unidos y en Europa, como Progressive Architecture o L'Architecture d'Aujourd'hui, su propia casa en Beverly Glen fue durante finales de los años 40 y primeros 50 un icono de la arquitectura californiana y una de las obras que más influyó sobre toda una generación de jóvenes arquitectos.

Drake era un idealista absorto en una incesante búsqueda de su lugar en el mundo. Su carrera fue meteórica en su experimentación de temas y en sus continuos cambios de escenario. Su mentor, el propio Harris, lo confirmaba con estas palabras: "no recuerdo que [Drake] fuera capaz de terminar ninguno de sus dibujos. Una vez se sentía satisfecho con el trabajo realizado, encontrando que no había nada más que descubrir en un determinado diseño lo abandonaba y se centraba en otro problema. Conociendo de antemano esa faceta suya aún me sorprende que le permitiera venir a trabajar conmigo" ${ }^{\prime \prime 28}$.

Sin embargo, Gordon Drake volvió del frente y se reincorporó directamente en el despacho de Harris, a quien profesó un auténtico fervor como maestro. Su regreso a Los Ángeles coincidió con las etapas finales de la construcción del estudio de Harris junto a su casa en Fellowship Park, una de las obras que más influyeron en la manera de Drake de entender la arquitectura y a la que su vivienda en Beverly Glen rendía un claro tributo con su raro equilibrio entre contención formal e impresionante despliegue de recursos proyectuales.

Como recordaba Harris en su tributo póstumo a Gordon Drake, "[éste] había comprado un pequeño solar $y$, durante sus horas libres en mi oficina revisaba una y otra vez el proyecto de su casa detallando las ideas en las que había empezado a pensar mientras servía en el Pacífico o en Camp Pendleton. Durante aquel tiempo, cada pocos meses, me hacía llegar su última versión del proyecto. Ahora, con la ayuda de un joven ingeniero que había conocido en el ejército y de otros de mis jóvenes delineantes, aprovechaba las noches y los fines de semana para terminar la obra. La casa obtuvo el Primer Premio de Progressive Architecture en la modalidad de viviendas unifamiliares construidas durante 1946 por ser la obra mejor ejemplarizaba la idea de progreso a través de un diseño arquitectónico innovador; a pesar de su reducido presupuesto contaba con todas las comodidades de una casa de varias veces su tamaño" 239 .

Como argumenta Roxanne K. Williamson en su trabajo ${ }^{240}$ sobre los mecanismos de la fama en la historia de la arquitectura norteamericana del pasado siglo, una de las constantes que más se repite en las biografías de muchos de sus protagonistas es el haber estado junto a otro arquitecto en el momento en el que el mentor adquiría notoriedad por alguna de las obras más significativas de su carrera. El paso de Drake por la oficina de Harris coincidió con uno de los mejores momentos del despacho de su maestro. En esa época se estaban gestando los planos de obra de la Weston Havens House en cuyo desarrollo Drake pudo colaborar. Harris acababa de concluir la Pumphrey House en el cañón de Santa Mónica y, entre los proyectos que ocupaban su tiempo, estaban el de viviendas tan significativas como las casas para Lodewijk Lek en La Jolla (1941) y la Cecil Birtcher House en Los Ángeles (1941-1942).

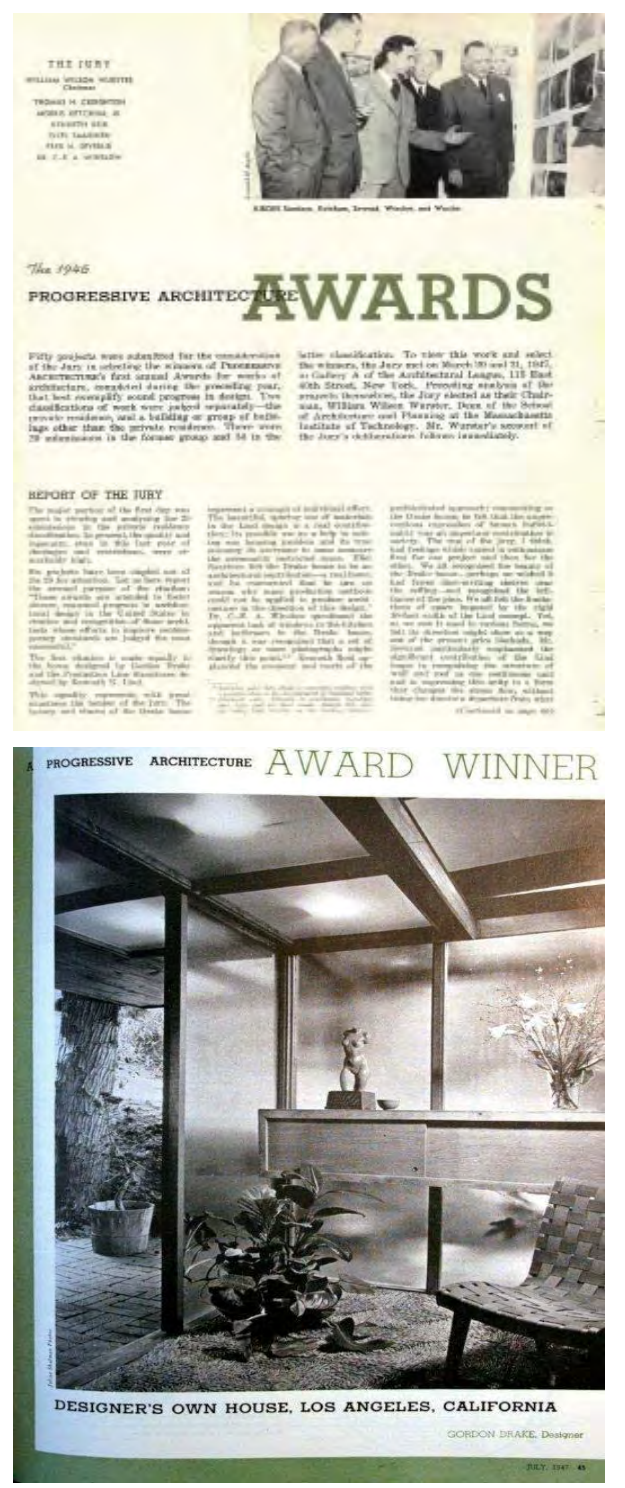

Arriba: Progressive Architecture, junio 1947, anuncio de los resultados de los premios convocados por la revista y publicación de las opiniones del Jurado, entre cuyos miembros figuraban Eliel Saarinen, Fred Severud, el paisajista Thomas Church y el editor de P/A Thomas Creighton

Abajo: Progressive Architecture, julio 1947, se publica otro reportaje especial dedicado a la casa de Drake House, ganadora del primer premio

Página anterior: Gordon Drak: Vivienda del arquitecto en Beverly Glen, Los Ángeles, 1946. Fotografía de Julius Shulman 

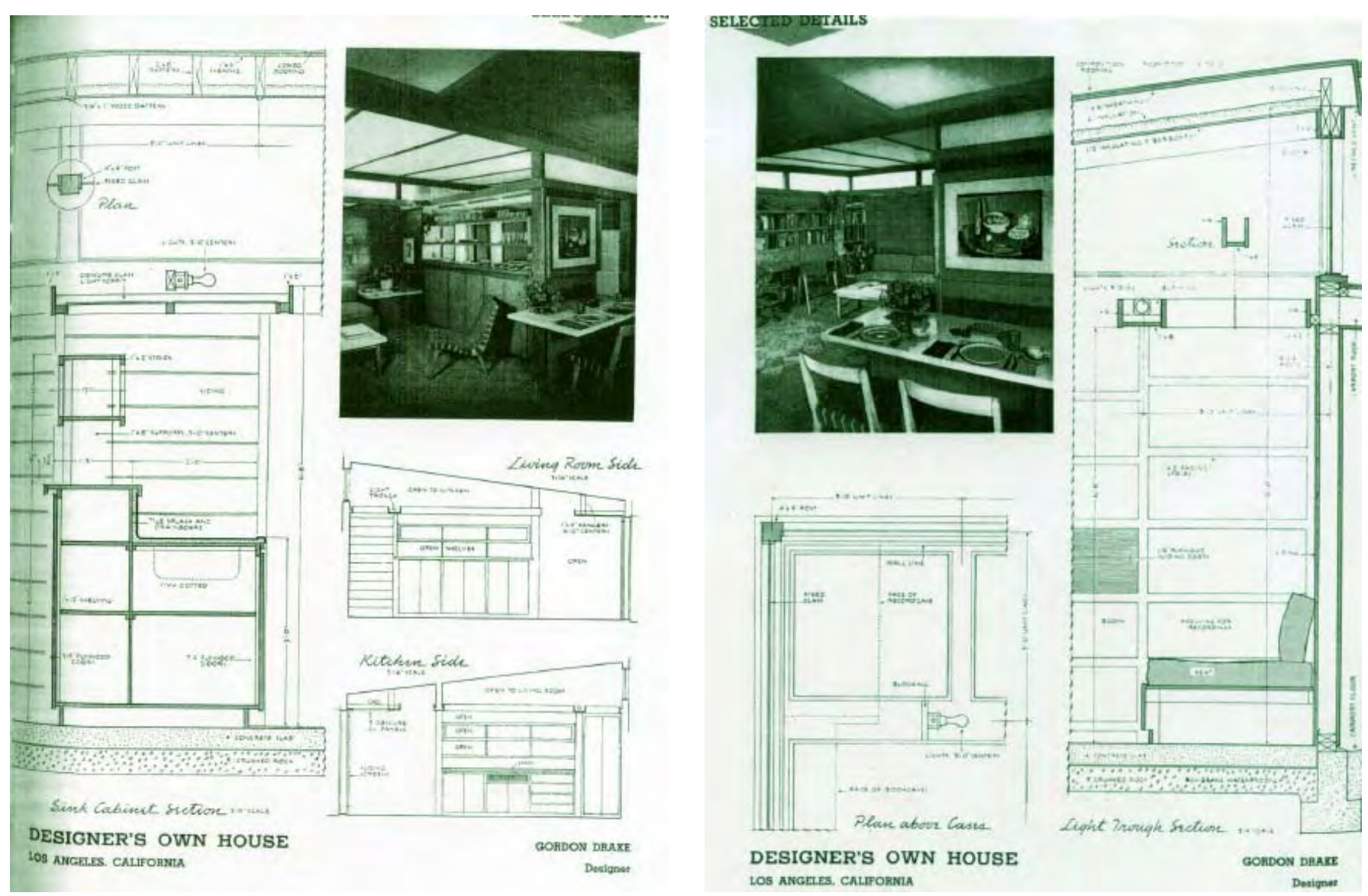

La decisiva influencia que ejerció la obra de Harris en la formación y en la manera de Drake de entender la arquitectura resulta especialmente evidente en la riqueza de las relaciones interior-exterior consecuencia del clima y del modo de vida californiano, en la ligereza de sus estructuras como herencia directa de las tradiciones arquitectónicas japonesas, en la atención por garantizar la privacidad de la vida familiar a pesar de la apertura de la vivienda al exterior, en el tratamiento tan libre e imaginativo de las superficies de madera y de contrachapado, materiales económicos que quedan directamente vistos como acabados, reforzados y puestos en valor con un expresivo uso de la iluminación natural y artificial, etc. Aunque, sobre todo, Drake aprendió de Harris el rigor constructivo y las ventajas de los trazados modulares, como la flexibilidad de las plantas pautadas y la rapidez de ejecución de una arquitectura sistematizada sobre la base de elementos estandarizados.

El recurso a las plantas moduladas a partir de las dimensiones de elementos prefabricados básicos interesó a Drake porque, simplificando enormemente el proceso constructivo, implicaban la democratización de la vivienda; permitían reducir considerablemente los costes sin tener que renunciar a una casa de estándares de calidad elevados y a la creación de un entorno cualificado para una familia de pocos recursos, favoreciendo una arquitectura más igualitaria. Todos estos ideales aparecen condensados en el optimismo que anima la concepción y el diseño de su primera obra construida tras regresar del frente, una casa para sí mismo levantada casi con sus propias manos y un pequeño grupo de amigos en Beverly Glen.

La obra no sólo constituye un experimento acerca de las nuevas posibilidades de la vivienda de posguerra, sino que plantea el guión o, mejor, la 


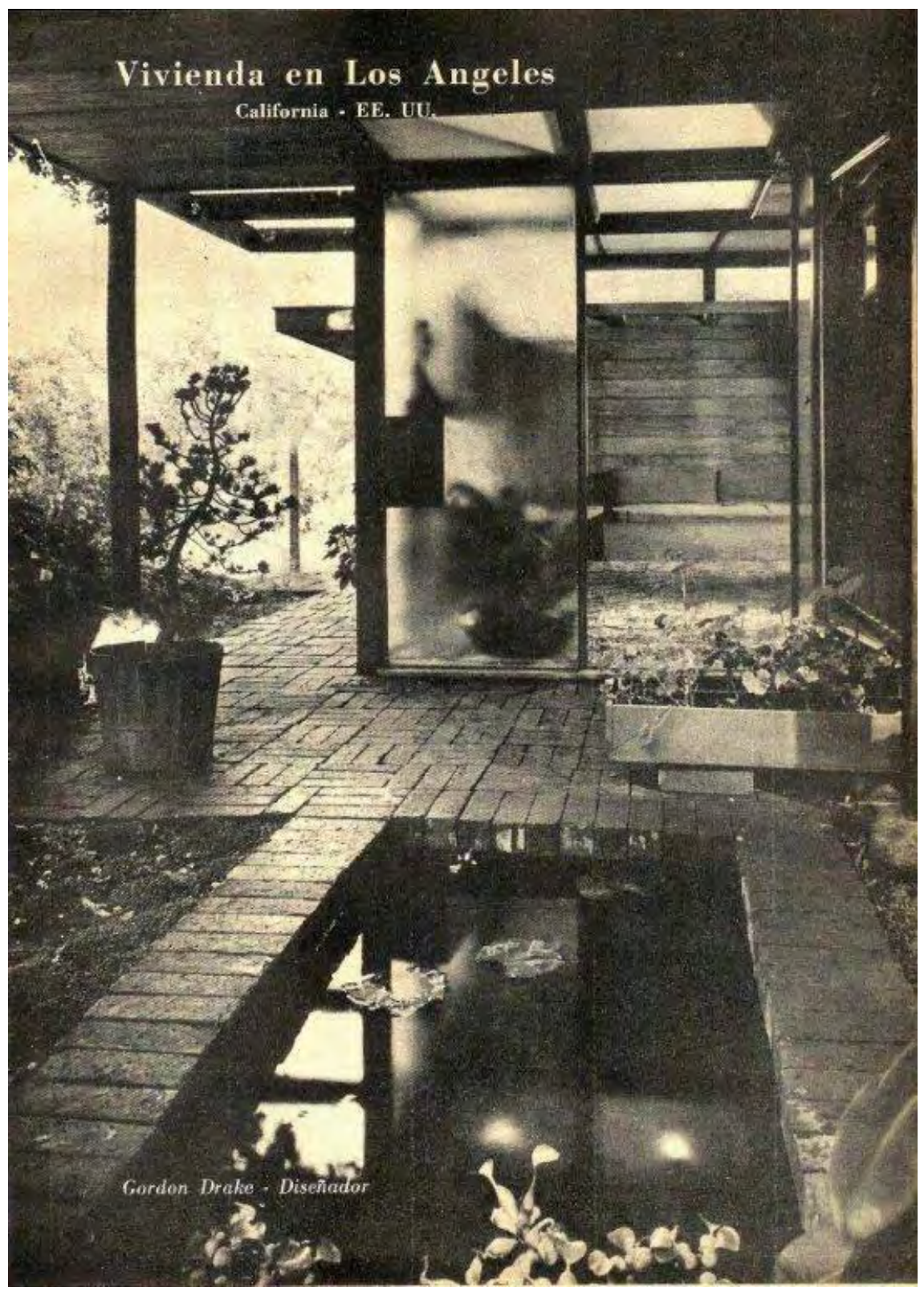

hoja de ruta para el desarrollo posterior de sus intereses como arquitecto, conteniendo las principales claves de todo su trabajo posterior. Como se ha apuntado y, así demuestra su correspondencia escrita desde el frente, durante los cinco años que pasó movilizado en el Pacífico, Gordon Drake pudo meditar sobre muchos aspectos en los que había trabajado durante su etapa en el despacho de Harris. Durante ese tiempo de separación del hogar, el arquitecto alimentó una serie de inquietudes profesionales unidas a deseos de realización personal que, lejos de volcarse impetuosamente en su primera obra, se muestran meditados, ordenados, precisamente dosificados. En efecto, es sorprendente la madurez con la que está resuelto el proyecto de su casa de Beverly Glenn a partir de un depurado diseño en planta, eficazmente modulada a partir de un sistema de construcción en seco a basado en elementos prefabricados con los que, por otra parte, el arquitecto había podido familiarizarse tras su paso por el ejército.

El acierto de Gordon Drake sería por tanto haber sabido reunir las ventajas de la incipiente tecnología de posguerra con su personal entendimiento del medio natural y del paisaje urbano del Sur de California ${ }^{241}$.
Revista de Arquitectura, Buenos Aires, febrero 1948. Reportaje sobre la Drake House en Los Ángeles de 1946

Página anterior: Progressive Architecture, junio 1947, detalles de la vivienda de Drake en Los Ángeles 


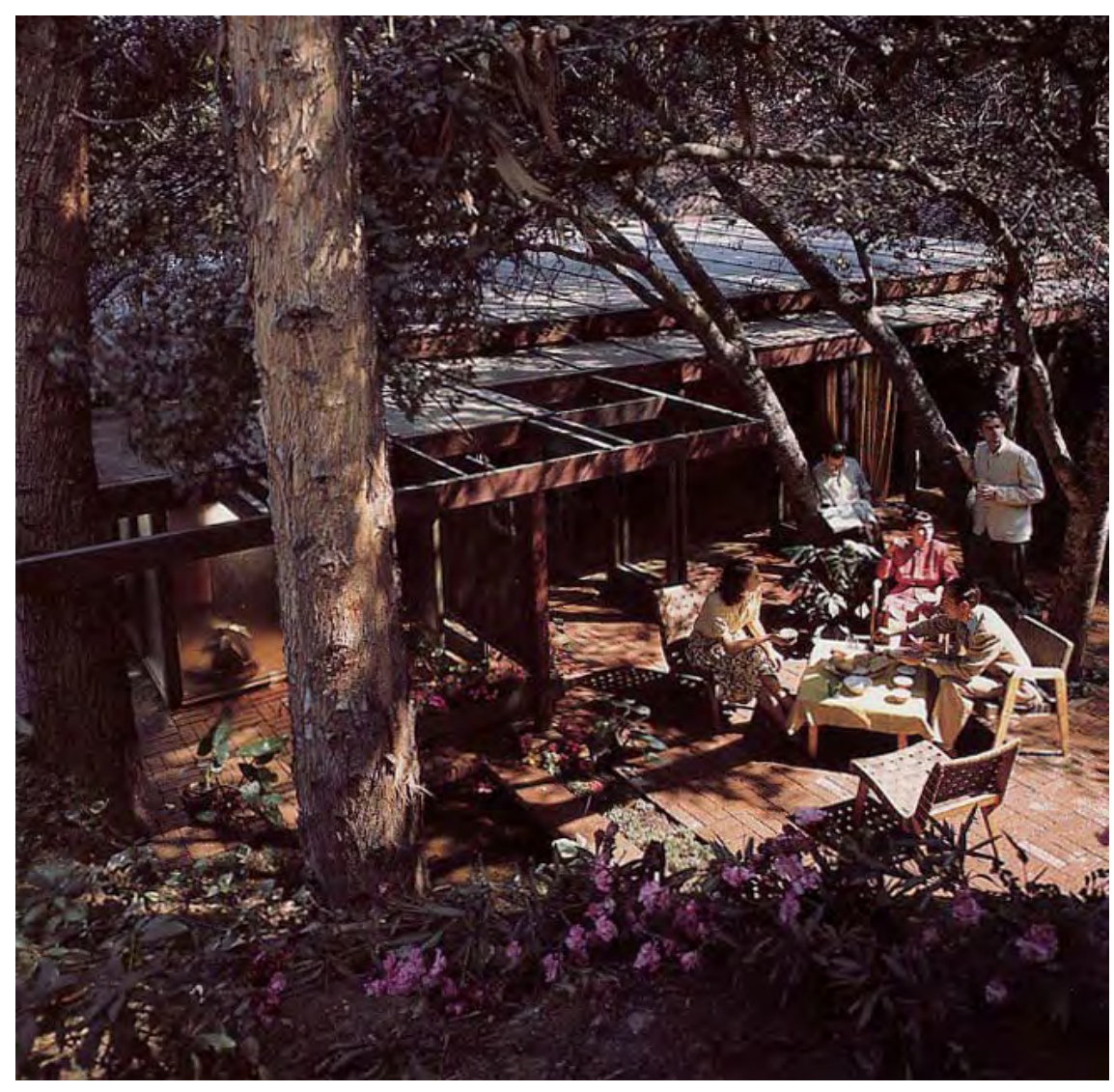

Gordon Drake y un grupo de amigos en el jardín de su casa de Beverly Glen Canyon, Los Ángeles. Drake es el primer personaje sentado empezando por la izquierda. Fotografía de Julius Shulman, 1946

Página siguiente: Drake House. Imagen del acceso a la vivienda. Fotogafía de Julius Shulman, agosto de 1946

\section{Beverly Glen House, la casa que hizo a Gordon Drake}

Al igual que tantos arquitectos y diseñadores californianos -es inmediato pensar en Schindler, Harris, los Eames... hasta el propio Gehry- que dieron forma a la mejor tradición experimental de la arquitectura californiana, Drake decidió ensayar en primera persona sus ideas acerca de una casa modesta en presupuesto y dimensiones, aunque radical en su visión de una nueva forma de vida. De hecho, exceptuando algunos proyectos anteriores del arquitecto como la vivienda para su hermano en San Diego, la primera obra significativa de Gordon Drake fue la casa que se construyó para él y su mujer en una de las colinas de Los Ángeles.

Con su vivienda, Drake quiso ejemplarizar el tipo de vida al que, gracias a la tecnología de posguerra, podrían aspirar las clases medias para disfrutar de un estilo de vida mucho más enriquecedor, por ejemplo, gracias a toda la serie de estímulos derivados de las relaciones interior-exterior propiciadas por la propia arquitectura. En palabras de William Wurster y Eliel Saarinen, miembros del Jurado del Concurso de Progressive Architecture que le concedió el Primer Premio, representaba "el mejor ejemplo de progreso en innovación en el diseño" ${ }^{242}$.

Se trataba de una obra de reducidísimas dimensiones, apenas 60 metros cuadrados, sencilla y económica, ingeniosamente organizada en torno a un único espacio al que recaen el resto de los elementos de la vivienda, en realidad una sola habitación. Una obra casi manufacturada, como corresponde a su condición de prototipo, enteramente construida en madera de reedwood y vidrio. Implantada con habilidad en una depresión excavada la colina, la modulación de la planta encuentra eco en la proyección de las vigas de cubierta, prolongadas al exterior en cuadrados que generan sombra y avanzan hacia el jardín, como para abrazar los árboles que salpican la terraza de ladrillo y que se han conservado a toda costa. La casa se aferra pues 


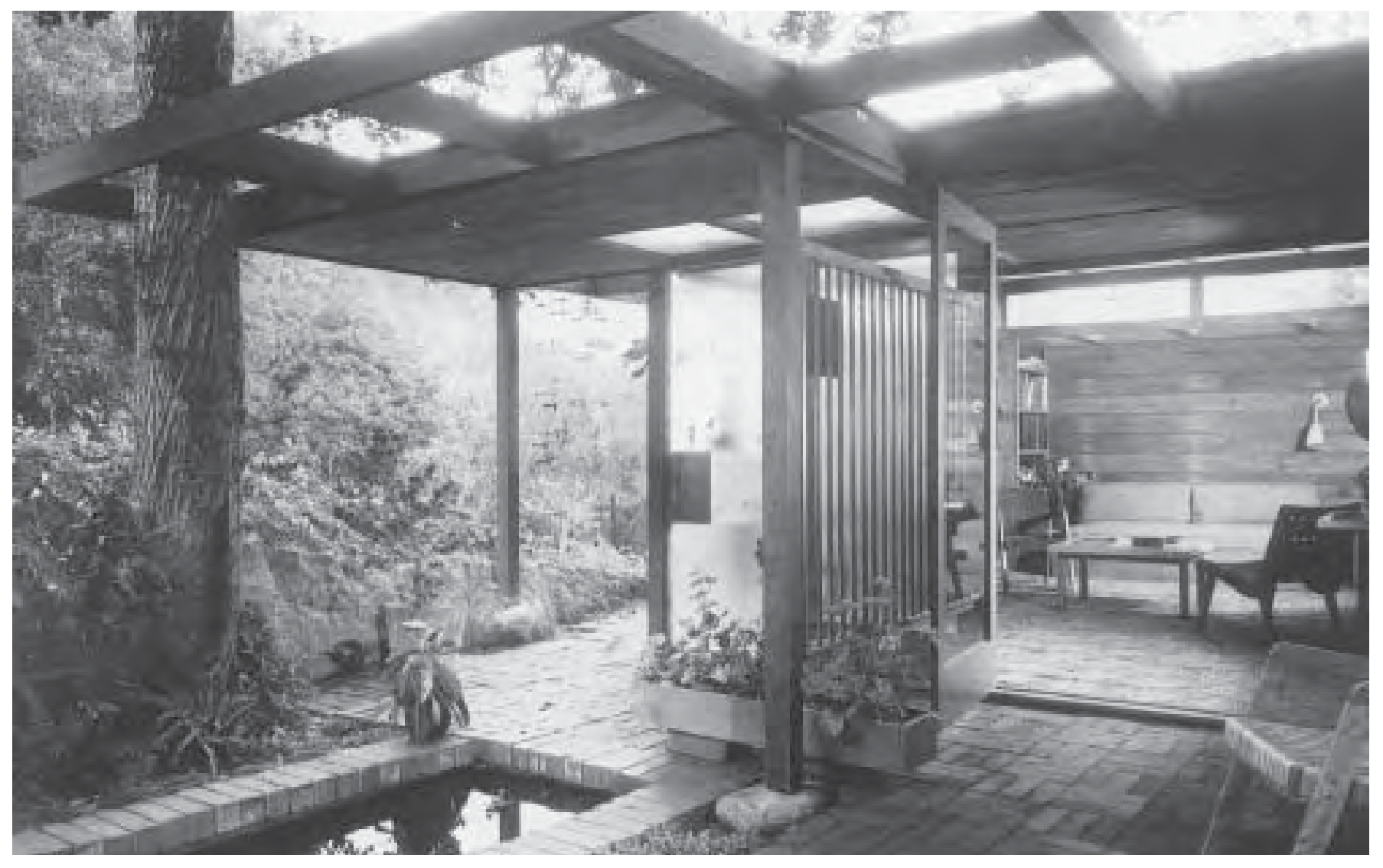

a los árboles, como si llevara años allí, conviviendo con ellos con la mayor naturalidad.

La planta es una retícula modulada sobre el módulo de 6 pies $(1.8 \mathrm{~m})$ que sirve de apoyo a una estructura de pilares cuadrados de madera de unos $10 \mathrm{~cm}$ de lado. Se genera un ritmo al que responden puertas, paneles de madera, paños de vidrio y pantallas traslúcidas repitiéndose a lo largo de la fachada oeste y extendiéndose al panelado del techo y a los lucernarios, ordenados en bandas continuas ubicadas en el encuentro con la cubierta en la fachada opuesta. De este modo, la iluminación natural, como también la artificial, responde al mismo ritmo del proyecto, apoyando su modulación al tiempo que refuerzan el carácter de cada espacio, perfectamente resuelto en sus necesidades lumínicas. Análogamente, la disposición de huecos asegura un perfecto funcionamiento de la ventilación natural de la vivienda.

La fachada oeste se abre en toda su longitud hacia el talud resultante de la excavación que cierra visualmente la parcela y el espacio doméstico. A pesar de las limitaciones de espacio de la casa, insertada en una concavidad ganada a la montaña y con las vistas limitadas por la propia pendiente de la colina, no existe sensación alguna de estar limitado por barrera física -arquitectónica o natural- alguna, el arquitecto ha conseguido conjurar "cualquier sensación de estar encerrado, agobio o pequeñez" ${ }^{\prime 243}$, más bien todo lo contrario, se trata de un recinto amable, donde todo remite a una sensación de calma y privacidad. Gracias al tratamiento de la vegetación como masas estratégicamente dispuestas rodeando la vivienda y conectando con los árboles existentes, el jardín no sólo garantiza la privacidad de la vivienda, sino que también es responsable último de su confort térmico.

Examinado las fotografías de la vivienda y reparando en cuestiones como la sensación de apertura, la desaparición virtual de los cerramientos cuando se 
abren las puertas, o los materiales empleados, desde la madera de la estructura, los paneles del techo a la propia alfombra de coco que recorre toda la casa, es inevitable comparar esta casa de Gordon Drake con la vivienda de Harris en Fellowship Park, también, una de sus primeras obras y como en el caso de Drake, no por casualidad, una de sus apuestas más arriesgadas por la que también recibió diferentes premios y reconocimientos en una fase muy temprana de su carrera.

El despliegue de recursos y, a la vez, la contención con la que están materializados para lograr una obra de gran coherencia remitiría también a Harris, cuyas enseñanzas encuentran un eco en esta casa a través de la personal evolución que Drake ha producido a partir de muchos de los temas de su mentor: la continuidad interior-exterior, el tratamiento de la luz mediante la confrontación de grandes paños con lucernarios y bandas alargadas de huecos altos (claristorios), el diseño modular, la integración de determinadas piezas de mobiliario en el espacio de la casa o el protagonismo de los colores y elementos más naturales que tamizan y ayudan a controlar la característica luz del Sur de California.

Como buen californiano, Drake sentía predilección por la madera y sus posibilidades, dejando al exterior una textura natural, cuyo acabado rugoso, como el mismo explicaría ${ }^{244}$, le gustaba contrastar con el pulido brillante del contrachapado encerado dispuesto en interior. No obstante, hay algunas diferencias importantes, como la preferencia de Drake por espacios interconectados visualmente que Harris trataba de limitar siempre a mínimos estrictos para que cada recinto tuviera asegurada su independencia funcional y su privacidad. Drake habría ideado esta vivienda mientras servía en el Pacífico. De regreso en California, la construyó con ayuda de un grupo de jóvenes amigos y veteranos de guerra quienes, como refería la revista Progressive Architecture, "se sentían responsables de una labor que iba más allá de la tarea que realizaban" 245 .

En su artículo publicado en 1996 en Architectural Review ${ }^{246}$, Neil Jackson sostenía que el objetivo de Drake de construir viviendas cuidadosamente diseñadas a bajo coste a partir de los componentes fabricados que posibilitaba la reconversión de la industria bélica en industria doméstica, en el fondo, se trataba del mismo enfoque que había inspirado a Entenza en su cometido de promover el programa Case Study Houses. Si bien, esta observación debería matizarse ya que las viviendas auspiciadas por John Entenza desde la plataforma brindada por Arts \& Architecture fueron en ocasiones experimentos excesivamente formales o las condiciones de producción, programa o emplazamiento de las mismas excesivamente particulares para que, a pesar de lo que se ha escrito, pudieran ser reproducidas en serie. Sólo muy pocos de los arquitectos que participaron en el programa, como Quincy Jones o Richard Neutra, lograron materializar desarrollos residenciales de gran envergadura a partir de prototipos. No obstante, estos proyectos de auténtica escala urbana e incluso, territorial, surgidos de una auténtica vocación social (por ejemplo la MHA de Jones o el complejo Channel Heights de Neutra) nunca formaron parte del programa de Entenza quien, en muchas ocasiones, escogía para el mismo las viviendas ya construidas que más le habían interesado, publicitándolas hábilmente como CSH en función de la imagen de vivienda que quería proyectar en cada momento.

Considerando la calidad y la aspiración de servicio a la sociedad de la obra de Drake, siendo sus viviendas más experimentales incluso que algunas de las Case Study Houses, resulta sorprendente que ninguna de ellas fuera nunca 


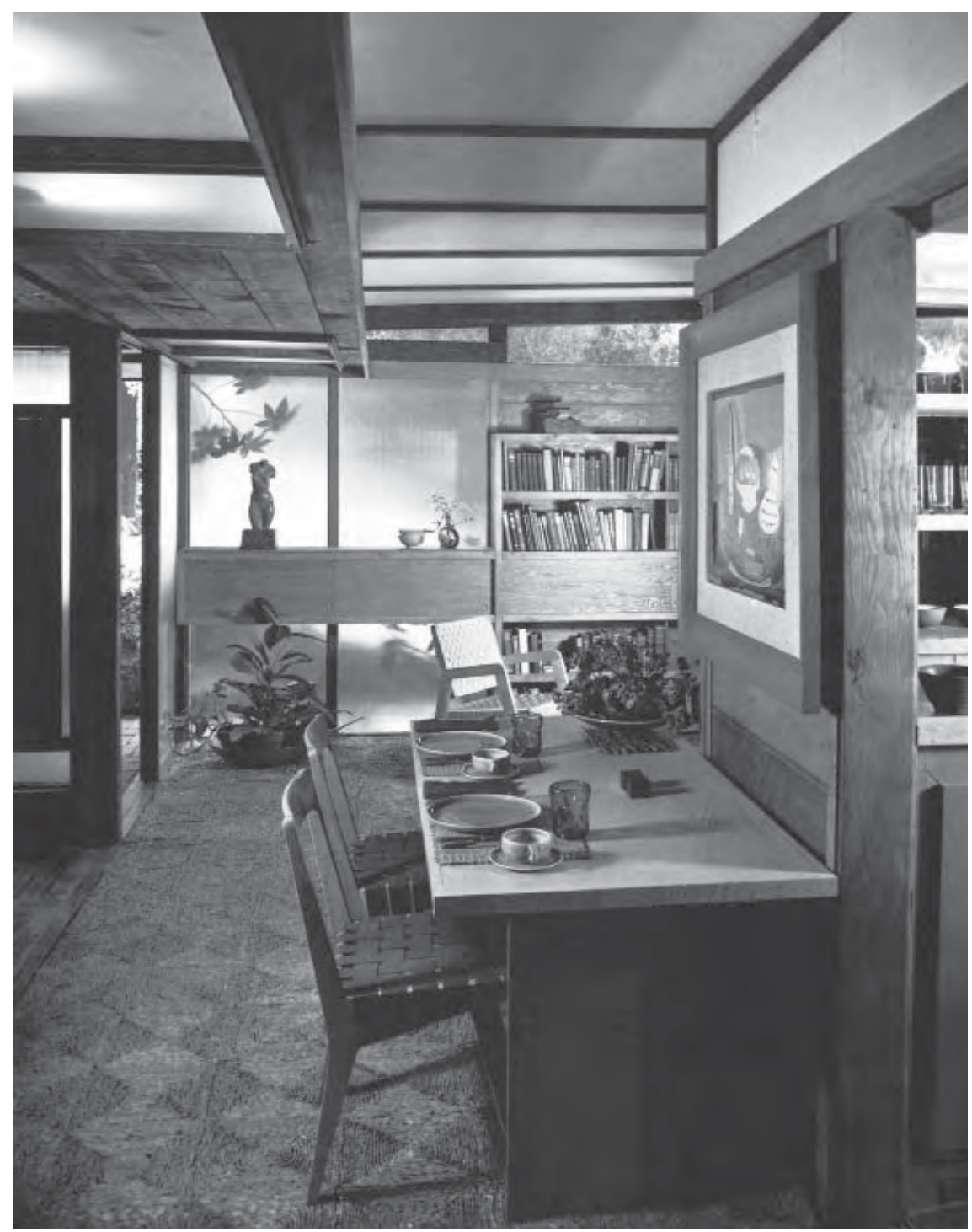

aceptada dentro del programa. Y, dada la repercusión mediática lograda por Drake con los galardones obtenidos entre 1946 y 1947 y su cobertura por parte de medios especializados de todo el país y del extranjero, igual de extraño es el hecho de que tampoco le fuera encargado un proyecto ad hoc para que formara parte del CSH Program. En opinión de Neil Jackson, quizás esto se debió a que el arquitecto murió demasiado joven o a que, probablemente, el hecho de que su trabajo estuviera demasiado vinculado a la construcción en madera hubiera influido en la decisión del editor de Arts \& Architecture, ya que "las ocho Case Study Houses que Entenza publicó entre 1949 y 1960 fueran casas realizadas con estructura de acero" 247 .

Sobre la primera cuestión es difícil conjeturar una respuesta, pero todo parece apuntar que, si durante los años en los que Drake recibió más cobertura mediática su obra no apareció ni siquiera mencionada en Arts \& Architecture, alguna razón de peso tuvo que haber para ello. La segunda aseveración de Jackson es más fácilmente rebatible ya que, de las $36 \mathrm{CSH}$ proyectadas se construyeron 25 , de las cuales, sólo 8 estaban realizadas enteramente en acero, mientras que el resto de ellas en madera u otros materiales, luego no pudo ser ésta la razón para su exclusión del programa. En cualquier caso, lo más sorprendente es el hecho de que Drake no fuera jamás publicado en las páginas de Arts \& Architecture, una cuestión sobre la que se volverá más adelante en este capítulo.
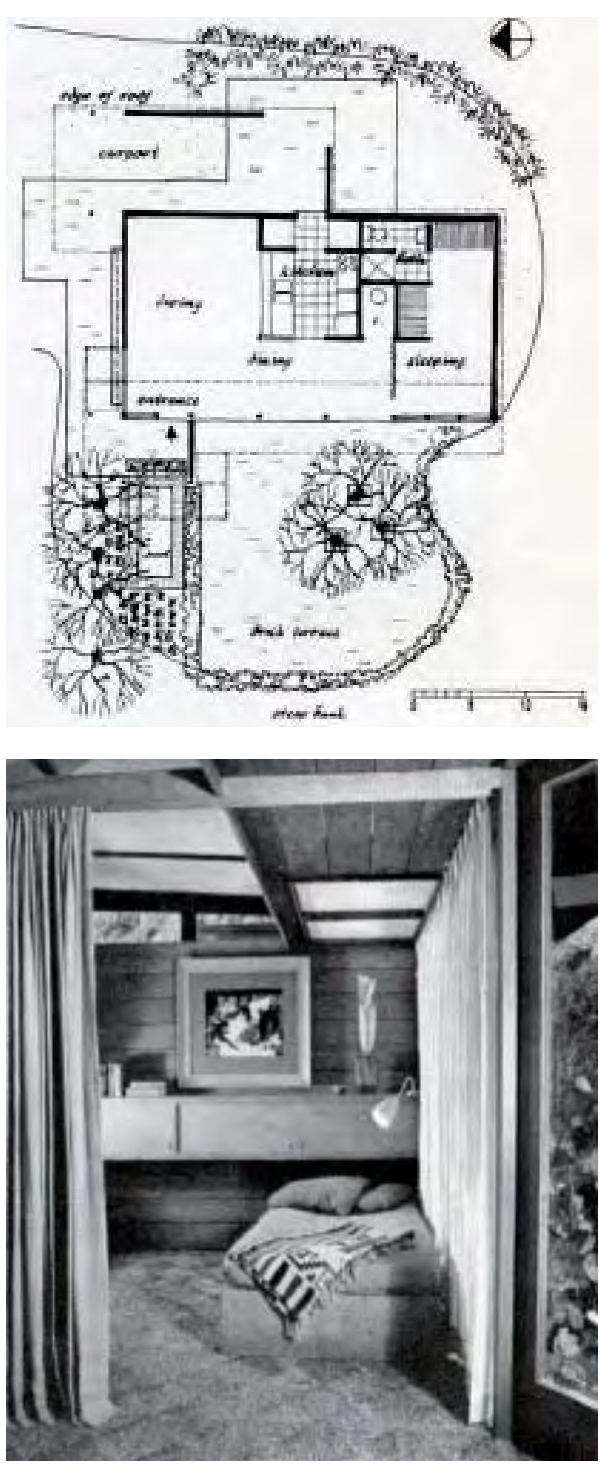

Izquierda: Gordon Drake House, área del comedor con el vidrio traslucido de la entrada al fondo. Fotografía de Julius Shulman, 1946 Derecha arriba: Gordon Drake House, planta Derecha abajo: Gordon Drake House, imagen del dormitorio con las cortinas de separación del estar descorridas. Fotografía de Julius Shulman, 1946

Página anterior: Harris: Casa en Fellowship Park, Los Ángeles, 1935. Fotografías de Fred Dapprich 

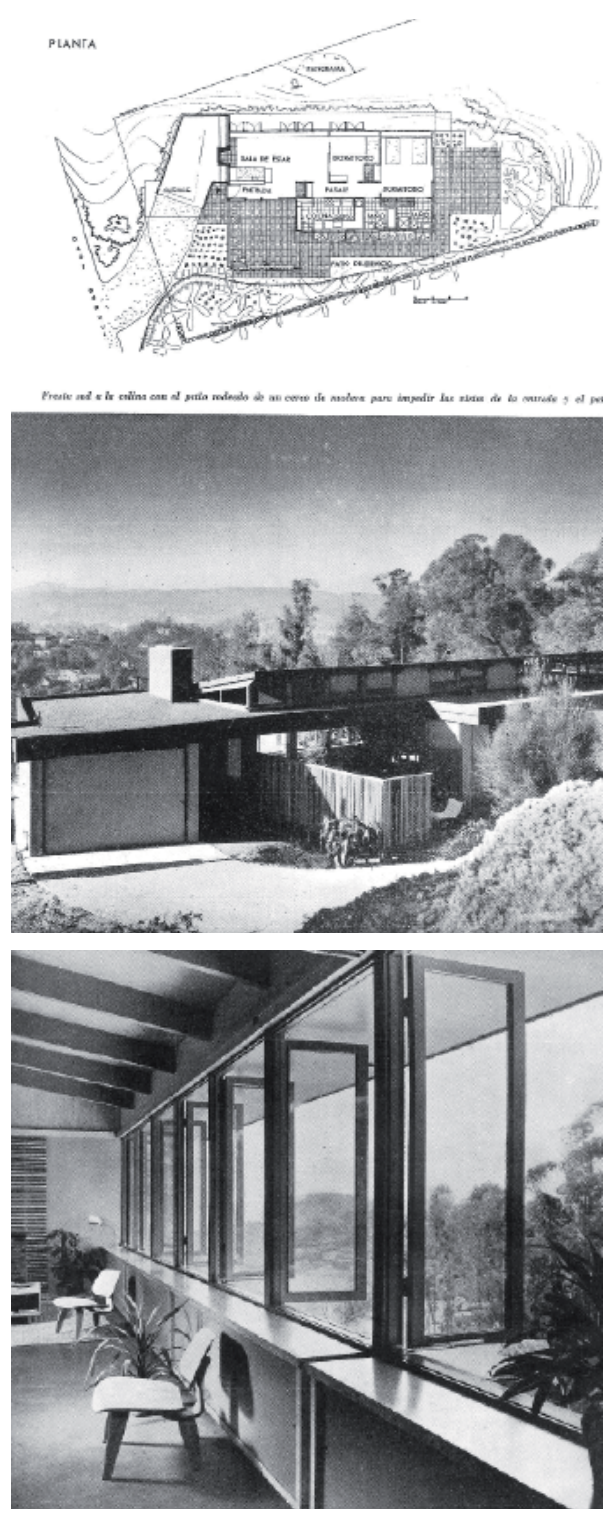

\section{La casa modular de la Costa Oeste}

Según el propio Drake describía en 1947, su casa para los Presley "investiga la viabilidad de un sistema constructivo puesto que la casa se mantiene dentro de los límites de un esquema básico de construcción en serie, puesto a prueba tanto por las condiciones del solar como por las necesidades del cliente. En este sentido, no puede ser comparada ni con una residencia diseñada especificamente para un usuario determinado, ni tampoco puede ser comparada con una casa de catálogo simplificada hasta el extremo de entrar en la categoría de vivienda de masas. Siento que se trata más bien de un punto medio entre ambos extremos, un compromiso que puede justificarse por el hecho de que la casa revisa un esquema tipo, en principio previsto para un cliente desconocido y prototípico en un lugar desprovisto de pendiente y visuales para acomodar las necesidades de un determinado cliente a un determinado lugar cargado de identidad y de relaciones visuales con su entorno" ${ }^{248}$.

La casa se plantea como un armazón que, proyectado en una retícula de $1,2 \mathrm{x}$ $1,2 \mathrm{~m}$., permita fácilmente el montaje en seco de sus paramentos a partir de módulos de la misma dimensión de la cuadrícula. Está construida con estructura de madera laminada y cerramientos prefabricados de paneles de contrachapado, en los cuales, incluso, se ha previsto que los huecos de puertas y ventanas se practiquen también directamente en taller como módulos tipo.

La casa fue un experimento para la empresa constructora de Chicago HomeOla Housing Co. No obstante, el hecho de que el solar presentara una fuerte pendiente y tuviera excelentes vistas, ponía a prueba la naturaleza misma de un sistema pensado para los solares planos y, seguramente, mucho más anodinos de las promociones de viviendas al uso que demandaban los productos de la empresa. Por ello, este proyecto planteaba el reto de explorar todas las posibilidades de un sistema constructivo predeterminado, más allá de la convencionalidad de los prototipos que hasta entonces se habían realizado en base a él.

Al igual que su propia casa, la Presley House, se acomodaba en la ladera de la colina, aunque diferencia de ésta abría las vistas de las estancias principales -el estar y el dormitorio de la pareja- hacia el norte, permitiendo que disfrutaran de la panorámica de Silver Lake. La cubierta, ligeramente inclinada y a una sola agua, era heredera de las cubiertas proyectadas por Harris en sus viviendas de la década anterior y que Drake reinterpretó hasta depurar su propia y característica solución de cubierta. Ésta tenía como ventaja el poder absorber la diferencia de cota entre los paños de cerramiento opuestos de la cubierta mediante una banda acristalada continua, responsable de garantizar el nivel de iluminación y ventilación deseados.

Otros dispositivos de esta casa también remiten a la influencia de Harris, como las piezas de mobiliario fijas construidas en torno al fireplace, o el tratamiento del vestíbulo de la vivienda como un espacio vinculado al estar pero hábilmente separado de éste por un elemento interpuesto para garantizar la privacidad de los ocupantes de la misma. Algo que, por otra parte, también favorece la distribución de las masas vegetales en el jardín, generando recintos de transición desde los lugares más públicos a las estancias más privadas de la vivienda.

Es significativo que, en la primera obra que construyó tras haber terminado su casa de Los Ángeles, el propio Drake quisiera dejar claro desde el principio que, cuando se trataba de proyectar para otros, la experimentación de 

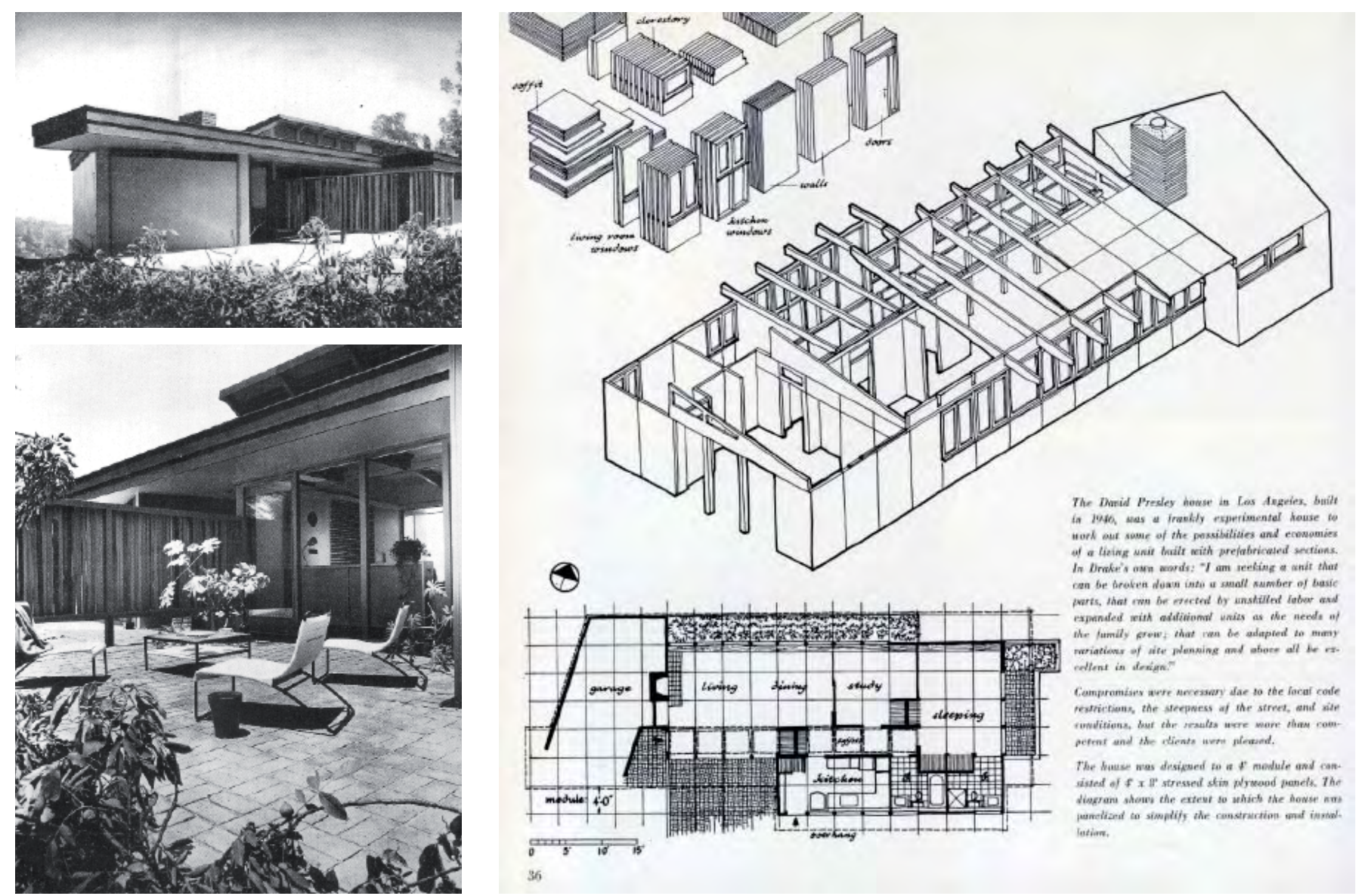

nuevas soluciones se había llevado a cabo con la complicidad de un cliente con el que compartía sus aspiraciones de validar fórmulas exportables para conseguir mejores viviendas a precios muy asequibles.

Su preocupación por contar con el beneplácito del cliente, para él, el auténtico protagonista de su trabajo, queda patente en sus propias palabras cuando, en la citada carta a Eleanor Bittermann de 1947 Drake escribía: "[Los Presley] son una pareja en sus veintitantos que, como la mayoría de la gente joven, nunca se han visto ante la posibilidad de afrontar el proyecto de su casa desde este nuevo espíritu... Mi trabajo les había llamado la atención justo en el momento en que los recientes sistemas de construcción basados en paneles prefabricados estaban comenzando a ser investigados en obra. Les advertimos de la naturaleza y de los riesgos que conllevaba la experimentación y ellos, voluntariamente, accedieron a ser el sujeto de la misma... Durante todo el proceso de proyecto y de construcción se han mostrado siempre dispuestos a colaborar en todo $y$, ahora que la casa está terminada, parecen encantados con el resultado final" ${ }^{249}$. Prueba de ello es que sus propietarios originales vivieron casi cuarenta años en esta casa, habitándola hasta su fallecimiento en 1986.

Otra de las obras excepcionales que Drake construyó durante su etapa en Los Ángeles es la Rucker, más tarde Spillman House. Una casa que, sin duda, debe mucho al planteamiento de las terrazas de la Weston Havens House de Harris como solución al problema de construir en pendiente. Emplazada en una empinada colina rocosa con una superficie edificable de 11 x 9 metros y limitada en sus espaldas por una carretera, Drake decidió colocar las estancias públicas en el acceso y proyectar las piezas que requerían más privacidad (el garaje, un lavadero y un jardín parcialmente cubierto) semiexcavadas 

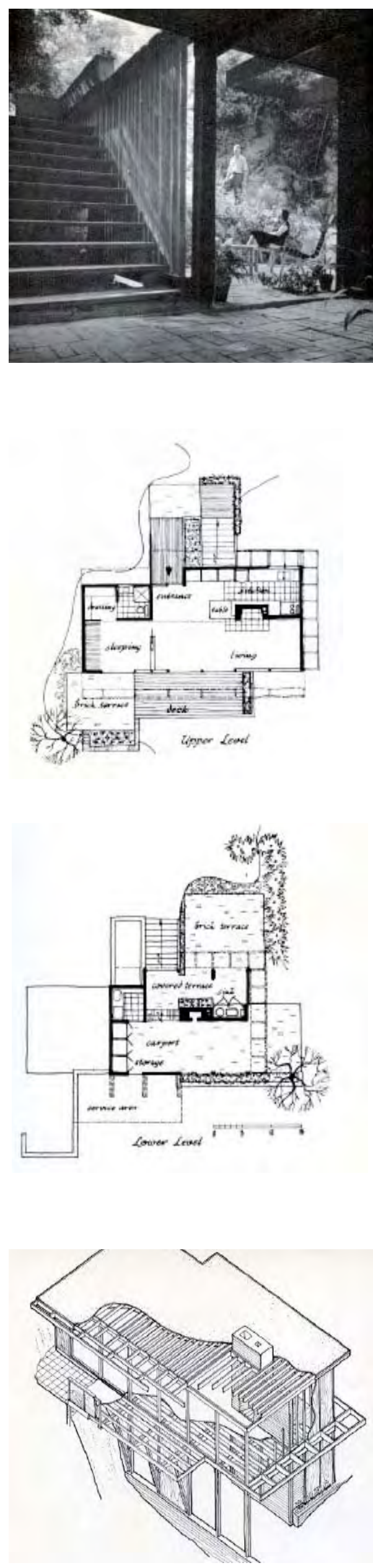

en la ladera. El estar, la cocina y el acceso forman parte de un único recinto separado del dormitorio por una tabiquería móvil. Esta flexibilidad de usos, la apertura al exterior, la cuidada iluminación natural y la fácil conexión entre los espacios interiores creaban una sensación de amplitud que compensaba con creces las mínimas dimensiones de la planta. La casa, como las anteriores construida en estructura de madera laminada y revestimientos de paneles de contrachapado, vidrio traslúcido y vidrio transparente, obtuvo el segundo de los premios convocados en 1947 por la revista House \& Garden y una mención en los Progressive Architecture Awards de 1948.

Todas estas viviendas materializan las ideas expresadas por Gordon Drake en uno de sus textos más representativos y ya citados: "La casa modular de la Costa Oeste" (Modular house on Pacific Coast capitalizes on the area famous topography, climate and materials), aparecido en el número de septiembre de Architectural Forum y cuyo texto se reproduce a continuación traducido al castellano como resumen de su filosofía arquitectónica:

"El factor dominante en el desarrollo de la arquitectura doméstica de California ha sido la existencia de una creciente tradición local, o, mejor, la falta de una tradición formal impuesta. Como consecuencia, esta libertad de pensamiento ha permitido a los arquitectos desarrollar conceptos libres de ataduras que no existen en otras partes del país. Desde el punto de vista geográfico, muchas ciudades californianas están localizadas en áreas montañosas que desafían la aplicación de una trama ortogonal; de este modo, los emplazamientos disfrutan de excelentes vistas, soleamiento, exposición a las brisas dominantes y privacidad. En cuanto a los condicionantes climáticos, una estación de lluvias prolongadas seguida de varios meses secos y cálidos ha permitido deshacerse de los cerramientos exteriores ganando una libertad harto impensable en otros lugares. Incluso, durante los meses de intenso calor, la brisa constante del océano aporta una constante refrigeración. Desde el punto de vista de los materiales, la disponibilidad de la madera como un material barato y abundante de construcción y el aprecio generalizado de sus condiciones estéticas y de resistencia ha tenido como consecuencia un perfeccionamiento de la estructura y de los detalles constructivos que resulta casi oriental en la depuración y simplicidad de sus técnicas. Por último, la concentración de riqueza -en cuanto a bienes disponibles para su uso inmediato- ha sido de vital importancia. En un principio, el desarrollo inmobiliario tuvo lugar en los valles más planos que existen al pie de las colinas. Se trataba de un desarrollo basado en la facilidad y economía de la construcción. En la actualidad, la construcción residencial empuja hacia las colinas o hacia ciudades satélite localizadas a varias millas de distancia. La consideración de las condiciones de implantación es por tanto extremadamente interesante. Conforme se asciende, desde cada cota se tiene una vista diferente, bien del extenso desarrollo suburbano -una panorámica que resulta especialmente elocuente de noche-, bien de las colinas de la cordillera costera, o incluso, a poniente, del océano.

Asumiendo las necesidades básicas del cliente, la distribución en planta queda liberada, aunque también viene determinada por los condicionantes del clima. Determinadas áreas de la casa deben dirigirse hacia las mejores vistas, debe haber también un jardín privado que sea una parte más de la zona de vida y de relación de la casa y, finalmente, deben existir también refugios de intimidad, estancias protegidas por completo del mundo exterior. Otras consideraciones que afectan la forma de la cubierta y la disposición de los cerramientos son los límites que marcan el soleamiento y la lluvia, de los que hay que protegerse en las condiciones más extremas de cada estación. 


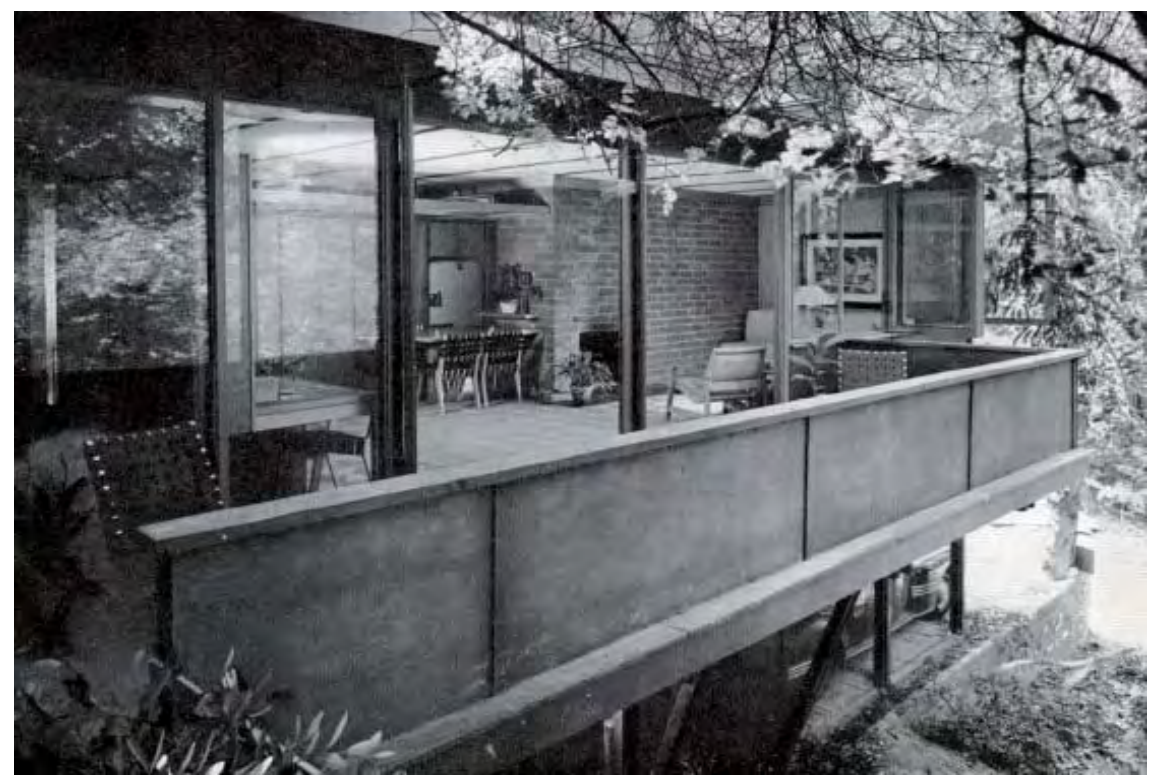

Quizás, el uso de la luz es el principal parámetro que hay que tener en cuenta al proyectar. La cualidad de la luz natural en cada momento del día, debe ser potenciada o matizada en función de las necesidades concretas de cada espacio de la vivienda. Esto puede resolverse gracias al uso de bandas corridas de huecos altos de iluminación y ventilación, de paredes ciegas de apoyo a los dormitorios, de pantallas traslúcidas que matizan la luz del sol haciéndola más fría, y de paños enteramente de vidrio que permiten que la luz del sol invada completamente determinados espacios de vida.

La utilización de la vegetación como atenuante de las duras condiciones de sequedad de los meses de verano debe servir como conexión del jardín con el interior de la vivienda. Y a la inversa, la proyección de la cubierta a modo de pérgola calada es una forma válida de prolongar la edificación hacia el exterior, conectando la casa con el jardín, como si ésta saliese al encuentro del elemento natural.

Por primera vez, la madera natural está disfrutando de un mayor uso en la arquitectura contemporánea que los muros de fábrica, y mucho más económica que como simple recubrimiento de paramentos de obra. Los tableros con terminación natural utilizados en estructura y como acabados pueden servir para poner en valor la atractiva sofisticación de los contrachapados encerados del interior.

Las generaciones más jóvenes han comprendido que la arquitectura contemporánea representa una forma de vida que transforma la casa, desde su mero papel de refugio a centro de la existencia. Los arquitectos capaces de llevar a cabo esta tarea deben enfocar su trabajo teniendo en cuenta que alcanzar esta meta será una fase importante de su actividad profesional. Por supuesto, esto sólo será posible económicamente desde la industrialización como base de la producción de masas o desde la aceptación por parte de la promoción privada de las innegables ventajas del buen diseño. Ha llegado un momento en el que la gran mayoría de la población americana que no puede pagarse un buen arquitecto pueda acceder a una casa que les permita una buena vida, un derecho que ya no es sólo exclusivo de personas con un nivel socioeconómico o de educación alto. Siendo consciente de las necesidades sociales de su tiempo, el arquitecto debe aceptar la responsabilidad de liderar procesos en este campo, más allá de cuestiones como sus honorarios o cualquier otra consideración que, hasta el momento, haya supuesto una barrera moral"250.
Gordon Drake: Rucker-Spillman House en Los Ángeles, 1947. Fotografía de Julius Shulman

Página anterior arriba: Rucker-Spillman House. Fotografía de Julius Shulman

Página anterior centro: Rucker-Spillman House, plantas

Página anterior abajo: Rucker-Spillman House esquema estructural 


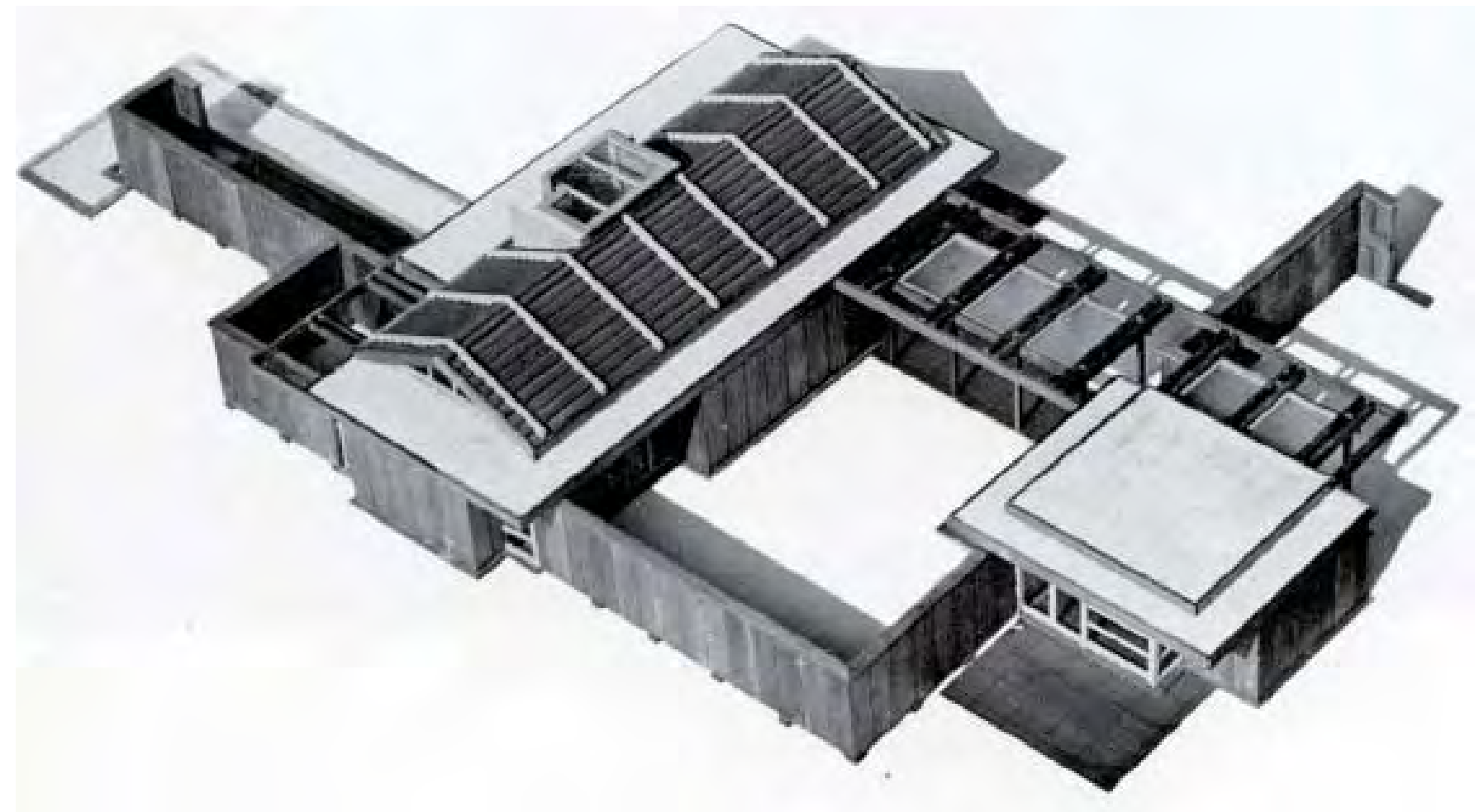

El sueño de Carmel

Tan sólo dos años después de construir su casa, en 1948, el carácter inquieto, a veces impaciente, de Drake le impulsó a abandonar la ciudad de Los Angeles para iniciar una nueva aventura profesional en Carmel. Dando un giro inesperado a su trayectoria, Drake volvía en cierto modo sobre las huellas de personajes como Charles Greene o Pauline Schindler que habían ido a buscar un sentido a su trabajo retirándose a los especiales ambientes culturales del norte de estado.

Drake seguía interesado en la construcción de auténticas viviendas de posguerra, pero sentía que debía profundizar aún más en sus ideas de proyectar para un cliente arquetípico de clase media prosiguiendo sus investigaciones proyectuales desde un enfoque más intelectualizado. No obstante, la idea que más le motivó para tomar la decisión de mudarse a Carmel fue su deseo de enseñar y de abrir una escuela de arquitectura desde la que transmitir las ideas modernas a la comunidad. Drake escribió a su amigo Edward Kennedy, editor jefe del The Monterrey Peninsula: "debo ir a Carmel y construir un edificio que exprese profesionalmente todo aquello en lo que creo. Tendré que construirlo con mis propias manos, como una expresión de $f e^{\prime \prime}$. La aspiración de Drake era fundar un estudio asociado a una escuela de arquitectura y diseño, una suerte de centro de investigación que aglutinara a un círculo de profesionales que compartirían muchas de sus ideas y hasta un estilo de vida comunitario.

Drake conectaba también con una determinada genealogía de artistas y arquitectos norteamericanos que, movidos por una idea whitmaniana de destino fundaron comunidades utópicas cuya vida se articulaba en torno a las artes y la producción artesanal viviendo de un modo más auténtico en relación directa con la naturaleza como, por ejemplo, el Craftsman Farms de Gustav Stickley o tantas otras comunidades Arts and Crafts de Nueva Inglaterra. Y, por supuesto, con la tradición de arquitectos californianos del siglo XX como Wright y los Taliesin Fellows; Rudolph Shindler en Kings Road; 
el propio Richard Neutra en Silver Lake, la escuela de William Wurster en el Área de la Bahía o, por aportar un ejemplo más, Christopher Alexander y su Center for Environmental Structure en Martinez, California.

Consecuencia de su temprano éxito en Los Ángeles y contando con el apoyo de Harris, Drake había comenzado a impartir algunas clases de proyectos en la Escuela de Arquitectura de la Universidad del Sur de California, donde junto a Carl Straub y, más tarde, Conrad Buff y Donald Hensman, formó un grupo de jóvenes profesores recién titulados tras la guerra, muy comprometidos y cuya labor experimental fue respaldada por los planes reformistas del Director de la Escuela, Arthur Gallion. Como Neutra y Harris, Drake tenía vocación docente y una auténtica necesidad de transmitir su visión de la modernidad no sólo a sus estudiantes, sino al conjunto de la ciudadanía.

Tras su breve paso por USC, Drake sintió que en Carmel podría realizar este sueño. En la pequeña ciudad costera de Carmel su escuela estaría abierta a estudiantes graduados que quisieran emprender un novedoso programa de tercer ciclo. No obstante, en la idea de Gordon Drake desaparecía la jerarquía de un maestro o doctor tutelando a sus estudiantes para fomentar más bien una estructura de trabajo comunitario a través de la práctica, una organización reticular mucho más contemporánea, donde los diferentes miembros activarían las sinergias del proyecto.

Drake quería implicar también al mundo de la industria en su empresa, de modo que se establecieran contratos o proyectos de investigación en torno a determinados productos o para desarrollar otros nuevos, lo que permitiría, a la vez que experimentar con nuevos materiales, elementos o sistemas constructivos, obtener financiación para su escuela. Esta colaboración se publicitaría a través de conferencias, encuentros, presentaciones en ferias, exposiciones y publicaciones en revistas especializadas. Drake pretendía incluso lanzar su propia revista.

Sus intereses no sólo se quedaban en el terreno de la arquitectura sino que se abrían hacia otras áreas técnicas y artísticas como el planeamiento urbano, la intervención territorial, el paisajismo y, por supuesto, la pedagogía en la formación integral de los jóvenes. No se trataba ya tanto de entender la arquitectura como marco para un proyecto total de integración de otras disciplinas artísticas, diseño de mobiliario, jardinería, etc., sino de fomentar la construcción de un proyecto multidisciplinar acorde a la escala y a la complejidad de la sociedad del momento. En este sentido, Drake era muy consciente de que el mundo había cambiado radicalmente tras la Segunda Guerra Mundial y de que se estaban operando profundas transformaciones de las que habría de emerger una nueva civilización.

Por ello, lo más importante para Drake es que su grupo de Carmel tuviera como principal objetivo una vocación de servicio a la comunidad. Como el mismo expresaría: "A través de la investigación llegar a la honestidad del proyecto. Construir. Evaluar. Ofrecer estas ideas y nuestros logros a la comunidad que las requiere. Alimentar, crear ese deseo" ${ }^{251}$.

Resulta interesante especular con la posibilidad de que Drake, durante aquellos meses en Carmel contactara con Charles S. Greene, que pasaba retirado allí los últimos años de su vida. La suposición parece razonable y, aunque no hay nada en los archivos de la Universidad de Berkeley que remita a un posible encuentro, esto no quiere decir que no sucediera. Por un lado, teniendo
Charles Greene: James House, Point LobosCarmel, 1922. Fuente: Ted Bosley. Durante su estancia en Carmel Drake habitó un apartamento muy próximo al estudio del mayor de los hermanos Greene en la ciudad

Página anterior: Gordon Drake: maqueta realizada por él mismo para el proyecto de su escuela de arquitectura en Point LobosCarmel. Fuente: Baylis

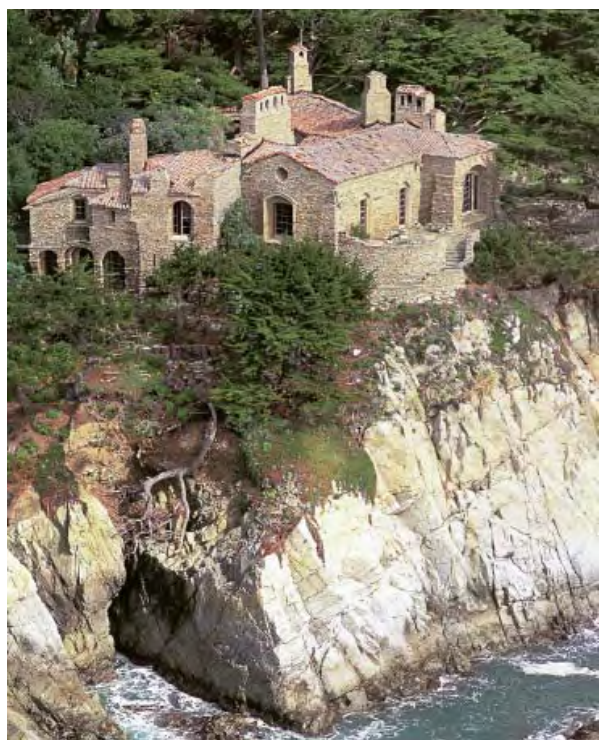



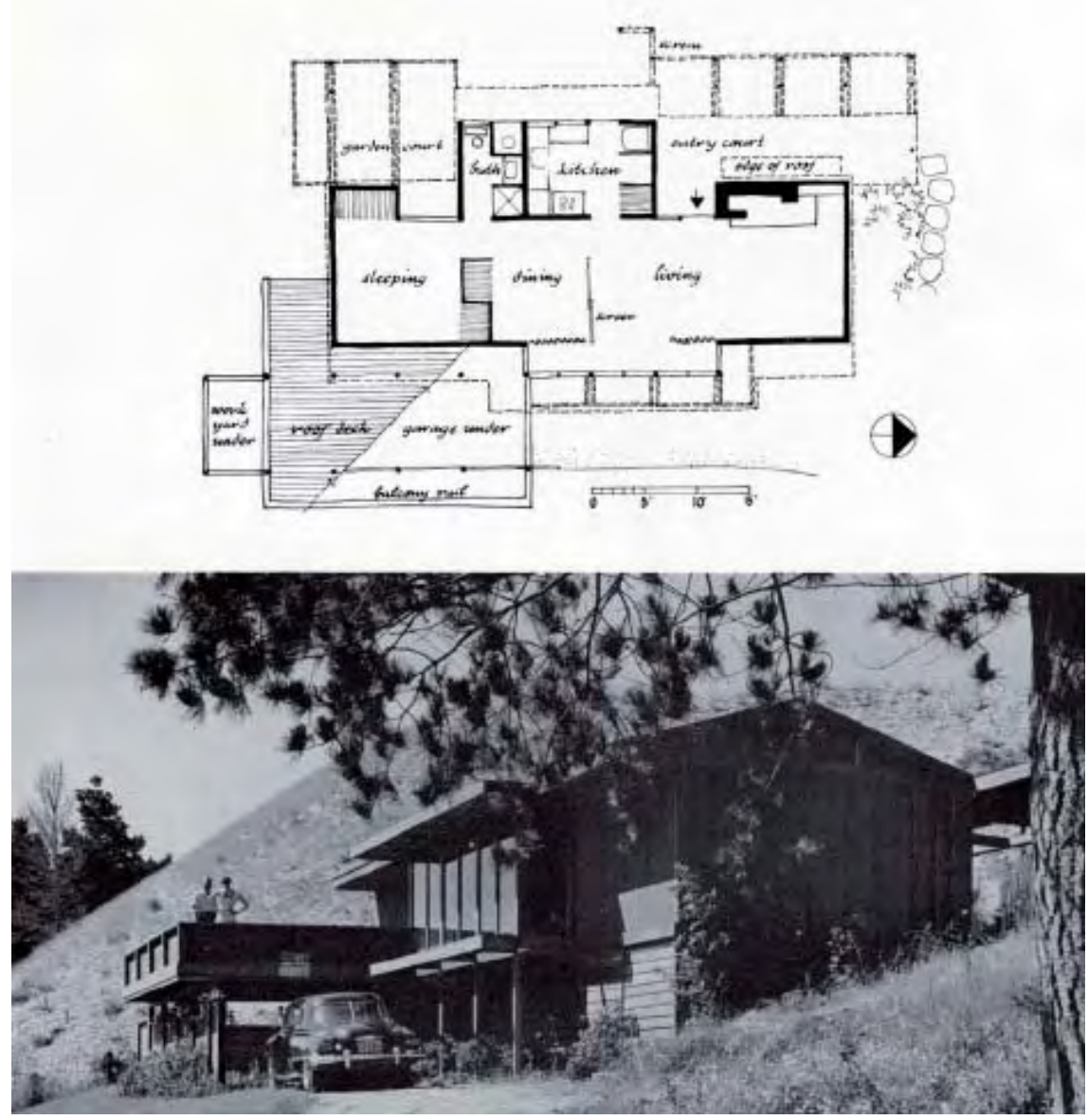
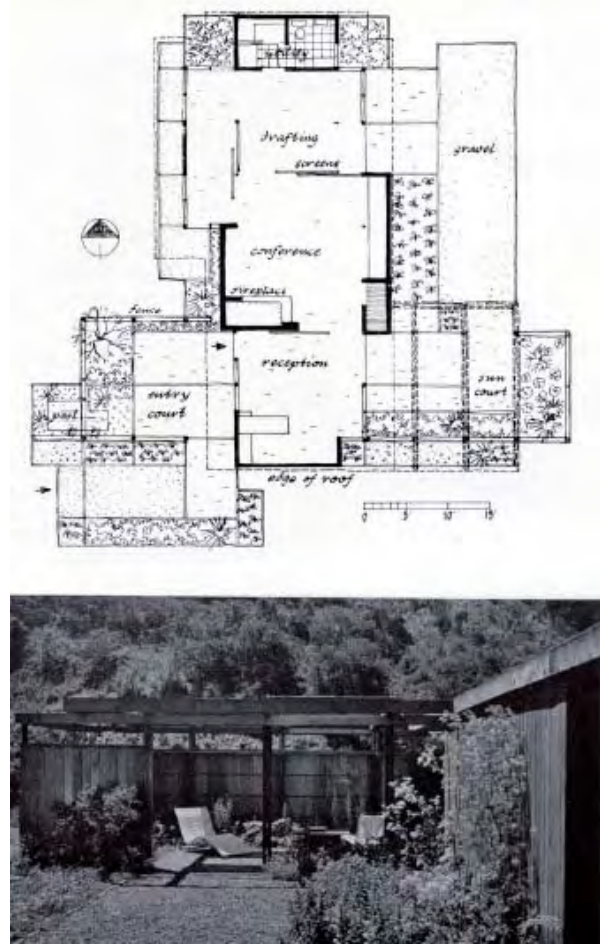

en cuenta que, justo en esa época el matrimonio Harris devolvió a los hermanos Greene a la actualidad con los diferentes artículos publicados sobre ellos en 1948 y, por otro, teniendo en cuenta la amistad de Gordon Drake con Harris y que éste había ido a Carmel a visitar a Charles Greene, tiene sentido pensar que Harris hubiera hablado a Drake sobre su investigación acerca de la obra de Greene \& Greene. Además, dada la curiosidad natural de Drake y el pequeño tamaño de la comunidad de Carmel, es lógico aventurar que Charles Greene y Gordon Drake hubieran coincidido en alguna ocasión. Es más, hubiera sido muy difícil que Drake no se hubiera preguntado nunca sobre el autor de la James House, permanecido indiferente ante esta imponente vivienda ubicada en unos acantilados por los que Drake tenía que pasar obligatoriamente en sus frecuentes escapadas a Point Lobos, el lugar de la costa adonde le gustaba retirarse a reflexionar.

Análogamente, habría que plantear la cuestión sobre una posible influencia de Wright en la temprana formación de Drake e, incluso, si llegaron a coincidir en Carmel durante la construcción de la Walker House. Éste es un asunto sobre el que se ha discutido con el historiador John Crosse ya que, teniendo en cuenta algunos hechos de la biografía del arquitecto, resulta de difícil de soslayar. Por ejemplo, durante su viaje a San Francisco en 1940 para visitar la Weston Havens House, Drake se detuvo en Carmel para conocer otra de las obras que Harris había terminado allí sólo un par de años antes, la Marion Clark House ${ }^{252}$. Muy cerca de esa casa, poco después Wright edificaría la Walker House en 1948, justo cuando Drake residía en Carmel. Muy cerca de ellas y del estudio de Charles Greene, del que están separadas unos cientos de metros, Drake alquiló un apartamento durante su estancia en la ciudad, de modo que es inevitable pensar que, dado que podría haber ido paseando 
hasta ellas, seguramente estas obras le habrían suministrado material para la reflexión.

Frustrado su sueño de crear una escuela radical en su independencia de criterio y en la novedad de sus planteamientos, el legado de Drake tras su paso por Carmel fueron dos viviendas y un estudio para sí mismo. Una de estas viviendas era una casa de vacaciones para Edward Kennedy, el editor del The Monterey Peninsula Herald. La otra, una vivienda experimental que se denominó Mesa House.

Su estudio, la oficina que Drake ocupó durante su estancia en Carmel estaba planteado como una unidad básica que podía readaptarse en función de las necesidades de espacio. Rodeada de jardines que conferían a la unidad construida un carácter diferente, la pieza podría abrirse por completo mediante tabiquerías móviles, resultando un único rectángulo, o ser compartimentada en tres ambientes distintos: recepción, sala de reuniones y despacho de trabajo o sala de delineación. El proyecto concedía tanta o más importancia a los espacios exteriores ajardinados y a las estructuras que se proyectaban hacia los mismos para generar recintos de sombra o lugares de esparcimiento como a la unidad construida misma, en la que es realmente difícil de discernir qué está dentro y qué está fuera. Cerramientos móviles de gran ligereza permitían también proteger la oficina del sol de poniente. Se trata claramente de una de sus obras más personales y donde la influencia de Harris haya quedado más patente.

Respecto a las dos casas citadas, ambos proyectos residenciales estaban animados por las mismas ideas que Drake había materializado unos meses antes en viviendas de Los Ángeles. La primera de ellas, la Vacation House, estaba concebida como una estructura empotrada en una colina que se generaba por la macla de tres rectángulos en planta. Un primero de ellos era el garaje, en una cota inferior y cubierto por una gran terraza de madera a la cota de la vivienda. El segundo de ellos albergaría el único dormitorio, el comedor y el estar. El tercer rectángulo recogía los espacios de servicio del baño y la cocina. Una serie de elementos vegetales, tratados como cerramientos delimitadores de patios garantizaban la privacidad de las estancias en su encuentro con la montaña.

La Mesa House fue construida para un promotor que quería vender un prototipo experimental de casa con dos dormitorios. La vivienda, ubicada en una diminuta parcela, es realmente modesta en dimensiones. Sin embargo, aumenta su superficie $y$, sobre todo, adquiere una mayor sensación de espacio por la disposición de patios, masas vegetales y jardines interiores que, aun garantizando la privacidad, permiten visuales largas y sesgadas a través de la casa, contribuyendo así a dar una mayor sensación de amplitud. A su fluidez espacial contribuye también el hecho de que los patios ajardinados están separados por pantallas bajas, permitiendo leer en su continuidad la cornisa que, como proyección de la cubierta, recorre el perímetro de la vivienda. La casa lograba sin duda su objetivo de dar "máxima prioridad a las relaciones interior-exterior en el uso de los espacios de la vivienda, a pasar de las limitaciones del solar"253.

De esta vivienda experimental de bajo coste es especialmente llamativo el esquema de montaje que, como en el caso de la Presley House, Drake había preparado cuidadosamente. El esquema axonométrico publicado, entre otros medios impresos de la época, en la monografía póstuma del arquitecto

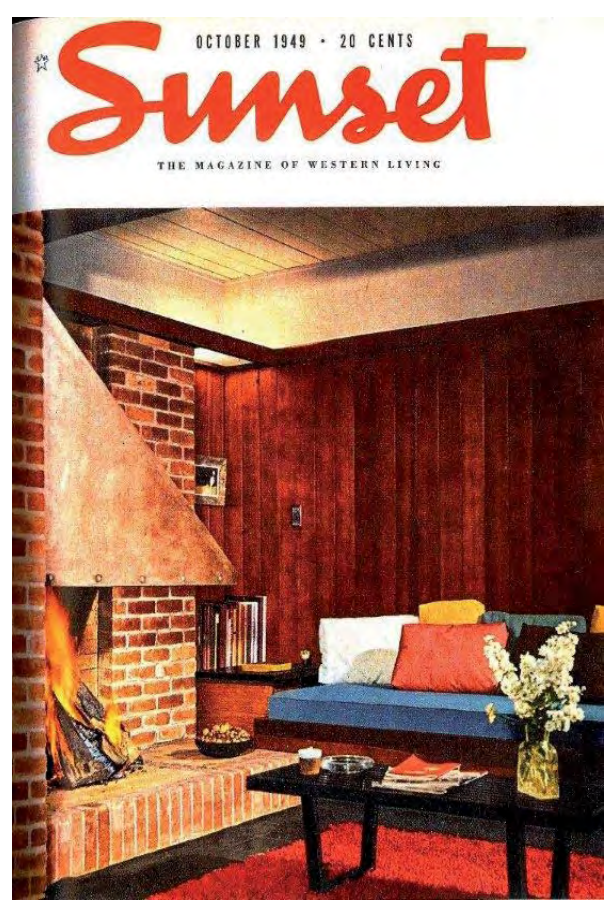

Portada de Sunset Magazine, octubre de 1949, reproduciendo el estar de la Mesa House de Gordon Drake en Carmel

Página anterior arriba: Gordon Drake, Vacation House, Carmel, 1948, Baylis Página anterior abajo: Gordon Drake, estudio del arquitecto, Carmel, 1948, Baylis 


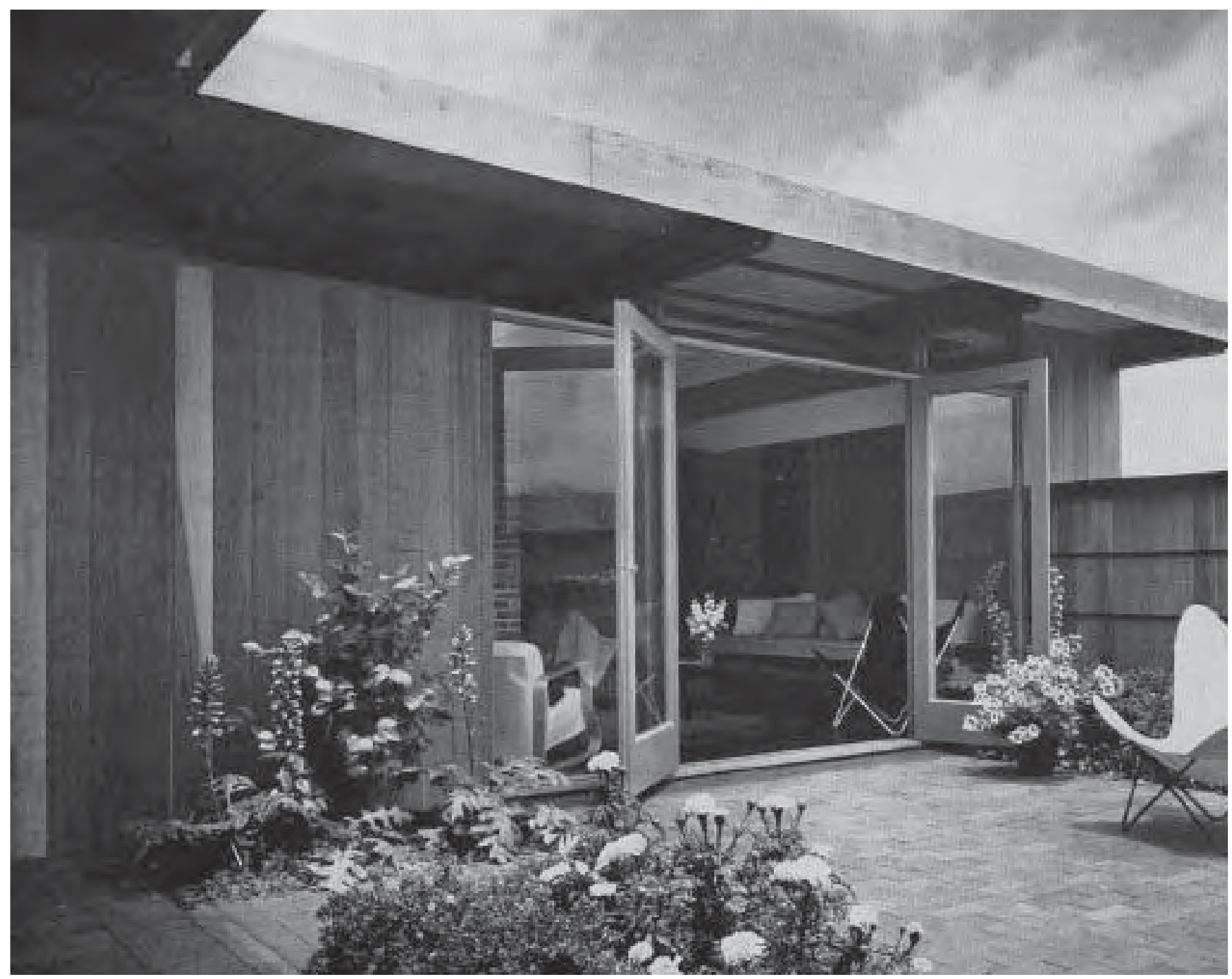

Gordon Drake, Mesa House, Carmel, 1948. Fotografía de Julius Shulman

Página siguiente: Gordon Drake, estudio del arquitecto, Carmel, 1948. Fotografías de Julius Shulman expresa perfectamente una construcción modular basada en la adición de piezas prefabricadas a una estructura de madera.

Desafortunadamente, el mercado no quiso asumir riesgos y la idea no pasó del prototipo frustrando, una vez más, las expectativas de Drake. En cualquier caso, la experiencia de Carmel dejó en Drake un sabor agridulce con sentimientos enfrentados que mezclaban la satisfacción personal por el reconocimiento a su labor y entrega manifestado por terceros, en particular por sus propios clientes, con una sensación de profundo fracaso que le hizo ver que este capítulo de su vida tocaba a su fin y que debía tomar distancia marchándose de la ciudad.

Por un lado en Carmel se quedaban los edificios construidos, su mayor éxito. Fue realmente un triunfo para él porque tanto los propietarios de la Vacation House como de la Mesa House quedaron encantados con su trabajo. Por ejemplo, los propietarios de esta última casa le escribieron personalmente para decirle: "Somos increíblemente felices en esta maravillosa casa. No creemos que puedas imaginarte lo importante es para nosotros. Muchas gracias" 254 . Drake sentía que había construido para la gente, no para su él mismo, su ego o el interés publicitario y económico de los medios. De hecho, al final del episodio de Carmel, afirmó: "Si mañana mismo fuera de nuevo llamado a filas, me sentiría bien porque, al menos, me iría con la tranquilidad de haber dejado estos tres últimos edificios" 255 . 
Y, por supuesto, tras su paso por Carmel quedaban también los contactos profesionales y las amistades afianzadas como su relación con Douglas Baylis, arquitecto paisajista con el que colaboró en el proyecto de su Vacation House y en su oficina-estudio en la ciudad y en la jardinería de la Mesa House o, también, su relación con Walter Doty, editor de la revista de cultura popular Sunset, the Magazine of Western Living, producida en San Francisco y de la que, por cierto, la Mesa House fue portada del número de octubre de 1949. Tanto Baylis como Doty serían los principales responsables de la recopilación de materiales para el monográfico póstumo que vio la luz en 1956.

Walter Doty fue además un gran apoyo para Drake, animándole a poner por escrito muchas de sus ideas, así como a dibujar propuestas teóricas de casas, estructuras, pequeños refugios de vacaciones, etc. que, regularmente, eran publicadas por su revista. Gracias a esta colaboración habitual con Sunset Magazine, han llegado hasta la actualidad varios textos de Drake que permiten aproximarse a su pensamiento arquitectónico y a las inquietudes que le rondaban la cabeza en aquellos años previos a su muerte.

Respecto a los fracasos, el principal de ellos fue su frustración por no poder llevar adelante su proyecto de una escuela y centro de investigación de arquitectura avanzada, sin la cual, Drake sentía que no tenía mucho sentido permanecer en Carmel pero tampoco volver a Los Ángeles y olvidarse por completo por su sueño, por lo que San Francisco, ciudad relativamente cercana y donde, además, vivían sus amigos y colaboradores más cercanos, se dibujaba en el horizonte como su mejor opción.

En julio de 1949, a punto de iniciar un nuevo rumbo profesional tras los amargos resultados profesionales obtenidos en su breve etapa de Carmel, Drake escribió a Harris: "Me ha llevado casi tres años escribirte esta carta y, quizás, mis fracasos hayan sido necesarios para decirte que si alguna vez llego hacer algo de interés en arquitectura será porque una vez tuve la suerte de trabajar bajo tu tutela" 256

Esta reflexión, no sólo es una prueba de la amistad y de la deuda intelectual de Drake con su maestro, sino que también deja constancia de su sentido de la autocrítica y del nivel de exigencia que se imponía a sí mismo tratando de avanzar como profesional. En cualquier caso, a finales de ese verano, Drake refiriéndose a la cantidad de proyectos que habían pasado por su mesa de dibujo, Drake también escribió "por lo menos, todo el trabajo realizado me deja la pequeña convicción de que algo sí he progresado en el último año"257.

\section{San Francisco, un nuevo comienzo}

En el otoño de 1949 Gordon Drake se trasladó definitivamente a San Francisco para trabajar con el arquitecto paisajista Douglas Baylis, con quien había entablado amistad tras haber colaborado con él en los proyectos de la Vacation House, Mesa House y, también, en el de su propia oficina en Carmel. En esta nueva etapa, Drake continuó suministrando material a la Sunset Magazine, principalmente artículos y proyectos donde reflexionaba sobre nuevas formas de vida asociadas al disfrute de la naturaleza, un tema que, junto con el paisajismo, la jardinería y los viajes, fueron prioritarios para la revista durante la etapa que estuvo dirigida por Walter Doty. A principios de los años 50, Sunset publicaba la obra de arquitectos californianos identificados con una mayor sensibilidad regional, como Harwell Hamilton Harris o John Laut-
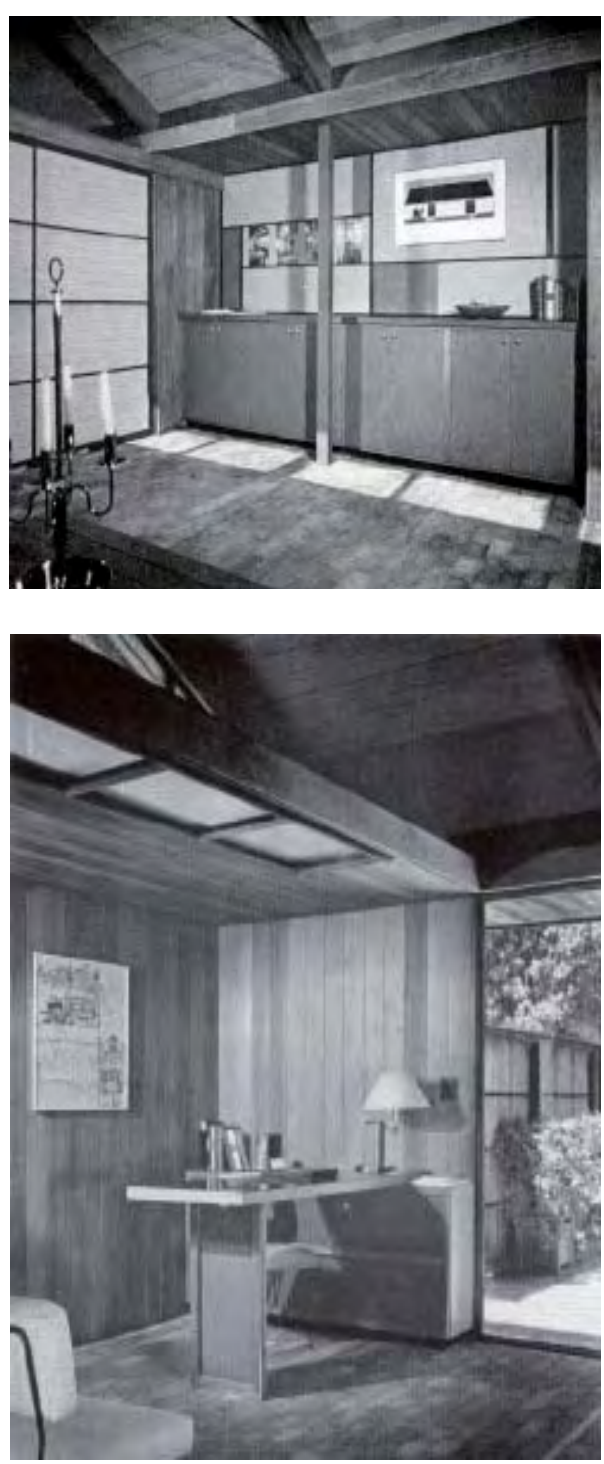


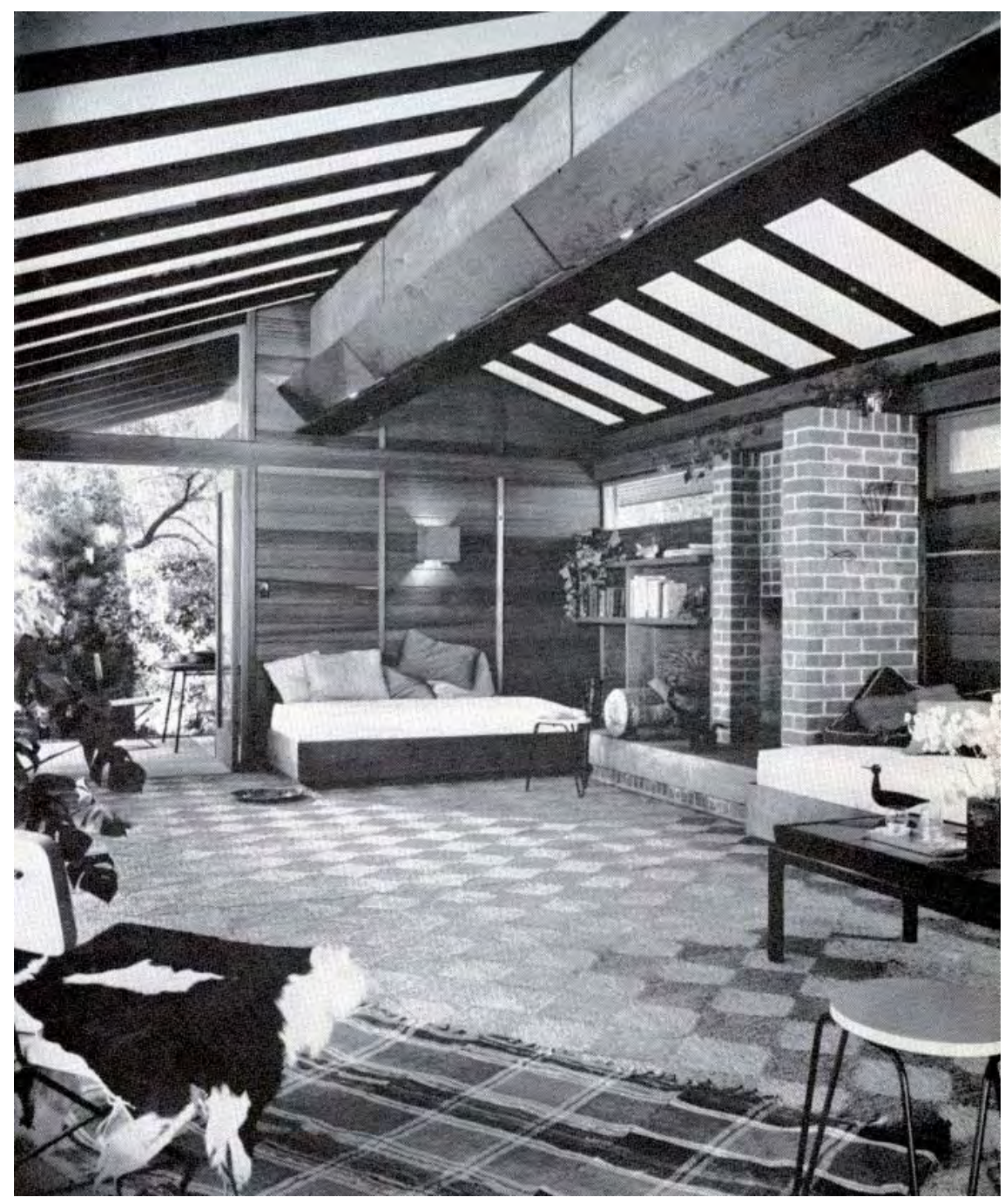

ner, aunque tenía muy en cuenta la obra producida por autores del norte del estado vinculados a la tradición del Bay Region, como William Wurtster o Pietro Beluschi. Igualmente, también prestaba una especial atención a la escuela de paisajistas del área de San Francisco como Thomas Church, Garret Eckbo y el propio Douglas Baylis.

En opinión de Neil Jackson ${ }^{25}$, fue a través de la publicación de estos diseños en una revista como Sunset -que, no hay que olvidar, estaba fundamentalmente orientada a un público no especializado- como Drake, al fin, pudo encontrar un canal para llegar a un cliente medio anónimo. Entre los proyectos y artículos publicados por Drake en Sunset Magazine sobre viviendas unifamiliares económicas y flexibles, sobre alojamientos de vacaciones para la playa o la montaña, o sobre pequeñas estructuras y piezas de mobiliario para la casa o el jardín pueden consultarse como ejemplos: "Design for Cabin Living", en Sunset, julio 1950, pp. 30-33; "Multi-purpose Garden Panels, You Can Build Almost Any Garden Structure", en Sunset, marzo 1951, pp. 40-43; "Good Ideas For your Garden Dining Room", en Sunset, julio 1951, pp. 36-38; o "How Tomorrow's Western Kitchens Will Extend to the Out-of-Doors", en Sunset, noviembre 1951, pp. 34-39 (el artículo se acompaña de una fotografía de Drake y de su entonces socio Douglas Baylis con una maqueta de la "kitchen glass room" de la casa de Drake en Los Ángeles).

Poco después de llegar a la ciudad, Drake se llevó la grata sorpresa de que su vivienda en Los Ángeles había sido seleccionada como portada del catálogo 


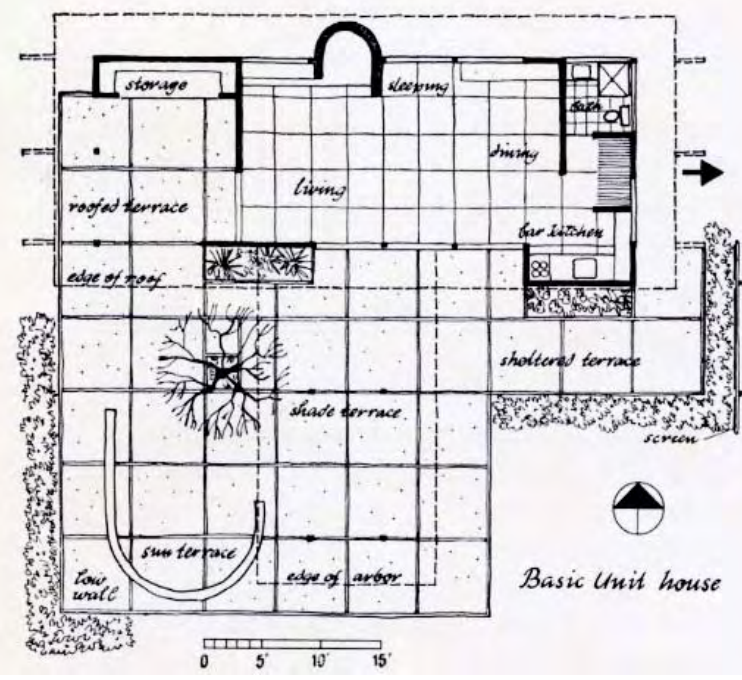

de arquitectura construida en los Estados Unidos entre 1900 y 1950 que la revista Progressive Architecture editó en enero de 1950 con motivo del inicio de la segunda década del siglo. Un espaldarazo que le animó a continuar sus investigaciones al tiempo que trataba de formarse en otros campos. Al finales de 1951, Drake entró a trabajar en el despacho del paisajista Lawrence Halprins en San Francisco. Ese año Drake pudo ver terminadas dos de sus últimas viviendas: la Unit House, también conocida como Scriber House, realizada en colaboración con Douglas Baylis y ubicada en Hayward, East Bay, a las afueras de Oakland, al noreste de la Bahía y, la otra obra, la casa para Robert Berns en Malibu, en cuyo proyecto llevaba trabajando varios años.

La primera de ellas, la Unit House, consistía en una vivienda prototipo de dimensiones muy modestas. Estaba constituida prácticamente por un único espacio y desarrollada a partir de una retícula de 1,8 metros que, como su nombre indica, podía evolucionar a través de un proceso de crecimiento modular muy similar a la propuesta de la Segmental House de Harris. El proyecto original planteaba una vivienda de una sola estancia que fue ampliada en dos etapas. En la primera, se añadió un dormitorio y se agrandó también la cocina. En la siguiente etapa, se construyó un segundo dormitorio y una zona de juegos para niños que conllevó pequeños ajustes en el tratamiento de los espacios exteriores. Culminado el proceso de ampliación, estos recintos exteriores que visualmente expandían la limitada superficie de la vivienda, dieron lugar a diferentes ambientes que complejizaron las relaciones espaciales que daban sentido a la vivienda: una terraza cubierta que ampliaba el área del estar; un solárium delimitado por un muro curvo; una terraza semicubierta bajo un porche de madera; otra terraza cubierta mediante paneles horizontales y protegida por vegetación; y una zona de juego de niños.

La Unit House, inspirada tanto en el paradigma modular de viviendas ampliables de Harris como en los principios de su producción anterior, surge como una combinación de ideas ya apuntadas en su propia casa de Los Ángeles con algunos de los diseños de cabaña desarrollados para la revista Sunset. El hecho de estar pensada para ser publicada en esta revista llevó a Drake a potenciar hábilmente algunas cuestiones de aspecto de la vivienda como las cubiertas inclinadas, los porches generadores de sombra o la utilización de la madera de redwood lo que, sin restarle un ápice de modernidad pero ser reconocibles en su condición doméstica, le permitiría ganarse la confianza de sus lectores e introducirlos en otras soluciones más experimentales.
Gordon Drake: planta y sistema de adición modular de la Unit House en el área de Oakland, Bahía de San Francisco, 1950

Página Anterior: Gordon Drake: Unit House. Fotografía de Julius Shulman 


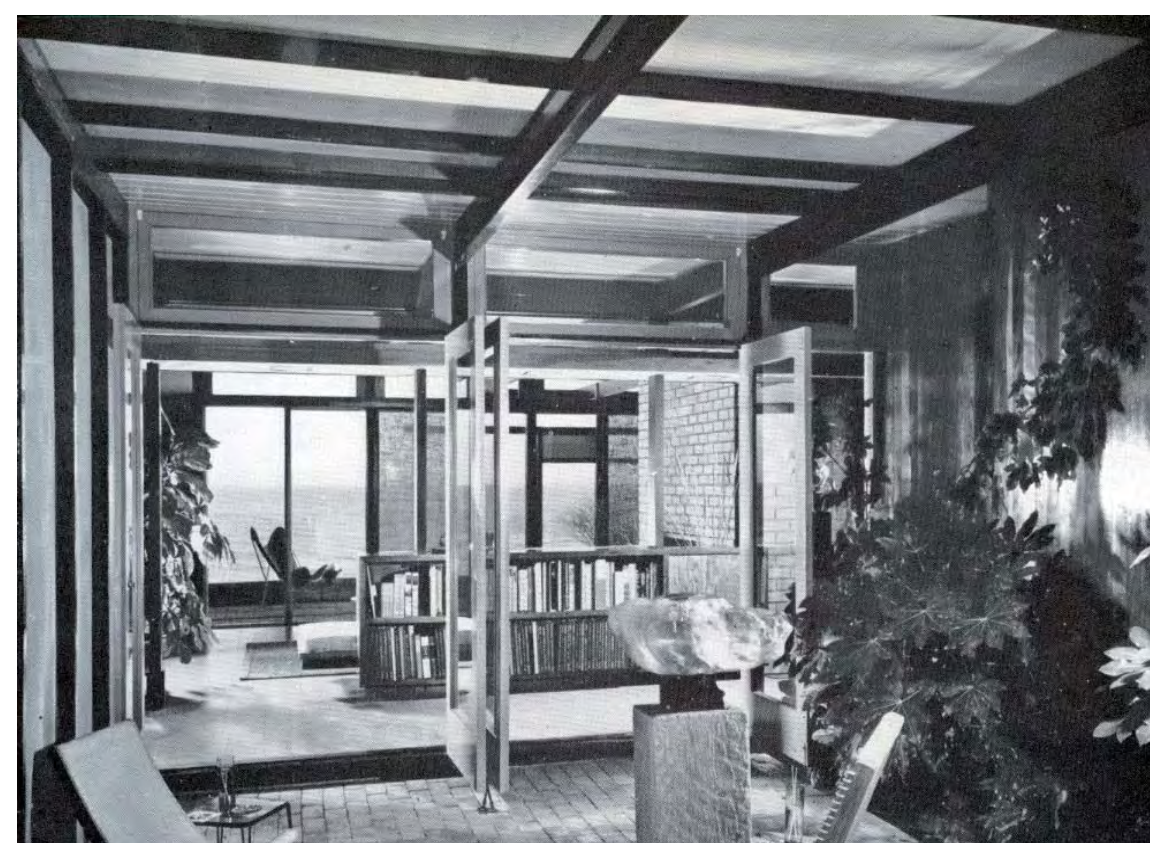

También construida en madera en primera línea de costa, la Robert S. Berns House en Trancas Beach, Malibu, está planteada, como la Unit House, a partir de una secuencia de patios y porches semicubiertos, filtros de sombra, y elementos vegetales de transición que llevan desde la calle hasta la terraza frente al Pacífico, de cuya luminosidad la casa se protege mediante un sistema de pantallas y tabiques móviles de papel de arroz.

La casa fue fotografiada por Julius Shulman en 1953, un año después de la muerte del arquitecto y posó para él la propia Esther McCoy, sentada en las escaleras que conducen de la terraza a la playa. En la fotografía más difundida de la casa, McCoy 259 , amiga tanto de Shulman como de Harris, departe amablemente con su anfitriona quien, de espaldas al océano, es captada en un gesto desprevenido mientras desplaza una silla para sentarse junto a su invitada. Una vez más, al fotografiar una casa de Drake, Shulman optó por una escena cotidiana para representar una auténtica domesticidad, completamente alejada de la desafectación de la imágenes de la vanguardia europea o del glamur de muchas de sus instantáneas de los años cincuenta, como si el fotógrafo reclamara, como hubiera hecho el propio Drake, la vida sencilla de un every day modernism.

El interés de los medios por la producción reciente de Drake no cesó durante su etapa en San Francisco, por ejemplo, la Unit House en Hayward fue objeto de un extensor reportaje del número de marzo de 1952 de House \& Home Magazine, una revista filial de Architectural Forum que enfocó su artículo hacia la idoneidad de este tipo de proyectos para los mercados de construcción local. Por su parte, el número de 1956 de Progressive Architecture, dedicado monográficamente al tema "The New House-to-Site Transition", entre otras viviendas de Drake, cargaba las tintas en los logros de la Berns House en Malibu Beach, publicada con las imágenes de Shulman comentadas en el párrafo anterior. El editor argumentaba: "esta última casa de Drake (una de sus pocas no publicadas todavía) resume admirablemente este tema de un nuevo enfoque de las relaciones interior-exterior [...] Con el proyecto de esta casa el arquitecto ha logrado con creces su objetivo de producir una sutil transición desde un espacio a cielo abierto plenamente iluminado hasta un recinto totalmente cerrado, ofreciendo toda una gama de diferentes grados de apertura y cierre, todo tipo de opciones de cerramiento"260. 


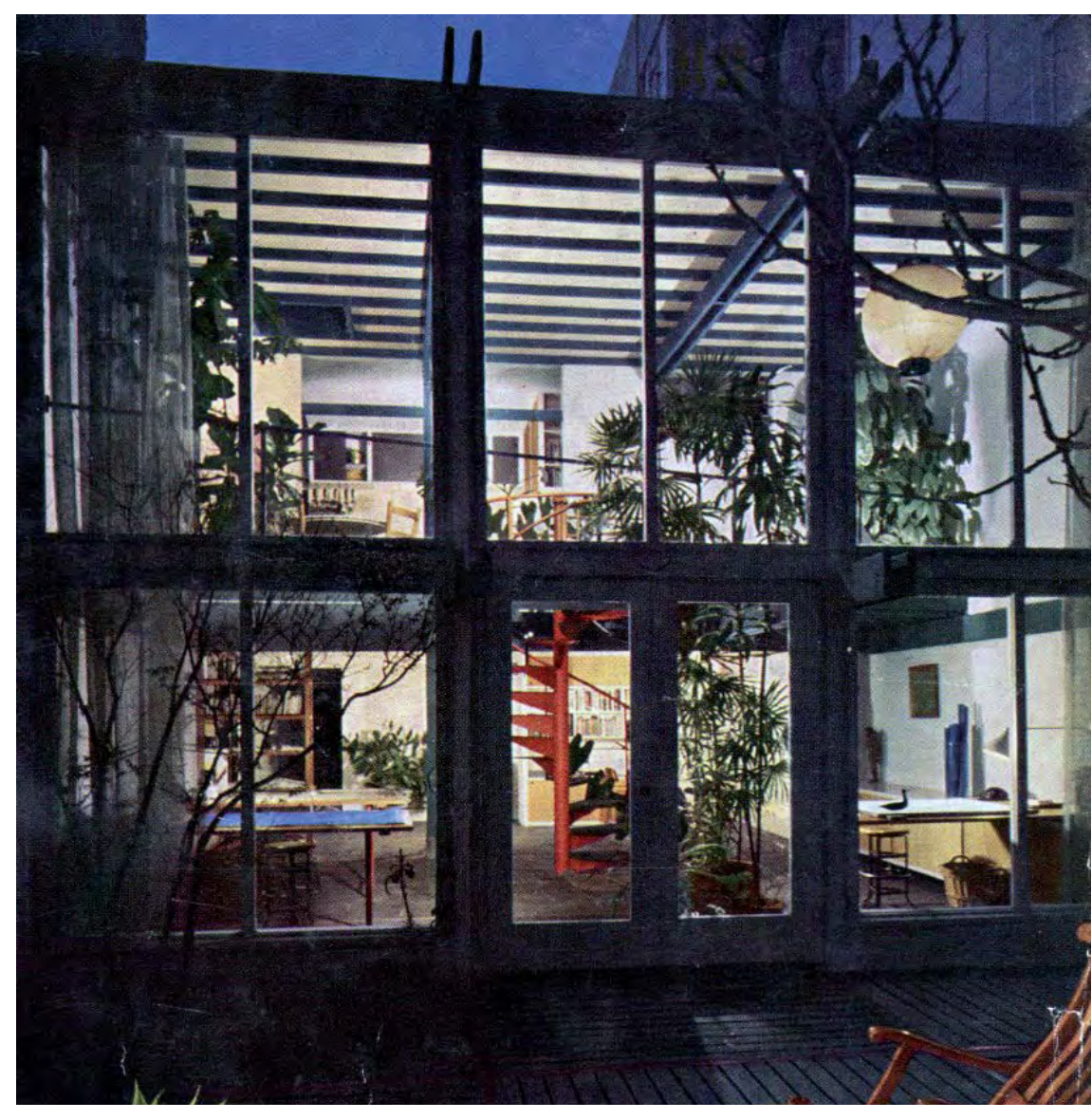

Por cierto que, un año después de la muerte de Drake, esta casa volvería a ser portada, esta vez de la revista Sunset en su número de marzo de 1953.

Poco antes de la Navidad de 1951, Drake supervisó los trabajos finales de estas dos obras y se mostró muy satisfecho con el resultado. Estaba tan ilusionado con el nuevo rumbo que tomaban los acontecimientos en su vida profesional que resolvió presentarse a los exámenes para obtener el título oficial de arquitecto. También en el terreno de lo personal parecían irle bien las cosas, afianzaba las relaciones con sus amigos y nuevos contactos en la ciudad y había decidido volverse a casar, prometiéndose con su nueva novia, Betsy Roeth. A principios de enero de 1952, Drake necesitaba unos días de descanso, y planificó unas pequeñas vacaciones para ir a esquiar al Lago Tahoe, en norte del Estado, en compañía de un amigo arquitecto neozelandés y de su nueva pareja. Las nevadas de aquella temporada estaban siendo especialmente intensas y durante varios días de fuertes ventiscas se vieron obligados a permanecer confinados en el refugio. Por fin, la mañana del 15 de enero dejó de nevar. Había amanecido un día radiante y las montañas cubiertas bajo un manto de varios metros de nieve virgen. Drake desayunó copiosamente $y$, sin esperar a sus compañeros, ansioso por recuperar el tiempo perdido, a pesar de no ser un buen esquiador, se lanzó solo colina abajo. Nunca completaría el descenso. Probablemente un corte de digestión le hizo perder el conocimiento y al caer de bruces en la nieve murió de asfixia. Doblada en su cartera, encontraron una cuartilla donde, premonitoriamente, había copiado a lápiz unos versos de las Devotions del poeta metafísico inglés John Donne:

"No man is an island, entire of it self; every man is a piece of the continent, a part of the main [...] Any man's death diminishes me, because I am involved in mankind" ${ }^{\prime 261}$.
Gordon Drake: Baylis House en San Francisco, terminado tras la muerte del arquitecto y fotografiado por Julius Shulman en 1956

Página anterior arriba: Gordon Drake, Berns House en Malibu. Fotografía de J. Shulman Página anterior abajo: Portada de Sunset Magazine de marzo de 1954 reproduciendo la casa en una fotografía en color con Esther McCoy sentada en la terraza frente al océano. Portada de Julius Shulman 


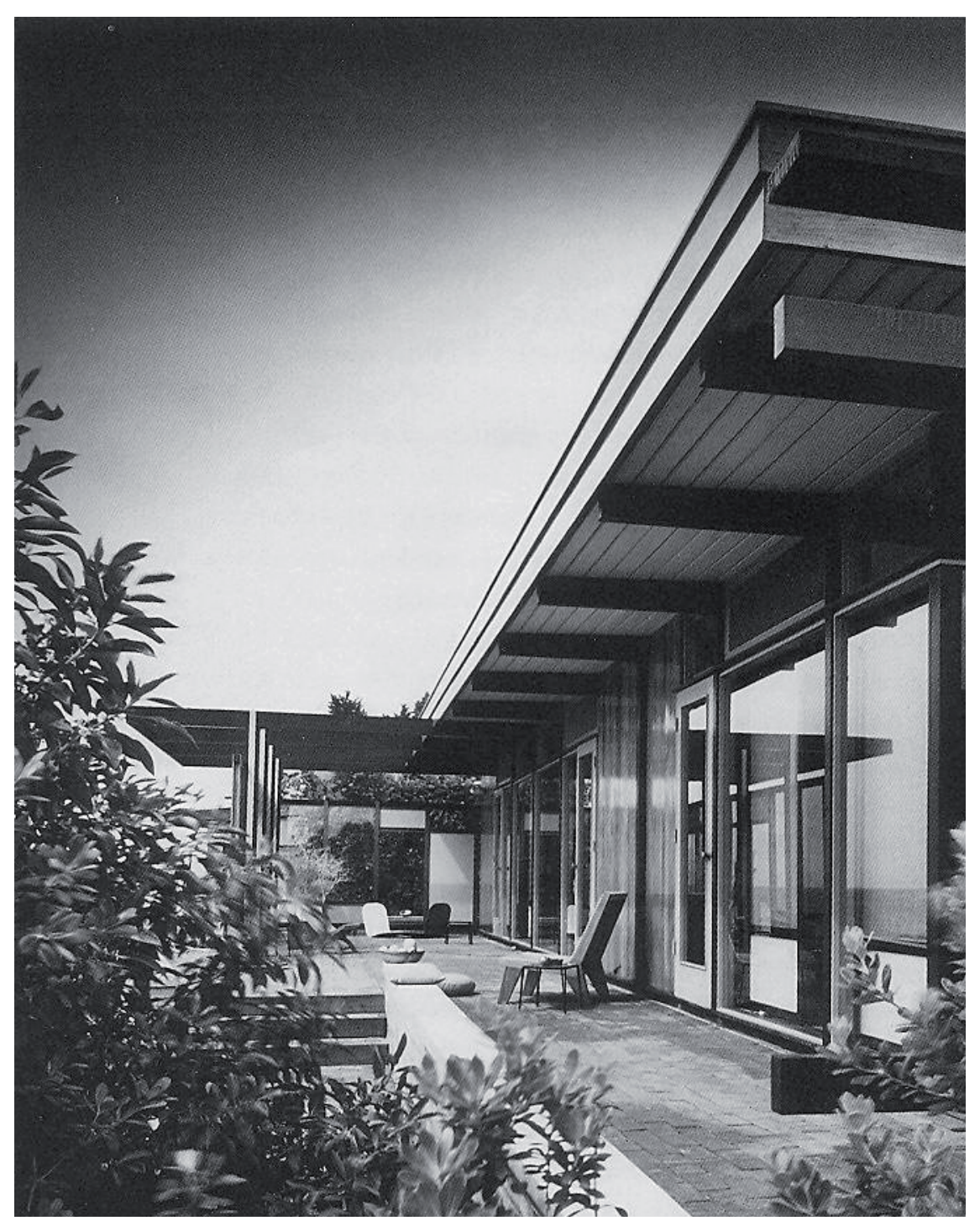

Gordon Drake, Berns House en Malibu. Fotografía de J. Shulman

\section{Harris en memoria de Gordon Drake}

Tras la desaparición de su antiguo colaborador, Harwell Hamilton Harris escribió un sentido texto en memoria de su discípulo. En su homenaje, que por el interés de sus palabras se reproduce íntegramente traducido al castellano, Harris alaba las cualidades de Drake y sus logros como arquitecto, descubría también cuáles de sus propios proyectos le habían interesado más a su antiguo estudiante y aportaba un sutil análisis de la personalidad de Drake:

"Conocí a Gordon cuando era estudiante. De hecho, era uno de los doce que, en 1940, asistían a mis clases en la Universidad del Sur de California donde, en aquel momento, se me había invitado como crítico para dirigir algunos de los cursos de verano. Examinábamos el trabajo que había realizado para otras asignaturas, así como para mi propia clase. Realmente, no recuerdo que fuera capaz de terminar ninguno de sus dibujos. Una vez se sentía satisfecho con el trabajo realizado, encontrando que no había nada más que descubrir continuando un determinado diseño lo abandonaba y se centraba en otro problema. Sabiendo esa faceta suya aún me sorprende que le permitiera venir a trabajar conmigo el otoño siguiente.

Entre los trabajos en marcha en el despacho en aquella ápoca estaban la Havens House en Berkeley, la Birtcher House en Los Angeles y la Lek House en La Jolla. No obstante, mi casa de Fellowship Park, terminada seis años antes, 
captó mucho más su interés que cualquier otro proyecto que pudiera encontrar sobre mis mesas de dibujo. Quizás fuera porque, al ser uno de mis primeros proyectos, este hecho llamara poderosamente su atención. Gordon estaba completamente absorbido por el diseño modular y el empleo de paneles prefabricados en construcción; temas que ya estaban presentes en Fellowship Park, además de una organización rítmica de esos paneles y de su relación con la continuidad del entramado estructural. Los paneles se agrupaban de dos en dos, lo que inmediatamente cambiaba el ritmo de una marcha monótona a algo más parecido a una danza; deslizando hacia la derecha el panel derecho de cada uno de estos pares y colocándolo delante del panel izquierdo se producía una serie de uno-dos elementos; desplazando primero el panel derecho y después el izquierdo en la seriación de pares surgía un ritmo más complejo; alternando paneles de vidrio con paneles textiles, con paneles de Celotex, e incluso, eliminando uno de los paneles, todavía podía complicarse más este ritmo inicial. Dividendo cada unidad en tercios con los que cambiar el ritmo disponiendo las piezas paralela o perpendicularmente a las unidades dobles, o al módulo completo, se conseguía un interesante efecto de profundidad. La continuidad del entramado estructural se conseguía recurriendo, en lugar de a un único elemento portante, a varias piezas que, una vez ensambladas, daban lugar a los pilares, vigas, riostras de suelo y que, al eliminar algunas de ellas estratégicamente en cada intersección, permitían a las demás proseguir libremente su camino a través. Cada uno de estos componentes estructurales se mantenía reconocible mediante pequeños desfases o espaciamientos a la vez que se conseguía una perfecta continuidad visual del conjunto de la estructura.

Éste era el principio que guiaba el diseño de la obra y Gordon lo descubrió inmediatamente. En él, mente, espíritu y el tipo de orden existente en la naturaleza puede que encontraran una expresión arquitectónica. Carácter arquitectónico era lo que, aparentemente, él estaba buscando. Durante una visita de obra a la casa Havens en Berkeley, tuvo la ocasión de admirar, por primera vez, la Christian Science Church de Maybeck. Uno de los edificios más expresivos y elocuentes que Gordon hubiera visto antes y que jamás olvidaría.

Después de la guerra volvió para trabajar durante unos meses a mi despacho que, para entonces, estabamos trasladando justo al lado de mi casa de Fellowship Park. El estudio tenía la misma estructura continua que la casa y Gordon llegó justo a tiempo para supervisar el final de las obras. También desarrolló parte del proyecto de una especie de casa portable que denominamos Tool \& Tea House -un módulo parcial de vivienda de 10 pies cuadrados con una cubierta en forma de pétalo ${ }^{262}$.

Gordon compró un pequeño solar y, durante sus horas libres en mi oficina revisaba una y otra vez el proyecto de su casa detallando las ideas en las que había empezado a pensar mientras servía en el Pacífico o en Camp Pendleton. Durante aquel tiempo, cada pocos meses, me hacía llegar su última versión del proyecto. Entonces, con la ayuda de un joven ingeniero que había conocido en el ejército y de otros de mis jóvenes delineantes, aprovechaba las noches y los fines de semana para terminar la obra. La casa obtuvo el Primer Premio de Progressive Architecture en la modalidad de viviendas unifamiliares construidas durante 1946 por ser la obra mejor ejemplarizaba la idea de progreso a través de un diseño arquitectónico innovador; a pesar de su reducido presupuesto contaba con todas las comodidades de una casa de varias veces su tamaño.

Gordon estaba lleno de ideas que necesitaba expresar con urgencia, experimentándolas de un modo u otro, mientras esperaba su oportunidad para materiali- 
zarlas físicamente. Estaba seguro de que sería capaz de encontrar la forma de crear pequeñas casas al alcance de los jóvenes veteranos de guerra cuyas necesidades no sólo conocía bien sino que, por lo visto, se sentía obligado a atender. Esta fue la razón por la que dejó mi estudio deseando proyectar y construir por su cuenta.

Exceptuando los cuatro o cinco años de la guerra que pasó sirviendo en la Marina, la arquitectura le absorbió completamente todo su tiempo. $Y$, en cierto modo, la experiencia a la que se vio obligado como oficial a cargo de un grupo de operaciones de tierra no hizo sino alimentar esa obsesión. La imagen constante de tantos compañeros cuyas vidas fueron sacrificadas le llevó a encontrar un consuelo desviando sus pensamientos hacia otra parte. Frente a la locura de un mundo en guerra, él encontraba consuelo imaginando las posibilidades de una nueva arquitectura. La arquitectura creció en su espíritu como una idea, alimentándose de todos los significados de lo que para él era noble, brillante y bueno. Fue la estrella que guió su vuelta a casa desde el frente.

Fue impaciente con el final de la guerra. Fue también impaciente con su propia lentitud pero, sobre todo, con la falta de voluntad de los demás para tratar de comprenderle. Estaba seguro de que la arquitectura era el camino: confiaba en que en el momento en que alcanzara la simplicidad, la unidad y el auténtico significado de su arquitectura, también lograría ser dueño de su propia vida. Para Gordon, proyectar era un modo de descubrir cosas y de desarrollar las consecuencias de sus descubrimientos. La perseverancia se convirtió para él en la realidad. Apenas había empezado cuando murión"263.

\section{Repercusión mediática: \\ Gordon Drake y la fotografía arquitectónica de Julius Shulman}

Todo el mundo en Los Ángeles sabía acerca de los excelentes contactos ${ }^{264} \mathrm{de}$ Julius Shulman con los editores y revistas de arquitectura de mayor difusión del momento de modo que, si se quería aparecer en los medios, Shulman era una de esas personas a las que primero se debía llamar. También era conocido por su buen ojo para descubrir talentos en ciernes. Julius Shulman apoyó incondicionalmente el trabajo de muchos arquitectos, especialmente los más jóvenes, cuya obra fotografió por muy poco dinero cuando creía en ellos, convencido también de su inversión a medio largo plazo.

Uno de estos casos, si no el más llamativo de toda su carrera como fotógrafo, fue el de Gordon Drake, con quien, desde el primer momento, sintió una especial conexión que inmediatamente dio paso a una mutua admiración profesional y a una gran amistad personal. Shulman compartía con Drake su energía vital y su capacidad de ilusionarse ante la novedad. Sus ideas le interesaron enormemente y puso todos los medios a su alcance para transmitir su esencia a través de sus fotografías.

La penetrante mirada de Shulman fue la principal responsable de la temprana fama que alcanzaron las obras de Gordon Drake. Shulman posó su objetivo para inmortalizar algunos de sus principales valores, que captó en una serie de fotografías memorables: integración en el lugar y fusión de la construcción con el elemento vegetal, hábil utilización de la luz, la solvencia de unas plantas trabajadas desde el rigor modular, la exacta y atractiva combinación de elementos naturales (madera) con otros fruto de la producción industrial (vidrios esmerilados), etc. 


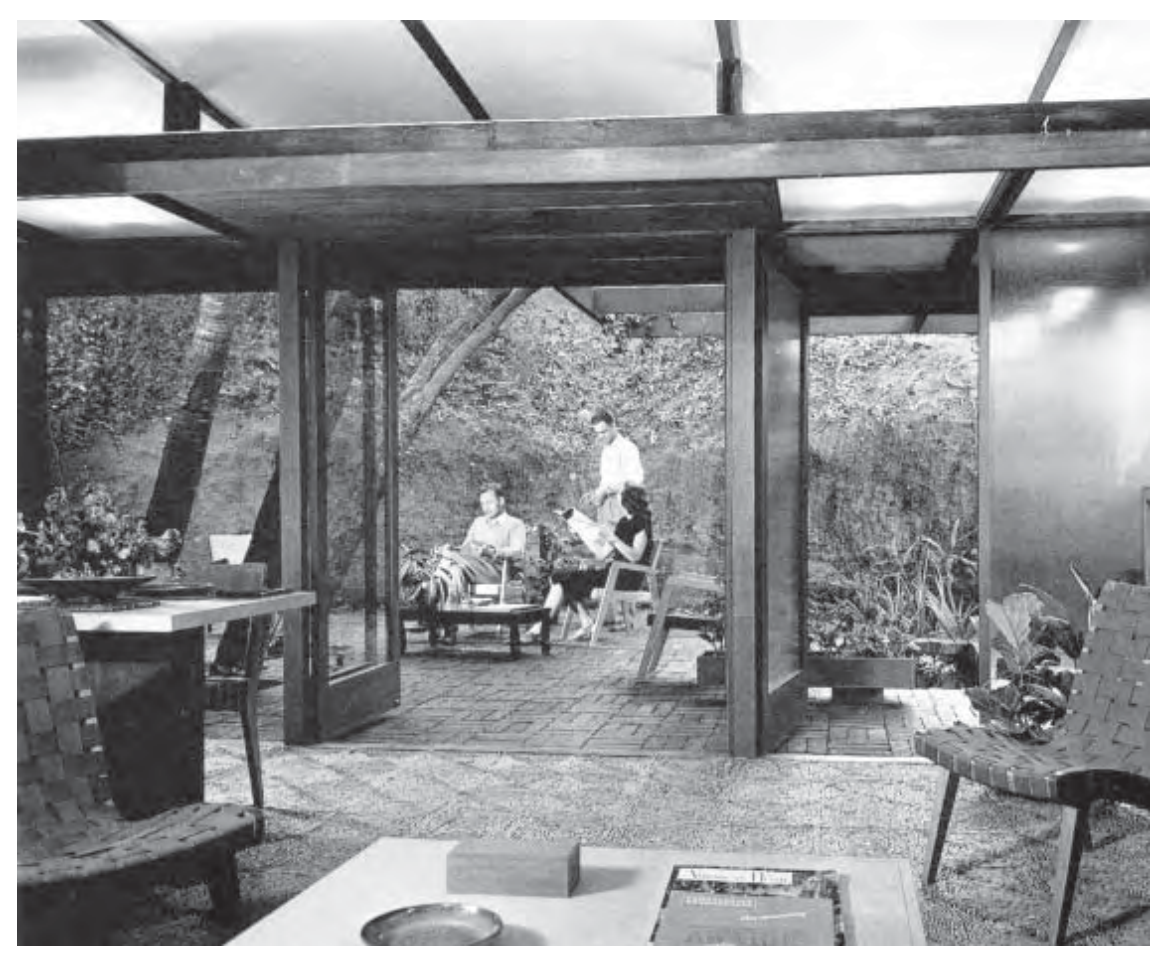

Las fotografías que Julius Shulman tomó de la casa de Drake en Beverly Glen constituyen el conjunto de imágenes más difundido de toda la producción del arquitecto. Precisamente, fueron estas mismas fotografías las que Drake envió a Progressive Architecture. Siendo evidente la capacidad de seducción de las instantáneas de Shulman, es lógico pensar que tuvieron que ejercer un poderoso efecto sobre los críticos que juzgaron la propuesta y que, finalmente, le otorgaron el máximo galardón en su categoría.

En ellas, Shulman dirige la atención del espectador hacia aquellos elementos que quiere destacar de la composición -él los denominaba eyestopper-, enfatizando todos los aspectos más dramáticos de la arquitectura, enviando al espectador desde la casa hasta la naturaleza y exagerando mediante efectos de iluminación las cualidades horizontales de los elementos que constituyen la vivienda. Precisamente, es a partir de ese momento, tras la guerra, cuando Shulman, en pleno dominio de la técnica fotográfica, dejó de actuar tanto como un documentalista de arquitectura para desplegar su personalidad como artista interesado en crear sus propias narrativas. Las fotografías de la vivienda de Gordon Drake suponen algunas de sus primeros éxitos personales y Shulman, orgulloso de su evolución como creador, las tuvo siempre muy presentes como uno de sus mejores trabajos de la primera década de su carrera ${ }^{265}$.

En una de ellas, como ha reparado Joseph Rosa ${ }^{266}$, el fotógrafo sitúa la cámara en el punto de vista de una persona sentada en el extremo opuesto del salón, mirando al jardín, donde tres personas, una de ella el propio Drake, también sentado, charlan relajadamente ojeando unas revistas. Con este punto de vista es como si el espectador no mirara la fotografía, sino que estuviera dentro de ella, sentado en el propio espacio del salón y, de este modo, tiene acceso a detalles como el techo proyectándose hacia el jardín que, difícilmente podrían haber sido apreciados desde otro punto de vista.

En otra de las fotografías de la casa, la cámara se introduce en el dormitorio, como si el espectador estuviera sentado en una esquina de la cama.
Arriba y abajo: Gordon Drake, vivienda del arquitecto en Beverly Glen Canyon, Los Ángeles, 1946. Fotografías tomadas por Julius Shulman en agosto de 1946. En la escena superior $G$. Drake es el personaje sentado en el patio a la izquierda de la composición

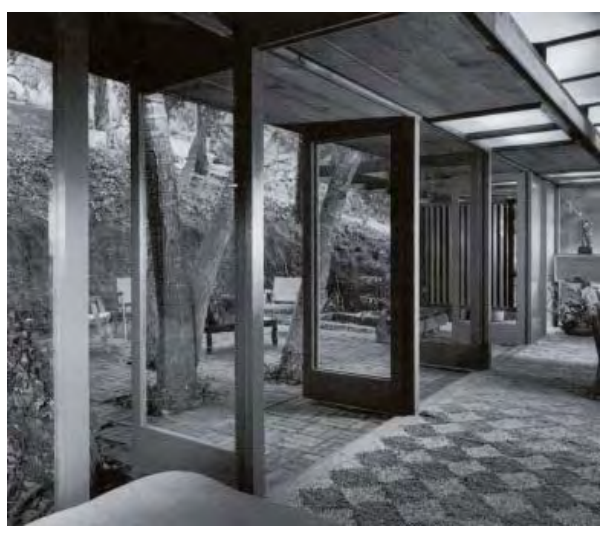




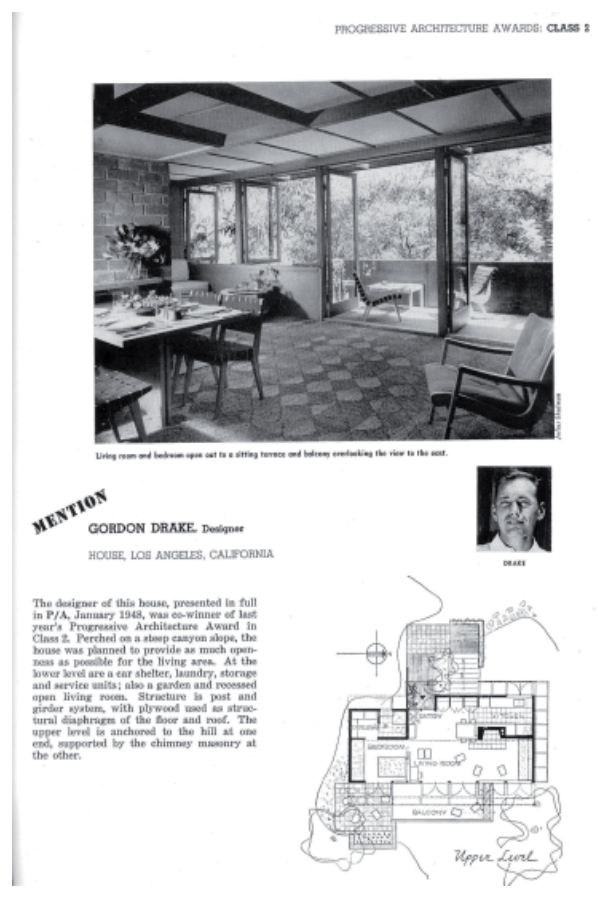

Izda: Página de Progressive Architecture, julio de 1948, anunciando la mención concedida a la Spillman-Rucker House

Dcha: Gordon Drake, Spillman-Rucker House en construcción, Los Ángeles. Fotografía tomada por Julius Shulman en agosto de 1946. El arquitecto aparece sentado entre dos de sus colaboradores en la esquina inferior izquierda de la composición

Página siguiente: Portada del número de marzo de 1947 de la revista House \& Home reproduciendo a todo color el estar de la Drake House con el arquitecto posando para la imagen. Fotografía de Julius Shulman

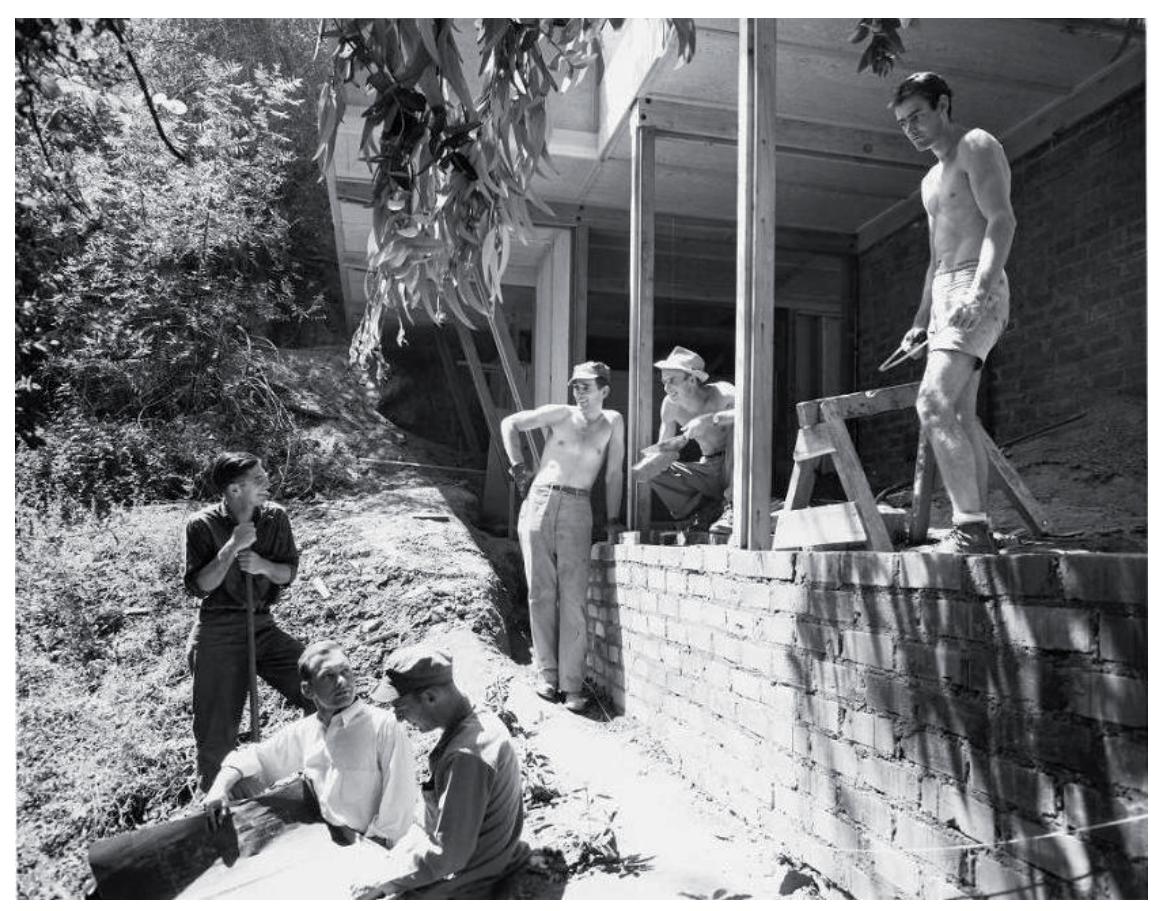

La cortina que separa estos espacios permanece oculta para no dar pistas de las dimensiones del espacio. Lograda toda la profundidad posible en la perspectiva, Shulman fuerza al espectador a mirar de nuevo hacia el jardín, ofreciendo la clave del proyecto: continuidad interior-exterior. $Y$ al mismo tiempo, pone en valor toda una serie de elementos como los árboles originales que rodean la casa, la excavación de la pendiente o la iluminación ambiental oculta en la estructura; presencias y ausencias que contribuyen a cualificar el espacio de la vivienda.

Drake quería que Shulman fotografiara sus casas captando la esencia de sus espacios llenos de vida, para que la "gente pudiera imaginarse cómo sería vivir en una casa moderna"267. Si se piensa en algunas de las más célebres fotografías de Shulman, como las de las Case Study Houses de Pierre Koenig o-para escoger un ejemplo de vivienda contemporánea exacta de la Drake Housecomo la instantánea tomada al anochecer en el jardín de la casa Kaufmann de Richard Neutra, con su propietario reclinado en borde de la piscina, es evidente la diferencia. En las casas de Drake no hay personas reunidas con ocasión de un cóctel o piscinas iluminadas sólo asequibles a una clase social elevada, ni siquiera hay fotografías nocturnas ${ }^{268}$, las escenas domésticas son de una absoluta cotidianidad: a veces es el propio Drake junto a su esposa, otras, rodeado de amigos disfrutando de un almuerzo de sábado en el jardín, o, incluso, de su grupo de colaboradores.

Éste sería el caso de la fotografía tomada en la Spillman House, todavía en obras, durante un descanso en el trabajo. La fotografía fue realizada el mismo día en el que se hicieron las de la casa de Drake, el 29 de agosto de 1946. El arquitecto aparece sentado a la izquierda, rodeado de su tropa de ex marines, algunos de ellos sin camisa. Esta imagen trasmite la camaradería, el esfuerzo compartido y la ilusión de todos los implicados, cada uno desde su propia responsabilidad, por construir una nueva realidad en la que se cree como proyecto colectivo. Sintomáticamente, a diferencia de las instantáneas de obras de muchos de los maestros de la generación anterior a la guerra, como por ejemplo las realizadas por el propio Shulman de Richard Neutra posando en sus obras, Drake nunca aparece fotografiado solo en sus viviendas. 
La serie de imágenes tomadas por Shulman de la vivienda del arquitecto constituyen algunas de las instantáneas favoritas del fotógrafo ${ }^{269}$. No obstante, la predilección de Shulman por estas fotografías resulta más que evidente a tenor del número de veces que, en su momento, decidió enviarlas a revistas de arquitectura o que, en los últimos años de su vida, volvió a recurrir a ellas, no sólo para ilustrar monografías o trabajos especializados que han ido apareciendo recientemente sobre determinados aspectos de su carrera de más de 6 o años sino, también, como ejemplo del éxito de las diferentes técnicas fotográficas empleadas en la vivienda de Gordon Drake. En este sentido, es obvio el orgullo con el que Shulman relataba una y otra vez el modo en que dispuso la cámara a la altura de la vista de un observador sentado, o cómo había conseguido un perfecto equilibrio entre las luces del interior y del exterior de la vivienda.

Un dato curioso es que en algunas de las escenas fotografiadas, Shulman colocó astutamente sobre una mesa la portada del número de Progressive Architecture donde se convocaban los premios. Tras completar el reportaje fotográfico de la vivienda, el fotógrafo coordinó con Drake su envío a ésta y otras revistas donde tenía buenos contactos. Tal como Shulman había vaticinado a Drake al deslizar esa portada de Progressive Architecture en primer término de una de sus fotografías, el arquitecto se hizo con el primer premio. La jugada resultó redonda para ambos, especialmente para Shulman, quien consiguió vender sus fotografías de la Drake House en los trece artículos que diferentes revistas de tirada nacional e internacional publicaron sobre la casa ese mismo año 1947 tras conocerse la resolución del concurso.

La primera vez que se publicó la vivienda tras el fallo del jurado fue en el número de junio de 1947 de Progressive Architecture, donde se anunciaba el veredicto del mismo. Este primer artículo en la revista, el detonante de la inmediata celebridad de Drake, estaba ilustrado con tres pequeñas imágenes de Shulman y algunos comentarios de los miembros del jurado. Su presidente, William Wurster, escribía: "la belleza y el atractivo de la Drake House representan el triunfo de un esfuerzo individual", alabando públicamente la planta de la casa que calificaba como brillante. Por su parte, Eliel Saarinen, respaldaba las aspiraciones del propio Drake implícitas en este trabajo cuando decía que se trataba de "una contribución arquitectónica concreta -una casapero que gracias a los sistemas de producción industrializada podría ayudar a que la nueva arquitectura de masas avanzara en la dirección de ha apuntado este diseño". Y Kenneth Reid afirmaba "que la expresión nada pretenciosa de la individualidad de un ser humano ha resultado ser una valiosa contribución al conjunto de la sociedad".

Shulman ya había publicado sus fotografías una década antes en Pencil Points, revista antecesora de Progressive Architecture antes de fundirse con ella en 1943. La primera vez había sido en 1937, en el especial dedicado a Richard Neutra publicado en el mes de julio, a partir del cual Shulman había iniciado una estrecha relación con su editor, Thomas H. Creighton. Gracias al cual el fotógrafo llegó a ilustrar casi 300 artículos en esta revista a lo largo de su carrera. En una tesis leída en 2010 en la Universidad del Sur de California, su autora, Deborah Howell-Ardila, sostiene que Creigthon recordaría más tarde la reunión del jurado que premió la Drake House escribiendo sobre el entusiasmo con el que, tanto Eliel Saarinen como Fred Severud, recibieron la noticia de que aquella obra que acababan de escoger como ganadora era la opera prima de un joven arquitecto que hasta entonces apenas había publicado nada ${ }^{270}$.

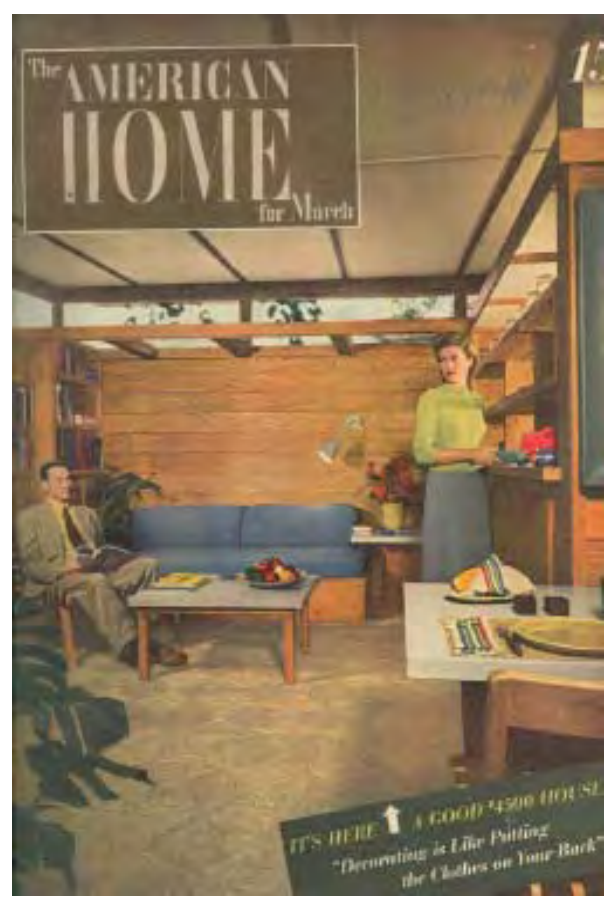



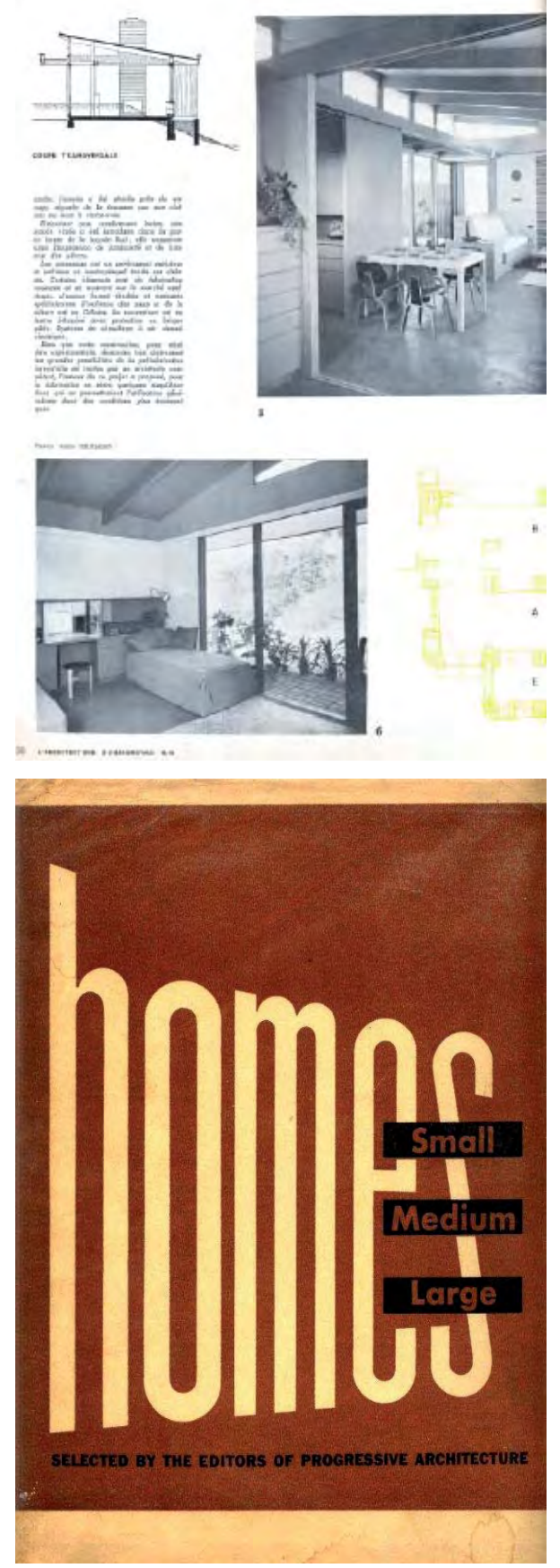

Arriba: Página de L'Architecture d'Aujourd'hui, junio de 1948 donde se publica la Presley House en Silver Lake

Abajo: Porta de P/A Small, Medium, Large, libro editado por Thomas Creighton en 1947 y que ya incluía la Drake House en Los Ángeles
No obstante, unos meses antes de fallo del concurso de Progressive Architecture, la revista The American Home ${ }^{271}$ se había adelantado publicando en el número de marzo de 1947, por primera vez, la casa del arquitecto en Beverly Glenn. La vivienda aparecía en portada, ilustrada con una fotografía del propio Drake y de su mujer a todo color y anunciando que el precio de la vivienda no había superado los 4.500 dólares. Llamativamente, esta revista de arquitectura doméstica y diseño de interiores destinada a un público femenino publicaba en su portada una imagen de una vivienda moderna con su arquitecto, además, ejerciendo de modelo. Esta circunstancia ofrece una medida del grado de aceptación del trabajo de Drake, tanto por parte de la profesión-cuyo reconocimiento alcanzaría a través de un jurado de renombre internacional (Wurster, Eliel Saarinen, Severud)- como por parte del público no especializado de la emergente clase media norteamericana.

Teniendo muy presente el perfil de sus lectores, American Home publicaba esta historia aportando además todos los detalles de las circunstancias humanas que habían hecho posible el milagro: "Two Ex-Marines Put an Ideal to Work... and Build a $\$ 4.500$ House". El artículo se ilustraba con nueve fotografías de Shulman de la Drake House y tres de la Spillman House, todavía en fase de construcción. A lo largo de las seis páginas que ocupaba el reportaje, la revista no escatimaba en información sobre cómo estos hombres, Drake y su amigo el ingeniero mecánico Louis Soltanoff, se habían conocido en el ejército $y$, tras regresar del frente, habían planeado llevar a cabo sus ideal de construir viviendas como ésa a precios asequibles para todo el mundo. American Home mostraba su entusiasmo por esta obra, que conoció a través de la labor publicitaria de Shulman, quien ya había ilustrado diez artículos anteriores de viviendas modernas de los cuales el primero de ellos, en 1941, había sido la propia casa de Richard Neutra, la primera VDL House en Silver Lake.

Numerosos artículos sobre la vivienda de Drake en Los Ángeles aparecieron en los meses siguientes en diversas publicaciones de tirada nacional de la importancia de Architectural Forum (septiembre 1947) o de la tirada de revistas de mayor difusión popular como Interiors (septiembre 1947) o House \& Garden (septiembre 1947). Y también en revistas de todo el mundo como el diario del RIBA, Architects' Journal, en Inglaterra (junio y julio de 1947), Domus en Italia (octubre 1947), la argentina Revista de Arquitectura (febrero y noviembre de 1948), la francesa L'Architecture d'Aujourd'hui (junio 1948), e incluso la revista sueca Form a finales de 1948. Tanto en Italia, Francia como en Argentina, había sido Neutra quien había introducido sus obras con las fotografías de Julius Shulman, que guardó sus contactos con los editores de las mismas para seguir enviando material por su cuenta.

Tras su publicación en Progressive Architecture, la casa fue inmediatamente catapultada al ámbito de las monografías temáticas de arquitectura. El primer libro que se ocupó de ella fue precisamente una consecuencia de su aparición en la revista P/A: Small, Medium, Large. Homes selected by the editors of Progressive Architecture ${ }^{272}$, coeditado por Thomas Creighton y publicado en Nueva York en 1947. Creighton, quien ya había publicado más de treinta artículos ilustrados con fotografías de Shulman cuando apareció este libro, volvería a incluir la vivienda en otra de las monografías de arquitectura de posguerra de las que formó parte en vida de Drake, The American House Today. 85 notable examples ${ }^{273}$, publicada también por la editorial Reinhold en Nueva York en 1951. También las revistas populares como Interiors o Sunset Magazine incluirían a lo largo de los siguientes años las obras de Drake en sus libros recopilatorios de artículos. 
Shulman era perfectamente consciente de que cuantos más premios y menciones ganaran sus clientes, más rápidamente podría incrementar sus honorarios. Los arquitectos cuya obra fotografió entre finales de 1946 y principios de 1947 ganaron 6 de los 14 premios convocados por la revista House \& Garden en 1947, incluyendo a Gordon Drake con su Spillman House que se alzó con el segundo premio en la categoría de viviendas con superficie inferior a 1.800 pies cuadrados). El jurado de los House \& Garden Awards de ese año 1947 estaba formado por Louis Skidmore, Katherine Ford (editora de Arquitectura de House \& Garden), George Howe, Vernon De Mars, Hugh Stubbins y Cameron Clark. La revista, con la que Shulman Ilevaba colaborando desde abril de 1937, publicaría al año siguiente, en 1948, dos extensos reportajes, muy bien ilustrados con plantas, imágenes y hasta detalles de montaje de las casas Spillman y Presley de Gordon Drake.

La colaboración entre los editores de revistas populares y de publicaciones especializadas con objeto de difundir, tanto entre profesionales como entre el gran público, las novedades y las ventajas de una nueva arquitectura de producción en serie como la que estaba proponiendo Gordon Drake resultó ejemplar durante aquellos años de posguerra. Éste sería el caso de Katherine Ford (House \& Garden) y Thomas Creighton (Progressive Architecture) publicitando la Presley House en el catálogo ya citado The American House Today.

Los esquemas explicativos que se reproducen en esta página, como el de la casa Presely, una obra sumamente experimental, demuestran el interés de los editores de arquitectura de revistas populares de posguerra por dar a conocer a sus lectores, poco familiarizados con aspectos técnicos, la novedad y el interés de las obras y proyectos a los que daban cobertura en sus páginas, tratando de suscitar su aprecio por estos temas. De hecho, estos detalles y esquemas de montaje eran los mismos que, paralelamente, estaban publicando revistas de arquitectura de la reputación de Progressive Architecture, Architectural Forum, Revista de Arquitectura, o L'Architecture d'Aujourd'hui, situando a Gordon Drake ante sus lectores en el centro de la vanguardia del diseño modular aplicado a las viviendas prefabricadas.

La exitosa maquinaria publicitaria puesta en funcionamiento por el tándem Drake-Shulman obtuvo también sus frutos en el caso de la revista L'Architecture d'Aujourd'hui. Como relató el propio Shulman ${ }^{274}$, el fotógrafo se las ingenió para incluir imágenes de las casas Drake y Presley en el mismo paquete con las fotografías de la Casas Kaufmann de Richard Neutra que tenía concertadas con la revista francesa para el número de junio-julio de 1948. El hecho de que Neutra no estuviera al tanto de la jugada de Shulman es revelador de la amistad que Shulman y Drake se profesaban y del interés del fotógrafo por beneficiar a su amigo.

La Drake House fue el primer trabajo de Shulman que apareció en L'Architecture d'Aujourd'hui y que no se trataba de una obra de Neutra, cuyas fotos de la Miller House en Palm Springs habían sido publicadas en fecha tan temprana como 1937. Una década después, Shulman, que a lo largo de su vida vería publicados 127 artículos ilustrados con sus fotografías en esta revista ${ }^{275}$, había vuelto a enviar fotografías de obras de Neutra para el número especial de L'Architecture d'Aujourd'hui dedicado monográficamente al arquitecto vienés en junio de 1946 y, en 1947, para los números que publicaron su extraordinario complejo de viviendas sociales Channel Heights en San Pedro y la Nesbitt House.

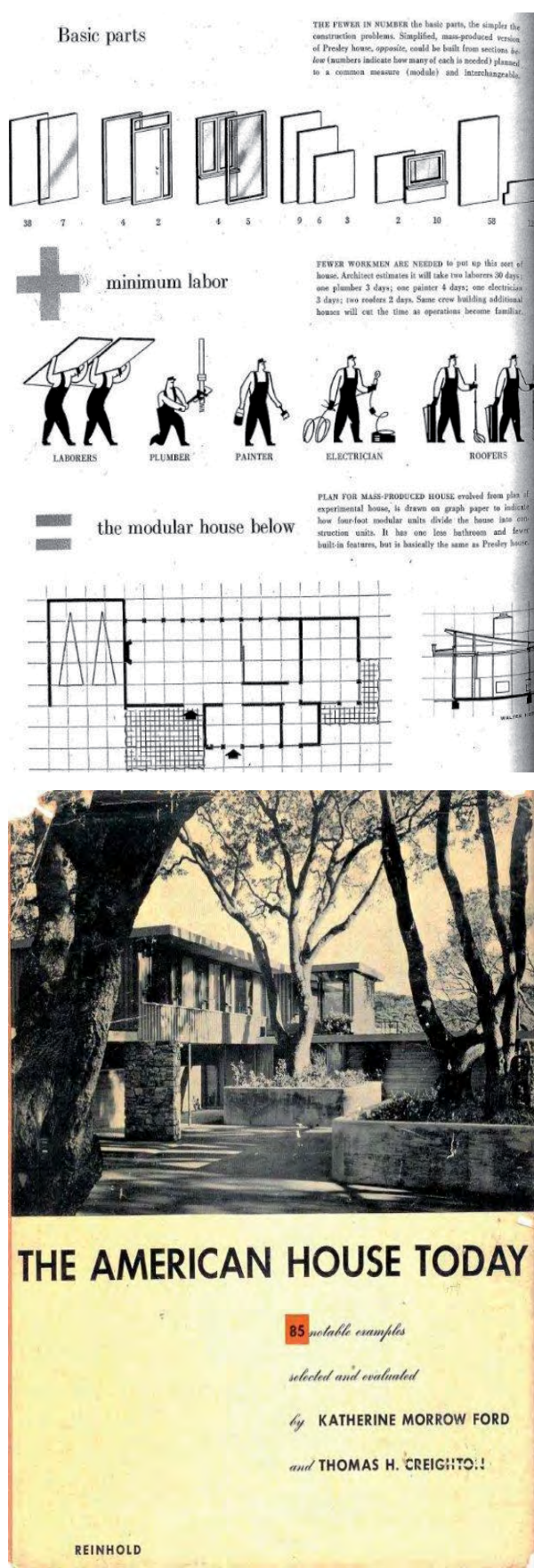

Arriba: House \& Home, febrero 1948, publicación de los esquemas de modulación y montaje de la Presley House en Silver Lake

Abajo: Porta del libro The American House Today, coeditado por Thomas Creighton $(P / A)$ y Katherine M. Ford (House \& Garden) en 1951 


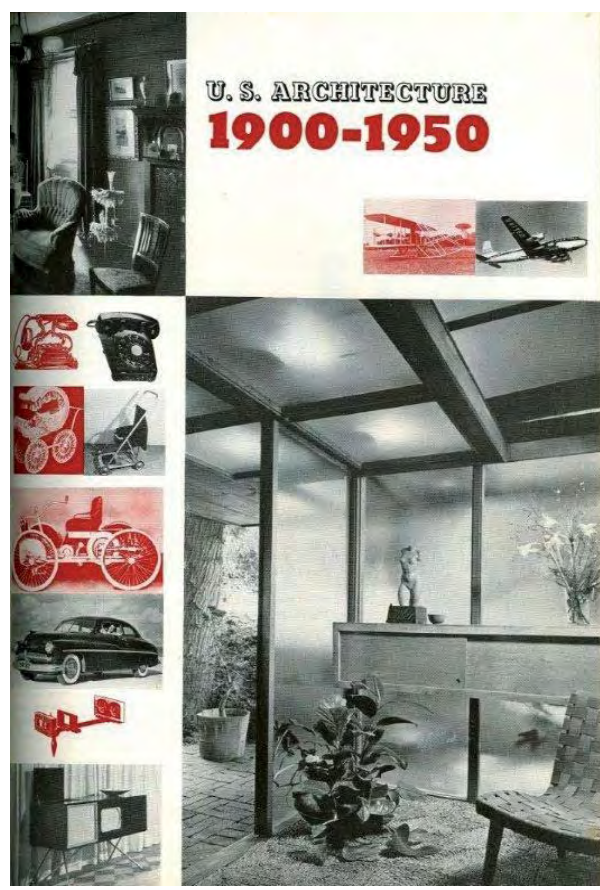

U. S. Architecture 1900-1950. Catálogo publicado en 1950 por la revista Progressive Architecture

Página siguiente: Porta de Progressive Architecture de junio de 1956 (The New House to Site Transition) con la Berns House de Drake en portada. El arquitecto había fallecido cuatro años antes
Gracias a esta maniobra de Shulman y al interés que rápidamente despertaron las fotografías de las obras de Drake, éste, a diferencia de su mentor Harris que nunca llegó a incluir un proyecto en ella, vio su trabajo publicado en L'Architecture d'Aujourd'hui en el número de junio de 1948. Es importante señalar esta fecha en plena posguerra. Dirigida entonces por André Bloc-muy comprometido con la realidad de su tiempo-, L'Architecture d'Aujourd'hui era producida desde el centro mismo de un continente física y moralmente devastado. Con la salvedad de figuras gran repercusión internacional como Richard Neutra o casos tan excepcionales como la inspirada renovación del panorama arquitectónico que estaban proponiendo los maestros brasileños, la revista francesa prefería centrar sus contenidos en temas de mayor urgencia como la reconstrucción a partir de las infraestructuras públicas y los programas de viviendas sociales. De este modo, el hecho de que en junio de 1948 se publicara a Gordon Drake, haciendo hincapié en la vocación social de su trabajo, es revelador del interés manifestado por los editores europeos hacia sus propuestas.

Apenas un año después de haber sido premiado en América, Drake aparecía con una ópera prima en las páginas de L'Architecture d'Aujourd'hui, la revista de arquitectura más leída del momento en Europa. Fue el reconocimiento definitivo a su obra que, inmediatamente, quedó fijada en la escena internacional. La revista remarcó el interés de sus viviendas experimentales construidas a partir de paneles modulares prefabricados. Significativamente, otra casa californiana surgida como aplicación directa de las nuevas tecnologías de la industrialización al ámbito doméstico, la Eames House (1945-1949), el proyecto por el que más había apostado la revista de John Entenza Arts \& Architecture, no sería recogida en las páginas de L'Architecture d'Aujourd'hui hasta diciembre de $1953^{276}$.

Es sintomático por tanto que, ni su casa en el cañón de Beverly Glen, ni ninguna otra de las obras proyectadas o construidas por Drake, fue nunca publicada en las páginas de Arts \& Architecture. Podrían apuntarse algunas hipótesis para explicar esta situación, cuanto menos intrigante.

En efecto, dado que tras la guerra el aparato mediático de John Entenza, al frente de Arts \& Architecture y de su bien publicitado programa Case Study Houses había irrumpido enérgicamente en la escena editorial estadounidense, comenzando a derivar la atención de los medios internacionales hacia el Oeste, muchos de los editores de la Costa Este habrían optado por no incluir en sus revistas proyectos o autores recientemente publicados en Arts \& Architecture, una revista que, tras la eliminación de la palabra California del nombre y el lanzamiento del CSH Program, habrían considerado como competidora directa de sus intereses de mercado.

Esta hipótesis es corroborada por John Crosse, quien afirma que John Blanton, antiguo colaborador de Neutra y conocedor de primera mano de sus estrategias de comunicación, le habría confirmado este recelo por parte de revistas como Progressive Architecture. En opinión de Crosse, Julius Shulman, quien al igual que Richard Neutra era una persona extraordinariamente capacitada para la publicidad y para maximizar el rédito económico y publicitario de trabajos realizados, dada su amistad con Gordon Drake, le habría aconsejado sobre cómo diseñar una estrategia efectiva de comunicación. En este sentido, Gordon Drake habría preferido llegar antes a publicaciones de tirada nacional e internacional que ser incluido en la revista de John Entenza. 
Por otra parte, debe tenerse en cuenta que en el momento en que su casa ganó el Primer Premio de la revista Progressive Architecture, en 1947, Arts \& Architecture estaba inmersa en la difusión del Case Study Program, por lo que, al no formar parte de éste, Drake debió pensar que su trabajo seguramente pasaría desapercibido. Esta reflexión a su vez abre otras cuestiones que es interesante plantear aquí: ¿fue invitado Drake a participar en el programa Case Study House y, al igual que su mentor, Harwell $\mathrm{H}$. Harris rehusó a ello? O, por el contrario, ¿no lo fue y, quizás, si su vida no hubiera acabado tan pronto, tarde o temprano, Entenza habría accedido a que alguna de sus viviendas formara parte de las Case Study Houses?

Es probable que, advertido por Shulman, Drake prefiriera en un primer momento mantenerse al margen del programa de Entenza para impulsar su carrera con independencia de la plataforma que podría brindarle Arts \& Architecture. También puede ser defendida la idea de que, como en el momento en que Entenza se hizo con la revista California Arts \& Architecture, es decir, a principios de 1940, Drake colaboraba con Harris y éste se sintió traicionado tanto por la manera en que esta adquisición tuvo lugar como por la desaparición de la palabra California del título de la revista, el arquitecto, por amistad con Harris, se mantuviese a la defensiva respecto a las intenciones de John Entenza. A la inversa, es lógico pensar que, dadas las discrepancias del editor con Harris, quien desde ese momento se negó a suministrar material a Arts \& Architecture y acababa de abandonar su consejo editorial en 1946, una vez que rehusó a participar en el Case Study House Program ${ }^{277}$, Entenza optara también por prescindir de Drake, dada la afinidad de éste con su mentor.

No obstante, podría especularse qué hubiese pasado si Drake hubiera permanecido en Los Ángeles en lugar de trasladarse a San Francisco en 1949. Quizás, dada su notoriedad, habría sido incluido en el Case Study Program una vez que, tras la construcción de la Eames House y, especialmente, con la relajación de ciertas posturas ideológicas derivada de la celebración de los debates del MoMA What's happening to modern architecture? que trataban de dar respuesta al polémico artículo de Lewis Mumford en defensa de una identidad regional, la revista de John Entenza dejó de enfatizar el paradigma de la construcción en acero para volverse más plural. Incluso, es muy probable que si el arquitecto no hubiera fallecido tan pronto hubiera accedido a formar parte del grupo de arquitectos del programa CSH ya que, con la presencia de su amigo Julius Shulman en el staff de la revista y la entrada de Esther McCoy en el consejo editorial de Arts \& Architecture en 1950 no parece aventurado pensar que éstos hubieran abogado por la candidatura de Drake ante John Entenza.

En cualquier caso, ninguna de las hipótesis que se han planteado hasta el momento justificaría la falta de una reseña necrológica en Arts \& Architecture tras la trágica muerte de éste en 1952. Especialmente cuando tanto las principales publicaciones especializadas como las revistas populares de todo el país, e incluso de fuera de los Estados Unidos, sintieron la prematura desaparición de Drake, como así lo demuestra la cantidad de notas necrológicas y de artículos memoria de su carrera profesional que, resaltando sus aportaciones a la cultura arquitectónica de la época, fueron publicadas entre 1952 y 1957, tal como se detalla en el apartado de bibliografía específica.

Por su profundo conocimiento del asunto, la opinión de Julius Shulman en este tema es altamente significativa. Él fue uno de los primeros en criticar como uno de los más graves errores de John Entenza el hecho de que su

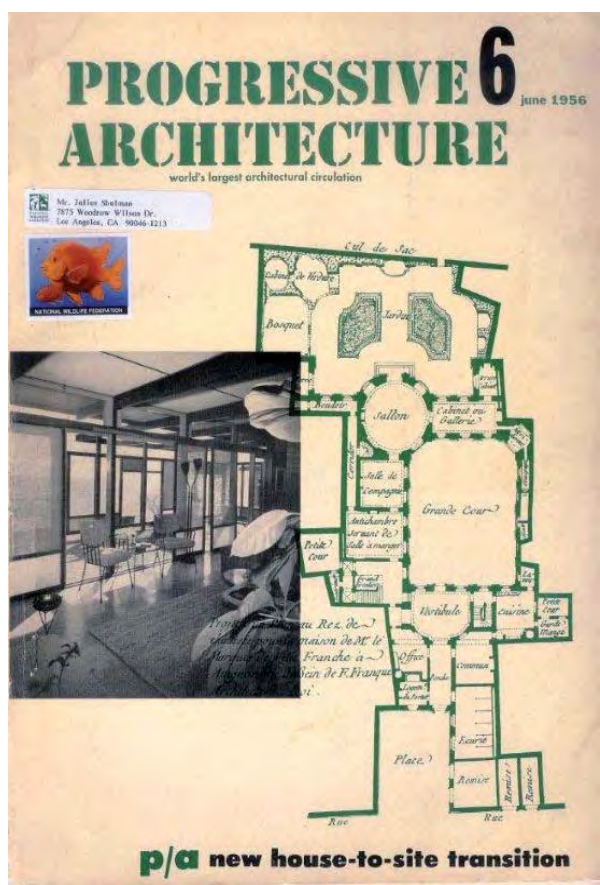

P/A new house-to-site transition 


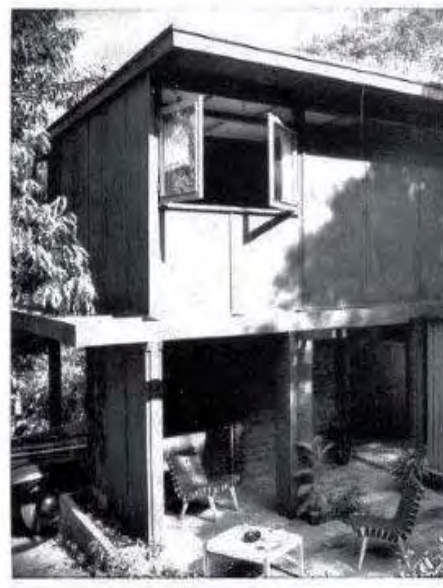

"With Plywood, Design and Structure Can Be Treafed as a Single, Infegrated Unit," Says Architect Gordon Dreke

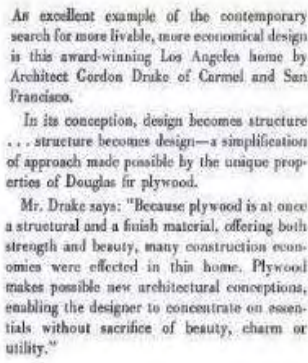
tials wility.

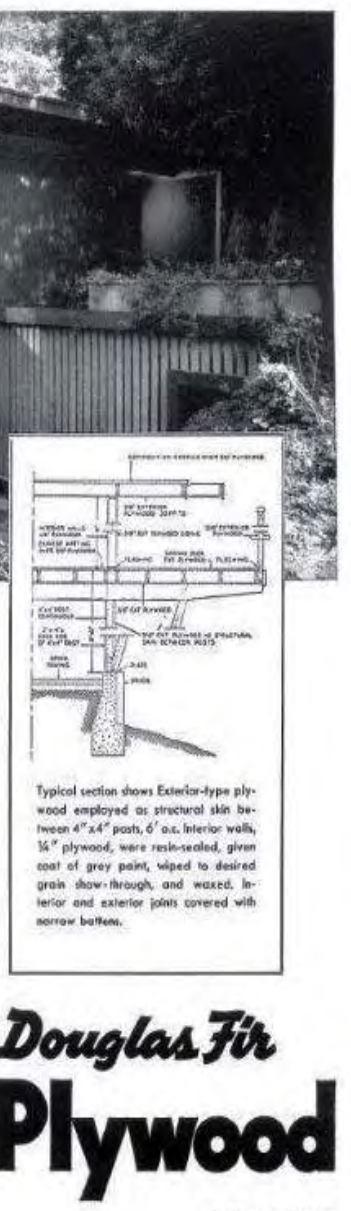

AMERICA'S
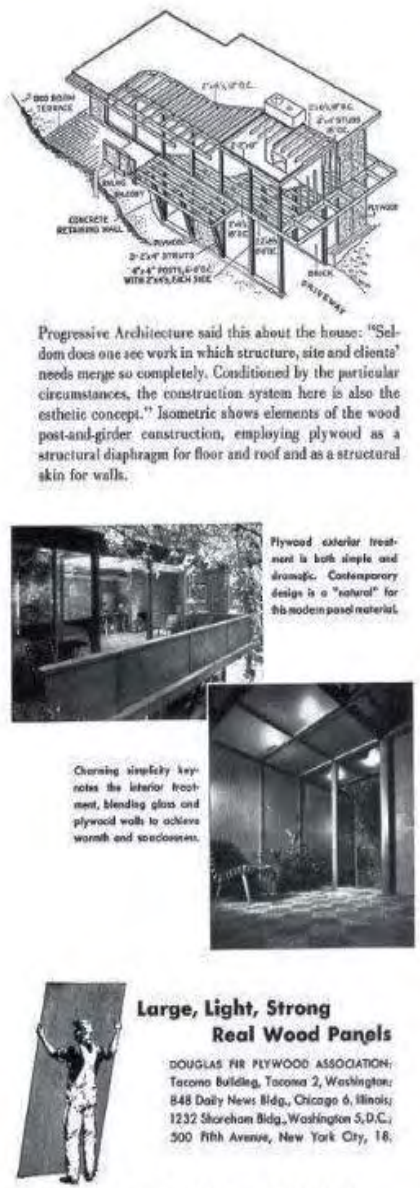

BUSIEST BUILDING MATERIAL

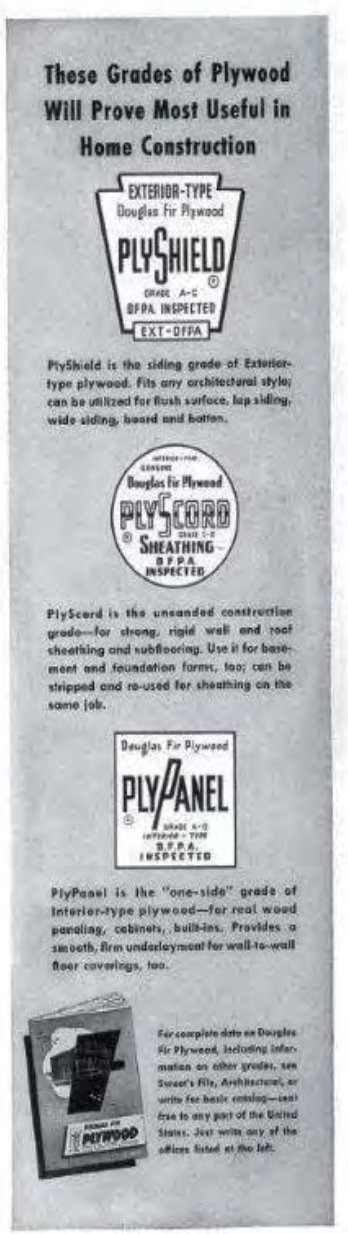

Anuncio de la compañía Douglas Fir Plywood publicado en Arts \& Architecture, abril de 1950, reproduciendo imágenes y detalles de la Spillman House de Gordon Drake personal selección de los arquitectos del programa Case Study Houses fuese, a menudo, subjetiva y arbitraria, dejando fuera a arquitectos con tanto talento como Gregory Ain o el propio Drake ${ }^{278}$; o que, en realidad, muy pocas de las viviendas promocionadas como CSH incorporaran una tecnología revolucionaria o fueran realmente prototipos susceptibles de una verdadera repetición en masa. Shulman, acreditado siempre en los títulos de la primera página de Arts \& Architecture como fotógrafo oficial de la revista, fotografió 15 de las 25 viviendas del programa que fueron construidas, por lo que conocía de cerca, o al menos intuía, las motivaciones de Entenza para publicitar su programa (de hecho, sus cautivadoras instantáneas de aquellas viviendas fueron en buena medida responsables del éxito del mismo, mostrando una imagen de glamur y modernidad que con la que buena parte del mundo identificó el ideal del modo de vida californiano).

Por otra parte, no deja de ser intrigante el hecho de que la única inclusión de Drake en las páginas de Arts \& Architecture viniera, por así decirlo, por la puerta de atrás, en concreto, a través de un anuncio a doble página de la compañía de estructuras de madera y de contrachapado Douglas Fir, incluido en el número de abril de 1950 (pp. 8-9) e ilustrado con imágenes y detalles constructivos de la Rucker-Spillman House ${ }^{279}$. Dado que Shulman, para apoyar la iniciativa de Entenza a la vez que se publicitaba a sí mismo, no cobraba por aquellas fotografías suyas que aparecían en Arts \& Architecture, debía obtener beneficios económicos de la venta de sus derechos a anunciantes que deseaban ejemplarizar el uso de sus productos con imágenes de 
obras u arquitectos representativos. Por ello, seguramente, debió ver en la inclusión de este anuncio ilustrado de la Douglas Fir Plywood Company una excelente oportunidad para hacer que Gordon Drake publicara, por fin, en la revista de John Entenza. De este modo, Shulman conseguía, por un lado, que al aparecer simplemente en un anuncio, Drake no quemara su obra para que ésta pudiera seguir siendo difundida por otras revistas $y$, por otro lado, el fotógrafo obtenía unos ingresos extra promoviendo la obra de su amigo ${ }^{280}$.

Aunque lo más llamativo de todo es que este anuncio, cuidadosamente diseñado e ilustrado con fotografías y detalles constructivos, incluye una serie de explicaciones gráficas y de definición del proyecto que supera con mucho los estándares de detalle de la revista de John Entenza. Es decir, que la única vez que Arts \& Architecture publicó una vivienda de Gordon Drake, no sólo lo hizo de manera extraoficial sino que, además, tratándose de un anuncio, la vivienda aportó un nivel de información sobre la obra que -exceptuando casos muy concretos como, por ejemplo, la vivienda de los Eames-, resultaba superior al habitual con el que se publicaban las viviendas escogidas por el propio consejo editorial.

Por supuesto, estos hechos contradicen muchas de las opiniones más ampliamente generalizadas, como las que dejó por escrito Esther $\mathrm{McCoy}^{281}$ cuando afirmaba que la revista de John Entenza era la principal plataforma para los arquitectos californianos de llegar al resto del mundo y que muchos de los editores de otros países le solicitaban permiso para publicar artículos que habían aparecido por primera vez en Arts \& Architecture. Esta afirmación, como se ha argumentado, carecería de fundamento en el caso de Gordon Drake.

Por último, se aporta un texto de Shulman donde el fotógrafo expresó toda la admiración que sentía por Drake y la indudable fascinación que, sobre él, ejercieron tanto el idealismo como su arrebatadora personalidad, dando además algunos datos sobre su primer encuentro en 1946:

"Un ejemplo de primer orden sería la estimulante obra de Gordon Drake, un arquitecto considerado sin embargo con cierto desdén por muchos de los investigadores que gestionan la información acerca de los autores que más han contribuido al progreso de la arquitectura contemporánea. A pesar de la brevedad de su carrera, Drake alcanzó una extraordinaria fama mundial, siendo sus proyectos premiados en diferentes foros y las fotografías de sus casas publicadas en revistas de todo el mundo donde, todavía hoy, continúan apareciendo.

Mi primer encuentro con Gordon Drake, en agosto de 1946, se me quedó grabado en la memoria. Este recuerdo es todavía para mí revelador de todo el potencial y la clarividencia de sus ideas. Aunque han pasado ya varias generaciones, creo que aquellos que han reconocido su talento, sabiendo extraer las lecciones de la obra de Drake, han podido luego poner en valor los objetivos de su propio trabajo como arquitectos. Yo deseo continuar honrando su memoria y pido por ello a mis contemporáneos que vuelvan sobre su legado para que sean capaces de apreciar el alcance del pensamiento y de las realizaciones arquitectónicas de Gordon Drake.

Desde el mismo día de nuestro primer encuentro, en agosto de 1946, nos hicimos amigos. Él acababa de terminar una casa en uno de los senderos del Cañón de Beverly Glen, al oeste de Los Ángeles. Me llamó por teléfono y me preguntó: ¿'Te importaría por favor pasarte por la obra para que nos conozcamos perso- 
nalmente y así, de paso, al resto de mi gente?'. Me llamó mucho la atención su forma de entablar contacto ya que la mayoría de los arquitectos que me telefoneaban para que fotografiase sus obras, lo primero que me preguntaban era '¿cuáles son sus tarifas?'. De algún modo, se trataba, como un arquitecto describió más tarde nuestra reunión, 'de hacer que nuestras almas gemelas se encontraran'. En el caso de Drake, fue incluso mucho más. Conforme entraba al patio de su casa me saludó diciendo 'llegas justo a tiempo para la comida'. Me presentó a su equipo, una tropa compuesta por un grupo de ex marines que habían servido con él en el Pacífico y algunos otros, como su secretaria, su novia y dos o tres amigos y socios. Con edades comprendidas entre los 20 y los primeros treinta-Gordon tenía entonces 29 años- todos ellos eran representativos de la juventud de posguerra: entusiastas, apasionados por hacer cosas útiles e importantes, por realizarse a través de la arquitectura. Y todos ellos inspirados por el espiritu del propio Drake.

Mi ayudante me había acompañado a la cita y tras la comida comenzamos a planificar la composición de las escenas. ¡Qué concepción tan innovadora se desplegaba en aquella casa tan pequeña! El estar apenas tenía 10 metros cuadrados [12 $\times 8$ pies]. ;La casa entera había sido edificada por 4.500 dólares! Acostumbrado a trabajar sin restricciones de espacio, me sorprendió descubrir que el diseño de Drake estaba tan bien armado, entretejiéndose unos ambientes con otros que, mirara donde mirara, siempre ocurría algo fascinante ante la cámara. Sentí que estaba ante el proyecto más ingenioso de todos los que me había encontrado hasta entonces. La serie de fotografías que tomé de su casa constituyen el episodio más feliz y gratificante de todos los que viví en mis diez primeros años como fotógrafo de arquitectura.

Aquel año, en agosto de 1946, la revista Progressive Architecture convocó un concurso para reconocer el trabajo de aquellos arquitectos que trataban de mejorar los estándares de la arquitectura contemporánea ('Recognition of architects attempting to improve contemporary standards'). La casa de Gordon Drake fue una de las obras premiadas. El primer premio para su primera casa construida. Yo tenía tan claro que iba a ser asíque, cuando, fotografiaba la casa, en la escena tomada desde el estar hacia el patio, coloqué sobre la mesa frente a la cámara un ejemplar del número de Progressive Architecture en el que se lanzaba la convocatoria de los premios (nótese su presencia en la mesa baja que aparece en primer plano de la fotografía). Bromeando con Drake esa mañana le dije: "mi vaticinio: ganarás el primer premio". Y no sólo mi predicción fue cierta sino que, finalmente, resultó también ganador del segundo premio del concurso convocado en 1947 por la revista House and Garden con su Spillman House (Richard Neutra se alzó con la primera posición). Fue realmente estimulante para mí, al final de mi primera década como fotógrafo de arquitectura, verme asociado con un hombre tan brillante y cuyos diseños no sólo eran estupendos por su expresión arquitectónica o sus ingeniosas soluciones a problemas funcionales sino porque, sobre todo, estaban consagrados a satisfacer las verdaderas necesidades de sus clientes. En muy poco tiempo sus proyectos se publicaron en revistas de todo el mundo cuyos editores proclamaban: "el mejor ejemplo de lo que significa progreso en arquitectura".

En marzo de 1996, la revista londinense Architectural Review, publicó un revelador artículo, 'Californian Promise', escrito por Neil Jackson, Profesor en la Escuela de Arquitectura de la Universidad de Nottingham. Jackon destacaba de Drake su asombroso entendimiento tanto de la tecnología de posguerra como de las particularidades del paisaje californiano. Visto desde la distancia, 
me siento profundamente orgulloso de haber podido tomar las fotografías que reflejan y expresan los ideales que animaron su carrera durante su corta vida.

Gordon Drake murió a la edad de 35 años cuando esquiaba en las Sierras en 1952. Como Neil Jackson, más críticos o arquitectos han reconocido que Drake se encontraba en ese momento en el umbral de lograr algo importante y que si no hubiera fallecido se hubiera convertido sin duda en uno de los grandes nombres de la arquitectura contemporánea. Echo en falta su amistad. También su preocupación por las necesidades y las vidas de los demás. Él fue un auténtico visionario que sintió la urgencia de dar solución a la falta de dignidad y calidad arquitectónica a las viviendas destinadas a minorías olvidadas o a los sectores económicamente más desfavorecidos de la población. Volviendo ahora la mirada sobre ese periodo imborrable de mi vida, me doy cuenta de que habiendo trabajado con innumerables arquitectos a lo largo de toda ella, no soy capaz de recordar a nadie que igualara la asombrosa conjunción entre el idealismo y la mente práctica de Drake ${ }^{1282}$.

\section{Reivindicación de Gordon Drake}

Considerando la brevedad de su carrera, desarrollada en apenas siete años, pocos arquitectos han sido tan innovadores y prolíficos como Gordon Drake (1917-1952). Quizás, sólo Matthew Nowicki, fallecido a la edad de 40 años, - Giuseppe Terragni, con sólo 39, serían casos comparables al de Gordon Drake, quien no llegó a cumplir los 35 años $^{283}$. Aunque todos ellos murieron demasiado pronto para poder especular sobre qué nuevos caminos hubieran podido llegar a explorar se podría afirmar que sus obras fueron como una supernova que, tras su rápida extinción, sembraron las décadas centrales del siglo Xx con nuevas ideas de las que se alimentaron sus contemporáneos.

La obra de Drake epitomiza la posibilidad material de realización del nuevo paradigma del ideal suburbano surgido tras la Segunda Guerra Mundial. Aunque socialmente se trataba de una aspiración de toda la nación norteamericana, en California, tierra de pioneros, antes incluso de la penetración de las ideas modernas a través de los primeros emigrados europeos, los arquitectos locales llevaban varias décadas extendiendo este ideal democrático de realización individual a través de la arquitectura, proponiendo viviendas modestas y bien diseñadas que propiciaran un estilo de vida sencillo en contacto con la naturaleza.

Gordon Drake, plenamente consciente de las posibilidades de la tecnología de posguerra y de la disponibilidad de determinados materiales mucho más económicos que el acero, como la madera laminada o los tableros prefabricados de contrachapado, llevó a cabo un paso más en la evolución y democratización de la arquitectura regional, transmutando efectivamente la solvencia de los acabados de madera propios de la tradición artesanal del Sur de California en soluciones industriales. En este sentido, aunque en su apuesta por relanzar las técnicas y el vocabulario de la madera, Drake se mantuvo al margen del nuevo paradigma de acero y cristal preconizado por la arquitectura californiana, habría que puntualizar que dicho paradigma sería más bien producto de un fenómeno de hiperpublicidad -a través de iniciativas, por ejemplo, como el Case Study House Program de la revista Arts \& Architecture- que de una auténtica realidad a tenor de la proporción de viviendas modernas construidas con ese material frente a las que se realizaron con estructura de madera. 
Igualmente, con algunas matizaciones como, por ejemplo, que habría que tener en cuenta la evolución de la arquitectura del propio Harris, o de autores como Wurster en los años cuarenta, podría argumentarse como hace Pierluigi Serraino ${ }^{284}$, que el imaginario arquitectónico de Drake, con su distintiva espacialidad y su contundente tono regional, proporcionó una tercera alternativa a la división de la arquitectura americana de posguerra entre las raíces de una tradición local y la celebración ideológica de la tecnología ejemplificada por la Lovell House de Richard Neutra o la Case Study House no 9 de Charles Eames. En palabras de Serraino:

"Drake supo reunir el compromiso regionalista de vincular la arquitectura al lugar con la aserción moderna de que el diseño fuera de los procesos industriales de la producción en masa nunca tendría relevancia en los discursos de la arquitectura del futuro. En lugar de tratar de explorar el potencial expresivo de la estructura de acero, como hicieron algunos de los autores modernos californianos, Drake conservó el contrachapado como su principal material de construcción, aunque empleándolo en el contexto de los últimos sistemas de prefabricación disponibles. Los paneles de contrachapado, puestos al día como productos militares durante la guerra, fueron un material abundante gracias al papel de la empresa Douglas Fir, de rápido crecimiento en San Francisco. Este material supuso un puente perfecto con el que resolver los conflictos entre los regionalistas militantes y los modernos más dogmáticos. Resultaba atractivo tanto para aquellos que buscaban los acabados de los materiales tradicionales de construcción como a aquellos jóvenes que recurrían entusiasmados a los últimos catálogos de productos de posguerra que inundaron la escena de la arquitectura americana a mediados de siglo. La resistencia, adaptabilidad y versatilidad del contrachapado en el ámbito de la arquitectura doméstica y su empleo en diseños asequibles para las masas distinguieron inmediatamente el trabajo de Gordon Drake, atrayendo sobre él tanto la atención de la profesión como de la prensa popular"285.

Ensayando consigo mismo y con la complicidad de parejas de amigos a quienes construyó viviendas para dar solución a sus necesidades concretas, Drake planteó estas experiencias como prototípicas de las aspiraciones de la nueva juventud estadounidense. En este sentido, el logro de Drake fue su compromiso fuerte para que su talento y dominio del oficio apuntalaran un nuevo paradigma arquitectónico basado en valores de igualdad social.

Para Drake, la arquitectura debía ser juzgada por las personas, decidiendo si son o no más felices habitando en sus casas. Pretendía llegar a la mayor cantidad de gente posible, de modo que el público pudiera tener la última palabra sobre el tipo de arquitectura que estaba proponiendo. Como sostuvo Walter L. Doty, editor de la revista Sunset Magazine en su reseña final al libro homenaje sobre Drake editado por Baylis y Parry en 1956, "[Drake] sentía que la arquitectura no significaba nada hasta que era habitada. La publicación de una casa ganadora de un premio tenía poco valor para él a no ser que esto le trajera la posibilidad de llegar a realizar miles de viviendas. La arquitectura, para cumplir con su destino, debía llegar a todo el mundo"286. Aunque su prematura muerte le imposibilitó llevar estas experiencias a la gran escala de proyectos de ámbito territorial como, por ejemplo, el de la Mutual Housing Association, la calidad y el torrente de nuevas ideas que encerraban el puñado de obras construidas por Drake y, sobre todo, el alcance de su difusión mediática, permitieron ejemplificar tanto a los arquitectos de su generación como al público en general la realidad de una arquitectura residencial que, por muy poco dinero, ponía la calidad y el diseño al servicio 
de sus usuarios, demostrando que el gran público podría acceder, por fin, a una buena casa.

Casi sesenta años después, la obra de Gordon Drake, sigue seduciendo por su rigor, claridad y sencillez; por la comodidad con la que se posa en el lugar para sacar todo el partido a los valores del medio natural del que se nutre y al que cualifica con su riqueza de relaciones interior-exterior; por la frescura y el optimismo que, como la luz y la brisa que inundan las terrazas, patios y jardines fotografiados por Shulman, emana de una arquitectura que invitaba a disfrutar despreocupadamente de un desayuno al sol o de una charla en compañía de amigos a toda una joven generación que, dejando atrás el trauma de la guerra, podía y se merecía abrazar el sueño de empezar una nueva vida.

La influencia de Drake en los arquitectos de su generación fue importante y puede rastrearse en arquitectos locales cuyas viviendas apostaron por el empleo de tecnologías locales de bajo presupuesto y altas prestaciones, plantas modulares, sistemas de iluminación natural y por una vocación de apertura al paisaje que remiten a muchas de las estrategias de Drake. Un claro ejemplo sería el diseño de terrazas y patios perfectamente enmarcados y modulados, llevando el orden de la vivienda hasta diluirse en el jardín como ocurre en las casas tres Case Study Houses construidas por Craig Ellwood en 1953, 1955 y 1958. Otro ejemplo sería el de la obra desarrollada por Buff \& Hensman en los años 60.

A pesar del discreto segundo -o, incluso, tercer- plano en el que ha permanecido su figura y a pesar también del más de medio siglo transcurrido desde su desaparición, destacados arquitectos han reconocido en algún momento de su carrera su interés por Gordon Drake; probablemente no sean los arquitectos que más páginas copen en los medios internacionales, pero sí algunos de los más interesantes como el también californiano Ray Kappe ${ }^{287}$ (co-fundador con Thom Mayne del SCl-Arq) o como el australiano Glenn Murcutt. Sus arquitecturas, tan discretas como electrizantes, ligeras en su materialización pero profundas y emocionantes en sus planteamientos, comparten muchos de los valores que animaron el trabajo de Drake: retículas planimétricas, modestia de medios, exactitud en la ejecución, conocimiento de la cultura y de las técnicas locales, sensibilidad paisajística, distanciamiento de las modas, etc. Por ello, es revelador el reconocimiento público que Murcutt realizó de la obra de Gordon Drake cuando, en el año 2002, en su Discurso de Aceptación del Pritzker28, se refirió a él como uno de los autores que más influencia habían ejercido durante su etapa de formación como arquitecto $y_{\text {, }}$ más tarde, sobre el conjunto de su obra construida ${ }^{289}$.

Pero también Gehry, curiosamente el Gehry de 1989, el que acababa de ampliar su casa de Santa Mónica y un año antes había sido proclamado por Mark Wigley y Philip Johnson en el MoMA como gurú de la Deconstructivist Architecture, en su discurso de aceptación del Pritzker, nombraba a Gordon Drake como una de sus tempranas influencias, afirmando: "es realmente una coincidencia aunque muy especial para mí recibir este premio en Japón ya que me formé como arquitecto en California, rodeado de tantas obras directamente inspiradas por la arquitectura japonesa: Greene and Greene, Harwell Hamilton Harris, Gordon Drake y tantos otros. Algunos de ellos han sido mis maestros, ellos me enseñaron a mirar hacia Japón y a entender su arquitectura [...] hasta hoy, creo que estas influencias tempranas todavía perviven en mi trabajo" ${ }^{\prime 290}$. 


\section{Notas y referencias bibliográficas}

1. Harwell Hamilton HARRIS: Prólogo al libro de Esther MCCOY: Vienna to Los Angeles. Two Journeys. Letters Between R. M. Schindler y Richard Neutra. Santa Monica, CA: Arts + Architecture Press, 1979 Op. cit., pp. 12-13

2. Harwell Hamilton HARRIS, en BAYLIS, Douglas y PARRY, Joan: California Houses of Gordon Drake. New York: Reinhold Pub., 1956, pp. 83-85

3. Bruno Zevi citado por Sylvia LAVIN en Form Follows Libido: Architecture and Richard Neutra in a Psychoanalytic Culture. Cambridge, MA: The MIT Press, 2004, p. 12.

4. Tomas Hines, en su recientemente publicada: Architecture of the Sun: Los Angeles Modernism 1900-1970 (New York: Rizzoli, 2010) dedica el noveno de los capítulos de esta historia panorámica a estudiar conjuntamente la obra de tres arquitectos, Gregory Ain, Raphael Soriano y Harwell Hamilton Harris. Todos ellos desarrollaron el grueso de su producción en Los Ángeles entre mediados de las décadas de los años 30 y 50 . Los tres fueron discípulos de Richard Neutra. Esther McCoy se refirió a ellos como la "Segunda Generación" (The Second Generation. Salt Lake City, UT: Gibbs Smith Publisher, 1984). El título del capítulo específico del libro de Hines dedicado a estos tres arquitectos de la segunda generación es Disciples and Masters y ha sido utilizado directamente para esta segunda parte por su claridad enunciativa. Sin embargo, como se ha expuesto en la presentación de los objetivos de esta tesis doctoral, se trataría de extender el traspaso de influencias hasta una tercera generación representada aquí por Gordon Drake. El objetivo, por tanto, sería establecer una determinada genealogía de arquitectos modernos californianos que iría de Richard Neutra a Gordon Drake pasando por Harwell Hamilton Harris. Entre otras cuestiones que se abordarán en profundidad en el desarrollo de esta sección, los tres arquitectos, discípulos y maestros, serán estudiados desde la singular relación que entablaron con los medios de su tiempo. Una relación que ver con estrategias aprendidas por cada uno de ellos durante su estancia en el estudio de su mentor.

5. Marc BOUTIN: Richard Neutra: The Idealization of Technology in America. Thesis for the Degree of Master of Arts. Department of Art. Calgary, Alberta: University of Calgary, 2000, p. 103

6. Baubücher (Libros de construcción)

7. Wie Baut Amerika? precedió a los libros de Hilberseimer: Internationale Neue Baukunst (Nueva arquitectura internacional), Julius Hoffmann, Stuttgart, 1927; y Großstadtarchitektur (La arquitectura de la gran ciudad), Julius Hoffmann, Stuttgart, 1927. En este último Hilberseimer incluyó el libro de Neutra en su bibliografía, contribuyendo así a su prestigio. Cfr. Rubén A. ALCOLEA: Picnic de Pione ros: Arquitectura, fotografía y el mito de la industria. Valencia: Ediciones Generales de la Construcción 2009, pp. 167-168.

8. De acuerdo con la conversación mantenida entre Thomas Hines y Dione Neutra en julio de 1979, la viuda del arquitecto habría confirmado la autoría de Pauline Schindler. Véase Thomas S. HINES: Richard Neutra and the Search for Modern Architecture: a Biography and History. New York: Rizzoli, 2006, p. 85, n. 47 (en adelante simplemente Thomas S. HINES: Richard Neutra. Op. cit)

9. Thomas S. HINES: Richard Neutra. Op, cit., p. 84

10 Pauline GIBLING SCHINDLER [publicado de manera anónima]: "Wie Bau Amerika? Book Review". Los Angeles City Club Bolletin, 30 julio-6 agosto 1927. Citado por Thomas S. HINES. Ibid., p. 84

11. Henry-Russell HITCHCOCK: "Wie Baut Amerika? " (Book review), en Architetcural Record, junio 1928, pp. 594-595
13. Cfr. Esther McCOY: Richard Neutra. New York: George Braziller, 1960, p. 12

14. Ibid., p. 159

15. Magazine for Politics and Culture, 1927. Traducción propia de los extractos procedentes de las citas al artículo realizadas por Thomas S. HINES: Richard Neutra. Op. cit., pp. $83-84$ y 85, n. 45

16. Ibid., p. 84

17. Thomas S. HINES: Richard Neutra. Op, cit., p. 118

18. Richard NEUTRA: Wie Baut Amerika? Stturgart: Julius Hoffman, 1927, p. 41.

19. Richard NEUTRA citado por Thomas S. HINES: Richard Neutra. Op. cit., p.78.

20. Richard NEUTRA: "Amerika. Bauliche Stilbildung. Bemühungen Einzelner", en Das Neue Frankfurt, septiembre 1928, pp. 173-174

21. Dato proporcionado por Philip Lovell en 1958 durante su entrevista con Esther McCoy. Cfr. Esther McCOY: Vienna to Los Angeles. Op. cit., p. 69

22. Alan COLQUHOUN: Essays in Architectural Criticism: Modern Architecture and Historicism. Cambridge, MA: The MIT Press, 1981, p. 29

23. Richard NEUTRA: Wie Baut Amerika? Op. cit., p.59

24. En su libro defendía además que la estructura en acerco era mucho más práctica y económica que otros sistemas constructivos y que, además, era tan racional que podía realizarse una proyección de futuro del precio del acero con una previsión de más 40 años. Richard NEUTRA: Wie Baut Amerika? Op. cit., p.47

25. Richard NEUTRA: Wie Baut Amerika? Ibid., p. 63

26. Cfr. Marc BOUTIN: Op. cit., pp. $27-28$

27. Cfr. Neil JACKSON: "Metal-Frame Houses of the Modern Movement in Los Angeles: Part 1: Developing a Regional Tradition". Journal of the Society of Architectural Historians of Great Britain, vol. 32, 1989, p. 152. Jackson basa su afirmación en la aseveración de Thomas Hines de que la Lovell Heatlh House es la primera casa moderna construida con estructura de acero en los Estados Unidos. David Gebhard, por su parte, sostiene que pueden identificarse ejemplos más tempranos de uso de este sistema en tipologías residenciales, aunque no se trata de viviendas modernas.

28. Thomas S. HINES: Richard Neutra. Op, cit., p. 100.

29. Ibid., p. 104.

30. En la versión definitiva, la planta de acceso contiene los dormitorios, los sleeping porches y un estudio. En el nivel inferior se disponen los espacios más públicos de la vivienda, incluyendo un gran estar cuya biblioteca e iluminación diseñó el propio Neutra como la pieza más relevante, un comedor, un comedor exterior, la cocina -que el arquitecto concibió según las indicaciones de los Lovell y de su propia cocinera-y los cuartos de invitados. La planta baja consiste básicamente en una piscina cubierta, un belvedere, un patio de juegos solicitado por Leah y el núcleo de instalaciones. Los garajes se disponen en un edificio anexo y apartado a la cota del acceso de Dundee Drive. 
32. Neil JACKSON: Op. cit., p. 154 .

33. Richard NEUTRA citado en el artículo "Los Angeles Architect Wins Awards on Three Homes in Competition", en Southwest Builder and Contractor, junio 1935, p. ii. Véase también Thomas HINES Richard Neutra. Op. cit., p. 140

34. Harwell Hamilton HARRIS: Prólogo a libro de Esther McCOY: Vienna to Los Angeles. Op. cit., p. 12

35. En ese momento -una vez Wright había abandonado la ciudad-Schindler, íntimo amigo de los Freeman, había ejercido ya también como su arquitecto. Realizó algunas reformas en su casa y les diseñó varias propuestas de mobiliario.

36. Dione NEUTRA: carta a su madre Lilly Niedermann fechada en abril de 1928 y reproducida en Dione NEUTRA (Compiladora y ed.): Richard Neutra. Promise and Fulfillment, 1919-1932. Selections from the Letters and Diaries of Richard and Dione Neutra. Carbondale, IL: Southern Illinois University Press, 1986, pp. 171-172 (en adelante simplemente Dione NEUTRA (ed.): Op. cit.).

37. Esther MCCOY: Vienna to Los Angeles. Op. cit., p.55.

38. Thomas S. HINES: Richard Neutra. Op. cit., p. 97.

39. De acuerdo con Thomas Hines esto habría ocurrido en mayo de 1927. Cfr. Ibid.

40. Todas las fuentes coinciden en que fue Galka Scheyer quien convenció a Richard Neutra para que aceptase el proyecto de la casa y evitar que éste fuera a parar a otras manos dado que Lovell había iniciado ya contactos con otros arquitectos, en concreto con Fred Monhoff. Posteriormente, Scheyer, a quien Schindler había iniciado en el estudio de la arquitectura moderna, desempeñó un pape decisivo en la obtención de algunos de los encargos más importantes de Neutra de principios de la década de 1930. Por ejemplo, aunque por su amistad con Schindler trató que éste accediera a Jose von Sternberg para construirle su nueva residencia, cuando el director rechazó esta posibilidad, Galka Scheyer intentó entonces que éste contratara a Neutra, como así sucedió finalmente. Scheyer encargó asimismo a Neutra su propia casa (1934-35), en la que también intervino Gregory Ain y donde albergó su extraordinaria colección de pintura moderna europea. Scheyer tenía a Josef von Sternberg entre e selecto grupo de clientes a quienes la marchante proporcionaba obras de los Cuatro Azules. Gracias a ella, Neutra entró en contacto también con los emigrados judíos y con aquellos círculos de Hollywood que querían identificarse con la vanguardia, como el propio von Sternberg, la guionista Anita Loos, e productor Albert Lewin, la actriz Ana Sten y su marido el también director Eugene Frenke.

41. Esther MCCOY: Vienna to Los Angeles. Op. cit., p. 55 .

42. A Course in the Fundamentals of Modern Architecture, que tuvo dos ediciones, una en verano otra en otoño de 1931. Cfr. "News of the Art World: Schools and Lecture Courses", en Los Angeles Times, 11 octubre 1931. p III-8.

43. Aunque en su entrevista para el Oral History Program de la Universidad de California en Los Ángeles, Dione Neutra refirió episodios de duras críticas de Schindler al trabajo de su marido, ella afirmó que el distanciamiento profesional entre ambos arquitectos fue progresivo y que nunca se trató de una ruptura acontecida en un momento concreto. De hecho, afirmaba que recordaba con cordialidad su salida de Kings Road en 1930. Véase Dione NEUTRA: Entrevista con Lawrence Weschler (abril, julio y agosto 1982). Los Angeles: Oral History Program, University of California Los Angeles (UCLA), 1983, p. 110 (en adelante simplemente Dione NEUTRA: Oral History Program, UCLA), pp. $155^{-156}$

44. Esther McCoy sostenía que tras el regreso de Neutra de su viaje promocional a finales de 1930, Schindler ya no quiso volver a ver a su antiguo socio, pero ambos accedieron a impartir un curso en dos ocasiones en 1931, como se acaba de comentar. Sin embargo, la última edición del curso en Chouinard, otoño de 1931, coincidiría con los meses previos a la preparación de la exposición de Nueva York y el momento en que Schindler supo de la misma, ya que comenzó a escribir a Philip Johnson el 5 de enero de 1932 con la intención de ser admitido en la muestra. Sobre la afirmación de McCoy puede consultarse su entrevista con Makoto Shin Watanabe publicada en la revista japonesa Space Design Magazine en 1984 y reproducida en Susan MORGAN y Kimberli MEYER (ed.): Sympathetic Seeing: Esther McCoy and the Heart of American Modernist Architecture and Design. Los Angeles: MAK Center, 2011, p. 128.

45. Ibid., pp. 128-129.

46. Thomas S. HINES: Richard Neutra. Op. cit., p. 97

47. Leah LOVELL entrevistada por Esther McCOY en Vienna to Los Angeles. Op. cit., p.68.

48. Richard NEUTRA: carta a su mujer Dione fechada en agosto de 1927 y reproducida en Dione NEUTRA: Op. cit., p. 168

49. Richard NEUTRA: Carta a Philip Lovell fechada el 28 de enero de 1969 y reproducida en el Apéndice B en Thomas HINES: Richard Neutra. Op. cit., p. 340 .

50. Esther MCCOY: Vienna to Los Angeles. Op. cit., p.71.

51. Artículo facilitado al autor. Raymond Neutra escribe a partir de sus recuerdos familiares y de un análisis minucioso de toda la documentación escrita de que dispone, reparando a partir del contenido de aquellas cartas en la evidencia de las versiones contradictorias que los Lovell, tanto conjuntamente como por separado, dieron a lo largo de los años.

52. Incluyendo en ambos casos los honorarios de los arquitectos, alrededor de un 10\%, la Lovell Health House costó poco más de 65.000 dólares (Thomas HINES. Richard Neutra. Op. cit., p. 107) mientras que la Lovell Beach House unos 22.000 dólares (Esther McCOY: Vienna to Los Angeles. Op. cit., p. 69), es decir, prácticamente tres veces más.

53. Ibid. p. 68 .

54. Cfr. Philip LOVELL: Carta a Richard Neutra escrita el 8 de febrero de 1969 y reproducida en el Apéndice B en Thomas HINES: Richard Neutra. Op. cit., pp. 340-341.

55. Cfr, Leah LOVELL: Carta a Richard y Dione Neutra, escrita el 13 de febrero de 1969 y reproducida en Ibid., p. 342

56. Cfr. Esther McCOY: Vienna to Los Angeles. Op. cit., p. 68

57. Judith Sheine: R. M. Schindler. London: Phaidon Press, 2001, pp. 66-67.

58. "Dear Richard. I enclose two checks on your account. As far I can see in a quick survey you still have coming the Barnsdall account, Shore account and the Sloan account If we can get a decision in September. The first two will be close to four hundred dollars. I do not have that much money and I think that some of it will be offset by the Lovell balance. For Lovell I received about eight hundred. The last check I received in January 1930 from you. Was it your intention to stop our cross payments at that date? Or shall I figure them until you left? Let me know my balance so I can figure yours". Rudolph SCHINDLER: Carta fechada el 15 de junio de 1931. Schinder Archive (ADC), University Art Museum de la University of California, Santa Barbara (en adelante SDC/UCSB). Carta proporcionada por John Crosse. En la discusión de la misma por correo electrónico con el autor en enero de 2012, Crosse sostenía que ese importe era elevado y, más o menos, para tener una cifra comparativa, aportaba el dato de que en 
el reparto de gastos con su socio Clyde Chace por la casa de King Road, Schindler había valorado sus honorarios de proyecto en 800 dólares, la dirección de obra en 500 dólares y su asistencia como arquitecto técnico a la labor de contratista ejercida por Chace en otros 500 dólares más.

59. Aproximadamente un $10 \%$ del presupuesto de ejecución material de la casa. Cfr. Thomas HINES. Richard Neutra. Op. cit., p. 107

6o. Para tener otra referencia, de acuerdo con Esther McCoy, los honorarios totales de Schindler en el proyecto de la Lovell Beach House, incluidos gastos, desplazamientos y la colaboración de Neutra en el proyecto de paisajismo fueron 3000 dólares. Véase Esther McCOY: Vienna to Los Angeles. Op.cit., p. 68.

61. Richard NEUTRA: Life and Shape. New York: Appleton Century Crofts, 1962, p. 220

62. En agosto de 1949, Neutra se convirtió en el segundo arquitecto en ser portada del prestigioso semanario después de Wright, que lo había sido en enero de 1938.

63. Esther McCOY: Richard Neutra. Op. cit., p. 13

64. Curiosamente, la sede de la Academy of Modern Art de Ferenz tuvo su sede en el Fine Arts Building, un edificio historicista con predominio del Spanish Revival finalizado el año anterior por la firma Walker \& Eisen en el 811 de la calle 7.

65. De acuerdo con las indicaciones de John Crosse, ha podido verificarse la coincidencia de Ferenz con estos arquitectos en diferentes actos sociales y eventos artísticos recogidos por la prensa local, como el Salon of Ultra Modern Art, organizado en honor de Schindler a finales de 1928 (Los Angeles Times, 21 octubre 1928, p.III-3) y donde aparecen tanto Richard Neutra como Gregory Ain en la relación de asistentes.

66. Harwell Hamilton HARRIS: The Organic View of Design. Entrevista con Judy Stonefield. Los An geles: Oral History Program, University of California Los Angeles (UCLA), 1985, P. 55-56 (en adelante simplemente Harwell Hamilton HARRIS: Oral History Program, UCLA).

67. Arthur MILLIER: "A New Art", en Los Angeles Times, 2 enero 1929, p. 11.

68. Ibid., p. 57

69 Harwell Hamilton HARRIS: Oral History Program, UCLA, p. 58.

70. Cfr. Anthony DENZER: Gregory Ain: The Modern Home as Social Commentary. New York: Rizzoli, 2008, p. 30 .

71. La identificación de los personajes de la fotografía fue realizada por Harwell Hamilton Harris en la correspondencia mantenida con Esther McCoy a finales de los años 70. Véase Harwell Hamilton HARRIS: Correspondencia con Esther McCoy (abril 1978-noviembre 1979). Esther McCoy Papers, Smithsonian Institution, Washington DC (en adelante simplemente McCoy Papers), Véase tambié Anthony DENZER: Op. cit., p. 234, nota 39 y Dione NEUTRA: Op. cit., p. 177. De acuerdo con John Crosse E. Merrill Owens es uno de los estudiantes sin identificar.

72. Schindler y Neutra eran activos conferenciantes, entre finales de los años 20 y principios de la década siguiente, de forma conjunta como miembros de AGIC o por separado recorrían la ciudad dando lecciones magistrales para difundir el evangelio moderno y, como expresó Esther McCoy (Richard Neutra. Op. cit., p. 7) "conseguir hacer realidad la promesa de una gran revolución". Ambos daban conferencias en clubes sociales, escuelas progresistas y hasta grupos de empresarios y banqueros ante los que hacían campaña buscando apoyos. Como escribió Harwell H. Harris a Esther
McCoy: "Neutra y Schindler aparecían como extravagantes hermanos gemelos, con sus diferentes maneras de vestir, de peinarse, con sus exóticos amigos bailarines y naturópatas", (H. H. Harris, carta a Esther McCoy, abril 1978, McCoy Papers). Figuras de referencia sin duda para una selecta élite de vanguardia, pero absolutamente extraños para el público general (Cfr. Natalie SHIVERS: "A new Creative Medium» en Victoria DAILEY, Natalie SHIVERS y Michael DAWSON: LA's Early Moderns. Art/ Architecture/Photography. Los Angeles: Balcony Press, 2003, p. 151.) .

73. Información facilitada por John Crosse.

74. David Gebhard: Rudolph Schindler. Barcelona: Oikos-tau, 1979 (edición original: Schindler. Prefacio de Henry Russell Hitchcock. New York: Viking Press, 1971), p. 98.

75. Philip M. LOVELL: "The House Built for Health", en Care of the Body. Los Angeles Times, (Sunday magazine section), 15 diciembre 1929, p. 26-27.

76. Cfr. Esther McCoy: Vienna to Los Angeles. Op. cit., p. 70.

77. Tolerancia de 1/8 de pulgada, según Hines. Cfr. Thomas HINES: Richard Neutra. Op. cit., p. 103.

78. Esther McCOY: Richard Neutra. Op. cit., p. 14

79. Realizados entre otros fotógrafos por Walker Evans o Dorothea Lange, varios retratos que integraban esta exposición se convirtieron en iconos de la fotografía del siglo pasado. Se trataba de un trabajo patrocinado por el gobierno federal con el objeto de poner rostro al drama humano de la Gran Depresión.

80. Todos ellos eran además miembros del California Art Club (CAC), una de las asociaciones culturales más antiguas de California, creada en 1909. Como institución socialmente progresista, el CAC apostó por su apertura a artistas procedentes de diferentes disciplinas así como a las mujeres. Durante el boom económico de la década de 1920, el CAC aumentó considerablemente el número de sus socios y también el prestigio de sus actividades, seguidas por atención por Los Angeles Times. Si bien, no dispuso de una sede acorde con sus necesidades hasta que, en 1927, el Ayuntamiento de Los Ángeles aceptó el regalo de Aline Barnsdall de su casa de Olive Hill y el CAC se trasladó a la Hollyhock House, donde permanecería hasta 1942 disfrutando del usufructo de quince años que Barnsdall había estipulado en su contrato de donación.

81. Para una discusión en mayor profundidad del mismo véase Ruben ALCOLEA: Op. cit., pp. 253255 .

82. Richard NEUTRA: "The Demostration Health-House", en Architectural Record, mayo 1930, pp. 433-39

83. Willard D. MORGAN: "An Architect's Warm-Air Heated Health House", en Sheet Metal Worker, 11 julio 1930, pp. 410-411 y 419

84. Rubén A. ALCOLEA: Op. cit., p. 259

85. Ibid.

86. Esther McCOY: Richard Neutra. Op. cit., p. 14

87. El episodio es descrito con detalle por Rubén A. ALCOLEA: Op. cit., pp. 269-271.

88. Cfr. Rubén A. ALCOLEA: Op. cit., p. 251. 
89. Esther McCoy atribuye a W. P. Woodcok algunas de las imágenes de la Lovell Beach House de las que en capítulos anteriores se ha valorado la posibilidad de que su autoría se debiera a Edward Weston o Willard Morgan. Véase Esther MCCOY: Vienna to Los Angeles. Op. cit., p. 92.

90. Julius Shulman entrevistado por Mark Edward Harris en Julius SHULMAN: Photographing Architecture and Interiors. Los Angeles: Balcony Press, 2000, (edición original Nueva York: Whitney Library of Design, 1962), p. iii.

91. Thomas S. HINES: Richard Neutra. Op, cit., p. 100

92. Richard NEUTRA: Introducción al libro de Julius SHULMAN: Photographing Architecture and In teriors. Op. cit., p. vii. Por Munich Neutra se refiere equivocadamente a la exposición Film und Foto de Sttutgart, 1929.

93. Julius SHULMAN: Entrevista con el autor, 22 marzo 2008.

94. Julius SHULMAN: The Photography of Architecture and Design. Nueva York: Whitney Library of Design, 1977, p.51

95. Julius SHULMAN: Entrevista con el autor, 22 marzo 2008

96. Ted WELLS: Julius Shulman: Architectural Photographer of the Modern Dreams, podcast publicado en noviembre de 2005 en http://twls.libsyn.com/

97. Julius SHULMAN: Entrevista con el autor, 22 marzo 2008.

98. Ibid.

99. Harwell Hamilton HARRIS: Oral History Program, UCLA, pp. 57-58.

100. Ibid., p. 63 .

101. Harwell Hamilton HARRIS: Prólogo al libro de Esther McCOY: Vienna to Los Angeles. Op. cit. pp. 8-9.

102. Thomas S. HINES: Richard Neutra. Op. cit., p. 85

103. Richard NEUTRA: "Um die neue Gestaltung", en Das Neue Frankfurt, 2 abril 1928, pp. 68-71

104. Esa tradición, al menos en su biografía, no era casual pues Neutra había conocido a Wright en Chicago precisamente en el entierro de Sullivan en abril de 1924, es decir, al mes siguiente de llegar a la ciudad.

105. Padre del arquitecto de posguerra Conrad Buff, del despacho californiano Buff and Hensman 106. Sobre este artículo véase la discusión en profundidad de Rubén A. ALCOLEA: Op. cit., p.185 107. Cfr. Thomas HINES: Richard Neutra, Op. cit., p. 91

108. Harwell Hamilton HARRIS: Prólogo al libro de Esther McCOY: Vienna to Los Angeles. Op. cit. p. 9

109. John Bullock había mostrado su interés por el arte, el diseño y la arquitectura modernas desde el proyecto para su nuevo edificio Bullock's Wilshire Department Store, cuyos interiores había encargado a Jock Peters, John Weber and Kem Weber. Como se trató en la primera parte de la tesis, sobre esta obra Pauline Schindler había publicado en el número de enero de 1930 de California Arts \& Architecture un artículo titulado "A Significant Contribution to Culture: The Interior of a Great California Store as an Interpretation of Modern Life". Conociendo la sensibilidad y receptividad de Bullock hacia las ideas modernas, Harris consideró que no sería difícil convencerle para que se convirtiese en uno de los patronos de la exposición. Sobre aquel episodio, Harris escribió: "Por teléfono le comenté que esta exposición revolucionaría la arquitectura en la misma medida que la Exposición de París de 1925 habia revolucionado las artes decorativa". Como afirma Lisa Germany en su transcripción de estas palabras de Harris procedentes de una carta enviada a la autora en 1988, es obvio que, en 1932, el arquitecto se mostró muy interesado por el contenido de la exposición. Cfr. Lisa GERMANY: Harwell Hamilton Harris. Prólogo de Kenneth Frampton e Introducción de Bruno Zevi. Berkeley, CA: University of California Press, 2000 (edición original Austin, TX: University of Texas Press, 1991), p. 41.

110. Beatriz COLOMINA: Privacidad y publicidad. La arquitectura moderna como medio de comunicación de masas. Yaiza Hernández y José Parra (dirs.). Traducción Isabel Hortal, Beatriz Preciado, Yaiza Hernández y José Parra. Murcia: CENDEAC, COAMU, OBS, 2010, p. 143 (edición original Privacy and Publicity. Modern Architecture as Mass Media. Cambridge, MA: The MIT Press, 1994).

111. Muy poco después, Melba Beard, otra mujer piloto, encargaba a Richard Neutra su casa en Altadena.

112. Concretamente en el Chouinard Art Institute. Información facilitada por John Crosse.

113. Harwell Hamilton HARRIS: California influences When Growing Up. Notas para la preparación de su entrevista para el Oral History Program de la Universidad de California. Archivo del arquitecto: H. H. Papers: Drawings, Photographs and Archival Records, California, Texas and North Carolina. Alexander Architectural Archive, University of Texas Library, Austin, 1979 (en adelante Harwell Hamilton HARRIS: Notas personales. Archivo de Arquitectura de la Universidad Texas).

114. Harris era nieto de forty-niners los cuales, tras la incorporación del territorio de California a la Unión, habían llegado al estado con la fiebre del oro de 1849

115. El adjetivo podría traducirse como "perteneciente al bosque".

116. Cfr. Lisa GERMANY: Harwell Hamilton Harris. Op. cit. p. 18.

117. Ruth Sowden, quien en aquel momento había encargado su vivienda a Lloyd Wright habló por primera vez a Harris de la obra del famoso arquitecto y padre de éste, Frank Lloyd Wright.

118. Cfr. Lisa GERMANY: Harwell Hamilton Harris. Op. cit. p. 21.

119. Harwell Hamilton HARRIS: Oral History Program, UCLA, pp. 22-23

120. Rudolph M. SCHINDLER: Carta a Richard Neutra enviada desde Los Ángles, presumiblemente en diciembre de 1920 ó enero de 1921 y citada por Esther McCOY en Vienna to Los Angeles. Op. cit. p. 130.

121. Esther MCCOY: The Second Generation. Salt Lake City, UT: Gibbs Smith Publisher, 1984, p. 40 Hay que gracias en buena medida al Wasmuth Portfolio tanto Schindler como Neutra se habían interesado por la obra de Wright, viajando a los Estados Unidos para trabajar con él.

122. Barbara LAMPRECHT: Neutra. Complete Works. Köln: Taschen, 2000, p. 16

123. "If any building can fire one with passion for simple living and high thinking, this is it". Harwell Hamilton HARRIS: Carta a Pauline Schindler, 1974. Citada por Esther MCCOY en Vienna to Los Angeles. Op. cit. p. 54 . 
124. Harwell Hamilton HARRIS: Prólogo al libro de Esther MCCOY: Vienna to Los Angeles. Op. cit., pp. $12-13$

125. Ibid., p.8

126. Ted WELLS: Harwell Hamilton Harris: My America is Really California. Notas compartidas con el autor para el capítulo homónimo de su monografía sobre el arquitecto, Romantic Modern: The California Architecture of Harwell Hamilton Harris (Los Angeles: Guardian Stewardship y Marquand Books, s. d.). El título del capítulo de Ted Wells, Mi América es realmente California, traducido en castellano, está basado en una declaración de Harris que por su fuerza expresiva se ha utilizado también como título para este subcapítulo.

127. Harwell Hamilton HARRIS: Carta enviada a la revista Progressive Architecture, 26 diciembre 1967. Citada por Ted WELLS: Ibid

128. Harwell Hamilton HARRIS: Notas personales. Archivo de Arquitectura de la Universidad Texas

129. Ibid.

130. Ted WELLS: Harwell Hamilton Harris: My America is Really California. Borrador del texto. Op. cit, s.p. (en adelante simplemente Ted WELLS: Harwell Hamilton Harris).

131. "Nature's meanings are so various [...] that they are suggestions and not blueprints". Harwell Hamilton HARRIS: Notas personales. Archivo de Arquitectura de la Universidad Texas.

132. Discusión con el autor. Según Wells, Harris mantuvo toda su vida una lucha personal para supe rar sus propios prejuicios intelectuales, que el puritanismo de su educación le había inculcado. Esta actitud a veces podría traducirse en el uso de determinados colores o materiales muy novedosos o llamativos para resolver un detalle que, probablemente, puede parecer forzado con respecto a resto del proyecto.

133. Ted WELLS: Harwell Hamilton Harris. Op. cit, s.p.

134. Thomas HINES: Architecture of the Sun. Op. cit., p.431.

135. North Carolina State University School of Design: Harwell Hamilton HARRIS: A Collection of His Writings and Buildings, vol. $14, \mathrm{p} . \mathrm{n}^{\circ} 5, \mathrm{p} 38$.

136. Jean Murray BANGS: Entrada de su curriculum vitae. Citado por Lisa GERMANY: Op. cit., p. 51.

137. Jean Murray Bangs había nacido en Calgary en 1894

138. Lisa GERMANY: Op. cit., p. 52.

139. Cfr. Lisa GERMANY: Harwell Hamilton Harris. Op. cit, p. 52.

140. Ibid., p. 212, nota 6

141. "The Schindler's open house on Sunday evenings attracted the 'arty' intellectuals of post-WorldWar I [...] Hollywood drew them like a magnet. There was Robert Nichols, a young English poet jus come from a year's teaching in Japan [...] There was Maurice Brown, an English playwright and actor known here for his and his wife's Little Theather work in Chicago. Brown and Nichols are remembered for their debates about art. There was John Bovignton, an adventurer living on his wits who had cured himself of neuritis by dancing, diet and lazy living. He had picked up dances in Bali. He choreographed one his own called 'Dance of the Evolution'. Beginning with his naked-breasted female partner as a mass of quivering protoplasm on the grass in the patio, the dance developed through various stages of lower animal forms to the ultimate human.

Edward Weston was a friend who came, showed contact prints from 8 by 10 negatives made with unheard of discipline. Common objects appeared in them as objects seen now for the first time. Weston's viewing, sensing and portraying by 'straight' means revolutionized our concept of photography as a fine art.

Doris Levings, a young pianist and later the wife of John Pennington, first violinist of the London String Quartet, rented the Schindler guest wing[...] When the Neutras arrived, Dione Nuetra with her cello and voice became a participant in these Sunday evening musical entertainments.

[...] Not all entertainment involved groups. Sometimes the only guests were another couple. If at dinner, they were apt to dine on ground meat and vegetables in a loaf. Pauline served each course on a separate large cane 'tea tray' resting on a low redwood table frame. The tray was the table top and was changed with each course. The seats were low redwood stools.

Whether the group was large, filling both studios and the garden, or small and restricted to one room or the patio, the place alone raised the common above the commonplace. It freed everyone's expression. It was a tool Pauline and RMS used with imagination and skill and it deserves to be remembered". Harwell Hamilton HARRIS: Introducción al libro de Esther McCOY Vienna to Los Angeles: Op. cit., pp. 13-14.

142. "Pauline-eager, ardent, ready for any new idea in any field-made an experience of everything and savored it to the full. [...] People who didn't like her called her a poseur, which was unjust. She worked hard and did without almost all the things women commonly want, and did it with a grace few women in her position have achieved". Harwell Hamilton HARRIS: Introducción al libro de Esther McCOY Vienna to Los Angeles: Op. cit., p. 13

143. Jean Murray Bangs Harris había tenido contacto con Maybeck durante sus tiempos de estudiante en la Universidad de Berkeley, donde le había entusiasmado su Hearst Hall. A principios de los años 40, mientras Harris dirigía las obras de la Weston Havens House en la ciudad, la pareja se instaló una breve temporada en la ciudad. Durante ese tiempo, ella se dedicó a entrevistar a Maybeck, ya retirado, y a organizar el material de su antiguo estudio con el objeto de realizar una publicación monográfica sobre el arquitecto y su influencia en la arquitectura del Área de la Bahía. No llegó a terminar el libro, pero la documentación recopilada sirvió de base para el archivo de Maybeck que ahora custodia la Universidad de Berkeley (Bernard Maybeck Papers. Environmental Design Archives. University of California at Berkeley).

144. Sobre Maybeck véase: Jean Murray BANGS HARRIS: "Bernard Ralph Maybeck, Architect, Comes into His Own: Notes from a Forthcoming Book on Maybeck", en Architectural Record, enero 1948, pp. 72-79; Y sobre Greene \& Greene véase: Jean Murray BANGS HARRIS: "Greene and Greene: the American House Owes Simplicity and Clarity to Two Almost-Forgotten Brothers Who Showed Us How to Build with Wood", en Architectural Forum, octubre 1948, pp. 80-89.

145. Monica M. PENICK: The Pace Setter Houses: Livable Modernism in Postwar America. Ph. D. Dis sertation. Austin, TX: Graduate School of Architecture. University of Texas at Austin, 2007, p. 147

146. Ibid. p.1.

147. Conversación con el autor

148. Colin ROWE: "Texas and Mrs. Harris", en As I Was Saying. Recollections and Miscellaneous Es says. Volume I: Texas, Pre-Texas, Cambridge. Cambridge, MA: The MIT Press, 1996, pp. 25-40.

149. Ibid., p. 28 .

150. El número recogía además obras de Richard Neutra (entre ellas, la Lovell Health House, la VDL Research House y la Beard House), de R. M Schindler (las casas Oliver, Gibling -para los padres de Pauline-y la casa Wolfe en Isla Catalina), además de J. R. Davidson, Kem Weber, Lloyd Wright, Jock 
Peters, etc. Además de su editorial, la propia Pauline publicaba un texto homenaje a Frank Lloyd Wright, "Modern Architecture Acknowledges the Light Which Kindled It", e incluía un resumen del texto de Schindler "Space Architecture".

151. Para una mayor información sobre este episodio véase el capítulo de este trabajo dedicado a la Entenza House.

152. David GEBHARD: "Harwell H. Harris", en AA. VV. Robert WINTER (ed.): Toward a Simpler Way of Life: the Arts \& Crafts Architects of California. Berkeley, Los Angeles, CA; London: University of California Press, 1997, p. 276.

153. Información compartida con John Crosse.

154. Los Angeles Times Home Magazine, 6 de mayo de 1945 , p. 3.

155. Una obra que, por cierto, fue utilizada para la portada del catálogo de la exposición sobre e arquitecto que organizó en 1985 la Universidad de Texas en Austin y que, hasta la fecha, sigue siendo la más completa muestra monográfica sobre Harris.

156. La casa está ubicada en el 475 de Mesa Road, Santa Mónica.

157. John Entenza también supo de su existencia a través de Stella Gramer, socia del bufete de abogados de su padre. En aquella época, Gramer había defendido a Harris en un litigio sobre com petencias profesionales y tras ganar el caso, interesada por la obra arquitectónica de su cliente, le había encargado una casa, que Harris no llegó a construir porque finalmente Gramer compró una residencia de Richard Neutra, concretamente la Plywood Model House de 1936.

158. Durante los primeros años después de su llegada a California John Entenza estuvo colaborando también con la industria cinematográfica, desarrollando junto a los directores Paul Bern e Irving Pitchel una producción experimental para la Metro Goldwyn Mayer. Cfr. Barbara GOLDSTEIN (ed.) The Entenza Years. Santa Mónica, CA: Hennessy + Ingalls, 1998 (edición original Cambridge, MA: The MIT Press, 1990), p.8.

159. Cfr. Lisa GERMANY: Op. cit., p. 217.

160. Resulta significativa la petición de John Entenza, teniendo en cuenta que era homosexual aunque nunca lo declarase públicamente. Más bien al contrario, tratase de ocultarlo siempre su vid bajo todo tipo de pretextos. Este calificativo, como el énfasis en su condición de soltero heterosexual en el enunciado del programa de su propia Case Study House son algunas de sus estrategias para construir un personaje público que ocultase su verdadera condición

161. Ibid., pp. 66 y 68

162. California Arts \& Architecture n 52 , julio 1937, p.33. En el número anterior la revista había publicado la casa de Harris en Fellowship Park y en el número siguiente (mayo de 1938) volvería a hacerse eco de la Entenza House en Santa Mónica.

163. Como se comentó en el capítulo anterior, en 1932, Richard Neutra confió a sus dos colaboradores, Harwell Hamilton Harris y Gregory Ain la tarea de buscar patrocinadores para llevar la Exposición del MoMA a Los Ángeles. Gracias a los esfuerzos de Harris la muestra se exhibió en California en e verano de ese mismo año.

164. Años después la vivienda fue adquirida por Ayn Rand, la novelista autora de El Manantial. La casa fue destruida en 1971.
165. Cfr. Harwell H. HARRIS: Prólogo al libro de Esther MCCOY: Vienna to Los Angeles. Op. cit., p. 11. En él escribía que no compartía todas las ideas de Neutra y que algunas de sus actitudes no las consideró nunca justificables, pero también afirmaba que de él había aprendido mucho, por lo que merecía todo su respeto y agradecimiento: "no sólo por sus revolucionarios conceptos y creaciones que afectaron el curso del desarrollo de la arquitectura, sino también por su valentía y tenacidad para hacer frente a una larga lista de obstáculos, dificultades, críticas, penurias económicas y falta de trabajo. Le admiro profundamente".

166. Lisa Germany cuenta que, según le relató el arquitecto en una entrevista, la idea de la escalera partió del propio Harris. Cfr. Lisa GERMANY: Op. cit., p. 68.

167. Cuando se prepararon los planos para el Pabellón de la Exposición de Viena de 1932, Harris aún continuaba trabajando para Neutra. Un año más tarde, en 1933, Schindler también se interesó por este tipo de escaleras ligeras y transparentes, realizando una personal interpretación en el exterior de su casa Oliver en Silver Lake.

168. Información proporcionada por Michael W. Folonis, quien afirma que el borde corrugado del carport se encontraba tan deteriorado que fue imposible su restauración. La banda de acero liso y estuco es, en principio, una solución provisional y está previsto fabricar expresamente una nueva pieza metálica que reproduzca la textura original de la cubierta del porche.

169. Lisa Germany ha querido ver en este remate de acero una cita abreviada de la refulgente curva de la casa de Josef von Sternberg de Neutra. Cfr. Lisa GERMANY: Op. cit., p. 68

170. Michael Folonis es también el autor de la restauración de otra vivienda de Harwell Hamilton Harris en Los Angeles, la Pumphrey House de 1939, una obra contemporánea de la vivienda de John Entenza que, sin embargo, estaba completamente alejada en sus planteamientos ya que había sido abordad desde su propia personalidad como arquitecto.

171. Cfr. Harwell H. HARRIS: Prólogo al libro de Esther MCCOY: Vienna to Los Angeles. Op. cit., p. 13

172. Opinión expresada por David Travers en el texto introductorio a la reimpresión de la revista realizada por Taschen en 2008. David TRAVERS: "AA: A Retrosepctive", en Arts \& Architecture. The Complete Reprint 1945-1954. Köln, Los Angeles et al.: Taschen, 2008, vol. I, primer cuadernillo, p. 6.

173. Esther MCCOY: Case Study Houses 1945-62. New York: Reinhold, 1962.

174. . Barbara GOLDSTEIN: Arts \& Architecture. The Entenza Years. Op. cit.

175. En opinión de John Crosse, el triunvirato McCoy-Travers-Goldstein, afines a círculo de John Entenza, habrían extendido este error para ensalzar los méritos su mentor, entonces al frente de la Graham Foundation, había sido su mentor. Otros autores como Smith, por su parte, habrían asumido el dato falsificado sin contrastarlo, extendiendo así el mito. Discusión del autor mantenida en varias ocasiones con John Crosse.

176. Elizabeth A. T. Smith : "Arts \& Architecture and the Los Angeles Vanguard", en Elizabeth A. T. SMITH (ed.): Blueprints for Modern Living: History and Legacy of the Case Study Houses. Cambridge, MA: The MIT Press, 1989, pp. 145-166.

177. En su carta fechada el 18 de mayo de 1989 a Esther McCoy, Harris sostenía "Jean and I were good friends of Jere Johnson who was the owner and editor of CA\&A. My office and the CA\&A offices were on the same floor of 2404 West Seventh Street (across from Westlake Park (later McArthur Park), and each of my houses was published in CA\&A before it appeared elsewhere. At length Jere told Jean she was expecting a baby and she didn't know who to get to run the magazine while she was out of the running. Knowing that John could at least write and probably edit, we immediately suggested him for 
the job. At the time John knew very little about Architecture, so his only contribution at the very begin ning was "Notes in Passing." John took it over and Jere never got it back. We never knew the details of the takeover. I suppose Jere was too chagrined at herfoolishness to want to talk about it. Stella was very sharp and undoubtedly directed John's maneuvers. This ended John's and our friendship". Información facilitada por Susan Morgan.

178. Harwell Hamilton HARRIS: Oral History Program, UCLA, pp. 130-131. Harris se refirió en numerosas ocasiones al importante papel desarrollado por Stella Gramer como mujer de negocios en e proceso de la construcción de la casa John Entenza. Afirmó que ésta había negociado directamente los precios con el constructor. Así, en esa misma carta de Harris a Esther McCoy fechada el 18 de mayo de 1989, el arquitecto afirmaba: "John had practically no money. He was living rent-free in a house his father, Tony Entenza, was keeping a congressional district from which he ran (unsuccessfully) for Congress every two years. On the basis of my drawings he asked for a bid from a young contractor brought to him. He talked to his father's law partner, Stella Gramer (Stella was more like a son to Tony that was John). When the contractor brought his bid into the Entenza office where John, Stella, and I were waiting, John and Stell took the contractor into the back office leaving me sitting out front. After what seemed an extremely long time the three of them returned, the contractor looking sober and un happy. Just how Stella operated on him I don't know but the full contract figure was only $\$ 3,120.00$. It's a figure I never forgot. There were no extras". (Fuente: Susan Morgan). En otra carta anterior de Harris a McCoy, fechada el 8 de noviembre de 1987, éste escribia: "Stella Gramer had done the dirty work for John when it came to completing the contract with the builder of my house for John. In the case of the contract for John's house, John and I sat in the outer office and the contractor was taken into Stella's office; when they came out the contract document had been altered and signed for only $\$ 3,120$, which was considerable less than the earlier figure. John looked and acted and probably felt entirely innocent.. Jean admired Stella as a lawyer. Jean always said that what she wanted in a lawyer was a fighter and not a legal expert who told her why something couldn't be done..." (Fuente: Susan Morgan). Fue esta misma dureza la que, según Harris, la abogada de John Entenza aplicó contra su amiga Jere Johnson para presionarla a vender la revista por muy poco dinero.

179. Hay quienes sostienen, incluido el propio David Travers, que en este caso se trató de una maniobra muy calculada de Robert Cron, director de publicidad de la revista, quien habría convencido a Entenza de las ventajas de ampliar miras hacia el mercado nacional e internacional.

180. Cfr. Harwell Hamilton HARRIS: Oral History Program, UCLA, p. 131

181. La Weston Havens House se ubica en el número 255 de Panoramic Way. Panoramic Hill, es uno de los distritos históricos de Berkeley, las privilegiadas vistas de la colina atrajeron la atención de clientes adinerados que optaron por arquitectos del prestigio de Bernard Maybeck, Julia Morgan o Frank Lloyd Wright, cuyas obras jalonan un vecindario dominado por una insólita concentración de Bay Region Style, análoga a la de arquitectura moderna en calles de Los Ángeles como Mulholland Drive o Michel Torena Street.

182. Esther McCOY: The Second Generation. Op. cit., p. 56.

183. David GEBHARD, Robert WINTER et al.: Guide to Architecture in San Francisco and Northern California. Salt Lake City, UT: Gibbs Smith Publisher, 1985. Revisada con Eric Sandweiss (edición original Santa Barbara, CA: Peregrine Smith, 1973, con John y Sally Woodbridge), p. 268.

184. Por su posición en el extremo oriental de la Bahía estas colinas suelen ser el lugar donde se detiene el avance de las nieblas procedentes del Pacífico, descargando sobre ellas su humedad.

185. Cfr. California Arts \& Architecture, agosto 1940, pp. 22-23.

186. Entre las revistas que continuaron publicando obras de Harris pueden citarse: Sunset, Pencil Points, Progressive Architecture, Interiors, Practical Builder, New Republic, Harpers, Mademoiselle,
Ladie's Home Journal, Household, House \& Garden, Better Homes \& Gardens, Good Housekeeping, Women's Home Companion, Holiday, Architects' Journal, Architectural Review, RIBA Architects' Journal, Architectural Review, Casabella, Kentiku Sekai, El Arquitecto Peruano, etc.

187. Esther McCoy: The Second Generation. Op. cit., p. 48.

188. Entrevista con el autor en marzo de 2009

189. Ibid.

190. En un correo electrónico al autor en octubre de 2009, Ted Wells afirmaba sobre la posible consideración de Harris hacia el trabajo que Julius Shulman realizaba a principios de la década de 1940 "I believe that Harris may have felt that Julius' work was too literal and did not capture the artistic qualities, or interpretive feelings, of the architecture in the way that, for example, Man Ray or other photographic artists could. Julius, during his prime years, was really known as a photographer who expertly documented architecture, he was not known as someone who interpreted architecture. He was a production photographer. Later on, his artistic qualities would be admired and celebrated, but during his most productive years, he was a non-stop workhorse".

191. Lisa GERMANY: Op. cit., p. 87

192. Cfr. Ted WELLS: Man Ray: Surrealist meets Architect (podcast). EnTed Wells living: simple. http:// www.twls.libsyn.com.

193. El capítulo central de la monografía deLisa Germany sobre Harris (el número 6: 1938-1942), donde se trata sobre la casa Weston Havens se titula Houses with Good Manners, el mismo título que por su carga expresiva se ha utilizado para el tercer subcapítulo del capítulo dedicado a Harris en esta tesis.

194. Lisa GERMANY: Op. cit., p. 90

195. Ibid.

196. Cfr. Ted WELLS: Man Ray: Surrealist meets Architect. Op. cit.

197. Cfr. Annmarie ADAMS: "Sex and the Single Building: The Weston Havens House, 1941-2001" en Buildings \& Landscapes: Journal of the Vernacular Architecture Forum 17, $\mathrm{n}^{\circ} 1$, primavera 2010, pp. 82-97.

198. La primera monografía sobre Harris, escrita por Lisa Germany -también la única hasta la aparición del trabajo de Ted Wells-, fue publicada en 1991, pocos meses después de la muerte del arquitecto en noviembre de 1990. Hasta esa fecha, lo más parecido a una investigación biográfica en paralelo a la trayectoria arquitectónica del personaje era el capítulo dedicado a Harris por Esther McCoy en su libro The Second Generation (Op. cit.).

199. Conversación del autor con Ted Wells en su casa de Laguna Beach, julio de 2011.

200. Revere Copper and Brass Corporation: A House With a Future, Revere's Part of Better Living, vol 11. New York, 1943. Catálogo promocional.

201. Ladies Home Journal, por ejemplo, dedicaba número de julio de 1942 ("Meet the Browns") a dar todo lujo de detalles sobre una pareja prototípica de San Diego, los Brown: el tipo de casa que tendrían tras la victoria, cómo vivirían, cuántos hijos tendrían, en qué gastarían su dinero, etc.; toda una estratégica planificación del consumo de masas y de promoción de estilos de vida. 
202. "California House. Harwell Hamilton Harris, Architect", en AA. VV., Maron J. SIMON (ed.): Your Solar House. New York: Simon and Schuster, 1946, p. 125

203. Por ejemplo, Harris, con catorce fotografías de su obra publicadas en el libro Tomorrow's House. A Complete Guide for the Home Builder, fue una de las figuras centrales del popular catálogo de 1945 compilado por George Nelson y Henry Wright, colaboradores de Architectural Forum y editado en Nueva York por Simon \& Schuster (para una mayor información véase el apartado de este trabajo sobre la bibliografía específica sobre H. H. Harris, concretamente, el subapartado HH.4, dedicado a capítulos de libros).

204. Sobre las obras de Harris que integran los catálogos de ambas exposiciones editados, respec tivamente, por Elisabeth Mock (Built in the USA, 1932-1944) y por Henry Russell Hitchcock y Arthur Drexler (Built in USA: Post-War Architecture), véase también el apartado de este trabajo sobre la bibliografía especifica sobre H. H. Harris.

205. Harwell Hamilton HARRIS: Oral History Program, UCLA, pp. 180

206. Harwell Hamilton HARRIS: Carta a Lisa Germany fechada en agosto de 1988. Citada por Lisa GERMANY en Op. Cit., p. 104.

207. Véase Lewis MUMFORD: Status Quo, en The Sky Line. The New Yorker, 11 octubre 1947

208. Sobre las ponencias de este simposio véase: AA. VV.: What is Happening to Modern Architecture? New York: The Museum of Modern Art Bulletin, vol. XV, nº 3, primavera 1948. En él participaron entre otros, Johnson, Barr, Hitchcock, Chermayeff, Blake, Scully y el propio Mumford.

209. David GEBHARD: Schindler. Op. cit., pp. 169-171.

210. Esta discusión fue presentada en el último capítulo de la primera parte de este documento Rudolph Schindler y la fenomenología del espacio moderno.

211. Información proporcionada por Ted Wells.

212. Harris realizó por cierto un proyecto de vivienda para Cole Weston que no llegó a construirse.

213. Véase Jean Murray BANGS: "Greene and Greene", en Architectural Forum, octubre 1948, pp. 81-88.

214. Uno de los principales logros de los hermanos Greene fue su combinación de diferentes tipos de madera. Utilizaban especies nativas como el abeto, el nogal, el roble o la secuoya, pero también recurrieron a maderas exóticas como la teca de Birmania o la caoba de Honduras para revestir sus interiores, o para realizar sus piezas de mobiliario, ensambladas con destreza de orfebre. Para ellos, las diferentes especies de madera escogidas en cada caso constituían una personal paleta cromática con la que lograron producir efectos plásticos tan reseñables como los de las escaleras de las casas Blacker (1907) o Gamble (1908) en Pasadena.

215. Elemento estructural de madera que, sin perder su continuidad, ata horizontalmente las cabezas de los pilares y rodea un recinto a la altura de los dinteles sosteniendo las puertas correderas. En los paramentos japoneses suele delimitar dos ámbitos, uno por debajo y otro que ocupa la distancia entre el nageshiy el techo.

216. Como un expresara una vez el dramaturgo Noël Coward, en el Sur de California, siempre hay algo deliciosamente real en todo lo que es falso y algo de mentira en aquello que parece real.

217. Harwell Hamilton HARRIS: "Regionalism", en North Carolina Architect, enero-febrero 1978, p. 10
218. En este sentido, es lógico que Frampton prologara la monografía de Lisa Germany sobre el arquitecto.

219. En Historia crítica de la arquitectura moderna. Sexta Edición Ampliada. Barcelona: Gustavo Gili, 1993 (edición original : Kenneth FRAMPTON y Yukio FUTAWAGA: Modern Architecture, 1851-1845. New York: Rizzoli, 1983), p. 325

220. En, AA. VV., FOSTER, Hal (ed.): La Posmodernidad. Barcelona: Kairós, 2002 (primera edición en castellano 1985; edición original en inglés The Anti-Aesthetic Essays on Postmodern Culture. Port Townsend, WA: Bay Press, 1983), p. 46

221. Entre los reconocimientos recibidos hacia el final de su vida pueden mencionarse, la Richard Neutra Medal for Professional Excellence (1982) y su doctorado honorífico por la Universidad de Carolina del Norte (1985). A pesar de no haber tenido nunca una titulación oficial como arquitecto, Harris fue nombrado Fellow del American Institute of Architects en 1965 en reconocimiento a toda una carrera profesional. La obra de Harris formó parte de algunas de las más importantes exposiciones colectivas sobre arquitectura organizadas por el MoMA a mitad del siglo pasado: 1939 (Three Centuries of American Architecture); 1944 (New Architeture in the US -exposición itinerante organizada por el Museo de Arte Moderno de NY y exhibida en El Cairo); 1944 (Outstanding Examples of Modern Architecture in the Last Decade_Built in USA 1932-1944); y 1953 (Built in USA: Post-war Architecture). Su obra también se exhibió en la National Gallery of Art de Washington (1957) y en el Cooper-Hewitt Museum de Nueva York (1977). A lo largo de su vida se organizaron diversas exposiciones sobre su trabajo en solitario, siendo algunas de las más recientes las que tuvieron lugar en: la North Carolina State University (1981), el Museo de Arte de Fayetteville, Carolina del Norte (1982) y la Escuela de Arquitectura de la Universidad de Texas en Austin (1985).

222. Los valores ambientales del entorno de Silver Lake eran muy apreciados durante los años primeros años 20, cuando, en una época dominada por los revivals históricos, comenzaron a construirse los primeros desarrollos residenciales cuya evolución, al igual que la ocupación de las colinas de Hollywood, ocurrió en paralelo con el desarrollo de la industria del cine. Actores, creativos, productores, etc., seducidos por las cualidades paisajísticas del lugar y por la posibilidad de tener vistas lejanas sobre la ciudad de Los Ángeles, comenzaron a construir sus residencias en estos privilegiados parajes. Mientras las cotas más elevadas de Hollywood Hills y de Los Feliz pronto alcanzaron precios prohibitivos, Silver Lake, todavía asequible hacia mitad de siglo, provocó un desplazamiento del interés hacia la zona este de la ciudad. A principios de los años treinta muchos de sus habitantes, en general personas culturalmente avanzadas, inclinaron sus preferencias hacia la arquitectura moderna, encargando sus viviendas a arquitectos como R.M. Schindler, Richard Neutra, Gregory Ain, Raphael Soriano, el propio Harris o John Lautner, cuya impresionante Reiner House (Silvertop), domina las colinas que rodean el lago.

223. Janet Eastman: "The door-to-door connection", en Los Angeles Times, 12 agosto 2004

224. Durante el proceso de investigación de esta tesis se ha visitado esta casa en tres ocasiones. En una de ellas, en marzo de 2008, su propietario Kirk Nozaki afirmó: "es asombrosa la relación que hemos establecido, frecuentemente soy invitado a sus casas, hemos programado algunos tours con estudiantes, sesiones para fotografiar los interiores... La arquitectura nos ha unido. Siempre somos bienvenidos unos en casa de los otros. Esto es Los Ángeles, ¿quién haría algo así?"

225. Cuando su agente inmobiliario le proporcionó el nombre del autor afirmando que se trataba de un arquitecto moderno, movido por la curiosidad, Nozaki comenzó a investigar sobre él. La recién publicada monografía de Lisa Germany le proporcionó suficientes datos sobre las obras y las ideas de Harris, y los planteamientos del arquitecto acerca del espacio doméstico como soporte de la buena vida (living simple) le sedujeron completamente, animándole a abordar la restauración de la casa de acuerdo con la filosofía original del proyecto. 
226. La Hanson House está ubicada en 2305 de West Silver Lake drive, Silver Lake (Los Ángeles).

227. Charles MOORE, con Peter BECKER y Regula CAMPBELL: Los Angeles. The City Observed. A Guide to its Architecture and Landscape. Santa Monica, CA: Hennessey + Ingalls, 1998 (edición original New York: Vintage Books, 1984), pp. 260-261.

228. Harwell Hamilton HARRIS: "Designing the Small House", en California Arts \& Architecture, enero 1935, p. 71.

229. Cfr. Bruno ZEVI: "L'Chaim! A Toast to H. H. Harris", en Lisa GERMANY: Op. cit., p. xiii.

230. Cfr. David GEBHARD: "Harwell H. Harris", en AA. VV. Robert WINTER (ed.): Toward a Simpler Way of Life: the Arts \& Crafts Architects of California. Op. cit., pp. 278-279.

231. Cfr. Natalie SHIVERS W.: "The Maturing of the Modern Movement", en DAILEY, Victoria; SHIVERS Natalie; y DAWSON, Michael: Op. cit., p. 170

232. Cfr. Esther McCoy: The Second Generation. Op. cit., p. 44

233. Cfr. Neil JACKSON: "Californian promise", en The Architectural Review, marzo 1996, p. 80.

234. A pesar de que Gordon Drake cursó estudios en la Universidad del Sur de California, colaboró con varios arquitectos en sus despachos profesionales (entre ellos Harwell H. Harris, Ernest J. Kumpf o el paisajista Lawrence Halprin) y, por supuesto, había construido varias obras, nunca obtuvo oficialmente el título de arquitecto (aunque, al parecer, semanas antes de morir, había decidido prepararse los exámenes estatales para obtener dicho reconocimiento). Como se indicó, en los Estados Unidos se podía ejercer como arquitecto aunque adoptando el calificativo de designer siempre que, para proyectos de presupuesto superior a los 20.000 dólares, se estuviera avalado por la firma de un técnico competente como un ingeniero de estructuras. Harris por ejemplo contaba cuando lo necesitaba con la firma de su amigo M.T. Cantell, miembro del RIBA y antiguo profesor suyo de estructuras.

235. Cfr. "Creative Art Contest Winning Entries Show", en Los Angeles Times, 1 mayo 1940, pp. I-10.

236. "The dominant factor in the development of California's domestic architecture has been the existence of a growing native tradition, or, rather, the lack of a stifling formal tradition. The resulting freedom of thought has given the architect an untrammeled concept that does not exist in other parts of the country". Gordon DRAKE: "Modular House on Pacific Coast Capitalizes on the Area Famous Topography, Climate and Materials", en Architectural Forum, septiembre 1947, p.110.

237. Cfr. Harwell Hamilton HARRIS: "Regionalism and Nationalism", conferencia que leyó por primera vez ante el Consejo Regional del Noroeste de la AIA en Eugene, Oregón, en 1954. Extractos del texto fueron recogidos en la reseña sobre el encuentro publicada como "A Regional Architectura Expression", en Architectural Record, enero 1955, Western Section y, de modo íntegro, como "Re gionalism and Nationalism in Architecture", en Texas Quartely 1, febrero 1958, pp. 115-124. Recientemente, este ensayo de Harris ha sido recopilado en una colección de escritos sobre la cuestión del regionalismo en AA. VV.: Vicent CANIZARO, Vincent (ed.): Architectural Regionalism. Collected Writings on Place, Identyty, Modernity and Tradition. New Jersey: Princeton Architectural Press, 2007 pp. 56-65.

238. Harwell Hamilton HARRIS, en BAYLIS, Douglas y PARRY, Joan: California Houses of Gordon Drake. New York: Reinhold Pub., 1956, p. 83

239. Ibid.
240. Roxanne K. WILLIAMSON: American Architects and the Mechanics of Fame. Austin (TX): University of Texas Press, 1991.

241. Es interesante reproducir aquí la breve mención a Gordon Drake que, en uno de sus últimos textos, realizó David Gebhard, uno de los principales nombres de la historiografía californiana. Gebhard ofrece un comentario sobre el joven arquitecto dentro de su artículo dedicado a Harwell Hamilton Harris publicado en el catálogo Towards a Simpler Way of Life. Es Ilamativo que Gebhard no haga referencia a su estatus de colaborador o estudiante de Harris, sino que en la enumeración de una serie de autores de referencia en el campo del trabajo con la madera y búsqueda de una carácter regional que precede a la propia discusión de la obra de Harris, incluya a Drake, por derecho propio, en la lista de arquitectos que sustentarían esa auténtica tradición vernácula cuya genealogía, en palabras del autor, se remonta a Greene and Greene: "La expresiva cualidad de la madera, tanto como estructura como revestimiento, fue uno de los principales temas del trabajo de Charles Warren Callister, Gordon Drake y Jack Hilme". David GEBHARD: "Harwell H. Harris", en AA. VV., Robert WINTER (ed.): Toward a Simpler Way of Life: the Arts \& Crafts Architects of California. Op. cit., 276.

242. Eliel SAARINEN y William WURSTER: "USA Architectural Awards", en The Architects' Journal, 12 junio 1947, p. 496

243. "Minimum House", en The Architects' Journal, 10 julio 1947, p. 36

244. Gordon DRAKE: "Modular House on Pacific Coast Capitalizes on the Area Famous Topography, Climate and Materials", en Architectural Forum, Op. cit., p.110.

245. Progressive Architecture, julio 1947, p. 14.

246. Cfr. Neil JACKSON: "Californian promise". Op.cit. p. 82.

247. Ibid

248. Gordon DRAKE: Carta a Eleanor Bittermann para Architectural Forum fechada el 9 de Julio de 1947. Documento conservado por Maggie Baylis y donado en 1998 como parte de su archivo a las Colecciones de la Universiad de California, Berkeley. Consultable en la Douglas and Maggie Baylis Collection 1938-1998 (periodo 1943-1971). Environmental Design Archives. College of Environmental Design. University of California, Berkeley (Caja 1, Carpeta 1).

249. Ibid.

250. Gordon DRAKE: "Modular House on Pacific Coast Capitalizes on the Area Famous Topography, Climate and Materials", en Architectural Forum, Op. cit., p.110

251. Ibid.

252. Por cierto, fue durante este viaje al norte del estado para conocer las obras de Harris cuando Drake tomó por primera vez conciencia del lugar y, cuando, al final de la década, decidió abandonar Los Ángeles y mudarse a Carmel, pesó mucho en su decisión aquel recuerdo romántico de sus viajes como estudiante a aquel paraje tan especial de la costa que, desde entonces, sintió como propio.

253. "House: Carmel", en Progressive Architecture, febrero 1952, p. 93.

254. En BAYLIS, Douglas y PARRY, Joan: California Houses of Gordon Drake. Op.cit. p. 62.

255. Ibid., p. 66. 
256. Gordon DRAKE: Carta a H. H. Harris fechada el 29 de Julio de 1949. Documento conservado por Maggie Baylis y donado en 1998 como parte de su archivo a las Colecciones de la Universiad de California, Berkeley. Consultable en la Douglas and Maggie Baylis Collection 1938-1998 (periodo 1943-1971). Environmental Design Archives. College of Environmental Design. University of California, Berkeley (Caja 1, Carpeta 1).

257. En BAYLIS, Douglas y PARRY, Joan: California Houses of Gordon Drake. New York: Reinhold Pub., 1956, p. 66 .

258. Cfr. Neil JACKSON: "Californian promise", en The Architectural review, marzo 1996. Op.cit. p. 84 .

259. McCoy, escribiría años más tarde sobre Gordon Drake una breve nota en el capítulo que dedicó a Harris en The Second Generation, afirmando: "Alguno de los ayudantes de Harris se habian mantenido en contacto con él durante la guerra, entre ellos, Gordon Drake, el joven e imaginativo estudiante que sobrevivió a la contienda mundial, recibió diversos premios por su primera casa y murió trágicamente en 1952 en un absurdo accidente de esquí. Mientras estaba movilizado mantuvo correspondencia con Harris, enviándole algunas cartas tan idealistas como sólo un muchacho de su edad podía escribir; en una de ellas le agradecía todo lo que había aprendido de él y, en especial, por su Fellowship Park House, donde, según decía, había descubierto la autenticidad de las relaciones entre las cosas. Drake había trabajado en las casas Lek y Havens y durante sus permisos en el frente regresaba las obras para ver cómo evolucionaban. Cuando acabó la guerra y Harris regresó a Los Angeles, volvió a encontrarse con Drake en el despacho, aunque éste ya estaba listo para establecerse por su cuenta y hacía planes para crear su propia firma, especializada en casa de bajo coste, asociándose con un ingeniero a quien había conocido durante la guerra". Esther McCOY: The Second Generation. Op.cit. p. 61.

260. "The New House-to-Site Transition: Malibu House", en Progressive Architecture, junio 1956, pp 104-105.

261. Las líneas, extraídas de la Meditación 17 de la obra de Donne Devotions Upon Emergent Occa sions and Death's Duel (1624) podrían traducirse como: "Ningún hombre es una isla, completa o en ella misma; cada hombre es una pieza del continente, una parte del todo". Los últimos versos copiados por Drake son reveladores de su carácter $y$, como diría Neil Jackson, bien podrían haber sido su propio su epitafio: "La muerte de cualquier hombre me disminuye, porque estoy inmerso en la humanidad". E papel que Drake llevaba encima el día que murió forma ahora parte de la colección de documentos donados por Maggie Baylis al Archivo del College of Environmental Design de la University of California, Berkeley.

262. A lo que Harris se estaba refiriendo como cubierta pétalo, (petal roof en el original inglés) era a una cubierta ensayada por él en diversas ocasiones y que, en la década de los años cuarenta, se convirtió en una de sus formas de cubrición preferidas para un espacio de planta cuadrada -precisamente por su imagen doméstica. Geométricamente, podría describirse, en realidad, como un plano horizontal cuadrado, ligeramente mayor que el de la planta, al que se hubieran practicado dos dobleces perpendiculares de modo que, una vez dibujados cuatro cuadrados idénticos sobre e plano original, éste se levantara tirando del vértice común para general cuatro cubiertas ligeramente inclinadas hacia los vértices de la planta y coincidentes en un punto central, o cumbrera, en mitad de cuadrado. Un delicado y convincente ejemplo construido de este elemento es el Rex Hardy Beach Cottage de 1950

263. Harwell Hamilton HARRIS, en BAYLIS, Douglas y PARRY, Joan: California Houses of Gordon Drake. Op.cit., pp. $83-85$

264. Gracias sobre todo a su primer cliente y mentor, Richard Neutra, y a su maquinaria publicitaria desplegada por casi todo el mundo, desde los Estados Unidos a Argentina y desde Japón a Europa (a la que Neutra se ocupaba personalmente de tener informada de sus progresos en América median- te ciclos de conferencias, exposiciones, catálogos y contactos directos con directores de revistas y agencias de prensa cuidadosamente planificados) Shulman había establecido excelentes contactos antes de la guerra de los que se beneficiaron también los arquitectos del círculo de Neutra como Raphael Soriano, Gregory Ain, J. R. Davidson y, en menor medida, R. M. Schindler. Por supuesto, su vinculación como fotógrafo oficial de la revista Arts \& Architecture tras la ascensión de Entenza fue otra plataforma de indudable interés para Shulman. Pocos fotógrafos, exceptuando quizás a Marvin Rand, contribuyeron tanto a la creación del imaginario moderno dela arquitectura californiana.

265. En este sentido es llamativo que en la selección de Pierluigi Serraino y Julius Shulman para la publicación de Modernism Rediscoverd, las fotografías de la casa de Drake sean las primeras que abren el libro tras la introducción del autor. Véase el apartado de bibliografía comentada sobre Gordon Drake al final de este trabajo, concretamente: Pierluigi SERRAINO y Julius SHULMAN: Modernism Rediscovered. Köln, New York, Los Angeles: Taschen, 2000 (reeditado en 2005 y 2009 en castellano), pp. 18-19 (Drake House).

266. Joseph Rosa escribió sobre esta imagen tan querida para Shulman en su monografía sobre el fotógrafo: "Shulman's photographs of Drake's home, taken in 1946, reveal another effect of dressing a photograph. One of the compositions constructed from the perspective of the viewer, who is presumably sitting on the couch or a chair in the living room, looking toward other people seated on the terrace. By setting up the photograph in this manner, Shulman forces the viewer to participate in the scene: the viewer occupies the photograph, acting not as a voyeur but as a presence in the room. The lower vantage point also reveals aspects of the home that would otherwise not be visible: the ceiling details and the landscape beyond the terrace". Joseph ROSA: A Constructed View: The Architectural Photography of Julius Shulman. New York: Rizzoli, 1994, p. 90.

267. Entrevista del autor con Julius Shulman en marzo de 2008

268. Podría exceptuarse de esta regla la imagen nocturna tomada de la vivienda de los Baylis en San Francisco y que ilustra la portada de la monografía sobre Drake editada por éstos. Sintomáticamente, la casa fue terminada y fotografiada años después de la muerte del arquitecto.

269. Así lo confirmaría el propio Shulman al autor de este trabajo en una de las entrevistas mantenidas en su casa de Los Ángeles en la primavera de 2008

270. "Upon seeing the 'simple richness' of Drake's hillside residence, Creighton later recalled the jury meeting at which the building was considered, writing that "I shall never forget the simultaneous enthusiasm of Eliel Saarinen and Fred Severud when we 'discovered' Drake's first to-be-published house". ("Designer's Own House, Los Angeles, California, Gordon Drake, Designer" Progressive Architecture, July 1947, 45-52). Progressive Architecture chose this small residence as the first prize winner in private residential design for its "imaginative contribution as an architectural concept as well as for its brilliant plan. The house is a minimum home-hardly more than a single room... Yet within these modest confines, plus the nicely schemed outside living terrace, it achieves the living amenity of a house many times its size". Deborah HOWELL-ARDILA: Writing Our Own Program. The USC Experiment in Modern Architectural Pedagogy 1930-1960, Tesis de Máster presentada en la USC School of Architecture de Los Ángeles como trabajo del Master of Historic Preservation. Los Angeles: University of Southern California, agosto 2010, p. 159

271. The American Home era entonces una revista mensual, publicada en Nueva York y destinada a un público fundamentalmente femenino, tratándose de lectoras con un nivel socioeconómico y cultural alto. Sus temas giraban en torno a cuestiones relacionadas con la arquitectura doméstica, el diseño de interiores, el paisajismo y la jardinería. Editada entre 1928 y 1977 como continuación de Garden \& Home Builder, hacia finales de los años cuarenta, la revista tenía una tirada aproximada de dos millones y medio de ejemplares. 
272. Véase AA. VV., Thomas CREIGHTON; Frank LOPEZ; Charles MAGRUDER y George SANDERSON (eds.): Small, Medium, Large. Homes selected by the editors of Progressive Architecture. New York: Reinhold Pub., 1947, p. 190. En este libro se publicaba la planta de la vivienda y ocho fotografías de Julius Shulman.

273. Véase AA. VV., Thomas CREIGHTON, y Katherine FORD (eds.): The American House Today. 85 Notable Examples. New York: Reinhold Pub., 1951, pp. 144-145 (Miller House en Carmel, 1949-fotografías de Morley Baer) y pp. 189-191 (Rucker-Spillman House en Los Angeles, 1947-fotografías de Julius Shulman).

274. Entrevista del autor con Julius Shulman en marzo de 2008.

275. Información proporcionada por John Crosse

276. Cfr. Beatriz COLOMINA: 1949, en AA. VV., Somol, Robert E. (ed.): Autonomy and Ideology. Positioning an Avant-Garde in America. New York: Monacelli Press, 1997, p. 304.

277. Seguramente Entenza quiso que Harris fuese miembro del consejo editorial de Arts \& Architecture porque le interesaba su fama creciente desde finales de los años 30 para la publicidad de la revista, no obstante, decidió prescindir de él cuando, desde 1945, ya quedó claro que este arquitecto no iba a formar parte del Case Study House Program.

278. Julius SHULMAN: "Epilogue", en SMITH, Elizabeth A. T., Peter Goessel (ed.): Case Study Houses. The Complete CSH Program 1945-1966. Köln, New York: Taschen, 2002, p. 436.

279. Véase Arts \& Architecture, abril 1950, pp. 8-9. Anuncio a doble página de los productos de la empresa de estructuras de madera laminada Douglas Fir Company ilustrada con fotografías de Julius Shulman de la casa Rucker-Spillman. Se incluyen detalles constructivos y de montaje y axonometrías del sistema estructural. La publicidad de Douglas Fir se introduce con el siguiente texto de Gordon Drake: "With Playwood, Desing and Structure can be Treated as a Single, Integrated Unit".

280. A finales de verano de 2010, planteada esta hipótesis a John Crosse, el historiador daba su opinión en un correo electrónico escrito en los siguientes términos: "Shulman was a master of maximizing income from his projects and knew how to compose for 'product placement'. Douglas Fir was a regular advertiser in A\&A and Shulman was also on the A\&A masthead as staff photographer. Since Entenza didn't pay Shulman anything he had to make up for it by selling photos to the advertisers and other magazine editors. The Douglas Fir Plywood ad could very well have been Shulman's shrewd way of killing two birds with one stone. He would generate some income for himself by selling the photos to Douglas Fir knowing that they would buy an ad in A\&A and thus getting his friend Drake into the magazine through the back door so to speak without jeopardizing his chances for publicity (and Shulman's source of income) from the East Coast and International journals. This begs the question, could this same ad have been in the other magazines and journals around the same time? It is such a nice ad I am going to add it to my article now that you bring it to my attention".

281. Cfr. Esther McCOY: "Arts \& Architecture Case Study House", en AA. VV. Elizabeth A. T. SMITH (ed.): Blueprints for Modern Living: History and Legacy of the Case Study Houses. Op. cit. p. 16.

282. Julius SHULMAN en Julius SHULMAN; Frank O.GEHRY y Peter GOSSEL: Julius Shulman: Architecture and Its Photography. Op. cit., pp. 91-94 (el texto aparece ilustrado con dos fotografías de la Drake House en Beverly Glen).

283. Pierluigi SERRAINO: Texto introductorio a la reimpresión del catálogo California Houses of Gordon Drake. San Francisco: William Stout, 2011, p. vii.
285. Ibid.

286. Walter L. DOTY, Director of Editorial Reseach, en Douglas y PARRY, Joan: California Houses of Gordon Drake. Op, cit., p. 85

287. Interrogado en una ocasión acerca de los principios que han regido su infatigable trabajo como arquitecto, urbanista y docente, Ray Kappe, elaboró el siguiente decálogo profesional que reproduce en su página web (http://www.kappedu.com/RayKappe.html) y sobre el cual, punto por punto, podrían establecerse paralelismos con el espíritu que animó la producción arquitectónica de Gordon Drake:

(1) Think positively, not negatively.

(2) Accept structure but know that it is to be questioned and broken when necessary.

(3) Always be willing to explore, experiment and invent. Do not accept the status quo.

(4) Know yourself and keep your work consistent with who you are and how you think.

(5) Maintain good moral and social values.

(6) Be humble, honest, compassionate, and egalitarian.

(7) Have conviction about your work.

(8) Be open and say yes to most ideas and requests. The good ones will be valuable; the bad ones will cease to exist.

(9) Allow employees and fellow workers freedom and the ability to work to their strengths. Avoid hierarchy.

(10) Money should be the residual of work, not the goal. But do not compromise your worth

288. "A partir de 1946, mi padre comenzó a traer a Australia revistas internacionales de arquitectura, especialmente de los Estados Unidos y, a través de ellas, aprendí del trabajo de arquitectos como Frank Lloyd Wright, Mies van der Rohe, Gordon Drake o Charles y Ray Eames... Fueron varios los arquitectos de los que tuve conocimiento cuando tenía 15 ó 16 años, y todos ellos han ejercido una gran influencia en $m$ trabajo posterior". Glenn MURCUTT: The Pritzker Architecture Prize. 2002 Laureate Acceptance Speech (http://www.pritzkerprize.com/laureates/2002/_downloads/2002_Acceptance_Speech.pdf).

289. Esas mismas ideas han sido expresadas en el prólogo realizado por Murcutt a la reimpresión de la monografía histórica de Gordon Drake. Véase Glen MURCUTT: Prólogo a California Houses of Gordon Drake. Op. cit., pp. ii-iv.

290. Frank GEHRY: The Pritzker Architecture Prize. 1989 Laureate Acceptance Speech (http://www. pritzkerprize.com/laureates/1989/ceremony_speech1.html).

284. Ibid. p. vi. 


\section{APUNTE HISTORIOGRÁFICO}

[ ESTHER MCCOY Y JOHN ENTENZA,

] ...

CREADORES DE MITOS MODERNOS 


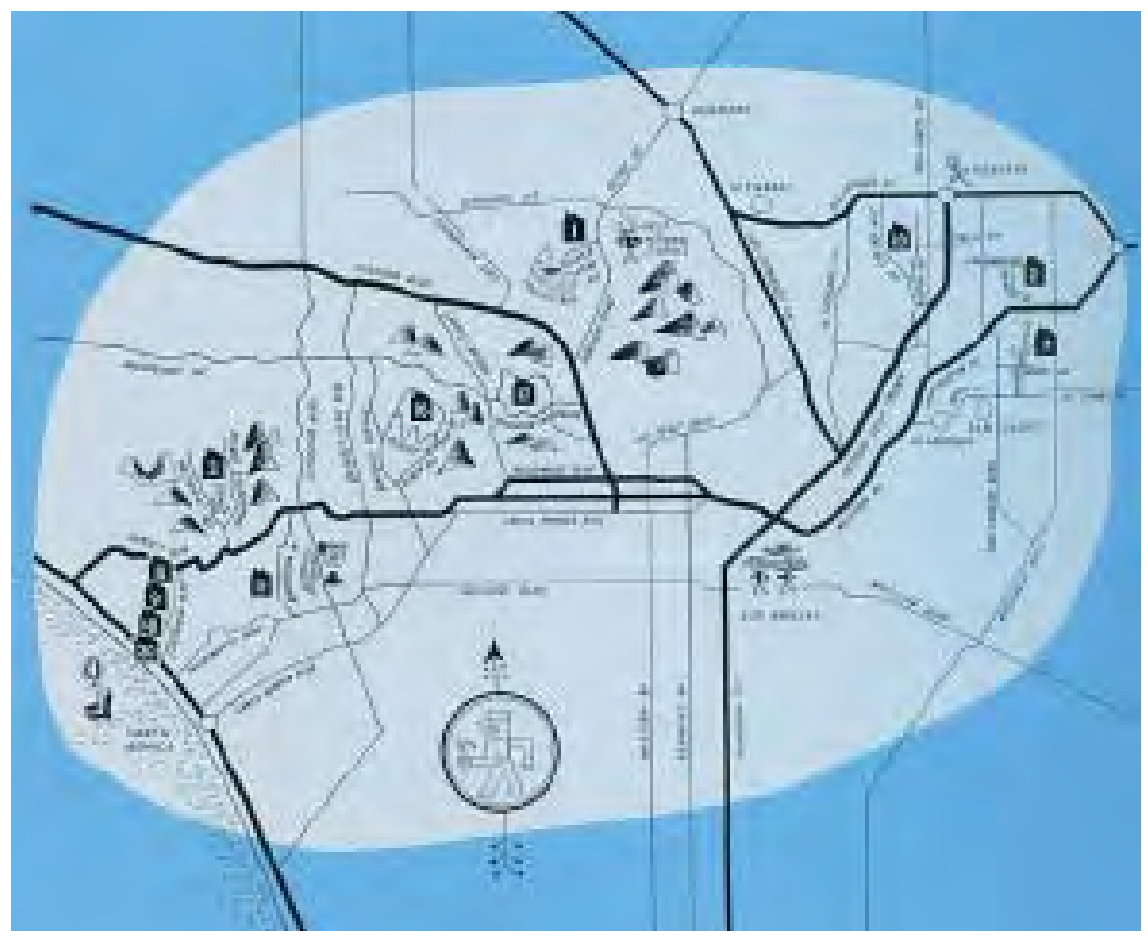

Los Ángeles no sólo fue el Case Study House Program. De hecho, cuando éste comenzó su andadura en 1945 algunos de los episodios arquitectónicos más interesantes de la ciudad hacía tiempo que ya habían ocurrido. $\mathrm{Ni}$ siquiera la revista Arts \& Architecture, responsable última de la celebridad internacional de algunos de los arquitectos que participaron en la iniciativa promovida por John Entenza -como Pierre Koenig o Craig Ellwood- consiguió reflejar en sus páginas la variedad y diversidad de lo sucedido el Sur de California durante las décadas centrales del siglo pasado.

En aquel momento, conocer personalmente a John Entenza, Esther McCoy o Julius Shulman aumentaba considerablemente las posibilidades de un arquitecto de difundir su obra en los medios. No obstante, el caso tratado anteriormente de Gordon Drake, es significativo debido al reconocimiento logrado en vida por un arquitecto que, puenteando uno de los principales canales de difusión, el de John Entenza, supo mantener la atención de las principales publicaciones de la época aunque esto sucedió, como se ha enfatizado, gracias a las hábiles estrategias de comunicación desarrolladas en colaboración con Julius Shulman.

El fotógrafo, asociado a la revista Arts \& Architecture desde los inicios del programa de Entenza, y Esther McCoy, miembro de su consejo editorial desde noviembre de 1951, formaron junto al editor una maquinaria publicitaria de insuperable efectividad, especialmente cuando los tres concurrían en la promoción de la obra de un arquitecto, como sucedió con Craig Ellwood en particular y, de un modo más generalizado, con el conjunto del programa de las Case Study Houses.

En su número de agosto de 1943, Arts \& Architecture anunciaba los ganadores del concurso Designs for Postwar Living, una convocatoria de ámbito nacional lanzada por la revista con el propósito de contribuir al debate arquitectónico del momento con un repertorio de soluciones modernas para la vivienda de clase media. El jurado del concurso, integrado por Richard Neutra, Sumner Spaulding, Gregory Ain, John Leon Rex y Charles Eames, declaró ganadora la propuesta de Eero Saarinen con Oliver Lundquist, quedando
Mapa de los Los Ángeles con la ubicación de las Case Study Houses. Fuente: Arts \& Architecture 
Charles y Ray Eames con John Entenza en el solar de sus futuras CSH en 1945. Fuente: Eames Office

Página siguiente arriba: Portada del libro de Esther McCoy Case Study Houses, 1962 Página siguiente abajo: Anuncio del CSH Program, programas de las casas Eames y Entenza. Arts \& Architecture, diciembre 1945

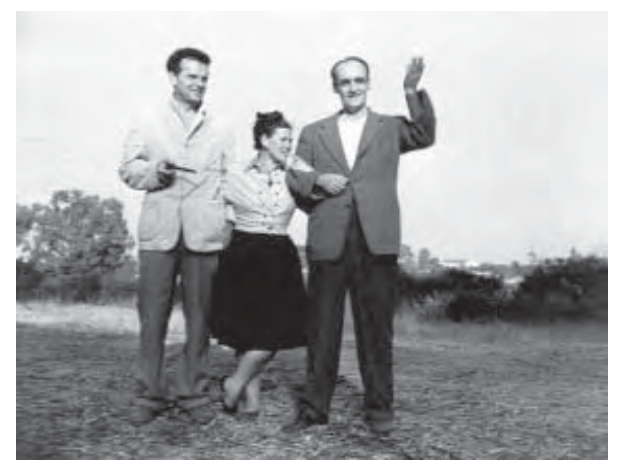

I. M. Pei en segundo lugar y Raphael Soriano en tercera posición. Algunos de los proyectos presentados consistieron en análisis urbanos, diseños de barrios o de vecindarios enteros, otros, en plantas detalladas de viviendas modulares. En las propuestas de edificación los materiales más recurrentes en el concurso fueron el acero, el contrachapado y el vidrio, haciendo de la prefabricación el leitmotiv del concurso.

Designs for Postwar Living constituyó el precedente conceptual del Case Study House Program, lanzado oficialmente en el número de enero de 1945 mediante una extensa declaración de intenciones y la presentación de sus ocho primeros arquitectos. En el anuncio del programa, escrito por John Entenza, se afirmaba que el objetivo del mismo era repensar la vivienda unifamiliar en relación con su nuevo contexto histórico, considerar todas las posibilidades de las nuevas técnicas, materiales y sistemas constructivos y, sobre todo, generalizar soluciones que sirvieran de base a prototipos susceptibles de reproducción más allá de las necesidades individuales propuestas para cada una de las ocho primeras casas -entre las que figuraba la del propio editor. En palabras de Entenza: "cada arquitecto ha asumido la responsabilidad de diseñar una casa que, bajo circunstancias normales, afrontaría las habituales (a veces lamentables) limitaciones de la construcción al uso. La casa debería ser capaz de ser duplicada y, en modo alguno, constituir un diseño personalizado. Cada una de las ocho casas será abierta al público durante un periodo de seis a ocho semanas y, después, se llevará a cabo un estudio para determinar el grado de éxito de cada propuesta. Cada casa será amueblada completamente a través de un trabajo colaborativo entre el arquitecto, el diseñador y el fabricante, tanto bajo las especificaciones del técnico como bajo su supervisión. Se trata por tanto de investigar y establecer con hechos (y esperemos que también con cifras) las bases de lo que se podrá considerar un diseño asequible al gran público una vez que sea posible construir casas. Para ello es importante que los mejores materiales disponibles sean usados de la mejor manera posible de modo que se llegue a una buena solución para cada problema, con lo cual, a través del conjunto del programa, se dispondrá de una casuistica general lo suficientemente amplia como para que éste pueda resultar una ayuda práctica al americano medio en busca de una casa que pueda permitirse ${ }^{\text {II }^{1}}$.

Como es sabido, la casa de posguerra, las nuevas tecnologías, los nuevos materiales, instalaciones y equipamientos domésticos, los nuevos sistemas de producción y, por supuesto, las nuevas formas de vida, fueron los temas centrales del debate arquitectónico norteamericano después de la Segunda Guerra Mundial. La revista Architectural Forum, por ejemplo, dedicó un considerable esfuerzo a justificar que la casa de preguerra no podía servir en modo alguno de modelo para las viviendas destinadas a la nueva sociedad surgida tras la contienda, argumentando, en una serie de artículos publicados entre enero y abril de 1944, que el comprador de posguerra tendría el deseo y las posibilidades económicas como para permitirse una mayor calidad de vida y exigir mejores estándares residenciales ${ }^{2}$. La democratización de la calidad arquitectónica fue el objetivo fundamental de los profesionales, críticos y editores modernos de posguerra quienes, a través de iniciativas como las de Architectural Forum o el propio Case Study House Program, enfatizaron la necesidad de que los arquitectos, por su conocimiento del nuevo paradigma industrial de posguerra, debían liderar procesos de cambio y "diseñar en términos de mercado"3. Ahora bien, mientras que revistas como Architectural Forum iban dirigidas a la media de los arquitectos, Arts \& Architecture pugnaba por alzarse como una voz de la vanguardia4. 


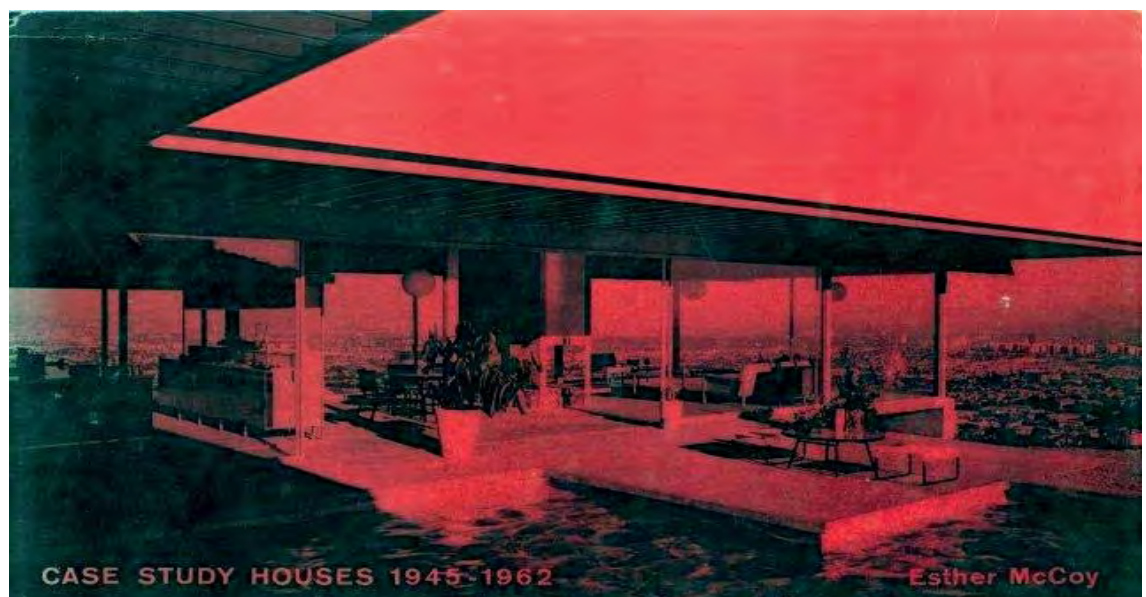

\section{MODERN CALIFORNIA HOUSES}

En su elogiosa monografía dedicada al programa Case Study Houses, EstherMcCoy defendía su éxito argumentando que éste había supuesto un efectivo llamamiento a la colaboración entre arquitectos, clientes, industriales y contratistas, logrando que estos últimos abandonaran las soluciones tradicionales para demostrar, a través de la construcción de modernos proyectos residenciales, todo el potencial del buen diseño. Sobre esta experiencia, la historiadora escribió: "En enero de 1945, cuando el programa fue anunciado estábamos aún a siete meses de la paz. La edificación se encontraba asediada por todo tipo de restricciones: los arquitectos proyectaban con materiales que aún no existían o de los que ni siquiera podían estar seguros de que algún día fueran a estar disponibles; los contratistas hacían acopio de material como podian, por las buenas o por las malas, recurriendo incluso al mercado negro o al mercado gris [...]. Pero había algo electrizante en el aire, una especie de particular excitación que venía del ruido de los martillos y las sierras que habían estado parados tanto tiempo. Los arquitectos se habían acostumbrado a una sobria espera durante los años 30 cuando la edificación virtualmente se había detenido y, después, durante los años de la guerra había habido muy pocas oportunidades de diseñar algo que no fuesen estructuras de subsistencia. Los jóvenes arquitectos dibujaban mapas militares en Europa, plantillas en las fábricas de aviones o construían barracones en el Pacífico. Mientras tanto, nuevas técnicas y materiales surgidos con la guerra comenzaban a desarrollarse con urgencia. Los nuevos plásticos posibilitaron la casa translúcida; la soldadura de arco dio a los acabados de acero una finura que permitió la utilización de este material en la casa; las resinas sintéticas, mucho más fuertes que las naturales permitieron paneles ligeros e impermeables; los nuevos pegamentos de la industria aeronáutica garantizaron una enorme posibilidad de laminados. Todo un conjunto de respuestas que estaban aguardando la pregunta que la arquitectura se hace en cada época: ¿cómo ser parte de las transformaciones? Durante el periodo de espera, los proyectos sobre el papel proliferaron como champiñones en el campo tras las primeras lluvias de invierno. Nuevos enfoques y aproximaciones al diseño, a la forma y a la estructura aguardaban en papel a ser testados [...]. Una persona inusualmente sensible a la excitación del momento, así como a la confusión de aquellos días, fue el joven editor y propietario de la revista Arts \& Architecture -John Entenza. Comenzando su labor al frente de la misma en 1938, la revista estableció una enérgica línea de comunicación entre los profanos y la profesión de la arquitectura. La arquitectura contemporánea nunca había carecido de figuras de referencia en el Sur de California; si bien necesitaba comprensión y apoyo, y la revista asumió el liderazgo indiscutible en la tarea

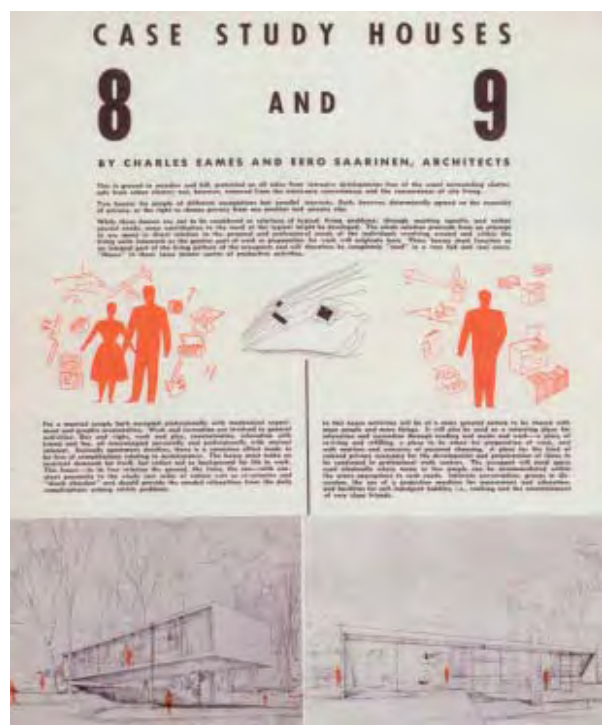




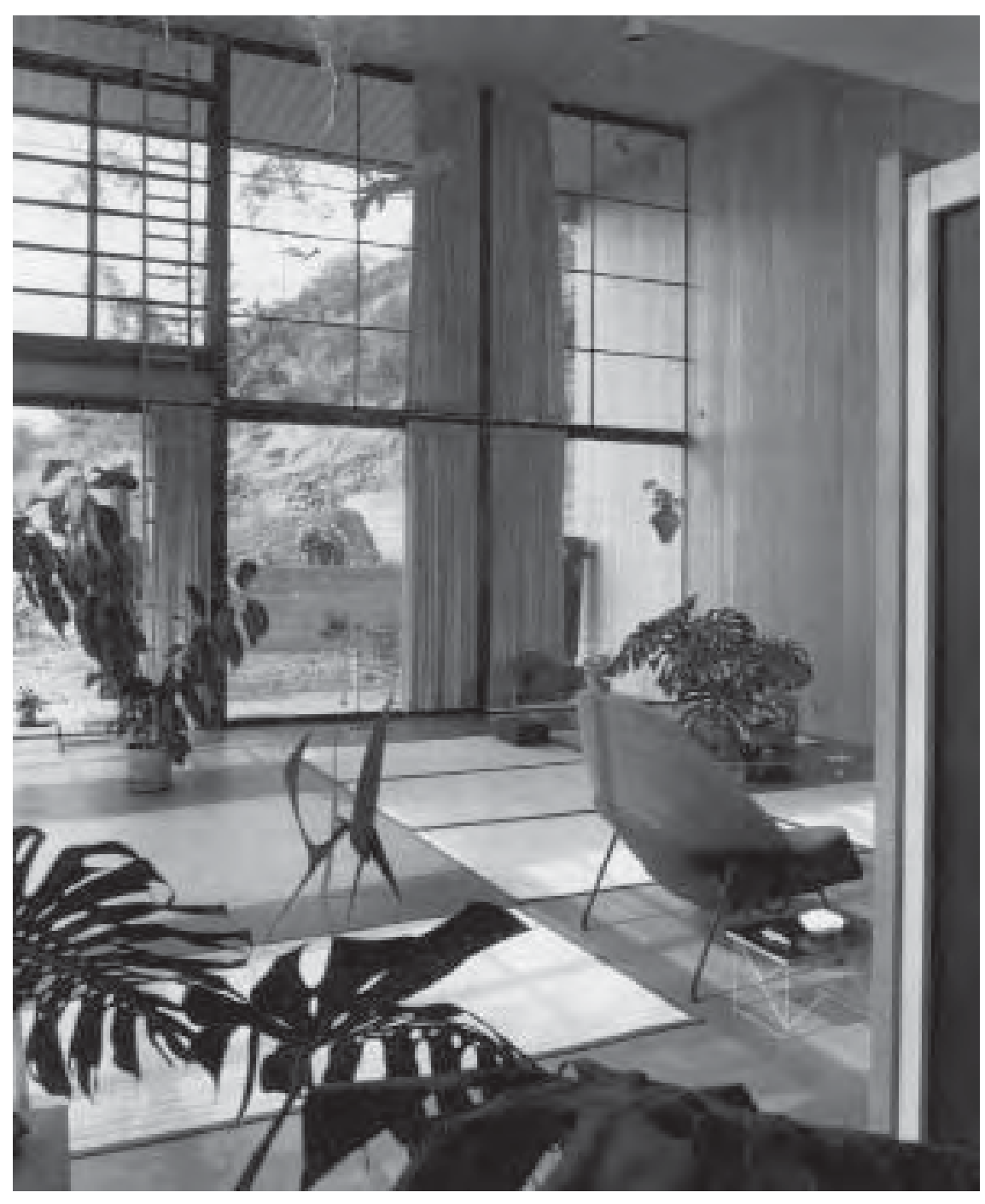

Eames House, CSH no8. Fotografía de Julius Shulman, 1950

Página siguiente: Ralph Rapson, $\mathrm{CHS}$ no 4, dibujo, 1945 de ganarse al público general, instruyéndolo y logrando que aceptase el buen diseño. Entenza encajaba admirablemente bien en aquella tarea. Este idealista editor, ajeno al mundo de la arquitectura y que actuaba él mismo sufragando los gastos de su revista [...] era esencialmente un educador, y su principal lección fue simplemente hacernos ver que vivimos rodeados de arquitectura y que ésta nos concierne a todos; se entregó a este cometido de una forma muy inteligente, desplegando todo su sentido común y buen hacer, manteniendo una fe democrática en la habilidad del público para entender las ventajas de vivir en un medio bien diseñado cuando el mensaje era presentado adecuadamente [...] En 1945, Entenza abandonó su rol pasivo como editor para convertirse en un agente dinámico de cambio en la arquitectura de posguerra"s.

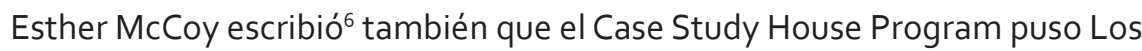
Ángeles en la escena arquitectónica internacional. En efecto, fue junto con la propia revista, la plataforma de difusión más significativa de la arquitectura californiana de posguerra. Por ejemplo, los ambientes culturales británicos reaccionaron muy pronto a esta iniciativa que deslumbró a los jóvenes arquitectos ingleses del Independent Group y de la AA. Reyner Banham -quien por cierto dedicó su Atlántida de Hormigón a John Entenza- fue uno de sus principales apologistas, junto con los Smithson, para quienes la casa de sus amigos Eames fue un auténtico regalo cultural. Si bien, ni Arts \& Architecture fue el único medio, como se justificó en los casos de Harris y Drake, ni los contenidos de la revista fueron representativos de la amplia y diversa realidad de la arquitectura moderna californiana. Y es importante señalar -sin 


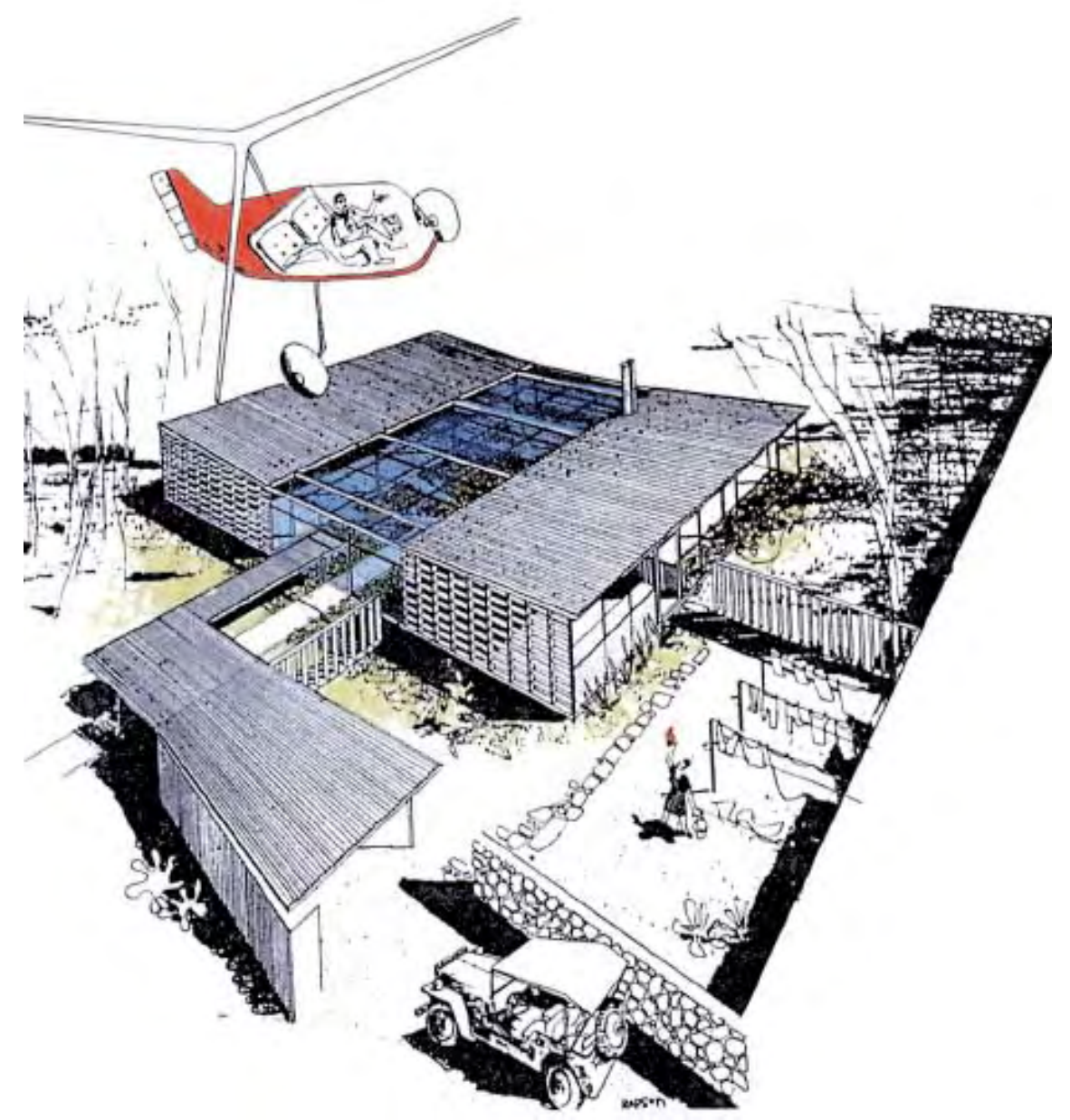

disminuir con ello el legado de John Entenza- que el editor de la revista, encumbrado por la fabulosa reputación que consiguió para sí mismo con su programa, dio a conocer sólo aquellas obras y autores que le interesaban a él y que casi siempre actuó movido por intereses personales, por filias y fobias. A pesar de que éste no es el lugar para analizar en profundidad el CSH Program, resulta necesario abordar algunas cuestiones relativas al mismo para poder entender con perspectiva crítica la posición de John Entenza y algunas de sus maniobras publicitarias y con ello precisar el verdadero alcance de su programa, por supuesto, más allá de lo que él y su círculo de protegidos, en especial Esther McCoy trataron de fijar en la memoria histórica de California.

Puede argumentarse una primera crítica a partir del desacuerdo entre la modernidad-epidérmica- con la que fueron presentadas las soluciones de las viviendas del Case Study House Program y su realidad sociocultural. Mientras que las casas se publicitaban como sofisticados dispositivos arquitectónicos, novedosos equipamientos y mobiliario de diseño, en el fondo, los arquitectos perdieron una valiosa oportunidad para cuestionar tipos de familia, formas de vida hegemónicas y categorías de género tradicionales en la definición y uso de los espacios de la casa. Un ejemplo extremo, casi una caricatura del modelo patriarcal sancionado por la revista lo constituye el dibujo de la vivienda proyectada por Ralph Rapson, la Case Study House no 4, que no se llegó a edificar. Esta innovadora vivienda modular, denominada Greenbelt House, planteaba un esquema abierto que, como su nombre sugería, permitía que la naturaleza entrara al interior mismo de la casa, se- 


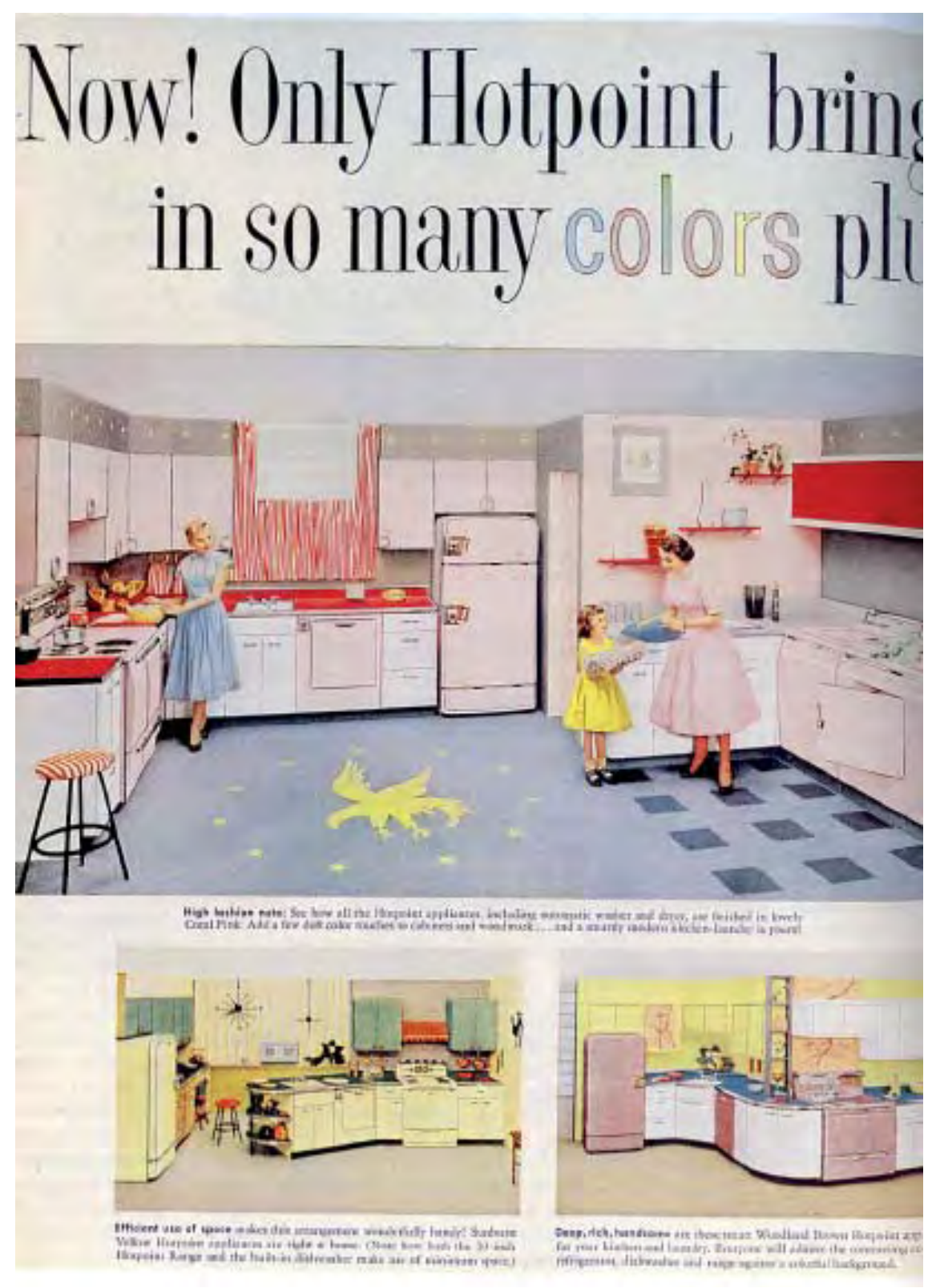

Anuncio de Hotpoint Kitchens, 1951. Fuente: Blueprints for Modern Living

Página siguiente: Postwar House, imagen publicitaria de la cocina. Fuente Dana Cuff Página siguiente: Anuncio de lavavajillas Kaiser publicado en Arts \& Architecture, mayo 1948 parando el ámbito más público de las estancias privadas. Sus dibujos mostraban instalaciones como suelo radiante, mobiliario moderno y vehículos futuristas. Sin embargo, es llamativa la imagen que resume el proyecto. En ella se representa una típica escena de despedida familiar antes de ir a trabajar por la mañana, pero mientras el marido acude a la oficina en helicóptero, su esposa pre-moderna, aún vinculada a las tareas domésticas, le despide tendiendo la ropa en el patio.

Como ha señalado Dana Cuff, en Norteamérica durante la posguerra "las cuestiones de género encerraban un doble rasero: la cultura estaba lista para avanzar decididamente hacia el futuro siempre y cuando se mantuvieran los símbolos de la tradición doméstica"7. En esta lógica discursiva, podría afirmarse que John Entenza, quiso plantear un revolucionario escenario arquitectónico sin importarle que sus fundamentos sociales permanecieran intactos. O, como ha expresado Dolores Hayden, a Entenza no le importaba realmente que la mujer hubiera conseguido un puesto de trabajo durante la guerra ${ }^{8}$ y que al finalizar ésta, muchas familias se compusieran de dos padres trabajadores ya que, en el fondo y a pesar del mantra de su programa de construir viviendas a precios asequibles, "Entenza no estaba interesado en la clase 


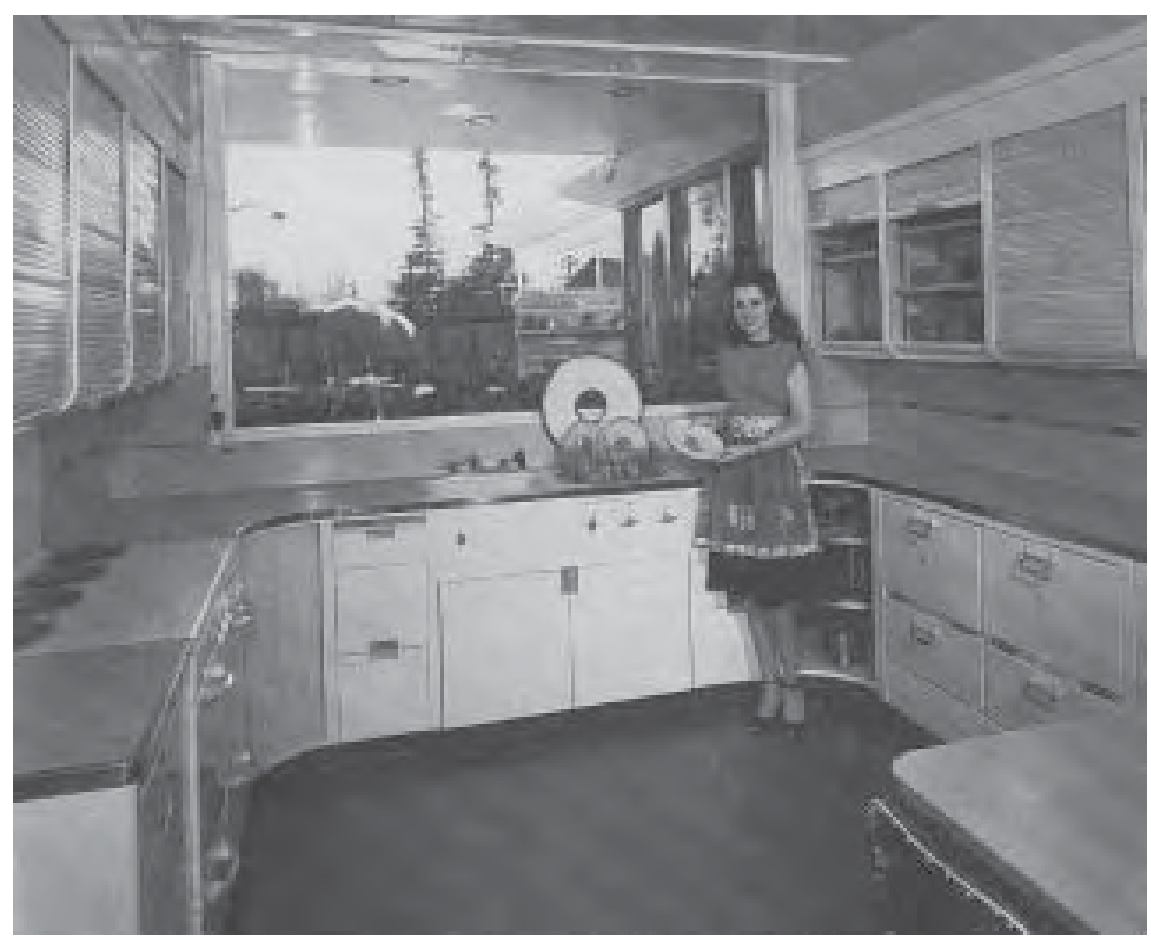

obrera y en el estilo de vida de las familias de clase media baja-el principal activo del mercado inmobiliario de la época [...] En lugar de ello, él se dirigió con su programa a propietarios de mayores recursos y formación cultural cuyos estilos de vida sugerían que apreciaban la novedad e, incluso, que generaban ellos mismos la novedad antes que ningún otro grupo social del país. Si bien, las diferencias sociales se obviaron por completo en la revista y la mayoría de los arquitectos generalizaron como 'familia americana media' a sus propios clientes, es decir, a una privilegiada y elitista clase media alta"g.

Sirviéndose de las seductoras fotografías de Shulman, el principal cronista visual del Case Study House Program, así como de los persuasivos escritos de Esther McCoy, el éxito de John Entenza fue construir un imaginario a través del cual supo conquistar el gusto de la clase media alta del Westside, los nuevos ricos de Los Ángeles, clientes procedentes de la industria del cine, la publicidad y del lobby judío que aceptaron en sus casas de las colinas de Hollywood una sofisticada versión local de la modernidad internacional. Este desajuste entre las pretensiones de universalidad con las que fue anunciado el programa y la realidad social de sus acomodados destinatarios finales pone de manifiesto toda la carga mediática de esta iniciativa destinada, más bien, a impactar determinados en ambientes culturales y rivalizar con las revistas del Este que a influir verdaderamente en su entorno próximo.

En efecto, frente al compromiso de numerosos arquitectos del programa -entre ellos Quincy Jones o Richard Neutra- con los grandes procesos de transformación de la ciudad y del territorio enunciados en las notas introductorias de esta tesis, y frente a la extinción de los programas de vivienda pública estigmatizados hasta su prohibición expresa en 1952 con una ordenanza contra los proyectos socialistas ${ }^{10}$, la defensa del reto social que supuso el programa de Entenza puede cuestionarse apelando a su condición mesocrática. Y frente a la necesidad de afrontar en toda su complejidad los cambios tecnológicos y sociales que se estaban produciendo en Los Ángeles, Entenza insistió en una estrategia promocional -genuinamente californiana-, que utilizó una visión romántica y estetizada del futuro para publicitar estilos de vida, en este caso modernos.

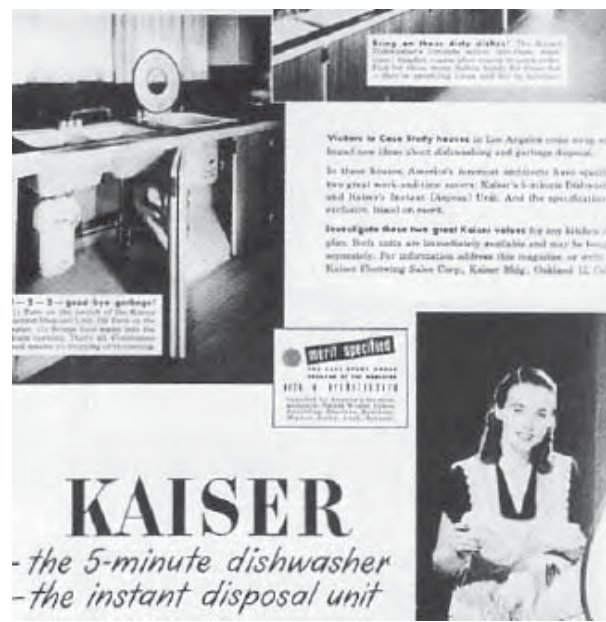




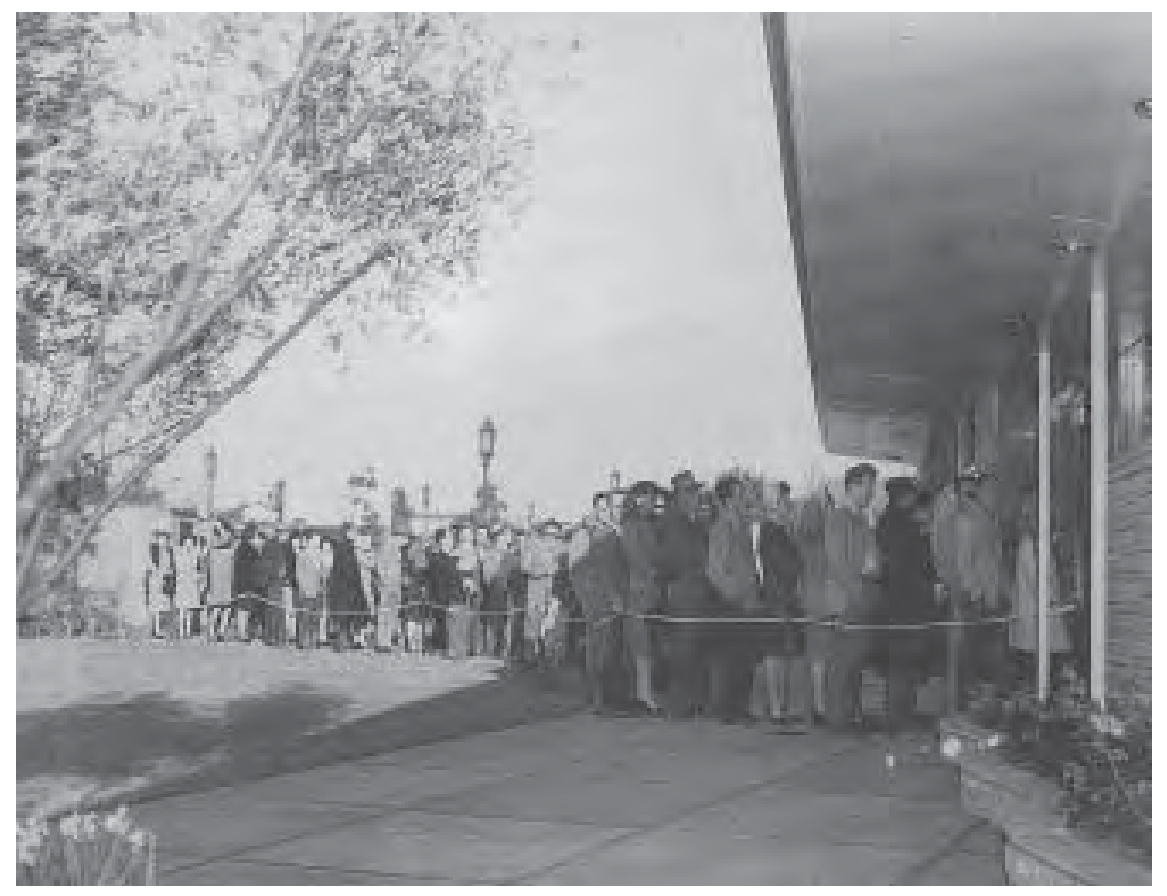

Postwar House, imagen de las colas para visitar el prototipo del promotor Fritz Burns en 1946. Fotografía de Dick Whittington. Fuente Dana Cuff

Página siguiente: Fábrica de Kaiser Community Homes en 1946. Fotografía de Dick Whittington. Fuente: Dana Cuff
Por ello, a pesar de lo escrito por McCoy, el calado popular de esta experiencia entre los sectores más amplios de la población fue muy reducido, especialmente si se compara con otras iniciativas similares llevadas a cabo en la ciudad de Los Ángeles por promotores de carácter comercial, como la Postwar House, la casa modelo construida a instancias del magnate inmobiliario Fritz. B. Burns en Wilshire Boulevard. Sin bien, Esther McCoy afirmó ${ }^{11}$, por ejemplo, que uno de los éxitos del CSH Program había sido que algunas de las plantas de aquellas viviendas, como la proyectada por J. R. Davidson, habían sido copiadas por multitud de promotores comerciales. Igualmente, McCoy atribuyó al CSH Program una dimensión pionera en el establecimiento de viviendas con cocinas abiertas o ausencia de comedores formales, flexibilizando el uso de los espacios de la casa tal como correspondería a una unidad familiar que no requería servicio. Aunque, en realidad, esta costumbre ya estaba extendida en el Sur de California desde la proliferación de los bungalows de principios de siglo. Por otra parte, dado que las viviendas del Case Study House Program fueron demandadas ante todo por personas de clase media alta, su primitivo interés de mercado se vio limitado, tal como ha reparado Dana Cuff ${ }^{12}$, precisamente por ese otro desacuerdo entre el producto y su destinatario último, personas con alto poder adquisitivo que anteriormente habían disfrutado de servicio y que ahora se veían obligadas a renunciar a ello por sus nuevas viviendas. Además, no deja de ser curioso que siendo pretendidamente un programa popular, uno de los criterios que McCoy utilizó ${ }^{14}$ para validar el éxito de la iniciativa de Entenza fue el económico, subrayando el dato de que, en 1962, en el momento de escribir su monografía sobre aquel experimento residencial, los propietarios de las viviendas originales habían visto incrementado el rendimiento de su inversión inmobiliaria en más del $125 \%$.

Finalmente, en su defensa de la popularidad del programa, Esther McCoy afirmó ${ }^{15}$ que 368.554 personas visitaron las primeras seis casas del programa durante los tres años, entre 1946 y 1948, que se organizaron visitas guiadas. Una cantidad, en realidad, mínima comparada con el más del millón de personas que -pagando un dólar por persona destinado a obras de caridaddesfilaron por la vivienda que el promotor Fritz B. Burns ${ }^{15}$ había instalado en Wilshire Boulevard. La Postwar House fue proyectada por William Wurde- 


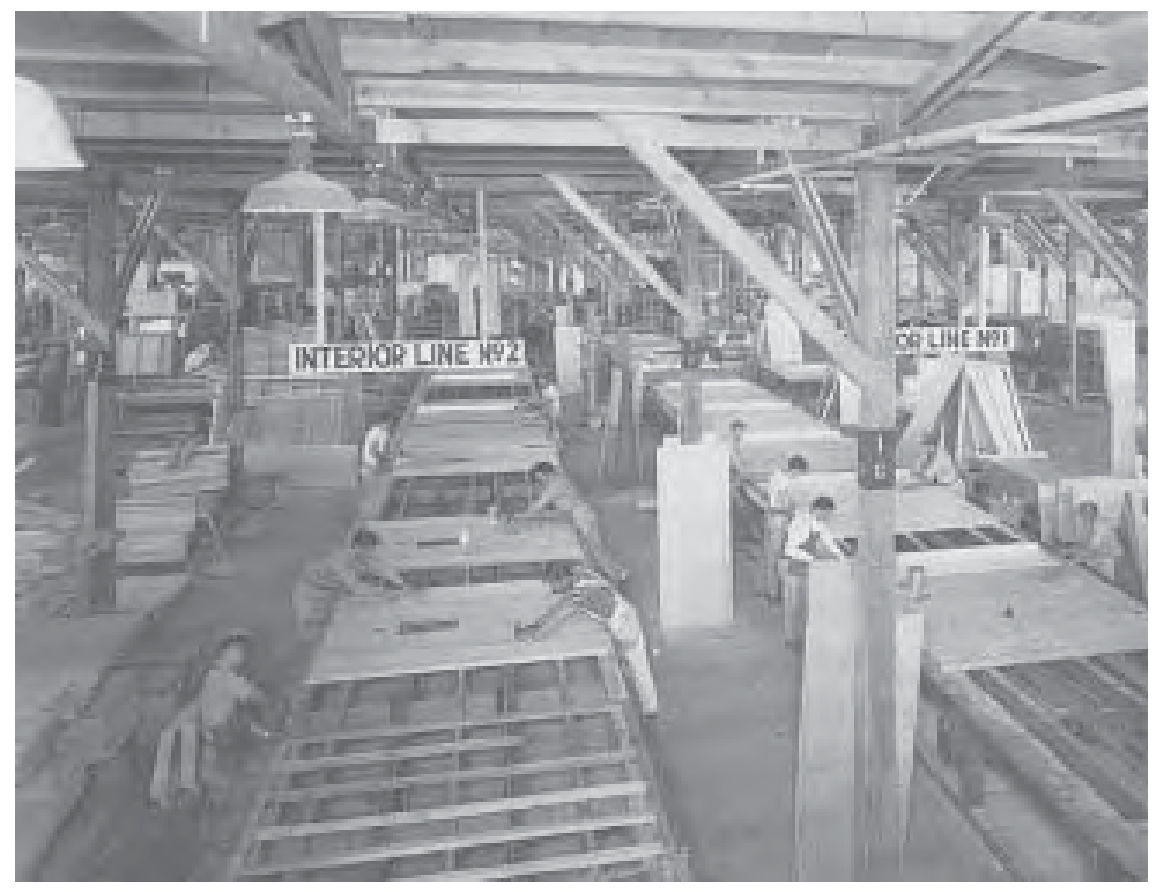

man y Welton Becket y su diseño de jardín estuvo cargo del paisajista Garret Eckbo. Como las primeras Case Study Houses, la Postwar House se abrió al público en 1946. Podía visitarse todos los días de la semana de 11 de la mañana a 9 de la noche y sus bondades fueron publicitadas por la editora y la revista rivales de John Entenza, Elizabeth Gordon y House Beautiful, que le dedicó un reportaje de 42 páginas en su número de mayo de 1946. El éxito de la iniciativa de Burns fue tal que, en 1951, repitió la experiencia con su Home of Tomorrow, diseñada también por Becket y Ekbo y amueblada por la Barker Brothers Company, una empresa de mobiliario asequible muy conocida entre las familias de clase media de la época.

Argumentando de nuevo en términos de mercado, es importante señalar que, frente al hecho de que las Case Study Houses se plantearan con estándares accesibles únicamente a una clase media alta, los empresarios locales de la industria inmobiliaria supieron aprovechar de manera muy inteligente los limitados recursos de sus potenciales clientes y, sobre todo, sus sueños, para crear un imperio de viviendas producidas en masa. La clase media de ajustados ingresos, a diferencia de las viviendas de Entenza, sí podían permitirse los productos ofrecidos por los todopoderosos promotores Fritz B. Burns o su socio Henry Kaiser. Y ambos, también a diferencia de Entenza, controlaban los medios de producción para generar viviendas industrialmente y desencadenar colosales operaciones capaces de transformar la geografía del Sur de California movilizando a millares de familias en apenas unos meses.

Desde finales de los años 30, la necesidad de alojamiento para los trabajadores de la industria armamentística y aeronáutica en la ciudad de Los Ángeles había beneficiado a los grandes promotores locales, favorecidos -como se apuntó también en las notas introductorias de esta tesis- por los contratos del gobierno federal y de las administraciones locales para construir miles de viviendas junto a las factorías militares. Esta experiencia llevó a promotores como Henry Kaiser a generar auténticas cadenas de montaje de viviendas prefabricadas en todos sus elementos constitutivos y cuya producción en serie se benefició de los procesos de fabricación de la industria bélica, generando todo tipo de elementos, acabados y equipamientos do- 


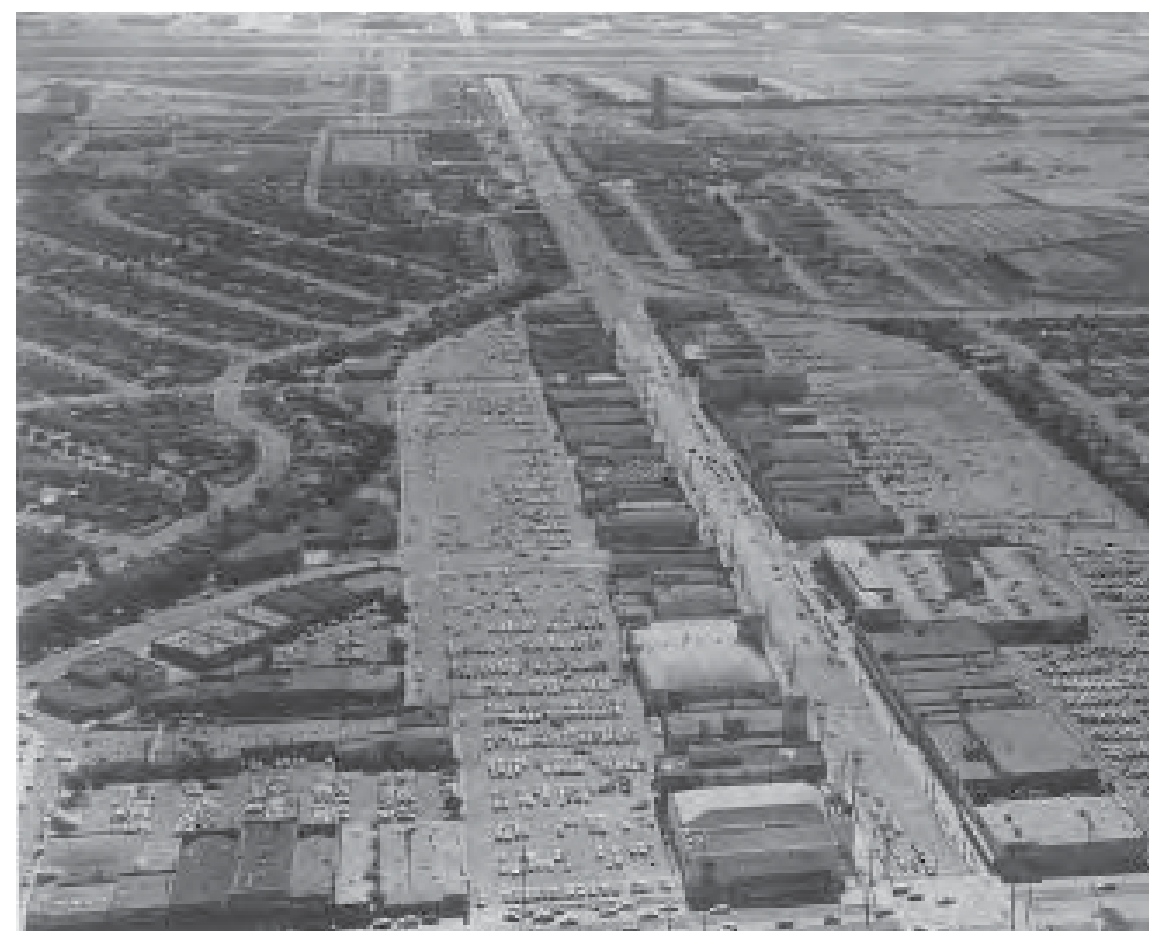

Vista aérea del Westchester Business Center en 1961, centro de la promoción de Burns y Kaiser. Fuente Dana Cuff

Página siguiente: Eames House. Fotografía del autor mésticos, desde paneles de cerramiento, a cubiertas y fachadas, sanitarios y hasta electrodomésticos.

Greg Hise, Profesor de Historia Urbana en la School of Policy, Planning and Development de la Universidad del Sur de California, dedica un capítulo de su libro Magnetic Los Angeles, Planning the Twentieth-Centuryt Metropolis, a estudiar los entresijos del imperio inmobiliario erigido por Henry Kaiser. Recurriendo a su documentado análisis sobre los métodos fordistas de producción en serie de viviendas desarrollados por este promotor y sus sofisticadas técnicas publicitarias y de venta, es inevitable la comparación con el Case Study House Program de Entenza. Mientras que, en 1945, Entenza llamaba a la movilización de arquitectos e industriales para adaptar los nuevos materiales y sistemas constructivos a la vivienda media, en 1946, Kaiser Homes tenía capacidad suficiente para producir cientos de tipos diferentes de unidades residenciales y de edificar hasta 150.000 casas en un año ${ }^{16}$.

Diseños como el de la Postwar House eran representativas del tipo de vivienda al que, por un precio inferior a 4.000 dólares (pagando un pequeño anticipo de 150 dólares), podían aspirar los americanos medios; casas donde el interés radicaba en determinados criterios de diseño antes que en la calidad de su arquitectura: una vivienda abierta al jardín, con un generoso estar sin comedor formal y varios dormitorios cuyo diseño hacía énfasis sobre todo en los modernos equipamientos de cocinas y baños. Como afirmó comparativamente Thomas Hines en su crítica al Case Study House Program para el catálogo de la exposición monográfica sobre el programa organizada por el MoCA en 1989 "Arts \& Architecture intentaba generar nuevas y ideas y darlas a conocer al público. Si bien, mientras que en las Case Study Houses la arquitectura era prioritaria, en las casas modelo de Fritz Burns, como en la experiencia de la mayoría de los americanos, la vida modera era definida de forma aditiva, es decir, a través de la compra de nuevos electrodomésticos o en la remodelación de la antigua casa [...] Mientras que los arquitectos del Case Study House Program estaban preocupados por crear nuevas tecnologías residenciales, la mayoría de la gente simplemente quería añadir nueva tecnología a su casa ${ }^{{ }^{{ }_{17}} \text {. }}$. 
Burns y Kaiser tuvieron bien presente esta realidad al generar nuevos dispositivos domésticos para sus clientes, a quienes reducaban sistemáticamente en sus valores tradicionales y en su deseo de adquirir nuevos equipamientos y bienes de consumo de cuya producción dependía gran parte de su negocio.

Comparadas por tanto con este impresionante despliegue de medios, es inevitable ver las Case Study Houses como experimentos artesanales con tecnología high tech y su impacto, a pesar de la calidad arquitectónica de la mayoría de ellas, como algo marginal y limitado al ámbito de proyectos personalizados de viviendas unifamiliares. Como ya se insistió, el único proyecto de CSH que tenía vocación de barrio fue la propuesta de Jones y Emmons de una casa modelo ( $\mathrm{CHS} \mathrm{n}{ }^{\circ} 24,1961$ ) susceptible de ser repetida para generar 260 viviendas. Esta propuesta, tras frustrarse como parte del experimento de Arts \& Achitecture porque el Ayuntamiento de Los Ángeles consideró las parcelas demasiado pequeñas, sería finalmente asumida por los desarrollos urbanos de Joseph Eichler, el más destacado promotor moderno del Sur de California. Sin la materialización del $\mathrm{CHS} \mathrm{n}{ }^{\circ} 24$, el programa quedó reducido a un catálogo de soluciones específicas. A pesar de ello, la revista insistió en la reproductibilidad de sus viviendas, haciendo de esta supuesta cualidad uno de los principales reclamos con los que se publicitó el CSH Program.

Por otra parte, aunque la aspiración y la estrategia comercial de Entenza consistía en presentar las viviendas de su programa como prototipos repetibles, en general, a partir de la segunda fase del CSH Program, se trató de diseños únicos de viviendas, en muchos casos ya construidas antes de que, por cuestiones de preferencias estéticas, intereses o relaciones personales, fueran seleccionadas directamente por el editor de la revista. Así lo relató Julius Shulman, uno de los principales artífices del programa y sin embargo, uno de sus más lúcidos críticos y a quien, según escribió el mismo fotógrafo, John Entenza le propuso incorporar al programa la vivienda que le había construido Raphael Soriano en 1950: "En cuanto Entenza supo que Soriano había construido mi casa-estudio percibió una oportunidad para mostrarla como parte del programa. Si bien, no me consultó nada creyendo que Soriano tenía capacidad para obrar en mi nombre. Mi mujer y yo teníamos una opinión diferente. Básicamente yo predicaba el diseño de mi estudio como resultado de mi experiencia personal más allá de un caso particular de casa modelo. Por ello, considerar su diseño como una 'Case Study' podría comprometer la objetividad del programa. Y eso fue exactamente lo que ocurrió cuando Entenza se fijó en otro proyecto. El arquitecto Kemper Nomland se estaba construyendo su propia casa y Entenza le hizo la misma proposición que a mí. Nomland aceptó por razones publicitarias y su vivienda se convirtió en una de las Case Study Houses. Ahora bien, si el proyecto ya estaba acabado y la obra en marcha ¿cómo es posible que pudiera ser representativa del ambicioso plan de Entenza ${ }^{118}$.

Pero incluso, las primeras casas, creadas ex profeso para el programa, se vieron afectadas negativamente en su condición de prototipos por la excepcionalidad de las condiciones bajo las que fueron concebidas, tanto en lo que se refiere a las restricciones gubernamentales que establecían por ley una superficie construida máxima de 1.100 pies cuadrados, como en lo concerniente a la escasez de materiales de los primeros años de posguerra y debido a la cual las viviendas con estructura de acero, como las casas Eames y Entenza proyectadas en 1945, no pudieron ser construidas hasta 1949.

El año 1949 marcó un punto de inflexión en el programa de las Case Study Houses. Por un lado, con el inicio de la siguiente década, Entenza dejó de

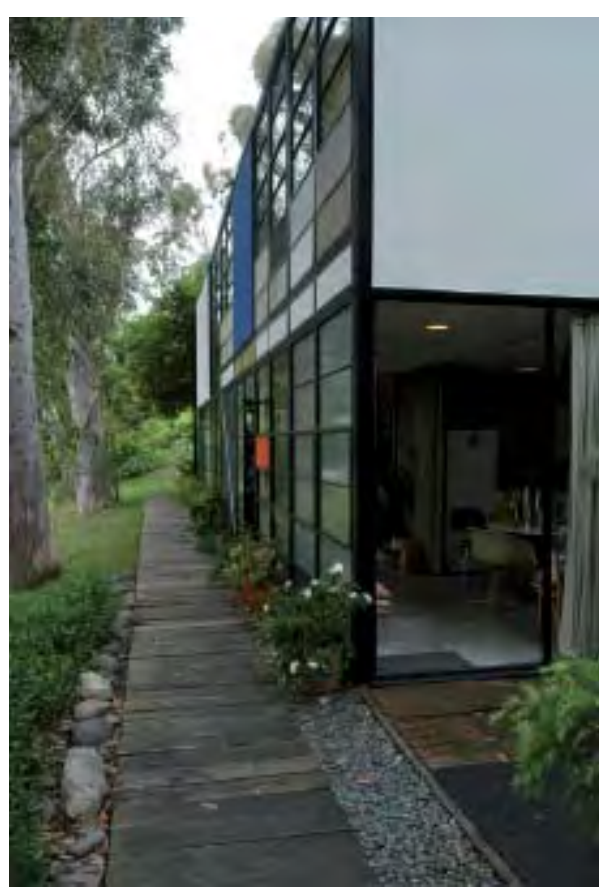


llamar a arquitectos consagrados, o al menos cuyo trabajo había alcanzado una cierta relevancia en el área de Los Ángeles, para apostar por jóvenes arquitectos locales pertenecientes a una generación posterior. Éstos encontraron en las páginas de la revista Arts \& Architecture, tanto dentro como fuera del Case Study House Program e, incluso, en la protección y ayuda personal brindada por Entenza, un ventajoso canal para dar a conocer su trabajo. Por otro lado -y a pesar de la incorporación de arquitectos jóvenes o, mejor, del relevo generacional-, es evidente que, a partir, de 1950 el programa en su conjunto abandonó buena parte de su carga experimental para centrarse más en cuestiones de aspecto que incidían en la casa de cristal como marca todavía hoy reconocible del California Mid-Century Modern e indisolublemente unida a un determinado estatus sociocultural.

Por último, otro de los mitos en torno al CSH Program es que el conjunto de arquitectos que participaron en él fuera representativo de la arquitectura moderna del Sur de California. Y, aunque es algo en lo que muchos historiadores insistieron-entre ellos la propia Esther McCoy-conviene recordar que Entenza dejó fuera del mismo a muchos autores, como Harwell Hamilton Harris (por voluntad propia) o Gordon Drake.

Otra de las ausencias más notables en el programa Case Study House y, probablemente, la más discutida por los historiadores de la arquitectura moderna californiana, es la de Gregory Ain. A pesar de la oportunidad proporcionada por el MoMA, la exhibición de su vivienda experimental en el patio del museo en 1950 no debió resultar una plataforma suficiente para John Entenza quien, a pesar de haberle invitado a formar parte del jurado del concurso Designs for Postwar Living y de ser durante muchos años miembro del consejo editorial de Arts \& Architecture, nunca le encargó el diseño de una casa modelo. Por otra parte, a pesar de la importancia y calidad de su trabajo, la presencia de Gregory Ain en Arts \& Architecture fue muy limitada. De hecho, hasta 1950, además de en la reseña de una exposición colectiva sobre arquitectura en el Sur de California en el Scripps College (Vivienda en Beverly Hills, Arts \& Architecture, abril 1950, p. 28), la obra de Gregory Ain sólo apareció cuatro veces más en las páginas de la revista de Entenza ${ }^{19}$.

No existe ningún dato histórico que induzca a pensar que Gregory Ain fuera deliberadamente excluido del Case Study House Program. Pero tampoco existe ningún testimonio que afirme que el arquitecto rehusara deliberadamente una supuesta invitación de Entenza, como sí que hizo Harris, su antiguo compañero en el estudio de Neutra. Una hipótesis podría ser que tras el encargo del MoMA de un prototipo de vivienda a Gregory Ain, el editor no quisiera involucrarle en el programa para que la asociación del arquitecto con el Museo de Arte Moderno de Nueva York no restara originalidad al Case Study House Program, o que pudiera considerarse que su iniciativa iba a remolque de otras instituciones con las que Entenza, dado su carácter receloso, no quería compartir protagonismo.

Esta omisión fue seguramente uno de los mayores errores de Entenza, cuyo experimento residencial se hubiera beneficiado considerablemente con las aportaciones de Gregory Ain. El compromiso social de este arquitecto emerge en su obra como un intento permanente de construir puentes entre la arquitectura doméstica y la industria de la vivienda. En este sentido, es obvio que su aspiración de democratizar el buen diseño compartía los objetivos iniciales del programa Case Study House, pero él fue mucho más allá de dichos objetivos. Ain dedicó buena parte de su trabajo a explorar diferentes formu- 


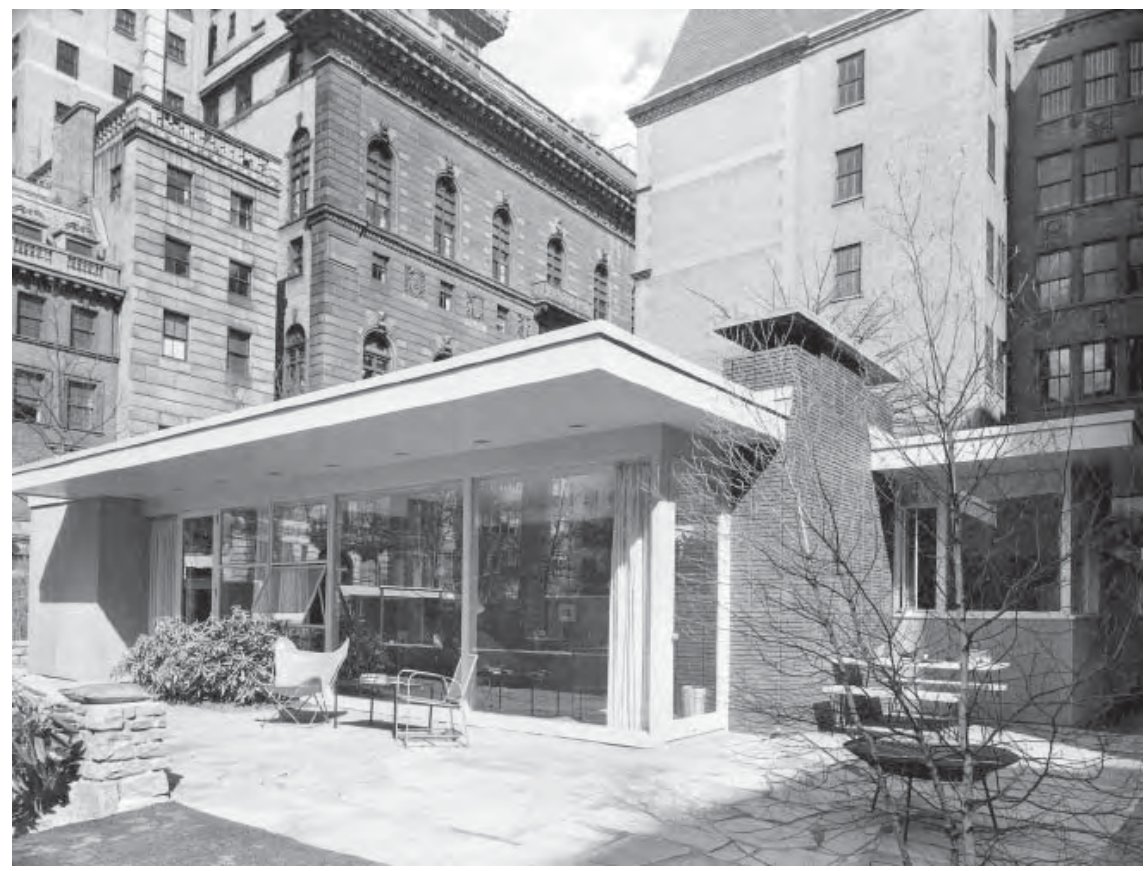

laciones de lo público y lo privado que pusieran en valor la condición urbana de sus complejos residenciales. Repensando la propia individualidad de sus unidades básicas, Ain trató de abordar los programas espaciales de sus viviendas unifamiliares vinculándolos a un proyecto de espacio público que permitiera entender pero, sobre todo, experimentar el suburbio en términos de comunidades cohesionadas. No obstante, como ha insistido su biógrafo Anthony Denzer, estas "ambiciones eran francamente imposibles de explicar en un museo y si Ain hubiera participado en el Case Study House Program probablemente hubiera sufrido los mismos programas de aislamiento y dislocación a los que se enfrentó con su casa en el patio del MoMA"20.

Esther McCoy, amiga y confidente de John Entenza debió conocer muchas de las verdaderas motivaciones del editor quien, lógicamente, habría compartido numerosos asuntos con ella en la privacidad de su casa o durante una de sus frecuentes comidas en trabajo, pero la historiadora, por lealtad, nunca hizo pública mucha de la información revelada por Entenza u obtenida de primera mano a través de cualquier otra fuente que pudiera comprometer la imagen de sí mismo creada por su amigo y benefactor. En el caso de la llamativa ausencia de Gregory Ain del Case Study House Program, hacia el final de su vida, McCoy vinculaba innecesariamente su caso al de otros dos arquitectos, Schindler y Harris, sobre los que la autora sí conocía a ciencia cierta por qué no habían participado en el programa, y daba, aún consciente de su ambigüedad y generalidad, las siguientes explicaciones: "Se plantea con frecuencia la cuestión de por qué Schindler y otros arquitectos modernos consagrados como Harris y Ain no fueron incluidos. Había numerosas razones. Algunos arquitectos prefirieron quedarse al margen del programa por considerarlo una campaña publicitaria. Otros fueron críticos con una política editorial que dirigía la mirada hacia Europa. Algunos arquitectos tenían clientes recelosos de abrir sus viviendas al público. Otros no disponían del encargo de una casa pequeña que encajara en el programa. Otros, sencillamente, no fueron preguntados. Más tarde, hacia 1950 el programa ya se había reestructurado prefiriéndose la presencia de jóvenes arquitectos de posguerra" ${ }^{\prime 21}$.

Respecto a la omisión de Schindler, su caso era tan flagrante que, en ese mismo texto -el último publicado por la historiadora (el catálogo de la exposi-
Gregory Ain: Prototipo de vivienda en el jardín del MoMA. Fotografía de Ezra Stoller, 1950 
ción del MoCA sobre el CSH Program)-, Esther McCoy se molestó en incluir una nota en la que aportaba su propia opinión sobre las particulares circunstancias de Schindler, un arquitecto cuya obra no fue plenamente entendida hasta varias décadas después. Sobre él escribió: "es bien sabido que, hacia 1945, Schindler se mostraba muy beligerante con el espiritu de la Bauhaus y del Estilo Internacional, siendo contrario a su adaptación a las particularidades del clima californiano. De hecho, su decisión de mantenerse apartado de las corrientes dominantes le valió que muchos no le consideraran nunca un arquitecto serio"/22.

Algunos de los comentarios de McCoy pueden atribuirse directamente a algunos de los arquitectos nombrados por la historiadora, aunque ella no quisiera entrar en detalles. Es el caso de Harris, que aunque fue invitado por Entenza, rehusó su propuesta por motivos personales (dado su disgusto por el modo en que el editor había llegado a hacerse con el control de California Arts \& Architecture), así como por considerar que el programa era ante todo una estrategia publicitaria y porque pensaba que el consejo editorial dirigido por John Entenza estaba más preocupado por su reconocimiento internacional que por poner en valor las especificidades de la arquitectura californiana.

Julius Shulman no tuvo reparos en criticar abiertamente la subjetiva elección de los arquitectos del programa por parte de John Entenza, así como que el editor, deseando poner rápidamente en marcha la iniciativa en 1945, no se tomara el tiempo necesario para "plantear a sus arquitectos una definición concreta de las condiciones y problemas relativos a la particular forma de vivir del Sur de California. Además [afirmaba Shulman], mi crítica a Entenza tiene que ver con que su elección de los arquitectos no fuera representativa del tipo de profesionales que trabajaban especificamente en el ámbito de la vivienda de bajo coste; por el contrario, su selección era en ocasiones arbitraria e incluía sólo a arquitectos que hacían viviendas con estructuras de vigas y pilares. Y en aquella época también hubo muchas críticas porque no se contara con Gregory Ain, quien había consagrado su carrera a investigar soluciones de vivienda económica. Sacando todo el partido a la economía de medios y concentrándose en la eficiencia de materiales y técnicas constructivas, Ain logró una arquitectura alejada de todo cliché. El Museo de Arte Moderno reconoció su extraordinario talento encargándole el diseño de una innovadora casa modelo de bajo coste. Él debería haber sido incluido en el Case Study House Program y sin embargo fue excluido por razones personales, probablemente porque tenía amigos demasiado escorados hacia las tesis del partido comunista" ${ }^{\prime 23}$. Es interesante esta declaración final de Shulman porque frente a los desvelos del editor por presentarse a sí mismo como un líder de la vanguardia editorial pondría de manifiesto la indolencia de Entenza en determinadas cuestiones con las que no quiso asumir riesgos como, por ejemplo, respaldando a arquitectos sobre los que existían sospechas políticas. De hecho y, una vez más hay que insistir, Entenza comprendió perfectamente que para tener éxito mediático en la conservadora sociedad de posguerra su programa debía tener un fondo mucho más conservador de lo que su revista se esforzaba por aparentar. Y, en este sentido, la discordancia entre la realidad y la apariencia del programa sería, como el decalaje entre la vida privada del editor y la construcción de su propia biografía, un calculado juego de ocultaciones y proclamas públicas ${ }^{24}$.

Otro arquitecto que tampoco figuró en el programa de viviendas modelo de la revista Arts \& Architecture fue John Lautner aunque, en este caso, dada la 
singularidad de su obra, el mismo Lautner ofreció su propia explicación en la entrevista biográfica que concedió al Oral History Program de la UCLA: "Creo que cuando comencé tuve la suerte de ser reconocido como un arquitecto moderno. Pero aparte de eso, yo no tenía nada que ver con el tipo de arquitectura que otros arquitectos denominados modernos estaban haciendo en ese momento. Yo trataba de encontrar la mejor solución arquitectónica a mis propias ideas. Comencé de esa manera y ha sido así toda mi vida. Ciertamente, Arts \& Architecture publicó varios de mis trabajos iniciales, pero cuando comenzaron a potenciar sus Case Study Houses, simplemente, se dedicaron a publicar una caja de cristal tras otra. De modo que sólo haciendo cajas de cristal estabas haciendo casas modernas. Y yo no he hecho nunca una caja de cristal, así que supongo que por esa razón no llegué nunca a hacer una Case Study House, porque eso era lo único que [John Entenza] entendía por arquitectura moderna" ${ }^{\prime 25}$.

En otro orden de cosas, en paralelo al prestigio fabricado para el programa, Entenza se esforzó en conseguir para sí mismo un reconocimiento a su labor al frente de la revista. Aunque se excedió en su atribución de méritos ya que, por medio de su círculo de íntimos, primeramente a través de Esther McCoy y posteriomente de David Travers -quien le sucedió al frente de Arts \& Architecture cuando Entenza se marchó a Chicago a dirigir la Graham Foundation en 1960-, el editor hizo circular la idea de que había pilotado la revista desde 1938 cuando esto no sucedió hasta 1940. Además, Entenza mostró un especial empeño en que todo el mundo creyera que había heredado una revista mediocre y arruinada y que él la había convertido en una referencia para la cultura arquitectónica internacional.

McCoy la fue responsable de iniciar el mito de que Arts \& Architecture había surgido de la nada, así como que Entenza había comprado la revista en 1938, tal como ella escribió en el texto citado de su monografía Case Study Houses de 1962: "Una persona inusualmente sensible a la excitación del momento, así como a la confusión de aquellos días, fue el joven editor y propietario de la revista Arts \& Architecture -John Entenza. Comenzando su labor al frente de la misma en 1938, la revista estableció una enérgica línea de comunicación entre los profanos y la profesión de la arquitectura ${ }^{\prime \prime 26}$. Con mucha seguridad, McCoy tomó esta idea directamente de Entenza, quien habría influido en sus opiniones, hasta el punto de que la historiadora no comprobó siquiera los créditos de la revista. Podría teorizarse que la intención de Entenza habría sido hacer creer que cuando la casa que le construyó Harris apareció en California Arts \& Architecture, él ya estaba al frente de la misma y que éste habría sido su primer cometido editorial pues, de otro modo, no se entiende su empeño en adelantar dos años la verdadera cronología y naturaleza de su relación con la revista.

Bastaría revisar los créditos de CA\&A para verificar que las fechas indican que, contrariamente a lo escrito por McCoy, en 1938 Jere Johnson era su propietaria y directora. En cuanto al episodio de la compra de la revista, cabe recordar según lo expuesto en el capítulo sobre Harris que un año después, Johnson había pedido a Jean Murray Bangs ser directora del número de octubre de 1939 de California Arts \& Architecture, el mismo número en el que Harris aparecía por primera vez nombrado como miembro del consejo editorial de la revista. Fue en ese momento cuando, por motivo de su embarazo, Johnson necesitaba ayuda extra por parte de sus amigos y les pidió opinión sobre a quién contratar temporalmente, siendo los Harris quien, como se explicó, recomendaron e introdujeron a Entenza como editor adjunto durante el tiempo que durase la baja de su amiga. Pero poco des- 
Portadas de Arts \& Architecture diseñadas por Ray Eames: noviembre 1943 (arriba) y enero 1944 (abajo)
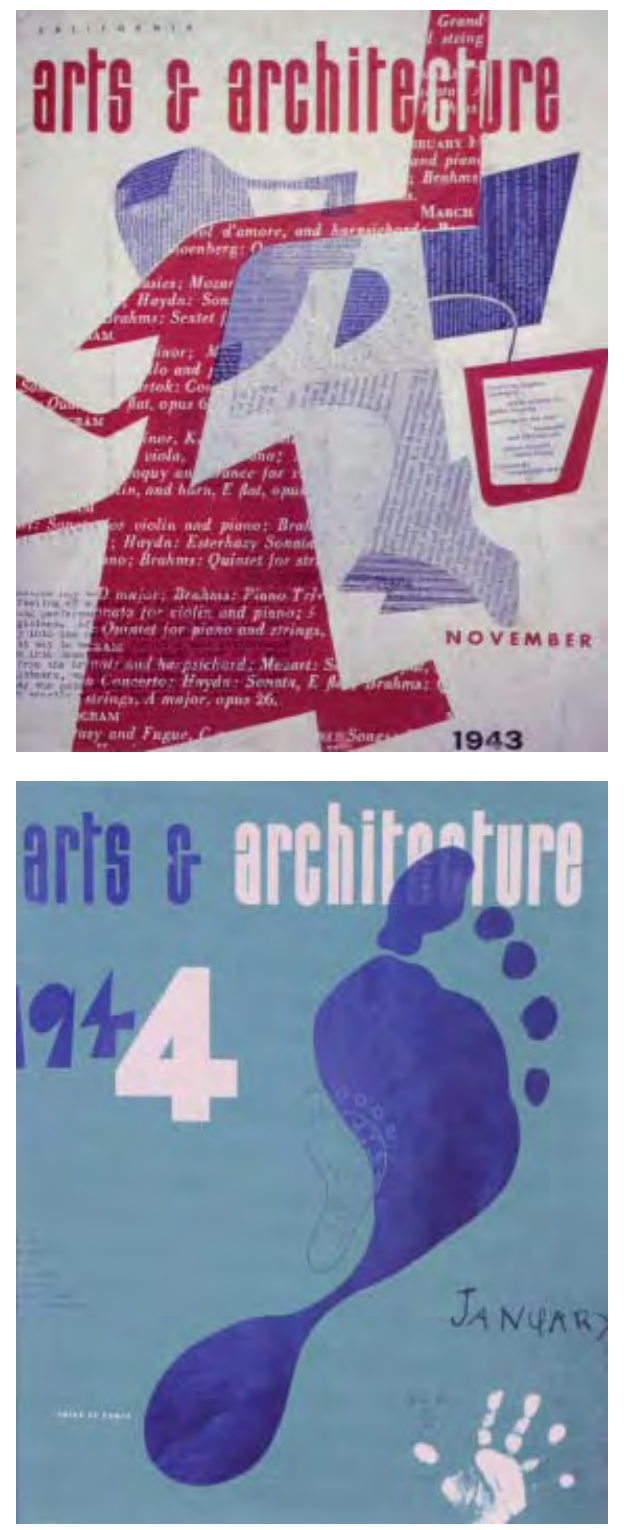

pués, de acuerdo con Harris, Stella Gramer, antigua abogada suya y socia del padre de John Entenza presionó a Johnson para que traspasase la revista al hijo de su socio. La venta debió formalizarse hacia finales de mayo o principios de junio de 1940, momento en el cual John Entenza, trasladó inmediatamente las oficinas de la revista para alejarse del matrimonio Harris ya que éstos tenían su estudio profesional en el mismo edificio donde se encontraba la sede de $C A \& A^{27}$.

En The Second Generation y en su citado ensayo para el catálogo de la exposición del MoCA sobre el CSH Program de 1989, McCoy volvió a incidir en que Entenza compró la publicación en 1938, aunque no fue hasta dos años más tarde cuando comenzó a desempeñar labores de editor ${ }^{28}$. A partir de McCoy, todas las fuentes, exceptuando la de Victoria Dalley en su ensayo sobre la primera arquitectura moderna californiana titulado Naturally Modern ${ }^{29}$ donde repara en que Entenza no apareció en los créditos de la revista hasta febrero de 1940, el resto de autores han repetido consciente o inconscientemente el error de McCoy. Por ejemplo, en ese mismo catálogo, su editora, Elizabeth A. T. Smith sostenía que "entre 1938 y febrero de 1939, la fecha en la que Entenza es listado oficialmente como editor de la revista, Arts \& Architecture comenzó a interesarse mucho más por la arquitectura y los interiores modernos aunque todavía daba cabida a diseños tradicionales. En noviembre de 1938 la revista anunció un nuevo giro, publicando viviendas de bajo coste con la primera de una serie de 'Small Houses of the West'". El encadenamiento de malentendidos de Smith es Ilamativo, como se adelantó en el capítulo sobre Harris: por un lado, Entenza no fue acreditado hasta 1940, tampoco la revista se llamó Arts \& Architecture hasta 1944 y, mucho menos, su interés por la modernidad fue responsabilidad exclusiva de Entenza sino fruto de una evolución en la que se ha incidido a lo largo de esta tesis.

Del mismo modo, influido por el propio Entenza, su amigo Stanley Tigerman, la persona que más datos ha ofrecido sobre la opaca biografía del editor, afirmaba que California $A \& A$ era básicamente una revista menor y con muchos problemas de contenidos antes de que Entenza llegara a ella en 1938 (él también asumió de modo erróneo la fecha adelantada por McCoy en dos años): "Entenza era la persona más culta relacionada con la arquitectura que conocí y no lo digo porque él fuera el Director de la Graham Foundation o porque fuera mi amigo - ambas cosas eran circunstanciales- sino porque era un hombre que hizo época en su campo. Compró una publicación comercial muy mala llamada California Arts \& Architecture en 1938, creo. Y si uno echa la vista atrás hacia finales de los años 40-digamos después de la Segunda Guerra Mundial- la única revista que estaba publicando sólo arquitectura moderna era Arts \& Architecture, ni siquiera Architectural Forum, la Record o Pencil Points. El único que se ocupaba en exclusiva de la arquitectura moderna era John. Es decir, fue por delante de su tiempo. Incluso, usó su propio dinero porque, en aquel momento de su vida, aunque no poseía una fortuna como para vivir sin trabajar, es cierto que tenía bastante dinero y que invirtió todo en el programa Case Study Houses. Así que hay que reconocer su mérito sólo por ser capaz de hacer algo así de altruista [...] Era un gran hombre. Y era mi amigo [...] Fue como un padre para mi"30.

No obstante, los errores más flagrantes son los de Barbara Goldstein y David Travers. Goldstein, protegida de Entenza y que, como McCoy, durante algún tiempo tuvo su despacho en la casa de Schindler, en su introducción a la monografía de 1990 dedicada a la revista Arts \& Architecture sostenía igualmente que Entenza publicó y editó la revista entre 1938 hasta $1962^{31}$. 
Recientemente, David Travers, en su texto introductorio a la reimpresión de todos los números de la revista entre 1945 y 1954 llevada a cabo por Taschen en 2008 silenciaba conscientemente toda referencia al legado de la revista California Arts \& Architecture heredado por Entenza, dando a entender que éste creó ex novo y, en tan sólo un par de años, una revista tan influyente como la que recibió al asumir sus tareas como editor ${ }^{32}$. Empeñado sin necesidad en salvaguardar los méritos de John Entenza, Travers perpetúa conscientemente el error de McCoy, afirmando que Entenza adquirió la revista en 1938. Consultado por correo electrónico a instancias de John Crosse, Travers sostiene ${ }^{33}$ que su versión difiere de la de Harris y que el relato de la compra de la revista no le vino a través de Entenza, sino de Stella Gramer, quien también era su abogada. No obstante, considerando el esfuerzo de los Harris por recopilar los escritos publicados por o sobre ellos, ordenar cuidadosamente esta bibliografía, comentarla con múltiples anotaciones, y clasificar rigurosamente todos sus materiales de archivo, es prudente compartir la opinión de John Crosse de que la fuente de los Harris sería más fiable que la de Gramer.

La falta de un archivo ${ }^{34}$ de John Entenza dificulta la confirmación de los hechos pero atendiendo, como sugiere Ted Wells ${ }^{35}$, al carácter ambicioso y vengativo de Entenza -a lo largo de su carrera fue eliminando todo tipo de relación personal con quienes discutía profesionalmente, ya fueran los $\mathrm{Ha}$ rris, los Eames $^{36}$ o Alvin Lustig- difícilmente si el editor hubiera comprado la revista en 1938 hubiera admitido no aparecer en los créditos hasta dos años después. Preguntado directamente sobre ello, Travers ha respondido a esta hipótesis con el argumento de que era costumbre en la época dejar el nombre del editor y propietario anteriores durante un tiempo, con objeto de no levantar así las suspicacias de los anunciantes o suscriptores de la revista. Pero esta posibilidad es muy remota. Más bien al contrario, nada más hacerse con la publicación en 1940, Entenza trasladó su sede y dejó de mencionar a Jere Johnson, que desapareció inmediatamente de los créditos en julio de ese año. Es más, el número de víctimas de Entenza nada más asumir el control de la revista fue notable, entre ellas los Harris, Cliff May, Merle Armitage o los Schindler, en especial la colaboración de Pauline por simpatía con Harwell Hamilton Harris; todos ellos dejaron California Arts \& Architecture poco tiempo después del cambio de régimen.

En la correspondencia que Harris mantuvo con McCoy a finales de los 70 para la redacción del capítulo que ésta le dedicó en The Second Generation, el arquitecto le relató su versión de los hechos, pero la historiadora no los creyó. Ella era amiga de Harris, pero más lo era de Entenza quien, además era su mentor y, por supuesto, aunque había dejado la dirección de la Graham Foundation por problemas de salud, seguía ejerciendo una gran influencia en esta institución a través de su sucesor, Carter Manny. McCoy, siempre presta a defender a su amigo y valedor llegó a mostrarse públicamente disgustada con Harris porque consideraba que el arquitecto había hablado mal de Entenza ${ }^{37}$. Incluso, en su afán por ensalzar la figura del editor, en ocasiones McCoy llegó a escribir cosas como que Arts \& Architecture "una revista tan delgada como una tortilla y tan elegante como un Bugatti, con muy poca publicidad y sin ningún respaldo económico se convirtió en la principal fuerza en la diseminación de información cultural y arquitectónica sobre California" ${ }^{\prime 3}$. Ciertamente influyente y un hito en el diseño gráfico de mediados del siglo pasado con sus magníficas portadas, si bien, contó con financiación externa, en especial cuando tras la salida de Entenza, la gestión de Travers casi la llevó a la ruina y su antiguo propietario hubo de sufragar parte de los gastos a través de la Graham Foundation y, aún más evidente, bastaría abrir cualquier 
número de la revista para comprobar la profusión de anuncios que pueblan sus páginas.

Hasta el final de su vida su vida McCoy mantuvo firmemente su versión de los hechos según la cual Entenza había liderado la revista desde 1938 y había hecho de aquella publicación mediocre y provinciana una eficaz plataforma internacional de difusión de la modernidad local. Poco antes de morir, en su artículo para Los Angeles Times sobre la exposición Case Study Houses inaugurada en el Museum of Contemporary Art de Los Ángeles el 17 de octubre de 1989, la historiadora reiteraba una vez más los mismos argumentos que había defendido durante casi 30 años: "Existía una publicación local, California Arts \& Architecture, dedicada más a la decoración que a la arquitectura. Si bien aquella revista tenía problemas y cuando se puso a la venta, Entenza, editor invitado durante algunos números decidió comprarla. Pronto eliminó la palabra 'California' del título, restringió sus contenidos al diseño moderno y optó por darle un enfoave internacional. Arts \& Architecture hizo mucho más para poner a Los Ángeles en el mapa cultural que cualquier otro artefacto. Arquitectos de numerosos países reconocieron posteriormente la enorme influencia que la publicación de Entenza ejerció sobre ellos durante su época de estudiantes. Uno de ellos fue César Pelli, quien dijo de ella que A\&A era a revista que la mayoría de los estudiantes argentinos esperaban. Después de la guerra, durante un viaje a Japón, un arquitecto y crítico me dijo que, dado que la suya era una nación derrotada, A\&A infundió a los arquitectos japoneses la fe necesaria para seguir adelante. $Y$, por supuesto, fue reconocida en Europa por la buena arquitectura moderna que publicaba. Sin ser arquitecto, el gusto de Entenza era infalible ${ }^{\prime 39}$.

En la segunda y última parte de este apunte historiográfico se abordarán algunas cuestiones biográficas relativas a la carrera como historiadora de Esther McCoy, incidiendo especialmente en las circunstancias que determinaron la investigación, el enfoque e incluso las condiciones materiales de sus principales libros, es decir, de aquellos relatos que a lo largo de esta tesis han constituido una de principales fuentes para la discusión de determinados episodios arquitectónicos, tanto por los datos aportados por McCoy como por el análisis de su propia objetividad y todo lo que este análisis revela en lo referente a filiaciones, preferencias personales e intereses editoriales.

Al igual que se afirmó con el legado de John Entenza, en el caso de McCoy tampoco se pretende cuestionar sus méritos como cronista o su encomiable labor de defensa del patrimonio moderno del Sur de California que tanto debe a esta historiadora. Se trataría ante todo de plantear el examen de algunos aspectos significativos de su obra, metodología de trabajo, influencias y contexto cultural de sus escritos para llamar la atención sobre la necesidad de considerar nuevos puntos vista que permitan entender los acontecimientos en toda su complejidad, más allá de la mera hagiografía que parece haber presidido los argumentos dominantes de la crítica arquitectónica de la modernidad del Sur de California.

En efecto, como sucede con John Entenza, Esther McCoy parece ser una autoridad incuestionable cuyos escritos son citados sin apenas distanciamiento crítico, una situación que se ha mantenido desde que, a mediados de los 6o, gracias a la promoción que John Entenza logró para sus libros, otros críticos e historiadores comenzaran a reverenciar su trabajo pionero. 
Reyner Banham dijo en una ocasión que nadie podría escribir sobre la arquitectura moderna de California sin reconocer a Esther McCoy (1904-1989) como la madre de todos los historiadores de la región ${ }^{40}$. Incluso, en su influyente Los Angeles, The Architecture of Four Ecologies, Banham reconocía en la primera página del primer capítulo del libro su deuda con los dos historiadores responsables de la primera guía de arquitectura de la ciudad, David Gebhard y Robert Winter a quienes consideraba a su vez, como a él mismo, en deuda con Esther McCoy y "su cruzada solitaria para registrar la arquitectura moderna del Sur de California y conseguir que sus monumentos fuesen apreciados" ${ }^{\prime \prime}$.

Recientemente, en el marco del ambicioso programa Pacific Standard Time, auspiciado por el Museo Getty, el MAK Center de Los Ángeles inauguró en septiembre de 2011 la exposición Sympathetic Seeing: Esther McCoy and the Heart of American Modernist Architecture and Design, comisariada por Susan Morgan, su principal biógrafa ${ }^{42}$. El catálogo ${ }^{43}$ homónimo de dicha exposición, comercializado a principios de 2012, supone el primer libro dedicado monográficamente a su vida, sus escritos y sus aportaciones a la cultura arquitectónica californiana. Enfocado desde el reconocimiento a la innegable influencia ejercida por McCoy en este campo y amparado por la relevancia cultural de la cita y del marco institucional, Morgan ha ratificado una vez más el estatus de Esther McCoy como figura clave de la historia de la arquitectura norteamericana.

Además de este esfuerzo expositivo, documental y biográfico, otra consecuencia de la investigación de Susan Morgan en los archivos de la Smithsonian Institution ha sido la labor de compilación de buena parte de los artículos de la prolífica McCoy (alrededor de 70 escritos) en el libro Piecing Together Los Angeles: An Esther McCoy Reader ${ }^{44}$, también de reciente aparición. El libro contiene desde el primero de los textos de McCoy, su artículo de 1945 sobre Rudolph Schindler aparecido en la revista Direction, "Schindler, Space Architect", hasta su último ensayo, el citado, "Arts \& Architecture: Case Study Houses" que, terminado pocas semanas antes de morir, fue un encargo del Museum of Contemporary Art de Los Ángeles para el también citado catálogo Blueprints for Modern Living ${ }^{45}$. Piecing Together Los Angeles materializa además una antigua aspiración de McCoy de conseguir publicar juntos sus artículos más significativos en una antología cuyo primer volumen trató de organizar ella misma en 1968 por encargo de W.W. Norton, pero que nunca vio la luz. En este sentido, partiendo de aquel proyecto inacabado, Morgan se ha basado en la selección preparada por McCoy para completar y ampliar una serie de textos que incluyen ensayos sobre arquitectura, reflexiones personales, conferencias, entrevistas, memorias y relatos cortos que abarcan desde sus primeras entregas para el New Yorker (sobre la vanguardia artística, el idealismo y el espíritu utópico del Greenwich Village en los años veinte), los inicios de su relación con la arquitectura y el diseño en California entre la Gran Depresión y el Fair Deal, hasta el optimismo de posguerra y su época como redactora de Arts \& Architecture en los años 50 y 60.

Todos estos materiales -introducidos por el laudatorio texto de su simpatética biógrafa- más allá de mostrar el alcance de la contribución de McCoy a la historia de la arquitectura moderna, permiten vislumbrar la complejidad de su relación con la realidad cultural del Sur de California pero, sobre todo, con los protagonistas de la modernidad de la región. No obstante, se echan en falta determinadas precisiones críticas como los frecuentes descuidos cronológicos de McCoy, su ocasional falta de rigor bibliográfico o su predi- 
lección por determinados personajes, como John Entenza o Craig Ellwood que, coincidentemente, fueron quienes sufragaron varios de sus libros.

Entre el reconocimiento de Banham y la celebración de Morgan han pasado casi cuarenta años en los que McCoy continúa sido venerada como la historiadora más preeminente del Sur de California. El hecho de asistir como testigo a muchos acontecimientos, siendo amiga de casi todos los arquitectos sobre los que escribió, la convirtió en una valiosa fuente, cuya autoridad y veracidad no parece haber sido cuestionada nunca. No obstante, si no se tiene en cuenta la circunstancia de que ella misma era en ocasiones parte de la historia como se ha demostrado en esta tesis, es fácil pasar por alto que sus relatos están mediados e, incluso a veces, consciente o inconscientemente, manipulados por sus intereses $y$ afectos personales.

Esther McCoy es una autora muy fácil de leer. Su estilo sin pretensiones se caracteriza por una prosa ágil, elegante y muy visual. Se apoya en un lenguaje expresivo, en ocasiones inesperadamente poético, que transporta inmediatamente al lector a la realidad de las obras que describe. Sus artículos captan la atención desde la primera línea y mantienen el interés a lo largo del texto. McCoy sabe cómo cautivar con metáforas ingeniosas y frases a menudo brillantes. Así, por ejemplo, definió la arquitectura moderna de Los Angeles como "a marriage between Walden Pond and Douglas Aircraft", una afirmación que suena con fuerza en inglés y cuyo sentido podría traducirse libremente en castellano como la fusión entre el amor por la vida en la naturaleza y la tecnología de la industria aeronáutica. McCoy resulta también muy didáctica, repite constantemente las ideas enfatizado conceptos, como las bases del buen diseño doméstico californiano que se encargó de difundir en todos sus escritos: desenfado y pragmatismo; depuración formal consecuencia de la sencillez de los nuevos programas residenciales propios de los modos de vida modernos de la región; aprecio por los valores paisajísticos del lugar; uso generoso e inteligente de la luz natural; plantas abiertas proyectadas desde la fluidez de las relaciones interior-exterior; y uso ejemplar de los nuevos materiales y técnicas constructivas.

Nacida en Horatio (Arkansas) en 1904, McCoy fue educada en un pequeño pueblo del Medio Oeste, Coffeyville (Kansas), donde su familia le inculcó unos hábitos de lectura que pronto despertaron su pasión por la literatura. Siendo todavía estudiante en la Universidad de Michigan envió una carta solicitando trabajo al controvertido escritor Theodore Dresiser, quien se convertiría en su mentor literario y en uno de sus mejores amigos y confidentes. A la edad de 21 años, McCoy se trasladó a Nueva York y se instaló en la bohemia del Greenwich Village. Era la época dorada del jazz y en esta parte del bajo Manhattan la ciudad alimentaba con interés las utopías modernas. Allí encontró trabajo como dependienta de una librería y también como asistente y documentalista de Dreiser. Socialista, feminista y crítico del sueño americano, este autor ejerció sobre ella una gran influencia, sentando las bases del estilo realista y sencillo con el que comenzó a escribir sus primeras historias de ficción y que, más tarde, tendría su reflejo en la amenidad de sus textos sobre arquitectura. Integrada plenamente en los círculos literarios progresistas, bajo la supervisión de Dreiser, McCoy pudo publicar algunos de esos relatos y artículos en rotativos tan prestigiosos como The New Yorker y Harper's Bazaar.

En 1931 McCoy residió durante nueve meses en París, donde pudo conocer personalmente algunos de los edificios más representativos de la moder- 


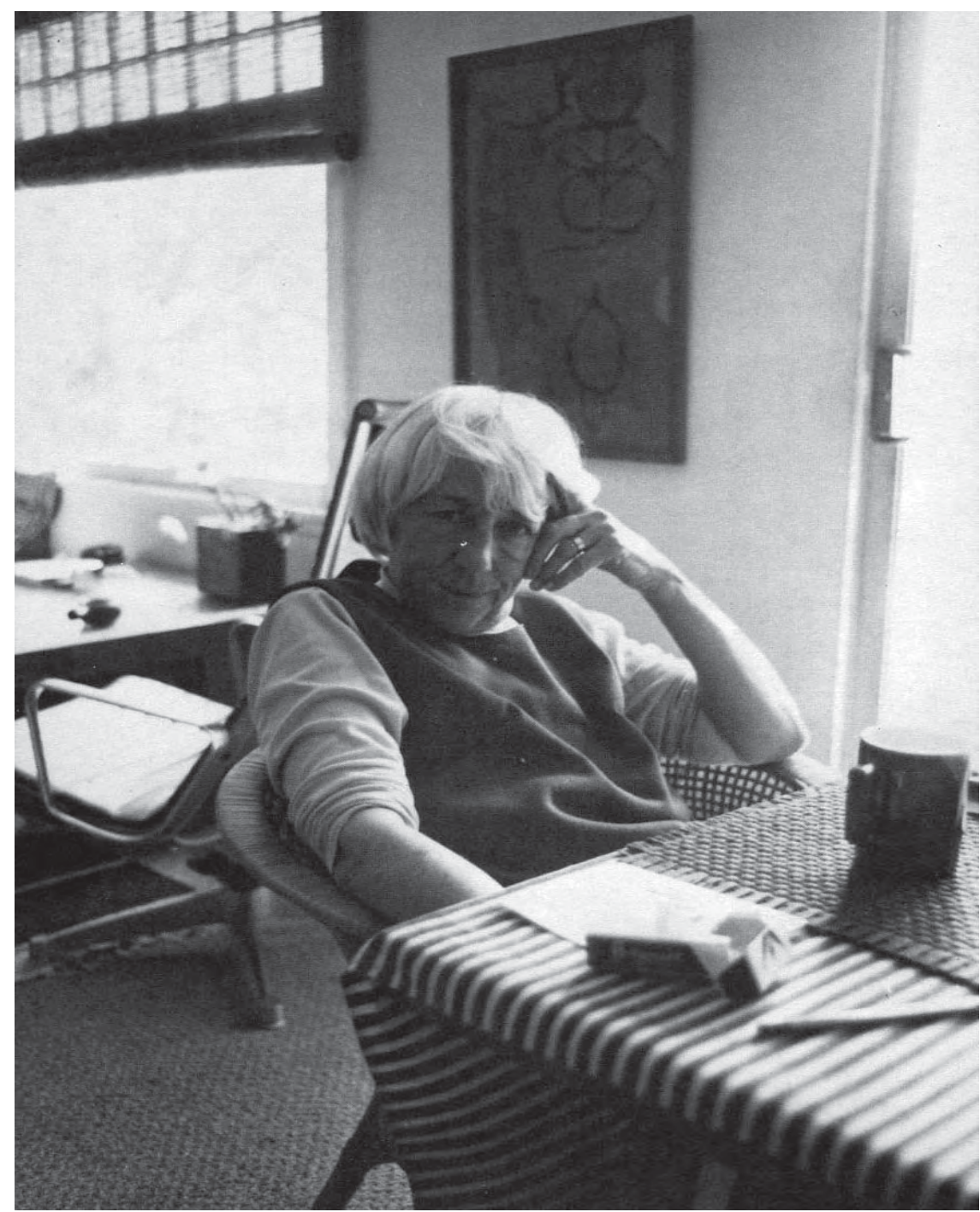

nidad europea antes de regresar a Nueva York. Aunque McCoy siempre se sintió ante todo escritora, la arquitectura fue para ella su otra gran pasión desde los tiempos del Village. Nueva York era el centro de los movimientos artísticos y literarios, de la vanguardia fotográfica y de la crítica arquitectónica más avanzada del momento. A principios de 1932, coincidiendo con la exposición del MoMA de Johnson, Hitchcock y Barr que llevó a los Estados Unidos la modernidad europea y la consagró como estilo internacional, McCoy fue diagnosticada y hospitalizada por un severo caso de doble neumonía. Se le recomendó que viajase a California para recuperarse de su enfermedad y, como ella misma diría, por ese motivo tuvo que abandonar Nueva York, la ciudad donde todo estaba ocurriendo para trasladarse a la costa equivocada, a un lugar como Los Ángeles donde, aparentemente, no sucedía nada de interés, o al menos, eso era lo que ella pensaba. Tenía previsto regresar en primavera pero el clima, el paisaje (del que le impresionó especialmente la imponencia de las Montañas de Santa Mónica en su encuentro con el océano Pacífico) y, por supuesto, la emergencia de una modernidad aún más original que la que se estaba celebrando la Costa Este, la retuvieron en el Sur de California el resto de su vida.

En plena recesión económica, McCoy sobrevivió trabajando como periodista freelance, enviando artículos a diferentes revistas locales y gacetas universitarias que publicaban sus reseñas de libros y críticas literarias. Colaboró también en guiones de cine y escribió pequeñas historias detectivescas am-
Esther McCoy en su casa de Santa Monica, 1985. Fuente: Susan Morgan 


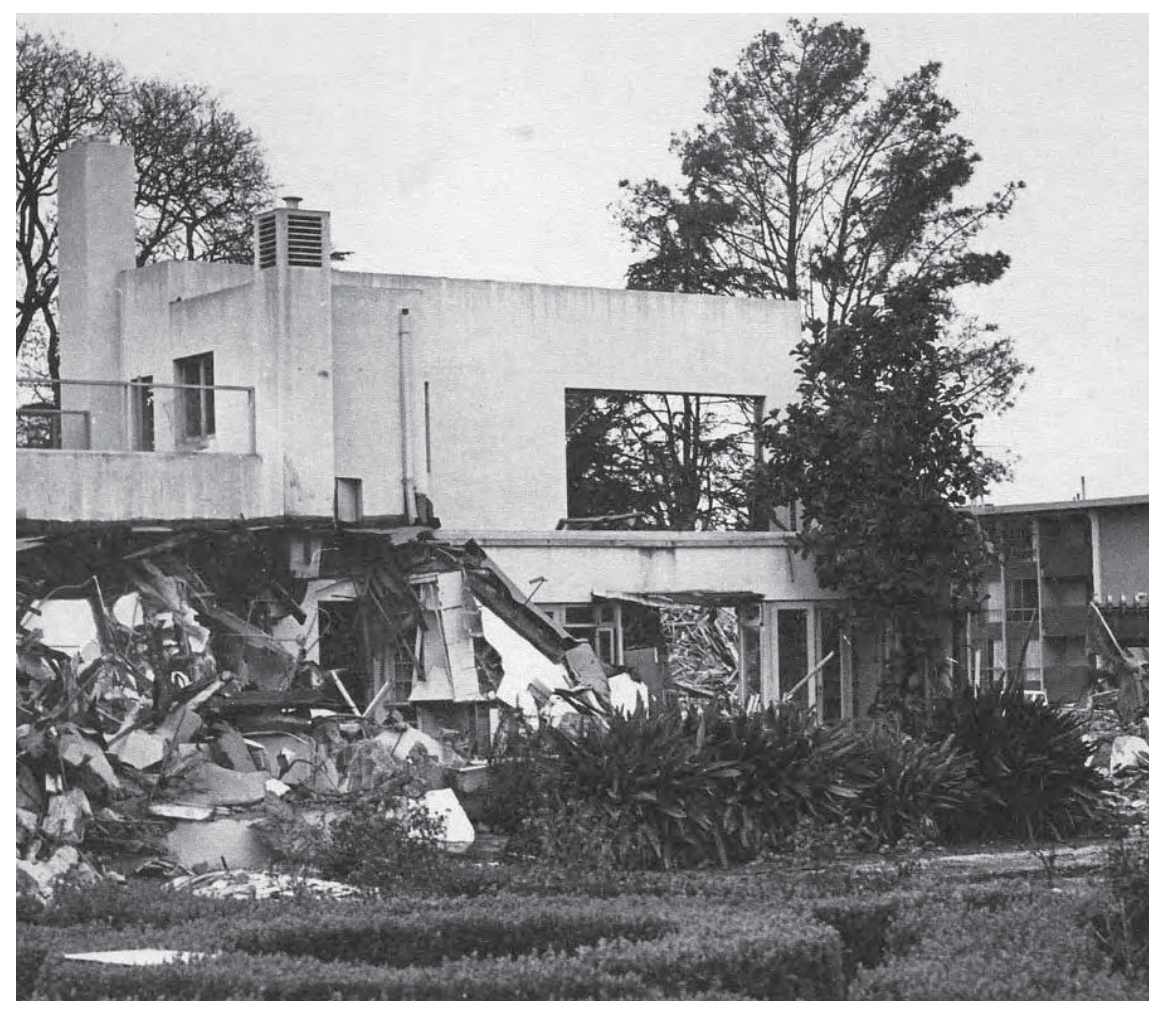

Demolición de la Dodge House de Irving Gill, 1970. Fuente: Susan Morgan

Página siguiente: Portada del libro de Esther McCoy 'Richard Neutra', 1960 bientadas en los bajos fondos de Los Ángeles. Uno de los temas urbanos que captó su atención nada más llegar a California fue, precisamente, el de la situación de degradación de inmensas áreas del centro de la ciudad, ocupadas por inmigrantes sin recursos y en las que la municipalidad, por medio de los fondos federales de los programas de erradicación del chabolismo de la Administración Roosevelt, estaba llevando a cabo una demolición sistemática de barriadas obreras. Fue su primera toma de conciencia con la necesidad de vivienda económica de calidad para hacer frente a la transformación del territorio que se estaba produciendo como consecuencia de la especulación y de la inmigración masiva al estado durante la época de la Gran Depresión y, después, durante la guerra. Ella misma vivió esos primeros años de forma muy modesta en una playa solitaria de Malibu, hasta que gracias a su trabajo y a los ahorros que traía de Nueva York pudo adquirir por apenas 1.500 dólares un bungalow en Santa Mónica, con vistas al océano y en el que vivió hasta su muerte en 1989 .

En plena movilización general de fuerzas productivas llevada a cabo durante la Segunda Guerra Mundial, McCoy fue contratada por la Douglas Aircraft como delineante en un departamento de ingeniería. Su supervisor directo fue el arquitecto ${ }^{46}$ y constructor Rodney Walker, antiguo colaborador de Schindler y futuro autor, entre 1946 y 1948 de tres Case Study Houses. Terminada la contienda trató de ingresar en la Escuela de Arquitectura ${ }^{47}$ de la Universidad de California que en los años 40 acababa de poner en marcha un novedoso programa académico. No obstante, el hecho de ser mujer y de tener más de cuarenta años motivó que su solicitud fuese denegada. Lejos de desanimarse, en cuanto se enteró de que Schindler buscaba un nuevo delineante fue a visitarle ofreciéndose para el puesto. Llevando como portfolio sólo los dibujos que ella misma había realizado para la renovación de su casa en Santa Mónica, no esperaba en absoluto una respuesta favorable pero el arquitecto valoró su resolución y la contrató inmediatamente como delineante. McCoy trabajó para él entre 1944 y 1947. Cada día ella escribía hasta las once de la mañana y luego se dirigía a Kings Road para pasar allí el resto 
de la jornada a las órdenes de Schindler dibujando en uno de los tableros tan bajos que se usaban en su estudio y que ella, bromeando sobre su afición a contravenir las convicciones de Schindler, ridiculizaba como muebles incómodos y poco prácticos. Por su parte, Schindler, solía tomarle el pelo por su perfección en el trazado de las líneas, que él prefería mucho más naturalistas e imperfectas, como su propia arquitectura. El arquitecto y la historiadora en ciernes se hicieron grandes amigos y, como ha sugerido Raymond Neutra, conociendo el carácter de Schindler, no es descartable, que ambos tuviesen algún tipo de affair, una hipótesis que, como se vio, defendía Dione Neutra.

Fue precisamente en esa época en Kings Road donde comenzó su carrera como crítica e historiadora de la arquitectura, publicando, en 1945, un artículo sobre su mentor en la revista de tendencias socialistas Direction, donde celebraba la arquitectura espacial de Schindler.

Justo enfrente del estudio de Schindler se ubicaba la Dodge House (1916) de Irving Gill. Años más tarde, en la década de los 60, McCoy lideró una campaña para salvaguardar esta obra maestra de la arquitectura californiana de la primera generación; escribió sobre ella e, incluso, produjo un pequeño corto dirigido por Robert Snyder. Pese a sus esfuerzos, la casa fue finalmente demolida en 1970, poniendo de manifiesto el desinterés generalizado de la ciudad y de sus autoridades por la arquitectura y la historia moderna de Los Ángeles. La desaparición de la Dogde House fue el inicio de un movimiento organizado para poner en valor la calidad de ese patrimonio y, por supuesto, para exigir la urgencia de políticas preservacioncitas que se tomaran en serio el legado de una modernidad cuya falta de aprecio local resultaba alarmante pese a su reconocimiento internacional.

Esther McCoy escribió seis libros de arquitectura. Algunos de ellos son estudios monográficos sobre un autor (Craig Ellwood, Richard Neutra), otros tienen un carácter temático (Five California Architects / Case Study Houses/ Vienna to Los Angeles, The Second Generation) pero en todos aparecen una y otra vez los mismos protagonistas, los arquitectos que la autora trata como héroes literarios que pueblan varias de sus obras. En unas, son caracteres principales; en otras se mantienen en un segundo plano, como figuras que enriquecen con sus matices un relato que se escribe una y otra vez desde distintos ángulos, pero siempre abordado desde sus propios afectos personales -una forma de hacer historia que, por cierto, elogiaron Robert Venturi y Denise Scott Brown cuando afirmaron: "En Five California Architects en 1961 [sic.] y en The Second Generation en 1984, Esther McCoy estableció lo que podríamos considerar un nuevo género, relacionando historia social y crítica de arquitectura con la minuciosa observación que realiza un novelista de sus propios personajes: McCoy produce una crítica arquitectónica con rostro humano" 48 .

Además de Entenza49, otro de los casos más fácilmente detectables de favoritismo de la autora por un arquitecto es el de Rudolph Schindler, su amigo, mentor y posiblemente amante durante algún tiempo y a quien benefició en sus historias, sobre todo si se compara con Richard Neutra con quien McCoy, como ya se comentó, chocó frontalmente durante la preparación de su monografía al detectar que éste pretendía influir en sus escritos y que trataba de engañarla con las fechas de la casa Lovell. Su primer artículo sobre arquitectura estuvo dedicado a Rudolph Schindler y éste fue también un autor clave de su primer libro, Five California Architects, una obra a todas luces fundamental para la historiografía californiana.
MASTERS OR WORLW ARCHUTECTULH richard neutra

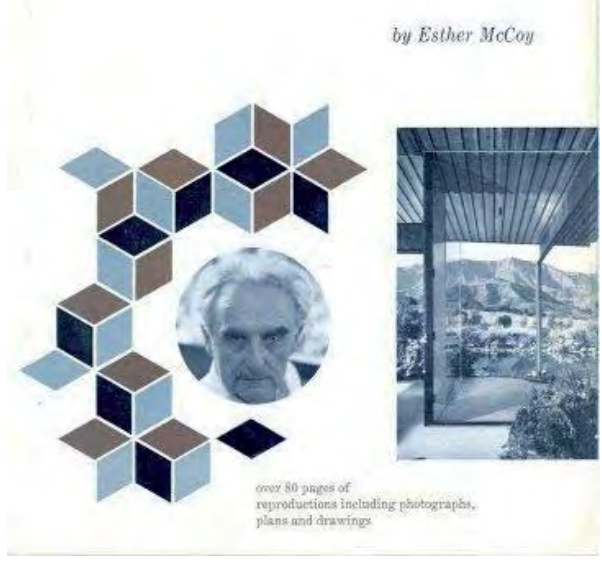




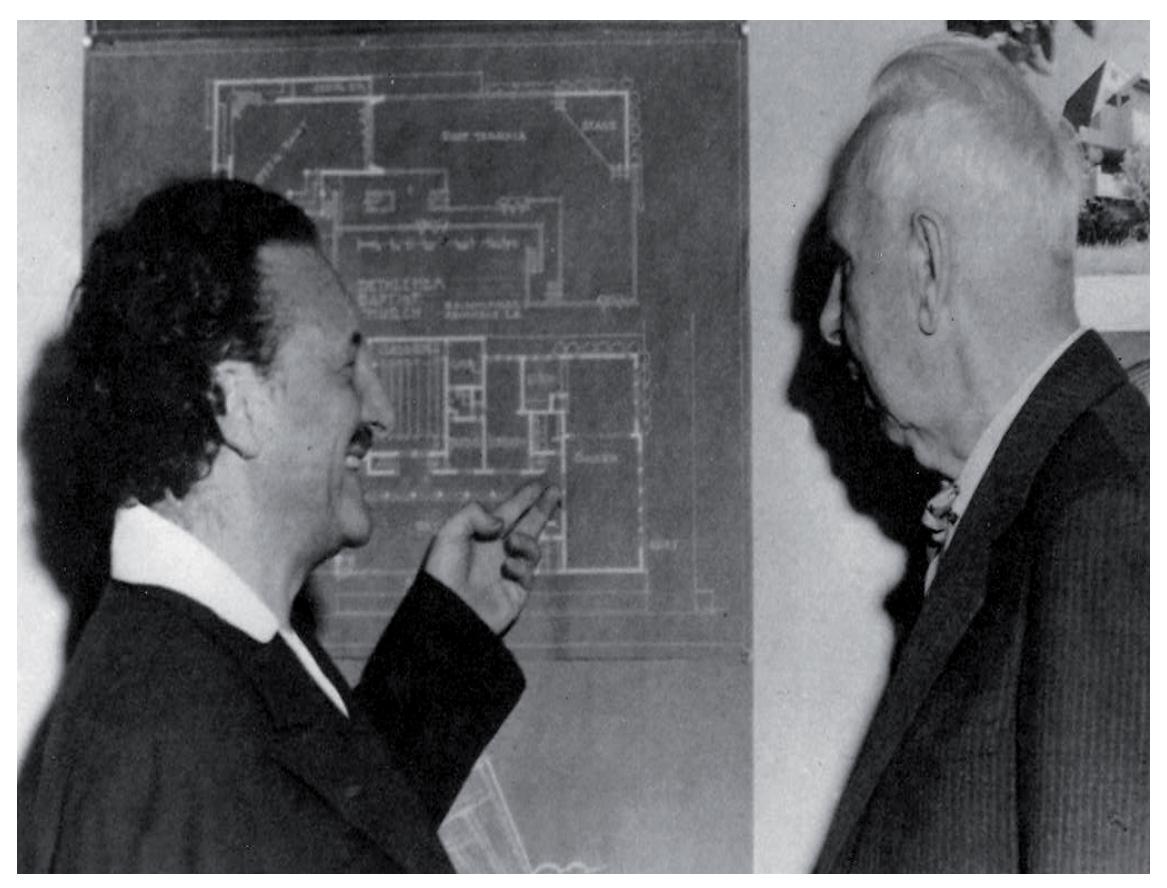

Rudolph Schindler y Theodore Dreiser en el estudio de Schindler en Kings Road, 1944. Fuente: Susan Morgan

Página siguiente: Portada del libro de Esther McCoy 'Vienna to Los Angeles', 1971
En 1953, Schindler fallecía en Los Ángeles prácticamente olvidado. Su muerte apenas atrajo la atención de los medios, salvo por unos cuantos arquitectos, críticos y amigos de su círculo próximo entre los que, tomando el relevo a Pauline, Esther McCoy lideró el proceso de su recuperación histórica. Después de haber escrito varios artículos sobre Schindler, en 1960, McCoy decidió publicar un libro integrado por varios capítulos dedicado a cinco de los arquitectos californianos más olvidados y que ella consideraba que debían ser urgentemente reivindicados en su faceta de pioneros de la modernidad del Sur de California. Five California Architects ${ }^{50}$ fue un trabajo inaugural. El libro se centraba en dos generaciones: una, la de Greene \& Greene (cuyo capítulo estaba escrito por Randell L. Makinson), Irving Gill y Bernard Maybeck; la otra, la del propio Schindler, inmediatamente posterior. Aunque la autora no se había propuesto en reescribir una nueva de la arquitectura californiana, su obra tuvo un efecto inesperado poniendo sobre la mesa algunos temas de discusión que, hasta el momento, no se habían considerado. Gracias a Five California Architects, hacia finales de los 60 y principios de los 70, otros autores como el austriaco Hans Hollein, el californiano David Gebhard o el británico Reyner Banham comenzaron a investigar sobre la obra de Schindler, intuyéndose sólo por aquel entonces que asunciones como que la importación de las ideas europeas directamente a California a través de autores como Schindler o Neutra no era el único fenómeno que podría explicar la gestación de una modernidad tan desconocida como original y que, en aquel territorio periférico, convivían otras tradiciones arquitectónicas locales de indudable interés y que debían ser exploradas.

Desde la muerte de Schindler, McCoy llevaba trabajando en esta genealogía en la que fueron fundamentales los trabajos de Lewis Mumford y, sobre todo, de Harwell Hamilton Harris y de su mujer Jean Murray Bangs, la auténtica descubridora de la obra de Maybeck y de los hermanos Greene. A pesar de su decisiva influencia sobre su trabajo, llamativamente, McCoy no reconoció en su libro la labor de ninguno de ellos. Es imprescindible señalar esta circunstancia pues McCoy conocía y había manejado la información y los escritos publicados por Jean Murray Bangs Harris. De hecho, un artículo de McCoy sobre estos arquitectos publicado en Los Angeles Times el 19 de julio de 1953 incluía la fotografía de los hermanos Greene que, por encargo 
de los Harris, había realizado Cole Weston en 1947 y que la historiadora no acreditó en su procedencia. En este sentido, también resulta significativo que Five California Architects carezca de una bibliografía final.

Por su parte, el libro de Lewis Mumford Roots of Contemporary American Architecture, publicado por Reinhold en 1952 y basado en los trabajos de recuperación de los Greene y de Maybeck llevados a cabo por los Harris, hacía referencias a la obra de Greene \& Greene, Maybeck y Gill como arquitectos pioneros en la Costa Oeste. McCoy tampoco lo citó a pesar de que, casi con total seguridad y a juzgar por la similitud de sus títulos, éste fue la inspiración para su exposición de 1956 Roots of California Contemporary Architecture y cuya investigación dio origen a Five California Architects.

Un par de años antes, la historiadora había organizado otra exposición en memoria de Schindler inaugurada en la galería Landau a finales de mayo de 1954, justo una semana antes de la apertura al público de la exposición itinerante sobre Wright (Sixty Years of Living Architecture). Su exhibición en Los Ángeles, en el Barnsdall Park -el mismo lugar que 30 años antes había traído a ambos arquitectos a Los Ángeles-, era la octava edición de una muestra que había suscitado una gran la atención por parte de los medios nacionales por lo que, consciente de la repercusión de la misma, McCoy hizo todo lo posible para adelantar la inauguración de su exposición sobre Schindler a la de Wright y que ambas coincidieran en el tiempo ${ }^{51}$.

A través de estas dos exposiciones y de la compilación de su contenido en Five California Architects, con el apoyo incondicional de John Entenza, que le prologó el libro, McCoy se garantizó una posición privilegiada como la principal historiadora de la modernidad de la Costa Oeste. McCoy y Entenza se habían conocido en 1932, aunque su colaboración profesional comenzó en 1950 y, desde entonces, fue cada vez más intensa. A partir de Five California Architects y de la monografía sobre Richard Neutra ${ }^{52}$, la influencia del editor en sus escritos resultó decisiva. Por un lado, como tributo a su amigo y soporte financiero -Entenza ya era oficialmente el Director de la Graham Foundation y estaba en disposición de sufragar mediante becas las obras de McCoy- la historiadora inició su siguiente trabajo, Case Study Houses como exaltación del legado de Entenza. Por otro lado, al igual que Entenza, consciente de que estaba haciendo historia con cada nuevo escrito, McCoy trató de ser reconocida como pionera, una razón que explicaría su interés por ocultar sus fuentes, ya fueran éstas Pauline Schindler o Jean Murray Bangs e, incluso, no pareció importarle extender errores o dar por válidas informaciones sin contrastar con tal de tener la exclusiva de una primicia o el argumento de una buena narración histórica, como se explicó en el apartado dedicado al episodio del encargo Lovell. En éste, se trató precisamente de demostrar que McCoy tomó partido por Schindler e hizo todo lo posible para hacer creer que dicho episodio había sido el motivo de su ruptura con Neutra. Por todo ello, resulta difícil respaldar la opinión de Paul Goldberger, crítico del New YorkTimes, cuando afirmó "no es cierto que no hubiera arquitectura en California antes de Esther McCoy, simplemente nadie antes había escrito sobre ella y, por eso, McCoy, marcó toda la diferencia"53. A pesar de haber sido una excelente divulgadora de la modernidad del Sur de California, McCoy no fue ni la figura pionera, ni el agente solitario que generalmente se piensa.

Como ejemplo de su mejor legado documental es imprescindible citar Vienna to Los Angeles: Two Journeys ${ }^{44}$ (De Viena a Los Ángeles: dos viajes), probablemente -junto con The Second Generation ${ }^{55}$ - el mejor libro de Esther

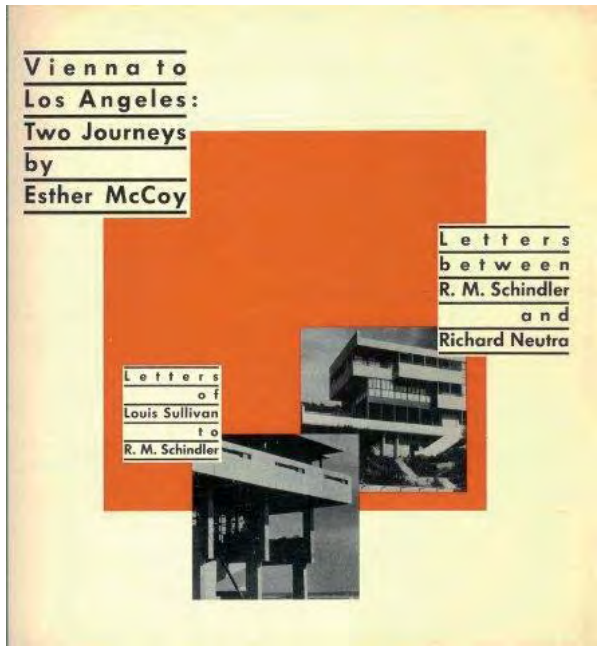


McCoy, además de la obra de la que quedó más satisfecha de todas sus publicaciones. Al igual que The Second Generation se trata de una obra de difícil localización ya que ambos textos no han sido reeditados desde su aparición hace más de treinta años.

John Entenza jugó un papel crucial en la producción de este libro que fue financiado gracias a una beca de la Graham Foundation for Advanced Studies in Fine Arts de la que el editor de Arts \& Architecture fue Director de 1960 a 1971. Entenza, junto con su sucesor al frente de la revista, David Travers, era además propietario de la editorial Arts + Architecture Press que publicó Vienna to Los Angeles.

Harris escribió un texto introductorio al libro cuya narración del ambiente de la casa de Kings Road, el reconocimiento de la importancia cultural del círculo de los Schindler y su experiencia formativa junto a Richard Neutra, así como su calidad literaria, ya justificarían por sí solos el interés de esta publicación. Es importante reparar en el hecho de que, a pesar de que Harris escribiera un texto tan beneficioso para el prestigio de McCoy, la historiadora, en el capítulo que le dedicó en The Second Generation, al hablar de la influencia de los hermanos Greene sobre la obra de Harris, como ya hiciera en Five California Architects, ignorara por completo a su mujer Jean Murray Bangs.

Vienna To Los Angeles relata la aventura profesional de Schindler y Neutra desde sus años de estudiantes en Viena hasta su llegada a Los Ángeles. A pesar de sus inexactitudes, errores cronológicos ${ }^{56}$ y evidente toma de partido por Schindler, éste es un libro fascinante. En efecto, en su crítica ${ }^{57}$ de 1979 al libro Vienna to Los Angeles, su discípula, la historiadora Kathryn Smith ensalzaba a McCoy subrayando su posición de observadora privilegiada y su "única cualificación para escribir sobre qué causó realmente la ruptura [entre Schindler y Neutra] y de quién fue la culpa". Smith afirmaba que a pesar de que aún no se había oído toda la historia y que aún estaba pendiente la aparición de la biografía de Neutra y la publicación de las cartas de Dione Neutra, el lector podría sacar sus propias conclusiones del libro de McCoy, respaldando implícitamente su versión de los hechos.

La investigación de Vienna to Los Angeles se basó en buena medida en la correspondencia del archivo de Schindler, entonces todavía en Kings Road, a la que la autora accedió libremente dada su estrecha amistad con Pauline. En su entrevista ${ }^{58}$ con Joseph Giovaninni realizada poco antes de morir, Esther McCoy relataba que buena parte del libro se basaba igualmente en las cartas procedentes del material de la Fundación Wright que la historiadora poseía de manera ilícita porque Betty Barnsdall, la hija de Aline Barnsdall, lo había sustraido de Taliesin y, más tarde, a través del arquitecto Bruce Richards, se lo había entregado a ella en los años 50. McCoy confesaba también que, por razones obvias, no citaba la procedencia de las cartas que reproducía en su libro -un modo de proceder habitual en la historiadora, como se ha comentado. McCoy afirmaba además que, tras concluir el libro, había encontrado la solución para devolver el material a Taliesin sin levantar sospechas. Ésta había consistido en encomendar la tarea a la historiadora Kathryn Smith quien, por aquel entonces (1978), trabajaba, también bajo otra beca de la Graham Foundation, en su estudio monográfico sobre la Hollyhock House -citado recurrentemente en el capítulo primero de esta tesis doctoral. En su entrevista McCoy decía haber entregado fotocopias de todos estos documentos junto con el resto de sus archivos que donó a la colección de los Archives of American Art de la Institución Smithsonian que se conserva en Pasadena. 
En esa misma entrevista, McCoy sostenía que su pupila Kathryn Smith, poco después de la muerte de Pauline Gibling Schindler había procedido de manera similar con parte de los documentos de Pauline que ésta guardaba en Kings Road. De acuerdo con la versión de McCoy, Smith le había pedido ayuda para sacar determinados materiales (notas biográficas, correspondencia, material sobre Wright y una novela no publicada con Schindler como protagonista), aduciendo que éstos debían quedar fuera del alcance de Thom Hines, dadas sus simpatías hacia la obra de Neutra por delante de la de Schindler y de la figura de Pauline. Eximiéndose de toda responsabilidad McCoy terminaba su relato justificando su confesión y advirtiendo que: "todo escritor o estudioso de los Schindler o de Wright debería saber acerca de la existencia de este material, como también de los documentos sustraídos por Betty Barnsdall y Bruce Ricahrds de los archivos de Taliesin" (La transcripción del fragmento completo correspondiente a este episodio se reproduce en su original en inglés en el apartado Notas ${ }^{59}$ ).

La apreciación, tanto por parte de McCoy como de Smith de Thomas Hines como partidario de Neutra frente a Schindler es insostenible. Así lo prueban los escritos de este historiador donde, en absoluto, la figura de Rudolph Schindler es menospreciada en favor de la de su compatriota. Al contrario, Hines fue uno de los primeros en dar a conocer la labor editorial de Pauline. Es más, la incorporación como material anexo al final de su monografía de las cartas que Richard Neutra y los Lovell intercambiaron a finales de los años 60 y principios de los 70, y en las que el arquitecto trataba de descargarse de la culpa histórica de haber robado el encargo a su amigo, a pesar de favorecer a Neutra, pueden considerarse como un intento por parte de Hines de ayudar a esclarecer la verdad. Por ello es relevante esta sospecha de McCoy hacia el trabajo de su colega. Si a esta cuestión se suma la amistad de McCoy con los Schindler y los recelos hacia Neutra, es evidente que el posicionamiento de McCoy siempre fue en favor de Schindler. En este sentido, contrastando su descripción de los hechos en Vienna to Los Angeles, teniendo en cuenta el análisis de la correspondencia aportado por Raymond Neutra y, más recientemente, el material de archivo localizado en la Universidad California en Santa Barbara por John Crosse, con documentos que vincularían a Schindler con la construcción de la Lovell House, es lógico pensar que el episodio de la supuesta ruptura entre ambos con motivo del célebre encargo fue deliberadamente novelado por Esther McCoy.

Una de las escasas posturas críticas respecto a determinadas actitudes de McCoy y sus procedimientos metodológicos, especialmente sobre la forma de adquirir o emplear documentos originales para promocionar a determinados arquitectos, es la que ha mantenido Meredith Clausen, Profesora de Historia de la Arquitectura en la Universidad de Washington y con quien se han intercambiado impresiones por correo electrónico a partir de la discusión de su artículo ${ }^{60}$ desmitificador de Craig Ellwood publicado en la revista Casabella en 1999. Ellwood utilizó hábilmente la atracción que sentían por él tanto Entenza como McCoy para promocionar su obra. Este argumento, apuntado por Erin Ellwood, la hija del arquitecto, y ratificado por otro de sus biógrafos, Neil Jackson ${ }^{61}$, abriría una compleja discusión en la que no conviene entrar en este documento. Simplemente, se ha recurrido a este ejemplo para señalar, una vez más, la necesidad de leer a McCoy con precaución ya que, en el caso de la monografía ${ }^{62}$ que dedicó a este arquitecto, la historiadora actuó por interés personal. McCoy escribió esta obra por encargo. El libro, todo un panegírico, fue enteramente sufragado por Craig Ellwood, evitaba la crítica y, como en Five California Architects, tampoco aportaba bibliografía.
Portada del libro de Esther McCoy 'Craig Ellwood', 1968

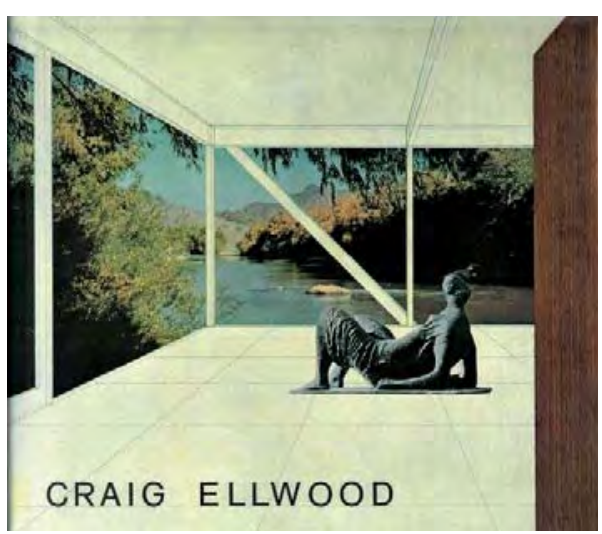




\section{Notas y referencias bibliográficas}

1. John ENTENZA: "The Case Study House Program. Announcement", en Arts \& Architecture, enero 1945 , p. 38.

2. Dana CUFF: The Provisional City: Los Angeles Stories of Architecture and Urbanism. Cambridge, MA: The MIT Press, 2002 (primera edición 2000), pp. 228-229.

3. Architectural Forum, enero de 1944, citado por Dana Cuff en Ibid., p. 229

4. En cualquier caso, todas estas publicaciones especializadas y también las revistas destinadas a un público más amplio, como House Beautiful, promovían que la casa fuera, ante todo, eficiente y práctica; que en la mayoría de las ocasiones que tuviera tres dormitorios y dos cuartos de baño, un estar, una cocina perfectamente equipada y un jardín, espacio suficiente para el almacenaje de vehículos y enseres, amplias superficies acristaladas e instalaciones de climatización. E independientemente de su formalización arquitectónica y preferencias estilísticas, estos criterios de diseño eran compartidos tanto por los arquitectos modernos como por los agentes del mercado inmobiliario, cuyos principales promotores en Los Ángeles -por acotar el área de la discusión-, en el fondo, manejaban una definición de lo doméstico y una serie de roles sociales compartidos tanto por sectores más conservadores como por plataformas progresistas como la de Arts \& Architecture.

5. Esther McCOY: Case Study Houses 1945-62. Santa Monica, CA: Hennessey + Ingalls, 1977 (edición orginal New York: Reinhold, 1962), pp. 8-9.

6. Cfr. Esther McCOY: "Los Angeles Case Study Houses: When Shelter was an ArtForm", en Los Angeles Times, 8 octubre 1989, artículo consultado en su edición digital.

7. Dana CUFF: Op.cit., p. 230

8. De acuerdo con Dolores Hayden, el $27 \%$ de la población femenina norteamericana fue empleada en la industria bélica durante la Segunda Guerra Mundial. Cfr. Dolores HAYDEN: "Model Houses for the Millions. Architect's Dreams, Builder's Boasts, Residents Dilemmas", en en AA. VV., Elizabeth A. T. SMITH, (ed.): Blueprints for Modern Living: History and Legacy of the Case Study Houses. Cambridge, MA: The MIT Press, 1989 , p. 203

9. Ibid.

10. Cfr. Mike Davis: Ciudad de Cuarzo. Arqueología del futuro en Los Angeles. Madrid Lengua de Trapo, 2004. (edición original City of Quartz: Excavating the Future in Los Angeles. London, New York: Verso, 1990), p. 45

11. Cfr. Esther McCOY: Case Study Houses 1945-62. Op. cit., p. 19.

12. Cfr. Dana CUFF: Op.cit., p. 230.

13. Cfr. Esther McCOY: Case Study Houses 1945-62. Op. cit., p. 10.

14. Ibid., p. 10

15. Fritz B. Burns, oriundo de Minneapolis, había llegado a Los Ángeles sirviendo como subteniente de infantería en los años de la Primera Guerra Mundial. Sus inicios profesionales en el campo de la industria inmobiliaria vinieron con una oportunidad de trabajo como comercial para la empresa Dickinson \& Gillespie, que estaba desarrollando gran parte del área de la ciudad conocida como Palisades del Rey. En pocos años, Burns logró crear su propia compañía y convertirse en uno de los promotores más importantes del Sur de California. Fundada en la década de 1930, la Marlow-Burns Development Company se caracterizó por su interés en la innovación constructiva, introduciendo muy pronto las más novedosas técnicas de prefabricación para producir viviendas económicas. Tras la Segunda Guerra Mundial, Burns se asoció con Henry J. Kaiser, formando Community Homes, compañía que orientó sus objetivos a suplir la escasez de vivienda derivada de las nuevas condiciones socioeconómicas impuestas por la guerra, en especial, los grandes movimientos migratorios que jalonaron los años centrales de la década de los años cuarenta. A través de estas empresas, Burns construyó miles de atractivas viviendas, muy bien equipadas a pesar de su asequible precio que consiguió ajustar a menos de 4.000 dólares y que vendía exigiendo sólo un primer pago de 150 dólares. Burns fue líder indiscutible en el desarrollo residencial del área de Westchester / LAX (las inmediaciones de Playa del Rey al Aeropuerto Internacional de Los Ángeles), aunque también construyó otras muchas urbanizaciones en otros lugares del Sur de California e, incluso, en el Área de la Bahía o Hawai.

16. Cfr. Greg HISE: Magnetic Los Angeles: Planning the Twentieth-Century Metropolis. Baltimore, MD: Johns Hopkins University Press, 1999 (primera edición 1997), p. 180.

17. Thomas HINES: "The Search for the Postwar House", en en AA. VV., Elizabeth A. T. SMITH, (ed.): Blueprints for Modern Living: History and Legacy of the Case Study Houses. Op. cit., p. 173 .

18. Julius SHULMAN: Epilogue, en Elizabeth A. T. SMITh, Peter Goessel (ed.): Case Study Houses. The Complete CSH Program 1945-1966. Köln, New York: Taschen, 2002, p. 436

19. Concretamente, Arts \& Architecture publicó los siguientes proyectos: Park Planned Homes, $A \& A$, noviembre 1945, pp. 32-35; edificio de apartamentos, $A \& A$, marzo 1946, p. 40; Hillside House, $A \& A$, diciembre 1948, pp.26-27; y Exhibition House at the Museum of Modern Art (vivienda experimental en el patio del MoMA), A\&A julio 1950, pp. 40-42 y 50, que, por cierto, se publicó justo a continuación de un extenso reportaje sobre la propia vivienda de John Entenza construida por Charles Eames y Eero Saarinen en Pacific Palisades ( $\mathrm{CSH} n^{\circ}$ g). Y no deja de ser llamativo el hecho de que de todos los conjuntos de vivienda proyectados o construidos por Gregory Ain, Arts \& Architecture únicamente publicara Park Planned Homes (Altadena, CA, 194648) y sólo en fase de proyecto.

20. Anthony DENZER: Gregory Ain. The Modern Home as Social Commentary. New York: Rizzoli, 2008, p. 171

21. Esther McCOY: "Arts and Architecture Case Study Houses", en AA. VV., Elizabeth A. T. SMITH, (ed.): Blueprints for Modern Living: History and Legacy of the Case Study Houses. Op. cit., p. 19

22. Ibid.,nota 2, p. 39

23. Julius SHULMAN: Epilogue, en Elizabeth A. T. SMITH, Peter Goessel (ed.): Case Study Houses. The Complete CSH Program 1945-1966. Op. cit., p. 436.

24. De acuerdo con su amigo el arquitecto Stanley Tigerman, el editor era receloso de hacer comentarios sobre sus propias ideas, especialmente las más conflictivas. Igualmente se esforzó por ocultar su orientación homosexual. Este desajuste entre su auténtica naturaleza y su fachada pública determinaron su compleja personalidad y limitaron 
asimismo sus relaciones con los demás, volviéndole desconfiado e, incluso, suspicaz, irascible y paranoico a pesar de que trató de mantener siempre un aura de serenidad y unos modales exquisitos que, lógicamente, chocan con sus traumáticas rupturas con antiguos amigos y colaboradores como, por ejemplo, el matrimonio Eames.

25. LAUTNER, John: Responsibility, Infinity, Nature. Entrevista con Marlene L. Laskey (junio-julio 1982). Los Angeles: Oral History Program, University of California Los Angeles (UCLA), 1986

26. Esther McCOY: Case Study Houses 1945-1962. Op. cit., p. 8.

27. Atendiendo a los créditos de la revista, las oficinas de California Arts \& Architecture estuvieron en el 3221 Oeste de la Calle Sexta hasta septiembre de 1935, momento en que se trasladaron al 2440 Oeste de la Calle Séptima, donde permanecieron hasta que, junio de 1940, Entenza las trasladó al 3305 de Wilshire Boulevard para alejarse del matrimonio Harris. Respecto a Johnson, ésta aparecía como secretaria en los créditos de la revista desde febrero de 1932. Jere Johnson se convirtió en propietaria de la revista en diciembre de 1936 tras la muerte de su predecesor, George Oyer, manteniendo a Mark Daniels como editor y se ocupó también de las tareas de dirección de la revista tras la marcha de Daniels. Merle Armitage permaneció en el consejo editorial de la revista desde 1933 hasta 1938 y, con casi toda probabilidad, fue a través de él como entraron en la revista tanto Pauline Schindler como Jean Murray Bangs, aunque -como se vioPauline Schindler ya había escrito un artículo en CA\&A en 1930 sobre los interiores de los almacenes Bullock's Wilshire.

28. Cfr. Esther McCOY: "Arts and Architecture Case Study Houses", en AA. VV., Elizabeth A. T. SMITH, (ed.): Blueprints for Modern Living: History and Legacy of the Case Study Houses. Op. cit., p. 19

29. Victoria DALLEY: "Naturally Modern", en victoria Dalley, Natalie SHIVERS y Michael DAWSON: Introducción de William Deverell: LA's Early Moderns. Art/Architecture/ Photography. Los Angeles: Balcony Press, 2003, nota 72, p. 99.

30. Stanley TIGERMAN: Entrevista con Betty J. Blum para el Chicago Architects Oral History Projects, Art Institute of Chicago, 1998, p. 77.

31. Cfr. Barbara GOLDSTEIN (ed.): Arts \& Architecture. The Entenza Years. Santa Monica, CA: Hennessey + Ingalls, 1998 (edición original Cambridge, MA:The MIT Press, 1990), p. 7 .

32. Taschen ha preferido la reimpresión de un producto de mercado acabado a mostrar la complejidad de un proceso de evolución, con todos sus errores, titubeos y hallazgos. El hecho de que se hayan reimpreso los números de Arts \& Architecture desde $1945 \mathrm{im}$ pide disfrutar del interés de autores, portadas, e iniciativas del propio Entenza como el concurso Designs for Postwar Living de 1943.

33. En un correo electrónico compartido con John Crosse de marzo de 2011.

34. Tanto Susan Morgan como Win de Witt confirman que no hay nada parecido a un archivo de Entenza o de Arts \& Architecture y que sólo hay menciones o documentos de Entenza en otros archivos. Según Stanley Tigerman los documentos del editor y de la revista fueron perdidos o destruidos por su joven amante, Ken Butts, a quien Entenza había conocido en la playa de Santa Mónica y presentaba como su sobrino o hijo adoptado.
35. Conversación con el autor y con John Crosse en Playa del Rey, julio 2011.

36. Tras el fallido negocio conjunto de mobiliario con sus íntimos amigos Charles y Ray Eames, Entenza rompió con ellos en 1952, prescindió de su colaboración en la revista y puso en venta inmediatamente la casa en el terreno que compartía con ellos en Pacific Palisades.

37. "Escribí a Harwell Harris reprochándole que dijera cosas desagradables de John Entenza a Carter Manny. Manny me lo confesó, así como que estaba dolido por ello ". Esther McCOY: Oral History Interview with Esther McCoy, 1987 June 7-Nov. 14, Archives of American Art, Smithsonian Institution, p.46. En una de las cartas que Harris envió a McCoy explicaba su posición en los siguientes términos: "I am sorry to have hurt Carter Manny with my remarks about John Entenza. I thought I was only answering his question why I had never done a Case Study house. Stella Gramer had done the dirty work for John when it came to completing the contract with the builder of my house for John. Later, when Jere Johnson, owner and publisher of California Arts \& Architecture, asked us if we could suggest someone to look after the magazine while she was having a baby, we immediately suggested John because we knew he could at least write. I don't know exactly what the arrangement was between them but the taste it gave John made him want to have it (CA\&A) for himself and Jere never got it back. In the case of the contract for John's house, John and I sat in the outer office and the contractor was taken into Stella's office; when they came out the contract document had been altered and signed for only $\$ 3,120$, which was considerable less than the earlier figure. John looked and acted and probably felt entirely innocent. In the case of C.A.\& A, Neither Jean nor I was as close to the alteration of the agreement tha led to John's takeover, and Jere refused to talk about it. Jean admired Stella as a lawyer. Jean always said that what she wanted in a lawyer was a fighter and not a legal expert who told her why something couldn't be done...". Harwell Hamilton HARRIS: Carta a Esther McCoy fechada el 8 de novimebre de 1978, cortesía de Susan Morgan.

38. "Entenza's assistant, Susan Jonas, born in France, carried on correspondence in three languages with foreign editors who wanted permission to reprint a story, sometimes a whole issue. European, Latin American and Japanese magazines soon began publishing work of architects who first appeared in Arts \& Architecture. A magazine as flat a tortilla and sleek as a Bugatti with little advertising and no financial backing became the greatest force in the dissemination of information, architectural and cultural about California". Esther McCoy: Arts \& Architecture Case Study Houses. En AA. VV. Elizabeth A. T. SMITH (ed.): Blveprints for Modern Living: History and Legacy of the Case Study Houses. Op. cit., p.16.

39. Esther McCOY: "Los Angeles Case Study Houses: When Shelter was an Art-Form", en Los Angeles Times, 8 octubre 1989, artículo consultado en edición digital.

40. "No-one can write about architecture in California without acknowledging her as the mother of us all". Reyner BANHAM citado por Susan MORGAN: "Mother Modern", en Los Angeles Times, 28 septiembre 2011 (sobre la exposición Sympathetic Seeing: Esther McCoy and the Heart of American Modernist Architecture and Design, comisariada por esta misma autora, producida en el marco del programa Pacific Standard Time e inaugurada en el MAK Center de Los Angeles e inaugurada en septiembre de 2011).

41. Reyner BANHAM: Los Angeles. The Architecture of Four Ecologies. Berkeley y Los Angeles: University of California Press, 2001 (primera edición: Baltimore, MD: Penguin Books Inc., 1971), p. 3. 
42. Morgan ha reorganizado parte de la documentación, textos y escritos de Esther McCoy disponibles en los Archives of American Art de la Smithsonian Institution en Washington D. C. y Pasadena.

43. Susan MORGAN y Kimberli MEYER (ed.): Sympathetic Seeing: Esther McCoy and the Heart of American Modernist Architecture and Design. Los Angeles: MAK Center, 2011.

44. Esther McCOY y Susan MORGAN (ed.): Piecing Together Los Angeles: An Esther McCoy Reader. Los Angeles, East Borneo, 2012.

45. AA. VV., Elizabeth A. T. SMITH, (ed.): Blueprints for Modern Living: History and Legacy of the Case Study Houses. Op. cit.

46. Propiamente hablando, Rodney Walker era architectural designer, dado que no había obtenido licencia oficial para firmar como arquitecto en el estado de California.

47. Abierta en 1916, fue la primera escuela de arquitectura del Sur de California. Se refundó como College en 1945, y sus programas académicos fueron reorientados hacia la enseñanza de una disciplina más acorde con las necesidades de los nuevos tiempos. La USC Architecture School creó una auténtica escuela, en el sentido más amplio del término. Cohesionada por su énfasis en teorías sociales y en un planeamiento urbano progresista, apostó por enfocar la arquitectura residencial como un problema de producción industrial para dar solución a la escasez de vivienda asequible, considerando la prefabricación y el uso de nuevos materiales como las bases de un estilo doméstico auténticamente californiano. Sobre dichos programas, el claustro de profesores y la influencia de esta escuela en varias generaciones de arquitectos véase el trabajo de Deborah HOWELL-ARDILA: Writing Our Own Program. The USC Experiment in Modern Architectural Pedagogy 1930-1960. Thesis for the Degree Master in Historic Preservation. Los Angeles: Faculty of Architecture. University of Southern California, 2010.

48. Robert VENTURI y Denise SCOTT BROWN: "Re-Evaluation: Esther McCoy and The Second Generation", en Progressive Architecture, febrero 1990, pp. 118.

49. Poco antes de morir John Entenza, Esther McCoy escribió un texto laudatorio a su persona. El agradecimiento de su amiga a su mentor de toda la vida queda patente en este escrito que fue leído durante el servicio celebrado en memoria de John Entenza en la Graham Foundation: "De la media docena de no arquitectos que han hecho contribuciones significativas a la arquitectura de este siglo, John Entenza, seguramente, sea el más importante. En un momento crucial de la historia de la arquitectura, él adoptó una posición clara y firme y la mantuvo durante un cuarto de siglo. Lo que consiguió defendiendo un determinado arte, entonces bajo sospecha, es algo que sólo llegan a alcanzar muy pocas instituciones culturales con el apoyo de importantes sumas de dinero. John Entenza logró hacerlo todo él solo y fue algo parecido a obrar un milagro.

Arts \& Architecture mantuvo vivo el espíritu de los pioneros de la Costa Oeste en el Case Study House Program que él lazó personalmente; este programa supuso un puente substancial entre los maestros de la primera generación y los jóvenes arquitectos, rebosantes de talento y energía. Su apoyo incondicional a la nueva hornada de arquitectos californianos creó escuela, pudo detener el imparable avance del eclecticismo que hacia el final de la Segunda Guerra Mudial estaba arrasando en el Oeste y, al mismo tiempo, preservó la región de las estrechas miras de un regionalismo restrictivo.

Ahora bien, la principal aportación de John Entenza a la cultura arquitectónica del momento no estriba en su selección y presentación del trabajo de ningún hombre o grupo de hombres, sino en desmontar la idea romántica de construcción artesanal y abrir la visión de los arquitectos hacia la realidad de nuestra tecnología. Demostró mejor que nadie que la arquitectura puede ir de la mano con la tecnología sin resentirse estéricamente. Lo hacía cada mes publicando ejemplos de arquitectura actual que mostraban cómo el arte y la máquina eran compatibles.

Durante los años cuarenta, cuando la buena arquitectura necesitaba todo el consuelo que podía conseguir Arts \& Architecture fue un faro para arquitectos, editores y críticos. Los editores de las revistas del Este se entusiasmaron con el camino abierto por Entenza, y precisamente gracias a su valentía como editor, otros le siguieron mostrándose más receptivos ante obras que habian pasado desapercibidas o tratadas tímidamente en sus respectivas sus publicaciones.

La nueva dirección imprimida por John Entenza-ahora ya antigua pues se trata un camino ampliamente aceptado- tuvo un efecto inmediato sobre los arquitectos de Europa, Japón, México y Sudamérica. Arts \& Architecture era la publicación que los jóvenes arquitectos extranjeros seguían como revista de cabecera, y la admiración que logró para la arquitectura de los Estados Unidos aún sigue vigente. Arquitectos de Stuttgart, Rio de Janeiro, Tokio, Milán, Ciudad de México y tantos otros lugares del mundo devoraban sus páginas en los años cuarenta. Ser publicado en Arts \& Architecture suponía para ellos el mayor de los honores.

Lo que un solo hombre consiguió estratégicamente en el ámbito de las relaciones internacionales manteniendo una postura firme y un punto de vista claro constituye, hasta la fecha, uno de los principales triunfos logrados en el mundo de las publicaciones de arquitectura. Mientras que las revistas del Este, infinitamente mejor dotadas económicamente, se esforzaban por agradar a su amplia y diversa audiencia, siguiendo las novedades en lugar de producirlas, una delgada revista editada por un pequeño grupo con fondos limitados, lideró la vanguardia arquitectónica en los Estados Unidos.

Ninguna revista que haya tratado con rigor y profundidad cualquier disciplina artística ha conseguido nunca éxito económico o independencia financiera. La mayoría han fracaso pronto o se han mantenido vivas gracias al patrocinio de benefactores privados o de instituciones culturales. La historia de cualquiera de las artes en los Estados Unidos puede leerse a través de estos brillantes fracasos. La deuda contraída era proporcional al tiempo de supervivencia o al número de sus subscritores. El hecho de que Arts \& Architecture se posicionara en este importante e influyente grupo de revistas y que se mantuviera ahi durante tantos años sin ningún tipo de financiación externa, se debió enteramente a la tenacidad de su editor. Fue precisamente gracias a los numerosos sacrificios personales de John Entenza como Arts \& Architecture se convirtió en una de las revistas que conformaron el destino de las artes en los Estados Unidos. Si bien, para ser un hombre capaz de realizar tan singular contribución a la cultura del país y cuya revista se tiene internacionalmente en tata estima, llama la atención que su persona haya recibido tan poca atención. Su desinterés por la autopromoción y su extraordinaria modestia hicieron que diera a la revista una importancia mucho mayor que la que se concedía a sí mismo como individuo y, como resultado, el creador quedó sepultado bajo el peso de su propia creación.

No obstante, como individuo, más allá de su papel de director y editor de la revista, Entenza desempeñó un papel crucial como educador en el sentido más amplio del término. A través de sus relaciones personales ayudó a crear un clima propicio para el florecimiento de la arquitectura, el arte y de las humanidades; él favorecía los contratos, las aportaciones institucionales, el interés de los clientes, las contribuciones de diseñadores y fabricantes de muebles y de tantas otras personas cuya actividad fue decisiva en la conformación de un medio y de un ideal de buena vida moderna. Era plenamente consciente de que sólo gracias a un proceso continuo de educación en determinados valores podía llegar a realizarse buena arquitectura.

Muchos jóvenes arquitectos locales que han llegado a alcanzar reconocimiento internacional se nutrieron durante sus años de formación del coraje que imprimían las páginas de su revista. Es evidente que los esfuerzos de John Entenza impulsando talentos dieron sus frutos, como puede comprobarse en la acogida tanto nacional como internacional que tuvo el trabajo de estos arquitectos californianos. Desde 1950 doce Case Study Houses han recibido premios nacionales y tres de ellas han sido galardonadas en la célebre exposición de la Bienal de Arquitectura de Sao Paulo en Brasil. 
La habilidad de John Entenza para descubrir y potenciar los valores y la energía de los jóvenes arquitectos es poco menos que prodigiosa. Su éxito para hacer florecer el talento de los demás sólo puede explicarse desde el profundo apoyo que han recibido de él, de cómo se han sentido arropados por su humanidad y su grandeza personal. Como Director actual de la GRAHAM FOUNDATION FOR ADVANCED STUDIES IN THE FINE ARTS se ha optado por orientar la actividad de esta institución hacia iniciativas relacionadas con el fomento de la arquitectura y el arte, en el sentido en que éste también puede contribuir a la arquitectura. Ha sido responsable de la creación de un progresista y estimulante programa anual de becas para individuos e instituciones, de proveer fondos de investigación en diseño y planeamiento urbano de carácter municipal y estatal, de fomentar programas académicos en escuelas de arquitectura y proyectos de estudios avanzados en arquitectura y diseño, de potenciar seminarios, conferencias y publicaciones destinados a discutir aportando nuevas perspectivas a problemas urbanos y territoriales de plena actualidad. Bajo su dirección la Fundación ha sufragado importantes exposiciones en el Museo de Arte Moderno de Nueva York, el Art Institute de Chicago y, en breve, en el Smithsonian. Y, por supuesto, ha continuado buscando y apoyando a jóvenes talentos con novedosas ideas en sus respectivos campos. Ayudando a establecer la identidad cultural $y$ creativa de cada arquitecto y artista como individuo, John Entenza ha posibilitado que numerosos creadores hayan iniciado y completado sus proyectos y que de este modo hayan podido ejercer una considerable influencia sobre otros. Su continuo trabajo con la Fundación y su entrega personal a tantas iniciativas privadas y puestos oficiales de responsabilidad han convertido su carrera un valioso activo en el desarrollo de patrones culturales".

50. Esther McCOY y Randell L. MAKINSON: Five California Architects. New York: Reinhold Pub. Corporation, 1960.

51. De acuerdo con la opinión de John Crosse, no es a venturado suponer que McCoy deseara que Wright visitara la exposición sobre Schindler, algo de lo que no hay constancia, como tampoco sobre si la historiadora y el arquitecto se encontraron durante el paso de éste por Los Ángeles.

52. Esther McCOY: Richard Neutra. New York: George Braziller Inc., 1960.

53. Paul GOLDBERGER: "Architecture View: Learning to Take California Seriously". The New YorkTimes, 14 enero 1990.

54. McCOY, Esther: Vienna to Los Angeles. Two Journeys. Letters Between R. M. Schindler y Richard Neutra. Prólogo de H. H. Harris. Santa Monica, CA: Arts + Architecture Press, 1979 .

55. Esther McCOY: The Second Generation. Salt Lake City: Gibbs Smith Publisher, 1984.

56. Entre algunos errores cronológicos detectados figuran la fecha del fallo y exposición del Concurso de la nueva sede de la Sociedad de Naciones (1930 en lugar de 1927), el regreso de Neutra a los EEUU en 1931, cuando fue otoño de 1930, tomas de posición partidistas por Schindler frente a Neutra por la Lovell, como la edición de la entrevista a los Lovell que ya se comentó.

57. Kathryn SMITH: "Vienna to Los Angeles: Two Journeys, Letters Between R. M Schindler and Richard Neutra, Letters of Louis Sullivan to R. M. Schindler. Book Review", en L.A. Architect, septiembre 1979, p. 3. Artículo facilitado por John Crosse.

58. Oral History Interview with Esther McCoy. Archives of American Art, Smithsonian Institution, 1987. Entrevista editada por Susan Morgan en 2009.
59. [TRANSCRIPCIÓN INICIO CINTA 5, CARA A]

"JG: ...for the Archives of American Art, on Saturday, November 14, 1987, in Santa Monica. Esther?

EM: Before we start, I want to say something about the papers that were in my possession for several years, that came from the files at Taliesin. They came to me through Bruce Richards. Bruce, from Oklahoma, was a student of art at U.C. Berkeley, where Wright met him, and he asked him to Taliesin after seeing the exhibit of Bruce's work. Bruce threw over his...the school (he would soon have gotten his degree) and went to Taliesin. Betty Barnsdall came to Taliesin while Bruce was there. She was the daughter of Aline Barnsdall, for whom Wright designed the Barnsdall Hollyhock house. While she was there, and Bruce was there, a basement flooded, and Wright directed his boys to put the Wasmuth portfolio out in the sun to dry, and each to take one themselves. Betty used the occasion to go into the dead files and remove a stack, a hundred pages or so, on her mother. Betty Barnsdall was unhappy about her status; she was an illegitimate child, and she must have been eighteen at the time, something like that. So she took the files out of the basement, and after she read them she was very unhappy, and she and Bruce went, several evenings, to a beer joint, near Taliesin, to talk. Then she left Taliesin suddenly, and she gave Bruce the files to return. He was called on the carpet, however... JG: Have you any idea what date this was?

EM: This would be the 30 's. Bruce was called on the carpet, and they were unfriendly about his going to beer joints, and he did not want to involve Betty Barnsdall, so he left. But he had no opportunity to return the files, so he took them with him. Wright was friendly with Bruce after Bruce began designing houses in La Jolla, where he opened an office. So Bruce was eager not to return the files, not knowing a way to return them without involving Betty. In the late 50's, he gave them to me, and asked me to find a way to return them. My concern with the removal of the files, in getting them back in, was that they not be laid to Schindler. Because of my connection with Schindler, it might be assumed that he had taken them out. I quoted from the letters in the files on several occasions, and very heavily in Vienna to Los Angeles, never attributing them. Then I found a way to get them back to Taliesin. I gave the files to Kathryn Smith in 1978. She was finishing a book she was writing on two grants on the Barnsdall house. She agreed not to mention Bruce Richards on returning them. She reported later to me that she had been forced to tell them, at Taliesin, where the files came from, but she did not return them. Nine years later, now, she still has them. I have photocopies of all, and they are with my papers at the Archives of American Art, at the Smithsonian collection point in Pasadena, where they are available to researchers. In the meantime, after the death of Pauline Schindler, Kathryn Smith asked if I would abet her in removing Pauline's papers to her place for safekeeping, as she expected to start a book on Pauline as soon as the one on the Barnsdall house was on the press. She especially wanted to keep them away from Tom Hines, for she considered that he would weight his sympathies to Neutra and away from Pauline. Kathryn still has the Pauline Schindler papers, which include material on Wright and also an unpublished novel, the protagonist of which is Schindler. Any [writer of a] study on Schindler as well as Wright should be aware of this material, and they should know of Betty Barnsdall and Bruce Richards' part in removal of the files from Taliesin".

6o. Véase Meredith L. CLAUSEN: "L'Art Center di Pasadena e lo strano caso di Craig Ellwood/The Pasadena Art Center and the Curious Case of Craig Ellwood"', en Casabella n०664, 1999, pp. 65-74.

61. Neil JACKSON: Craig Ellwood. London: Laurence King Publishing, 2002, p. 96.

62. Esther McCOY: Craig Ellwood. Venezia: Alfieri, 1968 (edición original New York: Walker Publishing Company, 1968. Reeditado por Santa Monica, CA: Hennessey + Ingalls, 1997). 



\title{
BIBLIOGRAFía
}

\author{
[ BILIOGRAFía ESPECífica ] ... \\ [ BILIOGRAFía CONSULtAdA ] ...
}


[ BILIOGRAFía ESPECífica ] ...

[ BILIOGRAFIA CONSULTADA 
HH. 1

RELACIÓN DE ARTÍCULOS CONSULTADOS ESCRITOS POR/SOBRE HARWELL HAMILTON HARRIS ENTRE 1934-1990 EN REVISTAS ESPECIALIZADAS/ PUBLICACIONES PERIÓDICAS INTERNACIONALES

La siguiente relación es cronológica, de fecha de publicación más antigua a más reciente:

\section{0}

POR H. H. HARRIS:

"Ein amerikanischer Flughafen", en Die Form 5, abril 19304, pp. 184-185 (artículo publicado por Neutra acreditando a Harris la autoría).

\section{4}

SOBRE H. H. HARRIS:

"Suggesting the Japanese", en House Beautiful, octubre 1934, pp. 72-73 (sobre la Pauline Lowe House).

SOBRE R. NEUTRA:

"Rush City Reformed", en A. C. n 5, Año IV, tercer trimestre 1934, p.15 (la revista del GATEPAC dedica un artículo al proyecto de Richard Neutra y cita, entre otros, a Harris como uno de los arquitectos colaboradores responsables de la propuesta).

\section{5}

POR H. H. HARRIS:

"In Designing the Small House", en California Arts and Architecture, enero 1935, pp. 20-21 (sobre la Pauline Lowe House. El número fue dirigido por Pauline Schindler quien, en calidad de editor invitada, seleccionó los textos, obras y proyectos que debían integrar este primer monográfico enteramente consagrado a la arquitectura moderna californiana). AVERY

SOBRE H. H. HARRIS:

OYER, George: "Concerning Competitions", en California Arts and Architecture, mayo 1935, p. 27 (sobre la Pauline Lowe House).

"California Charges", en Architectural Forum, junio 1935, p. 42 (sobre la Pauline Lowe house).

"101 New Small Houses", en The Architectural Forum, octubre 1935, pp. 316317 y 360-361 (sobre las casas Graham Laing y Pauline Lowe, respectivamente).

"A Frank Lloyd Wright House with a Hat On", en California Arts and Architecture, noviembre 1935, pp. 20-21 (sobre la Laing House). AVERY

"Pauline Lowe House, Graham Laing House", en Architect and Engineer, diciembre 1935, pp.42-45. AVERY 
"A House in Fellowship Park, Los Angeles", en California Arts and Architecture, marzo 1937, pp. 24-25 (sobre la propia casa de H. H. Harris en Los Angeles). AVERY

"Oriental Calm for the West", en House Beautiful, marzo 1937, p. 46 (sobre la casa de H. H. Harris en Fellowship Park, Los Angeles). AVERY

"House in Fellowship Park, Los Angeles, California", en Architectural Forum, abril 1937, pp. 278-81. AVERY

"Residence for John Entenza", en California Arts and Architecture, julio 1937, p. 33 (primera publicación del proyecto de la casa de John Entenza en Santa Monica). AVERY

"House in Fellowship Park", en Architectural Forum, agosto 1937, pp. 82-83 (Sobre las obras finalistas del Concurso organizado por el Glass Institute de Pittsburgh). AVERY

"Los Angeles Home of Miss Helene Kershner", en California Arts and Architecture, agosto 1937, p. 29. AVERY

"Walther Joel House, details", en The Architectural Forum, octubre 1937, pp. 264 y 353.

"Honor Awards for Residential Architecture. Southern California Chapter of the American Institute of Architects", en California Arts and Architecture, número especial noviembre 1937, pp. 10 y 12 (casas de Harris en Fellowship Park y Laing House).

1938

SOBRE H. H. HARRIS:

"A House for Miss Marion Clark at Carmel-by-the-Sea", en California Arts and Architecture, marzo 1938, pp. 27-29. AVERY

"Building types: Houses $\$ 7,500$ and under", en Architectural Record, marzo 1938, pp. 133-163 (en este amplio reportaje se cita la vivienda de Harris en Fellowship Park). AVERY

"A Dwelling for Mr. John Entenza, Santa Monica, California", en California Arts and Architecture, mayo 1938, pp. 26-27 (se publica, por primera vez, la casa ya construida). AVERY

"A Residence Designed for Miss Greta Granstedt in Hollywood", en California Arts and Architecture, julio 1938, p. 18 (publicación del proyecto). AVERY

"A House that Grows and Grows", en Sunset Magazine, agosto 1938, pp. 14-15 (Pauline Lowe House).

"Carmel by the Sea. House for Marion Clar", en Architectural Forum, septiembre 1938, pp. 213-216. AVERY 
"House for Miss Helene Kershner, Los Angeles, California", en Architectural Record, octubre 1938, pp. 100-102 . AVERY

"House for John Entenza, Santa Monica, California ", en The Architectural Forum, noviembre 1938, pp. 349-351. AVERY

"Fellowship Park House", en Architect and Engineer, diciembre 1938, p. 42 (sobre la propia casa de H. H. Harris en Los Angeles).

\section{9}

POR H. H. HARRIS:

"Wood", en California Arts and Architecture, mayo 1939, pp. 16-17 (artículo sobre la construcción californiana asociada al trabajo de la madera -redwood-, ilustrado con ejemplos del Easton Curtis Ranch en Altadena y otras estructuras como el Lamella dome). AVERY

SOBRE H. H. HARRIS:

"George Baver Residence", en Architect and Engineer, marzo 1939, pp. 38-39. AVERY

"House for George C. Baver ", en The Architectural Forum, julio 1939, Modern Houses in America, pp. 16-18. AVERY

"The Residence of Mr. and Mrs. George C. Baver", en California Arts and Architecture, agosto 1939, pp. 19-21. AVERY

MELVIN, William: "Fireplaces", en California Arts and Architecture, noviembre 1939, p. 18 (Robert Campbell House).

1940

SOBRE H. H. HARRIS:

SAMPSON, Foster: "Modern Light for Living", en California Arts and Architecture, enero 1940, pp. 28-29 (sobre la casa de Helene Kershner).

"Weston Havens House on Steep Hill", en California Arts and Architecture, marzo 1940, pp. 2 y 5 (sobre la casa de Weston Havens en Berkeley, cuya sección aparece en la portada de este número en el que John Entenza accede al cargo de editor de la revista. Sintomáticamente será uno de los últimos números donde se publique a Harris).

"Houses by Harwell Hamilton Harris", en The Architectural Forum, marzo 1940, pp. 171-186 (casas Granstedt, de Steiguer, Hawk, Blair y Powers House in La Canada). AVERY

"Three Modern California Houses", en California Arts and Architecture, California Arts and Architecture, abril 1940, pp. 18-19 (sobre la Greta Granstedt House).

"House in Pasadena", en The Architectural Forum, abril 1940, p. 243 (casa para Fred Harris). AVERY 
"The Highway Hotel", en The Architectural Forum, octubre 1940, p. 248 (publicación de los dibujos produciros por encargo de la propia revista para su Design Decade). AVERY

HITCHCOCK, Henry Russell: "An Eastern Critic Looks at Western Architecture", en California Arts and Architecture, diciembre 1940: pp. 21-23 y 40-41 (en uno de sus más polémicos artículos, contestado por H. H. Harris, R. M. Schindler y John Lautner, entre otros, el crítico, a su vuelta de un viaje por California hacía la siguiente afirmación por la que, más tarde, pediría disculpas: ante la evidente falta de una clara guía conceptual en la arquitectura americana, (...) en ausencia de un auténtico sentido de la forma y, sobre todo, en ausencia de genio alguno, nuestros arquitectos mejor deberían concentrarse en aceptar la modernidad europea - - .40).

\section{1}

SOBRE H. H. HARRIS:

"Houses", en Architectural Record, enero 1941, pp. 94-95 (sobre la Fred Harris House).

"Casas de Harwell H. Harris", en Kentiku Sekai, Japanese Journal of Building and Living Culture, abril 1941, pp. 12-14 (pocos meses antes de la declaración de guerra de los Estados Unidos tras el ataque japonés y del consiguiente cese información de todo tipo entre ambos países, esta revista japonesa exponía cuatro obras de Harris, las casas Granstedt, Entenza, Clark y Bauer).

"Two-way Cupboards", en The Architectural Forum, octubre 1941, p. 281 (sobre la casa Stan Hawk).

\section{2}

SOBRE H. H. HARRIS:

MORLEY, Grace L. McCann: "Architects in an Exhibition", en California Arts and Architecture, marzo 1942, pp. 24-35 (dando cobertura a la inminente exposición Western Living, organizada por el San Francisco Museum of Modern Art y en la que estaba incluido el trabajo reciente del arquitecto, se publican dibujos, citas de textos de Harris y se comentan los planos e imágenes de la Greta Granstedt House). AVERY

"New California Architecture", en Time, 20 abril 1942, p.48 (con motivo de la recientemente inaugurada exposición sobre nueva arquitectura californiana -Western Living, Five Houses under \$7,500-, en la que el Museo de Arte Moderno de San Francisco había seleccionado y mostrado obras de cinco arquitectos, la prestigiosa revista, tras introducir el tema con la figura de Richard Neutra, continúa hablando de Harris, para después enumerar, de modo más somero, el resto de los arquitectos presentes en la muestra y cuyos nombres están ahora indefectiblemente unidos al Área de la Bahía. Sobre Harris se afirma: Harwell Hamilton Harris, who used to be a sculptor, has been building houses for only seven years; his paper-paneled sliding doors, hip roofs and mat-floored interiors are strongly influenced by Japanese architecture and the work of Architect Frank Lloyd Wright. El resto de arquitectos, relacionados acertadamente en el artículo con la estela de Bernard Maybeck, son: William Wilson Wurster, Hervey Parke Clark y John Ekin Dinwiddie). 
"Chinatown Restaurant", en California Arts and Architecture, mayo 1942, p. 54 (restaurante en Grandview Garden encargado por dos jóvenes hermanos chinos deseosos de renovar la imagen tradicional de esta tipología en el New Chinatown de Los Angeles). AVERY

"The Browns Build a Wartime House with Peace Aims", en Ladies Home Journal, julio 1942, p. 66 (se publica el proyecto y la maqueta del prototipo residencial encargado por la revista).

"The New House 194X", en Architectural Forum, septiembre 1942, p. 46 (planta y perspectiva de un diseño de sala de baño). AVERY

"For Quicker Start in 194X", en The Architectural Forum, diciembre 1942, pp. 108-109 (Segmental House diseñada para la empresa Revere Copper and Brass Inc.).

\section{3}

POR H. H. HARRIS:

"Blueprints of Tomorrow", en Sunset Magazine, mayo 1943, pp. 12-15 (se publica un artículo suyo y el proyecto de la Cecil Birtcher House).

SOBRE H. H. HARRIS:

"Blueprints of Tomorrow", en Sunset Magazine, julio 1943, pp. 10-13.

"Multiple Dwelling in $194 X$ X", en The Architectural Forum, septiembre 1943, p. 26.

"Berkeley Hillside House for Weston Havens", en The Architectural Forum, septiembre 1943, pp. 76-87. AVERY

"A House with a View", en Interiors Magazine, septiembre 1943, pp. 18-23 (Weston Havens House, se publica la casa con las fotografías realizadas por May Ray). AVERY

\section{4}

SOBRE H. H. HARRIS:

"Scene from Above", en House and Garden, enero 1944, pp.54-56 (Weston Havens House en Berkeley). AVERY

"How to Judge Modern", en House Beautiful, agosto 1944, pp. 47-49 y 70-71 (Havens House). AVERY

"Harwell Hamilton Harris, Arquitecto. Casa para el Sr. Weston Havens", en El Arquitecto, Buenos Aires, agosto 1944, pp. 364-372 (se publican las fotografías tomadas por Man Ray de la casa de Weston Havens en Berkeley).

\section{5}

POR H. H. HARRIS:

"Modern or Traditional?", en Better Homes and Gardens, febrero 1945, pp.28 y 10-101 (Discusión razonada acerca de su propia visión de la modernidad como una actitud que mira al pasado sin nostalgia). 
SOBRE H. H. HARRIS:

"Portrait of H. H. Harris/In the Forum", en The Architectural Forum, abril 1945, p. 58 .

"People Who Influence Your Life: Meet Harwell Hamilton Harris", en House Beautiful, julio 1945, pp. 54-55 (en pocos meses, dos de las más importantes revistas americanas, una especializada en arquitectura, la otra desde la óptica del hogar en la cultura popular, hacen un retrato de la vida, personalidad y obra del arquitecto, cuyo trabajo, por entonces, captaba la atención de los medios tras una serie de viviendas tremendamente influyentes para la generación de arquitectos posteriores como el propio G.Drake. Ese mismo año, la influyente revista Life le también un artículo ilustrado con una de sus obras -véase apartado siguiente HH.2). AVERY

\section{6}

SOBRE H. H. HARRIS:

"Harwell H. Harris shows his West Coast skill in a Midwestern environment", en The Architectural Forum, febrero 1946, pp. 94-96 (Ingersoll House). AVERY

"Inventive Design", en House and Garden, mayo 1946, p. 78 (Weston Havens House).

"Three Houses in Western USA", en Architectural Review, diciembre 1946, pp. 157-161. AVERY

\section{7}

SOBRE H. H. HARRIS:

SCOTT, Walter Hylton: "H.H.Harris, obras y proyectos", en Nuestra Arquitectura, enero 1947, pp. 3-31 (casas Lek, Havens, Birtcher e Ingersoll; restaurante en Grandview Gardens y Pottenger Hospital). AVERY

"Adroit Handling of Wood Marks this Hilltop House", en The Architectural Forum, diciembre 1947, pp. 102-103 (Cecil Birtcher House).

\section{8}

SOBRE H. H. HARRIS:

"Sales Suite, Los Angeles, California", en Progressive Architecture, julio 1948, p. 62. AVERY

"Architects with Exhibit in Australia", en Architect and Engineer, agosto 1948, pp. 34-35 (con motivo de la exposición sobre arquitectura contemporánea californiana -Six West Coast Architects-, organizada por el Royal Victoria Institute of Architects e itinerante por Melbourne y Sidney ese mismo año, se publican dos casas de Harris presentes en la muestra de Australia: la Havens House y la Birtcher House).

\section{9}

SOBRE H. H. HARRIS:

"San Francisco Houses", en Life, 5 septiembre 1949, pp. 43-63 (se publican casas de Corbertt, Hilmer \& Callister, Anshen \& Allen, Esherick y de Harris, concretamente, de éste último se muestra la Weston Havens House). AVERY 
SOBRE H. H. HARRIS:

FITCH, James Marsten: "The New American Architecture Started 70 Years Ago", en House Beautiful, mayo 1950, pp. 134-137 (se publica de nuevo la casa del arquitecto en Fellowship Park, Los Angeles).

"A House with Disappearing Walls, or How to Live Attractively in One Room", en House and Garden, junio 1950, pp. 118-123 y 158-159 (Gerald Loeb House). AVERY

"Private Retreat: Redding, Connecticut", en Progressive Architecture, diciembre 1950, pp. 45-48 (Gerald Loeb House).

\section{1}

SOBRE H. H. HARRIS:

"A House to Grow with Your Future", en Los Angeles Times Home Magazine, 3 junio 1951, pp. 6-7 (artículo sobre el prototipo residencial de la Segmental House, desarrollado para la empresa Revere Copper and Brass Inc.).

BURDEN, Jean: "Timeless California", en Los Angeles Times Home Magazine, 29 julio 1951, pp. 3-5 (artículo sobre la Mulvihill House en Sierra Madre).

"Named by University of Texas", en Architectural Forum, agosto 1951, p. 68 (artículo sobre la designación de H. H. Harris como Dean de la School of Architecture de la Universidad de Texas, Austin).

"Harwell Hamilton Harris Heads Texas School of Architecture", en Architectural Record, septiembre 1951, p. 232 (otro artículo sobre la designación de H. H. Harris como Dean de la School of Architecture de la Universidad de Texas, Austin, en esta ocasión publicado por Architectural Record, lo que pone de manifiesto el interés de los medios por el nombramiento del arquitecto y su inminente marcha de California, donde todas las revistas parecen coincidir en que Harris ha completado un ciclo y su obra queda como un legado e inspiración para futuras generaciones de arquitectos).

"Three California Houses and a Tradition Revitalized. Harwell Harris Designer", en Architectural Forum, octubre 1951, pp. 162-170 (con motivo de la marcha de H. H. Harris de California para dirigir la School of Architecture de la Universidad de Texas, la revista publica un artículo sobre tres de los más recientes trabajos del arquitecto -las casas de Ralph Johnson, Alvin Ray y Harold English- precedido de una breve reflexión sobre el conjunto de su carrera. AVERY

\section{2}

POR H. H. HARRIS:

"Architecture as an Art", en Journal of the American Institute of Architects, noviembre 1952, pp. 216-219 (artículo donde el arquitecto expone su propia filosofía arquitectónica desde la discusión de los principios que dieron lugar a sus realizaciones californianas, sus influencias artísticas y el entendimiento del medio; el texto se centra fundamentalmente en el descubrimiento de la figura y la obra de Frank Lloyd Wright; originalmente se trataba de un artículo encargado para un catálogo sobre la exposición sobre Wright programa- 
da en 1940 por el Museum of Modern Art de Nueva York pero que el MoMA nunca llegó a publicar).

SOBRE H. H. HARRIS:

"Oasis for Good Living", en House and Home, marzo 1952, pp. $90-94$ (sobre los apartamentos encargados por Weston Havens en Berkeley). AVERY

"Gordon Drake, 1917-1952", en House and Home, marzo 1952, pp. 95-104 (la revista cita la influencia de Harris en el obituario Gordon Drake y su asimilación a través de éste de la ligereza de la cultura arquitectónica japonesa).

1953

POR H. H. HARRIS:

"Observations on Mexico's University City", en Journal of the American Institute of Architects n 19, enero 1953, p. 13.

"Rhythmic Integration of Panel Elements", en Perspecta $\mathrm{n}^{\circ} 2$, Yale Architectural Journal, 1953, pp. 37-44 (reeimpresión del artículo originalmente publicado en Practical Builder, diciembre 1949). AVERY

"How a House Can Enrich the Life Within", en House Beautiful, mayo 1953, p. 157.

SOBRE H. H. HARRIS:

"Above the Valley", en Los Angeles Times Home Magazine, 7 junio 1953, pp. 14-15 (Clarence Wyle House).

1954

POR H. H. HARRIS:

"The Art of Building", en The Alcalde, UT Alumni Magazine, junio 1954, p. 282.

SOBRE H. H. HARRIS:

"Northwest Architects Meet at Eugene", en Architectural Record no116, octubre 1954, p. 16 (Imagen del autor y cita procedente de su discurso Regionalism and Nationalism. En esta conferencia, leída por primera vez con ocasión de la reunión del capítulo Noroeste de la AIA en Eugene, Oregón, H. H. Harris plantea la necesidad de un regionalismo crítico, una idea que, años más tarde recogerá el crítico británico Kenneth Frampton, citando incluso textualmente el discurso de Harris en su influyente Historia crítica de la arquitectura moderna).

1955

POR H. H. HARRIS:

"A Regional Architectural Expression", en Architectural Record, enero 1955, Western Section - únicamente en la edición de la revista para la Costa Oeste (Harris resume las ideas de su discurso acerca del regionalismo crítico).

SOBRE H. H. HARRIS:

"The Pace Setter House", en House Beautiful, febrero 1955, número monográfico. AVERY 
"Harris Resigns as Head of Texas University School of Architecture", en Architectural Forum, agosto 1955, p. 29 (artículo sobre la dimisión de H. H. Harris como Dean de la School of Architecture de la Universidad de Texas y el debate sobre su sucesión).

\section{6}

SOBRE H. H. HARRIS:

"Western Architects to Design Exhibition Houses", en Architectural Record, enero 1956, p. 28 (artículo sobre la inclusión de arquitectos de la Costa Oeste en la futura exposición conmemorativa del centenario de la AIA).

"One Hundred Years of Significant Building: Houses Since 1907", en Architectural Record, febrero 1956, pp. 199-206. AVERY

GALLION, Arthur: "Architecture of the Los Angeles Region", en Architectural Record, mayo 1956, p. 164 (Clarence Wyle House).

"Two Motels: Atlantic Coast Motel Has Pacific Design", en Architectural Forum, agosto 1956, pp. 123-127 (Motel- on-the Mountain). AVERY

Folleto-catálogo de la Exposición sobre el Centenario de la AIA (Centennial of American Architecture_Exhibition in the National Gallery May 14-July 15, 1957).

Folleto-catálogo de la Exposición del MoMA Built in the USA, comisariada por Henry Russell Hitchcock y Arthur Drexler y que, tras su exhibición en Nueva York en 1953, itineró por las siguientes ciudades: Sao Paulo, Rio de Janeiro, México D.F., Guadalajara, Monterrey, Londres, Dublín, París, Zurich, Barcelona, Frankfurt, La Haya, Viena y Belgrado. H. H. Harris fue seleccionado con la Ralph Johnson (Véase apartado HH.4, sobre capítulos de libros dedicados al arquitecto o a sus obras).

"City Architect Named to Do Helsinki Design", 26 agosto 1956, recorte de prensa sin identificación de procedencia sobre el proyecto no realizado de H. H. Harris para la Embajada de los Estados Unidos en Finlandia y complejo de viviendas para el cuerpo diplomático en Helsinki.

"Premières Réalisations», en L'Architecture d'Aujourd'hui n 67-68, Californie, Venezuela, Constructions en pays chauds, octubre 1956. En un artículo sobre Richard Neutra y sus primeras obras en California -ilustrado con imágenes de la Lovell Health House-se menciona a sus discípulos, citándose a Harwell H. Harris, Gregory Ain y Raphael Soriano como parte de este selecto grupo de colaboradores formados en el despacho del arquitecto austriaco y que participaron en la introducción y evolución de la arquitectura moderna en la región. Se trata de un artículo tardío que forma parte de un monográfico sobre arquitectos californianos en los que hay representación de diferentes sensibilidades: Neutra, Wurster, Bernardi, Emmons, Gruen, Soriano, Halprin, etc., pero siendo conspicuas las ausencias de obras de Schindler y del propio Harris). 
"Houses Since 1907"; "One Hundred Years of Significant Building", en Architectural Record, febrero 1957, pp. 199-206 (Con motivo de la exposición One Hundred Years of American Architecture, organizada para conmemorar el centenario de la AIA y expuesta en la National Gallery of Art en Washington D.C., Architectural Record publica un artículo con las 10 mejores viviendas unifamiliares construidas en los Estados Unidos durante primer siglo de vida del Institute, votadas por sus miembros, se expusieron 14 viviendas ya que algunas empataban a votos en un determinado puesto. Es el caso de la Weston Havens House de Harris, publicada en la página 205 de la revista con un breve artículo de Talbot Hamlin y empatada en el puesto número nueve con la Lovell Health House de Richard Neutra (Los Angeles, CA, 1927-29) y la Ellen Scripps House de Irving Gill (La Jolla, CA, 1917).

"One Hundred Years of the American House", en House and Home, mayo 1957, p. 119 (con motivo de la celebración del centenario de la AIA, la revista recoge algunas de las casas americanas más influyentes de los últimos cien años y, así, dos décadas más tarde, vuelve a publicar la casa del arquitecto en Fellowship Park, englobada en el apartado Glamourous Vernacular of the 1930s).

\section{8}

POR H.H. HARRIS:

"Regionalism and Nationalism in Architecture", en Texas Quartely 1, febrero 1958, pp. 115-124.

SOBRE H. H. HARRIS:

"Making a Monument Work", en Architectural Forum, julio 1958, pp.98-103 (sobre la obra de restauración llevada a cabo por Harris del National Farmers Bank de Sullivan en Owatonna, Minnesota y FITCH, James M.: Discurso de 12 de junio de 1958 sobre la inauguración de la obra restaurada por Harris y denominada, desde entonces, Security Bank and Trust Co.).

\section{9}

POR H. H. HARRIS:

"The Achitecture", en Dallas Theatre Centre Brochure, 1959 (texto -obituario de F. L. Wright; Harris comenta algunas obras de Wright y elogia el conjunto de su trayectoria, reconociendo su influencia en su propio trabajo).

SOBRE H. H. HARRIS:

"Motel près de New York", en L'Architecture d'Aujourd'hui, octubre 1959, p. 48 (sobre el Motel-on-the-Mountain).

\section{1}

POR H. H. HARRIS:

"The Mind of an Architect", en The Berkeley Review, 30 noviembre 1961 (publicación del discurso de Harris tras su homenaje por la Universidad de Berkeley y la dedicación del Havens Memorial Fountain Plaza en la ciudad de Berkeley). 
SOBRE H. H. HARRIS:

"An Island of Beauty on Main Street", en Architectural Record, Western section, mayo 1961, pp. 32-33 (Havens Memorial Fountain Plaza).

\section{2}

SOBRE H. H. HARRIS:

"What's New with Harwell Hamilton Harris?", en House and Home, enero 1962, pp. 100-107 (casas Ralph Johnson, Alvin Ray, Clarence Wyle, Weston Havens, J. Lee Johnson/Ruth Carter Stevenson, John Treanor y Pace Setter). AVERY

\section{5}

SOBRE H. H. HARRIS:

ANDREWS, Wayne: "The Impatient Evolution of the American House", en House Beautiful, febrero 1965, p.91

"AIA Elects 37 Fellows", en Architectural Record, mayo 1965, p. 23 (sobre la elección y nombramiento de Harris como Fellow del American Institute of Architects en reconocimiento a su carrera).

\section{4}

SOBRE H. H. HARRIS:

McCOY, Esther: "Architecture West", en Progressive Architecture, mayo 1974, p.38 (la reputada historiadora de la región cita a Harris en esta página de un artículo más extenso sobre la evolución de la arquitectura californiana desde sus pioneros).

\section{5}

POR H. H. HARRIS:

"The Brothers Greene", en Architectural Record, noviembre 1975, pp. 45 y 47 (Harris parte de la crítica de los libros publicados recientemente sobre los hermanos Greene -A Greene \& Greene Guide, de Janann Strand; Greene \& Greene, Residential Style, de William R. y Karen Current; y, en especial, el texto de Randall L. Makinson, A Guide to the Work of Greene \& Greene- para reivindicar la figura de dos estos pioneros californianos, el trabajo de recuperación de su legado llevado a cabo por su mujer, la escritora y crítica Jean Murray Bangs y, también, la influencia de su arquitectura en su propia obra -cita, por ejemplo, la influencia de la tradición de los sleeping porches iniciada por los Greene y continuada por Shindler, en el diseño de los dormitoriopatio de su Lowe House de 1933, aunque, en realidad, en esa fecha Harris todavía no estaba familiarizado con la obra de Greene and Greene). AVERY

\section{7}

POR H. H. HARRIS:

"AIA Gold Medal Awarded to Richard Neutraure", en North Carolina Architect, mayo-junio 1977, pp. 8-11. AVERY 
1978

POR H. H. HARRIS:

"The Search for Postmodern Architecture", en Crit 4, The Architectural Student Journal, otoño 1978, p. 18. AVERY

"Regionalism", en North Carolina Architect, enero-febrero 1978, pp. 10-11. AVERY

1980

SOBRE H. H. HARRIS:

LAMB, Paul y SPECK, Lawrence: "Rediscovering Harwell Hamilton Harris", en Texas Architect, marzo-abril 1980, pp. 36-42.

"The Horizonal City", en The New Yorker, 15 septiembre 1980, pp. 109-146 (se hace mención a Harris en la página 141 de este artículo dedicado a la arquitectura y el urbanismo de la ciudad de Los Angeles).

\section{4}

SOBRE H. H. HARRIS:

LANDWORTH, W., et al.: "The plaisir of their company (book review) ", en LA Architect, septiembre 1984, p. 10. AVERY

\section{5}

SOBRE H. H. HARRIS:

FULLER, Larry Paul: "Harwell Hamilton Harris: Rediscovering a Tastemaker of the 50s", en Texas Homes, julio 1985, pp. 35-37.

GERMANY, Lisa: "H. H. Harris in Texas", en Texas Architect, julio-agosto 1985, pp. 66-69. AVERY

\section{9}

SOBRE H. H. HARRIS:

LONG, Christopher: "Harwell Hamilton Harris", en Texas Architect, noviembre-diciembre 1989, p. 57 (se trata de Harris como uno de los 50 arquitectos homenajeados por este número especial de la revista editado con motivo de la celebración del cincuenta aniversario de la AIA en Texas).

\section{0}

OBITUARIO:

FRASER, Gerald: "Harwell Harris, 87, An Architect Known For House Designs", en The New YorkTimes, 20 noviembre 1990, edición digital disponible en: http://www.nytimes.com/1990/11/20/obituaries/harwell-harris-87-an-architect-known-for-house-designs.html?scp=1\&sq=harwell\%2oharris\&st=cse (en el artículo publicado tras la muerte del arquitecto en Raleigh, a los 87 años, se cuenta la anécdota de que cuando Harris se encontró por primera vez con su admirado Frank Lloyd Wright éste le dijo: "Por supuesto que sé quién eres Harris, un gran artista que, cuando tenga mi edad, será un buen arquitecto". El NYTimes subrayó su inestimable contribución a la creación del ideal moderno del hogar americano. 
OBITUARIOS:

GERMANY, Lisa: "Harwell Hamilton Harris", en Texas Architect, enero 1991, p. 10. AVERY

GERMANY, Lisa: "Harwell Hamilton Harris 1903-1990", en Progressive Architecture, enero 1991, p. 25. AVERY

MAYS, V.: "Harwell Hamilton Harris: In Memory of a Legend", en Texas Architect, marzo-abril 1991, pp. 8-9. AVERY

1992

RESEÑA:

ENGEL, Peter: "Harwell Hamilton Harris by Lisa Germany (book review)", en Progressive Architecture, septiembre 1992, pp. 115 y 138 (reseña del libro de Germany).

1992

RESEÑAS:

ENGEL, Peter: "Harwell Hamilton Harris by Lisa Germany (book review)", en Progressive Architecture, septiembre 1995, pp. 115 y 138. AVERY

GOOD, R. L.: "A Californian in Texas: Harwell Hamilton Harris by Lisa Germany (book review)", en Texas Architect, noviembre 1992, p. 71. AVERY

1993

RESEÑA:

KAPPE, Ray: "Harwell Hamilton Harris by Lisa Germany (book review)", en Journal of the Society of Architectural Historians no 1, marzo 1993, pp. 119120. AVERY

KLIMEK, Ray: "Harwell Hamilton Harris by Lisa Germany (book review)", en Sites no 25, 1993, pp. 156-158. AVERY

\section{7}

GERMANY, Lisa: "Every inch alive: the Houses of Harwell Hamilton Harris", en Harvard Design Magazine, verano 1997, pp. 60-62. AVERY

\section{9}

ANDERTON, Frances: "They Built Los Angeles", en The New York Times (Home and Garden), 18 marzo 1999, edición digital: disponible en: http:// www.nytimes.com/1999/o3/18/garden/public-eye-they-built-los-angeles.

html?scp=7\&sq=harwell\%2oharris\&st=cse

LOOMIS, J. A., et al: "Power Rangers", en Design Book Review, otoño 1999, pp. 6o-62 (reseña literaria sobre la Universidad de Texas, Austin y el papel de Harris al frente de la Escuela de Arquitectura). AVERY 
2001

LOOMIS, J. A.: "Havens House: Forgotten Masterpiece of California Modernism", en ArcCA: the Journal of the american Insitute of Architects, California Council no 1, 2001, pp. 45-47. AVERY

BOSLEY, Edward R.: "Wild Wood Park: The Rediscovery of Henry Greene's Sylvan Secret", en American Bungalow, invierno 2000, pp. 38-43. AVERY

2003

VARNELIS, K, y FOLONIS, Michael W.: "John Entenza House Renovation", en LA Architect, julio-agosto, 2003, pp. 32-33 (artículo sobre la restauración recientemente completada (2001) de la Entenza House de Harris en el Cañón de Santa Mónica). AVERY

LOOMIS, J. A.: "UC Berkely gets Havens House", en Architecture, septiembre 2003, p. 21 (reseña sobre la aceptación de la donación de Mr. Havens a la Universidad de Berkeley tras la muerte del propietario. La vivienda se presenta ilustrada con una de las fotografías tomadas por Man Ray). AVERY

2004

EASTMAN, Janet: "The door-to-door connection", en Los Angeles Times, 12 agosto 2004 (artículo comentado en el texto del trabajo sobre la reunión de propietarios actuales viviendas de $\mathrm{H}$. H. Harris en Los Angeles que decidieron reunirse para poner en común sus experiencias. El subtítulo del artículo es suficientemente claro al respecto: A group of Angelenos finds a common link: They live in the small, distinctive homes designed by little-known Modernist architect Harwell Harris), edición digital disponible en: http://www.latimes.com/features/home/la-hm-harwell12aug12,1,2063962. story? coll=la-home-home.

2005

BARRIE-ANTHONY, Steven: "Landscape of constant change", en Los Angeles Times (Local), 7 julio 2005, edición digital disponible en: http://www.latimes. com/news/local/la-hm-timelinejjulo7,0,4422018.story

\section{6}

"English House Restoration", en Architectural Record, mayo 2006 (sobre la restauración de la Harold English House, y el premio (AIA Award) concedido a sus autores por la obre de recuperación de una de las mejores residencias del arquitecto en la ciudad de Los Angeles).

IVY, Robert: "When Worlds collide in today's Los Angeles", en Architectural Record, mayo 2006 (sobre la arquitectura actual de la región y sus raíces, hablando de la obra de Ray Kappe, fundador de las Escuelas de Arquitectura del California State Polytechnic Univertisty Pomona y del SCI-Arc), la revista subraya, entre otras, la influencia de Harwell $\mathrm{H}$. Harris en la obra del arquitecto afirmando: informed by ideals that we now label as sustainable), disponible en la edición digital de la revista: http://archrecord.construction. com/features/LA/projects.asp. 
YOSHIHARA, Nancy: "Watching LA grow", en Los Angeles Times (Real Estate), 30 abril 2006, edición digital disponible en: $h t t p: / / w w w$. latimes.com/classified/realestate/printedition/la-re-125yoshiharazoapr30,0,6494021.story

\section{8}

HAWTHORNE, Christopher: "A New and Native Beauty: The Art and Craft of Greene \& Greene", en Los Angeles Times (Entertainment), 22 octubre 2008, edición digital disponible en: http://www.latimes.com/entertainment/news/ arts/la-et-greene22-20080ct22,0,7273482.story

WEBB, Michael: "Magnetic Fields", en World of Interiors, junio 2008, pp. 140149 (sobre la restauración de la Harold English House en Beverly Hills). AVERY

HH. 2

OTROS ARTÍCULOS ESCRITOS SOBRE HARWELL HAMILTON HARRIS EN REVISTAS ESPECIALIZADAS, PERIÓDICOS Y PUBLICACIONES PERIÓDICAS DE ÁMBITO INTERNACIONAL

Harris anotaba anualmente en una lista los artículos que, ese año, se habían escrito sobre su trabajo. A partir de dicha lista, conservada en el Archivo de la Universidad de Austin en Texas, se han añadido otras publicaciones citadas por Germany y algunos textos encontrados por el autor de este trabajo en revistas europeas; con todo este material se ha confeccionado la siguiente relación de artículos que, complementando los anteriores textos consultados, constituyen una actualización del conjunto de artículos escritos sobre el arquitecto entre 1935 y el año de su muerte, 1990.

Anterior a la etapa de ejercicio profesional iniciada en 1934 se mencionan tres artículos escritos sobre Richard Neutra -o por Richard Neutra- donde se menciona a Harris expresamente como colaborador del arquitecto austriaco.

Los textos aparecidos a partir de 1990, año de la muerte de Harris, se han incluido en los apartados de bibliografía específica HH.3 a HH.8.

\section{0}

POR RICHARD NEUTRAY H. H. HARRIS:

"Ein Amerikanischer Flughafen", en Die Form 5 Jahr, abril 1930, pp. 184-185 (artículo de Richard Neutra firmado con Harwell Hamilton Harris).

SOBRE H. H. HARRIS COMO COLABORADOR DE RICHARD NEUTRA:

"Projekt fur Einen Flugverkehrs. Umschlaghof Rush City", en Deutsche Bauzeitung 64 Jahr, febrero 1930, pp. 21-23 (artículo sobre Richard Neutra y su equipo de colaboradores, entre ellos Harwell H. Harris y Gregory Ain).

NEUTRA, Richard: "Terminals?--Transfer!", en Architectural Record, agosto 1930, pp. 99-104 (artículo sobre la obra de Richard Neutra y su equipo de colaboradores, entre ellos Harwell H. Harris y Gregory Ain). 
"The Upper Ground", en Pencil Points, marzo 1935, p. 113.

"What Constitutes Plagiarism in Architecture?", en Aperitif 1, n 6, p. 12 (Pauline Lowe House).

1937

SOBRE H. H. HARRIS:

"Novel Nautical House Idea", en LAAC Mercury, 25 de septiembre 1937, p. 8 (John Entenza House en Santa Monica).

\section{8}

SOBRE H. H. HARRIS:

RICE, Norman: "Planning a Physician's Office Suite", en Architectural Record, febrero 1938, p.59 (proyecto dibujado).

"Industrial Design: Its Parentage and Motives", California Graduate School of Design, Pasadena, enero-febrero 1938.

EDGERTON, Giles: "The House Unpretentious But Convenient", en Arts \& Decoration, marzo 1938, pp. 27-29 (sobre la Fellowship Park House en Los Angeles). AVERY

\section{9}

SOBRE H. H. HARRIS:

"A House in Fellowship Park, Los Angeles", en Architecture and Building News, 27 de enero 1939, pp. 131-132 (sobre la propia casa de H. H. Harris en Los Angeles). AVERY

"People in Glass Houses Will be Very Comfortable", en Studebaker Wheel, mayo 1939, p. 11 (sobre la George Baver House).

"Buick salesroom's Lamella dome, Summerbell Roof structures", en Southwest Builder and Contractor, mayo 1939, p. 55.

"Ein Sommerhaus am Waldesrand", en Das Ideale Heim, octubre 1939, pp. 323-324 (Fellowship Park House).

1940

SOBRE H. H. HARRIS:

HAMLIN, Talbot: "Interior Decoration, 1940", en Pencil Points 21, Julio 1940, p. 438 (sobre la Feria de Nueva York: "New York World's Fair room-South of the Golden Gate") -Sobre esta Feria, la California Redwood Association también editó, en 1940, un folleto en el que se discutían las propuestas de Harris. AVERY

"Grandview Gardens Restaurant in China City", en California Arts and Architecture, agosto 1940, pp. 22-23. AVERY

"Villa a Los Angeles", Construzione Casabella, diciembre 1940, p. 42. AVERY 
1941

SOBRE H. H. HARRIS:

HAMLIN, Talbot: "Architecture in America Today", en New Republic, 4 agosto 1941, pp. 156-157.

"Young America Builds", en Mademoiselle, agosto 1941, pp. 238-239, 340, 342, 346-349 y 352 (sobre la producción arquitectónica de varios arquitectos nacidos a principios de siglo, entre ellos, H. H. Harris).

1942

SOBRE H. H. HARRIS:

HAMLIN, Talbot: "The Trend of American Architecture", en Harpers, enero 1942.

"Inn with Cottages", en New York Beaux Arts Institute of Design Bulletin n 18, marzo 1942, p. 35.

"Blueprints of Tomorrow", folleto separable de la revista Sunset Magazine de 1942, anunciando una nueva sección de contenidos de arquitectura y vivienda ilustrado con obras de Harris.

"A House With a Future", folleto con la Segmental House de Harris editado por la empresa Revere Copper and Brass Inc.

\section{3}

SOBRE H. H. HARRIS:

"La Jolla House", en Pencil Points, mayo 1943, pp. 50-55 (sobre la Louis Lek House). AVERY

"Multiple Dwelling in 194X", en Pencil Points, septiembre 1943, p. 27.

"Why Modern Design?", en American Lumberman,2 octubre 1943, pp. 18-21 (se publican las casas de Edward de Steiguer y de Greta Granstedt).

\section{4}

SOBRE H. H. HARRIS:

"Students Room", en New York Beaux Arts Institute of Design Bulletin n 20, febrero 1944, p. 19.

"Station for a Highway Hostelry", en Architectural Record, febrero 1944, pp. 79-8o. AVERY

"Our Homes and Our Children", en Household Magazine, octubre 1944, p. 1 (Edward de Steiguer House).

"Berkeley House for Weston Havens", en Studio 128, octubre 1944, pp. 101103.

"Harwell Harris Planned for Convenience First", en Better Homes and Gardens, noviembre 1944, pp. 20-21 (publicación del proyecto de prototipo de cocina encargado por la revista). 
"How the Shumways Can Build Their House", en Women's Home Companion, diciembre 1944, pp. 78-80.

"Residencia en Pasadena", en El Arquitecto Peruano, diciembre 1944, pp. 1112. AVERY

\section{5}

SOBRE H. H. HARRIS:

"A California House for the Berkshire Hills of Massachusetts", en Womens Home Companion, abril 1945, pp. 138-139 (Lawrence Shumway House).

"House of Timber in California", en Architects Journal n 101, mayo 1945, pp. 387-392. AVERY

"Modern in California", en Home Furnishings, junio 1945, p. 26 (Havens House en Berkeley).

"Western Family ", en Western Home, agosto 1945, pp. 10-1 y 23 (casa del arquitecto en Fellowship Park, Los Angeles, 1935).

"A House You Can Afford", en Household Magazine, agosto 1945, p. 4 (y portada).

"The California Way of Life", en Life, 22 octubre 1945, pp. 105 y 114-115 (Louis Lek House en La Jolla). AVERY

"Motel", en New York Beaux Arts Institute of Design Bulletin n० 21, octubre 1945, pp. 18-19.

"Havens House", en Magazine of Art, noviembre 1945 (la casa aparece en portada).

\section{6}

SOBRE H. H. HARRIS:

"Sales Building for Souvenirs in a National Park", en New York Beaux Arts Institute of Design Bulletin n²2, febrero 1946, p. 29.

"La Vivienda del Mañana", en Proyectos y Materiales, febrero 1946, pp. 10-11 (George Bauer House).

"Havens House», en Pageant, marzo 1946.

«Home of Mr. Weston Havens", en Homes and Interiors, abril 1946, pp. 72-74.

"Eight Men on a Unit", en Interiors Magazine, mayo 1946, pp. 83-84 (Ingersoll House). AVERY

"How to Successfully Mix New and Old", en House Beautiful, septiembre 1946, pp. 110-103 y portada (John Mason House).

"Hillside Sites Make the Most Interesting Houses", en House Beautiful, octubre 1946, pp. 165-168 (Lee Blair House). 
"San Mateo Country House for L. Allen", en Architectural Record, noviembre 1946 , pp. $84-85$.

"Eight rooms, four baths, six terraces", en Architectural Record, noviembre 1946, pp. 84-85. AVERY

Good Housekeeping, diciembre 1946, p. 59 (proyecto de vivienda diseñada para la revista).

"Residence on Washington Mountain", en Architectural Digest n' 11, 1946, pp. 1-7.

1947

SOBRE H. H. HARRIS:

"Dress for the Sun", en Holiday, febrero 1947, p. 82 (casa de H. H. Harris en Fellowship Park).

"The House You Want", en Mademoiselle, marzo 1947.

"Libbey-Owens-Ford Glass Co. ad", en American Builder, octubre 1947 (Weston Havens House).

"Tresnor Equipment Company", en Architectural Record, octubre 1947, p. 32. AVERY

\section{8}

SOBRE H. H. HARRIS:

"North Country Houses for Many Children", en Architectural Record, febrero 1948, pp. 106-111. AVERY

"Lookout Station", en New York Beaux Arts Institute of Design Bulletin n 24, mayo 1948, p. 30.

"Architects Down Under", en Fortnight, 10 septiembre 1948, pp. 8-11 (Cecil Birtcher House).

\section{9}

POR H. H. HARRIS:

"Rhythmic Integration of Panel Elements", en Practical Builder, diciembre 1949, pp. 76-79.

SOBRE H. H. HARRIS:

"House Plan: Illustrating Revival of Kitchen as Center of Home", en Architectural Record, abril 1949, p. 104. AVERY

\section{0}

SOBRE H. H. HARRIS:

"Motion Pictures Document Growth of Architecture's Western Movement", en Redwood News, verano 1950, p. 14 (Weston Havens House). 
EDGERG, Costa: "Bostadsbygge i Californien", en Byggmastaren, noviembre 1950, pp. 102-104 (Weston Havens House y Clarence Wyle House).

"Lodewijk Lek House", en Previews Inc., folleto-catálogo de ventas no 7030, junio 1950.

1951

SOBRE H. H. HARRIS:

"Fields of Light", en Sunset Magazine, octubre 1951, p. 47 (sobre la Harold English House en Beverly Hills, Los Angeles).

1952

SOBRE H. H. HARRIS:

"Weston Havens House", en California Redwood Association, NCC, AIA Bulletin, enero 1952.

"Television Sales Room", en New York Beaux Arts Institute of Design Bulletin no 27, febrero 1952, p. 28.

"Casa en Fellowship Park, Los Angeles", en Nuestra Arquitectura, marzo 1952, p. $82-85$.

"Modern with a Warm Look", en Los Angeles Times Home Magazine, 11 mayo 1952, pp. 4-5 (James Elliott House).

"The Small House on the Cover", en Sunset Magazine, septiembre 1952, pp. 44-45, 77-78 y portada (Rex Hardy House).

1953

SOBRE H. H. HARRIS:

"Simple Ideas from a Complex House", en House and Home, enero 1953, pp. 126-131 (sobre la Ralph Johnson House). AVERY

"Let's Include Everybody In", en House and Home, junio 1953, p. 114 (de nuevo, la Ralph Johnson House).

"Oriental Influence on American Art and Architecture", Actas de la 85th Convention, AIA, Seattle (15-19 junio 1953), p. 15.

ANDREWS, Wayne: "Like Your Veblen Hotter?", en Saturday Review, 25 julio 1953, pp. 19 y 30 (mención a Harris en la crítica del libro de Henry Russell Hitchcock y Arthur Drexler: Built in the USA: Postwar Architecture).

1954

POR H. H. HARRIS:

"Architectural Trends", en The Review, Society of Residential Appraisers, febrero 1954, pp. 7-11.

Crítica del libro de Gershon Canaan Rebuilding the Land of Israel, en Dallas Morning News, 15 agosto 1954 . 
SOBRE H. H. HARRIS:

"Work Has Begun at Fair Grounds on Harwell Harris' Model House" en Dallas Morning News, 4 julio 1954.

"The Pace Setter House", enThe Alcalde, UT Alumni Magazine, octubre 1954, p. 26.

"Pace Setter House", en Dallas Morning News, 10 octubre 1954.

"Pace Setter House", en Dallas Times Herald, 10 octubre 1954.

"Fireplace», en Sunset Magazine, noviembre 1954, p. 54 (Ralph Johnson House).

1955

POR H. H. HARRIS:

"Air Conditioning", en The New YorkTimes, 15 mayo 1955.

SOBRE H. H. HARRIS:

"Pace Setter House Took Best of the Old and Best of the New", en House and Home 7, enero 1955, pp. 146-147.

"Dressing Table", en Sunset Magazine, febero 1955, p. 50 (Ralph Johnson House).

"The Pace Setter House", en House and Home, marzo 1955, p. 65.

KENNEDY, Robert Woods: "Architecture and the New Package Style", en The New Republic, 4 abril 1955, p. 15.

"Pace Setter House", en House and Home, mayo 1955, p. 290.

"Pace Setter House", en Redwood News, primavera 1955, p. 15.

"Frigidaire 'Kitchen Plan' program", en House and Home, julio 1955.

"Award of Merit for Pace Setter House", en House and Home, octubre 1955.

"News from the Educational Field", en AIA Journal, noviembre 1955, p. 234 (sobre la dimisión de H. H. Harris como Director de la Escuela de Arquitectura de la Universidad de Texas).

\section{6}

SOBRE H. H. HARRIS:

"American Beauty", en The New Yorker, 3 marzo 1956, p. 24 (sobre el proyecto del Motel-on-the Mountain).

"The Motel on the Mountain", en Interiors Magazine, septiembre 1956, pp. 102-107.

"The Contemporary House in the American Southwest", en Roswell Museum Bulletin 4, verano 1956). 
"Homestyle Center. Museum for Houses, Grand Rapids, Mich.", en Architectural Record, septiembre 1956, pp. 217-225. AVERY

1957

POR H. H. HARRIS:

"What's Your Line?", University of Oklahoma 17th Annual Career Conference, abril 1957.

SOBRE H. H. HARRIS:

"By-Passed Land", en House and Home, febrero 1957, pp. 1081-113.

"Architect Designs 'House for Southwest', Finnish Embassy", enThe Royal Report, abril 1957, p. 4.

"Contemporary: the Hotels, the Holidays", en Vogue, julio 1957, pp. 74-75 (Motel-on-the-Mountain).

1958

SOBRE H. H. HARRIS:

"Pace Setter House in California Redwood Assn. ad", en Sunset Magazine, febrero 1958 , p. 73.

"Motel on the Mountains, Suffern, NY", en Sinkentiku, febrero 1958, pp. 25-33. AVERY

"Sullivan's Owatonna Bank, Saved from Unwise Remodeling, is Rededicated", en Northwest Architect, julio-agosto 1958, pp. 28-29, 41. AVERY

"The rise in apartments", en Architectural Forum, septiembre 1958, p. 109 (reforma del propio apartamento de Harris en el edificio de Howard Meyer, Dallas).

"Simple Plan for Privacy", en Life, 16 septiembre; 29 septiembre y 6 octubre 1958, (Courtney Townsend House, reimpresión de las series denominadas The US Need for More Livable Homes).

"Dining room and garden for the Ceramic Tile Council", en House Beautiful, noviembre 1958 (reimpresión).

"A House to Show the Fun of Family Life" en House and Home, diciembre 1958, pp. 128-129 (Courtney Townsend House, reimpresión del artículo Simple Plan for Privacy de la revista Life).

"Eight Houses to Help Home Buyers Rise Their Sights", en House and Home, diciembre 1958, pp. 129-140. AVERY

1959

SOBRE H. H. HARRIS:

"On View in Moscow", en Dallas Morning News, 6 julio 1959 (sobre el National Orange Show -USSR Exhibition in Moscow-, exhibido en Moscú). 
1960

POR H. H. HARRIS:

"Measuring the Architect's Professional Philosophy", en St. Lovis Construction

Record, 12 abril 1960, p. 13.

SOBRE H. H. HARRIS:

WRIGHT, Lloyd: Número monográfico en memoria de Frank Lloyd Wright. Architectural Design, enero 1960, p. 26 (se citan las casas Weston Havens y J. Lee Johnson/Ruth Carter de Harris).

"1960 National Gold Medal Exhibition of the Building Arts". The Architectural League of New York. (Premio por el Motel-on-the-Mountain).

1961

POR H. H. HARRIS:

Carta a Architectural Forum, febrero 1961 (Texto conservado en el Alexander Architectural Archive de la Universidad de Texas en Austin).

SOBRE H. H. HARRIS:

"Oasis Amid Showrooms_Dallas Trade Mart Court", en Architectural Record, abril 1961, p. 119. AVERY

LYNES, Russell: "Everything's Up-to-date in Texas... But Me", en Harpers, mayo 1961, pp. 38-42.

"The New Face of Texas", en Fortune, octubre 1961, p. 130.

"Harwell Hamilton Harris, Architect of Our New Unitarian Church Building" Unitarian Church of Dallas (Texto conservado en el Alexander Architectural Archive de la Universidad de Texas en Austin).

\section{2}

SOBRE H. H. HARRIS:

"Architects in the News", en AIA Journal, 15 enero 1962, p 3 (H. H. Harris se incorpora al Claustro de Profesores de la School of Design del North Carolina State College).

"Internationally Renowned Architect to Join North Carolina State School of Design Faculty", en Statelog, North Carolina State College, enero 1962.

"The WHY of an Architect's Design", en Architectural Record, Western section, febrero 1962, pp. 32-38 (Havens Memorial Plaza).

"First Person Bliss", en House Beautiful enero 1962, pp. 6-97 (Rex Hardy House).

"Fort Worth Mausoleum Named Outstanding by Architects", en National Association of Cemeteries/Southern Cemetery, enero-marzo 1962, p. 6 (Greenwood Mausoleum). 
1963

SOBRE H. H. HARRIS:

"The 2oth Century Look of a Gardener's Garden", en House Beautiful, mayo 1963, pp. 160-163 (J. Lee Johnson/Ruth Carter Stevenson House).

1965

SOBRE H. H. HARRIS:

"Two NCAIA Members Honored by AIA", en North Carolina Architect, mayo 1965 , p. 6.

"Honors/Fellowships for 37 Members", en AIA Journal, junio 1965, p. 22.

"Harris Named in Who's Who", en North Carolina Architect, julio 1965, pp. 8, 19, 20.

Image, Student Publication of the School of Architecture, The University of Texas, 1 mayo 1965, p. 28.

"Harwell Hamilton Harris: a sellection of his writings and buildings", Student Publication of the School of Design, vol 14, no. 5, 1965.

"Home of Mr. Weston Havens House, Berkeley, California", en Homes and Interiors, segundo cuatrimestre 1963, pp. 72-74.

"The Virile Roots", en AIA Journal, diciembre 1965, p. 39.

1966

POR H. H. HARRIS:

"Design Dimensions", en North Carolina Architect, septiembre 1966, pp. 8 y 16-17 (texto resumen de su conferencia ante el Northwest Regional Chapter de la AIA en Glacier National Park, 1965).

1967

SOBRE H. H. HARRIS:

"A Museum Building is Special", en North Carolina Architect, mayo-junio 1967, pp. 9 (editorial), 38-39, 42 y 45.

"The Restorarion of Sullivan's Bank in Owatonnal", en Prairie School Review no 4, segundo cuatrimestre 1967, pp. 22-23. AVERY

1968

SOBRE H. H. HARRIS:

"Why Nature?", en North Carolina Architect, junio-julio 1968, p. 11.

\section{6}

SOBRE H. H. HARRIS:

"Highlights of American Architecture 1776-1976", en AIA Journal, Julio 1976, pp. 125-126 (Weston Havens and H. H. Harris Fellowship Park Houses).

"Architect Now in Residence", en The Miamian, 18 noviembre 1976. 
SOBRE H. H. HARRIS:

"AlA Gold Medal, First in Five Years Awarded to Neutra", en North Carolina Architect, mayo-junio 1977, pp. 8-11.

\section{8}

SOBRE H. H. HARRIS:

KAMPHOEFNER, Henry: "Comments about Harris's Regionalism", en North Carolina Architect, enero-febrero 1978, p. 14.

"Dallas Market Center", en Architectural Review, noviembre 1978, p. 312.

"School of Design", en North Carolina Architect, 1978, p. sr. AVERY

\section{0}

SOBRE H. H. HARRIS:

DEVINS, K. J.: "Harwell Hamilton Harris: The Architect as Artist", en North Carolina Architect, mayo-junio 1980, pp. 17-21. AVERY

Anuncio y crítica del libro Contemporary Architects, en North Carolina Architect, septiembre-octubre 1980, pp. 16-17.

McKINLEY, C. C.: "Renewal: Blending Architecture and Decor", en Architectural Digest, noviembre 1980, pp. 76-83 (sobre la restauración de la Harold English House).

\section{1}

SOBRE H. H. HARRIS:

"The Coming of Age of Interior Design", en Spectator, 2 abril 1981, p.c6 (restauración de la Harold English House).

"Les Nouvelles Maisons Blanches», en Maison Francaise, junio 1981, pp. 88-93 ( restauración de la English House).

\section{2}

SOBRE H. H. HARRIS:

Devins, K. J.:"Harwell Hamilton Harris: the Architect as Artist", en North Carolina Architect, mayo-junio 1982, pp. 17-21 (crítica de la exposición sobre Harris). AVERY

WEINELL, Eleanor F.: "The Successes of Modern Architecture: The Architect as Artist", en North Carolina Architect, julio-agosto 1982, pp. 14-16 (crítica de exposición sobre Harris).AVERY

"A Legacy of Times and Places", The Museum of California Bulletin, noviembre-diciembre 1982, pp. 3-5.

\section{3}

SOBRE H. H. HARRIS:

DEVINS, Kim: "Reverence for Nature", en Spectator, 16 junio 1983, p.sec 2. 
"New church sanctuary harmonizes with nature", en The Raleigh Times, 14 mayo 1983, p. 6-A (St. Giles Presbyterian Church).

1985

SOBRE H. H. HARRIS:

"Harwell H. Harris", en Texas Homes, julio 1985, pp. 35-38.

GERMANY, Lisa: "Home Maker: The Architecture of Harwell Hamilton Harris", en Texas Monthly, marzo 1985, pp. 160-165.

MATUSTIK, Vicki: "Exhibit Looks at Work bay Former Head of Architecture", en On Campus, publicacion del clasutro de la Universidad de Texas en Austin, 25-31 marzo 1985, pp. 4-5.

DILLON, David: "Regional Design with Universal Appeal", en Dallas Morning News, 27 marzo 1985, pp. 1F-3F.

McCOMBIE, Mel: "Architect Exhibit Mirrors 'Comfort' Goal", en Austin American-Stateman, 12 abril 1985, pp. G5.

HARMON, Frank: "Harwell Hamilton Harris: A Tribute", en North Carolina Architect, mayo-junio 1985, pp. 10-15.

HOLMES, Ann: "Honoring Harwell Harris", en Houston Chronicle, 14 julio 1985.

\section{6}

"Design Merits Awards: Residential and Garden Design", en Landscape Architecture $n^{\circ}$ 5, septiembre-octubre 1986, pp. 72-74. AVERY

1988

SOBRE H. H. HARRIS:

STEVEN, Litt: "The Naturalistic Modernism of Harwell Hamilton Harris", en Arts Journal, agosto 1988, pp. 9-11.

HERGET, Barlow J.: "Harwell Hamilton Harris: A Raleigh Architect of International Repute", en Architecture in the Triangle, tercer cuatrimestre 1988, pp. 20A-21A.

ROBINSON, Mark: "Success is a Joint Venture for the Landscape Architect and Architect", en Architecture in the Triangle, tercer cuatrimestre 1988, pp. 26A$27 \mathrm{~A}$ (proyecto de jardinería, espacios exteriors y edificio del St. Giles Presbyterian Church).

\section{9}

SOBRE H. H. HARRIS:

BOUKNIGHT, Joanne K.: "Two houses by Harwell Hamilton Harris", en Fine Homebuilding, agosto-septiembre 1989, pp. 70-74 (sobre las casas del propio Harris en Fellowship Park, Los Angeles y en Raleigh, denominada como Pullen Park House). AVERY 
SELBY, Holly: "The Man of the House", en News and Observer (diario de Raleigh, Carlolina del Norte), 8 octubre 1989, pp. 1C-2C.

1991

WEIHSMANN, Helmut, et al.: "Im Garten Eden: Frank Lloyd Wrights Erbe. Dossier II: Gefuhl Kalkul", en Architektur \& Bauforum no 146, 1991, pp. 45-50. AVERY

1992

WEIHSMANN, Helmut; SERGEANT, John; ROSA, Joseph, y KIEF-NIEDERWOHRMEIER, Heidi: "Im Garten Eden: Frank Lloyd Wrights Erbe", en Architektur \& Bauforum no 147, 1992, pp. 47-66 (un artículo centrado en la cuestión de la arquitectura vernacular estadounidense del siglo XX, se cita, entre otros, la obra de Harris como deudora del trabajo de Wright). AVERY

TILEY, R. D.: "Wanted: One Working Drawing", en Texas Architect, julio-agosto 1992, p. 68. AVERY

2010

ADAMS, Annmarie: "Sex and the Single Building: The Weston Havens House, 1941-2001". Buildings \& Landscapes: Journal of the Vernacular Architecture Forum 17, $\mathrm{n}^{\circ} 1$, primavera 2010, pp. 82-97.

HH.3

ESTUDIOS MONOGRÁFICOS SOBRE HARWELL HAMILTON HARRIS

GERMANY, Lisa: Harwell Hamilton Harris. Prólogo de Kenneth Frampton e Introducción de Bruno Zevi. Berkeley, CA: University of California Press, 2000 (edición original Austin, TX: University of Texas Press, 1991). Para un comentario sobre esta obra véase el apartado Fuentes bibliográficas de este trabajo.

WELLS, Ted y ELLIS, John (fotógrafo): Romatic Modern: The California Architecture of Harwell Hamilton Harris (con contribuciones de Julius Shulman. Los Angeles: Guardian Stewardship y Marquand Books, s. d.). Libro en fase de edición. Durante el proceso de documentación de esta tesis se ha estado en contacto con Wells, autor de esta nueva monografía actualizada sobre la etapa californiana del arquitecto, así como con Ellis, responsable de fotografiar el estado actual de las casas de Harris incluidas en el libro; ambos han facilitado valiosos de materiales y comentarios para esta investigación. 
HH.4

CAPÍTULOS DE LIBROS SOBRE HARWELL HAMILTON HARRIS O ARTÍCULOS DE LIBROS DEDICADOS MONOGRÁFICAMENTE A SUS OBRAS

Se incluyen también catálogos de exposiciones. Ordenados cronológicamente, de fecha de edición original más antigua a publicación más reciente son:

"Harwell Hamilton Harris: House in Fellowship Park, 2311 Fellowship Parkway, Los Angeles, California, 1935", en MOCK, Elizabeth (ed.): Built in the USA, 1932-1944. Exhibition Catalogue. New York: Museum of Modern Art, 1944, pp. 34-35 y 118.

NELSON, George y WRIGHT, Henry (eds.): Tomorrow's House. A Complete Guide for the Home Builder. New York: Simon \& Schuster, 1945. El catálogo incluye: su propia casa en Fellowship Park, Los Ángeles, 1935; la Kershner House también en Los Ángeles, 1935, y la De Stiguer Residence en Pasadena, 1936.

"California House. Harwell Hamilton Harris, Architect", en AA. VV.,SIMON, Maron J. (ed.): Your Solar House. New York: Simon and Schuster, 1946, pp. $124^{-125}$.

"Ralph Johnson House", HITCHCOCK, Henry Russell y DREXLER, Arthur (eds.): Built in USA: Post-War Architecture. New York: Museum of Modern Art, 1952, pp. 64 y 65.

"Harwell Hamilton Harris", en McCOY, Esther: The Second Generation. Salt Lake City, UT: Gibbs Smith Publisher, 1984, pp. 36-81.

GEBHARD, David: "Harwell Hamilton Harris", en AA. VV., WINTER, Robert (ed.): Toward a Simpler Way of life: the Arts \& Crafts Architects of California. Berkeley, Los Angeles CA; London: University of California Press, 1997, pp. $275-282$.

"H. H. Harris: Alexander House (1940-41)" y "H. H. Harris: Weston Havens House (1939-41)", en WEBB, Michael: Modernism Reborn. Mid-century American Houses. New York: Universe Publishing, Rizzoli, 2001, pp. 52-56 y 82-86, respectivamente.

SHIVERS W. Natalie: "A Natured-Based Modernism" apartado del capítulo: The Maturing of the Modern Movement", en DAILEY, Victoria; SHIVERS Natalie; y DAWSON, Michael: LA's Early Moderns. Art/Architecture/Photography. Los Angeles: Balcony Press, 2003, pp. 167-173. Además de este subcapítulo dedicado a Harris, se cita su obra en las páginas siguientes: 58 (portada de California Arts \& Architecture) y 189. 
HH.5

PRINCIPALES PRÓLOGOS/ EPÍLOGOS REALIZADOS POR HARWELL H. HARRIS

HARRIS, Harwell Hamilton: Gordon Drake, en BAYLIS, Douglas y PARRY, Joan: California Houses of Gordon Drake. New York: Reinhold Pub. 1956, pp. $83-85$ (nota final).

HARRIS, Harwell Hamilton: Foreword, en MCCOY, Esther: Vienna to Los Angeles. Two Journeys. Santa Monica, CA: Arts + Architecture Press, 1979, pp. 8-14 (Texto crítico de McCoy y reproducción de la correspondencia entre Shindler y Neutra, Schindler y Wright y Schindler y Sullivan entre otras).

\section{HH.6}

PRINCIPALES CITAS LOCALIZADAS SOBRE HARWELL HAMILTON HARRIS EN HISTORIAS CRÍTICAS DE LA ARQUITECTURA MODERNA

Las referencias al autor en estos libros se relacionan ordenadas cronológicamente de fecha de edición original más antigua a fecha de publicación más reciente:

ANDREWS, Wayne: Architecture in America. New York: Atheneum Publishers, 1960, p. 173 (Weston Havens House).

ZEVI, Bruno: Towards an Organic Architecture. London: Faber \& Faber Ltd., 1960, pp. 120 y $126-128$.

AA. VV.: Architect's Bibliography. Rochester, NY: Image, 1965, pp. 28-29. AVERY

GREEN, Samuel M: American Art, a Historical Survey. New York: Ronald Press, 1966, pp. 474 y 493 (Weston Havens House).

ANDREWS, Wayne: Architecture, Ambitions and Americans: a Social History of American Architecture. New York: Free Prees, 1978, pp. XIV, 283 y284 (Andrews, que llegó a ser buen amigo de Harris, cita la Weston Havens House en Berkeley en una de las historias de la arquitectura norteamericana más influyentes de las publicadas en los Estados Unidos).

FRAMPTON, Kenneth: Historia crítica de la arquitectura moderna (sexta edición castellana). Barcelona: Gustavo Gili, 1993 (edición original London: Thames and Hudson Ltd., 1980), pp. 325 (Frampton cita textualmente parte del texto de la conferencia Regionalismo y nacionalismo, impartida por Harris en el Consejo Regional del Noroeste de la AIA celebrado en Eugene, Oregon, en 1954. Frampton volvió a citar de nuevo este texto de Harris en su artículo $\mathrm{Ha}$ cia un regionalismo crítico, editado por Hal Foster como parte de la relación ensayos recopilado bajo el título The Anti-Aesthetic: Essays on Postmodern Culture, traducido al castellano como La Posmodernidad).

HINES, Thomas S.: Richard Neutra and the Search for Modern Architecture: a Biography and History. New York: Oxford University Press, 1982 (reeditado por Rizzoli en 2006). En la reedición de Rizzoli de 2006, edición manejada 
para este trabjo, se cita a Harris en pp. 14, 57, 77, 87, 91, 104, 122-123, 131, 200-203

AA. VV.: MIDANT, Jean-Paul (dir.): Diccionario Akal de la Arquitectura del S. XX. Madrid: Akal, 2004, p. 386.

AA. VV.: CANIZARO, Vincent B. (ed.): Architectural Regionalism. Collected Writings on Place, Identyty, Modernity and Tradition. New Jersey: Princeton Architectural Press, 2007, pp. 36, 50-56, 66, 211, 380 y 407. Incluye dos textos de Harwell Hamilton Harris sobre la cuestión del Regionalismo: "Regionalism and Nationalism in Architecture", pp. 56-65 (publicado por primera vez en Texas Quarterly 1, febrero 1958, pp. 115-124) y "Regionalism", pp. 56-65 (escrito originalmente para North Carolina Architect, enero-febrero 1978, pp. 10-11).

FRAMPTON, Kenneth: Hacia un regionalismo crítico: Seis puntos para una arquitectura de resistencia, pp. 37-58, en AA. VV., FOSTER, Hal (ed.): La Posmodernidad (sexta edición castellana). Barcelona: Kairós, 2006 (edición original en inglés The Anti-Aesthetic: Essays on Postmodern Culture. Port Townsend, WA: Bay Press, 1983), p. 46.

\section{HH.7 \\ PRINCIPALES CITAS LOCALIZADAS SOBRE HARWELL HAMILTON HA- RRIS EN MONOGRAFÍAS SOBRE ARQUITECTOS CALIFORNIANOS Y/O TEMAS DE ARQUITECTURA ESPECÍFICOS DE LA REGIÓN}

Se refieren especialmente las monografías sobre arquitectos contemporáneos directamente relacionados (personal o profesionalmente) con Harwell Hamilton Harris. El orden es cronológico por fecha de aparición del texto original, de más antiguo a más moderno:

GEBHARD, David: Rudolph Schindler. Barcelona: Oikos-tau, 1979 (edición original: Schindler. Prefacio de Henry Russell Hitchcock. New York: Viking Press, 1971. Reeditado por William Stout, San Francisco, 2001) pp. 155, 159, $161,174,193,195,200,204$ y 215.

GEBHARD, David y VON BRETON, Harriette: LA in the Thirties (1931-1941). Santa Monica, CA: Hennessey + Ingalls, 1989 (edición original Salt Lake City, UT: Peregrine Smith, 1975） pp. 3, 24, 37, 44-45, 99, 101-102,154 y 156-157.

AA. VV., EMANUEL, Muriel ( ed.): Contemporary Architects. New York: St. Martin's Press, 1980, pp. 345-348.

HINES, Thomas S.: Richard Neutra and the Search for Modern Architecture. New York: Rizzoli, 2006 (edición original New York: Oxford University Press, 1982), pp. 14, 57, 77, 87, 91, 104, 122-123, 131, 200-203 у 245.

AA. VV., SMITH, Elizabeth A. T. (ed.): Blueprints for Modern Living: History and Legacy of the Case Study Houses. Cambridge, MA: The MIT Press, 1989. Catálogo de la Exposición del MoCA, Los Angeles Museum of Contemporary, 17 octubre 1989-18 febrero 1990 (reeditado en paperback en 1999), pp. 
15, 16, 33 (Fellowship Park House), 34, 96 (Entenza House), 99 y 140. No se cita a G. Drake.

ROSA, Joseph: A Constructed View: The Architectural Photography of Julius Shulman. New York: Rizzoli, 1994, p 9.

AA. VV., TREIB, Marc (ed.): An Everyday Modernism: The Houses of William Wurster. San Francisco, CA: San Francisco Museum of Modern Art y Berkeley, CA; London: University of California Press, 1995, pp. 22, 35-36 (Fellowship Park House), 37 (comparación con Wurster), 56, 65, 167, 175, 177-178 (Weston Havens House) y 227.

ADAMSON, Paul y ARBUNICH, Marty: Eichler: Modernism Rebuilds the American Dream. Salt Lake City, UT: Gibbs Smith Publisher, 2002, pp. 24-25, $31,34-35,88$ y 92.

BURTON, Pamela y BOTNICK, Marie: Private Landscapes. Modernist Gardens in Southern California. Introducción de Kathryn Smith. New York: Princeton Architectural Press, 2002, pp. 106-113 (Dean McHenry House, West Los Angeles, 1940, análisis del jardín).

JACKSON, Neil: Craig Ellwood. London: Laurence King Publishing, 2002 Publicado en los Estados Unidos como California Modern: The Architecture of Craig Ellwood. New York: Princeton Architectural Press, 2002, p. 27.

SMITH, Elizabeth A. T., Peter Goessel (ed.): Case Study Houses. The Complete CSH Program 1945-1966. Epílogo de Julius Shulman. Köln, New York: Taschen, 2002, pp. 8, 9, 423, 426, 432 y 433 .

MACY, Christine y BONNEMAISON, Sarah: Architecture \& Nature. Creating the American Landscape. London; New York: Routledge, 2003, p. 228 (se cita a Harris y a Drake como dos arquitectos cuya obra epitomiza el concepto de disolución de los límites entre el exterior y el interior en la vivienda california, una actitud heredera, en palabras de las autoras, de la tradición de vida simple en contacto con la naturaleza del movimiento Arts \& Crafts americano, materializado en terrazas cubiertas y sleeping porches cuya importancia funcional se traslada en la arquitectura de posguerra al comedor $y_{\text {, }}$ sobre todo, al living, como espacios enteramente abiertos al exterior hasta fundirse con él).

COLL-BARREU, Juan: Construcción de los paisajes inventados. Los Ángeles doméstico 1900-1960. Arquithesis. Barcelona: Fundación Caja de Arquitectos, 2004, pp. 186-187 (breve referencia a la Entenza House).

WRIGHT, Eric Lloyd: "La utopía en construcción", en AA. VV., HESS, Alan (dir.): Las casas de Frank Lloyd Wright. Barcelona: Gustavo Gili, 2006 (edición original Frank Lloyd Wright, The Houses. New York: Rizzoli, 2005), p. 378 (discutiendo sobre la influencia de su abuelo en arquitectos más jóvenes, el nieto de Wright afirma sobre Harris: Harwell Hamilton Harris y O'Neil Ford ayudaron a establecer la tipología de la casa-rancho contemporánea (...) exenta de detalles pintorescos, dotando a este tipo arquitectónico de una imagen contemporánea elegante antes de que Wright hubiera resuelto su casa usoniana).

SERRAINO, Pierluigi: NorCalMod: Icons of Nothern California Modernism. San Francisco: Chronicle Books, 2006, pp. 20-21, 39-41 (Weston Havens 
House en Berkeley. La vivienda se publicada con las fotografías tomadas por Roger Sturtevant de 1941), 40, 45, 50, 52, 63, 95, 102, 169-170, 174, 230 y 274.

HESS, Alan: Forgotten Modern: California Houses 1940-1970. Salt Lake City, UT: Gibbs Smith Publisher, 2007, p.8.

HINES, Thomas S.: Architecture of the Sun: Los Angeles Modernism 19001970. New York: Rizzoli, 2010, pp. 366, 431, 433, 483-502.

\section{HH.8}

PRINCIPALES CITAS LOCALIZADAS SOBRE HARWELL HAMILTON HARRIS EN GUÍAS DE AROUITECTURA DE CALIFORNIA

GEBHARD, David y WINTER, Robert: An architectural Guidebook to Los Angeles. Salt Lake City, UT: Gibbs Smith Publisher, 2003, pp. 7, 23, 28, 47, 152, $173,198,447$.

Ha sido consultada también su edición precedente: Los Angeles. An Architectural Guide. Salt Lake City, UT: Gibbs Smith Publisher, 1994. Ambas son reediciones de un exhaustivo trabajo de documentación y crítica que ha venido actualizándose y ampliándose desde 1965. Éste se inició con Guide to Architecture in Southern California (Los Angeles: Los Angeles County Museum of Art, 1965); y continuó con A Guide to Architecture in Los Angeles \& Southern California (Santa Barbara, CA: Peregrine Smith, 1977). En 1985 sus autores revisaron su ya entonces imprescindible guía concentrándose específicamente en el área de Los Angeles y publicaron Architecture in Los Angeles: a Complete Guide. Salt Lake City, UT: Gibbs Smith Publisher, 1985. Hasta la fecha es la más completa guía de arquitectura de la región de Los Angeles. En la guía de Gebhard/Winter se relacionan además y del modo que se reproduce a continuación las siguientes obras de H. H. Harris en Los Angeles. Adviértase que la cronología no hace referencia al año de proyecto sino a la finalización de la obra o a la última intervención producida en ella:

Alexander House (1941), p. 200.

Baver House (1938), p. 334.

Birtcher House (1942), p. 306.

Dean McHenry House (1940), p. 141.

Elliott House (1951), p. 343.

English House (1950), p. 154.

Entenza House (1937), p. 48.

Granstedt House (1938), p. 189.

Hansen House (1951), p. 200.

Harris House (1939), p. 391.

Harrison House (1950), p. 46.

Hawk House (1939), p. 201.

Hopmans House (1951), p. 200.

Johnson House (1949), p. 134.

Laing House (1935), p. 391.

Lowe House (1934), p. 432.

Mulville House (1949), p. 447.

Pumphrey House (1939), p. 48.

Schwenk House (1940), p. 348. 
Sobieski House (1946), p. 442.

Walther House (1937), p. 203.

GEBHARD, David, WINTER, Robert et al.: Guide to Architecture in San Francisco and Northern California. Salt Lake City, UT: Gibbs Smith Publisher, 1985. Revisada con Eric Sandweiss (edición original Santa Barbara, CA: Peregrine Smith, 1973, con John y Sally Woodbridge), pp. 259, 268 y 534 (se cita principalmente la Weston Havens House en Berkeley). MOORE, Charles con BECKER, Peter y CAMPBELL, Regula: Los Angeles. The City Observed. A Guide to its Architecture and Landscape. Santa Monica, CA: Hennessey + Ingalls, 1998 (edición original New York: Vintage Books, 1984), pp. 223, 258 y 260-261 (Obras en Silver Lake. Moore dedica un breve apartado a la Hansen House, si bien, apenas comenta la fachada y la casa sólo sirve de excusa para introducir al lector en el conjunto de la obra de Harris y aportar algunos datos biográficos del arquitecto).

WOODBRIGE, Sally B., WOODBRIDGE, John M. y BYRNE, Chuck: San Francisco Architecture: An Illustrated Guide to the Oustanding Buildings, Public Artworks and Parks in the Bay Area of California. Berkeley, CA: Ten Speed Prees, 2005 (edición revisada a partir de la edición original San Francisco Architecture: The Illustrated Guide to Over 1.000 of the Best Buildings, Parks, and Public Artworks in the Bay Area. San Francisco: Chronicle Books, 1992), p. 287 (cita a Harris pero no su obra más significativa en el Área de la Bahía, la Weston Havens House).

\section{HH.9 \\ PRINCIPALES ARTÍCULOS PUBLICADOS POR JEAN HARRIS (JEAN MU- RRAY BANGS) SOBRE AROUITECTOS DE CALIFORNIA}

BANGS HARRIS, Jean M.: "Bernard Ralph Maybeck, Architect, Comes into His Own: Notes from a Forthcoming Book on Maybeck", en Architectural Record, enero 1948, pp. 72-79. AVERY

BANGS HARRIS, Jean M.: "Greene and Greene: the American House Owes Simplicity and Clarity to Two Almost-Forgotten Brothers Who Showed Us How to Build with Wood", en Architectural Forum, octubre 1948, pp. 80-89. AVERY

BANGS HARRIS, Jean M.: "A obra dos irmos Greene", en Arquitectura Portuguesa, abril-junio 1949, pp. 6-9. AVERY

BANGS HARRIS, Jean M.: "Bernard Ralph Maybeck", en American Institute of Architects Journal, mayo 1951, pp. 221-223. AVERY

BANGS HARRIS, Jean M.: "Maybeck-Medallist", en Architectural Forum, mayo 1951, pp. 160-62. AVERY

BANGS HARRIS, Jean M.: "Prophet without Honor", en American Institute of Architects Journal, julio 1952, pp. 11-16 (sobre los hermanos Greene). AVERY 


\section{BIBLIOGRAFÍA ESPECÍFICA SOBRE GORDON DRAKE}

\section{GD.1}

ARTÍCULOS ESCRITOS SOBRE GORDON DRAKE EN REVISTAS ESPECIALIZADAS/ PUBLICACIONES PERIÓDICAS INTERNACIONALES

Se incluyen todos aquellos artículos encontrados sobre Drake y que han podido ser consultados. Como puede comprobarse, son escasos los documentos publicados tras la muerte del autor, apenas unas pocas referencias en publicaciones sobre otros temas o sobre arquitectos californianos y que, por lo general, sólo citan, o bien la condición de Drake como discípulo de Harris, o bien hacen referencia a las fotografías que Julius Shulman tomó de la Drake House (1946) en Los Angeles.

Desde el breve artículo escrito en 1996 por Neil Jackson, no ha vuelto a publicarse nada sobre Gordon Drake, siendo conspicua la inexistencia de una monografía crítica sobre el personaje más allá de la reimpresión del libro sobre el arquitecto publicado tras su muerte (BAYLIS, Douglas y PARRY, Joan: California Houses of Gordon Drake. New York: Reinhold Pub., 1956) a cargo del librero y editor de San Francisco William Stout (2011).

La siguiente relación de entradas es cronológica, de fecha de publicación más antigua a más reciente:

\section{7}

"Two Ex-Marines Put an Ideal to Work... and Build a $\$ 4,500$ House", en The American Home, marzo 1947. Portada (el propio Gordon Drake aparece en la portada de la revista, fotografiado con su mujer en su casa de Beverly Glen. En la fotografía, tomada por Julius Shulman, ambos posan en una actitud relajada, como una joven pareja de posguerra feliz en su recién estrenado hogar) y pp. 30-35 (Incluye doce fotografías de la vivienda tomadas por Julius Shulman).

Reseña: "1946 Progressive Architecture Awards", en Architectural Forum, junio 1947, p.15 (se publica un retrato del arquitecto ¿realizado por Julius Shulman?).

"Progressive Architecture Awards", en Progressive Architecture, julio 1947, pp. 10-14, 53-60 (sobre la edición de los premios convocados en año anterior y en el que Gordon se ha alzado con la victoria gracias a su propia casa en Beverly Glen, compartiendo premio con la Case Study House diseñada por J . R. Davidson).

"USA Architects Awards", en The Architects Journal, RIBA, 12 junio 1947, pp. 496-497 (veredicto del Jurado sobre los premios de la revista Americana Progressive Architecture. Drake House en Beverly Glen, Los Ángeles. Se publican tres fotografías de Julius Shulman y la planta de la vivienda).

"Progressive Architecture Award Winner. Designer's Own House, Los Angeles, California. Gordon Drake", en Progressive Architecture, julio 1947, p. 45-52 (nueva celebración de la obra ganadora del premio convocado por la revista americana, publicada con fotografías de Julius Shulman a toda página y una planta de la vivienda). AVERY 
"Minimun House", en The Architects Journal, RIBA, 10 julio 1947, p. 36-39 (de nuevo sobre la propia residencia de Gordon Drake en Los Angeles. Se alaba la calidad espacial de la vivienda a pesar de las dimensiones mínimas y las restricciones presupuestarias. De nuevo se utilizan las fotografías de Julius Shulman).

"Modular House en Pacific Coast capitalizes on the area 's famous topography, climate and materials", en Architectural Forum, septiembre 1947, pp. 110-116 (En este número Drake expone con detalle sus ideas acerca del hogar americano de posguerra. Incluye fotografías de su propia casa tomadas por Julius Shulman, así como fotografías, dibujos y diagramas de montaje de la Presley House en Silver Lake).

"Hillside Hideway, Gordon Drake, Los Angeles", en Interiors, septiembre 1947, pp. 78-81 (sobre la propia vivienda de Drake en Los Ángeles, una vez más fotografiada por Julius Shulman).

"Modular Units, Los Angeles", en House \& Garden, septiembre 1947, pp. 99101 (sobre la vivienda para los Presley en Silver Lake, Los Ángeles, presentada como ejemplo de diseño experimental basado en la construcción modular con el que propiciar el desarrollo de una vivienda de masas. Se publican fotografías de Julius Shulman).

"Casa in California", Domus no. 223-225, octubre-diciembre 1947, pp. 24-29 (el interés por la vivienda de Drake en Los Ángeles llega a Europa, siendo recogida por Domus a finales de ese mismo año. El hecho de que la vía de llegada a Italia sea a través de las páginas de Progressive Architecture, pone de manifiesto, por otra parte, la labor de las agencias de noticias funcionando ya a pleno rendimiento en Europa tras la guerra). AVERY

"Gordon Drake House", en Form, 1947 (La revista sueca incluye las imágenes tomadas por Shulman de la propia vivienda de Drake en Los Ángeles. Esta referencia bibliográfica está tomada BAYLIS, Douglas: California Houses of Gordon Drake, p. 22).

\section{8}

"Materials for '48: House, Los Angeles, California, Gordon Drake, designer", en Progressive Architecture, enero 1948, pp.50-54 (se publica la Rucker-más tarde-Spillman House, ilustrada con 9 imágenes de Julius Shulman). AVERY

"Vivienda modular en California, EEUU, Sobre la Costa del Pacífico", en Revista de Arquitectura, febrero 1948, pp. 40-47 (con esta inclusión en la revista argentina, Drake es publicado en castellano y, por segunda vez, en un contexto diferente del ámbito anglosajón. Se publican 9 fotografías de Julius Shulman de la casa de los Presley en Silver Lake, una planta, un plano de emplazamiento y diferentes detalles del montaje de las piezas industrializadas). AVERY

"This House is the Sum of its Modular Parts", en House \& Garden, febrero 1948, pp. 98-103 y 132 (Se publica la casa Presley, incluyendo 8 fotografías de Shulman).

"House \& Garden Architectural Award Winners", en Architectural Record, febrero 1948, p.10. AVERY 
"Announcing the Prize-Winning Houses in House \& Garden's 1947 Awards in Architecture", en House \& Garden, abril 1948, p.171-172 (Spillman-Rucker House, ganadora del Segundo Premio en la Class I, viviendas inferiores a 1800 pies cuadrados de superficie).

"A House for the Early Years", en House \& Garden, mayo 1948, pp. 140-143 (Se publica la casa Rucker-Spillman, ganadora del Segundo Premio en el House \& Garden's 1947 Architectural Arwards Competition).

"Annual Progressive Architecture Awards", en Progressive Architecture, junio 1948, p. 49 (retrato del arquitecto) y p. 47-73 (publicación de la relación completa de premios del año anterior, en los que Drake ha obtenido una nueva distinción. En pp. 59-61, Mention: House, Los Angeles, California, Gordon Drake. Se publica una imagen de Julius Shulman de la casa Presley, ganadora de una Mención en los Second Annual Progressive Architecture Awards). AVERY

"Deux habitations à Los Angeles", en L'Architecture d'Aujourd'hui no 18-19, Habitations individuelles, junio 1948, pp. 30-37 (en un número doble de la revista francesa dedicado a viviendas unifamiliares se incluyen dos casas de Gordon Drake de 1946, su propia vivienda en Beverly Glen -"Habitation de l'architecte", pp. 30-33- y la Casa Presley en Silver Lake -"Maison Experimentale. Construction par panneaux sur trame modulée», pp. 34-37-. La revista se interesa por el experimentalismo y la radicalidad de las propuestas y, especialmente, por la calidad espacial de las viviendas a pesar de estar construidas con estándares extraordinariamente económicos. En el apartado dedicado a Norteamérica, las obras de Drake aparecen publicadas entre las de otros autores consagrados como Marcel Brever, Hugh Stubbins o Richard Neutra, lo que da una idea del prestigio que, en tan poco tiempo estaba alcanzando el joven arquitecto californiano que, entonces, contaba sólo 29 años de edad. Se publican 13 fotografías de Shulman de las casas de Drake, 8 de su propia vivienda y 5 de la Presley House).

"Vivienda en Los Ángeles, California, EEUU. Diseñador Gordon Drake", en Revista de Arquitectura, noviembre 1948 (se publica su propia casa en un artículo de 5 páginas ilustrado con siete fotografías de Julius Shulman).

\section{9}

"In Search of a Plan for the Western home", en Sunset Magazine, octubre 1949, portada (fotografía de Morley Baer) y pp. 30-31 (sobre las investigaciones proyectuales de las viviendas de Carmel).

\section{0}

"US Architecture 1900-1950", en Progressive Architecture, enero 1950, pp. 49103 (Gordon Drake Residence en Los Ángeles en p. 49).

"Los Angeles, Wohnhaus", en Werk, febrero 1950, pp. 34-35 (dibujos, plantas y fotos de Julius Shulman de la casa del arquitecto).

Publicidad de Douglas Fir Plywood, en Arts \& Architecture, abril 1950, pp. 8-9 (se incluye, a doble página, publicidad de la empresa de estructuras de madera laminada ilustrada con fotografías de Julius Shulman de la casa RuckerSpillman, detalles constructivos y de montaje y axonometrías del sistema 
estructural. La publicidad de Douglas Fir se introduce con el siguiente texto de Gordon Drake: "With Playwood, Desing and Structure can be Treated as a Single, Integrated Unit". Curiosamente, se trata de la única vez que la revista de John Entenza publicó una vivienda de Drake, pero no como parte de sus contenidos, sino a través de la publicidad suministrada por el propio anunciante. Es además llamativo que el grado de detalle con el que se explica el proyecto, al tratarse de publicidad de un sistema constructivo, sea bastante superior al habitual con el que se publicaban las viviendas escogidas por el consejo editorial.

"Design for Cabin Living", en Sunset Magazine, julio 1950, pp. 30-33 (Diseño de diferentes cabañas-refugio de montaña y playa).

"Maison pour un jeune ménage à Los Angeles", en L'Architecture d'Aujourd'hui n 30 , julio 1951, pp. 67-69.

«Four Houses: 1. Carmel, California; Designer: Gordon Drake», en Progressive Architecture, agosto 1950, pp. 49-56).

1951

"Twelve Architects Suggestions for the Merchant Builder: 3. The Mirror Trick / 10. Reflecting Pools", en Architectural Forum, enero 1951, pp. 112-126 (se publican fotografías de Julius Shulman de espejos instalados en un dormitorio de una casa de Richard Neutra y en el bar de la Dammann Residence de Gordon Drake, así como de piscinas fotografiadas por Shulman también en casas de Neutra y de Gordon Drake).

"The Next Fifty Years", en Architectural Forum, junio 1951, pp. 165-170 (Gordon Drake House).

"Multi-purpose Garden Panels, You Can Build Almost Any Garden Structure ", en Sunset Magazine, marzo 1951, pp. 40-43.

"Good Ideas For your Garden Dining Room", en Sunset Magazine, julio 1951, pp. 36-38.

"How Tomorrow's Western Kitchens Will Extend to the Out-of-Doors", en Sunsent Magazine, noviembre 1951, pp. 34-39 (el artículo se acompaña de una fotografía de Drake y de su entonces socio el arquitecto paisajista Douglas Baylis con una maqueta de la "kitchen glass room" de la propia casa de Drake en Los Ángeles).

\section{2}

"House: Carmel, California", en Progressive Architecture, febrero 1952, pp. 9295 (sobre la E. Kennedy Vacation House). AVERY

"Gordon Drake (Obituary)", en Progressive Architecture, marzo 1952, p. 212.

"Gordon Drake 1917-1952: His Place in Contemporary Architecture", en Progressive Architecture, marzo 1952, pp. 94-103 (obituario).

"Obituary. Gordon Drake, 1957-1957", en House \& Home, marzo 1952, pp. 94-103 (para el primer número siguiente a la fecha de su muerte, la revista preparó con rapidez este sentido homenaje al arquitecto entonces recien- 
temente fallecido, recopilando, a través de sus amigos, documentación de sus obras y proyectos que luego sirvieron para la monografía publicada por su amigo Duglas Baylis. El artículo iba precedido de un texto de H. H. Harris: Oasis for Good Living. Se publican fotografías de Julius Shulman de las casas Drake, Rucker-Spillman y Dammann en Los Ángeles y Scribner en Hayward. Se publica también una fotografía a doble página de Shulman de la Unit House en Alameda County y se incluye una fotografía de Morley Baer de la Carmel House). El artículo se divide en los siguientes apartados:

"This Expanding House Has Five Zones for California Oudoor Living", pp. 96-97 (Unit House, Drake Residence, Dammann House, Carmel House).

"Modular Structure Gave Drake's Work Flexibility, Discipline, Prefab Possibilities", pp.97-98 (Unit House, 1947 Prefabricated Residence, Dammann House, Carmel House e incluye la Weston Havens House de Harwell Hamilton Harris).

"Play of Light Gave Drake's Houses Their Poetic Quality", pp.100-101 (Unit House, Drake Residence, Rucker-Spillman House y se incluye de nuevo la Weston Havens House de Harwell Hamilton Harris).

"Japanese Details Gave Drake's Houses Lightness and Grace", pp.97-98 (Unit House y Carmel Vacation House, publicando también una fotografía de Fred Dapprich del Pabellón en Fellowship Park de 1935 de Harris).

En ese mismo número de marzo de 1952 de House \& Home, en las pp. 126129, se publica el artículo "Garages and carpots as storage space", en el que se da cobertura al garaje diseñado por Drake para la Dammann House en Los Ángeles. AVERY

\section{3}

"Les architectes de la jeune génération aux États Unis, en L'Architecture d'Aujourd'hui no 50-51, Contribution américaine à l'architecture contemporaine, diciembre 1953, pp. 86-9o (en este número doble de la revista francesa dedicado a la producción arquitectónica reciente en los Estados Unidos, resulta curioso encontrar los proyectos más representativos de dos jóvenes y prometedores arquitectos prematuramente fallecidos, Matthew Nowicki y Gordon Drake, del que se publica, una vez más ilustrada con fotografías de Shulman su propia casa en Los Ángeles.

\section{4}

"Progressive Architecture Design Data: Terraces", en Progressive Architecture, febrero 1954, pp. 122-123 y 138-139 (incluye tres fotografías de Shulman de la Berns Beach House en Encinal, Malibu).

"This Cheerful Beach House Gives You a Choice of Outdoor Weathers" en Progressive Architecture, marzo 1954, portada y pp. 58-59 (Berns Beach House en Encinal, Malibu. Tanto la fotografía de portada como las seis imágenes con las que se ilustra el artículo sobre esta casa póstuma fueron cedidas por Julius Shulman, quien incluyó a Esther McCoy como modelo de su fotografía de portada).

Publicidad "Natural Beauty for Redwood", en Sunset Magazine, abril 1954, p. 96 (incluye una imagen de la Mesa House de Drake en Carmel). 
"A Bedroom Deck or Patio", en Sunset Magazine, marzo 1955, pp. 62-63 (incluye fotografías de Schulman de la Berns House en Malibu).

"Pass-through Serving Counters", en Sunset Magazine, junio 1955, p. 90 (Malibu House).

"How to Use the Problem Lot", en House \& House, agosto 1955, p. 116 (publica un proyecto de casa en una colina de Drake).

1956

"The New House-to-Site Transition: Malibu House", en Progressive Architecture, junio 1956, portada y pp. 114-117 (en un artículo publicado en páginas precedentes (104-105) donde se discute sobre la relación interior-exterior en el hogar americano de posguerra, tratando de desmontar determinados clichés cuya repetición en las revistas especializadas o populares -se afirmaestá vaciando de contenido los principios de dicha relación, se aportan varios ejemplos de los que se destaca su autenticidad e interés de la investigación proyectual materializando la idea de disolver los límites de la vida dentrofuera, entre ellos, la casa del fotógrafo Julius Shulman y, en lo que a Gordon Drake respecta, su Berns House en Malibu. Tras esta breve introducción teórica, la revista dedica varias páginas a analizar la vivienda construida por Drake en Malibu, una de las últimas realizaciones del arquitecto, afirmándose, curiosamente además, que esta casa se está publicando por primera vez, cuando la propia revista la había presentado ya en 1954 ). AVERY

"House: San Francisco, California: Home and Ofice of Landscape Architect Douglas Baylis", en Progressive Architecture, diciembre 1956, pp. 106-111. AVERY

En ese mismo número de la revista, en la página 112 se publica una crítica (Book review) de la monografía publicada por su antiguo socio Douglas Baylis y por Joan Parris como homenaje al autor, fallecido cuatro años antes, titulada: "California Houses of Gordon Drake" (Véase apartado siguiente de esta bibliografía). La crítica del libro se ilustra con fotografías de Shulman de las casas Presley, Drake y Unit House.

\section{7}

"California Houses of Gordon Drake", en Interiors, enero 1957, p. 20 (Reseña del libro monográfico sobre el arquitecto editado por Douglas Baylis y Joan Parry y publicado por Reinhold, Nueva York, 1956).

"100 Years of the American House", en House and Home, mayo 1957, pp. 110128 (se incluye una mención a la propia vivienda de Drake en Los Ángeles, ilustrada por una fotografía de Julius Shulman).

"California Houses of Gordon Drake", en L'Architecture d'Aujourd'hui n 72, junio-julio 1957, p. XXXV (Otra reseña sobre la entonces recién aparecida monografía sobre el arquitecto).

\section{8}

"Americane Moderne Correntie" (Nota encontrada en el catálogo general de Julius Shulman, en su propio estudio en 2008. Dicha nota hace referencia a 
la publicación, entre otros autores californianos, de 2 fotografías de la Unit House de Drake en San Francisco. No se han podido encontrar más datos sobre si esta publicación es un artículo de revista o libro).

\section{8}

"Conservancy Tour to Visit Neutra, Schindler Houses", en Los Angeles Times, 6 abril 1986, p. 12 (se publica un artículo sobre la visita a seis viviendas de Los Ángeles, entre ellas, la casa Presley de Drake en Silver Lake).

1992

"The Influence of Richard Neutra", en LA Architect, abril 1992, pp. 13-14 (artículo de Kappe que incluye mención y fotografía de Shulman, entre otras viviendas de Los Ángeles, como la del propio Ray Kappe, a la Drake House).

1993

SHULMAN, Julius y WINTER, Robert: "Design for Living 1993 Calendar. The Work of 12 Visionary Architects in Southern California" (se incluyen fotografías de la casa de Gordon Drake en Los Ángeles, publicado junto a Neutra, Kappe, Gill, Judge, Black, Schindler, Maston, Wright, Koenig, Eames y Lautner).

\section{4}

"Sharper of Perceptions", en Progressive Architecture, abril 1994, pp. 80-84 (reseña editorial sobre el libro de Joseph Rosa: A constructed view: The Architectural Photography of Julius Shulman. New York: Rizzoli, 1994, véase apartado correspondiente de esta bibliografía).

\section{6}

JACKSON, Neil: "Californian Promise", en The Architectural Review n 1189, marzo 1996, pp. 80-84 (como se ha comentado en el texto del trabajo, este breve texto firmado por el crítico británico Neil Jordan, Hoffman Wood Chairman of Architectural Engineering en la Universidad de Leeds, es el primer artículo crítico sobre Gordon Drake publicado en 50 años y, sorprendentemente, el último escrito monográfico sobre el arquitecto californiano hasta la fecha. El texto aparece ilustrado con plantas, esquemas constructivos y siete fotografías de Shulman de diferentes casas de Drake). AVERY

\section{8}

"Julius Shulman", en LA Architect, diciembre 1998, portada y pp. 8-11 (artículo de M. Newman sobre el fotógrafo, ilustrado, entre otras fotografías con una imagen de la Drake House).

SHULMAN, Julius: "My Beginnings as a Photographer", en Echoes nº3, invierno 1998 , pp. 58-63 (el artículo se ilustra también, entre otras fotografías con una imagen de la Drake House). 
"Still Building on His Art", en Los Angeles Times, 16 noviembre 2000, p. E1 (se cita a Drake en este artículo sobre la figura de Shulman como cronista del estilo de vida californiano a lo largo del siglo XX).

\section{1}

"Modernism Rediscovered", reseña del libro homónimo de Pier Luigi Serraino en Whole Earth, San Rafael, verano 2001, p. 57 (referencias a Gordon Drake).

"Modernist Melding of Elements", artículo sobre Richard Neutra en Los Angeles Times Orange County Edition, 13 julio 2001, p. 57 (referencias a Gordon Drake).

\section{6}

POSTREL, V.: "The Iconographer", artículo sobre la técnica de Julius Shulman en Atlantic Monthky, 4 noviembre 2006 (se discute sobre el modo de fotografiar la diminuta Drake House en Los Ángeles para lograr la vista tan larga que cruza el estar y el patio, tomada sentado desde el dormitorio). http://www. dynamist.com/articles-speeches/atlantic/shulman.htnl/

\section{9}

MELTON, Mary: "Julius Shulman in 36 Exposures", en Los Angeles Magazine, enero 2009, portada y pp. 6, 80-87 y 149-155 (artículo sobre la trayectoria profesional de Shulman, donde se incluyen fotografías de la Drake House). Disponible online en http://www.lamag.com/article.aspx?id=12464

WEINBERG, Larry: "The Brief but Notable Career of Gordon Drake", en Interior Design, octubre 2009 (breve reseña sobre el arquitecto, incluye imágenes de Julius Shulman)

http://www.interiordesign.net/blog/Cindy_s_Salon/35292-The_Brief_but_Notable_Career_of_Gordon_Drake.php

\section{0}

HAWTHORNE, C. "Modern Giants Under the Sun", en Los Angeles Times Calendar Section, 1 agosto 2010, p. E1 (reseña sobre el libro de Thomas S. Hines Architecture of the Sun: Los Angeles Modernism 1900-1970, se incluye referencia sin fotografía a Gordon Drake).

\section{GD.2}

\section{MONOGRAFÍAS EXISTENTES SOBRE GORDON DRAKE}

BAYLIS, Douglas y PARRY, Joan: California Houses of Gordon Drake. New York: Reinhold Pub., 1956. El libro incluye textos en memoria de Drake escritos por Carl Troedsson (Profesor de Drake en USC), Harwell Hamilton Harris (Profesor y mentor de Drake), así como de Walter Doty (editor de Sunset Magazine). La única publicación monográfica existente sobre Gordon Drake es el pequeño catálogo de sus obras publicado por su socio y amigo Douglas Baylis, a modo de homenaje póstumo. 
La publicación incluye 5 fotografías de Julius Shulman de la Drake House en Beverly Glen; 8 fotografías de la Rucker-Spillman House, en Los Ángeles; 9 fotografías de la Berns House en Malibu; 5 imágenes de la Unit House y la maqueta del estudio en Carmel.

La monografía ha sido reeditada en 2011 por William Stout. Durante la investigación de esta tesis doctoral, la editorial de San Francisco, informó de su inminente aparición en otoño de 2010, fecha que, finalmente, se retrasó hasta el verano de 2011. La reimpresión del catálogo original va precedida de un prólogo de Glenn Murcutt y de un ensayo introductorio de Pier Luigi Serraino.

BAYLIS, Douglas y PARRY, Joan: California Houses of Gordon Drake. Reimpresión de la monografía original con prólogo de Glenn Murcutt e introducción de Pier Luigi Serraino. San Francisco: William Stout, 2011.

GD.3

CITASY/O REFERENCIAS PUNTUALES LOCALIZADAS SOBRE GORDON DRAKE EN HISTORIAS CRÍTICAS DE LA AROUITECTURA DEL SIGLO XX, MONOGRAFÍAS SOBRE AROUITECTOS CALIFORNIANOS Y/O CATÁLOGOS SOBRE TEMAS DE AROUITECTURA ESPECÍFICOS DE LA REGIÓN

Del mismo modo que se ha procedido en el caso de Harwell Hamilton Harris, se refieren especialmente las monografías sobre arquitectos contemporáneos directamente relacionados (personal o profesionalmente) con Gordon Drake y, por extensión, Harwell Hamilton Harris, vinculado al cual suelen aparecer las referencias a la obra de su discípulo.

El considerable número de entradas existentes relacionadas con libros de fotografía sobre Julius Shulman, propuestos, editados o asesorados por éste que, en una recopilación general de fotografías representativas de la trayectoria profesional del fotógrafo en su conjunto incluyen alguna imagen de la Drake House (la propia casa del arquitecto en Los Ángeles), así como la gran difusión que tuvieron las mismas en publicaciones especializadas y populares de la época, ponen de manifiesto la predilección de Shulman por las instantáneas tomadas en 1947 en la vivienda de Drake. También es llamativo el hecho de que, en no pocas ocasiones, Shulman comentara las técnicas de encuadre e iluminación desplegadas en este pequeño espacio, prueba de la satisfacción del fotógrafo ante el resultado de estas imágenes.

Como siempre, el orden de las siguientes referenciases cronológico, por fecha de aparición del texto original, de más antiguo a más reciente:

AA. VV., CREIGHTON, Thomas H.; LOPEZ, Frank G.; MAGRUDER, Charles y SANDERSON George A. (eds.): Small, Medium, Large. Homes selected by the editors of Progressive Architecture. New York: Reinhold Pub., 1947, p. 190 (Gordon Drake House en Beverly Glen, Los Angeles, 1946. Incluye 8 fotografías de Julius Shulman y la planta de la vivienda).

AA. VV., HENNESSEY, William J.: America's Best Small Houses. Selected by a Jury of Architectural Photographers. New York: Viking Press, 1949, (Rucker 
House), pp. 69-73 ("Designed for Opnenness, Los Angeles, California, Built for $\$ 10,000$, Gordon Drake, Designer").

AA. VV., CREIGHTON, Thomas y FORD, Katherine M. (eds.): The American House Today. 85 notable examples. New York: Reinhold Pub., 1951, pp. 144-145 (Miller House en Carmel, 1949 -fotografías de Morley Baer) y pp. 189-191 (Rucker-Spillman House en Los Angeles, 1947-fotografías de Julius Shulman).

AA. VV., KORNFELD, A. (ed.): House \& Garden's Book of Buildings 1952. New York: Conde Nast Pub., 1952, pp. 144-145 ("Choose Roof and Wall Materials for Durability", apartado donde se publica la Rucker-Spillman House en Los Angeles, 1947-con fotografías de Julius Shulman).

AA. VV.: Sunset Patio Book: Menlo Park, CA: Lane, 1952, pp. 18-19 ("How large should it be?", incluye una fotografía tomada por Morley Baer del patio de la Mesa House en Camel de 1948) y pp. 24-25 ("Tie It with the House", apartado ilustrado también con una fotografía de Morley Baer de la Mesa House en Carmel).

NELSON, George: Living Spaces. New York: Whitney., 1952, p. 146-147 (Se publica con fotografías de Julius Shulman la Drake House en Los Ángeles. El libro forma parte de una colección de cuatro volúmenes sobre espacios y mobiliario representativo de la época del que éste constituye su primer volumen).

AA. VV., CREIGHTON, Thomas (ed.): Quality Budget Houses: A Treasury of 100 Architect-Designed Houses From \$5,000 to \$20,000. New York: Reinhold Pub., 1954, pp. 64-65 (Unit House fotografiada por Julius Shulman).

AA. VV., CREIGHTON, Thomas (ed.): Selected Houses from Progressive Architecture. New York: Reinhold Pub., 1954, p. 159 (Berns Beach House en Encinal, Malibu, terminada en 1952 y fotografiada por Julius Shulman).

AA. VV.: New Homes for Western Living. Menlo Park, CA: Lane, 1956, pp. 8-9 y 36-37 (Malibu Beach House previamente publicada a través de la fotografía de Julius Shulman en el número de marzo de Sunset Magazine de 1954).

AA. VV.: Landscape Architecture Exhibition. Catálogo de Exposición. San Francisco: San Francisco Museum of Art, junio 1957 (incluye la obra de Drake y Baylis Unit House, también llamada Scribner House, en Hayward, Alameda County).

AA. VV.: How to Plan and Build Your Own Fireplace. Menlo Park, CA: Lane, 1962 (catálogo editado por Sunset Magazine en el que se publica una imagen de la Mesa House en Carmel).

ROGERS, Kate Ellen (ed.): The Modern House, USA: Its Design and Decoration. New York: Harper \& Row Publishers, 1962 (entre las imágenes publicadas de Shulman hay fotografías de la Drake House en Los Ángeles, portada урр. $75,78,110$ у 113$)$.

AA. VV.; SHULMAN, Julius (consultor y fotógrafo); y GOTTLIEB, L. D. (ed.).: Environment and Design in Housing. NewYork: Macmillan, 1965, pp. XIV y 258 (Drake House). 
FAULKNER, R. S. y NISSEN, L.: Inside Today's Homes. New York: Holt, Rhinehart \& Winston, 1965, p. 598, fig. 837 (se publica una imagen de la Unit House de Drake en San Francisco).

SHULMAN, Julius, et al.: Photographing Architecture and Interiors. NewYork: Whitney Library of Design, 1965, pp. Ix y 154 (Portada, texto e imágenes de Shulman, con introducción de Richard Neutra, incluye una imagen de la propia vivienda de Drake en Los Ángeles, con una explicación de la técnica de iluminación para compensar las diferencias de nivel de iluminación entre el interior y el exterior de la estancia).

BALLINGER, R. M. yYORK, H.: The Illustrated Guide to the House of America. New York: Galahad Books, 1971, p. 260 (Gordon Drake House).

McCOY, Esther: The Second Generation. Salt Lake City, UT: Gibbs Smith Publisher, 1984, p. 61 (la autora refiere la estrecha relación profesional establecida entre Harris y Drake y cómo durante los años de la Segunda Guerra Mundial, ambos se mantuvieron en contacto a través de la correspondencia que Drake, desde el frente, enviaba a Harris).

GERMANY, Lisa: Harwell Hamilton Harris. Prólogo de Kenneth Frampton e Introducción de Bruno Zevi. Berkeley, CA: University of California Press, 2000 (edición original Austin, TX: University of Texas Press, 1991), nota 30 en p. 214 (es revelador que en esta monografía sobre H. H. Harris, Gordon Drake sólo aparezca en una nota final donde simplemente se enumeran los jóvenes colaboradores que el arquitecto tenía en su oficina hacia 1940, lo que da una idea sobre el olvido en el que, a principios de los noventa, había caído el personaje).

ROSA, Joseph: A Constructed View: The Architectural Photography of Julius Shulman. New York: Rizzoli, 1994, pp. 90, 92 y 93 (imágenes de la Drake House en Los Angeles tomadas por Shulman).

GEBHARD, David: "William Wurster and His California Contemportaries: The Idea of Regionalism and Soft Modernism", en AA. VV., TREIB, Marc (ed.): An Everyday Modernism: The Houses of William Wurster. San Francisco, CA: San Francisco Museum of Modern Art y Berkeley, CA; London: University of California Press, 1995, p. 178 (David Gebhard a Drake al hablar de Harris y de la Weston Havens House como contemporáneo de Wurster).

JACKSON, Neil: The Modern Steele House. London: E \& FN Spon y New York: Reinhold, 1996, pp. x y 245.

GEBHARD, David: "Harwell Hamilton Harris", en AA. VV., WINTER, Robert (ed.): Toward a simpler way of life: the Arts \& Crafts architects of California. Berkeley, Los Angeles CA; London: University of California Press, 1997, p. 276 y $282 n$ (se cita a Drake en una ocasión dentro del capítulo del libro dedicado a Harris pero, en este caso, la cita se refiere al conjunto de su trabajo como joven diseñador, vinculándole por pleno derecho a la generación de Charles Warren Callister y Jack Hilmer, y no limitándose meramente a su condición de colaborador de Harris).

ARTEAGA-JOHNSON, Giselle: "Narrating Modern Space: The Interior View", en AA. VV., HOLO, Selma (ed.): Los Angeles Obscura: The Architectural Photography of Julius Shulman (catálogo de exposición). Los Angeles: Fisher 
Gallery, University of Southern California, 1998, p. 26-33 (se publican fotografías de la vivienda de Drake en Los Ángeles). Existe edición en castellano del catálogo con anexo de traducción al valenciano: Los Angeles Obscura: La fotografía arquitectónica de Julius Shulman. La exposición fue mostrada en la Sala de Exposiciones del Diario Club Levante de Valencia y en el Museo de la Universidad de Alicante en 1999.

SHULMAN, Julius; GEHRY, Frank O.; y GOSSEL, Peter: Julius Shulman: Architecture and Its Photography. Köln, New York, Los Angeles: Taschen, 1998, pp. 91-94 (se publica una nota sobre la buena relación profesional y de amistad entre Shulman y Drake, así como dos fotografías de la propia casa de Drake en Beverly Glen, Los Ángeles).

SERRAINO, Pierluigi y SHULMAN, Julius (fotografías): Modernism Rediscovered. Köln, New York, Los Angeles: Taschen, 2000 (reeditado en 2005 y 2009 en castellano), pp. 18-19 (Drake House), 34-35 (Rucker-Spillman House), 103 (Scribner House), 136-137 (Berns House), 560 (nota biográfica). Serraino utiliza la vivienda de Drake en Los Ángeles como el proyecto que abre la serie de obras tratadas en su libro.

SHULMAN, Julius, et al.: Photographing Architecture and Interiors. New York: Balcony Press, 2000 (segunda edición del libro publicado originalmente en 1965), pp. IX Y 154 (Portada, texto e imágenes de Shulman, con introducción de Richard Neutra, incluye una imagen de la propia vivienda de Drake en Los Ángeles, con una explicación de la técnica de iluminación para compensar las diferencias de nivel de iluminación entre el interior y el exterior de la estancia).

ADAMSON, Paul y ARBUNICH, Marty: Eichler: Modernism Rebuilds the American Dream. Salt Lake City, UT: Gibbs Smith Publisher, 2002, pp. 85, 88 (referencias a Drake) y 94 (imagen de su propia vivienda en Los Ángeles fotografiada por Julius Shulman).

MURCUTT, Glenn; BECK, Haig; y COOPER, Jackie: Glenn Murcutt: A Singular Architectural Practice. Mulgrave, VIC, Australia: Images Publising Group, 2002, p. 38 (Murcutt cita a Drake como referencia para su trabajo, algo que haría también, al igual que Frank Gehry, en su discurso de aceptación del Priztker: véase: $h t t p: / / w w w$. pritzkerprize.com/main.htm).

SMITH, Elizabeth A. T., Peter Goessel (ed.): Case Study Houses. The Complete CSH Program 1945-1966. Epílogo de Julius Shulman. Köln, New York: Taschen, 2002, p. 9 (la autora, en su texto de presentación cita a Drake al nombrar una serie de personajes cuya no inclusión en el programa es llamativa, aduciendo a que fueron sobre todo motivos, relaciones personales e intereses particulares de John Entenza los únicos que pueden justificar la ausencia).

MACY, Christine y BONNEMAISON, Sarah: Architecture \& Nature. Creating the American Landscape. London; New York: Routledge, 2003, p. 228 (se cita a Harris y a Drake como dos arquitectos cuya obra epitomiza el concepto de disolución de los límites entre el exterior y el interior en la vivienda californiana; véase apartado $\mathrm{HH}$. 7).

BUCKNER, Cory "Introduction", en SWATT, Robert; BUCKNER, Cory (Introducción); y KAPPE, Ray (Prólogo): Swatt Architects. Livable Modern. Mulgra- 
ve, VIC, Australia: Images Publising Group, 2004, pp. 9-10 (Cory Bucker cita a Drake como referencia e incluye una fotografía de Shulman de la Drake House en Los Ángeles).

SHULMAN, Julius: Modernism 2005 Taschen Diary. Köln, New York: Taschen, 2004, p. 29 (se publica una fotografía de la Berns Beach House).

SERRAINO, Pierluigi, y SHULMAN, Julius (fotografías): Modernism Rediscovered. Köln, New York, Los Angeles: Taschen, 2005, pp. 18-19 (Drake House), 34-35 (Rucker-Spillman House), 103 (Scribner House), 136-137 (Berns House), 560 (nota biográfica). Edición en castellano.

SERRAINO, Pierluigi: NorCalMod: Icons of Nothern California Modernism. San Francisco: Chronicle Books, 2006, pp. 20 y 230-231.

SHULMAN, Julius (fotografías): Julius Shulman: Modernity and the Metropolis (exposición). Getty Museum (25 octubre 2005-22 enero 2006).

http://www.getty.edu/art/exhibitions/shulman/

Exposición exhibida en el National Building Museum de Washington en 2006 y en la Sala de Exposiciones del Canal de Isabel II en Madrid (reeditada como Los Ángeles de Julius Shulman) en 2010. La muestra incluía, entre las 130 obras presentadas una fotografía de la vivienda de Drake en Los Ángeles.

WELLS, Ted: Man Ray: Surrealist Meets Architect. Podcast publicado en 2006 sobre la relación entre Harris y Man Ray, principalmente con motivo de las fotografías de la Weston Havens House en Berkeley. Disponible online en: http://twls.libsyn.com/index.php?post_id=145774

SEAVY, K. Carmel: A History of Architecture. Images of America. San Francisco: Arcadia, 2007, p. 120 (incluye una imagen de Shulman de la maqueta de la vivienda y complejo-estudio comunitario de Drake en Carmel y una imagen de la casa de vacaciones en Flanders Way, también en Carmel).

SHULMAN, Julius: Julius Shulman: Architectural Photography of the $20^{\text {th }}$ Century: Portfolio Calendar 2008, Vol. 4. Los Angeles, Art Museum Council of Los Angeles Museum of Art, 2008 (incluye una imagen de la Drake House tomada por Shulman).

HINES, Thomas S.: Architecture of the Sun: Los Angeles Modernism 19001970, New York, Rizzoli, 2010, pp. 494-497 (hace mención a Drake e incluye 3 fotografías de Shulman de la Drake House en Los Ángeles).

HOWELL-ARDILA, Deborah: Writing Our Own Program. The USC Experiment in Modern Architectural Pedagogy 1930-1960, Tesis de Máster presentada en la USC School of Architecture de Los Ángeles como trabajo del Master of Historic Preservation. Los Angeles: University of Southern California, agosto 2010, pp. VI, 69n, 132, 155, 156, 156n, 157-159, 159n, 160-163, 163n, 164-165, $169,173,175,176,224,238,247,251,252,255$ y 260. 
GD.4

REFERENCIAS A GORDON DRAKE O SUS OBRAS LOCALIZADAS EN GUÍAS DE AROUITECTURA DE CALIFORNIA

GEBHARD, David y WINTER, Robert: A Guide to Architecture in Southern California. Los Angeles: Los Angeles County Museum of Art, 1965, p. 24 Y 164. En la primera edición de la mítica guía de Gebhard/Winter se recogen dos obras de Gordon Drake en Los Angeles: Berns House (31654 W. Broad Beach Road en Trancas Beach, Malibu, 1951) y Presley House (2114 Fargo Street en Silver Lake, 1946).

GEBHARD, David y WINTER, Robert: A Guide to Architecture in Los Angeles and Southern California. Santa Barbara, CA: Peregrine Smith, 1977, pp. 37-38 (Berns House en Malibu) y p. 172 (Presley House).

GEBHARD, David y WINTER, Robert: Architecture in Los Angeles: A Complete Guide. Santa Barbara, CA: Peregrine Smith, 1984, p. 33 (Berns House en Malibu) y p. 187 (Presley House).

GEBHARD, David y WINTER, Robert: Los Angeles, An Architectural Guide. Salt Lake City, UT: Gibbs Smith Publisher, 1994, p. XXXIV y 486. Además de estas referencias al autor, se vuelve a tratar, como entradas independientes, las casas de Gordon Drake: Berns en Malibu (p.1) y Presley en Los Ángeles (p. 181).

GEBHARD, David y WINTER, Robert: An Architectural Guidebook to Los Angeles. Salt Lake City, UT: Gibbs Smith Publisher, 2003. En la última edición de la guía de Gebhard/Winter se vuelven a citar las dos mismas obras de Gordon Drake recogidas en las ediciones anteriores: p. 40 (Berns House en Malibu - la casa ha sido exhaustivamente restaurada recientemente, invisible desde la calle, resulta prácticamente irreconocible) y p. 203 (Presley House en Silver Lake-la única vivienda de Drake en el área de Los Ángeles que ha llegado en un estado aceptable de conservación). 
[ biliografía especíFICA

[ BILIOGRAFía CONSULTADA ] ... 


\section{CALIFORNIA: AROUITECTURA, ARTE, FOTOGRAFÍA}

AA. VV., DARLING, Michael y SMITH, Elizabeth A. T. (eds.): The Architecture of R. M. Schindler. New York: Harry N. Abrams, 2001. (Catálogo de la exposición homónima, Museum of Contemporary Art, Los Angeles, 2001).

AA. VV., KARLSTROM, Paul J. (ed.): On the Edge of America. California Modernist Art 1900-1950. Berkeley y Los Angeles, CA: University of California Press, 1996.

AA. VV.' PEABODY, Rebecca et al. (eds.): Pacific Standard Time: Los Angeles Art, 1945-1980. Los Angeles: The Getty Research Institute, 2011.

AA. VV., POLYZOIDES, Stefanos (ed.): Courtyard Housing in Los Angeles: A Typological Analysis. New York: Princeton Architectural Press, 1992 (edición original Berkeley: University of California Press, 1982).

AA. VV., SMITH, Elizabeth A. T. (ed.): Blueprints for Modern Living: History and Legacy of the Case Study Houses. Cambridge, MA: The MIT Press, 1989. Catálogo de la Exposición del MoCA, Los Angeles Museum of Contemporary (reeditado en 1999).

AA. VV., TREIB, Marc (ed.): An Everyday Modernism: The Houses of William Wurster. San Francisco, CA: San Francisco Museum of Modern Art y Berkeley, CA; London: University of California Press, 1995.

AA. VV., WINTER, Robert (ed.): Toward a Simpler Way of Life: the Arts \& Crafts Architects of California. Berkeley, Los Angeles CA; London: University of California Press, 1997.

AA. VV., WOODBRIGE, Sally B. (ed.): Bay Area Houses. Salt Lake City, UT: Gibbs Smith Publisher, 1988.

AA. VV.: AV Monografías n 32. Los Ángeles. Noviembre-Diciembre 1991.

AA. VV.: AV Monografías no 84. El siglo americano. Julio-Agosto 2000.

AA. VV.: AV Monografías nº 132. Casas de maestros. Julio-Agosto 2008.

AA. VV.: $2 \mathrm{G}, \mathrm{n}^{\circ}$ 7. Revista Internacional de Arquitectura: Schindler. Barcelona: Gustavo Gili, 1998.

AA. VV.: 2G, nº 12. Revista Internacional de Arquitectura: Craig Ellwood. Barcelona: Gustavo Gili, 1999.

ADAMSON, Paul: Eichler: Modernism Rebuilds the American Dream. Salt Lake City, UT: Gibbs Smith Publisher, 2002.

BAYLIS, Douglas y PARRY, Joan: California Houses of Gordon Drake. New York: Reinhold Pub., 1956.

BAYLIS, Douglas y PARRY, Joan: California Houses of Gordon Drake. Reimpresión de la monografía original. Prólogo de Glenn Murcutt e Introducción de Pier Luigi Serraino. San Francisco: William Stout, 2011. 
BOSLEY, Edward R.: Greene \& Greene. London: Phaidon Press, 2000.

BOSLEY, Edward R.: Gamble House. Greene \& Greene. Architecture in detail. London: Phaidon Press, 2002 (primera edición 1992).

BOUTIN, Marc: Richard Neutra: The Idealization of Technology in America. (Thesis for the Degree of Master of Arts. Department of Art). Calgary, Alberta: University of Calgary, 2000.

BUCKNER, Cory: A. Quincy Jones. London: Phaidon Press, 2002.

BURTON, Pamela y BOTNICK, Marie: Private Landscapes. Modernist Gardens in Southern California. Introducción de Kathryn Smith. New York: Princeton Architectural Press, 2002.

CAMPBELL-LANGE, Barbara-Ann: John Lautner. Köln, New York: Taschen, 1999.

CASTLE, Jane: Vernacular, Regional and Modern/ Lewis Mumford's Bay Region Style and the Architecture of William Wurster. Tesis Doctoral. Sydney: School of Architecture, University of New South Wales, 2006. Disponible en http://handle.unsw.edu.au/1959.4/26245.

CHUSID, Jeffrey Mark: Historic Structures Report Samuel and Harriet Freeman House. Los Angeles: School of Architecture. University of Southern California, 1989.

COLL-BARREU, Juan: Construcción de los paisajes inventados. Los Angeles Doméstico 1900-1960. Arquithesis. Barcelona: Fundación Caja de Arquitectos, 2004 .

CORNETT, Michael R.: Splendid Survivors: San Francisco's Downtown Architectural Heritage. San Francisco: California Living Books, 1979.

COX, Julian Y TESKE, Edmund. Spirit into Matter: The Photographs of Edmund Teske. Los Angeles: The J. Paul Getty Museum, 2004.

CYGELMAN, Adele y ROSA, Joseph (prólogo): Palm Springs Modern: Houses in the California Desert. New York: Rizzoli, 1999.

DALLEY, Victoria, SHIVERS, Natalie y DAWSON, Michael. Introducción de William Deverell: LA's Early Moderns. Art/Architecture/ Photography. Los Angeles: Balcony Press, 2003.

DANLEY, Susan y NAEF, Weston J.: Edward Weston in Los Angeles. San Marino, CA: Huntington Library, 1986 (Catálogo de la exposición realizada por la Huntington Library y el J. Paul Getty Museum).

DEMETRIOS, Eames: An Eames Primer. London: Thames \& Hudson, 2001.

DENZER, Anthony. Introducción de Thomas S. Hines: Gregory Ain: The Modern Home as Social Commentary. New York: Rizzoli, 2008.

DITTO, Jerry; STERN, Lanning y WOODBRIDGE, Sally: Eichler Homes: Design for Living. San Francisco: Chronicle Books, 1995. 
DREXLER, Arthur y HINES, Thomas S.: The Architecture of Richard Neutra. From International Style to California Modern. New York: The Museum of Modern Art, 1984 (primera edición 1982).

ECKBO, Garret: Landscape for Living. New York: Duell, Sloan \& Pearce, 1950.

FREY, Albert: In Search of a Living Architecture. Santa Monica, CA: Hennessey + Ingalls, 1999 (Impresión como cuaderno facsímil del manifiesto publicado en 1939. New York: The Architectural Book Publishing Co. 1939).

FRIEDMAN, Alice T.: Women and the Making of the Modern House. A Social and Architectural History. New York: Harry N. Abrams, 1998.

GEBHARD, David y VON BRETON, Harriette: LA in the Thirties (1931-1941). Santa Monica, CA: Hennessey + Ingalls, 1989 (edición original Salt Lake City, UT: Peregrine Smith, 1975).

GEBHARD, David: Romanza. The California Architecture of Frank Lloyd Wright. San Francisco: Chronicle Books, 1988.

GEBHARD, David: Rudolph Schindler. Barcelona: Oikos-tau, 1979 (edición original: Schindler. Prefacio de Henry Russell Hitchcock. New York: Viking Press, 1971. Reeditado por William Stout, San Francisco, 2001).

GEBHARD, David; VON BRETON, Harriette y WEISS, Lauren: The Architecture of Gregory Ain: The Play between the Rational and High Art. Santa Monica, CA: Hennessey + Ingalls, 1997 (reedición del Catálogo de la exposición homónima: Universidad de California Santa Barbara, 1980).

GERMANY, Lisa: Harwell Hamilton Harris. Prólogo de Kenneth Frampton e Introducción de Bruno Zevi. Berkeley, CA: University of California Press, 2000 (edición original Austin, TX: University of Texas Press, 1991).

GOLDSTEIN, Barbara (ed.): Arts \& Architecture. The Entenza Years. Santa Monica, CA: Hennessey + Ingalls, 1998 (edición original Cambridge, MA: The MIT Press, 1990).

HENSMAN, Donald C. y Steele, James (ed.): Buff \& Hensman. Los Angeles: Balcony Press, 2004.

HESS, Alan: Architecture of John Lautner. New York: Universe Publishing, Rizzoli 2003 (primera edición 1999).

HESS, Alan: Forgotten Modern: California Houses 1940-1970. Salt Lake City, UT: Gibbs Smith Publisher, 2007.

HESS, Alan: Googie Redoux. Ultramodern Roadside Architecture. San Francisco: Chronicle Books, 2004.

HESS, Alan y DANISH, Andrew: Palm Springs Weekend:The Architecture and Design of a Midcentury Oasis. San Francisco: Chronicle Books, 2001.

HINES, Thomas S.: Architecture of the Sun: Los Angeles Modernism 19001970. New York: Rizzoli, 2010. 
HINES, Thomas S.: Irving Gill and the Architecture of Reform: a Study in Modernist Architectural Culture. New York: Monacelli Press, 2000.

HINES, Thomas S.: Richard Neutra and the Search for Modern Architecture: a Biography and History. New York: Rizzoli, 2006 (primera edición New York: Oxford University Press, 1982).

HOWELL-ARDILA, Deborah.: Writing Our Own Program. The USC Experiment in Modern Architectural Pedagogy 1930-1960. Trabajo de investigación inédito (Thesis for the Degree Master in Historic Preservation). Los Angeles: Faculty of Architecture. University of Southern California, 2010.

JACKSON, Neil: Craig Ellwood. London: Laurence King Publishing, 2002 Publicado en los Estados Unidos como California Modern: The Architecture of Craig Ellwood. New York: Princeton Architectural Press, 2002.

JACKSON, Neil: The Modern Steel House. London, New York: E \& FN Spon, 1996.

KAPLAN, Sam Hall y SHULMAN, Julius (fotografías): LA Lost \& Found: An Architectural History of Los Angeles. Santa Monica, CA: Hennessey + Ingalls, 2000 (edición original New York: Crown, 1987).

KIRKHAM, Pat: Charles and Ray Eames: Designers of the Twentieth. Cambridge, MA: The MIT Press, 1998 (primera edición 1995).

KOENIG, Gloria: Albert Frey. Köln: Taschen, 2008.

KOENIG, Gloria: Eames. Köln: Taschen, 2005.

KOENIG, Gloria (Prólogo de Frank Gehry): Iconic L.A., Stories of LA's Most Memorable Buildings. Santa Monica, CA: Angel City Press Inc., 2006 (primera edición 2000).

LAMPRECHT, Barbara: Neutra. Köln: Taschen, 2005.

LAMPRECHT, Barbara: Neutra. Complete Works. Köln: Taschen, 2000.

LAVIN, Sylvia: Form Follows Libido: Architecture and Richard Neutra in a Psychoanalytic Culture. Cambridge, MA: The MIT Press, 2004 (reeditado en 2007).

LIND, Carla: Frank Lloyd Wright's California Houses. Petaluma, CA: Pomegranate Communications, 1996.

LONGSTRETH, Richard: On the Edge of the World: Four Architects in San Francisco at the Turn of the Century. Los Angeles y Berkeley, CA; London: University of California Press, 1998 (edición original Cambridge, MA: The MIT Press, 1983).

MAKINSON, Randell L.: Greene and Greene: Architecture as a Fine Art; Furniture and Related Designs. Salt Lake City, UT: Gibbs Smith Publisher, 2001 (primera edición 1977). 
MAKINSON, Randell L. y HEINZ, Thomas A.: Greene \& Greene. Creating a Stlye. Salt Lake City, UT: Gibbs Smith Publisher, 2004.

MAKINSON, Randell L. y FUTAGAWA, Yukio (ed.): Greene and Greene: David B. Gamble House, Pasadena, California 1908. Tokyo: A.D.A. Edita Tokyo, 1984 .

MARCH, Lionel y SHEINE, Judith (eds.): RM Schindler. Composition and Construction. London: Academy Editions y Berlin: Ernst \& Sohn, 1993.

McCOY, Esther: Case Study Houses 1945-62. Santa Monica, CA: Hennessey + Ingalls, 1977 (edición orginal New York: Reinhold, 1962).

McCOY, Esther: Craig Ellwood. Venezia: Alfieri, 1968 (edición original New York: Walker Publishing Company, 1968. Reeditado por Santa Monica, CA: Hennessey + Ingalls, 1997).

McCOY, Esther: Richard Neutra. New York: George Braziller Inc., 1960.

McCOY, Esther y MAKINSON L., Randell: Five California Architects. Santa Monica, CA: Hennessey + Ingalls, 2004 (edición original New York: Reinhold Pub. Corporation, 1960).

McCOY, Esther: The Second Generation. Salt Lake City, UT: Gibbs Smith Publisher, 1984.

McCOY, Esther: Vienna to Los Angeles. Two Journeys. Letters Between R. M. Schindler y Richard Neutra. Prólogo de H. H. Harris. Santa Monica, CA: Arts + Architecture Press, 1979.

McCOY, Esther y MORGAN, Susan (ed.): Piecing Together Los Angeles: An Esther McCoy Reader. Los Angeles, East Borneo, 2012.

MORGAN Susan y MEYER, Kimberli (ed.): Sympathetic Seeing: Esther McCoy and the Heart of American Modernist Architecture and Design. Los Angeles: MAK Center, 2011 (Catálogo de la exposición homónina inaugurada en el MAK Center de Los Ángeles -Schindler House- en septiembre de 2011 y clausurada en enero de 2012).

NEUHART, John y NEUHART, Marilyn, con Ray EAMES: Eames Design. The Work of the Office of Charles and Ray Eames. New York: Harry N. Abrams, 1989.

NEUHART, John y NEUHART, Marilyn: Eames House. Berlin: Ernst \& Sohn, 1994.

NEUTRA, Dione (Compiladora y ed.): Richard Neutra. Promise and Fulfillment, 1919-1932. Selections from the Letters and Diaries of Richard and Dione Neutra. Carbondale, IL: Southern Illinois University Press, 1986.

NEUTRA, Richard J.: Amerika. Neves Baven in der Welt. Wien: Anton Schroll, 1930.

NEUTRA, Richard J.: Wie Baut Amerika? Stturgart: Julius Hoffman, 1927. 
NEUTRA, Richard J.: Life and Shape. New York: Appleton Century Crofts, 1962 (reeditado por Los Angeles: Atara Press, 2009).

NEUTRA, Richard J.: Survival through Design. London: Oxford University Press, 1969.

OLSBERG, Nicholas; COHEN, Jean-Louis y ESCHER, Frank: Between Earth and Heaven: The Architecture of John Lautner. New York: Rizzoli, 2008 (Catálogo de la exposición homónima. Hammer Museum de Los Angeles, juliooctubre de 2008).

PÉREZ-MÉNDEZ, Alfonso: Craig Ellwood. Con el espíritu de la época. BarceIona: Gustavo Gili, 2002.

ROSA, Joseph: A constructed view: The Architectural Photography of Julius Shulman. New York: Rizzoli, 1994.

ROSA, Joseph: Albert Frey, Architect. New York: Rizzoli, 1990 (reeditado por Princeton Architectural Press, 1999).

ROWE, Colin y CARAGONNE, Alexander (ed.): As I Was Saying. Recollections and Miscellaneous Essays. Volume I:Texas, Pre-Texas, Cambridge. Cambridge, MA: The MIT Press, 1996.

SARNITZ, August y SHULMAN, Julius (fotografías): R. M. Schindler. Architect 1887-1953. New York: Rizzoli, 1988 (edición original en alemán: $R$. M. Schindler. Architekt 1887-1953. Wien-München: Akademie der bildenden Künste \& Christian Brandstätter Verlag, 1986).

SERRAINO, Pierluigi y SHULMAN, Julius (fotografías): Modernism Rediscovered. Köln, New York: Taschen, 2000

SERRAINO, Pierluigi: NorCalMod: Icons of Nothern California Modernism. San Francisco: Chronicle Books, 2006.

SHEINE, Judith: R. M. Schindler. London: Phaidon Press, 2001.

SHEINE, Judith: R. M. Schindler. Barcelona: Gustavo Gili, 1998.

SHULMAN, Julius: Photographing Architecture and Interiors. Introducción de Richard Neutra. Los Angeles: Balcony Press, 2000, (edición original Nueva York: Whitney Library of Design, 1962).

SHULMAN, Julius: The Photography of Architecture and Design. Nueva York: Whitney Library of Design, 1977.

SHULMAN, Julius: Vest Pocket Pictures. Portland, OR: Nazraeli Press City Press, 2006.

SMITH, Elizabeth A. T., Peter Goessel (ed.): Case Study Houses. The Complete CSH Program 1945-1966. Epílogo de Julius Shulman. Köln, New York: Taschen, 2002.

SMITH, Bruce: Greene \& Greene: Masterworks. San Francisco: Chronicle Books, 1998. 
SMITH, Kathryn: Frank Lloyd Wright, Hollyhock House and Olive Hill: buildings and projects for Aline Barnsdall. Santa Monica, CA: Hennessey + Ingalls, 2006 (edición original New York: Rizzoli, 1992).

SMITH, Kathryn: Schindler House. New York: Harry N. Abrams, 2001.

STEELE, James: Barnsdall House: Frank Lloyd Wright. Architecture in detail. London: Phaidon Press, 1992.

STEELE, James: Eames House. Architecture in detail. London: Phaidon Press, 2002 (primera edición 1998).

STEELE, James: Los Angeles Architecture: The Contemporary Condition. London: Phaidon Press, 1993.

STEELE, James y Jenkins, David: Pierre Koenig. London: Phaidon Press, 1998.

STEELE, James: R. M. Schindler. Köln: Täschen, 1999 y 2005.

STEELE, James: Salk Institute. Architecture in detail. London: Phaidon Press, 2002 (primera edición 1993).

STERN, Michael y HESS, Alan: Julius Shulman: Palm Springs. New York: Rizzoli y Palm Springs Art Museum, 2008 (Catálogo de la Exposición homónima, febrero-mayo 2008).

SWEENEY, Robert: Wright in Hollywood: Visions of a New Architecture. New York: The Architectural History Foundation y Cambridge, MA: The MIT Press, 1994.

TRAVERS, David y WEINER, Nina: Arts \& Architecture, 1945-1954: The Complete Reprint (10 vols.). Köln: Taschen, 2008 (paperback de la edición original de la revista publicada por John Entenza).

TREIB, Marc e IMBERT, Dorothée: Garrett Eckbo: Modern Landscapes for Living. Berkeley y Los Angeles: University of California Press, 1997.

TREIB, Marc: The Donnell and Eckbo Gardens: Modern California Masterworks. San Francisco: William Stout, 2005.

TREIB, Marc: Thomas Church, Landscape Architect: Designing a Modern California Landscape. San Francisco: William Stout, 2004.

WARREN, Beth G.: Artful Lives: Edward Weston, Margrethe Mather and the Bohemians of Los Angeles. Los Angeles: The J. Paul Getty Museum, 2011.

WESTON, Edward y NEWHALL, Nancy (ed.): The Daybooks of Edward Weston. Volume 1: Mexico y Volume 2: California. Millerton, NY: Aperture, 1973, impresión paperback (primera edición Rochester, NY: George Eastman House, 1961).

WINTER, Robert: Architecture of Entertainment. LA in the Twenties. Salt Lake City, UT: Gibbs Smith Publisher, 2006. 
WINTER, Robert: Craftsman Style. New York: Harry N. Abrams, 2004.

WINTER, Robert: Hidden LA. Salt Lake City, UT: Gibbs Smith Publisher, 1998.

WINTER, Robert: The California Bungalow. Prólogo de David Gebhard. Santa Monica, CA: Hennessey + Ingalls, 1998 (primera edición 1980).

WOODBRIDGE, Sally: Bernard Maybeck: Visionary Architect. Berkeley: University of California Press, 2006 (edición original New York: Abbeville Press, 1992).

WOODS, John Charles: A Restless Eye: A Biography of Photographer Brett Weston. Richmond, MO: Erica Weston Editions, 2010.

\section{CULTURA ARQUITECTÓNICA, MODERNIDAD Y AROUITECTOS NORTEAMERICANOS}

AA. VV., BRENNAN, Ann Marie; COLOMINA Beatriz y KIM, Jeannie (eds.): Cold War Hothouses: Inventing Postwar Culture, from Cockpit to Playboy. New York: Princeton Architectural Press, 2004.

AA. VV., CANIZARO, Vincent B. (ed.): Architectural Regionalism. Collected Writings on Place, Identity, Modernity and Tradition. New York: Princeton Architectural Press, 2007.

AA. VV. COBB, Henry N. (ed.): The Architecture of Frank Gehry. Minneapolis, MN: Walker Art Center y New York: Rizzoli, 1986.

AA. VV., HESS, Alan (dir.): Las Casas de Frank Lloyd Wright. Barcelona: Gustavo Gili, 2006 (edición original Frank Lloyd Wright, The Houses. New York: Rizzoli, 2005).

AA. VV., RAGHEB, Fiona J. (ed.): Frank Gehry Architect. New York: Guggenheim Museum, Harry N. Abrams, 2001.

AA. VV.,SIMON, Maron J. (ed.): Your Solar House. New York: Simon and Schuster, 1946.

AA. VV., SOMOL, Robert E. (ed.): Autonomy and Ideology. Positioning an Avant-Garde in America. New York: Monacelli Press, 1997.

ALCOLEA, Rubén A.: Picnic de Pioneros: Arquitectura, fotografía y el mito de la industria. Valencia: Ediciones Generales de la Construcción, 2009.

ALOFSIN, Anthony: Frank Lloyd Wright: The Lost Years (1910-1922). A Studie of Influence. Chicago: Chicago University Press, 1993.

ANDREWS, Wayne: Architecture, Ambitions and Americans: a Social History of American Architecture. New York: Free Prees, 1978.

ANDREWS, Wayne: Architecture in America. New York: Atheneum Publishers, 1960. 
CLARK, Clifford E.: The American Family Home 1800-1960. Raleigh, NC: The University of North Carolina Press, 1986.

COLOMINA, Beatriz: La Domesticidad en Guerra. Traducción Beatriz Preciado. Barcelona: Actar, 2006. (edición original Domesticity at War and Publicity. Barcelona: Actar, 2006).

COLQUHOUN, Alan: Essays in Architectural Criticism: Modern Architecture and Historicism. Cambridge, MA: The MIT Press, 1981.

CURTIS, William J. R.: Modern Architecture Since 1900. London: Phaidon Press, 1996 (primera edición, 1982).

DAL CO, Francesco y FORSTER, Kurst W.: Frank Gehry. Complete Works. London: Electa (Phaidom), 2003 (primera edición en lengua inglesa New York: Monacelli Press, 1998; edición original Frank Gehry. Tutte le Opera. Milano: Electa, 1998).

DREXLER, Arthur y HITCHCOCK, Henry-Russell (eds.): Built in USA. Post-war Architecture. New York: MoMA, Simon \& Schuster, 1952.

DREXLER, Arthur: The Drawings of Frank Lloyd Wright. New York: Horizon Press, 1962

FRAMPTON, Kenneth y Futawaga, Yukio: Modern Architecture, 1851-1945. New York: Rizzoli, 1983.

FRIEDMAN, Alice T.: American Glamour and the Evolution of Modern Architecture. New Haven, CT:Yale University Press, 2010.

FULLAONDO BUIGAS DE DALMAU, María: Casas en el jardín del MoMA. La consolidación de un museo. Arquithesis. Barcelona: Fundación Caja de Arquitectos, 2010.

GEHRY, Frank O. y SORKIN, Michael; FRIEDMAN, Mildred S. (ed.): Gehry Talks. New York: Universe Publishing, Rizzoli, 1999.

GELENTER, Mark: A History of American Architecture: Buildings in Their Cultural and Technological Context. Hanover, NH: University Press of New England, 1999.

HEYER, Paul: American Architecture: Ideas and Ideologies in Late Twentieth Century. New York: Van Nostrand Reinhold, 1993.

HITCHCOCK, Henry-Russell: In the Nature of Materials. The Buildings of Frank Lloyd Wright, 1887-1941. New York: Da Capo Press, 1973 (edición original New York: Duell, Sloan \& Pearce, 1942).

HITCHCOCK, Henry Russell y JOHNSON, Philip: The International Style: Architecture Since 1922. New York: W. W. Norton, 1932 (reeditado en 1997).

LEVINE, Neil: The Architecture of Frank Lloyd Wright. New York: Princeton Architectural Press, 1996. 
MACY, Christine y BONNEMAISON, Sarah: Architecture \& Nature. Creating the American Landscape. London; New York: Routledge, 2003.

McCARTER, Robert: Frank Lloyd Wright Architect. London: Phaidon Press, 1999, impresión paperback de la edición original de 1997.

MOCK, Elizabeth (ed.): Built in the USA, 1932-1944. Exhibition Catalogue. New York: Museum of Modern Art, 1944.

MUMFORD, Lewis: Roots of Contemporary American Architecture. New York: Dover Publications Inc., 1972 (primera edición 1952).

MUMFORD, Lewis: The South in Architecture. New York: Harcourt, Brace \& Co., 1941.

PENICK, Monica M.: The Pace Setter Houses: Livable Modernism in Postwar America. Tesis doctoral inédita. Ph. D. Dissertation. Austin, TX: Graduate School of Architecture. University of Texas at Austin, 2007.

ROTH, Leland M.: Shingle Styles. Innovation and Tradition in American Architecture 1874 to 1982. New York: Harry N. Abrams, 1999.

ROTH, Leland M.: American Architecture: a History. Boulder, Colorado: Westview Press, 2003 (primera edición 2001).

SHANKEN, Andrew M.: 194X: Architecture, Planning, and Consumer Culture on the American Home Front. Minneapolis, MN: University Of Minnesota Press, 2009.

SCULLY, Vincent: Frank Lloyd Wright. New York: G. Braziller, 1960.

SCULLY, Vincent: Lovis I. Kahn. New York: G. Braziller, 1962.

SCULLY, Vincent y LEVINE, Neil (introducción y selección de textos): Modern Architecture and Others Essays. New York: Princeton Architectural Press, 2003.

SMITHSON, Peter y SMITHSON, Alison: Cambiando el arte de habitar. Barcelona: Gustavo Gili, 2001 (edición original Changing the Art of Inhabitation. London: Artemis London Ltd., 1994).

TZONIS, Alexander y LEFAIVRE, Liane: Critical Regionalism: Architecture and Identity in a Globalized World. New York: Prestel Publishing, 2003.

WEBB, Michael: Modernism Reborn. Mid-Century American Houses. New York: Universe Publishing, Rizzoli, 2001.

WILLIAMSON, Roxanne K.: American Architects and the Mechanics of Fame.. Austin, TX: University of Texas Press, 1991.

WINTER, Robert: American Bungalow Style. New York: Simon \& Schuster, 1996.

WHITELEY, Nigel: Reyner Banham. Historian of the Immediate Future. Cambridge, MA: The MIT Press, 2002. 
WRIGHT, Frank Lloyd: An Autobiography. Petaluma, CA: Pomegranate Communications, 2005. Reimpresión facsímil de la biografía publicada en 1943 (New York: Duell, Sloan \& Pearce), como ampliación de la edición original de 1932 (New York: Longmans, Green and Company).

WRIGHT, Frank Lloyd: An Organic Architecture: The Architecture of Democracy (Recopilación y reedición de ensayos basados en sus cuatro conferencias pronunciadas en 1939 en el Royal Institute of British Architects de Londres). Cambridge, MA: The MIT Press, 1970.

WRIGHT, Frank Lloyd y FUTAGAWA, Yukio (ed.): Frank Lloyd Wright Monograph 1914-1923. Tokyo: A.D.A. Edita Tokyo, 1985.

WRIGHT, Frank Lloyd y Futagawa, Yukio (ed.): Frank Lloyd Wright. Preliminary Studies 1917-1932. Tokyo: A.D.A. Edita Tokyo, 1986.

WRIGHT, Frank Lloyd et al.: The Complete 1925 Wendingen Series. Introducción de Donald Hoffman. New York: Dover Books on Architecture, impresión paperback, 1992.

WRIGHT, Gwendolyn: USA. Modern Architectures in History. London: Reaktion Books, 2008.

WOJTOWICZ, Robert (ed.): Sidewalk Critic: Lewis Mumford's writings on New York. New York: Princeton Architectural Press, 2000 (primera edición 1998). 


\section{LOS ÁNGELES: CIUDAD, URBANISMO, TERRITORIO Y POLÍTICAS URBANAS}

AA. VV., DEVERELL, William y HISE, Greg (eds.): Land of Sunshine. An Environmental History of Metropolitan Los Angeles. Pittsburgh, PA: University of Pittsburgh Press, 2006, impresión paperback de la primera edición de 2005.

AA. VV., REID, David (ed.): Sex, Death, and God in L.A. Berkeley, CA: University of California Press, 1994 (primera edición 1992).

AA. VV., ROTONDI, Michael (ed.): From the Edge: Southern California Institute of Architecture Student Work. New York: Princeton Architectural Press, 1991.

AA. VV., SALAS, Charles G. y ROTH, Michael S. (eds.): Looking for Los Angeles: Architecture, Film, Photography and the Urban Landscape. Los Angeles: The Getty Research Institute (Publication Program: Issues \& Debates), 2001.

AA. VV., SOJA, Edward W. y SCOTT, Allan J. (eds.): The City. Los Angeles and Urban Theory at the End of the Twentieth Century. Berkeley y Los Angeles, CA: University of California Press, 1998 (primera edición, 1996).

AA. VV., SORKIN, Michael (ed.): Variaciones sobre un parque temático. La nueva ciudad americana y el fin del espacio público. Barcelona: Gustavo Gili, 2004 (edición original Variations on a Themepark. The New American City and the End of Public Space. New York: Hill and Wang, 1992).

AA. VV., VARNELISR, Kazys (ed.): The Infrastructural City. Networked Ecologies in Los Angeles. Barcelona: Actar, 2008.

AVILA, Eric: Popular Culture in the Age of White Flight: Fear and Fantasy in Suburban Los Angeles. Berkeley y Los Angeles: University of California Press, 2004 .

BANHAM, Reyner: Los Angeles. The Architecture of Four Ecologies. Berkeley y Los Angeles: University of California Press, 2001, impresión paperback (primera edición: Baltimore, MD: Penguin Books Inc., 1971).

BAUER, Catherine: Modern Housing. Boston, MA : Houghton Mifflin, 1934.

BAUER, Catherine: "Redeveloptment: A Misfit in the Fifties", en AA. VV., WOODBURY, Coleman (ed.): 'The Future of Cities and Urban Redevelopment. Chicago, IL: University of Chicago Press, 1953.

BOTTLES, Scott L.: Los Angeles and the Automobile: The Making of the Modern City. Berkeley, CA: University of California Press, 1987.

CUFF, Dana: The Provisional City: Los Angeles Stories of Architecture and Urbanism. Cambridge, MA: The MIT Press, 2002 (primera edición 2000).

DAVIS, Mike: Ciudad de Cuarzo. Arqueología del futuro en Los Angeles. Madrid: Lengua de Trapo, 2004. (edición original City of Quartz: Excavating the Future in Los Angeles. London, New York: Verso, 1990). Verso ha reeditado el texto actualizado en 2006. 
DAVIS, Mike: Ciudades muertas. Ecología, catástrofe y revuelta. Madrid: Traficantes de sueños, 2007. Traducción castellana disponible en formato pdf en la página web de la editorial www.traficantes.net (edición original en inglés Dead Cities and OtherTales. New York: The New York Press, 2002).

DAVIS, Mike: Ecology of fear: Los Angeles and the Imagination of Disaster. New York: Metropolitan Books, 1998.

DAVIS, Mike: Magical Urbanism: Latinos Reinvent the US City. London, New York: Verso, 2000.

DAVIS, Mike: Prisoners of the American Dream: Politics and Economy in the History of the US Working Class. London: Verso, 1986.

DAVIS, Mike; Mayhew, Kelly y Miller, Jim: Under the Perfect Sun: the San Diego Tourists Never See. New York: New York Press, 2003.

DAVIS, Margaret L.: Rivers in the Desert: William Mulholland and the Inventing of Los Angeles. New York: Harper Collins, 1993.

DEVERELL, William: Whitewashed Adobe: The Rise of Los Angeles and the Remaking of Its Mexican Past. Berkeley y Los Angeles: University of California Press, 2004.

FULTON, William: The Reluctant Metropolis: the Politics of Urban Growth in Los Angeles. Baltimore, MD: Johns Hopkins University Press, 2004 (primera edición 1997).

GARCÍA VÁZQUEZ, Carlos: Ciudad Hojaldre. Visiones urbanas del siglo XXI. Barcelona: Gustavo Gili, 2004.

HAYDEN, Dolores: Seven American Utopias: The Architecture of Communitarian Socialism, 1790-1975. Cambridge, MA: The MIT Press, 1976.

HAYDEN, Dolores: Redesigning the American Dream: Gender, Housing, and Family Life. New York: W. W. Norton: 1984.

HAYDEN, Dolores: The Grand Domestic Revolution: A History of Feminist Designs for American Homes, Neighborhoods and Cities. Cambridge, MA: The MIT Press, 1981.

HAYDEN, Dolores: The Power of Place: Urban Landscapes as Public History. Cambridge, MA: The MIT Press, 1995.

HISE, Greg: Magnetic Los Angeles: Planning the Twentieth-Century Metropolis. Baltimore, MD: Johns Hopkins University Press, 1999 (primera edición 1997).

HISE, Greg y DEVERELL, William F.: Eden by Design: The 1930 Olmsted-Bartholomew Plan for the Los Angeles Region. Berkeley y Los Angeles: University of California Press, 2000.

JACOBS, Jane: Death and Live of Great American Cities. New York: Random House, 2002 (primera edición 1961). 
JENCKS, Charles: Heteropolis: Los Angeles, the Riots and the Strange Beauty of Hetero-Architecture. London: St. Martin's Press, 1993.

KEANE, James T.: Fritz B. Burns and the Development of Los Angeles. LoS Angeles: Historical Society of Southern California, 2001.

KUNSTLER, James Howard: The Geography of Nowhere: The Rise and Decline of America's Man-Made Landscape. New York: Touchstone, 1994.

McCLUNG, William A.: Landscapes of Desire: Anglo Mythologies of Los Angeles. Berkeley y Los Angeles: University of California Press, 2000.

McWILLIAMS, Carey: Southern California, an Island on the Land. Salt Lake City, UT: Gibbs Smith Publisher, 1980 (edición original Southern California Country, an Island on the Land. New York: Duell, Sloan \& Pearce, 1946).

OVNICK, Merry: Los Angeles: The End of the Rainbow. Los Angeles: Balcony Press, 1994 .

PARSON, Don: Making a Better World. Public Housing, the Red Scare and the Direction of Modern Los Angeles. Prólogo de Kevin Starr. Minneapolis, MN: University of Minnesota Press, 2005.

PÉREZ DE LAMA, José: Entre Blade Runner y Mickey Mouse. Nuevas condiciones urbanas. Una perspectiva desde Los Ángeles, California (1999-2002). Tesis Doctoral. Sevilla: Departamento de Historia, Teoría y Composición Arquitectónicas de la Universidad de Sevilla, 2007. Disponible versión pdf en la página web www.hackitectura.net.

RADFORD, Gail: Modern Housing for America: Policy Struggles in the New Deal Era. Chicago, IL: The University of Chicago Press, 1996.

SOJA, Edward W.: Postmetrópolis. Estudios críticos sobre las ciudades y las regiones. Madrid: Traficantes de sueños, 2008. Traducción castellana disponible en formato pdf en la página web de la editorial www.traficantes.net (edición original en inglés: Postmetropolis. Critical Studies of Cities and Regions. London: Blackwell, 2000).

SOJA, Edward W.: Thirdspace. Journeys to Los Angeles and Other Real-andImagined Places. London: Blackwell, 1996.

STARR, Kevin: Americans and the California Dream 1850-1915. New York: Oxford University Press, 1986 (primera edición 1973).

STARR, Kevin: California, a History. New York: Modern Library, 2007 (primera edición 2005).

STARR, Kevin: Endagered Dreams: The Great Depression in California. New York: Oxford University Press, 1996.

STARR, Kevin: Inventing the Dream. California through the Progressive Era. New York: Oxford University Press, 1985.

WRIGHT, Gwendolyn: Building the Dream. A Social History of Housing in America. Cambridge, MA: The MIT Press, 1981. 
AA. VV., CORNELL, Daniell (ed.): Backyard Oasis. The Swimming Pool in Southern California Photography 1945-1982. New York: Prestel Publishing, 2012.

AA. VV., FOSTER, Hal (ed.): La Posmodernidad. Barcelona: Kairós, 2002 (primera edición en castellano 1985; edición original en inglés The Anti-Aesthetic Essays on Postmodern Culture. Port Townsend, WA: Bay Press, 1983).

AA. VV., MINK, Gwendolyn y O'CONNOR, Alice (eds.): Poverty in the United States. An Encyclopedia of History, Politics and Policy . Santa Barbara, CA. ABC-Clio, 2004.

AA. VV.' WARE, susan (ed.): Notable American Women: A Biographical Dictionary, Volume 5: Completing the Twentieth Century. Cambridge, MA: Belknap Press of Harvard University Press, 2004.

ALBRECHT, Donald: Designing Dreams. Modern Architecure in the Movies. Santa Monica, CA : Hennessey + Ingalls, 2000.

BAUDRILLARD, Jean: Amérique. Paris: Descartes, 2000 (primera edición Paris: Grasset \& Fasquelle, 1986).

COLOMINA, Beatriz: Doble Exposición. Arquitectura a través del Arte. Madrid: Akal, 2006.

COLOMINA, Beatriz: Privacidad y publicidad. La arquitectura moderna como medio de comunicación de masas. Yaiza Hernández y José Parra (dirs.). Traducción Isabel Hortal, Beatriz Preciado, Yaiza Hernández y José Parra. Murcia: CENDEAC, COAMU, OBS, 2010 (edición original Privacy and Publicity. Modern Architecture as Mass Media. Cambridge, MA: The MIT Press, 1994).

FOSTER, Hal: Diseño y delito. Madrid: Akal, 2004 (edición original Design and Crime. London: Verso, 2002).

GOLDMAN, Emma: Living my Life. Vol. I. New York: Cosimo, 2008 (edición original, New York: Da Capo Press, 1931).

GREEN, Samuel M: American Art, a Historical Survey. New York: Ronald Press, 1966.

KLUBER George: The Shape of Time: Remarks on the History of Things. New Haven, CT:Yale University Press, 1962.

MACLUHAN, Marshall: Understanding Media The Extension of Man. New York: McGraw Hill, 1964.

MACLUHAN, Marshall: The Medium and the Messenger. MA: The MIT Press, 1989

SCHAFFNER, Ingrid: Essential Man Ray. New York: Harry N. Abrams, 2003. 


\section{GUÍAS DE ARQUITECTURA DE LA REGIÓN}

CERNY, SUSAN: Architectural Guidebook to San Francisco and the Bay Area. Salt Lake City, UT: Gibbs Smith Publisher, 2007.

GEBHARD, David, WINTER, Robert et al.: Guide to Architecture in San Francisco and Northern California. Salt Lake City, UT: Gibbs Smith Publisher, 1985. Revisada con Eric Sandweiss (edición original Santa Barbara, CA: Peregrine Smith, 1973, con John y Sally Woodbridge).

GEBHARD, David y WINTER, Robert: An architectural Guidebook to Los Angeles. Salt Lake City, UT: Gibbs Smith Publisher, 2003.

Ha sido consultada también su edición precedente: Los Angeles. An Architectural Guide. Salt Lake City, UT: Gibbs Smith Publisher, 1994.

Ambas son reediciones de un exhaustivo trabajo de documentación y crítica que ha venido actualizándose y ampliándose desde 1965. Éste se inició con $A$ Guide to Architecture in Southern California (Los Angeles: Los Angeles County Museum of Art, 1965); y continuó con A Guide to Architecture in Los Angeles \& Southern California (Santa Barbara, CA: Peregrine Smith, 1977).

En 1985 sus autores revisaron su ya entonces imprescindible guía concentrándose específicamente en el área de Los Angeles y publicaron Architecture in Los Angeles: a Complete Guide. Salt Lake City, UT: Gibbs Smith Publisher, 1985 .

MOORE, Charles con BECKER, Peter y CAMPBELL, Regula: Los Angeles. The City Observed. A Guide to its Architecture and Landscape. Santa Monica, CA: Hennessey + Ingalls, 1998 (edición original New York: Vintage Books, 1984).

WILEY, Peter B.: National Trust Guide. San Francisco: America's Guide for Architecture and History Travelers. New York: John Wiley \& Sons, 2000.

WOODBRIGE, Sally B., WOODBRIDGE, John M. y BYRNE, Chuck: San Francisco Architecture: An Illustrated Guide to the Oustanding Buildings, Public Artworks and Parks in the Bay Area of California. Berkeley, CA: Ten Speed Prees, 2005 (edición revisada a partir de la edición original San Francisco Architecture: The Illustrated Guide to Over 1.000 of the Best Buildings, Parks, and Public Artworks in the Bay Area. San Francisco: Chronicle Books, 1992). 


\section{ARTÍCULOS CITADOS, PUBLICACIONES OFICIALES, PRENSA y ACTAS DE CONGRESOS}

AA. VV.: "What is Happening to Modern Architecture?" New York: The Museum of Modern Art Bulletin, vol. XV, $n^{\circ} 3$, primavera 1948.

"A Lovell Beach House for Dr. P. Lovell at Newport Beach, California". Architectural Record, septiembre 1929, pp. 257-261.

"A House for Writer Affords Privacy and Spectacular View. Alexander Levy, Designer". Architectural Record, octubre 1938, pp. 47-51.

"Houses for Otdoor Life. A Vacation Settlement on the Pueblo Ribera, La Jolla, California". Architectural Record, julio 1930, pp. 17-21

"Famed Olympic Architectural Exhibition Opened". Los Angeles Times, 24 julio 1932, p. I-16.

"Modern Architecture". Los Angeles Times, 24 julio 1932, p. VI-2.

"Neutra to Lecture". Los Angeles Times, 3 febrero 1929, p. III-14.

ALCOLEA, Ruben A.: "De AC a De 8 en Opbouw: La Casa Lovell Health". Barcelona: Actas del Congreso DOCOMOMO Ibérico El G.A.T.E.P.A.C. y su tiempo, COAC, 2006, pp. 213-218.

ADAMS, Annmarie: "Sex and the Single Building: The Weston Havens House, 1941-2001". Buildings \& Landscapes: Journal of the Vernacular Architecture Forum 17, no 1, primavera 2010, pp. 82-97.

ALLEN, Harris: "A Building Design for Today". California Arts \& Architecture, enero 1930, pp. 21-22.

Reyner BANHAM: "The Master Builders: 5. The Gamble House and Schindler House". Sunday Times Magazine (London), 8 agosto 1971, pp. 26-27

BAUER, Catherine: "The Dreary Deadlock of Public Housing". Architectural Forum, mayo 1957, pp. 140-142 y 219-221.

BAUER, Catherine: "The Social Front of Modern Architecture in the 1930s". Journal of the Society of Architectural Historians, vol. 24, marzo 1965, pp. 4852.

BENJAMIN, Walter : "Pequeña historia de la fotografía". Discursos interrumpidos I. Prólogo, traducción y notas de Jesús Aguirre. Madrid: Taurus, 1973.

BIRCH, Eugenie L.: "Woman-Made America. The Case of Early Public Housing Policy". Journal of the American Planning Association, 1939-0130, vol. 44, $n^{\circ} 2$, 1978, pp. 130-144.

GOLDBERGER, Paul: "Architecture View: Learning to Take California Seriously". The New YorkTimes, 14 enero 1990. 
CLAUSEN, Meredith L.: "L'Art Center di Pasadena e lo strano caso di 'Craig Ellwood'/The Pasadena Art Center and the Curious Case of 'Craig Ellwood'". Casabella no 664, 1999, pp. 65-74.

CRAWFORD, Margaret: "Olvidando y recordando a Schindler: la historia arquitectónica de una reputación arquitectónica", en $2 \mathrm{G} \mathrm{n}{ }^{\circ}$ 7, Schindler, 1998, pp. 129-143.

BANGS HARRIS, Jean M.: "Bernard Ralph Maybeck, Architect, Comes into His Own: Notes from a Forthcoming Book on Maybeck". Architectural Record, enero 1948, pp. 72-79.

BANGS HARRIS, Jean M.: "Greene and Greene: the American House Owes Simplicity and Clarity to Two Almost-Forgotten Brothers Who Showed Us How to Build with Wood". Architectural Forum, octubre 1948, pp. 80-89.

ENTENZA, John: "Announcement. The Case Study House Program". Arts \& Architecturer, enero 1945, pp. 37-39.

FRAMPTON, Kenneth: "The Usonian Legacy". Architectural Review, diciembre 1987, pp. 26-31.

FRIEDMAN, Alice T.: "No Ordinary House: Frank Lloyd Wright, Aline Barnsdall and Hollyhock House". FRIEDMAN, Alice T.: Women and the Making of the Modern House. A Social and Architectural History. NewYork: Harry N. Abrams, 1998 , pp. 32-63.

GIBLING SCHINDLER, Pauline [publicado de manera anónima]: "Wie Bau Amerika? Book Review". Los Angeles City Club Bolletin, 30 julio-6 agosto 1927.

GIBLING SCHINDLER, Pauline: "Richard Neutra, Modern Architect to Speak Here". The Carmelite, 28 noviembre 1928, p. 2.

GIBLING SCHINDLER, Pauline: "The Architecture of the Future". The Carmelite, 28 noviembre 1928, p. 11.

GIBLING SCHINDLER, Pauline: "Richard Neutra Renders Modern Architecture Intelligible". The Carmelite, 5 diciembre 1928, p. 4.

GIBLING SCHINDLER, Pauline: "Edward Weston on the Way". The Carmelite, 26 diciembre 1928, p.2.

GIBLING SCHINDLER, Pauline: "Utopia Found". The Carmelite, 6 marzo 1929.

GIBLING SCHINDLER, Pauline: "Schindler Modern Speaks on Architecture". The Carmelite, 4 septiembre 1929, p. 4.

GIBLING SCHINDLER, Pauline: "A Significant to Culture. The Interior of a Great California Store as an Interpretation of Modern Life". California Arts \& Architecture, enero 1930, pp. 23-28 y 74.

GIBLING SCHINDLER, Pauline: "Modern California Architects". Creative Art, febrero 1932, p. 113. 
GIBLING SCHINDLER, Pauline: "Note on the Contemporary Art". Dune Forum. Suscribrers' Number (Oceano CA), otoño 1933, pp. 7-8.

GIBLING SCHINDLER, Pauline: "The Guilty Liberals". Dune Forum n 2 (Oceano (A), febrero 1934, pp. 94-95.

GIBLING SCHINDLER, Pauline: "Oceano Dunes and Their Mystics". Westways $n^{\circ} 26$, febrero 1934, pp.12-13.

GIBLING SCHINDLER, Pauline: Editorial. California Arts \& Architecture, enero 1935, p.11.

GORDON Elizabeth: "The Threat to the Next America", en House Beautiful, abril 1953, pp. 126-130.

HARRIS, Harwell Hamilton: "Regionalism and Nationalism in Architecture". Texas Quarterly, febrero 1958, p. 115-24.

HARRIS, Harwell Hamilton: "Regionalism". North Carolina Architect, enerofebrero 1978, p. 10-11.

HINES, Thomas: "Home Sweet Home. The Architecture of R. M. Schindler". Los Angeles Times, 11 marzo 2001.

HINES, Thomas: "Machines in the Garden: Notes Toward a History of Modern Los Angeles Architecture". David REID (ed.): Sex, Death and God in L.A. New York: Pantheon, 1992.m pp. 259-318.

HINES, Thomas: "The Search for Frank Lloyd: History, Biography and Autobiography". Journal of the Society of Architectural Historians, vol. 54, 1995, pp. $467-476$.

HITCHCOCK, Henry-Russell: "Wie Baut Amerika?" (Crítica del libro). Architetcural Record, junio 1928, pp. 594-595.

HITCHCOCK, Henry-Russell: "An Eastern Critic Looks at Western Architecture", en California Arts \& Architecture, diciembre 1940, pp. 221-223.

HUNT, D. Bradford: "Was the 1937 US Housing Act a Pyrrhic Victory?". Journal of Planning History, vol. 4 nº $^{\circ}$, agosto 2005, pp. 195-221.

HUNT, D. Bradford: "Why Did the Working Class Reject Public Housing in America?". Journal of Planning History, vol. 2 n 1, febrero 2003, pp. 79-93.

JACKSON, Neil: "Metal-Frame Houses of the Modern Movement in Los Angeles: Part 1: Developing a Regional Tradition". Journal of the Society of Architectural Historians of Great Britain, vol. 32, 1989, pp. 152-172.

JACKSON, Neil: "Metal-Frame Houses of the Modern Movement in Los Angeles: Part 2: The Style that Nearly...". Journal of the Society of Architectural Historians of Great Britain, vol. 33, 1990, pp. 167-187.

JACKSON, Neil: "Californian Promise". The Architectural Review, marzo 1996, pp. 8o-84. 
LEVINE, Neil: "Hollyhock House and the Romance of Southern California". Art in America, septiembre 1983, pp. 150-165.

LOVELL, Philip M.: "Building Homes for Health", en Care of the Body. Los Angeles Times, (Sunday magazine section), 29 junio 1924, pp. 25-26.

LOVELL, Philip M.: «The House Built for Health», en Care of the Body. Los Angeles Times, (Sunday magazine section), 15 diciembre 1929, p. 26-27.

McCOY, Esther: "Schindler, Space Architect". Direction no 8, otoño 1945, pp. $14-15$.

McCOY, Esther: "Four Schindler Houses of the 1920s". Arts \& Architecture, septiembre 1953, pp. 12-14.

McCOY, Esther: "R. M. Schindler Houses". Arts \& Architecture, mayo 1954, pp. $12-15$ y $35-36$.

McCOY, Esther: "Roots of California Contemporary Architecture". Arts \& Architecture, octubre 1956, pp. 14-17 y 36-39.

McCOY, Esther: "Pauline Schindler, 1893-1977". Progressive Architecture, septiembre 1977, pp. 28 y 33.

McCOY, Esther: "Schindler: A Personal Reminiscence". L.A. Architect, noviembre 1987, pp. 5-9.

McCOY, Esther: "Persistence of Vision: The Encompassing Eye of Architectural Photographer Julius Shulman". Angeles, diciemrbe 1989, pp. 84-91 y 133.

MARMORSTEIN, Gary: "Steel and Slurry: Dr. Philip M. Lovell, Architectural Patron". Southern California Quarterly no 84, otoño-invierno 2002, pp. 241270.

MILLIER Arthur: "A New Art". Los Angeles Times, 2 enero 1929, p. 11.

MILLIER Arthur: "Brush Strokes: The International Exhibition of Modern Architecture". Los Angeles Times, 31 julio 1932, p. II-19.

MILLIER Arthur: "Building for Our Age: California Designers of Modern Style Architecture Distinguished from Those Who Imitate". Los Angeles Times, 27 abril 1930, p. 11.

MILLIER Arthur: "Photographs for Himself". Los Angeles Times, 25 julio 1930, p.12

MORGAN, Susan: "Being There: Esther McCoy the Accidental Architectural Historian". Archives of American Art Journal, primavera 2009, pp. 24-26.

MORGAN, Willard D.: "An Architect's Warm-Air Heated Health House". Sheet Metal Worker, 11 julio 1930, pp. 410-411 y 419. 
MUMFORD, Lewis: "Status Quo", en The Sky Line. The New Yorker, 11 octubre 1947.

MURRAY BANGS HARRIS, Jean: "Greene \& Greene". Architectural Forum, octubre 1948, pp. 81-88.

NEUTRA, Richard, J.: "Um die neue Gestaltung". Das Neue Frankfurt, abril 1928, pp. 68-71.

NEUTRA, Richard J.: "Amerika. Körperübung und gegenwärtige Bauarbait", en Das Neue Frankfurt, mayo 1928, p.91.

NEUTRA, Richard J.: "Amerika. Bauliche Stilbildung. Bemühungen Einzelner". Das Neue Frankfurt, septiembre 1928, pp. 173-174.

NEUTRA, Richard J.: "The Demostration Health-House". Architectural Record, mayo 1930, pp. 433-39.

NEUTRA, Richard J.: "Terminals?-Trasnfer!". Architectural Record, agosto 1930, p. 103.

NEUTRA, Richard J.: "International Stylists' Designs Thrill Crowds". Los Angeles Times, 24 julio 1932, pp. 16-17.

NEUTRA, Richard J.: "Balancing the Two Determinates of Creation". Dune Forum $n^{\circ}{ }_{5}$ (Oceano, CA), mayo 1934, pp. 136-139.

PRECIADO, Beatriz: "Mies-conception: La casa Farnsworth y el misterio del armario transparente". Zehar: revista de Arteleku-ko aldizkaria n²44, 2000, pp. 23-32.

ROWE Colin: "Texas y Mrs. Harris", en As I Was Saying. Recollections and Miscellaneous Essays. Volume I: Texas, Pre-Texas, Cambridge. Cambridge, MA: The MIT Press, 1996, pp. 25-40.

SARNITZ, Agust E.: "Proportion and Beauty-The Lovell Beach House by Rudolph Michael Schindler, Newport Beach, 1922-1926". Journal of the Society of Architectural Historians, vol. 45, diciembre 1986, pp. 347-388.

SCHINDLER, Pauline Gibling: "Modern California Architects". Creative Art, febrero 1932, pp. 111-115.

SCHINDLER, Pauline Gibling: "Modern Architecture Acknowledge the Light which Kindled It: Frank Lloyd Wright". California Arts \& Architecture, enero 1935 (El número de la revista y la selección de contenidos se realizaron bajo su dirección).

SCHINDLER, Rudolph M.: "Who will save Hollywood?" Holly Leaves, noviembre 1922, p. 32.

SCHINDLER, Rudolph M.: "Ventilation", en Care of the Body. Los Angeles Times (Sunday magazine section), 14 marzo 1926, pp. 25-26.

SCHINDLER, Rudolph M.: "Plumbing and Health ", en Care of the Body. Los Angeles Times, (Sunday magazine section), 21 marzo 1926, pp. 25-26. 
SCHINDLER, Rudolph M.: "About Heating", en Care of the Body. Los Angeles Times, (Sundayagazine section), 4 abril 1926, pp. 24-25.

SCHINDLER, Rudolph M.: "About Lighting", en Care of the Body. Los Angeles Times, (Sunday magazine section), 11 abril 1926, pp. 30-31.

SCHINDLER, Rudolph M.: "About Furniture", en Care of the Body. Los Angeles Times, (Sunday magazine section), 18 abril 1926, pp. 26-27.

SCHINDLER, Rudolph M.: "Shelter or Playground", en Care of the Body. Los Angeles Times, (Sunday magazine section), 2 mayo 1926, pp. 26-27.

SCHINDLER, Rudolph M.: "A Cooperation Dwelling".T-Square, febrero 1932, pp. 20-21.

SCHINDLER, Rudolph M.: "Points of View-Contra". Southwest Review, primavera 1932, pp. 353-354.

SCHINDLER, Rudolph M.: "Space Architecture". Dune Forum no 2 (Oceano, (A), febrero 1934, pp. 44-46.

SCHINDLER, Rudolph M.: "Space Architecture". California Arts \& Architecture, enero 1935, pp. 18-19.

SCHINDLER, Rudolph M.: "Furniture and the Modern House: A Theory of Interior Design". Architect and Engineer, diciembre 1935 (Part I), pp. 20-25.

SCHINDLER, Rudolph M.: "Furniture and the Modern House: A Theory of Interior Design". Architect and Engineer, marzo 1936 (Part II), pp. 24-28.

SCHINDLER, Rudolph M.: "Prefabrication Vocabulary: The Panel-Post Construction". California Arts \& Architecture, junio 1936, pp. 25-27.

SCHINDLER, Rudolph M.: "Notes. Modern Architecture", 1944. Manuscrito inédito. Schindler Archive. The Architecture \& Design Collection (ADC). University Art Museum. University of California, Santa Barbara (UCSB).

SCHINDLER, Rudolph M.: "Discussion". Pencil Points, noviembre 1944, p.16.

SCHINDLER, Rudolph M.: "Reference Frames in Space". Architect and Engineer, abril 1946, pp. 10, 40 y 44-45. Un manuscrito de 1944 previo al texto publicado por la revista de San Francisco puede localizarse en el Schinder Archive (ADC), University Art Museum de la University of California, Santa Barbara (UCSB).

SCHINDLER, Rudolph M.: "Portrait". Architectural Forum, febrero 1947, pp. 100-102.

SCHINDLER, Rudolph M.: "The Schindler Frame". Architectural Record, mayo 1947, pp. 143-146. Una versión anterior inédita de 1945 puede consultarse el Schinder Archive (ADC), University Art Museum de la University of California, Santa Barbara (UCSB).

SCHINDLER, Rudolph M.: "Houses USA (Letters to the publisher)". Architectural Forum, agosto 1947, p. 22. 
SCHINDLER, Rudolph M.: "Visual Technique", 1952. Manuscrito inédito. Schindler Archive (ADC). University Art Museum, University of California, Santa Barbara (UCSB).

SHEINE, Judith: "R. M. Schindler y la reintegración radical del espacio interior-exterio". RA. Revista de Arquitectura, vol. 6, 2004, pp. 31-42.

SMITH, Kathryn: "Frank Lloyd Wright, Hollyhock House and Olive Hill, 19141924". Journal of the Society of Architectural Historians, vol. 38, n' 1, marzo 1979, pp. 15-33.

STRINGFELLOW, Jamie: "Building a Reputation". Westways magazine, octubre 2007, p.64.

SWEENEY, Robert: "His House, Her House, Their House". MAK Center for Art and Architecture (NOEVER, Peter, ed.). New York: Prestel Publishing, 1995.

SWEENEY, Robert; SHEINE Judith y BRICKER, Lauren W.: The Lovell Houses. Los Angeles: MAK Center, 2012 (recopilación de ensayos publicados como folleto del MAK Center Tour 2003).

WOOD, Edith Elmer: "Is Governmental Aid Necessary in House Financing? ". AA. VV.: Housing Problems in America. New York: National Housing Association, 1929.

WOOD, Edith Elmer: Introduction to Housing. Facts and Principles. Washington D. C.: Federal Works Agency. United States Housing Authority, 1940.

WOOD, Edith Elmer: "Building for Defense: Emergency Housing Proposals". Architectural Forum, abril 1941, pp. 18, 98, 102 y 106.

WOOD, Edith Elmer: "Danger Points in Defense Housing". Survey Graphic, agosto 1941, p. 433.

\section{ENTREVISTAS/TRANSCRIPCIONES HISTÓRICAS/ ORAL HISTORY PROGRAMS}

ALEXANDER, Robert: Architecture, Planning and Social Responsibility. Entrevista con Marlene L. Laskey (julio y octubre 1986). Los Angeles: Oral History Program, University of California Los Angeles (UCLA), 1989.

DELANO, Annita: Southwest Artist and Educator. Entrevista con James V. Mink (enero-febrero 1971). Los Angeles: Oral History Program, University of California Los Angeles (UCLA), vol. 1, 1976.

HARRIS, Harwell Hamilton: The Organic View of Design. Entrevista con Judy Stonefield (agosto 1979). Los Angeles: Oral History Program, University of California Los Angeles (UCLA), 1985.

LAUTNER, John: Responsibility, Infinity, Nature. Entrevista con Marlene L. Laskey (abril-julio 1982). Los Angeles: Oral History Program, University of California Los Angeles (UCLA), 1988. 
MANNY, Carter: Entrevista con Franz Schulze (marzo-abril, 1992): Chicago: Chicago Architects Oral History Projects, Art Institute of Chicago, 1992.

McCOY, Esther: Entrevista con Joseph Giovannini (junio-noviembre 1987), editada por Susan Morgan (julio 2009). Pasadena: Oral History Interview. Archives of American Art, Smithsonian Institution, 1987.

NEUTRA, Dione: To Tell the Truth. Entrevista con Lawrence Weschler (abril, julio y agosto 1982). Los Angeles: Oral History Program, University of California Los Angeles (UCLA), 1983.

SORIANO, Raphael: Substance and Function in Architecture. Entrevista con Marlene L. Laskey (julio 1985). Los Angeles: Oral History Program, University of California Los Angeles (UCLA), 1988.

TIGERMAN Stanley: Entrevista con Betty J. Blum (agosto 1998): Chicago: Chicago Architects Oral History Projects, Art Institute of Chicago, 1998.

\section{FUENTES DISPONIBLES ONLINE}

Archives of American Art. Smithsonian Institution

Oral history interview with Esther McCoy

http://digital-libraries.saic.edu/cdm4/index_caohp.php?CISOROOT=/caohp

Art Center College of Design. Pasadena

http://www.artcenter.edu

Art Institute of Chicago. The Chicago Architects Oral History Project

http://digital-libraries.saic.edu/cdm4/index_caohp.php?CISOROOT=/caohp

Arts and Architecture. Taschen

http://www.artsandarchitecturemag.com

Avery Index to Architectural Periodicals

http://library.columbia.edu/indiv/avery/avery_index.html

Eames House

http://www.eamesgallery.com; http://www.eamesfoundation.org

Environmental Design Archives. Univeristy of California Berkeley

Douglas and Maggie Baylis Collectionhttp://www.ced.berkeley.edu/cedar-

chives/profiles/baylis.htm

Friends of Havens House

http://www.havenshouse.org

Gamble House

http://www.gamblehouse.org

Getty Center Research Institute

http://www.getty.edu

Greene \& Greene Archives 
http://www.usc.edu/dept/architecture/greeneandgreene

Hollyhock House

http://www.hollyhockhouse.net

Huntington Research Library

http://www.huntington.org/huntingtonlibrary.aspx?id=576

Letters: The Brief Love of John Cage for Pauline Schindler, 1934-1935

(Correspondencia entre Pauline Schindler y John Cage. Transcripción: Maureen Mary): www.ex-tempore.org/ExTemporeg6/cageg6.htm

Los Angeles Conservancy Modern Committee

http://www.modcom.org

Pritzker Prize

http://www.pritzkerprize.com/main.htm

Richard Neutra VDL Research House

http://www.neutravdl.org/mainpage.htm

San Francisco Bay Architecture (Vernacular Language North)

http://www.verlang.com

Schindler House / MAK Center

http://www.makcenter.org

Schindler Archives. Architecture \& Design Collection. University Art Museum. University of California Santa Barbara

http://www.uam.ucsb.edu/collections/adc/index.html

Southern California Architectural History

http://socalarchhistory.blogspot.com.es

Southern California Institute of Architecture

http://www.sciarc.edu

"Talking Gordon Drake". Entrevista con Pier Luigi Serraino. A/N blog. The Architect's Newspaper: http://blog.archpaper.com/wordpress/archives/16790

Ted Wells Living: Simple. Podcasts

http://www.twls.libsyn.com

UCLA Center for Oral History Research

http://oralhistory.library.ucla.edu

UCLA, Department of Architecture and Urban Design

http://www.aud.ucla.edu 